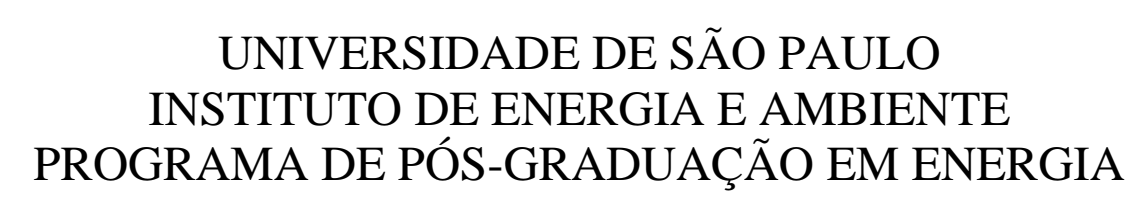

ALCANTARO LEMES RODRIGUES

INFORMAÇÕES MACROCLIMÁTICAS APLICADAS NA PREVISÃO DE VAZÕES 


\section{ALCANTARO LEMES RODRIGUES}

\section{INFORMAÇÕES MACROCLIMÁTICAS APLICADAS NA PREVISÃO DE VAZÕES}

Tese apresentada ao Programa de Pós-Graduação em Energia do Instituto de Energia e Ambiente da Universidade de São Paulo para obtenção do título de Doutor em Ciências.

Orientador: Prof. Dr. ${ }^{\circ}$ Ildo Luís Sauer

Versão Corrigida

SÃO PAULO

2016 
AUTORIZO A REPRODUÇÃo E DIVULGAÇÃo TOTAL OU PARCIAL DESTE TRABALHO, POR QUALQUER MEIO CONVENCIONAL OU ELETRÔNICO, PARA FINS DE ESTUDO E PESQUISA, DESDE QUE CITADA A FONTE.

\section{FICHA CATALOGRÁFICA}

Rodrigues, Alcantaro Lemes.

Informações macroclimáticas aplicadas na previsão de vazões / Alcantaro Lemes Rodrigues; orientador, Ildo Luís Sauer. - São Paulo, 2016.

506 f.: il.; $30 \mathrm{~cm}$

Tese (Doutorado) - Programa de Pós-Graduação em Energia - Instituto de Energia e Ambiente da Universidade de São Paulo

1. Climatologia estatística. 2. Hidroeletricidade. 3. Afluentes. 4. Energia 5. Séries Temporais. I. Título. 
FOLHA DE APROVAÇÃO 
DEDICATÓRIA

Dedico essa obra à minha esposa Laudiceia mais uma vez pelo apoio e compreensão em relação a essa importante etapa de minha vida.

Às minhas filhas Laura e Vitória por tornarem a vida mais alegre e especial. 


\section{EPÍGRAFE}

$\underline{\operatorname{Marcos} 4,39 \text { e } 41^{1}}$

${ }^{37}$ E levantou-se grande temporal de vento, e subiam as ondas por cima do barco, de maneira que já se enchia.

38 E ele estava na popa, dormindo sobre uma almofada, e despertaram-no, dizendo-lhe: Mestre, não se te dá que pereçamos?

${ }^{39}$ E ele, despertando, repreendeu o vento, e disse ao mar: Cala-te, aquieta-te. E o vento se aquietou, e houve grande bonança.

${ }^{40}$ E disse-lhes: Por que sois tão tímidos? Ainda não tendes fé?

${ }^{41}$ E sentiram um grande temor, e diziam uns aos outros: Mas quem é este, que até o vento e o mar lhe obedecem?"

Oração de São Jorge ${ }^{2}$

Eu andarei vestido e armado com as armas de São Jorge para que meus inimigos, tendo pés não me alcancem, tendo mãos não me peguem, tendo olhos não me vejam, e nem em pensamentos eles possam me fazer mal. Armas de fogo o meu corpo não alcançarão, facas e lanças se quebrem sem o meu corpo tocar, cordas e correntes se arrebentem sem o meu corpo amarrar. Jesus Cristo, me proteja e me defenda com o poder de sua santa e

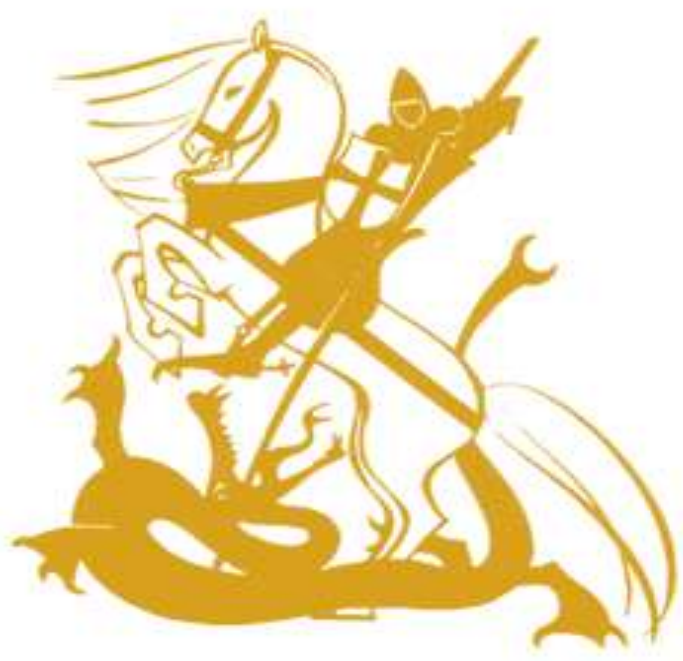
divina graça, Virgem de Nazaré, me cubra com seu manto sagrado e divino, protegendo-me em todas as minhas dores a aflições, e Deus, com sua divina misericórdia e grande poder, seja meu defensor contra as maldades e perseguições dos meus inimigos. Glorioso São Jorge, em nome de Deus, estenda-me o seu escudo e as suas poderosas armas, defendendo-me com a sua força e com a sua grandeza, e que debaixo das patas de seu fiel ginete meus inimigos fiquem humildes e submissos a vós. Assim seja com o poder de Deus, de Jesus e da falange do Divino Espírito Santo. São Jorge Rogai por nós.

\footnotetext{
${ }^{1}$ Novo Testamento Evangelho segundo Marcos capítulo IV, versículo 39 na Bíblia Online: https://biblia.gospelmais.com.br/marcos 4:39/. Acesso em julho 2016.

${ }^{2}$ Oração de São Jorge. Url: http://oracaodesaojorge.com/. Acesso em julho de 2016.
} 


\section{AGRADECIMENTO}

Ao Professor Ildo Luís Sauer, pela oportunidade, paciência, fé e amizade.

Ao Professor Tércio Ambrizzi, pela paciência, observações e opiniões.

A Professor Molion, pelas correções e sugestões, e o reconhecimento da importância do trabalho.

À Professora Airlane Alencar, pelas dicas sobre significância em matemática.

Ao Mestre Eng. ${ }^{\circ}$. Ricardo Santos d'Avila, pelas correções e ajuda na tradução do abstract.

Ao Eng. ${ }^{\circ}$ Douglas Domingos Cruz, e também ao Nilton, pelas correções na parte de unidades.

Ao Professor Renato Zambon, pelas sugestões, atenção e ajuda com o software Hidroterm.

À Professora Adriana Uquillas, pelas revisões da parte matemática, sugestões, orientações, tempo e coleguismo.

Ao Sérgio e a Juliana, pela ajuda com os dados do NEWAVE.

À Lívia Márcia Mosso Dutra, em levantar dados dos modelos climáticos e ao Igor Stivanelli Custódio em ensinar a trabalhar com o software Grads.

À Mestre Giovana Luz e ao Dr. Caio A. S. Coelho, os códigos em R utilizados para fazer os estudos de correlações e análise de componentes principais com mapas.

À Professora Lucélia Alencar, à minha filha Laura Alencar Rodrigues e ao Prof. Molion, as correções do português no texto.

Ao Mestre e Economista Carlos Germán Meza González, pela ajuda com a formatação da parte dos modelos SARIMAX.

Ao Doutor Nilton Bispo Amado, pelas leituras, revisões, sugestões e boas ideias.

Ao IEE/USP, pelo apoio que tornou possível a realização desse trabalho.

E a todos que de forma direta ou indireta fizeram parte da minha formação no doutorado na USP, o meu muito obrigado. 


\section{RESUMO}

RODRIGUES, Alcantaro Lemes. Informações macroclimáticas aplicadas na previsão de vazões. 2016. 506 f. Tese (Doutorado em Ciências) - Programa de Pós-Graduação em Energia da Universidade de São Paulo, São Paulo, 2016.

Fontes renováveis de energia representam alternativas para a mitigação da mudança do clima global, no entanto, são mais suscetíveis a mudanças nas condições climáticas. O sistema elétrico brasileiro (SEB) possui a peculiaridade de ter maior parte de sua energia gerada a partir de fontes renováveis, principalmente usinas hidrelétricas. Por essa razão, constitui uma amostra representativa das dificuldades de operar uma matriz energética de base predominantemente renovável. A geração predominantemente hidrelétrica de energia permite operar com baixas emissões e baixos custos operacionais, nada obstante a forte dependência dessa envolve considerável risco hidrológico, principalmente em um contexto em que as restrições à armazenagem de energia em grandes barragens são maiores. Por conseguinte, a combinação de investimentos inadequados na capacidade de geração com escassez de chuvas pode, eventualmente, levar a situações nas quais a capacidade de oferta seja inferior à demanda e até mesmo a racionamentos (2001). É evidente que a capacidade de prever com precisão o índice de chuvas e, consequentemente, as vazões disponíveis para o próximo período caracteriza-se como uma importante ferramenta para a operação do setor elétrico brasileiro. Hoje, as previsões de vazões futuras são realizadas com base na observação de vazões passadas sem incorporar nas análises as variáveis que as determinam (por exemplo, variáveis climáticas). Entretanto, existem evidências de que a variabilidade das vazões na América do Sul é cadenciada pelos sistemas acoplados do tipo oceano-atmosférico, os chamados fenômenos de grande escala como é o caso do El Niño. No entanto as técnicas tradicionais de previsão até então não utilizam de forma sistêmica as informações climáticas. A metodologia aqui apresentada incorpora informações sobre o clima para tomada de decisões envolvendo recursos hídricos, sendo demonstrada sua aplicação para a região Sudeste do Brasil. Demonstra-se que o manuseamento de variáveis climáticas (mais particularmente aquelas vinculadas ao fenômeno do El Niño) permite calcular a previsão de vazões tão bem quanto os programas oficiais, tendo como vantagem acompanhar as mudanças climáticas eminentes. A metodologia proposta é formada pelas seguintes partes: Modelo SARIMAX; Levantamento de Dados; Análise Gráfica de Correlações; Análise de Séries Temporais; Análise de Gráfica de wavelets e Análise de correlação em Mapas georreferenciados. Esses procedimentos são necessários para visualizar-se com clareza o histórico embutido nas informações analisadas e uma melhor compreensão para a fase de modelagem com o método SARIMAX. Os resultados indicam que o modelo SARIMAX, com variáveis macroclimáticas, é melhor que o NEWAVE.

Palavra Chave: Climatologia estatística. Hidroeletricidade. Afluentes. Energia. Heurística. Séries temporais. 


\section{ABSTRACT}

RODRIGUES, Alcantaro Lemes. Large scale information applied in the forecast streamflow. 2016. 506 f. Thesis (PhD Degree) - Graduate Program on Energy, Universidade de São Paulo, São Paulo, 2016.

Renewable energy sources represent alternatives to the mitigation of global climate change, but they are more susceptible to changing on weather conditions. The Brazilian electricity system has the peculiarity that most of its energy is generated from renewable sources, mainly by hydroelectric plants. For this reason, it provides a representative sample of the difficulties for operating a predominantly renewable basis energy matrix. On one hand, the main hydroelectric generation allows low emissions and low operating costs; on the other hand, the heavy dependence on hydropower involves considerable hydrological risks, specially in an environment where restrictions on energy storage (large dams) are high. Thus, the combination of inadequate investment in generation capacity with low rainfall may, eventually, lead to situations in which the supply capacity is less than the demand, leading even rationing (2002). It is then clear that the ability to accurately predict the rainfall index and hence flow rates available for the next period is an important tool for the operation of the Brazilian electric sector (SEB). Presently, future flows forecasting are only based on observation of past flows without incorporating the analysis of the variables that determine such flows (e.g. climate variables). However, there are evidences that the variability of flows in South America is punctuated by coupled ocean-atmosphere type systems, the so-called large-scale phenomena such as El Niño. However, the traditional forecasting techniques still do not use climate information in a systematic way. The methodology presented here incorporates weather information for decision making in water resources, and demonstrates its applicability to the Southeastern region of Brazil. It is showed that the use of climatic variables (particularly those related to the El Niño phenomenon) predicts streamflow forecasting as well as the official programs do, with the advantage of following eminent climate change. The proposed methodology is formed of the following parts, not necessarily in this order: Model SARIMAX; Data Collection; Graphic analysis of correlations; Time Series Analysis; Wavelets Graphical analysis and Correlation analysis of geo-referenced maps. These procedures are necessary to clearly see the embedded historical information of the information analyzed and better understanding of the modeling stage with SARIMAX method. The results indicate that the SARIMAX model, with large scale variables, is better than the NEWAVE.

Keyword: Statistical Climatology. Hydroelectricity. Inflow. Power. Time series Heuristic. 


\section{Índice de tabelas}

Tabela 3.1 Relação das áreas de medição TSM do Pacífico - El Niño ....................................87

Tabela 3-2 Empreendimentos em Operação no SEB Set-2015 _............................................99

Tabela 3-3 - Planejamento de Usinas para Geração Elétrica no Brasil - GW ......................... 99

Tabela 3-4 Fenômenos e padrões de variabilidade observados no Brasil. Fonte: Nascimento

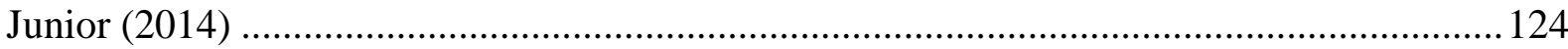

Tabela 4-1 - Fontes de dados coletados para análise ........................................................... 134

Tabela 4-2 Localização original das variáveis macroclimáticas coletadas. ..........................135

Tabela 4-3 Localização original das variáveis solares coletadas ......................................... 135

Tabela 4-4 Fases conhecidas da AMO (ENFIELD et al., 2001) .......................................... 145

Tabela 5-1 Critérios para identificação da ordem dos parâmetros dos modelos ARIMA

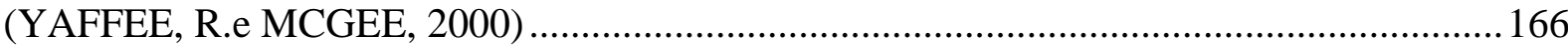

Tabela 5-2 Resumo para identificar processo estacionário conforme as funções ACF e PACF

Tabela 5-3 Resultado do comando TSA::eacf() para dados ENA Sudeste 1931-2015 indica $\operatorname{ARIMA}(2,0,1)$

Tabela 7-1 Resultado da Função de Autocorrelação estendida - eacf - ENA-SE 209

Tabela 7-2 Critérios de adequação dos modelos ENA SE (AIC, AICc, BIC, Sigma2, R2, R2a,

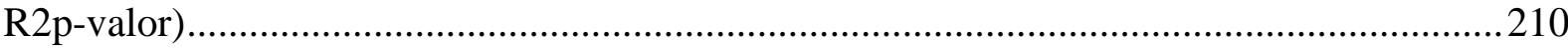

Tabela 7-3 Valores parâmetros estimados e estatísticas correspondentes

Tabela 7-4 Valores parâmetros estimados dos coeficientes das variáveis explicativas e as estatísticas correspondentes

Tabela 7-5 Análise de Erros de Resíduos ..............................................................................2 213

Tabela 7-6 Dados validação modelo de regressão dinâmica SARIMAX (101)(103) ............215

Tabela 7-7 Dados validação NEWAVE Região Sudeste Decks 2003 a 2009.......................215

Tabela 7-8 Resultado da Função de Autocorrelação estendida - eacf - ENA-S ...................221

Tabela 7-9 Critérios de adequação dos modelos ENA SUL (AIC, AICc, BIC, Sigma2, R2,

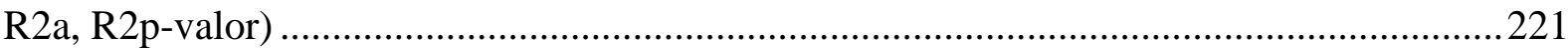

Tabela 7-10 Valores parâmetros estimados e estatísticas correspondentes...........................222

Tabela 7-11 Valores parâmetros estimados dos coeficientes das variáveis explicativas e as

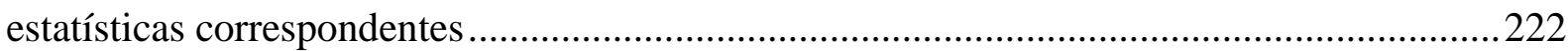

Tabela 7-12 Análise de Resíduos - Modelo escolhido em amarelo ......................................223

Tabela 7-13 Dados validação modelo de regressão dinâmica SARIMAX (100)(101) ..........225 
Tabela 7-14 Dados validação NEWAVE Região Sul Decks 2003 a 2009

Tabela 7-15 Resultado da Função de Autocorrelação estendida - eacf - ENA-NE 231

Tabela 7-16 Critérios de adequação dos modelos ENA NE (AIC, AICc, BIC, Sigma ${ }^{2}, \mathrm{R}^{2}, \mathrm{R}^{2} \mathrm{a}$, $\mathrm{R}^{2} \mathrm{p}$-valor) 231

Tabela 7-17 Valores parâmetros estimados e estatísticas correspondentes 232

Tabela 7-18 Valores parâmetros estimados dos coeficientes das variáveis explicativas e as estatísticas correspondentes 232

Tabela 7-19 Análise de Resíduos - Modelo escolhido em amarelo 234

Tabela 7-20 Dados validação modelo de regressão dinâmica MODELO SARIMAX (112)(200) .235

Tabela 7-21 Dados validação NEWAVE Região Nordeste Decks 2003 a 2009 235

Tabela 7-22 Resultado da Função de Autocorrelação estendida - eacf - ENA-N 242

Tabela 7-23 Critérios de adequação dos modelos ENA Norte (AIC, AICc, BIC, Sigma2, R2, R2a, R2p-valor). 242

Tabela 7-24 Valores parâmetros estimados e estatísticas correspondentes 243

Tabela 7-25 Valores parâmetros estimados dos coeficientes das variáveis explicativas e as estatísticas correspondentes 243

Tabela 7-26 Análise de Resíduos - Modelo escolhido em amarelo 245

Tabela 7-27 Dados validação modelo de regressão dinâmica MODELO SARIMAX $(100)(011)$ 246

Tabela 7-28 Dados validação NEWAVE Região Norte Decks 2003 a 2009 246

Tabela 8.1 Relação das áreas de medição TSM do Pacífico - El Niño................................... 258

Tabela 8-2 - Fontes de dados coletados para análise. 262

Tabela 8-3 Localização original das variáveis macroclimáticas coletadas. 262

Tabela 8-4 Resultado do comando TSA::eacf() para dados ENA Sudeste 1931-2015 indica $\operatorname{ARIMA}(2,0,1)$ 267

Tabela 8-5 Resultado da Função de Autocorrelação estendida - eacf - ENA-SE 275

Tabela 8-6 Critérios de adequação dos modelos ENA SE (AIC, AICc, BIC, Sigma2, R2, R2a, R2p-valor) 276

Tabela 8-7 Valores parâmetros estimados e estatísticas correspondentes 277

Tabela 8-8 Valores parâmetros estimados dos coeficientes das variáveis explicativas e as estatísticas correspondentes 277

Tabela 8-9 Análise de Erros de Resíduos 279

Tabela 8-10 Dados validação modelo de regressão dinâmica SARIMAX (101)(103) 281 xviii 
Tabela 8-11 Dados validação NEWAVE Região Sudeste Decks 2003 a 2009.

Tabela 8-12 Indicador MAPE NEWAVE Regiões brasileiras Decks 2003 a 2009 versos MAPE modelos Tese

Tabela 8-13 Inferência estatística p-valores das variáveis explicativas modelos da Tese .....286 Tabela APÊNDICE E.1 Terminologia de uma regressão simples (WOOLDRIDGE, 2009, p. 23). 324

Tabela APÊNDICE J-2 Análise gráficos séries históricas das Usinas de Cabeceira 402

Tabela APÊNDICE J-3 Análise gráfico tendência das séries históricas das Usinas de Cabeceira 403

Tabela APÊNDICE L-4 Percentual de variabilidade por componente principal 427

Tabela APÊNDICE N-5 Análise de Resíduos Intercepto 497

Tabela APÊNDICE N-6 Análise de Resíduos parâmetro phi 497

Tabela APÊNDICE N-7 Análise de Resíduos Parâmetros PHI 498

Tabela APÊNDICE N-8 Análise de Resíduos parâmetros theta 498

Tabela APÊNDICE N-9 Análise de Resíduos Parâmetros de Regressão 499

Tabela APÊNDICE O-10 Análise de Resíduos Parâmetros phi 1..........................................500

Tabela APÊNDICE O-11 Análise de Resíduos Parâmetros theta 1 .......................................500

Tabela APÊNDICE O-12 Análise de Resíduos Parâmetros THETA 1 ..................................501

Tabela APÊNDICE O-13 Análise de Resíduos Parâmetros THETA 2 ...................................501

Tabela APÊNDICE O-14 Análise de Resíduos Parâmetros THETA 3 ..................................501

Tabela APÊNDICE O-15 Análise de Resíduos Parâmetros de Regressão Nino ....................502

Tabela APÊNDICE O-16 Análise de Resíduos Parâmetros de Regressão AMO ..................502

\section{Índice de figuras}

Figura 1-1 Evolução da Produção versos Consumo de Energia Elétrica no Brasil em GWh. Fonte: BEN, 2015.

Figura 1-2 - Ano de ocorrência fenômenos El Niño e La Niña entre 1931 a 2015

Figura 1-3 - Fenômenos El Niño e La Niña versos ENA Sudeste e Sul em TWh. Elaboração própria com dados do ONS.

Figura 1-4 - Fenômenos El Niño e La Niña versos ENA Nordeste e Norte em TWh. Elaboração própria com dados do ONS.

Figura 1-5 - Energia Armazenada (MWmédios) versos Custo Marginal de Operação (CMO R\$) para o patamar pesado - Região Sudeste. Fonte ONS \& CCEE, 2015. 
Figura 1-6 Dilema do ONS na decisão de despachar ou não usinas hidrelétricas - elaboração própria

Figura 1-7 Nível dos reservatórios. Elaboração própria com dados ONS 2014 e 2015. 71

Figura 1-8 Evolução da anomalia de temperatura da superfície do mar (TSM) região Niño 3. Fonte http://enos.cptec.inpe.br/ acesso 02/10/2015. 72

Figura 1-9 Sistema Interligado Nacional versos tamanho da Europa + parte da Rússia. Fonte: Souza \& Oliveira, 2012 e de Melo, Alberto, 2007. C.. Hydropower in a Brazilian Perspective. IEA NEET Workshop. Brasília, 19-20 Nov., 2007 .... 73

Figura 1-10 Evolução do Sistema Climático 75

Figura 1-11 Elementos que formam o Ciclo Hidrológico. Adaptado Fonte: IPCC, 2013 ....... 76

Figura 1-12 Tipo de eventos macro climáticos que afetam a hidrologia do Brasil Fonte: adaptado de Hernández, 2011. 77

Figura 1-13 Elementos do Clima versos Integração Eletroenergética Fontes: a. Grau de previsibilidade climática na AS (SAMPAIO, 2014) b. Setor Energético Brasileiro (ONS, 2015) 78

Figura 1-14 Reservatório Região SE/CO 2000/2001. Percentagem da capacidade. 79

Figura 3-1 Modelo simplificado das partes de uma barragem com usina - adaptação elaboração própria. 84

Figura 3-2 - Reservatório equivalente de energia. Círculos - usinas de fio d'água. Triângulos - usinas com reservatório- adaptado (RAMOS, 2009) 85

Figura 3-3 - Relatório preliminar dos oceanos de números recentes do ICOADS (baseado nos dados do NOAA/NCEP) estratificados por tipo de plataforma (a-b), e a amostra do último mês para 1 grau (c) e 2 graus (d) resumos mensais (com base nos valores médios para duas variáveis selecionadas, e média de longo-termode 1971-2000) 86

Figura 3-4 Regiões de larga escala do El Niño - TSMNINO1+2, NINO3, NINO3.4, NINO4 87 Figura 3-5 El Niño fase Neutra - TSM, dinâmica atmosférica Célula de Walker. Fonte: Clutz, 2016 . 88

Figura 3-6 El Niño fase neutra - TSM, dinâmica atmosférica. Fonte: Peixoto \& Oort, 199289 Figura 3-7 El Niño fase Neutra - TSM - Fonte: CPTEC, 2016 .............................................. 89

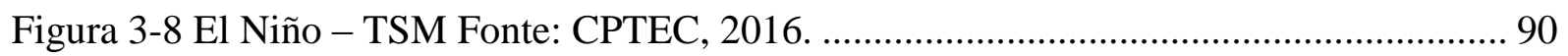

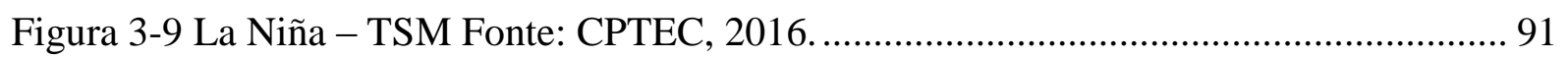

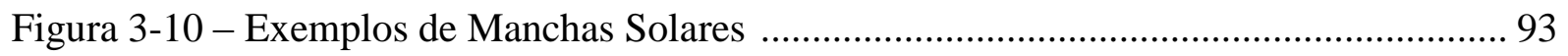

Figura 3.11 - Número de manchas solares internacional .................................................... 93

Figura 3.12 - Série Histórica das Manchas Solares Médias Anuais e Boxplot 1931-2011 ..... 94 
Figura 3. 13 - Áreas de Manchas Solares Médias Diárias (\% do Hemisfério Visível) Set-2015

Figura 3.14 - Grupos de manchas solares observadas a cada ano 1826-1843 por Heinrich Schwabe (1844). Fonte: Schwabe, H., 1844 Apud Hathaway, 2010. .95

Figura 3.15 - Médias mensais de manchas solares registradas pelo International Sunspot

Number .96

Figura 3.16 - Proxis de atividade solar 97

Figura 3.17 - Carbono 14 e fenômenos climáticos correspondentes 97

Figura 3.18-Manchas Solares e período do mínimo de Maunder entre 1650 e 1700 98

Figura 3-19 Demanda Energia Prevista até 2050 - elaborações próprias com dados de Capítulo 5 - Balanços dos Centros de Transformação (BEN, 2015). 100

Figura 3-20 Diagrama Esquemático das Usinas Hidroelétricas do SIN. Metade da esquerda. Fonte: ONS, 2015 . 101

Figura 3-21 Diagrama Esquemático das Usinas Hidroelétricas do SIN. Metade da direita. Fonte: ONS, 2015. 102

Figura 3-22 Crescimento populacional através história da humanidade - Bilhões Pessoas .. 103 Figura 3-23 Crescimento populacional Regiões Pouco Desenvolvidas versos Regiões Mais Desenvolvidas Fonte: ONU, 1998. 104

Figura 3-24 População em 2014 é de 202.768.562.Pico previsto em 2042 de 228.350.924, Brasil. Fonte: IBGE, 2013. 104

Figura 3-25 Energia consumida no a) mundo e b) América Latina.Unidade Pentawatt-hora (1.000 TWh). Fonte: DOE/EIA, 2013 105

Figura 3-26 Fluxo Divergente (LIMA ET AL 2014) 114

Figura 3-27 Diagrama conceitual sobre os mecanismos físicos que podem favorecer a ocorrência de frentes frias. Fonte: Müller e Ambrizzi (2007). 118

Figura 3-28 Regionalização dos diferentes ciclos anuais de precipitação na América do Sul. R1 Sudoeste da AS; R2 ao norte do Chile, noroeste e centro-sul da Argentina; R3 ao oeste do Peru, oeste e sul da Bolívia, norte e centro-leste da Argentina e centro-norte do Paraguai; R4 ao sul do Brasil, sul do Paraguai e Uruguai; R5 a área de noroeste a sudeste do Brasil incluindo ainda o Equador e norte do Peru, R6 ao norte da região norte do Brasil e litoral do nordeste do Brasil; R7 ao sertão nordestino do Brasil e R8 ao norte da AS incluindo o estado de Roraima. Fonte: Reboita et al (2010, APUD ATLAS CLIMÁTICO DE SUDAMERICA). 
Figura 3-29 Representação esquemática dos sistemas atmosféricos na baixa e alta troposfera atuantes na América do Sul Fonte Reboita et al (2010; adaptada SATYAMURTY et al., 1998, pag. 125).

Figura 3-30 Padrões de circulação atmosférica e de anomalias de TSM no Atlântico Tropical Norte e Sul, durante anos secos (a) e chuvosos (b) no Nordeste. A área em verde representa a posição da ZCIT (MARENGO, 2006) 121

Figura 3-31 Áreas de TSM: EEP. TNA. TSA E SWA

Figura 3-32 Fluxo divergente de umidade anual mm/ano 1980-2012

Figura 3-33 Representação para a ocorrência da seca no verão austral de 2014 sobre sudeste do Brasil Fonte: Coelho et al, 2015

Figura 3-34 Área média austral verão (janeiro-fevereiro-março) 1961-2014 precipitação séries temporais anomalia (barras de cor), expresso em mm sobre a região sudeste do Brasil. Fonte: Coelho et al, 2015

Figura 4.1 -Manchas Solares a) SSN quantidade período de 1749 a 2015 b) Área total 1874 a 2015 c) Área Hemisfério Norte e d) Área Hemisfério Sul 136

Figura 4.2 -Exemplo da proporção entre uma Mancha Solar e o planeta Terra...... 137

Figura 4-3 - Observatórios de Hartland (HAD) e Canberra (CNB) 138

Figura 4.4 - Anomalias de TSM e concentração de gelo - Junho de 2016 139

Figura 4-5 - TSM(cores) Pressão ao Nível do Mar (contornos) Magnitude e direção dos Ventos (setas) 140

Figura 4.6 - Climatologias de 30 anos da TSM região NINO 3.4. 143

Figura 4.7 - Áreas utilizadas para compor o cálculo do índice MODOKI..... 143

Figura 4.8 - a) El Niño. b) El Niño Modoki. c) La Niña. d) La Niña Modoki 144

Figura 4-9- Oscilação Multidecadal do Atlântico - AMO. Fonte: Deser et al., 2010 146

Figura 4-10- Modo Meridional do Atlântico - AMM. Fonte: (CHIANG; VIMONT, 2004) 147

Figura 4.11 -Índice de TSM do a) Atlântico Sul e b) Atlântico Norte. 148

Figura 4.12 -Índices medidos da TSM do Atlântico. NAT e SAT não são abordados 148

Figura 4.13 - Diagrama descritivo do desenvolvimento da Oscilação Madden-Juliana sobre o Pacífico Tropical. 150

Figura 4. 14 - a) Regiões com cobertura de gelo do polo Ártico e b) tendência entre 1978 a 2013

Figura 4.15 - a) Regiões com cobertura de gelo do polo Antártico Ártico e b) tendência entre 1978 a 2013 153 
Figura 5-1 Critérios para identificação da ordem dos parâmetros dos modelos AR (BOX \& JENKINS, 2008).

Figura 5-2 Critérios para identificação da ordem dos parâmetros dos modelos. Quatro exemplos teóricos de ACFs e PACFs para $\operatorname{AR}(2)$ a) $\phi 1=0,5, \phi 2=0,3$. b) $\phi 1=-0,5, \phi 2=0,3$. c) $\phi 1=-1,2, \phi 2=-0,7$. d) $\phi 1=1,3, \phi 2=0,7,($ PANKRATZ, 1999, 42)

Figura 5-3 Critérios para identificação da ordem dos parâmetros dos modelos MA (BOX \& JENKINS, 2008).

Figura 5-4 Critérios para identificação da ordem dos parâmetros dos modelos. Quatro exemplos teóricos de ACFs e PACFs para $\mathrm{MA}(2)$ a) $\theta 1=0,5, \theta 2=0,3$. b) $\theta 1=0,8, \theta 2=0,5$. c) $\theta 1=-0,8, \theta 2=-0,5$. d) $\theta 1=0,8, \theta 2=-0,5$, (PANKRATZ, 1991, 45)

Figura 5-5 Critérios para identificação da ordem dos parâmetros dos modelos ARMA (BOX \& JENKINS, 2008) 165

Figura 5-6 Exemplo gráficos para avaliar os resíduos do modelo SARIMA(111300) com AMO e NINO1+2. 168

Figura 6-1 - Gráfico Boxplot todas as séries normalizadas com cálculode de anomalias 170 Figura 6-2 - Variáveis - Médias mensais normalizadas: Na ordem: MANCHAS, AMO, PDO, NINO1+2, ENA-SE

Figura 6-3 - Manchas Solares . a) Médias mensais normalizadas. b) Série com uma diferença. c) Suavização com wavelet.

Figura 6-4 - TSM Região 1+2 do Pacífico - NINO 1+2. a) Médias mensais normalizadas. b) Série com uma diferença. c) Suavização com wavelet. 172

Figura 6-5 - Índice de Oscilação Multidecadal do Atlântico - AMO. a) Médias mensais normalizadas. b) Série com uma diferença. c) Suavização com wavelet. 172 Figura 6-6 - Índice de Oscilação Decadal do Pacífico - PDO. a) Médias mensais normalizadas. b) Série com uma diferença. c) Suavização com wavelet. 173 Figura 6-7 - Variável dependente ENA-SE - Médias mensais expressas em MWMédios .... 174 Figura 6-8 Boxplot ENA SE por mês e Descrição Estatística 175

Figura 6-9- Submercado do Sudeste - ENA-SE - Médias mensais a) normalizadas, b) com uma diferença sobre a série normalizada e c) suavizada com wavelets 175 Figura 6-10 - Variável dependente ENA-SE Máximos Anuais normalizadoss MWmédios . 176 Figura 6-11 - Variável dependente ENA-S - Médias mensais MWmédios 176

Figura 6-12 Boxplot ENA-S por mês e Descrição Estatística. 177 Figura 6-13ENA-S - Médias mensais normalizadas, com uma diferença e suavizada com wavelets 177 
Figura 6-14 - Variável dependentes -ENA-S- Máximos Anuais normalizadas MWmédios 178 Figura 6-15 - Variável dependente -ENA-NE - Médias mensais MWmédios

Figura 6-17 ENA-NE - Médias mensais normalizadas, com uma diferença e suavizada com wavelets.

Figura 6-18 - Variável dependentes - ENA-NE - Máximos Anuais normalizadas MWmédios

Figura 6-19 - Variável dependenteENA-N - Médias mensais MWmédios

Figura 6-20 Boxplot ENA-N por mês e Descrição Estatística.

Figura 6-21 ENA-N - Médias mensais normalizadas, com uma diferença e suavizada com wavelets

Figura 6-22 - Variável dependentes -ENA-N - Máximos Anuais normalizadas MWmédios

Figura 6-23 - TSM Região NINO 1+2 do Pacífico - Médias mensais expressos em ${ }^{\circ} \mathrm{C} \ldots . . .183$

Figura 6-24 - TSM Região NINO 1+2 do Pacífico - Desvios padrões mensais

Figura 6-25 -Boxplot Índice TSM NINO 1+2 por mês e Descrição Estatística 184

Figura 6-26 -Gráfico Índice NINO1+2(barras) versos ENA SE (linhas)- Máximos Anuais normalizadas MWmédios 185

Figura 6-27 -Gráfico Índice NINO1+2 versos ENA S - Máximos Anuais normalizadas MWmédios 185

Figura 6-28 -Gráfico Índice NINO1+2 versos ENA NE - Máximos Anuais normalizadas MWmédios 186

Figura 6-29 -Gráfico Índice NINO1+2 versos ENA N - Máximos Anuais normalizadas MWmédios 186

Figura 6-30 Índice TSM Multidecadal do Atlântico - AMO - Médias mensais expressas em ${ }^{\circ}$ C, sem transformações . 187

Figura 6-31 Índice TSM Oscilação Multidecadal do Atlântico - AMO - Desvios padrões mensais normalizados expressos em ${ }^{\circ} \mathrm{C}$

Figura 6-32-Boxplot Índice AMO por mês e Descrição Estatística expressos em ${ }^{\circ} \mathrm{C}$ 188 Figura 6-33 -Gráfico Índice AMO versos ENA SE - Máximos Anuais normalizadas MWmédios

Figura 6-34 -Gráfico Índice AMO versos ENA S - Máximos Anuais normalizadas MWmédios. 189 
Figura 6-35 -Gráfico Índice AMO versos ENA NE - Máximos Anuais normalizadas MWmédios

Figura 6-36 -Gráfico Índice AMO versos ENA N - Máximos Anuais normalizadas MWmédios

Figura 6-37 -Índice Decadal do Pacífico -PDO - Médias mensais normalizadas 191

Figura 6-38 -Boxplot Índice PDO por mês e Descrição Estatística 191

Figura 6-39 -Gráfico Índice PDO versos ENA SE - Máximos Anuais normalizadas MWmédios 192

Figura 6-40 -Gráfico Índice PDO versos ENA S - Máximos Anuais normalizadas MWmédios 192

Figura 6-41 -Gráfico Índice PDO versos ENA NE - Máximos Anuais normalizadas MWmédios 193

Figura 6-42 -Gráfico Índice PDO versos ENA N - Máximos Anuais normalizadas MWmédios 193

Figura 6-43 - Matrix de correlações e causalidades. Exemplo V4 versos V8 194 Figura 6-44 - Correlação de Pearson e respectivos valores p e atraso entre as variáveis. Em roxo o valor $\mathrm{p}>0,05$. Em azul os valores $\mathrm{r}$ e p aceitáveis. Em vermelho valores $\mathrm{r}$ e $\mathrm{p}$ ambos não aceitáveis 195

Figura 6-45 - Causalidade de Granger. Em azul, causalidade bidirecional. Em roxo, causalidade unidirecional. Em vermelho não há causalidade. 195

Figura 6-46 - Gráficos de relação entre as séries independentes e dependentes. 196 Figura 6-47 Correlação entre as variáveis quantidade de manchas solares versos regiões de ENA SE, S, NE e N

Figura 6-48 Correlação entre as variáveis de índice ONI e MEI de ENOS versos ENA Regiões SE, S, NE e N 198

Figura 6-49 Correlação entre as variáveis de TSM áreas NINO1+2, 3, 3.4 e 4 versos regiões ENA SE, S, NE e N

Figura 6-50 Correlação entre as variáveis Decadal do Pacífico e Multidecadal do Atlântico versos ENA Regiões SE, S, NE e N

Figura 6-51 Correlação entre as variáveis dos polos Ártico / Antártico versos Regiões ENA SE, S, NE e N

Figura 6-52 Correlação entre as regiões do polo Antártico versos Regiões ENA SE, S, NE e N 
Figura 6-53 Correlação entre as variáveis de ENA agregada por bacias e vazões das Usinas das Bacias do Paraná, São Francisco, Tocantins e Parnaíba.

Figura 7-1 - Efeitos conhecidos do fenômeno El Niño. Fonte: http://enos.cptec.inpe.br/ .... 206 Figura 7-2 - Série Histórica ENA Sudeste expressas em MW Médios- Período de Jan/1931 a Dez/2014 207

Figura 7-3 - Série Histórica em MW Médios ENA Sudeste e transformada logarítmica dos dados- Período de Jan/1978 a Dez/2008 207

Figura 7-4 - Decomposição: Original, Sazonal, Tendência e Aleatório. ENA Sudeste Período de Jan/1978 a Dez/2008. 208

Figura 7-5 - Gráfico Caixa Série Histórica log (MW Médios) ENA Sudeste - Período de Jan/1931 a Dez/2014 208

Figura 7-6 - Gráficos: a) Série Transformada com log, ACF e PACF. 209

Figura 7-7 - Gráfico análise de resíduos modelo SARIMAX (100)(003): a) Resíduos versos modelo ajustado. b) FAC c) QQ-Plot d) Histograma. 212

Figura 7-8 Esquema de validação cruzada k-fold com intervalos de treinamento com o ano inicial fixo em 1978

Figura 7-9 Erros médios absolutos resultados da validação cruzada com o modelo SARIMAX $(101)(103)$ 214

Figura 7-10 Validação Cruzada NEWAVE :: Decks 2003 a 2009........................................ 216

Figura 7-11 Validação Cruzada Erro =NEWAVE - ONS :: Decks 2003 a 2009................... 216

Figura 7-12 Validação cruzada modelos SARIMAX (100)(103) Região Sudeste 217

Figura 7-13 Validação Cruzada Erro = SARIMAX(100)(103) :: Conjuntos de teste 2003 a 2009 Região Sudeste.

Figura 7-14 - Série Histórica em MW Médios ENA Sul - Período de Jan/1931 a Dez/2014 218

Figura 7-15 - Série Histórica em MW Médios ENA Sul - Período de Jan/1978 a Dez/2008 218

Figura 7-16 - Decomposição: Original. Sazonal. Tendência e Aleatório. ENA Sul - Período de Jan/1978 a Dez/2008 .

Figura 7-17 - Gráfico Caixa Série Histórica log (MW Médios) ENA Sul - Período de Jan/1931 a Dez/2013 219

Figura 7-18 - Gráficos: a) Série Transformada com log, ACF e PACF. 220

Figura 7-19 - Gráfico análise de resíduos modelo SARIMAX (100)(101):a) Resíduos versos modelo ajustado. b) FAC c) QQ-Plot d) Histograma. 223 
Figura 7-20 Validação cruzada com o modelo SARIMAX (100)(101)

Figura 7-21 Validação Cruzada NEWAVE Região Sul :: Decks 2003 a 2009.

Figura 7-22 Validação Cruzada Erro =NEWAVE- ONS Região Sul:: Decks 2003 a 2009..226

Figura 7-23 Validação cruzada modelos SARIMAX (100)(101) Região Sul

Figura 7-24 Validação Cruzada Erro =SARIMAX(100)(101) :: Conjuntos de teste 2003 a 2009 Região Sul

Figura 7-25 - Série Histórica em MW Médios ENA Nordeste - Período de Jan/1931 a Dez/2014

Figura 7-26 - Série Histórica em MW Médios ENA Nordeste - Período de Jan/1978 a Dez/2008

Figura 7-27 - Decomposição: Original. Sazonal. Tendência e Aleatório. ENA Nordeste Período de Jan/1978 a Dez/2008 229

Figura 7-28 - Gráfico Caixa Série Histórica log (MW Médios) ENA Nordeste - Período de Jan/1931 a Dez/2013 229

Figura 7-29 - Gráficos: a) Série Original b) Série Transformada com log, ACF e PACF e c) com uma diferença.

Figura 7-30 - Gráfico análise de resíduos modelo SARIMAX (112)(200):a) Resíduos versos modelo ajustado. b) FAC c) QQ-Plot d) Histograma 233

Figura 7-31 Validação cruzada com o modelo SARIMAX (112)(200) .... 234

Figura 7-32 Validação Cruzada NEWAVE Região Nordeste :: Decks 2003 a 2009. 236 Figura 7-33 Validação Cruzada Erro =NEWAVE- ONS Região Nordeste:: Decks 2003 a 2009. 236

Figura 7-34 Validação cruzada modelos SARIMAX (112)(200) Região Nordeste 237 Figura 7-35 Validação Cruzada Erro =SARIMAX(112)(200) :: Conjuntos de teste 2003 a 2009 Região Nordeste 237

Figura 7-36 - Série Histórica em MW Médios ENA Norte- Período de Jan/1931 a Dez/2014 238

Figura 7-37 - Série Histórica em MW Médios ENA Norte e transformada logarítmica dos dados- Período de Jan/1978 a Dez/2008 238 Figura 7-38 - Decomposição: Original. Sazonal. Tendência e Aleatório. ENA Norte - Período de Jan/1978 a Dez/2008. 239 Figura 7-39 - Gráfico Caixa Série Histórica log (MW Médios) ENA Norte - Período de Jan/1931 a Dez/2013 239 
Figura 7-40 - Gráficos: a) Série Original , ACF e PACF b) Série Transformada com uma diferença, ACF e PACF e b) com uma diferença sazonal, , ACF e PACF. 240 Figura 7-41 - Gráficos: a) Série Transformada com log e com uma diferença, ACF e PACF e b) com log e com uma diferença sazonal. 241

Figura 7-42 - Gráficos: a) Série Transformada com log, diferença com lag 12 e mais uma diferença lag=1. ACF e PACF. 241

Figura 7-43 - Gráfico análise de resíduos modelo SARIMAX (100)(011):a) Resíduos versos modelo ajustado. b) FAC c) QQ-Plot d) Histograma. 244 Figura 7-44 Validação cruzada com o modelo SARIMAX (100)(011) 245

Figura 7-45 Validação Cruzada NEWAVE Região Norte :: Decks 2003 a 2009 247

Figura 7-46 Validação Cruzada Erro =NEWAVE- ONS Região Norte:: Decks 2003 a 2009.

Figura 7-47 Validação cruzada modelos SARIMAX (100)(011) Região Norte 248 Figura 7-48 Validação Cruzada Erro =SARIMAX(100)(011) :: Conjuntos de teste 2003 a 2009 Região Norte 248

Figura 8-1 Evolução da Produção versos Consumo de Energia Elétrica no Brasil em GWh. Fonte: BEN, 2015. 251

Figura 8-2 - Fenômenos El Niño e La Niña versos ENA Sudeste e Sul em TWh. Elaboração própria com dados do ONS. 252 Figura 8-3 - Energia Armazenada (MWmédios) versos Custo Marginal de Operação (CMO R\$) para o patamar pesado - Região Sudeste. Fonte ONS \& CCEE, 2015. 253 Figura 8-4 Dilema do ONS na decisão de despachar ou não usinas hidrelétricas - elaboração própria 254

Figura 8-5 Modelo simplificado das partes de uma barragem com usina - adaptação própria 256

Figura 8-6 - Matrix de correlações e causalidades. Exemplo V4 versos V8. 263 Figura 8-7 - Correlação de Pearson e respectivos valores p e atraso (lag) entre as variáveis. Em roxo o valor $p>0,05$. Em azul os valores $r$ e $p$ aceitáveis. Em vermelho valores $r$ e $p$ ambos não aceitáveis 264

Figura 8-8 - Causalidade de Granger. Em azul, causalidade bidirecional. Em roxo, causalidade unidirecional. Em vermelho não há causalidade. 265

Figura 8-9 Exemplo gráficos para avaliar os resíduos do modelo SARIMA(111300) com AMO e NINO1+2 268

Figura 8-10 - Variável dependente ENA-SE - Médias mensais expressas em MWMédios.. 269 xxviii 
Figura 8-11 Boxplot ENA SE por mês e Descrição Estatística.

Figura 8-12- Submercado do Sudeste - ENA-SE - Médias mensais a) normalizadas, b) com uma diferença sobre a série normalizada e c) suavizada com wavelets

Figura 8-13 - Variável dependente ENA-SE Máximos Anuais normalizadoss MWmédios .271

Figura 8-14 - Gráficos de relação entre as séries independentes e dependentes.

Figura 8-15 - Série Histórica ENA Sudeste expressas em MW Médios- Período de Jan/1931

a Dez/2014.

Figura 8-16 - Série Histórica em MW Médios ENA Sudeste e transformada logarítmica dos dados- Período de Jan/1978 a Dez/2008

Figura 8-17 - Decomposição: Original, Sazonal, Tendência e Aleatório. ENA Sudeste Período de Jan/1978 a Dez/2008

Figura 8-18 - Gráfico Caixa Série Histórica log (MW Médios) ENA Sudeste - Período de Jan/1931 a Dez/2014

Figura 8-19 - Gráficos: a) Série Transformada com log, ACF e PACF

Figura 8-20 - Gráfico análise de resíduos modelo SARIMAX (100)(003): a) Resíduos versos modelo ajustado. b) FAC c) QQ-Plot d) Histograma

Figura 8-21 Erros médios absolutos resultados da validação cruzada com o modelo SARIMAX (101)(103) 280

Figura 8-22 Validação Cruzada NEWAVE :: Decks 2003 a 2009. 282

Figura 8-23 Validação Cruzada Erro =NEWAVE - ONS :: Decks 2003 a 2009. 282

Figura 8-24 Validação cruzada modelos SARIMAX (100)(103) Região Sudeste

Figura 8-25 Validação Cruzada Erro = SARIMAX(100)(103) :: Conjuntos de teste 2003 a 2009 Região Sudeste.

Figura APÊNDICE A-1- Procedimentos metodológicos

Figura APÊNDICE B-2 Esquema de validação cruzada k-fold com intervalos de treinamento com o ano inicial fixo em 1931

Figura APÊNDICE B-3 Esquema de validação cruzada k-fold com amostras intervalos treinamento fixo em 30 anos

Figura APÊNDICE D-4 Exemplo de autocorrelação da série histórica ENA-SE.

Figura APÊNDICE D-5 Exemplo de correlação cruzada das séries históricas NINO1+2 e ENA-SE.

Figura APÊNDICE G-6 Produto uma função de um sinal em (a) pelo sinal da wavelet (b), gerando sinais resultantes (d) e (f), cujas áreas são os coeficientes wavelets. Fonte: (FAYAL, 2008) 
Figura APÊNDICE G-7 Exemplo de wavelet vazões da Usina de Porto Primavera. a) Série original $\mathrm{m}^{3} \mathrm{~s}^{-1} 1931$ a 2013 b) Domínio de espectro de ondaletas c) Espectro global da ondaletas. d) Série temporal de escala média para faixa de 1-32 anos. 332 Figura APÊNDICE G-8 a) wavelet "Chapéu Mexicano" b) wavelet Morlet 332 Figura APÊNDICE G-9 Transformada wavelet a) Niño 1+2 b) Vazões Porto Primavera .... 333 Figura APÊNDICE G-10 Transformada cross wavelet para a precipitação das vazões da Usina de Porto Primavera e as TSM EL Niño 1+2. O nível de significância de 5\% aparece em destaque, na cor vermelha. A relação entre os fenômenos pode ser identificada pelo sentido das setas (com o sentido para a direita indicando que estão em fase, o sentido para a esquerda indicando que estão em anti-fase, ou seja, defasados, e o sentido apontando para baixo mostrando que há forte influência do valor do TSM El Niño 1+2 e medições de vazões da Usina de Porto Primavera) 334 Figura APÊNDICE G-11 Coerência wavelet entre TSM El Niño 1+2 e as vazões Usina de Porto Primavera. O nível de significância de 5\% aparece novamente em vermelho, com o sentido para a direita indicando que estão em fase, o sentido para a esquerda indicando que estão em anti-fase, ou seja, defasados, e o sentido apontando para baixo mostrando que há forte influência do valor do índice TSM NINO 1+2 sobre a média mensal de vazões da usina de Porto Primavera. 334 Figura APÊNDICE H-12 Análise por wavelets Manchas Solares por Área com filtro de altas frequências 335

Figura APÊNDICE H-13 Análise por wavelets Manchas Solares por Área. 336 Figura APÊNDICE H-14 Análise por wavelets a) Série Histórica ENA da Bacia do Paraná normalizada. b) Domínio Espectro de Ondaletas. c) Espectro Global de Ondaletas. d) Escalas Médias de Séries Temporais 337 Figura APÊNDICE H-15 Análise por wavelets a) Manchas Solares versos b) ENA da Bacia do Paraná. c) Trans.Cruzada - XWT d) Trans.Contínua - CWT. 338 Figura APÊNDICE H-16 Análise por wavelets a) Multidecadal do Atlântico versos b) ENA da Bacia do Paraná. c) Trans.Cruzada - XWT d) Trans.Contínua - CWT ............................ 338 Figura APÊNDICE H-17 Análise por wavelets a) El Niño 1+2 versos b) ENA da Bacia do Paraná. c) Trans.Cruzada - XWT d) Trans.Contínua - CWT. 339

Figura APÊNDICE H-18 Análise por wavelets a) Decadal do Pacífico versos b) ENA da Bacia do Paraná. c) Trans.Cruzada - XWT d) Trans.Contínua - CWT . 339 
Figura APÊNDICE H-19 Análise por wavelets a) Série Histórica Vazão da Usina Barra Bonita normalizada. b) Domínio Espectro de Ondaletas. c) Espectro Global de Ondaletas. d) Escalas Médias de Séries Temporais.

Figura APÊNDICE H-20 Análise por wavelets a) Manchas Solares versos b) Vazões da Usina de Barra Bonita. c) Trans.Cruzada - XWT d) Trans.Contínua - CWT. 341

Figura APÊNDICE H-21 Análise por wavelets a) Multidecadal do Atlântico versos b) Vazões da Usina de Barra Bonita. c) Trans.Cruzada - XWT d) Trans.Contínua - CWT..... 341

Figura APÊNDICE H-22 Análise por wavelets a) El Niño 1+2 versos b) Vazões da Usina de Barra Bonita. c) Trans.Cruzada - XWT d) Trans.Contínua - CWT. 342 Figura APÊNDICE H-23 Análise por wavelets a) Decadal do Pacífico versos b) Vazões da Usina de Barra Bonita. c) Trans.Cruzada - XWT d) Trans.Contínua - CWT. 342

Figura APÊNDICE H-24 Análise por wavelets a) Série Histórica Vazão da Usina Boa Esperança normalizada. b) Domínio Espectro de Ondaletas. c) Espectro Global de Ondaletas. d) Escalas Médias de Séries Temporais .343

Figura APÊNDICE H-25 Análise por wavelets a) Manchas Solares versos b) Vazões da Usina de Boa Esperança. c) Trans.Cruzada - XWT d) Trans.Contínua - CWT. 344 Figura APÊNDICE H-26 Análise por wavelets a) Multidecadal do Atlântico versos b) Vazões da Usina de Boa Esperança. c) Trans.Cruzada - XWT d) Trans.Contínua - CWT 344 Figura APÊNDICE H-27 Análise por wavelets a) El Niño 1+2 versos b) Vazões da Usina de Boa Esperança. c) Trans.Cruzada - XWT d) Trans.Contínua - CWT. 345 Figura APÊNDICE H-28 Análise por wavelets a) Decadal do Pacífico versos b) Vazões da Usina de Boa Esperança. c) Trans.Cruzada - XWT d) Trans.Contínua - CWT. 345 Figura APÊNDICE H-29 Análise por wavelets a) Série Histórica Vazão da Usina Camargos normalizada. b) Domínio Espectro de Ondaletas. c) Espectro Global de Ondaletas. d) Escalas Médias de Séries Temporais 346

Figura APÊNDICE H-30 Análise por wavelets a) Manchas Solares versos b) Vazões da Usina de Camargos. c) Trans. Cruzada - XWT d) Trans.Contínua - CWT. 347

Figura APÊNDICE H-31 Análise por wavelets a) Multidecadal do Atlântico versos b) Vazões da Usina de Camargos. c) Trans. Cruzada - XWT d) Trans.Contínua - CWT 347 Figura APÊNDICE H-32 Análise por wavelets a) El Niño 1+2 versos b) Vazões da Usina de Camargos. c) Trans. Cruzada - XWT d) Trans.Contínua - CWT 348

Figura APÊNDICE H-33 Análise por wavelets a) Decadal do Pacífico versos b) Vazões da Usina de Camargos. c) Trans. Cruzada - XWT d) Trans.Contínua - CWT . 348 
Figura APÊNDICE H-34 Análise por wavelets a) Série Histórica Vazão da Usina Foz do Areia normalizada. b) Domínio Espectro de Ondaletas. c) Espectro Global de Ondaletas. d) Escalas Médias de Séries Temporais

Figura APÊNDICE H-35 Análise por wavelets a) Manchas Solares versos b) Vazões da Usina de Foz do Areia. c) Trans. Cruzada - XWT d) Trans.Contínua - CWT 350 Figura APÊNDICE H-36 Análise por wavelets a) Multidecadal do Atlântico versos b) Vazões da Usina de Foz do Areia. c) Trans. Cruzada - XWT d) Trans.Contínua - CWT 350 Figura APÊNDICE H-37 Análise por wavelets a) El Niño 1+2 versos b) Vazões da Usina de Foz do Areia. c) Trans. Cruzada - XWT d) Trans.Contínua - CWT 351 Figura APÊNDICE H-38 Análise por wavelets a) Decadal do Pacífico versos b) Vazões da Usina de Foz do Areia. c) Trans. Cruzada - XWT d) Trans.Contínua - CWT 351

Figura APÊNDICE H-39 Análise por wavelets a) Série Histórica Vazão da Usina Furnas normalizada. b) Domínio Espectro de Ondaletas. c) Espectro Global de Ondaletas. d) Escalas Médias de Séries Temporais 352

Figura APÊNDICE H-40 Análise por wavelets a) Manchas Solares versos b) Vazões da Usina de Furnas. c) Trans. Cruzada - XWT d) Trans.Contínua - CWT .... 353 Figura APÊNDICE H-41 Análise por wavelets a) Multidecadal do Atlântico versos b) Vazões da Usina de Furnas. c) Trans. Cruzada - XWT d) Trans.Contínua - CWT . 353 Figura APÊNDICE H-42 Análise por wavelets a) El Niño 1+2 versos b) Vazões da Usina de Furnas. c) Trans. Cruzada - XWT d) Trans.Contínua - CWT 354

Figura APÊNDICE H-43 Análise por wavelets a) Decadal do Pacífico versos b) Vazões da Usina de Furnas. c) Trans. Cruzada - XWT d) Trans.Contínua - CWT 354 Figura APÊNDICE H-44 Análise por wavelets a) Série Histórica Vazão da Usina Guaporé normalizada. b) Domínio Espectro de Ondaletas. c) Espectro Global de Ondaletas. d) Escalas Médias de Séries Temporais 355 Figura APÊNDICE H-45 Análise por wavelets a) Manchas Solares versos b) Vazões da Usina de Guaporé. c) Trans. Cruzada - XWT d) Trans.Contínua - CWT 356 Figura APÊNDICE H-46 Análise por wavelets a) Multidecadal do Atlântico versos b) Vazões da Usina de Guaporé. c) Trans. Cruzada - XWT d) Trans.Contínua - CWT 356 Figura APÊNDICE H-47 Análise por wavelets a) El Niño 1+2 versos b) Vazões da Usina de Guaporé. c) Trans. Cruzada - XWT d) Trans.Contínua - CWT 357

Figura APÊNDICE H-48 Análise por wavelets a) Decadal do Pacífico versos b) Vazões da Usina de Guaporé. c) Trans. Cruzada - XWT d) Trans.Contínua - CWT . 357 
Figura APÊNDICE H-49 Análise por wavelets a) Série Histórica Vazão da Usina Nova Ponte normalizada. b) Domínio Espectro de Ondaletas. c) Espectro Global de Ondaletas. d) Escalas Médias de Séries Temporais 358

Figura APÊNDICE H-50 Análise por wavelets a) Manchas Solares versos b) Vazões da Usina Nova Ponte. c) Trans. Cruzada - XWT d) Trans.Contínua - CWT 359

Figura APÊNDICE H-51 Análise por wavelets a) Multidecadal do Atlântico versos b) Vazões da Usina Nova Ponte. c) Trans. Cruzada - XWT d) Trans.Contínua - CWT. .359

Figura APÊNDICE H-52 Análise por wavelets a) El Niño 1+2 versos b) Vazões da Usina Nova Ponte. c) Trans. Cruzada - XWT d) Trans.Contínua - CWT 360

Figura APÊNDICE H-53 Análise por wavelets a) Decadal do Pacífico versos b) Vazões da Usina Nova Ponte. c) Trans. Cruzada - XWT d) Trans.Contínua - CWT 360

Figura APÊNDICE H-54 Análise por wavelets a) Série Histórica Vazão da Usina Passo Fundo normalizada. b) Domínio Espectro de Ondaletas. c) Espectro Global de Ondaletas. d) Escalas Médias de Séries Temporais 361

Figura APÊNDICE H-55 Análise por wavelets a) Manchas Solares versos b) Vazões da Usina Passo Fundo. c) Trans. Cruzada - XWT d) Trans.Contínua - CWT . 362 Figura APÊNDICE H-56 Análise por wavelets a) Multidecadal do Atlântico versos b) Vazões da Usina Passo Fundo. c) Trans. Cruzada - XWT d) Trans.Contínua - CWT. 362

Figura APÊNDICE H-57 Análise por wavelets a) El Niño 1+2 versos b) Vazões da Usina Passo Fundo. c) Trans. Cruzada - XWT d) Trans.Contínua - CWT 363

Figura APÊNDICE H-58 Análise por wavelets a) Decadal do Pacífico versos b) Vazões da Usina Passo Fundo. c) Trans. Cruzada - XWT d) Trans.Contínua - CWT 363 Figura APÊNDICE H-59 Análise por wavelets a) Série Histórica Vazão da Usina Queimado normalizada. b) Domínio Espectro de Ondaletas. c) Espectro Global de Ondaletas. d) Escalas Médias de Séries Temporais 364

Figura APÊNDICE H-60 Análise por wavelets a) Manchas Solares versos b) Vazões da Usina Queimado. c) Trans. Cruzada - XWT d) Trans.Contínua - CWT 365

Figura APÊNDICE H-61 Análise por wavelets a) Multidecadal do Atlântico versos b) Vazões da Usina Queimado. c) Trans. Cruzada - XWT d) Trans.Contínua - CWT. 365

Figura APÊNDICE H-62 Análise por wavelets a) El Niño 1+2 versos b) Vazões da Usina Queimado. c) Trans. Cruzada - XWT d) Trans.Contínua - CWT..... 366

Figura APÊNDICE H-63 Análise por wavelets a) Decadal do Pacífico versos b) Vazões da Usina Queimado. c) Trans. Cruzada - XWT d) Trans.Contínua - CWT. .366 
Figura APÊNDICE H-64 Análise por wavelets a) Série Histórica Vazão da Usina Retiro Baixo normalizada. b) Domínio Espectro de Ondaletas. c) Espectro Global de Ondaletas. d) Escalas Médias de Séries Temporais 367

Figura APÊNDICE H-65 Análise por wavelets a) Manchas Solares versos b) Vazões da Usina Retiro Baixo. c) Trans. Cruzada - XWT d) Trans.Contínua - CWT 368 Figura APÊNDICE H-66 Análise por wavelets a) Multidecadal do Atlântico versos b) Vazões da Usina Retiro Baixo. c) Trans. Cruzada - XWT d) Trans.Contínua - CWT 368

Figura APÊNDICE H-67 Análise por wavelets a) El Niño 1+2 versos b) Vazões da Usina Retiro Baixo. c) Trans. Cruzada - XWT d) Trans.Contínua - CWT 369

Figura APÊNDICE H-68 Análise por wavelets a) Decadal do Pacífico versos b) Vazões da Usina Retiro Baixo. c) Trans. Cruzada - XWT d) Trans.Contínua - CWT . 369

Figura APÊNDICE H-69 Análise por wavelets a) Série Histórica Vazão da Usina Samuel normalizada. b) Domínio Espectro de Ondaletas. c) Espectro Global de Ondaletas. d) Escalas Médias de Séries Temporais 370

Figura APÊNDICE H-70 Análise por wavelets a) Manchas Solares versos b) Vazões da Usina Samuel. c) Trans. Cruzada - XWT d) Trans.Contínua - CWT 371

Figura APÊNDICE H-71 Análise por wavelets a) Multidecadal do Atlântico versos b) Vazões da Usina Samuel. c) Trans. Cruzada - XWT d) Trans.Contínua - CWT. 371

Figura APÊNDICE H-72 Análise por wavelets a) El Niño 1+2 versos b) Vazões da Usina Samuel. c) Trans. Cruzada - XWT d) Trans.Contínua - CWT 372

Figura APÊNDICE H-73 Análise por wavelets a) Decadal do Pacífico versos b) Vazões da Usina Samuel. c) Trans. Cruzada - XWT d) Trans.Contínua - CWT. 372 Figura APÊNDICE H-74 Análise por wavelets a) Série Histórica Vazão da Usina Serra da Mesa normalizada. b) Domínio Espectro de Ondaletas. c) Espectro Global de Ondaletas. d) Escalas Médias de Séries Temporais 373

Figura APÊNDICE H-75 Análise por wavelets a) Manchas Solares versos b) Vazões da Usina Serra da Mesa. c) Trans. Cruzada - XWT d) Trans.Contínua - CWT . 374

Figura APÊNDICE H-76 Análise por wavelets a) Multidecadal do Atlântico versos b) Vazões da Usina Serra da Mesa. c) Trans. Cruzada - XWT d) Trans.Contínua - CWT . 374 Figura APÊNDICE H-77 Análise por wavelets a) El Niño 1+2 versos b) Vazões da Usina Serra da Mesa. c) Trans. Cruzada - XWT d) Trans.Contínua - CWT 375

Figura APÊNDICE H-78 Análise por wavelets a) Decadal do Pacífico versos b) Vazões da Usina Serra da Mesa. c) Trans. Cruzada - XWT d) Trans.Contínua - CWT. 375 
Figura APÊNDICE H-79 Análise por wavelets a) Série Histórica Vazão da Usina Três Marias normalizada. b) Domínio Espectro de Ondaletas. c) Espectro Global de Ondaletas. d) Escalas Médias de Séries Temporais 376

Figura APÊNDICE H-80 Análise por wavelets a) Manchas Solares versos b) Vazões da Usina Três Marias. c) Trans. Cruzada - XWT d) Trans.Contínua - CWT . 377

Figura APÊNDICE H-81 Análise por wavelets a) Multidecadal do Atlântico versos b) Vazões da Usina Três Marias. c) Trans. Cruzada - XWT d) Trans.Contínua - CWT . 377

Figura APÊNDICE H-82 Análise por wavelets a) El Niño 1+2 versos b) Vazões da Usina Três Marias. c) Trans. Cruzada - XWT d) Trans.Contínua - CWT . 378

Figura APÊNDICE H-83 Análise por wavelets a) Decadal do Pacífico versos b) Vazões da Usina Três Marias. c) Trans. Cruzada - XWT d) Trans.Contínua - CWT .............................378 Figura APÊNDICE H-84 Análise por wavelets Vazões de Rio Usina de Porto Primavera ... 379 Figura APÊNDICE H-85 Análise por wavelets Vazões de Rio Usina de Sobradinho............380 Figura APÊNDICE H-86Análise por wavelets Vazões de Rio Boa Esperança ...................... 381 Figura APÊNDICE H-87 Análise por wavelets Vazões de Rio Usina de Lajeado ..................382 Figura APÊNDICE H-88 Análise por wavelets do número de Manchas Solares ...................383 Figura APÊNDICE H-89 Análise por wavelets TSM - Área El Niño 1+2 ............................384 Figura APÊNDICE H-90 Análise por wavelets a) Série Histórica Índice de Oscilação Multidecadal do Atlântico normalizada. b) Domínio Espectro de Ondaletas. c) Espectro Global de Ondaletas. d) Escalas Médias de Séries Temporais. 385

Figura APÊNDICE H-91 Análise por wavelets a) Série Histórica Índice de Oscilação Multidecadal do Atlântico sem transformações e normalizada. b) Domínio Espectro de Ondaletas. c) Espectro Global de Ondaletas. d) Escalas Médias de Séries Temporais 386 Figura APÊNDICE H-92 Análise por wavelets a) Série Histórica Índice de Oscilação Decadal do Pacífico normalizada. b) Domínio Espectro de Ondaletas. c) Espectro Global de Ondaletas. d) Escalas Médias de Séries Temporais 387

Figura APÊNDICE H-93Análise por wavelets a) Série Histórica ENA do Sudeste normalizada. b) Domínio Espectro de Ondaletas. c) Espectro Global de Ondaletas. d) Escalas Médias de Séries Temporais wavelets Análise relação variáveis explicativas e ENA SE .....388 Figura APÊNDICE H-94 Análise por wavelets a) Manchas Solares versos b) ENA do Sudeste. c) Trans. Cruzada - XWT d) Trans.Contínua - CWT.

Figura APÊNDICE H-95 Análise por wavelets a) Multidecadal do Atlântico versos b) ENA do Sudeste. c) Trans.Cruzada - XWT d) Trans. Contínua - CWT. 389 
Figura APÊNDICE H-96 Análise por wavelets a) El Niño 1+2 versos b) ENA do Sudeste. c) Trans. Cruzada - XWT d) Trans. Contínua - CWT 390

Figura APÊNDICE H-97 Análise por wavelets a) Decadal do Pacífico versos b) ENA do Sudeste. c) Trans. Cruzada - XWT d) Trans. Contínua - CWT. 390

Figura APÊNDICE H-98 Análise por wavelets a) Série Histórica ENA do Sul. b) Domínio Espectro de Ondaletas. c) Espectro Global de Ondaletas. d) Escalas Médias de Séries Temporais wavelets Análise relação variáveis explicativas e ENA S 391

Figura APÊNDICE H-99 Análise por wavelets a) Manchas Solares versos b) ENA do Sul. c) Trans. Cruzada - XWT d) Trans. Contínua - CWT 392

Figura APÊNDICE H-100 Análise por wavelets a) Multidecadal do Atlântico versos b) ENA do Sul. c) Trans. Cruzada - XWT d) Trans. Contínua - CWT. 392

Figura APÊNDICE H-101 Análise por wavelets a) El Niño 1+2 versos b) ENA do Sul. c) Trans. Cruzada - XWT d) Trans. Contínua - CWT 393

Figura APÊNDICE H-102 Análise por wavelets a) Decadal do Pacífico versos b) ENA do Sul. c) Trans. Cruzada - XWT d) Trans. Contínua - CWT... 393

Figura APÊNDICE H-103 Análise por wavelets a) Série Histórica ENA do Norte. b) Domínio Espectro de Ondaletas. c) Espectro Global de Ondaletas. d) Escalas Médias de Séries Temporais Wavelets Análise relação variáveis explicativas e ENA N 394 Figura APÊNDICE H-104 Análise por wavelets a) Manchas Solares versos b) ENA do Norte. c) Trans. Cruzada - XWT d) Trans. Contínua - CWT 395 Figura APÊNDICE H-105 Análise por wavelets a) Multidecadal do Atlântico versos b) ENA do Norte. c) Trans. Cruzada - XWT d) Trans. Contínua - CWT 395

Figura APÊNDICE H-106 Análise por wavelets a) El Niño 1+2 versos b) ENA do Norte. c) Trans. Cruzada - XWT d) Trans. Contínua - CWT 396

Figura APÊNDICE H-107 Análise por wavelets a) Decadal do Pacífico versos b) ENA do Norte. c) Trans. Cruzada - XWT d) Trans. Contínua - CWT. 396

Figura APÊNDICE H-108 Análise por wavelets a) Série Histórica ENA do Nordeste. b) Domínio Espectro de Ondaletas. c) Espectro Global de Ondaletas. d) Escalas Médias de Séries Temporais Wavelets Análise relação variáveis explicativas e ENA NE. 397 Figura APÊNDICE H-109 Análise por wavelets a) Manchas Solares versos b) ENA do Nordeste. c) Trans. Cruzada - XWT d) Trans. Contínua - CWT...... 398

Figura APÊNDICE H-110 Análise por wavelets a) Multidecadal do Atlântico versos b) ENA do Nordeste. c) Trans. Cruzada - XWT d) Trans. Contínua - CWT. 398 
Figura APÊNDICE H-111 Análise por wavelets a) El Niño 1+2 versos b) ENA do Nordeste. c) Trans. Cruzada - XWT d) Trans. Contínua - CWT. 399 Figura APÊNDICE H-112 Análise por wavelets a) Decadal do Pacífico versos b) ENA do Nordeste. c) Trans. Cruzada - XWT d) Trans. Contínua - CWT 399

Figura APÊNDICE J-113 Análise das Séries Históricas de Vazões de Usinas de Cabeceira401 Figura APÊNDICE K-114 Análise gráfica séries temporais Manchas solares a) decomposição da série em sazonalidade, tendência e resíduos b) série original c) domínio frequência d) FAC e) FACP. 405

Figura APÊNDICE K-115 Sazonalidade anual das séries temporais número de Manchas solares. a) Meses jan. a dez; b) médias trimestrais; c) somente jan., abr., jun. e out; d) Sazonalidade mensal por ano; e) Variabilidade mês a mês; f) Boxplot do período 405 Figura APÊNDICE K-116 Análise gráfica séries temporais El Niño 1+2. a) decomposição da série em sazonalidade, tendência e resíduos b) série original c) domínio frequência d) FAC e) FACP. 406

Figura APÊNDICE K-117 Séries temporais El Niño 1+2 a) JAN a DEZ. b) Média Trimestral. c) JAN ABR JUL OUT. d) Sazonalidade mensal todos os anos. e) Gráfico sazonalidade mês a mês. f) Gráfico de caixa. 406

Figura APÊNDICE K-118 Análise gráfica séries temporais Multidecadal do Atlântico. a) decomposição da série em sazonalidade, tendência e resíduos b) série original c) domínio frequência d) FAC e) FACP. 407

Figura APÊNDICE K-119 Séries temporais Multidecadal do Atlântico a) JAN a DEZ. b) Média Trimestral. c) JAN ABR JUL OUT. d) Sazonalidade mensal todos os anos. e) Gráfico sazonalidade mês a mês. f) Gráfico de caixa

Figura APÊNDICE K-120 Análise gráfica séries temporais Manchas solares por área. a) decomposição da série em sazonalidade, tendência e resíduos b) série original c) domínio frequência d) FAC e) FACP. 408

Figura APÊNDICE K-121 Séries temporais manchas solares por área hemisfério Norte a) JAN a DEZ. b) Média Trimestral. c) JAN ABR JUL OUT. d) Sazonalidade mensal todos os anos. e) Gráfico sazonalidade mês a mês. f) Gráfico de caixa 408 Figura APÊNDICE K-122 Análise gráfica séries temporais Manchas solares hemisfério Norte. a) decomposição da série em sazonalidade, tendência e resíduos b) série original c) domínio frequência d) FAC e) FACP. 409 
Figura APÊNDICE K-123 Séries temporais manchas solares por área hemisfério Norte a) JAN a DEZ. b) Média Trimestral. c) JAN ABR JUL OUT. d) Sazonalidade mensal todos os anos. e) Gráfico sazonalidade mês a mês. f) Gráfico de caixa. 409 Figura APÊNDICE K-124 Análise gráfica séries temporais Manchas solares hemisfério Sul. a) decomposição da série em sazonalidade, tendência e resíduos b) série original c) domínio frequência d) FAC e) FACP. 410 Figura APÊNDICE K-125 Sazonalidade anual das séries temporais Manchas solares por área hemisfério Sul a) JAN a DEZ. b) Média Trimestral. c) JAN ABR JUL OUT. d) Sazonalidade mensal todos os anos. e) Gráfico sazonalidade mês a mês Séries Históricas Bacia do Paraná Vazões Usina de Porto Primavera 410 Figura APÊNDICE K-126 Análise gráfica séries temporais Vazões Usina de Porto Primavera. a) decomposição da série em sazonalidade, tendência e resíduos b) série original c) domínio frequência d) FAC e) FACP.... 411 Figura APÊNDICE K-127 Sazonalidade anual das séries temporais Vazões Usina de Porto Primavera a) JAN a DEZ. b) Média Trimestral. c) JAN ABR JUL OUT. d) Sazonalidade mensal todos os anos. e) Gráfico sazonalidade mês a mês. f) Gráfico de caixa 411 Figura APÊNDICE K-128 Análise gráfica séries temporais Vazões Usina de Sobradinho. a) decomposição da série em sazonalidade, tendência e resíduos b) série original c) domínio frequência d) FAC e) FACP..... 412 Figura APÊNDICE K-129 Sazonalidade anual das séries temporais Vazões Usina de Sobradinho a) JAN a DEZ. b) Média Trimestral. c) JAN ABR JUL OUT. d) Sazonalidade mensal todos os anos. e) Gráfico sazonalidade mês a mês. f) Gráfico de caixa Séries Históricas Bacia do Tocantins - Vazões Usina Estreito Tocantins 412 Figura APÊNDICE K-130 Análise gráfica séries temporais Vazões Usina Estreito Tocantins. a) decomposição da série em sazonalidade, tendência e resíduos b) série original c) domínio frequência d) FAC e) FACP... 413 Figura APÊNDICE K-131 Sazonalidade anual das séries temporais Vazões Usina Estreito Tocantins a) JAN a DEZ. b) Média Trimestral. c) JAN ABR JUL OUT. d) Sazonalidade mensal todos os anos. e) Gráfico sazonalidade mês a mês. f) Gráfico de caixa. 413 Figura APÊNDICE K-132 Análise gráfica séries temporais Vazões Usina Camargos. a) decomposição da série em sazonalidade, tendência e resíduos b) série original c) domínio frequência d) FAC e) FACP..... 414 
Figura APÊNDICE K-133 Séries temporais Vazões Usina de Camargos. a) JAN a DEZ. b) Média Trimestral. c) JAN ABR JUL OUT. d) Sazonalidade mensal todos os anos. e) Gráfico de sazonalidade mês a mês. f) Gráfico de caixa.

Figura APÊNDICE K-134 Análise gráfica séries temporais Vazões Usina Nova Ponte. a) decomposição da série em sazonalidade, tendência e resíduos b) série original c) domínio frequência d) FAC e) FACP.

Figura APÊNDICE K-135 Séries temporais Vazões Usina de Nova Ponte a) JAN a DEZ. b) Média Trimestral. c) JAN ABR JUL OUT. d) Sazonalidade mensal todos os anos. e) Gráfico sazonalidade mês a mês. f) Gráfico de caixa.

Figura APÊNDICE K-136 Análise gráfica séries temporais Vazões Usina Furnas. a) decomposição da série em sazonalidade, tendência e resíduos b) série original c) domínio frequência d) FAC e) FACP. 416

Figura APÊNDICE K-137 Séries temporais Vazões Usina de Furnas a) JAN a DEZ. b) Média Trimestral. c) JAN ABR JUL OUT. d) Sazonalidade mensal todos os anos. e) Gráfico sazonalidade mês a mês. f) Gráfico de caixa Séries Históricas Bacia do Tiete - Vazões da Usina de Barra Bonita.

Figura APÊNDICE K-138 Análise gráfica séries temporais Vazões Usina de Barra Bonita. a) decomposição da série em sazonalidade, tendência e resíduos b) série original c) domínio frequência d) FAC e) FACP.

Figura APÊNDICE K-139 Séries temporais Vazões Usina de Barra Bonita a) JAN a DEZ. b) Média Trimestral. c) JAN ABR JUL OUT. d) Sazonalidade mensal todos os anos. e) Gráfico sazonalidade mês a mês. f) Gráfico de caixa.

Figura APÊNDICE K-140 Análise gráfica séries temporais Vazões Usina de Foz do Areia. a) decomposição da série em sazonalidade, tendência e resíduos b) série original c) domínio frequência d) FAC e) FACP. 418

Figura APÊNDICE K-141 Séries temporais Vazões Usina Foz do Areia. a) JAN a DEZ. b) Média Trimestral. c) JAN ABR JUL OUT. d) Sazonalidade mensal todos os anos. e) Gráfico sazonalidade mês a mês. f) Gráfico de caixa.

Figura APÊNDICE K-142 Análise gráfica séries temporais Vazões Usina Serra da .Mesa a) decomposição da série em sazonalidade, tendência e resíduos b) série original c) domínio frequência d) FAC e) FACP.

Figura APÊNDICE K-143 Séries temporais Vazões Usina de Serra da Mesa a) JAN a DEZ. b) Média Trimestral. c) JAN ABR JUL OUT. d) Sazonalidade mensal todos os anos. e) Gráfico sazonalidade mês a mês. f) Gráfico de caixa. 
Figura APÊNDICE K-144 Análise gráfica séries temporais Vazões Usina Queimado a) decomposição da série em sazonalidade, tendência e resíduos b) série original c) domínio frequência d) FAC e) FACP..... 420 Figura APÊNDICE K-145 Séries temporais Vazões Usina de Queimado a) JAN a DEZ. b) Média Trimestral. c) JAN ABR JUL OUT. d) Sazonalidade mensal todos os anos. e) Gráfico sazonalidade mês a mês. f) Gráfico de caixa 420 Figura APÊNDICE K-146 Análise gráfica séries temporais Vazões Usina de Bom Retiro a) decomposição da série em sazonalidade, tendência e resíduos b) série original c) domínio frequência d) FAC e) FACP.

Figura APÊNDICE K-147 Séries temporais Vazões Usina Retiro Baixo a) JAN a DEZ. b) Média Trimestral. c) JAN ABR JUL OUT. d) Sazonalidade mensal todos os anos. e) Gráfico sazonalidade mês a mês. f) Gráfico de caixa 421

Figura APÊNDICE K-148 Análise gráfica séries temporais Vazões Usina Três Marias. a) decomposição da série em sazonalidade, tendência e resíduos b) série original c) domínio frequência d) FAC e) FACP......

Figura APÊNDICE K-149 Séries temporais Vazões Usina Três Marias. a) JAN a DEZ. b) Média Trimestral. c) JAN ABR JUL OUT. d) Sazonalidade mensal todos os anos. e) Gráfico sazonalidade mês a mês. f) Gráfico de caixa.

Figura APÊNDICE K-150 Análise gráfica séries temporais Vazões Usina de Boa Esperança. a) decomposição da série em sazonalidade, tendência e resíduos b) série original c) domínio frequência d) FAC e) FACP... 423 Figura APÊNDICE K-151 Temporais Vazões Usina de Boa Esperança a) JAN a DEZ. b) Média Trimestral. c) JAN ABR JUL OUT. d) Sazonalidade mensal todos os anos. e) Gráfico sazonalidade mês a mês. f) Gráfico de caixa.

Figura APÊNDICE K-152 Análise gráfica séries temporais Vazões Usina de Guaporé. a) decomposição da série em sazonalidade, tendência e resíduos b) série original c) domínio frequência d) FAC e) FACP. 424

Figura APÊNDICE K-153 Temporais Vazões Usina de Guaporé a) JAN a DEZ. b) Média Trimestral. c) JAN ABR JUL OUT. d) Sazonalidade mensal todos os anos. e) Gráfico sazonalidade mês a mês. f) Gráfico de caixa. Séries Históricas Bacia Amazônica - Vazões Usina de Samuel.

Figura APÊNDICE K-154 Análise gráfica séries temporais Vazões Usina de Samuel. a) decomposição da série em sazonalidade, tendência e resíduos b) série original c) domínio frequência d) FAC e) FACP. 425 
Figura APÊNDICE K-155 Temporais Vazões Usina de Samuel a) JAN a DEZ. b) Média Trimestral. c) JAN ABR JUL OUT. d) Sazonalidade mensal todos os anos. e) Gráfico sazonalidade mês a mês. f) Gráfico de caixa.

Figura APÊNDICE K-156 Análise gráfica séries temporais Vazões Usina de Passo Fundo. a) decomposição da série em sazonalidade, tendência e resíduos b) série original c) domínio frequência d) FAC e) FACP. 426

Figura APÊNDICE K-157 Temporais Vazões Usina de Passo Fundo a) JAN a DEZ. b) Média Trimestral. c) JAN ABR JUL OUT. d) Sazonalidade mensal todos os anos. e) Gráfico sazonalidade mês a mês. f) Gráfico de caixa 426

Figura APÊNDICE L-158 Análise por componentes principais $1^{\text {a }}$ Componente Principal a) TSM HadISST b) ERSST. Média $1^{\circ}$. Semestre. 428

Figura APÊNDICE L-159 Análise por componentes principais $2^{\mathrm{a} C o m p o n e n t e ~ P r i n c i p a l ~ a) ~}$ TSM HadISST b) ERSST. Média $1^{\circ}$. Semestre.

Figura APÊNDICE L-160 Análise por componentes principais $3^{\mathrm{a}}$ Componente Principal a) TSM HadISST b) ERSST. Média $1^{\circ}$. Semestre

Figura APÊNDICE L-161 Análise por componentes principais $4^{\mathrm{a} C o m p o n e n t e ~ P r i n c i p a l ~ a) ~}$ TSM HadISST b) ERSST. Média $1^{\circ}$. Semestre.

Figura APÊNDICE L-162 Correlação TSM HadISST versos ENA SE a) Correlação b) PValor 1931 - 2014 433

Figura APÊNDICE L-163 Correlação TSM ERSST versos ENA SE a) Correlação b) P-Valor $1931-2014$ 434

Figura APÊNDICE L-164 Correlação TSM HadISST versos ENA SE a) Correlação b) PValor $1973-2014$ 435

Figura APÊNDICE L-165 Correlação TSM ERSST versos ENA SE a) Correlação b) P-Valor $1973-2014$ 436

Figura APÊNDICE L-166 Correlação TSM HadISST versos ENA SE a) Correlação b) PValor 1984 - 2014 437

Figura APÊNDICE L-167 Correlação TSM ERSST versos ENA SE a) Correlação b) P-Valor $1984-2014$ 438

Figura APÊNDICE L-168 Correlação TSM HadISST versos ENA SUL a) Correlação b) PValor $1931-2013$ 439

Figura APÊNDICE L-169 Correlação TSM ERSST versos ENA SUL a) Correlação b) PValor 1931 - 2013. 440 
Figura APÊNDICE L-170 Correlação TSM HadISST versos ENA Sul a) Correlação b) PValor $1973-2013$. 441

Figura APÊNDICE L-171 Correlação TSM ERSST versos ENA SUL a) Correlação b) PValor $1973-2013$. 442

Figura APÊNDICE L-172 Correlação TSM HadISST versos ENA SUL a) Correlação b) PValor 1983 - 2013. 443

Figura APÊNDICE L-173 Correlação TSM ERSST versos ENA SUL a) Correlação b) PValor $1983-2013$ 444

Figura APÊNDICE L-174 Correlação TSM HadISST versos ENA NORTE a) Correlação b) P-Valor 1931 - 2013 445

Figura APÊNDICE L-175 Correlação TSM ERSST versos ENA NORTE a) Correlação b) PValor 1931 - 2013. 446

Figura APÊNDICE L-176 Correlação TSM HadISST versos ENA NORTE a) Correlação b) P-Valor 1973 - 2013 447

Figura APÊNDICE L-177 Correlação TSM ERSST versos ENA NORTE a) Correlação b) PValor $1973-2013$. 448

Figura APÊNDICE L-178 Correlação TSM HadISST versos ENA NORTE a) Correlação b) P-Valor 1983 - 2013 449

Figura APÊNDICE L-179 Correlação TSM ERSST versos ENA NORTE a) Correlação b) PValor $1983-2013$. 450

Figura APÊNDICE L-180 Correlação TSM HadISST versos ENA NORDESTE a) Correlação b) P-Valor 1931 - 2013 451

Figura APÊNDICE L-181 Correlação TSM ERSST versos ENA NORDESTE a) Correlação b) P-Valor 1931 - 2013 452

Figura APÊNDICE L-182 Correlação TSM HadISST versos ENA Nordeste a) Correlação b) P-Valor 1973 - 2013 453

Figura APÊNDICE L-183 Correlação TSM ERSST versos ENA Nordeste a) Correlação b) PValor $1973-2013$. 454

Figura APÊNDICE L-184 Correlação TSM HadISST versos ENA NORDESTE a) Correlação b) P-Valor $1983-2013$. 455

Figura APÊNDICE L-185 Correlação TSM ERSST versos ENA NORDESTE a) Correlação b) P-Valor 1983 - 2013 456

Figura APÊNDICE M-186 Análise por componentes principais $1{ }^{\mathrm{a} C o m p o n e n t e ~ P r i n c i p a l ~ a) ~}$ TSM HadISST b) ERSST. 458 
Figura APÊNDICE M-187 Análise por componentes principais $2^{\mathrm{a}}$ Componente Principal a) TSM HadISST b) ERSST....

Figura APÊNDICE M-188 Análise por componentes principais $3^{\mathrm{a} C o m p o n e n t e ~ P r i n c i p a l ~ a) ~}$ TSM HadISST b) ERSST

Figura APÊNDICE M-189 Análise por componentes principais $4^{\mathrm{a}}$ Componente Principal a) TSM HadISST b) ERSST

Figura APÊNDICE M-190 Correlação TSM HadISST versos ENA SE a) Correlação b) PValor. 1931 - 2014 462

Figura APÊNDICE M-191 Correlação TSM ERSST versos ENA SE a) Correlação b) PValor. $1931-2014$ 463

Figura APÊNDICE M-192 Correlação TSM HadISST versos ENA SE a) Correlação b) PValor $1974-2014$ 464

Figura APÊNDICE M-193 Correlação TSM ERSST versos ENA SE a) Correlação b) P-Valor $1974-2014$ 465

Figura APÊNDICE M-194 Correlação TSM HadISST versos ENA SE a) Correlação b) PValor $1984-2014$

Figura APÊNDICE M-195 Correlação TSM ERSST versos ENA SE a) Correlação b) P-Valor $1984-2014$ 467

Figura APÊNDICE M-196 Correlação TSM HadISST versos ENA Bacia do Paraná a) Correlação b) P-Valor. 1931 - 2014 468

Figura APÊNDICE M-197 Correlação TSM ERSST versos ENA Bacia do Paraná a) Correlação b) P-Valor. 1931 - 2014

Figura APÊNDICE M-198 Correlação TSM HadISST versos ENA Bacia do Paraná a) Correlação b) P-Valor. 1973 - 2014

Figura APÊNDICE M-199 Correlação TSM ERSST versos ENA Bacia do Paraná a) Correlação b) P-Valor. 1973 - 2014

Figura APÊNDICE M-200 Correlação TSM HadISST versos ENA Bacia do Paraná a) Correlação b) P-Valor. 1984 - 2014

Figura APÊNDICE M-201 Correlação TSM ERSST versos Vazão Usina Barra Bonita a) Correlação b) P-Valor. 1984 - 2014

Figura APÊNDICE M-202 Correlação TSM HadISST versos Vazão Usina Barra Bonita a) Correlação b) P-Valor. 1931 - 2014 474

Figura APÊNDICE M-203 Correlação TSM ERSST versos Vazão Usina Barra Bonita a) Correlação b) P-Valor. 1931 - 2014 475 
Figura APÊNDICE M-204 Correlação TSM HadISST versos Vazão Usina Barra Bonita a) Correlação b) P-Valor 1973 - 2014. 476

Figura APÊNDICE M-205 Correlação TSM ERSST versos Vazão Usina Barra Bonita a) Correlação b) P-Valor 1973 - 2014 477

Figura APÊNDICE M-206 Correlação TSM HadISST versos Vazão Usina Barra Bonita a) Correlação b) P-Valor 1984 - 2014 . 478

Figura APÊNDICE M-207 Correlação TSM ERSST versos Vazão Usina Barra Bonita a) Correlação b) P-Valor 1984 - 2014 .

Figura APÊNDICE N-208 Correlação entre as vazões das Usinas da Bacia dos rios a) Paraná, b) São Francisco e c) Tocantins 481

Figura APÊNDICE N-209 Correlação entre as variáveis de índice SOI MEI de ENOS e as vazões das Usinas das Bacias a) Paraná, b) São Francisco, c) Tocantins e d) Parnaíba Correlação áreas TSM Pacífico El Niño 1+2, 3, 3.4 e 4 ...................................................... 483

Figura APÊNDICE N-210 Relação entre variável NINO 1+2 Usinas escolhidas.................. 484 Figura APÊNDICE N-211 Relação entre variável NINO 1+2 Usinas escolhidas................. 484 APÊNDICE N-212 Correlação entre as variáveis de TSM El Niño regiões 1+2, 3, 3.4 e 4 e vazões da Usinas da Bacia dos rios a) Paraná, b) São Francisco, c) Parnaíba e d) Tocantins486 Figura APÊNDICE N-213 Relação entre variável Atlântico Multidecadal e Usinas escolhidas 487

Figura APÊNDICE N-214 Relação entre variável Atlântico Multidecadal e Usinas escolhidas com função de autocorrelação cruzada. 488

Figura APÊNDICE N-215 Correlação entre as variáveis Decadal do Pacífico e Multidecadal do Atlântico e vazões das Usinas da Bacia dos rios a) Paraná, b) São Francisco c) Parnaíba d) Tocantins. 490

Figura APÊNDICE N-216 Correlação entre as variáveis dos Polos Ártico e Antártico e vazões das Usinas da Bacia dos rios a) Paraná, b) São Francisco, c) Parnaíba e d) Tocantins. 492 Figura APÊNDICE N-217 Relação entre variável Manchas Solares e Usinas escolhidas com função de autocorrelação cruzada. 493 Figura APÊNDICE N-218 Correlação entre as variáveis quantidade de manchas solares e as vazões das Usinas das Bacia a) Paraná, b) São Francisco, c) Parnaíba e d) Tocantins. 496 Figura APÊNDICE O-219 Validação Cruzada Modelos SARIMAX 101300, 101300x e 101310x. 499 


\section{Lista Siglas}

A - Temperatura do ar na superfície

aa - Atividade magnética da Terra

AAO - Antarctic Oscillation

AB - Alta da Bolívia

Acf - Autocorrelation function

ACF1 - Autocorrelation of errors at lag 1 (Autocorrelação de erros com 1 atraso)

ACP - Análise de Componentes Principais

AGU - Corrente das Agulhas

AIC -Akaike's Information Criterion (Critério de Informação de Akaike)

AICc - Corrected Akaike's Information Criterion (Critério de Informação de Akaike corrigida)

AMM - Atlantic Meridional Mode

AMO - Atlantic Multidecadal Oscillation

ANE -Ventos Alísios de Nordeste

Aneel - Agência Nacional de Energia Elétrica

ANFIS - Adaptive neuro fuzzy inference system (Redes Neurais Difusas Adaptativas)

ANFIS - Redes neurais difusas adaptativas

AO - Artic Oscillation

APC - Análise de Componentes Principais

AR - Autorregressivo

$\mathrm{AR}(1)$ - Operador autorregressivo de ordem 1

$\mathrm{AR}(2)$ - Operador autorregressivo de ordem 2

$\mathrm{AR}(\mathrm{p})$ - Operador autorregressivo de ordem $\mathrm{p}$

ARAB - Oceano da Arábia

ARFIMA- Autoregressive fractionally integrated moving average

ARIMA - Modelos de combinação entre médias móveis e autorregressivos e integrados

ARMA Modelos de Autorregressivos e Médias Móveis

$\operatorname{ARMA}(p, q)$ - Operador autorregressivo, ordem p, e médias móveis, ordens q.

ARx - Autorregressivos com variável exógena

AS - América do Sul

ASAS - Anticiclone Subtropical do Atlântico do Sul

ASE - Ventos Alísios de Sudeste

ASPS - Anticiclone Subtropical do Pacífico Sul 
ATU - Rio Atuel

B -Baixa Pressão

BACIAS - Energia Natural Afluente Bacias

BC - Baixa do Chaco - Região de baixas térmicas

BEN - Balanço Energético Brasileiro

BIC - Schwarz Bayesian Information Criterion (Critério Bayesiano de Schwarz)

Big - Banco de Informações de Geração

BL - Região de Bloqueios Atmosféricos

BNE - Região de baixas térmicas no Noroeste Argentino

BRAMS - Regional Atmospheric Modelling System with Brazilian Developments

C - Fração de nebulosidade total do céu

CCEE - Câmara Comercializadora de Energia Elétrica

CCM - Complexo Convectivo de Mesoescala

CE - Ceará

Cepel - Centro de Pesquisas de Energia Elétrica

$\mathrm{CGH}$ - Central Geradora Hidrelétrica

CLIVAR - Climate Variability and Predictability

CMO - Custo Marginal de Operação

CNB - Canberra

CNE - Cavado do Nordeste do Brasil

CORALS - Oceano de Coral

CPC - Climate Prediction Center

CPTEC - Centro de Estudos de Previsão de Tempo e Clima

CVU - Custo Variável Unitário

DECOMP - Determinação da Coordenação da Operação a Curto Prazo

DJ - dezembro-janeiro

DNA - Deoxyribonucleic acid (ácido desoxirribonucleico)

Eaf - Função de autocorrelação estendida

EEP - Pacifico Equatorial Leste

ENA - Energia Natural Afluente

ENA-N - Energia Natural Afluente Região Norte

ENA-NE - Energia Natural Afluente Região Nordeste

ENA-S - Energia Natural Afluente Região Sul

ENA-SE - Energia Natural Afluente Região Sudeste 
ENOS - El Niño Oscilação Sul

ENSO - El Niño/Southern Oscillation

EOF - Empirical Orthogonal Functions (Funções Ortogonais Empíricas)

EOL - Central Geradora Eólica

EPE - Empresa de Pesquisas Energética

EPUSP - Escola Politécnica da Universidade de São Paulo

ERSST - Extended Reconstructed Sea Surface Temperature

ESP - Ensemble Streamflow Prediction

EXT - Multivariate ENSO Index Ext.

FAC - Função de Autocorrelação

FACP - Função de Autocorrelação Parcial

FF - Frente Fria

FQ - Frente Quente

FRCGC - Frontier Research Center for Global Change

GAMS - General Algebraic Modeling System

GERAVAZ - Geração de Vazões

GW - Gigawatt

GWh - a Gigawatt-hora

H.N. - Hemisfério Norte

H.S. - Hemisfério Sul

h0 - hipótese nula

h1 - hipótese alternativa

HAD - Hartland

HadISST - Hadley Centre Sea Ice and Sea Surface Temperature Dataset

Hidroterm - Sistema integrado de hidrelétricas e termelétricas

i.i.d. - Erros aleatórios, independentes e igualmente distribuídos

IBGE - Instituto Brasileiro de Geografia e Estatística

IC - Intervalo de confiança

ICOADS - International Comprehensive Ocean-Atmosphere Data Set

IND - Oceano Índico

INMET - Instituto Nacional de Meteorologia

INPE - Instituto Nacional de Pesquisas Espaciais

IPCC - Painel Intergovernamental sobre Mudanças Climáticas

IPCC -Intergovernmental Panel on Climate Change 
IPHMEN - Inst. Pesquisas Hidrológicas - Modelo chuva-vazão de discretização mensal JBN - Jato de Baixos Níveis a Leste dos Andes

$\mathrm{JF}$ - janeiro - fevereiro

JP - Jato Polar

JS - Jato Subtropical

KPSS - KWIATKOWSKI PHILLIPS SCHMIDT SHIN

LI - Linha de Instabilidade Tropical

LIP - Linha de Instabilidade Pré-frontal

Log - Logaritmo

MA - Médias móveis

MA(1) - Operador de média móvel de ordem 1

MA(2) - Operador de média móvel de ordem 2

MA(q) - Operador de média móvel de ordem q

MAE - Mean Absolute Error (Erro Médio Absoluto)

MAPE - Mean Absolute Percentage Error (Percentual Erro Absoluto)

MASE - Mean Absolute Scaled Error (Escala de Erro Médio Absoluto)

MCGA - Modelos de circulação geral da atmosfera

ME - Mean Error (Erro médio)

MED - Mediterrâneo

MEI - Multivariate ENSO Index

MESA - Monsoon Experiment in South America

MEXCAR - México Caribenho

MH - Milionésimos de um hemisfério solar

MJO - Oscilação Madden-Julian

MLE - Modelo Linear Estocástico

MME - Ministério de Minas e Energia

MODOKI - El Niño Modoki

MPE - Mean Percentage Error (Percentual Erro Médio)

MW - Megawatt

MW méd - Megawatts médios

MWmédios - Megawatts médios

$\mathrm{N}$ - Norte

NAO - North Atlantic Oscillation

NAO - Oscilação do Atlântico Norte 
NATL - Norte do Atlântico

NCAR - National Center for Atmospheric Research

NCEP - National Centers for Environmental Prediction

ND - novembro-dezembro

NE - Nordeste

NEWAVE - Modelo de Planejamento da Operação de Sistemas Hidrotérmicos Interligados de Longo e Médio Prazo

NINO1+2 - El Niño 1+2

NINO3 - El Niño 3

NINO3.4 - El Niño 3.4

NINO3WL - Transformação NINO3 com wavelet

NINO4 - El Niño 4

NOAA - National Oceanic and Atmospheric Administration

NPAC - Norte do Pacífico

NRC - National Research Council

NSIDC - Snow and Ice Data Center

nT - nano Tesla

NV - Nuvem Vírgula

OAS - Oceano Atlântico Sul

OECD - Organisation for Economic Co-operation and Development

OECD - Organização para o Desenvolvimento e Cooperação Econômica

OMA - Oscilação Multidecadal do Atlântico

ONI - Oceanic Niño Index

ONS - Operador Nacional do Sistema Elétrico

ONU - Organização da Nações Unidas

P - Pressão do nível do mar

P\&D - Pesquisa e Desenvolvimento

Pacf - Partial autocorrelation function

PAR - Modelo Periódico Autorregressivo

PAR - Rio Paraná

PC - Componente principal sem rotação

PCH - Pequena Central Hidrelétrica

PD - Programação Dinâmica

PDDE - Programação Dinâmica Dual Estocástica 
PDED - Programação Dinâmica Estocástica Dual

PDO - Oscilação Decadal do Pacífico

PDO - Pacific Decadal Oscillation

PGE - Parque Gerador Existente

PGF - Parque Gerador Futuro

PL - Programação Linear

PLIM - Programação Linear Inteira Mista

PNL - Programação Não Linear

PNLIM - Programação Não Linear Inteira Mista

PTPI - Índice total de precipitação

PWh - Pentawatt-hora (Quatrilhões de Watt-hora)

Qa - Vazão afluente

QBO - Quasi-Biennial Oscillation

Qd - Vazão defluente

QQ-Plot - Quantile-Quantile Plot

Qt - Vazão turbinada

$\mathrm{R}$ - Reservatório ou Pacote programas estatísticos $\mathrm{R}$

R2 - Coeficiente de determinação

R2 - Coeficiente de determinação ajustado

R2p - Valor p nível de significância estatística

RANK - Multivariate ENSO Index Rank

RBG - Ruído Branco Gaussiano

RC - Regiões Ciclogenéticas

RED-PON - Redes Neurais Artificiais Polinomiais

REDS - Mar Vermelho

RMSE - Root Mean Squared Error (Erro médio quadrático)

RMSP - Região Metropolitana de São Paulo

RNA - Redes Neurais Artificiais

RS - Rio Grande do Sul

S - Sul

SAM - Modo Anular Sul

Sarima - Sazonal Autorregressivo Integrado e de Médias Móveis

SarimaX - Sazonal Autorregressivo Integrado e de Médias Móveis com Regressão

SATL - Sul do Atlântico 
SE/CO - Sudeste e Centro Oeste

SEB - Setor Elétrico Brasileiro

SIN - Sistema Interligado Nacional

SLC - Simple Linear Correlation (Correlação Linear Simples)

SLP - Sea Level Pressure

SMAP - Soil Moisture Accounting Procedure

SMAS - Sistema de Monção da América do Sul

SNGRH - Sistema Nacional de Gerenciamento do Recursos Hídricos

SNN - Sunspot Number

SOI - Southern Oscillation Index

SOI_DAR - Southern Oscillation Index Darwin

SOI_TAH - Southern Oscillation Index Tahiti

SPAC - Sul do Pacifico

SSA - Manchas solares por Área

SSA - Sul da América do Sul

SSA - Sunspot Area

SSAN - Manchas solares por Área Hemisfério Norte

SSAS - Manchas solares por Área Hemisfério Sul

SSD - Sistema de Suporte à Decisão

SSN - Número de Manchas solares

SVD - Singular Value Decomposition (Decomposição de Valores Singulares)

SWA - Sudoeste do Atlântico Sul

TNA - Tropical Northern Atlantic Index

TSA - Atlântico Tropical Sul

TSA - Tropical Southern Atlantic Index

TSI - Total Sun Radiation - Irradiação Solar Total

TSM - Temperatura da Superfície do Mar

TWh - Terawatt-hora

U - Componentes do vento de superfície zonal

UCLA - Universidade da Califórnia

UFV - Central Geradora Solar Fotovoltaica

UHE - Usina Hidrelétrica

UNFCC - Nações Unidas sobre Mudanças Climáticas

US - Umidade do Solo 
USAF - United States Air Force

UTE - Usina Termelétrica

UTN - Usina Termonuclear

$\mathrm{V}$ - Componentes do vento de superfície meridional

VAMOS - Variability of American Monsoon Systems

VAZ - Vazões Usinas

VCAN subtrop - Vórtices Ciclônicos de Altos Níveis Subtropicais

VCAN trop- Vórtices Ciclônicos de Altos Níveis Tropicais.

Vd - Vazões Defluentes

Vt - Vazão turbinada

WCRP - World Climate Research Program

WCRP CLIVAR - World Climate Research Program- Climate Variability and Predictability

X100E - Variável MJO longitude de $100^{\circ} \mathrm{L}$

X10W - Variável MJO longitude de $10^{\circ} \mathrm{O}$

X120E - Variável MJO longitude de $120^{\circ} \mathrm{L}$

X120W - Variável MJO longitude de $120^{\circ} \mathrm{O}$

X140E - Variável MJO longitude de $140^{\circ} \mathrm{L}$

X160E - Variável MJO longitude de $160^{\circ} \mathrm{L}$

X20E - Variável MJO longitude de $20^{\circ} \mathrm{L}$

X40W - Variável MJO longitude de $40^{\circ} \mathrm{O}$

X70E - Variável MJO longitude de $70^{\circ} \mathrm{L}$

X80E - Variável MJO longitude de $80^{\circ} \mathrm{L}$

ZAN - Corrente Zanzibar

ZCAS - Zona de Convergência do Atlântico Sul

ZCIT - Zona de Convergência Intertropical 


\section{Sumário}

1.1 Formulação do Problema

$\begin{array}{lll}1.2 & \text { JUSTIFICATIVA } & 78\end{array}$

\begin{tabular}{lr} 
CAPÍTULO 2 OBJETIVOS & 81 \\
\hline
\end{tabular}

2.1 OBJETIVO GERAL $\quad 81$

2.2 OBJETIVOS ESPECÍFICOS

2.3 QUESTÃO CENTRAL E HIPÓTESE

2.4 DESCRIÇÃO DA POPULAÇÃO

$2.5 \quad$ LIMITAÇÕES DA TESE

CAPÍTULO 3 REVISÃO BIBLIOGRÁFICA

3.1 ENERgia NATURAL AfLUENTE (ENA)

3.2 TEMPERATURA Da SUPERFície do MAR (TSM) 86

$\begin{array}{lll}3.3 & \text { EL NIÑO-OSCILAÇÃO SUL (ENOS) } & 87\end{array}$

3.3.1 FASE NEUTRA DO El NIÑO

3.3.2 FASE DE OCORRÊNCIA DO EL NIÑO 90

3.3.3 FASE DE OCORRÊNCIA DA LA NIÑA 91

3.3.4 ABAIXO DA SUPERFÍCIE 92

3.4 MaNCHAS SOLARES

3.4.1 CiClo DE SCHWABE $\quad 95$

3.4.2 CiClo De WOLF 95

3.4.3 CiClo DE GLEISSBERG 97

3.4.4 MÍNIMO DE MAUNDER 98

3.5 O SETOR ELÉTRICO BRASILEIRO (SEB) 98

3.6 CRESCIMENTO POPULACIONAL E CONSUMO DE ENERGIA NO MUNDO E NO BRASIL 103

3.7 TRABALHOS SOBRE INFORMAÇÕES CLIMÁTICAS DE LARGA ESCALA NA PREVISÃO DE PRECIPITAÇÕES OU DE VAZÕES DE RIO

3.8 MODELAGEM DE OPERAÇ̃̃o DE RESERVATÓRIOS 109 
3.9 MODELOS DE PREVISÃO DE VAZÕES 113

3.10 TELECONEX̃̃ES E PADRÕES DE CIRCULAÇÃO ATMOSFÉRICA 116

3.11 TELECONEXõeS COM El NiÑo OSCILAÇÃO SUL 125

3.12 EXEMPLO TELECONEXÃO - SECA ATÍPICA DO SUDESTE NO VERÃO DE 2014

3.13 INFLUÊNCIA SOLAR NO CLIMA E VAZÕES

CAPÍTULO 4 FONTES DE DADOS MACROCLIMÁTICOS 133

4.1 MANCHAS SOLARES (SNN) E ÁREA (SSA) 136

4.2 ÍNDICE ATIVIDADE MAGNÉTICA AA 137

4.3 FONTES DE DADOS GEORREFERENCIADAS HADISST E ERSST 138

4.4 ÍNDICES DE TSM EL NIÑO

4.5 ÍNDICE DE OSCILAÇão DECADAL do PACIFICO (PDO) 140

4.6 ÍNDICE MULTIVARIAdo ENOS (MEI) 141

4.7 ÍNDICE DE OSCILAÇão SUL (SOI)

4.8 ÍNDICE OCEÂNICO NIÑO (ONI)

4.9 ÍNDICE EL NiÑO MODOKI (MODOKI) 143

4.10 ÍNDiCE OSCILAÇÃo MULTIDECADAL do ATLÂNTICO - AMO 145

4.11 ÍNDICE DE TSM MOdO MERIDIONAL DO ATLÂNTICO - AMM 146

4.12 ÍNDICES Tropicais NORTE E SUL do ATLÂNTICO (TNA / TSA) 147

4.13 ÍNDICE OSCILAÇão do ATLÂNTICO NORTE (NAO) 149

4.14 ÍNDICE DE OSCILAÇÃO MADDEN-JULIAN (MJO) 149

4.15 ÍNDICE OSCILAÇÃo QUASE-BIANUAL - QBO 151

4.16 ÍNDICE DE OSCILAÇÃO DA ANTÁRTICA (AAO) 151

4.17 ÍNDICE DE OSCILAÇÃO do ÁRTICO (AO) 152

4.18 Índice de Gelo Polos Ártico e ANTÁrtico 152

CAPÍTULO 5 MÉTODO

5.1 ESTACIONARIEDADE E PRÉ-TRATAMENTO DAS SÉRIES 155

5.1.1 DIFERENCIAÇÃO 156

5.1.2 DIFERENÇA SAZONAL 156

5.1.3 ESTABILIZAÇÃO DA VARIÂNCIA

5.2 MODELOS DE REGRESSÃO 157

5.3 SÉRIES TEMPORAIS

5.4 OPERADOR BACKSHIFT (ATRASO)

$\begin{array}{lll}5.5 & \text { SARIMAX } & 160\end{array}$ 
5.5.1 ESPECIFICAÇÃO 161

5.5.2 IDENTIFICAÇÃO 161

5.5.3 ESTIMAÇÃO 167

5.5.4 VERIFICAÇÃO OU DIAGNÓSTICO 167

5.5.4.1 Gráfico de dispersão de resíduos contra os valores ajustados 168

5.5.4.2 Gráfico de autocorrelação (FAC) dos resíduos 168

5.5.4.3 Gráfico Q-Q normal 168

$\begin{array}{lll}\text { 5.5.4.4 Histograma dos resíduos } & 168\end{array}$

6.1 VARIÁVEIS ESCOLHIDAS PARA O ESTUDO 169

6.2 ANÁLISE DE ESTACIONARIEDADE DAS VARIÁVEIS 170

6.3 VARIÁVEIS DEPENDENTES

6.3.1 FONTE DE DADOS DECK NEWAVE 173

6.3.2 ENERGia NATURAL AFLUENTE DO SUDESTE (ENA-SE) 174

6.3.3 ENERGia NATURAL AfLUENTE do SUl (ENA-S) 176

6.3.4 ENERGia NATURAL AFLUENTE do NoRdESTE (ENA-NE) 178

6.3.5 ENERGia NATURAL AfLUENTE do Norte (ENA-N) 180

6.4 VARIÁVEIS MACROCLIMÁTICAS INDEPENDENTES

6.4.1 ÍNDICE TEMPERATURA DA SUPERFÍCIE DO MAR - TSM REGIÃo NINO 1+2 182

6.4.2 ÍNDICE OSCILAÇÃO MULTIDECADAL DO ATLÂNTICO (AMO) 187

6.4.3 ÍNDICE OSCILAÇÃO DECADAL DO PACÍFICO (PDO) 191

6.5 MATRIX PARA CORRELAÇÃo DAS SÉRIES HISTÓRICAS 194

6.5.1 CORRELAÇÃO ENA-SE X VARIÁVEIS MACROCLIMÁTICAS 196

6.5.2 CORRELAÇÃO MANCHAS SOLARES 196

6.5.3 CORRELAÇÃO ÍNDICES DE ONI E MEI 198

6.5.4 CORRELAÇÃO ÍNDICES DE TSM ELNIÑO 1+2 - 3-4 199

6.5.5 ÍNDICES OSCILAÇão MULTIDECADAL DO ATLÂNTICO E DECADAL DO PACIFICO 200

6.5.6 ÍNDICES DE OSCILAÇÃO DOS POLOS 201

6.5.7 ÍNDICE DE ACUMULO DE GELO 202

6.5.8 ENA DE DIFERENTES BACIAS 203

7.1 MODELO SARIMAX ENA-SE 206

7.1.1 ESPECIFICAÇÃO 206 
7.1.2 IDENTIFICAÇÃO 209

$\begin{array}{lll}\text { 7.1.3 ESTIMAÇÃO } & 210\end{array}$

7.1.4 VERIFICAÇÃO OU DIAGNÓSTICO 212

7.1.5 VALIDAÇÃO CRUZADA 213

7.2 MODELO SARIMAX ENA SUL 218

$\begin{array}{lll}7.2 .1 & \text { ESPECIFICAÇÃO } & 218\end{array}$

7.2.2 IDENTIFICAÇÃO 220

$\begin{array}{lll}7.2 .3 & \text { ESTIMAÇÃO } & 221\end{array}$

7.2.4 VERIFICAÇÃO OU DIAGNÓSTICO 222

7.2.5 VALIDAÇÃO CRUZADA 223

7.3 MODELO SARIMAX ENA NORDESTE 228

$\begin{array}{lll}\text { 7.3.1 ESPECIFICAÇÃO } & 228\end{array}$

$\begin{array}{lll}\text { 7.3.2 IDENTIFICAÇÃOO } & 230\end{array}$

$\begin{array}{lll}\text { 7.3.3 ESTIMAÇÃOO } & 232\end{array}$

7.3.4 VERIFICAÇ̃̃O OU DIAGNÓSTICO 232

7.3.5 VALIDAÇÃO CRUZADA 234

7.4 MODELO SARIMAX ENA NORTE 238

$\begin{array}{lll}\text { 7.4.1 } & \text { ESPECIFICAÇÃO } & 238\end{array}$

7.4.2 IDENTIFICAÇÃO 240

$\begin{array}{lll}\text { 7.4.3 } & \text { ESTIMAÇÃO } & 242\end{array}$

7.4.4 VERIFICAÇÃO OU DIAGNÓSTICO 243

7.4.5 VALIDAÇÃO CRUZADA 245

CAPÍTULO 8 SUMÁRIO, CONCLUSÕES RECOMENDACÕES

$\begin{array}{lll}\text { 8.1 SUMÁRIO } & 250\end{array}$

$\begin{array}{lll}8.1 .1 & \text { INTRODUÇÃO } & 250\end{array}$

8.1.2 OBJETIVOS 254

8.1.2.1 Objetivo Geral 254

8.1.2.2 Objetivos Específicos 254

8.1.2.3 Questão central e hipótese 255

8.1.3 REVISÃO BIBLIOGRÁFICA 255

8.1.3.1 Número de Manchas Solares - SSN 255

8.1.3.2 Energia Natural Afluente - ENA 255

8.1.3.3 Temperatura da Superfície do Mar (TSM) 257

8.1.3.4 Fenômeno El Niño Oscilação Sul 257

8.1.3.5 Índice de Oscilação Decadal do Pacífico - PDO 258 
8.1.3.6 Índice Multivariado ENOS - MEI 258

8.1.3.7 Índice Oceânico Niño - ONI - NINO3.4 259

8.1.3.8 Índice de Oscilação Sul - SOI 259

8.1.3.9 El Niño Modoki - MODOKI 259

8.1.3.10 Atlântico Tropical Norte - TNA e Atlântico Tropical Sul - TSA 260

8.1.3.11 Modo Meridional do Atlântico - AMM 260

8.1.3.12 TSM do Sudoeste do Atlântico Sul - SWA 260

8.1.3.13 Índice Oscilação Quase-Bianaual - QBO 260

8.1.3.14 Oscilação Madden-Julian MJO 260

8.1.4 MATERIAIS E MÉTODOS 261

8.1.4.1 Fonte de Dados 261

8.1.4.2 Correlação das Séries históricas 263

8.1.4.3 Método SARIMAX 265

8.1.5 ANÁLISE SÉRIES HISTÓRICAS 269

8.1.5.1 Energia Natural Afluente do Sudeste (ENA-SE) 269

8.1.5.2 Correlação ENA-SE x variáveis Macroclimáticas 271

8.1.5.3 Modelagem SARIMAX de ENA-SE 272

8.2 CONCLUSÕES 284

8.3 RECOMENDAÇÕES PARA TRABALHOS FUTUROS 286

REFERÊNCIAS BIBLIOGRÁFICAS $\quad 289$

\begin{tabular}{lr} 
APENNDICES & 313 \\
\hline
\end{tabular}

APÊNDICE A Métodos de apoio 313

APÊNDICE B Validação dos modelos de previsão 314

APÊNDICE B.1 Coeficiente de determinação $\left(\mathrm{R}^{2}\right) \quad 315$

APÊNDICE B.2 $\mathrm{R}^{2}$ ajustado 316

APÊNDICE B.3 Critério de Informação de Akaike (AIC) 316

APÊNDICE B.4 AIC Corrigido $\left(\mathrm{AIC}_{\mathrm{c}}\right) \quad 316$

APÊNDICE B.5 Critério de Informação Bayesiana Schwarz (BIC) 317

APÊNDICE B.6 Validação Cruzada 317

APÊNDICE C Correlação de Pearson 319

APÊNDICE C.1 Testes de hipóteses sobre coeficiente de correlação 319

APÊNDICE C.2 Comando stats::cor.test() 320

APÊNDICE D Função de autocorrelação (ACF) 321

APÊNDICE D.1 Análise de Correlação Cruzada 322 
APÊNDICE E.1 Correlação e Causalidade 323

APÊNDICE E.2 Causalidade de Granger 323

APÊNDICE E.3 Exemplo teste de Granger 326

APÊNDICE FDecomposição de Séries Históricas $\quad 329$

APÊNDICE G Wavelets (Ondaletas) 330

APÊNDICE G.1 Transformada cross wavelet 333

APÊNDICE H Apêndice Análise com wavelets

APÊNDICE H.1 Wavelets número de Manchas Solares 335

APÊNDICE H.2 Wavelets Manchas Solares Total por Área (MH) 336

APÊNDICE H.3 Wavelets Energia Natural Afluente da Bacia do Paraná - ENA PR 337

APÊNDICE H.3.1 Análise relação variáveis explicativas e ENA PR 338

APÊNDICE H.4 Wavelets Vazão da Usina Barra Bonita 340

APÊNDICE H.4.1 Análise relação variáveis explicativas e usina Barra Bonita 341

APÊNDICE H.5 Wavelets Vazão da Usina Boa Esperança 343

APÊNDICE H.5.1 Análise relação variáveis explicativas e usina Boa Esperança 344

APÊNDICE H.6 Wavelets Vazão da Usina Camargos 346

APÊNDICE H.6.1 Análise relação variáveis explicativas e usina Camargos 347

APÊNDICE H.7 Wavelets Vazão da Usina Foz do Areia 349

APÊNDICE H.7.1 Análise relação variáveis explicativas e usina Foz do Areia 350

APÊNDICE H.8 Wavelets Vazão da Usina Furnas $\quad 352$

APÊNDICE H.8.1 Análise relação variáveis explicativas e usina Furnas 353

APÊNDICE H.9 Wavelets Vazão da Usina Guaporé 355

APÊNDICE H.9.1 Análise relação variáveis explicativas e usina Guaporé 356

APÊNDICE H.10 Wavelets Vazão da Usina Nova Ponte 358

APÊNDICE H.10.1 Análise relação variáveis explicativas e usina Nova Ponte 359

APÊNDICE H.11 Wavelets Vazão da Usina Passo Fundo 361

APÊNDICE H.11.1 Análise relação variáveis explicativas e usina Passo Fundo 362

APÊNDICE H.12 Wavelets Vazão da Usina Queimado 364

APÊNDICE H.12.1 Análise relação variáveis explicativas e usina Queimado 365

APÊNDICE H.13 Wavelets Vazão da Usina Retiro Baixo 367

APÊNDICE H.13.1 Análise relação variáveis explicativas e usina Retiro Baixo 368

APÊNDICE H.14 Wavelets Vazão da Usina Samuel 370

APÊNDICE H.14.1 Análise relação variáveis explicativas e usina Samuel 371

APÊNDICE H.15 Wavelets Vazão da Usina Serra da Mesa 373

APÊNDICE H.15.1 Análise relação variáveis explicativas e usina Serra da Mesa 374

APÊNDICE H.16 Wavelets Vazão da Usina Três Marias 376 
APÊNDICE H.16.1 Análise relação variáveis explicativas e usina Três Marias

APÊNDICE H.17 Wavelets Vazões rio Usina Porto Primavera $\left(\mathrm{m}^{3} \mathrm{~s}^{-1}\right)$

APÊNDICE H.18 Wavelets Vazões rio Usina Sobradinho $\left(\mathrm{m}^{3} \mathrm{~s}^{-1}\right) \quad 380$

APÊNDICE H.19 Wavelets Vazões rio Usina Boa Esperança $\left(\mathrm{m}^{3} \mathrm{~s}^{-1}\right)$

APÊNDICE H.20 Wavelets Vazões rio Usina Lajeado $\left(\mathrm{m}^{3} \mathrm{~s}^{-1}\right)$

APÊNDICE H.21 Número de Manchas Solares 383

APÊNDICE H.22 El Niño Área 1+2 do Oceano Pacífico 384

APÊNDICE H.23 Índice de Oscilação Multidecadal do Atlântico com transformações 385

APÊNDICE H.24 Índice de Oscilação Multidecadal do Atlântico sem transformações 386

APÊNDICE H.25 Índice de Oscilação Decadal do Pacífico 387

APÊNDICE H.26 Wavelets - ENA SE 388

APÊNDICE H.26.1 Análise relação variáveis explicativas e ENA SE 389

APÊNDICE H.27 Wavelets - ENA SUL 391

APÊNDICE H.27.1 Análise relação variáveis explicativas e ENA S 392

APÊNDICE H.28 Wavelets - ENA NORTE 394

APÊNDICE H.28.1 Análise relação variáveis explicativas e ENA N 395

APÊNDICE H.29 Wavelets - ENA NORDESTE 397

APÊNDICE H.29.1 Análise relação variáveis explicativas e ENA NE 398

APÊNDICE I Análise de Componentes Principais $\quad 400$

APÊNDICE J Apêndice Análise Gráfica das Séries Temporais $\quad 401$

APÊNDICE J.1 Resumo análise das Séries Históricas de Usinas 401

APÊNDICE K Apêndice Séries Históricas de Usinas 404

APÊNDICE K.1 Séries Históricas Número de Manchas Solares 405

APÊNDICE K.2 Séries Históricas TSM Niño 1+2 406

APÊNDICE K.3 Séries Históricas Oscilação Multidecadal do Atlântico 407

APÊNDICE K.4 Séries Históricas Manchas solares por áreas 408

APÊNDICE K.5 Séries Históricas Áreas manchas do hemisfério norte solar 409

APÊNDICE K.6 Séries Históricas Área manchas do hemisfério sul solar 410

APÊNDICE K.7 Séries H. Bacia do Paraná - Vazões Usina de Porto Primavera 411

APÊNDICE K.8 Séries H. Bacia do São Francisco - Vazões Usina de Sobradinho 412

APÊNDICE K.9 Séries Históricas Bacia do Rio Grande - Vazões da Usina Camargos 414

APÊNDICE K.10 Séries Históricas Bacia do Rio Grande - Vazões da Usina Nova Ponte 415

APÊNDICE K.11 Séries Históricas Bacia do Rio Grande - Vazões da Furnas 416

APÊNDICE K.12 Séries Históricas Bacia do Rio Paraná - Vazões da Usina de Barra Bonita 417

APÊNDICE K.13 Séries Históricas Bacia do Iguaçu - Vazões da Usina de Foz do Areia 418

APÊNDICE K.14 Séries H. Bacia do Tocantins - Vazões da Usina de Serra da Mesa 419

APÊNDICE K.15 Séries Históricas Bacia do São Francisco -Usina de Usina Queimado 420 
APÊNDICE K.16 Séries Históricas Bacia do São Francisco -Usina de Retiro Baixo 421

APÊNDICE K.17 Séries Históricas Bacia do São Francisco - Usina de Três Marias 422

APÊNDICE K.18 Séries Históricas Bacia do Parnaíba - Vazões Usina de Boa Esperança 423

APÊNDICE K.19 Séries Históricas Bacia Amazônica - Vazões Usina de Guaporé 424

APÊNDICE K.20 Séries Históricas Bacia do Uruguai - Vazões Usina de Passo Fundo 426

APÊNDICE L Análise de mapas de TSM georreferenciada $\quad 427$

APÊNDICE L.1 ACP TSM HadISST versos TSM ERSST 427

APÊNDICE L.2 Correlação ENA Região Sudeste versos TSM oceanos mundo 432

APÊNDICE L.2.1 1931-2014 HadISST

APÊNDICE L.2.2 1931-2014 ERSST

APÊNDICE L.2.3 1973-2014 HadISST

APÊNDICE L.2.4 1973-2014 ERSST

APÊNDICE L.2.5 1984-2014 HadISST

APÊNDICE L.2.6 1984-2014 ERSST

APÊNDICE L.3 Correlação ENA Região Sul versos TSM dos oceanos 439

APÊNDICE L.3.1 1931-2013 HadISST

APÊNDICE L.3.2 1931-2013 ERSST 440

APÊNDICE L.3.3 1973-2013 HadISST

APÊNDICE L.3.4 1973-2013 ERSST $\quad 442$

APÊNDICE L.3.5 1983-2013 HadISST

APÊNDICE L.3.6 1983-2013 ERSST

APÊNDICE L.4 Correlação ENA Região Norte versos TSM dos oceanos 445

APÊNDICE L.4.1 1931-2013 HadISST $\quad 445$

APÊNDICE L.4.2 1931-2013 ERSST 446

APÊNDICE L.4.3 1973-2013 HadISST 447

APÊNDICE L.4.4 1973-2013 ERSST $\quad 448$

APÊNDICE L.4.5 1983-2013 HadISST $\quad 449$

APÊNDICE L.4.6 1983-2013 ERSST $\quad 450$

APÊNDICE L.5 Correlação ENA Região Nordeste versos TSM dos oceanos 451

APÊNDICE L.5.1 1931-2013 HadISST $\quad 451$

APÊNDICE L.5.2 1931-2013 ERSST $\quad 452$

APÊNDICE L.5.3 1973-2013 HadISST

APÊNDICE L.5.4 1973-2013 ERSST $\quad 454$

APÊNDICE L.5.5 1983-2013 HadISST

APÊNDICE L.5.6 1983-2013 ERSST 456

APÊNDICE M Análise de Mapas versos Usinas 457

APÊNDICE M.1 HadISST e ERSST - JAN/DEZ 458 
APÊNDICE M.1.1 Sudeste

APÊNDICE M.1.1.1 1931 - 2014 HadISST

APÊNDICE M.1.1.2 1931 - 2014 ERSST

APÊNDICE M.1.1.3 1974 - 2014 HadISST

464

APÊNDICE M.1.1.4 1974 - 2014 ERSST

465

APÊNDICE M.1.1.5 1984 - 2014 HadISST

466

APÊNDICE M.1.1.61984 - 2014 ERSST

467

APÊNDICE M.2 HadISST e ERSST - JAN/DEZ

468

APÊNDICE M.2.1 Bacia Paraná

468

APÊNDICE M.2.1.1 1931-2014 HadISST

468

APÊNDICE M.2.1.2 1931-2014 ERSST

469

APÊNDICE M.2.1.3 1973-2014 HadISST

470

APÊNDICE M.2.1.4 1973-2014 ERSST

471

APÊNDICE M.2.1.5 1984-2014 HadISST

472

APÊNDICE M.2.1.61984 - 2014 ERSST

473

APÊNDICE M.2.2 Usina Barra Bonita

474

APÊNDICE M.2.2.1 1931 - 2014 HadISST

474

APÊNDICE M.2.2.2 1931 - 2014 ERSST

475

APÊNDICE M.2.2.3 1973 - 2014 HadISST

476

APÊNDICE M.2.2.4 1973 - 2014 ERSST

477

APÊNDICE M.2.2.5 1984 - 2014 HadISST

478

APÊNDICE M.2.2.61984 - 2014 ERSST

479

APÊNDICE N Correlação Clima x Energia

480

APÊNDICE N.1 Correlações Entre Usinas

480

APÊNDICE N.1.1 ONI e MEI versos ENA

482

APÊNDICE N.1.2 El Niño 1+2 versos usinas

484

APÊNDICE N.1.3 TSM El Niño 1+2, 3, 3.4e 4

485

APÊNDICE N.1.4 Índices de TSM EINiño 1+2, 3, 3.4 e 4 versos ENA e bacias

APÊNDICE N.1.5 Índices de AMO

APÊNDICE N.1.5.1 Índices de AMO versos usinas

APÊNDICE N.1.5.2 Índices de AMO versos ENA e bacias

APÊNDICE N.1.5.3 Índices de Oscilação dos Polos

APÊNDICE N.1.6 Solar

APÊNDICE N.1.6.1 Número de Machas Solares

APÊNDICE N.1.6.2 Machas Solares versos Usinas

APÊNDICE N.1.6.3 Machas Solares versos ENA e Bacias 
APÊNDICE N.2.1 Intercepto

APÊNDICE N.2.2 Parâmetros autorregressivos $\phi \quad 497$

APÊNDICE N.2.3 Parâmetros médias móveis $\Theta \quad 498$

APÊNDICE N.2.4 Parâmetros autorregressivos sazonais $\Phi \quad 498$

APÊNDICE N.2.5 Parâmetros médias móveis sazonais $\Theta \quad 499$

APÊNDICE N.2.6 Parâmetros de regressão 499

APÊNDICE O Apêndice Validação Cruzada 499

ANEXO - A OBSERVING A QUIETER SUN: A WEAK CYCLE OFFERS OPPORTUNITY FOR

EXPANDING SOLAR UNDERSTANDING 503 


\section{CAPÍTULO 1}

\section{INTRODUÇÃO}

De acordo com a Empresa de Pesquisas Energética (EPE), a geração de energia elétrica chegou a 590.479 Gigawatt-hora (GWh) em 2014, 73\% dessa produção foi realizada por usinas com fontes renováveis $(\mathbf{6 3} \%$ hidrelétricas, $5 \%$ bagaço de cana, $2 \%$ lixívia e $2 \%$ por usinas eólicas) e $27 \%$ por usinas com fontes não renováveis (14\% gás natural, 3\% carvão vapor, $3 \%$ óleo combustível, $3 \%$ urânio, $2 \%$ óleo diesel, $2 \%$ outras fontes não renováveis). Na Figura 1-1, apresentam-se a evolução das usinas e a importância das hidrelétricas no Setor Elétrico Brasileiro (SEB). Em termos de capacidade de geração instalada no Brasil, havia aproximadamente $142 \mathrm{GW}$ no ano de 2015. As usinas de fonte renovável correspondem a 113,3 GW (75,3\%) e as de fonte não renovável equivalem a 29,1 GW (19,33 \%), Tabela 3-2, p. 99. As usinas de fontes renováveis são mais dependentes das condições do tempo, como por exemplo, as hidrelétricas e as termoelétricas a biomassa, que dependem da chuva, e as eólicas, que dependem da força resultante dos ventos. As renováveis têm como vantagem a energia potencial proveniente das chuvas ou mesmo do processo de fotossíntese que não oferecem nenhum custo às usinas, como por exemplo, o custo de combustível para as usinas termelétricas movidas com combustíveis fósseis. A principal desvantagem é sua dependência a fatores climáticos provocados pela variabilidade climática que pode resultar em secas, cheias, geadas e outros que de certa forma podem ser impactantes.

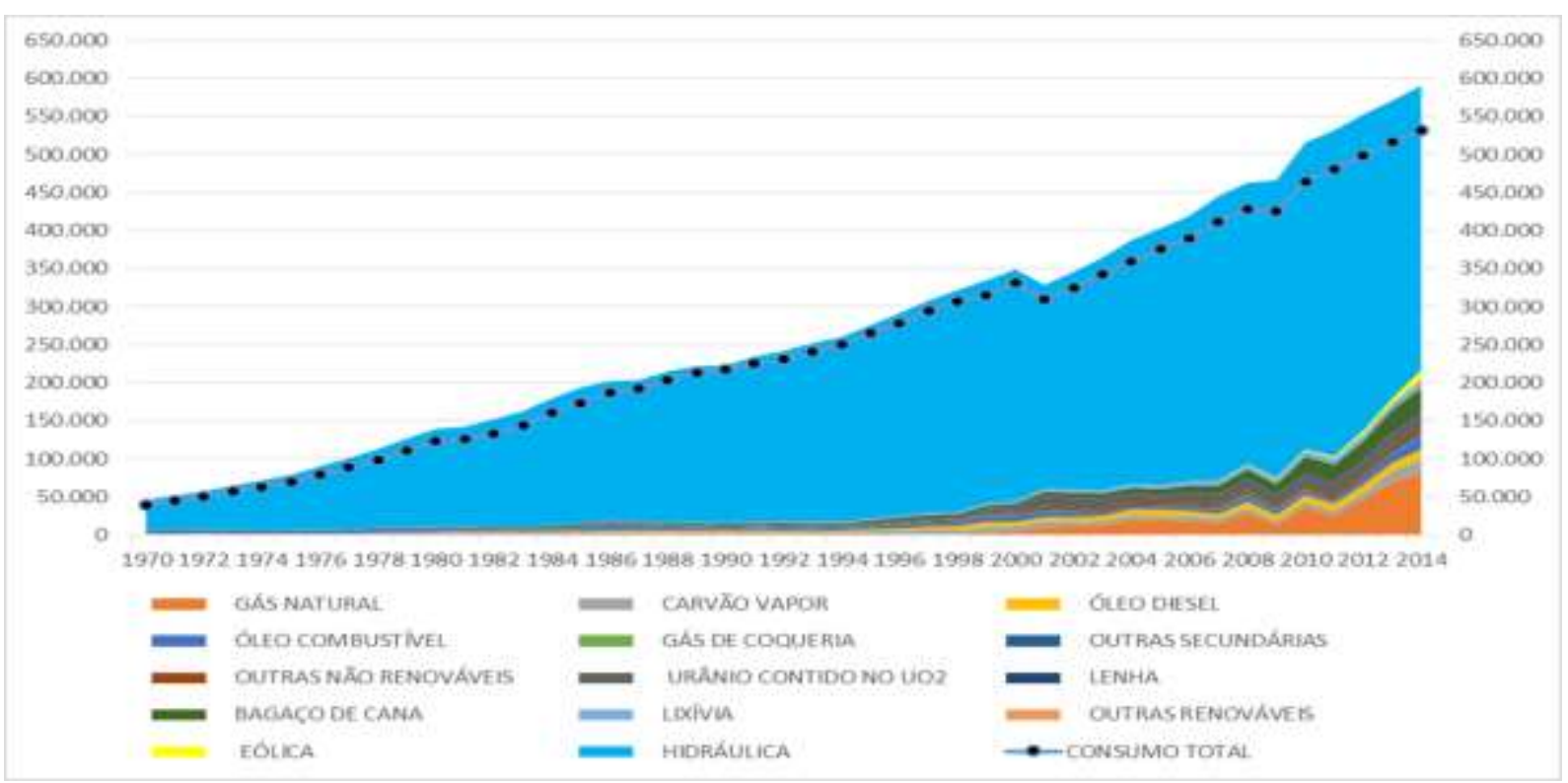

Figura 1-1 Evolução da Produção versos Consumo de Energia Elétrica no Brasil em GWh. Fonte: BEN, 2015. 


\subsection{Formulação do Problema}

No mundo, gestores do setor de água e energia enfrentam novos desafios para atender a grande demanda de uso, em razão das mudanças da variabilidade climática, crescimento populacional, evolução econômica e questões ambientais. No Brasil, em virtude das ocorrências de períodos secos na região Sudeste em 2014 e na região Nordeste, em 2014 e 2015, ocorreu um importante impacto no fornecimento de eletricidade, onde os reservatórios das hidrelétricas encontravam-se deplecionados e que, por conseguinte tornou necessário o acionamento de usinas térmicas (ONS-OPHEN, 2016) produtoras de maiores despesas, pois utilizam combustíveis em seu funcionamento. Desse modo, não obstante os recursos renováveis como chuva, sol e o vento serem fornecidos pela natureza, o Operador Nacional do Sistema Elétrico (ONS) planeja e opera os reservatórios das usinas que compõe o Sistema Interligado Nacional (SIN) por intermédio de um conjunto de modelos que valoriza monetariamente a oportunidade de usar ou não as águas represadas. Mesmo com a grande importância das chuvas, os modelos utilizados pelo ONS, na operação e planejamento da expansão e construção das hidrelétricas, não consideram os efeitos do clima em seus cálculos. Um indicador de possíveis chuvas na região Sudeste é o fenômeno chamado El Niño, onde geralmente, quando ocorre, há maior incidência de chuvas nas regiões Sul, Sudeste e Centro Oeste e favorecimento dos grandes reservatórios. Já, para o Norte e Nordeste, geralmente, ocorre períodos de estiagem. A ocorrência do fenômeno El Niño ou La Niña (base índice ONI, p. 142) pode ser observado na Figura 1-2. Aqui as barras classificadas pelo tamanho da barra, do menor ao maior, para indicar a intensidade das ocorrências dos fenômenos El Niño ou La Niña que são: fraco, moderado, forte e muito forte, mais o ano correspondente. Maiores detalhes sobre esse fenômeno podem ser vistos na seção 3.3 El Niño-Oscilação Sul (ENOS), p. 87.

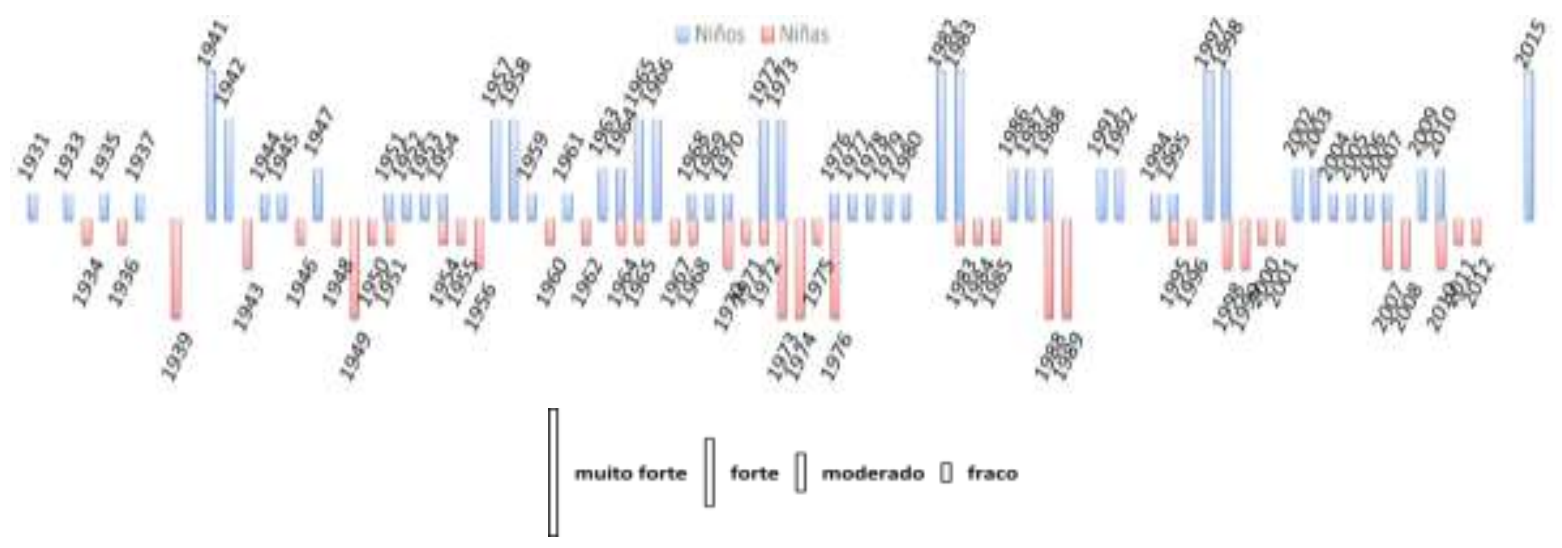

Figura 1-2 - Ano de ocorrência fenômenos El Niño e La Niña entre 1931 a 2015 
Na Figura 1-3, apresentam-se (gráfico de área) a série histórica de Energia Natural Afluente (ENA) medidas aqui em Terawatt-hora (TWh) dos submercados do Sudeste (ENA-SE) e Sul (ENA-S) de 1931 a 2015, frente às ocorrências do fenômeno El Niño ou La Niña (gráfico de barras). Para a ENA-SE constata-se que, nos anos de 1957, 1965,1982, 1983, 1997, 1998 e 2015, ocorreram fenômenos El Niño forte ou muito forte, com os aumentos expressivos da Temperatura da Superfície do Mar (TSM), e na ENA-SE há coincidências em picos e vales que indicam possíveis correlações entre ambas a série histórica de ENA e os eventos do El Niño. Mais adiante uma análise com o uso de ferramenta de correlação é elaborada na seção 6.5 Matrix para Correlação das Séries históricas, p. 194.

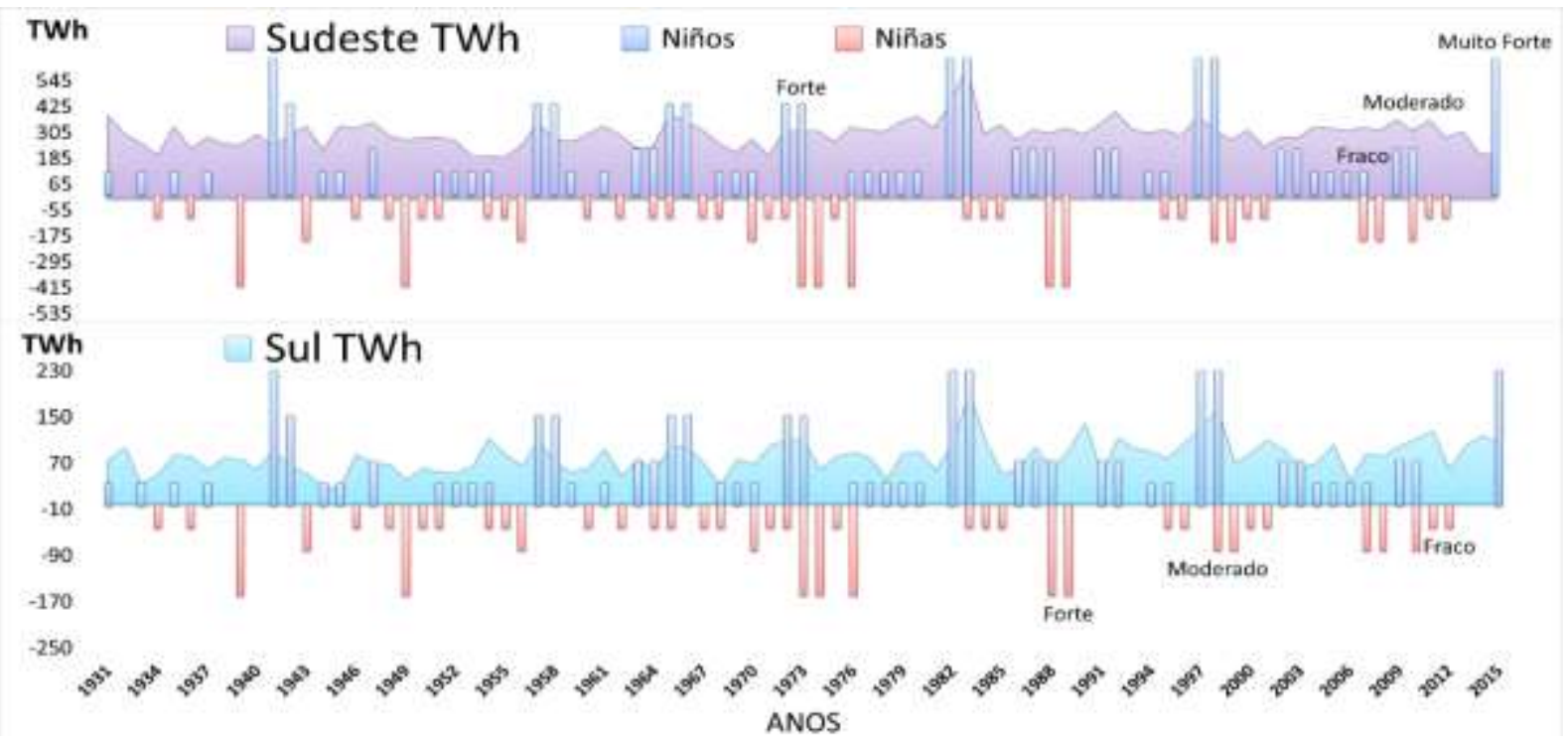

Figura 1-3 - Fenômenos El Niño e La Niña versos ENA Sudeste e Sul em TWh. Elaboração própria com dados do ONS.

Para a região Sul há ocorrências coincidentes entre os fenômenos El Niño e La Niña e a ENASUL, como em 1982, 1983, 1997, 1998, porém, devido o Sul receber chuva o ano todo, resultado de diferentes fenômenos, além do El Niño, há ocorrências do fenômeno muito forte (El Niño ou La Niña), porém, não há um correspondente na ENA-S, como em 1941, 1942, 1957, 1958, 1965 e 1966, pois podem ocorrer outros fenômenos que potencializam ou inibem a influência do El Niño nas chuvas. Maiores detalhes são abordados em seções posteriores. 
Na Figura 1-4, apresentam-se as séries históricas de ENA dos submercados Nordeste (ENANE) e Norte (ENA-N) de 1931 a 2015 frente aos fenômenos El Niño e La Niña que ocorrem no oceano Pacífico. Observa-se, em 1956, 1982 e 1998 aumentos expressivos nas TSM e também há correspondentes nas ENA-NE e ENA-N. Porém, nos demais anos, há picos e vales que não coincidem principalmente no gráfico da região Norte, que indica possível existência de correlações inversas, entre as séries históricas de El Niño e ENA-NE ou ENA-N. Mais adiante uma análise com o uso de ferramenta de correlação é elaborada na seção 6.5 Matrix para Correlação das Séries históricas, p. 194.

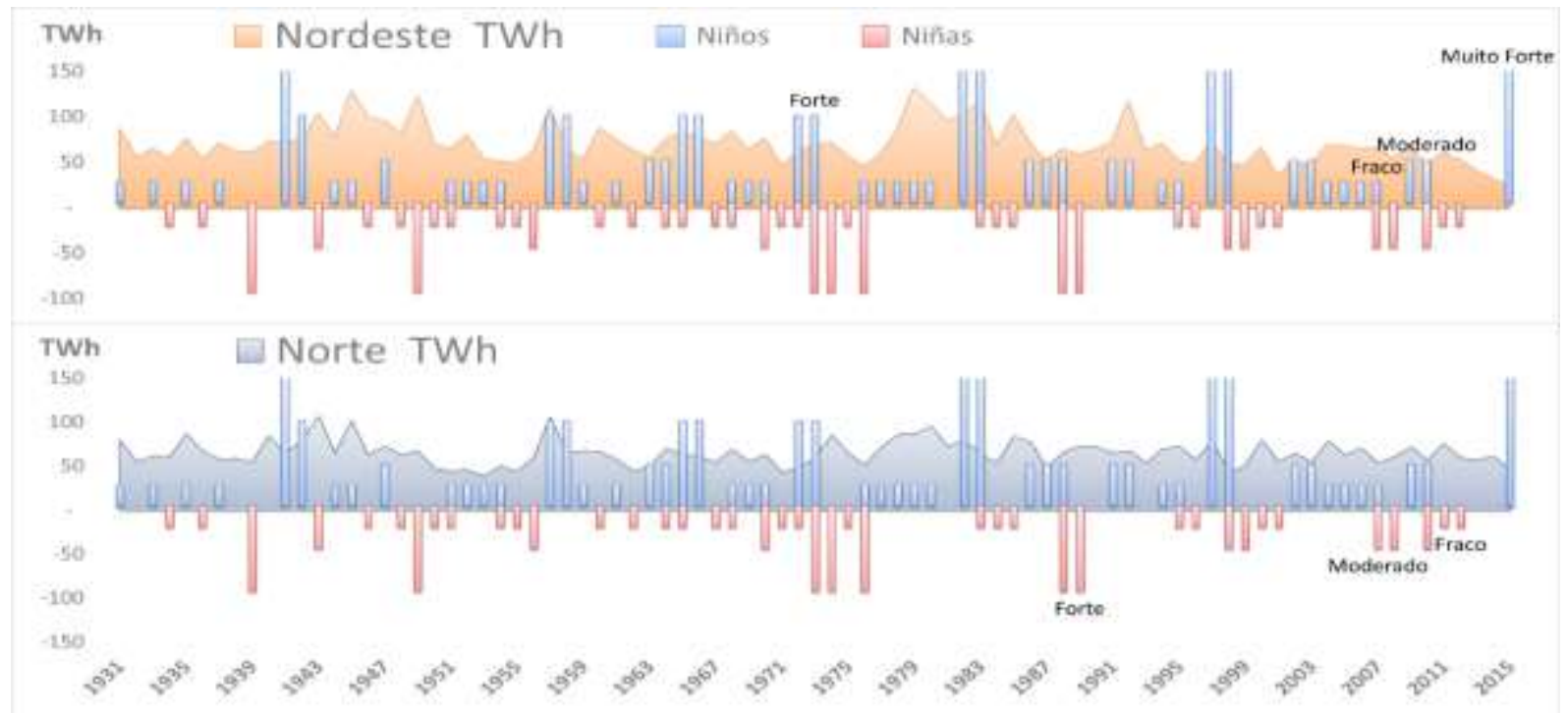

Figura 1-4 - Fenômenos El Niño e La Niña versos ENA Nordeste e Norte em TWh. Elaboração própria com dados do ONS.

Portanto, a região Norte, sofre o processo inverso da região Sudeste, em geral, há estiagem nessa região em períodos de El Niño. Há também influência do oceano Atlântico devido à formação de grandes sistemas de massas de ar de alta ou baixa pressão e zonas de instabilidade que contribuem ou inibem a formação de chuvas no Norte. Também há o deslocamento da Zona de Convergência Intertropical (ZCIT), levando umidade de precipitações para perto ou longe das regiões Norte ou Nordeste. Portanto, além dos fenômenos do El Niño, outros fenômenos são associados com as precipitações das regiões Norte e Nordeste e, posteriormente são considerados. 
O planejamento operacional das usinas do SEB é realizado por intermédio do uso dos sistemas do Modelo de Planejamento da Operação de Sistemas Hidrotérmicos Interligados de Longo e Médio Prazo (NEWAVE) e o Determinação da Coordenação da Operação à Curto Prazo (DECOMP), atualizados pelo ONS e pela Câmara Comercializadora de Energia Elétrica (CCEE), é de suma importância para o planejamento do setor com os objetivos de manter e expandir o sistema. Um indicador gerado nesses sistemas é o Custo Marginal de Operação (CMO). Na Figura 1-5, apresenta-se o valor do CMO, que em geral, apresenta alta volatilidade, frente aos valores de Armazenamento, nos anos mais secos, com os reservatórios deplecionados, e, com valores moderados e estáveis, em anos com reservatórios cheios. As previsões desses custos está associado ao preço do Custo Variável Unitário (CVU) das usinas térmicas, nível dos reservatórios, afluências históricas e futuras, todos incluídos no NEWAVE/DECOMP, e que evidenciam a necessidade de inúmeras pesquisas na ciência do funcionamento e aperfeiçoamento dessas ferramentas ou mesmo elaboração de novas (RODRIGUES, 2009), para se evitar a volatilidade inerente em sistemas dinâmicos e estocásticos e melhorar seus resultados.

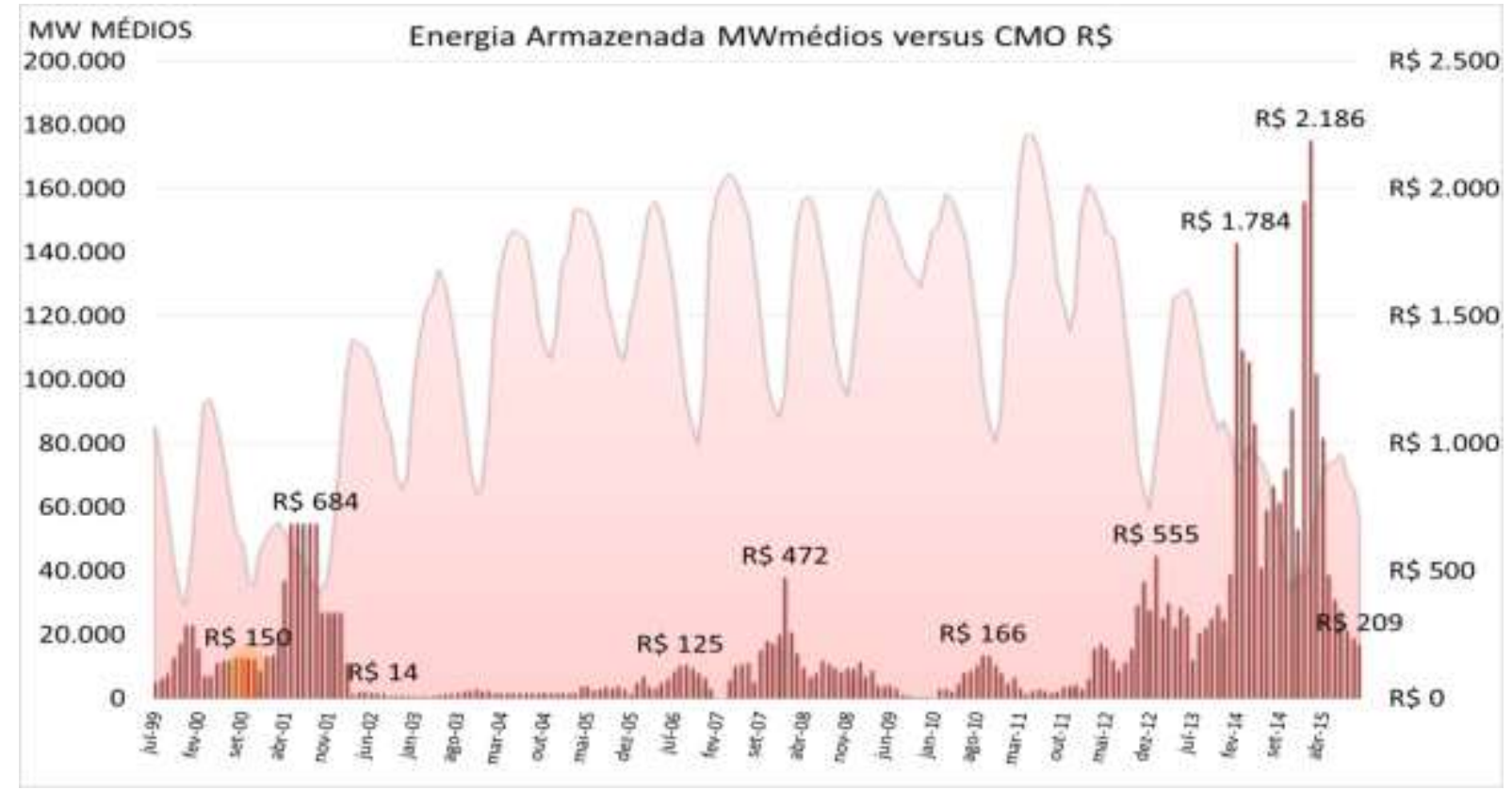

Figura 1-5 - Energia Armazenada (MWmédios) versos Custo Marginal de Operação (CMO - R\$) para o patamar pesado - Região Sudeste. Fonte ONS \& CCEE, 2015. ${ }^{3}$

Um aspecto que gera discussões (ONS, 2007; MARKETS, 2008; ENERGIAS do Brasil, 2008) é o NEWAVE, única ferramenta computacional oficial para realizar o planejamento da

\footnotetext{
${ }^{3}$ Fonte

http://www2.aneel.gov.br/aplicacoes/Audiencia_Publica/audiencia_proton/2001/ap002/Nota\%20Tecnica.pdf
} 
operação e expansão do SIN, o que impossibilita outras abordagens de serem utilizadas oficialmente. E também, outro aspecto, é que a Ciência de planejamento de operação poderia ser aperfeiçoada e validada por mais instituições, além do Centro de Pesquisas de Energia Elétrica (Cepel) órgão vinculado a Eletrobrás e sediado no Rio de Janeiro - detentor dos direitos de propriedade e venda da licença de uso do NEWAVE, que em 2015 estava R\$ $122.000,00$, e renovações anuais de $\mathrm{R} \$ 8.000,00$.

A metodologia utilizada no NEWAVE é o modelo periódico autorregressivo (PAR) que utiliza em sua estrutura a geração de 2000 séries sintéticas de vazões futuras mensais aproveitadas no algoritmo de simulação da operação, de custo ótimo, com base no uso da Programação Dinâmica Estocástica Dual (PDED), que será descrita na seção de revisão bibliográfica. Em nenhum momento são inseridas informações climáticas nesse modelo. Segundo Hernandez (2011), os modelos autorregressivos (AR) foram muito utilizados no Setor Elétrico da Colômbia na década de 1980 e, atualmente, foram substituídos pelos modelos de Programação Não Linear (PNL) que incorporam a análise de variáveis macroclimáticas, como o El Niño Oscilação Sul (ENOS).

A metodologia que combina diversas técnicas de Hernandez (2011), o modelo de PNL e Sistema de Suporte à Decisão (SSD) Hidroterm de Zambon et al (2012), o qual trabalha com usinas individualizadas, ou o trabalho SolverSIN de Lopes (2007), trabalha com reservatórios equivalentes como é realizado no NEWAVE, são exemplos que contribuem para a representação e modelagem do SIN, que, contrariamente ao NEWAVE, utiliza PNL. Tais modelos consideram não somente aspectos equivalentes ou aproximados (linearização), mas também aspectos com maior representatividade com a realidade técnica, física, hidrológica e econômica dos sistemas de planejamento e operação existentes.

Esses trabalhos, exceto o de Hernandez (2011), até o momento não utilizam, em seus sistemas, variáveis macroclimáticas para explicar as vazões. Basicamente, focam a história e a operação do sistema. Esse trabalho busca contribuir para o preenchimento dessa lacuna.

A decisão de utilizar água de reservatórios como base na produção de eletricidade é um problema difícil de ser solucionado em razão da estocasticidade do sistema (MOROMISATO, 2012). Nessa tese, o problema a ser abordado é justamente como melhorar a predição ou construção de cenários da disponibilidade de água e energia futuras, com a inclusão das informações climáticas. Na Figura 1-6, descreve-se o dilema da tomada de decisão da operação de usinas, utilizar ou não utilizar as águas armazenadas para gerar energia. Torna-se evidente que, a decisão depende de mecanismos climatológicos, além dos hidrológicos, uma 
vez que a afluência futura, de forma simplificada, traduz-se na ocorrência das chuvas que dependem de estudos meteorológicos e climatológicos para sua predição.

Na Figura 1-6, apresenta-se o dilema do ONS em utilizar ou não a água dos reservatórios.

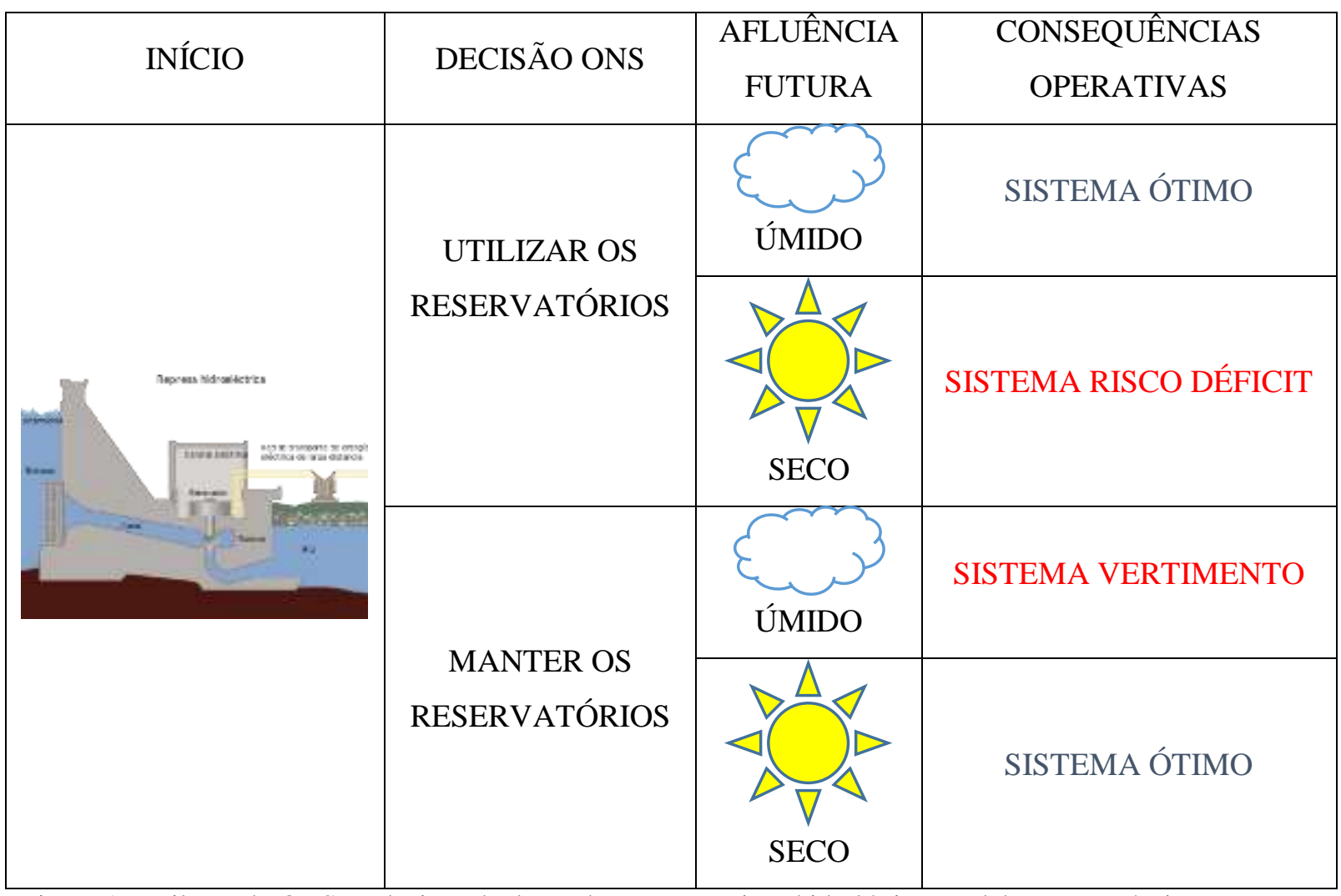

Figura 1-6 Dilema do ONS na decisão de despachar ou não usinas hidrelétricas - elaboração própria

A seguir, são descritas resumidamente as decisões do ONS e as suas consequências:

- Se o ONS decidir despachar a água dos reservatórios, o operador espera que as afluências futuras reabasteçam os reservatórios: Decisão correta. Caso as afluências futuras não sejam as esperadas, consequentemente haverá um custo adicional pela utilização das usinas térmicas e também um risco de déficit de energia (com a possibilidade de racionamento de energia ou corte de carga);

- Se o ONS decidir não despachar a água dos reservatórios e utilizar as usinas térmicas, o operador mantem as afluências futuras até o valor do armazenamento máximo: Decisão correta. Caso as afluências futuras sejam maiores que os valores esperados, o armazenamento máximo dos reservatórios é ultrapassado e o operador é obrigado a verter água, desperdiçando energia.

Outra característica intrínseca do sistema elétrico brasileiro é a distribuição do parque gerador hidrelétrico nas quatro regiões ou submercados (N, S, SE/CO e NE). Na maioria delas, as usinas hidráulicas são organizadas ao longo de cascatas. Isso significa que todo o volume de água turbinado ou vertido numa usina pode ser reaproveitado na usina que está imediatamente 
à jusante dessa e, assim, sucessivamente, até a última usina do curso do rio. Essa característica é denominada acoplamento espacial da operação (TERRY ET AL, 1986).

As vazões afluentes estão ligadas à enorme variabilidade do macroclima que influem na hidrologia em diversas escalas espaciais e temporais. Qualquer evento hidrológico dispõe de uma característica altamente não linear e sua previsão está sujeita a mudanças drásticas definidas por condições iniciais e posição espaço-temporal onde se analisam as variáveis e fenômenos envolvidos. Ademais, a otimização da operação do sistema elétrico brasileiro apresenta-se como um problema complexo em razão de alguns fatores relevantes que dificultam o planejamento como, a seguir.

- Estocasticidade das chuvas (quantidade e local onde há precipitações);

- Estocasticidade dos ventos (intermitência, rajadas, calmaria, mudança de direção e magnitude);

- Estocasticidade das vazões naturais dos rios;

- Demanda crescente da água;

- Grande número de usinas hidráulicas (usinas com reservatório e fio d'água), Figura $3-2, \mathrm{p} 85$

- Preço dos combustíveis das usinas térmicas de fontes não renováveis (gás natural, óleo combustível, diesel, carvão, urânio).

Esses fatores evidenciam o sistema elétrico brasileiro como único no mundo por seu tamanho e características (Figura 1-9).

E a operação tem despachado usinas térmicas para compensar o ciclo hidrológico desfavorável. Antes planejadas para serem despachadas em pequenos períodos, usinas a óleo combustível ou óleo diesel, foram despachadas durante muitos meses (ONS, 2015) e a conta de seus gastos com combustíveis foi repassada para a população.

O Brasil, detentor de 8,5 milhões de $\mathrm{km}^{2}$ de território continental, ocupa uma extensão longitudinal que vai de $5^{\circ} \mathrm{N}$ a $34^{\circ} \mathrm{S}$ englobando o Equador e o Trópico de Capricórnio. Ademais dispõe de uma extensa faixa litorânea com $7.362 \mathrm{~km}$ voltada para o oceano Atlântico e dele sofre influências climáticas, e seu território que envolve cerca de $40 \%$ da América Latina. Desse modo, em virtude de suas dimensões continentais e da influência de diferentes padrões climatológicos, existe a possibilidade de desenvolvimento de pesquisa no planejamento de operação de usinas hidrelétricas. Esse planejamento é de suma importância, pois busca garantir o fornecimento de energia elétrica à população com baixo risco de falhas, com qualidade e modicidade dos custos. O planejamento se empenha em criar um sistema 
para longo prazo e faz projeções com base no crescimento populacional, econômico e nas previsões de afluências por intermédio de seus modelos de otimização de operação do setor. Usufruir de variáveis climáticas para reduzir o risco hidrológico é um caso particular onde se procura minimizar o impacto da variabilidade de sua oferta. Desse modo, o Brasil pode ser caracterizado como laboratório de um sistema elétrico largamente dependente de fontes renováveis que é capaz de ser operado para minimizar os riscos associados à utilização de tais fontes.

O ONS monitora o nível dos reservatórios, coleta informações sobre o nível de água armazenado nas usinas hidrelétricas e a partir dessas informações atualiza seu planejamento. Para os anos de 2014 e 2015, na Figura 1-7, apresenta-se os níveis dos reservatórios organizados por região. Em outubro de 2014, os reservatórios da região Sudeste apresentavam-se com $19 \%$ de sua capacidade o que gerou várias notícias de um possível racionamento.

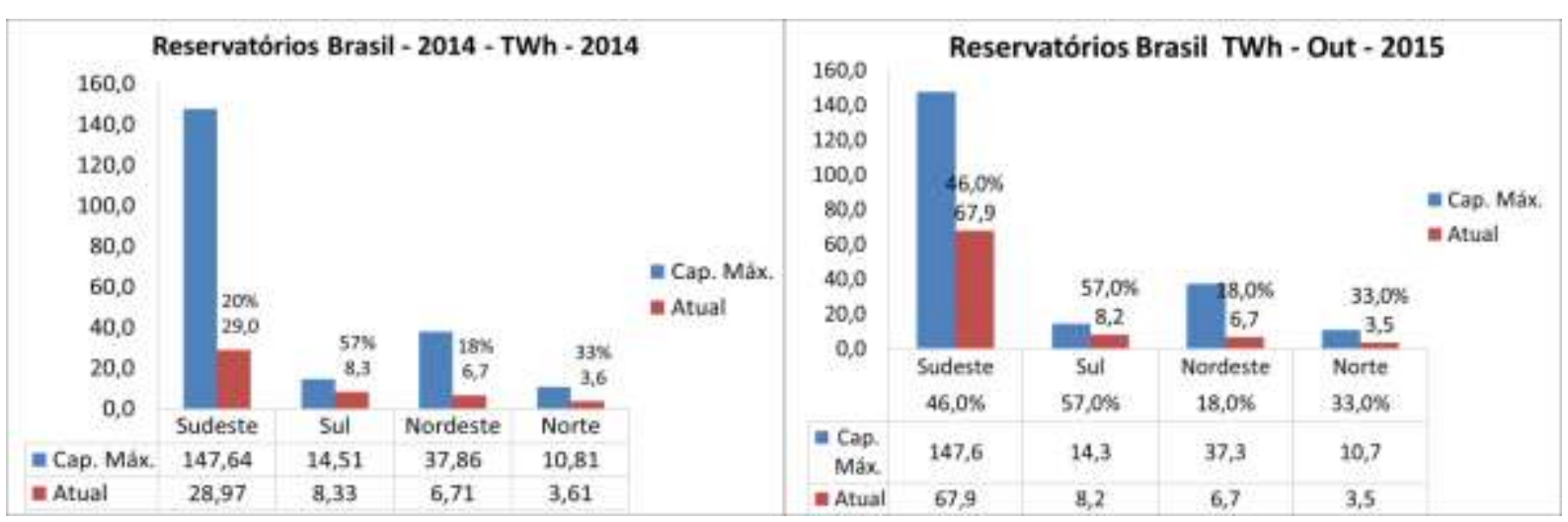

Figura 1-7 Nível dos reservatórios. Elaboração própria com dados ONS 2014 e 2015.

Em outubro de 2015, os reservatórios apresentaram um melhor desempenho em consequência à recessão econômica e também à maior oferta de energia provocada pelo fenômeno forte do El Niño-Oscilação Sul (ENOS) o qual promove chuvas sobre a América do Sul (AS). Os meteorologistas ${ }^{4}$ observaram, no início de 2015, a atuação do fenômeno até o final do verão de 2015/2016, Figura 1-8.

Na Figura 1-8 a), apresenta-se anomalias de TSM na região Leste da América do Sul, próxima a linha do equador, onde surgem águas com temperaturas de $4^{\circ} \mathrm{C}$ ou até $5^{\circ} \mathrm{C}$ acima da média, e em b), há evidência de que as temperaturas começaram a subir a partir do mês de abril de 2014, porém sem ultrapassar $1^{\circ} \mathrm{C}$. O fenômeno El Niño será apresentado mais adiante na revisão bibliográfica, seção 3.2 Temperatura da Superfície do Mar (TSM), p. 86.

\footnotetext{
${ }^{4}$ http://enos.cptec.inpe.br/
} 


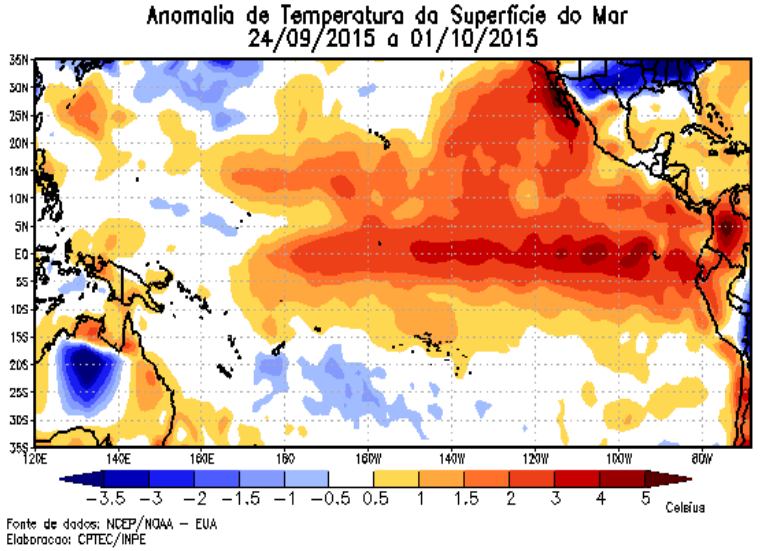

a)

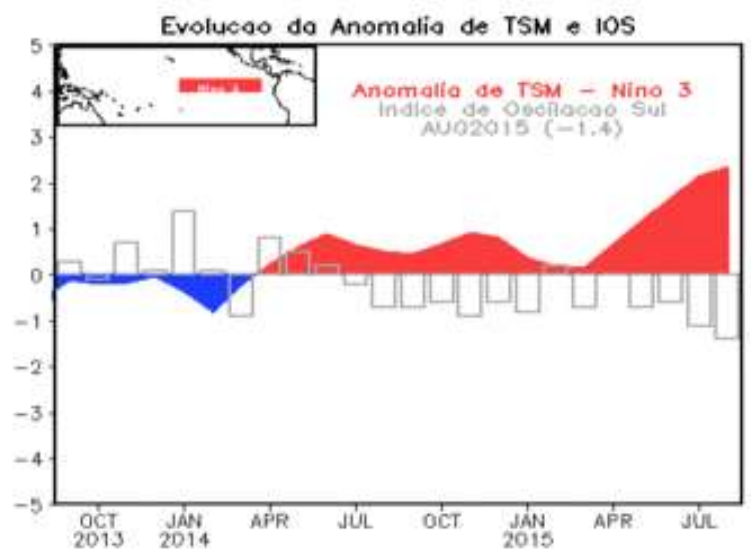

b)

Figura 1-8 Evolução da anomalia de temperatura da superfície do mar (TSM) região Niño 3. Fonte http://enos.cptec.inpe.br/ acesso 02/10/2015.

No início da construção do SEB, no século XIX, a alta disponibilidade de potencial hidráulico próxima dos grandes centros de consumo foi um dos fatores preponderantes para que o Brasil optasse pelo desenvolvimento da hidroeletricidade. As atividades de geração, transmissão e distribuição de energia no país passaram para o controle de empresas privadas e estrangeiras responsáveis pelo serviço de atendimento de grandes cidades (MENDES, 2015). Na década de 1950, a forte industrialização do Brasil e o crescimento urbano implicaram o investimento no setor elétrico realizado pelos governos federal e alguns estaduais. Construiu-se, de forma gradativa, a interligação de várias das usinas de grande porte que hoje constituem o Sistema Interligado Nacional (SIN) ${ }^{5}$.

O crescimento industrial, o aumento dos usos consuntivos da água, a crescente demanda e os diferentes fins dessa, intensificaram o consumo de recursos hídricos. Por outro lado, a redução da oferta hídrica ocasionou, em algumas regiões brasileiras, situações onde os múltiplos usos da água tornaram-se concorrentes e acarretaram conflitos entre os usuários (MENDES, 2015). Em 2001, a crise de energia ocorrida no País demonstrou os conflitos e os impactos negativos desencadeados em um cenário de disputa pelo escasso recurso hídrico. As regras de operação dos reservatórios, impostas para suprir a demanda de energia, trouxeram consequências indesejáveis a outras atividades econômicas como a navegação, a agricultura irrigada, o

\footnotetext{
${ }^{5}$ Kelman et al, 2006.
} 
turismo e o abastecimento público. Tal situação repetiu-se em 2014 com a seca do Sudeste na época do verão austral ${ }^{6}$ (COELHO ET AL, 2015).

O SIN, formado por 4258 usinas (ANEEL, 2015) para geração de eletricidade no Brasil, e o ONS realiza a gestão de um sistema de dimensões continentais. Na Figura 1-9, apresenta-se as principais fontes, linhas de transmissão entre usinas que cobre pouco mais da metade do território nacional e na Tabela 3-2, p. 99, apresenta-se as fontes com maior detalhamento. O SIN pode ser identificado como um dos maiores sistemas de energia elétrica do mundo e chega a ter dimensões equivalentes à Europa.

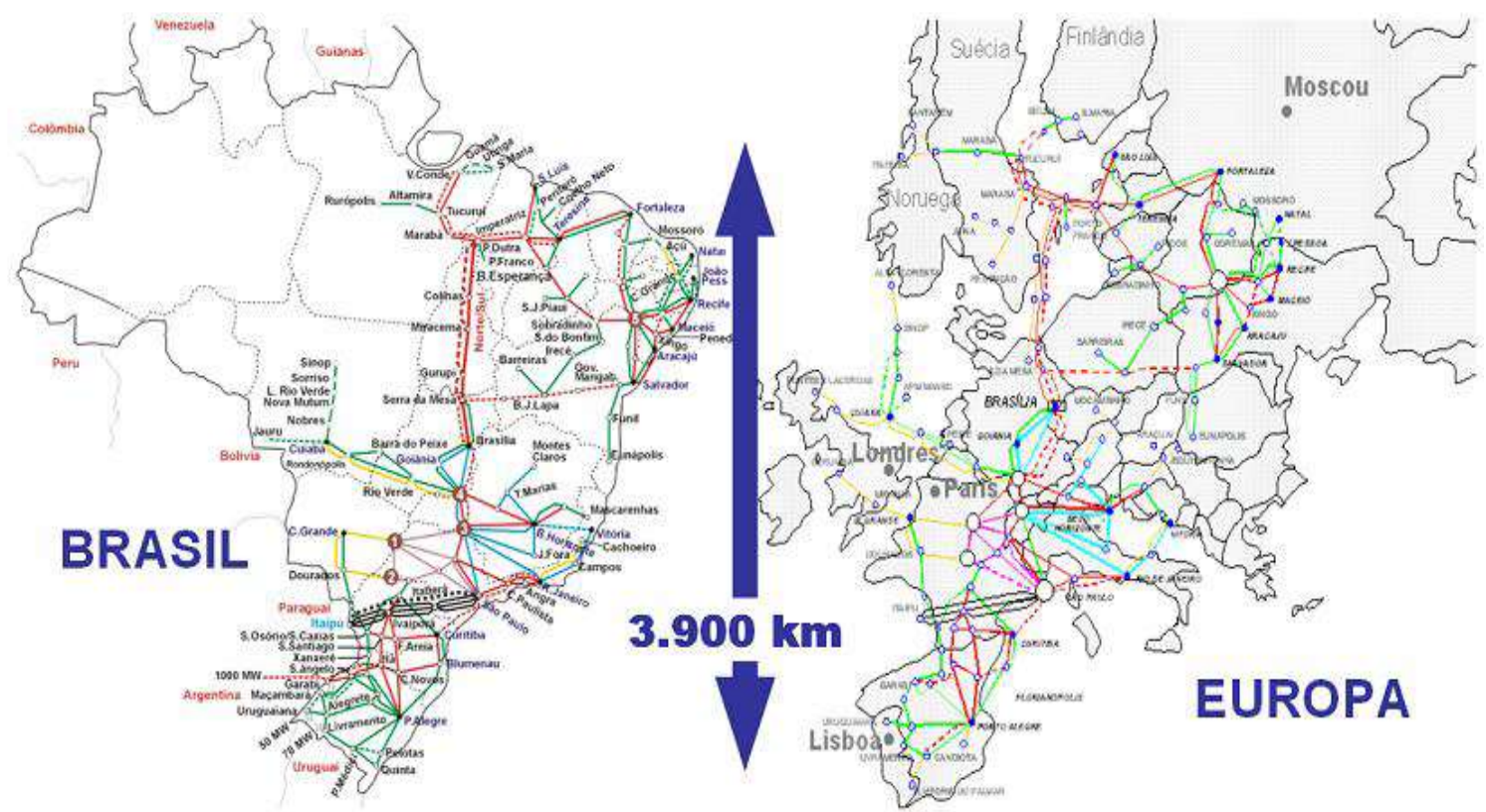

Figura 1-9 Sistema Interligado Nacional versos tamanho da Europa + parte da Rússia. Fonte: Souza \& Oliveira, 2012 e de Melo, Alberto, 2007. C.. Hydropower in a Brazilian Perspective. IEA NEET Workshop. Brasília, 1920 Nov., 2007

O Painel Intergovernamental sobre Mudanças Climáticas (IPCC) menciona um possível aumento de $90 \%$ da frequência de chuvas intensas no século $\mathrm{XXI}^{7}$, e uma intensificação potencial de escoamento superior ao intervalo de $10 \%$ a $40 \%$ (METZ, 2007), que teria repercussões negativas sobre a gestão de recursos hídricos, pois o aumento da variabilidade implica o aumento das incertezas. Esse acréscimo de incertezas dificulta a previsão, o

\footnotetext{
${ }^{6} \mathrm{O}$ verão do hemisfério norte é chamado de "verão boreal", e o do hemisfério sul é chamado de "verão austral". O "verão boreal" tem início com o solstício de verão do Hemisfério Norte, que acontece cerca de 21 de Junho, e termina com o equinócio de Outono nesse mesmo hemisfério, por volta de 23 de Setembro.

O "verão austral" tem início com o solstício de verão do Hemisfério Sul, que acontece cerca de 21 de Dezembro, e finda com o equinócio de outono, por volta de 20 de Março nesse mesmo hemisfério. Fonte: https://pt.wikipedia.org/wiki/Verão. Acesso Ago/2016.

${ }_{7}$ Apesar de chuvas intensas soarem como positivo para o SEB, podem trazer riscos como rompimento de barragens ou o efeito de afogamento do escoadouro da usina (RAMOS, 2009), que ocorrem quando o nível a jusante de uma usina sobe o que acaba por diminuir sua altura potencial, como ocorreu nas de Jirau e Santo Antônio com as fortes cheias de 2014.
} 
planejamento e operação dos reservatórios. A difícil busca por um planejamento eficiente para a expansão e operação de reservatórios que têm como finalidade gerar eletricidade necessita de um longo tempo e maior exatidão nas previsões de vazões da água dos rios, para desse modo fornecer informações que sirvam de suporte para tomada de decisões.

O clima, apresenta-se comum comportamento aproximadamente estacionário, (tempo não), pois o balanço de energia e a temperatura média mudam lentamente uma vez que o posicionamento dos continentes leva centenas de milhões de anos (WEGENER, 1922), a orientação do eixo de rotação, levam dezenas a centenas de milhares de anos (MILANKOVITCH, 1930), e a composição da atmosfera, se não for considerada a atividade humana, varia entre as duas escalas de tempo (FELDMAN et al., 2015).

Os padrões de grande escala da circulação atmosférica determinam a distribuição de temperatura e precipitação sobre a superfície terrestre, por intermédio de elementos chave de controle (por exemplo, vazão, umidade do solo e evaporação) do ciclo hidrológico, Figura 1-11. Abordagens mais detalhadas sobre esses processos dinâmicos podem ser consultadas em Peixoto \& Oort (1992), Wilks (2006), Jacobson (2005), Deser et al (2010), Sampaio (2014) e Barbosa (2015).

Na Figura 1-10, como é a distribuição de energia no sistema climático e resume décadas de medidas experimentais tanto terrestres quanto espaciais, com instrumentos a bordo de satélites. Esses dados experimentais mostram que o sistema climático está em equilíbrio, uma vez que a radiação solar absorvida equivale ao total de radiação de onda longa emitida pela Terra para espaço, ou seja, a quantidade de energia média armazenada no sistema climático é constante, e, portanto, a temperatura média é constante. 


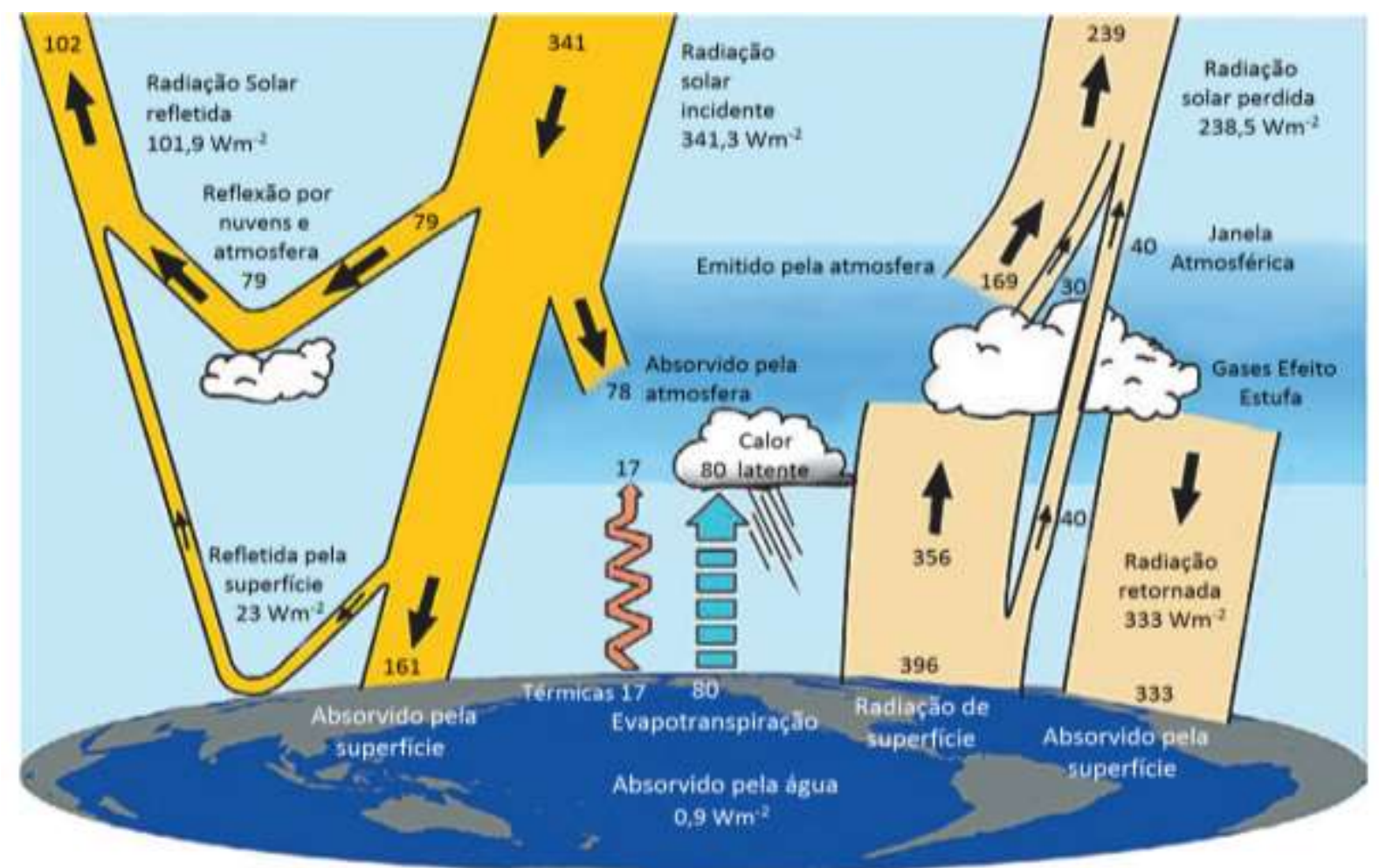

Figura 1-10 Evolução do Sistema Climático ${ }^{8}$

O conceito de balanço de energia tem coerência se considerada a média global de longo prazo relacionada à radiação solar absorvida e a emissão de radiação de onda longa no topo da atmosfera. Uma vez que as regiões tropicais recebam uma maior quantidade de energia do Sol tornam-se mais quentes se comparadas às regiões polares. A diferença de temperatura implica que uma quantidade diferente de radiação de onda longa é perdida para o espaço em cada região, mas isso não é suficiente para compensar o excesso de radiação solar absorvido. Dessa maneira, sempre há uma desigualdade regional entre as duas componentes do balanço de radiação: saldo positivo nas regiões tropicais e saldo negativo nas regiões polares. Como os trópicos não se aquecem indefinidamente, existe outro mecanismo de redistribuição de energia no sistema climático. A distribuição irregular de energia na superfície do planeta induz gradientes horizontais de temperatura e, consequentemente, gradientes de pressão que empurram os ventos na troposfera. Os mesmos ventos que, por sua vez, empurram a água na superfície do oceano formando correntes oceânicas, transportam o excesso de energia dos trópicos para as regiões polares.

8 As setas largas indicam esquematicamente o fluxo de energia na proporção de sua importância. Adaptado Fonte: (CAmerican Meteorological Society. (KIEHL \& Trenberth et al., 1997, p. 209). (CAVALCANTI, et al. , 2002) 
A identificação e compreensão de padrões climáticos consistentes e recorrentes, aliada as suas conexões com a variabilidade temporal e espacial da precipitação, pode ser relevante para a interpretação e elaboração de cenários futuros das variações nos registros hidrológicos que apresentam persistência de longo prazo (COULIBALY, 2006; MARENGO, 2006 e 2008; AMBRIZZI et al, 2007). Ademais, uma melhor compreensão das ligações temporais e regionais entre flutuações climáticas e variações sazonais das vazões pode influir em uma modelagem hidrológica mais adequada (melhorar a previsão das afluências ou a previsão do enchimento de reservatórios), e, consequentemente, aperfeiçoar o planejamento e a gestão dos recursos hídricos.

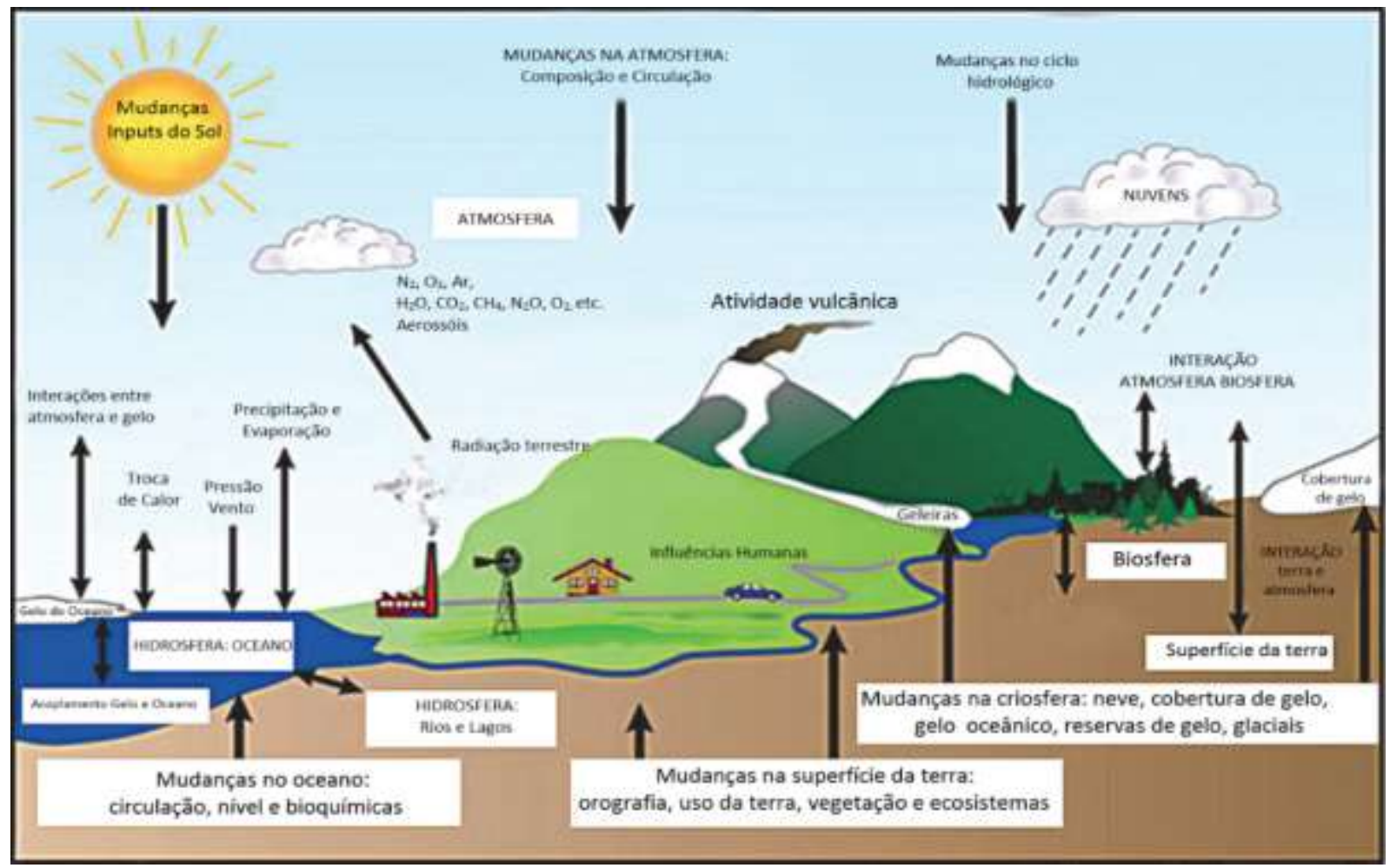

Figura 1-11 Elementos que formam o Ciclo Hidrológico. Adaptado Fonte: IPCC, 2013

Utiliza-se a informação, apresentada acima, para avaliar de forma mais sensata o impacto das alterações climáticas nos sistemas de recursos hídricos de escala regional. No entanto, a avaliação das alterações nos padrões atmosféricos e suas relações com a variabilidade da precipitação continuam sendo uma difícil tarefa em razão de sua natureza complexa e não linear.

O clima do Brasil responde a diversos eventos macro climáticos relacionados à variabilidade de diferentes escalas temporais de sua hidrologia. Podem ser relacionados em primeiro lugar com eventos astronômicos, que contribuem forçando o clima, mediante períodos em ciclos anuais, e insolação diurna; em segundo lugar, oscilações climáticas autorreguladas originárias 
da realimentação não-linear entre distintos sistemas; e em terceiro lugar flutuações aleatórias de fatores químico-físicos que compõe o sistema climático, como exemplo, erupções vulcânicas que emitem material particulado na atmosfera, e impede a incidência dos raios solares na Terra e ocorre um período de resfriamento do planeta (HERNÁNDEZ, 2011), Figura 1-12.

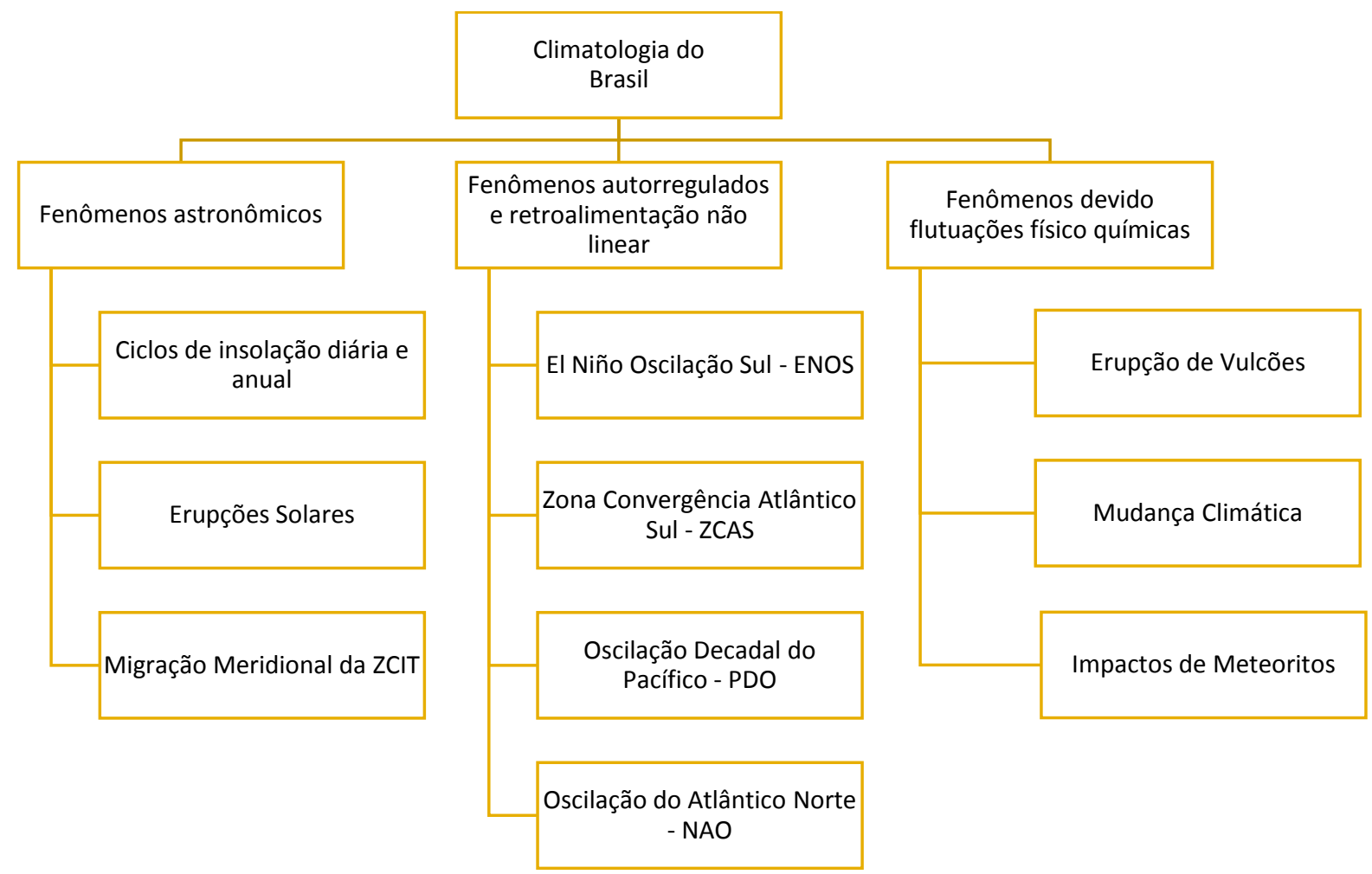

Figura 1-12 Tipo de eventos macro climáticos que afetam a hidrologia do Brasil Fonte: adaptado de Hernández, 2011.

A combinação da variabilidade climática levando-se em conta os eventos macroclimáticos e os ciclos anuais permite aos institutos de previsão de tempo e clima do Brasil identificar diferentes graus de previsibilidade no território, variados regimes de chuva sobre o sistema de geração elétrica distribuído em grande parte do país . Na seção 3.10 Teleconexões e padrões de circulação atmosférica, p. 116. 


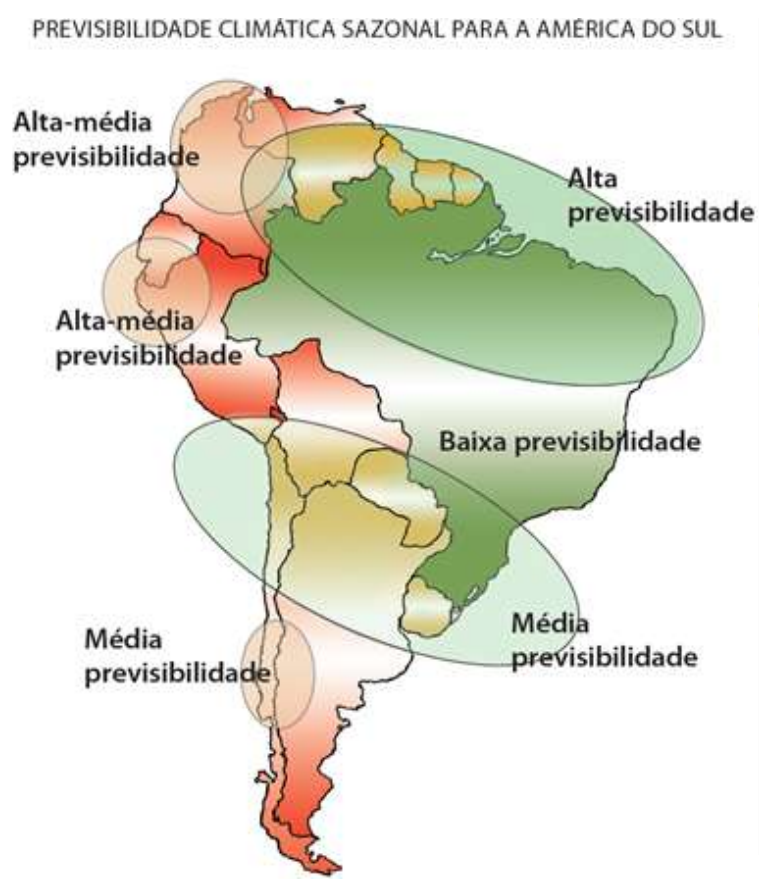

a.

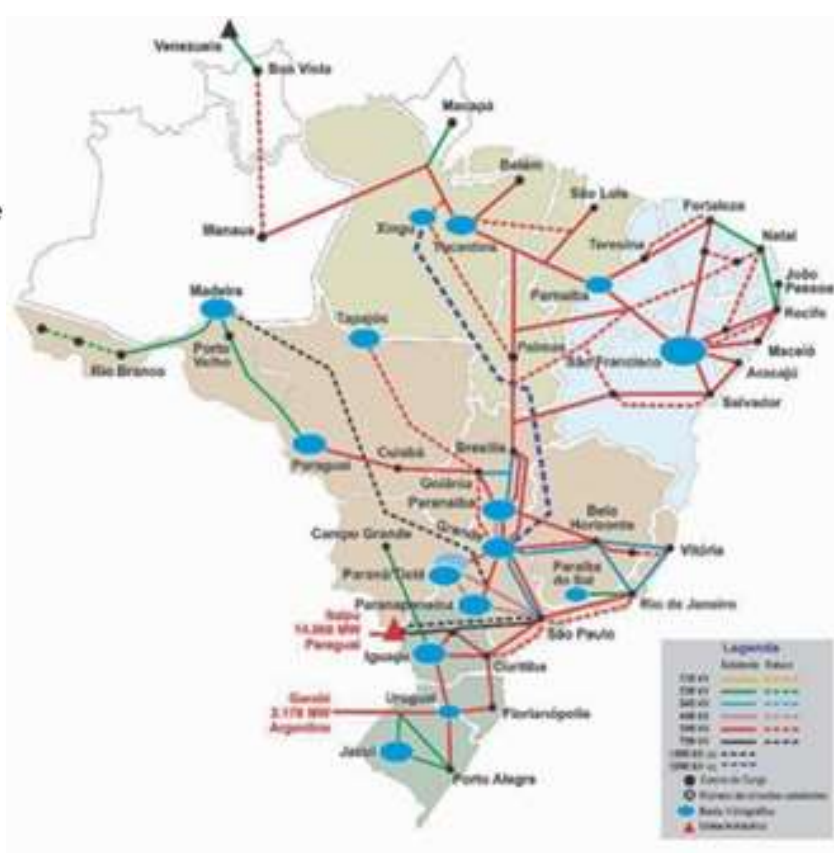

b.

Figura 1-13 Elementos do Clima versos Integração Eletroenergética Fontes: a. Grau de previsibilidade climática na AS (SAMPAIO, 2014) b. Setor Energético Brasileiro (ONS, 2015)

\subsection{Justificativa}

Em 2001, o SEB foi incapaz de evitar o déficit de energia em consequência da falta de usinas, linhas de transmissão e baixas afluências no Sudeste, cujo reservatório atingiu cerca de $30 \%$ de capacidade em 05/05/2001 (ONS, 2015 - Figura 1-14), o que acarretou um subsequente racionamento com corte de $20 \%$ da carga de eletricidade. Durante esse período, surgiu uma necessidade de adequar o atual modelo para cenários de baixas afluências, com a inserção de mecanismos de aversão ao risco de déficit, com um progressivo aumento em suas elaborações (RAMOS, 2009). Entretanto, em nenhum momento pensou-se em criar um módulo que tratasse das informações meteorológicas de tempo e clima (exemplo variabilidade climática interanual) dentro dos modelos oficiais. O trabalho realizado pela AES, que buscou preencher parcialmente essa lacuna, consistiu na organização de um Projeto de Pesquisa e Desenvolvimento (P\&D) dentro da chamada pesquisa estratégica Agência Nacional de Energia Elétrica (Aneel) ANEEL $010^{9}$ que procura estudar os efeitos das mudanças climáticas sobre o SEB e teve como resultado a integração de diferentes ciências, a climatológica, os

\footnotetext{
${ }^{9}$ Nome da chamada 010: "Efeitos de mudanças climáticas no regime hidrológico de bacias hidrográficas e na energia assegurada de aproveitamentos hidrelétricos"
} 
usos do solo, e a hidrológica onde um dos produtos foi o livro de Lima et al (2014). ${ }^{10}$ Não obstante, contrariamente ao trabalho de Lima et al (2014) que estuda previsões para 2050 e 2100 dentro dos diferentes cenários de mudanças climáticas e atividades antrópicas definidos pelo IPCC, essa tese busca utilizar a previsão em um intervalo de tempo de aproximadamente cinco anos à frente. Ainda que exista essa divergência entre os trabalhos, a obra de Lima et al (2014) corrobora com a proposta dessa tese no que tange o uso das informações climáticas junto ao SEB.

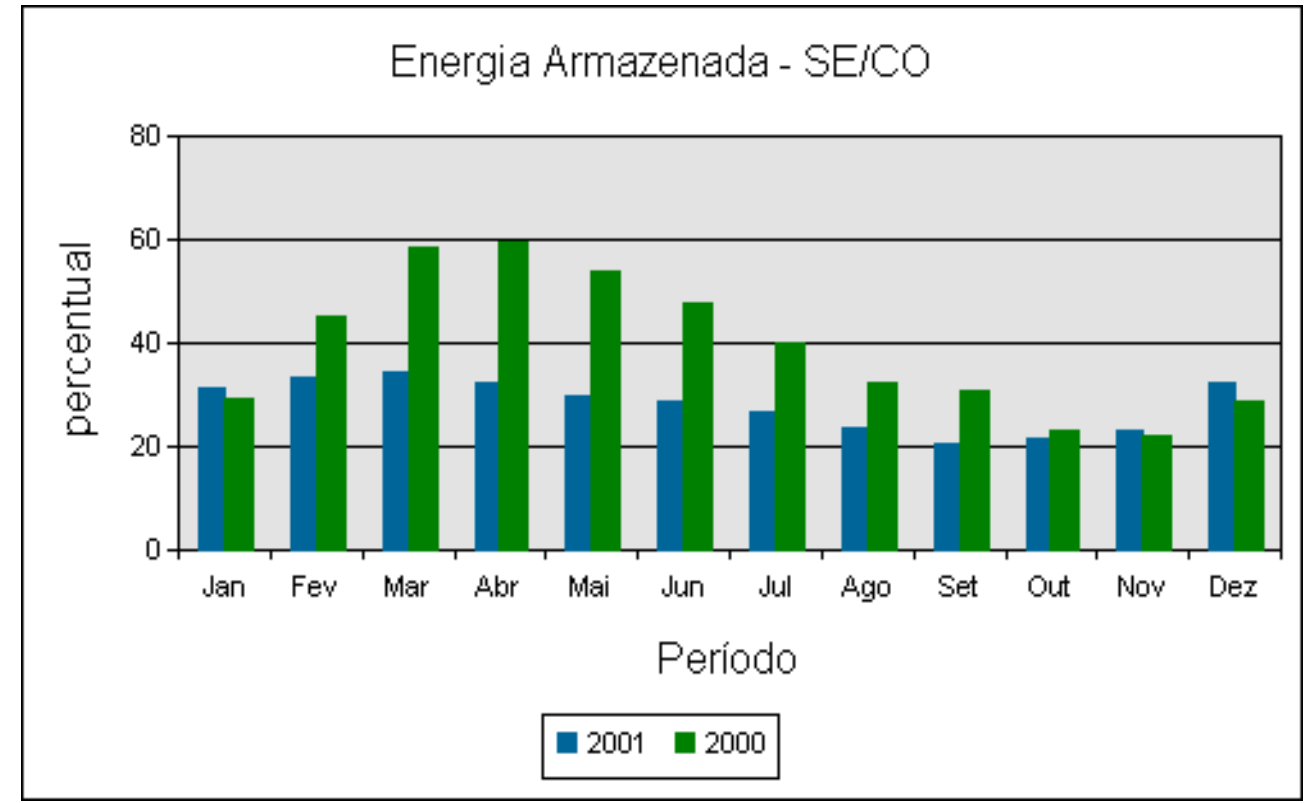

Figura 1-14 Reservatório Região SE/CO 2000/2001. Percentagem da capacidade.

\footnotetext{
${ }^{10}$ Nome do projeto "Efeitos das Mudanças Climáticas na Geração de Energia Elétrica”
} 


\section{CAPÍTULO 2 OBJETIVOS}

\section{$2.1 \quad$ Objetivo Geral}

Essa tese tem como objetivo geral propor uma metodologia para melhorar a previsibilidade ou a cenarização de vazões, e energia, com a aplicação de informações macroclimáticas como variáveis exógenas. O trabalho aqui apresentado foca em elaborar um modelo paramétrico que tem como função calcular a oferta de energia para um período de cinco anos e, assim, obter modelos interpretáveis e com sentido climatológico para, dessa maneira, determinar o efeito causal do clima na energia resultante das afluências.

\subsection{Objetivos Específicos}

Para alcançar o objetivo geral apresentado anteriormente são considerados os seguintes objetivos específicos:

- Analisar séries históricas com ferramentas matemáticas e gráficas para melhor compreender variáveis explicativas que refletem o comportamento do macroclima

- Incorporar, na construção do modelo, variáveis explicativas que refletem o comportamento climático de larga escala.

- Desenvolver e aplicar um protótipo de software para a predição de vazões com base em modelos matemáticos.

\subsection{Questão central e hipótese}

A questão central que essa tese busca responder pode ser resumida da seguinte forma, é possível calcular e prever as afluências dos rios e, como consequência, a energia produzida pelas usinas hidrelétricas, através de informações climáticas de larga escala?

Esse trabalho pretende demonstrar que a modelagem de dados macroclimáticos, relacionados de alguma forma com as fontes de ENA (energia potencial que pode ser futuramente convertida em eletricidade), fornece elementos suficientes para prover cenários do potencial de incorporação desses dados nas ferramentas de planejamento e operação da matriz elétrica brasileira e contribui para mostrar como e quais variáveis podem ser utilizadas.

A metodologia utilizada nessa tese, a princípio, baseia-se na pesquisa de tipo indutivo e tem, como procedimentos, o estudo de caso, o estudo comparativo e estatístico, e a documentação indireta de pesquisa bibliográfica. 


\subsection{Descrição da população}

Os modelos e métodos desenvolvidos serão utilizados para prever as vazões de rios de bacias hidrológicas. As informações de vazão e da ENA são fornecidas publicamente pelo ONS em seu website www.ons.org.br. Os dados utilizados são de janeiro de 1931 até o mês de dezembro de 2014. Os horizontes de previsão levantados para o desenvolvimento desse estudo são de cinco anos.

\subsection{Limitações da tese}

São apresentados ao decorrer do trabalho modelos estocásticos autorregressivos do tipo vazão-vazão por usina, vazão-vazão por bacia, chuva-vazão que podem ser do tipo conceitualdeterminístico, com base física, ou de natureza estocástica (FARIA, 2012). Desse modo, são analisados dados e informações emitidos por sistemas existentes e bases de dados públicas. Tem-se como proposta a interpretação e identificação de relações entre variáveis macroclimáticas e oferta de energia e a criação de um modelo do tipo clima-vazão, portanto, esse trabalho não aborda modelos dinâmicos ou físicos.

Ademais, existem limitações temporais determinadas pelas bases de dados encontradas para o desenvolvimento da tese, uma vez que as séries históricas organizadas pelo ONS são registradas desde 1931 até 2014. A ideia inicial era analisar vazões para as quatro bacias: Bacias do Paraná, Tocantins, São Francisco e Parnaíba, porém como não existem bases de dados de vazões por bacias, utilizaram-se bases de dados de ENA por bacia.

Para descomplicar a apresentação do estudo restringiu-se às quatro regiões, pois a quantidade de gráficos e análise de mapas de quatro bacias e, também, das 13 usinas, gerou uma assustadora quantidade de dados, os quais se encontram no apêndice.

Quanto ao modelo de previsão de energia, são descritos modelos existentes e frequentemente utilizados como o programa NEWAVE que é baseado no modelo de programação dinâmica dual estocástica, propondo algumas técnicas para melhorar sua capacidade de previsão ou produção de cenários. O Modelo Autorregressivo integrado de Média Móvel e Sazonal (MORETTIN \& TOLOI, 2006; WEI, 2006; PANKRATZ, 1991; BOX; JENKINS; REINSEL, 2008; COWPERTWAIT \& METCALFE, 2009; SHUMWAY \& STOFFER, 2011) acompanhado de variáveis regressivas (SARIMAX) é utilizado nesse trabalho para simular a previsibilidade de vazões e energia. 


\section{CAPÍTULO 3}

\section{REVISÃO BIBLIOGRÁFICA}

A geração de energia por hidrelétricas no Brasil segue alguns conceitos necessários para o entendimento da relação entre usinas e o clima. A usina hidrelétrica convencional é formada por uma barragem construída geralmente em quedas d'água de rios ou em regiões com correnteza e volume expressivo de água. Nesse segundo caso é utilizada uma turbina adequada para esse tipo de queda como exemplo as usinas de Jirau e Santo Antônio em Rondônia. Desse modo conclui-se que, ainda que as condições naturais não favoreçam a construção de uma barragem haverá algum mecanismo que a adapte à região tornando possível seu funcionamento. Assim, esse capítulo, apresenta-se alguns dos conceitos utilizados, nas seções 3.1 Energia Natural Afluente (ENA), e 3.2 Temperatura da Superfície do Mar (TSM), explica fenômenos como 3.3 El Niño Oscilação Sul (ENOS), 3.4 Manchas Solares, 3.5 Setor Elétrico Brasileiro (SEB), 3.6 Crescimento Populacional e Consumo de Energia no Mundo e no Brasil, 3.7 Trabalhos sobre informações climáticas de larga escala na previsão de precipitações ou de vazões de rio, 3.8 Modelagem de operação dos reservatórios, 3.9 Modelos de previsão de vazões, 3.10 Teleconexões e padrões de circulação atmosférica, 3.11 Teleconexões com El Niño Oscilação Sul, 3.12 Exemplo de teleconexão - Seca atípica do Sudeste no Verão de 2014 e 3.13. Influência Solar no Clima e Vazões.

\subsection{Energia Natural Afluente (ENA)}

Um ponto essencial para demonstrar a ligação entre o "mundo" da eletricidade e o "mundo" da climatologia é o conceito de ENA. Para sua existência é necessária a presença de uma usina implantada em um rio, que possua um reservatório, receba água de outros rios abastecidos pela chuva originada na atmosfera, a qual interage através de fenômenos físicos com os sistemas terrestres da biosfera, criosfera, hidrosfera que por sua vez são acionados pela energia da radiação solar (PEIXOTO \& ORT, 1992).

A ENA é a "energia afluente a um sistema de aproveitamentos hidrelétricos, calculada a partir da energia produzível pelas vazões naturais afluentes a estes aproveitamentos, em seus níveis a $65 \%$ dos volumes úteis operativos", (ONS, 2016, p.5).Na Figura 3-1, representa-se 
um modelo simplificado do arranjo de uma usina, seus tipos de vazão e sua nomenclatura.

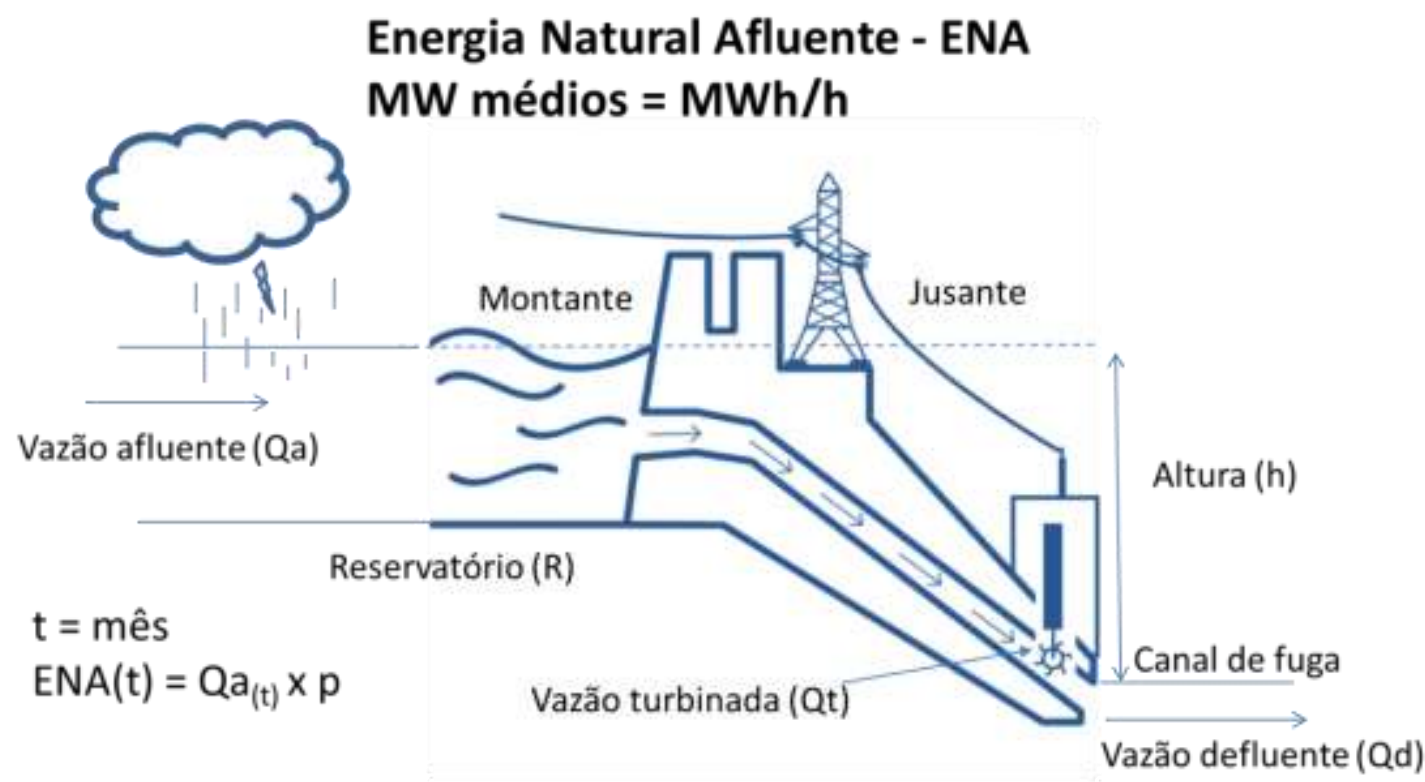

Figura 3-1 Modelo simplificado das partes de uma barragem com usina - adaptação elaboração própria ${ }^{11}$

$E=m \times g \times h \times \eta$

$\tau=F \times d=m \times a \times d$

$[\tau]=K g \times \frac{m}{s^{2}} \times m=\frac{K g \times m^{2}}{s^{2}}$

$E=m \times g \times h \times \eta=\rho \times V \times g \times h \times \eta=\rho \times \underbrace{\frac{V}{t}}_{\underset{Q}{t}} \times g \times h \times t \times \eta$

$E=Q \times(\underbrace{\rho \times g \times h \times t) \times \eta}_{\text {produtibilidade }=p}$

$p=\rho \times g \times h \times t \times \eta$

$[p]=\frac{K g}{m^{3}} \times \frac{m}{s^{2}} \times m \times s \times 1=\frac{K g}{m \times s}$

$E=Q \times p$

$[E]=\frac{m^{3}}{s} \times \frac{K g}{m \times s}=\frac{K g \times m^{2}}{s^{2}}$

$E N A_{(t)}=Q a_{(t)} \times p$

em que

- $t$ corresponde ao mês corrente;

- A transformação da energia e suas unidades são demonstradas da equação 3-1 até 3-9;

- $\operatorname{ENA}_{(t)}$ energia natural afluente, correspondente à média de energia do mês t, calculada através da equação 3-10;

\footnotetext{
${ }^{11}$ Fonte imagem: http://br.freepik.com/icones-gratis/usina-hidreletrica-em-producao_733525.htm
} 
- $\quad$ é a índice de produtibilidade média do conjunto turbina-gerador do aproveitamento hidrelétrico;

- h é valor altura entre o nível do reservatório e o nível do rio a jusante (pós) a barragem;

- Qa é a vazão afluente medida $\mathrm{em}^{3} \mathrm{~s}^{-1}$;

- Qt é a vazão turbinada medida $\mathrm{em}^{3} \mathrm{~s}^{-1}$; e

- Qd é a vazão defluente medida $\mathrm{em} \mathrm{m}^{3} \mathrm{~s}^{-1}$.

As usinas podem apresentar-se organizadas em um mesmo rio, com reservatório (R), sem reservatório (fio d’água) ou por condutor forçado. As vazões podem ser divididas em: vazões defluentes $(\mathrm{Qd})$ que ocorrem após o acionamento da turbina, vazão turbinada $(\mathrm{Qt})$ que ocorre durante o acionamento da turbina e vazão vertida, que ocorre quando o reservatório está acima de sua capacidade e por motivos de segurança o vertedouro é aberto e a água liberada (para efeito de simplificação não há vazão vertida no desenho). Esse modelo reduzido mostra um nível de escala relacionado a uma unidade de usina, lembrando que para analisar um grupo de usinas em um rio é necessário calcular a ENA de cada usina e posteriormente somar os resultados para obter uma energia equivalente ao agrupamento, Figura 3-2.

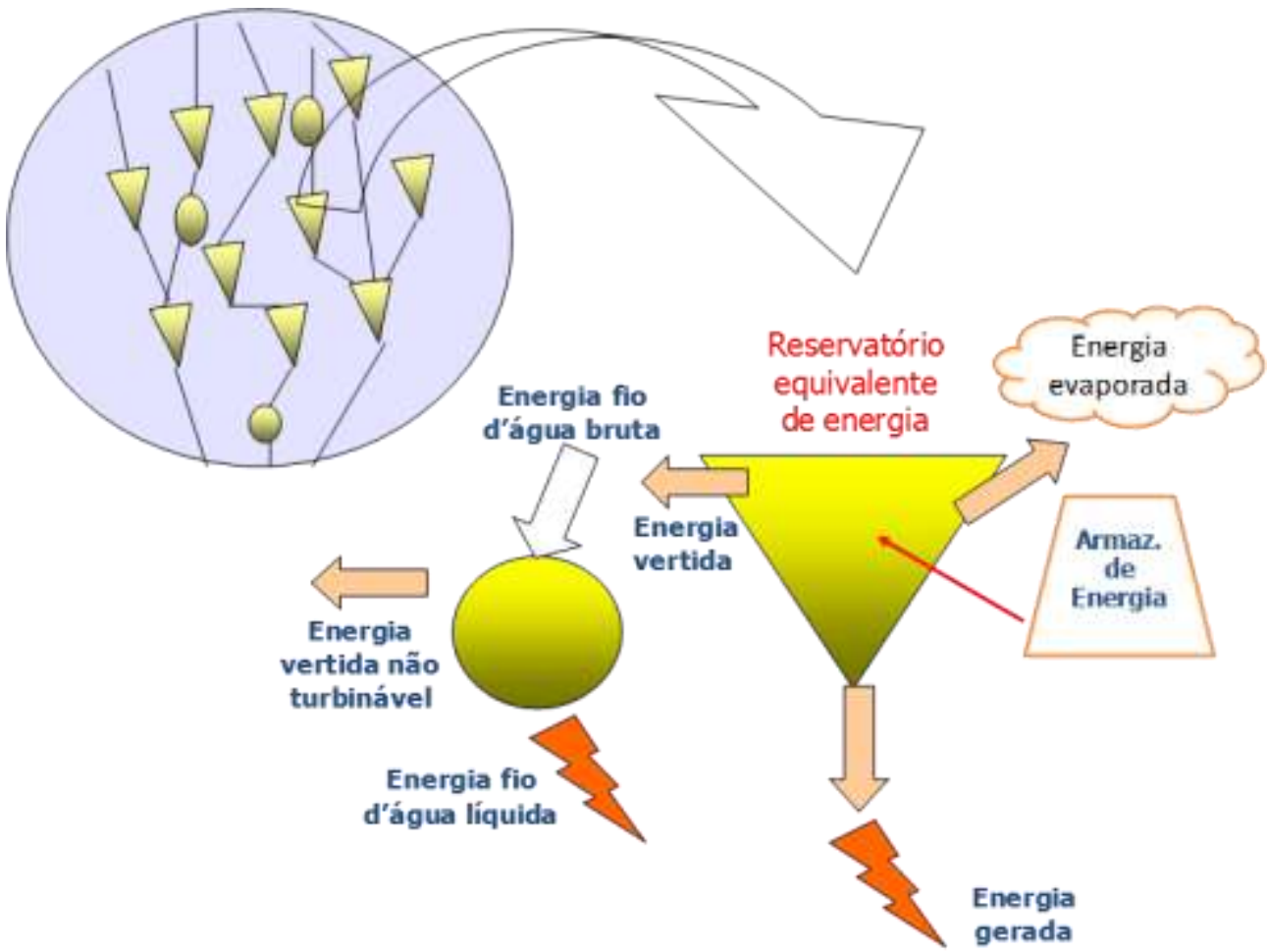

Figura 3-2 - Reservatório equivalente de energia. Círculos - usinas de fio d'água. Triângulos - usinas com reservatório- adaptado (RAMOS, 2009)

Esse agrupamento geralmente é realizado em um rio, uma bacia ou uma região. Para calcular a ENA equivalente ao Brasil basta somar os resultados das quatro regiões. 


\subsection{Temperatura da Superfície do Mar (TSM)}

A temperatura da superfície do Mar é um indicador muito utilizado em ciências atmosféricas para analisar padrões de variabilidade do clima. Sua medição é realizada através de leituras de fotografias captadas via satélite, embarcações e boias meteorológicas (tanto na superfície quanto submersas), infravermelho ou fotografias feitas por aeronaves, dentre outras. Essas medidas são interpretadas, analisadas, interpoladas, reanalisadas e publicadas em domínio público para uso de instituições das ciências atmosféricas encontradas em todo o mundo. Pode-se utilizar como exemplo o International Comprehensive Ocean-Atmosphere Data Set (ICOADS), que administra de forma organizada três séculos de medidas e cria resumos mensais com grades de $2^{\circ}$ latitude por $2^{\circ}$ de longitude desde 1800 e $1^{\circ}$ x $1^{\circ}$ desde 1960 (). Seu acesso é permitido ao mundo todo e é provavelmente a coleção mais completa e heterogênea de dados de superfície do mar existente.

O oceano interfere no sistema climático devido à sua grande capacidade de armazenar calor, e, assim, como a atmosfera, distribui energia da radiação solar que chega ao equador em direção aos polos. Os padrões de variabilidade da temperatura de superfície do mar (TSM) em escalas de tempo interanuais e interdecadais são resultados da combinação de processos acoplados do tipo oceânico-atmosféricos.
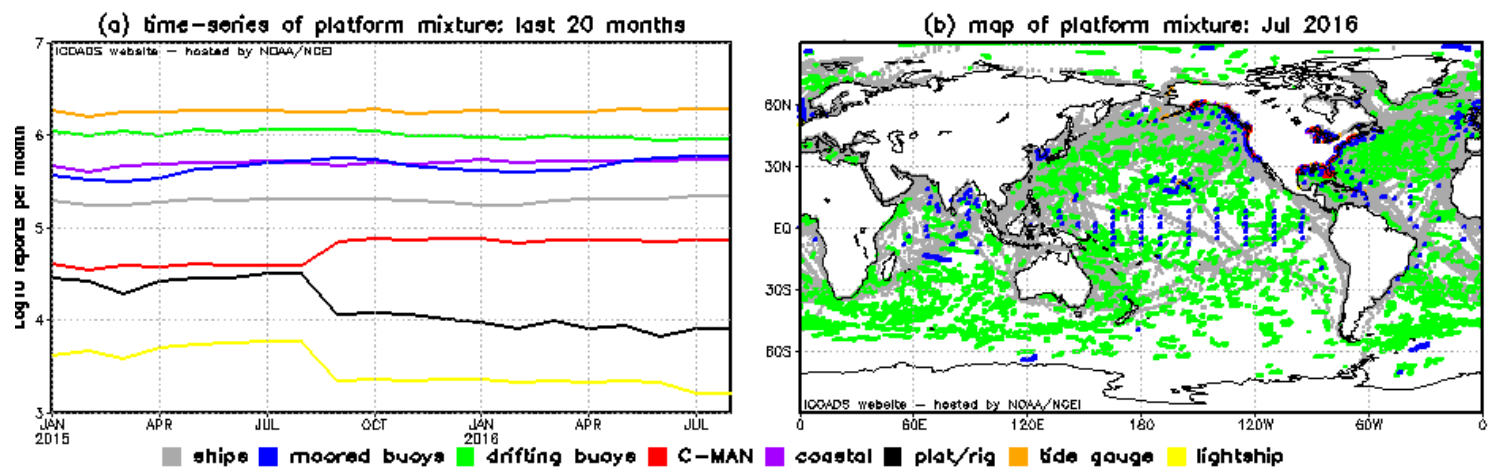

(c) seo level pressure (hPo): Jul 2016
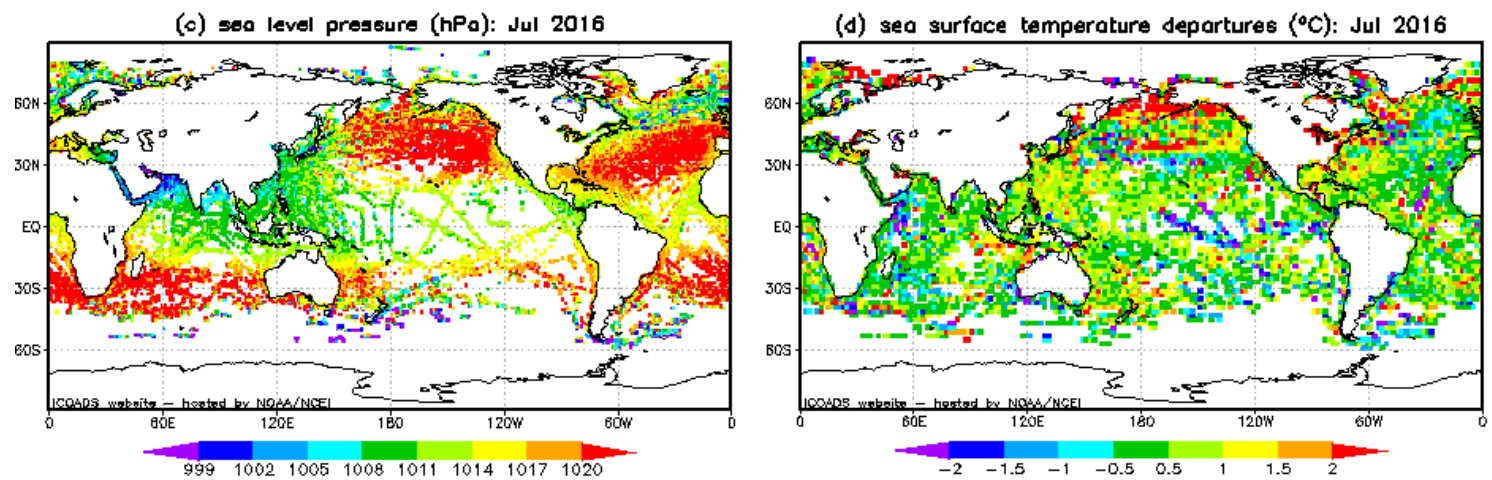

Figura 3-3 - Relatório preliminar dos oceanos de números recentes do ICOADS (baseado nos dados do NOAA/NCEP) estratificados por tipo de plataforma (a-b), e a amostra do último mês para 1 grau (c) e 2 graus (d) resumos mensais (com base nos valores médios para duas variáveis selecionadas, e média de longo-termode 1971-2000) 


\subsection{El Niño-Oscilação Sul (ENOS)}

O El Niño-Oscilação Sul (ENOS) é um fenômeno de grande escala que ocorre no Oceano Pacífico, formado pelas ocorrências El Niño (fase quente) e La Niña (fase fria). O ENOS apresenta acoplamento entre o oceano (El Niño e La Niña) e a atmosfera (Oscilação Sul) (PHILANDER, 1990). Para monitorar estes fenômenos são feitas medições de Temperatura da Superfície do Mar (TSM) pelo National Oceanic and Atmospheric Administration (NOAA) em quatro diferentes regiões de grande escala: NINO1+2, NINO3, NINO4 e NINO3.4, Figura 3-4. A partir dessas medidas são calculados índices de anomalias que representam os desvios padrões calculados com relação a sua média histórica ou climatológica.

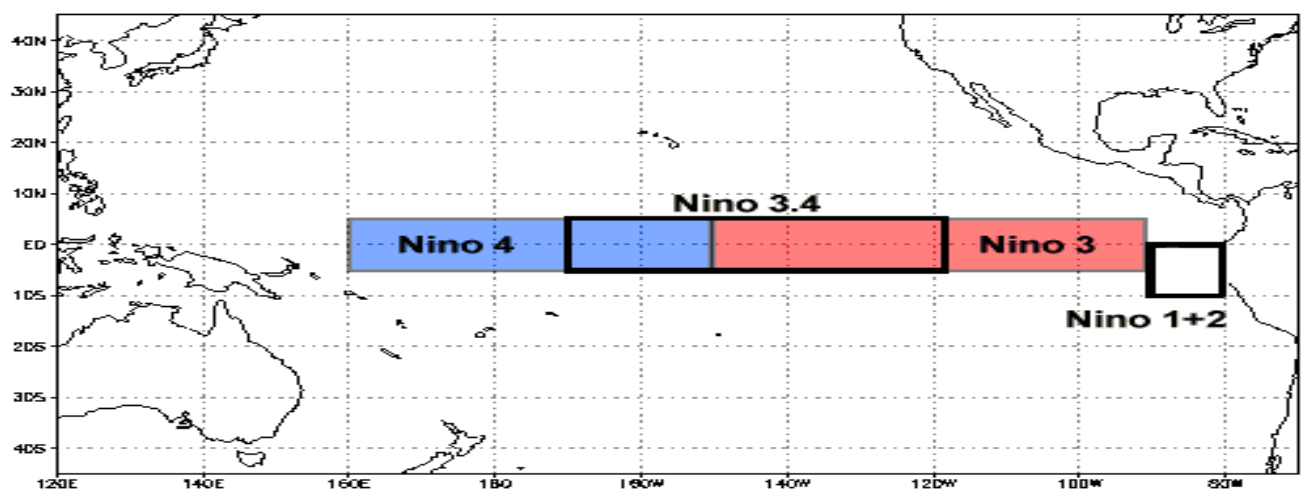

Figura 3-4 Regiões de larga escala do El Niño - TSM ${ }^{12}$ NINO1+2, NINO3, NINO3.4, NINO4

As coordenadas das regiões geográficas relacionadas com ás áreas de medições de temperatura são descritas na Tabela 3.1, a seguir.

Tabela 3.1 Relação das áreas de medição TSM do Pacífico - El Niño

\begin{tabular}{|l|l|l|}
\hline Niño $1+2$ & $0-10^{\circ} \mathrm{Sul}$ & $90^{\circ}$ Oeste $-80^{\circ}$ Oeste \\
\hline Niño 3 & $5^{\circ}$ Norte $-5^{\circ} \mathrm{Sul}$ & $150^{\circ}$ Oeste $-90^{\circ}$ Oeste \\
\hline Niño 4 & $5^{\circ}$ Norte $-5^{\circ} \mathrm{Sul}$ & $160^{\circ}$ Leste $-150^{\circ}$ Oeste \\
\hline Niño 3.4 & $5^{\circ}$ Norte $-5^{\circ}$ Sul & $170^{\circ}$ Leste $-120^{\circ}$ Oeste \\
\hline
\end{tabular}

\footnotetext{
${ }^{12}$ Acesso 23/01/2016 url: http://www.ncdc.noaa.gov/teleconnections/enso/indicators/sst.php
} 


\subsubsection{Fase Neutra do El Niño}

Na fase neutra do El Niño, os Ventos Alísios sopram de leste para oeste ao longo do Oceano Pacífico tropical, transportando ar quente e úmido e as águas superficiais mais quentes em direção ao Pacífico Ocidental enquanto mantêm o Oceano Pacífico Central mais frio (ressurgência $\left.{ }^{13}\right),(\mathrm{BOM}, 2012)$.

A termoclina ${ }^{14}$ é mais profunda no Oeste em relação ao Leste. As temperaturas de superfície do mar aquecidas no oeste do Pacífico liberam calor e umidade para os altos níveis da atmosfera. Nesse processo, conhecido como convecção, o ar quente sobe na atmosfera e, se apresentar um alto nível de umidade, provoca a formação de enormes nuvens cumulonimbos e chuva. Após a chuva, o ar nesse instante seco, viaja para o leste antes de descer sobre o Pacífico Tropical mais frio. Esse padrão de circulação de ar, ascendente no Oeste e descendente no Leste, é denominado Célula de Walker, Figura 3-5 e Figura 3-6.

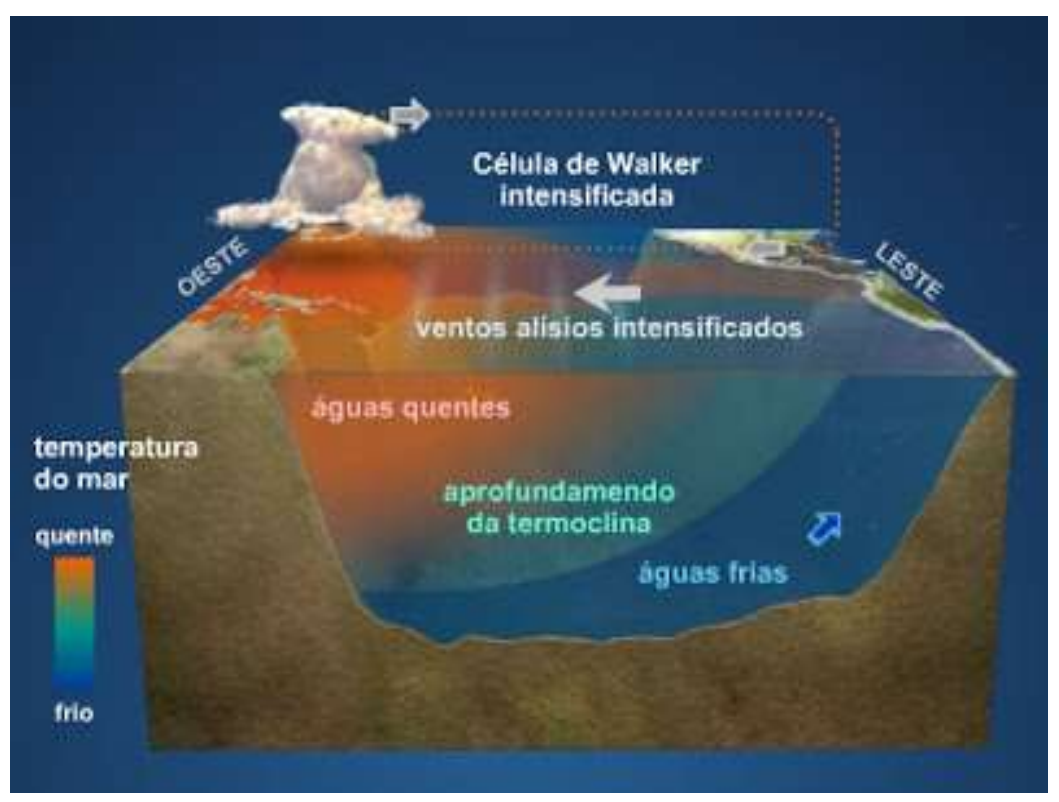

Figura 3-5 El Niño fase Neutra - TSM, dinâmica atmosférica Célula de Walker. Fonte: Clutz, 2016

Fonte imagem:

http://4.bp.blogspot.com/_O5SYkhjuJxg/TUBeJ_62zBI/AAAAAAAAAu8/MUq19byAQAA/s400/ganoslani.jpg

${ }^{13}$ Ressurgência (upwelling) é um movimento ascendente da água. Quando o vento e as correntes oceânicas deslocam água na superfície do oceano, a água mais profunda no oceano ascende para substituir a água deslocada da superfície. As águas profundas são geralmente mais frias e mais ricas em nutrientes do que a água da superfície, assim, a ressurgência é importante no apoio à produtividade nos oceanos do mundo.

${ }^{14}$ Termoclina é a camada nos oceanos onde o gradiente vertical de temperatura é máximo e sua profundidade varia com a latitude. Está relacionada com a ressurgência em seu balanço vertical, onde a mistura entre água mais quente e mais leve da superfície com águas mais frias e densas do fundo. Fonte: Saito, 2012 Acesso em 25/01/2015 em ftp://io.usp.br/los/IOF5841/aula03_ts.pdf 

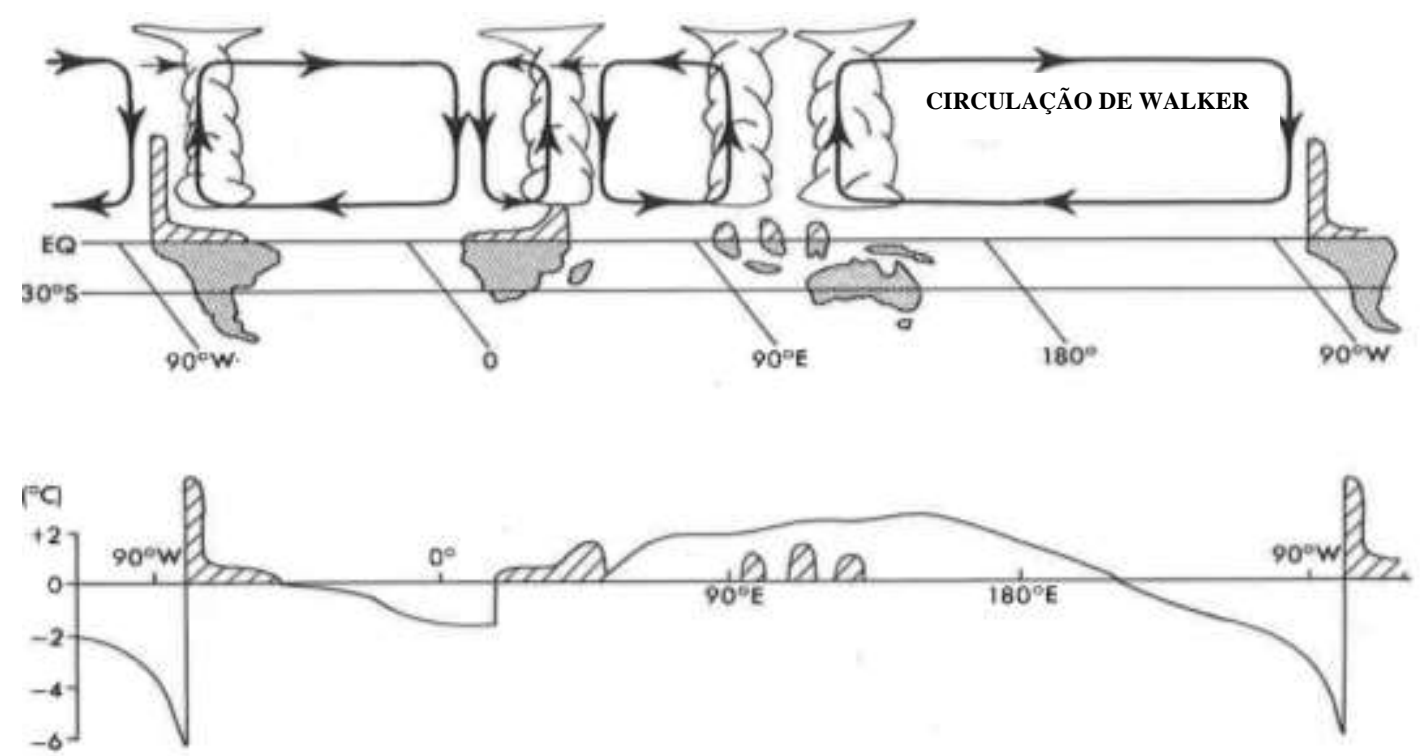

Figura 3-6 El Niño fase neutra - TSM, dinâmica atmosférica. Fonte: Peixoto \& Oort, 1992

Nos períodos, em que TSM estão próximas da média histórica (fase neutra, Figura 3-6) as chuvas ocorrem nas proximidades da Austrália, como em épocas de La Niña, porém menos intensas. Os fenômenos El Niño e La Niña, bem como os padrões de chuva descritos, ocorrem, geralmente, na época do Verão Austral (dezembro, janeiro e fevereiro).

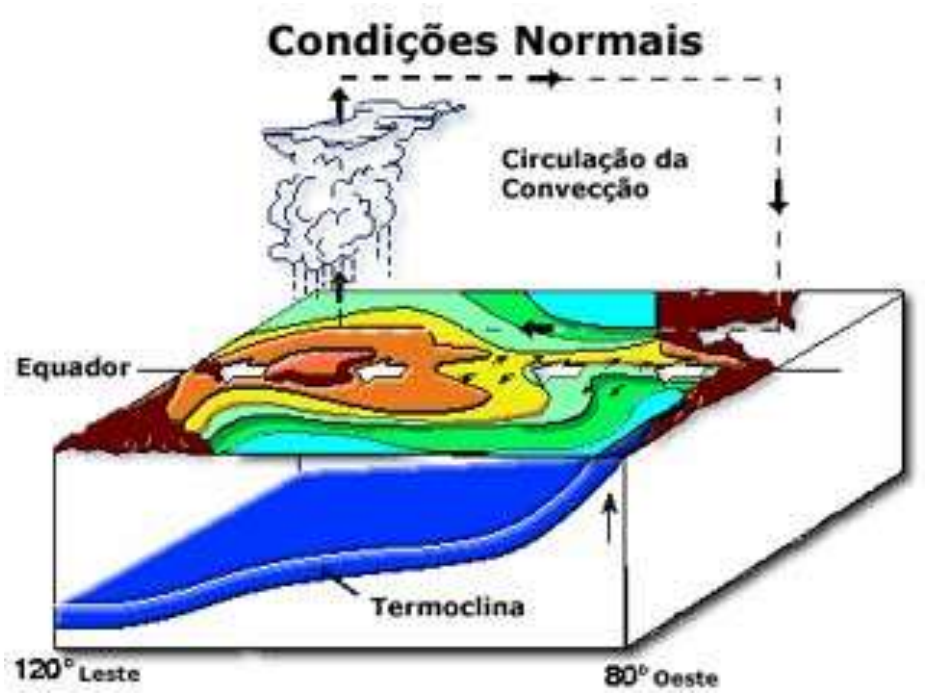

Figura 3-7 El Niño fase Neutra - TSM - Fonte: CPTEC, $2016^{15}$.

${ }^{15}$ http://enos.cptec.inpe.br/elnino/pt 


\subsubsection{Fase de ocorrência do EI Niño ${ }^{16}$}

O El Niño é um fenômeno relacionado ao aumento da TSM em determinadas regiões na altura do equador no Oceano Pacífico Centro-Oriental e, em consequência, há diminuição da magnitude ou mesmo a inversão de direção dos ventos vindos de Leste para Oeste em baixas altitudes (Ventos Alísios), próximas ao nível do mar. A temperatura do Oceano Pacífico, mais quente do que o normal, está associada a um aprofundamento da termoclina da área central para a oriental. A ressurgência mais fraca de águas mais frias do oceano também contribui para TSM mais quentes, (BOM,2012).

A diminuição da magnitude dos ventos permite a formação de zonas de baixa pressão nas áreas central e oriental do Oceano Pacífico e há convergência e convecção mais próximas da América do Sul, o que pode ocasionar chuvas nas áreas do Tahiti e da América do Sul e secas na região da Austrália Oriental, indicando a alteração do padrão climático dessas regiões, Figura 3-8.

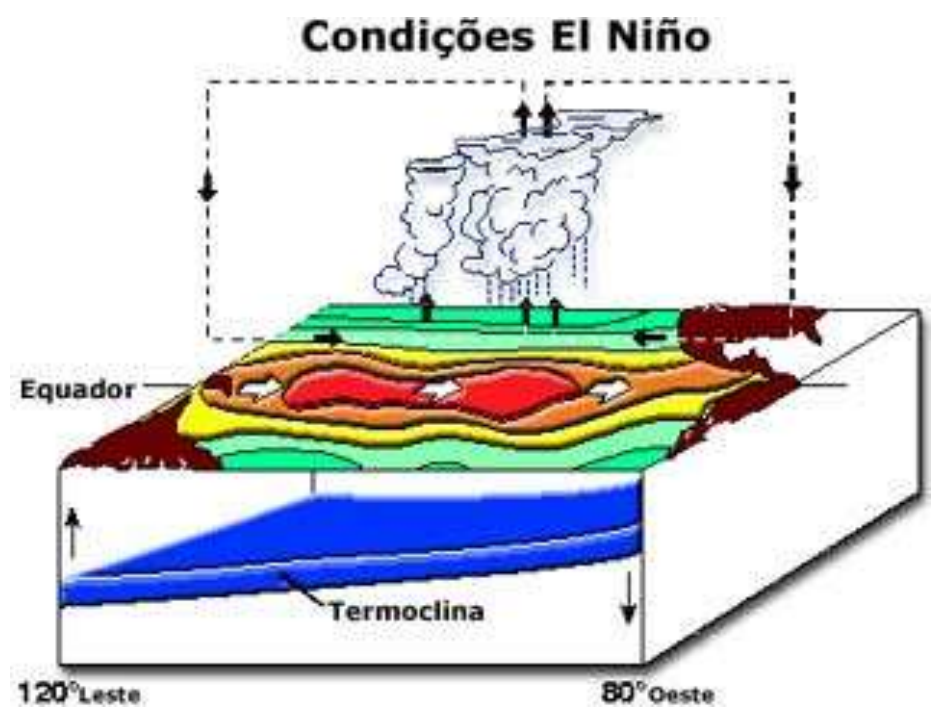

Figura 3-8 El Niño - TSM Fonte: CPTEC, 2016.

\footnotetext{
${ }^{16} \mathrm{O}$ termo El Niño é traduzido do espanhol como "o menino-criança". Pescadores peruanos utilizaram o termo para descrever o surgimento, por volta do Natal, de uma corrente oceânica quente ao largo da costa Oeste Sulamericana. O termo é comumente aceito para descrever o aquecimento do Oceano Pacífico Tropical Central e Oriental. La Niña se traduz como "menina-criança" e é a fase ENOS oposta ao El Niño.
} 


\subsubsection{Fase de ocorrência da La Niña}

A La Niña é um fenômeno referente à diminuição das TSM em determinadas regiões na altura do equador no Oceano Pacífico e ao aumento da magnitude dos Ventos Alísios em baixas altitudes, o que faz a circulação de Walker intensificar-se, com maior convecção sobre o Pacífico Ocidental, (BOM,2012).

Com Ventos Alísios de maior magnitude, a piscina de água mais quente é confinada no Pacífico tropical ocidental, resultando em TSM mais quentes do que as habituais na região norte da Austrália.

A TSM em toda a área central e oriental do Oceano Pacífico tropical se apresenta mais fria do que o habitual e faz a termoclina aproximar-se da superfície. Com isso, a ressurgência se intensifica e as águas frias do oceano profundo são deslocadas para a superfície.

O aumento da magnitude dos ventos promove a formação de zonas de baixa pressão sobre a Austrália, convecção e, portanto, ocasionando nebulosidade sobre a região norte da Austrália que se intensifica a medida que ventos mais fortes fornecem uma maior quantidade de umidade para a atmosfera sobrejacente e favorece a Circulação Walker. Por conseguinte, fortalece a monção australiana e, se as condições forem adequadas, conduz ao aumento da umidade e chuvas no interior da Austrália. Eventos de La Niña estão associados com o aumento da precipitação sobre grande parte do norte e leste da Austrália. Partes norte e central tendem a sofrer os impactos de La Niña mais do que impactos do El Niño. O evento La Niña, diferente do El Niño impede a formação de zonas de baixa pressão ao Sul do Oceano Pacífico, através da subsidência de ar seco, mais próxima à América do Sul, alterando o padrão climático dessas regiões, Figura 3-9.

\section{Condições La Niña}

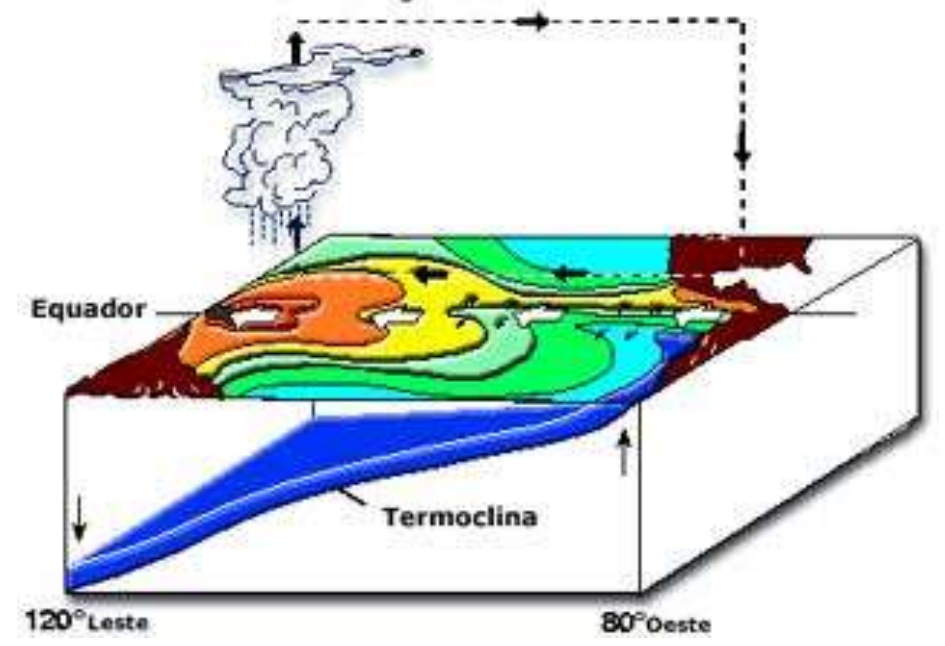

Figura 3-9 La Niña - TSM Fonte: CPTEC, 2016. 


\subsubsection{Abaixo da superfície}

Os eventos El Niño são tipicamente conduzidos e sustentados por mudanças na quantidade de calor encontradas nas águas abaixo da superfície do Oceano Pacífico tropical. O oceano profundo é importante para aferir a força, e, portanto, longevidade potencial de um evento. Esses grandes armazenamentos de calor (El Niño) ou falta de calor (La Niña) atuam como um mantenedor e garantem que um evento não irá dissipar-se rapidamente. Por exemplo, durante o evento El Niño 1997-1998 - que muitos consideram o El Niño do Século XX - as temperaturas de superfície foram cerca de $3{ }^{\circ} \mathrm{C}$ mais quentes que a média no Pacífico tropical oriental, mas as temperaturas, a $150 \mathrm{~m}$ abaixo da superfície, foram até $8{ }^{\circ} \mathrm{C}$ acima da média. Pode-se observar um acontecimento contrário durante o evento La Niña de 2010-11, onde temperaturas da superfície do Oceano Pacífico oriental foram até $2{ }^{\circ} \mathrm{C}$ mais frias do que as normais e as temperaturas subsuperficiais foram quase $7{ }^{\circ} \mathrm{C}$ abaixo da média. Essas grandes mudanças no oceano mais profundo garantem que as águas superficiais permaneçam quentes ou frias, mesmo quando a atmosfera acima tenta empurrar o sistema de volta para a neutralidade, e, assim, pode manter ou levar um evento ENOS a persistir por mais de um ano.

\subsection{Manchas Solares}

As manchas solares são manchas escuras na superfície do sol em razão uma temperatura inferior a local. As temperaturas no centro das manchas solares decrescem para cerca de 3.700 $\mathrm{K}$ (em comparação com $5.700 \mathrm{~K}$ para a fotosfera circundante). Elas duram vários dias e normalmente podem persistir por várias semanas. As manchas solares são regiões do Sol com fortes campos magnéticos (milhares de vezes mais fortes que o campo magnético da Terra), normalmente surgem em grupos com dois conjuntos de pontos. Um conjunto será o positivo ao norte do campo magnético, enquanto o outro grupo será negativo ao sul do campo magnético. O campo mostra-se mais forte nas partes mais escuras das manchas solares - a umbra, e mais fraco e horizontal na parte mais clara - a penumbra ${ }^{17}$, Figura 3-10.

\footnotetext{
${ }^{17} \mathrm{http} / / /$ solarscience.msfc.nasa.gov/greenwch.shtml
} 


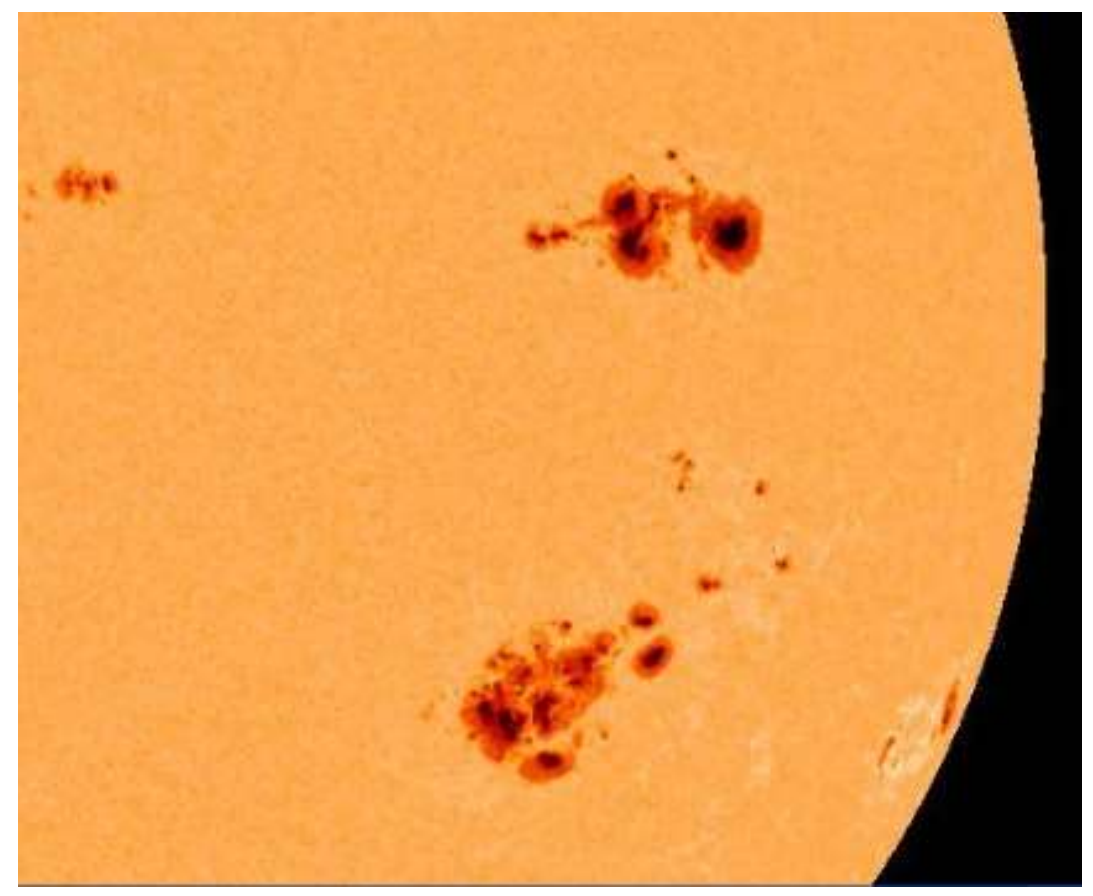

Figura 3-10 - Exemplos de Manchas Solares ${ }^{18}$

O índice número de manchas solares (sunspot number) é dado pela soma do número de manchas solares individuais, multiplicada por 10. Como muitos grupos apresentam em média cerca de 10 pontos de manchas, utiliza-se essa fórmula para contar as manchas e obter um resultado confiável, mesmo que as condições de observação não sejam ideais e pequenas manchas sejam difíceis de observar. Atualmente há dois relatórios oficiais do número de manchas solares calculado pelo Solar Influences Data Analysis Center ${ }^{19}$ na Bélgica e pelos US National Oceanic and Atmospheric Administration (NOAA).

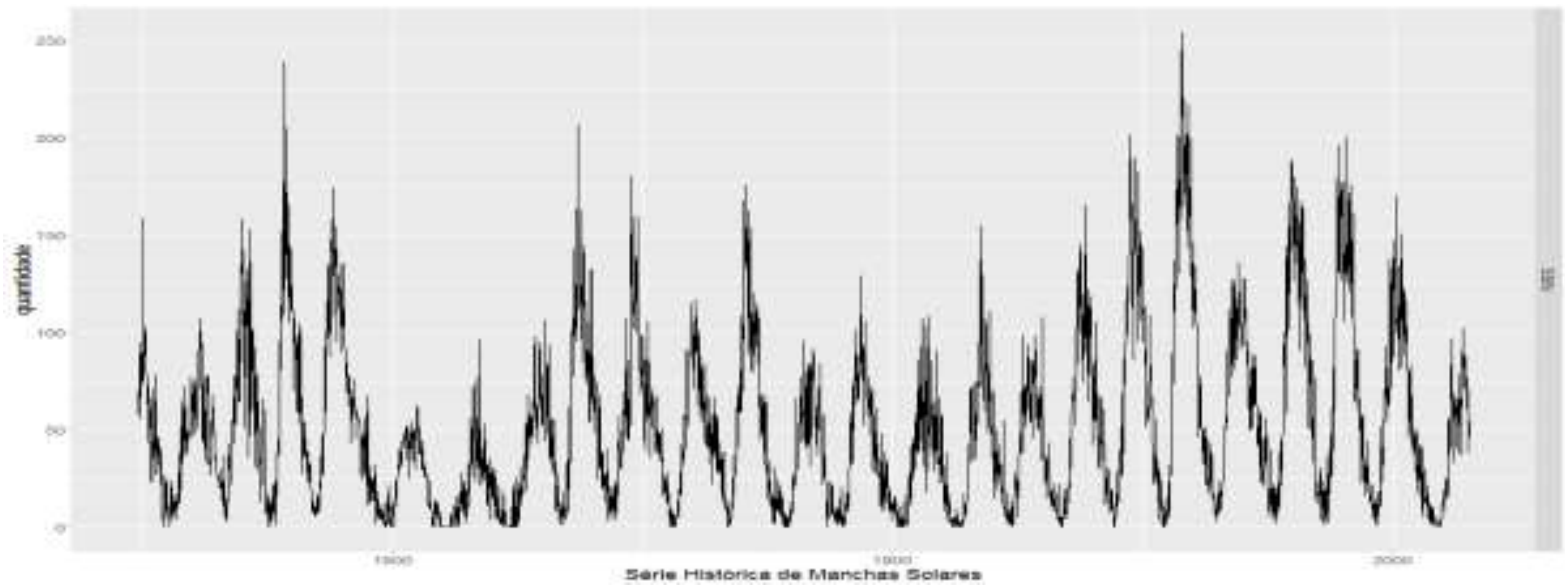

Figura 3.11 - Número de manchas solares internacional

\footnotetext{
18 http://www.leif.org/research/SSN/Hathaway2.pdf

${ }^{19} \mathrm{http}: / /$ solarscience.msfc.nasa.gov/SunspotCycle.shtml
} 
Ao decorrer do trabalho são utilizadas as séries históricas de manchas solares SIDAC da Bélgica. O período dessa série corresponde ao período das vazões dos rios, onde estão localizadas as hidroelétricas que vem de 1931 até 2011, Figura 3.12.
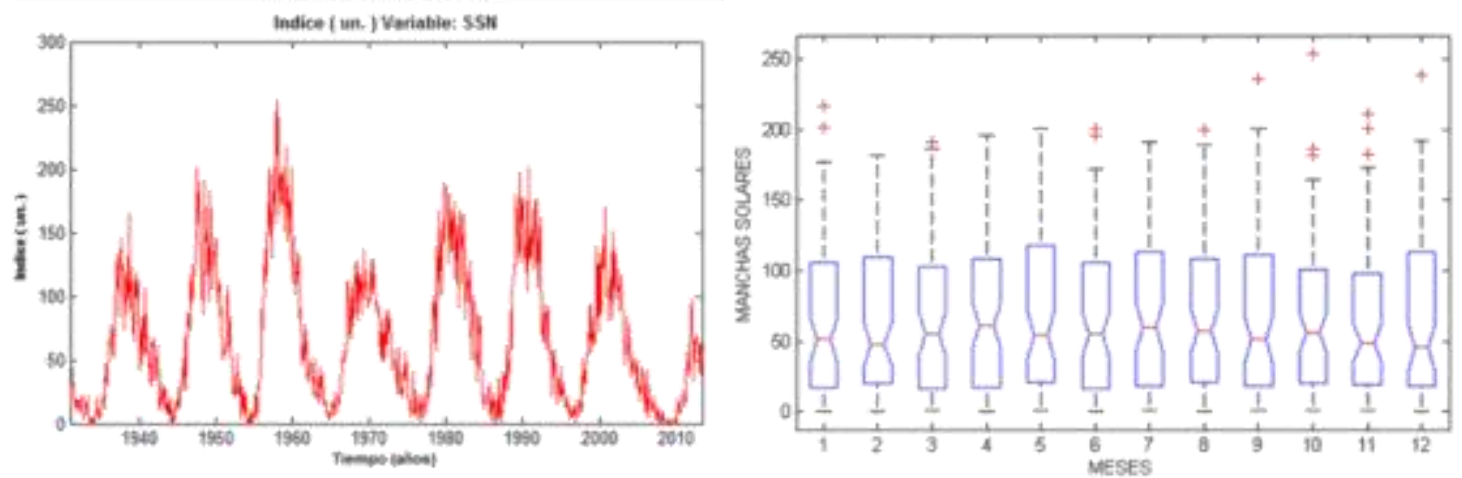

Figura 3.12 - Série Histórica das Manchas Solares Médias Anuais e Boxplot 1931-2011

As observações detalhadas de manchas solares foram obtidas pelo Observatório Real de Greenwich desde 1874, incluem informações sobre os tamanhos e posições das manchas solares, bem como seus números. Esses dados mostram que as manchas solares não aparecem aleatoriamente sobre a superfície do sol, mas estão concentradas em duas bandas de latitude de cada lado do equador.

Um diagrama de borboleta (atualizado mensalmente) mostra as posições dos pontos para cada rotação do sol desde maio 1874. Na Figura 3. 13, apresentam-se essas bandas, que são formadas primeiramente em latitudes médias, alargam-se e, em seguida movem-se em direção ao equador conforme cada ciclo evolui. Em 2010 iniciou-se o ciclo solar número 24.

DAILY SUNSPOT AREA AVERAGED OVER INDIVIDUAL SOLAR ROTATIONS
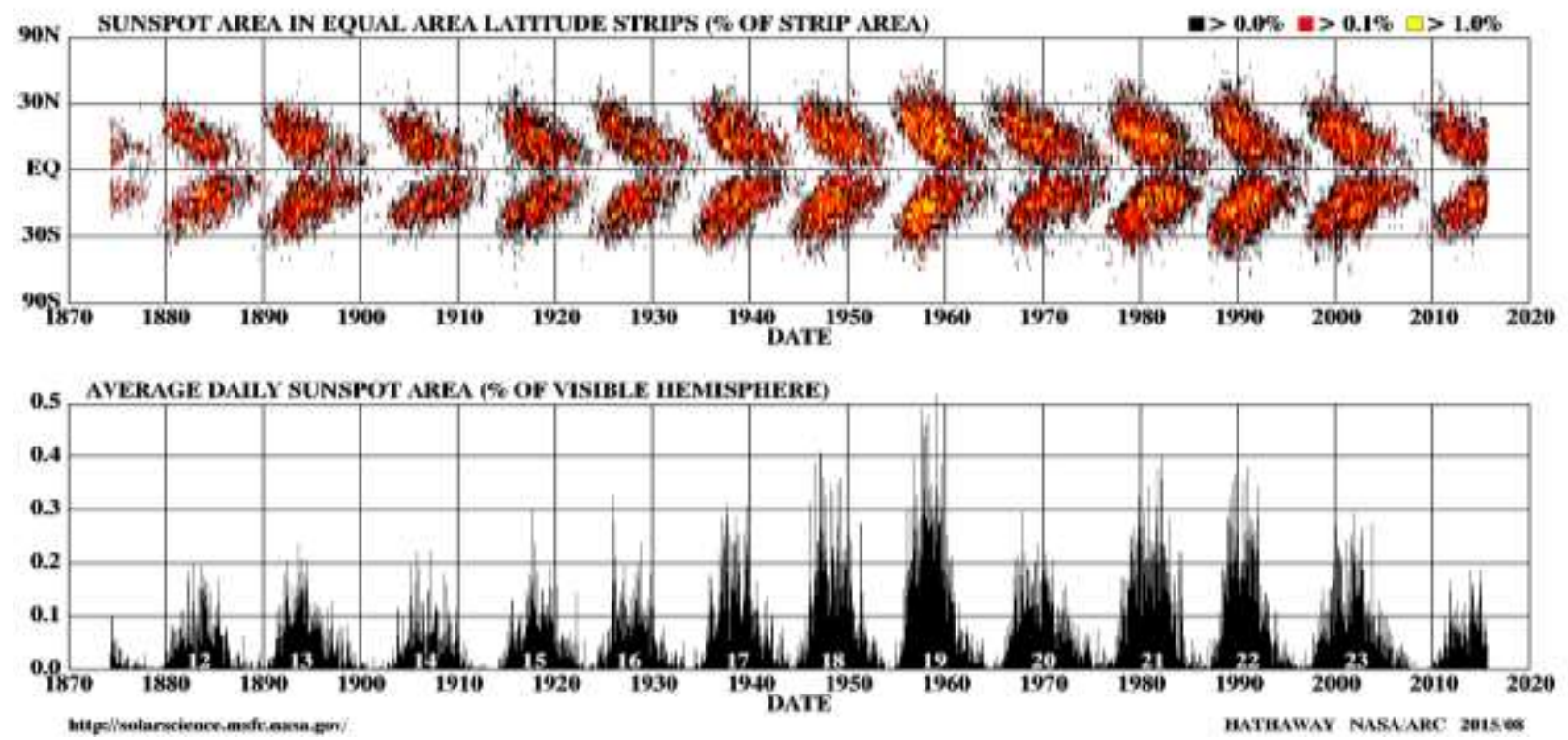

Figura 3. 13 - Áreas de Manchas Solares Médias Diárias (\% do Hemisfério Visível) Set-2015

Fonte: http://solarscience.msfc.nasa.gov/images/bfly.gif 


\subsubsection{Ciclo de Schwabe}

Grupos de manchas solares observadas a cada ano 1826-1843 por Heinrich Schwabe (1844) o influenciaram em sua descoberta sobre o ciclo de manchas solares (HATHAWAY, 2010).

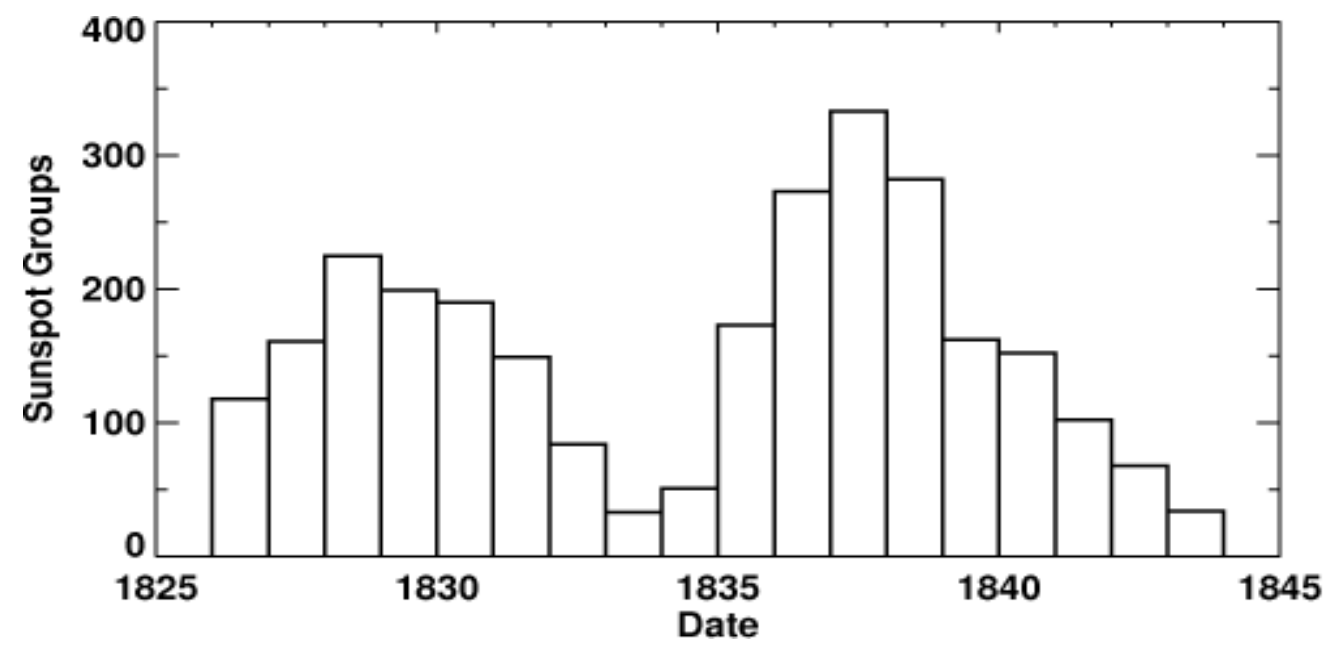

Figura 3.14 - Grupos de manchas solares observadas a cada ano 1826-1843 por Heinrich Schwabe (1844). Fonte: Schwabe, H., 1844 Apud Hathaway, 2010.

\subsubsection{Ciclo de Wolf}

Na Figura 3.15, apresenta-se o ciclo solar e as variações de amplitude, forma e duração. Os meses com observações de todos os dias são mostradas em preto, os com 1 - 10 dias de observação em falta são mostrados em verde, os com 11 - 20 dias de observação em falta são mostrados em amarelo e os com 20 dias de observação em falta são mostrados em vermelho. Dias faltantes de 1818 até o presente foram obtidos a partir dos International Sunspot Number de manchas solares, de 1750-1818 foram estimados de agrupamentos das manchas solares e provavelmente estão sobrestimados. 

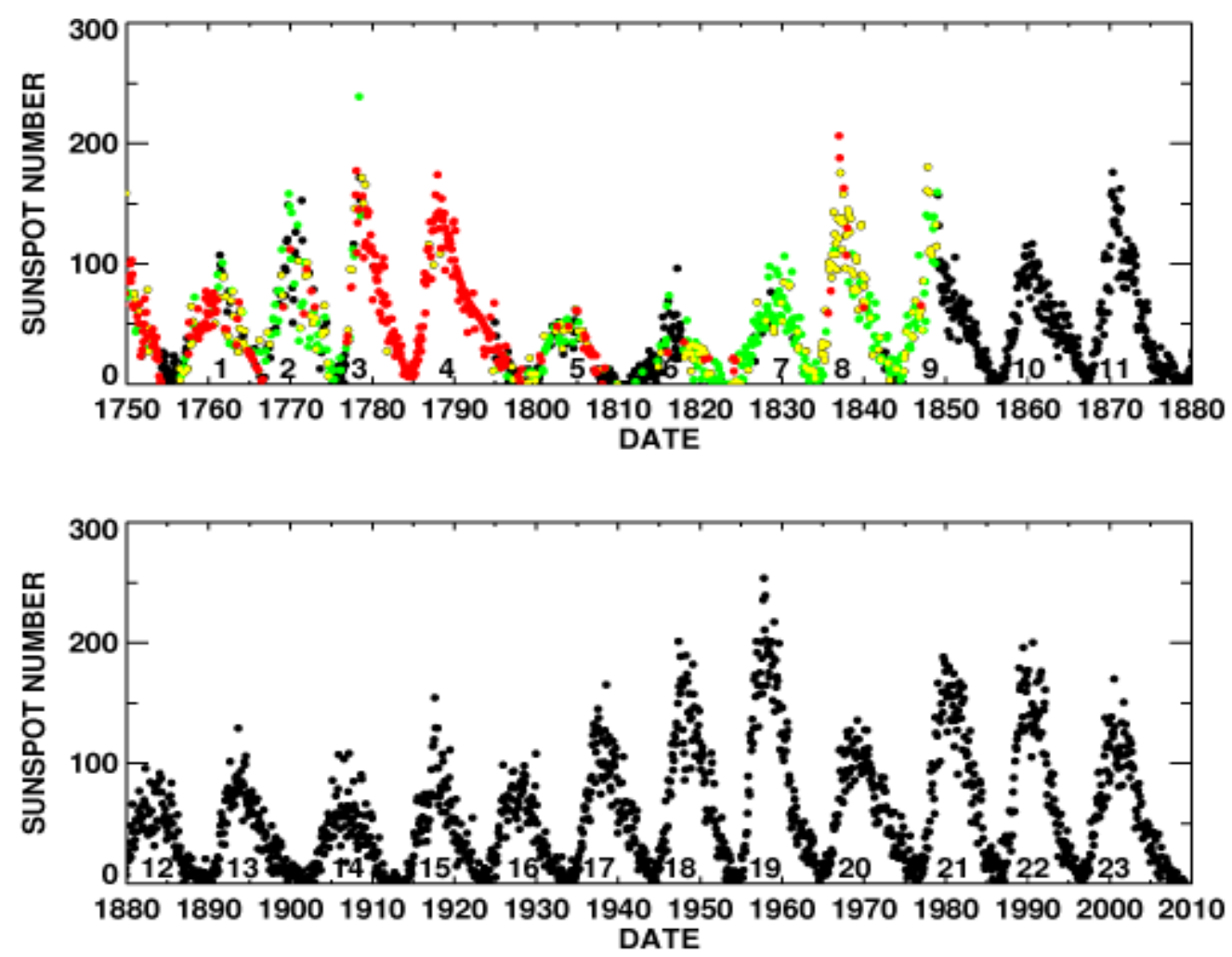

Figura 3.15 - Médias mensais de manchas solares registradas pelo International Sunspot Number

Fonte: Hathaway, 2010.

$\mathrm{O}$ interesse de $\mathrm{Wolf}^{20} \mathrm{em}$ manchas solares iniciou-se por sua observação de um agrupamento delas particularmente enorme e espetacular em dezembro 1847. A partir de então, ele começou suas próprias observações telescópicas e registros de manchas solares que foram realizadas continuamente durante os 46 seguintes anos. Muito impressionado com a descoberta do ciclo de manchas solares de Samuel Schwabe e seguro em sua posição no Observatório de Bern (e mais tarde Zürich), Wolf embarcou em um programa de estudos históricos que visa reconstruir a variação no número de manchas solares, mais antiga possível, com base em cadernos sobreviventes e desenhos de astrônomos antigos. É no curso da execução desse programa que Wolf define seu agora famoso "número de manchas solares relativo". Por volta de 1868, Wolf teve uma reconstrução do número de manchas solares, significativamente confiável, até meados de 1745. Avançou com a reconstrução até 1610, apesar da carência de dados e a falta de critérios adequados de coleta. Wolf foi o primeiro a

\footnotetext{
${ }^{20}$ Fonte: https://www2.hao.ucar.edu/Education/FamousSolarPhysicists/rudolf-wolf-1816-1893. Acesso em 09/09/2015. Hoyt, D.V., and Schatten, K.H. 1997, The Role of the Sunin Climate Change, Oxford University Press.
} 
notar a possível existência no registro de manchas solares de um período de modulação de aproximadamente 55 anos.

\subsubsection{Ciclo de Gleissberg}

A proximidade em que o sol se encontra do mínimo de um Ciclo Gleissberg pode ser considerada como uma possível explicação para o recente declínio na atividade solar (2013). Enquanto observações das manchas solares regulares começaram no século XVIII, os cientistas voltaram para os raios cósmicos, como uma proxy para a compreensão da atividade solar que ocorreu antes de haver um registro observacional direto. Isótopos (Berrylium-10 e Carbono-14), que fornecem uma visão sobre a variação na radiação cósmica incidente na Terra, indicam que a quantidade de energia radioativa emitida pelo sol parece mudar ao longo de um período de cerca de 80-100 anos.

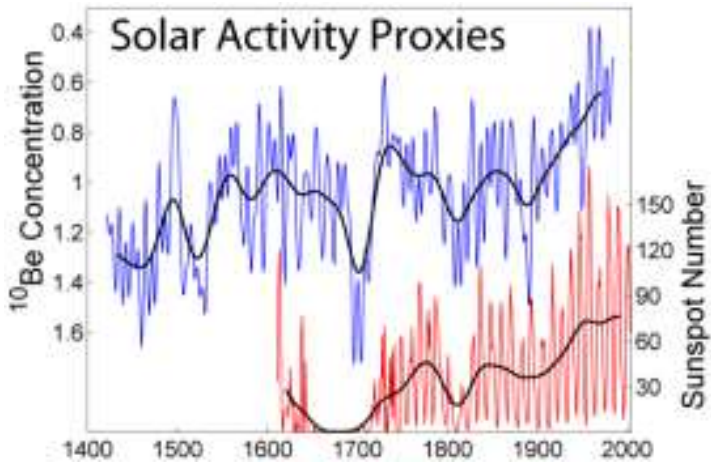

Figura 3.16 - Proxis de atividade solar ${ }^{21}$

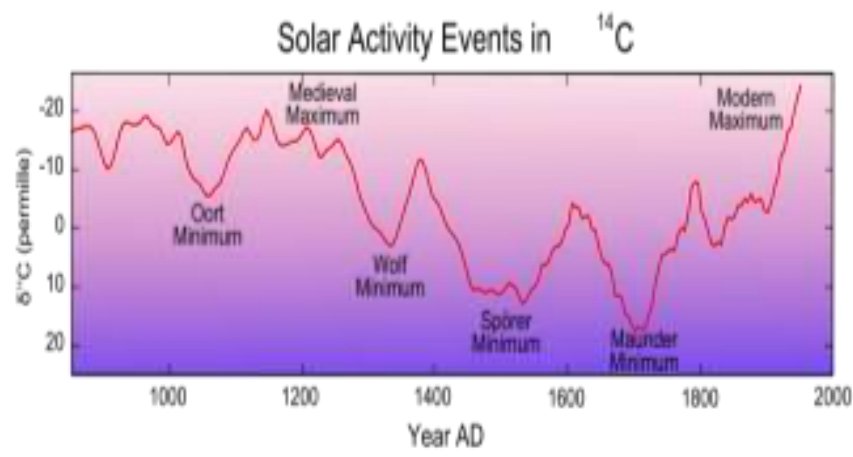

Figura 3.17 - Carbono 14 e fenômenos climáticos correspondentes $^{22}$

Embora essa teoria seja consistente com o fato de que os padrões de ciclo de manchas solares foram igualmente fracos no início de 1800 e 1900, dada a brevidade de um registro observacional solar direto, os cientistas não tem certeza se esse é um fenômeno real e, se real, o que pode causar tal modulação na atividade solar a cada 100 anos. Se válido, um Ciclo Gleissberg poderia explicar por que o Sol está atualmente mais tranquilo, (DE TOMA, 2013 ANEXO).

\footnotetext{
21 "Solar Activity Proxies". Licensed under CC BY-SA 3.0 via Commons https://commons.wikimedia.org/wiki/File:Solar_Activity_Proxies.png\#/media/File:Solar_Activity_Proxies.png 22 "Carbon14 with activity labels" Essa figura foi produzida por Leland McInnes e é licenciada sobre o GFDL. (traço vermelho) Carbon 14 record: http://www.radiocarbon.org/IntCal04\%20files/intcal04.14c. Licensed under CC BY-SA 3.0 via Commons https://commons.wikimedia.org/wiki/File:Carbon14_with_activity_labels.svg\#/media/File:Carbon14_with_activ ity_labels.svg
} 


\subsubsection{Mínimo de Maunder}

O Mínimo de Maunder, que durou de 1645-1715, foi um período em que as manchas solares apareceram com pouca frequência. Embora pouco se saiba sobre as causas do Mínimo de Maunder, a coincidência com as temperaturas médias mais baixas na Europa e América do Norte pode ser considerada com um aspecto interessante desse período. No entanto, foi também uma época de alta atividade vulcânica que provavelmente contribuiu para o arrefecimento observado. Apesar de acontecer apenas uma vez em centenas de anos os cientistas contam manchas solares com o uso de raios cósmicos como proxy da atividade solar pré-histórica, o Mínimo de Maunder não é uma ocorrência única (DE TOMA, 2013).

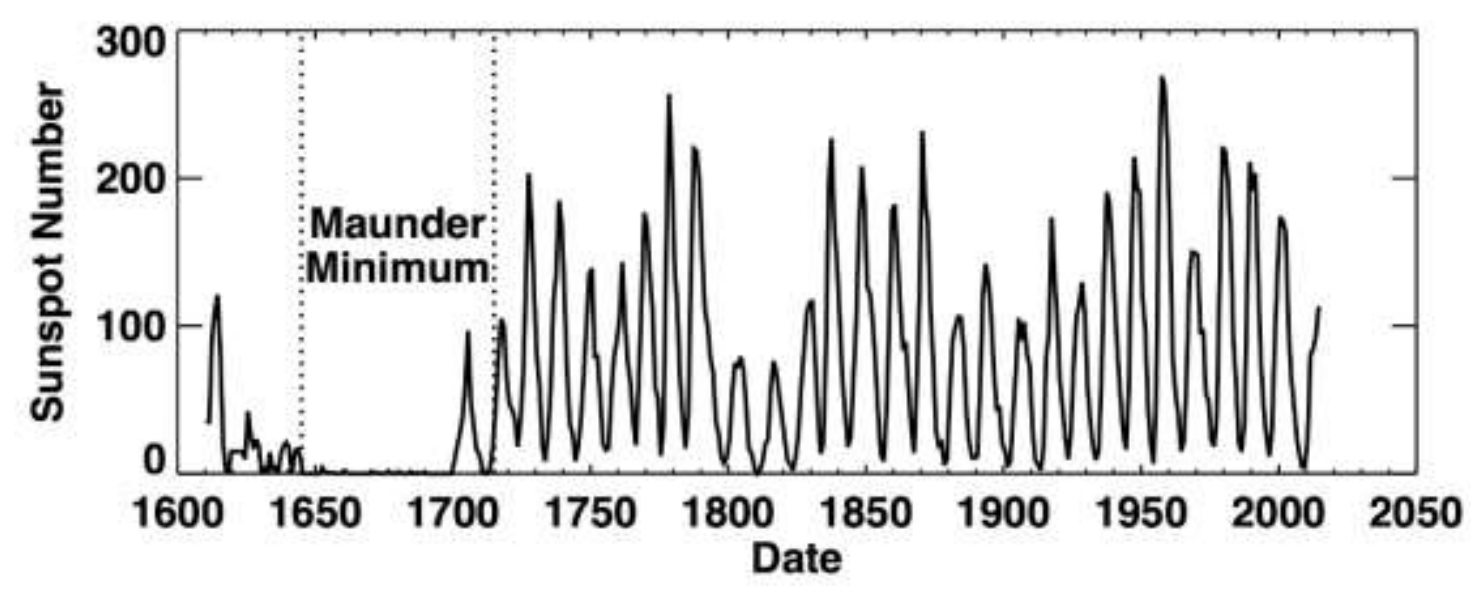

Figura 3.18 -Manchas Solares e período do mínimo de Maunder entre 1650 e $1700^{23}$

\subsection{O Setor Elétrico Brasileiro (SEB)}

O Brasil, ao contrário da maioria dos países do mundo, é um dos poucos onde a matriz elétrica em sua maioria é constituída de fontes renováveis. Como demonstrado na Tabela 3-2, os valores de geração de eletricidade das usinas organizados por de fonte primária de energia, o Brasil possui experiência e vocação em utilizar fontes renováveis de energia no setor elétrico. No planejamento de usinas do país, ao somar as usinas em estado de operação, construção e construção não iniciada totaliza-se 184 GW de potência (ANEEL, 2015; MME, 2015), Tabela 3-3.

\footnotetext{
${ }^{23} \mathrm{http}$ ///solarscience.msfc.nasa.gov/images/ssn_yearly.jpg
} 
Tabela 3-2 Empreendimentos em Operação no SEB Set-2015.

\begin{tabular}{|c|c|c|c|c|c|c|c|}
\hline \multicolumn{8}{|c|}{ EMPREENDIMENTOS USINAS EM OPERAÇÃO } \\
\hline \multirow{2}{*}{\multicolumn{2}{|c|}{ Tipo }} & \multicolumn{2}{|c|}{$\begin{array}{l}\text { Capacidade } \\
\text { Instalada }\end{array}$} & \multirow[t]{2}{*}{$\%$} & \multicolumn{2}{|r|}{ Total } & \multirow[t]{2}{*}{$\%$} \\
\hline & & Num & $\mathbf{k W}$ & & N. ${ }^{\circ}$ & $\mathbf{k W}$ & \\
\hline \multirow[t]{3}{*}{ Hídrica } & Usina Hidrelétrica & 197 & 87.699 .904 & $58,21 \%$ & \multirow[t]{3}{*}{1.187} & \multirow[t]{3}{*}{92.897 .754} & \multirow[t]{3}{*}{$61,66 \%$} \\
\hline & $\begin{array}{ll}\text { Pequena } & \text { Central } \\
\text { Hidrelétrica } & \end{array}$ & 468 & 4.834 .527 & $3,21 \%$ & & & \\
\hline & $\begin{array}{ll}\text { Central } & \text { Geradora } \\
\text { Hidrelétrica } & \end{array}$ & 522 & 363.324 & $0,24 \%$ & & & \\
\hline \multirow[t]{4}{*}{ Fóssil } & Gás natural & 142 & 13.210 .941 & $8,77 \%$ & \multirow[t]{4}{*}{2.264} & \multirow[t]{4}{*}{ 27.132.266 } & \multirow[t]{4}{*}{$18,01 \%$} \\
\hline & Petróleo & 2.098 & 10.159 .871 & $6,74 \%$ & & & \\
\hline & Carvão mineral & 23 & 3.614 .155 & $2,40 \%$ & & & \\
\hline & Outros Fósseis & 1 & 147.300 & $0,10 \%$ & & & \\
\hline \multirow[t]{5}{*}{ Biomassa } & Agroindustriais & 406 & 10.992 .992 & $7,30 \%$ & \multirow[t]{5}{*}{509} & \multirow[t]{5}{*}{13.852 .327} & \multirow[t]{5}{*}{$9,19 \%$} \\
\hline & Floresta & 81 & 2.779 .227 & $1,84 \%$ & & & \\
\hline & Resíduos sólidos urbanos & 9 & 1.804 & $0,00 \%$ & & & \\
\hline & Biocombustíveis líquidos & 2 & 4.350 & $0,00 \%$ & & & \\
\hline & Resíduos animais & 11 & 73.953 & $0,05 \%$ & & & \\
\hline Eólica & Ventos & 269 & 6.586 .133 & $4,37 \%$ & 269 & 6.586 .133 & $4,37 \%$ \\
\hline Nuclear & Urânio & 2 & 1.990 .000 & $1,32 \%$ & 2 & 1.990 .000 & $1,32 \%$ \\
\hline Solar & Radiação Solar & 27 & 25.236 & $0,02 \%$ & 27 & 25.236 & $0,02 \%$ \\
\hline \multirow[t]{4}{*}{ Import. } & Paraguai & & 5.650 .000 & $3,75 \%$ & & \multirow[t]{4}{*}{8.170 .000} & \multirow[t]{4}{*}{$5,42 \%$} \\
\hline & Argentina & & 2.250 .000 & $1,49 \%$ & & & \\
\hline & Venezuela & & 200.000 & $0,13 \%$ & & & \\
\hline & Uruguai & & 70.000 & $0,05 \%$ & & & \\
\hline & TOTAL & 4.258 & 150.653.717 & $94,58 \%$ & 4.258 & 150.653.716 & $100 \%$ \\
\hline
\end{tabular}

Fonte: Banco de Informações de Geração (Big) - Aneel, 2015.

É também importante destacar, que em relação aos usos múltiplos, além da produção de energia, foi criado o Sistema Nacional de Gerenciamento dos Recursos Hídricos (SNGRH) o qual determina as prioridades de uso da água dos rios que segundo Mendes (2010) são significativas quando relacionadas à geração de energia elétrica brasileira.

Tabela 3-3 - Planejamento de Usinas para Geração Elétrica no Brasil - GW ${ }^{24}$.

\begin{tabular}{lrrrrrrrrrrrr}
\hline \multicolumn{4}{c}{ Operação } & \multicolumn{4}{c}{ Construção } & \multicolumn{3}{c}{ Construção não iniciada } & \multicolumn{3}{c}{ TOTAL } \\
\hline Tipo & Quant. & \multicolumn{1}{c}{ W } & \multicolumn{1}{c}{$\%$} & Quant. & \multicolumn{1}{c}{ W } & $\%$ & Quant. & W & $\%$ & Quant. & W & $\%$ \\
\hline UHE & 198 & 85.279 & $60 \%$ & 11 & 15.269 & $68 \%$ & 40 & 1.143 & $6 \%$ & 249 & 101.691 & $55,2 \%$ \\
\hline UTE & 2.809 & 39.694 & $28 \%$ & 20 & 1.635 & $7 \%$ & 4 & 447 & $2 \%$ & 2.833 & 41.775 & $22,7 \%$ \\
\hline PCH & 466 & 4.817 & $3 \%$ & 34 & 416 & $2 \%$ & 299 & 7.065 & $37 \%$ & 799 & 12.298 & $6,7 \%$ \\
\hline UTN & 2 & 1.990 & $1 \%$ & 1 & 1.350 & $6 \%$ & 150 & 8.454 & $45 \%$ & 153 & 11.794 & $6,4 \%$ \\
\hline EOL & 273 & 6.629 & $5 \%$ & 159 & 3.856 & $17 \%$ & 1 & 0 & $0, \%$ & 433 & 10.485 & $5,7 \%$ \\
\hline UFV & 25 & 21 & $0 \%$ & 0 & - & $0 \%$ & 132 & 1.856 & $10 \%$ & 157 & 1.877 & $1,0 \%$ \\
\hline CGH & 525 & 371 & $0 \%$ & 1 & 1 & $0 \%$ & 40 & 28 & $0,1 \%$ & 566 & 399 & $0,2 \%$ \\
\hline Total & 4.298 & 142.551 & $100 \%$ & 226 & 22.527 & $100 \%$ & 666 & 18.992 & $100 \%$ & 5.190 & 184.070 & $100,0 \%$ \\
\hline
\end{tabular}

\footnotetext{
${ }^{24}$ Fonte: Elaboração própria com base dados da Aneel 2015 UTE - Usina Termelétrica UTN - Usina Termonuclear UFV - Central Geradora Solar Fotovoltaica
}

EOL - Central Geradora Eólica UHE - Usina Hidrelétrica PCH - Pequena Central Hidrelétrica CGH - Central Geradora Hidrelétrica 
Observa-se, em amarelo, uma grande potência de fonte eólica em outorga o que demonstra a grande competitividade dessa fonte nos últimos anos dentro dos leilões de energia organizados pela Aneel.

Em relação ao consumo, o Brasil atingiu, em 2014, 590 Terawatt-hora (TWh) e, segundo o cálculo de estimativa da tendência (Figura 3-19), pode chegar ao ano de 2050 a 942 TWh, o que significa um crescimento de aproximadamente $60 \%$, salvo se programas de energia mais eficientes, restruturação do setor como o proposto por Sauer (2003), ou mesmo crises econômicas e prováveis déficits de energia não ocorram futuramente.

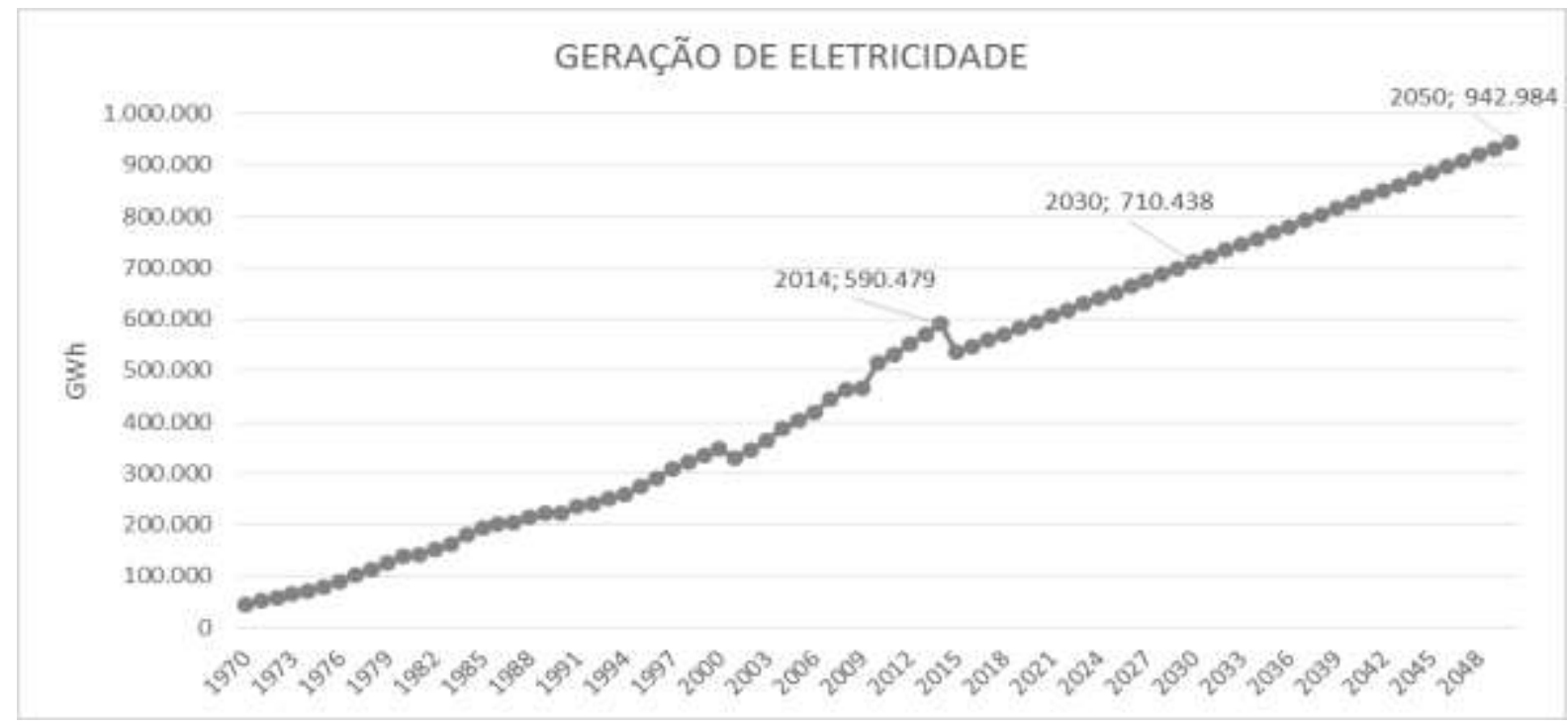

Figura 3-19 Demanda Energia Prevista até 2050 - elaborações próprias com dados de Capítulo 5 - Balanços dos Centros de Transformação (BEN, 2015).

Na Figura 3-20 e na Figura 3-21, apresentam-se a integração eletroenergética entre as diversas bacias hidrográficas do Brasil (ONS, 2015). Nessas figuras, observam-se a abrangência do SIN no território brasileiro. 


\section{ONS Soraderscioul Diagrama Esquemáticc \\ Usinas Hidroelétricas Despachadas pelo ONS na I}

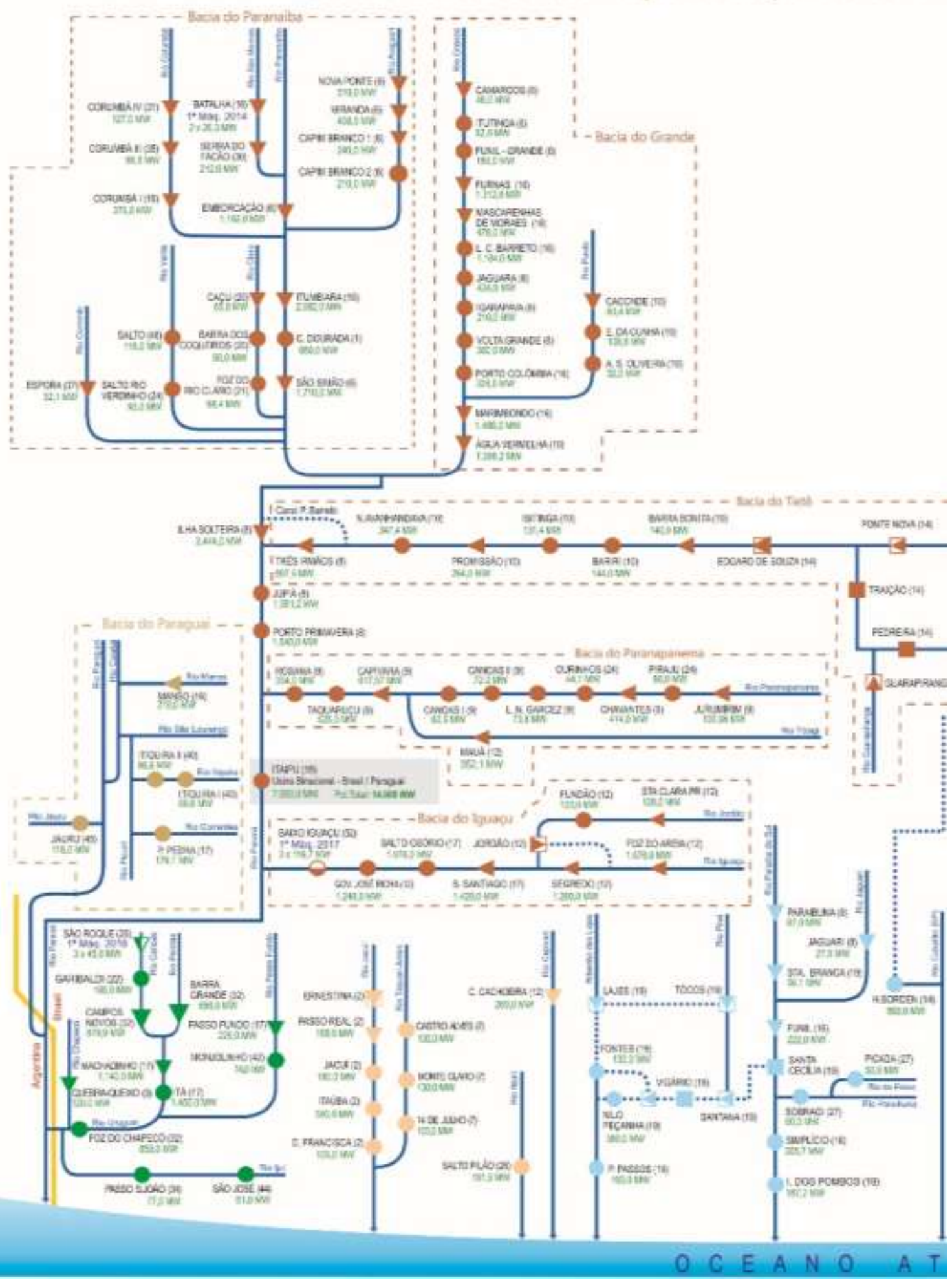

Figura 3-20 Diagrama Esquemático das Usinas Hidroelétricas do SIN. Metade da esquerda. Fonte: ONS, 2015 


\section{, das Usinas Hidroelétricas do SIN}

\section{)timização da Operação Eletroenergética do Sistema Interligado Nacional}

Horizonte: $2015-2019$

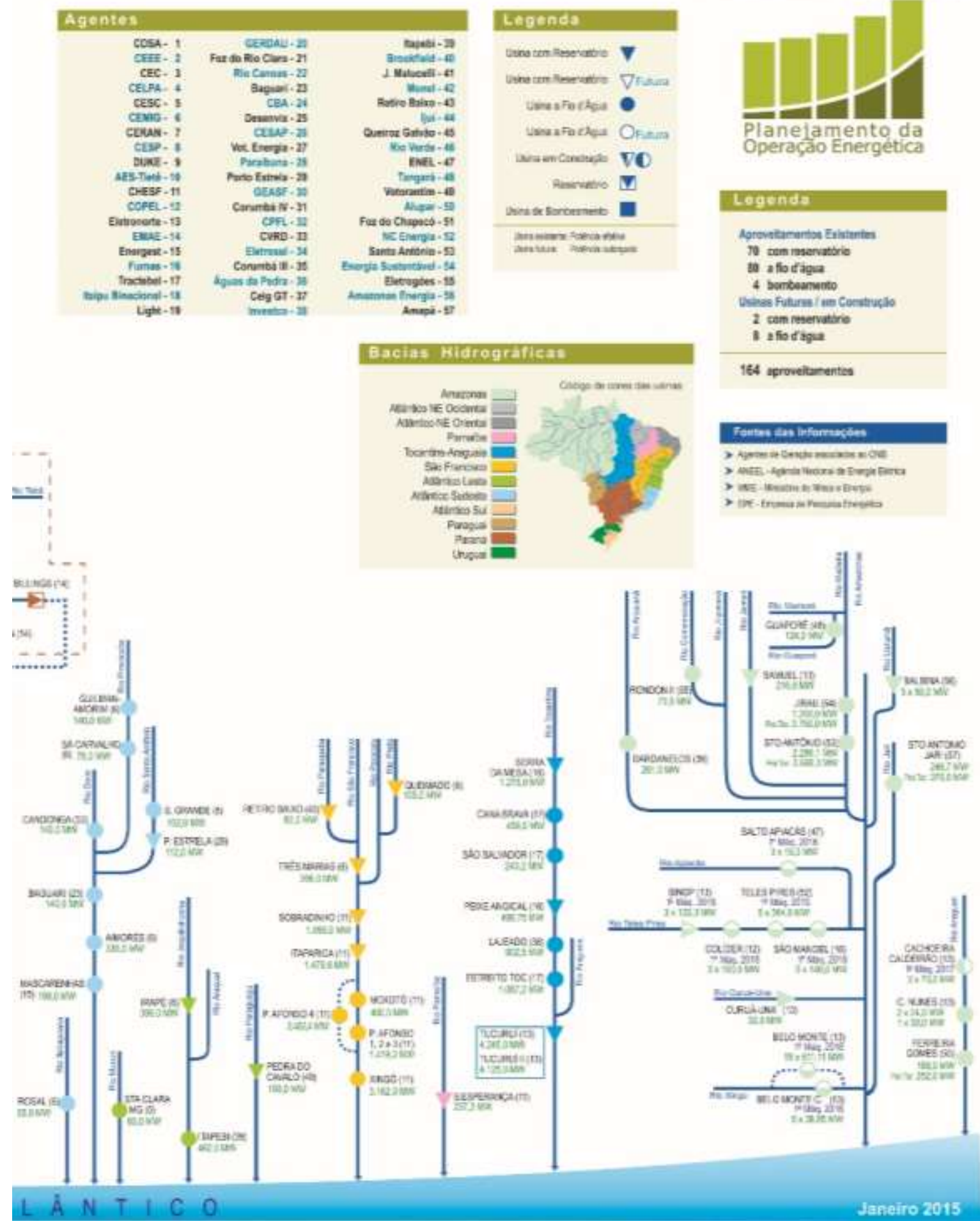

Figura 3-21 Diagrama Esquemático das Usinas Hidroelétricas do SIN. Metade da direita. Fonte: ONS, 2015 


\subsection{Crescimento populacional e consumo de energia no mundo e no Brasil}

O crescimento populacional caracteriza-se como um indicador para o aumento de consumo humano. Conforme a população cresce o consumo de energia, principalmente em países emergentes, aumenta simultaneamente. No último milênio da história da humanidade, a população mundial cresceu de forma exorbitante, Figura 3-22.

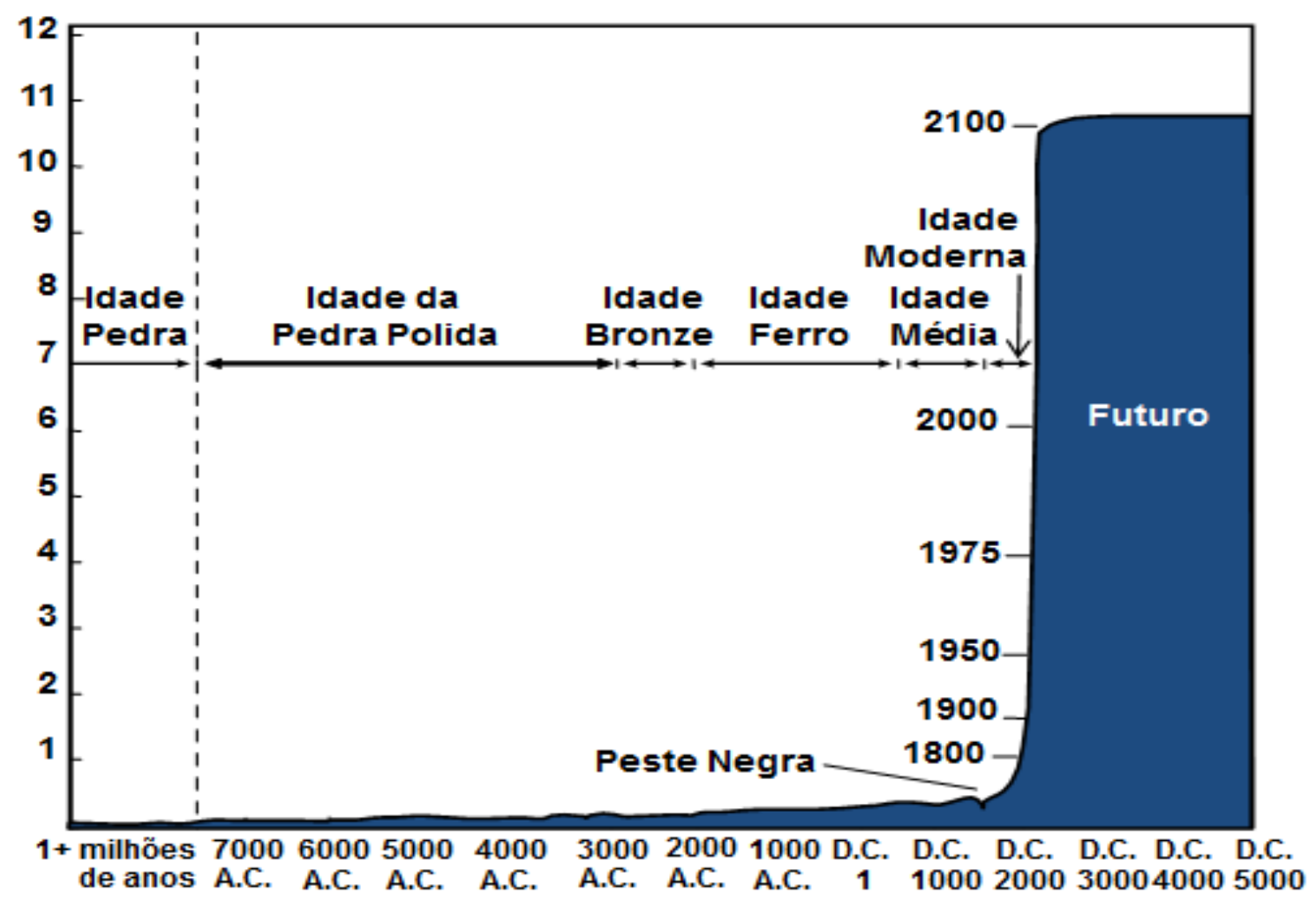

Figura 3-22 Crescimento populacional através história da humanidade - Bilhões Pessoas ${ }^{25}$

Grande parte desse crescimento populacional recente concentram-se em países pouco desenvolvidos. Segundo previsões da ONU (2004), chega-se a quase de 11 bilhões de habitantes em 2100 (Figura 3-23).

\footnotetext{
25 Fonte: Population Reference Bureau; and United Nations, World Population Projections to 2100 (1998).
} http://www.prb.org/presentations/gb-poptrends_all.ppt. 


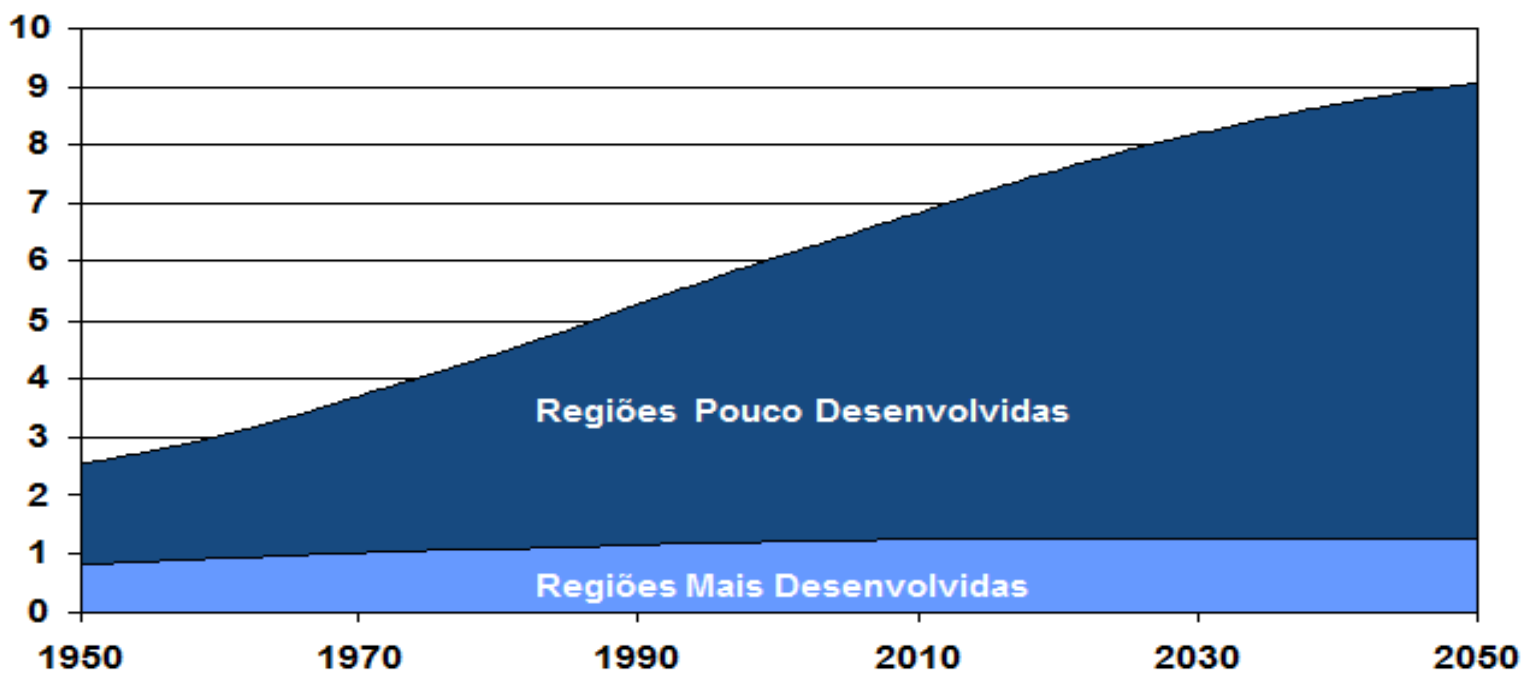

Figura 3-23 Crescimento populacional Regiões Pouco Desenvolvidas versos Regiões Mais Desenvolvidas Fonte: ONU, $1998^{26}$

No Brasil, a população em 2014 é de 203 milhões e, para 2042, é estimado atingir o pico de 228 milhões (Figura 3-24, IBGE, 2013).

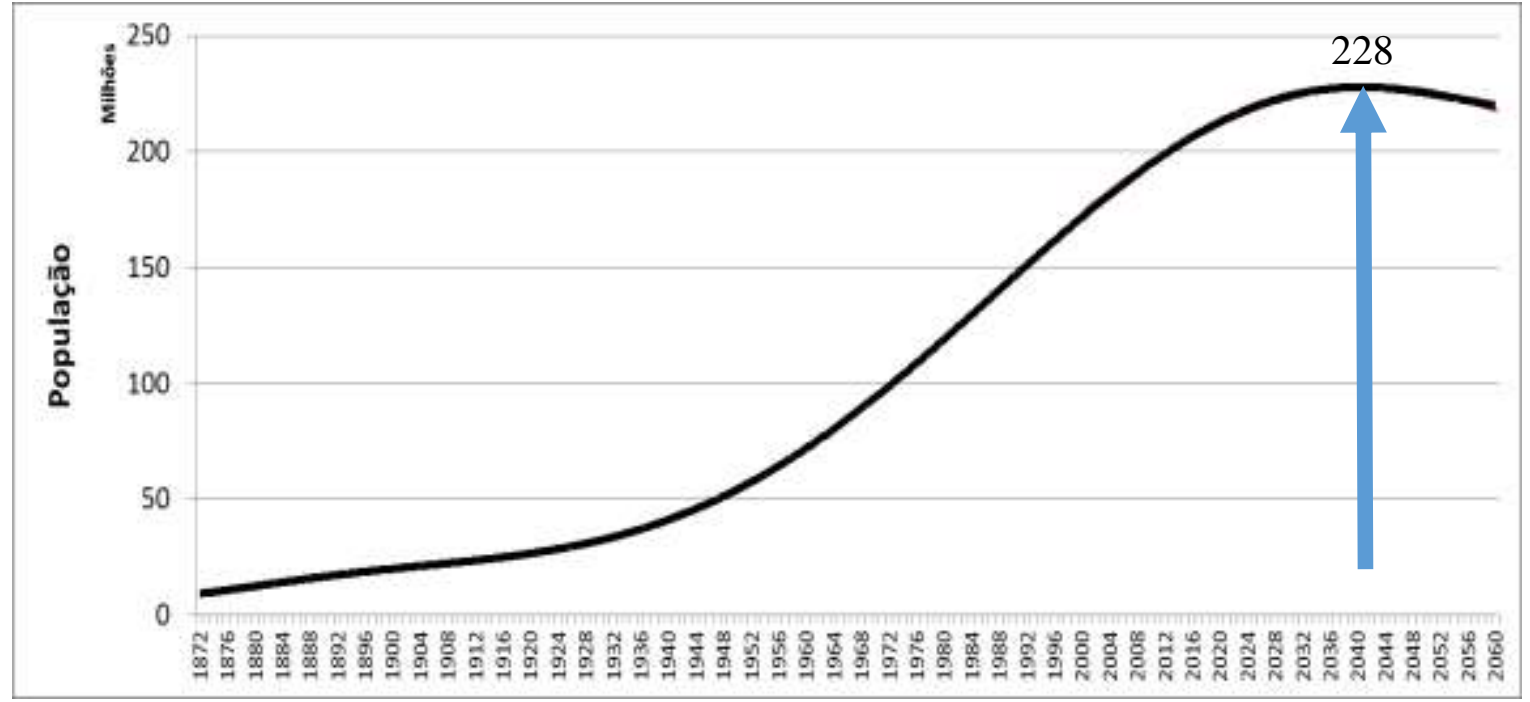

Figura 3-24 População em 2014 é de 202.768.562.Pico previsto em 2042 de 228.350.924, Brasil. Fonte: IBGE, 2013

A demanda de energia cresce conjuntamente com a população. Estima-se que a previsão de energia a ser consumida para 2040, segundo a OECD, está na faixa de 40 Pentawatt-hora (PWh), um crescimento de cerca de duas vezes o consumo de 2010. Na Figura 3-25, observase que, enquanto os países da Organização para o Desenvolvimento e Cooperação Econômica

\footnotetext{
${ }^{26}$ Fonte: http://www.prb.org/presentations/gb-poptrends_all.ppt.
} 
(OECD) ${ }^{27}$ mantêm seu crescimento de consumo de energia muito pequeno, os países não pertencentes à OECD apresentam um crescimento maior, bem como o Brasil que pode chegar a quase 1,2 PWh anuais em 2040, segundo a IEA (2010).

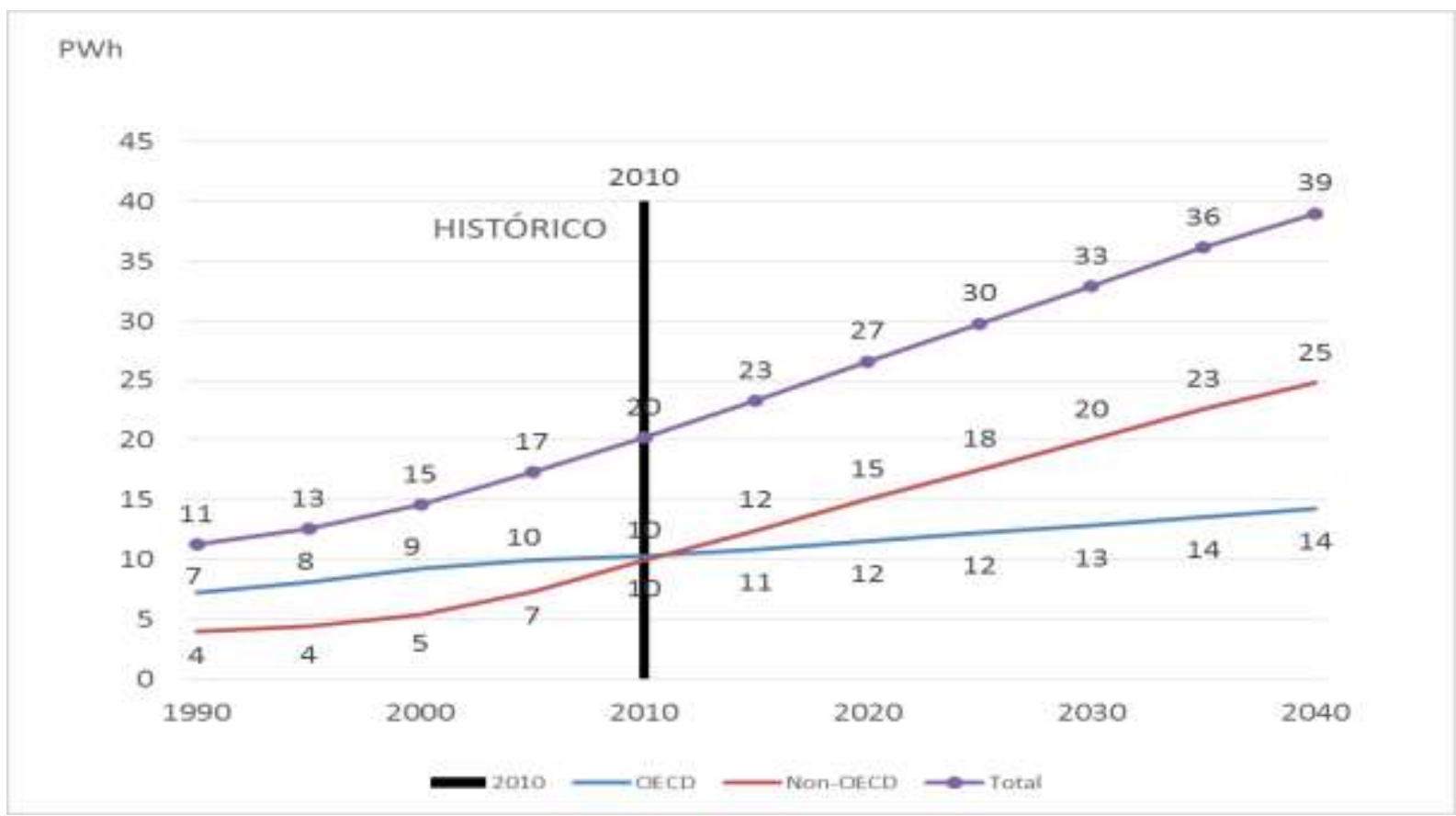

(a)

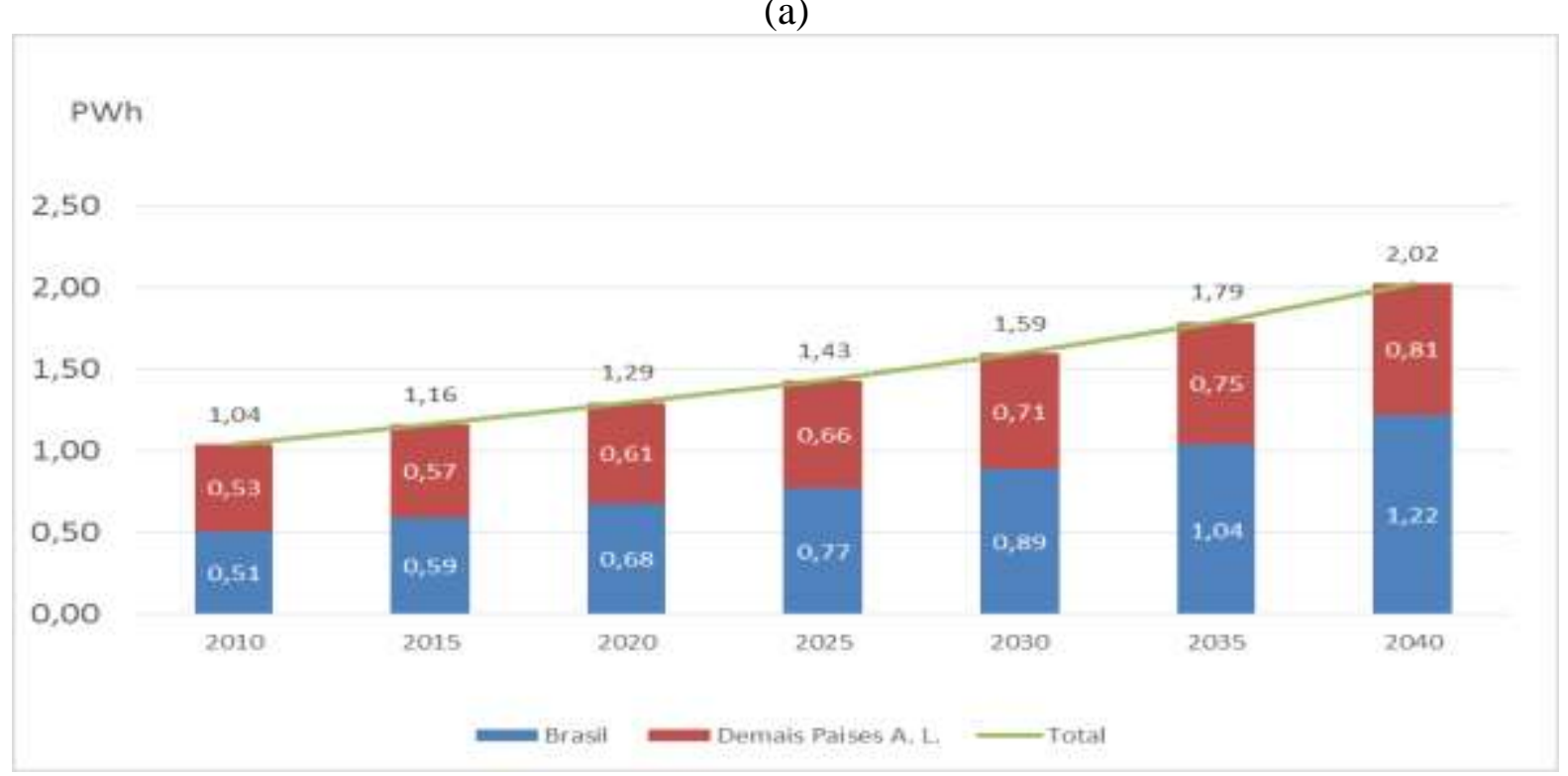

(b)

Figura 3-25 Energia consumida no a) mundo e b) América Latina ${ }^{28}$.Unidade Pentawatt-hora (1.000 TWh). Fonte: DOE/EIA, 2013

27 Organisation for Economic Co-operation and Development (OECD)

${ }^{28} \mathrm{http}: / / \mathrm{www}$. eia.gov/forecasts/ieo/index.cfm

http://www.eia.gov/forecasts/archive/ieo13/electricity.cfm 
Para acompanhar o aumento da demanda, a oferta de energia cresce e novas fontes são mencionadas com crescimento no planejamento dos países.

\subsection{Trabalhos sobre informações climáticas de larga escala na previsão de precipitações ou de vazões de rio}

No Brasil o trabalho de Souza Filho e Lall (2003) utiliza informações do Atlântico e Pacifico para previsão de vazões em regiões do Ceará. Guarnier et al (2012) faz utilização o método de clusterização para classificação de séries históricas de ENA e de valores indicativos do fenômeno El Niño através do índice MEI-ENSO. Sá et al (1998) utilizam transformadas de wavelets de Morlet e Nordemann (1999) utiliza análise espectral para verificas as periodicidades para a bacia do Rio Paraguai e as suas interações com variáveis macroclimáticas que apresentam periodicidades semelhantes. Nos EUA outros trabalhos demonstram que a incorporação de informações climáticas de larga escala na previsão de precipitações, ou de vazões de rio o que pode aumentar a precisão (ou destreza) do período previsto. As técnicas tradicionais de previsão, no entanto, não utilizam, de forma sistêmica, as informações climáticas (GRANTZ et al 2007) como também ocorre no Brasil com o sistema NEWAVE.

Outras pesquisas têm identificado a influência dos fenômenos do Pacífico tropical como através de estudos de correlação entre os índices climáticos Oscilação Decadal do Pacífico (PDO), (MATUA ET AL 1997), e El Niño Oscilação Sul (ENOS), (PHILANDER, 1990), e localizações do mundo (ALLAN et al., 1996), e também localizações do Oeste dos EUA (ROPELEWSKI E HALPERT, 1986).

Os trabalhos de Mishra et al (2011), por exemplo, estudam a relação de vazões dos rios de bacias do Texas como o rio Colorado e rio Trinity nos períodos pré-industrial (1925-1964) e pós-industrial (1965-2003) com índices sazonais baseados no ENOS, PDO e índice de Oscilação Sul (Southern Oscillation Index - SOI). Indicam padrões de crescimento ou redução em ambos os períodos.

O artigo de Grantz et al (2007) trata da relação entre previsores como neve equivalente a agua $^{29}$, e variáveis macroclimáticas como altura geopotencial a 500 mbar, precipitação região das montanhas da Califórnia Serra Nevada, TSM, pressão ao nível do mar, magnitude dos ventos, derivados de dados de reanálise NCEP/NCAR do NOAA. Citam-se outros trabalhos

\footnotetext{
${ }^{29}$ SWE - Snow Water Equivalent
} 
semelhantes como exemplos: Cayan e Peterson (2013) estudam a relação entre os índices PNA (Pacific-North America), CNP (Central North Pacific) e anomalias de pressão ao nível do mar no sul dos Aleutians e oeste do Golfo do Alaska e vazões de rios no Norte e Sudoeste dos EUA; Cayan e Webb (1992) estudam a correlação do índice SOI e as vazões dos rios Yellowstone em Montana e Salt River no Arizona; Kahya e Dracup (1993) analisam a influência do ENOS, em escalas globais e locais, em quatro grandes regiões ao longo dos EUA, através da extração da harmónica principal do ENOS semelhante às fases das harmónicas encontradas em estações localizadas nas quatro regiões, e o estudo demonstra e corrobora com estudos anteriores, sobre a relação entre o ENOS frente a precipitações e temperaturas, bem como a resposta hidrológica localizada nas latitudes médias; Dracup e Kahya (1994) tratam as mesmas quatro regiões do trabalho anterior (1993) que são analisadas frente ao evento La Niña, fase fria da Oscilação Sul, e demonstram de maneira consistente e significativa, as respostas das vazões, localizadas nas latitudes médias, para o fenómeno tropical da Oscilação Sul; Enfield et al (2001) analisa a correlação entre as fases quentes e frias do índice AMO (Atlantic Multidecadal Oscillation), e secas ocorridas no meio Oeste dos EUA, as bacias de Ohio e Tennessee, as vazões dos rios Mississippi e cheias do Lago Okeechobee na Flórida; Rogers e Coleman (2003) mostram a relação de 554 fontes de dados de estações de medições hidrológicas e as correlações entre AMO, PNA e o NINO 3.4 e as variações de descarga da bacia do rio Mississippi; Maurer et al (2004) analisam o resultados de um modelo escoamento (runoff), entre as latitudes $25^{\circ} \mathrm{N} 53^{\circ} \mathrm{N}$, nos EUA e a contribuição da variabilidade de teleconexões climáticas para a acumulação da neve e seu escoamento ao derreter, e afirmam que relações estatisticamente significativas foram identificadas, e também, que o estado de umidade da superfície proporciona um grau adicional de previsibilidade da variabilidade do escoamento para um período de 4,5 meses a frente; McCabe et al (2004) após aplicarem analise de componentes principais em dados de 20 anos de seca nos EUA, afirmam que $52 \%$ da variância espacial e temporal da frequência de secas, são atribuídas a PDO e a AMO, e $22 \%$ da mesma variância é atribuída a padrões espaciais complexos, e para cenários futuros, sugerem que podem ocorrem eventos de seca semelhantes aos padrões de escala continental da década de 1930 (PDO positivo) e 1950 (PDO negativo), no caso do atual cenário de AMO positiva persista (Atlântico Norte aquecido) Tootle e Piechota (2006) utilização técnicas de SVD e analisam a relação de regiões dos oceanos Pacifico e Atlântico e, também, os indicies AMO, PDO frente as vazões de diferentes partes dos EUA; Hunter et al (2006) analisam os índices macroclimáticos frente a 32 estações de medições de acumulo de neve; trabalhos similares são: Soukup et al (2009) aplicam os índices macroclimáticos frente 
as vazões do alto do rio North Platte, no Colorado; Matter et al (2010); Rajagopalan et al (2000) estudam as relações frente a seca no Sul do Texas e Arizona; Özger et al (2009) também estudam a seca no Texas.

Há estudos, além das relações entre ENOS e vazões, que também consideram as precipitações: Redmond e Koch (1991); Eltahir (1996); Chiew et al (1998); Kawamura et al (1998); Berri e Flamenco (1999); Simpson e Colodner (1999).

E também, a resposta das vazões para ENOS ou regiões do Atlântico foi investigada para alguns rios pelo mundo, além dos EUA, em Elsanabary et al (2014), Elsanabary et al (2015) e Wang e Eltahir (1996), rio Nilo; Whitaker et al (2001), rio Ganges; Dettinger et al (2000), rios da América do Sul e do Norte.

Há também trabalhos que abordam a influência do Sol sobre o clima e por sua vez, sobre as precipitações e vazão de rio: Souza Echer et al (2007), precipitação em Pelotas, Brasil; de Compagnucci et al (2014) e Mauas $(2008,2011)$ número de manchas solares versos a vazão dos rios Paraná, no Brasil, e Atuel, na Argentina, Antico e Kröhling (2011) e Cionco e Abuin (2015), o momentum angular, e torque solar, e também o posicionamento dos grandes planetas do sistema solar versos vazão dos rios Paraná, Brasil, e Pó da Itália. Todos os trabalhos têm a intenção de mostrar os impactos da variabilidade global dos fenômenos oceânicos e atmosféricos (índices) sobre a hidrologia. Constatou-se que a variabilidade climática influencia a atividade hidrológica regional (KAHYA E DRACUP, 1993), mas as causas não são bem compreendidas.

Agosta (2014) analisa a relação do ciclo lunar de 18,4 anos e aponta evidências estatísticas da influencia do ciclo lunar e a variabilidade de baixa frequência da precipitação em planícies a Oeste dos Andes subtropicais na América do Sul. Nos anos que há marés fortes ou fracas, há influência da diapycnal ${ }^{30}$, que torna a TSM mais quente ou mais fria e combinada as baixas ou elevadas pressões do ar no entorno das Ilhas Malvinas e Falklands. A identificação da periodicidade nodal na variabilidade das precipitações de verão é estatisticamente robusta.

Kwon et al (2012) apontam a necessidade de se calcular as incertezas associadas às previsões de vazão de rio, visto que uma previsão não pode ser considerada se não forem apresentadas essas incertezas. Afirmam que as incertezas de modelos que utilizam o clima para realizar previsão são maiores em relação aos que utilizam somente dados hidrológicos e que o esforço

\footnotetext{
${ }^{30}$ Diapycnal é um conceito físico relacionado a inclinação das camadas de superfície dos oceanos, que são formadas pela mistura de camadas com densidade homogêneas (isopycnal). A inclinação ocorre devido a dinâmica da ressurgência, promovida pela dinâmica atmosférica, através dos ventos, e dos gradientes de temperatura encontrados em diferentes profundidades, nos oceanos.
} 
para as pesquisas futuras é melhorar a previsão dos índices climáticos. Nessa tese realiza-se o cálculo das incertezas como será visto mais adiante.

Vários estudos foram realizados para o entendimento da relação entre vazão e índices climáticos e muitos outros sobre precipitação e índices climáticos, no entanto poucas são as investigações desse tema para os rios brasileiros e muito menos para a previsão de oferta de energia.

\subsection{Modelagem de operação de reservatórios}

Labadie (2004) apresenta a modelagem de operação de reservatórios e o cálculo de seu estado ótimo, realizada por meio de diversas técnicas que calculam a otimização como Programação Linear (PL), Programação Não Linear (PNL) e Programação Dinâmica (PD). Uma das formas para aumentar o nível de confiança na utilização de modelos de otimização é a aplicação desses modelos acoplados aos Sistemas de Suporte à Decisão (SSD). Segundo Mendes (2010), no Brasil, os modelos de sistemas complexos aplicados à otimização empregam PL, PD, PNL, programação linear inteira mista (PLIM) e programação não-linear inteira mista (PNLIM). O SSD ACQUANET, desenvolvido por Porto et al (2005), cujas primeiras versões foram baseadas no modelo MODSIM, e é mais um exemplo de modelagem tipo PL.

Barros et al (2003) em um convênio entre Escola Politécnica da Universidade de São Paulo (EPUSP) com a Universidade da Califórnia (UCLA), criou o modelo SISOPT, pioneiro na modelagem com usinas individualizadas, utilizado no sistema hidrelétrico brasileiro com diferentes funções objetivo e três diferentes modelos de estimação (PL, PNL e Programação Linear Sucessiva - PLS).

O modelo SISAGUA, desenvolvido por Barros et al (2008), aplica algoritmos PLIM e PNLIM na operação de sistemas complexos de adução de água formados por reservatórios, estações de tratamento e elevatórias (MENDES, 2010, 2015). O SISAGUA foi aplicado no estudo do sistema de abastecimento da RMSP e também ao sistema de Taiwan, com a otimização processada com o software General Algebraic Modelling System (GAMS).

Em relação aos modelos utilizados para prever vazões médias no Brasil, o SEB emprega os modelos de gerenciamento de reservatórios e despacho de geração hidrotérmica, como o NEWAVE e o DECOMP, com o objetivo de minimizar os custos de geração térmica e atender a demanda de eletricidade com certa garantia (MME, 2008). 
No Brasil, o governo federal, através do Gabinete do Ministério de Minas e Energia, promulgou a Portaria n $^{\text {o }} 258$ de 28 de julho de 2008 determina $^{31}$ :

GABINETE DO MINISTRO

PORTARIA N ${ }^{\circ} 258$, DE 28 DE JULHO DE 2008.

Texto Compilado

O MINISTRO DE ESTADO DE MINAS E ENERGIA, no uso das atribuições que lhe confere o art. 87, parágrafo único, incisos II e IV, da Constituição, tendo em vista o disposto no art. $2^{\circ}, \S 2^{\circ}$ e no art. $4^{\circ}, \S 1^{\circ}$ do Decreto $n^{\circ} 5.163$, de 30 de julho de 2004, e considerando o relatório EPE-DEE-RE-099/2008-r0, de 2 de julho de 2008, da Empresa de Pesquisa Energética - EPE; e a Nota Técnica $\mathrm{n}^{\circ}$ 115/2008/DPE/SPE/MME, de 24 de julho de 2008, do Departamento de Planejamento Energético, da Secretaria de Planejamento e Desenvolvimento Energético do Ministério de Minas e Energia, resolve:

Art. $1^{\circ}$ Definir a metodologia de cálculo da garantia física de novos empreendimentos de geração de energia elétrica do Sistema Interligado Nacional SIN, conforme metodologia constante do Anexo I.

\section{ANEXO I}

1. Premissas Gerais e Metodologia de Cálculo da Garantia Física de Energia

O processo de determinação da garantia física das novas usinas contempla um conjunto de premissas e metodologias de cálculo que serão apresentados a seguir.

1.1 Premissas Gerais

I. Modelos e Parâmetros de Simulação

Para as simulações energéticas a sistemas equivalentes será utilizado o modelo NEWAVE, desenvolvido pelo CEPEL, na versão para cálculo de garantia física. [...]

Essa portaria Ministerial impede que outras abordagens façam parte do SEB e monopoliza o uso do ferramental computacional para qualquer agente do SEB.

\section{O NEWAVE emprega a programação dinâmica dual estocástica (PDDE) para} minimizar o valor esperado do custo de operação do sistema. São considerados o custo presente do combustível das térmicas e o custo futuro de oportunidade de uso da água. As variáveis de decisão são a geração hidroelétrica, a térmica e os intercâmbios entre os subsistemas do SIN. Toma-se a decisão sobre quanto será gerado por hidrelétricas e por térmicas para atender à demanda de energia, considerando um horizonte de um a cinco anos com passo de tempo mensal. O NEWAVE agrega todas as usinas pertencentes a determinado subsistema em um único reservatório equivalente de energia (como já abordado anteriormente no conceito de ENA) com volume igual ao total da energia armazenada em cada reservatório do subsistema. Assim, o NEWAVE simplifica a representação do SIN, ao tratar apenas de quatro reservatórios equivalentes relativos aos quatro subsistemas (CEPEL, 2011). O uso de sistemas equivalentes permite o emprego do PDDE e evita a "maldição da dimensionalidade" característica da PD.

\footnotetext{
${ }^{31}$ Fonte: http://www.aneel.gov.br/cedoc/prt2008258mme.pdf
} 
Os resultados do NEWAVE constituem os dados de entrada DECOMP, que desagrega os quatro subsistemas equivalentes em usinas individualizadas para um horizonte de tempo de cinco semanas. O DECOMP, que emprega PL, define a geração hidráulica e térmica de cada usina do sistema, bem como o Custo Marginal de Operação (CMO), que pode ser entendido como um custo futuro atribuído à água a ser utilizada e à decisão de despachar ou não despachar a usina. Para cada subsistema é calculado seu CMO, que junto com o despacho de usinas térmicas por ordem de mérito é o principal parâmetro que define o preço da energia elétrica no mercado de curto prazo (LOPES, 2007; SILVA, 2001).

O NEWAVE baseia-se no modelo $\mathrm{AR}(\mathrm{p})$, abaixo é apresentada a equação que governa o NEWAVE para o cálculo da função de custo futuro (MACEIRA et al., 1999):

$\left(\frac{Z_{t}-\mu_{m}}{\sigma_{m}}\right)=\phi_{1}^{m}\left(\frac{Z_{t-1}-\mu_{m-1}}{\sigma_{m-1}}\right)+\cdots+\phi_{p}^{m}\left(\frac{Z_{t-p_{m}}-\mu_{m-p_{m}}}{\sigma_{m-p_{m}}}\right)+a_{t}$

ou, resumidamente $\Phi^{m}(B)\left(\frac{Z_{t}-\mu_{m}}{\sigma_{m}}\right)=a_{t}$

em que

$\mu_{m} \sigma_{m} m$ é o índice do período sazonal, $\mathrm{m}=$ jan., fev., mar., abr., mai., jun., jul., ago., set., out., nov. e dez.;

$Z_{t}$ é a série sazonal, ou o processo estocástico;

$\Phi^{m}(B) \phi_{\mathrm{i}}{ }^{\mathrm{m}}$ é o i-ésimo coeficiente autorregressivo do período m;

$\mathrm{p}_{\mathrm{m}}$ é a ordem do operador autorregressivo do período $\mathrm{m}$;

$\mu_{m}$ é a média sazonal;

$\sigma_{m}$ é desvio-padrão sazonal;

$\Phi^{m}(B)$ é o operador autorregressivo de ordem $\mathrm{p}_{\mathrm{m}}$;

$a_{t}$ é a série de ruídos independentes com média zero e variância $\sigma_{a}^{2(m)} \sigma_{a}^{2(m)}$.

Os modelos NEWAVE e Determinação da Coordenação da Operação à Curto Prazo (DECOMP) são executados uma vez por mês em uma reunião conhecida por Programa Mensal da Operação (PMO), na qual participam os agentes do processo de planejamento do SEB. Em função da persistente atualização das previsões hidrológicas, semanalmente realizase uma revisão do processamento do DECOMP pelo ONS. Previsões de seca tendem a elevar o valor do CMO, previsões de grandes afluências tendem a reduzi-lo (LOPES, 2007).

Zambon et al (2012) desenvolveu um SSD para o planejamento de sistemas hidrotérmicos de grande porte chamado SSD Hidroterm. O modelo Hidro é um programa que parte do Hidroterm e otimiza o sistema de usinas individualizadas, sendo essa uma diferença significativa em relação ao SoverSIN e ao NEWAVE, buscando o aproveitamento máximo da 
capacidade hidrelétrica instalada. O modelo TERM otimiza o despacho das usinas térmicas e os intercâmbios entre os subsistemas. Ambos os modelos apresentados anteriormente podem ser empregados isoladamente ou integrados no modelo Hidroterm.

O modelo HIDRO corresponde a uma evolução do SISOPT sem o emprego da PL e da PLS.

Lopes (2007) apresenta, em sua tese de doutorado, um sistema de otimização para planejamento da operação de sistemas hidrotérmicos de produção de energia elétrica no Brasil, chamado SolverSin. O sistema usa como base o balanço de energia entre fontes de produção de energia elétrica e as equações de balanço hidroenergético aplicadas aos reservatórios equivalentes de energia potencial. O sistema dispõe de três propriedades relevantes: eficiência, transparência e precisão. Resolve o problema de otimização através de Programação Não Linear (PNL) utilizando "solvers" 32 comerciais de grande confiabilidade no meio técnico internacional.

$\mathrm{Na}$ Colômbia, os modelos autorregressivos (AR), os modelos de combinação entre autorregressivos e médias móveis (ARMA) ou integrados (ARIMA) e a geração de séries históricas sintéticas foram utilizados nos anos setenta e oitenta (HERNÁNDEZ, 2011). Enquanto no Brasil estes modelos ainda são utilizados e combinados com diversos outros modelos em vários módulos de sistemas (CEPEL, 2011).

O modelo de Despacho de Geração Hidrotérmica (NEWAVE) emprega a Programação Dinâmica Dual Estocástica (PDDE) para minimizar o valor esperado do custo de operação do sistema. São considerados o custo presente do combustível das térmicas e o custo de oportunidade de uso futuro da água com o cálculo do Custo Futuro da Água. Toma-se a decisão sobre quanto será gerado por hidrelétricas e por térmicas para atender a demanda de energia, considerando um horizonte de um a cinco anos com passo de tempo mensal. $\mathrm{O}$ NEWAVE agrega todas as usinas pertencentes a determinado subsistema em um único reservatório equivalente de energia, com volume igual ao total da "energia armazenada" em cada reservatório do subsistema (CEPEL, 2011).

Os modelos autorregressivos dependentes de regimes são modelos tipo PNL, onde o regime hidrológico está relacionado com variações macroclimáticas, explorando a possibilidade das séries de precipitação e vazões possuírem propriedades estatísticas dependentes dos estados apresentados pelas variáveis macroclimáticas. Assim o modelo procura ajustar as propriedades estocásticas, de uma série histórica dependente do estado de uma variável

\footnotetext{
${ }^{32}$ O Solver é programa utilizado para realizar rotinas de otimização, através da minimização ou maximização de uma função objetivo e busca seguir algumas restrições ou limites.
} 
externa, que considera-se influente no comportamento do fenômeno analisado (HERNANDEZ, 2011).

\subsection{Modelos de previsão de vazões}

O livro de Lima, Colischonn e Marengo (2014) é o resultado de um trabalho de pesquisa em conjunto ao chamado de Projeto P\&D Estratégico 010 - "Efeitos de mudanças climáticas no regime hidrológico de bacias hidrográficas e na energia assegurada de aproveitamentos hidrelétricos", liderado pela empresa AES Tietê. Foram gerenciadas equipes multidisciplinares. O livro apresenta três seções: 1 - Modelos Climáticos, 2 - Hidrologia e 3 Cálculo de Energia Assegurada. Através de seu código PE-0064-1024/2011, foi possível levantar os recursos para viabilizar o projeto que totalizou cerca de 3,7 milhões de reais (2008-2009 418 mil, 2009: 551 mil e 2011 2,79 milhões de reais ${ }^{33}$ ).

Esse projeto foi organizado em quatro grandes grupos: Clima, Hidrologia, Uso do Solo e Energia. Em seu livro, José Wanderley Marangon Lima descreve a formulação e organização dos trabalhos conforme a Figura 3-26.

Segundo palavras de Lima (LIMA et al., 2014):

“... duas equipes que trabalharam com cenários de mudanças climáticas e definiram um conjunto de casos ou possibilidades de comportamento do clima considerando os atuais modelos globais. Cinco deles pertencem ao conjunto de dados do ETA de maior resolução geográfica, cuja origem é o modelo global do Hadley Center, e outros cinco diretamente retirados de outros centros de desenvolvimento. Desde 1995, o modelo climático regional ETA-CPTEC tem sido usado no Instituto Nacional de Pesquisas Espaciais (INPE) como modelo operacional de previsão de tempo e previsão climática sazonal.

A partir das variáveis climáticas obtidas da simulação dos modelos globais, duas equipes de Hidrologia converteram as precipitações em afluências aos reservatórios das usinas do Sistema Interligado Nacional (SIN). Uma equipe (Hidrologia I) deteve-se nas bacias da Região Sul e Amazonas, e outra (Hidrologia II) nas bacias da Região Sudeste e Nordeste. Foram, também, feitos alguns cenários de uso do solo e de demanda de água par uso urbano e rural pela equipe de Usos Consuntivos, cujos resultados foram agregados e representados nas afluências.

A partir desses resultados hidrológicos, a equipe de Energia calculou as energias asseguradas para os casos apresentados pela equipe do Clima. Nessa transformação de afluências em energia, foram considerados dois parques geradores: Parque Gerador Existente (PGE) e Parque Gerador Futuro (PGF). O PGE representa o conjunto de usinas geradoras existentes no Plano Mensal de Operação de Janeiro de 2012, e o PGF o conjunto de usinas previstas para estar em operação no ano de 2030. Esta última configuração é a considerada no PNE2030 da EPE. O cálculo das energias asseguradas foi feito para os horizontes de 2040, 2070 e 2100 . No processo de cálculo para esses anos, utilizaram-se, como histórico para o Newave, os anos

${ }^{33}$ Duto Aneel arquivo Projetos_PED-ANEEL_(Res_Norm_316-2008)_Ver2014.06.20. Acesso em 29/09/2015 end.; <http://www.aneel.gov.br/arquivos/PDF/Projetos_PED-ANEEL_(Res_Norm_316-

2008)_Ver2014.06.20.xls> 
anteriores simulados pelos modelos globais. O programa Newave é utilizado para determinar a estratégia de operação do sistema elétrico que minimiza o custo operacional presente e futuro."

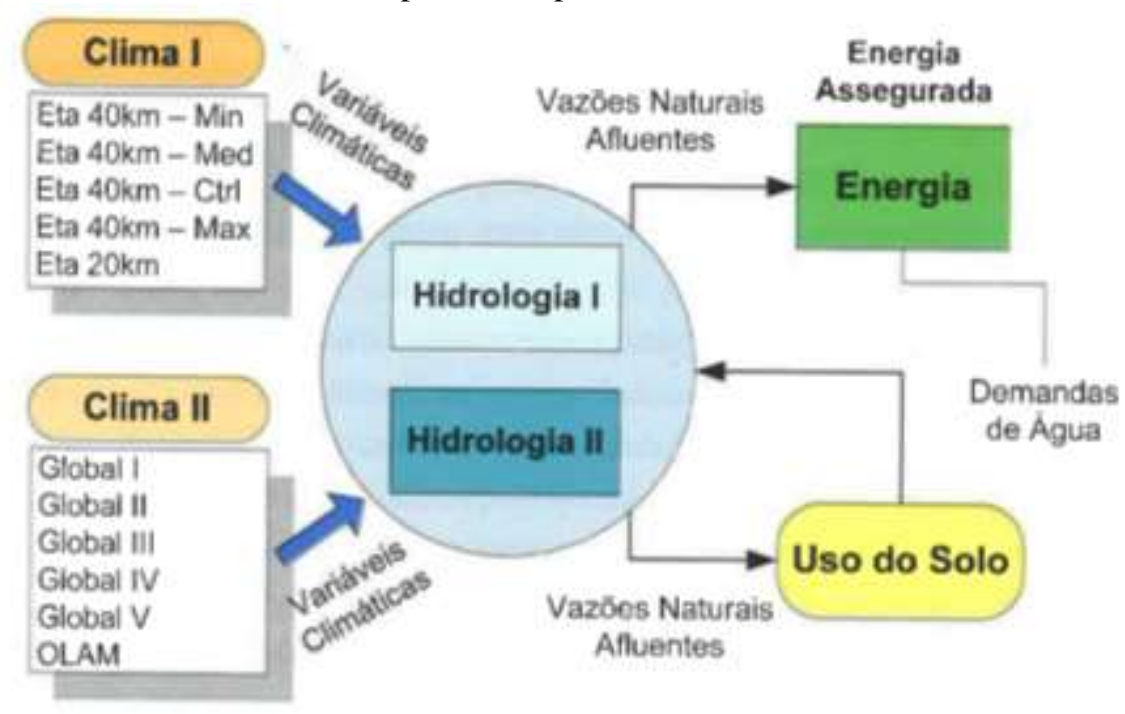

Figura 3-26 Fluxo Divergente (LIMA ET AL 2014)

Nesse trabalho, fica evidente o esforço humano, financeiro e logístico para organizar uma equipe tão ampla. Infelizmente, por ser um $\mathrm{P} \& \mathrm{D}$, os únicos produtos públicos são os livros, os métodos, dados e resultados mais detalhados, ficam a cargo do sigilo da concessionária e das instituições participantes do P\&D.

Farias (2012) apresenta, em sua tese de doutorado, uma melhoria para geração de cenários de vazões para um horizonte de até três meses. Utiliza em seu modelo autorregressivo multivariado com variável exógena (ARx) as precipitações como variável explicativa, que segundo suas análises apresentam correlação acima de 0,7 com a vazão da usina hidroelétrica de Furnas, localizada no Rio Grande, apesar dos meteorologistas afirmarem que nessa região a baixa previsibilidade por parte dos modelos climáticos para a formação das ZCAS, um dos sistemas que promovem as precipitações no verão austral. Utiliza defasagem (lag) de um mês e afirma apresentar melhores resultados comparados com modelo autorregressivo convencional. Utiliza dados da precipitação observada e, para gerar as variáveis exógenas de previsão, utiliza o modelo de previsão de precipitações ECHAM 4.5. Seus resultados indicam que modelos AR capturam a sazonalidade do regime de afluências, mas não conseguem antecipar variações da vazão. Com o modelo ARx, os cenários gerados capturaram melhor a variabilidade do estado da vazão futura, destacando um desempenho mais adequado desse tipo de modelagem quando comparada à modelagem univariada.

Os resultados apresentados na tese de Farias (2012) assemelham-se à proposta dessa tese que opta por trabalhar com modelos mais complexos do tipo Sazonal Autorregressivo Integrado e 
de Médias Móveis com Regressão (SARIMAX), com variáveis exógenas, em contrapartida Farias utilizou somente modelos autorregressivos.

O trabalho de Barros et al (2009) apresenta um modelo para previsão de vazões, denominado GERAVAZ, considerando previsão de precipitações para seis meses a diante. As previsões de precipitações são feitas pelo Centro de Estudos de Previsão de Tempo e Clima (CPTEC). O modelo do CPTEC abrange a América do Sul e produz previsões em grades de 200 por 200 $\mathrm{km}$ e em 40 por $40 \mathrm{~km}$. A predição das vazões é realizada através de dois métodos hidrológicos: o Soil Moisture Accounting Procedure (SMAP), (LOPES, 1982), um modelo determinístico de simulação hidrológica do tipo transformação chuva-vazão. O outro é um modelo linear estocástico (MLE).As predições finais são definidas por uma função matemática de pesos entre o SMAP e MLE. O modelo GERAVAZ nesse trabalho foi aplicado a 20 (vinte) bacias cobrindo os principais rios brasileiros e os resultados preliminares foram muito promissores e tem grandes evidências do potencial de aplicação da ferramenta na modelagem.

O trabalho de Hernández (2011) discorreu sobre 12 rios em diferentes localizações da Colômbia optando como dados das variáveis de estudo as vazões dos rios $\mathrm{em}^{3} / \mathrm{s}$. Aborda o uso de seis diferentes técnicas estatísticas para a formação de modelos não-lineares com objetivo de calcular a previsão de vazões de rios em 1, 3, 6 e 12 meses à frente. Utiliza diversas técnicas matemáticas para pré-processamento da Análise de Componentes Principais (APC), (HOTELLING, 1933), e métodos de regressão como médias simples, médias ponderadas, redes neurais artificiais (DEMUTE E BEALE, 2002), redes neurais difusas adaptativas (ANFIS ${ }^{34}$ ), modelos autorregressivos, regressão mínimos quadrados móveis, redes neurais polinomiais (IVAHNENKO, 1971), árvores de decisão com sistemas especialistas. ${ }^{35}$ Também usufrui de análises espectrais como Análise Espectral Singular, wavelets e Transformada de Hilbert Huang. Afirma que obteve resultados com $\mathrm{R}^{2}$ acima de 0,8 considerando a amostra analisada.

O trabalho em questão serve como referencial teórico para essa tese, uma vez que faz um compêndio de diferentes técnicas de modelagem e análise espectral.

Machado et al (2011) utilizam técnicas de Redes Neurais Artificiais (RNA) para a modelo de chuva-vazão na bacia da Jangada, no Estado do Paraná. Os resultados são comparados com o

\footnotetext{
${ }^{34}$ Adaptive neuro fuzzy inference system

35 Os sistemas especialistas são programas de computadores, que utilizam técnicas de inteligência computacional, nas quais procuram encontrar soluções para determinados problemas de modos semelhantes a especialistas humanos, estando sobre mesmas condições. (GARDNER; HATCH, 1989)
} 
modelo conceitual IPHMEN ${ }^{36}$, um modelo de chuva-vazão de base mensal que é formado por três algoritmos para calcular volume de distribuição, vazão de superfície, e para otimização de parâmetros. Conclui-se que o modelo de RNA foi superior em reproduzir as vazões observadas apresentando como melhor $\mathrm{R}^{2} 0,94$.

Najafi et al (2012) apresentam conjuntos para previsão de vazões (ensemble streamflow prediction - ESP), na Bacia de East River, que fornece meios para o pós-processamento de previsão estatística com estimativas de incertezas inerentes. Ademais, as informações macroclimáticas fornecem dados para a previsão hidrológica. Análises de componentes principais (EOF ${ }^{37}$, do Inglês) são utilizadas para melhorar a acurácia do método utilizado. São comparados cinco métodos paramétricos e não-paramétricos incluindo agrupamento de médias c-nebulosas, probabilidades formais e informais, e duas variantes da metodologia aproximação de vizinhança k. Os resultados aparentemente promissores são baseados em médias simples ou médias das coleções de membros, combinados com o peso de suas previsões. A melhora na metodologia de pesos foi obtida com a seleção de sinais climáticos, escolha do número correto de componentes principais e considerando várias metodologias de peso. Nesse trabalho é importante registrar o uso das EOF para análise das regiões em questão.

\subsection{Teleconexões e padrões de circulação atmosférica}

A teleconexão por ser descrita como a relação existente entre fenômenos locais e regiões remotas. Segundo Nigam e Baxter (2015) o termo é frequentemente utilizado em ciências atmosféricas para descrever ligações entre regiões geograficamente separadas. Os padrões de teleconexão são extraídos da análise de variações de pressão ao nível do mar e ao nível da troposfera em escalas de tempo semanal ou mensal. Os primeiros estudos foram relacionados com a Oscilação Sul (anomalia atmosférica), através de análise de dados de pressão do mar. Walker e Bliss (1932) encontraram correlações negativas entre as regiões do Oceano Pacífico, da Austrália e Oceano Índico ${ }^{38}$.

Cinco configurações de Teleconexões para o Inverno do Hemisfério Norte (H.N.) foram identificadas por Wallace e Gutzler (1981), através da análise de correlação de altura geopotencial em $500 \mathrm{hPa}$ e pressão à superfície, trabalho semelhante ao de Lorenz (1951). Mo

\footnotetext{
${ }^{36}$ Modelo criado pela Universidade Federal do Rio Grande do Sul (TUCCI, 2005)

${ }^{37}$ Empirical Orthogonal Functions

${ }^{38} \mathrm{http} / / /$ climanalise.cptec.inpe.br/ rclimanl/boletim/cliesp10a/esteleg.html
} 
e White (1985) aplicaram o mesmo método de Wallace e Gutzler (1981) para análises de teleconexões no Hemisfério Sul (H.S.).

Ambrizzi et al (1995) estudaram a propagação das ondas de Rossby e padrões de teleconexão no inverno austral e concluíram que existem três possíveis rotas do Atlântico Sul, que são: às margens da Região nordeste do Brasil, até o Sul do continente Africano e em direção a região do polo Sul.

Ambrizzi (2003) apresenta um trabalho que analisa Teleconexão através da correlação do fenômeno El Niño Oscilação Sul (ENOS) com as precipitações que ocorrem na América do Sul (AS). Utiliza técnicas estatísticas como Correlação Linear Simples (SLC ${ }^{39}$ ) e Decomposição de Valores Singulares (sigla em Inglês SVD $^{40}$ ). Em suas análises, o autor demonstra que existem relações entre as informações macroclimáticas do ENOS e as precipitações na América do Sul. Afirma que os resultados da SLC indicaram que a TSM no Pacífico tropical leste, em torno de $100^{\circ} \mathrm{W}$, é a variável mais significativa para afetar os padrões de chuva sobre o Continente Sul Americano. Durante eventos La Niña, a área central do Pacífico, em torno de $170^{\circ} \mathrm{W}$, mostra uma maior influência. Afirma que as teleconexões são modos preferenciais da variabilidade de baixa frequência que apresentam padrões em escala planetária, cobrindo áreas oceânicas e continentais e exemplifica preceitos teóricos de indução e propagação das ondas de Rossby e seus efeitos no clima em regiões remotas. Para Müller e Ambrizzi (2007), a indução de uma forçante térmica no oceano Índico Tropical com o uso de modelos numéricos foi capaz de gerar um duplo trem de ondas, propagando-se em associação aos jatos polar e subtropical no Hemisfério Sul e, unindo-se mais adiante, após cruzar a barreira orográfica da cadeia montanhosa andina. Segundo os autores, a unificação dos trens de ondas contribuiu para alteração do padrão de circulação atmosférica do sul da América do Sul e forçou o surgimento de fenômenos extremos de advecção de ar frio, como a ocorrência de geadas na região dos pampas argentinos. A configuração espacial desse duplo trem de ondas é ilustrada na Figura 3-27.

\footnotetext{
${ }^{39}$ Simple Linear Correlation

${ }^{40}$ Singular Value Decomposition
} 


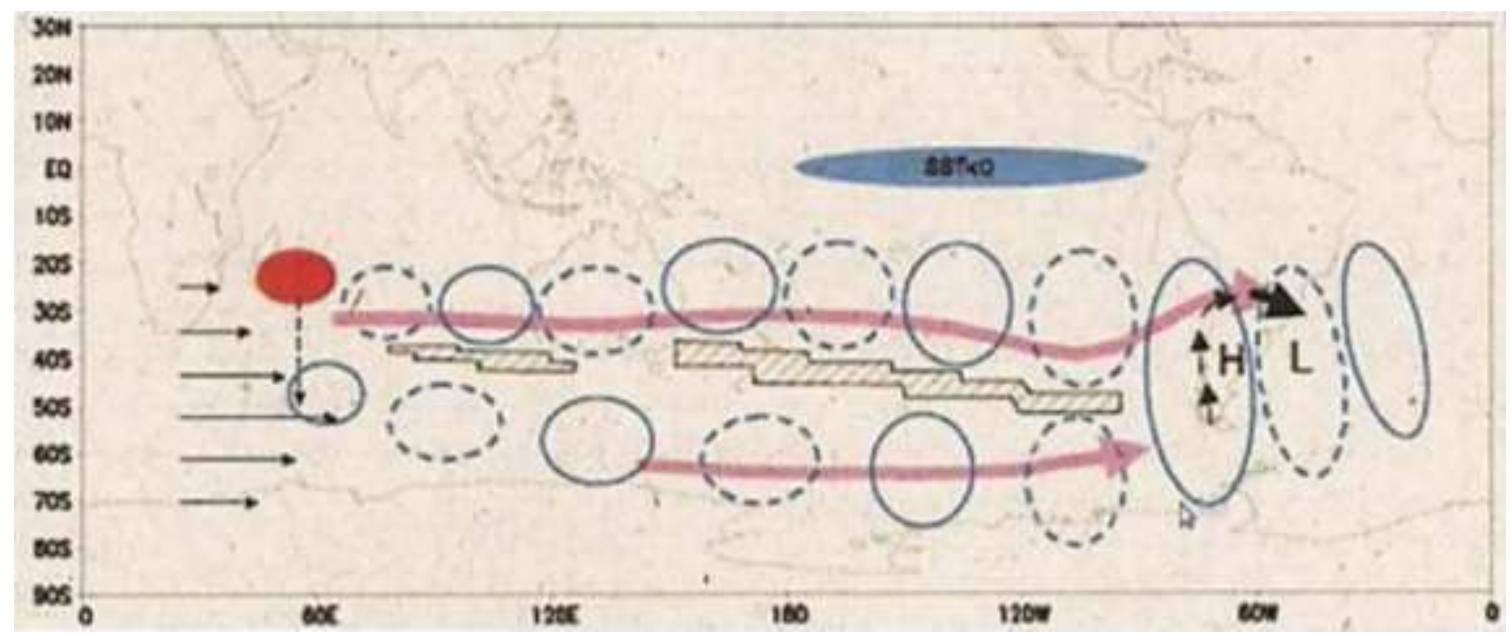

Figura 3-27 Diagrama conceitual sobre os mecanismos físicos que podem favorecer a ocorrência de frentes frias. Fonte: Müller e Ambrizzi (2007).

Reboita et al (2010) revisam os regimes de chuva da América do Sul. Identificam regiões que apresentam padrões semelhantes de precipitação, no caso do Brasil, são 5 regiões R4 ao sul do Brasil; R5 a área de noroeste a sudeste do Brasil; R6 ao norte da região norte do Brasil e litoral do nordeste do Brasil; R7 ao sertão nordestino do Brasil e R8 o estado de Roraima. Em R4 a precipitação é praticamente homogênea ao longo do ano (1050 a 1750mm/ano), e é maior na região fronteiriça com o Paraguai ao oeste do sul do Brasil (1750-2100mm/ano). Em R5, há máximos de precipitação no verão e mínimos no inverno. O total anual varia ao longo da R5. No setor Norte é superior a $2450 \mathrm{~mm}$, já no centro-oeste e sudeste é de $1500 \mathrm{~mm}$. Em R6, são apresentados os máximos de precipitação no inverno e mínimos no verão, e máximos superando $2000 \mathrm{~mm} / \mathrm{ano}$. Ao norte do Brasil, o total anual é de 2000mm, enquanto, no litoral do nordeste do Brasil, é de 1500mm. Em R7, são encontrados máximos de precipitação no verão e mínimos no inverno, mas os totais são reduzidos, entre 200 e 500mm/ano.

Na Figura 3-28, apresentam-se a regionalização, conforme a similaridade visual dos gráficos de precipitação mensal de várias estações meteorológicas, extraída do Atlas Climático de Sudamerica, onde os dados são do período de 1931 a 1960 ou 1951 a 1960. 


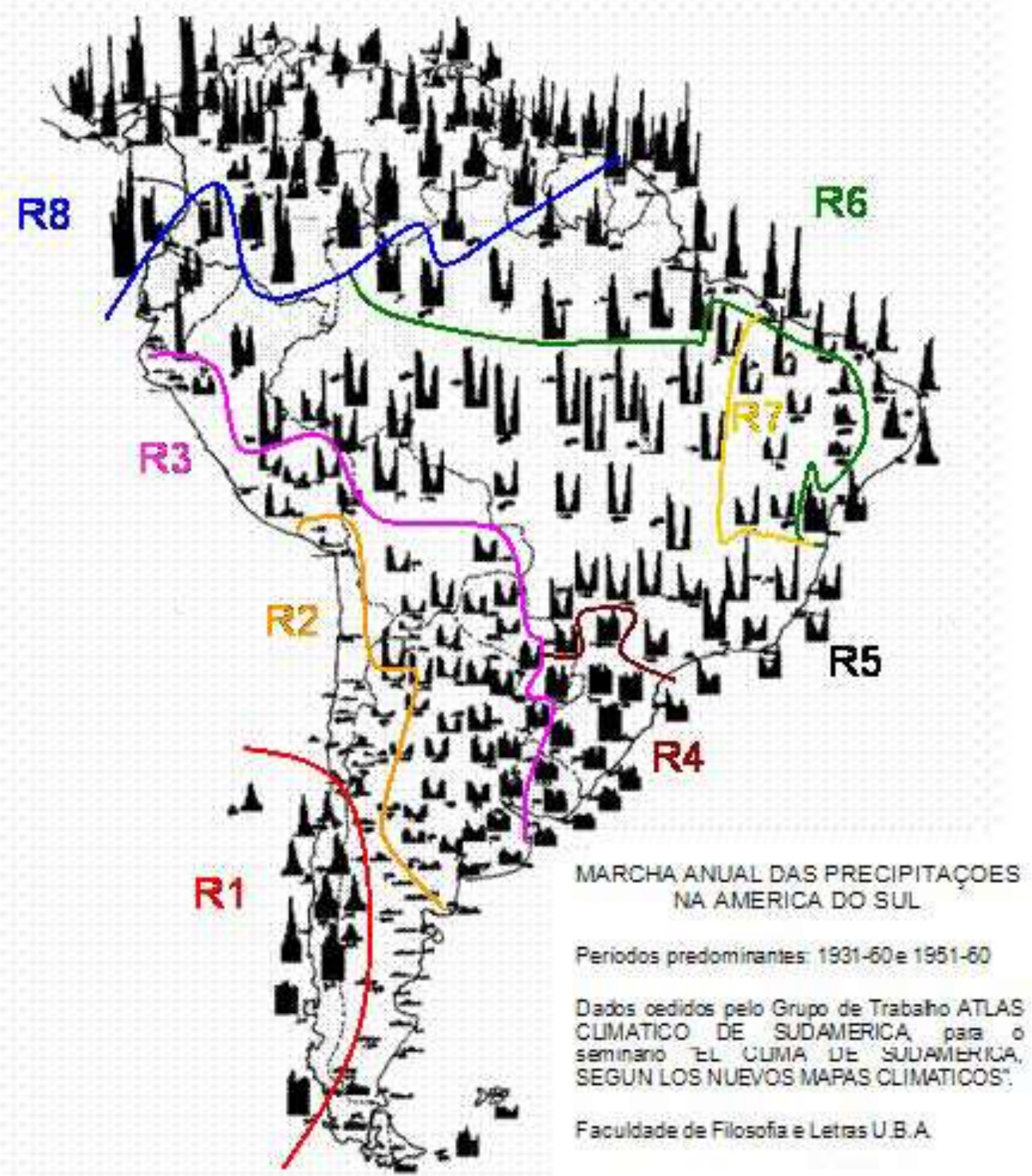

Figura 3-28 Regionalização dos diferentes ciclos anuais de precipitação na América do Sul. R1 Sudoeste da AS; R2 ao norte do Chile, noroeste e centro-sul da Argentina; R3 ao oeste do Peru, oeste e sul da Bolívia, norte e centro-leste da Argentina e centro-norte do Paraguai; R4 ao sul do Brasil, sul do Paraguai e Uruguai; R5 a área de noroeste a sudeste do Brasil incluindo ainda o Equador e norte do Peru, R6 ao norte da região norte do Brasil e litoral do nordeste do Brasil; R7 ao sertão nordestino do Brasil e R8 ao norte da AS incluindo o estado de Roraima. Fonte: Reboita et al (2010, APUD ATLAS CLIMÁTICO DE SUDAMERICA).

Reboita et al (2010) também apresentam os sistemas atmosféricos atuantes na América do Sul na Baixa Troposfera e Alta Troposfera. Ambos os sistemas são importantes para o processo de precipitação. 


\section{Baixa Troposfera}

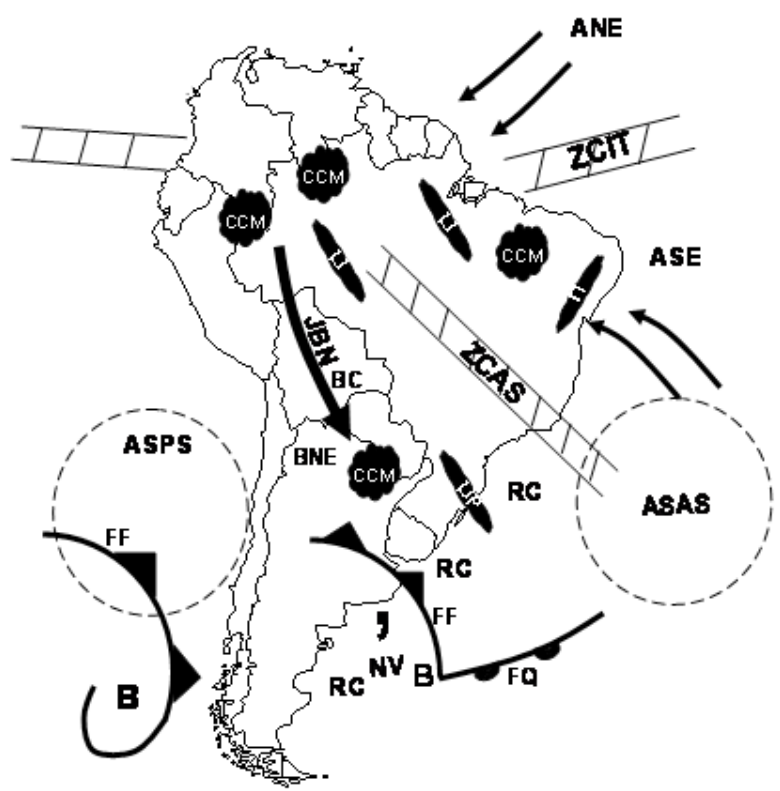

ANE

ASE

ASAS

ASPS

B

BC Baixa do Chaco - região de baixas térmicas

BNE Região de B. Térmicas no Noroeste Argentino

CCM Complexo convectivo de mesoescala

FF Frente Fria

FQ Frente Quente

JBN Jato de Baixos Níveis a Leste do Andes

LI Linha de Instabilidade Tropical

LIP Llinha de Instabilidade Pré-frontal

NV Nuvem Vírgula

RC Regiões Ciclogenéticas

ZCAS Zona de Convergência do Atlântico Sul

ZCIT Zona de Convergência Intertropical

Figura 3-29 Representação esquemática dos sistemas atmosféricos na baixa e alta troposfera atuantes na América do Sul Fonte Reboita et al (2010; adaptada SATYAMURTY et al., 1998, pag. 125).

$\mathrm{A} A B$ e o CNE são sistemas que se configuram no verão e desaparecem no inverno e também, no verão, o JP e JS se fundem em apenas um jato. Maiores detalhes sobre cada um desses sistemas podem ser consultados em Cavalcanti et al (2009).

Marengo (2006) apresenta o importante papel da ZCIT nas precipitações nas regiões Norte e Nordeste do Brasil e como a temperatura da superfície do oceano Atlântico influencia em seu deslocamento. Na Figura 3-30, apresentam-se a dinâmica das zonas de pressão e temperatura no Atlântico que promovem o deslocamento da ZCIT, na época do verão, o que por sua vez promove ou inibe as chuvas no Nordeste brasileiro. 

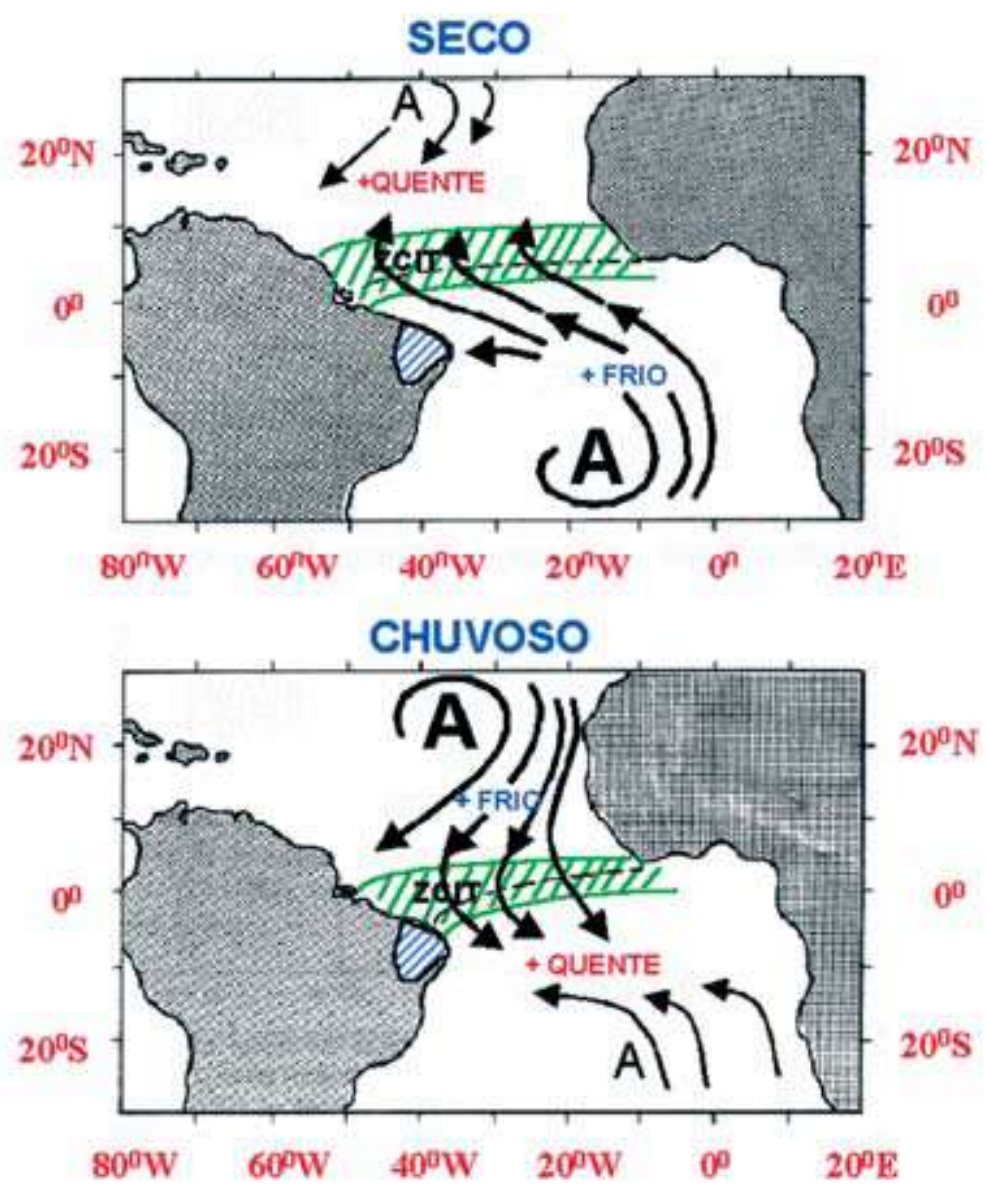

Figura 3-30 Padrões de circulação atmosférica e de anomalias de TSM no Atlântico Tropical Norte e Sul, durante $\operatorname{anos} \operatorname{secos}(\mathrm{a})$ e chuvosos (b) no Nordeste. A área em verde representa a posição da ZCIT (MARENGO, 2006)

O artigo de Kayano et a. (2009) aponta diferentes padrões entre os diferentes períodos antes e depois do ano de 1976 através do exame de correlações entre as TSM e as precipitações da AS. Utiliza diferentes índices de TSM como: Pacifico Equatorial Leste (EEP), Atlântico Tropical Sul (TSA), Sudoeste do Atlântico Sul (SWA). Esses índices de TSM apresentam correlações que aparentam serem influencias pelas teleconexões do ENOS e também possivelmente as diferentes fases do PDO, embora os autores afirmem que não é possível concluir essa influência do PDO e mais estudos são necessários. Nessa tese, procura-se utilizar também estes índices para os modelo de previsão de ENA. 


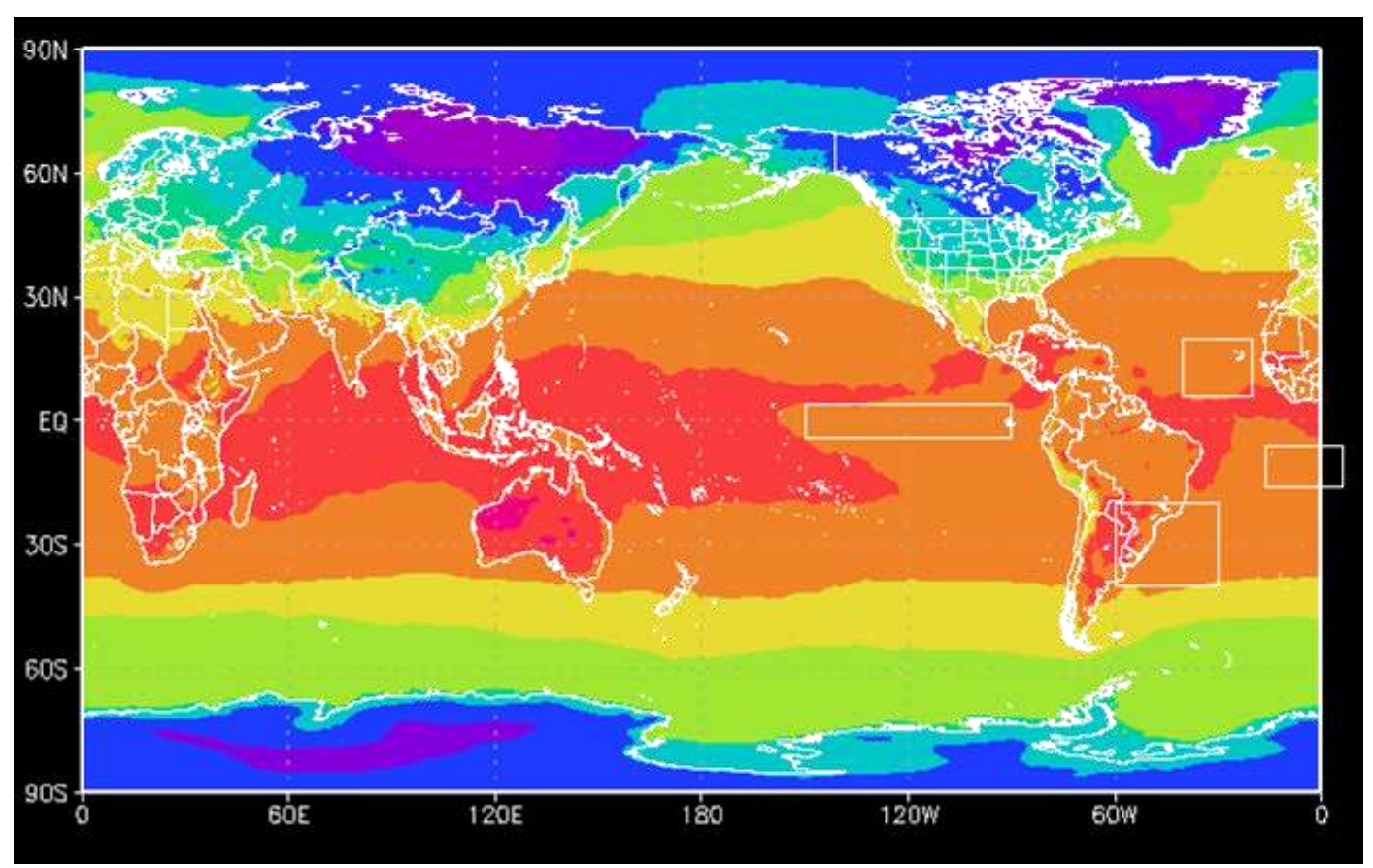

Figura 3-31 Áreas de TSM: EEP. TNA. TSA E SWA

Shimizu e Ambrizzi (2011) pesquisaram sobre a influência do fenômeno Oscilação Madden Julian (MJO) sobre o ENOS e apresentaram que os fenômenos combinados durante o verão ou inverno austral podem fortalecer ou enfraquecer o ENOS e, portanto, influenciar as precipitações na AS.

Silvia et al (SILVA, DRUMOND \& AMBRIZZI, 2011) analisaram os impactos das diferentes fases de PDO, sobre o ENOS e sua consequência sobre as precipitações na América do Sul (AS) com as mudanças de posicionamento do fluxo meridional das divergências de umidade no oceano Atlântico, da altura dos trópicos para os extratrópicos no sudeste da AS, na época do verão austral. Durante o ENOS com PDO fase negativa as precipitações tendem a ficar acima do normal no Sudeste da AS e abaixo no Norte. Diferentes anomalias de TSM no Atlântico e no oceano Pacífico podem ser disparados por distintos padrões de teleconexão relacionados as combinações de diferentes fases do PDO, eventos ENOS e o gelo oceânico. O trabalho também contribui para melhor entendimento do impacto da variabilidade de baixa frequência sobre a AS.

Trabalho semelhante é o de Prado (2011) que analisa as fases de PDO e as precipitações no Estado de São Paulo.

Pampuch et al (PAMPUCH, DRUMOND \& AMBRIZZI, 2016) apresentam um trabalho sobre os mecanismos de transporte de umidade no Sudeste do Brasil e padrões de TSM do oceano Atlântico, através de modelos atmosféricos com abordagens eulerianas e lagrangianas e análise de bases de dados gerados pelos modelos do IPCC. Apontam a existência de um 
tripolo de TSM no oceano Atlântico responsável pela evolução das precipitações no sudeste do Brasil.

Prado e Wainer (2013) analisam as relações entre índices climáticos e a precipitação do Nordeste (NE) e Sul (S) do Brasil, em escala Decadal para o período de 1948 a 2008. Posteriormente, calculam os valores dos coeficientes de correlação entre os índices e as anomalias de precipitação nessas regiões, utilizando séries não filtradas e séries filtradas na frequência decadal. Os resultados sugerem que o principal fenômeno que modula a precipitação no NE e o El Niño-Oscilação Sul (ENOS), devido as alterações na circulação tropical, e também o ciclo anual da Zona de Convergência Intertropical (ZCIT), que modula a estação chuvosa do NE. Na região $\mathrm{S}$, o fenômeno que mais influencia a precipitação em escala decadal e o Modo Anular Sul (SAM), por modular a atividade ciclogenética em latitudes medias, além do índice do dipolo do Atlântico Tropical (WAINER et al, 2014), que pode estar ligado ao aporte de umidade oceânica para o continente, e levada ao S pelo jato de baixos níveis. Também sugerem que a variabilidade Decadal do Atlântico tropical e sua influência na precipitação no NE sejam episódicas, e não periódica, já que não foram obtidas correlações importantes para esse índice, na frequência estudada. Finalmente, a análise espectral revelou que a escala interanual e a principal frequência de variabilidade temporal em ambas as regiões, com efeitos diversos em cada uma delas.

Prado (2011) mostra três mecanismos dinâmicos/termodinâmicos que são observados: na área da Zona de Convergência do Atlântico Sul (ZCAS), que vai da Amazônia ao Sudeste do Brasil; no Nordeste brasileiro por meio do ramo descendente da célula de Hadley; e no norte da América do Sul, no deslocamento sazonal da Zona de Convergência Intertropical (ZCIT). O leste da Amazônia e o Sul do Brasil recebem influência combinada da topografia e da dinâmica.

Nascimento Júnior (2014) apresenta as diferentes escalas climáticas e o conceito de teleconexões que em grande escala revelam flutuações de sistemas e componentes do tempo e do clima importantes para o estudo da variabilidade climática. As que atuam em médio e longo prazo, ou seja, na escala da variabilidade climática, são observadas em escala intrassazonal, sazonal e anual, interanual, decadal a multidecadal.

$\mathrm{Na}$ Tabela 3-4, apresenta-se de forma esquemática os principais padrões que compõem a variabilidade no Brasil, suas escalas temporais, ferramentas formais de observações e indicações de estudos e aplicações. 
Tabela 3-4 Fenômenos e padrões de variabilidade observados no Brasil. Fonte: Nascimento Junior (2014)

\begin{tabular}{|c|c|c|c|c|c|}
\hline Fenômeno & Modo & Prazo & $\begin{array}{c}\text { Escala } \\
\text { Temporal }\end{array}$ & $\begin{array}{l}\text { Ferramentas de } \\
\text { observação }\end{array}$ & Aplicação \\
\hline $\begin{array}{l}\text { Zona de } \\
\text { Convergência } \\
\text { do Atlântico Sul } \\
\text { - ZCAS }\end{array}$ & $\begin{array}{l}\text { Sazonal e } \\
\text { Intrassazonal }\end{array}$ & $\begin{array}{l}8 \text { a } 50 \\
\text { dias }\end{array}$ & $\begin{array}{l}\text { Dias e } \\
\text { meses }\end{array}$ & $\begin{array}{l}\text { Cartas Sinóticas e } \\
\text { Sensoriamento } \\
\text { Remoto }\end{array}$ & $\begin{array}{l}\text { Análise rítmica diária e } \\
\text { mensal / eventos extremos } \\
\text { de tempo e de clima }\end{array}$ \\
\hline $\begin{array}{l}\text { Oscilação } \\
\text { Madden e } \\
\text { Julian - MJO }\end{array}$ & $\begin{array}{l}\text { Intrassazonal a } \\
\text { interanual }\end{array}$ & $\begin{array}{l}30 \text { a } 60 \\
\text { dias }\end{array}$ & $\begin{array}{l}\text { Meses e } \\
\text { estações }\end{array}$ & $\begin{array}{l}\text { Sensoriamento } \\
\text { Remoto e índices } \\
\text { de pressão }\end{array}$ & $\begin{array}{l}\text { Análise rítmica mensal / } \\
\text { Eventos extremos de clima }\end{array}$ \\
\hline $\begin{array}{l}\text { El Niño } \\
\text { Oscilação Sul - } \\
\text { ENOS }\end{array}$ & $\begin{array}{l}\text { Interssazonal a } \\
\text { interanual }\end{array}$ & $\begin{array}{l}14 \text { a } 22 \\
\text { meses }\end{array}$ & $\begin{array}{l}\text { Meses, } \\
\text { estações e } \\
\text { anos }\end{array}$ & $\begin{array}{l}\text { Associação com } \\
\text { índices climáticos } \\
\text { e comparação em } \\
\text { ocorrência na } \\
\text { história }\end{array}$ & $\begin{array}{l}\text { Análise de variabilidade } \\
\text { intrassazonal, intersazonal } \\
\text { e interanual / meses, } \\
\text { estações e anos padrão / } \\
\text { Eventos estremos de chuva }\end{array}$ \\
\hline $\begin{array}{l}\text { Oscilação } \\
\text { Multidecadal do } \\
\text { Atlântico - } \\
\text { AMO }^{41}\end{array}$ & $\begin{array}{l}\text { Interanual, } \\
\text { decadal e } \\
\text { multidecadal }\end{array}$ & $\begin{array}{l}10 \text { a } 14 \\
\text { anos }\end{array}$ & $\begin{array}{l}\text { Anos e } \\
\text { décadas }\end{array}$ & $\begin{array}{l}\text { Associação com } \\
\text { os índices } \\
\text { climáticos e } \\
\text { comparação em } \\
\text { ocorrência na } \\
\text { história }\end{array}$ & $\begin{array}{l}\text { Estudos de variabilidade } \\
\text { decadal e multidecadal / } \\
\text { meses, estações e anos } \\
\text { padrão / Eventos estremos } \\
\text { de chuva }\end{array}$ \\
\hline $\begin{array}{l}\text { Oscilação } \\
\text { Decadal do } \\
\text { Pacífico ODP }\end{array}$ & $\begin{array}{l}\text { Decadal a } \\
\text { Multidecadal }\end{array}$ & $\begin{array}{l}\text { De } 20 \text { a } \\
30 \text { anos }\end{array}$ & $\begin{array}{l}\text { Anos e } \\
\text { décadas }\end{array}$ & $\begin{array}{l}\text { Associação com } \\
\text { os índices } \\
\text { climáticos e } \\
\text { comparação em } \\
\text { ocorrência na } \\
\text { história }\end{array}$ & $\begin{array}{l}\text { Variabilidade decadal e } \\
\text { multidecadal / meses, } \\
\text { estações e anos padrão / } \\
\text { Eventos extremos de chuva }\end{array}$ \\
\hline
\end{tabular}

Marengo et al (2012) revisam os progressos no entendimento do funcionamento da variabilidade dos Sistemas de Monções da América do Sul (SMAS) em escalas de tempo que variam do sinótico à variabilidade de longo prazo e mudanças climáticas. A região do SMAS é suscetível particularmente às variações do clima devido à importância das economias locais baseadas na geração de hidroeletricidade e agricultura. Discorrem sobre vários programas de estudos climáticos como Monsoon Experiment in South America (MESA) do World Climate Research Programme- Climate Variability and Predictability (WCRP CLIVAR), Variability of American Monsoon Systems (VAMOS) que propõem estudos e observações da variabilidade do clima e da hidrologia em várias escalas de tempo, de intrassazonal a multidecadal e incluem mudanças climáticas. Discutem o progresso dos estudos sobre a Monção da América do Sul e as contribuições do MESA para o conhecimento do clima na

\footnotetext{
${ }^{41}$ Índice AMO - refere-se à variabilidade da temperatura de superfície do Atlântico Norte.

Índice NÃO - refere-se à variabilidade da diferença entre a baixa pressão na Islândia e a Alta Subtropical do Atlântico ao Norte (Açores e Madeira).
} 
região.Apresentam projeções de mudanças extremas do clima, o que é importante para impactar a avaliação de vulnerabilidade.

Luz (2009), em sua dissertação de mestrado, procura analisar a interação entre a TSM no Oceano Atlântico Sul (OAS) e a precipitação no Estado de São Paulo, e utiliza técnicas estatísticas multivariadas chamadas Análise de Componentes Principais (ACP) ou também chamada de EOF. Os resultados do cálculo de correlação linear com defasagem temporal entre o comportamento oceânico e continental não apresentaram significância estatística superior a 95\%, portanto não foram considerados nas análises. Em contrapartida, há correlações significativas (maior que 95\%) entre dados com defasagem temporal, entre o Oceano Atlântico Sul e a precipitação no Estado de SP.

Nóbile (2010) faz uma análise da relação entre umidade do solo (US) e a TSM através da associação da Zona de Convergência do Atlântico Sul (ZCAS) e o Continente Brasileiro. Utiliza o modelo regional BRAMS (Regional Atmospheric Modelling System with Brazilian Developments) para casos de ZCAS e El Niños e La Niñas para previsão de precipitação nas regiões que compõem a ZCAS: oceânica, costeira e amazônica. Faz discussão sinótica sobre a ZCAS e concluí em suas análises que o modelo BRAMS é adequado para a quantificação das precipitações, apesar de ser voltado a medições de seca. Também afirma que, em seu estudo, identificou influência do ENOS, da Alta da Bolívia (AB), associada a frentes, sobre as ZCAS. "Observa-se, assim, a importância da circulação de altos níveis atuante na região do Sistema de Monção da América do Sul (SMAS) como suporte para a manutenção da ZCAS”.

\subsection{Teleconexões com El Niño Oscilação Sul}

Coelho, Uvo e Ambrizzi (2002) realizaram um trabalho sobre os dados coincidentes de anomalias TSM do oceano Pacífico e integrações mensais de precipitação de diversas estações de observação sobre a América do Sul para estudar sua relação com as anormalidades do El Niño Oscilação Sul (ENOS) ${ }^{42}$. Aplicaram os métodos de decomposição singular de valor (SVD) e correlação linear simples (SLC). Os resultados obtidos de SVD para eventos mais quentes no Pacífico corroboram com pesquisas anteriores que identificam uma região de transição entre as condições mais secas no Nordeste do Brasil e as condições mais úmidas das regiões Sudeste e Sul do país além de regiões de transição identificadas através do Peru e da Amazônia central. Os resultados de SLC indicam que as anomalias de

\footnotetext{
${ }^{42}$ Do inglês: El Niño-Southern Oscillation (ENSO)
} 
TSM ocorrem no leste do Oceano Pacífico tropical e tem maior influência nas precipitações sobre a América do Sul durante eventos de El Niño. Durante os eventos de La Niña a área central do Pacífico, em torno de $180^{\circ}$, apresenta também uma influência significativa nas precipitações.

Boulanger et al (2005) discorrem sobre as precipitações observadas na bacia do Paraná, sua média de longo prazo, e suas condições extremas relacionadas ao sistema de teleconexão com ENOS nos últimos 50 anos. Define-se um índice total de precipitação (PTPI) que corresponde a uma média espacial sobre a área da bacia e a pesquisa aponta que, em escala interanual, ocorrem anomalias de monção no norte da bacia devido ao padrão ENOS, e conclui que houve mudanças significativas entre os padrões encontrados entre 1950-2001 e 1976-2001 onde observam-se meses de maio com menos eventos de grande escala de secas e mais eventos úmidos de grande escala. Afirma, também, que devido a padrões não antissimétricos de precipitações entre condições El Niños e La Niñas e a relação não linear entre precipitação e as TSM, os sistemas de previsão estatísticos lineares são atualmente muito limitados para prever impactos na sociedade em escala local ou regional.

Castillo et al (2014) investigam a influência que a evolução do ciclo ENOS tem sobre o transporte das principais fontes de umidade oceânica do planeta usando uma abordagem Lagrangiana de transporte de umidade e utiliza dados de reanálise ERA-interim $^{43}$ para o período climatológico de 1980-2012. As variações nos sumidouros de umidade associados com cada uma dessas fontes de evaporação durante o ciclo de ENOS reproduzem os padrões conhecidos de variações dos sistemas atmosféricos e precipitações em larga escala ao longo desse ciclo. Tais variações incluem as observadas nas chuvas sobre o Pacífico equatorial, nos principais sistemas de monção de verão e nas chuvas subtropicais. O novo método foi capaz de identificar 10 regiões de fonte oceânica de umidade: denominadas Norte do Pacífico (NPAC); Sul do Pacifico (SPAC), Norte do Atlântico (NATL), Sul do Atlântico (SATL), México Caribenho (MEXCAR), Oceano da Arábia (ARAB), Corrente Zanzibar (ZAN), Corrente das Agulhas (AGU), Oceano Indico (IND) e Oceano de Coral (CORALS) e mais duas regiões foram incluídas: Mediterrâneo (MED) e Vermelho (REDS). Na Figura 3-32, valores superiores a $250 \mathrm{~mm} / \mathrm{ano}$ são apresentados em escala de cinza com intervalos entre isolinhas de 250 milímetros/ano. As áreas envolvidas pelas linhas de contorno vermelhas indicam as regiões consideradas como fontes de umidade integradas. Dez dessas regiões de

\footnotetext{
${ }^{43}$ http://www.ecmwf.int/en/research/climate-reanalysis/era-interim
} 
origem foram definidas usando o limiar de $750 \mathrm{~mm} /$ ano do fluxo de umidade integrada para as fontes oceânicas.

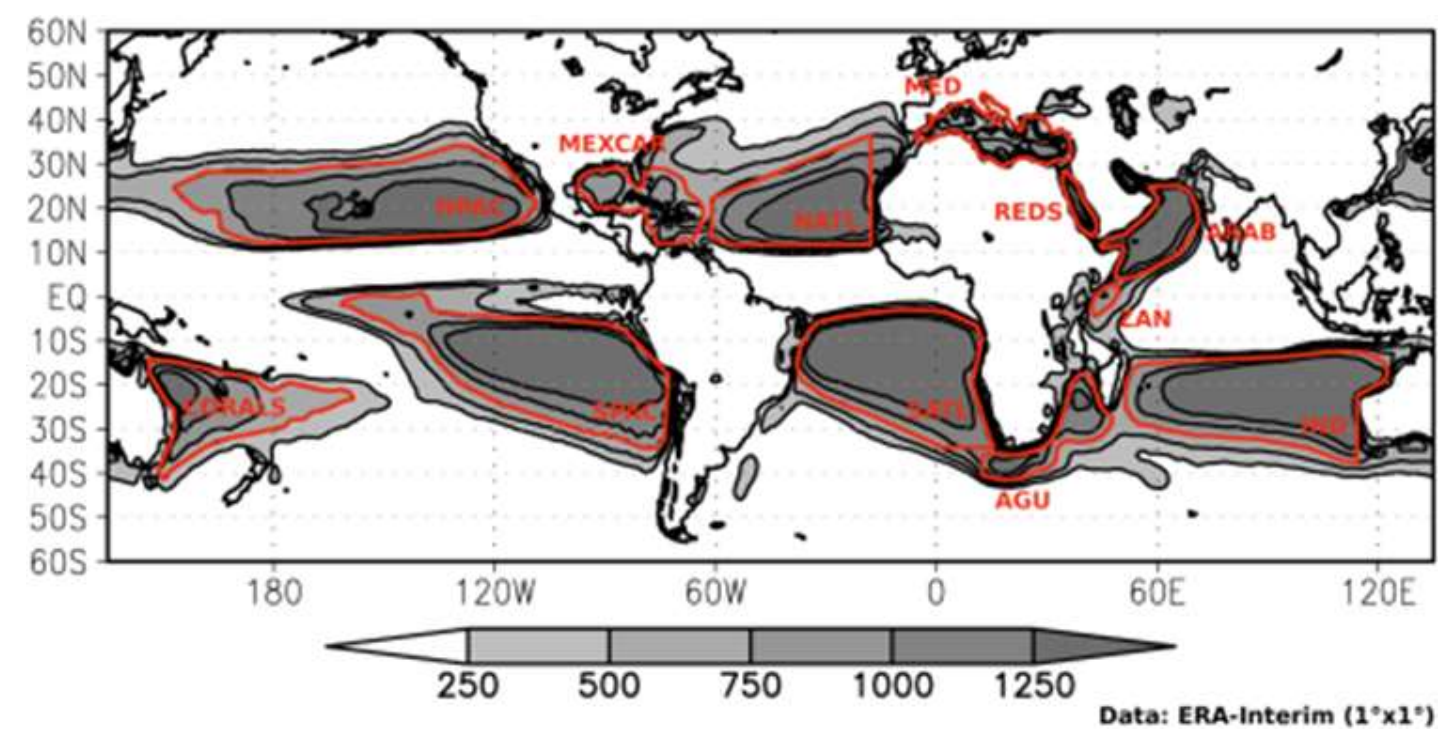

Figura 3-32 Fluxo divergente de umidade anual mm/ano 1980-2012

Castillo et al (2014) sugerem que existam diferenças significativas entre ambas as fases. Em termos gerais, as variações nos sumidouros de umidade associadas às fontes de evaporação coincidem com os padrões conhecidos de variação dos sistemas atmosféricos em larga escala ao longo dos ciclos de ENOS. Tais variações incluem a precipitação equatorial do Pacífico, os principais sistemas de monção de verão e a precipitação subtropical.

\subsection{Exemplo teleconexão - Seca atípica do Sudeste no Verão de 2014}

O trabalho de Coelho et al (2015) apresenta um evento de seca, ocorrido em 2014, e discorre sobre todos os fenômenos físicos atmosféricos responsáveis em regular o clima da América do Sul. No verão austral (J-F-M) de 2014, um fenômeno climático de seca ocorreu apresentando diminuição cerca de 249,7 mm, abaixo da média histórica, de 1961 a 2014, de $574,3 \mathrm{~mm}$, levando a uma série de impactos no fornecimento de água para produção de hidrelétricas e usos consuntivos. Na Figura 3-33, apresenta-se a dinâmica desse fenômeno:

- Calor equatorial originado do norte e nordeste da Austrália que através da circulação da célula de Walker promoveu uma teleconexão tropical.

\footnotetext{
${ }^{44}$ Water Resources Research Volume 50, Issue 2, pages 1046-1058, 6 FEB 2014 DOI:10.1002/2013WR013900 http://onlinelibrary.wiley.com/doi/10.1002/2013WR013900/full\#wrcr20746-fig$\underline{0001}$
} 
- Convergências do nível superior e subsidência no centro e leste do Pacífico equatorial, que associadas às ondas de Rossby e à circulação da célula de Hadley, promoveram as teleconexões:tropical e extratropical.

- A formação de padrão ondulado estacionário em forma de U sobre a América do Sul resultou em uma onda de estrutura barotrópica.

- Centros anômalos de alta pressão sobre o Pacífico e Atlântico nas proximidades da América do Sul, a anomalia de baixa pressão no extremo sul da América do Sul e um centro de alta pressão anômalo do Atlântico Sul que bloquearam a migração dos sistemas de baixa pressão (frontais) e favoreceram a manutenção de temperaturas quentes da superfície do mar, perto da costa do sudeste do Brasil.

- A circulação de um anticiclone anômalo estende-se sobre a região sudeste do Brasil transportando uma grande quantidade de ar seco que ultrapassa o Atlântico e um grande volume de ar úmido, da região da Amazônia para o sul do Brasil, que extrapola os níveis normais. Consequentemente, são observados com menos frequência episódios de Zona de Convergência do Atlântico Sul são observados.

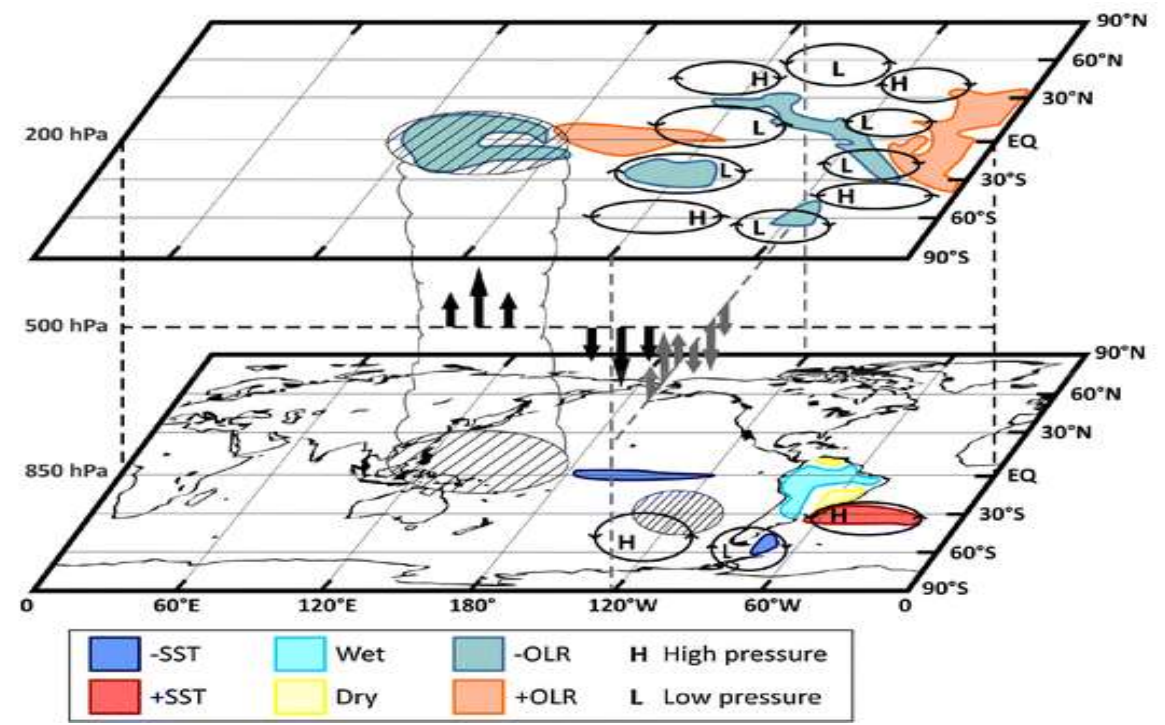

Figura 3-33 Representação para a ocorrência da seca no verão austral de 2014 sobre sudeste do Brasil Fonte: Coelho et al, 2015.

Na Figura 3-34, apresentam-se dados de precipitação utilizados para construir essa série de tempo a partir da rede brasileira de estações mantidas pelo Instituto Nacional de Meteorologia (INMET), Instituto Nacional de Pesquisas Espaciais (INPE) e centros meteorológicos regionais. 


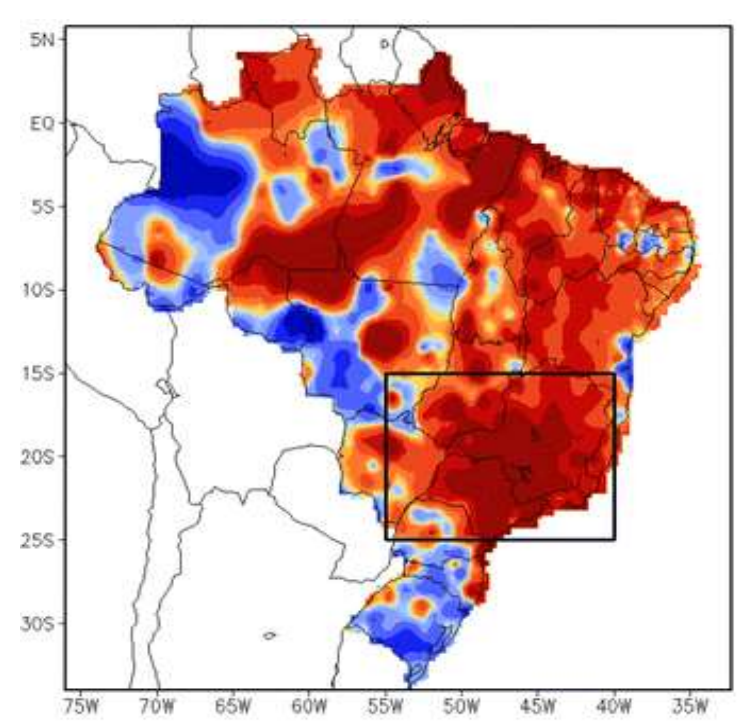

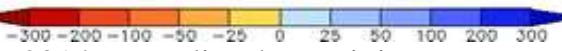
(a) JFM 2014 anomalias de precipitação - mm

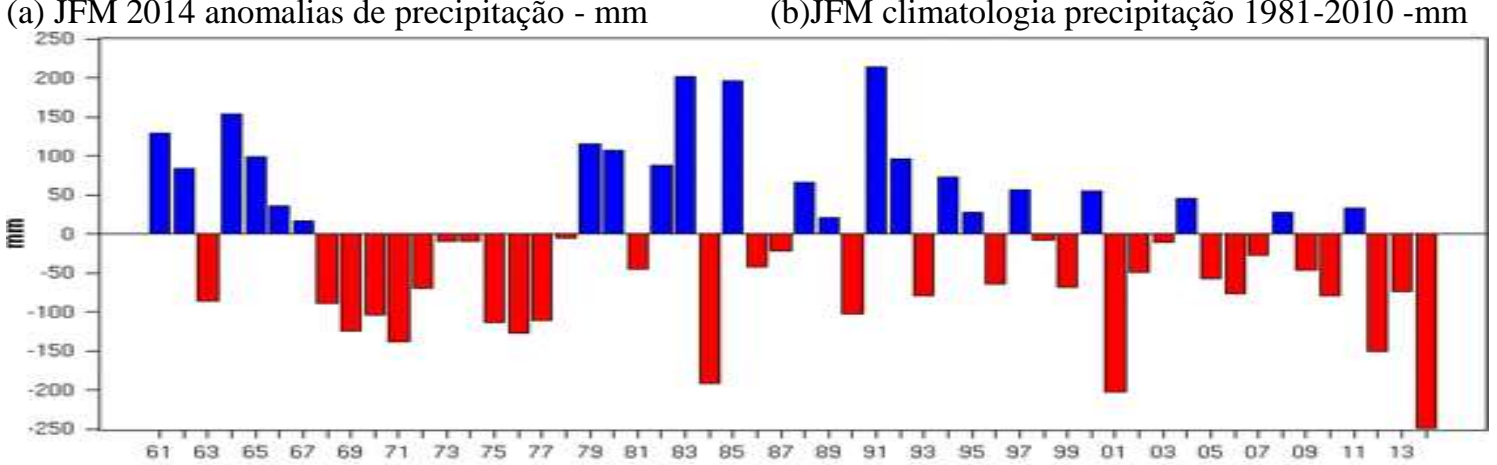

(c) Anomalias de Precipitação JAN-FEV-MAR - média anual - mm

Figura 3-34 Área média austral verão (janeiro-fevereiro-março) 1961-2014 precipitação séries temporais anomalia (barras de cor), expresso em mm sobre a região sudeste do Brasil ${ }^{45}$. Fonte: Coelho et al, 2015

\subsection{Influência Solar no Clima e Vazões}

O National Research Council (NRC) promoveu dois seminários sobre a questão da influência do Sol sobre o clima da Terra, um em 1982 (NRC, 1982) e outro mais recente em 2012 (NRC, 2012). Durante o primeiro seminário a questão dividia-se em dois grupos distintos, aqueles que acreditavam que a superfície solar tem relações com a meteorologia terrestre, e que consequentemente influência na temperatura, pressão barométrica, precipitação, ciclones, agricultura, e até mesmo na economia; o outro grupo defendia que não existia possibilidade de pequenas variações, de luz e calor do Sol, exercerem quaisquer influências sobre a Terra.

\footnotetext{
${ }^{45}$ Figura 3-34 (c) Anomalias são calculados em relação à média climatológica 1981-2010 para a região de 574,3 $\mathrm{mm}$. Anos com anomalias de precipitação positivos (excesso de precipitação) são mostrados em azul e aqueles com anomalias negativas de precipitação (déficit de precipitação) são mostrados em vermelho. Fonte: Coelho et al, 2015
} 
Em 2012, novo o seminário ${ }^{46}$ é organizado, onde se afirma que atualmente existam diversos dispositivos tecnológicos de medição como satélites e radares, porém nos últimos 50 anos, não registraram-se nenhuma influência do Sol sobre a temperatura terrestre. Destacaram-se as dificuldades sobre a necessidade de melhor entendimento dos índices de atividade solar, como o uso dos isótopos de cosmogênese e irradiância solar, através de registros paleoclimáticos, para estudos mais aprofundados da influência do Sol sobre a Terra. Muitos trabalhos apontaram questões relacionadas à variabilidade climática em escala temporal atribuída a pequena era do Gelo e ao mínimo de Maunder, o que intensificou a credibilidade desses estudos. Um dos trabalhos apresenta uma nova abordagem do tipo top-down onde a variabilidade solar afeta primeiro a estratosfera que influencia a troposfera e em seguida a superfície, ainda que esse não aborde a influência do buraco de ozônio da Antártica e aerossóis vulcânicos sobre a estratosfera. Em contraste a abordagem top-down, apresenta-se a abordagem bottom-up onde as interações da energia solar com os oceanos implicam em mudanças termométricas. Diversas questões sobre a resposta da dinâmica climática frente à variabilidade espectral e sobre a irradiância solar total produziram uma discussão que deixou em aberto a questão da influência solar que segundo o NRC deve ser mais apurada antes de qualquer conclusão.

Almeida (2001), em sua dissertação de mestrado, aborda a questão da influência dos ciclos solares em relação às chuvas. Afirma que as séries anuais de chuvas das regiões do litoral brasileiro, Fortaleza (CE) e Pelotas (RS), exibem ciclos com grande variabilidade de amplitudes entre mínimos e máximos, e periodicidades bem definidas entre 20 e 25 anos por mais de 100 anos. Essas características sugerem um mecanismo físico que atua em longo prazo e de forma contínua. As séries de chuvas apresentam fases de (anti) correlação consistentes e bem definidas com a série de ciclos solares magnéticos. Afirma, também, que o período de mudança de fase de correlação entre as séries de chuva e de ciclos solares magnéticos ocorreu quando a polaridade do campo magnético solar foi negativa ${ }^{47}$.

Mauas et al (2008) desenvolvem uma análise quantitativa da relação entre ciclos solares, vazões de quatro rios: Paraná, Colorado, San Juan e Atuel e níveis de neve nos Andes. Afirmam que, depois de eliminar as tendências seculares e suavizar o ciclo solar, encontraram uma forte correlação positiva entre os resíduos, tanto do número de manchas solares quanto

\footnotetext{
46 http://www.nap.edu/read/13519/chapter/1 Acesso em 15/01/2016.

${ }_{47}$ Cometário Prof. Molion: "A variável principal é irradiação solar total - TSI, siglas em Inglês) para determinar evaporação e chuva, e não há evidências que a TSI varia quando o Sol inverte sua polaridade.”
} 
das vazões. Com esses resultados, concluíram que a maior atividade solar corresponde a maior precipitação, tanto no verão quanto no inverno, não só na grande bacia do Paraná, mas também na região andina ao norte da fronteira com Patagônia. Argumentam que as vazões são excelentes indicadores climáticos, já que integram precipitação em grandes áreas. Apontam que o mínimo incomum da atividade solar nos últimos anos tem uma correlação com os baixos níveis do fluxo do rio Paraná, e também relatam evidências históricas de baixos níveis de água durante a Pequena Era do Gelo.

Rampelotto et al (2011) afirmam que o clima da Terra é afetado por vários fatores e atua em diferentes escalas temporais e espaciais. Nesse trabalho, analisam-se a variabilidade de longo prazo de chuva e temperatura (1912-2008) de Santa Maria $\left(29^{\circ} \mathrm{S}, 53^{\circ} \mathrm{W}\right)$ e sua possível conexão com influências naturais, como a atividade solar e ENOS. As séries temporais de temperatura e precipitação apresentam frequências semelhantes como as demonstradas por análises espectrais. Seus resultados indicam que, em baixas frequências, o ciclo solar de 22 anos é um fator importante na modulação do clima durante o período de análise. Sobreposto ao ciclo Hale, o ciclo de Schwabe também é estatisticamente significativo contudo, a sua influência é intermitente. Em termos de altas frequências (2-8 anos), o ENOS é a principal influência da temperatura e da variabilidade da precipitação, especialmente durante eventos El Niño. Além disso, os possíveis efeitos não lineares da variabilidade do Sol e fenômenos naturais (QBO ${ }^{48}$ BALDWIN et al., 2001 - ENOS) podem contribuir significativamente para a variabilidade meteorológica regional.

Compagnucci et al (2014) elaborou um artigo que explora a influência do Sol no ciclo hidrológico do sul da América do Sul (SSA) na gama de escalas interanuais a multidecadal do início de 1900 até 2011. A variabilidade solar é descrita pelo índice de número de manchas solares (SSN). O ciclo hidrológico é analisado através de vazões médias anuais do rio Paraná (PAR) e do Rio Atuel (ATU) que representam o comportamento do sistema hidrológico Argentino Andino Subtropical. Métodos baseados em ondaletas (wavelets) são usados para descrever as relações no domínio do tempo-frequência. A conexão SSN-PAR é fraca, estatisticamente, em oscilações com período de cerca de 11 anos (ciclo solar de Schwabe). Desse modo, a energia solar quando utilizada nessa escala deve ser considerada com grande cautela. A periodicidade de cerca de 30 anos é altamente significativa ao longo do período

\footnotetext{
${ }^{48}$ Quasi-Biennial Oscillation. QBO é uma oscilação quase periódica dos ventos zonais na estratosfera tropical caracterizada por regimes de ventos descendentes de leste e oeste, com períodos entre de 2234 meses.
} 
analisado. Dois mecanismos físicos potenciais que afetam a descarga Paraná poderiam ser envolvidos, são eles, a influência da irradiância solar (TSI) na Zona de Convergência Inter Tropical (ZCIT) e a influência solar sobre a variabilidade de longo prazo do Pacífico. A conexão SSN-ATU mostra de longe o resultado mais surpreendente, robusto e convincente para o ciclo de Schwabe. Um ciclo com amplitude elevada e estatisticamente significativa com um período de cerca de 11 anos é observado não só no espectro global e local, de ondaletas de Morlet, das vazões Atuel e SSN, mas também no espectro global e local de wavelets cruzadas coerente ao período de análise. Altas vazões (baixas) ocorrem após máxima (mínima) dos ciclos Schwabe com defasagens de até aproximadamente 2 anos. Estudos anteriores demonstraram uma estreita relação entre os rios subtropicais Argentinos Andinos e El Niño / Oscilação Sul (ENOS), bem como uma influência solar sobre a variabilidade ENOS. Sugerem que os eventos de El Niño ocorrem poucos anos depois da máxima solar e poderiam ser indicativos da relação máxima solar - ENOS e vazões, para periodicidades superiores há 30 anos, e lembram que apesar dessa indicação, deve ser analisada com cuidado, uma vez que a série de vazões utilizada apresenta pouco mais de 100 anos. 


\section{CAPÍTULO 4}

\section{FONTES DE DADOS MACROCLIMÁTICOS}

Na Tabela 4-1, estão relacionadas as variáveis macroclimáticas, que representam as medidas de TSM e alguns índices que tratam de diferentes partes do globo terrestre, relacionadas aos padrões climáticos utilizados como indicadores. Sua localização, na Internet, está relacionada nos endereços da Tabela 4-2. Já, na Tabela 4-3, estão relacionadas as variáveis que representam medidas do Sol e fluxo magnético na Terra. O critério de escolha dessas variáveis foi adotado com base na literatura sobre climatologia e testes de correlação realizados conforme a seção 6.5 Matrix para Correlação das Séries históricas, p. 194. Os dados de vazões publicados pelo ONS apresentam-se com a periodicidade mensal e compreendem o período de 1931 a 2014. Os dados de vazão são organizados por usina em uma planilha fornecida pelo ONS, e utiliza-se o pacote de programas R para sua leitura e organização. São encontrados também dados agregados por bacias e macrorregiões Norte, Sul, Sudeste / Centro-Oeste e Nordeste, que correspondem aos quatro submercados onde o SIN é organizado. Não há dados agregados por vazões, pois essas são informações registradas por usinas hidrelétricas, diferente de energia, não podem ser integradas por escalas espaciais maiores como vazões por bacia, ou vazões por região.

As variáveis NINO 1+2 e AMO foram as que apresentaram valores de correlação com as variáveis de vazões superiores a 0,6. Embora na literatura a variável PDO seja relacionada aos eventos na América do Norte e se correlacione às regiões do Niño, essa análise de dados não apresenta correlações expressivas, nas vazões ou ENA do Brasil. Os outros índices também apresentaram correlações menores que 0,6, são eles: aa, número de manchas solares e manchas solares por área, QBO, MEI, SOI, ONI, AAO, AO, NAO, TNA, TSA e MODOKI. 
Tabela 4-1 - Fontes de dados coletados para análise

Nome original

\begin{tabular}{|c|c|c|c|c|}
\hline Atlantic Multi-decadal Oscillation & AMO & ${ }^{\circ} \mathrm{C}$ & Interdecadal & 1856 - presente \\
\hline Atlantic Meridional Mode & AMM & $\operatorname{Idx}$ & Sazonal & 1948 - presente \\
\hline El Niño $1+2$ & NINO $1+2$ & ${ }^{\circ} \mathrm{C}$ & Interanual & 1870 - presente \\
\hline El Niño 3 & NINO 3 & ${ }^{\circ} \mathrm{C}$ & Interanual & $1870-$ presente \\
\hline El Niño 3.4 & NINO 3.4 & ${ }^{\circ} \mathrm{C}$ & Interanual & 1870 - presente \\
\hline El Niño 4 & NINO 4 & ${ }^{\circ} \mathrm{C}$ & Interanual & $1870-$ presente \\
\hline Quasi-Biennial Oscillation & QBO & ${ }^{\circ} \mathrm{C}$ & Interanual & 1948 - presente \\
\hline Pacific Decadal Oscillation & PDO & ${ }^{\circ} \mathrm{C}$ & Interdecadal & $1854-$ presente \\
\hline Atividade magnética da Terra & aa & $\mathrm{nT}$ & Interdecadal & 1869 - presente \\
\hline Manchas solares por Área & SSA & $\mathrm{MH}$ & Interdecadal & $1874-$ presente \\
\hline Manchas solares por Área H. Sul & SSAS & MH & Interdecadal & 1874 - presente \\
\hline Manchas solares por Área H.. Norte & SSAN & $\mathrm{MH}$ & Interdecadal & $1874-$ presente \\
\hline Número de Manchas solares & SSN & Quant. & Interdecadal & 1749-presente \\
\hline Oscilação Madden-Jullian ${ }^{49}$ & MJO & $\operatorname{Idx}$ & Intrassazonal & 1978-presente \\
\hline Multivariate ENSO Index & MEI & $\operatorname{Idx}$ & Interanual & 1950-2014 (bim.) \\
\hline Multivariate ENSO Index Ext. & MEI.EXT & $\operatorname{Idx}$ & Interanual & 1871-2005 (bim) \\
\hline Multivariate ENSO Index Rank & MEI.RANK & $\mathrm{Idx}$ & Interanual & $1871-2005$ (bim) \\
\hline Southern Oscillation Index & SOI & Idx & Interanual & $1866-2014$ \\
\hline Southern Oscillation Index Darwin & SOI_DAR & $\operatorname{Idx}$ & Interanual & $1867-2014$ \\
\hline Southern Oscillation Index Tahiti & SOI_TAH & $\operatorname{Idx}$ & Interanual & $1868-2014$ \\
\hline Oceanic Niño Index & ONI & $\operatorname{Idx}$ & Interanual & 1950-presente \\
\hline Antarctic Oscillation & $\mathrm{AAO}$ & Idx & Interanual & 1979-presente \\
\hline Artic Oscillation & $\mathrm{AO}$ & $\mathrm{Idx}$ & Interanual & 1950-presente \\
\hline North Atlantic Oscillation & $\mathrm{NAO}$ & $\operatorname{Idx}$ & Interanual & 1950-presente \\
\hline Tropical Northern Atlantic Index & TNA & Idx & Interanual & 1948-presente \\
\hline Tropical Southern Atlantic Index & TSA & $\operatorname{Idx}$ & Interanual & 1948-presente \\
\hline El Niño Modoki & MODOKI & $\mathrm{Idx}$ & Interanual & 1870-presente \\
\hline Energia Natural Afluente Regiões & ENA & MWmed & Sazonal & 1931-presente \\
\hline Energia Natural Afluente Bacias & BACIAS & MWmed & Sazonal & 1931-presente \\
\hline Vazões Usinas & VAZ & $\mathrm{m}^{3} \mathrm{~s}^{-1}$ & Sazonal & 1931-presente \\
\hline
\end{tabular}

\footnotetext{
${ }^{49}$ Formado por dez índices engloba latitude entre 30N e a linha do Equador e longitudes centradas em: 20E, 70E, $80 \mathrm{E}, 100 \mathrm{E} 120 \mathrm{E}, 140 \mathrm{E}, 160 \mathrm{E}, 120 \mathrm{~W}, 40 \mathrm{~W}$ and $10 \mathrm{~W}$

Fonte: http://gcmd.nasa.gov/records/GCMD_NOAA_NWS_CPC_MJO.html
} 
Tabela 4-2 Localização original das variáveis macroclimáticas coletadas. ${ }^{50}$

\begin{tabular}{|c|c|}
\hline Sigla & URL \\
\hline AMO & http://www.esrl.noaa.gov/psd/data/correlation/amon.us.long.mean.data \\
\hline AMM & http://www.esrl.noaa.gov/psd/data/timeseries/monthly/AMM/ \\
\hline NINO $1+2$ & http://www.esrl.noaa.gov/psd/gcos_wgsp/Timeseries/Data/nino12.long.data \\
\hline Nino 3 & http://www.esrl.noaa.gov/psd/gcos_wgsp/Timeseries/Data/nino3.long.data \\
\hline Nino 3.4 & http://www.esrl.noaa.gov/psd/gcos_wgsp/Timeseries/Data/nino34.long.data \\
\hline Nino 4 & http://www.esrl.noaa.gov/psd/gcos_wgsp/Timeseries/Data/nino4.long.data \\
\hline QBO & http://www.esrl.noaa.gov/psd/data/correlation/qbo.data \\
\hline PDO & http://jisao.washington.edu/pdo/PDO.latest \\
\hline MJO & $\begin{array}{l}\text { http://www.cpc.ncep.noaa.gov/products/precip/CWlink/daily_mjo_index/proj_norm_order. } \\
\text { ascii }\end{array}$ \\
\hline Mei & http://www.esrl.noaa.gov/psd/enso/mei/table.html \\
\hline Mei.Ext & http://www.esrl.noaa.gov/psd/enso/mei.ext/table.ext.html \\
\hline Mei.Rank & http://www.esrl.noaa.gov/psd/enso/mei.ext/rank.ext.html \\
\hline SOI & ftp://ftp.bom.gov.au/anon/home/ncc/www/sco/soi/soiplaintext.html \\
\hline SOI_DAR & http://www.cru.uea.ac.uk/cru/data/soi/soi_dar.dat \\
\hline SOI_TAH & http://www.cru.uea.ac.uk/cru/data/soi/soi_tah.dat \\
\hline ONI & http://www.cpc.ncep.noaa.gov/data/indices/oni.ascii.txt \\
\hline $\mathrm{AAO}$ & $\begin{array}{l}\text { http://www.cpc.ncep.noaa.gov/products/precip/CWlink/daily_ao_index/aao/ } \\
\text { monthly.aao.index.b79.current.ascii.table }\end{array}$ \\
\hline $\mathrm{AO}$ & $\begin{array}{l}\text { http://www.cpc.ncep.noaa.gov/products/precip/CWlink/daily_ao_index/ } \\
\text { monthly.ao.index.b50.current.ascii.table }\end{array}$ \\
\hline NAO & $\begin{array}{l}\text { http://www.cpc.ncep.noaa.gov/products/precip/CWlink/pna/ } \\
\text { norm.nao.monthly.b5001.current.ascii.table }\end{array}$ \\
\hline TNA & http://www.esrl.noaa.gov/psd/data/correlation/tna.data \\
\hline TSA & http://www.esrl.noaa.gov/psd/data/correlation/tsa.data \\
\hline MODOKI & http://www.jamstec.go.jp/frcgc/research/d1/iod/DATA/emi.monthly.txt \\
\hline TELE-INDEX & http://ftp.cpc.ncep.noaa.gov/wd52dg/data/indices/tele_index.nh \\
\hline SSN & http://solarscience.msfc.nasa.gov/greenwch/spot_num.txt \\
\hline ENA & http://www.ons.org.br/download/operacao/hidrologia/Enas_Subsistemas_1931_2014.xls \\
\hline BACIAS & http://www.ons.org.br/download/operacao/hidrologia/Enas_Bacias_1931_2014. xls \\
\hline VAZ & http://www.ons.org.br/download/operacao/hidrologia/Vazões_Mensais_1931_2014.xls \\
\hline
\end{tabular}

Tabela 4-3 Localização original das variáveis solares coletadas ${ }^{51}$

\section{Sigla $\quad$ URL}

SSN http://solarscience.msfc.nasa.gov/greenwch/spot_num.txt

SSA http://solarscience.msfc.nasa.gov/greenwch/sunspot_area.txt

SSAS http://solarscience.msfc.nasa.gov/greenwch/sunspot_area_south.txt

SSAN http://solarscience.msfc.nasa.gov/greenwch/sunspot_area_north.txt

aa http://solarscience.msfc.nasa.gov/greenwch/Sunspots/aa_month.txt

\footnotetext{
${ }^{50}$ Fonte: http://www.esrl.noaa.gov/psd/data/climateindices/list/ Acesso em 25/09/2015.

${ }^{51}$ http://solarscience.msfc.nasa.gov/greenwch/Sunspots/
} 


\subsection{Manchas solares $\left(\mathrm{SNN}^{52}\right)$ e área $(\mathrm{SSA})^{53}$}

No site da Marshal Space Flight Center da $\mathrm{Nasa}^{54}$ são publicadas séries históricas mensais de medições do número das manchas solares ou por área (hemisférios norte e sul) que utilizam a unidade $\mathrm{MH}^{55}$ e são compilados pelo Prof. David Hathaway (HATHAWAY, 2010) com dados organizados pelo United States Air Force (USAF) e NOAA (Figura 4.1 e Figura 4.2).
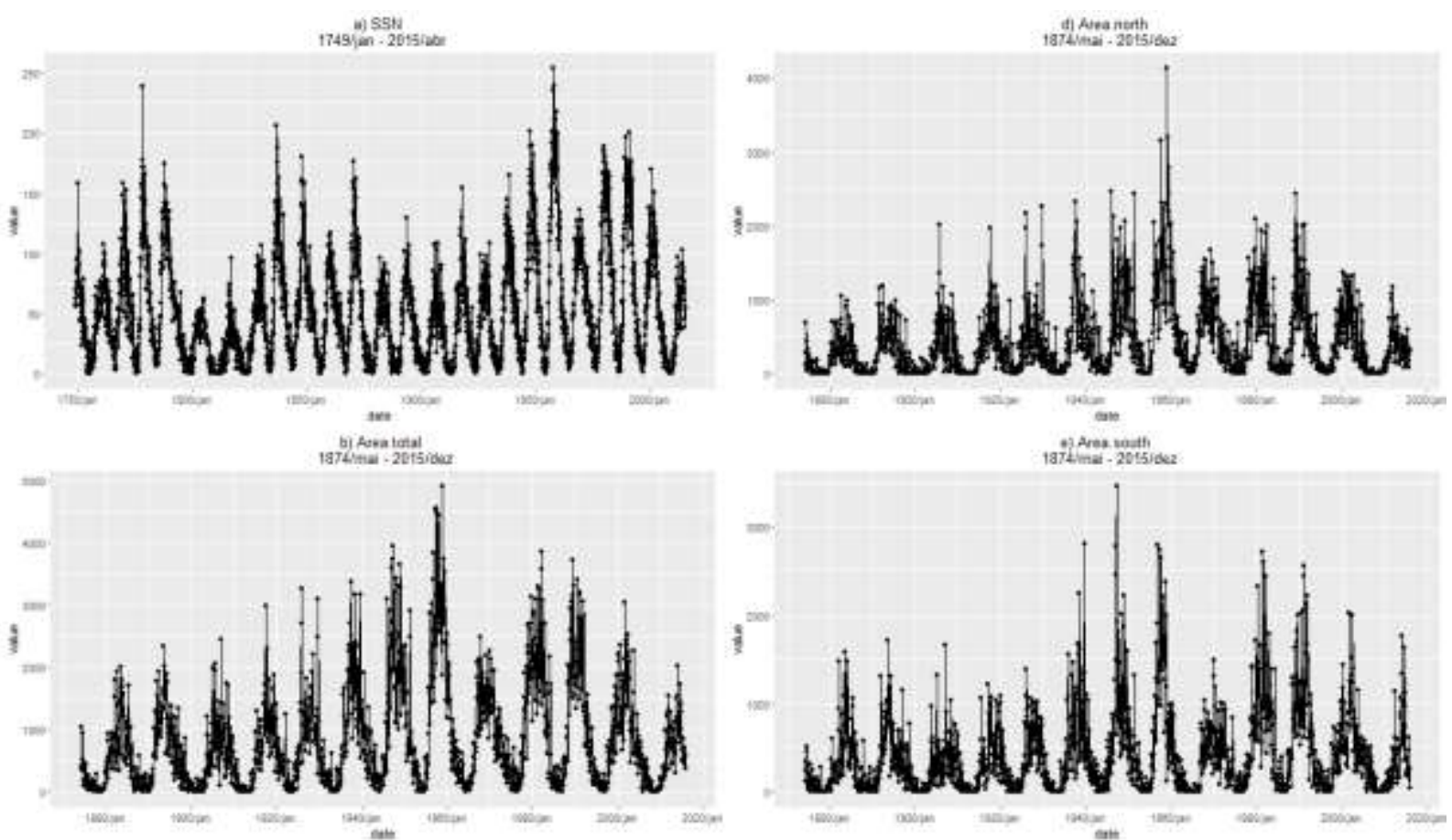

Figura 4.1 -Manchas Solares a) SSN quantidade período de 1749 a 2015 b) Área total 1874 a 2015 c) Área Hemisfério Norte e d) Área Hemisfério Sul

\footnotetext{
${ }^{52}$ Sunspot Number

53 Sunspot Area

${ }^{54} \mathrm{http}: / /$ solarscience.msfc.nasa.gov/SunspotCycle.shtml

55 A área de grupos de manchas solares é expressa em "milionésimos de um hemisfério solar" (MH), com 1000MH correspondente a 3.043,7 milhões de quilômetros quadrados. Isso significa que um grupo de manchas solares que abrange uma área $1870 \mathrm{MH}$ cobre $0,187 \%$ de superfície da face solar em direção a terra. A maioria dos grupos de manchas solares cobrem áreas do tamanho da superfície da Terra (o que equivale a quase $170 \mathrm{MH})$, mas os maiores grupos de manchas solares chegam facilmente a 1000MH.
} 


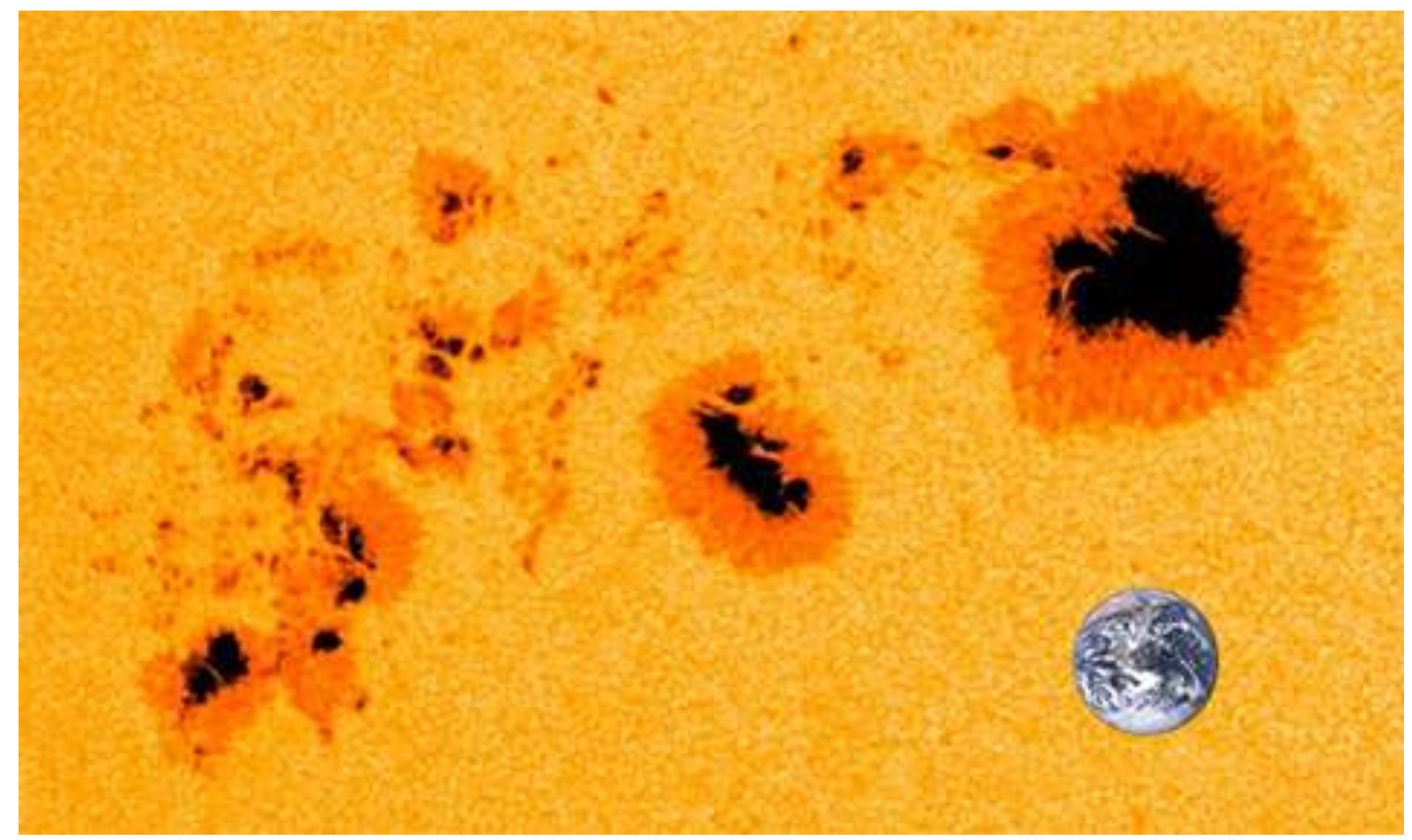

Figura 4.2 -Exemplo da proporção entre uma Mancha Solar e o planeta Terra

Fonte: http://www.spaceweatherlive.com/en/help/how-do-you-determine-the-size-of-a-sunspot-region

\section{2 Índice atividade magnética aa}

O índice $a^{56}$ é derivado das medições geomagnéticas realizadas por duas instituições localizadas nos diferentes hemisférios terrestres, atualmente conhecidos como observatório de Hartland, hemisfério norte, e observatório de Camberra, hemisfério sul. Esse índice utiliza para as medições a unidade nT (nano Tesla) a qual mede densidade de fluxo magnético (Figura 4-3). Estudos apontam que o índice aa é correlacionado com as atividades solares (ZERBO et al, 2013).

\footnotetext{
${ }^{56}$ http://isgi.unistra.fr/indices_aa.php
} 


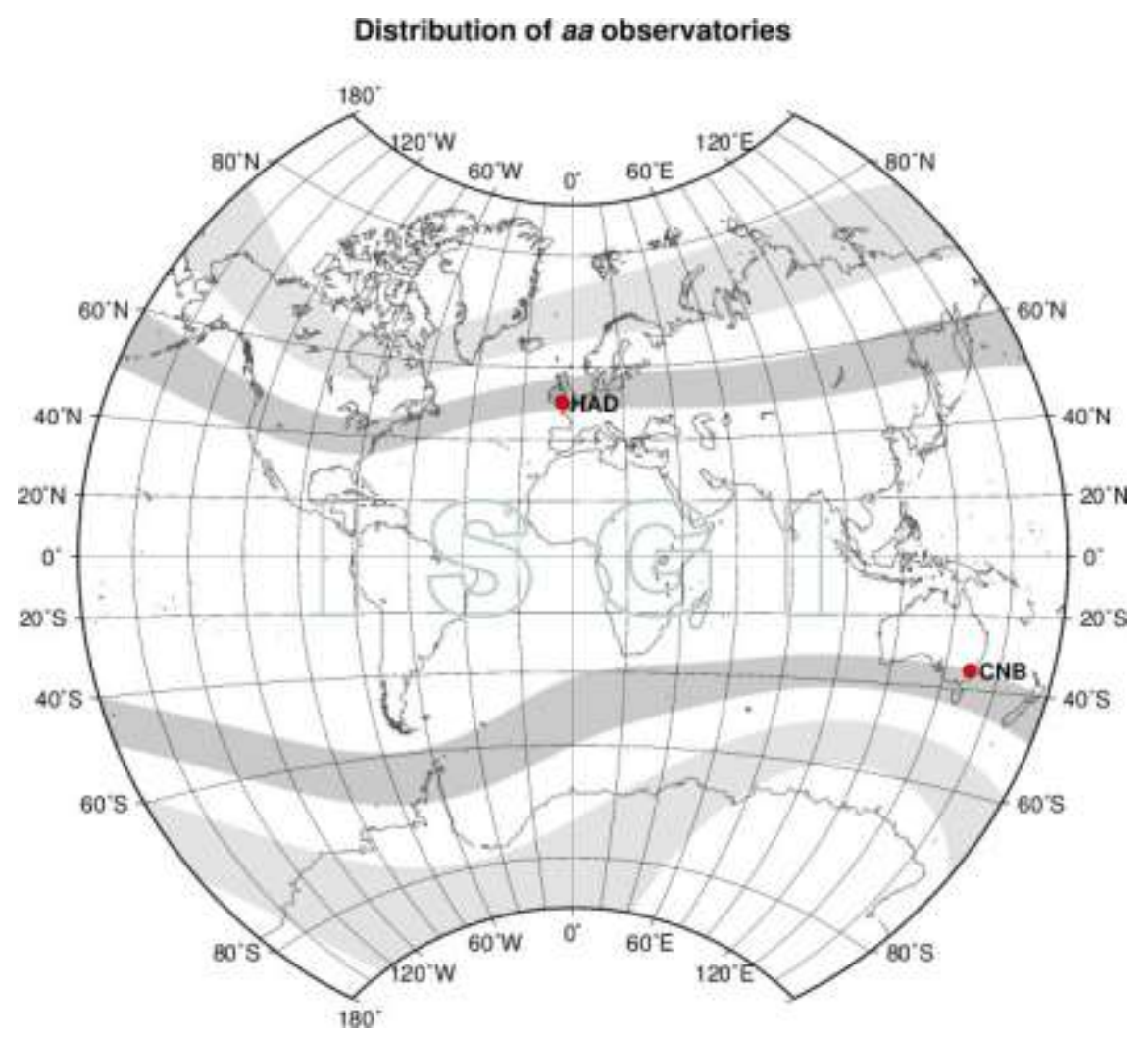

Figura 4-3 - Observatórios de Hartland (HAD) e Canberra (CNB)

\subsection{Fontes de dados georreferenciadas HadISST e ERSST}

Nesse trabalho, são utilizadas duas fontes de dados georreferenciadas a HadISST (RAYNER, 2003) do Hadley Centre ${ }^{57}$ e o ERSST ${ }^{58}$ (SMITH et al., 2008) do NOAA ${ }^{59}$ que está na versão três.

O HadISST é uma base de dados mensais de TSM global e concentração de gelo, que iniciouse em 1871 e perdura até o presente. Possui uma grade de dados de $360^{\circ}$ por $180^{\circ}$ e com resolução de 1 grau de latitude por 1 grau de longitude começando em $-179,5^{\circ}$ Oeste e 89, $5^{\circ}$ Norte até $179,5^{\circ}$ Leste e $89,5^{\circ} \mathrm{Sul}$ (Figura 4.4).

\footnotetext{
${ }^{57}$ http://www.metoffice.gov.uk/hadobs/hadisst/index.html

${ }^{58}$ Extended Reconstructed Sea Surface Temperature - ) (SMITH et al., 2008)

${ }^{59}$ http://www.esrl.noaa.gov/psd/data/gridded/data.noaa.ersst.html
} 


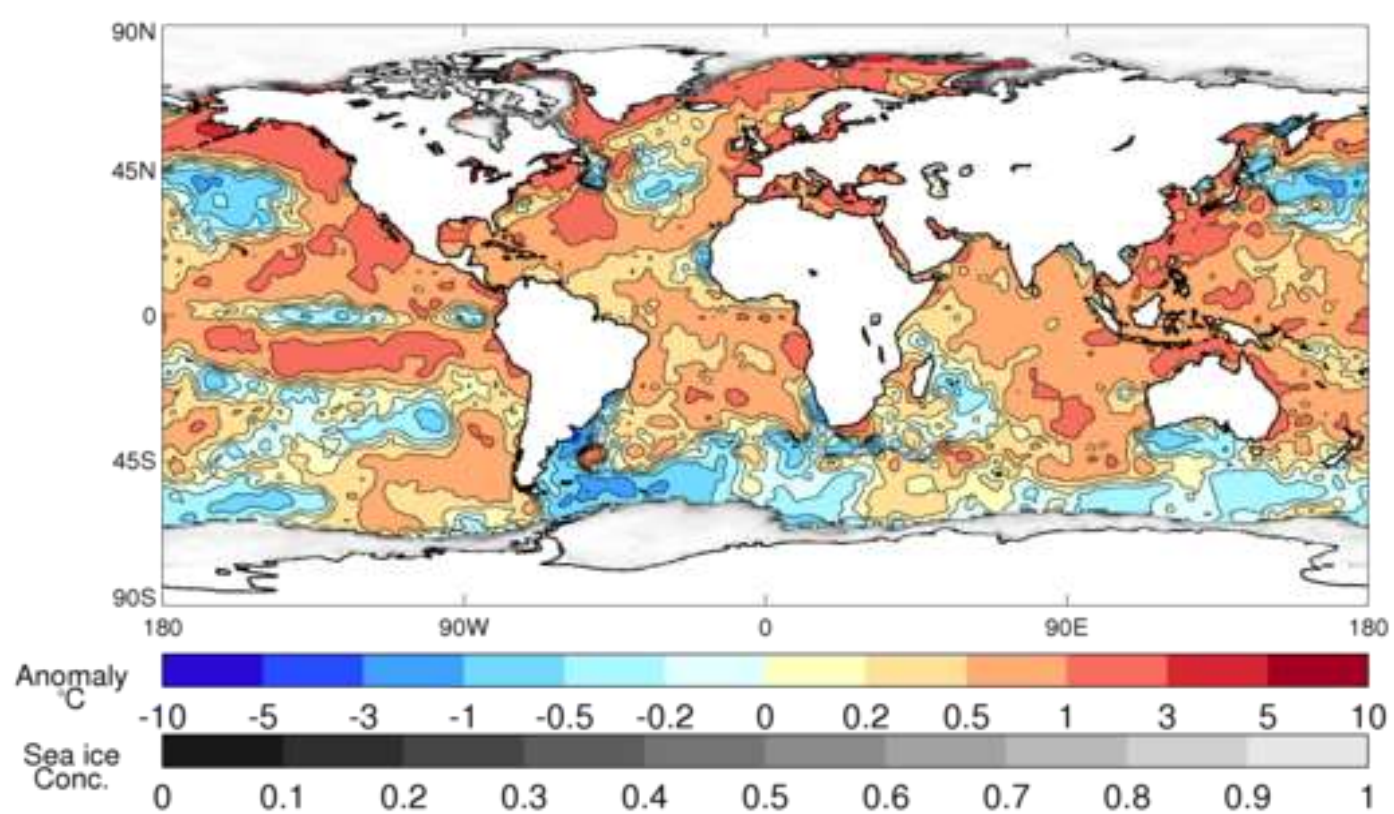

Figura 4.4 - Anomalias de TSM e concentração de gelo - Junho de 2016

O ERSST é uma base de dados mensais, de TSM global, que iniciou-se em janeiro de 1854 e perdura até o presente. Possui uma grade de dados de 89 por 180 e com resolução de $2^{\circ}$ de latitude por $2^{\circ}$ de longitude e começa em a 0 grau Leste e $88,0^{\circ}$ Norte até $-358,0^{\circ}$ Leste e $88,0^{\circ}$ Sul.

As duas bases são os resultados de métodos estatísticos de interpolação das temperaturas de superfície de áreas de larga escala dos oceanos, medidas por navios e satélites.

Observa-se que nos mapas, apresentam-se diferentes pontos centrais de zero grau $\left(0^{\circ}\right)$, HadISST apresenta o Pacífico ao centro do mapa e ERSST apresenta a África ao centro do mapa. A análise de mapas encontra-se na seção 8.4.1.1APÊNDICE L Análise de mapas de TSM georreferenciada, p. 427. 


\section{4 Índices de TSM EI Niño}

Os índices de TSM das quatro regiões NINO1+2, NINO3, NINO3.4 e NINO4 são construídos com base na reanálise HadISST1, com periodicidade mensal e período de janeiro de 1870 a dezembro de 2015 (RAYNER, 2003).

\section{5 Índice de Oscilação Decadal do Pacifico (PDO)}

Os valores padronizados do Índice de Oscilação Decadal do Pacífico (PDO) ${ }^{60}$ são calculados a partir da primeira componente principal das TSM do Pacífico no lado polar de $20^{\circ} \mathrm{N}$. Contrariamente ao El Niño, o sinal é mais notado da direção Leste-Oeste, que nos trópicos. A PDO apresenta duas fases uma fria e outra fase quente, conforme Figura 4-5, a seguir, (ZHANG ET AL 1997; MATUA ET AL 1997):

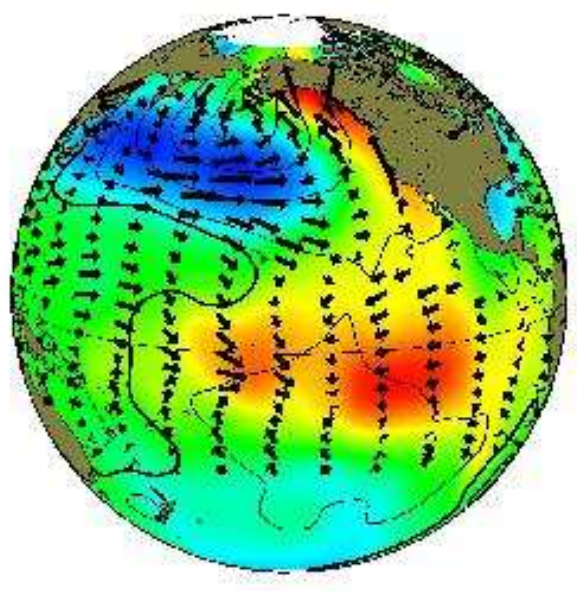

Fase quente

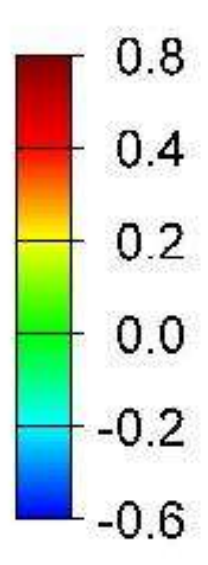

Fase fria

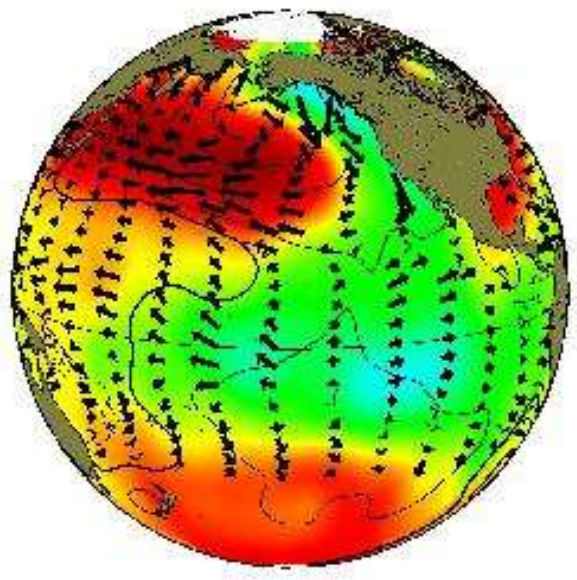

Figura 4-5 - TSM(cores) Pressão ao Nível do Mar (contornos) Magnitude e direção dos Ventos (setas) ${ }^{61}$

O PDO é um padrão parecido com o El Niño, porém, os eventos duram entre 20 e 30 anos e utilizam mecanismos um pouco diferentes do EL Niño que apresenta persistência de 6 a 18 meses. Estudos indicam dois eventos frios que ocorreram entre 1890 e 1924 e posteriormente de 1947 a 1976, já os períodos quentes aconteceram entre 1925 e 1946 e de 1977 a 1998. Atualmente, a PDO parece ter entrado em uma nova fase fria.

\footnotetext{
${ }^{60}$ Do inglês: Pacific Decadal Oscillation (PDO);

${ }^{61} \mathrm{http} / / /$ research.jisao.washington.edu/pdo/
} 


\section{6 Índice Multivariado ENOS (MEI ${ }^{62}$ )}

O índice MEI é calculado com base em seis principais variáveis observadas sobre o Pacífico tropical. Essas seis variáveis que são: pressão do nível do mar (P), componentes do vento de superfície zonal (U) e meridional (V), a temperatura da superfície do mar (S), temperatura do ar na superfície (A) e fração de nebulosidade total do céu (C). Essas observações foram coletadas e publicadas em ICOADS ${ }^{63}$ por muitos anos. O MEI é calculado separadamente para cada um dos doze bimestres (DJ, JF, ..., ND). Após a filtragem espacial dos campos individuais em agrupamentos (WOLTER, 1987), o MEI é calculado como o primeiro componente principal sem rotação (PC) de todos os seis campos combinados. Isso é feito através da normalização da variância total de cada campo e em seguida, a extração do primeiro PC na matriz de covariância dos campos combinados (WOLTER e TIMLIN, 1998). A fim de manter o MEI comparável, todos os valores sazonais são normalizados. Outra base é o MEI ext. que utiliza como base a reanálise elaborada pelo Hadley Centre, e trabalha com a pressão ao nível do mar e dados de TSM (WOLTER e TIMLIN, 2011). Outra variante é o MEI Rank, onde o ranqueamento é realizado por uma ponderação no índice, que utiliza 67 números para representar o fenômeno, entre o intervalo entre 1e 7, que correspondem a La Niña e entre 61 a 67 que corresponde a El Niño ${ }^{64}$.

\section{7 Índice de Oscilação Sul (SOI $\left.{ }^{65}\right)$}

O Índice de Oscilação Sul (SOI) ${ }^{66}$ é padronizado e baseado nas diferenças das anomalias de pressão ao nível (SLP) ${ }^{67}$ do mar observadas entre Taiti e Darwin, Austrália, dividida pelo desvio-padrão mensal (ROPELEWSKI e JONES, 1987; ALLAN et al 1991; KÖNNEN et al 1998) ${ }^{68}$. O SOI é caracterizado como uma medida das flutuações de grande escala na pressão do ar, que ocorrem entre o Pacífico tropical ocidental e oriental (ou seja, o estado da Oscilação do Sul), durante os episódios de El Niño e La Niña. Em geral, séries temporais suavizadas do SOI correspondem muito bem com mudanças na temperatura dos oceanos em todo leste do Pacífico tropical. A fase negativa do SOI representa a pressão do ar abaixo do

\footnotetext{
${ }^{62}$ Multivariate ENSO Index

${ }^{63}$ International Comprehensive Ocean-Atmosphere Data Set

${ }^{64}$ Acesso em 2/1/2016: http://www.esrl.noaa.gov/psd/enso/mei/rank.html

${ }^{65}$ Southern Oscillation Index

${ }^{66} \mathrm{https}$ //www.ncdc.noaa.gov/teleconnections/enso/indicators/soi/

${ }^{67}$ Sea Level Pressure

${ }^{68} \mathrm{https} / / /$ crudata.uea.ac.uk/cru/data/soi/
} 
normal no Tahiti e acima do normal em Darwin. Períodos prolongados de valores SOI negativos (positivos), coincidem com águas anômalas quentes (frias) do mar em toda a faixa leste do Pacífico tropical típico de El Niño (La Niña). Sua base de dados é atualizada pelo NOAA. Encontra-se atualmente dois índices que representam cada um dos pontos de pressão em Darwin o SOI_DAR e em Taiti o SOI_TAH.

\section{8 Índice Oceânico Niño $(\mathrm{ONI})^{69}$}

O índice Oceânico Niño (ONI) foi criado no International Research Institute for Climate and Society, devido a tendência significativa de aumento de temperatura na região do NINO 3.4, desde 1950, e incorpora as tendências de longo prazo, que não se refletem na variabilidade interanual do ENOS. Assim, os cientistas dediciram utilizar médias fixas de 30 anos, para cada 5 anos de medições. Os episódios de El Niño e La Niña são definidos com base em um período de 30 anos (1971 a 2000).

Há muitos períodos base de 30 anos que podem ser usados para definir o ONI. Esses períodos são usados para a normalização e cálculo das anomalias para cada cinco anos históricos, registrados e apresentados na Figura 4.6. Assim valores do período de 1950-1955 são baseados no período de 1936-1965, e o período de 1956-1960, baseados no período de 19411970, e, assim, sucessivamente ${ }^{70}$, até o período de 1996 a 2000, que é baseado em 1981 a 2010. Assim o período de 2001 a 2005 será baseado em 1985 a 2015, e 2006 a 2010, baseado na média de 1991 a 2021. Caso o clima não mude, a diferença entre quaisquer das médias de 30 anos será muito pequena, e os impactos sobre a aparente força de episódios El Niño e La Niña seriam insignificantes (L'HEUREUX, COLLINS e HU, 2013).

\footnotetext{
${ }^{69}$ Oceanic Niño Index

${ }^{70} \mathrm{http}$ //www.cpc.ncep.noaa.gov/products/analysis_monitoring/ensostuff/ONI_change.shtml
} 


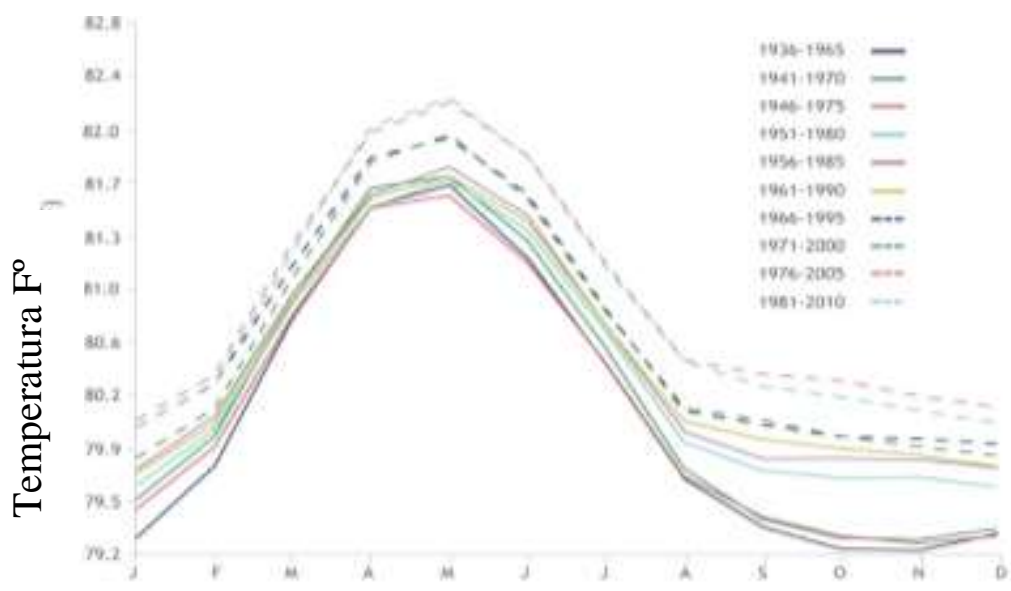

Figura 4.6 - Climatologias de 30 anos da TSM região NINO 3.4

Fonte: https://www.climate.gov/news-features/understanding-climate/watching-el-ni\%C3\%B1o-and-lani\%C3\%B1a-noaa-adapts-global-warming

\section{9 Índice EI Niño Modoki (MODOKI)}

El Niño Modoki é um fenômeno acoplado oceano-atmosfera, no Pacífico tropical, e está associado com o forte aquecimento anômalo no Pacífico Tropical Central e arrefecimento no Leste e Oeste do Pacífico Tropical (Figura 4.7). As teleconexões associadas aos padrões de aquecimento e arrefecimento do El Niño Modoki são muito diferentes dos padrões de teleconexões do El Niño (L’HEUREUX, COLLINS e HU, 2013).

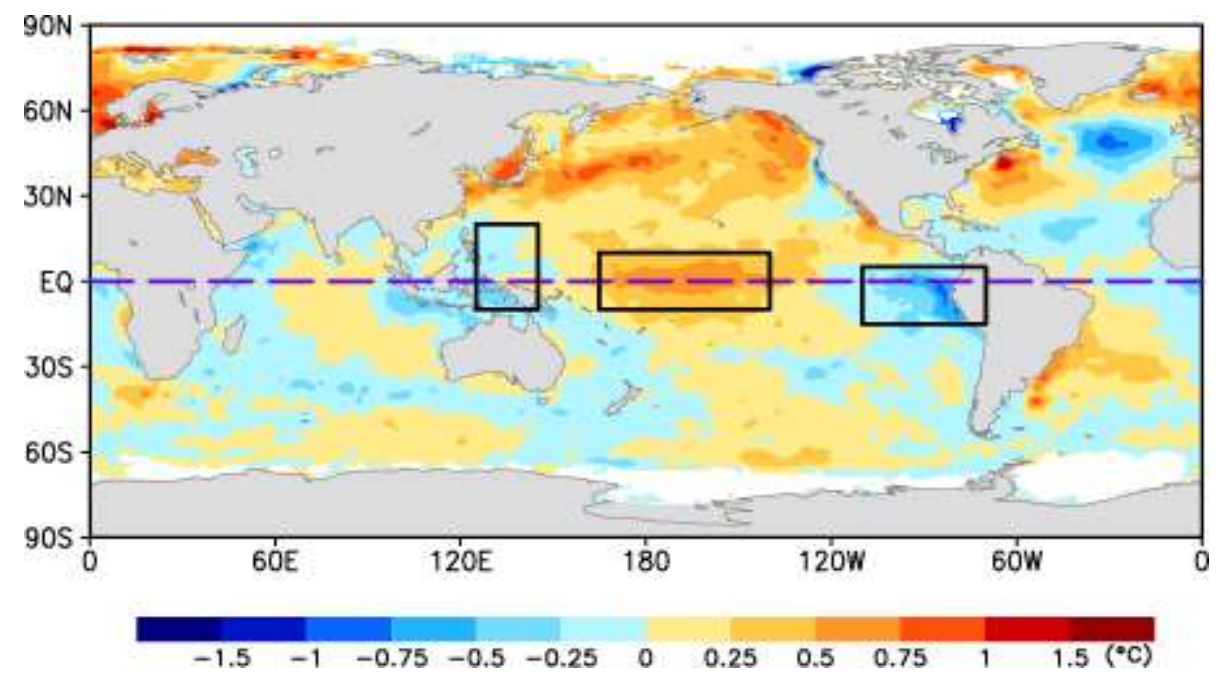

Figura 4.7 - Áreas utilizadas para compor o cálculo do índice MODOKI ${ }^{71}$

\footnotetext{
${ }^{71} \mathrm{O}$ nome " El Niño Modoki " foi inventado pela primeira vez pelo Prof. Yamagata em vários comunicados.
} Pesquisadores do Climate Variations Research Program of Frontier Research Center for Global Change 
Na Figura 4.8, apresentam-se a comparação entre EL NIÑO e EL NIÑO MODOKI. Em a) um evento El Niño ocorre quando os ventos de Leste enfraquecem e os ventos de Oeste prevalecem. Essa condição ocorre devido às TSM serem mais quentes que o normal, no Leste do oceano, e está associada a alterações na termoclina e na circulação atmosférica que tornam o Leste mais úmido e o Oeste mais seco (também descrito na seção 3.3 El Niño-Oscilação Sul (ENOS), p. 87); b) um evento El Niño Modoki é uma condição anómala. As TSM mais quentes ocorrem no Pacífico Central, cercado por águas frias para o Leste e Oeste, e estão associadas a padrões distintos de convecção atmosférica; c) e d) As fases opostas (La Niña) do El Niño e El Niño Modoki, respectivamente. Yeh et al (2009) argumentam que o aumento da frequência da condição Modoki deriva do aquecimento antropogênico, e que esses eventos no Pacífico central ocorreram com mais frequência, caso o aquecimento global aumente (ASHOK e YAMAGATA, 2009).

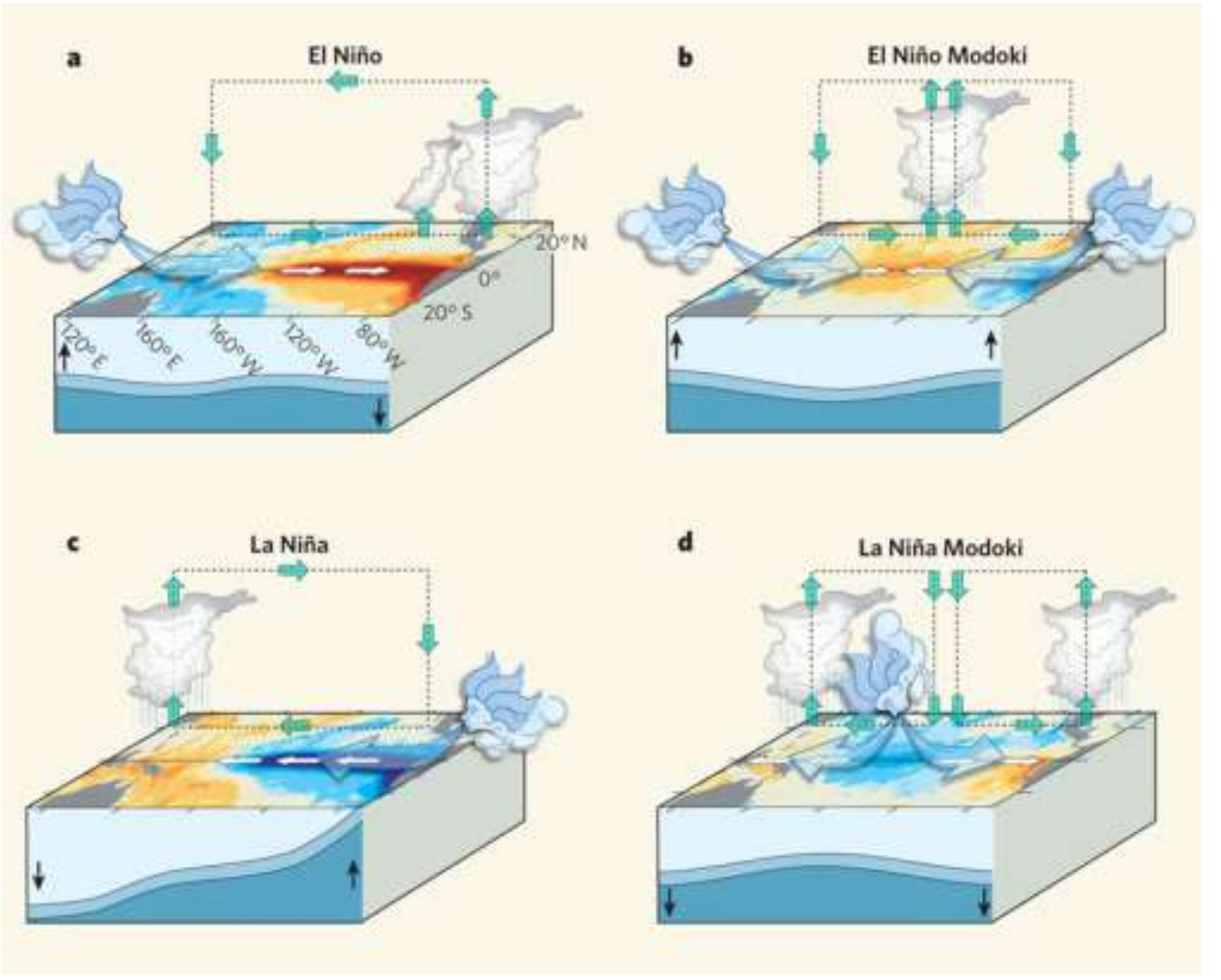

Figura 4.8 - a) El Niño. b) El Niño Modoki. c) La Niña. d) La Niña Modoki ${ }^{72}$

(FRCGC) liderados pelo Prof. Yamagata documentara esse fenômeno pela primeira vez. Acesso em 02/01/2016 site: http://www.jamstec.go.jp/frcgc/research/d1/iod/enmodoki_home_s.html.en

${ }^{72}$ Fonte do artigo: Climate change: The El Niño with a difference Karumuri Ashok \& Toshio Yamagata Nature 461, 481-484(24 September 2009) doi:10.1038/461481a. Acesso 02/01/2016 site http://www.nature.com/nature/journal/v461/n7263/fig_tab/461481a_F2.html. 


\subsection{0 Índice Oscilação Multidecadal do Atlântico - AMO}

A Oscilação Multidecadal do Atlântico - AMO ${ }^{73}$ corresponde às oscilações de TSM do Atlântico Norte com mudanças de fase entre 20 e 40 anos (31 anos em média, e ciclo total entre 65-70 anos), sendo que entre 1929 a 1964 foi a fase positiva e teve maior duração (DESER et al.,2010; ENFIELD et al., 2001), Tabela 4-4.

Tabela 4-4 Fases conhecidas da AMO (ENFIELD et al., 2001)

\begin{tabular}{lcc}
\hline Fase AMO & Período & Total de Anos \\
\hline Negativa & $1900-1928$ & 29 \\
\hline Positiva & $1929-1964$ & 36 \\
\hline Negativa & $1965-1994$ & 30 \\
\hline Positiva & $1995-2015$ & 21
\end{tabular}

Combinado com padrão do El Niño, a AMO promove diferentes configurações de chuva na América do Sul e engloba uma imensa área que começa no norte do oceano Atlântico, próximo ao Ártico até a linha do equador (Figura 4-9).

O índice AMO compõe uma série histórica calculada com base nos dados de médias ponderadas TSM do Atlântico Norte entre as latitudes $0^{\circ}$ e $70^{\circ} \mathrm{N}$, (ENFIELD et al 2001) e normalizada após remover a média climatológica de temperatura. A resolução espacial dos dados de temperatura apresenta-se como $5^{\circ} \times 5^{\circ}$. Também há a série sem retirada da tendência e sem normalização.

\footnotetext{
${ }^{73}$ Do inglês: Atlantic Multidecadal Oscillation (AMO)
} 


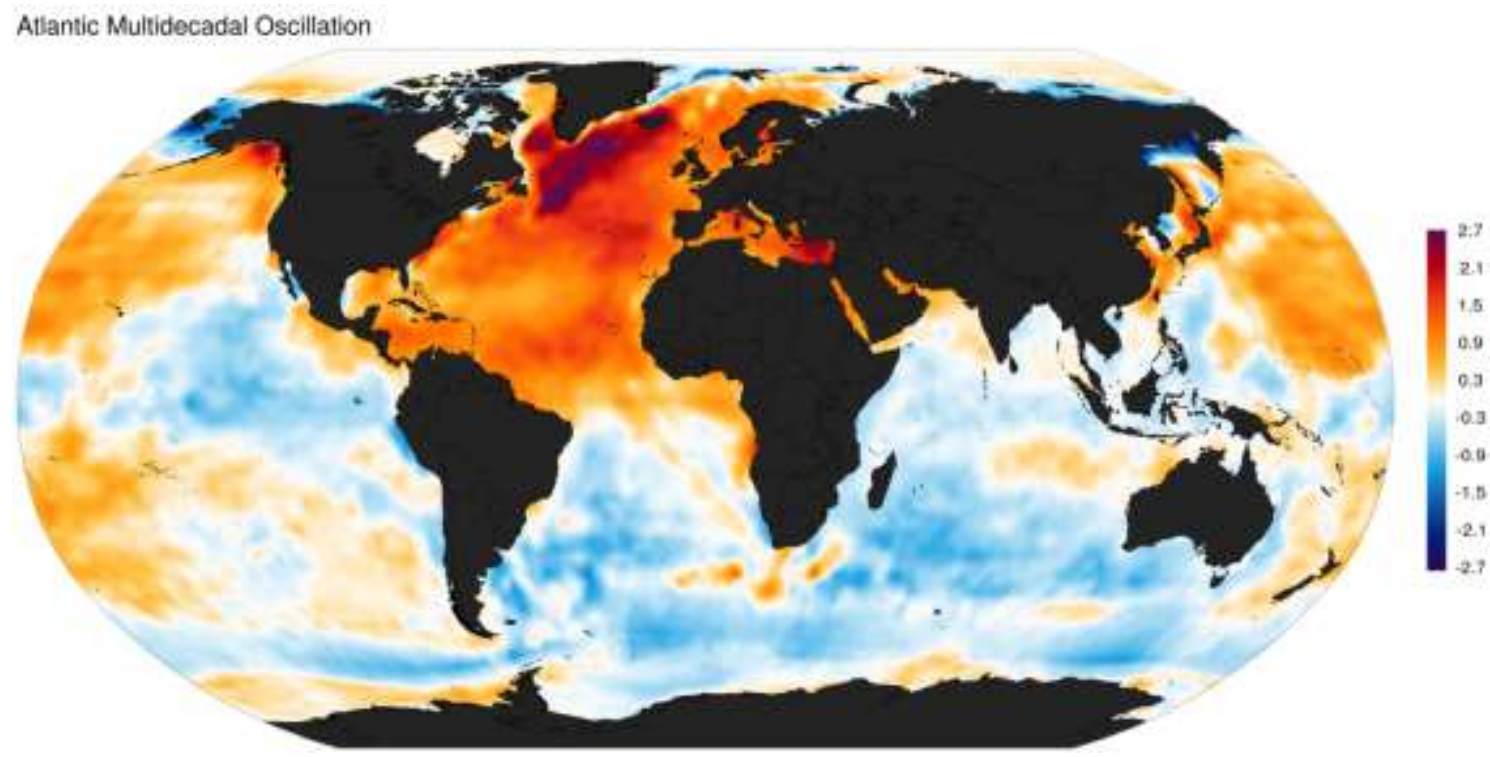

Figura 4-9- Oscilação Multidecadal do Atlântico - AMO. Fonte: Deser et al., 201074

Na América do Sul, sabe-se que a precipitação sobre o Atlântico é deslocada para norte durante a fase quente AMO que corresponde em uma posição diferente da média climatológica da Zona de Convergência Intertropical (ZCIT), mais ao norte, o que diminui a precipitação durante a estação chuvosa no Nordeste brasileiro de março a maio.

\subsection{1 Índice de TSM Modo Meridional do Atlântico - AMM75}

O padrão espacial $\mathrm{AMM}^{76}$ é definido, através de aplicação da análise de covariância máxima (MCA) à TSM e os componentes zonal e meridional do campo vento a $10 \mathrm{~m}$ de altura ao longo do período 1950-2005, a partir da base de dados de reanálise do NCEP / NCAR. A área analisada no Atlântico corresponde a região $\left(21^{\circ} \mathrm{S}-32^{\circ} \mathrm{N}, 74^{\circ} \mathrm{W}-15^{\circ} \mathrm{E}\right)$, e espacialmente suavizados (três pontos de longitude por dois pontos de latitude).

Na Figura 4-9, apresentam-se coeficientes de expansão de TSM normalizados e vetores de vento de $10 \mathrm{~m}$. Os vetores de vento são representados graficamente, em que a soma dos seus coeficientes de correlação ultrapassa 0,27 (nível de confiança de 95\%). Na figura de preciptações (Inferior), que está em mm por dia. As regiões sombreadas apresentam-se dentro do intervalo de confiança de $95 \%$.

\footnotetext{
${ }^{74} \mathrm{https}: / /$ en.wikipedia.org/wiki/Atlantic_multidecadal_oscillation

75 Atlantic Meridional Mode

${ }^{76} \mathrm{http}: / /$ www.esrl.noaa.gov/psd/data/timeseries/monthly/AMM/
} 


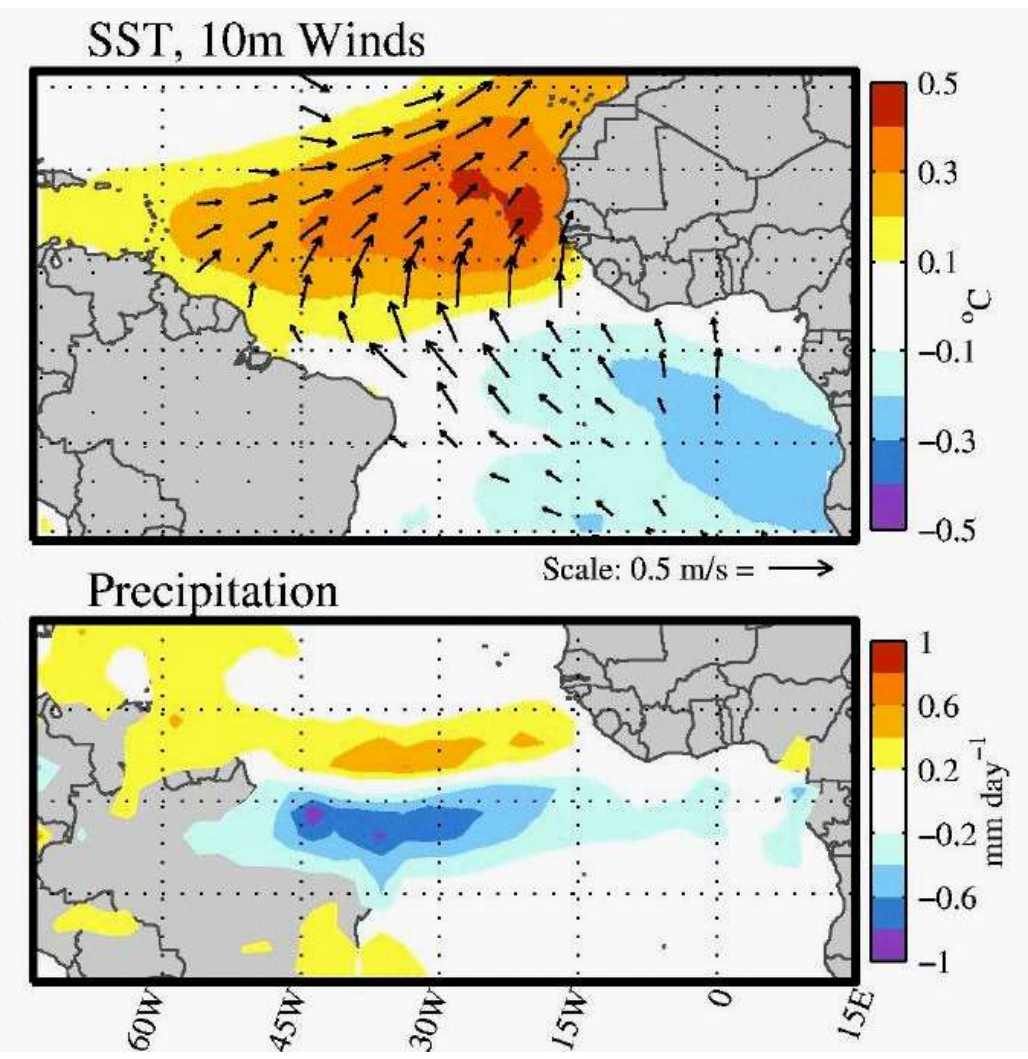

Figura 4-10- Modo Meridional do Atlântico - AMM. Fonte: (CHIANG; VIMONT, 2004)

O ciclo sazonal e a tendência são removidos, e é aplicada uma média móvel de três meses, e também é feito o ajuste linear junto ao Índice de Cold Tongue (uma medida da variabilidade ENOS) que é subtraída de cada ponto espacial. Os padrões espaciais são definidos, conforma o mapa da primeira figura à esquerda (TSM) e à direita (ventos), resultantes da SVD da matriz de covariância entre os dois campos(CHIANG; VIMONT, 2004).

\subsection{2 Índices Tropicais Norte e Sul do Atlântico (TNA / TSA) ${ }^{77}$}

A TNA (Figura 4.11 a.) e a $\operatorname{TSA}^{78}$ (Figura 4.11 b.) são índices de anomalias de TSM do Atlântico. A TNA corresponde a uma caixa de coordenadas: $55^{\circ}$ Oeste a $15^{\circ}$ Oeste e $5^{\circ}$ Norte a $25^{\circ}$ Norte. A TSA corresponde a uma caixa de coordenadas: $30^{\circ}$ Oeste - $10^{\circ}$ Leste, $20^{\circ} \mathrm{Sul}$ $0^{\circ}$. Os gráficos mostram as médias mensais com sinal de + e resultados filtrados com a média de três meses são apresentados em áreas sombreadas. O desvio padrão semanal é feito sobre o período de 1982 a 2005.

\footnotetext{
77 TSA - Tropical Southern Atlantic TNA - Tropical Northern Atlantic

${ }^{78} \mathrm{http}: / /$ stateoftheocean.osmc.noaa.gov/sur/atl/tna.php
} 


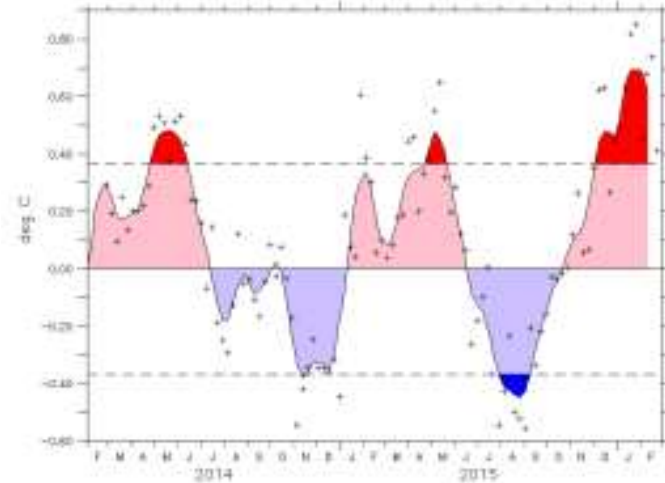

a)

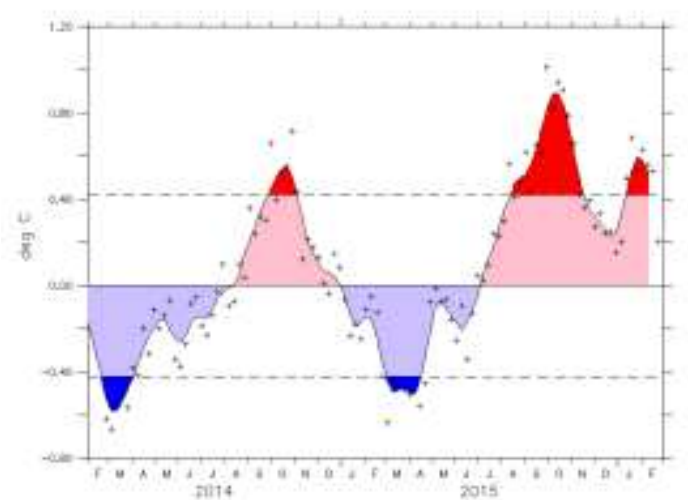

b)

Figura 4.11 -Índice de TSM do a) Atlântico Sul e b) Atlântico Norte

A TNA e a TSA são índices onde padrões dipolares ao longo do Atlântico Tropical, e são identificados com periodicidade de 8 a 12 meses para o inverno-outono boreal, e 2 a 3 anos para o verão-inverno boreal (ENFIELD, 1999). Os índices são calculados com o uso de dados de reanálises Reynolds OIv2 SST ${ }^{79}$ (REYNOLDS ET AL, 2002).

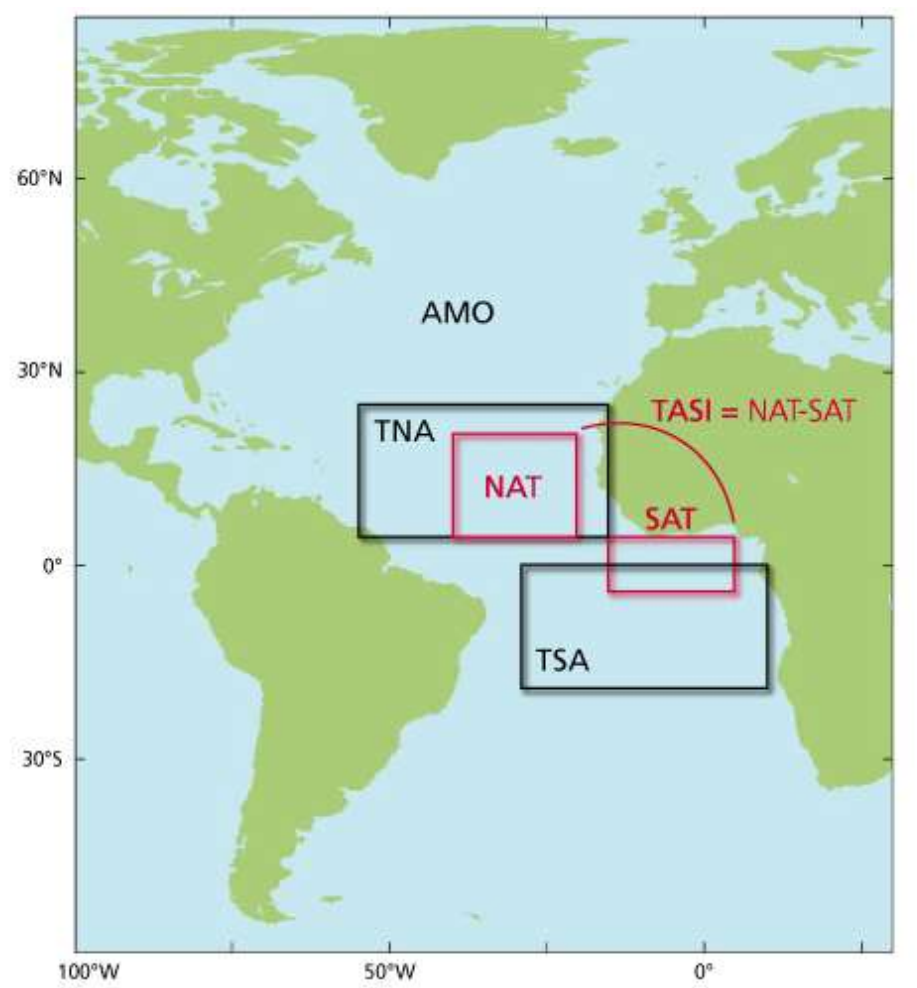

Figura 4.12 -Índices medidos da TSM do Atlântico. NAT e SAT não são abordados ${ }^{80}$

\footnotetext{
${ }^{79} \mathrm{http} / / / \mathrm{www} . e m c . n c e p . n o a a . g o v /$ research/cmb/sst_analysis/
}

${ }^{80} \mathrm{http}: / /$ stateoftheocean.osmc.noaa.gov/sur/atl/ 


\subsection{3 Índice Oscilação do Atlântico Norte (NAO) ${ }^{81}$}

O índice NAO baseia-se na diferença de pressão do nível do mar de superfície entre a Alta Subtropical (Açores) e a Baixa Subpolar. O NAO combina regiões do Oceano Atlântico Leste e Atlântico Oeste, inicialmente identificados por Wallace e Gutzler (1981) ${ }^{82}$. A fase positiva da NAO reflete alturas abaixo do normal, e pressão através das altas latitudes do Atlântico Norte, e alturas acima do normal e pressão sobre o centro do Atlântico Norte, o Leste dos Estados Unidos e da Europa Ocidental. A fase negativa reflete um padrão oposto de altura e pressão e anomalias sobre essas regiões. Ambas as fases da NAO, estão associadas a mudanças em larga escala na intensidade e localização da corrente de jato e tempestades do Atlântico Norte, e em modulações de grande escala meridional dos padrões normais de calor zonal e transporte de umidade, o que por sua vez resulta em mudanças de temperatura e padrões de precipitação estendendo-se muitas vezes de leste da América do Norte para a Europa ocidental e central (BARNSTON e LIVEZEY, 1987; CHEN e VAN DEN DOOL, 2003; VAN DEN DOOL, SAHA e JOHANSSON, 2000).

\subsection{4 Índice de Oscilação Madden-Julian (MJO)}

A Oscilação Madden-Julian (MJO) é uma perturbação tropical, que propaga-se de Oeste para Leste, através do redor da região do trópico global com um ciclo da ordem de 30 a 60 dias (MADDEN; JULIAN, 1972). O MJO impacta os padrões de precipitação tropical e extratropical, circulação atmosférica e temperatura de superfície. Existem evidências que a MJO influencie o ciclo do ENOS e contribuí para acelerar o desenvolvimento e intensidade dos fenômenos de El Niño e La Niña. ${ }^{83}$. Sobre a América do Sul, a MJO, em períodos de El Niño e La Niña moderados, pode inibir ou intensificar a formação de nuvens de chuva. A identificação da ocorrência do MJO acontece por meio de medições de velocidade potencial, pressão atmosférica a 200 mbar (aproximadamente $12 \mathrm{~km}$ de altura), (HIGGINS e MO, 1997; HIGGINS e SCHUBERT, 1996; KOUSKY e KAYANO, 1994).

Na Figura 4.13, apresentam-se a dinâmica da Oscilação MJO. As etapas de evolução da MJO, podem ser definidas e apresentadas na seguinte ordem (SIQUEIRA, 2016):

\footnotetext{
${ }^{81}$ North Atlantic Oscillation

$82 \mathrm{http} / / / \mathrm{www} . c p c . n c e p . n o a a . g o v /$ data/teledoc/nao.shtml

${ }^{83} \mathrm{http}: / /$ www.cpc.ncep.noaa.gov/products/precip/CWlink/MJO/MJO_1page_factsheet.pdf
} 
1. Formação de um sistema de baixa pressão e convecção profunda no oceano Índico, próximo à Indonésia;

2. O sistema desloca-se para a região da piscina de água quente do Pacífico, na costa Norte da Austrália, ganha força e o desenvolvimento vertical das nuvens se intensifica (linhas verdes, na Figura 4.13);

3. A Oeste e a Leste das nuvens de desenvolvimento vertical são formados sistemas de alta pressão, que inibem a formação de nebulosidade (linhas marrons, na Figura 4.13);

4. O sistema desloca-se para Leste, e próximo da América do Sul, desenvolve-se um sistema de alta pressão, que se intensifica e inibe a formação de nuvens, principalmente na região tropical da América do Sul, sobre o Brasil;

5. Com a continuidade do movimento para Leste, o sistema de baixa pressão passa sobre a América do Sul, e favorece a formação de nebulosidade, que pode ou não aumentar a precipitação.

O índice da MJO é formado por oito fases, onde cada fase corresponde a uma posição de convecção do MJO sobre a Índia e o Oceano Pacifico entre $15^{\circ} \mathrm{S}$ e $15^{\circ} \mathrm{N}$ (WHEELER e HENDON, 2004). Sobre a América do Sul, a MJO está relacionada com o a intensidade da Zona de Convergência Atlântico Sul - ZACS (DE SOUZA e AMBRIZZI, 2006).

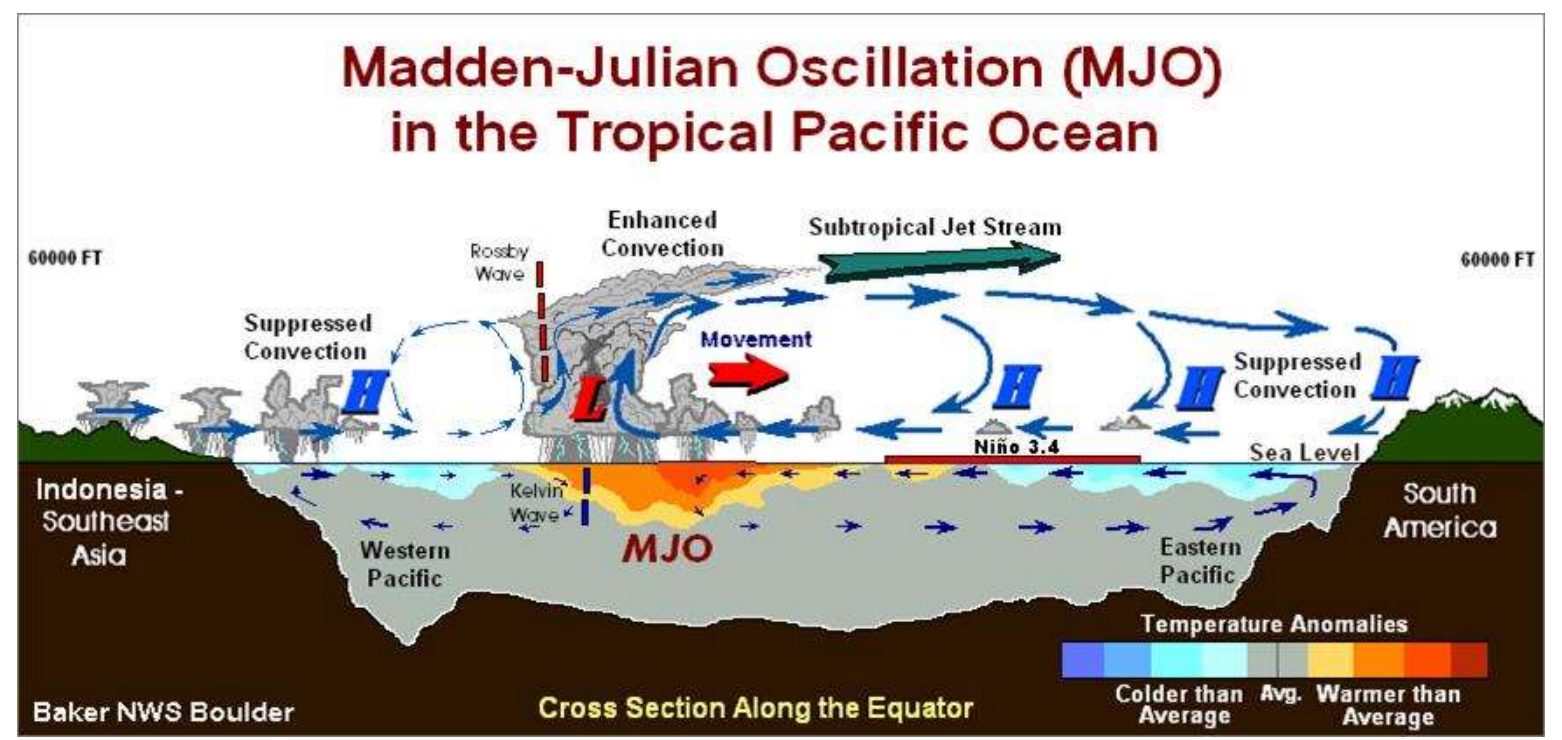

Figura 4.13 - Diagrama descritivo do desenvolvimento da Oscilação Madden-Juliana sobre o Pacífico Tropical ${ }^{84}$

\footnotetext{
84 Fonte: SIQUEIRA, 2016 Apud https://rclutz.wordpress.com/2015/05/11/dynamic-duo-the-ocean-airpartnership/
} 


\subsection{5 Índice Oscilação Quase-Bianual - QBO}

$\mathrm{O} \mathrm{QBO}^{85}$ é uma oscilação quase periódica dos ventos zonais na estratosfera tropical caracterizada por regimes de ventos descendentes de Leste e Oeste, com períodos entre de 2234 meses (BALDWIN et al., 2001). O QBO é o único tipo de teleconexão estratosférico que compreende a zona de inversão cíclica natural, e que compreende as correntes equatoriais entre 50-30 hPa. A inversão propaga-se de cima para baixo, a partir de $10 \mathrm{hPa}$ para $100 \mathrm{hPa}$. A fase Leste (QBO negativo) é geralmente mais intensa e breve que a fase Oeste (QBO positivo). A propagação para baixo as westerlies ocorre mais rápido do que os easterlies, e no entanto, em ambos os casos, a intensidade diminui com a diminuição da quota ${ }^{86}$.

A QBO influência a atividade tropical no Atlântico, e é amplamente utilizado na edição de previsões da temporada de furacões. A fase ocidental (positiva) da QBO está associada com um aumento no número de tempestades tropicais. A QBO em conjunto com as anomalias de temperaturas do Oceano Índico e regiões ENSO, influencia a estação das monções. A frequência de ciclones tropicais no noroeste do Pacífico aumenta durante a fase ocidental de QBO, enquanto que, ao contrário, a atividade se intensifica no Oceano Índico Sudoeste tropical durante a fase de Leste. As previsões ENSO utilizam a fase de espera do QBO a 30 hPa e 50 hPa para determinar sua intensidade e duração.

\subsection{6 Índice de Oscilação da Antártica (AAO) ${ }^{87}$}

A AAO pode ser definida como um índice de anomalias, relacionado as medições de pressão atmosférica na altura de $500 \mathrm{hPa}$, entre o polo $\mathrm{Sul}$ e $20^{\circ} \mathrm{S}$, das reanálises, de dados de medição climatológica, feitas pelo $\mathrm{NCEP}^{88}-\mathrm{NCAR}^{89}$. As EOF são aplicadas nas medições filtradas onde algumas áreas de influência são destacadas, caracterizando o padrão da AAO, que corresponde a teleconexão entre AAO e o aquecimento da TSM no Leste do Pacífico, Sul do Atlântico, Oceano Indico, e esfriamento no Norte do Pacifico e no Norte do Atlântico (MO, 2000).

\footnotetext{
${ }^{85}$ Quasi-Biennial Oscillation

${ }^{86} \mathrm{http}$ ://www.firenzemeteo.it/indici_teleconnettivi/indici_teleconnettivi.php?Indice=Indice26

${ }^{87}$ Antarctic Oscillation

${ }^{88}$ National Center for Environmental Prediction

${ }^{89}$ National Center for Atmospheric Research
} 


\subsection{7 Índice de Oscilação do Ártico (AO) ${ }^{90}$}

A AO é um índice relacionado com anomalias pressão atmosférica na altura de $1000 \mathrm{mb}$ entre o Polo Norte e $20^{\circ} \mathrm{N}$ das reanálises, de dados de medição climatológica, do NCEP-NCAR. As EOF são aplicadas nas medições filtradas e algumas áreas de influência sobre a Eurásia são destacadas, o que caracterizam o padrão da $\mathrm{AO}$ e sua influência na variabilidade climática, através da teleconexão entre AO e os fenômenos de oscilação NAO, PDO e AMO com diferentes escalas de tempo (THOMPSON e WALLACE, 1998; HIGGINS, et al 2002).

\subsection{8 Índice de Gelo Polos Ártico e Antártico}

Os dados de gelo nos polos foram obtidos através de satélites equipados com sensores de radiofrequência e micro-ondas capazes de medir a cobertura de gelo. Os mapas são projeções estereográficas polares com concentração de gelo, e são arquivados pelo Snow and Ice Data Center $\left(\mathrm{NSIDC}^{91}\right)$. As concentrações são calculadas, para cada elemento de grade, e são usadas para derivação da "extensão de gelo no mar", que é calculada como a soma de todos os elementos do mar com concentração de gelo acima de $15 \%$. Os conjuntos de dados fornecem o total de cada hemisfério e os valores são também divididos em nove regiões no Polo Ártico, e cinco regiões no Polo Antártico.

Detalhes relacionados com os cálculos da cobertura de gelo podem ser encontrados em Cavalieri et al (1999) e Cavalieri et al (2012). Os resultados para o Ártico podem ser encontrados em Parkinson et al. (1999) e Cavalieri e Parkinson (2012), e os resultados para o Antártico podem ser encontrados em Zwally et al. (2002) e de Parkinson e Cavalieri (2012).

Na Figura 4. 14, apresentam-se (a) as nove regiões do Polo Ártico onde é monitorada a cobertura de gelo e (b) a área de cobertura de gelo que estava diminuindo, e em 2016 começa a se recuperar.

\footnotetext{
${ }^{90}$ Artic Oscillation

${ }^{91}$ http://nsidc.org
} 


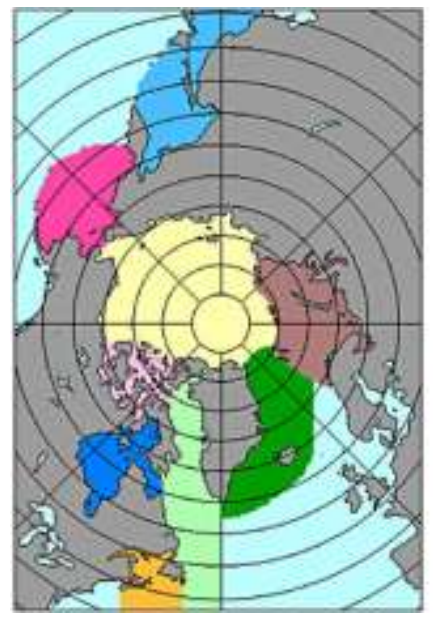

(a)

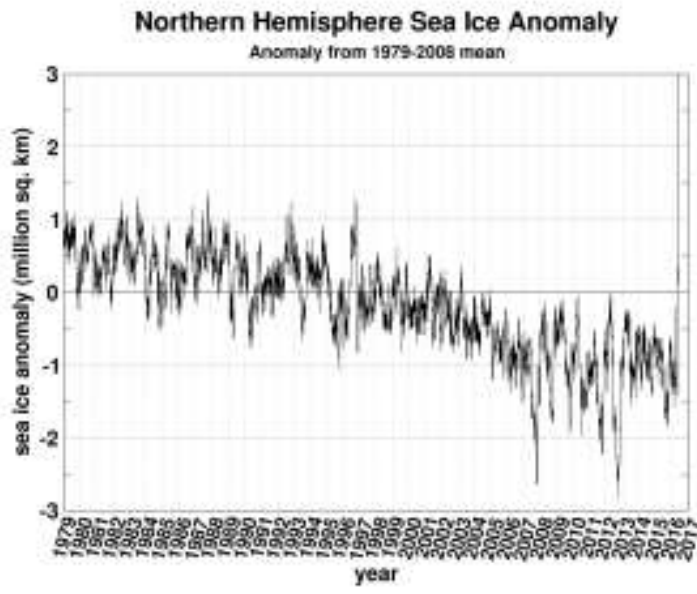

(b)

Figura 4. 14 - a) Regiões com cobertura de gelo do polo Ártico e b) tendência entre 1978 a 2013

Na Figura 4. 15, apresentam-se as (a) cinco regiões do polo Antártico, onde é monitorada a cobertura de gelo e (b) á área de cobertura de gelo que está aumentando.

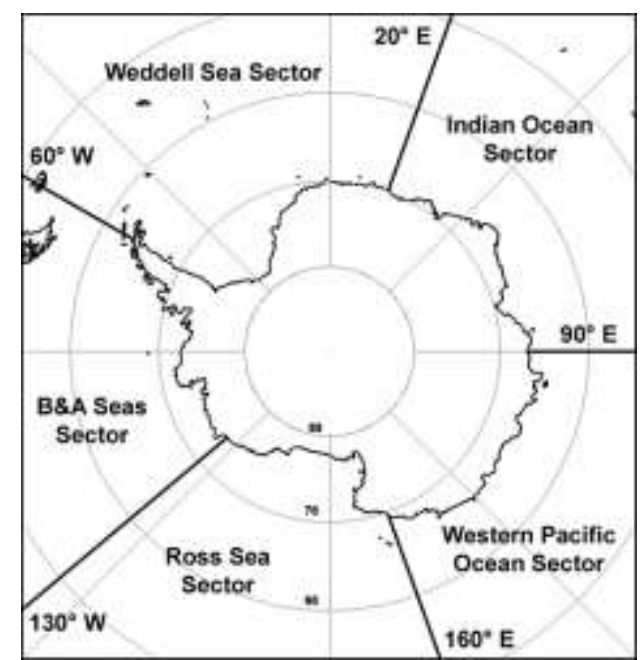

(a)

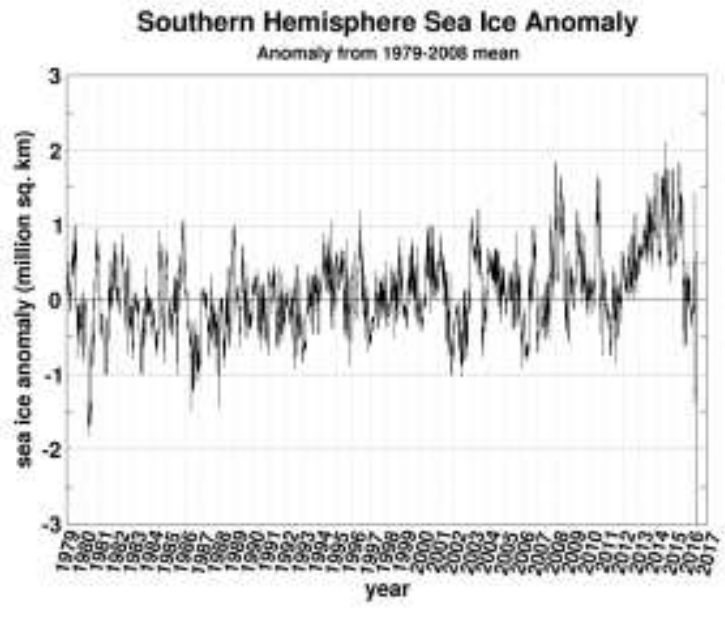

(b)

Figura 4. 15 - a) Regiões com cobertura de gelo do polo Antártico Ártico e b) tendência entre 1978 a 2013 


\section{CAPÍTULO 5 MÉTODO}

Os Modelos de previsão são aplicados a diversos problemas das ciências, comércio, engenharia, medicina, biologia e meteorologia. Uma ferramenta estatística, utilizada frequentemente, para estudar fenômenos e suas relações é a regressão. Em 1886, Sir Francis Galton publicou seu trabalho "Regression Towards Mediocrity in Hereditary Stature", em razão de sua crença na passagem hereditária de características genéticas, baseada em uma análise de registros sobre a relação entre as alturas dos pais e de seus filhos. A partir de suas análises, realizadas com base na regressão simples, apontou a possibilidade da herança genética, mesmo isento do conhecimento de seu funcionamento. Posteriormente, em 1953, como base em estudos similares e novas teorias, o norte americano James Watson e o britânico Francis Crick descobriram a estrutura do DNA $^{92}$, através de análise de fotos de raios X ampliadas, o que lhes valeu, em 1962, o prêmio Nobel de Fisiologia ou Medicina.

Os modelos de séries temporais são diferentes de modelos de regressão, uma vez que as medidas de um processo ao longo do tempo introduzem autocorrelações (ou seja, correlações entre os valores passados e os valores presentes da série histórica). A natureza da série deve ser considerada com cuidadosa avaliação das estruturas de atrasos no modelo.

\subsection{Estacionariedade e pré-tratamento das Séries}

, que descreve os fenômenos estudados, não muda com o tempo. Evidentemente, tal hipótese não é uma descrição adequada em inúmeros sistemas que fazem uso de séries temporais (sistemas climáticos, econômicos, energéticos, etc.). Na prática, a forma forte da condição de estacionariedade (função de distribuição de probabilidade sempre a mesma independentemente do momento em que são feitas as observações) é substituída pela forma fraca, na qual um processo é considerado estacionário quando a média, a variância e a função autocorrelação são constantes ao longo do tempo (PANKRATZ, 1991). Em Box, Jenkins e Reinsel (2008) a condição de restrição da estacionariedade é utilizada simultaneamente a conceitos da Teoria de Controle (tais como função de transferência e equilíbrio dinâmico) para a construção do conceito de equilíbrio estatístico, no qual o sistema é representado como variando em torno de um nível médio constante e com variância constante.

\footnotetext{
${ }^{92}$ Deoxyribonucleic acid
} 
Em geral, quando os dados primários não constituem uma série estacionária, é possível transformá-los de modo a obter uma correspondente série estacionária (PANKRATZ, 1991). Uma vez que as transformações são conhecidas, podem ser revertidas e as previsões podem ser comparadas como os dados originais. Além das transformações para obter estacionariedade, também é comum que seja necessário aplicar transformações para estabilizar a variância ou a média em séries sazonais.

No pacote $\mathrm{R}$, o comando ndiff indica se uma série temporal é estacionária ou não, dependendo da quantidade de diferenças necessárias para torna-la estacionária. Esse comando usufrui da teoria encontrada em Kwiatkowski et al (1992) utilizada para o teste de raiz unitária chamado KPSS. Utiliza-se também o comando nsdiff para identificar a parte sazonal da série que necessita uma aplicação de diferenças sazonais para tornar a parte sazonal da série também estacionária. Esse comando usa como referência a teoria encontrada em Canova e Hansen (1995).

\subsubsection{Diferenciação}

Assume-se que os dados seguem uma distribuição normal. Frequentemente as transformações os induzem a uma variância constante e podem aproximá-los da normalidade.

Se uma série $z^{\prime}$ não flutua em torno de uma média constante pode-se criar uma nova série com média constate ao aplicar uma diferença nos dados, isso é, calcula-se mudanças sucessivas nas séries para todos os valores de t conforme a seguinte equação:

$w_{t}=z_{t}-z_{t-1}$

Caso a séries continue apresentando valor não constante em torno de uma média calcula-se a $1^{\mathrm{a}}$ diferença para todos os valores de $\mathrm{t}$. Assim assumindo-se a $1^{\mathrm{a}}$ diferença de $\mathrm{z}_{\mathrm{t}}$ como $\mathrm{w}_{\mathrm{t}}{ }^{*}$ $w_{t}=w_{t}^{*}-w_{t-1}^{*}=\left(z_{t}-z_{t-1}\right)-\left(z_{t-1}-z_{t-2}\right)$

O resultado da série é chamado de $2^{\mathrm{a}}$ diferença de $\mathrm{z}_{\mathrm{t}}$ dados e d denota o grau da diferenciação. Para a primeira diferença $d=1$, para a segunda diferença $d=2$. Geralmente para alcançar-se a média constante uma diferença é suficiente.

\subsubsection{Diferença Sazonal}

Caso a série apresente padrões de ondas isso pode indicar um padrão de movimentação periódica ou sazonal. Para tratar desse tipo de série pode-se aplicar uma diferença com o intervalo de tempo do período aqui denominado $s$. 
Assim, a diferenciação sazonal induz a média constante na série que se desloca na forma sazonal através do cálculo de sucessivas mudanças entre as observações separadas no tempo pelo período de tempo $s$, onde s é o número da frequência sazonal. Para frequência anual s é igual a doze; para frequência trimestral s é igual quatro; quadrimestre s igual a três e, assim, conforme a frequência informada.

\subsubsection{Estabilização da variância}

Para estabilizar a variância tipicamente utilizam-se transformações com log natural ou com raiz quadrada. Se o desvio padrão da série é proporcional aos seus valores observados, utilizase o logaritmo natural e produz séries com variância constante; ou se a variância da seria original é proporcional a seus valores observados utiliza-se a raiz quadrada o que resulta em uma variância constante.

As transformações de log e a raiz quadrada são membros da família de transformações de potência chamada transformações de Box-Cox, que são definidas como:

$z_{t}^{\prime}=\frac{z_{t}^{\lambda}-1}{\lambda}$

em que $\lambda$ é um número real. Quando $\lambda$ igual a 0,5 fornece a transformação da raiz quadrada, por exemplo. Durante a observação do gráfico se for constatado que os dados indicam uma tendência de aumento da variância e os das séries tendem a crescer, deve atribuir a $\lambda$ valores menores que um. Se a tendência é de uma diminuir, assim como, os dados da série deve-se atribui a $\lambda$ valores maiores que um. Conforme a atribuição dos valores dos gráficos, apresentam-se linhas adequadas para a modelagem, flutuando em torno de uma constante. Porém deve-se ter cuidado com a inspeção visual. Transformações mais simples ou interpretáveis são mais comuns, assim, o valor de $\lambda$ igual a 0,5 é frequentemente utilizado (transformação de raiz quadrada) ao invés 0,54 e $\lambda=0$ (transformação com log natural) no lugar de escolher, por exemplo, $\lambda=-0,08$ (PANKRATZ, 1991).

\subsection{Modelos de regressão}

Os modelos de regressão univariados seguem a seguinte forma:

$y=b_{0}+x b_{1}+n_{t}$ 
em que y é a variável dependente que, no modelo adotado, tem seu comportamento explicado a partir da variável independente ${ }^{93}, \mathrm{x} ; \mathrm{b}_{0}$ é uma constante que aponta a interceptação da reta com o eixo de y; $b_{1}$ é uma constante que representa o coeficiente angular da reta; $\mathrm{n}_{\mathrm{t}}$ é um termo de perturbação estocástica.

$\mathrm{O}$ termo $\mathrm{n}_{\mathrm{t}}$ incorpora todas as variações na variável dependente y que não estão incluídas no modelo escolhido, ou seja, representa a variação da saída que não está associada com movimentos da entrada. Desse modo, a perturbação estocástica $n_{t}$ pode ser interpretada como uma medida da nossa ignorância em relação ao fenômeno modelado.

O modelo correspondente à equação 5-17 pode ser expandido para incluir mais de uma variável explicativa, obtendo, assim, os chamados modelos multivariados que seguem a seguinte forma:

$y_{t}=b_{0}+b_{1} x_{1, t}+\cdots+b_{k} x_{k, t}+n_{t}$ $5-18$

$\mathrm{y}_{\mathrm{t}}$ é modelada como função de $\mathrm{k}$ variáveis explicativas $\mathrm{x}_{1, \mathrm{t}}, \ldots, \mathrm{x}_{\mathrm{k}, \mathrm{t}}$.

Conforme já mencionado, $\mathrm{n}_{\mathrm{t}}$ incorpora toda variação de $\mathrm{y}_{\mathrm{t}}$ não incluída no modelo. Quando as variações observadas em $n_{t}$ são totalmente independentes de $x_{t}$, então $n_{t}$ constitui um ruído branco definido como uma sequência de variáveis aleatórias mutuamente independentes e identicamente distribuídas (PANKRATZ, 1991, 9). O ruído branco $\mathrm{n}_{\mathrm{t}}$ possui média zero e apresenta distribuição normal $-\mathrm{N}\left(0, \sigma^{2}\right)$, geralmente representado na literatura como at ou também como $e_{t}$. Nesse caso, $n_{t}=a_{t}$ ou $n_{t}=e_{t}$. Quando $n_{t}$ é diferente de $a_{t}$ significa que $n_{t}$ ainda possui informações, além do ruído branco, sendo possível melhorar o ajuste do modelo pela incorporação de novas variáveis explicativas, até que $\mathrm{n}_{\mathrm{t}}$ se iguale a $\mathrm{a}_{\mathrm{t}}$.

\subsection{Séries temporais}

Uma série temporal é um conjunto de medidas $\left\{\mathrm{Y}_{\mathrm{t}}\right\}$ coletadas sequencialmente com intervalos de tempo com pontos igualmente espaçados. Os modelos de séries podem ser caracterizados em termos de uma estrutura de atrasos (lags, do Inglês).

Para um modelo autorregressivo (AR) de ordem $\mathrm{p}$, a variável resposta, $\mathrm{Y}_{\mathrm{t}}$, é uma combinação de valores passados p e um termo de erro:

$y_{t}=\phi_{0}+\phi_{1} Y_{t-1}+\phi_{2} Y_{t-2}+\cdots \phi_{p} Y_{t-p}+\epsilon_{t}$

\footnotetext{
${ }^{93}$ A terminologia adotada para as variáveis yt e xt emprega sinônimos. yt pode ser denominada como variável dependente, endógena, ou resposta; xt é chamada de variável independente, exógena, explicativa, exploratória.
} 
Para um modelo de médias móveis (MA) de ordem q, a variável resposta é uma combinação linear de erros do passado e um termo aditivo de ruído branco Gaussiano (RBG):

$y_{t}=\theta_{0}-\theta_{1} \epsilon_{t-1}-\theta_{2} \epsilon_{t-2}-\cdots \theta_{q} \epsilon_{t-q}+\epsilon_{t}$

Para um modelo autorregressivo e de médias móveis (ARMA) de ordem (p,q), a variável resposta é uma combinação linear construída a partir de p respostas passadas e q erros passados com um termo aditivo RBG:

$y_{t}=\theta_{0}+\phi_{1} Y_{t-1}+\phi_{2} Y_{t-2}+\cdots \phi_{p} Y_{t-p} \theta_{1} \epsilon_{t-1}+\theta_{2} \epsilon_{t-2}+\cdots \theta_{q} \epsilon_{t-q}+\epsilon_{t}$

\subsection{Operador Backshift (atraso)}

Obviamente, na análise de séries temporais, é recorrente a utilização de valores passados para determinar valores futuros. $\mathrm{O}$ ato de incorporar uma observação passada no modelo é representado, matematicamente, pelo operador backshift, indicado na equação abaixo:

$B Y_{t}=Y_{t-1}$, quando transladamos da observação $t$ para a observação $t-1$,

$\mathrm{B}^{2} \mathrm{Y}_{\mathrm{t}}=\mathrm{Y}_{\mathrm{t}-2}$, quando transladamos da observação $\mathrm{t}$ para a observação $\mathrm{t}-2$,

$\mathrm{B}^{3} \mathrm{Y}_{\mathrm{t}}=\mathrm{Y}_{\mathrm{t}-3}$, quando transladamos da observação $\mathrm{t}$ para a observação $\mathrm{t}-3$.

Em termos gerais:

$\mathrm{B}^{\mathrm{m}} \mathrm{Y}_{\mathrm{t}}=\mathrm{Y}_{\mathrm{t}-\mathrm{m}}$, quando transladamos da observação $\mathrm{t}$ para a observação $\mathrm{t}-\mathrm{m}$.

Observa-se que, a notação empregada, transforma uma regra de recorrência (tomar a observação $\mathrm{t}-\mathrm{m})$ numa operação algébrica $\left(\mathrm{B}^{\mathrm{m}} \mathrm{Y}_{\mathrm{t}}\right)$. Tal procedimento permitirá expressar as séries temporais na forma de polinômios.

Ao aplicar essa transformação em um modelo AR(p) tem-se:

$Y_{t}=\phi_{0}+\phi_{1} B Y_{t}+\phi_{2} B^{2} Y_{t}+\cdots \phi_{p} B^{p} Y_{t}+\epsilon_{t}$

O modelo $\mathrm{AR}(\mathrm{p})$ na forma polinomial torna-se:

$\left(1-\phi_{1} B-\phi_{2} B^{2}-\cdots-\phi_{p} B^{p}\right) Y_{t}=\epsilon_{t}+\phi_{0}$

e o modelo MA(q) na forma polinomial torna-se:

$Y_{t}=\theta_{1}+\left(1-\theta_{1} B-\theta_{2} B^{2}-\cdots-\theta_{q} B^{q}\right) \epsilon_{t}$ 


\subsection{SARIMAX}

O modelo escolhido foi o Sazonal Autorregressivo Integrado e de Médias Móveis com acréscimo de variáveis explicativas regressivas (SARIMAX). O motivo dessa escolha, baseiase nesse modelo que foi feito para tratar com séries temporais, as quais apresentam algumas propriedades como autocorrelação, tendências e sazonalidade. Modelos alternativos foram testados com o uso das ferramentas desenvolvidas por Hernández (2011), todavia os resultados apresentados, aproximaram-se aos do Modelo SARIMAX e, em vista disso não são utilizados nessa tese.

A estrutura do modelo é denominada SARIMA (p, d, q) $(\mathrm{P}, \mathrm{D}, \mathrm{Q})^{\mathrm{m}} \mathrm{x}$, onde:

$\mathrm{m}$ é a periodicidade da sazonalidade no ano;

p: número de valores passados dos parâmetros autorregressivos $\phi$;

d: valor de diferença, utilizado quando a série possui tendência;

q: número de valores defasados dos parâmetros de médias móveis $\theta$;

P: número de valores de parâmetros autorregressivos sazonais $\Phi$;

D: valor de diferença, quando a série sazonal possui tendências sazonais;

Q: número de valores defasados dos parâmetros de médias móveis sazonais $\Theta$;

$\mathrm{B}$ : operador de atraso (backshift), onde $\mathrm{BY} \mathrm{t}_{\mathrm{t}}=\mathrm{Y}_{\mathrm{t}-1 ; \mathrm{e}}$

x: valor de variável ou variáveis exógenas utilizadas como variáveis regressivas no modelo.

$$
\begin{gathered}
\underbrace{\left(1-\phi_{1} B-\cdots \phi_{p} B^{p}\right)}_{A R_{(p)} \text { não sazonal }} \underbrace{\left(1-\Phi_{1} B^{m}-\cdots \Phi_{P} B^{m P}\right)}_{A R_{(P)} \text { sazonal }} \underbrace{\left.\beta-B^{m}\right)^{D}}_{\begin{array}{c}
\text { diferença } \\
\text { não sazonal }
\end{array} \underbrace{(1-\mathrm{B})^{d}}_{\begin{array}{c}
\text { diferença } \\
\text { sazonal }
\end{array}} y_{\text {regressor } X} \underbrace{\beta x_{t}}} \\
\underbrace{\left(1+\theta_{1} B+\cdots \theta_{q} B^{q}\right)}_{M A_{(q)} \text { não sazonal }} \underbrace{\left(1+\Theta_{1} B^{m}+\cdots+\Theta_{Q} B^{m Q}\right)}_{M A_{(Q)} \text { sazonal }} e_{t}
\end{gathered}
$$

Os parâmetros $\phi_{1}, ., \phi_{\mathrm{p}}$ e $\theta_{1}, \ldots \theta_{\mathrm{q}}$ são, respectivamente, autorregressivos de ordem p e de médias móveis de ordem q e os parâmetros $\Phi_{1}, \ldots, \Phi_{\mathrm{P}}$ e $\Theta_{1}, \ldots, \Theta_{\mathrm{Q}}$ são autorregressivos sazonais de ordem $\mathrm{P}$ e de médias móveis sazonais de ordem Q.

Os parâmetros $(1-B)^{d}$ e $\left(1-B^{m}\right)^{\mathrm{D}}$ são, respectivamente, a diferença ordinária e a diferença sazonal.

\footnotetext{
94 Fonte: Adaptado de (HYNDMAN, R.J. and ATHANASOPOULOS, 2013) Acesso em 19/01/2016 url:
} https://www.otexts.org/fpp/8/9, 
$\beta \mathrm{x}_{\mathrm{t}}$ representa a variável ou variáveis exógenas acrescidas no modelo.

O modelo geral pode ser apresentado como (BOX; JENKINS; REINSEL, 2008 ; HYNDMAN, R.J. \& ATHANASOPOULOS, 2013):

$\phi_{p}(B) \Phi_{P}\left(B^{m}\right)(1-B)^{d}\left(1-B^{m}\right)^{D} Z_{t}=\theta_{0}+\theta_{q}(B) \Theta_{Q}\left(B^{m}\right) \beta x_{t} e_{t}$

As suposições sobre o modelo sazonal consistem em apresentar média zero, variância constante, erros $e_{t}$ aleatórios, independentes e igualmente distribuídos (i.i.d.) A identificação das ordens dos parâmetros, estimação de seus valores e suas predições são análogas às do modelo ARIMA (WEI, 2006; PANKRATZ, 1991; BOX; JENKINS; REINSEL, 2008; COWPERTWAIT \& METCALFE, 2009; SHUMWAY \& STOFFER, 2011), e tendo em vista sua realização pelas funções Arima() e auto.arima() do pacote estatístico R.

As etapas para elaboração do modelo são especificação, identificação, estimação e verificação ou diagnóstico demonstradas, através de sua aplicação sobre as variáveias macroclimáticas e a previsão das ENA das quatro regiões, no Capítulo 7.

\subsubsection{Especificação}

Nessa etapa, são definidas as variáveis a serem utilizadas no modelo, o conjunto de dados para sua identificação e estimação e outro para verificação e diagnóstico. Em Hyndman \& Athanasopoulos (2013), os conjuntos de dados para estimação e identificação foram denominados dados para treinamento e os conjuntos de dados para verificação ou diagnóstico foram denominados dados para testes. Outras referências chamam o conjunto de dados de treinamento de variáveis "in sample" e as variáveis de teste conjunto de variáveis "out of sample 95 (TASHMAN, 2000).

Para esse trabalho, o uso das variáveis climáticas energia é aplicado no Capítulo 7, seções 7.1.1, 7.2.1, 7.3.1 e 7.4.1, somado às variáveis de energia.

\subsubsection{Identificação}

A etapa de identificação tem como objetivo determinar a ordem dos parâmetros do modelo. Apresenta uma descrição visual dos critérios para identificar a ordem dos parâmetros (BROOKS, 2002), pelo o uso de gráficos da Função de Autocorrelação (FAC) e Função de Autocorrelação Parcial (FACP). Nesse exemplo (Figura 5-1), os valores da ordem de $\phi$ e de $\theta$ são iguais a 1. Em modelos autorregressivos, AR(p) puros, o gráfico da FAC apresenta suas

\footnotetext{
${ }^{95}$ Acesso em 15/01/2016: http://people.duke.edu/ rnau/three.htm
} 
barras com um decaimento exponencialmente ou uma curva senoidal amortecida. O padrão exato depende do valor do sinal de $\phi 1, \ldots, \phi$ p. Já, no gráfico da FACP, apresenta-se as barras com defasagens de 1 até p, depois corta para zero.

Para ordens maiores, os padrões aumentam e sua interpretação se torna mais complicada, o que depende da experiência do analista para identificar a ordem p e os sinais dos parâmetros AR.

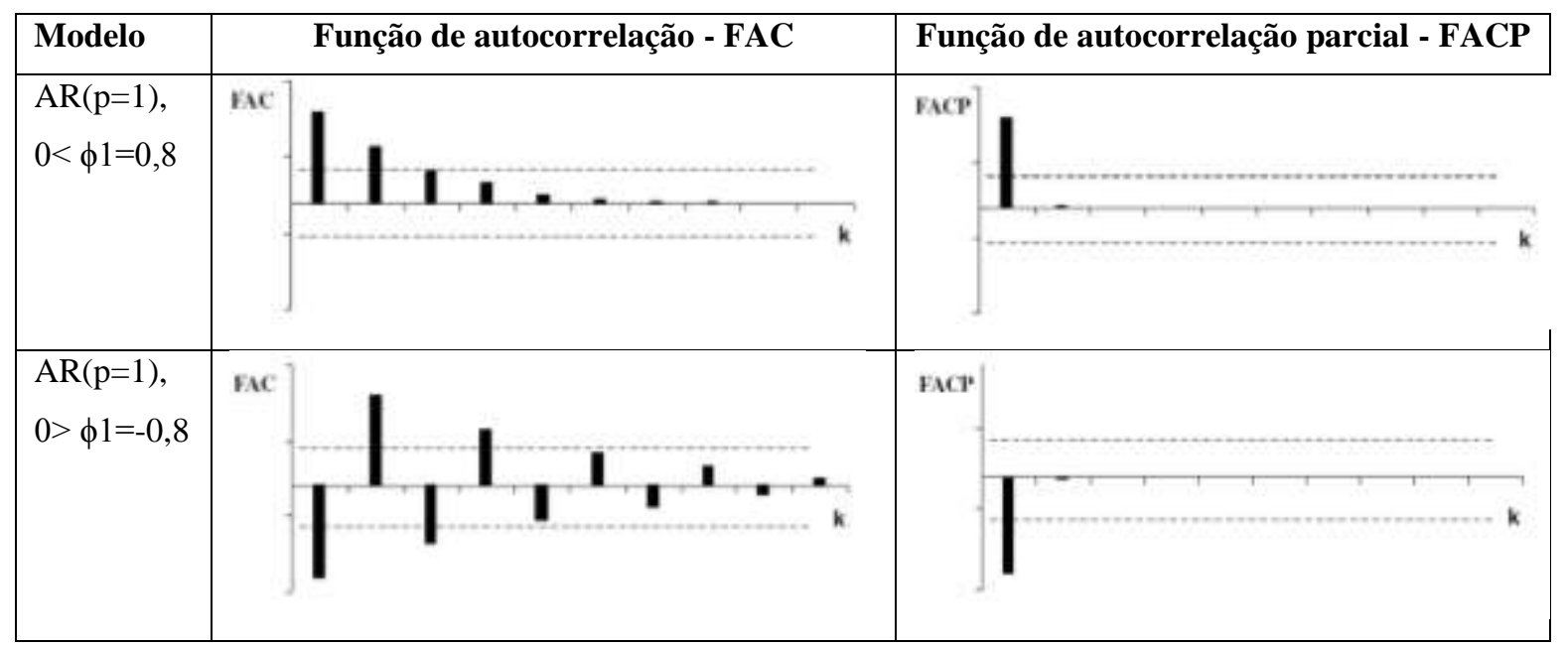

Figura 5-1 Critérios para identificação da ordem dos parâmetros dos modelos AR (BOX \& JENKINS, 2008)

Para a ordem $\mathrm{p}=2$, na Figura 5-2, revelam-se diferentes configurações dos correlogramas FAC e FACP que determinam a ordem, os valores e seus sinais $\phi 1$ e $\phi 2$ do modelo $\operatorname{AR}(2)$. Quatro exemplos teóricos de ACFs e PACFs para $\operatorname{AR}(2)$ são: a) $\phi 1=0,5, \phi 2=0,3$. b) $\phi 1=$ $0,5, \phi 2=0,3$. c) $\phi 1=-1,2, \phi 2=-0,7$. d) $\phi 1=1,3, \phi 2=0,7$; (PANKRATZ, 1999, 42) 
(a) $\mathrm{AR}(2), \phi_{1}=0.5, \phi_{2}=0.3$

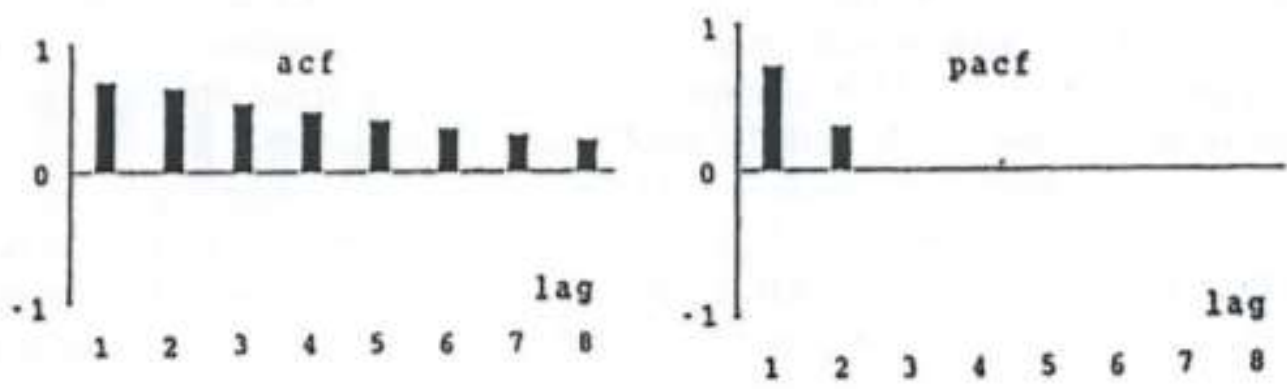

(b) $\operatorname{AR}(2), \phi_{1}=-0.5, \phi_{2}=0.3$

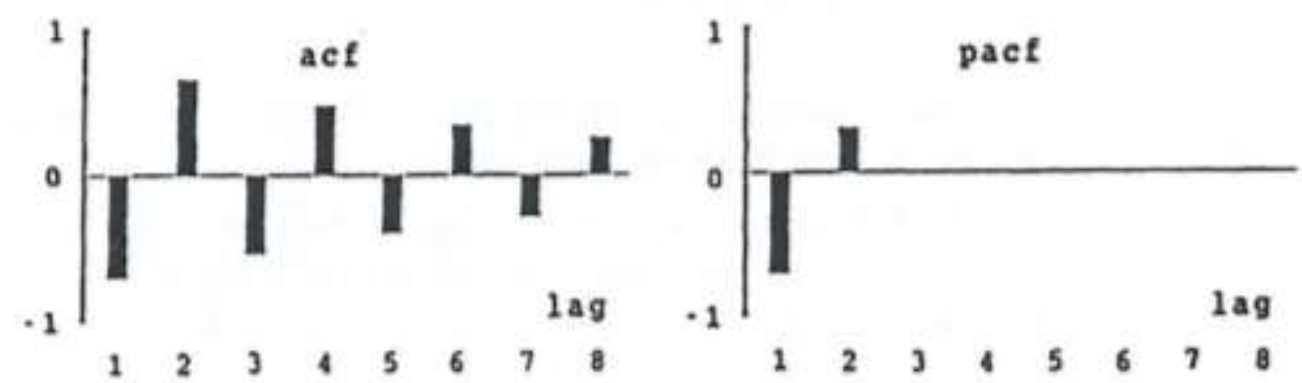

(c) $A R(2), \phi_{1}=-1.2, \phi_{2}=-0.7$

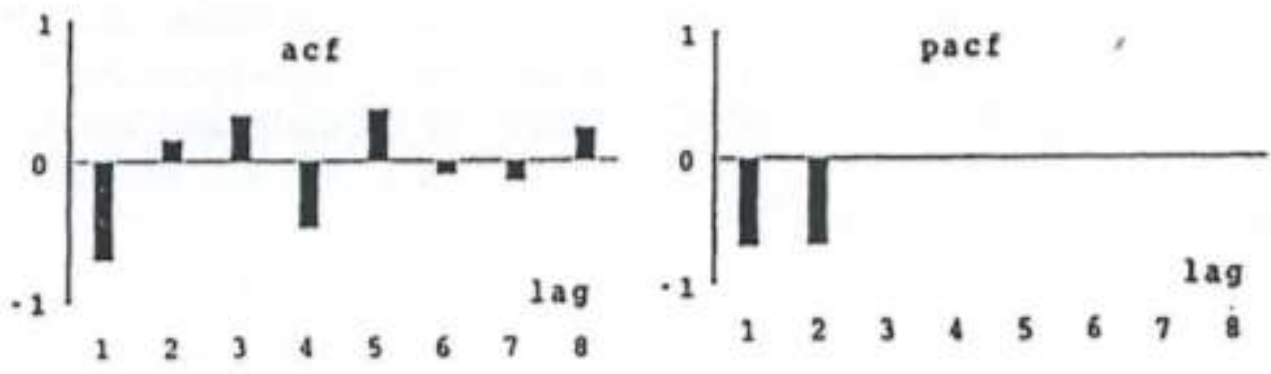

(d) $\operatorname{Ar}(2), \phi_{1}=1.3, \phi_{2}=-0.7$

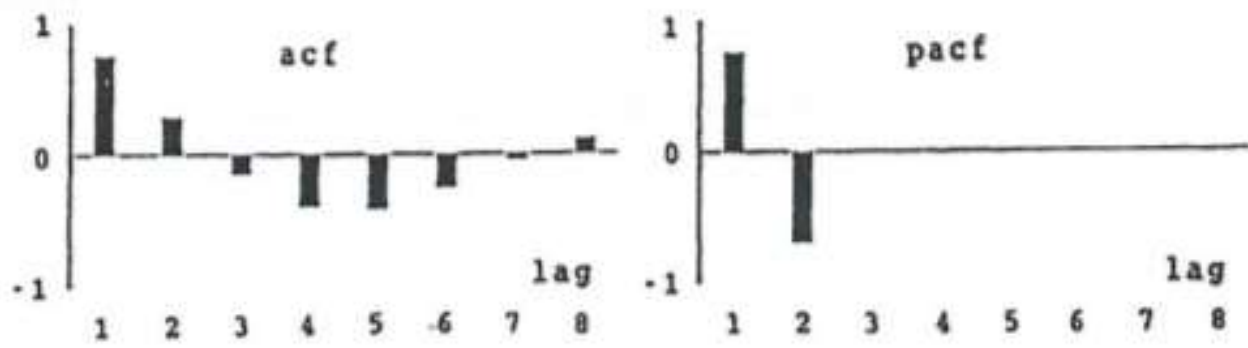

Figura 5-2 Critérios para identificação da ordem dos parâmetros dos modelos. Quatro exemplos teóricos de ACFs e PACFs para AR(2) a) $\phi 1=0,5, \phi 2=0,3$. b) $\phi 1=-0,5, \phi 2=0,3$. c) $\phi 1=-1,2, \phi 2=-0,7$. d) $\phi 1=1,3, \phi 2=0,7$, (PANKRATZ, 1999, 42) 
Nos modelos médias móveis MA(q) puros, o gráfico da FAC apresenta as barras nas defasagens de 1 até q e posteriormente corta para zero. O gráfico da FACP decai exponencialmente ou apresenta uma curva senoidal amortecida. $\mathrm{O}$ padrão exato depende do valor e sinal de $\theta_{1}, \ldots \theta_{\mathrm{q}}$, (Figura 5-3).

\begin{tabular}{|l|c|c|c|}
\hline Modelo & $\begin{array}{c}\text { Função de autocorrelação - } \\
\text { FAC }\end{array}$ & $\begin{array}{c}\text { Função de autocorrelação parcial - } \\
\text { FACP }\end{array}$ \\
\hline $\begin{array}{l}\text { MA(q=1) } \\
0>\theta_{1}=-0,8\end{array}$ & & & \\
\hline $\begin{array}{l}\text { MA(q=1) } \\
0<\theta_{1}=0,8\end{array}$ & & & \\
\hline
\end{tabular}

Figura 5-3 Critérios para identificação da ordem dos parâmetros dos modelos MA (BOX \& JENKINS, 2008)

Para modelos MA com ordem q =2, na Figura 5-4, apresentam-se diferentes configurações dos correlogramas FAC e FACP que determinam a ordem, os valores e os sinais de $\theta 1$ e $\theta 2$. Quatro exemplos teóricos de ACFs e PACFs para MA(2) são:a) $\theta 1=0,5, \theta 2=0,3$. b) $\theta 1=0,8$, $\theta 2=0,5$. c) $\theta 1=-0,8, \theta 2=-0,5$. d) $\theta 1=0,8, \theta 2=-0,5$, (PANKRATZ, 1991, 45).
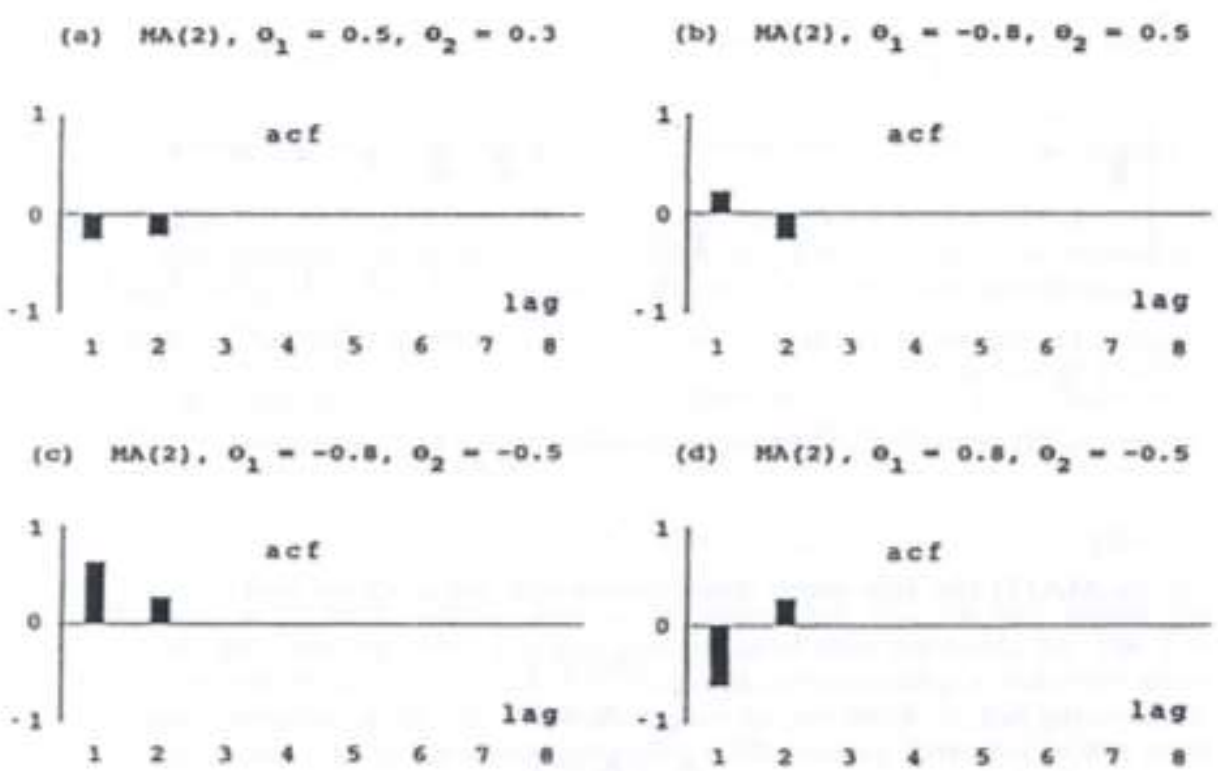

Figura 5-4 Critérios para identificação da ordem dos parâmetros dos modelos. Quatro exemplos teóricos de ACFs e PACFs para MA(2) a) $\theta 1=0,5, \theta 2=0,3$. b) $\theta 1=0,8, \theta 2=0,5$. c) $\theta 1=-0,8, \theta 2=-0,5$. d) $\theta 1=0,8, \theta 2=-0,5$, (PANKRATZ, 1991, 45)

Os modelos do tipo autorregressivos e de médias móveis - ARMA(p,q) apresentam queda gradual das barras bem definidas em ambos os gráficos de correlogramas. O modelo autorregressivo, integrado e de médias móveis - ARIMA(p,d,q) assemelhasse ao modelo 
ARMA com a preocupação da média da série seja constante, o que é alcançado com a aplicação de diferenças através do parâmetro d com o acompanhamento do critério AIC. O modelo que apresenta menor AIC deve ser escolhido. Maiores detalhes sobre AIC são apresentados no Apêndice, seção 1.1.1.1APÊNDICE B.3 Critério de Informação de Akaike (AIC), p. 316, (AKAIKE, 1974, 1998).

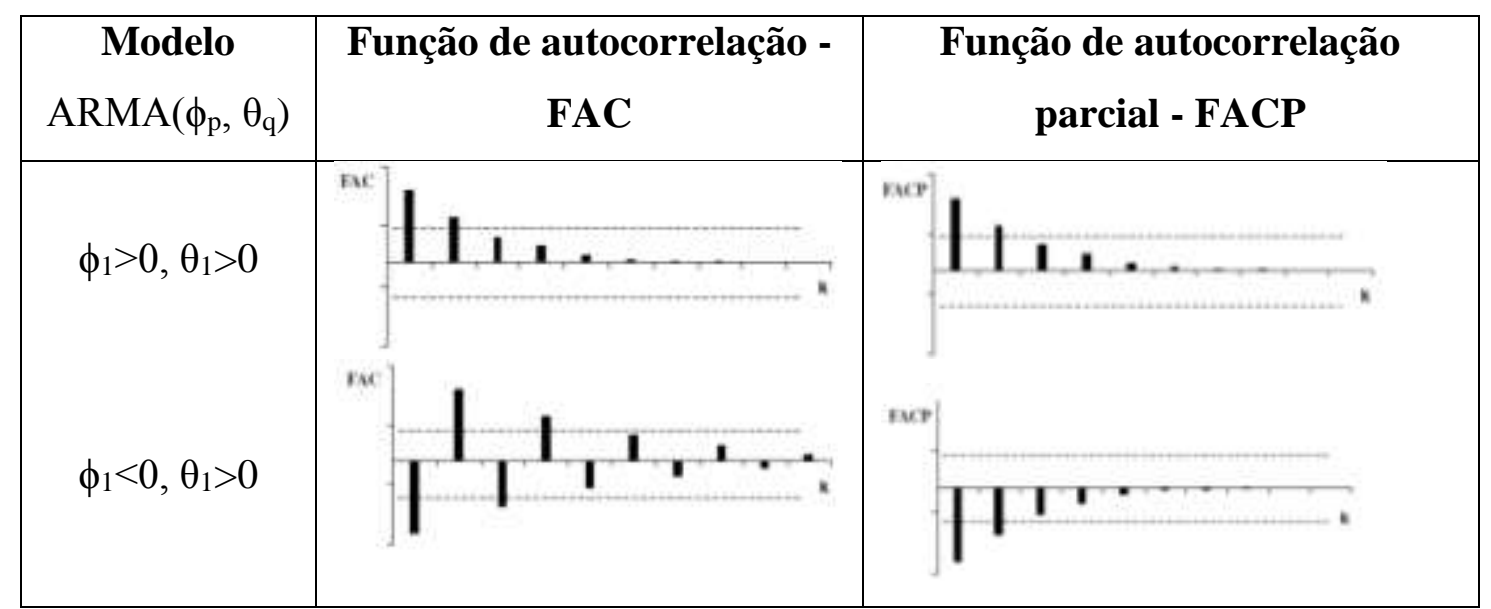

Figura 5-5 Critérios para identificação da ordem dos parâmetros dos modelos ARMA (BOX \& JENKINS, 2008)

No modelo tipo $\operatorname{SARIMA}(\mathrm{p}, \mathrm{d}, \mathrm{q})(\mathrm{P}, \mathrm{D}, \mathrm{Q})^{\mathrm{m}}$, a avaliação gráfica dos correlogramas é semelhante à avaliação dos gráficos do modelo ARIMA, porém com a aplicação dos parâmetros $\mathrm{P}, \mathrm{D}, \mathrm{Q}$ e um parâmetro $\mathrm{m}$ de frequência que pode ser igual a 12 meses, pois depende da frequência dos dados da série histórica dentro de um ano. Acompanha o critério AIC e outros critérios como AICc e BIC. Utilizando-se esses critérios de seleção, é possível estimar diversos modelos concorrentes que passaram por uma seleção onde será escolhido o modelo com menor valor para o critério de informação. Esses critérios são descritos em detalhe no Apêndice1.1.1.1APÊNDICE B.3 Critério de Informação de Akaike (AIC), p. 316. Na Tabela 5-1, apresentam-se padrões apontados na apresentação dos correlogramas de ACF e PACF de acordo com o processo ARIMA correspondente (YAFFEE, R.e MCGEE, 2000). Os correlogramas para sistemas puros AR ou MA são suficientes para identificar a ordem dos parâmetros do processo. Já, para modelos de processo ARMA ou ARIMA, os correlogramas para as ordens maiores que 1 apresentam complicação na interpretação. Uma opção para esse tipo de problema é o uso da função eacf ${ }^{96}$, encontrada no pacote estatístico R.

\footnotetext{
${ }^{96}$ Função de autocorrelação estendida
} 
Tabela 5-1 Critérios para identificação da ordem dos parâmetros dos modelos ARIMA (YAFFEE, R.e MCGEE, 2000)

\begin{tabular}{|c|c|c|c|}
\hline \multicolumn{2}{|l|}{ Processo } & $\mathrm{ACF}$ & \multirow{2}{*}{$\begin{array}{l}\text { PACF } \\
\begin{array}{l}\text { Nenhuma } \\
\text { significativa }\end{array}\end{array}$} \\
\hline Ruído Branco & $\operatorname{ARIMA}(0,0,0)$ & $\begin{array}{l}\text { Nenhuma barra } \\
\text { significativa }\end{array}$ & \\
\hline $\begin{array}{l}\text { Processo } \\
\text { Integrado }\end{array}$ & $\operatorname{ARIMA}(0,1,0) \mathrm{d}=1$ & Atenuação lenta & $\begin{array}{l}1 \text { barra na ordem da } \\
\text { diferenciação }\end{array}$ \\
\hline \multicolumn{4}{|c|}{ Processo autorregressivo } \\
\hline & $\operatorname{ARIMA}(1,0,0) \phi 1>0$ & $\begin{array}{l}\text { Decaimento } \\
\text { exponencial, barras } \\
\text { positivas }\end{array}$ & $\begin{array}{l}1 \text { barra positiva na } \\
\text { posição } 1\end{array}$ \\
\hline & $\operatorname{ARIMA}(1,0,0) \phi 1<0$ & $\begin{array}{l}\text { Decaimento } \\
\text { oscilatório, começa } \\
\text { com barra negativa }\end{array}$ & $\begin{array}{l}1 \text { barra negativa na } \\
\text { posição } 1\end{array}$ \\
\hline & $\operatorname{ARIMA}(2,0,0) \phi 1, \phi 2>0$ & $\begin{array}{l}\text { Decaimento } \\
\text { exponencial, barras } \\
\text { positivas }\end{array}$ & $\begin{array}{l}2 \text { barras positivas na } \\
\text { posição } 1 \text { e } 2\end{array}$ \\
\hline & $\operatorname{ARIMA}(2,0,0) \phi 1<0, \phi 2>0$ & $\begin{array}{l}\text { Decaimento } \\
\text { oscilatório } \\
\text { exponencial }\end{array}$ & $\begin{array}{l}1 \text { barra negativa na } \\
\text { posição } 1,1 \text { barra } \\
\text { positiva na posição } 2\end{array}$ \\
\hline \multicolumn{4}{|c|}{ Processo de Médias Móveis } \\
\hline & $\operatorname{ARIMA}(0,0,1) \theta 1>0$ & $\begin{array}{l}1 \text { barra negativa na } \\
\text { posição } 1\end{array}$ & $\begin{array}{l}\text { Decaimento } \\
\text { exponencial, barras } \\
\text { negativas }\end{array}$ \\
\hline & $\operatorname{ARIMA}(0,0,1) \theta 1<0$ & $\begin{array}{l}1 \text { barra positiva na } \\
\text { posição } 1\end{array}$ & $\begin{array}{l}\text { Decaimento } \\
\text { exponencial, barras } \\
\text { positivas e negativas }\end{array}$ \\
\hline & $\operatorname{ARIMA}(0,0,2) \theta 1, \theta 2>0$ & $\begin{array}{l}2 \text { barras negativas na } \\
\text { posição } 1 \text { e } 2\end{array}$ & $\begin{array}{l}\text { Decaimento } \\
\text { exponencial, barras } \\
\text { negativas }\end{array}$ \\
\hline & $\operatorname{ARIMA}(0,0,2) \theta 1, \theta 2<0$ & $\begin{array}{l}2 \text { barras positivas na } \\
\text { posição } 1 \text { e } 2\end{array}$ & $\begin{array}{l}\text { Decaimento } \\
\text { oscilatório com } \\
\text { barras positivas e } \\
\text { negativas }\end{array}$ \\
\hline \multicolumn{4}{|c|}{ Processo misturado } \\
\hline & $\operatorname{ARIMA}(1,0,1) \phi 1>0, \phi 2>0$ & $\begin{array}{l}\text { Decaimento } \\
\text { exponencial, barras } \\
\text { positivas }\end{array}$ & $\begin{array}{l}\text { Decaimento } \\
\text { exponencial, barras } \\
\text { positivas }\end{array}$ \\
\hline & $\operatorname{ARIMA}(1,0,1) \phi 1>0, \phi 2<0$ & $\begin{array}{l}\text { Decaimento } \\
\text { exponencial, barras } \\
\text { positivas }\end{array}$ & $\begin{array}{l}\text { Decaimento } \\
\text { exponencial, barras } \\
\text { positivas }\end{array}$ \\
\hline & $\operatorname{ARIMA}(1,0,1) \phi 1<0, \phi 2>0$ & $\begin{array}{l}\text { Decaimento } \\
\text { oscilatório }\end{array}$ & $\begin{array}{l}\text { Decaimento } \\
\text { exponencial, barras } \\
\text { negativas }\end{array}$ \\
\hline & $\operatorname{ARIMA}(1,0,1) \phi 1<0, \phi 2<0$ & $\begin{array}{l}\text { Decaimento } \\
\text { oscilatório com } \\
\text { barras positivas e } \\
\text { negativas }\end{array}$ & $\begin{array}{l}\text { Decaimento } \\
\text { oscilatório com } \\
\text { barras positivas e } \\
\text { negativas }\end{array}$ \\
\hline
\end{tabular}

Em Wei $(2008,109)$ também apresenta-se um resumo para identificar o processo estacionário conforme as características teóricas das funções de ACF e PACF conforme a Tabela 5-2. 
Tabela 5-2 Resumo para identificar processo estacionário conforme as funções ACF e PACF

\begin{tabular}{|l|l|l|}
\hline Processo & ACF & PACF \\
\hline AR(p) & $\begin{array}{l}\text { Decaimento das barras como uma } \\
\text { exponencial ou uma senoidal }\end{array}$ & Corte em zero após o lag $\mathrm{p}$ \\
\hline MA(q) & Corte em zero após o lag $\mathrm{q}$ & $\begin{array}{l}\text { Decaimento das barras como } \\
\text { uma exponencial ou uma } \\
\text { senoidal }\end{array}$ \\
\hline ARMA(p,q) & Corte em zero após o lag(q-p) & Corte em zero após o lag(p - q) \\
\hline
\end{tabular}

A Função de autocorrelação estendida (eaf) é uma ferramenta capaz de identificar a ordem dos parâmetros através da Tabela 5-3, que cruza os parâmetros AR com os parâmetros MA. Sua estrutura matemática é descrita em Wei (2008) e Pankratz (1991).

O comando TSA::eacf() do R para os dados da ENA do Sudeste é apresentado na Tabela 5-3, onde um triângulo formado pelos zeros, indica a posição da ordem do modelo $\operatorname{ARIMA}(2,0,1)$, com limite, na Tabela 5-3, de médias móveis com 13 meses e autorregressivos com 7 meses.

Tabela 5-3 Resultado do comando TSA::eacf() para dados ENA Sudeste 1931-2015 indica ARIMA(2,0,1)

\begin{tabular}{|c|c|c|c|c|c|c|c|c|c|c|c|c|c|c|c|}
\hline & 0 & 1 & 2 & 3 & 4 & 5 & 6 & 7 & 8 & 9 & 10 & 11 & 12 & 13 & MA \\
\hline 0 & $x$ & $x$ & $X$ & $x$ & $X$ & $x$ & $x$ & $x$ & 0 & $x$ & $x$ & $x$ & $x$ & $x$ & \\
\hline 1 & $x$ & $x$ & $X$ & $X$ & $X$ & $x$ & $x$ & $x$ & 0 & $X$ & $x$ & $x$ & $X$ & $x$ & \\
\hline 2 & $x$ & 0 & 0 & 0 & 0 & 0 & 0 & 0 & 0 & 0 & 0 & 0 & 0 & 0 & \\
\hline 3 & $x$ & $x$ & 0 & 0 & 0 & 0 & $x$ & 0 & 0 & 0 & 0 & 0 & $x$ & 0 & \\
\hline 4 & $x$ & $x$ & 0 & 0 & 0 & 0 & 0 & 0 & 0 & 0 & 0 & 0 & $x$ & 0 & \\
\hline 5 & $x$ & $x$ & 0 & $x$ & 0 & 0 & 0 & 0 & 0 & 0 & 0 & 0 & 0 & 0 & \\
\hline 6 & $x$ & $x$ & 0 & 0 & 0 & 0 & 0 & 0 & 0 & 0 & 0 & 0 & 0 & 0 & \\
\hline 7 & $X$ & $X$ & $X$ & $X$ & 0 & 0 & 0 & 0 & 0 & 0 & 0 & 0 & 0 & 0 & \\
\hline AR & & & & & & & & & & & & & & & \\
\hline
\end{tabular}

\subsubsection{Estimação}

Uma vez identificada a ordem dos parâmetros, seus valores são estimados através da aplicação de métodos de máxima verossimilhança ou métodos dos mínimos quadrados ordinários. No R, utiliza-se os comandos Arima ou Sarima para estimação.

\subsubsection{Verificação ou diagnóstico}

Para a verificação ou diagnóstico, faz-se a análise de resíduos. Segundo o esquema de Hyndman \& Athanasopoulos (2013), os gráficos gerados para analisar os resíduos foram: 1) gráfico de dispersão dos resíduos, 2) Gráfico de autororrelação dos resíduos; 3) Gráfico QQPlot e;4) Histograma dos resíduos. 
Resid vs ajust(p-valor McLeod-Li: $<0.0001)$
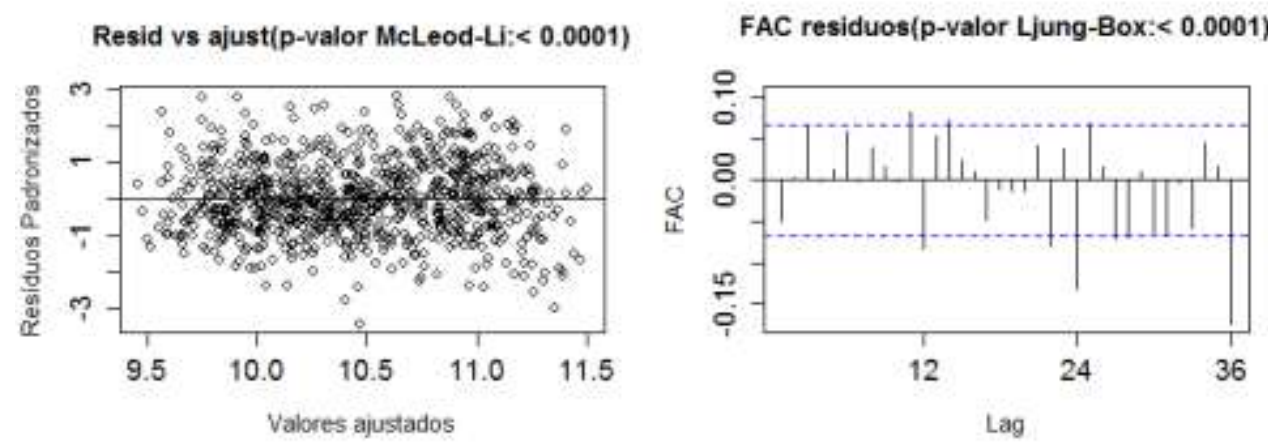

Q-Q plot normal(p-valor shapiro:0.041)

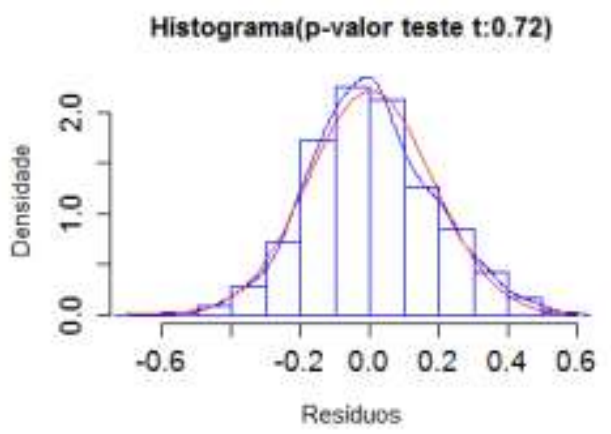

Figura 5-6 Exemplo gráficos para avaliar os resíduos do modelo SARIMA(111300) com AMO e NINO1+2

\subsubsection{Gráfico de dispersão de resíduos contra os valores ajustados}

Verifica a presença de padrões que indica heterocedasticidade, com o p-valor do teste de MclLeod-Li, equivale ao teste de Ljung-Box para os resíduos ao quadrado, obtendo a hipótese nula de que não há efeito de heterocedasticidade nos erros (BOX e PIERCE,1970, LJUNG e BOX,1978, e HARVEY, 1993).

\subsubsection{Gráfico de autocorrelação (FAC) dos resíduos}

Verifica-se a existência de correlações significativamente diferentes de zero. Logo é possível constatar que existem informações não consideradas pelo modelo obtendo a hipótese nula de que os resíduos não são correlacionados;

\subsubsection{Gráfico Q-Q normal}

Verifica-se a distribuição normal dos resíduos, com o p-valor do teste de Shapiro-Wilk obtendo a hipótese nula de uma normalidade na distribuição dos erros (ROYSTON, 1982a; ROYSTON, 1982b; e ROYSTON, 1995);

\subsubsection{Histograma dos resíduos}

Apresenta as densidades estimadas parametricamente, em vermelho, supondo uma distribuição normal dos erros, e não parametricamente, em azul, utilizando estimativa via kernels gaussianos, além do p-valor do teste t Student e obtém-se a hipótese nula de que a média dos erros é igual a zero. 


\section{CAPÍTULO 6}

\section{ANÁLISE GRÁFICA E ESTATÍSTICA PRELIMINAR}

Neste capítulo, são apresentadas algumas das séries históricas, que segunda a literatura, tem influencia nos padrões climáticas e de tempo. As séries foram escolhidas e uma análise preliminar dos dados, para detalhar as características estatísticas dos dados, bem como a necessidade ou não de transformações dos dados com objetivos de seguir as suposições determinadas pela modelagem utilizada. Nas seções 6.1, 6.2 e 6.3 são apresentadas, de forma gráfica e estatística as variáveis macroclimáticas MANCHAS, AMO, NINO1+2, PDO e as variáveis de ENA. Também é feita uma análise de correlação entre as séries na seção 6.5 Matrix para Correlação das Séries históricas, p. 194. Após essa análise preliminar é aplicado o método descrito no CAPÍTULO 5 e os resultados são apresentados no CAPÍTULO 7.

\subsection{Variáveis escolhidas para o estudo}

As variáveis foram normalizadas ${ }^{97}$ com o cálculo de suas anomalias, ou seja, o quanto as variáveis se deviam da médio em número de desvio-padrão; para análise da distribuição estatística e comparação entre séries, uma vez que haja a possibilidade de existência de diferentes grandezas (temperatura, pressão, densidade). As séries, que podem ser importantes para o estudo estão abaixo em representação gráfica Boxplot, na Figura 6-1.

As séries históricas de número de manchas solares, apesar de não apresentarem correlações, foram utilizadas durante a modelagem, para verificar se as séries históricas do Sol podem ter alguma influência na ENA-SE. O mesmo é realizado para AMO e PDO, uma vez que AMO pode ter relação com o deslocamento da ZCIT, fenômeno relacionado com a formação de chuvas nas proximidades da linha do equador, devido ao aumento de temperatura no Atlântico Norte, e a PDO que tem relação com o fenômeno El Niño e os trens de ondas de Rossby, que se formam no Pacífico, e influencia o clima na América do Norte e também na América do Sul.

\footnotetext{
${ }^{97}$ Alguns gráficos apresentam no eixo y valores adimensionais onde as séries são normalizadas para facilitar sua comparação, as medidas x são subtraídas pela média da série histórica completa, $\mu$, e o resultado é divido pelo desvio padrão $\sigma$ das séries históricas completas $[(\mathrm{x}-\mu) / \sigma]$
} 


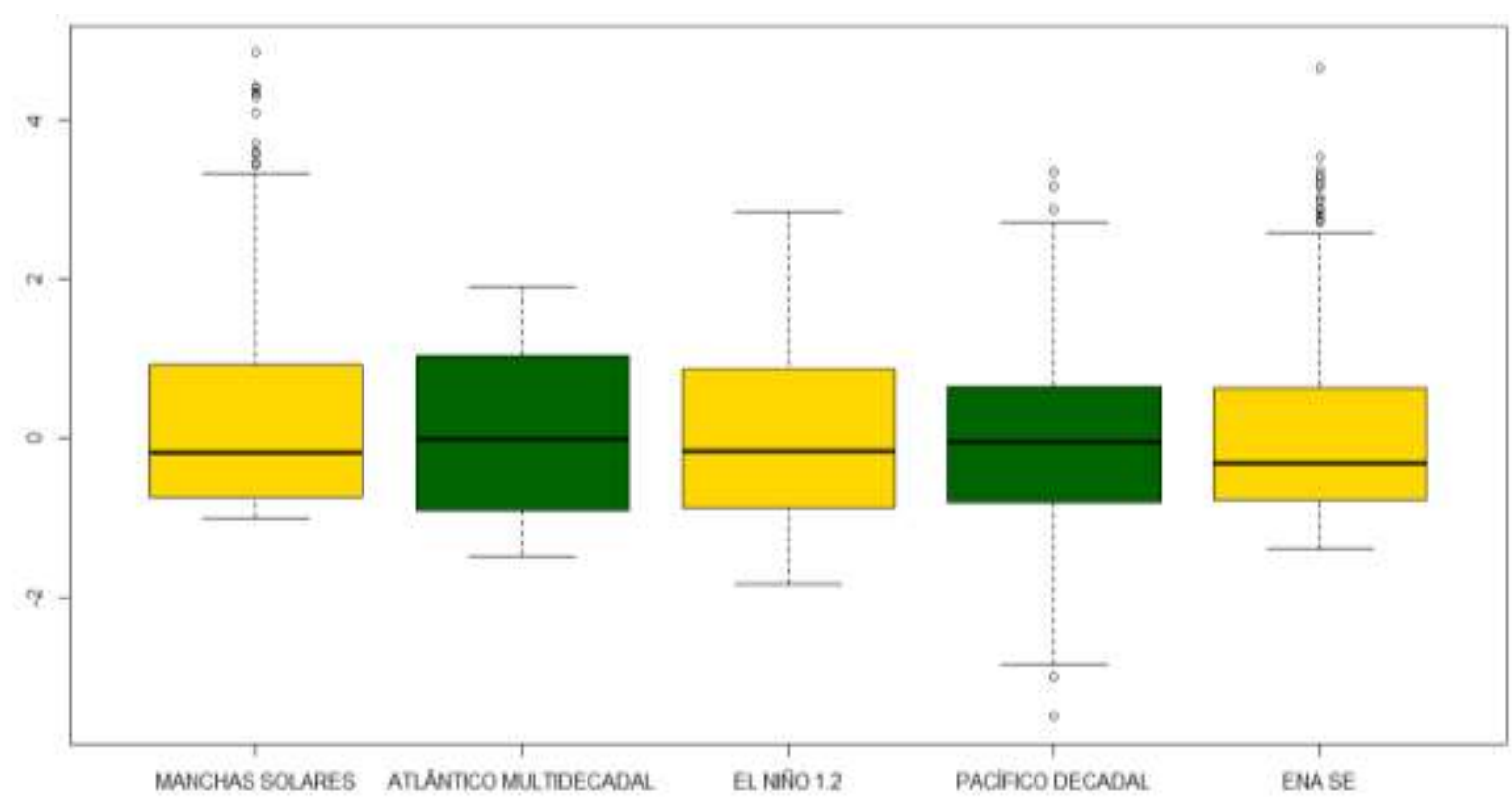

Figura 6-1 - Gráfico Boxplot todas as séries normalizadas com cálculode de anomalias

\subsection{Análise de estacionariedade das variáveis}

Ao visualizar a variabilidade das séries, à primeira vista, não é explícito se todas são estacionárias. Assim, são utilizados testes de estacionariedade para aplicar, se necessário, diferenças nas séries. NaFigura 6-2, são apresentadas as séries históricas de MANCHAS, AMO, NINO1+2, PDO E ENA-SE. Observa-se que as séries apresentam diferentes inícios, e são explicitas as diferenças de período, sazonalidade, variabilidade e tendência. A série dependente ENA-SE, assim como as demais séries de ENA e vazões, possui um registro, comparado com as variáveis dependentes, curto, reproduzindo, assim, a dificuldade de modelagem da regressão entre essas séries.

$\mathrm{Na}$ análise de estacionariedade das variáveis identificou-se que as variáveis independentes MANCHAS e AMO não são estacionárias e, portanto, foram ajustadas com uma diferença. $\mathrm{O}$ PDO e o NINO1+2 apresentaram-se estacionários. As variáveis dependentes ENA-SE não apresentam estacionariedade e são ajustadas com uma diferença. Todas as séries foram normalizadas para facilitar a comparação, a transformação de uma diferenças foi aplicada, e, também, a suavização por wavelets, para verificar os ciclos de diferentes períodos, combinados (Figura 6-3, Figura 6-4, Figura 6-5, Figura 6-6 e Figura 6-7). 


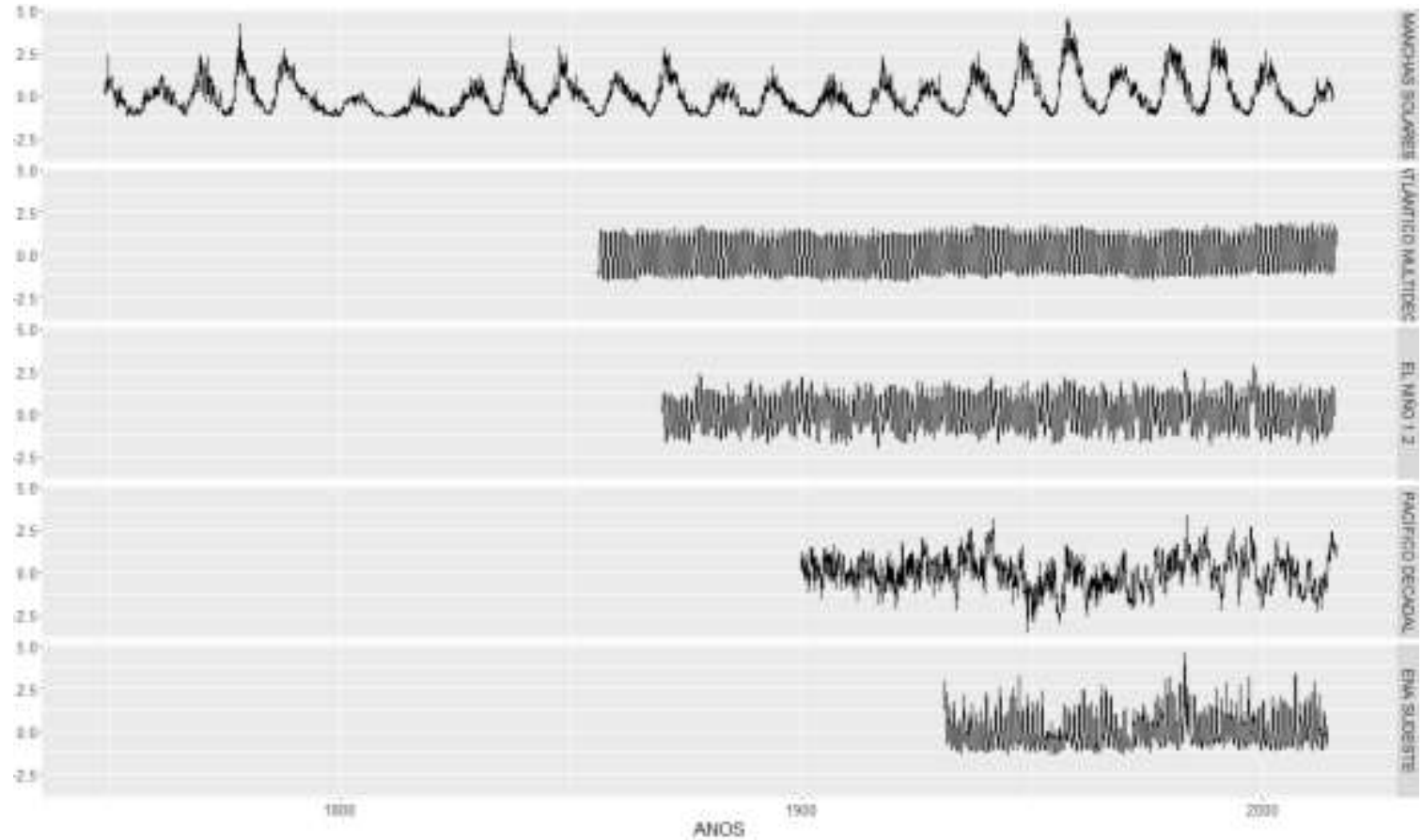

Figura 6-2 - Médias mensais normalizadas: Na ordem: MANCHAS, AMO, PDO, NINO1+2, ENA-SE

Na Figura 6-3, apresentam-se em a) a série histórica de mancha solares (MANCHAS), b) a aplicação de uma diferença que a torna estacionária, e em c) uma suavização da série é realizada, o que mostra quatro picos bem marcados ao longo de toda a série, que indica ciclos multidecadais.

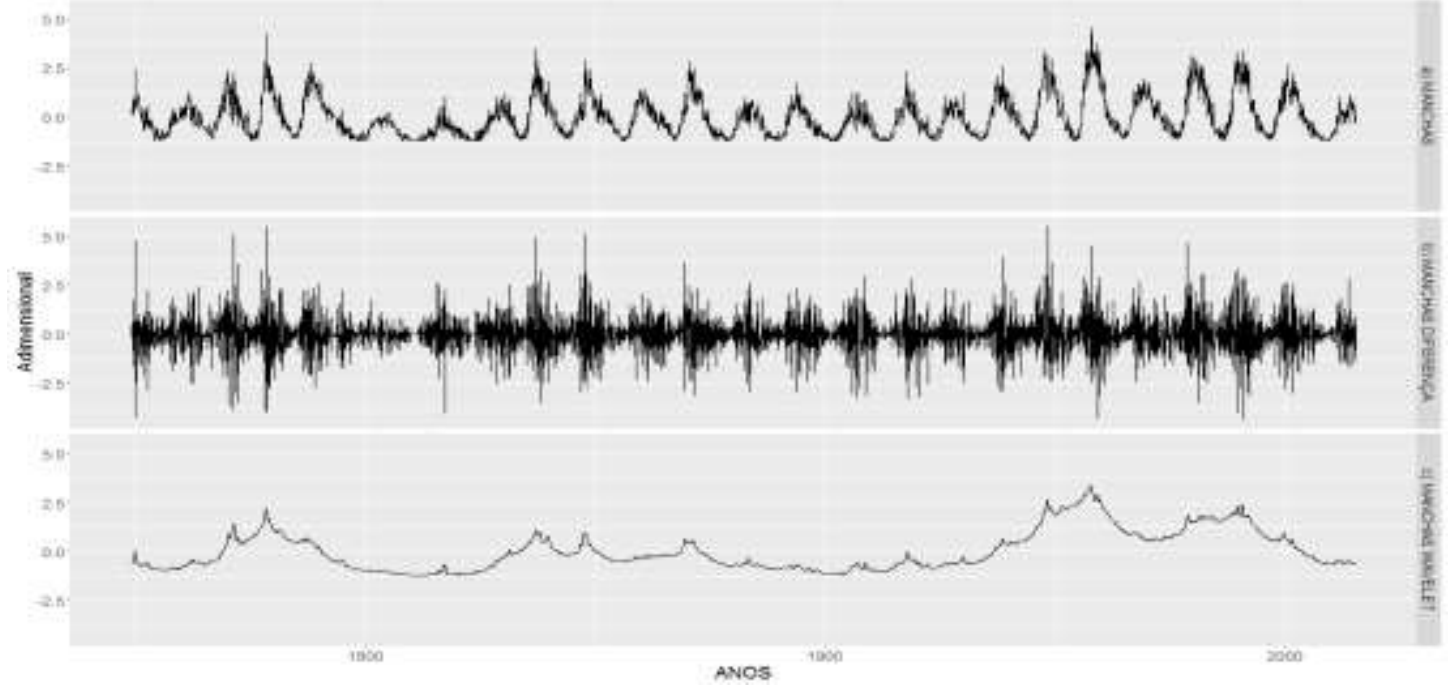

Figura 6-3 - Manchas Solares . a) Médias mensais normalizadas. b) Série com uma diferença. c) Suavização com wavelet.

Na Figura 6-4, apresenta-se em a) a série histórica NINO1+2, b) a existência de aplicação de uma diferença que aqui parece ser desnecessária, pois a série é igual a original, e em c), uma suavização com wavelets da série é realizada o que mostra vários picos, bem marcados, ao longo de toda a série, que indica o comportamento interanual. 

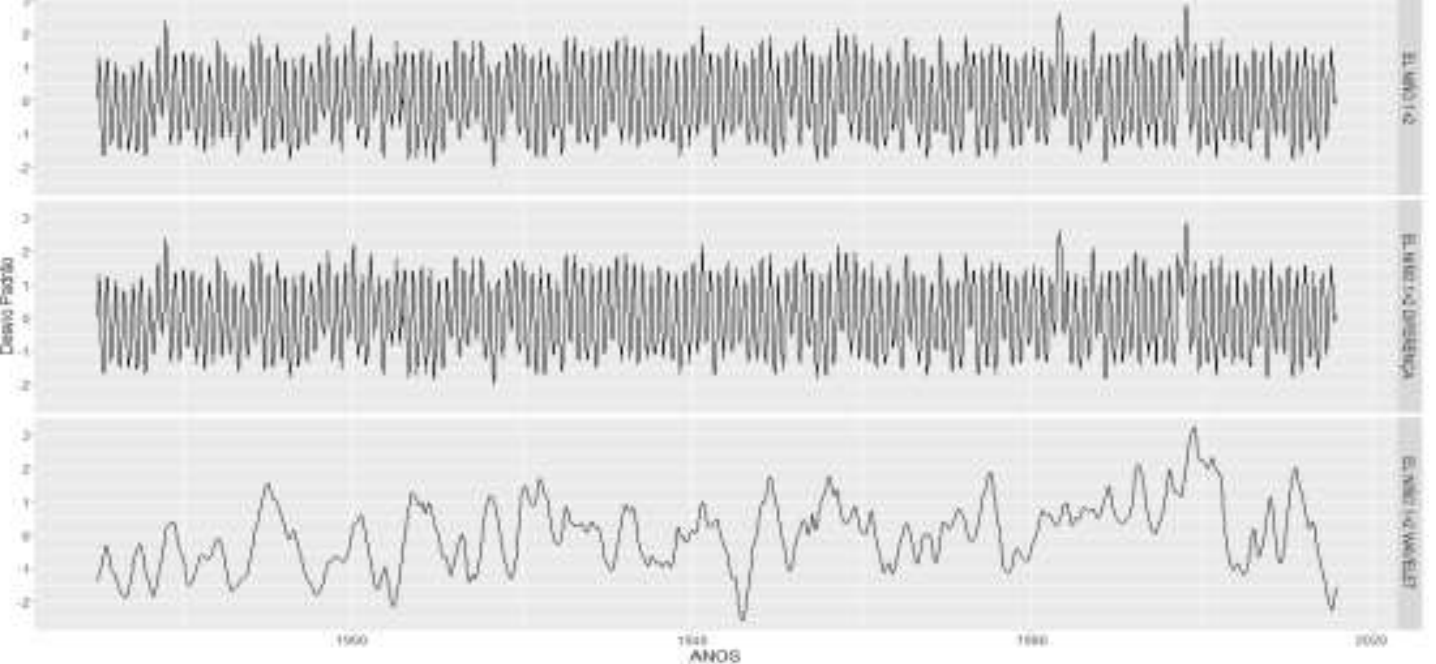

(c)

Figura 6-4 - TSM Região 1+2 do Pacífico - NINO 1+2. a) Médias mensais normalizadas. b) Série com uma diferença. c) Suavização com wavelet.

Na Figura 6-5, apresenta-se em a) a série histórica normalizada de AMO, b) a existência de aplicação de uma diferença que aqui torna a série estacionária c) uma suavização com wavelets da série é realizada o que mostra vários picos bem marcados ao longo de toda a série que indica o comportamento interdecadal.

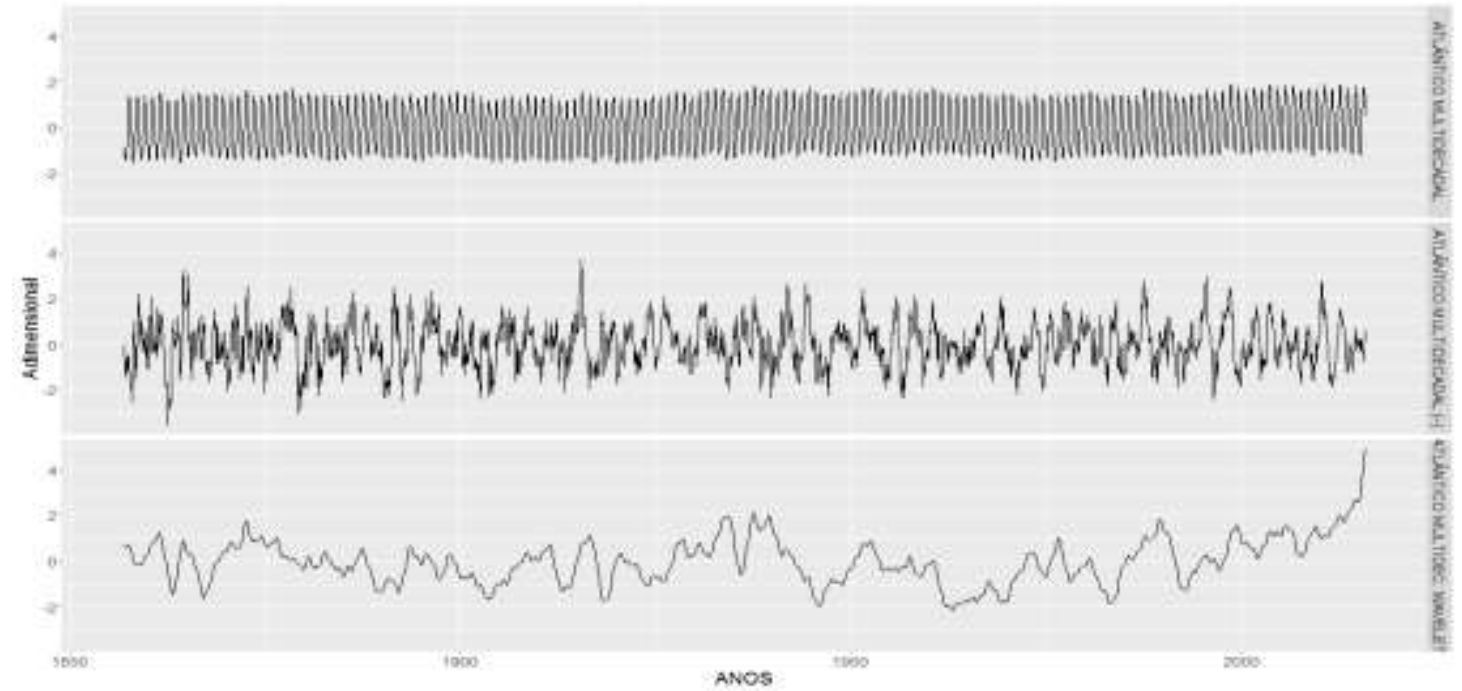

Figura 6-5 - Índice de Oscilação Multidecadal do Atlântico - AMO. a) Médias mensais normalizadas. b) Série com uma diferença. c) Suavização com wavelet.

Na Figura 6-6, apresenta-se em a) a série histórica normalizada de PDO, b) a existência de aplicação de uma diferença que aqui parece ser desnecessária, pois a série é igual a original e, em c), uma suavização com wavelets da série é realizada o que mostra quatro picos bem marcados ao longo de toda a série que indica o comportamento interdecadal. 


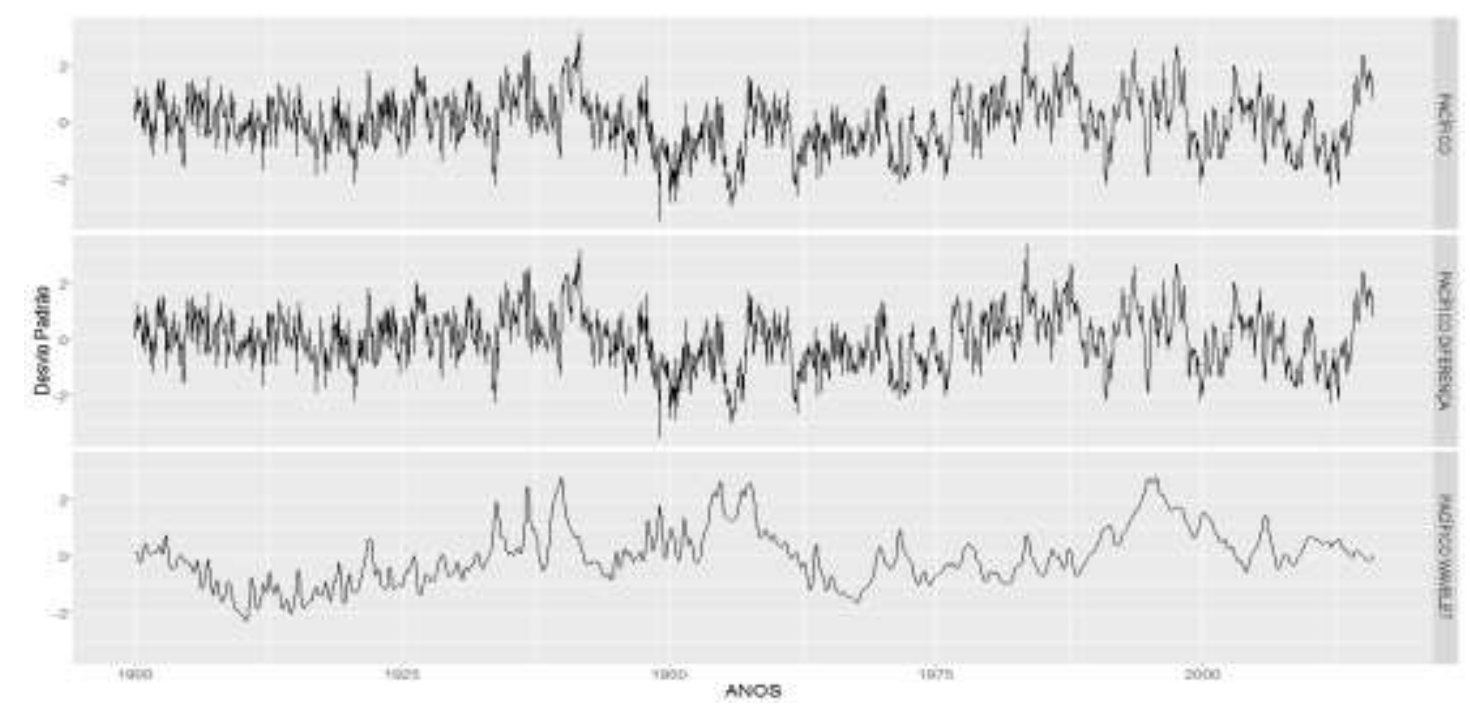

Figura 6-6 - Índice de Oscilação Decadal do Pacífico - PDO. a) Médias mensais normalizadas. b) Série com uma diferença. c) Suavização com wavelet.

\subsection{Variáveis dependentes}

Nessa seção, são apresentadas as variáveis dependentes através de gráficos e informações estatísticas, e não são feitas análises de correlação, os quais encontram-se na seção 6.5 Matrix para Correlação das Séries históricas.

\subsubsection{Fonte de dados deck NEWAVE}

As variáveis dependentes de ENA englobam as regiões Sudeste, Sul, Nordeste e Norte e corresponde a ENA que chega aos reservatórios equivalentes, que corresponde à soma da energia de diferentes bacias, construídos dentro do software NEWAVE. Os Decks ou arquivos de configuração possuem informações utilizadas pelo NEWAVE para executar suas rotinas de otimização com base na PDDE, simulação de Monte Carlo e cortes de Benders. Uma informação que vale destacar é o acréscimo de novas usinas, que entram no cálculo do custo futuro da água, de acordo com custo de oportunidade do uso das aguas armazenadas no futuro e a possibilidade das novas usinas produzirem mais eletricidade.

No arquivo de configuração do NEWAVE, deck de 2014 (NW201412), as novas usinas Belo Monte, Jirau e Santo Antônio apresentam a entrada de novas turbinas ou máquinas (14.455 MW). A usina de Belo Monte tem previsão de entrada inicial em abril de 2016 até dezembro de 2018 de 10.622 MW de potência. A Usina de Jirau já está em operação e faltam mais 2.550 MW de potência, sendo que a previsão da $17^{a}$ turbina ser instalada é janeiro de 2015 e a última em dezembro de 2017. A usina de Santo Antônio já possui 16 turbinas instaladas e a $17^{a}$ foi prevista a instalação para dezembro de 2015 e a última em dezembro de 2017 
totalizando 1.283 MW de potência. A usina de Belo Monte já sofreu vários atrasos por conta de questões judiciais, ambientais e sociais. No deck de 2014 há mais 4.338 MW de potência de diferentes usinas com potencias menores. A maior é a usina de Teles Pires, com previsão de entrada das turbinas em julho e agosto de 2015 e totaliza $1.820 \mathrm{MW}$ de potência. As demais, Baixo Iguaçu (setembro 2016 a janeiro de 2017, 350 MW); São Roque (julho 2016 a outubro de 2016, 135 MW); Colider (junho 2016 a outubro de 216, 300 MW); Santo Antônio do Jari (fevereiro 2015, 123,3 MW); Salto de Apiacas (dezembro 2016, 45 MW); Sinop (março 2018, 400 MW); São Manoel (janeiro de 2018 até setembro 2018, 700 MW); Coaracy Nunes (janeiro 2015, 78 MW); Ferreira Gomes (fevereiro 2015 a abril de 2015, 168 MW); e Cachoeira Caldeira (janeiro 2017 a maio 2017, 219 MW).

\subsubsection{Energia Natural Afluente do Sudeste (ENA-SE)}

Nessa seção, são apresentadas de forma gráfica e descritiva a variável dependente ENA do Sudeste (ENA-SE) corresponde à soma da ENA de todas as bacias que pertencem a região ou submercado Sudeste e tem como unidade MWmédios ${ }^{98}$, Figura 6-7. Seu registro inicia-se em janeiro de 1931 e termina em dezembro de 2014. Posteriormente, são feitas análises de comparação e correlação como já mencionado.

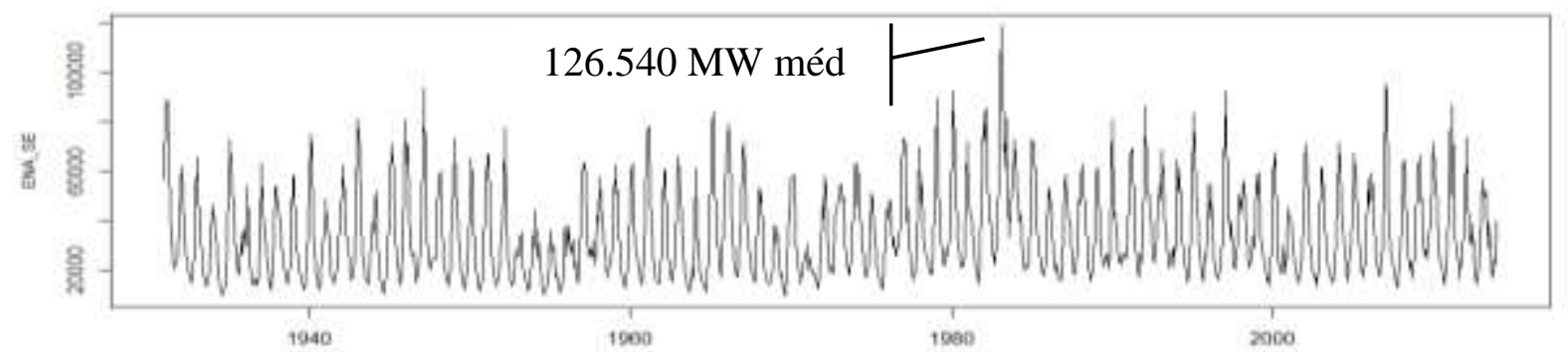

Figura 6-7 - Variável dependente ENA-SE - Médias mensais expressas em MWMédios

Nesse período há uma variação expressiva, que começa de um mínimo de 10.730 MWmédios até 126.500 MWmédios, com mediana em torno de 34.660 MWmédios como apresentado na Figura 6-8, além da distribuição mensal das medianas e quartis no gráfico boxplot dos meses de janeiro a dezembro bem como sua descrição estatística.

\footnotetext{
${ }^{98}$ Megawatts-médios em um mês ou milhões de Watts médios em um mês
} 


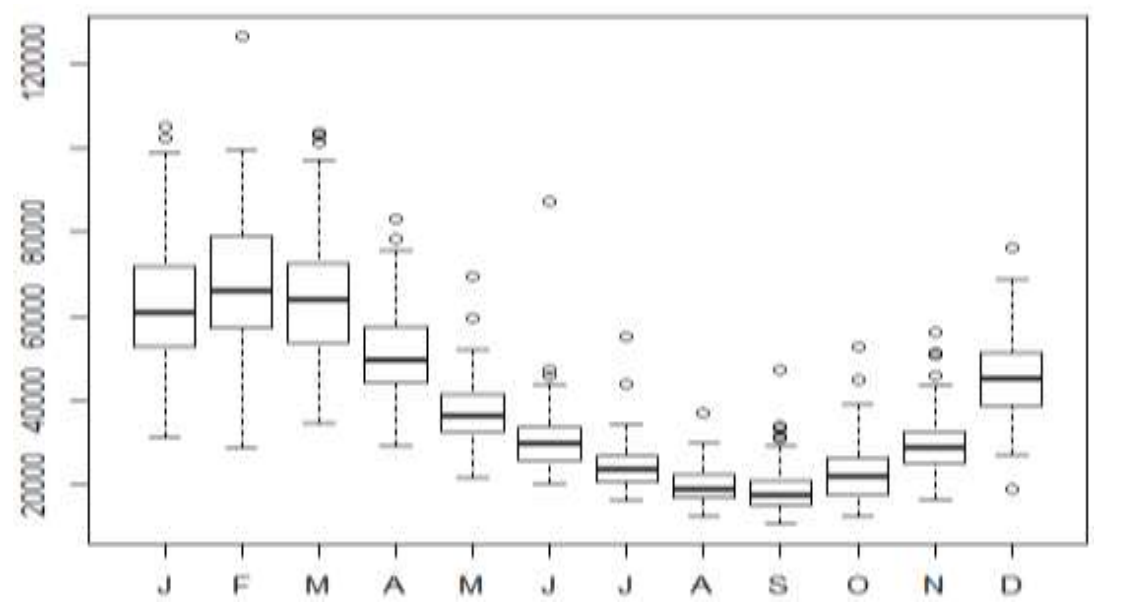

Mínimo: $\quad 10.730$

$1^{\circ}$. quartil: $\quad 23.440$

Mediana: $\quad 34.660$

Média: $\quad 39.680$

$3^{\circ}$. quartil: $\quad 53.510$

Máximo: $\quad 126.540$

Unidade: $\quad$ MW Médios

Figura 6-8 Boxplot ENA SE por mês e Descrição Estatística

Na Figura 6-9, apresentam-se três gráficos da ENA-SE, em a) apresenta-se uma série normalizada, b) ${ }^{99}$ apresenta-se a aplicação de uma diferença que, aparentemente, retira as tendências locais e c) apresenta-se suavização da série com a aplicação de uma transformada wavelet. A transformada wavelet mostra a magnitude dos dados, dentro de ciclos entre 1 e 32 anos, com IC de 95\%, e a variância combinada dos diferentes ciclos é represetanda.

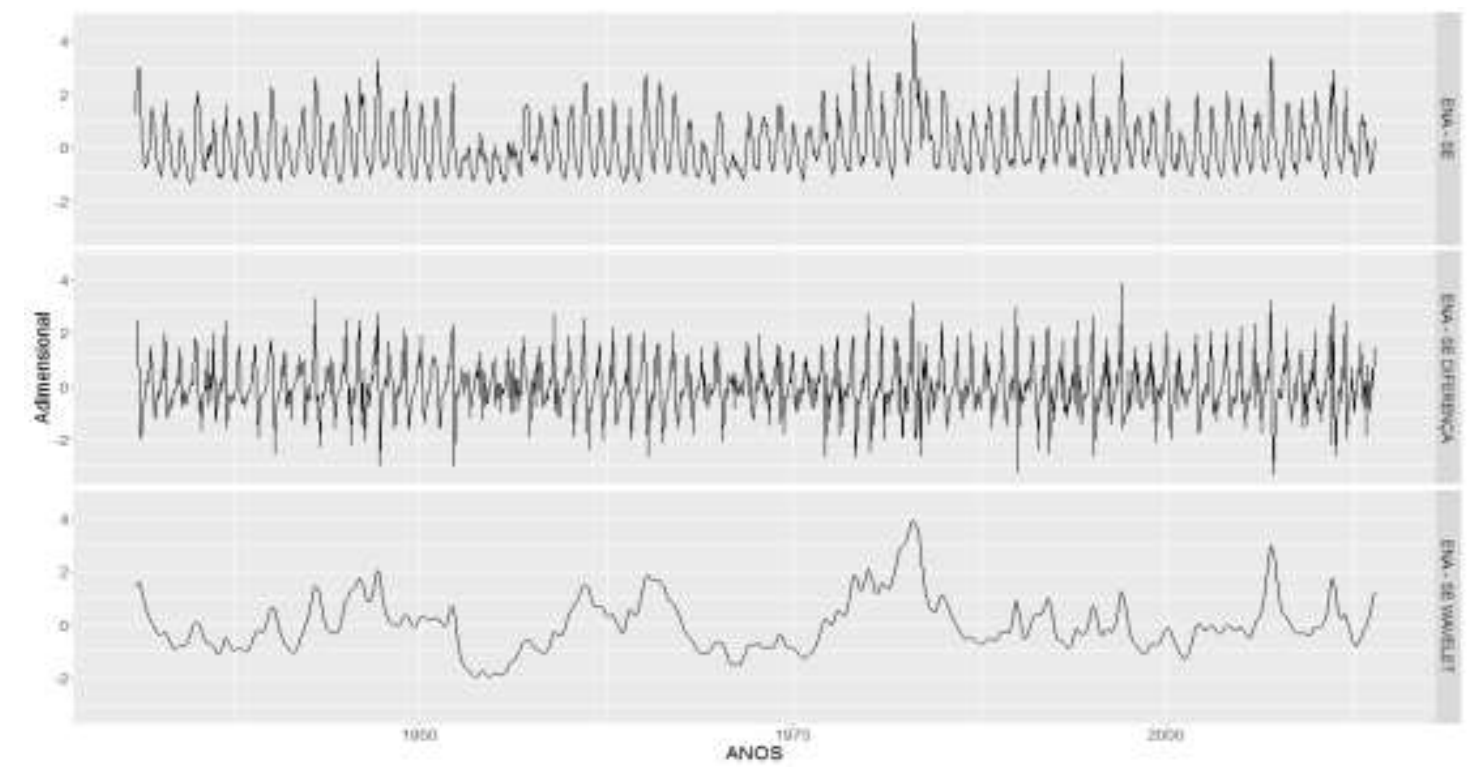

Figura 6-9- Submercado do Sudeste - ENA-SE - Médias mensais a) normalizadas, b) com uma diferença sobre a série normalizada e c) suavizada com wavelets

\footnotetext{
${ }^{99}$ Apesar das séries temporais geofísicas não são estacionárias, para o período de 1931 a 2014, é necessário aplicar a diferença para atender as suposições determinadas no modelo SARIMAX e tem o único objetivo de eliminar as tendêndias, e tornar a média da série histórica constante. Há maiores detalhes na seção 5.1.1 Diferenciação, p. 248.
} 
Os máximos anuais da ENA-SE são apresentadas na Figura 6-10. Observa-se um pico em 1983, com quase cinco desvios padrões acima da média, enquanto a maior parte dos demais pontos situa-se no intervalo $[-2 \sigma ;+2 \sigma]$ ( $\sigma$ é o desvio padrão). Esse pico explica-se pela a grande quantidade de chuvas devido ao fenômeno de ENOS muito forte que ocorreu entre 82 e 83. Posteriormente será abordado estes efeitos com mais detalhes, através da análise de correlação.

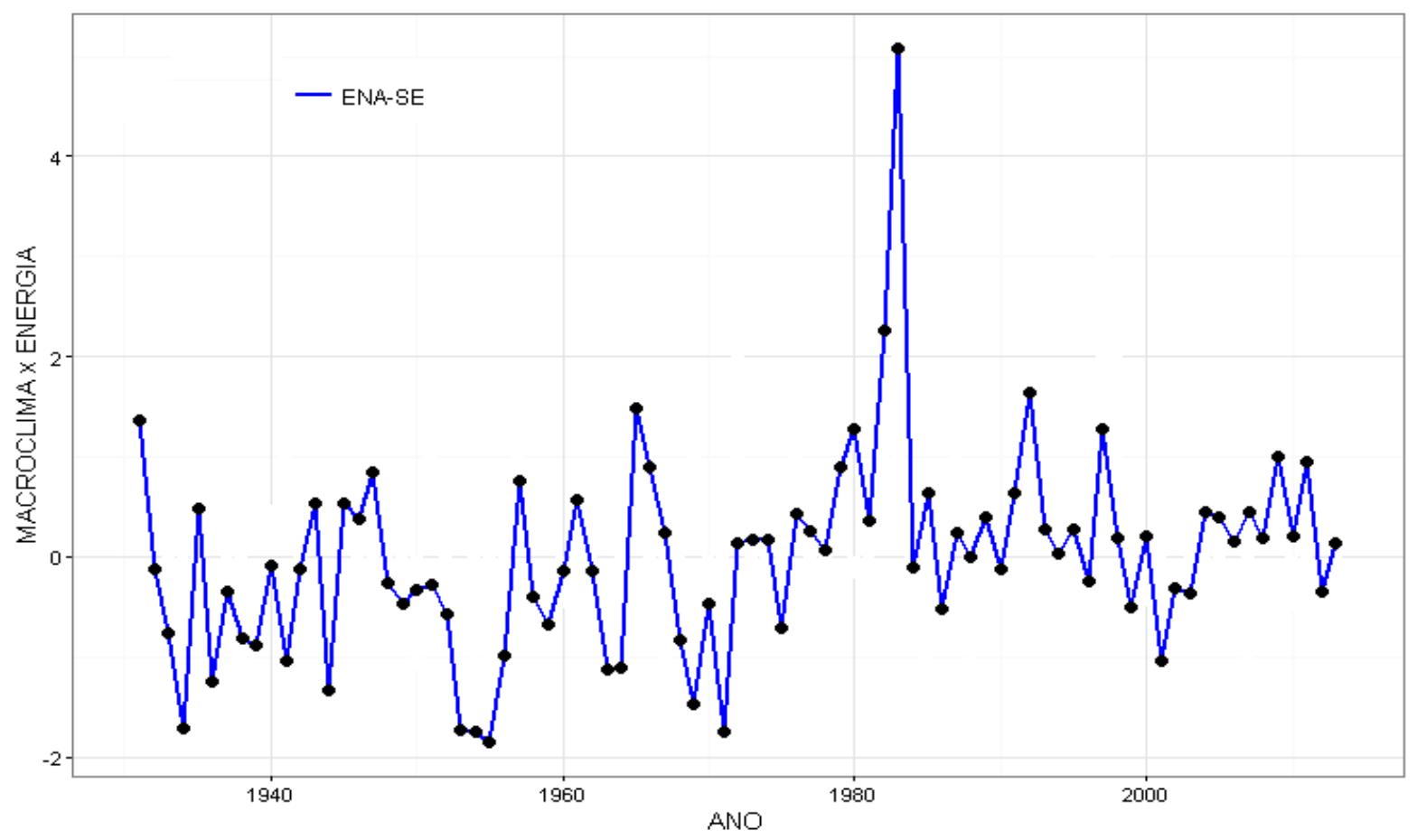

Figura 6-10 - Variável dependente ENA-SE Máximos Anuais normalizadoss MWmédios

\subsubsection{Energia Natural Afluente do Sul (ENA-S)}

A variável dependente ENA-S corresponde à soma da ENA de todas as bacias que pertencem à região ou submercado Sul e sua unidade está em MWmédios, Figura 6-11. Seu registro inicia-se em janeiro de 1931 e mantem-se até dezembro de 2014.

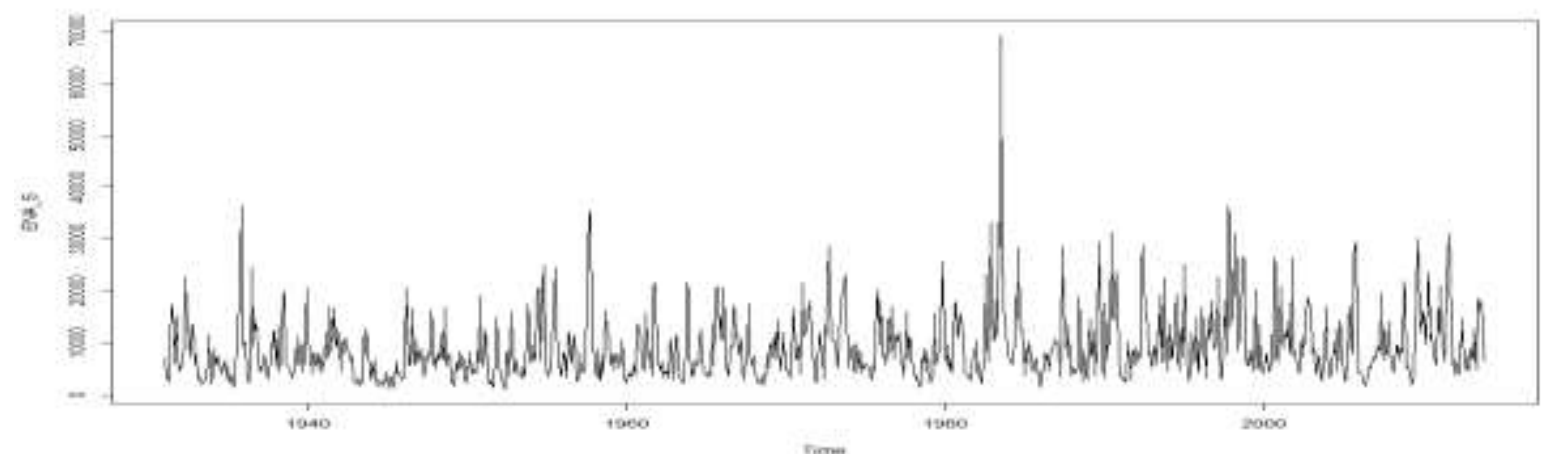

Figura 6-11 - Variável dependente ENA-S - Médias mensais MWmédios 
Nesse período há uma variação expressiva, que começa de um mínimo de 1.042 MWmédios até 69.440 MWmédios, com mediana em torno de 7.620 MWmédios como apresentado na Figura 6-12, além da distribuição mensal das medianas e quartis no gráfico boxplot dos meses de janeiro a dezembro bem como sua descrição estatística.

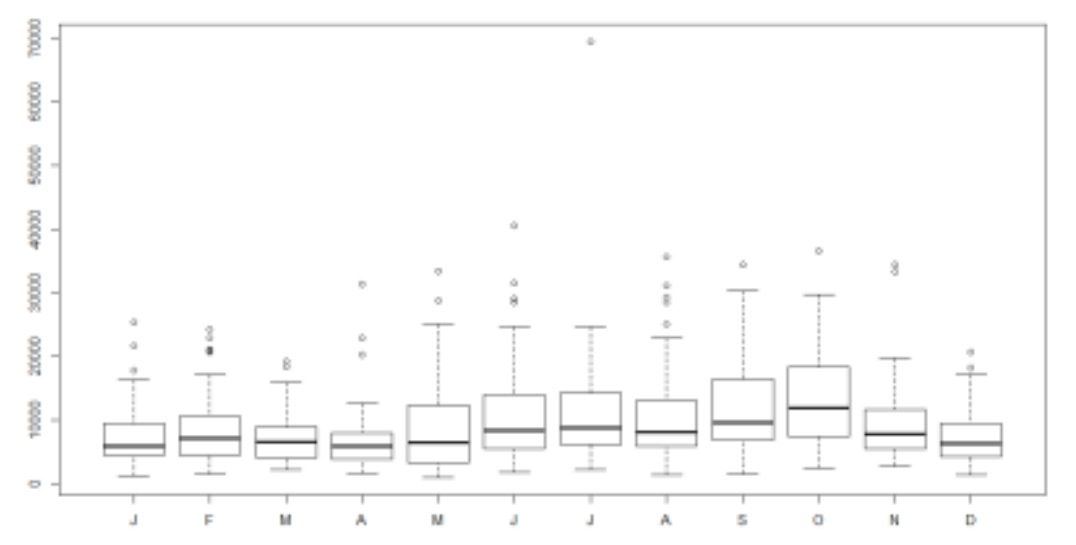

$\begin{array}{cc}\text { Mínimo: } & 1.042 \\ \text { 1º quartil: }^{\circ} & 4.695 \\ \text { Mediana: } & 7.620 \\ \text { Média: } & 9.289 \\ 3^{\circ} \text {. quartil: } & 11.760 \\ \text { Máximo: } & 69.440 \\ \text { Unidade: } & \text { MWmédios }\end{array}$

Figura 6-12 Boxplot ENA-S por mês e Descrição Estatística

Na Figura 6-13, apresentam-se três gráficos da ENA-S. Em a) apresenta-se a série normalizada; em b) apresenta-se uma diferença que foi aplicada na série temporal para retirar as tendências e c) apresenta-se uma suavização da série com a aplicação de uma transformada wavelet.

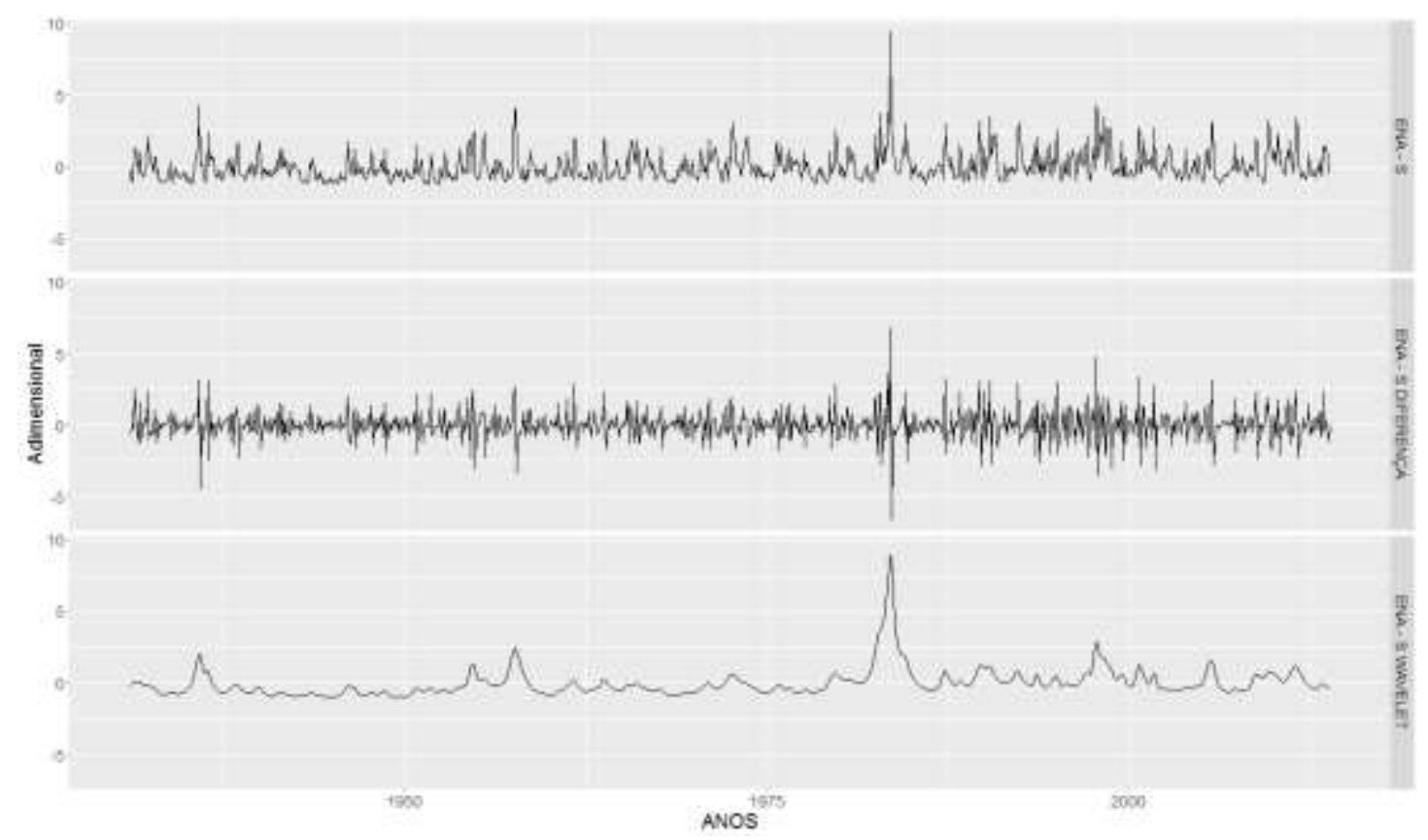

(a)

(b)

Figura 6-13ENA-S - Médias mensais normalizadas, com uma diferença e suavizada com wavelets 
Os máximos anuais da ENA-S são apresentadas na Figura 6-14. É possível observar um pico em 1983 com mais de três desvios padrão acima da média enquanto a maioria dos demais pontos situa-se no intervalo $[-2 \sigma ;+2 \sigma]$.

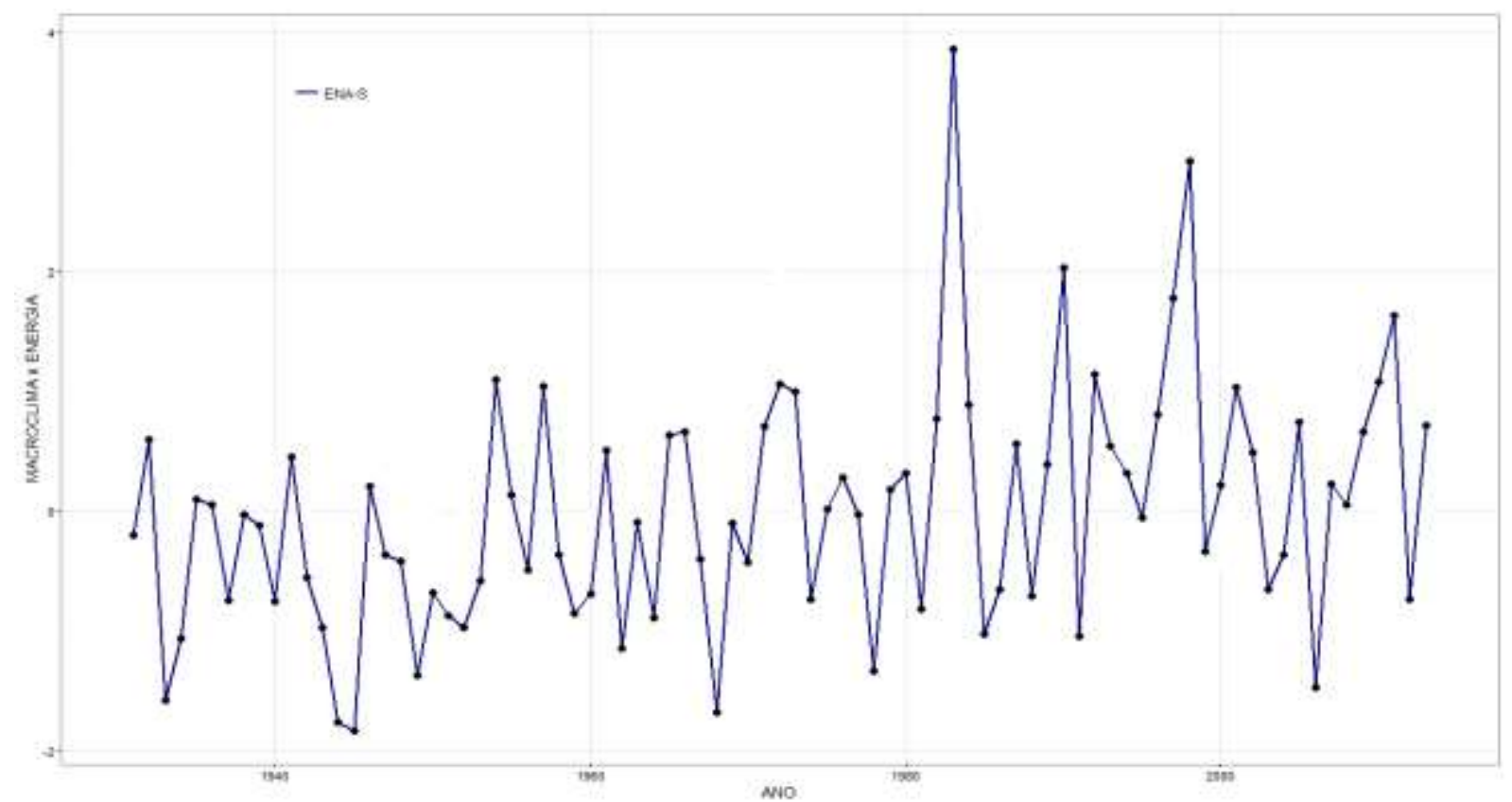

Figura 6-14 - Variável dependentes -ENA-S- Máximos Anuais normalizadas MWmédios

\subsubsection{Energia Natural Afluente do Nordeste (ENA-NE)}

A variável dependente ENA-NE corresponde à soma da ENA de todas as bacias que pertencem à região ou submercado Nordeste e utiliza a unidade de MWmédios, Figura 6-15. Seu registro inicia-se em janeiro de 1931 e termina em dezembro de 2014.

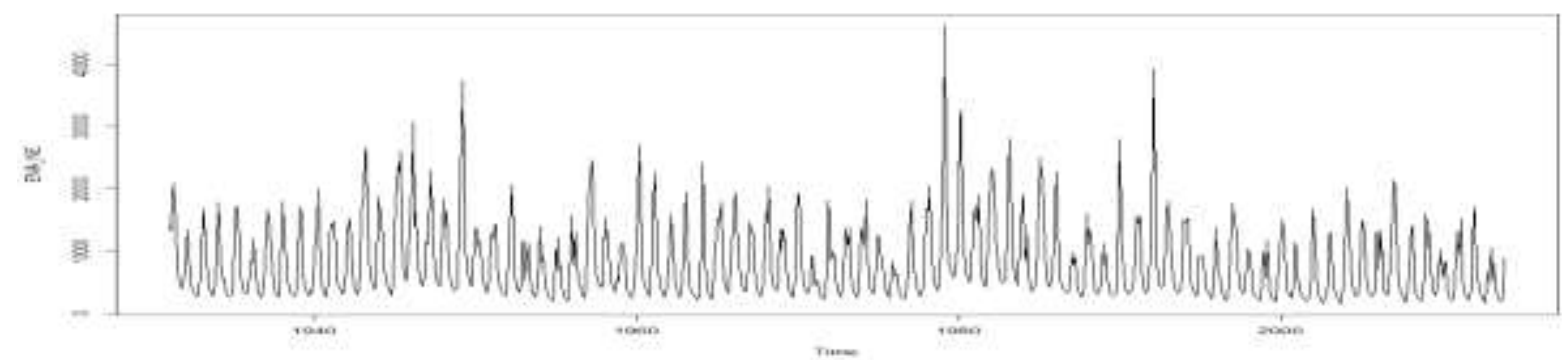

Figura 6-15 - Variável dependente -ENA-NE - Médias mensais MWmédios

Nesse período há uma variação expressiva, que começa de um mínimo de 1.535 MWmédios até 46.244 MWmédios, com uma média em torno de 5.734 MWmédios como apresentado na Figura 6-16, além da distribuição mensal das medianas e quartis no gráfico boxplot dos meses de janeiro a dezembro bem como sua descrição estatística. 


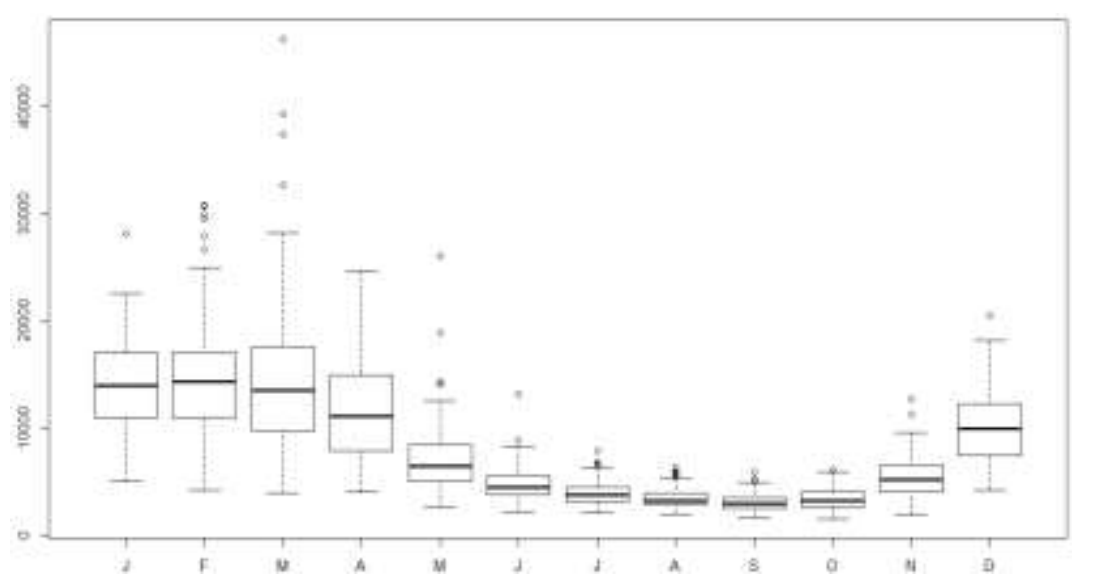

Mínimo: $\quad 1.535$

$1^{\circ}$. quartil: $\quad 3.652$

Mediana: $\quad 5.734$

Média: $\quad 8.098$

$3^{\circ}$. quartil: $\quad 11.430$

Máximo: $\quad 46.244$

Unidade: MWmédios

Figura 6-16 Boxplot ENA-NE por mês e Descrição Estatística

Na Figura 6-17, apresentam-se três gráficos da ENA da região Nordeste. Os três são normalizados em que a) apresenta-se a série normalizada; em b) foi aplicada uma diferença para retirar as tendências, e em c) apresenta-se suavização da série com a aplicação de uma transformada wavelet.

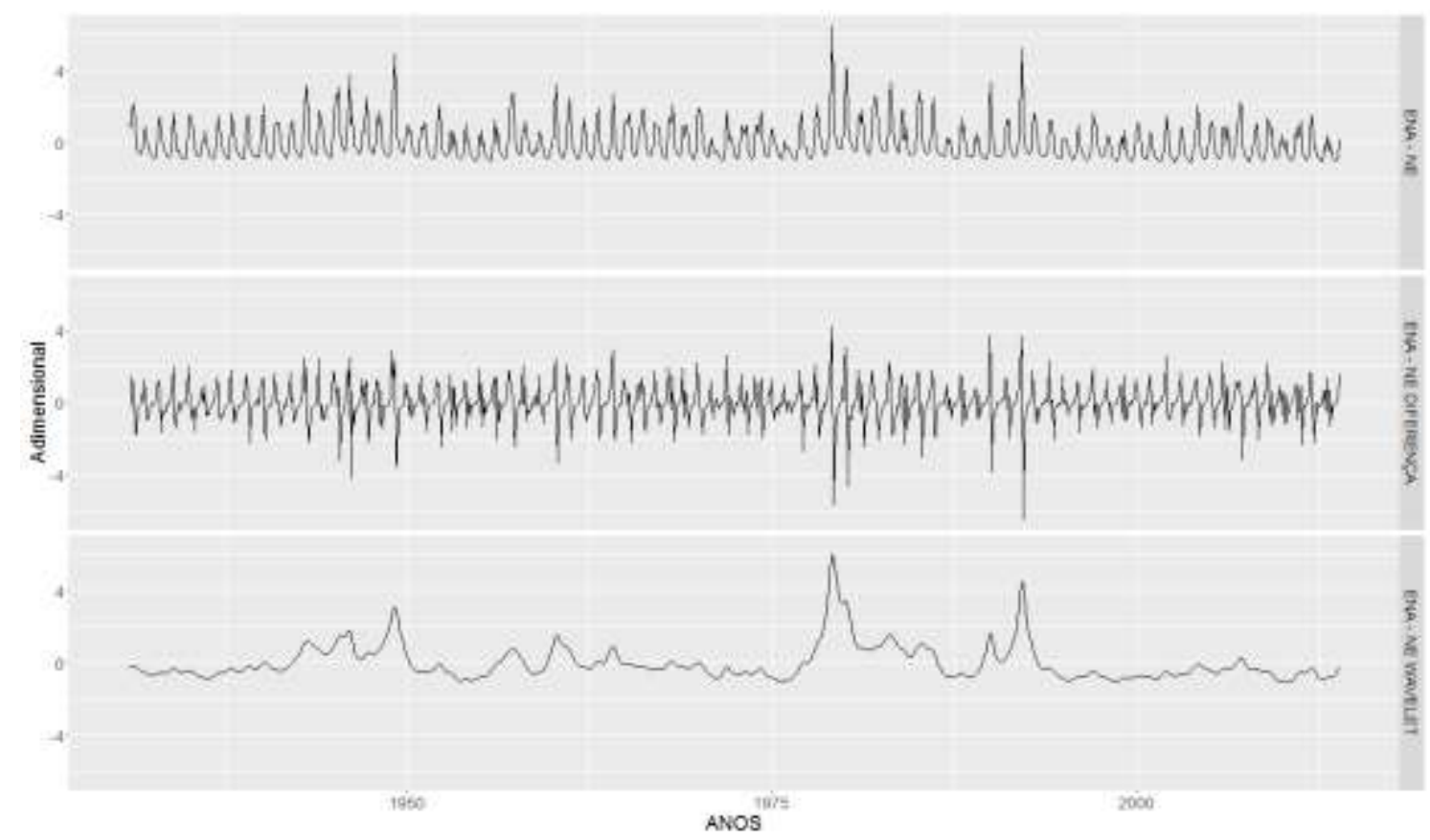

Figura 6-17 ENA-NE - Médias mensais normalizadas, com uma diferença e suavizada com wavelets

Os máximos anuais da ENA-NE são apresentadas na Figura 6-18. São encontrados diversos picos em: em 1945, 1946, 1979, 1983, 1985 e 1992 com quase de três desvios padrão acima da média enquanto a quase totalidade dos demais pontos situam-se no intervalo $[-2 \sigma ;+2 \sigma]$. 


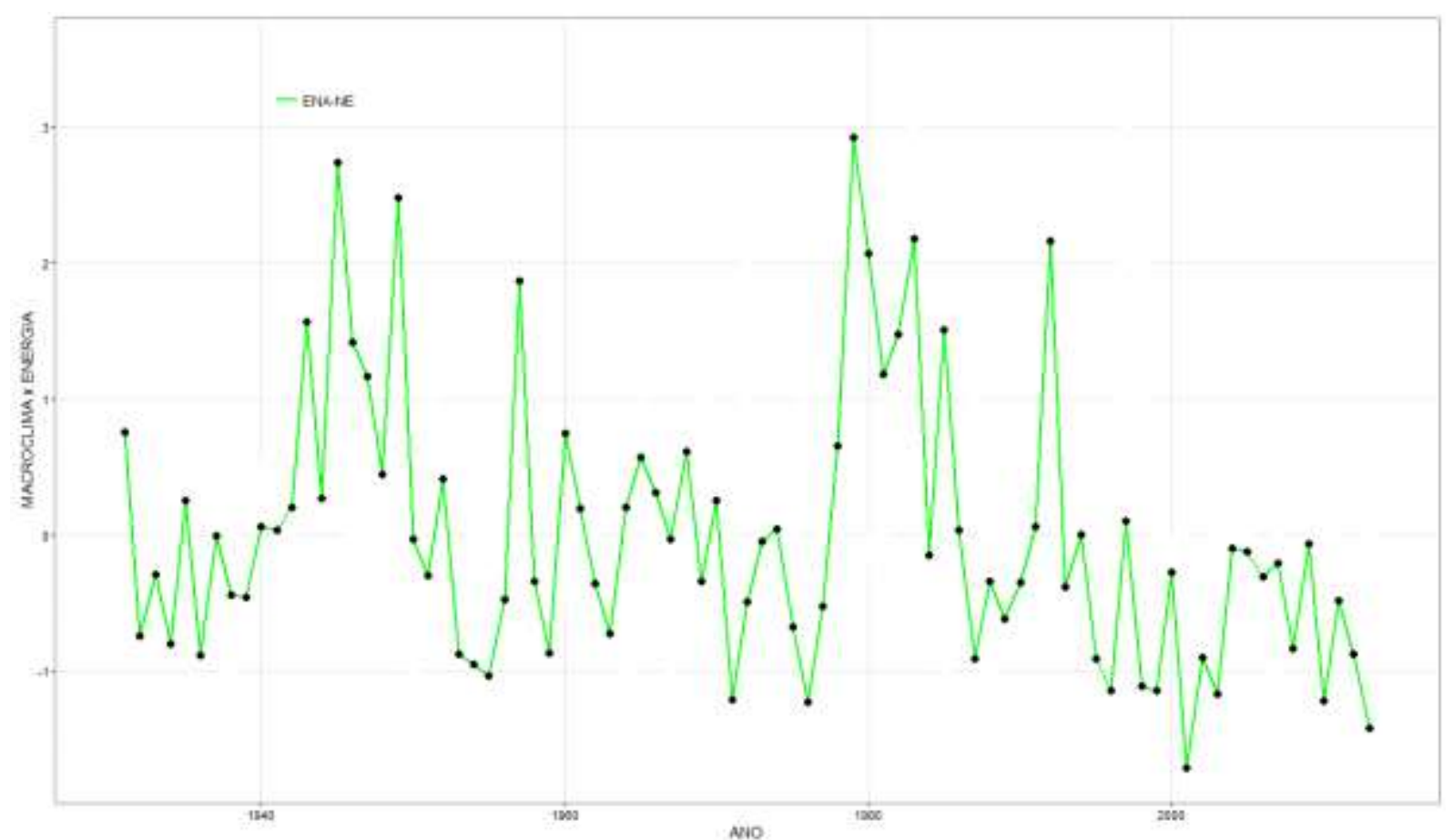

Figura 6-18 - Variável dependentes - ENA-NE - Máximos Anuais normalizadas MWmédios

\subsubsection{Energia Natural Afluente do Norte (ENA-N) ${ }^{100}$}

A variável dependente ENA-N corresponde à soma da ENA de todas as bacias que pertencem à região ou submercado Norte e sua unidade está em MWmédios, Figura 6-19. Seu registro inicia-se em janeiro de 1931 e termina em dezembro de 2014.

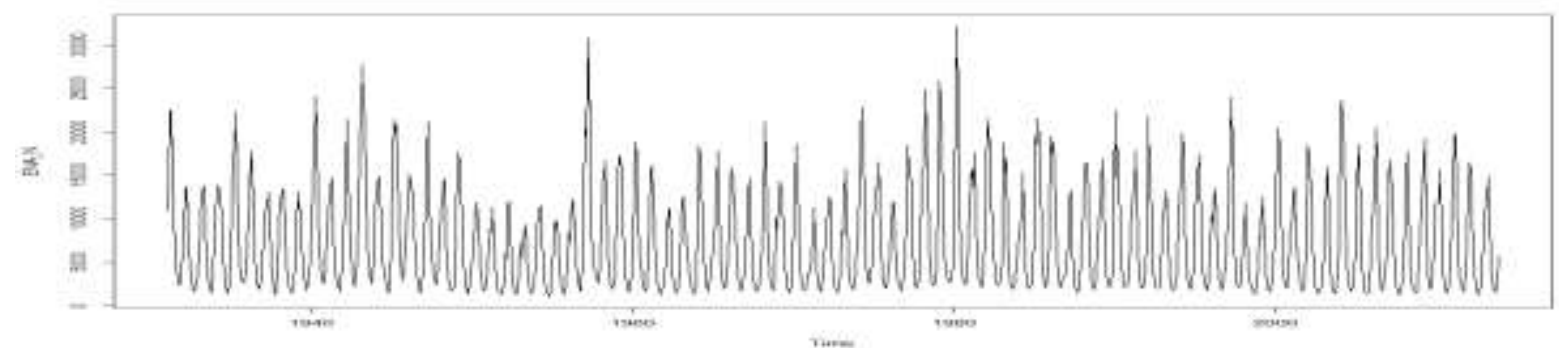

Figura 6-19 - Variável dependenteENA-N - Médias mensais MWmédios

Nesse período há uma variação expressiva, que começa de um mínimo de 1.002 MWmédios até 32.183 MWmédios, com mediana em torno de 5.228 MWmédios como apresentado na Figura 6-20, além da distribuição mensal das medianas e quartis no gráfico boxplot dos meses de janeiro a dezembro bem como sua descrição estatística.

\footnotetext{
${ }^{100}$ Nota Prof. Molion: "Cuidado! Não existia dados de vazão no rio Tocantins antes de planejarem a Usina de Tucuruí. O início da série é sintético! Veja (MOLION ET AL, 2006 - CLIMANÁLISE). A vazão foi estimada em $68.000 \mathrm{~m}^{3} \mathrm{~s}^{-1}$. Tucuruí não existia!"”
} 


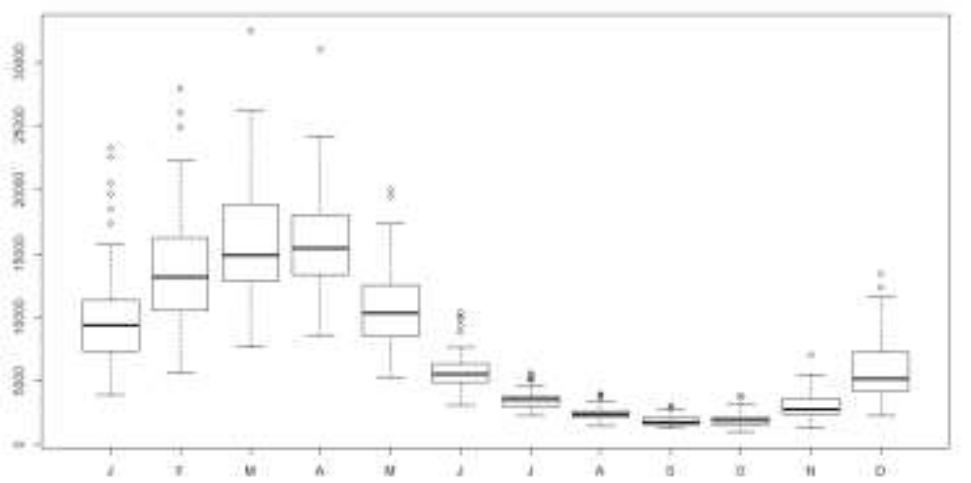

Mínimo: $\quad 1.060$

$1^{\circ}$. quartil: $\quad 2.593$

Mediana: $\quad 5.403$

Média: $\quad 7.601$

$3^{\circ}$. quartil: $\quad 11.610$

Máximo: $\quad 32.420$

Unidade: MWmédios

Figura 6-20 Boxplot ENA-N por mês e Descrição Estatística

Na Figura 6-21, apresentam-se três gráficos da ENA da região Norte. Em que a) apresenta-se a série normalizada, em b) foi aplicada uma diferença, não necessária, pois a série transformada é igual a original, possivelmente por conta da série ser sintética, antes da construção da Usina de Tucuruí; e em c) apresenta-se suavização da série com a aplicação de uma transformada wavelet, onde aparecem quatro picos bem marcados, acima de dois $\sigma$.

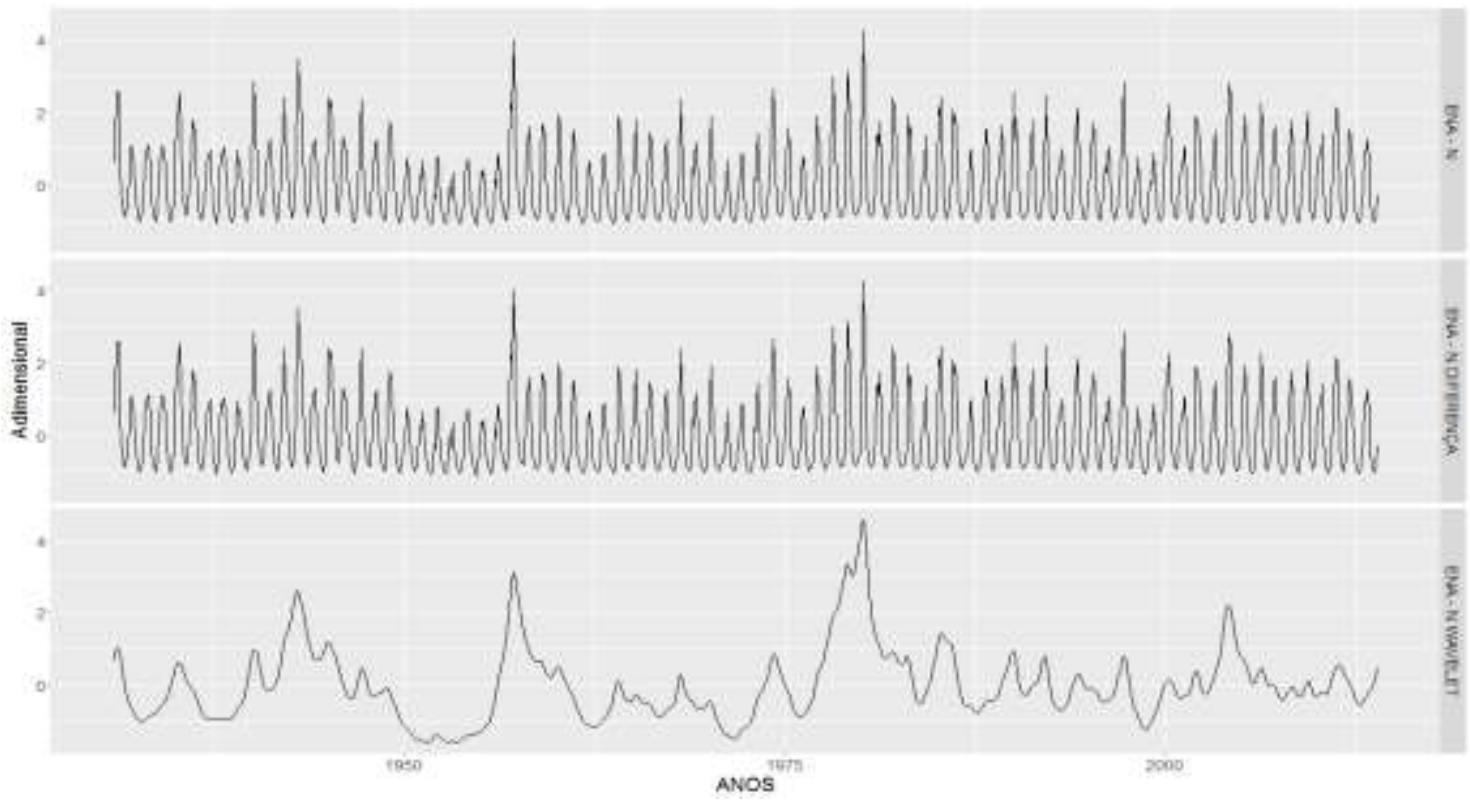

Figura 6-21 ENA-N - Médias mensais normalizadas, com uma diferença e suavizada com wavelets

Os máximos anuais da ENA-N são apresentadas na Figura 6-22. Pode-se observar picos em 1943, 1945, 1957 e 1980 com mais de dois desvios padrão acima da média enquanto grande parte dos demais pontos situa-se no intervalo $[-2 \sigma ;+2 \sigma]$. 


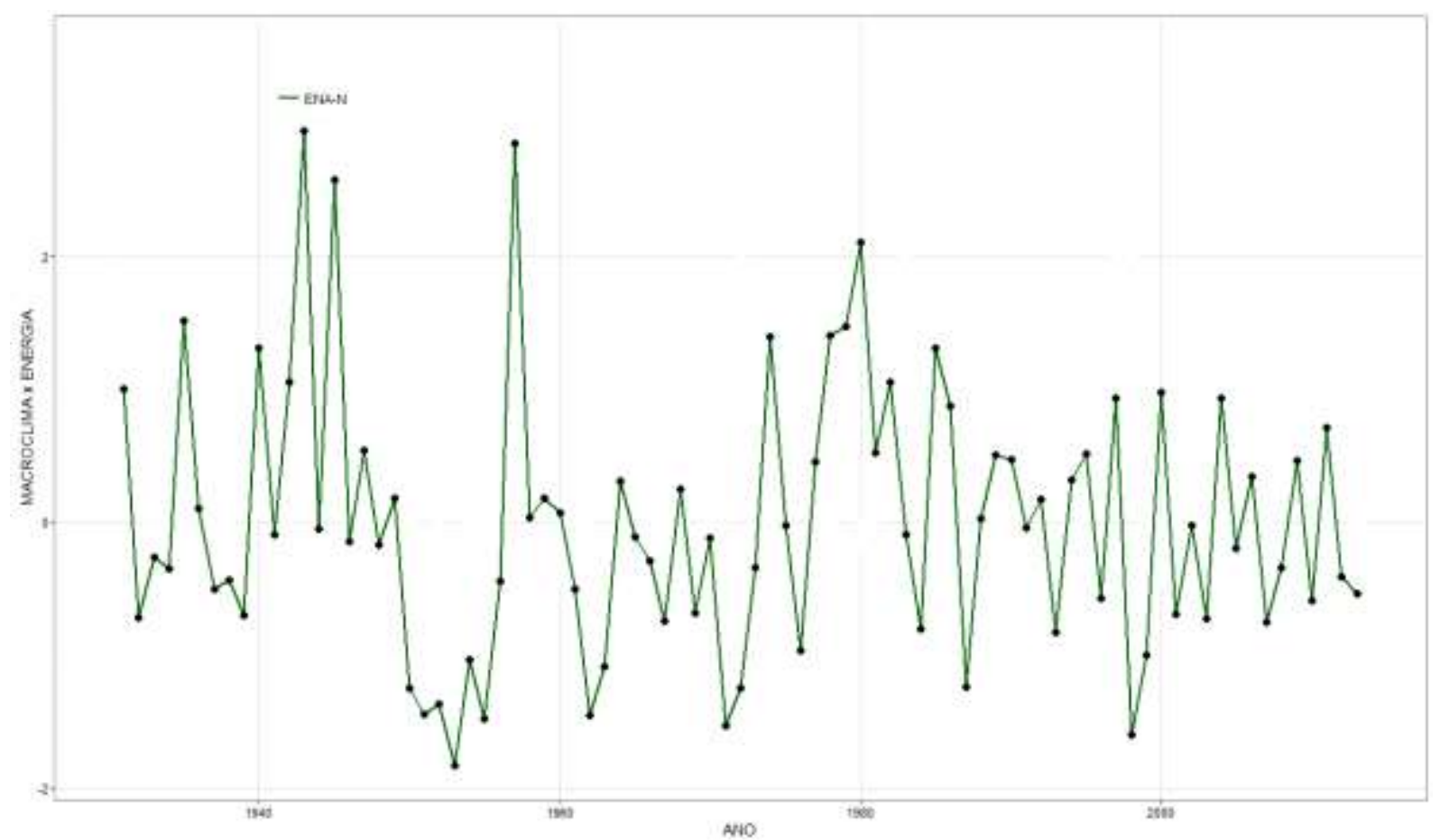

Figura 6-22 - Variável dependentes -ENA-N - Máximos Anuais normalizadas MWmédios

\subsection{Variáveis macroclimáticas independentes}

As variáveis macroclimáticas NINO1+2, AMO e PDO são analisadas nesse momento e apresentam diferentes períodos. AMO se inicia no ano de 1856, e é apresentada na Figura 6-30; NINO1+2 se inicia no ano de 1870, e é apresentada na Figura 6-23; e PDO se inicia no ano de 1854 e é apresentada na Figura 6-37. Todas finalizam em 2015. Alguns gráficos apresentam no eixo y valores adimensionais onde as anomalias das séries são calculadas para facilitar sua comparação, as medidas dos valores $\mathrm{x}$ das séries são subtraídas pela média da série histórica completa, $\mu$, e o resultado é divido pelo desvio padrão $\sigma$, das séries históricas completas, $[(\mathrm{x}-\mu) / \sigma]$.

\subsection{1 Índice Temperatura da Superfície do Mar - TSM Região NINO 1+2}

O Nino 1+2 compreende a TSM média de áreas de grande escala localizada no oceano Pacífico descrita na seção 3.3 El Niño-Oscilação Sul (ENOS), p. 87. Na Figura 6-23 apresenta-se a série histórica original de NINO1+2 em graus Celsius do período de janeiro de 1870 a outubro de 2015. 


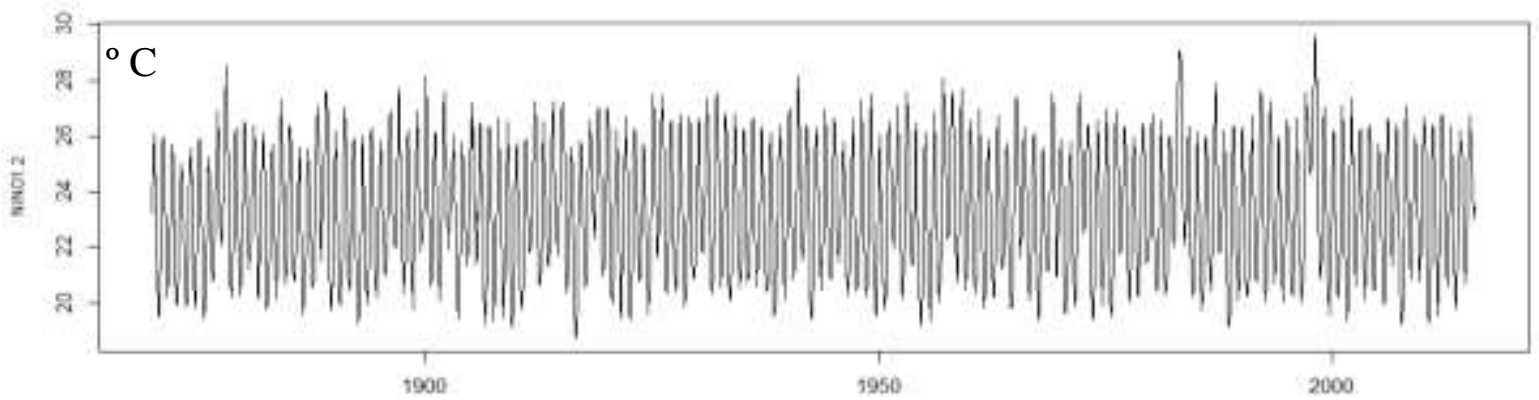

Figura 6-23 - TSM Região NINO 1+2 do Pacífico - Médias mensais expressos em ${ }^{\circ} \mathrm{C}$

Na Figura 6-24, os dados são normalizados para visualizar os períodos associados aos fenômenos de El Niño e La Niña.

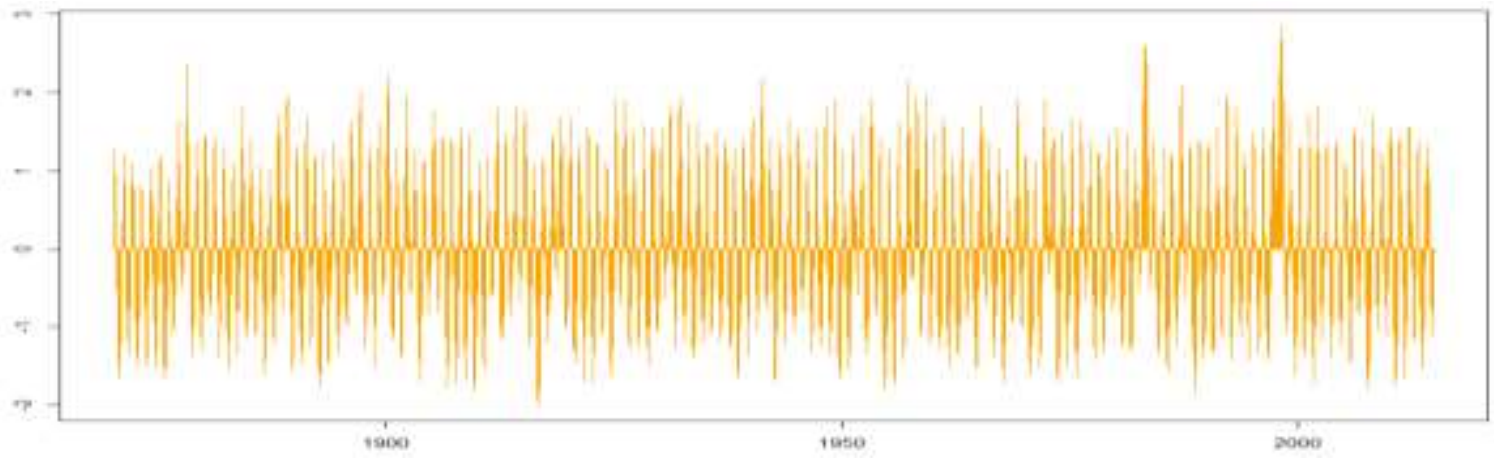

Figura 6-24 - TSM Região NINO 1+2 do Pacífico - Desvios padrões mensais

Na Figura 6-25, apresenta-se o gráfico caixa (boxplot) da variável NINO 1+2, com dados do período de janeiro de 1870 a outubro de 2015, apresenta-se, também, a distribuição estatística mensal desse período, com as medianas, os quartis e os máximos e mínimos mensais bem como a descrição estatística de NINO1+2 ao lado direito do gráfico. O intervalo entre o mínimo e o máximo de temperatura compreende $10,9^{\circ} \mathrm{C}$. Nota-se que a TSM apresenta comportamento sazonal, dependente do mês, coincidindo com os períodos secos e úmidos das ENA-SE, ENA-NE e ENA-N. 


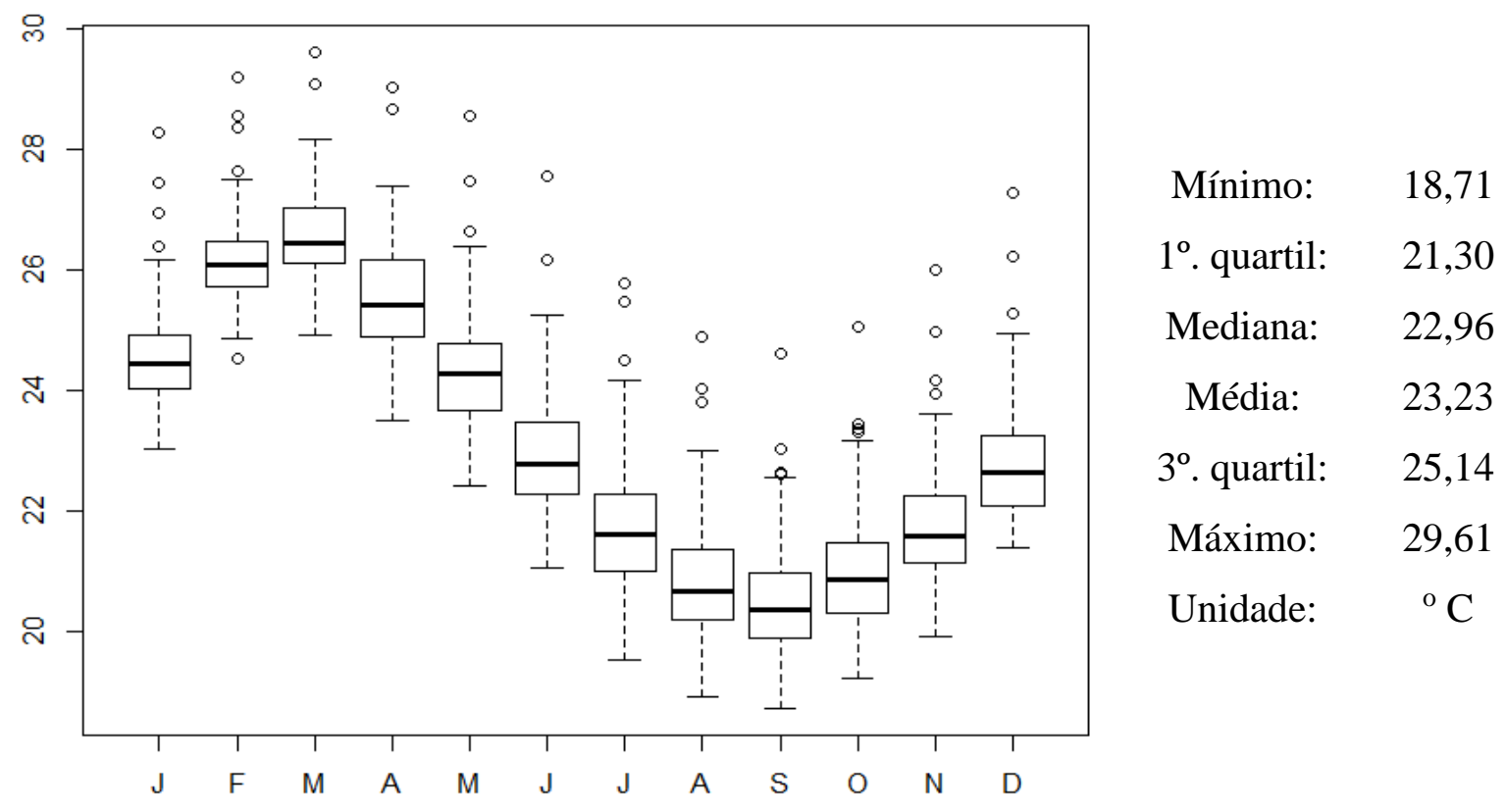

Figura 6-25 -Boxplot Índice TSM NINO 1+2 por mês e Descrição Estatística

Ao comparar a série histórica de máximas anuais de ENA-SE e NINO1+2, observa-se que a variação de ambas apresenta uma certa relação das variações de temperatura e energia. Por exemplo, em 1982/83 verifica-se um pico que indica um fenômeno El Niño muito forte (as TSM do oceano Pacífico atingiram temperatura acima de $8^{\circ} \mathrm{C}$ ) e a ENA-SE apresentou um valor elevado com uma quantidade de energia de aproximadamente de 72.000 MWmédios (quase o triplo de sua média), também é possível constatar a partir da observação do gráfico que vales e picos seguem uma mesma direção, o que indica a possibilidade do uso dessa série no modelo, Figura 6-26, o que é analisado na seção 6.5 Matrix para Correlação das Séries históricas, p. 194. 


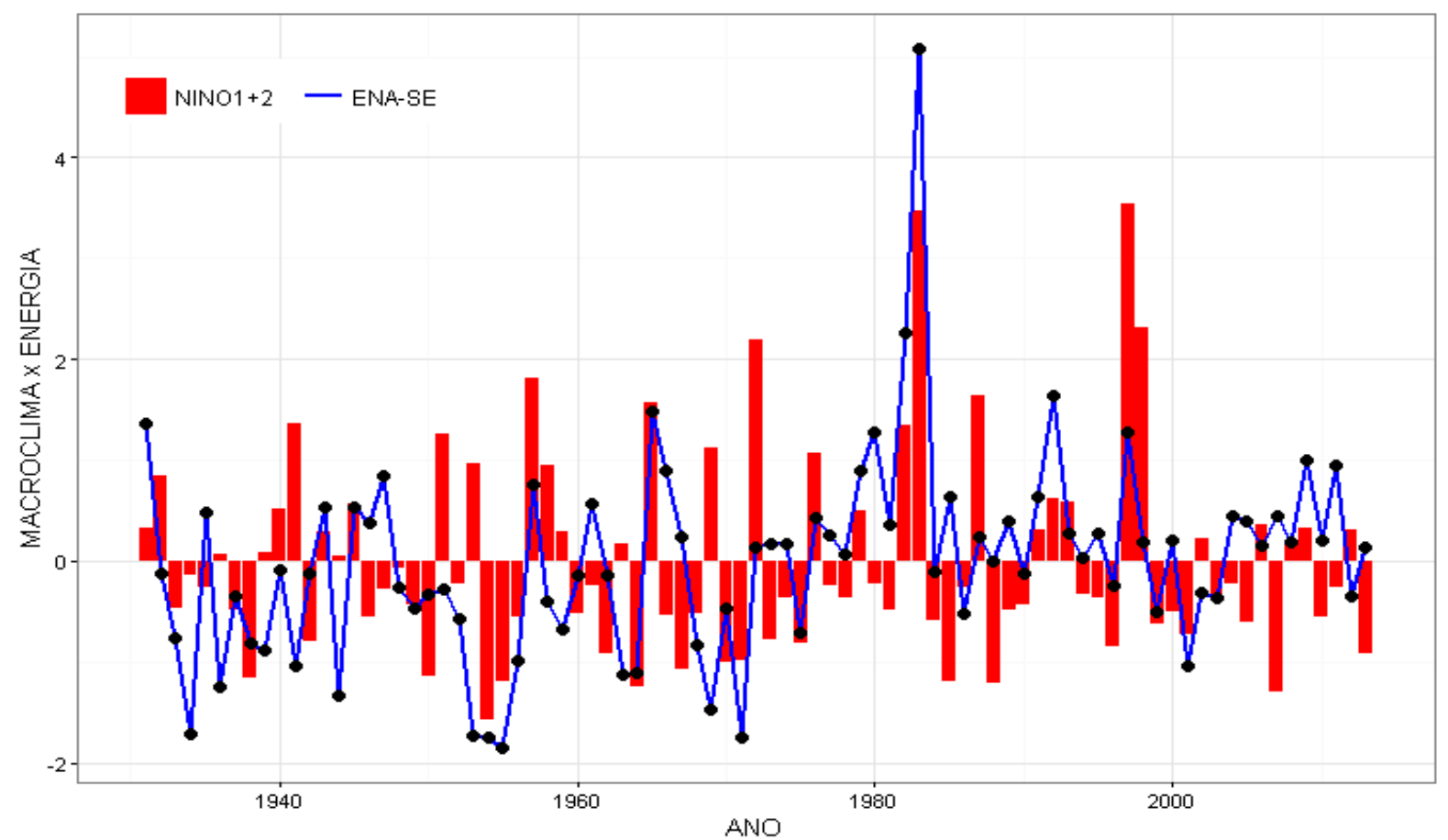

Figura 6-26 -Gráfico Índice NINO1+2(barras) versos ENA SE (linhas)- Máximos Anuais normalizadas MWmédios

O mesmo aplica-se ao Sul, Figura 6-27, Nordeste, Figura 6-28 e ao Norte, Figura 6-29.

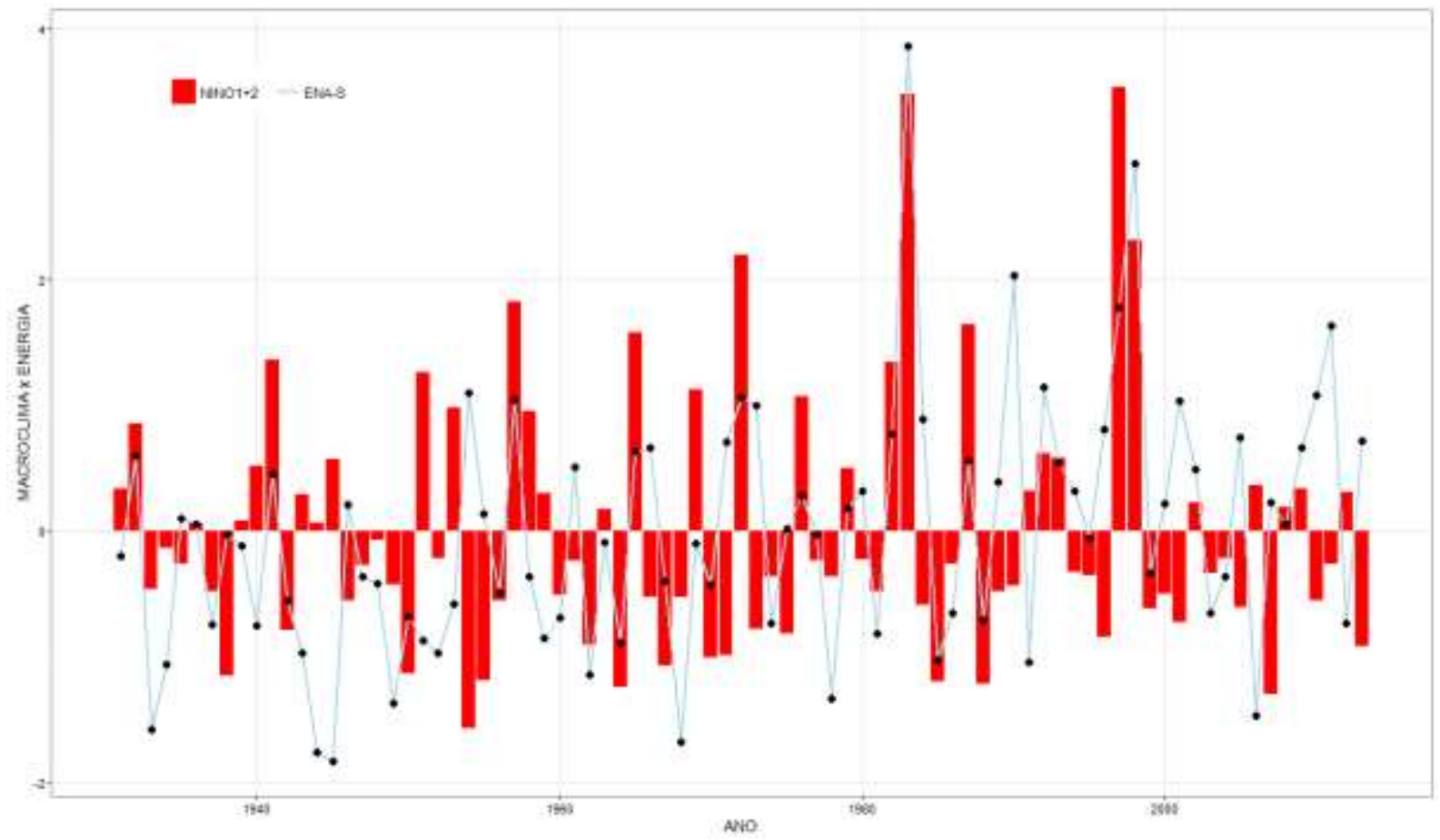

Figura 6-27 -Gráfico Índice NINO1+2 versos ENA S - Máximos Anuais normalizadas MWmédios 


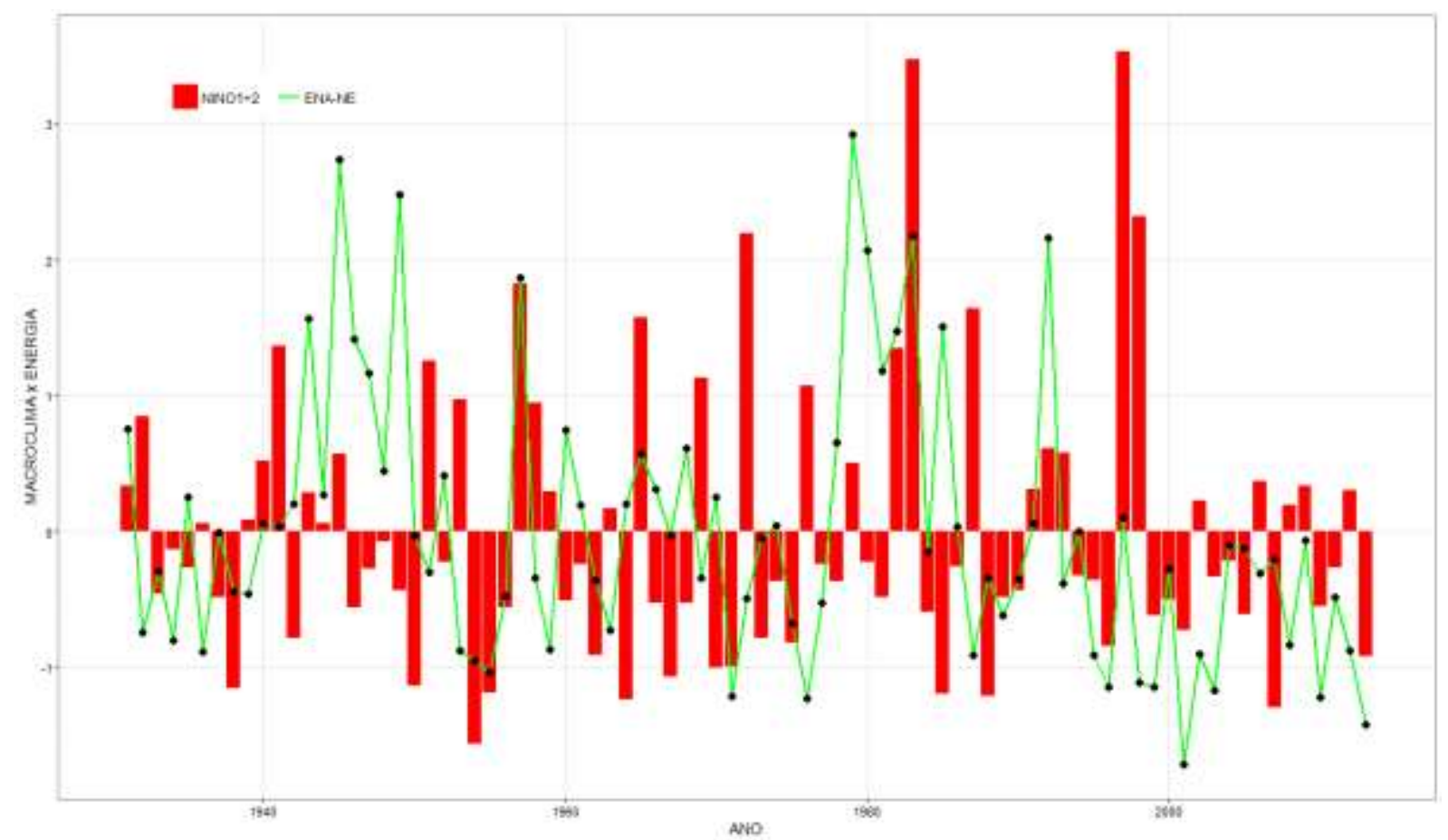

Figura 6-28 -Gráfico Índice NINO1+2 versos ENA NE - Máximos Anuais normalizadas MWmédios

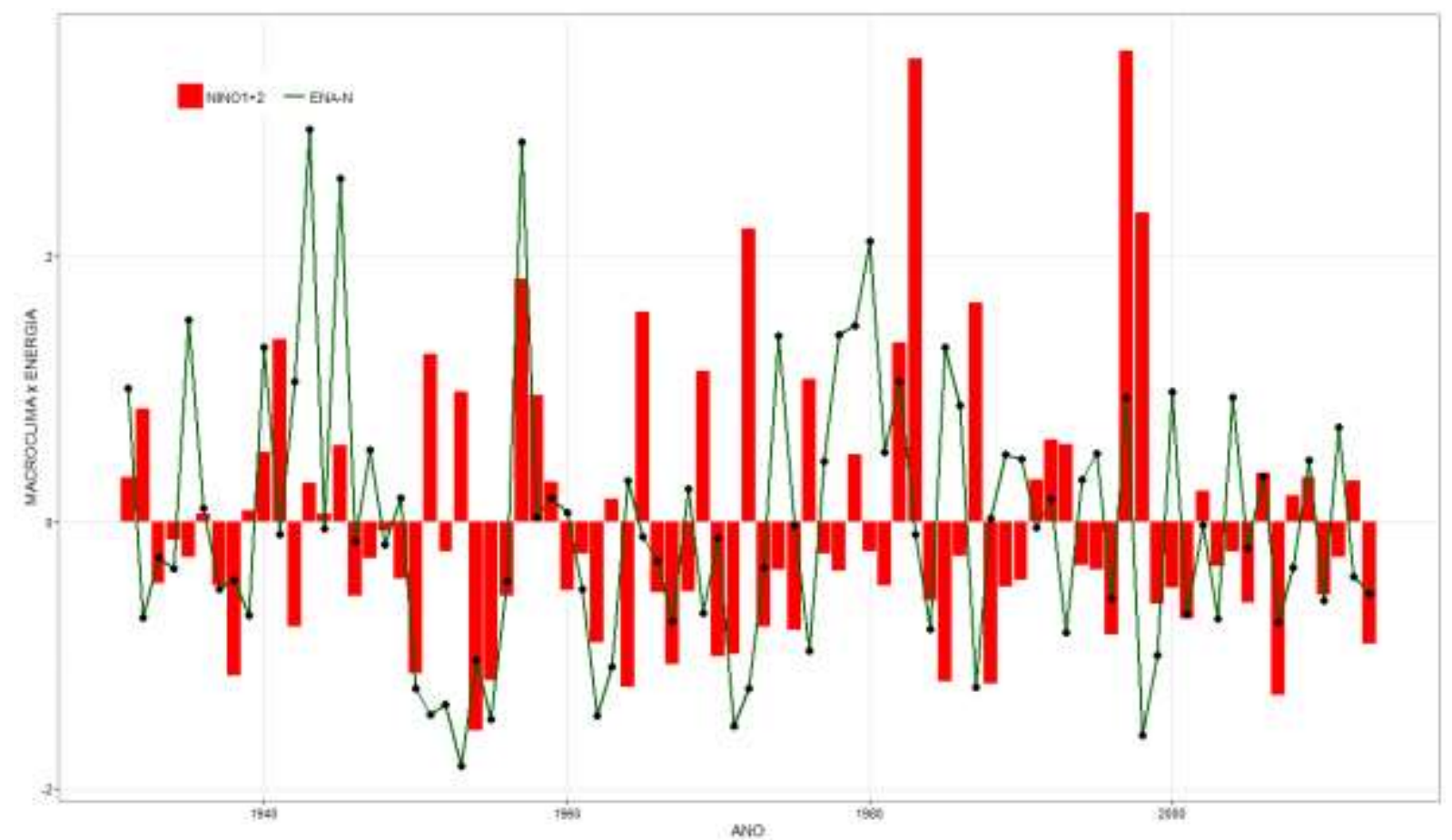

Figura 6-29 -Gráfico Índice NINO1+2 versos ENA N - Máximos Anuais normalizadas MWmédios 


\subsection{2 Índice Oscilação Multidecadal do Atlântico (AMO) $)^{101}$}

O índice AMO apresenta as temperaturas da superfície do mar (TSM) de uma região que compreende desde a linha do equador até $70^{\circ}$ Norte, é também descrita na seção 4.1 Índice Oscilação Multidecadal do Atlântico - AMO, p.145. Na Figura 6-30, apresenta-se a série histórica original em graus Celsius do período de janeiro de 1856 a dezembro de 2015, sem transformações.

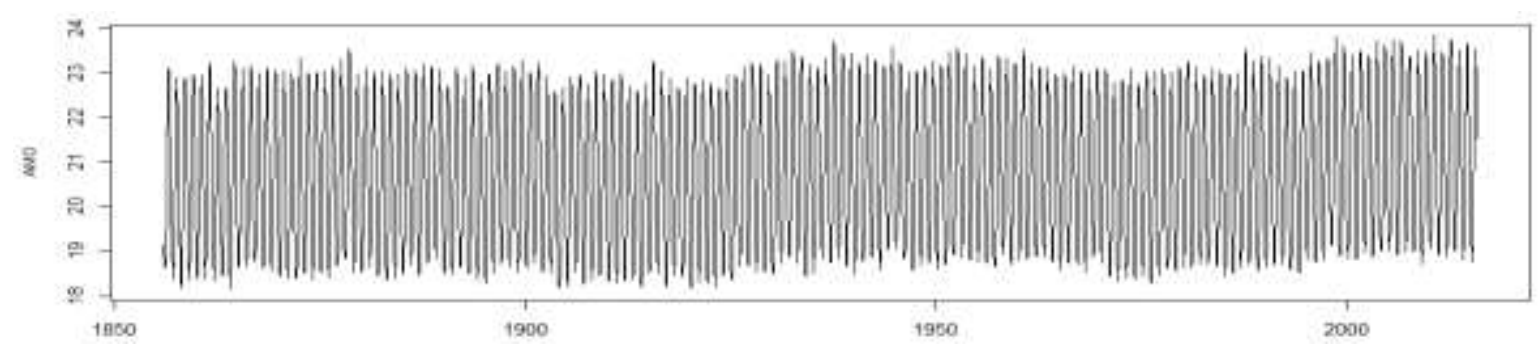

Figura 6-30 Índice TSM Multidecadal do Atlântico - AMO - Médias mensais expressas em ${ }^{\circ} \mathrm{C}$, sem transformações

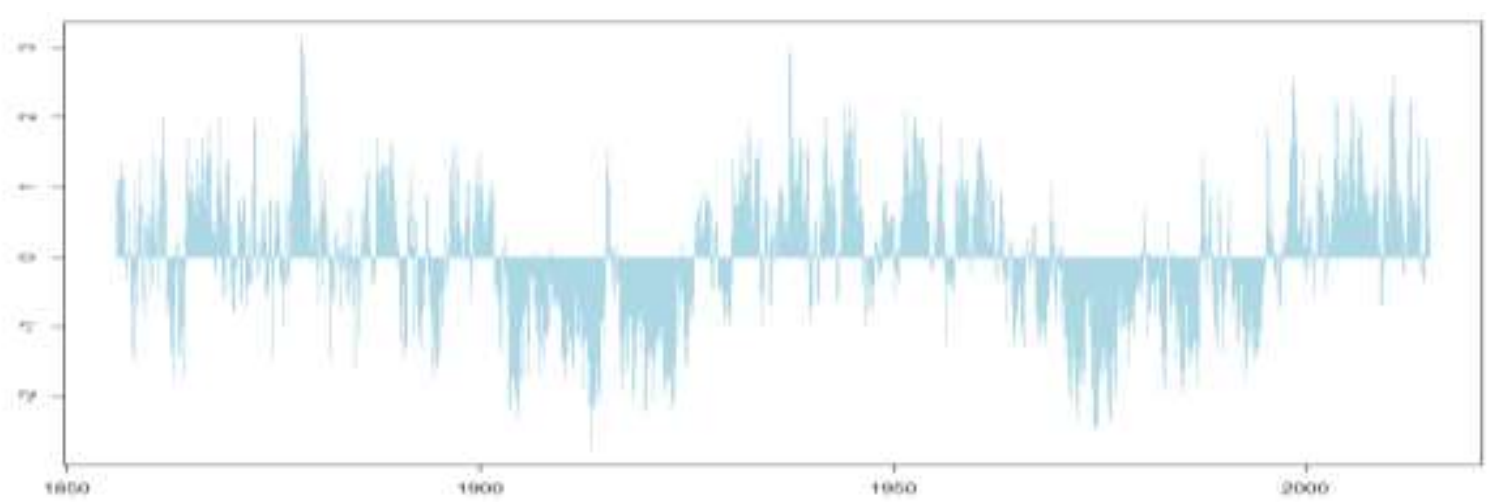

Figura 6-31 Índice TSM Oscilação Multidecadal do Atlântico - AMO - Desvios padrões mensais normalizados expressos em ${ }^{\circ} \mathrm{C}$

Na Figura 6-32, apresentam-se a distribuição estatística mensal, com as medianas, os quartis, os máximos e mínimos mensais bem como a descrição estatística de AMO ao lado direito do gráfico. O intervalo entre o mínimo e o máximo de temperatura compreende $5,7^{\circ} \mathrm{C}$.

${ }^{101}$ Atlantic Multidecadal Oscillation 


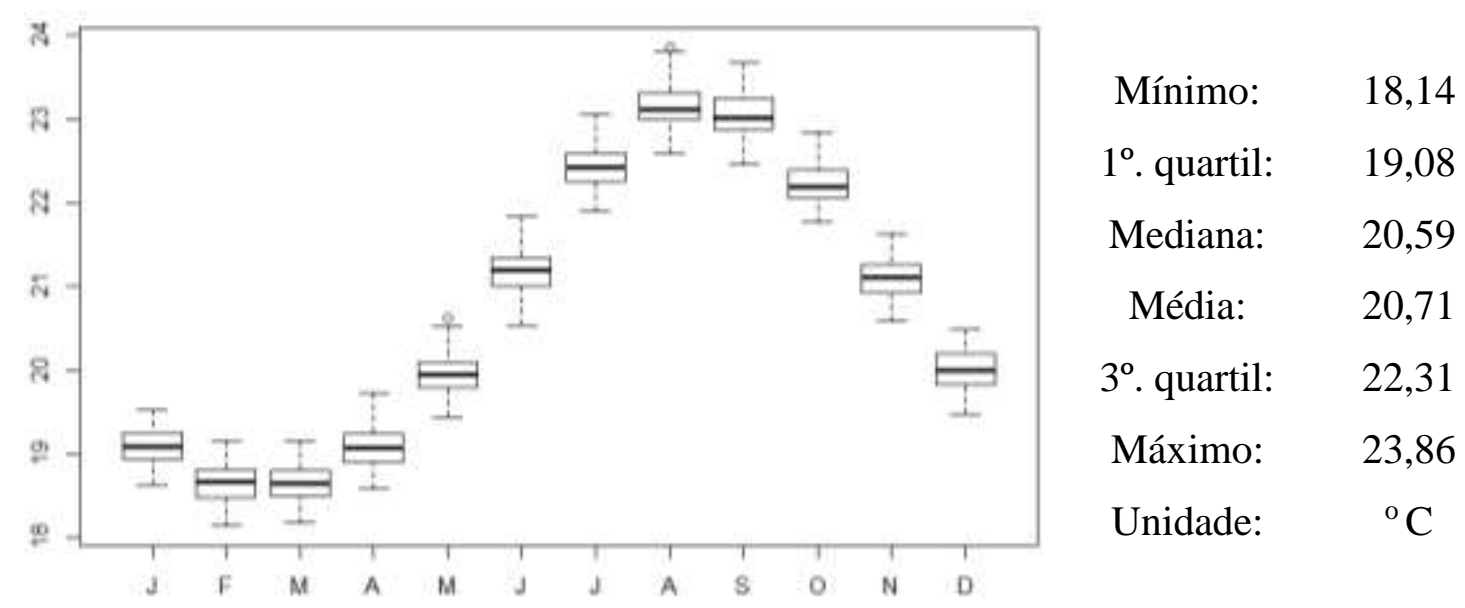

Figura 6-32-Boxplot Índice AMO por mês e Descrição Estatística expressos em ${ }^{\circ} \mathrm{C}$

Ao comparar graficamente as séries históricas de médias anuais normalizadas de ENA-SE e AMO observa-se uma correlação ora negativa dos desvios padrões até meados dos anos 2000 e ora positiva após 2001, o que indica um comportamento de mudança de sinal da correlação entre escalas de tempo interdecadal, embora, na Figura mostre o pico de 1983 da ENA-SE, não há um pico correspondente na série da AMO no mesmo período ou mesmo com algum atraso, Figura 6-33.

O mesmo aplica-se ao Sul, Figura 6-34, Nordeste, Figura 6-35 e ao Norte, Figura 6-36. Posteriormente, são feitas análises de correlação como já mencionado. 


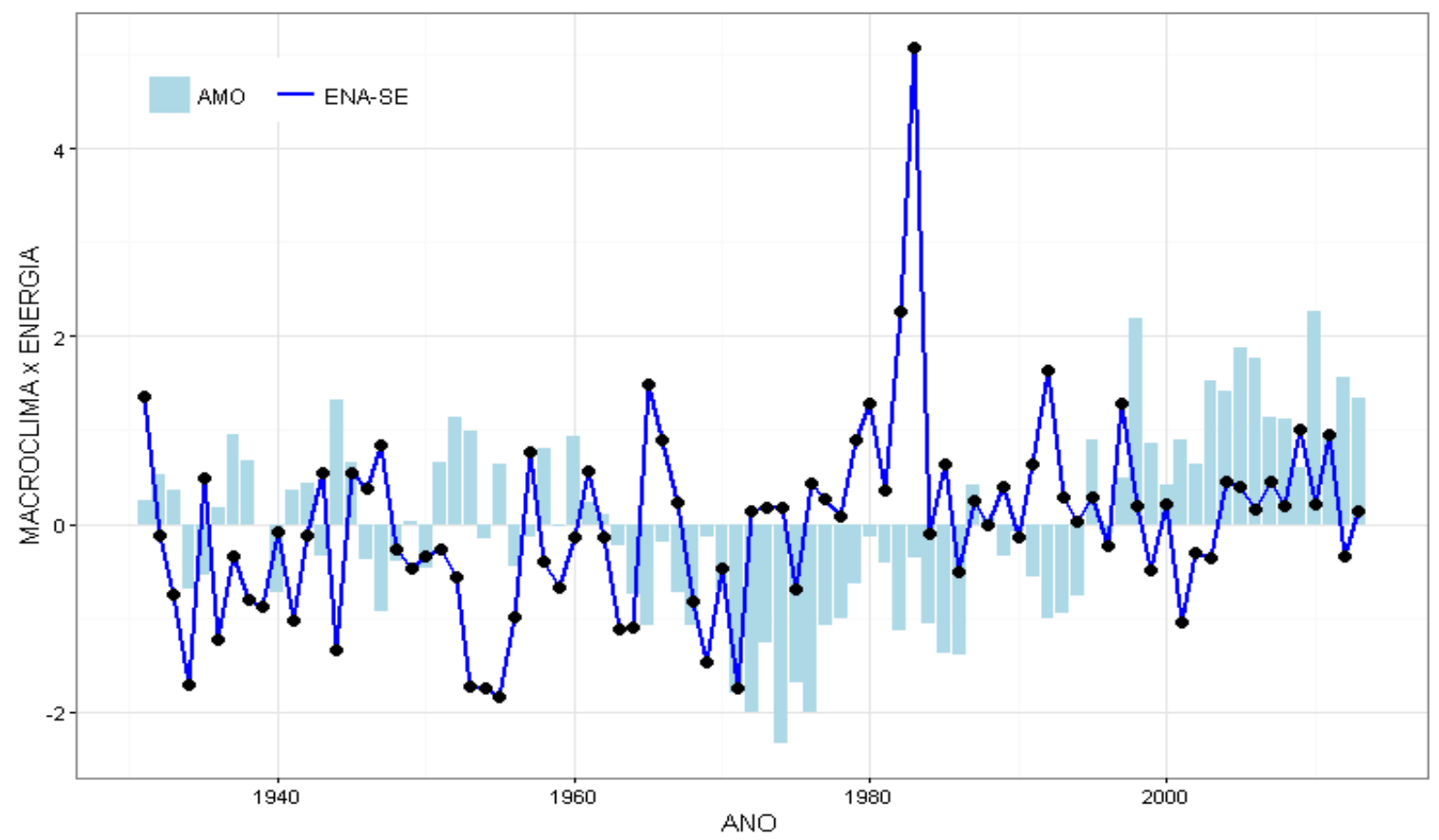

Figura 6-33 -Gráfico Índice AMO versos ENA SE - Máximos Anuais normalizadas MWmédios

Para o ENA-SUL, Figura 6-34, nota-se que no geral, quando a energia está abaixo da média, AMO está acima e vice-versa, de depois do ano 2000 fica misturado.

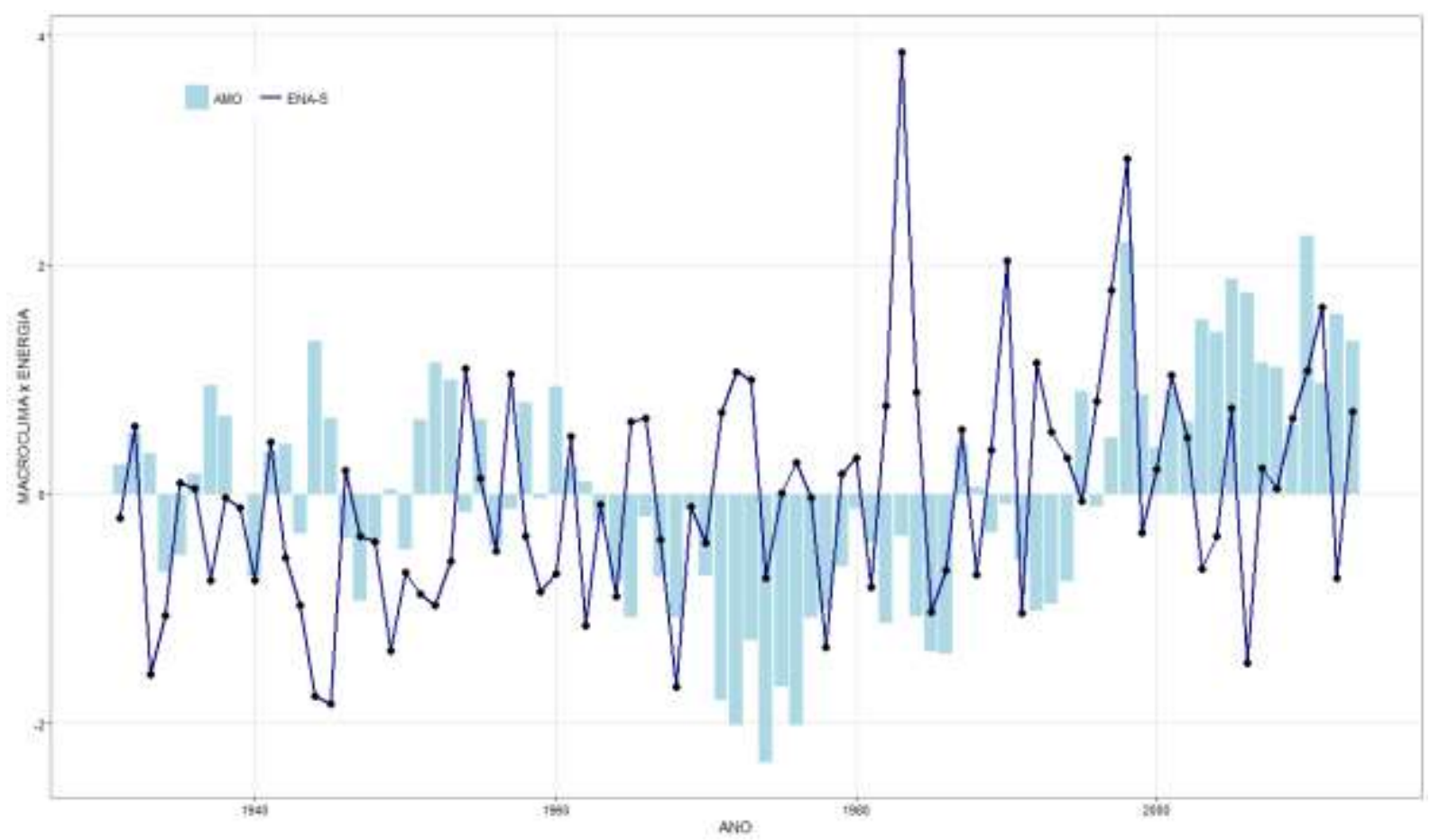

Figura 6-34 -Gráfico Índice AMO versos ENA S - Máximos Anuais normalizadas MWmédios 
Para ENA-NE, Figura 6-35, quando ENA-NE está acima da média, no geral AMO está abaixo e vice versa.

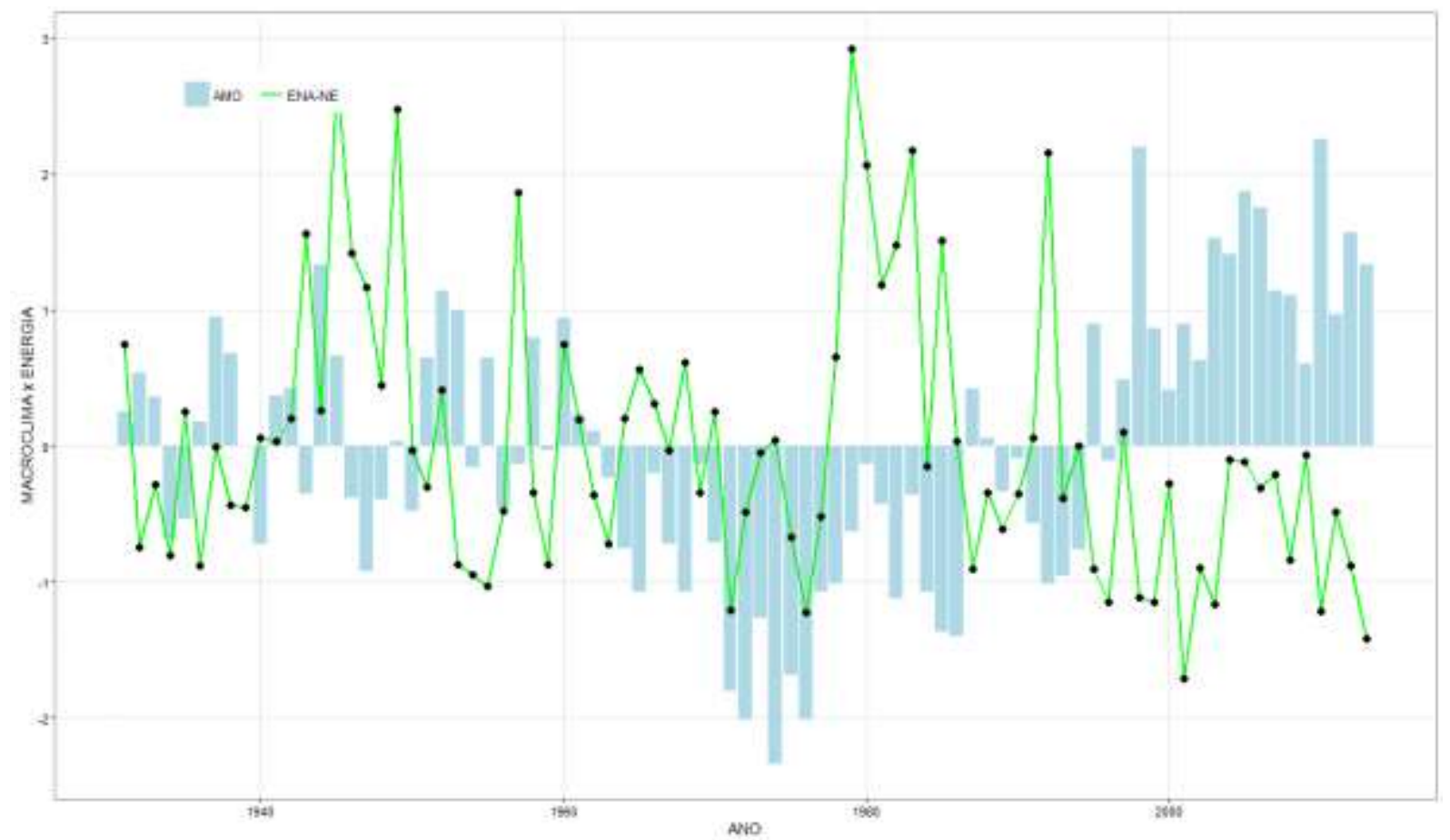

Figura 6-35 -Gráfico Índice AMO versos ENA NE - Máximos Anuais normalizadas MWmédios

Para ENA-N, Figura 6-36, enquanto ENA-N está cima da média, há momentos que AMO está também acima ou também abaixo. Após o ano 2000 parece bem misturado.

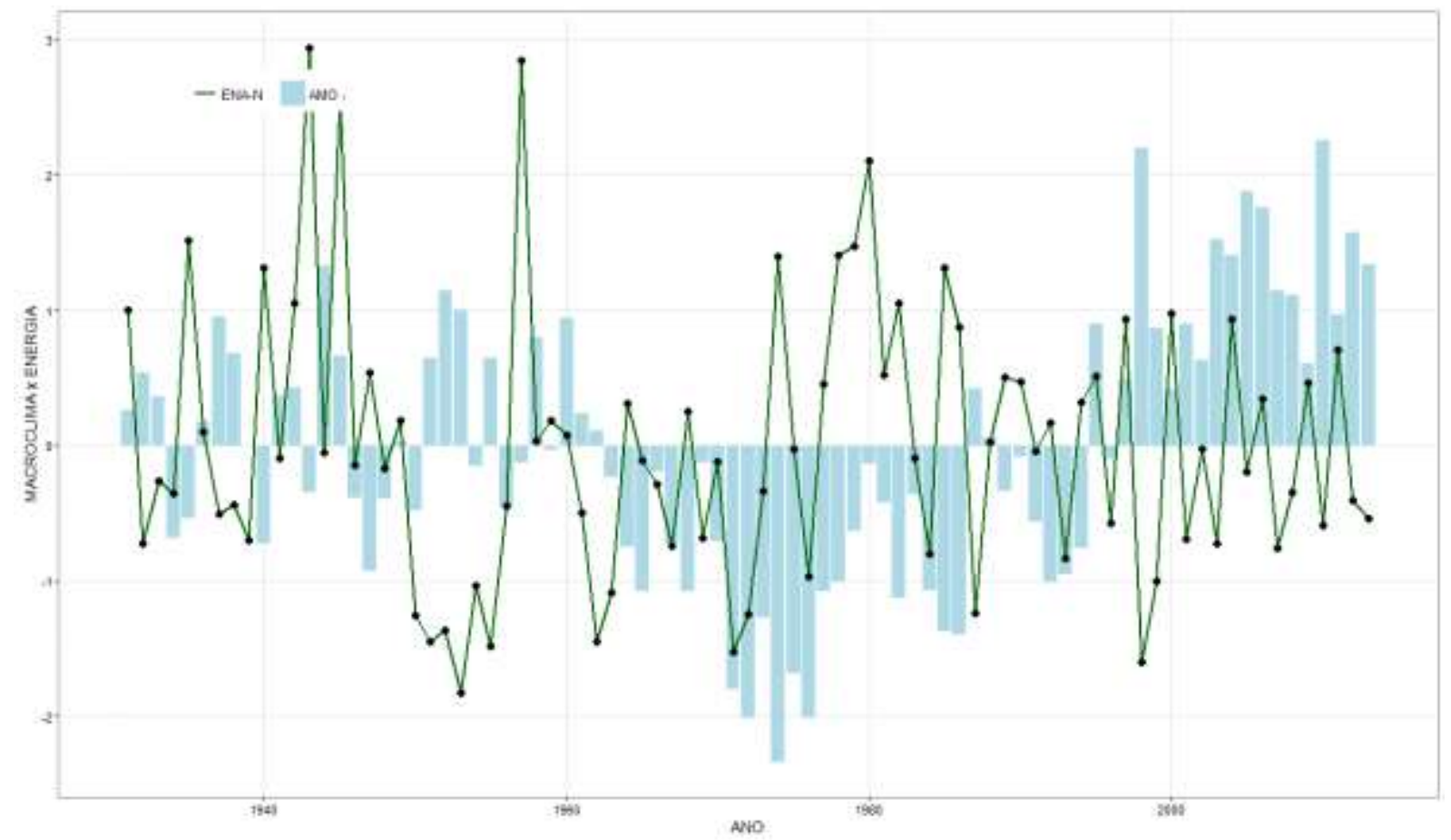

Figura 6-36 -Gráfico Índice AMO versos ENA N - Máximos Anuais normalizadas MWmédios 


\subsection{3 Índice Oscilação Decadal do Pacífico (PDO)}

O PDO compreende um índice calculado com base na região do Pacífico Norte, conforme descrito na seção 4.5 Índice de Oscilação Decadal do Pacifico (PDO), p. 140., Figura 6-37

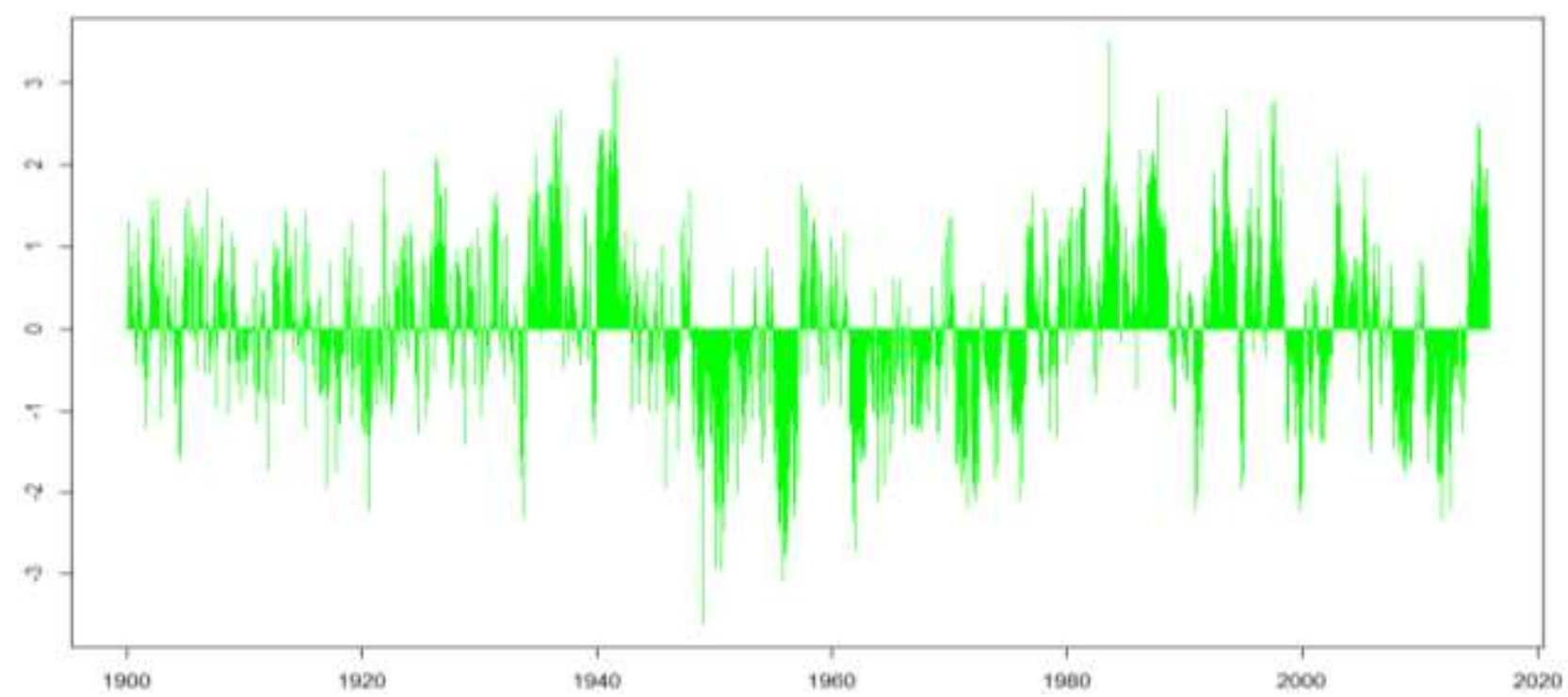

Figura 6-37 -Índice Decadal do Pacífico -PDO - Médias mensais normalizadas

Na Figura 6-38, apresentam-se a distribuição estatística mensal, com as medianas, os quartis e os máximos e mínimos mensais bem como a descrição estatística de PDO ao lado direito do gráfico. O intervalo entre o mínimo e o máximo de temperatura compreende 7,11 desvios padrões.

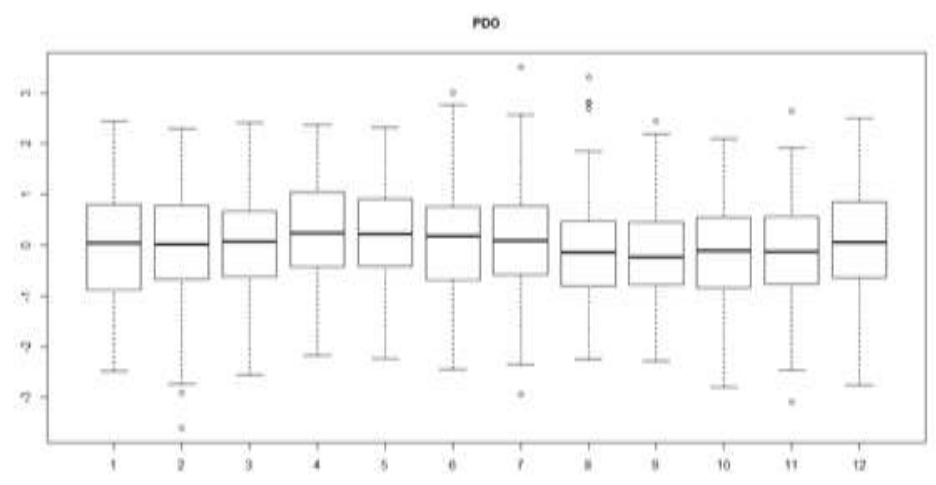

$\begin{array}{cc}\text { Mínimo: } & -3,6 \\ \text { 1. quartil: }^{\text {o }} & -0,7 \\ \text { Mediana: } & 0,0 \\ \text { Média: } & 0,0 \\ 3^{\circ} \text {. quartil: } & 0,7 \\ \text { Máximo: } & 3,5 \\ \text { Unidade: } & \text { Adimen. }\end{array}$

Figura 6-38 -Boxplot Índice PDO por mês e Descrição Estatística

Ao comparar graficamente as séries históricas anuais normalizada da ENA-SE (linha tracejada) e do PDO observa-se que em geral quando a ENA foi negativa a PDO também foi negativa e vice-versa, Figura 6-39. 


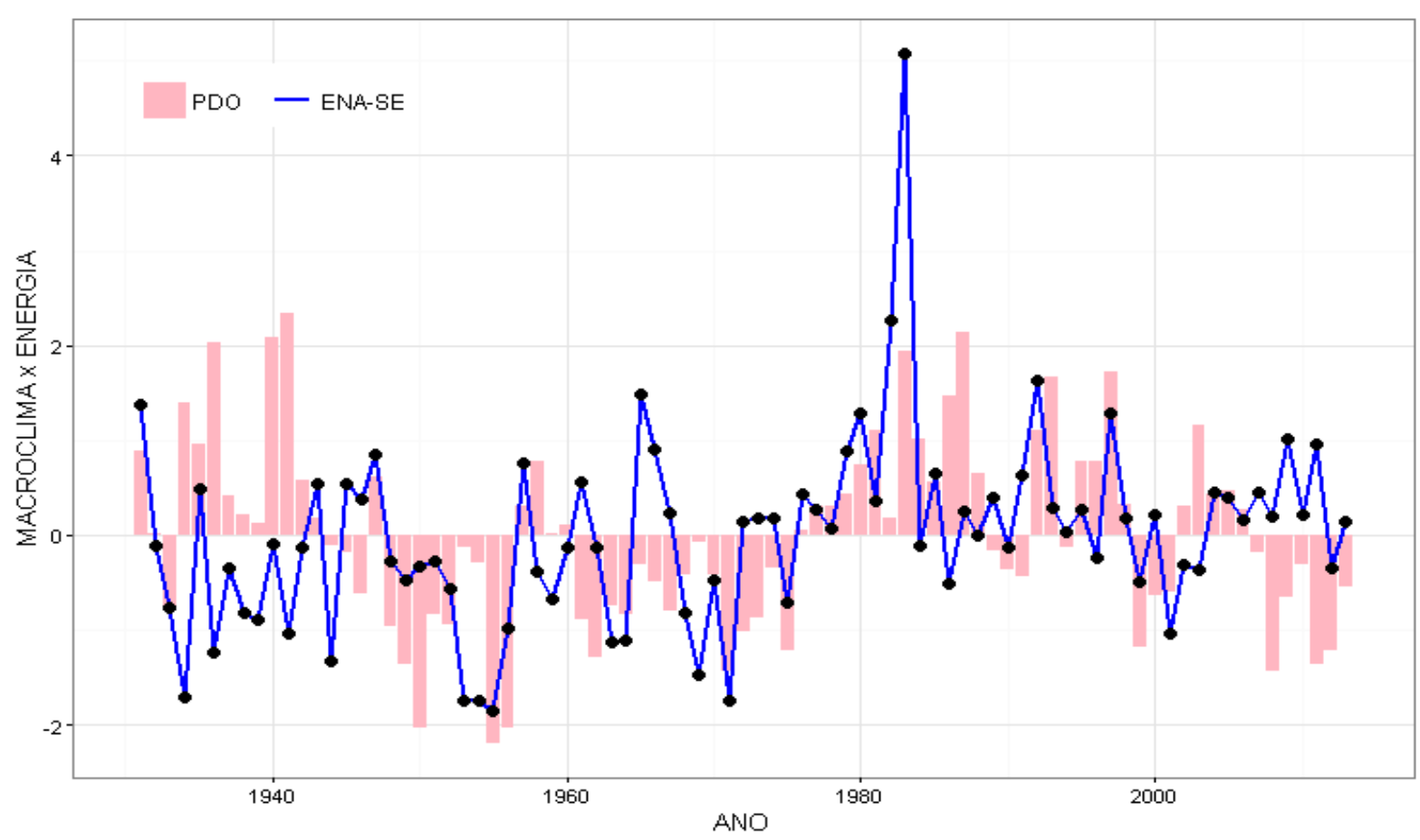

Figura 6-39 -Gráfico Índice PDO versos ENA SE - Máximos Anuais normalizadas MWmédios

O mesmo aplica-se ao Sul, Figura 6-40, Nordeste, Figura 6-41 e ao Norte, Figura 6-42. Posteriomente, são feitas análises de correlação como já mencionado.

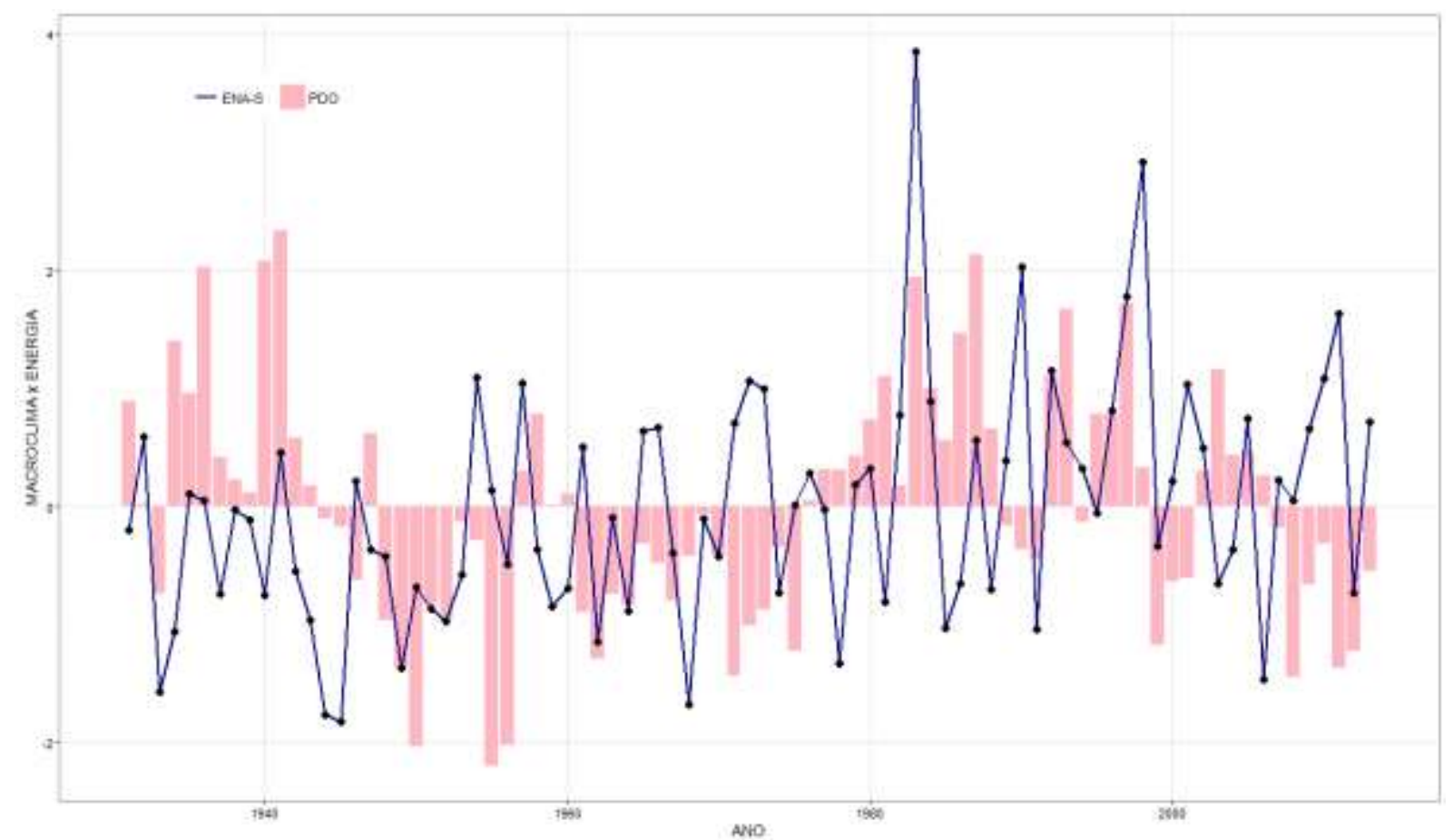

Figura 6-40 -Gráfico Índice PDO versos ENA S - Máximos Anuais normalizadas MWmédios 


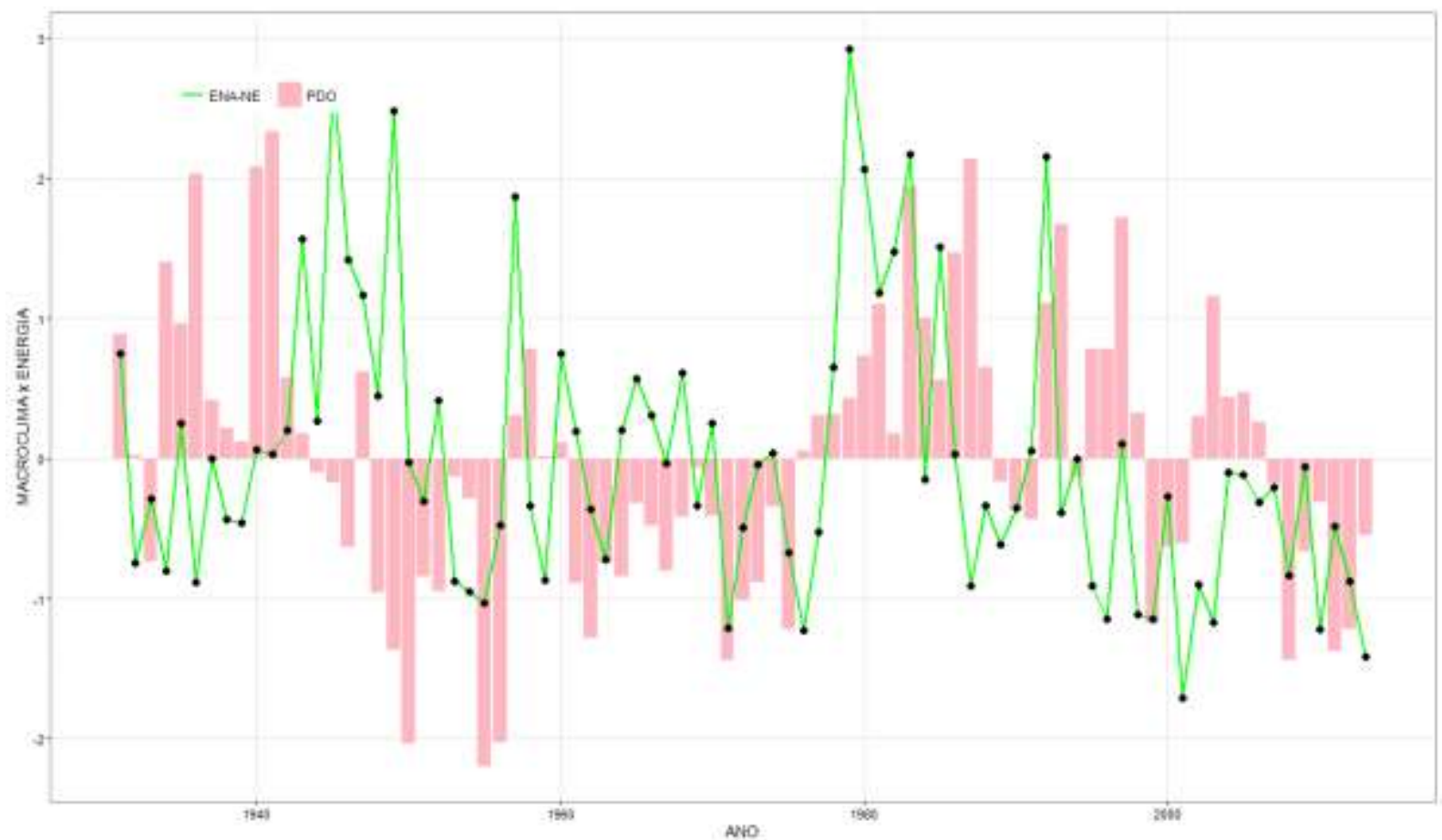

Figura 6-41 -Gráfico Índice PDO versos ENA NE - Máximos Anuais normalizadas MWmédios

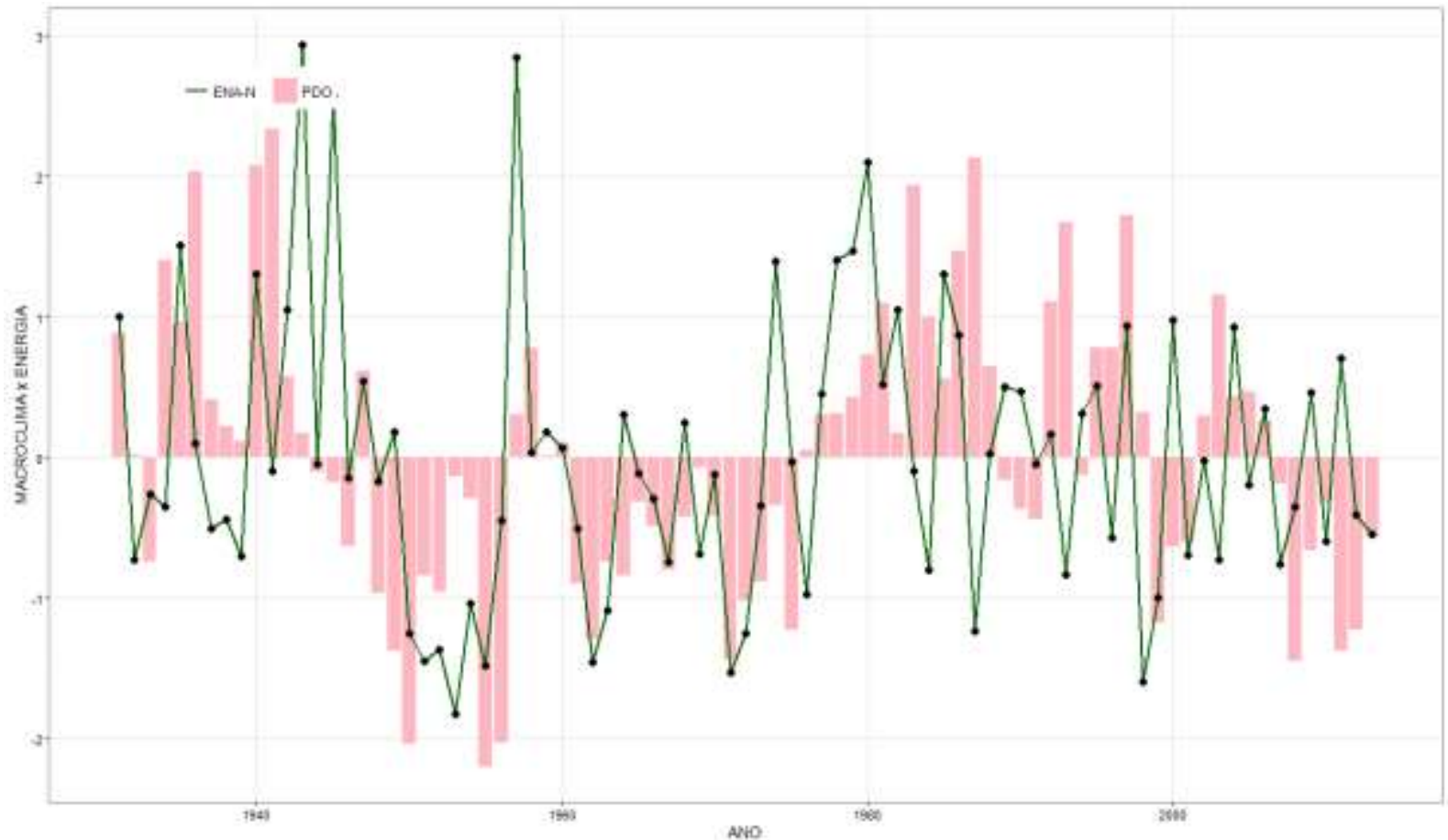

Figura 6-42 -Gráfico Índice PDO versos ENA N - Máximos Anuais normalizadas MWmédios 


\subsection{Matrix para Correlação das Séries históricas}

Nessa seção, são apresentadas análises de correlação feitas entre as variáveis escolhidas para o estudo. O objetivo é verificar se os dados de vazões ou ENA têm alguma relação direta com os dados climáticos. Para verificar a correlação foi utilizado o coeficiente de correlação de Pearson (PEARSON, 1901), que é apresentada na seção 1.1.1.1APÊNDICE C Correlação de Pearson, p. 319. Ademais, tendo em vista que a análise das correlações é feita sem adotar nenhum modelo físico, a aplicação do método de causalidade Granger (GRANGER, 1969, GREENE, 2003, FEIGL. 1953, p.408, Apud. GRILICHES \& INTRILIGATOR, 2007 GUJARATI e PORTER, 2009).fez-se necessária para identificar eventuais correlações espúrias (BOUDJELLABA et al., 1992).

As series históricas disponíveis são as amostras de dados utilizadas nas análises estatísticas. Na correlação de Pearson, o teste de hipóteses aplicado assume-se que $h_{0}: \rho=0$ e $h_{1}: \rho \neq 0$. No teste de causalidade Granger o teste de hipóteses (em que $\mathrm{h}_{0}=n \tilde{a} o$ existe causalidade Granger e $\mathrm{h}_{1}=$ existe causalidade Granger) assume uma distribuição F. Em ambos os testes ${ }^{102}$, para valores $\mathrm{p}$ menores que 0,05 rejeita-se $\mathrm{h}_{0}$.

Os gráficos são do tipo matricial, apresentam em sua diagonal principal o nome e o histograma das variáveis. A matriz é dividida, pela diagonal principal, em duas partes, conforme indicado pela Figura 6-43 abaixo:

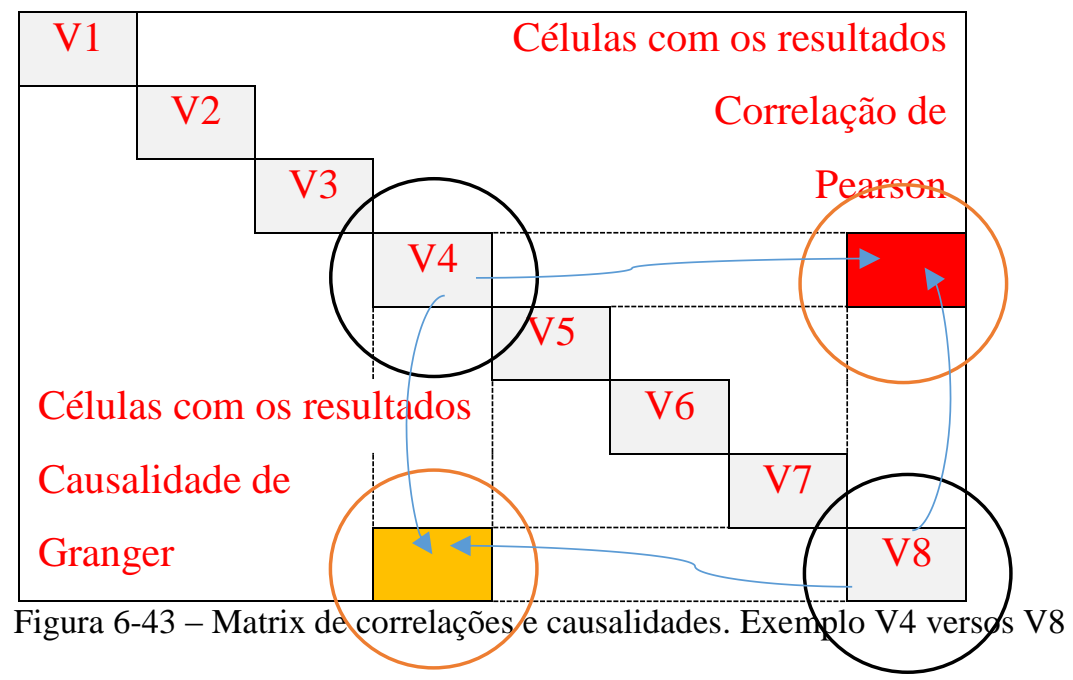

$\mathrm{Na}$ parte superior da diagonal são indicadas as medidas referentes à correção de Pearson (correlação $r$, p-valor e atraso para o qual ocorre a melhor correlação). Rejeita-se $\mathrm{h}_{0}$ caso valor

\footnotetext{
${ }^{102}$ Maiores detalhes sobre a teoria de correlação e causalidade de Granger ver no apêndice: 1.1.1.1APÊNDICE C Correlação de Pearson, p. 352 e 1.1.1.1APÊNDICE E 


\subsubsection{Correlação ENA-SE x variáveis Macroclimáticas}

Na Figura 6-46, a seguir, é verificam-se o resultado do teste de causalidade de Granger com os valores de $\mathrm{p}$, atrasos (lags) e correlação de Pearson associados à variável dependente ENASE. Nas células, que apresentam-se resultados entre variáveis independentes versos ENA-SE somente NINO1+2, apresenta-se correlação com seus valores na cor azul (rejeita $\mathrm{h}_{0}$ ) e as causalidades de Granger aceitáveis, conforme critérios de cores, explicados anterioremente, e bidirecionais. Para o Pacífico (PDO), apresenta-se teste de Granger aceitável frente à ENASE, porém a correlação foi abaixo de 0,5 .

Para o Atlântico (AMO), apresento-se causalidade de Granger unidirecional sendo caracterizado como causa da ENA-SE, porém, apresentam-se correlações abaixo de 0,5. No mesmo gráfico, a variável número de manchas solares (MANCHAS), apresentam-se resultados em vermelho, ou seja, não aceitáveis.

Para o índice ONI, não apresentam-se valores aceitáveis, exceto em relação ao AMO. Como o objetivo é verificar relações com ENA-SE, o ONI é ignorado. Para o gelo acumulado no Polo Antártico, apresentam-se valores de Granger aceitáveis, porém apesar da correlação ser acima de 0,5 seu p-valor correspondente foi de 0,23 o que está acima de 0,05 e, portanto, ho é aceita, lembrando $h_{0}: \rho=0$, ou seja, não há correlação, para um IC de $95 \%$.

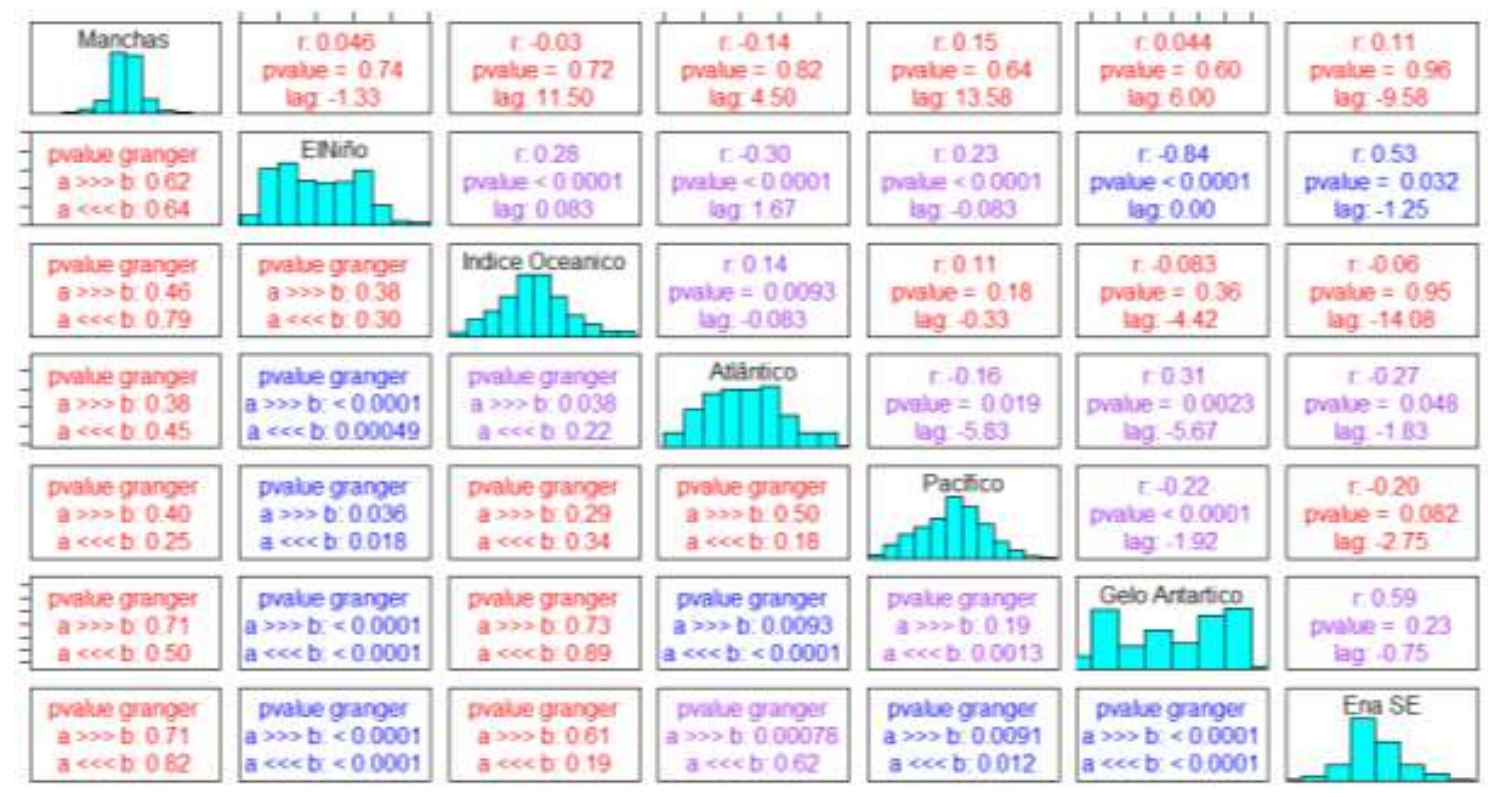

Figura 6-46 - Gráficos de relação entre as séries independentes e dependentes.

\subsubsection{Correlação Manchas Solares}

$\mathrm{Na}$ análise das variáveis de manchas solares são utilizadas como variáveis explicativas diferentes séries históricas como: número de manchas solares, onde a quantidade indica o número de machas observada na face do Sol; manchas solares por área, em que as machas são 
medidas por área de ocupação na face visível do Sol; manchas solares por área do hemisfério norte, as machas são medidas por área, considerando somente o hemisfério norte da face visível do Sol e manchas solares por área do hemisfério sul, em que as manchas são medidas, por área, considerando somente a região do hemisfério sul da face visível do Sol.

Observa-se no gráfico da Figura 6-47, MANCHAS(qtd, área, área norte, área sul) versos ENA-SE, ENA-S, ENA-NE, ENA-N. Entre as variáveis de manchas solares e as vazões das usinas nenhum dos gráficos apresentou correlação expressiva.

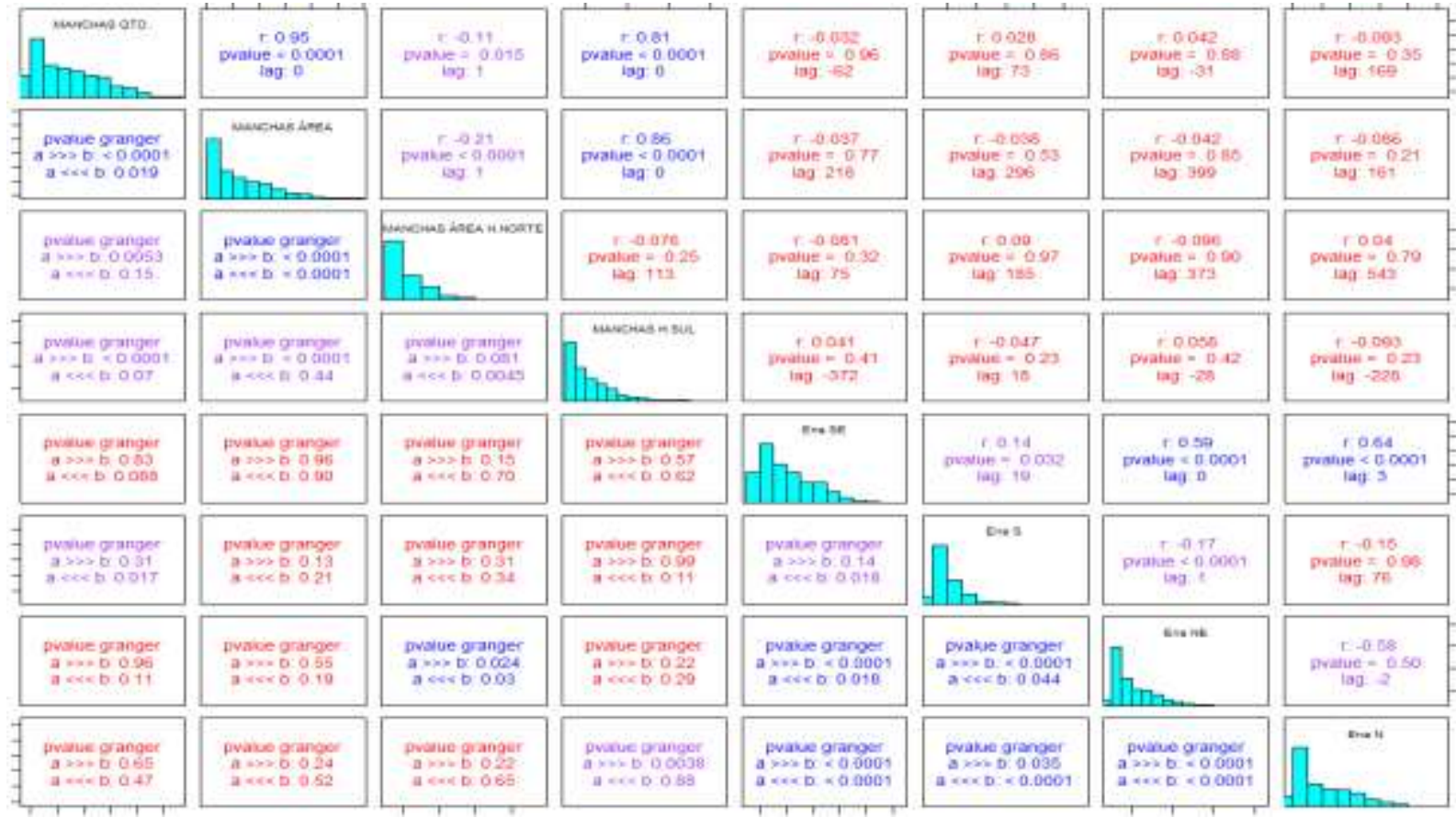

Figura 6-47 Correlação entre as variáveis quantidade de manchas solares versos regiões de ENA SE, S, NE e N 


\subsubsection{Correlação Índices de ONI e MEI ${ }^{104}$}

Os índices ONI e MEI estão relacionados com os fenômenos de ENOS, Figura 6-48. Observase nestes gráficos que entre as variáveis de índices de ONI e MEI e as vazões das usinas

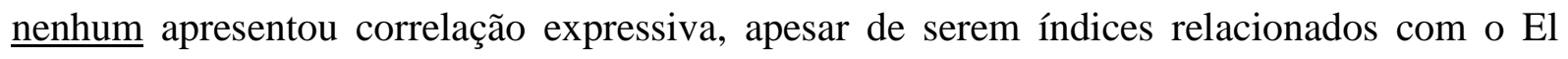
Niño. Na seção seguinte um resultado positivo para NINO1+2 e NINO3. ONI são calculados com NINO 3.4 e MEI utiliza em seus cálculos dados bimestrais e não mensais. Isso pode explicar a falta de correlações.

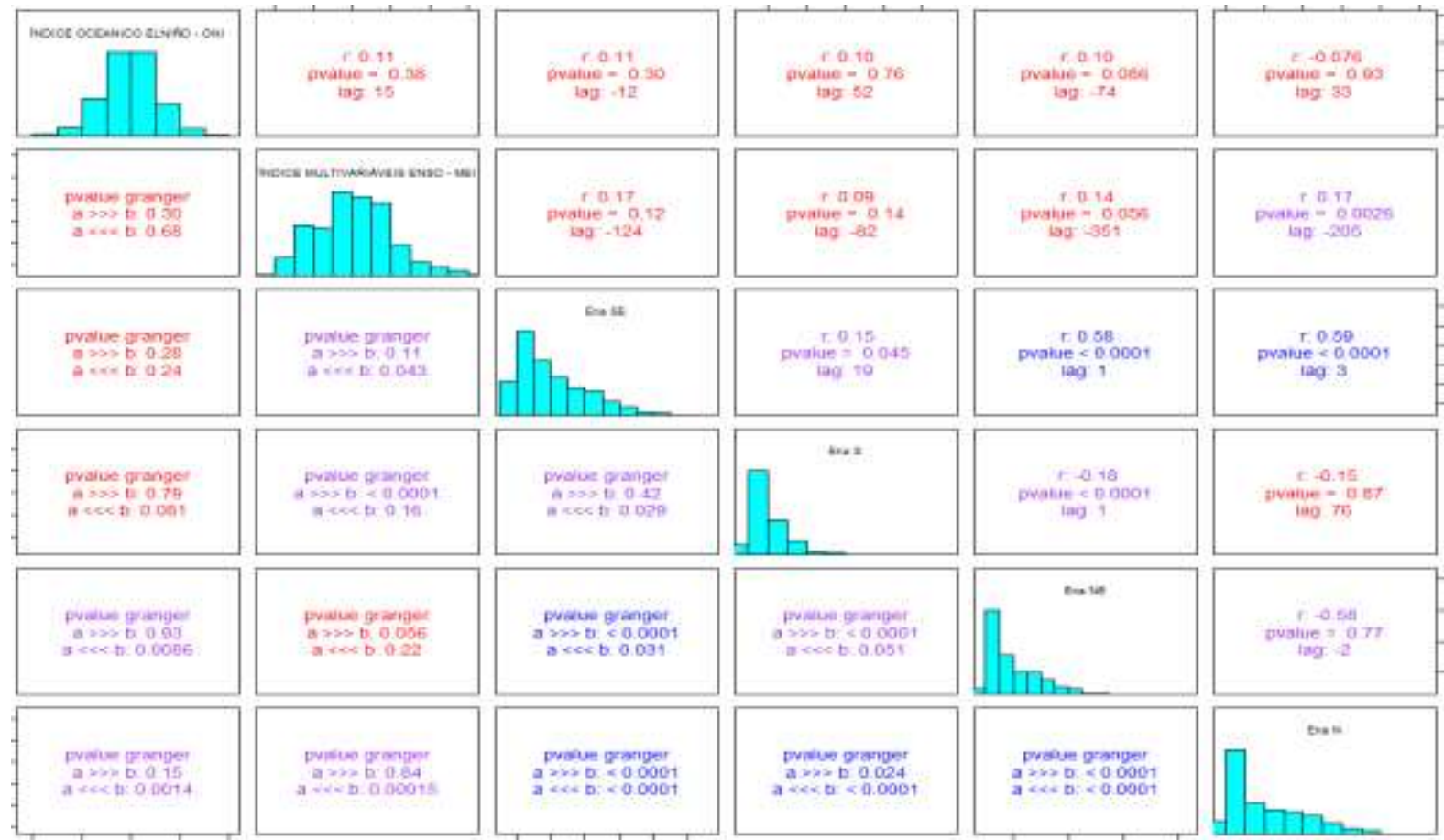

Figura 6-48 Correlação entre as variáveis de índice ONI e MEI de ENOS versos ENA Regiões SE, S, NE e N

104 Índice Oceânico EL NIÑO: 4.8 Índice Oceânico Niño (ONI), p. 110

Índice de Multivariáveis ENOS: 4.6 Índice Multivariado ENOS (MEI), p. 109 


\subsubsection{Correlação Índices de TSM EINiño 1+2 - 3 -4}

Observa-se nestes gráficos que entre as variáveis de TSM das áreas El Niño, NINO 1+2, r = 0,56 para ENA-SE, $r=0,53$ para ENA-ENE e $r=0,80$ para ENA-N; e NINO 3, $r=0,69$ para ENA-N, NINO3.4 e NINO4, todas as ENA $r<0,5$. Isso significa que a série de médias mensais de TSM mais próximas da América do Sul tem maior influência nas energia das regiões Sudeste e Sul, comparado as TSM mais próximas do continente Australiano.

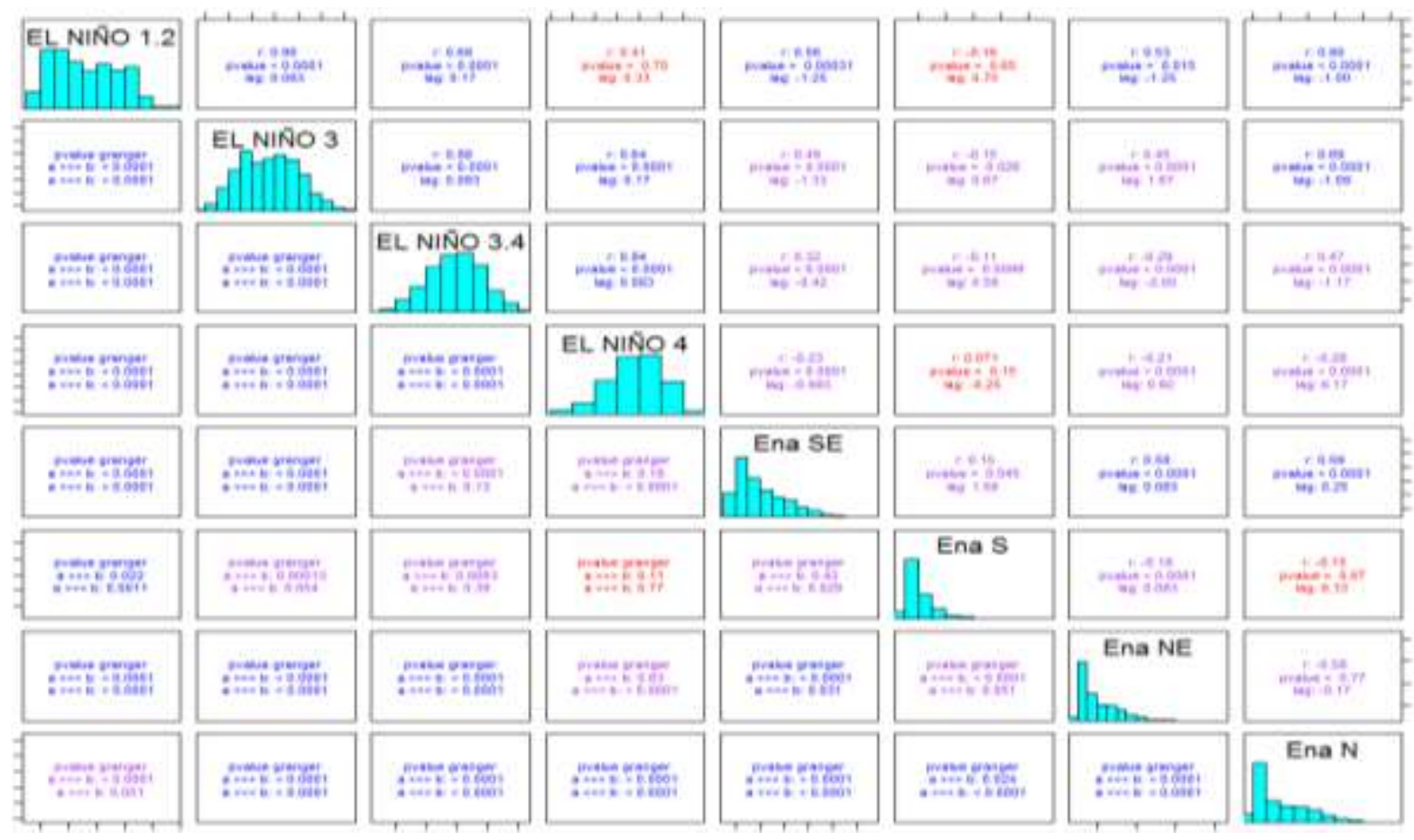

Figura 6-49 Correlação entre as variáveis de TSM áreas NINO1+2, 3, 3.4 e 4 versos regiões ENA SE, S, NE e N 


\subsection{5 Índices Oscilação Multidecadal do Atlântico e Decadal do Pacifico}

Observa-se neste gráfico (Figura 6-50) que entre as variáveis de TSM do AMO e PDO e as vazões das usinas escolhidas, somente PDO apresentou correlação com $r=0,13$, que apesar de ser menor que 0,5 , pode ser utilizado nos modelos, pois pode contribuir na explicação da ENA do Norte, além do que, apresentou p-valor 0,00022, que indica significância da correlação.

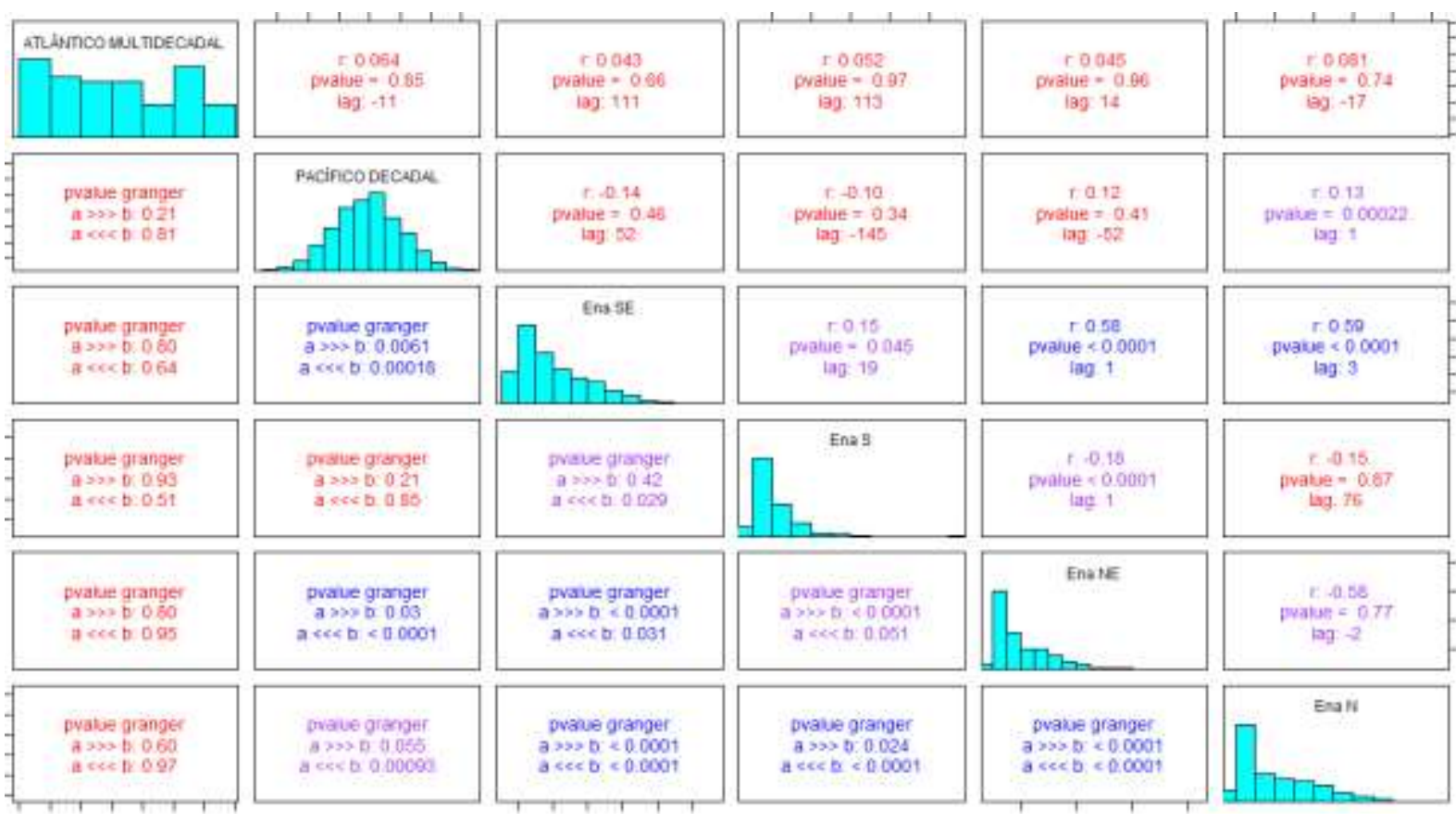

Figura 6-50 Correlação entre as variáveis Decadal do Pacífico e Multidecadal do Atlântico versos ENA Regiões SE, S, NE e N 


\subsection{6 Índices de Oscilação dos Polos}

Na Figura 6-51, observa-se no gráfico que entre as variáveis de índices dos Polos, e as vazões

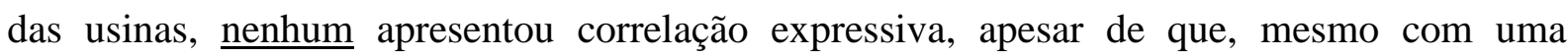
correlação $r=0,08$, o Índice de Oscilaçaõ do Ártico pode também ser utilizado nos modelo, afinal o evento ocorrido em Marabá, (MOLION, 2006), foi por causa de um sistema frontal, vindo do Norte, o qual provocou um grande pico de precipitações em 1980, como já vista nas análises preliminares.

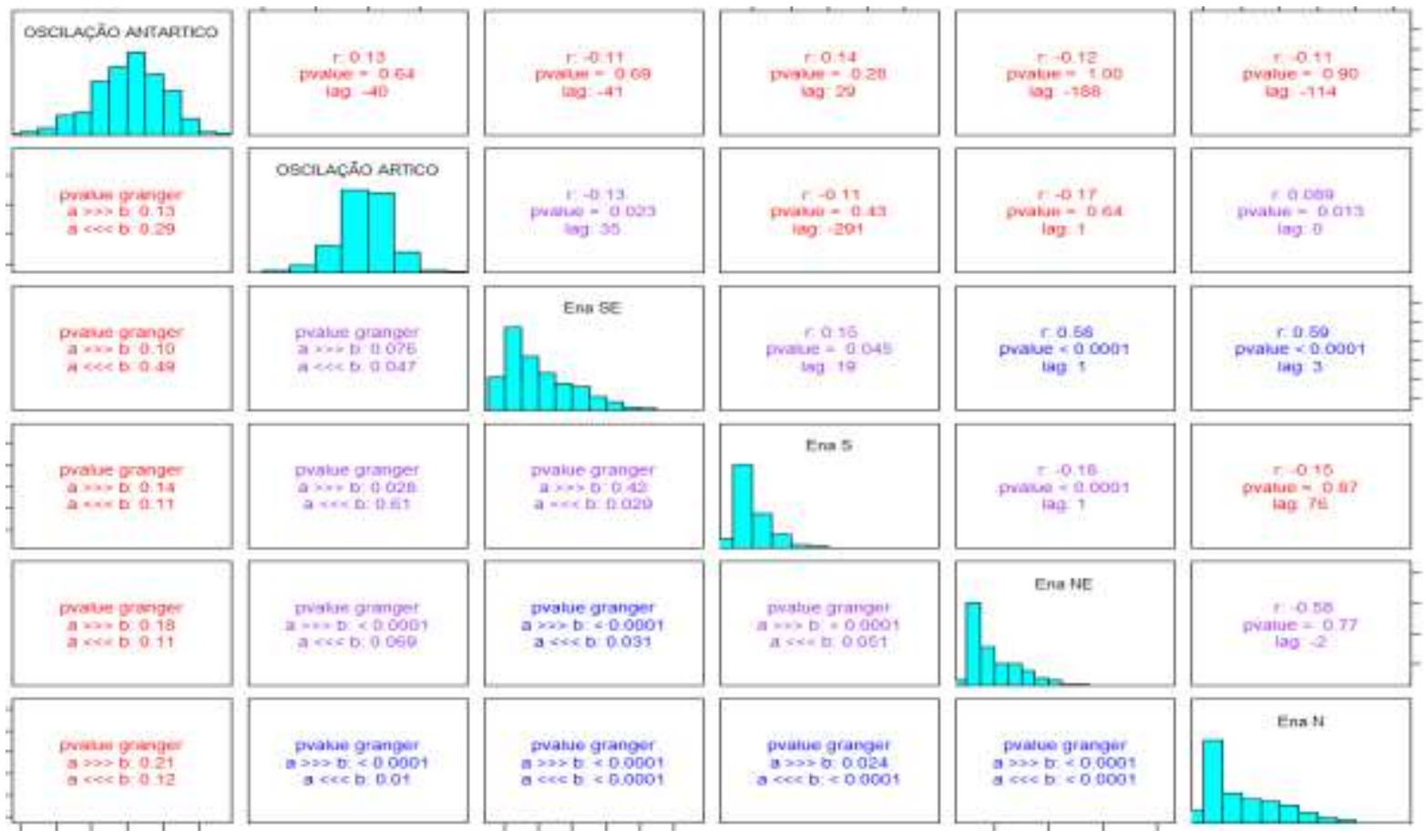

Figura 6-51 Correlação entre as variáveis dos polos Ártico / Antártico versos Regiões ENA SE, S, NE e N 


\subsection{7 Índice de acumulo de Gelo}

Na Figura 6-52, os índices de gelos referem-se a cinco grandes áreas do Polo Antártico e um índice agregado dos quais quatro apresentaram correlação e causalidade de Granger significativas (Bell Amun, Ross, W. Pacific, Wedell, porém alguns não apresentaram-se significativas. A área BellAmun é significativa com ENA SE e ENA N. A área Indian não é significativa com nenhuma das ENAs. A área Ross é significativa com ENA SE e ENA Norte. A área W. Pacific é significativa com ENA-SE e ENA-N. A área de BellAmin apresenta coeficientes de correlação de ENA-SE, $r=-0,74$, e ENA-N, $r=0,79$. A área de Ross apresenta, ENA-SE, $r=-0,83$, ENA-NE, 0,52, e, ENA-N, r=-0,87. A área de W. Pacific apresenta, ENA-SE, r=-0,78, ENA-NE, r=0,52, e ENA-N, r= -0,87. A área Wedell apresenta, ENA SE, $r=-0,80$, apesar do granger $p=0,9$ e ENA Norte, $r=-0,85$. Estas séries mostram que o Polo Sul influência as ENA, porém há o problema de ter um atraso de dois anos na sua publicação na Internet. Para simulações de previsão retroativa, pode ser útil.

\begin{tabular}{|c|c|c|c|c|c|c|c|c|c|}
\hline Antartis & $\begin{array}{l}\text { rosel } \\
\text { manesaet } \\
\text { act }\end{array}$ & 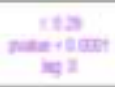 & $\begin{array}{c}1020 \\
\text { mane } \\
\text { mets }\end{array}$ & 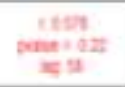 & 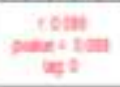 & $\begin{array}{c}149 \\
\text { manes } \\
\text { is }\end{array}$ & $\begin{array}{c}c a t \\
\text { pous }=3 x \\
\text { an } 4\end{array}$ & $\begin{array}{c}1210 \\
\text { whers ae } \\
\text { aq. }\end{array}$ & $\begin{array}{c}r \text { en } \\
\text { nans ox } \\
\text { ing } 2\end{array}$ \\
\hline 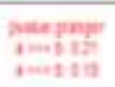 & BetA & $\begin{array}{l}\text { cals } \\
\text { moancain } \\
\text { is ? }\end{array}$ & 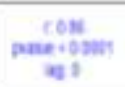 & 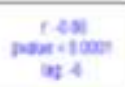 & 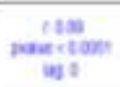 & 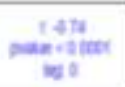 & $\begin{array}{c}\text { tax } \\
\text { xasosiam } \\
\text { in } x\end{array}$ & 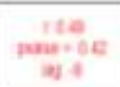 & 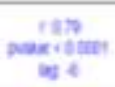 \\
\hline 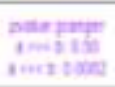 & 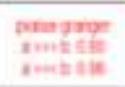 & Indian & $\begin{array}{c}\text { tite } \\
\text { pones } \\
\text { ny }\end{array}$ & $\begin{array}{c}\text { retit } \\
\text { manevde } \\
\text { a da }\end{array}$ & $\begin{array}{c}\text { rater } \\
\text { punats } \\
\text { is }\end{array}$ & 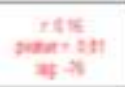 & 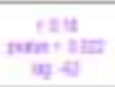 & 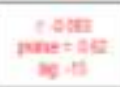 & 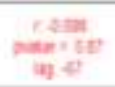 \\
\hline 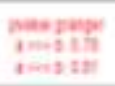 & 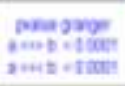 & 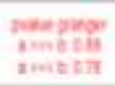 & Ross & 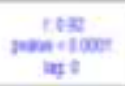 & $\begin{array}{c}\text { retu } \\
\text { mentetion } \\
\text { og a }\end{array}$ & 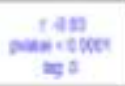 & 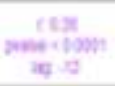 & 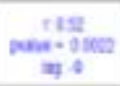 & $\begin{array}{c}\text { tas } \\
\text { sastiven } \\
\text { का }\end{array}$ \\
\hline 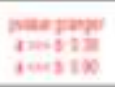 & 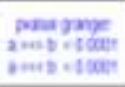 & 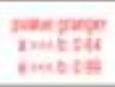 & 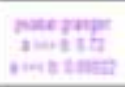 & $\begin{array}{l}\text { W.Pacife } \\
\text { H.r. }\end{array}$ & 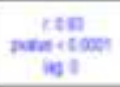 & 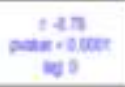 & 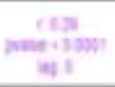 & 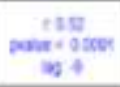 & 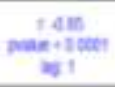 \\
\hline $\begin{array}{l}\text { Nowe ywy } \\
\text { two b it } \\
\text { ines ift }\end{array}$ & 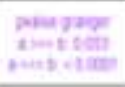 & 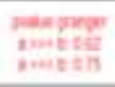 & 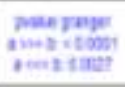 & 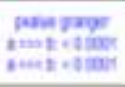 & & 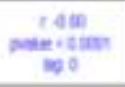 & 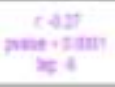 & $\begin{array}{c}\operatorname{rin} \\
\operatorname{man}+20 \\
24\end{array}$ & 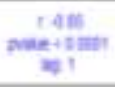 \\
\hline 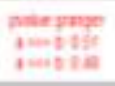 & 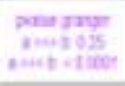 & 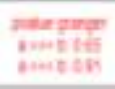 & 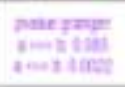 & 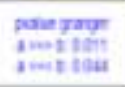 & 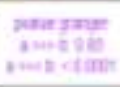 & Ena SE & 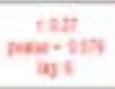 & $\begin{array}{c}\text { rade } \\
\text { peonesicer } \\
\text { ing }\end{array}$ & 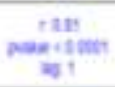 \\
\hline 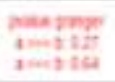 & 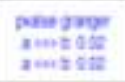 & 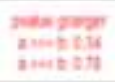 & 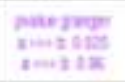 & 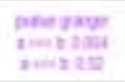 & 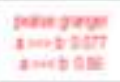 & 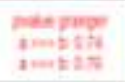 & Eea S & 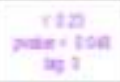 & 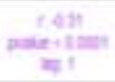 \\
\hline 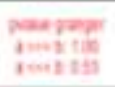 & 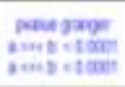 & 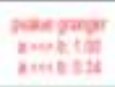 & 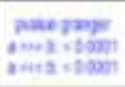 & 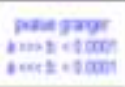 & 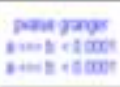 & 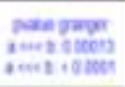 & 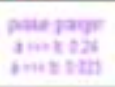 & Ena ke & $\begin{array}{l}\text { cese } \\
\text { noter } \\
\text { ing }\end{array}$ \\
\hline 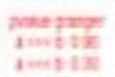 & 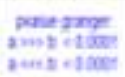 & 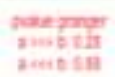 & 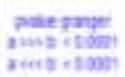 & 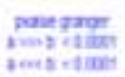 & 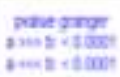 & 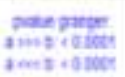 & 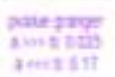 & 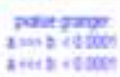 & Era N \\
\hline
\end{tabular}

Figura 6-52 Correlação entre as regiões do polo Antártico versos Regiões ENA SE, S, NE e N 


\subsubsection{ENA de Diferentes Bacias}

Na Figura 6-53, ao correlacionar as vazões das ENA de regiões versos as ENA de Bacias, ENA regiões, para a ENA-SE apresenta com ENA-B-PR, r=0,97, com ENA-NE, $r=0,59$, com ENA-SF, $r=0,6$, com ENA-PA, $r=0,58$, ENA-N, 0,64 e ENA-TC, 0,61, exceto ENA-S, $\mathrm{r}=0,15$, todas as demais apresentaram correlação com $r>0,5$. Isso pode explicar que há fenômenos que influência a região Sudeste, como é o caso das ZCAS, e todas as regiões, do país, com menor grau a região Sul, como é o caso dos sistemas frontais.

A ENA-NE apreseta o, em módulo, $r>0,5$ frente todas demais, exceto região Sul que o $r<0,5$; ENA-N, resultado parecido com a ENA-SE.

ENA-B-PR, ENA-SF, ENA-TC são influenciadas pelo fenomeno de precipitação das ZCAS.

ENA-S é influenciada pelas zonas de instabilidade e sistemas frontais, devido a proximidade com o Polo Sul, recebe maior número de sistemas frontais, e portanto, não é aderente as demais regiões do Brasil.

\begin{tabular}{|c|c|c|c|c|c|c|c|}
\hline ENA-SE & $\begin{array}{c}\text { c.0.97 } \\
\text { pralue < < oon } \\
\text { lag } 0\end{array}$ & $\begin{array}{c}f 0.15 \\
\text { pvalue }=0.022 \\
\text { tag } 19\end{array}$ & $\begin{array}{c}r .059 \\
\text { pwatue }<0.0004 \\
\text { lag } 0\end{array}$ & $\begin{array}{c}<0.60 \\
\text { praiue }<0.0001 \\
\log 0\end{array}$ & $\begin{array}{l}\text { t. 0.56 } \\
\text { pvabue < }<00001 \\
\text { lag } 2\end{array}$ & $\begin{array}{l}\text { r. } 0.64 \\
\text { pvatue <.0.0001 } \\
\text { lag } 3\end{array}$ & $\begin{array}{c}\text { rost } \\
\text { pvalun }=0 \text { as } \\
\text { lag a }\end{array}$ \\
\hline $\begin{array}{l}\text { pvake granger } \\
\text { a }>2>\text { in }<0,0001 \\
a<e c 0<0,0001\end{array}$ & ENA-B-PR & $\begin{array}{c}\text { ro } 015 \\
\text { pvalue }=0.95 \\
\text { lag } 19\end{array}$ & $\begin{array}{l}r 0.52 \\
\text { pvatue }<0000 \mathrm{Dt} \\
\text { lag } 0\end{array}$ & $\begin{array}{l}r 0.04 \\
\text { praiue }<0.0001 \\
\text { lag } 0\end{array}$ & $\begin{array}{l}\text { ro.5t } \\
\text { pratue < } 0.0001 \\
\text { tag } 2\end{array}$ & $\begin{array}{l}\text { T. } 0.56 \\
\text { pvahue }<0.000 \text { s } \\
\text { lag } 9\end{array}$ & $\begin{array}{c}r 0.54 \\
\text { pvakut }=0.40 \\
\text { iag. } 3\end{array}$ \\
\hline 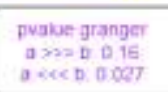 & $\begin{array}{l}\text { pvane granger } \\
\text { a >ss o o } 62 \\
\text { a sec b. } 0 \text {. } 0075\end{array}$ & ENA-S & $\begin{array}{c}r=18 \\
\text { pvatue }=0.000 \text {. } \\
\text { iag } 1\end{array}$ & $\begin{array}{l}r-0,111 \\
\text { pratiue }<0 \text { opor } \\
\text { lag } 1\end{array}$ & $\begin{array}{c}r-0.16 \\
\text { pvalue }=0.023 \\
\operatorname{lag} 2\end{array}$ & $\begin{array}{c}r-0.15 \\
\text { pustue }=091 \\
\text { lag } 76\end{array}$ & 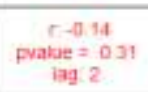 \\
\hline $\begin{array}{l}\text { pvalue granger } \\
\text { a >s> b: }<0 \text { 0001 } \\
\text { a cec b } 0.013\end{array}$ & $\begin{array}{l}\text { pvalue granger } \\
\text { a }>>20 \text { o } 0.0004 \\
a<c<b: 0.00016\end{array}$ & 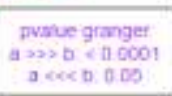 & ENA-NE & $\begin{array}{l}11.00 \\
\text { praiue }=0.0001 \\
\operatorname{lag} 0\end{array}$ & $\begin{array}{l}r-0,04 \\
\text { pratue }<0.0001 \\
\text { tag }-3\end{array}$ & $\begin{array}{c}x-0 \leq 8 \\
\text { praiue }=0.54 \\
\text { tag }-2\end{array}$ & $\begin{array}{c}r-0.57 \\
\text { pvatue }<0.0001 \\
\operatorname{lag}-2\end{array}$ \\
\hline $\begin{array}{l}\text { pvakue granger } \\
\text { a }>>>\text { b }<0.0001 \\
\text { a }<<<\text { b } 0.020\end{array}$ & $\begin{array}{l}\text { pvave granger } \\
a \gg \rightarrow b: 0.0001 \\
a \ll<b: 0.00051\end{array}$ & 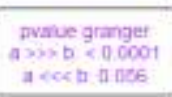 & $\begin{array}{l}\text { pvave granget } \\
a \geqslant>>b<0.0001 \\
a<<<b<0.0001\end{array}$ & ENA SF & $\begin{array}{c}r-0.05 \\
\text { pwatue }<0.0001 \\
\operatorname{lag}-3\end{array}$ & $\begin{array}{c}\text { t- }-06 \\
\text { pvatue }=0.68 \\
\text { tag }-2\end{array}$ & $\begin{array}{c}r=0.57 \\
\text { pvake }<0.000+ \\
\text { lag }-2\end{array}$ \\
\hline $\begin{array}{l}\text { pvake granger } \\
a>0>\text { b }<0.0001 \\
a<<<b: 0.0001\end{array}$ & $\begin{array}{l}\text { pvane granger } \\
\text { a } \gg>0<0.0001 \\
\text { a } \ll<0<0=0.000 t\end{array}$ & $\begin{array}{l}\text { pvave granget } \\
\text { a }>>0 \text { b a } 00012 \\
\text { a cce th of } .668\end{array}$ & $\begin{array}{l}\text { pvave granget } \\
a \geqslant>b<<0.0001 \\
a<<<b<0.0001\end{array}$ & $\begin{array}{l}\text { pvatue granger } \\
a \gg>b<0.0001 \\
a \ll<<=0.000 \text { t }\end{array}$ & ENA-PA & $\begin{array}{c}+0.112 \\
\text { pvalue }<0.0001 \\
\text { lag } 1\end{array}$ & $\begin{array}{c}r 0.67 \\
\text { pvake }<0 \text {. oont } \\
\text { lag } 0\end{array}$ \\
\hline $\begin{array}{l}\text { puake granger } \\
a \geqslant 2>b<0<001 \\
a<<<b ;<00001\end{array}$ & $\begin{array}{l}\text { pvave granger } \\
a \gg r 0<<0.0001 \\
a \ll<0<0.0001\end{array}$ & $\begin{array}{l}\text { pvave granger } \\
a \gg b \quad 0.027 \\
a \ll<b<0.0001\end{array}$ & $\begin{array}{l}\text { pwave granger } \\
a \geqslant s>b<0.0001 \\
a<<<b<0.0001\end{array}$ & $\begin{array}{l}\text { pvare granger } \\
a \gg m b<0.0001 \\
a \ll b: 0.0001\end{array}$ & $\begin{array}{l}\text { pvave granger } \\
a>2>0<00001 \\
a<<<b<0.0001\end{array}$ & ENA-N & $\begin{array}{c}c 000 \\
\text { pvalue }<0 \text { oont } \\
\text { lag } 0\end{array}$ \\
\hline $\begin{array}{l}\text { pwatue granger } \\
a \geqslant 2>b<0.0001 \\
a<6<b<0,0001\end{array}$ & $\begin{array}{l}\text { pvave granger } \\
a m b<<0.0001 \\
a<e<b: 0.0001\end{array}$ & $\begin{array}{l}\text { pvatue granger } \\
a>>>b<0.0001 \\
a<<<0.0001\end{array}$ & $\begin{array}{l}\text { Dvave granger } \\
a \geqslant>b<<0.0001 \\
a<<<b<0.0001\end{array}$ & $\begin{array}{l}\text { pvakue granger } \\
a \geqslant \infty \mathrm{b}<0.0001 \\
\mathrm{a}<6<\mathrm{b}<0.0001\end{array}$ & $\begin{array}{l}\text { pvaiue granger } \\
a \geqslant 2>0<0,0001 \\
a<<<b<0,0001\end{array}$ & $\begin{array}{l}\text { pvaue gravger } \\
a>s>b<0<0001 \\
a<<<b<0,000 t\end{array}$ & ENA TC \\
\hline
\end{tabular}

Figura 6-53 Correlação entre as variáveis de ENA agregada por bacias e vazões das Usinas das Bacias do Paraná, São Francisco, Tocantins e Parnaíba. 


\section{CAPÍtULO 7}

\section{MODELOS DE ENA DAS REGIÕES E}

\section{RESULTADOS}

Neste capítulo, é aplicado o modelo SARIMAX apresentado no Capítulo 6, em cada uma das seguintes fases 1 - Especificação, 2 - Identificação, 3 - Estimação, 4 - Verificação ou diagnóstico e 5 - Validação Cruzada; e são executadas para as quatro regiões ou submercados de energia do SEB (SE, S, NE, N) e descritas nas subseções seguintes.

As variáveis macroclimáticas que apresentaram valores de p-valor e correlação de Pearson aceitáveis nos gráficos de correlação elaborados na seção 6.5 Matrix para Correlação das Séries históricas, p 194, foram utilizadas para cada uma das regiões. Os dados são organizados em dois conjuntos: Dados das variáveis dependentes do modelo que são series históricas de ENA das regiões com o período de jan.1931 a dez.2014 e dados das variáveis explicativas do modelo de regressão dinâmica, as séries históricas das variáveis macroclimáticas escolhidas, conforme os resultados obtidos para cada região, com o período de jan. 1931 a dez. 2014.

Os dados de treinamento compreendem o período entre 1978 e 2008, pois para os dados anteriores a 1978 as variáveis macroclimáticas podem apresentar problemas, uma vez que as tecnologias de medições e reanálise anteriores a esse ano eram menos sofisticadas que as tecnologias recentes ${ }^{105}$, já, os dados de teste compreendem o período de 2009 a 2013.

Não foi utilizado o ano de 2014, porque os testes iniciais foram feitos até 2013 e para efeito de comparação foi mantido 2013 para todos.

Na Figura 7-1, apresentam-se que em tempos de El Niño, os meses de junho a agosto, dezembro a fevereiro, as regiões do Sudeste e Nordeste ficam mais quentes, e as regiões Sul e Sudeste mais chuvosas. Com a passagem dos sistemas frontais, o calor no continente e a umidade vinda da Amazonia ou do Oceano Atlântico, ou ora de ambos, formam as zonas de umidade, onde a ZCAS é a que apresenta maior persistência. Para os meses de dezembro a fevereiro, as regiões Norte e Nordeste ficam mais secas. Esses padrões indicam a importância do estudo desses fenômenos e sua relação com a oferta de energia.

\footnotetext{
${ }^{105}$ Essa informação foi passada pelo Doutor Cristiano Prestrelo de Oliveira, em conversa informal sobre seu trabalho (KAYANO, 2009). Também optou-se pelo ano de 1978 para ter-se um conjunto de dados para treinamento de 30 anos, 1978 a 2008.
} 


\section{EL NIÑO - JUNHO - AGOSTO}

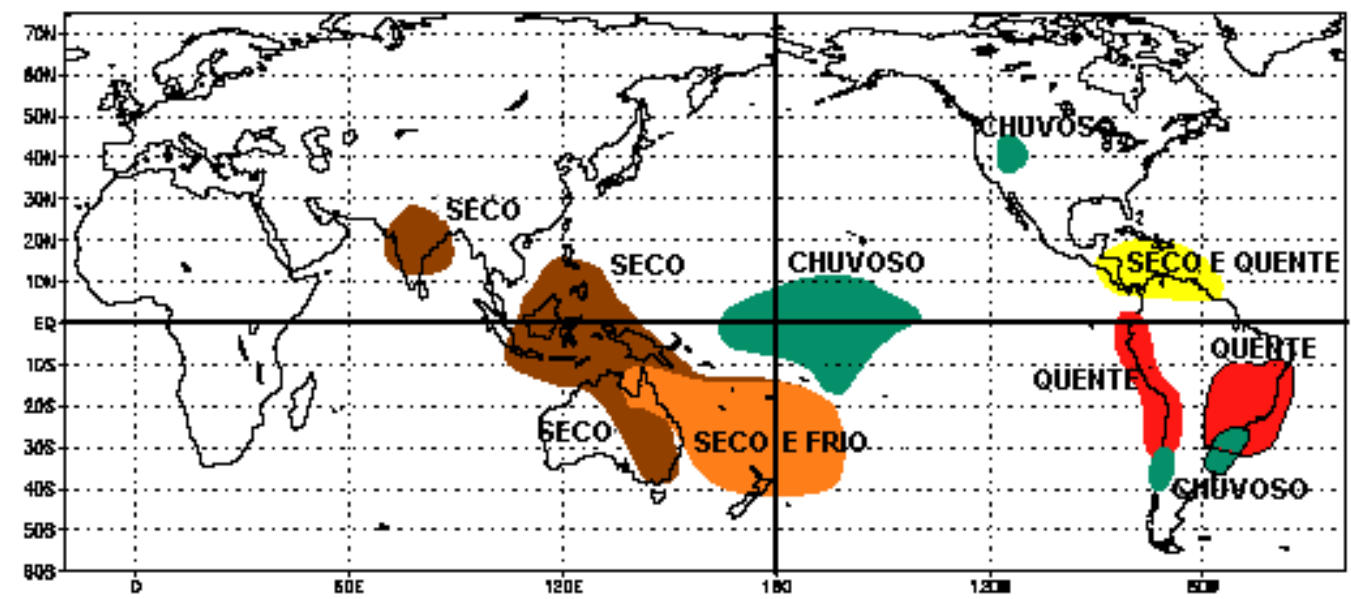

\section{EL NIÑO - DEZEMBRO - FEVEREIRO}

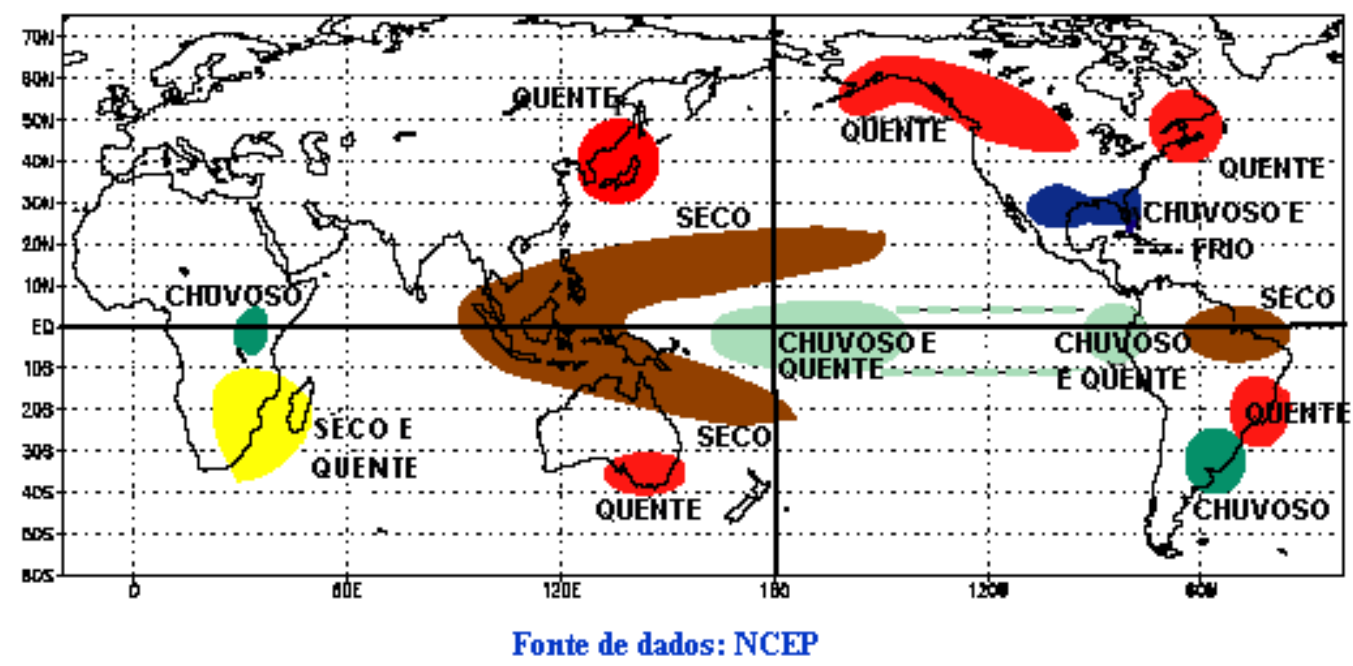

Figura 7-1 - Efeitos conhecidos do fenômeno El Niño. Fonte: http://enos.cptec.inpe.br/

\subsection{Modelo SARIMAX ENA-SE}

\subsubsection{Especificação}

Ao examinar os gráficos, os mapas e as análises de séries históricas escolheram-se as variáveis explicativas NINO1+2, AMO, PDO, TSA, SWA, EEP, X70E, X120E, X40W, AO e SAM frente variável dependente ENA do Sudeste (Figura 7-2). Essa varáveis são descritas no CAPÍTULO 4 FONTES DE DADOS MACROCLIMÁTICOS, p. 133. 


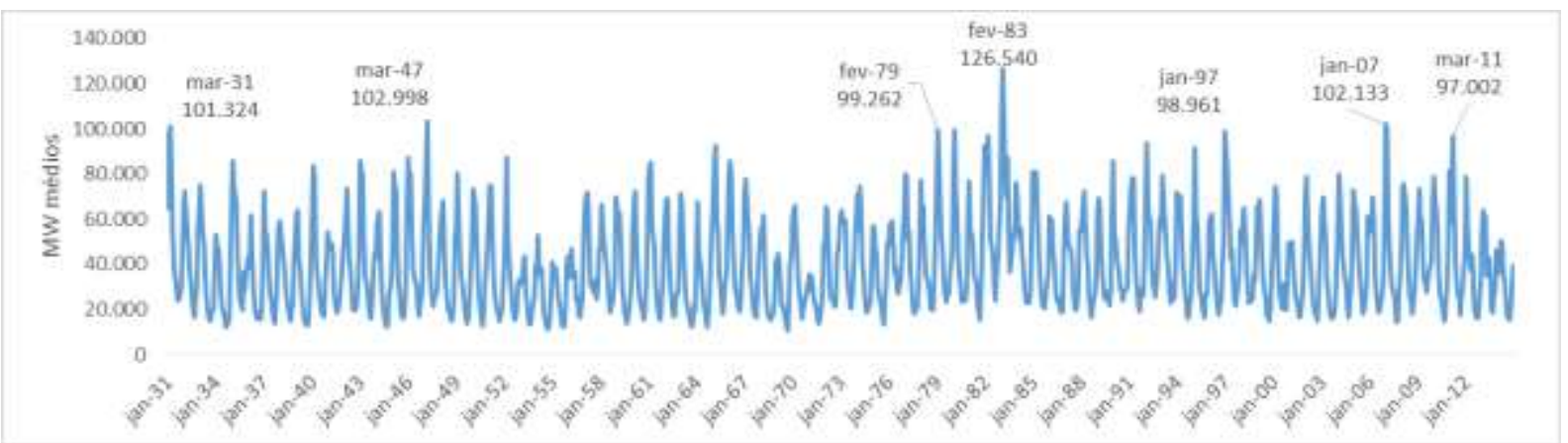

Figura 7-2 - Série Histórica ENA Sudeste expressas em MW Médios- Período de Jan/1931 a Dez/2014

Na Figura 7-3, apresenta-se a série histórica que exibe sazonalidade e tendências localizadas, que são explicadas pela dinâmica sazonal das chuvas e a localização geográfica das bacias hidrográficas, na região que integram o submercado do Sudeste onde, geralmente, há formação das ZCAS (Figura 3-29 a.). Com o objetivo de estabilizar a variância e atender as suposições do modelo, foi aplicada uma transformação logarítmica.

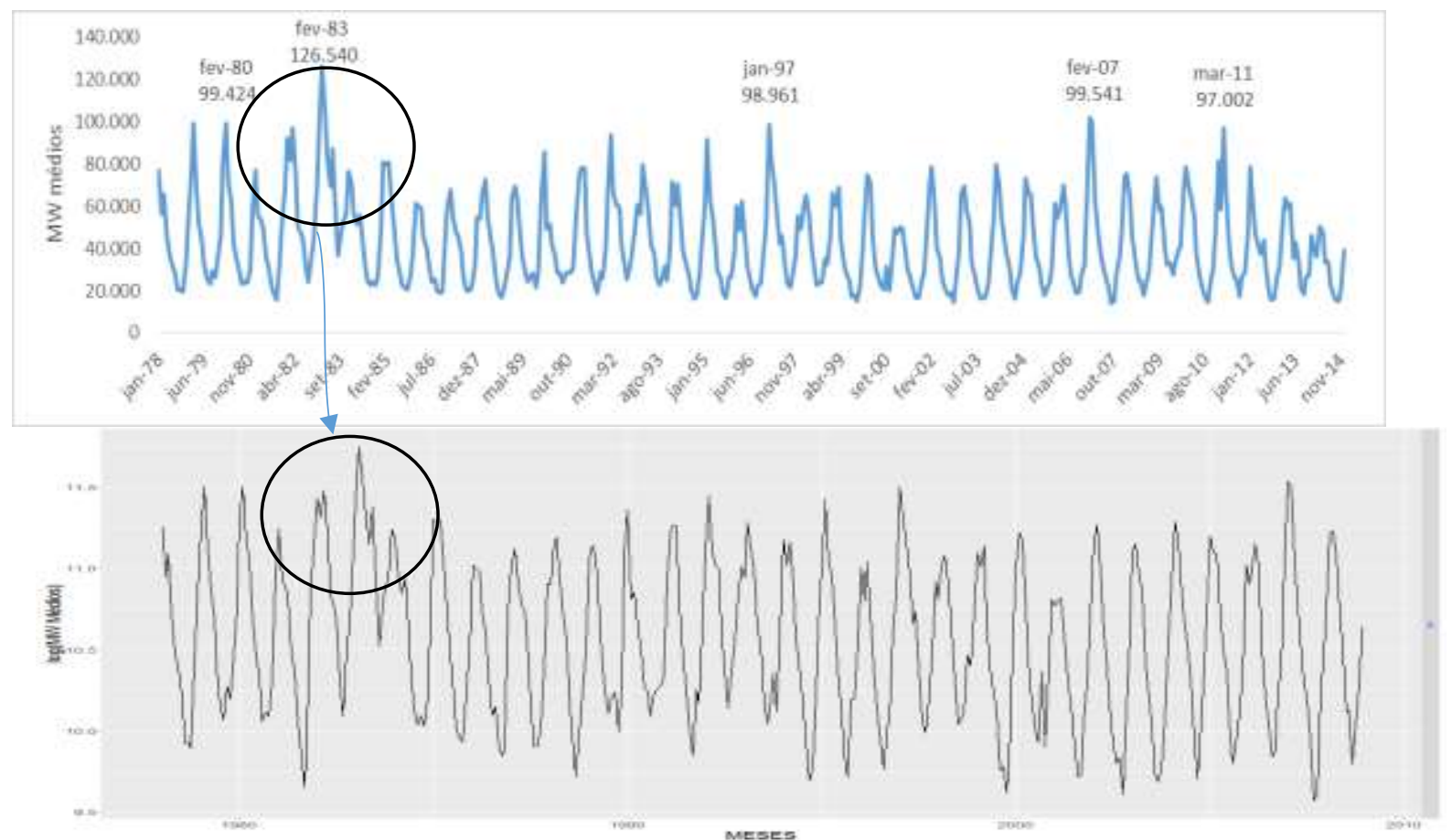

Figura 7-3 - Série Histórica em MW Médios ENA Sudeste e transformada logarítmica dos dados- Período de Jan/1978 a Dez/2008 106

106 Comentário Prof. Molion: "Tranformação de log reduz valores altos e aumenta os valores baixos adjacentes". Nota autor: Aqui procurou-se atender as suposições do modelo, e o log é utilizado, segundo o modelo SARIMAX, para estabilizar a variância da série histórica, o que também é explicado na seção 5.1.3 Estabilização da variância, p. 250. 
Na Figura 7-4, apresenta-se a decomposição aditiva da série observada em sazonalidade, tendência e aleatório. Nota-se que na sazonalidade, a amplitude está aumentando, e a tendência é decrescente no geral, e crescente mais para o final, o que pode indicar a necessidade de transformações na série histórica.

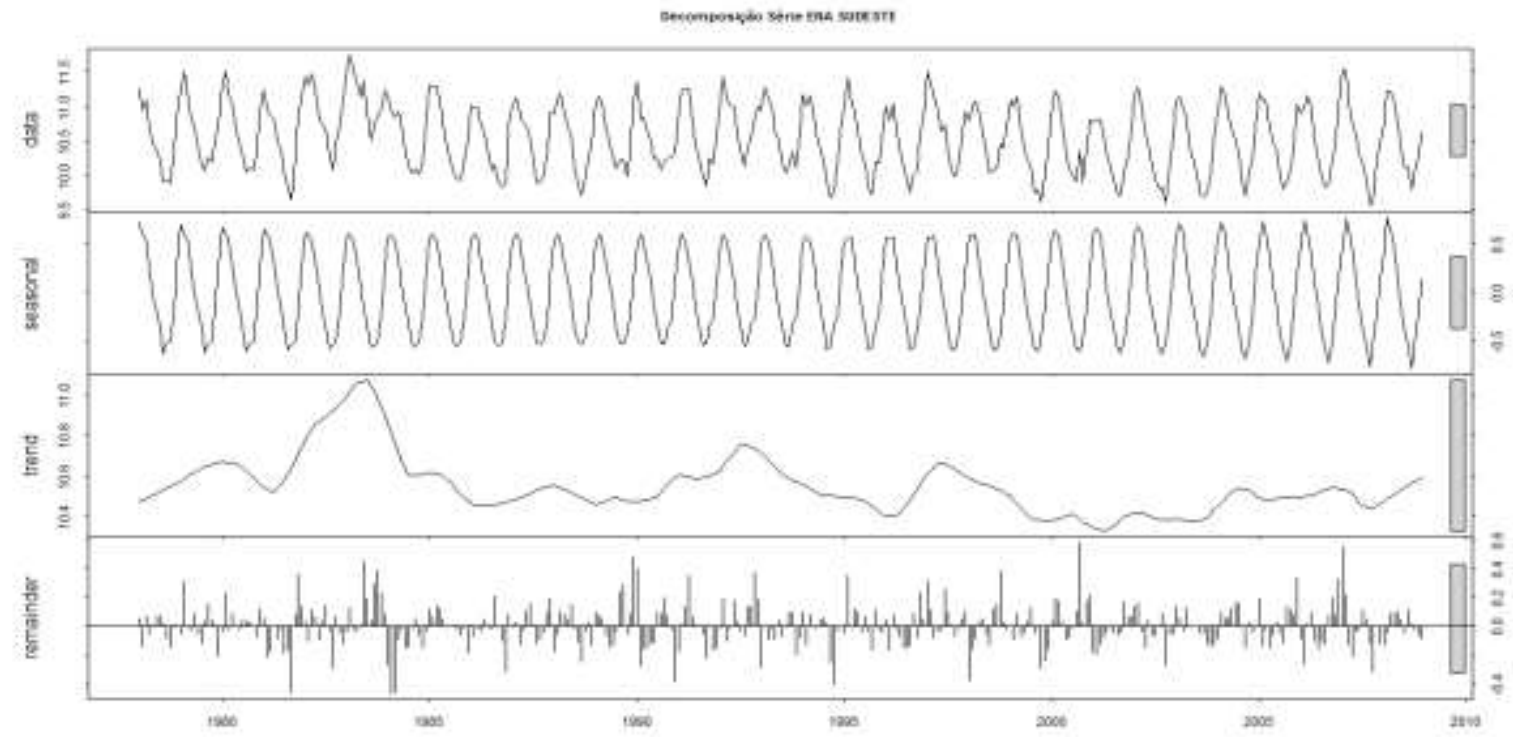

Figura 7-4 - Decomposição: Original, Sazonal, Tendência e Aleatório. ENA Sudeste - Período de Jan/1978 a Dez/2008

Na Figura 7-5, apresenta-se o componente sazonal mês a mês mostrando valores da variabilidade crescente entre os meses de setembro a março (período úmido) e decrescentes de abril a outubro (período seco), o que corrobora com a formação de ZCAS, em geral, na época do verão austral.

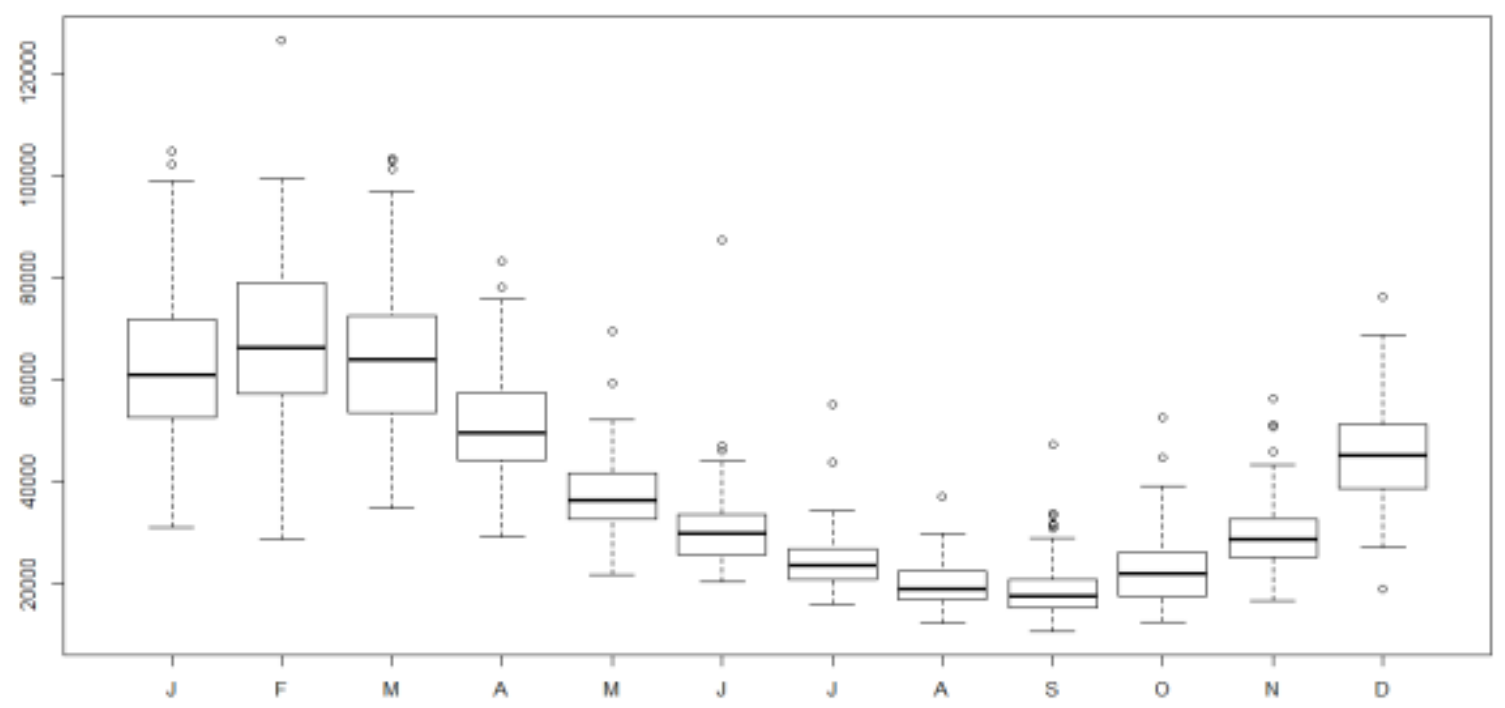

Figura 7-5 - Gráfico Caixa Série Histórica log (MW Médios) ENA Sudeste - Período de Jan/1931 a Dez/2014 


\subsubsection{Identificação}

Nessa fase, são avaliadas as funções de autocorrelação (ACF) e autocorrelação parcial (PACF) para se estimar a ordem em que apresentam-ser os parâmetros do modelo. A seguir, a avaliação inicial da série histórica da ENA-SE.

A série é aparentemente estacionária, para o período de 1978 a 2008, e. foi aplicada uma transformação de log e também as funções ACF e PACF e seus gráficos são apresentados na Figura 7-6. Os resultados indicam um pico significativo no lag 1, o que indica um modelo AR(1), e componentes sazonais nos lags múltiplos de 12 e, assim, indicam o uso de modelos SARIMAX(100)(100).
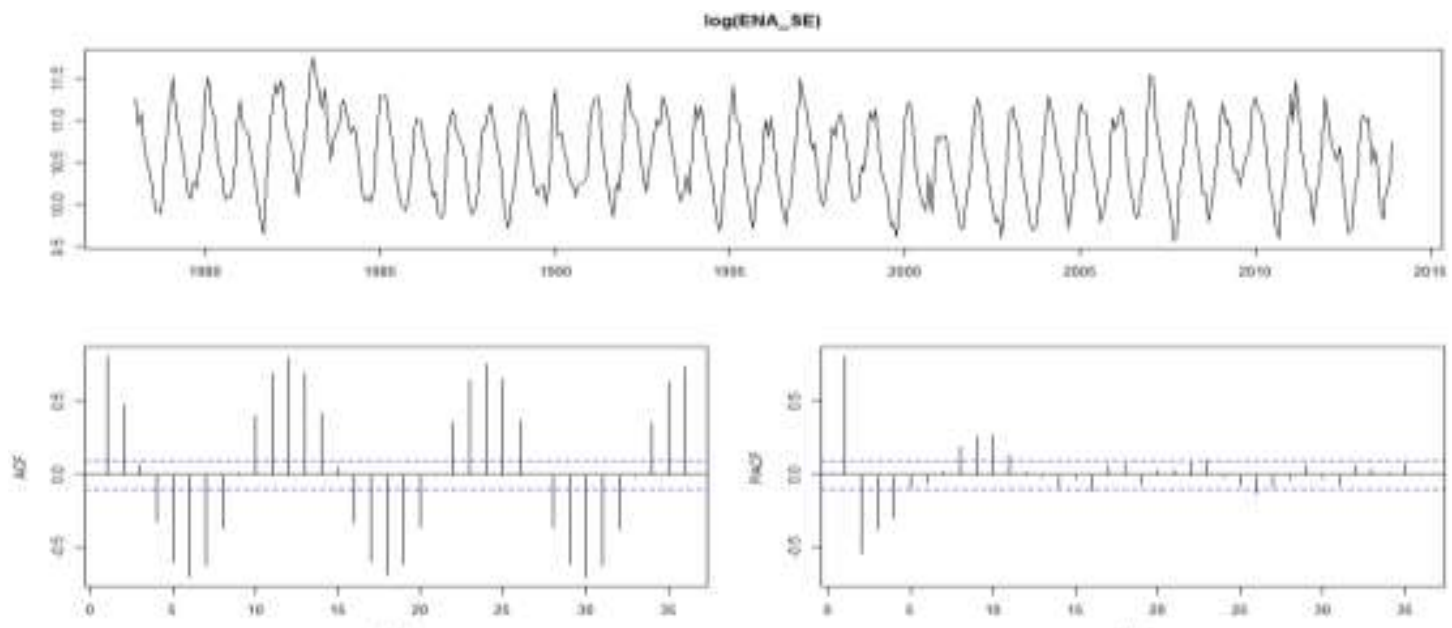

Figura 7-6 - Gráficos: a) Série Transformada com log, ACF e PACF

Ao aplicar a Função de Autocorrelação Estendida (EACF), indica-se um modelo AR(2) e uma média móvel MA(1) que corroboram com as análises anteriores, Tabela 7-1.

Tabela 7-1 Resultado da Função de Autocorrelação estendida - eacf - ENA-SE

\begin{tabular}{|c|c|c|c|c|c|c|c|c|c|c|c|c|c|c|}
\hline AR/MA & 0 & 1 & 2 & 3 & 4 & 5 & 6 & 7 & 8 & 9 & 10 & 11 & 12 & 13 \\
\hline 0 & $x$ & $x$ & $x$ & $x$ & $x$ & $x$ & $x$ & $x$ & 0 & $x$ & $x$ & $x$ & $x$ & $x$ \\
\hline 1 & $x$ & $x$ & $x$ & $x$ & $x$ & $x$ & $x$ & $x$ & 0 & $x$ & $x$ & $x$ & $x$ & $x$ \\
\hline 2 & $x$ & 0 & 0 & 0 & 0 & $x$ & 0 & 0 & 0 & 0 & 0 & 0 & 0 & 0 \\
\hline 3 & $x$ & $x$ & 0 & 0 & 0 & 0 & $x$ & 0 & 0 & 0 & 0 & 0 & $x$ & 0 \\
\hline 4 & $x$ & $x$ & $x$ & 0 & 0 & 0 & 0 & 0 & 0 & 0 & 0 & 0 & $x$ & 0 \\
\hline 5 & $x$ & $x$ & 0 & $x$ & 0 & $x$ & 0 & 0 & 0 & 0 & 0 & 0 & 0 & 0 \\
\hline 6 & 0 & $x$ & 0 & $x$ & 0 & 0 & 0 & 0 & 0 & 0 & 0 & 0 & 0 & 0 \\
\hline 7 & 0 & $x$ & $x$ & $x$ & $x$ & 0 & 0 & 0 & 0 & 0 & 0 & 0 & 0 & 0 \\
\hline
\end{tabular}

Em modelos tipo ARMA, essa configuração indica um modelo com p e q iguais a 2 e 1, respectivamente. Com o objetivo de auxiliar o processo de identificação, foram também utilizadas duas funções do pacote estatística $\mathrm{R}$, os comandos auto.arima e get.best.arima (COWPERTWAIT \& METCALFE, 2009; R, 2005) para identificar os parâmetros. O comando auto.arima retornou o modelo SARIMAX(212)(102). Já, o comando get.best.arima retornou o modelo SARIMAX(022)(221). Todos os possíveis modelos foram testados sendo 
selecionados somente os melhores conforme o critério de AIC e o valor de Sigma ${ }^{2}$, apresentados na Tabela 7-2 onde também há coeficiente de determinação, para avaliar a relação entre as variáveis explicativas e os valores do modelo ajustado. Diferente do que foi apresentado pelos comandos auto.arima e get.best.arima, o melhor modelo foi o SARIMAX(100)(103), que apresentou o menor AIC, igual a -268,9 e sigma² igual a 0,02.

Tabela 7-2 Critérios de adequação dos modelos ENA SE (AIC, AICc, BIC, Sigma2, R2, R2a, R2p-valor) ${ }^{107}$

\begin{tabular}{lrrrrrrr}
\hline Modelo SARIMAX & AIC & AAIC & BIC & Sigma $^{\mathbf{2}}$ & $\mathbf{R}^{\mathbf{2}}$ & $\mathbf{R}^{\mathbf{2} a}$ & $\mathbf{R}^{\mathbf{2}} \mathbf{p}$-valor \\
\hline $\mathbf{( 1 0 0 ) ( 1 0 3 )}$ & $-268,9$ & $-266,7$ & $-194,4$ & 0,02 & 0,96 & 0,95 & 0,0000 \\
\hline $\mathbf{( 1 0 0 ) ( 0 0 3 )}$ & $-253,6$ & $-251,6$ & $-183,0$ & 0,03 & 0,96 & 0,95 & 0,0000 \\
\hline $\mathbf{( 2 1 1 ) ( 1 0 2 )}$ & $-253,1$ & $-252,3$ & $-210,0$ & 0,03 & 0,95 & 0,95 & 0,0000 \\
\hline $\mathbf{( 2 1 1 ) ( 1 0 2 )}$ & $-253,1$ & $-252,3$ & $-210,0$ & 0,03 & 0,95 & 0,95 & 0,0000 \\
\hline $\mathbf{( 2 1 2 ) ( 1 0 2 )}$ & $-251,8$ & $-250,9$ & $-204,8$ & 0,03 & 0,95 & 0,95 & 0,0000 \\
\hline $\mathbf{( 1 0 0 ) ( 0 0 4 )}$ & $-251,6$ & $-249,5$ & $-177,2$ & 0,03 & 0,96 & 0,95 & 0,0000 \\
\hline
\end{tabular}

\subsubsection{Estimação}

Após a fase de identificação, partiu-se para a estimação dos valores dos parâmetros que devem cumprir com as condições de estacionariedade e invertibilidade (valores em módulo dos parâmetros menores do que 1).

As análises da fase de identificação sugerem um ajuste de modelos do tipo SARIMAX (p,d,q) $(\mathrm{P}, \mathrm{D}, \mathrm{Q})$, por se tratarem de dados mensais, e apresentarem sazonalidade.

Para identificação das ordens do modelo, foram utilizadas evidências empíricas da ACF, PACF e EACF (lags não nulos 1 e 12 e seus múltiplos). Experimentalmente, ajustaram-se vários modelos sendo que um em especial apresentou resultados AIC melhores, o modelo da classe SARIMAX $(1,0,0)(1,0,3)$ da forma:

$\left(1-\phi_{1} B\right)\left(1-\phi_{1} B\right) Y_{t}=e_{t}\left(1-\theta_{1} B\right)\left(1-\Theta_{1} B\right)\left(1-\Theta_{2} B\right)\left(1-\Theta_{3} B\right)$,

onde $\mathrm{e}_{\mathrm{t}} \sim \mathrm{RB}^{108}\left(0, \sigma^{2}\right), \sim \mathrm{N}^{109}$

As estimativas dos parâmetros do modelo ajustado são apresentadas na Tabela 7-3 e na Tabela 7-4, são apresentados o resultado do modelo de regressão dinâmica, que compara os

\footnotetext{
107 Siglas cabeçalho:

AIC -Akaike's Information Criterion (Critério de Informação de Akaike)

AICc-Corrected Akaike's Information Criterion (Critério de Informação de Akaike corrigida)

BIC -Schwarz Bayesian Information Criterion (Critério Bayesiano de Schwarz)

$\mathrm{R}^{2}$ - Coeficiente de determinação

$\mathrm{R}^{2} \mathrm{a}$ - Coeficiente de determinação ajustado

$\mathrm{R}^{2} \mathrm{p}$ - Valor $\mathrm{p}$ nível de significância estatística

${ }^{108}$ Ruído branco

${ }^{109}$ Distribuição Normal
} 
dados gerados pelo modelo ajustado e os dados utilizados para treinamento, considerando o IC de $95 \%$.

Tabela 7-3 Valores parâmetros estimados e estatísticas correspondentes

Modelo

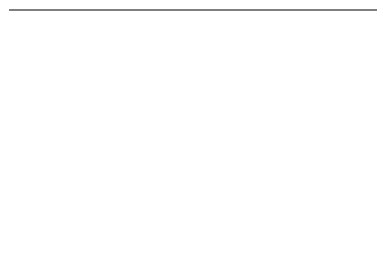

SARIMAX(100)(103)
Parâmetros Estimativas Erro Padrão

\begin{tabular}{crrr}
$\phi_{1}$ & 0,64 & 0,05 & 0,0000 \\
\hline$\phi_{1}$ & 1,00 & 0,00 & 0,0000 \\
\hline$\Theta_{1}$ & $-1,18$ & 0,06 & 2,0000 \\
\hline$\Theta_{2}$ & 0,21 & 0,09 & 0,0219 \\
\hline$\Theta_{3}$ & $-0,01$ & 0,06 & 1,1560 \\
\hline Intercepto & $-1,77$ & 8,66 & 1,1620 \\
\hline NINO12 & 0,09 & 0,02 & 0,0000 \\
\hline TSA & 0,06 & 0,03 & 0,0705 \\
\hline SWA & 0,09 & 0,02 & 0,0000 \\
\hline X70E & 1,05 & 0,26 & 0,0001 \\
\hline X120E & 2,25 & 0,56 & 0,0001 \\
\hline X40W & 2,78 & 0,69 & 0,0001 \\
\hline SAM & 0,01 & 0,01 & 0,3270
\end{tabular}

mativa de

$\sigma^{2}$

0,02

Na Tabela 7-4 são apresentados os valores estimados e as estatísticas associadas ao modelo de regressão dinâmica. As variáveis SWA, EEP, X70E, X120E, X40W e SAM apresentaram significância estatística, diversamente as variáveis AMO, PDO, TSA, AO e SAM2.

Tabela 7-4 Valores parâmetros estimados dos coeficientes das variáveis explicativas e as estatísticas correspondentes

\begin{tabular}{lrrrrr}
\hline Parâmetros & Estimativas & Erro Padrão & Estatística t & Valor p & $\#^{\mathbf{1 1 0}}$ \\
\hline NINO12 & $6.162,48$ & 487,12 & 12,651 & 0,0000 & $* * *$ \\
\hline AMO & $-2.588,44$ & 2098,79 & $-1,233$ & 0,2183 & \\
\hline PDO & 187,14 & 437,00 & 0,428 & 0,6687 & \\
\hline TSA & $1.023,66$ & 653,37 & 1,567 & 0,1181 & \\
\hline SWA & $3.527,95$ & 346,77 & 10,174 & 0,0000 & $* * *$ \\
\hline EEP & $-3.868,86$ & 675,61 & $-5,726$ & 0,0000 & $* * *$ \\
\hline X70E & $68.731,69$ & $11.643,17$ & 5,903 & 0,0000 & $* * *$ \\
\hline X120E & $142.878,10$ & $25.223,89$ & 5,664 & 0,0000 & $* * *$ \\
\hline X40W & $178.098,10$ & $30.858,21$ & 5,771 & 0,0000 & $* * *$ \\
\hline AO & $-815,52$ & 414,35 & $-1,968$ & 0,0498 & $*$ \\
\hline SAM & $-96,36$ & 12,72 & $-7,574$ & 0,0000 & $* * *$ \\
\hline SAM2 & $-149,18$ & 219,34 & $-0,680$ & 0,4969 & \\
\hline
\end{tabular}

\footnotetext{
110 Significado dos asteriscos: $0^{(* * * \prime} 0,001^{\prime * * \prime} 0,01^{\prime * \prime} 0,05^{\prime \prime}, 0,1^{\prime \prime} 1$

$0>={ }^{\prime} * * * \prime<0,001$

$0,001>={ }^{* * *}<0,01$

$0,01>={ }^{\prime * \prime}<0,05$

$0,05>=", \quad<0,1$

$0,1>=" \prime<1$
} 


\subsubsection{Verificação ou diagnóstico}

A análise dos resíduos é utilizada para verificar a adequação dos modelos e o potencial sucesso para modelagem. Os diagnósticos dos erros do modelo são apresentados na Figura 7-7, nos resultados da análise dos resíduos do modelo em a) indica-se a aceitação da hipótese do modelo não ser heterocedástico; em b) o gráfico ACF indica que os resíduos apresentam um comportamento aleatório (ruído branco) e o valor de Ljung-Box aceita a hipótese que as autocorrelações estimadas são gaussianas com média zero e variância $1 / \mathrm{n}$; em c) o Gráfico QQ indica aceitação da hipótese de normalidade, pois se ajusta a uma linha reta e dentro das fronteiras estabelecidas; e em d) indica-se que a média é zero e há normalidade. Todos os valores da inferência estatística apresentaram p-valor com nível de significância maior que 0,05, o que caracteriza aceitação das hipóteses nulas.

a) Resid vs ajust(p-valor McLeod-LI: 0.11 )

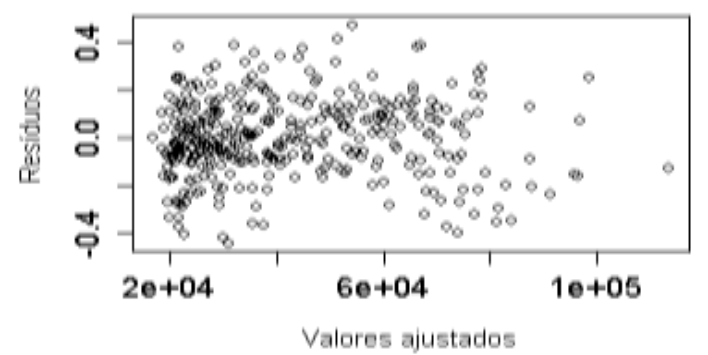

c) Q-Q plot normal (p-valor Shapiro-Wilk:0.65)

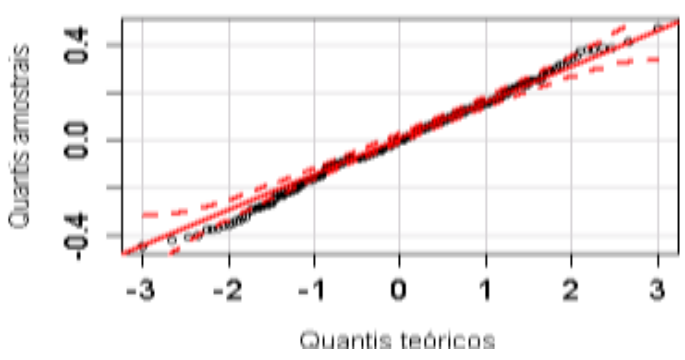

b) FAC residuos(p-valor Ljung-Box:0.16)

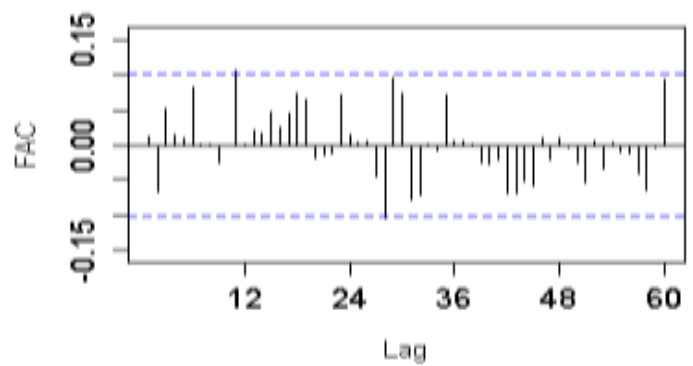

d) Histograma(p-valor teste t:0.96)

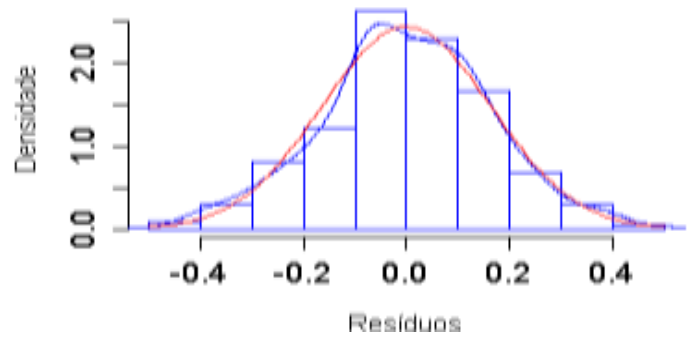

Figura 7-7 - Gráfico análise de resíduos modelo SARIMAX (100)(003): a) Resíduos versos modelo ajustado. b) FAC c) QQ-Plot d) Histograma

Assim, o modelo cumpre com as suposições dos erros: $e_{t}$ independentes, $E\left(e_{t}\right)=0$, variância constante, e autocorrelação constante seguindo a distribuição normal. Os critérios AIC, AICc e BIC são muito similares, com uma leve melhora no Erro Médio Quadrático (RMSE), como pode apresenta-se na Tabela 7-5. Estes indicadores de erro, e qualidade do modelo são gerados através do comando accuracy do R. A teoria sobre avaliação de qualidade e erros de resíduos encontram-se na 1.1.1.1APÊNDICE B Validação dos modelos de previsão, 314. Ao analisar os resíduos, verifica-se que os p-valores correspondentes às respectivas hipóteses nulas são aceitáveis para os modelos SARIMAX (100)(103) SARIMAX (100)(004). Os valores p-valor são apresentados na Tabela 7-5 com os critérios de informação e resíduos. 
Observa-se que nem sempre um modelo com um valor AIC menor tem também os p-valores aceitáveis. Somente os modelos da primeira e última linha atendem as suposições.

Tabela 7-5 Análise de Erros de Resíduos ${ }^{111}$

\begin{tabular}{lllllllllllll}
\hline SARIMAX & \multirow{2}{*}{ AIC } & \multirow{2}{*}{ AAIC } & BIC & ME & RMSE & MAE & MPE & MAPE & $\begin{array}{l}\text { Shapiro } \\
\text { Wilk }\end{array}$ & $\begin{array}{l}\text { Teste } \\
\text { t }\end{array}$ & $\begin{array}{l}\text { McLeod } \\
\text { Li }\end{array}$ & $\begin{array}{l}\text { Ljung } \\
\text { Box }\end{array}$ \\
\hline $\mathbf{( 1 0 0 ) ( 1 0 3 )}$ & $-253,6$ & $-251,6$ & $-183,0$ & 688 & 8.286 & 5.812 & -1 & 13 & 0,55 & 0,96 & 0,11 & 0,16 \\
\hline $\mathbf{( 2 1 1 ) ( 1 0 2 )}$ & $-253,1$ & $-252,3$ & $-210,0$ & 673 & 8.100 & 5.658 & -2 & 13 & 0,28 & 0,75 & 0,00 & 0,38 \\
\hline $\mathbf{( 2 1 1 ) ( 1 0 2 )}$ & $-253,1$ & $-252,3$ & $-210,0$ & 673 & 8.100 & 5.658 & -2 & 13 & 0,28 & 0,75 & 0,00 & 0,38 \\
\hline $\mathbf{( 2 1 1 ) ( 1 0 2 )}$ & $-253,1$ & $-252,3$ & $-210,0$ & 673 & 8.100 & 5.658 & -2 & 13 & 0,28 & 0,75 & 0,00 & 0,38 \\
\hline $\mathbf{( 2 1 2 ) ( 1 0 2 )}$ & $-251,8$ & $-250,9$ & $-204,8$ & 674 & 8.088 & 5.649 & -2 & 13 & 0,33 & 0,75 & 0,00 & 0,40 \\
\hline $\mathbf{( 1 0 0 ) ( 0 0 4 )}$ & $-251,6$ & $-249,5$ & $-177,2$ & 690 & 8.282 & 5.810 & -1 & 13 & 0,54 & 0,97 & 0,11 & 0,13 \\
\hline
\end{tabular}

\subsubsection{Validação Cruzada}

Na validação cruzada são realizadas "previsões retroativas" com dados do passado prevendo o passado, e os erros médios absolutos, calculados entre o previsto e o realizado, são armazenados, e a média dos erros é calculada, posteriormente, para cada mês previsto, para um período de 60 meses a frente. Na Figura 7-8, apresenta-se os períodos do passado para treinamento, em verde, e testes, em amarelo. O mesmo se aplica para as seções 7.2.5, 7.3.5 e 7.4.5. Mais informações sobre validação cruzada são encontradas na seção 1.1.1.1APÊNDICE B.6 Validação Cruzada, p. 317.

\begin{tabular}{|c|c|c|c|c|c|c|c|c|c|c|c|c|c|c|}
\hline 1978 & $\cdots$ & 1987 & $\rightarrow$ & 1988 & 1992 & & & & & & & & & \\
\hline 1978 & $\ldots$ & $\ldots$ & 1988 & $\rightarrow$ & 1989 & 1993 & & & & & & & & \\
\hline 1978 & $\ldots$ & $\ldots$ & $\ldots$ & 1989 & $\rightarrow$ & 1990 & 1994 & & & & & & & \\
\hline 1978 & $\ldots$ & $\ldots$ & $\ldots$ & $\ldots$ & 1990 & $\rightarrow$ & 1991 & 1995 & & & & & & \\
\hline 1978 & $\ldots$ & $\ldots$ & $\ldots$ & $\ldots$ & $\ldots$ & 1991 & $\rightarrow$ & 1992 & 1996 & & & & & \\
\hline 1978 & $\ldots$ & $\ldots$ & $\ldots$ & $\ldots$ & $\ldots$ & $\ldots$ & 1992 & $\rightarrow$ & 1993 & 1997 & & & & \\
\hline 1978 & $\ldots$ & $\ldots$ & $\ldots$ & $\ldots$ & $\ldots$ & $\ldots$ & $\ldots$ & 1993 & $\rightarrow$ & 1994 & 1998 & & & \\
\hline 1978 & $\ldots$ & $\ldots$ & $\ldots$ & $\ldots$ & $\ldots$ & $\ldots$ & $\ldots$ & $\ldots$ & 1994 & $\rightarrow$ & 1995 & 1999 & & \\
\hline 1978 & $\ldots$ & $\ldots$ & $\ldots$ & $\ldots$ & $\ldots$ & $\ldots$ & $\ldots$ & $\ldots$ & $\ldots$ & $\ldots$ & $\rightarrow$ & $\ldots$ & $\ldots$ & \\
\hline 1978 & $\ldots$ & $\ldots$ & $\ldots$ & $\ldots$ & $\ldots$ & $\ldots$ & $\ldots$ & $\ldots$ & $\ldots$ & $\ldots$ & 2008 & $\rightarrow$ & 2009 & 2013 \\
\hline
\end{tabular}

Figura 7-8 Esquema de validação cruzada k-fold com intervalos de treinamento com o ano inicial fixo em 1978

$\mathrm{Na}$ validação cruzada são experimentados quatro modelos com variáveis explicativas diferentes e com a ordem do modelo SARIMAX(101)(103). O modelo com variáveis

\footnotetext{
111 AIC -Akaike's Information Criterion (Critério de Informação de Akaike)

AICc - Corrected Akaike's Information Criterion (Critério de Informação de Akaike corrigida)

BIC - Schwarz Bayesian Information Criterion (Critério Bayesiano de Schwarz)

ME - Mean Error (Erro médio)

RMSE - Root Mean Squared Error (Erro médio quadrático)

MAE - Mean Absolute Error (Erro Médio Absoluto)

MPE - Mean Percentage Error (Percentual Erro Médio)

MAPE - Mean Absolute Percentage Error (Percentual Erro Absoluto)

MASE - Mean Absolute Scaled Error (Escala de Erro Médio Absoluto)

ACF1 - Autocorrelation of errors at lag 1 (Autocorrelaçao de erros com 1 atraso)
} 
explicativas tem vantagem em relação aos modelos com uma única ou mesmo nenhuma variável explicativa, como visto na Figura 7-9. Nesta figura, há quatro resultados da média de erros padrões das previsões retroativas da validação cruzada, conforme explicação feita anteriormente, de modelos com diferentes configurações das variáveis macroclimáticas, que são: um modelo sem variáveis explicativas, um modelo com todas as variáveis explicativas SWA, EEP, X70E, X120E, X40W e SAM, um modelo somente com a variável explicativa AMO e outro modelo somente com a variável explicativa NINO1+2.

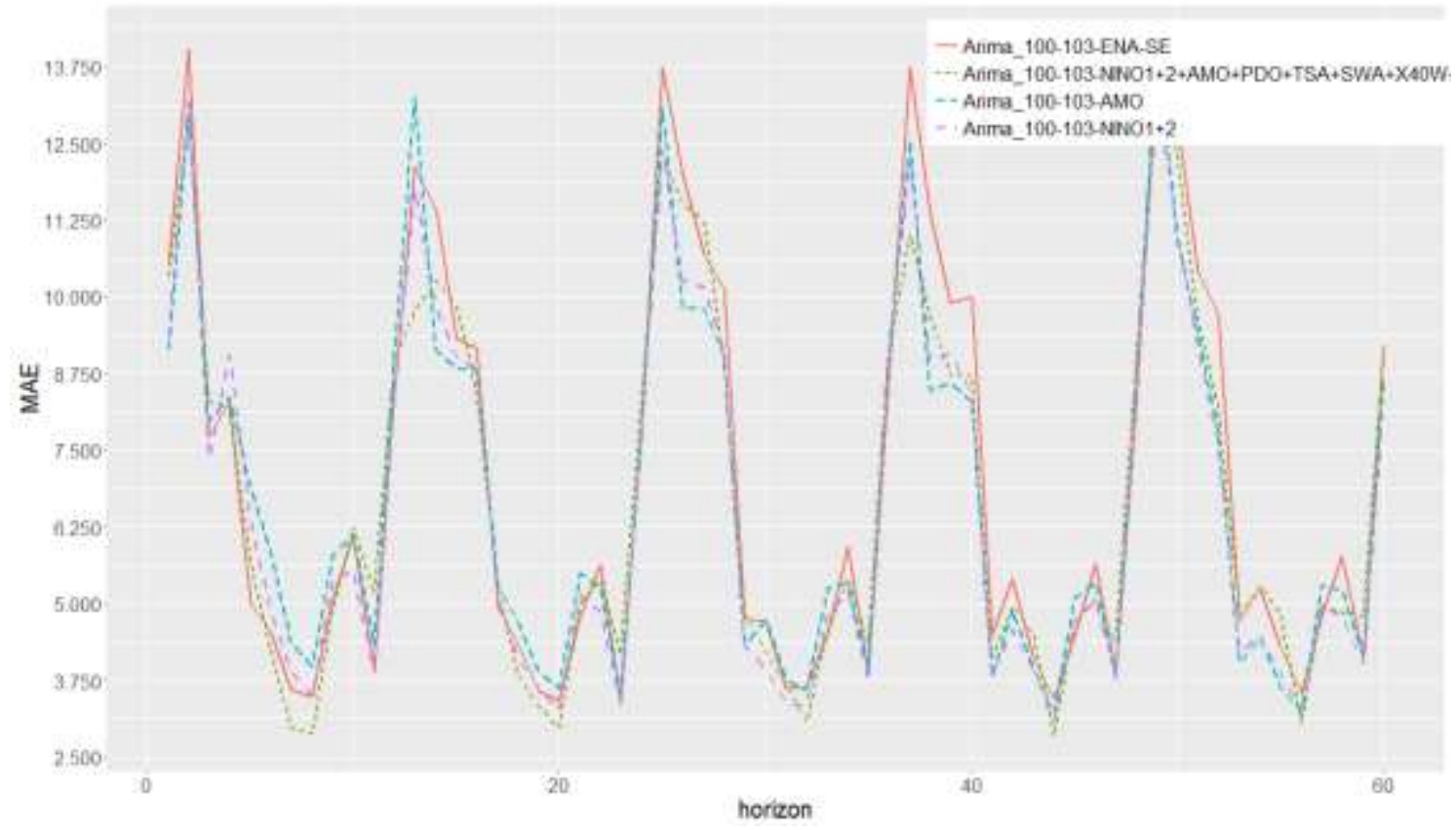

Figura 7-9 Erros médios absolutos resultados da validação cruzada com o modelo SARIMAX (101)(103)

Na validação (Tabela 7-6) com RMSE e R2, é possível observar um resultado com o maior erro dentre os demais (1978-1997: 10.531 MWmédios), lembrando que em 1979, 1980, 1982, 1983, 1992, 1995 e 1997 há picos (outliers), todos relacionados com El Niño, que podem explicar esses erros. Os demais agrupamentos apresentam erro menores, assim como o menor erro absoluto (1978-2004: 5.914). Todos os valores de coeficientes de determinação e de determinação ajustados são iguais ou próximos a 1. Os valores p são menores que 0,0001 o que indica que os coeficientes de determinação são significativos. 
Tabela 7-6 Dados validação modelo de regressão dinâmica SARIMAX (101)(103)

\begin{tabular}{rrrrrrrrrc}
\multicolumn{2}{c}{ JANELA } & ME & \multicolumn{1}{c}{ RMSE } & MAE & MPE & MAPE & R2 & R2a & R2p \\
\hline $\mathbf{1 9 7 8}$ & 1997 & -6.898 & 10.531 & 8.190 & $-22 \%$ & $25 \%$ & 1,00 & 1,00 & 0,0000 \\
\hline $\mathbf{1 9 7 8}$ & 1998 & -5.821 & 9.121 & 7.340 & $-21 \%$ & $24 \%$ & 1,00 & 1,00 & 0,0000 \\
\hline $\mathbf{1 9 7 8}$ & 1999 & -3.523 & 8.650 & 7.152 & $-15 \%$ & $22 \%$ & 1,00 & 1,00 & 0,0000 \\
\hline $\mathbf{1 9 7 8}$ & 2000 & -4.037 & 8.891 & 7.179 & $-16 \%$ & $22 \%$ & 1,00 & 1,00 & 0,0000 \\
\hline $\mathbf{1 9 7 8}$ & 2001 & -1.845 & 7.560 & 6.294 & $-11 \%$ & $19 \%$ & 1,00 & 0,99 & 0,0000 \\
\hline $\mathbf{1 9 7 8}$ & 2002 & 1.378 & 8.707 & 6.018 & $-3 \%$ & $15 \%$ & 1,00 & 1,00 & 0,0000 \\
\hline $\mathbf{1 9 7 8}$ & 2003 & 3.301 & 9.322 & 6.236 & $3 \%$ & $14 \%$ & 1,00 & 1,00 & 0,0000 \\
\hline $\mathbf{1 9 7 8}$ & 2004 & 2.640 & 8.785 & 5.914 & $\mathbf{2} \%$ & $13 \%$ & 1,00 & 1,00 & 0,0000 \\
\hline $\mathbf{1 9 7 8}$ & 2005 & 390 & 9.149 & 6.068 & $-2 \%$ & $14 \%$ & 0,99 & 0,99 & 0,0000 \\
\hline $\mathbf{1 9 7 8}$ & 2006 & 2.137 & 8.669 & 6.341 & $1 \%$ & $15 \%$ & 0,99 & 0,99 & 0,0000 \\
\hline $\mathbf{1 9 7 8}$ & 2007 & 1.700 & 9.393 & 7.116 & $1 \%$ & $17 \%$ & 0,99 & 0,99 & 0,0000 \\
\hline $\mathbf{1 9 7 8}$ & 2008 & 2.087 & 8.867 & 6.380 & $3 \%$ & $15 \%$ & 0,99 & 0,99 & 0,0000 \\
\hline
\end{tabular}

Ao verificar os valores nos gráficos a seguir, observa-se que as previsões do modelo oficial NEWAVE, apresentam valores muito próximos de um ano para outro. Na Figura 7-10, são apresentados, no início, o valor observado registrado pelo ONS e, em seguida, os valores dos decks de previsão do modelo NEWAVE. Cada deck faz uma previsão de 5 anos à frente, ou seja, se o deck é de 2003 fará a previsão de 2003 a 2007, e assim, sucessivamente. Esses resultados podem ser avaliados com os indicadores de erro apresentados na Tabela 7-7, a seguir:

Tabela 7-7 Dados validação NEWAVE Região Sudeste Decks 2003 a 2009

\begin{tabular}{llllrr}
\hline Deck & ME & RMSE & MAE & MPE & MAPE \\
\hline $\mathbf{2 0 0 3}$ & 5.126 & 10.615 & 6.416 & $9 \%$ & $15 \%$ \\
\hline $\mathbf{2 0 0 4}$ & 5.565 & 10.955 & 7.057 & $11 \%$ & $16 \%$ \\
\hline $\mathbf{2 0 0 5}$ & 5.172 & 10.847 & 7.084 & $10 \%$ & $17 \%$ \\
\hline $\mathbf{2 0 0 6}$ & 3.751 & 10.475 & 6.729 & $5 \%$ & $16 \%$ \\
\hline $\mathbf{2 0 0 7}$ & 4.454 & 10.438 & 7.170 & $7 \%$ & $17 \%$ \\
\hline $\mathbf{2 0 0 8}$ & 4.449 & 10.039 & 7.302 & $8 \%$ & $18 \%$ \\
\hline $\mathbf{2 0 0 9}$ & 3.786 & 9.738 & 6.988 & $7 \%$ & $18 \%$ \\
\hline
\end{tabular}


Na Figura 7-10, são apresentados os valores de ENA-SE observados e na sequência as previsões feitas pelo NEWAVE a partir dos decks de dados 2003, 2004, 2005, 2006, 2007, 2008 e 2009, para 5 anos à frente ${ }^{112}$.

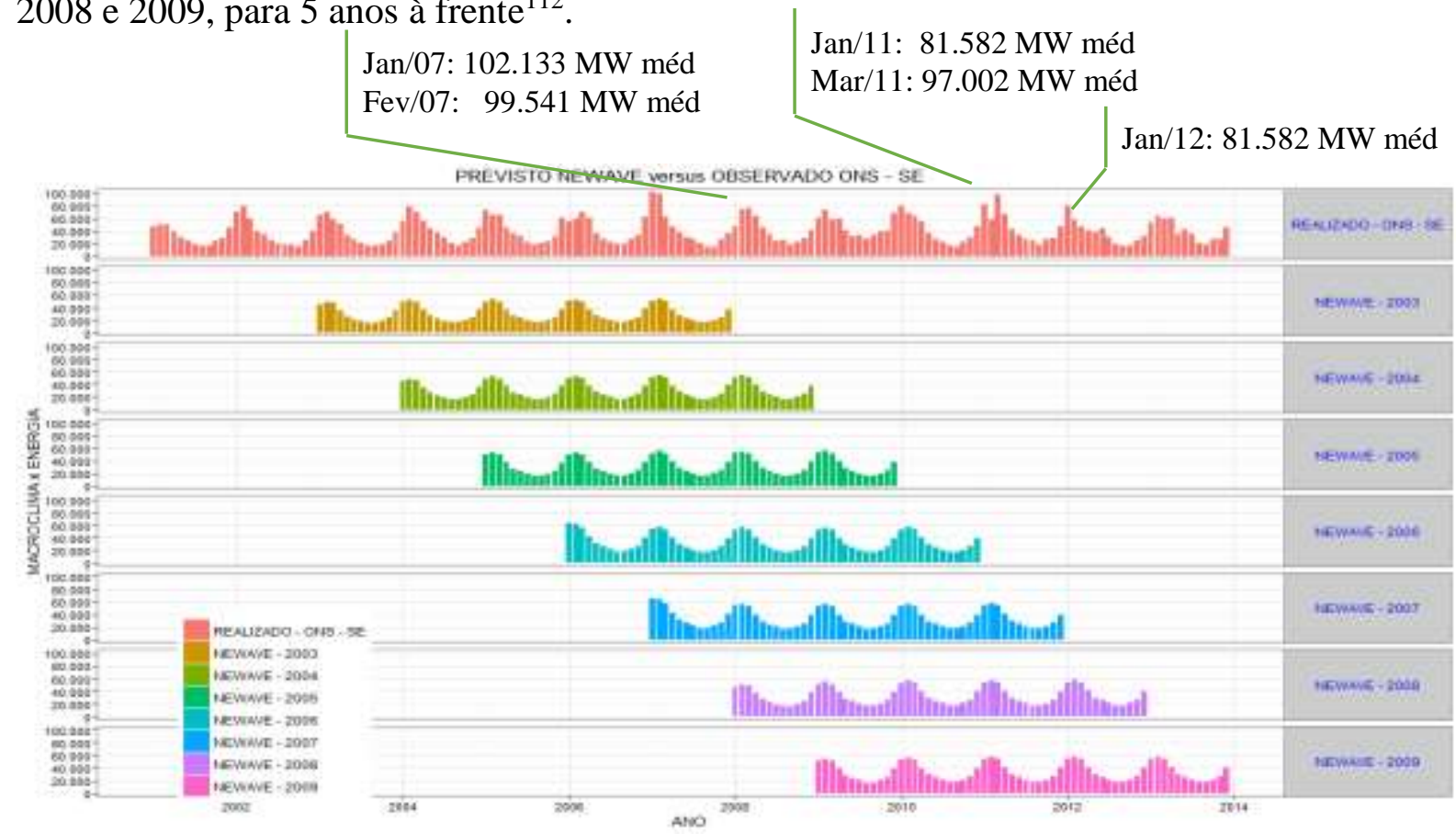

Figura 7-10 Validação Cruzada NEWAVE :: Decks 2003 a 2009.

Na Figura 7-11, apresenta-se a diferença, ou erro, entre o observado e o previsto. Nota-se que os valores de erro são aproximados nos meses de jan. e fev.2007, apesar de serem previsões realizadas com decks diferentes.

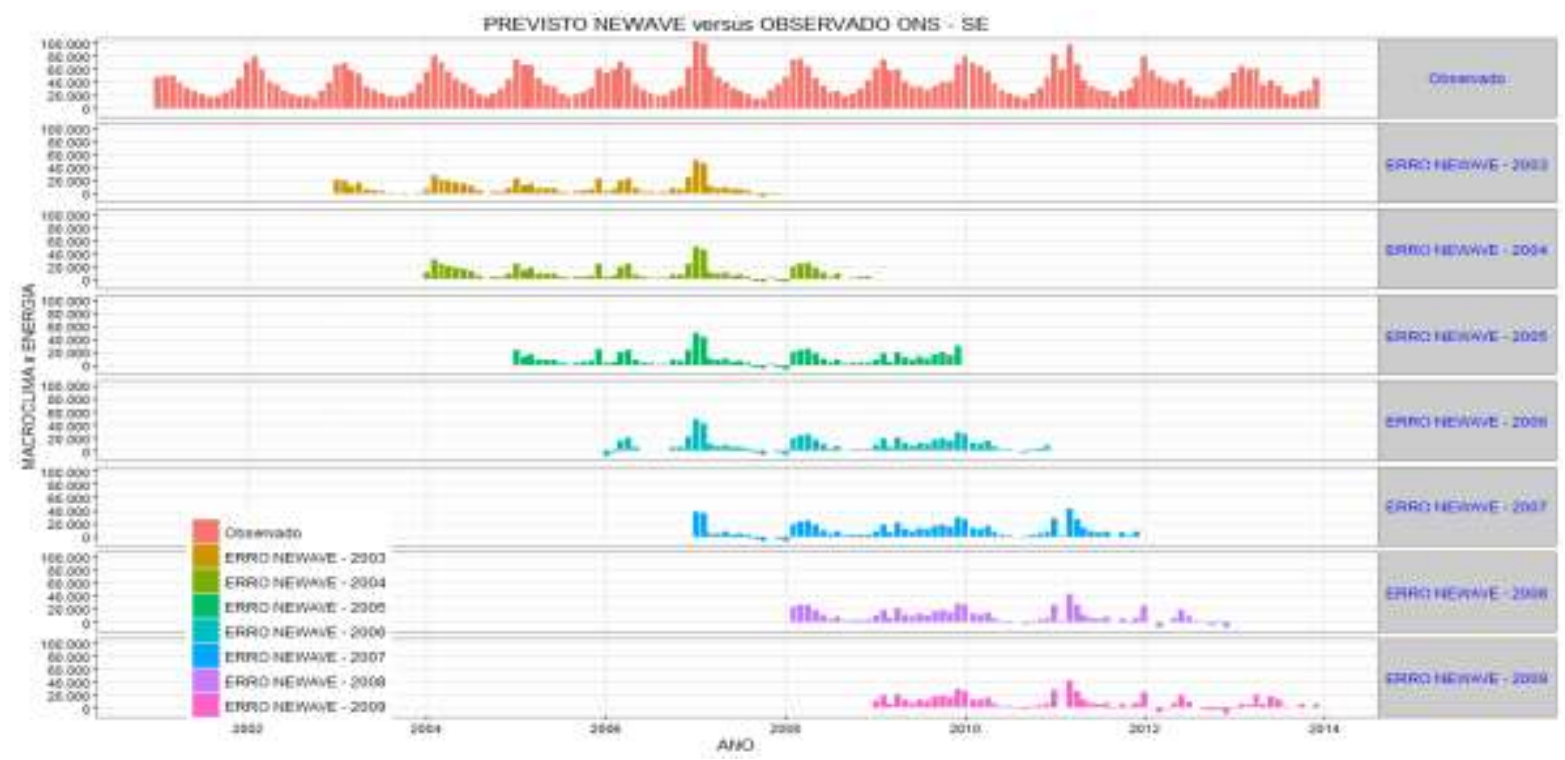

Figura 7-11 Validação Cruzada Erro =NEWAVE - ONS :: Decks 2003 a 2009.

${ }^{112}$ Comentário Prof. Molion: “ Nota-se que o NEWAVE corta todos os picos e parece uma janela móvel e não um previsor." 
O modelo SARIMAX(100)(103) é apresentado nas Figura 7-12 e Figura 7-13, e os resultados são melhores do que o NEWAVE. Nota-se que também apresentam erros similares nos mesmos meses, apesar de utilizarem conjuntos de testes diferentes.

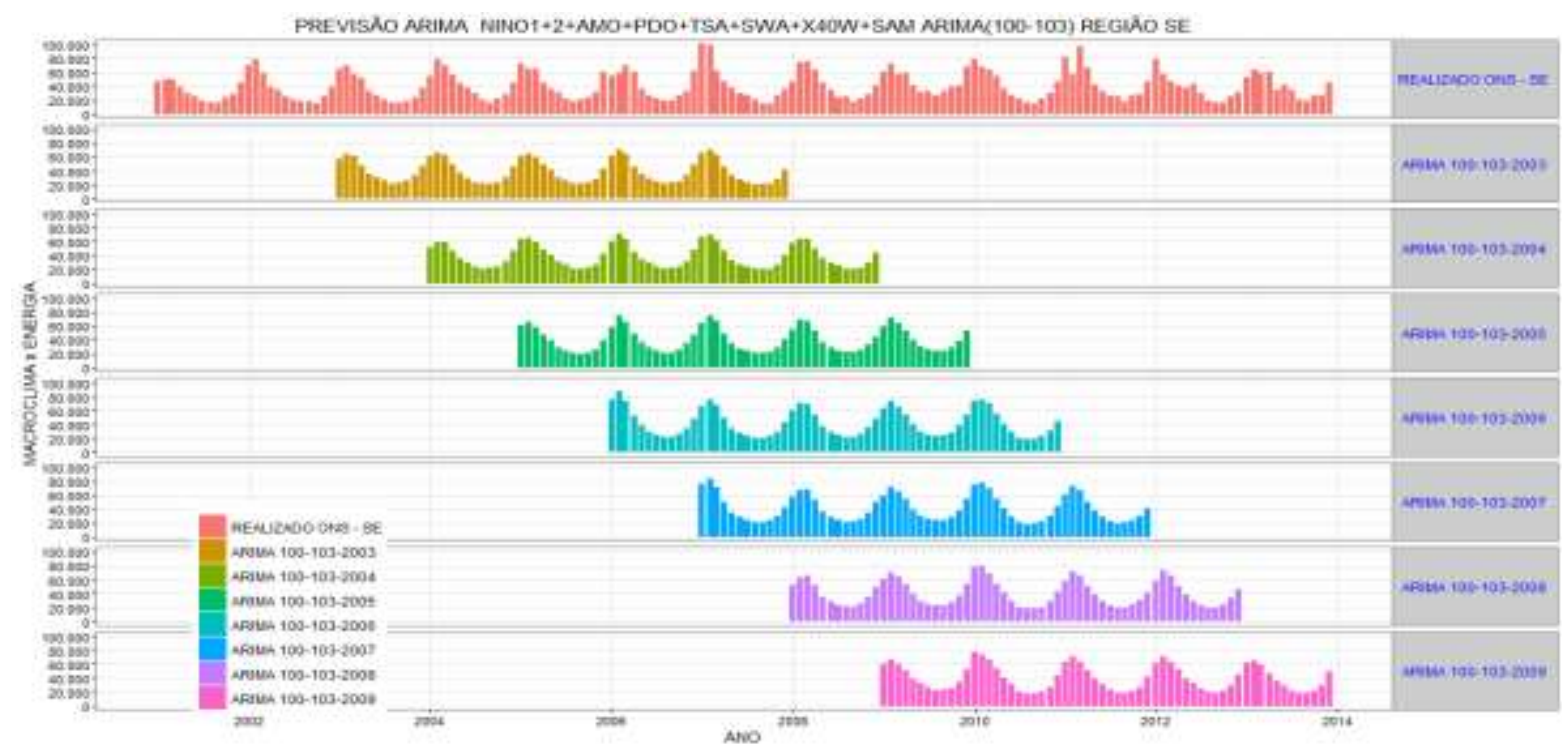

Figura 7-12 Validação cruzada modelos SARIMAX (100)(103) Região Sudeste

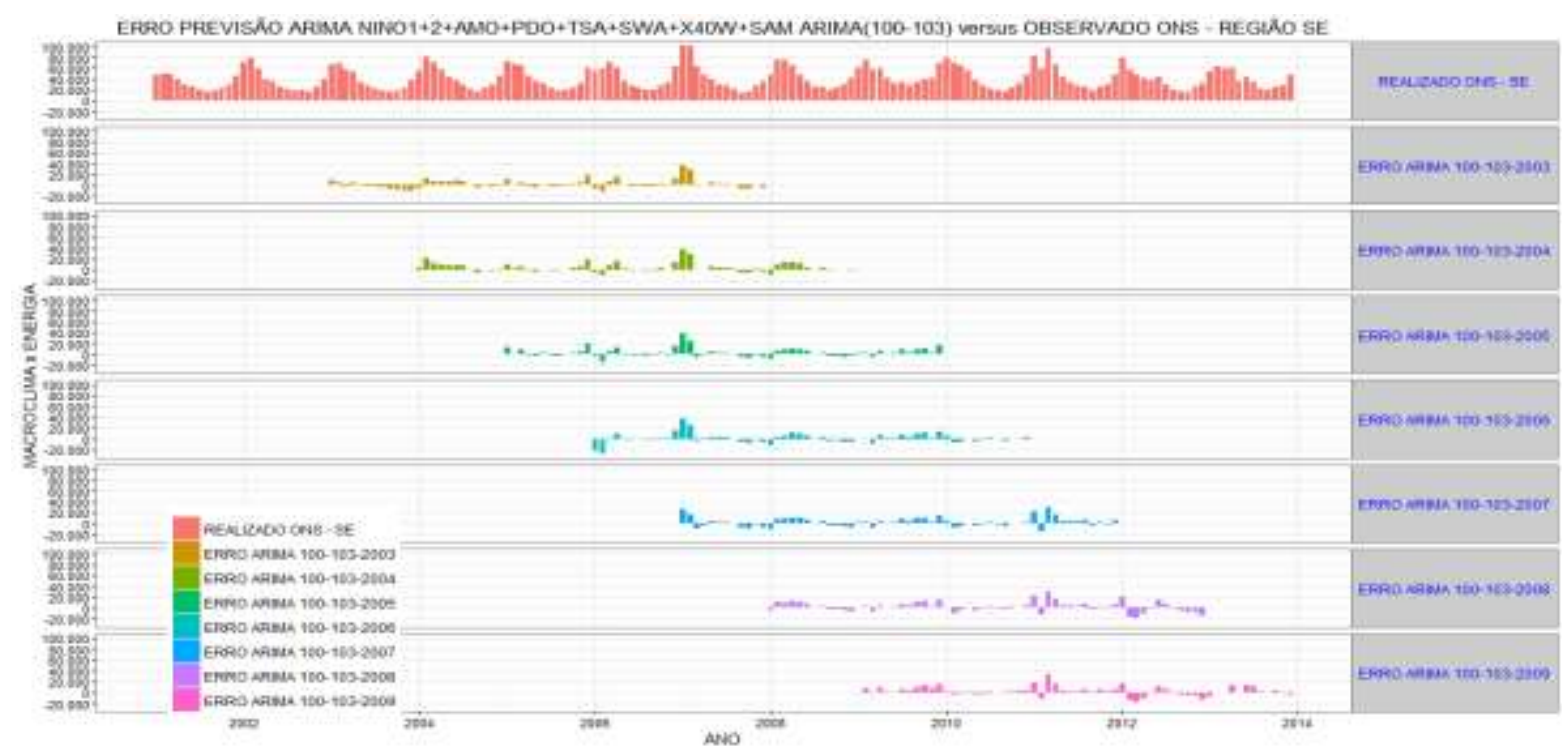

Figura 7-13 Validação Cruzada Erro = SARIMAX(100)(103) :: Conjuntos de teste 2003 a 2009 Região Sudeste. 


\subsection{Modelo SARIMAX ENA SUL}

\subsubsection{Especificação}

Ao analisar os gráficos, os mapas e as análises de séries históricas escolheram-se as variáveis explicativas NINO3 ${ }_{\mathrm{WL}}$, TSI, MEI, ONI, PDO, X40W, AO e SAM e frente a variável dependente a ENA-Sul (Figura 7-14).

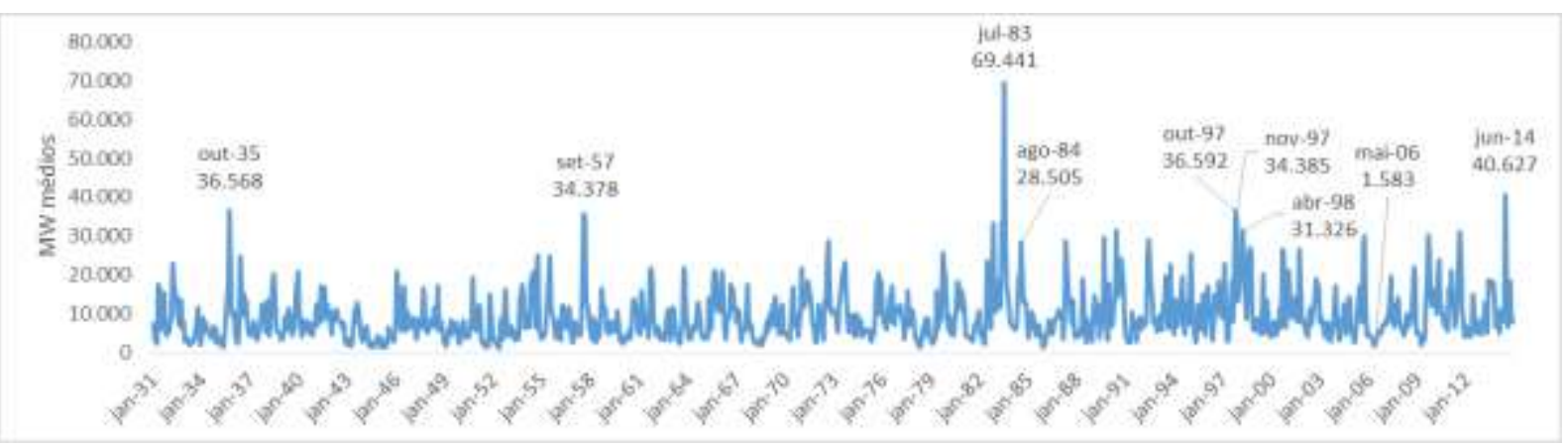

Figura 7-14 - Série Histórica em MW Médios ENA Sul - Período de Jan/1931 a Dez/2014

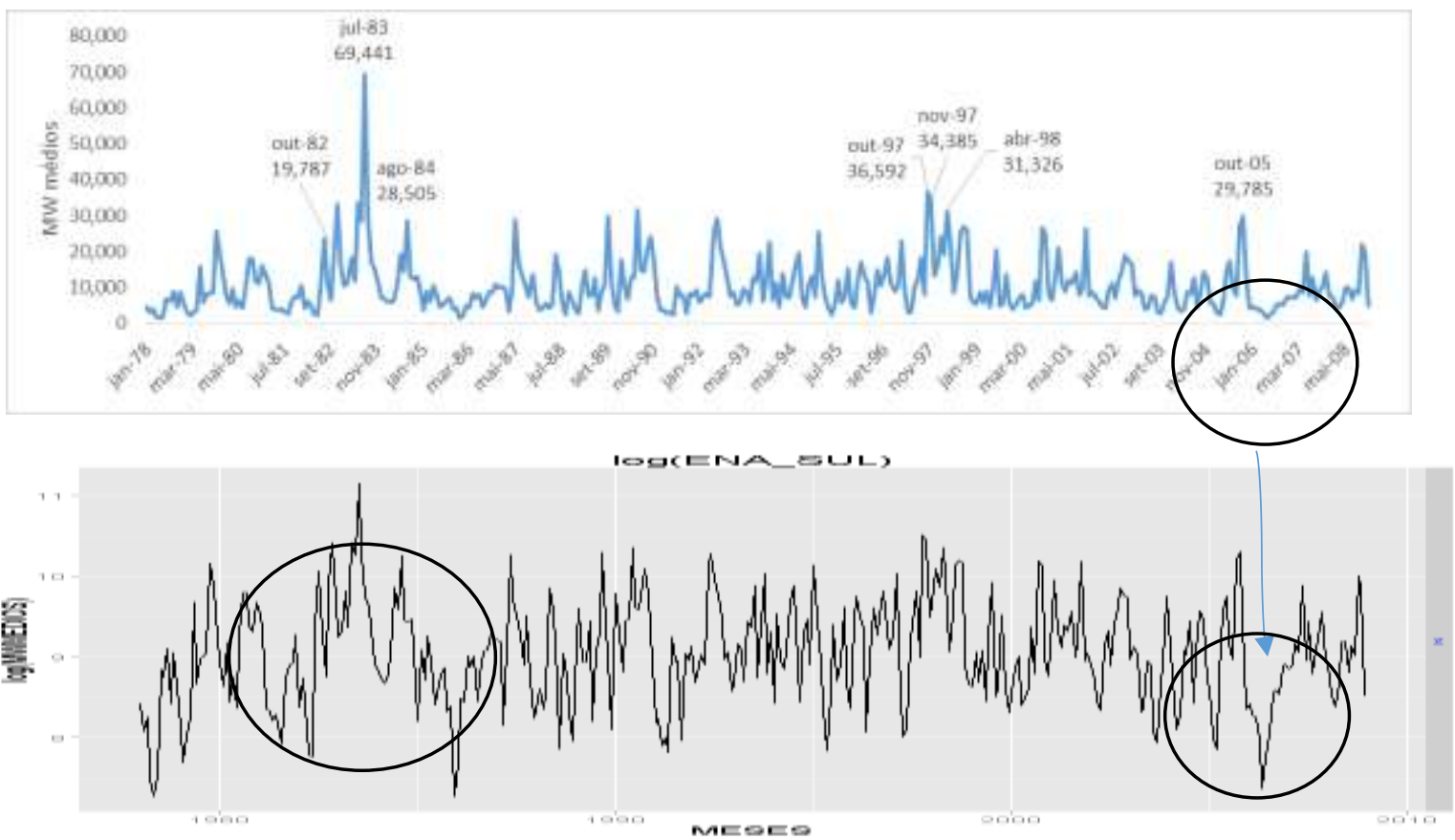

Figura 7-15 - Série Histórica em MW Médios ENA Sul - Período de Jan/1978 a Dez/2008113

Na Figura 7-15, apresenta-se a série histórica com sazonalidade e tendências localizadas e explicadas pela dinâmica das chuvas e pela localização geográfica das bacias hidrográficas que integram o submercado do Sul. Com o objetivo de estabilizar a variância, foi aplicada uma transformação logarítmica.

\footnotetext{
113 Comentário Prof. Molion: “ A transformação log parece reduzir os valores altos e aumentar os valores
} adjacentes." 
Na Figura 7-16, apresenta-se a decomposição aditiva da série observada em sazonalidade, tendência e parte aleatória. Nota-se que a sazonalidade, a amplitude ora aumenta e ora diminui, a tendência apresenta crescimentos e decrescimentos.

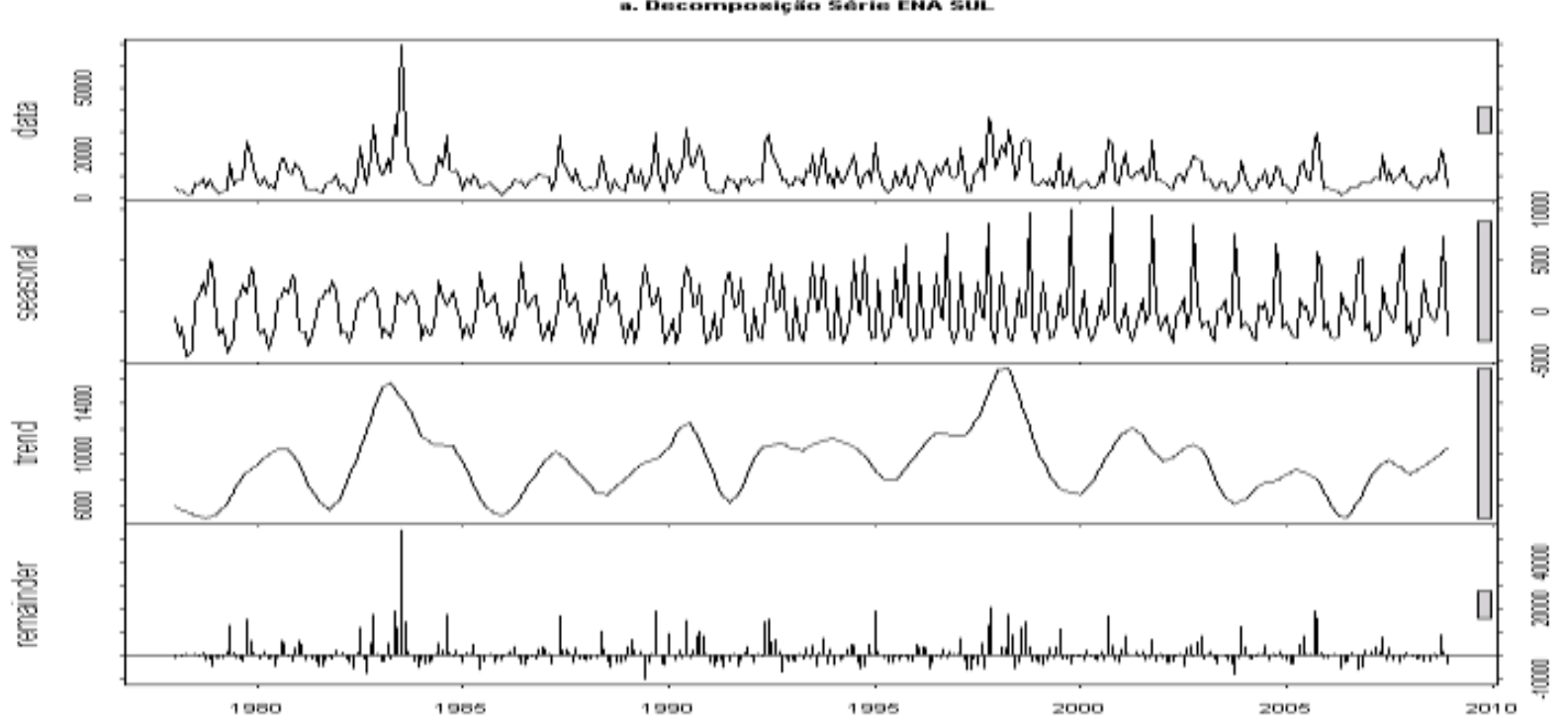

Figura 7-16 - Decomposição: Original. Sazonal. Tendência e Aleatório. ENA Sul - Período de Jan/1978 a Dez/2008

Na Figura 7-17, apresenta-se o componente sazonal mês a mês mostrando valores da variabilidade entre os meses de janeiro a dezembro. Nota-se que, diferente da ENA do Sudeste, não há períodos secos e úmidos destacados e as medianas são aproximadas. O mês de outubro apresenta variabilidade levemente maior que os demais meses.

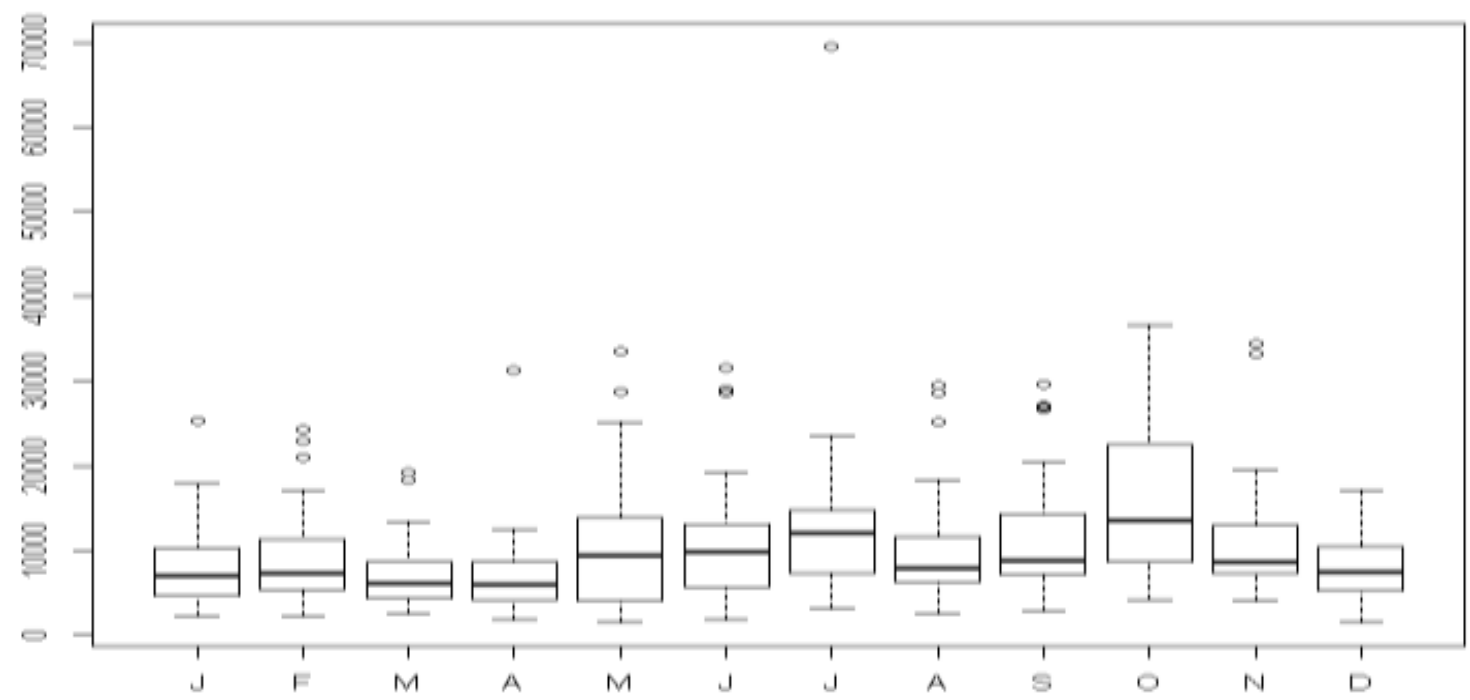

Figura 7-17 - Gráfico Caixa Série Histórica log (MW Médios) ENA Sul - Período de Jan/1931 a Dez/2013

Isso ocorre porque, a região Sul recebe chuva, geralmente, o ano todo, e as precipitações são provacadas por sistemas climáticos de diferentes origens, como, por exemplo, as zonas de instabilidades e frentes frias, promovidas por sistemas frontais vindos do Polo Sul, o vento 
que trás umidade do oceano Atlântico, devido aos ventos de Leste, e Ventos Alísios no litoral, e a proximidade com a formação de ciclones extratropicais no Atlântico, e influência exercida pelas massas de ar de alta pressão, tanto Alta da Bolívia como também Alta do Atlântico e outras forçantes sinóticas, que contribuem para que ocorra precipitações quase o ano todo na região Sul.

\subsubsection{Identificação}

Nessa fase, são avaliadas as funções de autocorrelação (ACF) e autocorrelação parcial (PACF) para se estimar a ordem dos parâmetros do modelo. A seguir, a avaliação inicial da série histórica da ENA-S.

A série é aparentemente estacionária, para o período de 1978 a 2008, e foi aplicada uma transformação de log e também as funções ACF e PACF, e seus gráficos são apresentados na Figura 7-18, que indicam um decaimento senoidal no gráfico ACF e um lag significativo com valor 1 no gráfico PACF, sugerindo um parâmetro AR(1) e o uso do modelo $\operatorname{ARIMA(100).~}$

log(ENA_S)
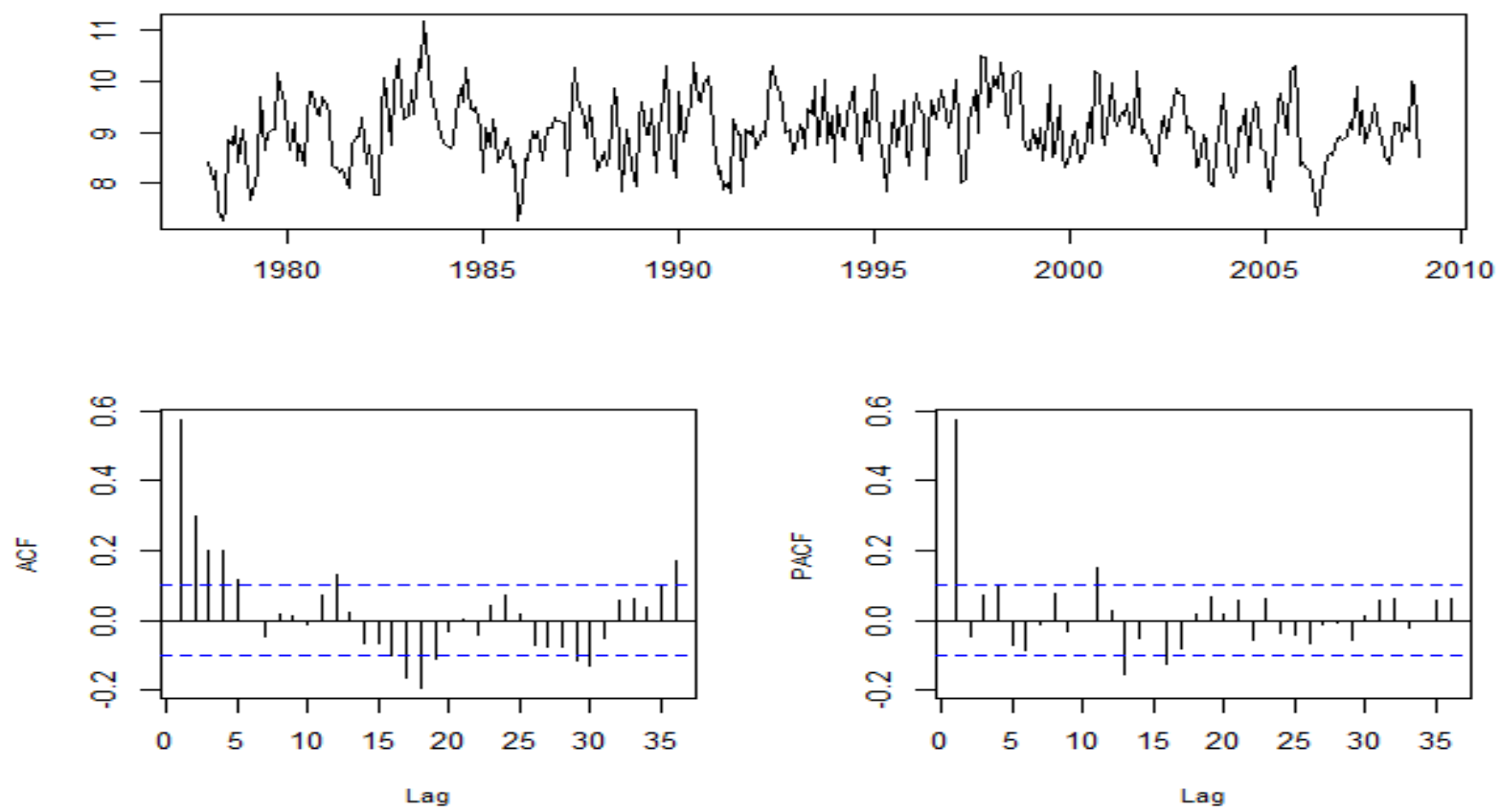

Figura 7-18 - Gráficos: a) Série Transformada com log, ACF e PACF.

Ao aplicar a EACF são indicados os modelos ARIMA(303) ou ARIMA(100) o que corrobora com as análises anteriores, Tabela 7-8. 
Tabela 7-8 Resultado da Função de Autocorrelação estendida - eacf - ENA-S

\begin{tabular}{|c|c|c|c|c|c|c|c|c|c|c|c|c|c|c|}
\hline AR/MA & $\mathbf{0}$ & 1 & 2 & 3 & 4 & 5 & 6 & 7 & 8 & 9 & 10 & 11 & 12 & 13 \\
\hline 0 & $\mathrm{X}$ & $\mathrm{X}$ & X & $\mathrm{X}$ & $\mathrm{O}$ & $\mathrm{O}$ & $\mathrm{O}$ & $\mathrm{O}$ & $\mathrm{O}$ & $\mathrm{O}$ & O & $\mathrm{X}$ & O & $\mathrm{O}$ \\
\hline 1 & O & $\mathrm{X}$ & $\mathrm{O}$ & $\mathrm{X}$ & $\mathrm{O}$ & $\mathrm{O}$ & $\mathrm{O}$ & $\mathrm{O}$ & $\mathrm{O}$ & $\mathrm{O}$ & O & $\mathrm{X}$ & O & $\mathrm{X}$ \\
\hline 2 & O & O & $\mathrm{X}$ & $\mathrm{X}$ & $\mathrm{O}$ & $\mathrm{O}$ & $\mathrm{O}$ & $\mathrm{O}$ & $\mathrm{O}$ & $\mathrm{O}$ & $\mathrm{O}$ & $\mathrm{O}$ & O & $\mathrm{O}$ \\
\hline 3 & $\mathrm{X}$ & X & X & O & O & O & $X$ & $\mathrm{O}$ & $\mathrm{O}$ & $\mathrm{O}$ & O & O & $\mathrm{O}$ & $\mathrm{O}$ \\
\hline 4 & $\mathrm{X}$ & X & X & O & O & O & $\mathrm{O}$ & $\mathrm{O}$ & O & $\mathrm{O}$ & O & O & O & $\mathrm{X}$ \\
\hline 5 & $\mathrm{X}$ & $\mathrm{X}$ & $\mathrm{X}$ & $\mathrm{O}$ & O & O & $\mathrm{O}$ & $\mathrm{O}$ & O & $\mathrm{O}$ & $\mathrm{O}$ & $\mathrm{O}$ & O & $\mathrm{O}$ \\
\hline 6 & $\mathrm{X}$ & $\mathrm{X}$ & $\mathrm{X}$ & $\mathrm{X}$ & $\mathrm{O}$ & $\mathrm{O}$ & $\mathrm{O}$ & $\mathrm{O}$ & $\mathrm{O}$ & $\mathrm{O}$ & $\mathrm{O}$ & $\mathrm{O}$ & $\mathrm{O}$ & $\mathrm{O}$ \\
\hline 7 & $\mathrm{X}$ & $X$ & $\mathrm{X}$ & $\mathrm{O}$ & O & $\mathrm{O}$ & $\mathrm{X}$ & $\mathrm{O}$ & $\mathrm{O}$ & $\mathrm{O}$ & $\mathrm{O}$ & $\mathrm{O}$ & $\mathrm{O}$ & $\mathrm{O}$ \\
\hline
\end{tabular}

Em modelos tipo ARMA, essa configuração indica um modelo com p igual a 1, e q iguais a 0 ou 3. Com o objetivo de agilizar o processo de identificação, foram utilizadas também duas funções do pacote estatística $\mathrm{R}$, os comandos auto.arima e get.best.arima para identificar os parâmetros. O comando auto.arima retornou o modelo SARIMAX(100)(200). Já, o comando get.best.arima retornou o modelo SARIMAX(100)(211). Todos os possíveis modelos foram testados, sendo selecionados somente os melhores conforme o critério de AIC e o valor de Sigma $^{2}$, apresentados na Tabela 7-9, onde também há coeficiente de determinação para avaliar a relação entre as variáveis explicativas e os valores do modelo ajustado. Diferente do que foi apresentado pelo comando get.best.arima, o melhor modelo foi o SARIMAX(100)(101), indicado pelo comando auto.arima o qual apresentou AIC igual a 539 e sigma ${ }^{2}$ igual a 0,23 e $\mathrm{R}^{2} 0,77$.

Tabela 7-9 Critérios de adequação dos modelos ENA SUL (AIC, AICc, BIC, Sigma2, R2, R2a, R2p-valor)

\begin{tabular}{llllrlll}
\hline Modelo SARIMAX & AIC & AAIC & BIC & Sigma $^{\mathbf{2}}$ & $\mathbf{R}^{\mathbf{2}}$ & $\mathbf{R}^{\mathbf{2} a}$ & $\mathbf{R}^{\mathbf{2}} \mathbf{p}$-valor \\
\hline $\mathbf{( 1 0 0 ) ( 2 1 1 )}$ & 367,8 & 369,1 & 409,5 & 0,25 & 0,43 & 0,42 & 0,0000 \\
\hline $\mathbf{( 1 0 0 ) ( 2 0 1 )}$ & 394,0 & 395,3 & 436,4 & 0,25 & 0,43 & 0,42 & 0,0000 \\
\hline $\mathbf{( 1 0 0 ) ( 0 0 0 )}$ & 394,4 & 395,3 & 429,7 & 0,26 & 0,73 & 0,72 & 0,0000 \\
\hline $\mathbf{( 1 0 0 ) ( 1 0 1 )}$ & 539,2 & 542,8 & 632,4 & $\mathbf{0 , 2 3}$ & $\mathbf{0 , 7 7}$ & 0,75 & 0,0000 \\
\hline $\mathbf{( 1 0 0 ) ( 1 0 2 )}$ & 556,5 & 557,7 & 611,4 & 0,24 & 0,61 & 0,60 & 0,0000 \\
\hline $\mathbf{( 1 0 0 ) ( 1 0 0 )}$ & 557,0 & 557,8 & 600,1 & 0,25 & 0,74 & 0,73 & 0,0000 \\
\hline
\end{tabular}

\subsubsection{Estimação}

Para identificação das ordens do modelo foram utilizadas evidências empíricas da ACF, PACF e EACF (lags não nulos 1). Experimentalmente, ajustaram-se vários modelos, sendo que um em especial apresentou resultados AIC melhores, o modelo da classe SARIMAX $(1,0,0)(1,0,1)$ da forma:

$\left(1-\phi_{1} B\right)\left(1-\Phi_{1} B\right) Y_{t}=e_{t}\left(1-\Theta_{1} B\right)$,

onde $\mathrm{e}_{\mathrm{t}} \sim \mathrm{RB}\left(0, \sigma^{2}\right), \sim \mathrm{N}$ 
As estimativas dos parâmetros do modelo ajustado são apresentadas na Tabela 7-10 e na Tabela 7-11, são apresentados o resultado do modelo de regressão dinâmica, que compara os dados gerados pelo modelo ajustado e os dados utilizados para treinamento, considerando o IC de $95 \%$.

Tabela 7-10 Valores parâmetros estimados e estatísticas correspondentes

\begin{tabular}{|c|c|c|c|c|c|}
\hline Modelo & Parâmetros & Estimativas & $\begin{array}{c}\text { Erro } \\
\text { Padrão }\end{array}$ & Valor $\mathbf{p}$ & $\begin{array}{c}\text { Estimativa } \\
\text { de } \sigma^{2}\end{array}$ \\
\hline \multirow{12}{*}{$\begin{array}{l}\text { SARIMAX }(\mathbf{1 , 0 , 0}) \\
(\mathbf{1 , 0 , 1 )}\end{array}$} & $\phi_{1}$ & 0,50 & 0,05 & 0,0000 & \multirow{12}{*}{0,25} \\
\hline & $\Phi_{1}$ & 0,95 & 0,06 & 0,0000 & \\
\hline & $\Theta_{1}$ & $-0,86$ & 0,11 & 2,0000 & \\
\hline & Intercepto & 8,85 & 0,12 & 0,0000 & \\
\hline & NINO3 ${ }_{W L}$ & 0,15 & 0,04 & 0,0004 & \\
\hline & TSI & 0,00 & 0,00 & 0,8674 & \\
\hline & MEI & 0,23 & 0,11 & 0,0333 & \\
\hline & ONI & 0,02 & 0,14 & 0,8740 & \\
\hline & PDO & $-0,02$ & 0,05 & 1,3993 & \\
\hline & X40W & 0,13 & 0,05 & 0,0050 & \\
\hline & $\mathrm{AO}$ & 0,03 & 0,03 & 0,2490 & \\
\hline & SAM2 & $-0,02$ & 0,01 & 1,8854 & \\
\hline
\end{tabular}

Na Tabela 7-11 são apresentados os valores estimados e as estatísticas associadas ao modelo de regressão dinâmica. As variáveis NINO3 ${ }_{w L}$, MEI, SOL, ONI e X40W apresentaram significância estatística, inversamente as variáveis, PDO, AO E SAM2.

Tabela 7-11 Valores parâmetros estimados dos coeficientes das variáveis explicativas e as estatísticas correspondentes

\begin{tabular}{lrrrcr}
\hline Parâmetros & Estimativas & Erro Padrão & Estatística t & Valor p & \\
\hline WLNINO3 & 1.793 & 225 & 7,97 & 0,0000 & $* * *$ \\
\hline TSI & 51 & 3 & 15,15 & 0,0000 & $* * *$ \\
\hline MEI & 6.279 & 834 & 7,53 & 0,0000 & $* * *$ \\
\hline ONI & -3.539 & 984 & $-3,60$ & 0,0004 & $* * *$ \\
\hline PDO & 267 & 310 & 0,86 & 0,3900 & \\
\hline X40W & 3.199 & 546 & 5,86 & 0,0000 & $* * *$ \\
\hline AO & -66 & 289 & $-0,23$ & 0,8207 & \\
\hline SAM2 & -129 & 153 & $-0,84$ & 0,4024 & \\
\hline
\end{tabular}

\subsubsection{Verificação ou diagnóstico}

Os diagnósticos dos erros do modelo são apresentados na Figura 7-19 a) indica aceitação da hipótese do modelo não ser heterocedástico. b) o Gráfico ACF indica que os resíduos apresentam um comportamento aleatório (ruído branco) e o valor de Ljung-Box aceita a hipótese que as autocorrelações estimadas são gaussianas com média zero e variância $1 / n$. c) o 
Gráfico QQ indica aceitação da hipótese de normalidade, pois se ajusta a uma linha reta. d) a distribuição está em torno da média e também há normalidade.

a) Resid vs ajust(p-valor McLeod-Li: 0.45 )

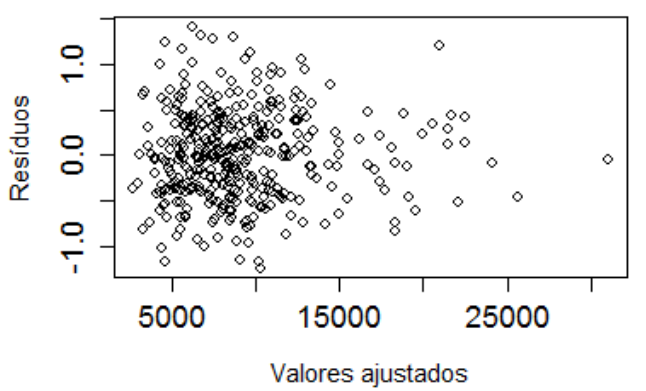

c) Q-Q plot normal (p-valor Shapiro-Wilk:0.39)

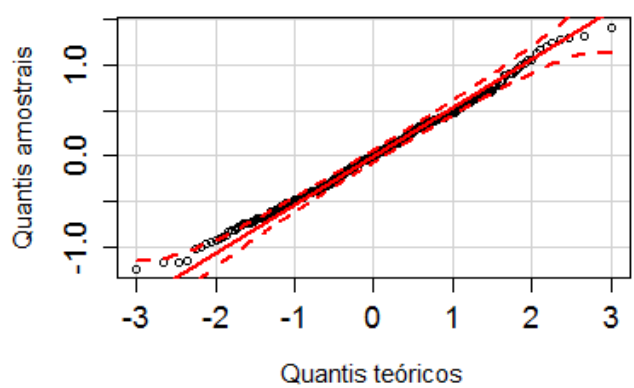

b) FAC residuos(p-valor Ljung-Box:0.96)

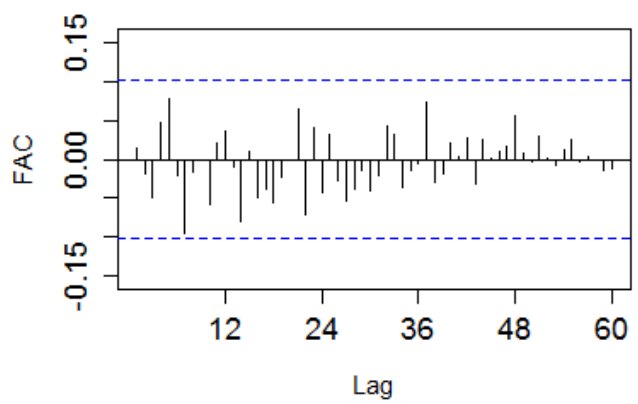

d) Histograma(p-valor teste t:0.73)

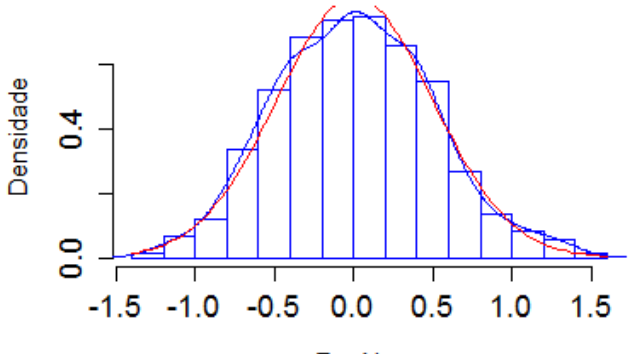

Figura 7-19 - Gráfico análise de resíduos modelo SARIMAX (100)(101):a) Resíduos versos modelo ajustado. b) FAC c) QQ-Plot d) Histograma

Assim, o modelo cumpre com as suposições dos erros: $e_{t}$ independentes, $E\left(e_{t}\right)=0$, variância constante e autocorrelação constante seguindo a distribuição normal. Os critérios AIC, AICc e BIC são muito similares, com uma leve melhora no Erro Médio Quadrático (RMSE).

Ao analisar os resíduos, verifica-se que os p-valores correspondentes às respectivas hipóteses nulas que são aceitáveis para os modelos SARIMAX (100)(101)e SARIMAX (100)(102) . Os valores p-valor são apresentados na Tabela 7-12, onde todas as colunas do modelo escolhido apresentam valores aceitáveis. Observa-se que nem sempre um modelo com um valor AIC menor tem também os p-valores aceitáveis.

Tabela 7-12 Análise de Resíduos - Modelo escolhido em amarelo

\begin{tabular}{lllllllllllll}
\hline $\begin{array}{l}\text { MODELO } \\
\text { SARIMAX }\end{array}$ & AIC & AAIC & BIC & ME & RMSE & MAE & MPE & MAPE & $\begin{array}{l}\text { Shapiro } \\
\text { Wilk }\end{array}$ & $\begin{array}{l}\text { Teste } \\
\text { t }\end{array}$ & $\begin{array}{l}\text { McLeod } \\
\text { Li }\end{array}$ & $\begin{array}{l}\text { Ljung } \\
\text { Box }\end{array}$ \\
\hline $\mathbf{( 1 0 0 ) ( 2 1 1 )}$ & 367 & 369 & 409 & 1.353 & 5.468 & 3.742 & $-7,46$ & 38,84 & 0,84 & 0,16 & 0,00 & 0,85 \\
\hline $\mathbf{( 1 0 0 ) ( 2 0 0 )}$ & 394 & 395 & 436 & 1.290 & 5.857 & 4.201 & $-12,73$ & 44.71 & 0,30 & 0,88 & 0,89 & 0,14 \\
\hline $\mathbf{( 1 0 0 ) ( 1 0 1 )}$ & 556 & 557 & 607 & 1.289 & 6.045 & 3.931 & $-11,45$ & 41,74 & $\mathbf{0 , 3 9}$ & $\mathbf{0 , 7 3}$ & $\mathbf{0 , 4 5}$ & $\mathbf{0 , 9 6}$ \\
\hline $\mathbf{( 1 0 0 ) ( 1 0 2 )}$ & 556 & 558 & 611 & 1.313 & 6.019 & 3.916 & $-10,78$ & 41,29 & 0,40 & 0,61 & 0,54 & 0,94 \\
\hline $\mathbf{( 3 0 3 ) ( 0 0 4 )}$ & 568 & 570 & 646 & 1.198 & 6.076 & 3.973 & $-12,74$ & 42,56 & 0,30 & 0,91 & 0,60 & 0,78 \\
\hline
\end{tabular}

\subsubsection{Validação Cruzada}

Uma explicação de como é feita a validação cruzada é mencionada na seção 7.1.5 Validação

Cruzada, p. 213 
$\mathrm{Na}$ validação cruzada são experimentados quatro modelos com variáveis explicativas diferentes, com a ordem SARIMAX (100)(101). O modelo com variáveis explicativas tem vantagem em relação aos modelos com uma única ou mesmo nenhuma variável explicativa, como visto na Figura 7-20. Há quatro resultados da média de erros padrões das previsões retroativas da validação cruzada, de modelos com diferentes configurações das variáveis explicativas, que são: um modelo sem variáveis explicativas, um modelo com todas as variáveis explicativas, e um modelo somente com a variável explicativa SOL (irradiância solar total) e outro modelo somente com a variável explicativa NINO ${ }_{\mathrm{WL}} 3 . \mathrm{O}$ modelo com variáveis explicativas tem vantagem em relação aos modelos com uma única ou mesmo sem nenhuma variável explicativa.

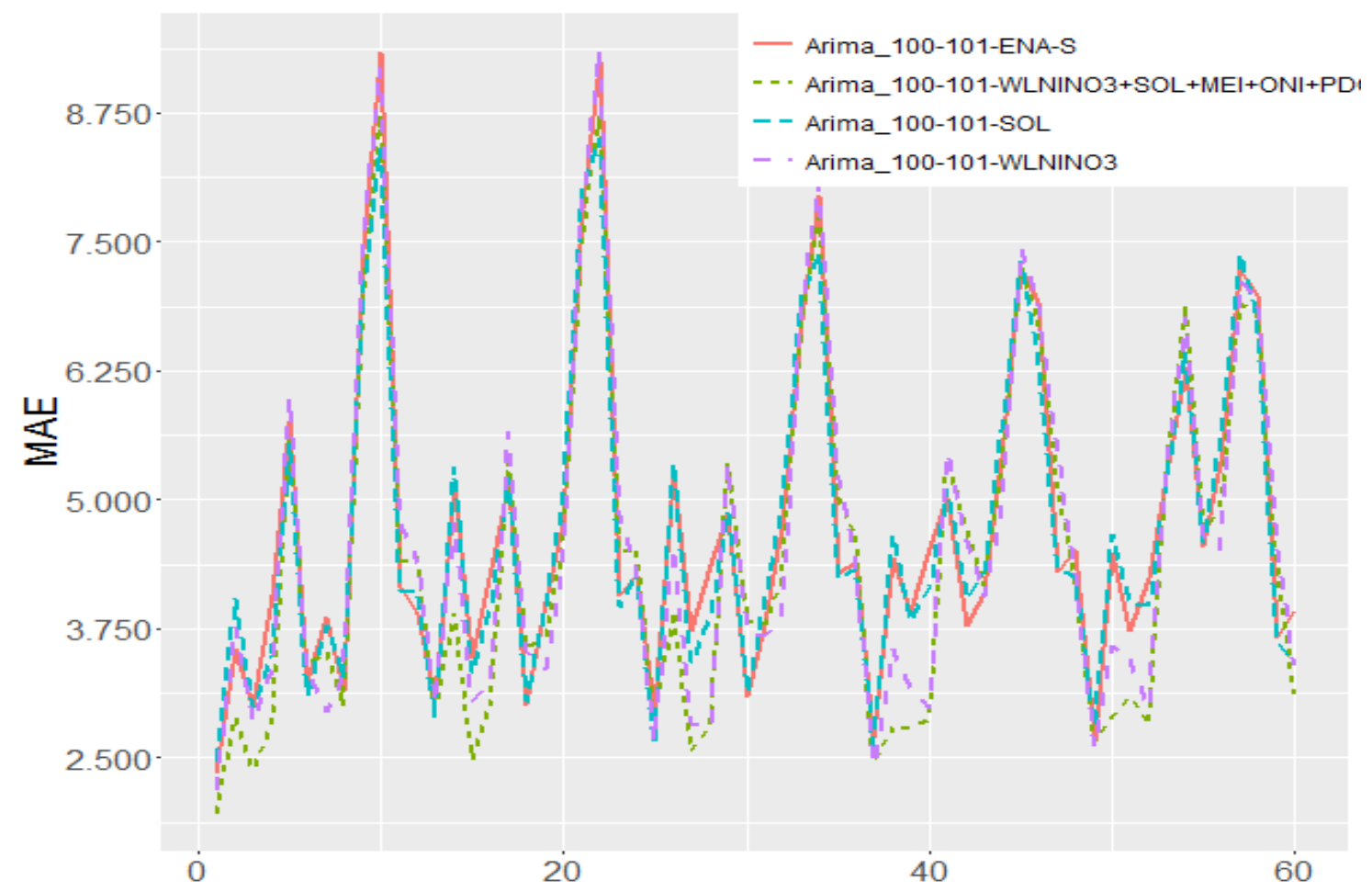

Figura 7-20 Validação cruzada com o modelo SARIMAX (100)(101) 
Na validação (Tabela 7-13) com RMSE e R2, há alguns resultados com grandes erros (19782009: 7.728 MWmédios). Os demais agrupamentos apresentam erros menores, onde o menor erro médio quadrático é 5.307 (1978-2002). Todos os valores de coeficiente de determinação e ajustados são próximos e acima de 0,6. Os valores p são menores que 0,0001, o que indica que os coeficientes de determinação são significativos.

Tabela 7-13 Dados validação modelo de regressão dinâmica SARIMAX (100)(101)

\begin{tabular}{rrrrrrrrrrr}
\multicolumn{2}{c}{ JANELA } & $\begin{array}{l}\text { MODELO } \\
\text { SARIMAX }\end{array}$ & ME & RMSE & MAE & $\begin{array}{r}\text { MPE } \\
\text { \% }\end{array}$ & $\begin{array}{r}\text { MAPE } \\
\text { \% }\end{array}$ & R2 & R2a & R2P \\
\hline $\mathbf{1 9 7 8}$ & 1997 & $(100)(101)$ & 3.293 & 7.154 & 5.098 & 7 & 39 & 0,95 & 0,95 & 0,0000 \\
\hline $\mathbf{1 9 7 8}$ & 1998 & $(100)(101)$ & 2.569 & 6.050 & 4.246 & 7 & 40 & 0,91 & 0,89 & 0,0000 \\
\hline $\mathbf{1 9 7 8}$ & 1999 & $(100)(101)$ & 3.530 & 6.125 & 4.258 & 21 & 37 & 0,88 & 0,87 & 0,0000 \\
\hline $\mathbf{1 9 7 8}$ & 2000 & $(100)(101)$ & 4.082 & 6.692 & 4.632 & 23 & 39 & 0,84 & 0,82 & 0,0000 \\
\hline $\mathbf{1 9 7 8}$ & 2001 & $(100)(101)$ & 1.778 & 5.636 & 3.888 & 11 & 50 & 0,79 & 0,75 & 0,0000 \\
\hline $\mathbf{1 9 7 8}$ & 2002 & $(100)(101)$ & 950 & 5.307 & 3.696 & -21 & 52 & 0,70 & 0,66 & 0,0000 \\
\hline $\mathbf{1 9 7 8}$ & 2003 & $(100)(101)$ & 1.490 & 5.702 & 3.923 & -15 & 51 & 0,79 & 0,75 & 0,0000 \\
\hline $\mathbf{1 9 7 8}$ & 2004 & $(100)(101)$ & 1.816 & 6.386 & 4.316 & -20 & 55 & 0,70 & 0,65 & 0,0000 \\
\hline $\mathbf{1 9 7 8}$ & 2005 & $(100)(101)$ & 1.509 & 5.653 & 3.967 & -19 & 52 & 0,72 & 0,68 & 0,0000 \\
\hline $\mathbf{1 9 7 8}$ & 2006 & $(100)(101)$ & 3.971 & 7.280 & 5.027 & -12 & 40 & 0,73 & 0,69 & 0,0000 \\
\hline $\mathbf{1 9 7 8}$ & 2007 & $(100)(101)$ & 2.715 & 6.934 & 4.823 & 5 & 45 & 0,87 & 0,85 & 0,0000 \\
\hline $\mathbf{1 9 7 8}$ & 2008 & $(100)(101)$ & 2.969 & 7.171 & 5.248 & -4 & 49 & 0,87 & 0,85 & 0,0000 \\
\hline $\mathbf{1 9 7 8}$ & 2009 & $(100)(101)$ & 3.520 & 7.728 & 5.273 & -9 & 40 & 0,92 & 0,91 & 0,0000 \\
\hline
\end{tabular}

Ao verificar os valores nos gráficos a seguir observa-se que as previsões do modelo oficial NEWAVE apresentam-se previsões muito aproximadas de um ano para outro. Na Figura 7-21, são apresentados, no início, o valor observado registrado pelo ONS e, em seguida, os valores dos decks de previsão do modelo NEWAVE. Esses resultados podem ser avaliados através dos indicadores de erro apresentados na Tabela 7-14.

Tabela 7-14 Dados validação NEWAVE Região Sul Decks 2003 a 2009

$\begin{array}{rlrlrr}\text { Deck } & \text { ME } & \text { RMSE } & \text { MAE } & \text { MPE } & \text { MAPE } \\ \mathbf{2 0 0 3} & 1.156 & 5.405 & 3.588 & -20 \% & 52 \% \\ \mathbf{2 0 0 4} & 1.392 & 5.492 & 3.652 & -16 \% & 49 \% \\ \mathbf{2 0 0 5} & 1.771 & 6.481 & 4.407 & -22 \% & 57 \% \\ \mathbf{2 0 0 6} & 1.818 & 6.202 & 4.372 & -16 \% & 52 \% \\ \mathbf{2 0 0 7} & 3.493 & 7.339 & 5.286 & 5 \% & 45 \% \\ \mathbf{2 0 0 8} & 2.758 & 7.348 & 5.297 & -6 \% & 49 \% \\ \mathbf{2 0 0 9} & 2.931 & 7.349 & 5.429 & -5 \% & 50 \%\end{array}$


Na Figura 7-21, são apresentados os valores de ENA-S observados e na sequência as previsões feitas pelo NEWAVE a partir dos decks de dados 2003, 2004, 2005, 2006, 2007, 2008 e 2009, para 5 anos a frente

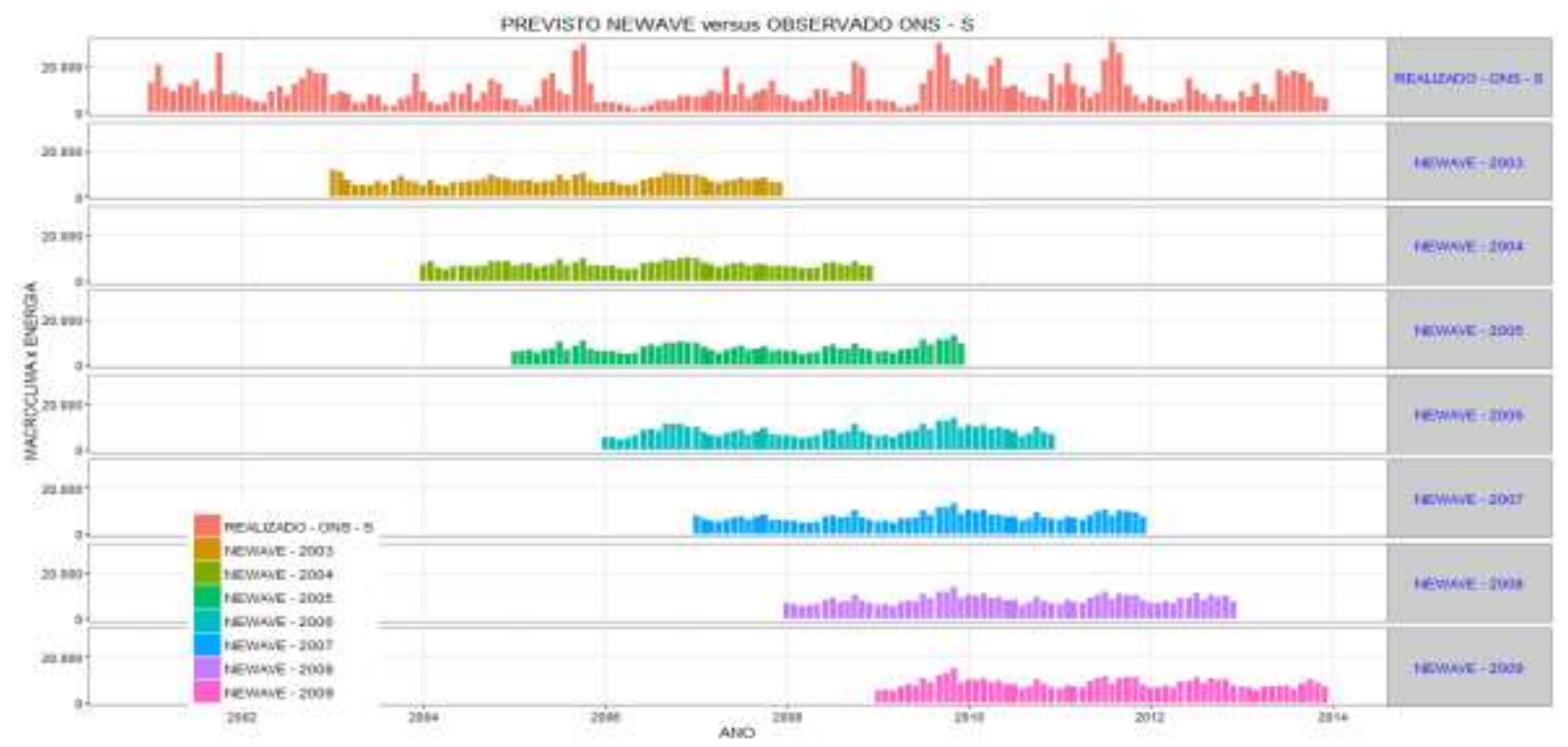

Figura 7-21 Validação Cruzada NEWAVE Região Sul :: Decks 2003 a 2009.

Na Figura 7-22, apresenta-se a diferença ou erro entre o observado e o previsto. Nota-se que os valores de erro são aproximados nos mesmos meses, apesar de serem previsões realizadas com decks diferentes.

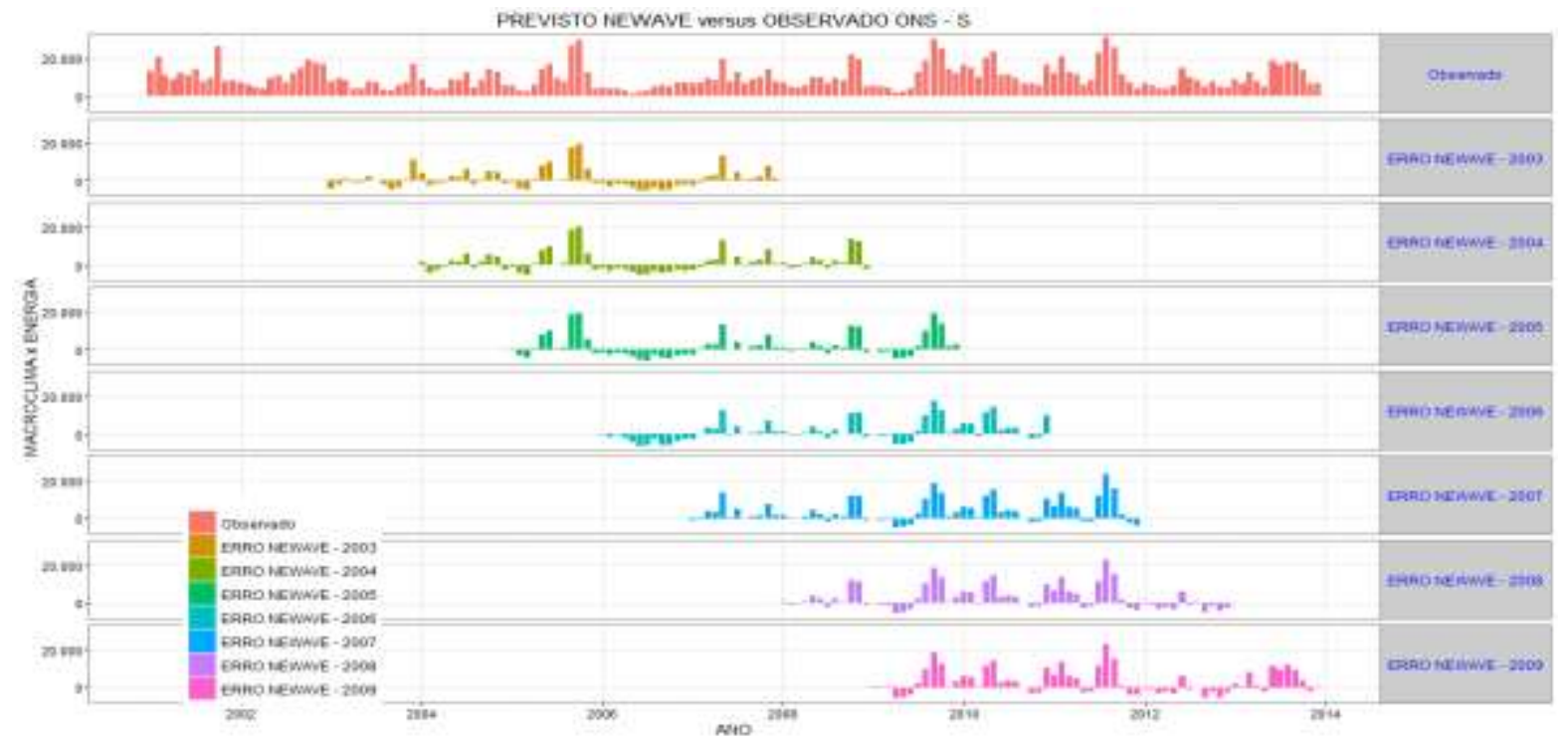

Figura 7-22 Validação Cruzada Erro =NEWAVE- ONS Região Sul:: Decks 2003 a 2009. 
O modelo SARIMAX(100)(101) é apresentado nas Figura 7-23 e Figura 7-24, e os resultados de erros são melhores frente aos do NEWAVE. Nota-se que também, apresentam-se erros similares nos mesmos meses, apesar de utilizarem conjuntos de testes diferentes.

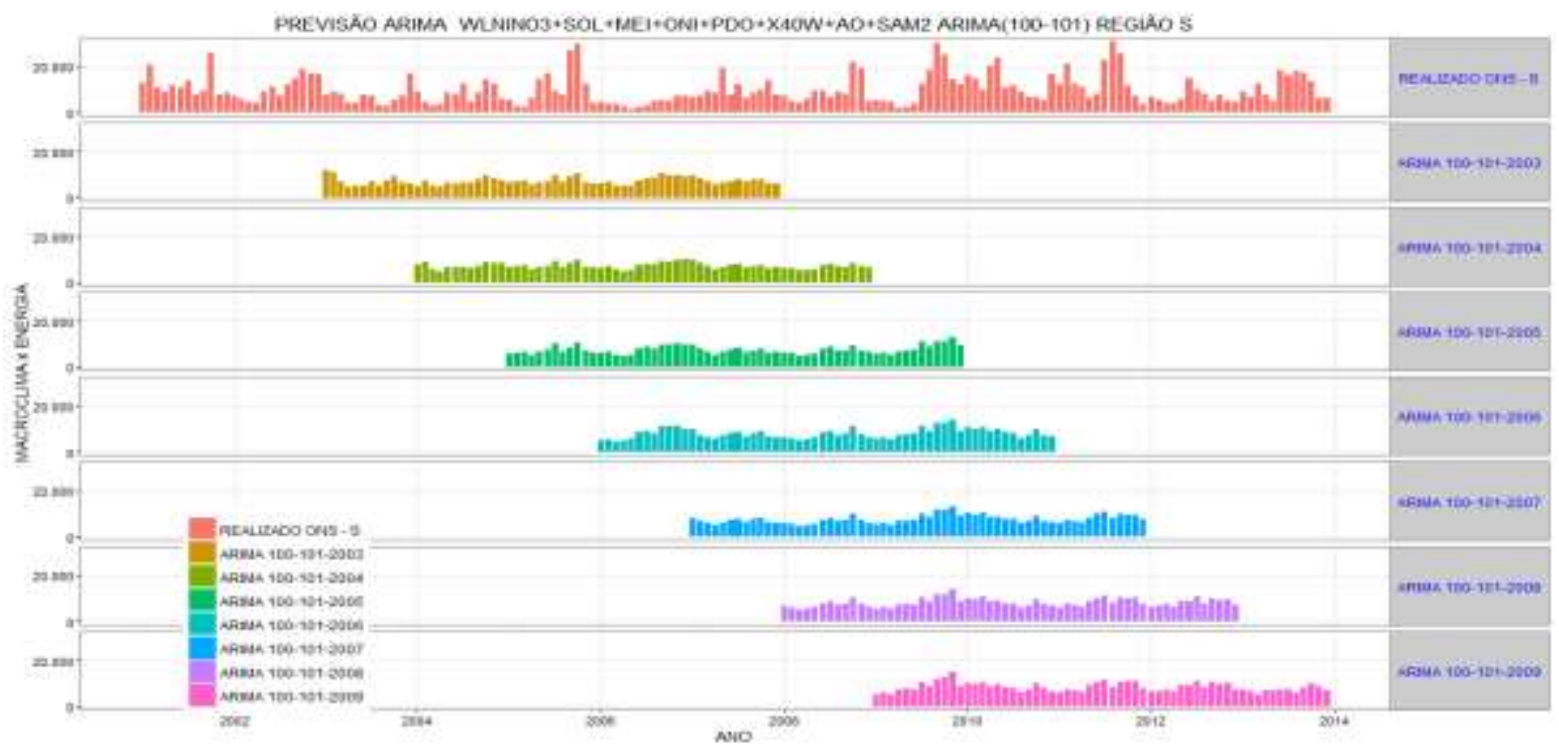

Figura 7-23 Validação cruzada modelos SARIMAX (100)(101) Região Sul

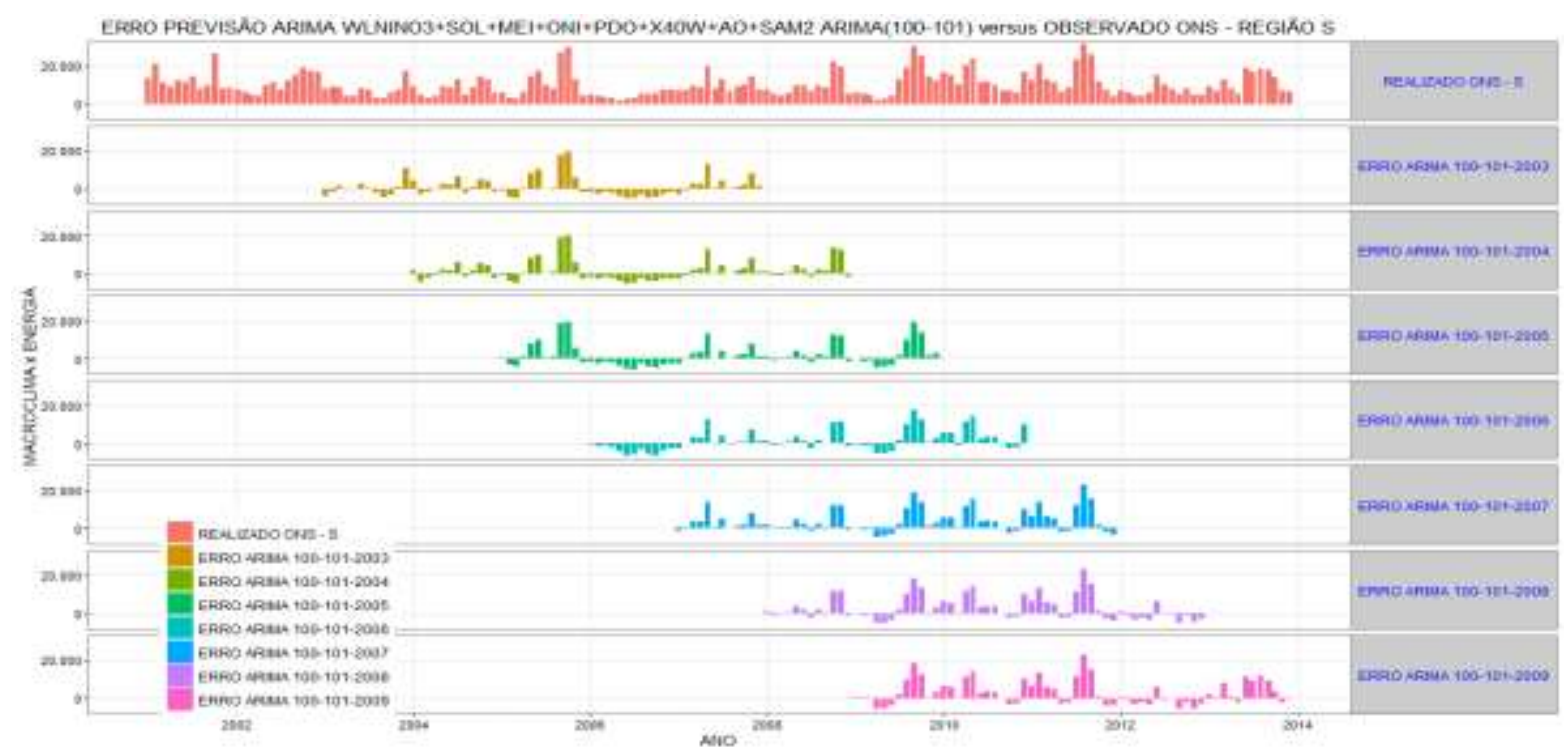

Figura 7-24 Validação Cruzada Erro =SARIMAX(100)(101) :: Conjuntos de teste 2003 a 2009 Região Sul 


\subsection{Modelo SARIMAX ENA NORDESTE}

\subsubsection{Especificação}

Ao examinar os gráficos, os mapas e as análises de séries históricas escolheram-se as variáveis explicativas AMM, AMO, TNA2, X70E, X120E e X40W e frente a variável dependente a ENA do Nordeste (Figura 7-25).

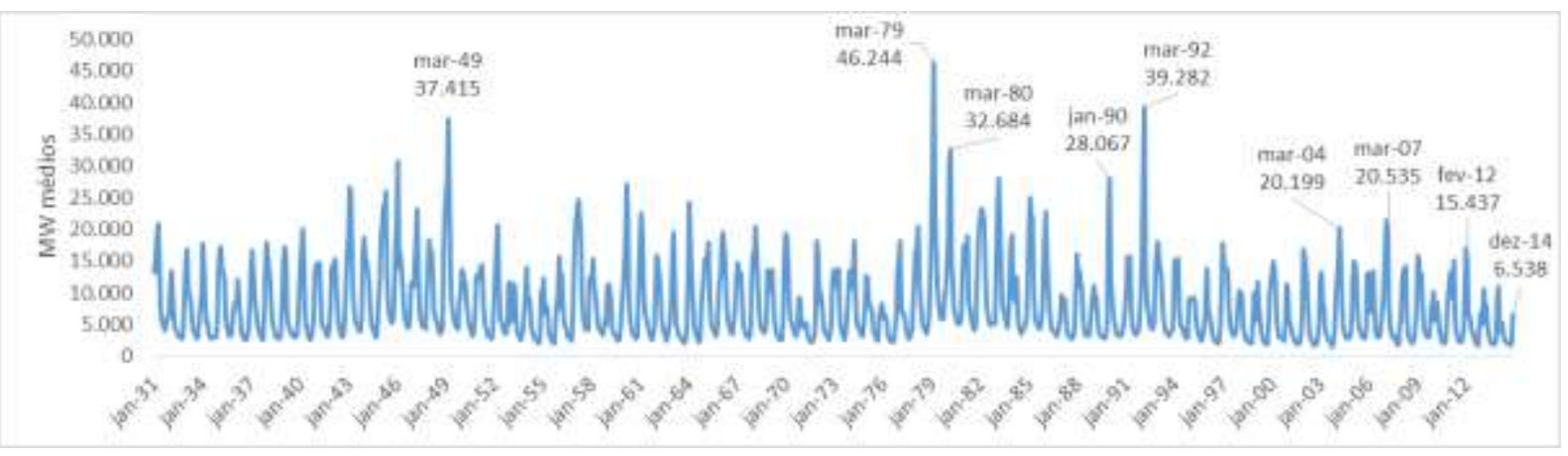

Figura 7-25 - Série Histórica em MW Médios ENA Nordeste - Período de Jan/1931 a Dez/2014

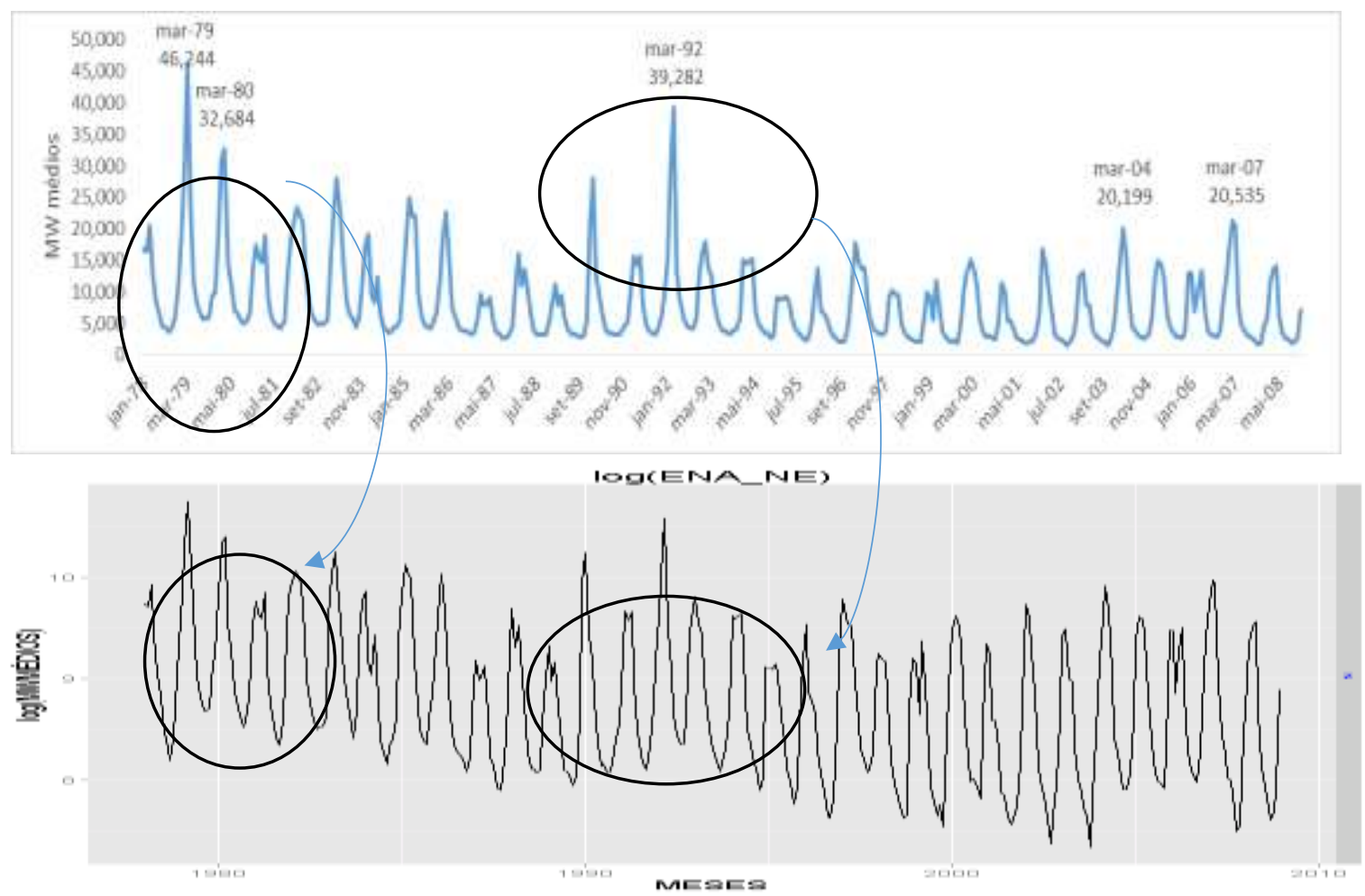

Figura 7-26 - Série Histórica em MW Médios ENA Nordeste - Período de Jan/1978 a Dez/2008 ${ }^{114}$

Na Figura 7-26, apresenta-se a série histórica com sazonalidade e tendências localizadas e explicadas pela dinâmica sazonal das chuvas e localização geográfica das bacias hidrográficas

\footnotetext{
${ }^{114}$ Comentário Prof. Molion: “ A transformada log descaracteriza totalmente a série original. ”
} 
que integram o submercado do Nordeste. Com o objetivo de estabilizar a variância, foi aplicada uma transformação logarítmica.

Na Figura 7-27, apresentam-se a decomposição aditiva da série observada: sazonalidade, tendência e aleatório. Nota-se que a sazonalidade diminui sua intensidade e a tendência apresenta queda, no geral.

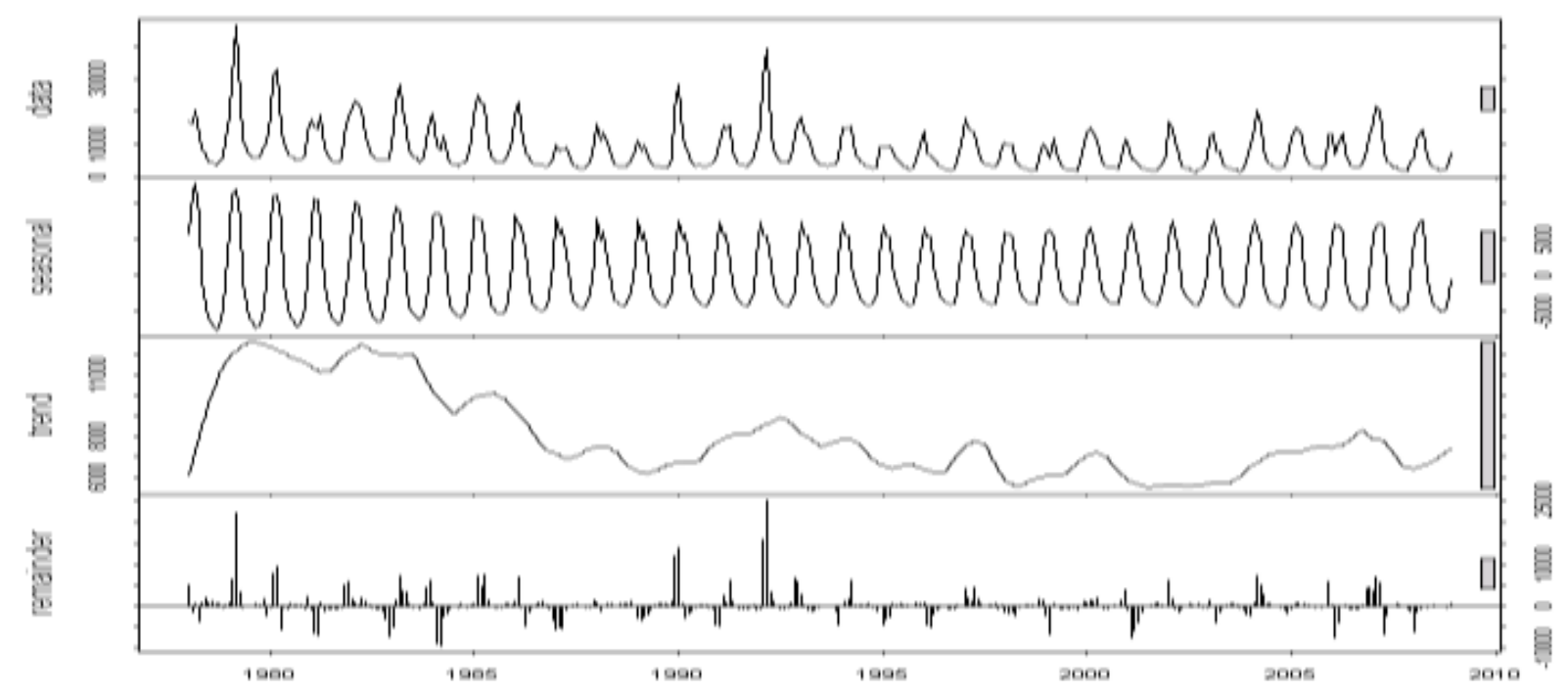

Figura 7-27 - Decomposição: Original. Sazonal. Tendência e Aleatório. ENA Nordeste - Período de Jan/1978 a Dez/2008

Na Figura 7-28, apresenta-se o componente sazonal mês a mês, mostrando valores da variabilidade crescente entre os meses de novembro a março (período úmido) e decrescentes de abril a outubro (período seco).

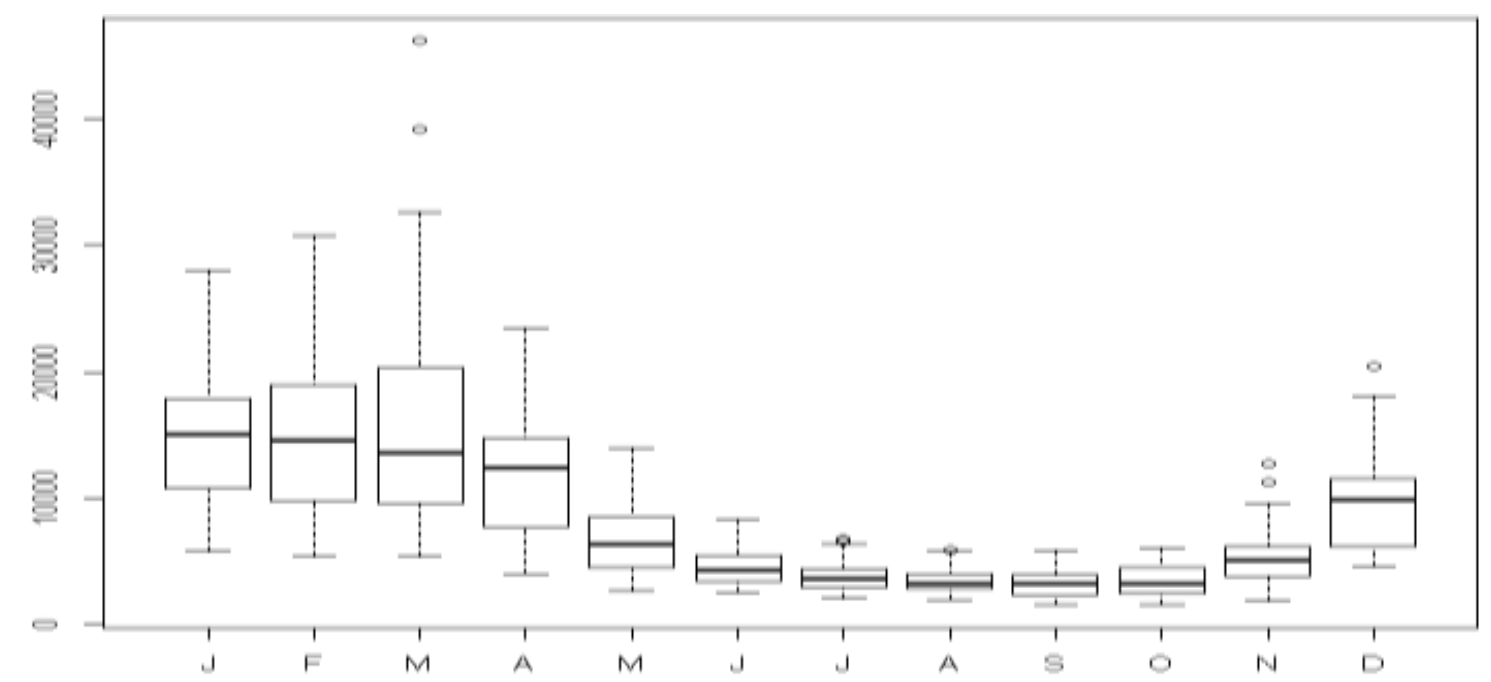

Figura 7-28 - Gráfico Caixa Série Histórica log (MW Médios) ENA Nordeste - Período de Jan/1931 a Dez/2013

Nessa região há influência dos Ventos Alísios, que transportam umidade para o litoral, e influencía as precipitações no Litoral, já, a orografia impede a passagem de umidade para as regiões do sertão nordestino. Em ocorrencias de El Niño, em geral, desenvolve-se períodos de 
estiagem na região. Há também influência nas precipitações, causada pela ZCIT, que atua mais ao Norte da região Nordeste, que ao migrar para o Sul, promove precipitações, e quando migra para o Norte, as precipitações ocorrem no oceano. O posicionamento da ZCIT, como visto na literatura, é provocado pelo aquecimento ou esfriamento das águas do Oceano Atântico Sul, e outros fenômenos associados.

\subsubsection{Identificação}

Nessa fase, são avaliadas as funções de autocorrelação (ACF) e autocorrelação parcial (PACF) para se estimar a ordem dos parâmetros do modelo. A seguir, a avaliação inicial da série histórica da ENA NORDESTE.

A série original (Figura 7-29 a) apresenta tendências, e, portanto, foi aplicada uma diferença com o objetivo de elimina-las, originando os resultados das Funções ACF e PACF apresentadas em b) a transformada com uma diferença. Os resultados indicam nos gráficos PACF dois componentes autorregressivos, pois apresenta dois picos significativos, o que indica o uso do modelo $\mathrm{AR}(2)$, e com a transformação por uma diferença o componente que se destaca está no lag 1 e, assim, há indicação do uso do modelo ARIMA(110).
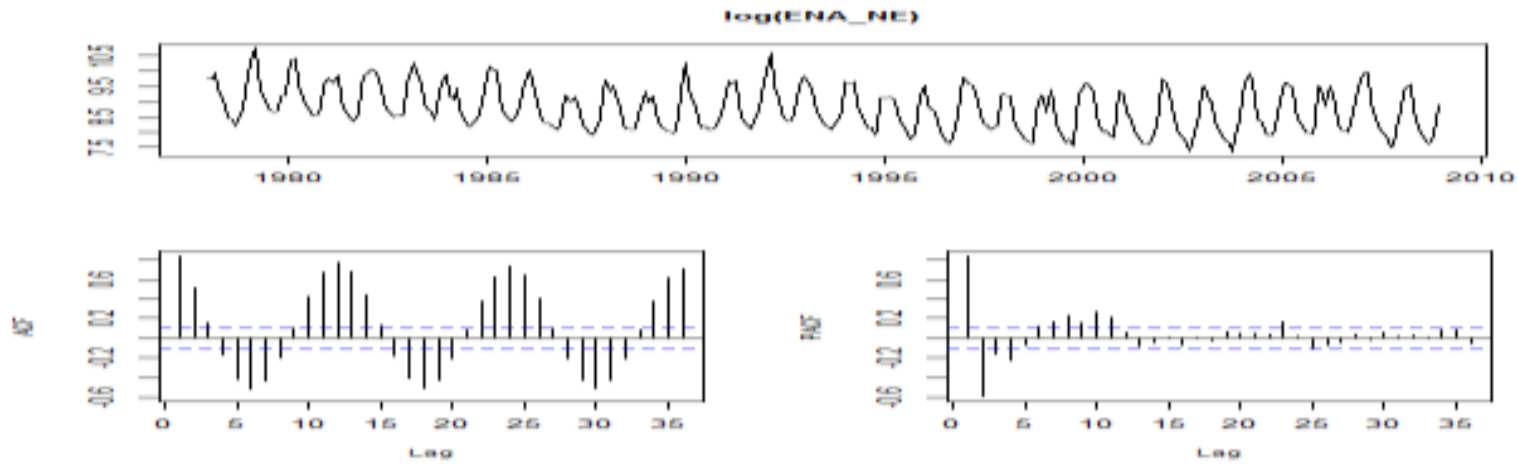

(a)
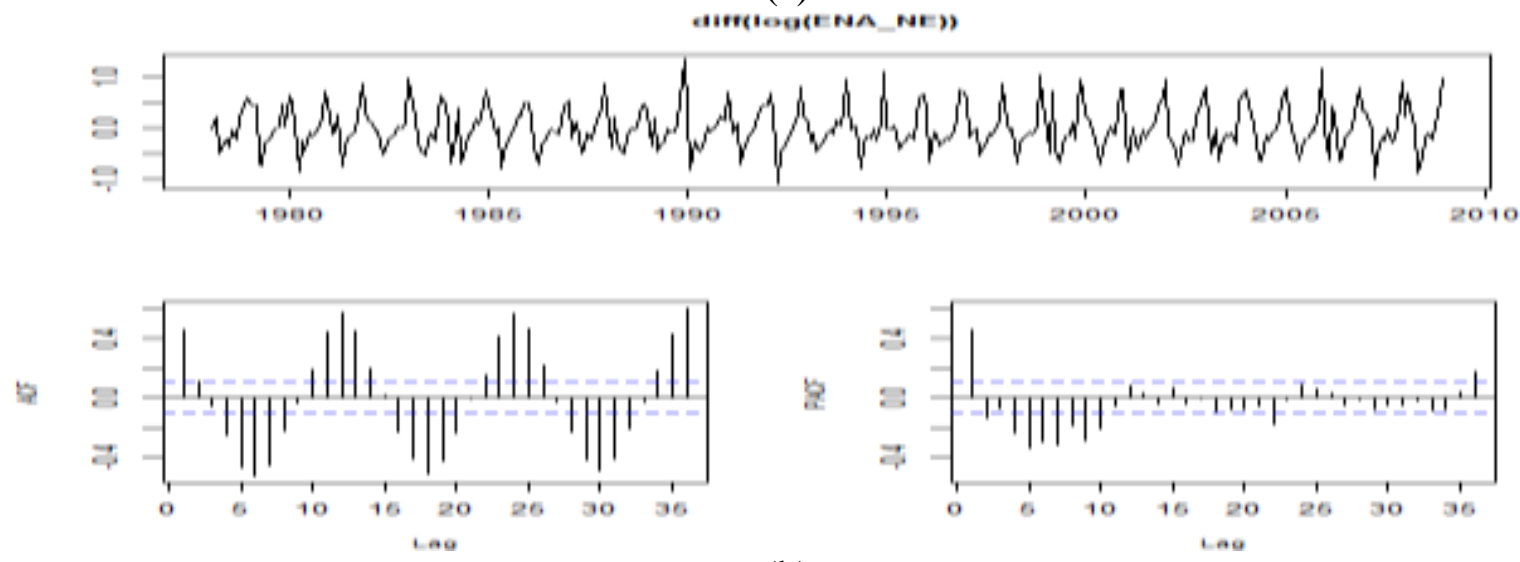

(b)

Figura 7-29 - Gráficos: a) Série Original b) Série Transformada com log, ACF e PACF e c) com uma diferença. 
Ao aplicar a Função de Autocorrelação Estendida (EACF) indica-se os modelos $\operatorname{ARIMA(202)o~que~se~aproxima~com~as~análises~anteriores,~Tabela~7-15.~}$

Tabela 7-15 Resultado da Função de Autocorrelação estendida - eacf - ENA-NE

\begin{tabular}{|c|c|c|c|c|c|c|c|c|c|c|c|c|c|c|}
\hline AR/MA & 0 & 1 & 2 & 3 & 4 & 5 & 6 & 7 & 8 & 9 & 10 & 11 & 12 & 13 \\
\hline $\mathbf{0}$ & $\mathrm{X}$ & $\mathrm{X}$ & $\mathrm{O}$ & X & X & $\mathrm{X}$ & $\mathrm{X}$ & $\mathrm{X}$ & $\mathrm{O}$ & $X$ & $\mathrm{X}$ & $\mathrm{X}$ & $X$ & $\mathrm{x}$ \\
\hline 1 & $\mathrm{X}$ & X & 0 & X & $\mathrm{X}$ & $\mathrm{X}$ & $\mathrm{X}$ & $\mathrm{X}$ & O & $\mathrm{X}$ & $\mathrm{X}$ & $\mathrm{X}$ & X & $\mathrm{X}$ \\
\hline 2 & $\mathrm{X}$ & X & O & O & 0 & 0 & $\mathrm{O}$ & 0 & 0 & $\mathrm{O}$ & $\mathrm{O}$ & $\mathrm{X}$ & $\mathrm{O}$ & $\mathrm{O}$ \\
\hline 3 & $\mathrm{X}$ & $\mathrm{X}$ & $\mathrm{X}$ & 0 & 0 & O & 0 & 0 & O & O & 0 & $\mathrm{X}$ & 0 & $\mathrm{O}$ \\
\hline 4 & $\mathrm{X}$ & 0 & $\mathrm{X}$ & 0 & 0 & O & 0 & 0 & o & o & $\mathrm{O}$ & 0 & 0 & o \\
\hline 5 & $\mathrm{X}$ & $\mathrm{X}$ & 0 & 0 & 0 & O & 0 & 0 & 0 & o & o & 0 & o & O \\
\hline 6 & 0 & $\mathrm{O}$ & $\mathrm{O}$ & $\mathrm{X}$ & $\mathrm{O}$ & O & O & 0 & O & O & $\mathrm{O}$ & $\mathrm{O}$ & $\mathrm{O}$ & $\mathrm{O}$ \\
\hline 7 & $\mathrm{O}$ & $\mathrm{X}$ & $\mathrm{X}$ & $\mathrm{X}$ & $\mathrm{O}$ & $\mathrm{O}$ & $\mathrm{O}$ & $\mathrm{O}$ & $\mathrm{O}$ & O & $\mathrm{O}$ & $\mathrm{O}$ & $\mathrm{O}$ & $\mathrm{O}$ \\
\hline
\end{tabular}

Em modelos tipo ARMA, essa configuração indica um modelo com p e q iguais a 2. Com o objetivo de agilizar o processo de identificação foram utilizadas duas funções do pacote estatística $\mathrm{R}$, os comandos auto.arima e get.best.arima para identificar os parâmetros. O comando auto.arima retornou o modelo SARIMAX(211)(000). Já, o comando get.best.arima retornou o modelo SARIMAX(201)(112). Todos os possíveis modelos foram testados sendo selecionados somente os melhores, conforme o critério de AIC e o valor de sigma ${ }^{2}$, apresentados na Tabela 7-16, onde também há o coeficiente de determinação para avaliar a relação entre as variáveis explicativas e os valores do modelo ajustado. Diferente do que foi apresentado pelo comando get.best.arima, o melhor modelo foi o $\operatorname{SARIMAX(112)(200),~que~}$ apresentou AIC igual a -431 e sigma ${ }^{2}$ igual a 0,02 e resíduos adequados. Esse modelo foi escolhido, pois também apresentou melhores análises de resíduos, descritos posteriormente, comparado ao modelo SARIMAX(112)(203), apesar de esse apresentar AIC menor de -482 e sigma $^{2}$ igual a 0,01 .

Tabela 7-16 Critérios de adequação dos modelos ENA NE (AIC, AICc, BIC, Sigma², $\mathrm{R}^{2}, \mathrm{R}^{2} \mathrm{a}, \mathrm{R}^{2} \mathrm{p}$-valor)

\begin{tabular}{|c|c|c|c|c|c|c|c|}
\hline $\begin{array}{l}\text { MODELO } \\
\text { SARIMAX }\end{array}$ & AIC & AAIC & BIC & SIGMA $^{2}$ & $\mathbf{R}^{2}$ & $\mathbf{R}^{2} \mathbf{A}$ & $R^{2}$ P-VALOR \\
\hline$(112)(203)$ & -482 & -479 & -400 & 0,01 & 0,92 & 0,92 & 0,0000 \\
\hline$(112)(200)$ & -431 & -429 & -361 & 0,02 & 0,92 & 0,92 & 0,0000 \\
\hline$(112)(101)$ & -290 & -289 & -232 & 0,02 & 0,87 & 0,87 & 0,0000 \\
\hline$(112)(201)$ & -286 & -285 & -227 & 0,02 & 0,77 & 0,76 & 0,0000 \\
\hline$(112)(203)$ & -286 & -284 & -219 & 0,02 & 0,77 & 0,76 & 0,0000 \\
\hline$(112)(304)$ & -283 & -280 & -194 & 0,02 & 0,88 & 0,87 & 0,0000 \\
\hline$(112)(302)$ & -274 & -271 & -192 & 0,02 & 0,88 & 0,87 & 0,0000 \\
\hline$(112)(200)$ & -270 & -268 & -218 & 0,02 & 0,78 & 0,77 & 0,0000 \\
\hline$(112)(203)$ & -261 & -259 & -195 & 0,03 & 0,76 & 0,76 & 0,0000 \\
\hline
\end{tabular}




\subsubsection{Estimação}

Para identificação das ordens do modelo, foram utilizadas evidências empíricas da ACF, PACF e EACF (lags não nulos 1). Experimentalmente, ajustaram-se vários modelos, sendo que um em especial apresentou resultados AIC e resíduos melhores, o modelo da classe SARIMAX(112)(200) da forma:

$(1-B)\left(1-\phi_{1} B\right)\left(1-\phi_{2} B\right)\left(1-\Phi_{1} B\right)\left(1-\Phi_{2} B\right) Y_{t}=\left(1-\theta_{1} B\right)\left(1-\theta_{2} B\right) e_{t}$,

onde $\mathrm{e}_{\mathrm{t}} \sim \mathrm{RB}\left(0, \sigma^{2}\right), \sim \mathrm{N}$

As estimativas dos parâmetros do modelo ajustado são apresentadas na Tabela 7-17, considerando o IC de $95 \%$.

Tabela 7-17 Valores parâmetros estimados e estatísticas correspondentes

\begin{tabular}{|c|c|c|c|c|c|}
\hline Modelo & Parâmetros & Estimativas & $\begin{array}{c}\text { Erro } \\
\text { Padrão }\end{array}$ & $\begin{array}{c}\text { Valor } \\
\mathbf{p}\end{array}$ & $\begin{array}{c}\text { Estimativa } \\
\text { de } \sigma^{2}\end{array}$ \\
\hline \multirow{11}{*}{ SARIMAX (112) (200) } & $\phi_{1}$ & 0,5416 & 0,0693 & 0,0000 & \multirow{11}{*}{0,06} \\
\hline & $\theta_{1}$ & $-0,7242$ & 0,0828 & 0,0000 & \\
\hline & $\theta_{2}$ & $-0,2757$ & 0,0815 & 0,0007 & \\
\hline & $\Phi_{1}$ & 0,1118 & 0,0655 & 0,0879 & \\
\hline & $\Phi_{2}$ & 0,1587 & 0,0664 & 0,0169 & \\
\hline & AMM & 0,0414 & 0,0144 & 0,0040 & \\
\hline & AMO & $-0,2326$ & 0,2066 & 0,2604 & \\
\hline & TNA2 & $-0,414$ & 0,0358 & 0,0000 & \\
\hline & X70E & 1,7922 & 0,4359 & 0,0000 & \\
\hline & $\mathrm{X} 120 \mathrm{E}$ & 3,8479 & 0,9305 & 0,0000 & \\
\hline & $\mathrm{X} 40 \mathrm{~W}$ & 4,7251 & 1,1405 & 0,0000 & \\
\hline
\end{tabular}

são apresentados os valores estimados e as estatísticas associadas ao modelo de regressão dinâmica. As variáveis AMO, TNA, X70E, X120E e X40W apresentaram significância estatística, inversamente a variável AMM, Tabela 7-18.

Tabela 7-18 Valores parâmetros estimados dos coeficientes das variáveis explicativas e as estatísticas correspondentes

\begin{tabular}{lrrrrl}
\hline Parâmetros & Estimativas & Erro Padrão & Estatística t & Valor p & $\#$ \\
\hline AMM & 186 & 138 & 1,35 & 0,1781 & \\
\hline AMO & -8.415 & 1.808 & $-4,65$ & 0,0000 & $* * *$ \\
\hline TNA & 289 & 12 & 23,84 & 0,0000 & $* * *$ \\
\hline X70E & 21.868 & 8.155 & 2,68 & 0,0077 & $* *$ \\
\hline X120E & 48.915 & 17.605 & 2,78 & 0,0058 & $* *$ \\
\hline X40W & 59.310 & 21.597 & 2,75 & 0,0064 & $* *$ \\
\hline
\end{tabular}

\subsubsection{Verificação ou diagnóstico}

Os diagnósticos dos erros do modelo são apresentados na Figura 7-30, os resultados das análises de resíduos, em que a) indica rejeição da hipótese de o modelo não ser 
heterocedástico b) o Gráfico ACF indica que os resíduos apresentam um comportamento aleatório (ruído branco) e o valor de Ljung-Box aceita a hipótese que as autocorrelações estimadas são gaussianas com média zero e variância 1/n. c) o Gráfico QQ indica aceitação da hipótese de normalidade, pois se ajusta a uma linha reta; e d) indica que a média é zero e há normalidade. Com exceção de a), que apresentou o valor McLeod-Li menor que 0,01 e, portanto, rejeita a hipótese do modelo não ser heterocedástico, os demais valores de inferência estatística apresentaram p-valor com maior que 0,05 , o que caracteriza aceitação das hipóteses nulas.
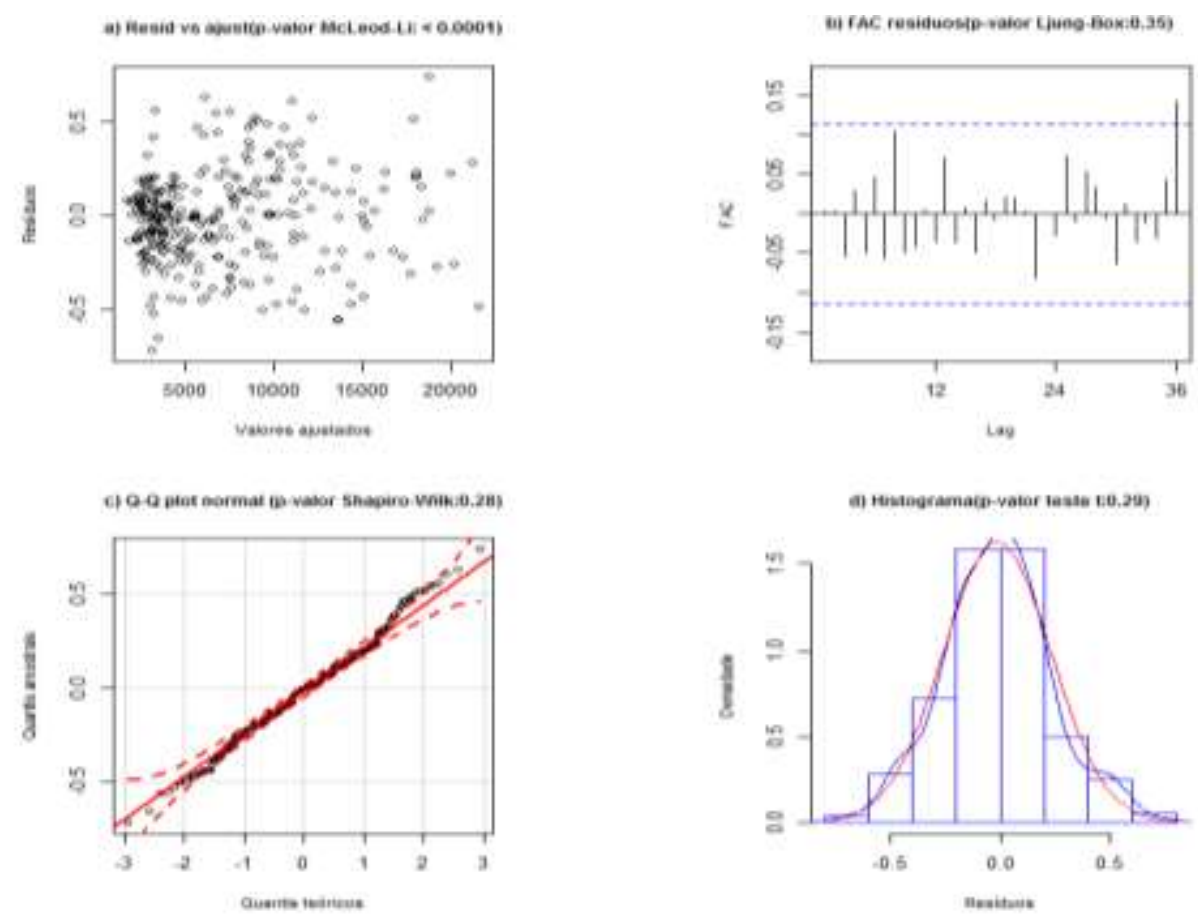

Figura 7-30 - Gráfico análise de resíduos modelo SARIMAX (112)(200):a) Resíduos versos modelo ajustado. b) FAC c) QQ-Plot d) Histograma

Assim, o modelo cumpre com quase todas as suposições dos erros: $e_{t}$ independentes, $E\left(e_{t}\right)=0$, variância constante e autocorrelação constante seguindo a distribuição normal. Os critérios AIC, AICc e BIC são muito similares, com uma leve melhora do RMSE.

Ao analisar os resíduos verifica-se que os p-valores correspondentes, as respectivas hipóteses nulas são quase todas aceitáveis para os modelos SARIMAX (112)(200). Os valores p-valor são apresentados na Tabela 7-19, onde todas as colunas do modelo escolhido apresentam valores aceitáveis, exceto o teste de McLeod-Li. 
Tabela 7-19 Análise de Resíduos - Modelo escolhido em amarelo

\begin{tabular}{lrllllllllllll}
\hline $\begin{array}{l}\text { MODELO } \\
\text { SARIMAX }\end{array}$ & AIC & AAIC & BIC & ME & RMSE & MAE & MPE & MAPE & $\begin{array}{l}\text { Shapiro } \\
\text { Wilk }\end{array}$ & $\begin{array}{l}\text { Teste } \\
\text { t }\end{array}$ & $\begin{array}{l}\text { McLeod } \\
\text { Li }\end{array}$ & $\begin{array}{l}\text { Ljung } \\
\text { Box }\end{array}$ \\
\hline $\mathbf{( 1 1 2 ) ( 2 0 3 )}$ & -482 & -479 & -400 & 182 & 1276 & 778 & $-0,7$ & 8,7 & 0,000 & 0,840 & $<0.001$ & 0,340 \\
\hline $\mathbf{( 1 1 2 ) ( 2 0 3 )}$ & -482 & -479 & -400 & 182 & 1276 & 778 & $-0,7$ & 8,7 & 0,000 & 0,026 & $<0.001$ & 0,280 \\
\hline $\mathbf{( 1 1 2 ) ( 2 0 0 )}$ & -431 & -429 & -361 & 170 & 1392 & 853 & $-1,6$ & 9,7 & 0,280 & 0,290 & $<0.001$ & 0,350 \\
\hline $\mathbf{( 1 1 2 ) ( 1 0 1 )}$ & -290 & -289 & -232 & 264 & 2536 & 1201 & $-1,3$ & 11,4 & 0,000 & 0,730 & $<0.001$ & 0,350 \\
\hline $\mathbf{( 1 1 2 ) ( 2 0 1 )}$ & -286 & -285 & -227 & 243 & 2507 & 1198 & $-1,5$ & 11,5 & $<0.0001$ & 0,760 & $<0.001$ & 0,073 \\
\hline $\mathbf{( 1 2 ) ( 2 0 3 )}$ & -286 & -284 & -219 & 239 & 2457 & 1174 & $-1,4$ & 11,2 & $<0.0001$ & 0,170 & $<0.001$ & 0,002 \\
\hline $\mathbf{( 1 1 2 ) ( 3 0 4 )}$ & -283 & -280 & -194 & 214 & 2410 & 1155 & $-1,5$ & 11,2 & 0,000 & 0,920 & $<0.001$ & 0,360 \\
\hline $\mathbf{( 1 1 2 ) ( 3 0 4 )}$ & -283 & -280 & -194 & 214 & 2410 & 1155 & $-1,5$ & 11,2 & 0,000 & 0,730 & $<0.001$ & 0,410 \\
\hline
\end{tabular}

\subsubsection{Validação Cruzada}

Uma explicação de como e feita a validação cruzada é mencionada na seção 7.1.5 Validação Cruzada, p. 213.

$\mathrm{Na}$ validação cruzada, são experimentados quatro modelos com variáveis explicativas diferentes de ordem SARIMAX (112) (200). O modelo com variáveis explicativas tem vantagem em relação aos modelos com uma única ou mesmo sem nenhuma variável explicativa como visto na Figura 7-31. Há quatro resultados da média de erros padrões das previsões retroativas da validação cruzada, de modelos com diferentes configurações das variáveis explicativas, que são: um modelo sem variáveis explicativas, um modelo com todas as variáveis explicativas, um modelo somente com a variável explicativa AMO e outro modelo somente com a variável explicativa AMM.O modelo com variáveis explicativas tem vantagem em relação aos modelos com uma única ou mesmo sem nenhuma variável explicativa.

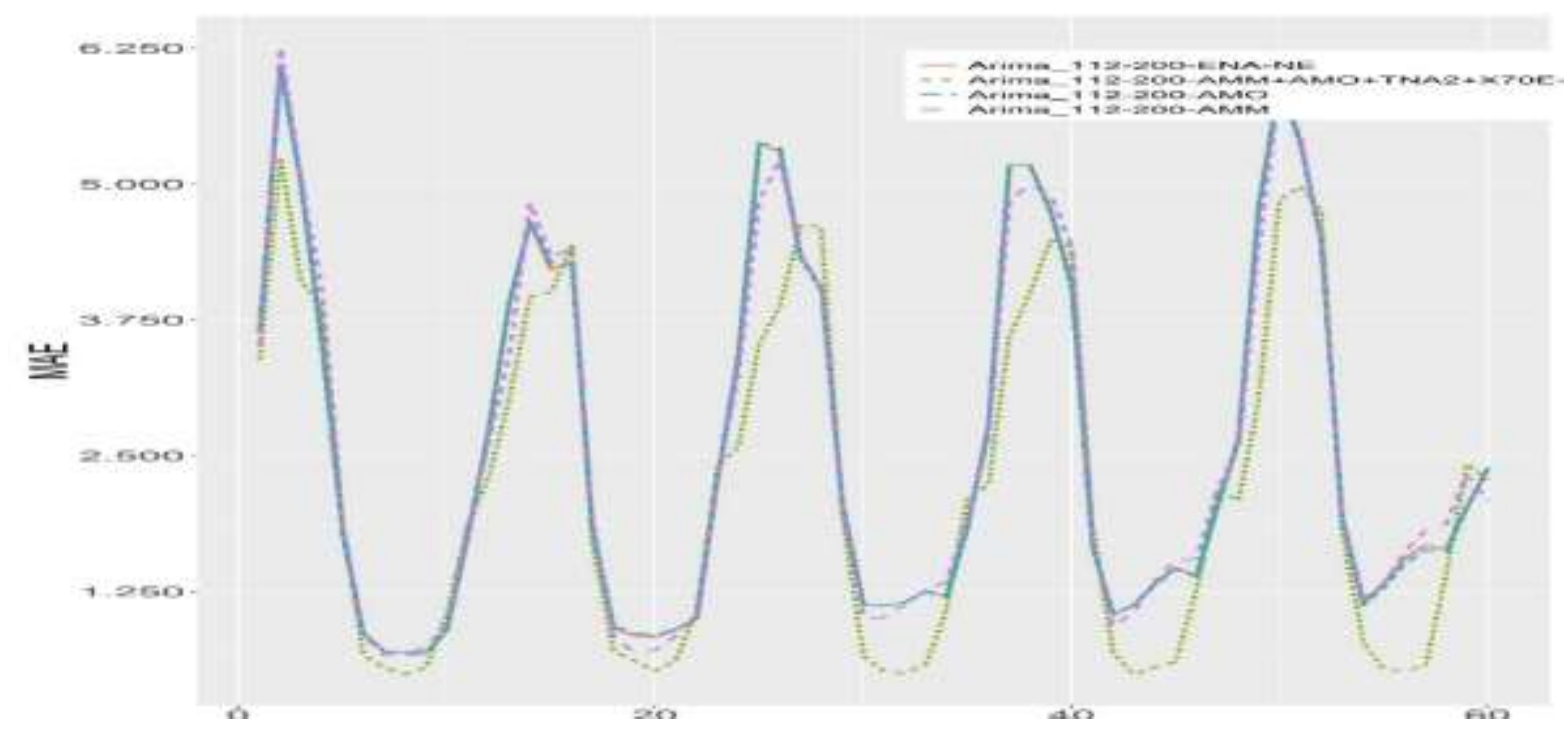

Figura 7-31 Validação cruzada com o modelo SARIMAX (112)(200)

Na validação (Tabela 7-20) com RMSE e R2, há resultados com grandes erros (1978-2003: 4.608 MWmédios). Os demais agrupamentos apresentam erros menores, onde o menor erro 
médio quadrático é 2.352 (1978-1997). Todos os valores de coeficiente de determinação e ajustados são próximos de 0,8 . Os valores p são menores que 0,0001 , o que indica que os coeficientes de determinação são significativos.

Tabela 7-20 Dados validação modelo de regressão dinâmica MODELO SARIMAX (112)(200)

\begin{tabular}{rllrrrrrrrr}
\hline \multicolumn{1}{c}{ JANELA } & $\begin{array}{l}\text { MODELO } \\
\text { SARIMAX }\end{array}$ & ME & RMSE & MAE & \multicolumn{1}{l}{$\begin{array}{l}\text { MPE } \\
\text { (\%) }\end{array}$} & $\begin{array}{l}\text { MAPE } \\
\text { (\%) }\end{array}$ & R2 & R2a & R2p \\
\hline $\mathbf{1 9 7 8}$ & 1997 & $(112)(200)$ & -1.088 & 2.352 & 1.800 & -38 & 43 & 0,84 & 0,82 & 0,000 \\
\hline $\mathbf{1 9 7 8}$ & 1998 & $(112)(200)$ & -709 & 2.209 & 1.649 & -31 & 38 & 0,83 & 0,82 & 0,000 \\
\hline $\mathbf{1 9 7 8}$ & 1999 & $(112)(200)$ & 704 & 2.831 & 1.818 & -7 & 29 & 0,86 & 0,84 & 0,000 \\
\hline $\mathbf{1 9 7 8}$ & 2000 & $(112)(200)$ & 488 & 3.022 & 1.994 & -12 & 33 & 0,85 & 0,84 & 0,000 \\
\hline $\mathbf{1 9 7 8}$ & 2001 & $(112)(200)$ & 1.942 & 3.611 & 2.431 & 14 & 30 & 0,85 & 0,84 & 0,000 \\
\hline $\mathbf{1 9 7 8}$ & 2002 & $(112)(200)$ & 2.519 & 4.416 & 2.938 & 19 & 35 & 0,87 & 0,86 & 0,000 \\
\hline $\mathbf{1 9 7 8}$ & 2003 & $(112)(200)$ & 2.639 & 4.608 & 3.104 & 20 & 36 & 0,87 & 0,85 & 0,000 \\
\hline $\mathbf{1 9 7 8}$ & 2004 & $(112)(200)$ & 2.047 & 3.941 & 2.725 & 12 & 34 & 0,86 & 0,85 & 0,000 \\
\hline $\mathbf{1 9 7 8}$ & 2005 & $(112)(200)$ & 492 & 3.136 & 2.141 & -9 & 33 & 0,82 & 0,80 & 0,000 \\
\hline $\mathbf{1 9 7 8}$ & 2006 & $(112)(200)$ & 19 & 2.908 & 2.039 & -21 & 37 & 0,84 & 0,83 & 0,000 \\
\hline $\mathbf{1 9 7 8}$ & 2007 & $(112)(200)$ & 723 & 2.584 & 1.785 & -2 & 27 & 0,86 & 0,85 & 0,000 \\
\hline $\mathbf{1 9 7 8}$ & 2008 & $(112)(200)$ & 319 & 2.333 & 1.704 & -9 & 30 & 0,86 & 0,84 & 0,000 \\
\hline
\end{tabular}

Ao verificar os valores nos gráficos a seguir, observa-se que as previsões do modelo oficial NEWAVE apresentam previsões muito aproximadas de um ano para outro. Na Figura 7-32, são apresentados, no início, o valor observado registrado pelo ONS e em seguida os valores dos decks de previsão do modelo NEWAVE. Esses resultados podem ser avaliados através dos indicadores de erro apresentados na Tabela 7-21, e comparados com os resultados da Tabela 7-20.

Tabela 7-21 Dados validação NEWAVE Região Nordeste Decks 2003 a 2009

\begin{tabular}{rrrrrr}
\hline Deck & ME & RMSE & MAE & MPE & MAPE \\
\hline $\mathbf{2 0 0 3}$ & -577 & 2.737 & 2.008 & $-26 \%$ & $36 \%$ \\
\hline $\mathbf{2 0 0 4}$ & -530 & 2.998 & 2.101 & $-25 \%$ & $35 \%$ \\
\hline $\mathbf{2 0 0 5}$ & -713 & 2.673 & 1.926 & $-25 \%$ & $34 \%$ \\
\hline $\mathbf{2 0 0 6}$ & -1.458 & 3.255 & 2.397 & $-37 \%$ & $44 \%$ \\
\hline $\mathbf{2 0 0 7}$ & -1.425 & 3.079 & 2.291 & $-38 \%$ & $43 \%$ \\
\hline $\mathbf{2 0 0 8}$ & -1.570 & 2.897 & 2.122 & $-37 \%$ & $42 \%$ \\
\hline $\mathbf{2 0 0 9}$ & -1.874 & 3.371 & 2.453 & $-44 \%$ & $49 \%$ \\
\hline
\end{tabular}




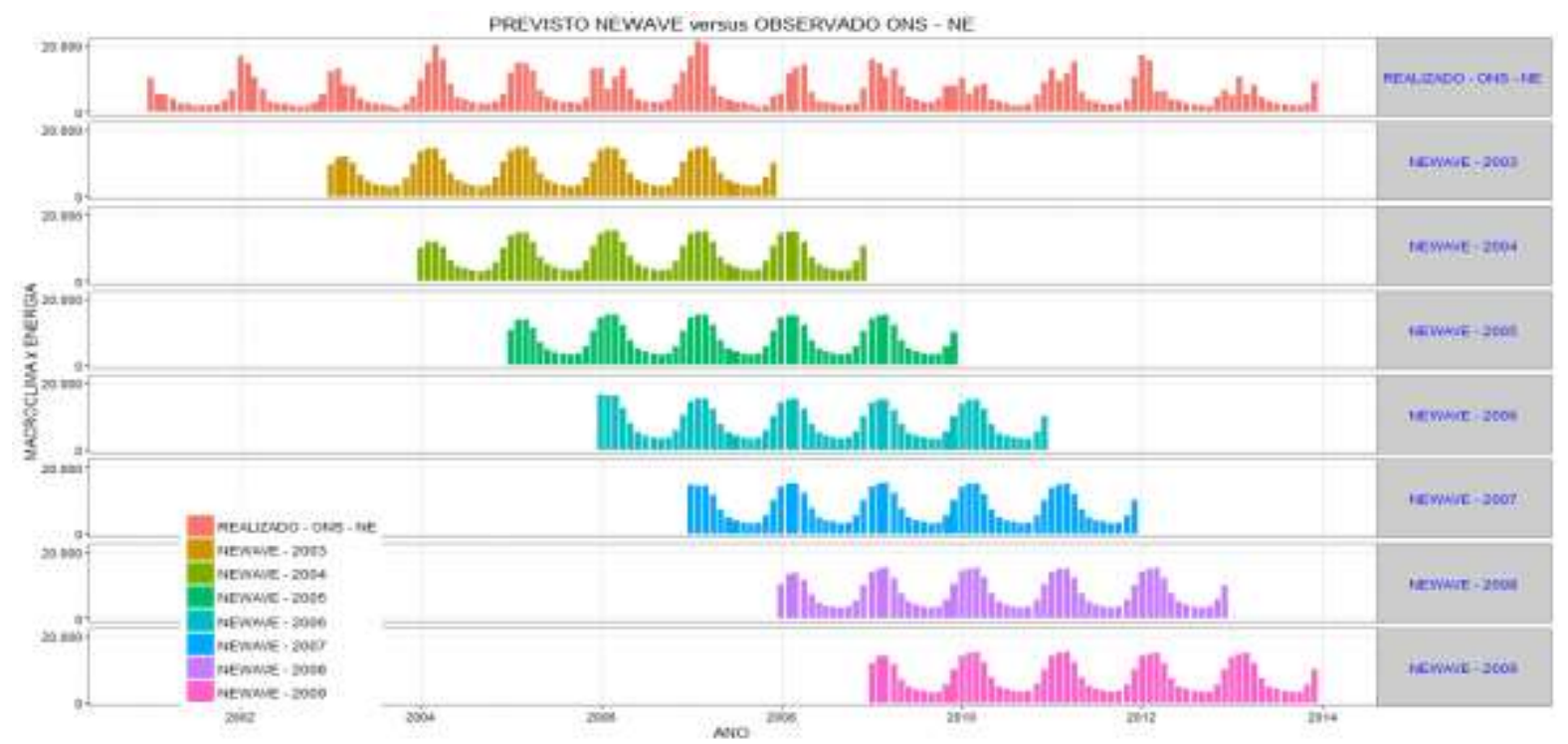

Figura 7-32 Validação Cruzada NEWAVE Região Nordeste :: Decks 2003 a 2009.

Na Figura 7-33, apresenta-se a diferença ou erro entre o observado e o previsto. Nota-se que os valores de erro são aproximados, nos mesmos meses, apesar de serem previsões realizadas com decks diferentes. Nota-se que o NEWAVE subestima a ENA-NE, pois apresenta valores menores que o realizado, em suas previsões.

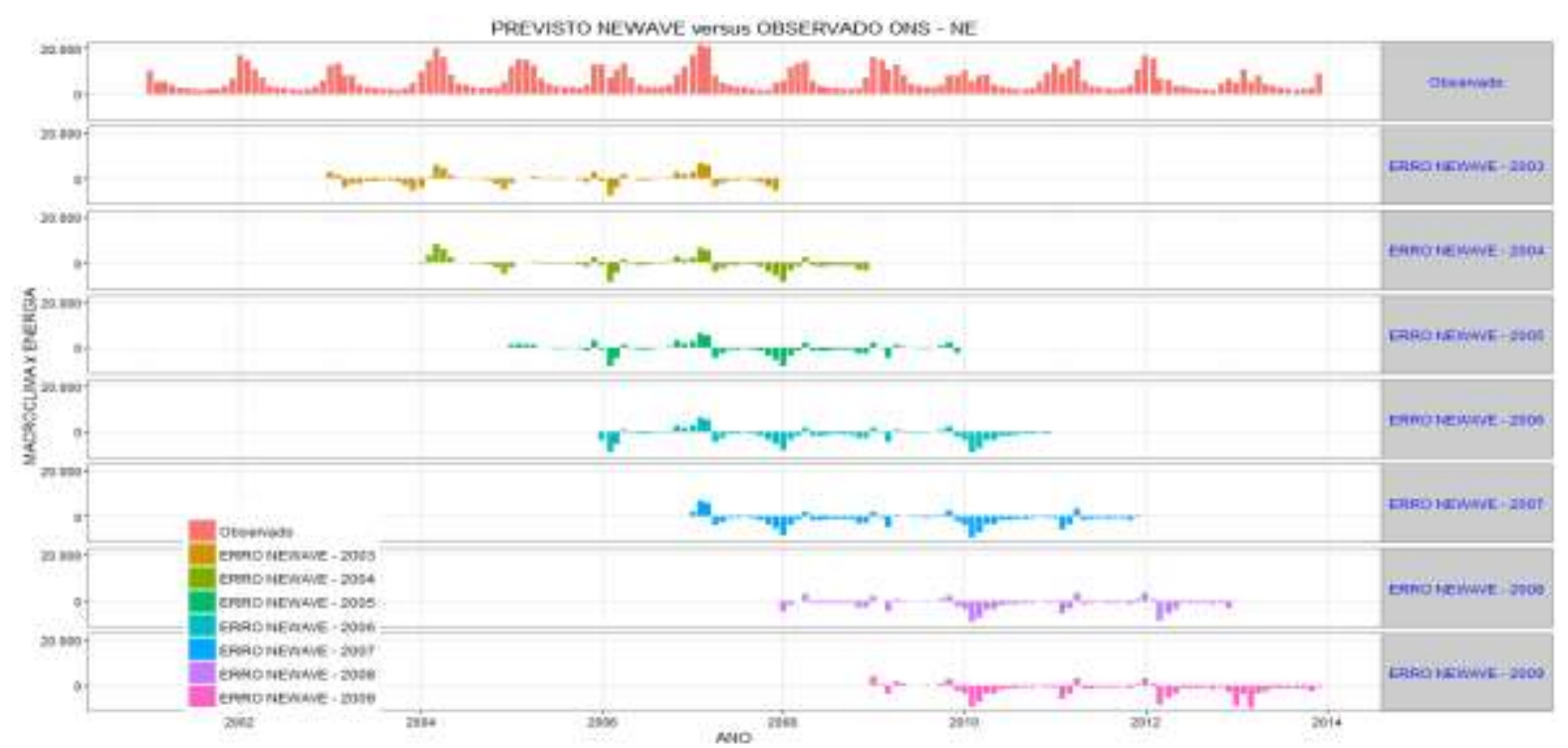

Figura 7-33 Validação Cruzada Erro =NEWAVE- ONS Região Nordeste:: Decks 2003 a 2009. 
O modelo SARIMAX(112)(200) é apresentado na Figura 7-34 e Figura 7-35, onde os resultados do erros são melhores, do que o NEWAVE.. Nota-se que nos anos de 2006 a 2008, também, apresentam-se erros similares nos mesmos meses, apesar de utilizarem conjuntos de testes diferentes.

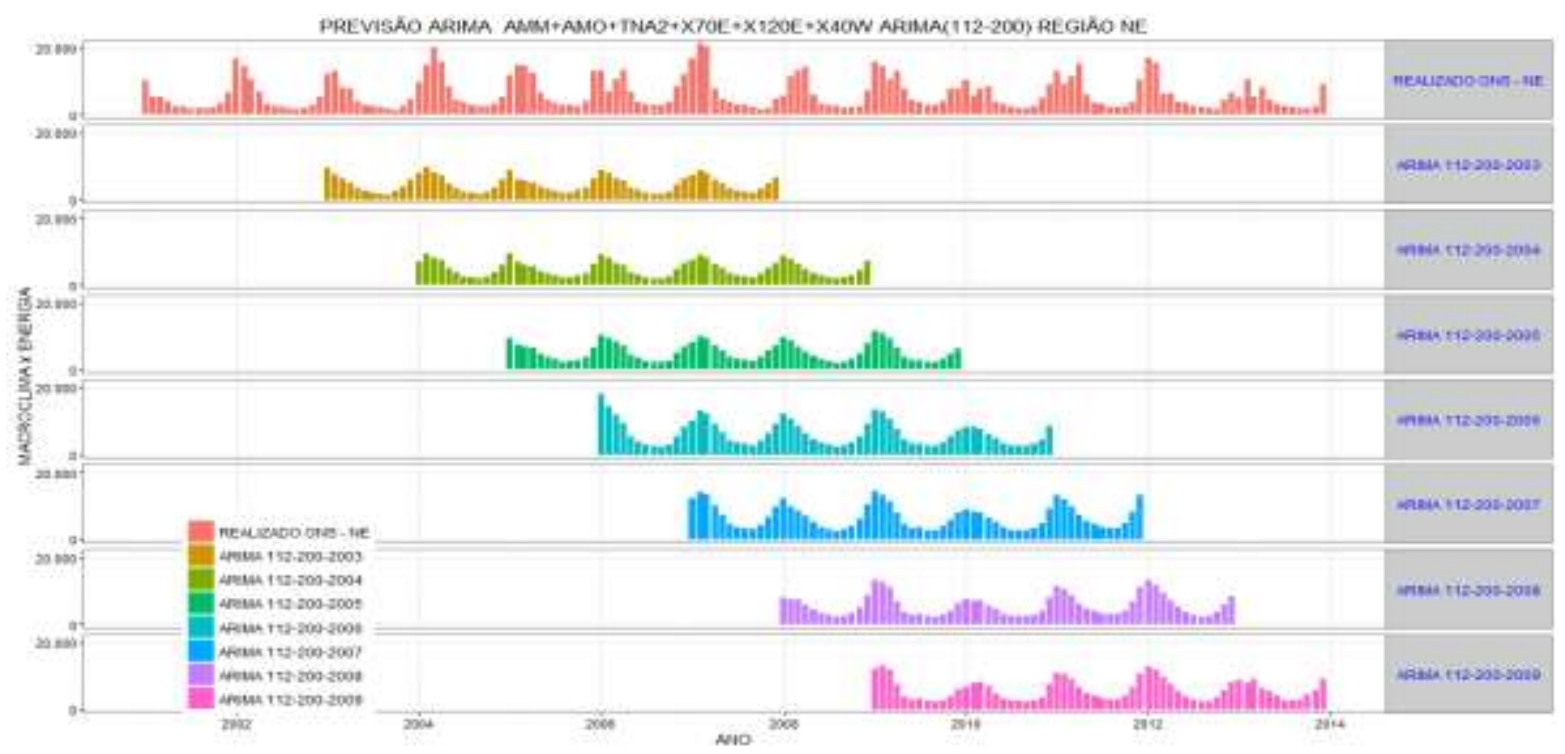

Figura 7-34 Validação cruzada modelos SARIMAX (112)(200) Região Nordeste

Na Figura 7-35, apresentam-se o resultado dos erros do modelos SARIMAX (112)(200) ENA-NE. Nota-se que o modelo superestima as previsões de ENA-NE.

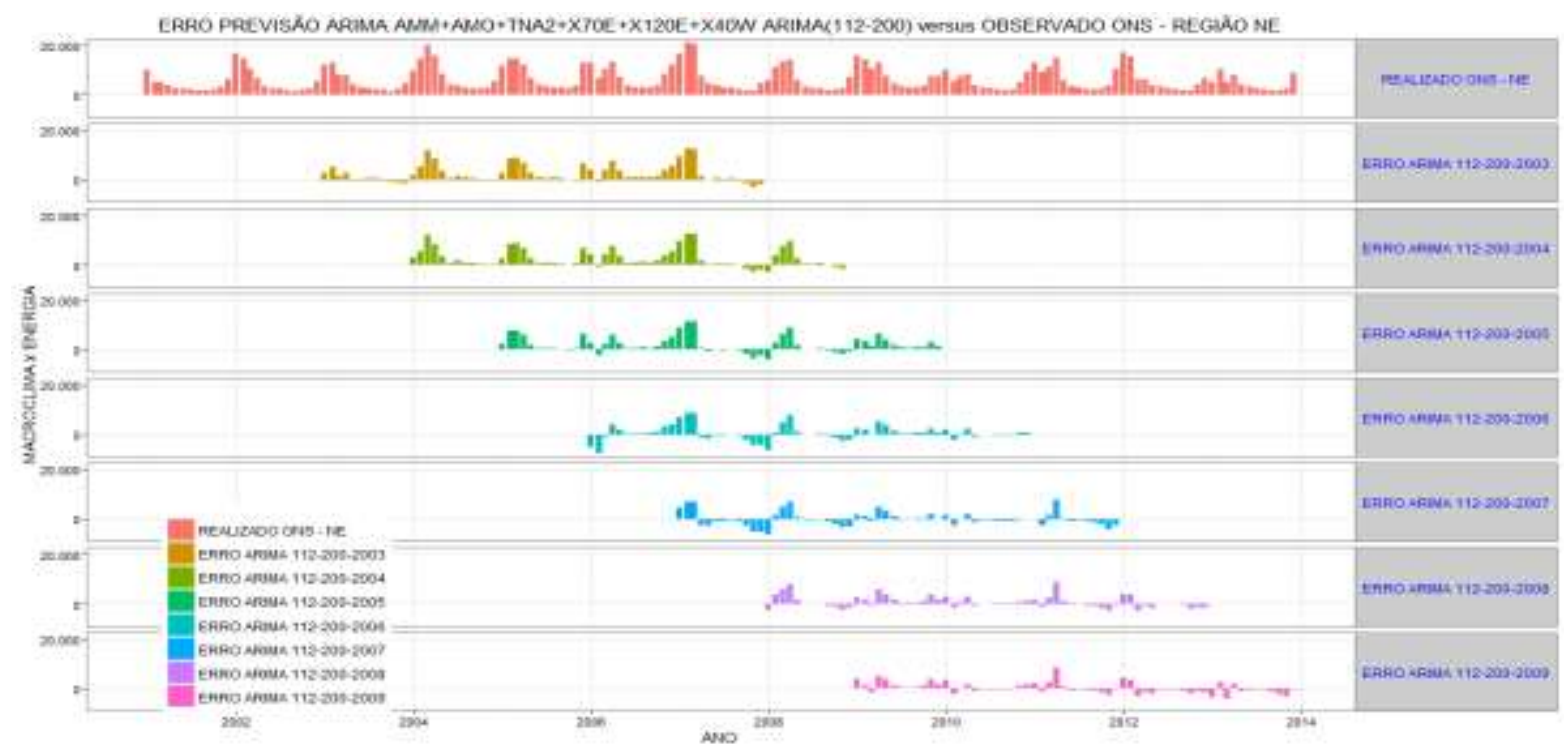

Figura 7-35 Validação Cruzada Erro =SARIMAX(112)(200) :: Conjuntos de teste 2003 a 2009 Região Nordeste 


\subsection{Modelo SARIMAX ENA NORTE}

\subsubsection{Especificação}

Ao analisar os gráficos, os mapas e as análises de séries históricas, escolheram-se as variáveis explicativas: MANCHA, MODOKI, AMM, ONI, SOIDAR, QBO, AMO, PDO, X120 e SAM e a variável dependente a ENA da Região Norte (Figura 7-36).

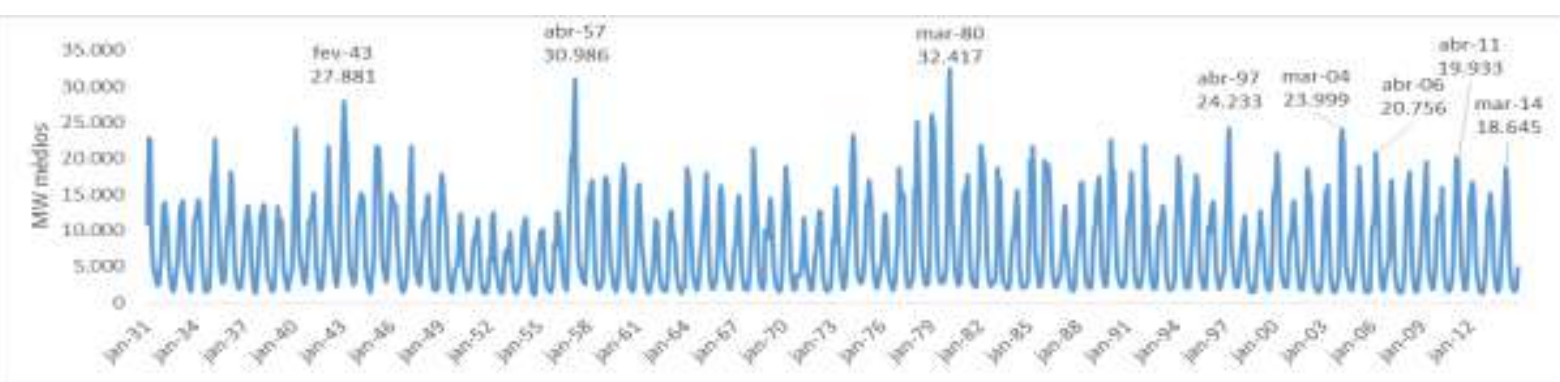

Figura 7-36 - Série Histórica em MW Médios ENA Norte- Período de Jan/1931 a Dez/2014

Os dados de treinamento compreendem o período entre 1998 e 2008 e os dados de teste compreende o período de 2009 a 2013.

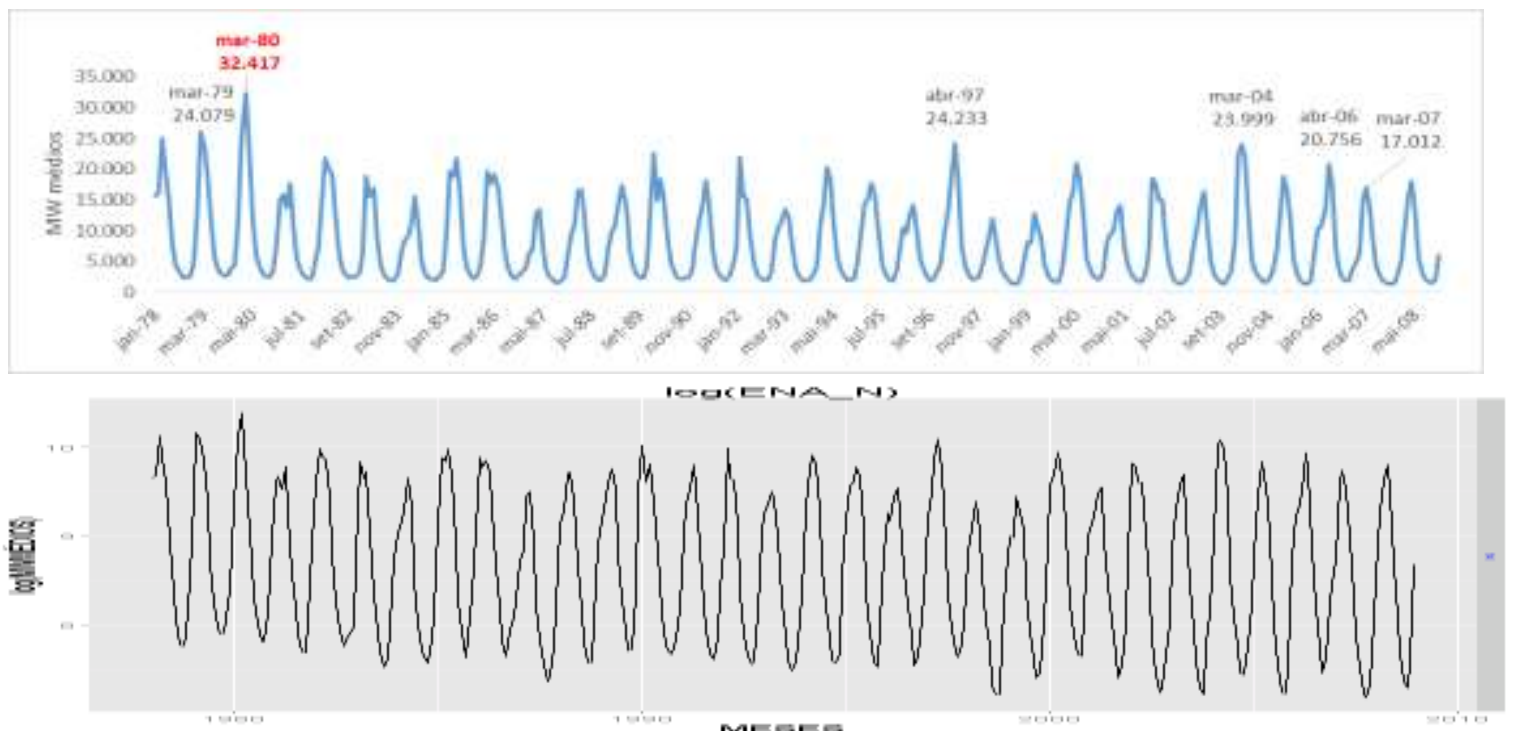

Figura 7-37 - Série Histórica em MW Médios ENA Norte e transformada logarítmica dos dados- Período de Jan/1978 a Dez/2008 ${ }^{115}$

Na Figura 7-37, apresenta-se a série histórica com sazonalidade e tendências localizadas explicadas pela dinâmica sazonal das chuvas e pela localização geográfica das bacias hidrográficas. Em períodos de El Niño, a região Norte passa por períodos de estiagem. Também há influência das chuvas resultantes da localização da ZCIT. Se o Atlântico Sul essta

\footnotetext{
115 Comentários Prof. Molion: "Cuidado! Não existia dados de vazões no rio Tocantins antes de planejarem Tucuruí. O início da série é sintético. A vazão de Marabá excedeu $68.000 \mathrm{~m}^{3} \mathrm{~s}^{-1}$ em 03/1980, e Tucuruí não existia (MOLION ET AL, 2006).”
} 
quente, a ZCIT migra mais para o Sul, e posiciona-se sobre o continente, e favorece a formação de convecção e precipitação, caso as águas do Oceano Atlântico Sul estão mais frias, a tendência é a ZCIT migrar para o Norte, e as precipitações acabam ocorrendo no mar. Com o objetivo de estabilizar a variância, foi aplicada uma transformação logarítmica.

Na Figura 7-38, apresenta-se a decomposição aditiva da série observada: sazonalidade, tendência e aleatório. Nota-se que a sazonalidade diminui de intensidade até meados de 2000 e volta a aumentar, e tendência apresenta comportamento similar.

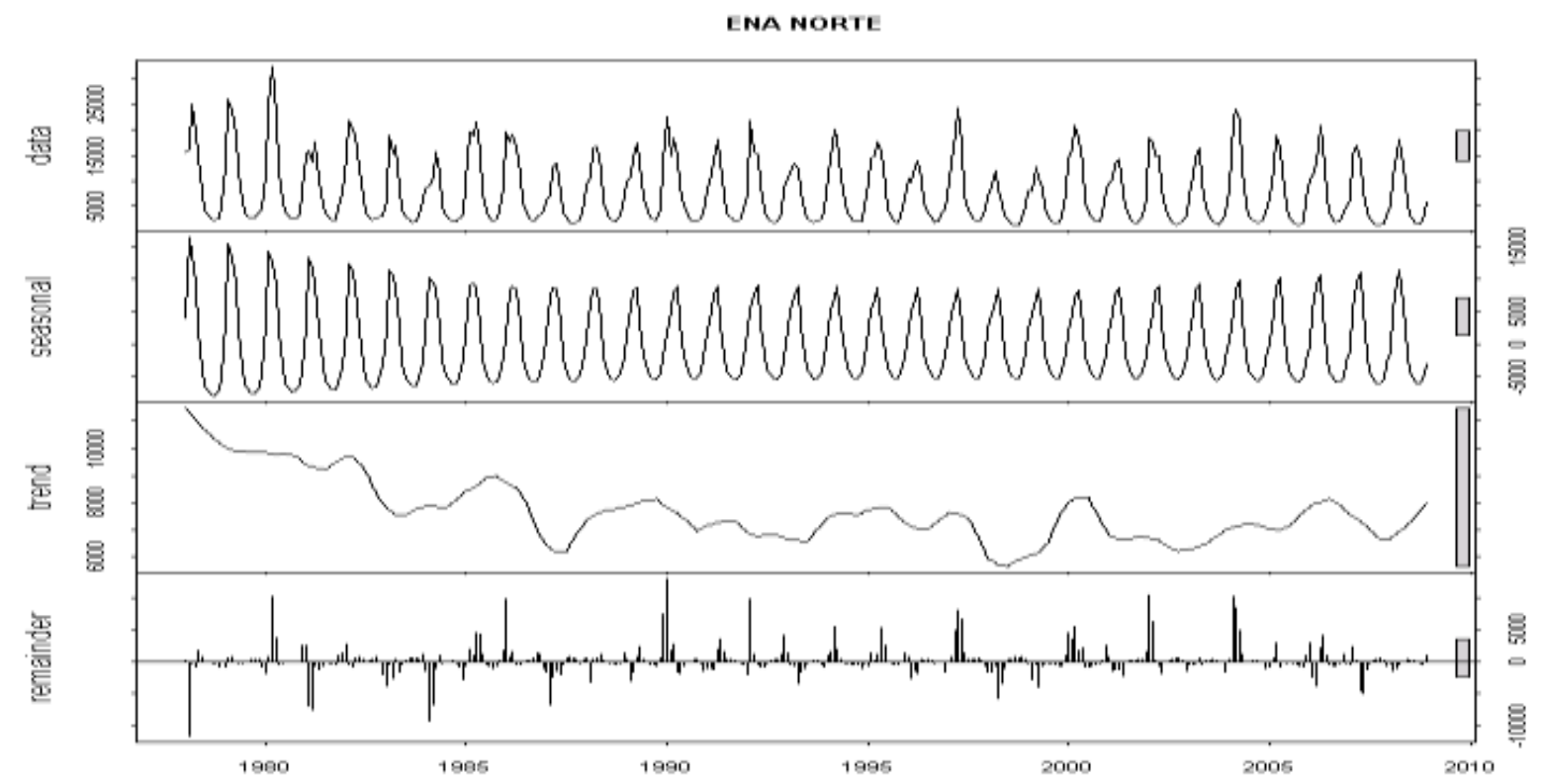

Figura 7-38 - Decomposição: Original. Sazonal. Tendência e Aleatório. ENA Norte - Período de Jan/1978 a Dez/2008

Na Figura 7-39, apresenta-se o componente sazonal mês a mês, mostrando valores da variabilidade crescente entre os meses de novembro a março (período úmido) e decrescentes de abril a setembro (período seco).

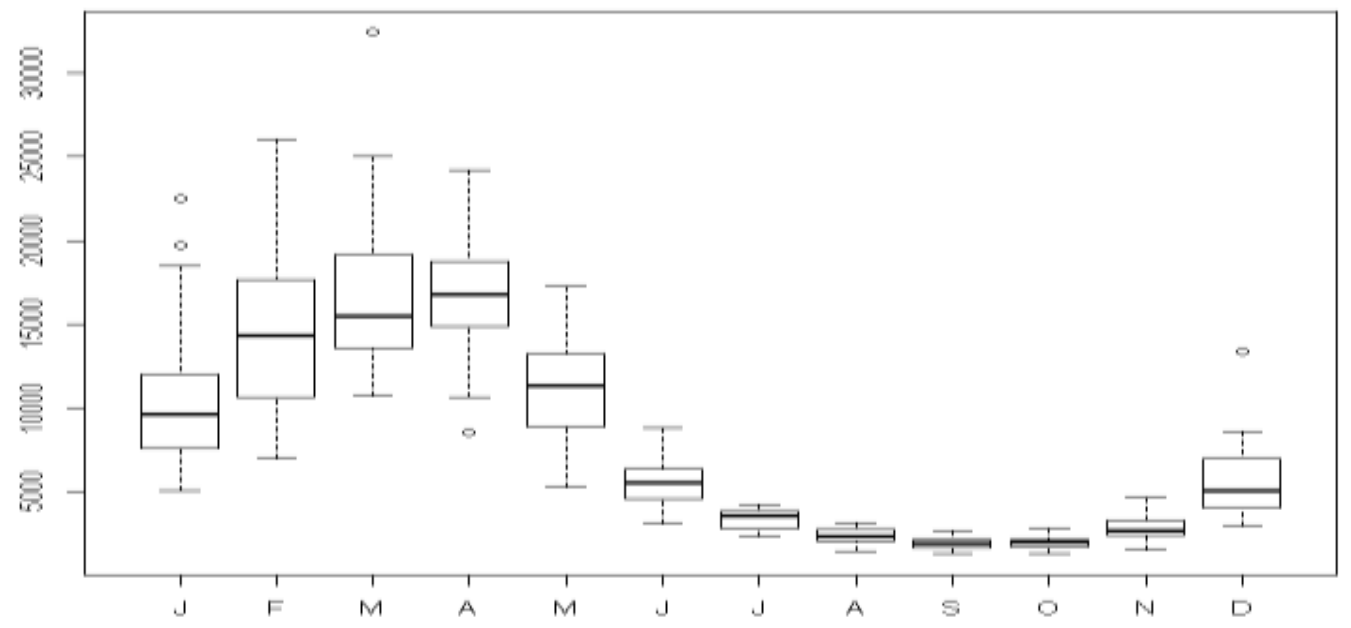

Figura 7-39 - Gráfico Caixa Série Histórica log (MW Médios) ENA Norte - Período de Jan/1931 a Dez/2013 


\subsubsection{Identificação}

Nessa fase, são avaliadas as funções de autocorrelação (ACF) e autocorrelação parcial (PACF) para se estimar a ordem dos parâmetros do modelo. A seguir a avaliação inicial da série histórica da ENA NORTE.

A série é aparentemente não estacionária, portanto, foi aplicada uma diferença originando os resultados das Funções ACF e PACF apresentadas na Figura 7-40 a) Série original, b) transformada com uma diferença e c) transformada e uma diferença sazonal, e na Figura 7-41, com transformação dos dados com o $\log$ e as mesmas diferenças anteriores. Os resultados indicam no gráfico PACF componente autorregressivo no lag um e, assim, demonstram o uso de modelos AR (1). Como a série original, e série a transformada com uma diferença, aparentam ser semelhantes, identificou-se não ser necessário aplicar uma diferença.
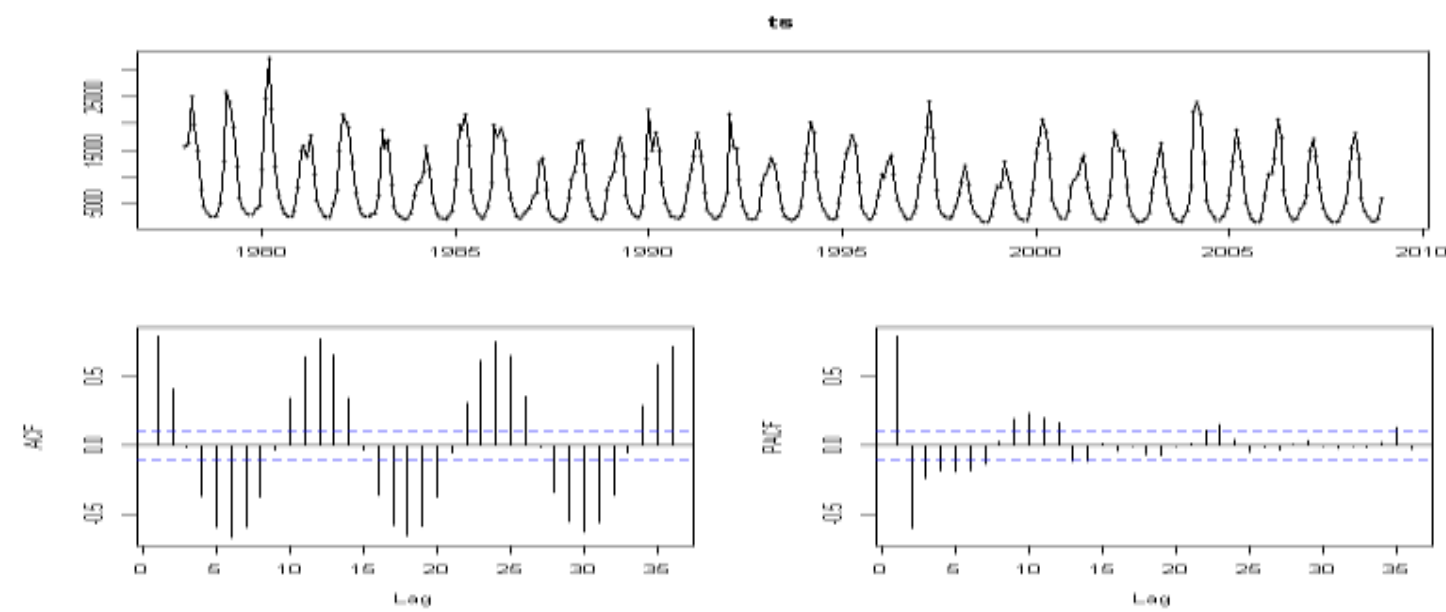

(a)
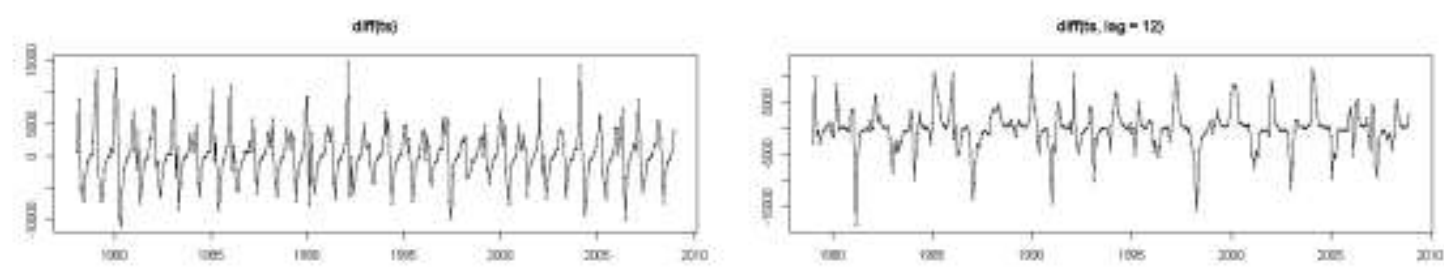

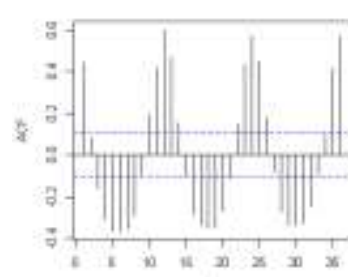

$+4$

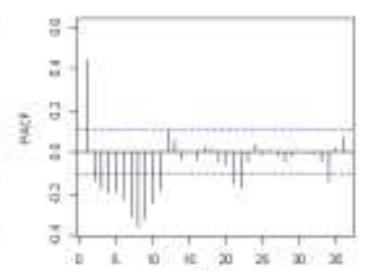

(b)

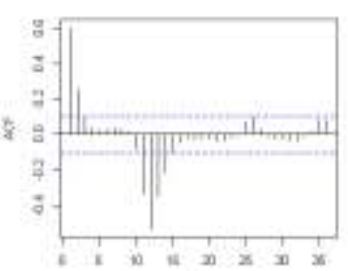

$+4$

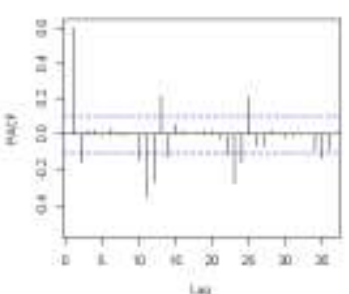

(c)

Figura 7-40 - Gráficos: a) Série Original , ACF e PACF b) Série Transformada com uma diferença, ACF e PACF e b) com uma diferença sazonal, , ACF e PACF.

No gráfico ACF, Figura 7-41, o pico significativo no lag um sugere um componente autorregressivo AR(1) e os picos significativos do lags 12 e 24 sugerem duas componentes 
sazonais autorregressivas $\operatorname{AR}(2)_{12}$ e um componente sazonal de médias móveis MA(1), uma vez que no ACF existam picos significativos em um e 12.
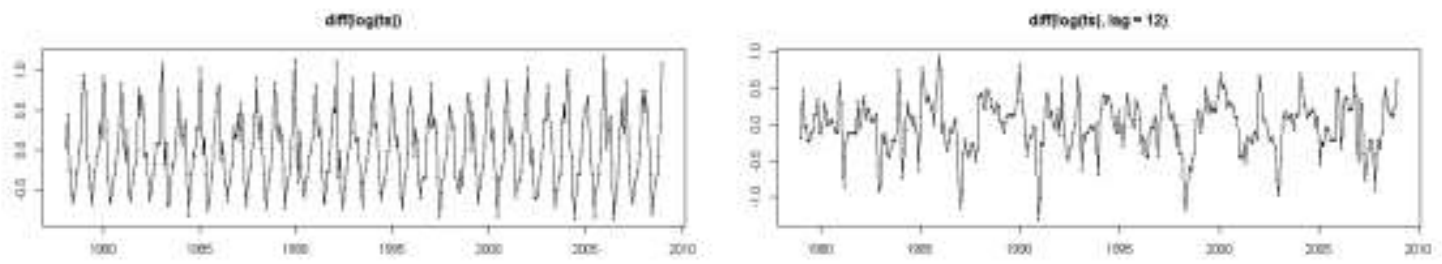

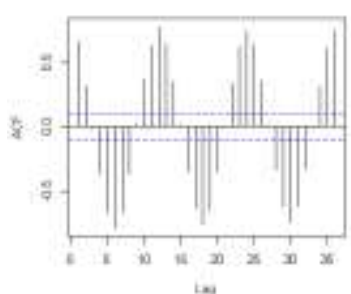

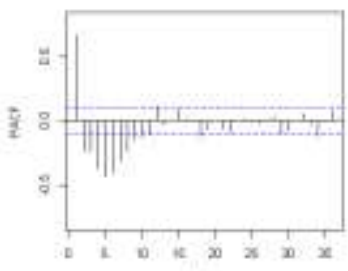

(a)

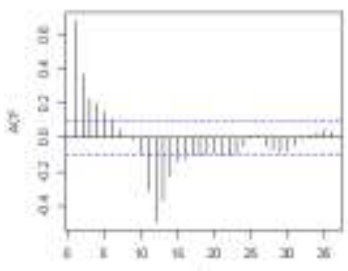

se

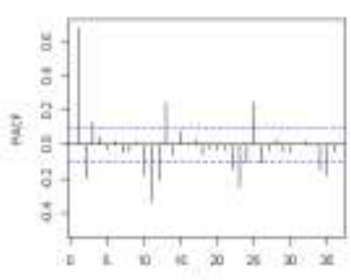

(b)

Figura 7-41 - Gráficos: a) Série Transformada com log e com uma diferença, ACF e PACF e b) com log e com uma diferença sazonal.

No gráfico ACF, Figura 7-42, o pico significativo no lag 2 sugere um componente autorregressivo AR(2) e os picos significativos do lags 12 e 24 sugerem duas componentes sazonais autorregressivas $\operatorname{AR}(2)_{12}$ e um componente de médias móveis $\mathrm{MA}(1)$ e mais um componente sazonal de médias móveis MA(1), uma vez que no ACF existam picos significativos em um e 12. Por fim, há sugestão de um modelo SARIMAX(211)(211).
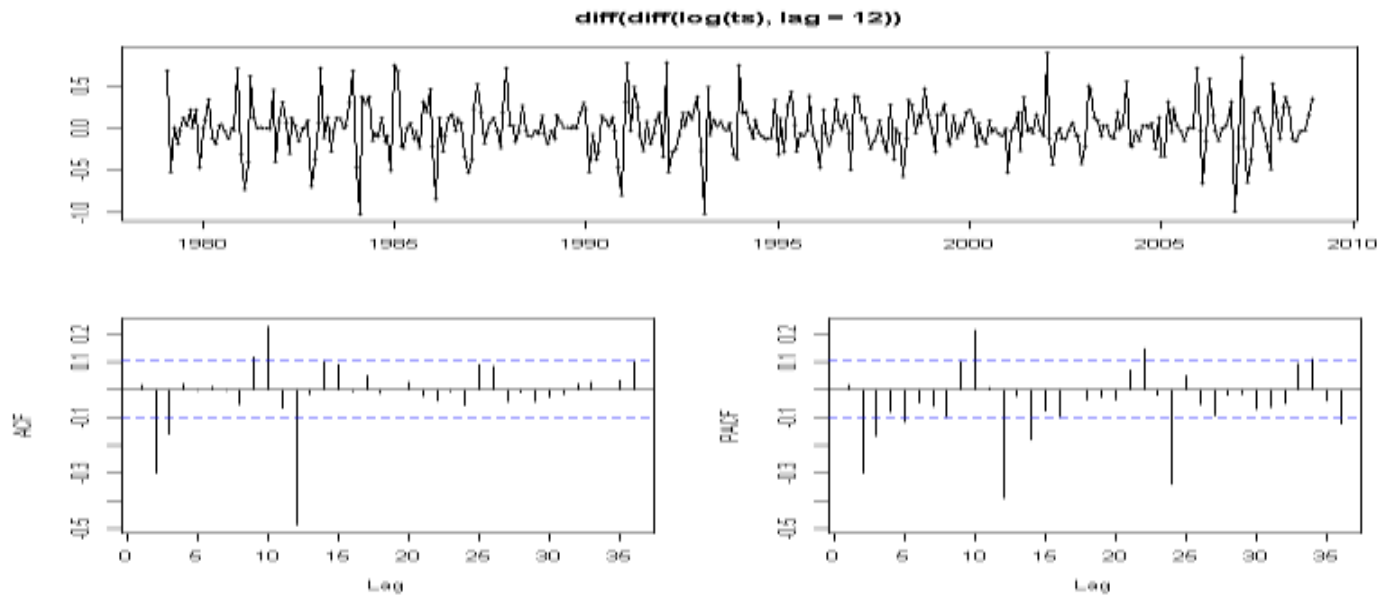

Figura 7-42 - Gráficos: a) Série Transformada com log, diferença com lag 12 e mais uma diferença lag=1. ACF e PACF

Ao aplicar a Função de Autocorrelação Estendida (EACF) indicam-se os modelos $\operatorname{ARIMA(301)~o~que~se~aproxima~com~as~análises~anteriores,~Tabela~7-22.~}$ 
Tabela 7-22 Resultado da Função de Autocorrelação estendida - eacf - ENA-N

\begin{tabular}{|c|c|c|c|c|c|c|c|c|c|c|c|c|c|c|}
\hline AR/MA & 0 & 1 & 2 & 3 & 4 & 5 & 6 & 7 & 8 & 9 & 10 & 11 & 12 & 13 \\
\hline 0 & $\mathrm{X}$ & $X$ & $\mathrm{O}$ & $\mathrm{X}$ & $\mathrm{X}$ & $\mathrm{X}$ & $\mathrm{X}$ & $\mathrm{X}$ & $\mathrm{O}$ & $\mathrm{X}$ & $\mathrm{X}$ & $X$ & $\mathrm{X}$ & $\mathrm{X}$ \\
\hline 1 & $\mathrm{X}$ & $\mathrm{X}$ & O & $\mathrm{X}$ & $\mathrm{X}$ & $\mathrm{X}$ & $\mathrm{X}$ & $\mathrm{X}$ & $\mathrm{O}$ & $\mathrm{X}$ & $\mathrm{X}$ & $\mathrm{X}$ & $\mathrm{X}$ & $\mathrm{X}$ \\
\hline 2 & $\mathrm{X}$ & $\mathrm{X}$ & O & O & O & O & O & o & O & O & O & $\mathrm{X}$ & O & $\mathrm{X}$ \\
\hline 3 & $\mathrm{X}$ & O & O & O & O & O & O & O & $\mathrm{O}$ & O & O & $\mathrm{X}$ & $\mathrm{X}$ & O \\
\hline 4 & $\mathrm{X}$ & $\mathrm{X}$ & O & O & o & O & O & O & O & O & O & $\mathrm{X}$ & O & $\mathrm{X}$ \\
\hline 5 & $\mathrm{X}$ & $\mathrm{X}$ & O & o & O & O & o & o & O & O & O & $\mathrm{X}$ & O & $\mathrm{X}$ \\
\hline 6 & $\mathrm{X}$ & $\mathrm{X}$ & O & O & $\mathrm{O}$ & O & O & O & O & $\mathrm{O}$ & O & $\mathrm{O}$ & O & O \\
\hline 7 & $\mathrm{O}$ & $\mathrm{X}$ & $\mathrm{O}$ & O & O & O & O & O & O & O & O & $\mathrm{X}$ & $\mathrm{O}$ & $\mathrm{O}$ \\
\hline
\end{tabular}

Em modelos tipo ARIMA, essa configuração indica um modelo com p e q iguais a 3 e 1, respectivamente. Com o objetivo de auxiliar o processo de identificação, foram utilizadas duas funções do pacote estatístico R, os comandos auto.arima e get.best.arima para identificar os parâmetros. O comando auto.arima retornou o modelo ARIMA(112). Já, o comando get.best.arima retornou o modelo SARIMAX(313)(303). Todos os possíveis modelos foram testados, sendo selecionados somente os melhores conforme o critério de AIC e o valor de sigma $^{2}$, apresentados na Tabela 7-23, onde também há coeficiente de determinação para avaliar a relação entre as variáveis explicativas e os valores do modelo ajustado. Diferente do que foi apresentado pelo comando get.best.arima, o melhor modelo foi $o$ SARIMAX(100)(011), que apresentou AIC igual a -44,41 e sigma ${ }^{2}$ igual a 0,03. O modelo SARIMAX (002)(013), apesar de apresentar AIC menor que os outros, não atende todas as suposições na analise de resíduos.

Tabela 7-23 Critérios de adequação dos modelos ENA Norte (AIC, AICc, BIC, Sigma2, R2, R2a, R2p-valor)

\begin{tabular}{llllllll}
\hline $\begin{array}{l}\text { Modelo } \\
\text { SARIMAX }\end{array}$ & AIC & AAIC & BIC & Sigma $^{2}$ & $\mathbf{R}^{2}$ & $\mathbf{R}^{2} \mathbf{a}$ & $\mathbf{R}^{\mathbf{2}} \mathbf{p}$-valor \\
\hline $\mathbf{( 1 0 1 ) ( 0 1 1 )}$ & -45.99 & -43.97 & -18.11 & 0.03 & 0.69 & 0.68 & 0.00 \\
\hline $\mathbf{( 0 0 2 ) ( 0 1 3 )}$ & -44.33 & -40.89 & -8.09 & 0.03 & 0.69 & 0.67 & 0.00 \\
\hline $\mathbf{( 1 0 0 ) ( 0 1 1 )}$ & -44.41 & -40.98 & -8.18 & 0.03 & 0.78 & 0.76 & 0.00 \\
\hline $\mathbf{( 1 1 0 ) ( 0 1 1 )}$ & -30.18 & -27.24 & 3.17 & 0.04 & 0.78 & 0.76 & 0.00 \\
\hline $\mathbf{( 0 0 2 ) ( 0 1 5 )}$ & -31.54 & -23.94 & 21.42 & 0.03 & 0.84 & 0.82 & 0.00 \\
\hline $\mathbf{( 0 0 2 ) ( 0 1 4 )}$ & -38.13 & -33.52 & 3.68 & 0.03 & 0.70 & 0.68 & 0.00 \\
\hline $\mathbf{( 0 0 2 ) ( 0 1 5 )}$ & -33.16 & -28.54 & 8.65 & 0.03 & 0.71 & 0.69 & 0.00 \\
\hline $\mathbf{( 0 0 2 ) ( 0 1 3 )}$ & -33.78 & -27.78 & 13.61 & 0.03 & 0.90 & 0.89 & 0.00 \\
\hline $\mathbf{( 0 0 2 ) ( 0 1 2 )}$ & -41.36 & -38.45 & -7.91 & 0.03 & 0.69 & 0.67 & 0.00 \\
\hline $\mathbf{( 0 0 2 ) ( 0 1 5 )}$ & -30.09 & -22.49 & 22.88 & 0.03 & 0.90 & 0.89 & 0.00 \\
\hline
\end{tabular}

\subsubsection{Estimação}

Para identificação das ordens do modelo foram utilizadas evidências empíricas da ACF, PACF e EACF (lags não nulos 1). Experimentalmente, ajustaram-se vários modelos, sendo 
que um em especial apresentou resultados AIC melhores, o modelo da classe SARIMAX(100)(011) da forma:

$(1-B)^{m}\left(1-\phi_{1} B Y_{t}\right)=\left(1-\Theta{ }_{1} B\right) e_{t}$,

onde $\mathrm{e}_{\mathrm{t}} \sim \mathrm{RB}\left(0, \sigma^{2}\right), \sim \mathrm{N}$

As estimativas dos parâmetros do modelo ajustado são apresentadas na Tabela 7-24, considerando o IC de $95 \%$.

Tabela 7-24 Valores parâmetros estimados e estatísticas correspondentes

\begin{tabular}{|c|c|c|c|c|c|}
\hline Modelo & Parâmetros & Estimativas & $\begin{array}{c}\text { Erro } \\
\text { Padrão }\end{array}$ & Valor $\mathbf{p}$ & $\begin{array}{c}\text { Estimativa } \\
\text { de } \sigma^{2}\end{array}$ \\
\hline \multirow{12}{*}{ SARIMAX(100)(011) } & $\phi_{1}$ & 0,6881 & 0,0761 & 0,0000 & \multirow{12}{*}{0,03} \\
\hline & $\Theta_{1}$ & $-0,6984$ & 0,0962 & 0,0000 & \\
\hline & MANCHA & 0,0012 & 0,0008 & 0,1290 & \\
\hline & MODOKI & 0,1563 & 0,0766 & 0,0413 & \\
\hline & AMM & 0,0431 & 0,0176 & 0,0141 & \\
\hline & ONI & $-0,1913$ & 0,0653 & 0,0034 & \\
\hline & SOIDAR & $-0,0326$ & 0,0433 & 0,4521 & \\
\hline & QBO & 0,0104 & 0,0029 & 0,0003 & \\
\hline & AMO & 0,0414 & 0,2770 & 0,8813 & \\
\hline & PDO & 0,0736 & 0,0332 & 0,0269 & \\
\hline & $\mathrm{X} 120 \mathrm{E}$ & 0,0133 & 0,0274 & 0,6283 & \\
\hline & SAM & $-0,0160$ & 0,0088 & 0,0686 & \\
\hline
\end{tabular}

As estimativas dos parâmetros do modelo ajustado são apresentadas, considerando o IC de 95\%. Na Tabela 7-25, são apresentados os valores estimados e as estatísticas associadas ao modelo de regressão dinâmica. As variáveis AMM, ONI, QBO e PDO apresentaram significância estatística, inversamente as variáveis MANCHA, MODOKI, SOIDAR, AMO, X120 e SAM.

Tabela 7-25 Valores parâmetros estimados dos coeficientes das variáveis explicativas e as estatísticas correspondentes

\begin{tabular}{lrrrrr}
\hline Parâmetros & \multicolumn{1}{c}{ Estimativas } & \multicolumn{1}{c}{ Erro Padrão } & Estatística t & Valor p & $\#$ \\
\hline MANCHA & $-2,39$ & 8,88 & $-0,27$ & 0,7884 & \\
\hline MODOKI & 535,62 & $1,015,43$ & 0,53 & 0,5988 & \\
\hline AMM & $-318,37$ & 267,41 & $-1,19$ & 0,2361 & \\
\hline ONI & $-2,641,07$ & 867,83 & $-3,04$ & 0,0029 & $* *$ \\
\hline SOIDAR & $-1,902,98$ & 556,76 & $-3,42$ & 0,0009 & $* * *$ \\
\hline QBO & 137,53 & 30,01 & 4,58 & 0,0000 & $* * *$ \\
\hline AMO & $-169,71$ & $4,490,74$ & $-0,04$ & 0,9699 & \\
\hline PDO & $2,758,82$ & 537,73 & 5,13 & 0,0000 & $* * *$ \\
\hline X120E & $1,485,07$ & 785,25 & 1,89 & 0,0610 & $\cdot$ \\
\hline SAM & 8,03 & 0,92 & 8,70 & 0,0000 & $* * *$ \\
\hline
\end{tabular}

\subsubsection{Verificação ou diagnóstico}

Os diagnósticos dos erros do modelo são apresentados na Figura 7-43, em que a) indica aceitação da hipótese do modelo não ser heterocedástico; b) o Gráfico ACF indica que os 
resíduos apresentam um comportamento aleatório (ruído branco) e o valor de Ljung-Box aceita a hipótese que as autocorrelações estimadas são gaussianas com média zero e variância 1/n; c) o Gráfico QQ indica aceitação da hipótese de normalidade, pois se ajusta a uma linha reta; e d) a distribuição dos valores está em torno da média zero e há normalidade. Todos os valores da inferência estatística apresentaram p-valor maior que 0,05 , o que caracteriza aceitação das hipóteses nulas.
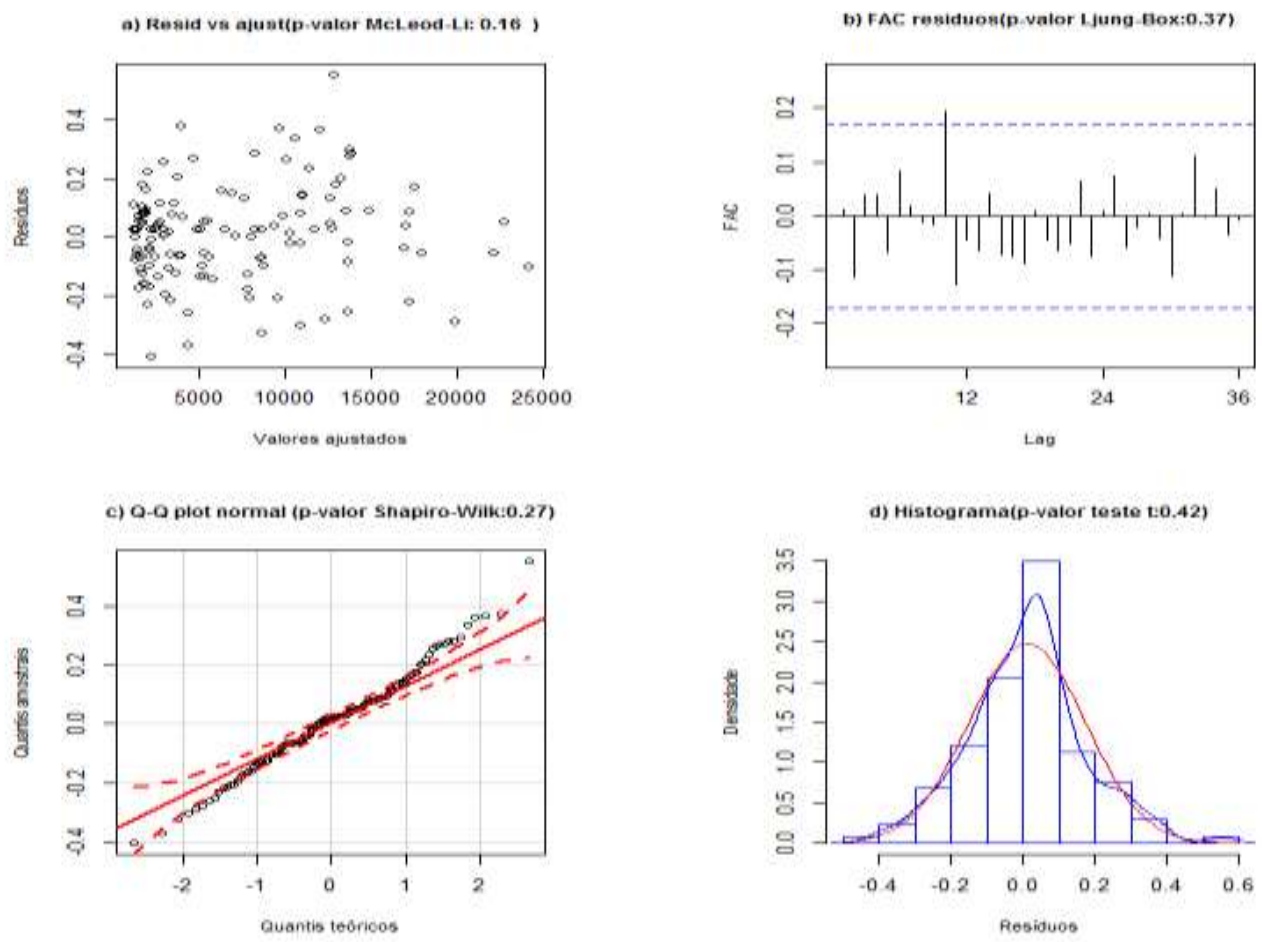

Figura 7-43 - Gráfico análise de resíduos modelo SARIMAX (100)(011):a) Resíduos versos modelo ajustado. b) FAC c) QQ-Plot d) Histograma

Assim, o modelo cumpre com todas as suposições dos erros: $e_{t}$ independentes, $E\left(e_{t}\right)=0$, variância constante e autocorrelação constante seguindo a distribuição normal. Os critérios AIC, AICc e BIC são muito similares, com uma leve melhora no Erro Médio Quadrático (RMSE).

Ao analisar os resíduos, verifica-se que os p-valores correspondentes às respectivas hipóteses nulas que são aceitáveis para o modelo SARIMAX (100)(011) e SARIMAX (101)(011) . Os valores p-valor são apresentados na Tabela 7-26, onde todas as colunas do modelo escolhido apresentam valores aceitáveis. 
Tabela 7-26 Análise de Resíduos - Modelo escolhido em amarelo

\begin{tabular}{lcccccccccccc}
\hline $\begin{array}{l}\text { MODELO } \\
\text { SARIMAX }\end{array}$ & AIC & AAIC & BIC & ME & RMSE & MAE & MPE & MAPE & Wilk & t & Li & $\begin{array}{c}\text { Ljung } \\
\text { Box }\end{array}$ \\
\hline $\mathbf{( 1 0 1 ) ( 0 1 1 )}$ & 0,46 & 12,27 & $-45,99$ & 291 & 1701 & 974 & $-43,97$ & $-18,11$ & 0,12 & 0,42 & 0,31 & 0,58 \\
\hline $\mathbf{( 1 0 0 ) ( 0 1 1 )}$ & $-0,14$ & 12,18 & $-44,41$ & 282 & 1726 & 990 & $-40,98$ & $-8,18$ & 0,27 & 0,42 & 0,16 & 0,37 \\
\hline $\mathbf{( 1 0 0 ) ( 0 1 2 )}$ & $-0,09$ & 12,19 & $-45,00$ & 306 & 1760 & 987 & $-43,36$ & $-19,91$ & 0,10 & 0,39 & 0,13 & 0,80 \\
\hline $\mathbf{( 1 0 0 ) ( 1 1 1 )}$ & $-0,12$ & 12,21 & $-44,98$ & 301 & 1756 & 987 & $-43,35$ & $-19,90$ & 0,10 & 0,39 & 0,13 & 0,80 \\
\hline $\mathbf{( 1 0 0 ) ( 0 0 1 )}$ & 0,06 & 11,94 & 23,28 & 310 & 1757 & 981 & 26,36 & 60,76 & 0,03 & 0,34 & 0,46 & 0,59 \\
\hline $\mathbf{( 1 0 2 ) ( 0 1 1 )}$ & 0,35 & 12,15 & $-45,17$ & 293 & 1695 & 961 & $-42,72$ & $-14,50$ & 0,12 & 0,42 & 0,31 & 0,58 \\
\hline $\mathbf{( 0 0 2 ) ( 0 1 1 )}$ & 0,35 & 12,15 & $-44,13$ & 293 & 1695 & 961 & $-42,11$ & $-16,25$ & 0,12 & 0,42 & 0,31 & 0,58 \\
\hline $\mathbf{( 0 0 3 ) ( 0 1 1 )}$ & 0,35 & 12,15 & $-43,21$ & 293 & 1695 & 961 & $-40,77$ & $-12,55$ & 0,12 & 0,42 & 0,31 & 0,58 \\
\hline
\end{tabular}

\subsubsection{Validação Cruzada}

Uma explicação de como e feita a validação cruzada é mencionada na seção 7.1.5 Validação Cruzada, p. 213.

$\mathrm{Na}$ validação cruzada, são experimentados quatro modelos com variáveis explicativas diferentes com a ordem SARIMAX (100)(011). O modelo com variáveis explicativas tem uma leve vantagem em relação aos modelos com uma única ou mesmo sem nenhuma variável explicativa (Figura 7-44).

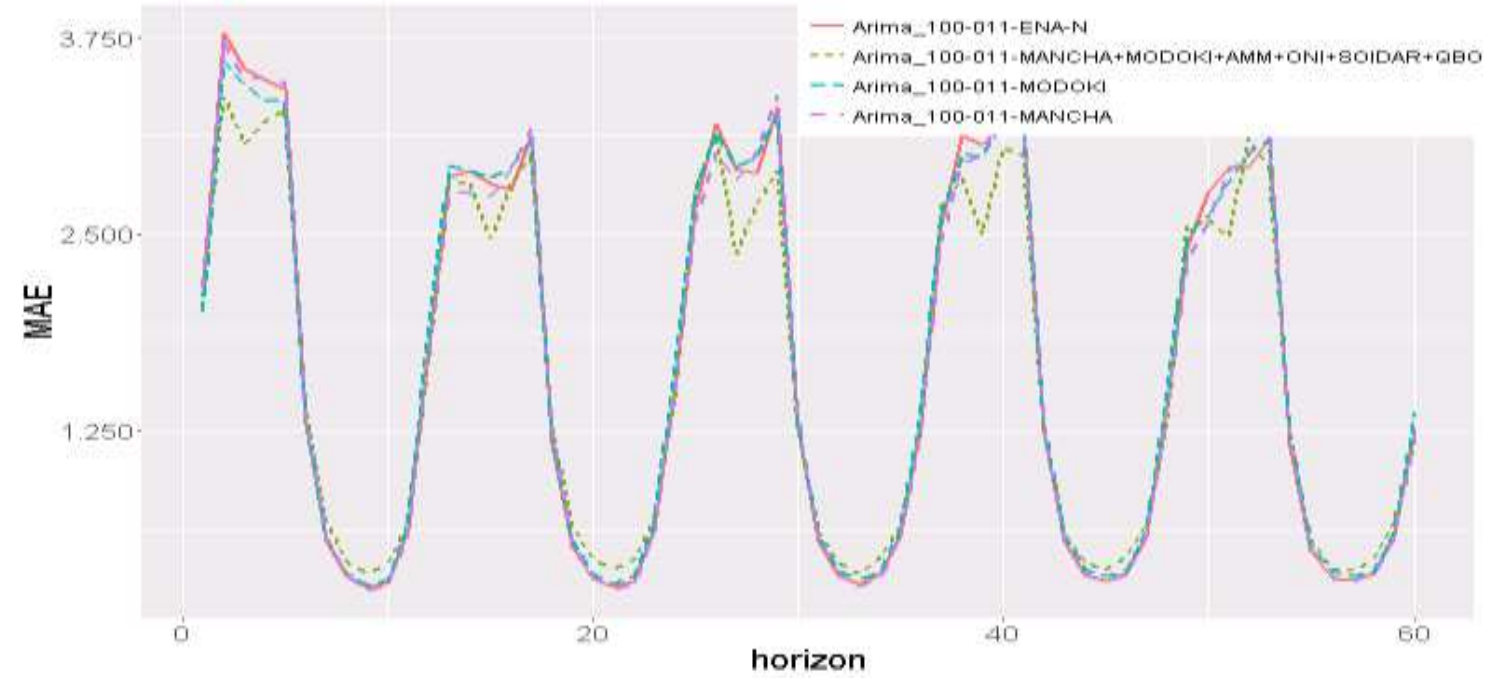

Figura 7-44 Validação cruzada com o modelo SARIMAX (100)(011)

Na validação com RMSE e R2, há alguns resultados com grandes erros (1998-2003: 2.883 MWmédios). Nos demais agrupamentos, apresentam-se erros menores, onde o menor erro médio quadrático é 2.392 (1998-2006), Tabela 7-27. Todos os valores de coeficiente de determinação e ajustados são próximos de 0,8 . Os valores p são menores que 0,0001 , o que indica que os coeficientes de determinação são significativos, . 
Tabela 7-27 Dados validação modelo de regressão dinâmica MODELO SARIMAX (100)(011)

\begin{tabular}{rrrrrrrrrrr}
\hline \multicolumn{2}{c}{ JANELA } & $\begin{array}{l}\text { MODELO } \\
\text { SARIMAX }\end{array}$ & ME & RMSE & MAE & $\begin{array}{r}\text { MPE } \\
\text { (\%) }\end{array}$ & $\begin{array}{r}\text { MAPE } \\
\text { (\%) }\end{array}$ & R2 & R2a & R2P \\
\hline $\mathbf{1 9 9 8}$ & 2003 & $(100)(011)$ & 674 & 2883 & 1600 & -5 & 20 & 0,87 & 0,85 & 0,0000 \\
\hline 1998 & 2004 & $(100)(011)$ & 852 & 2485 & 1495 & 6 & 20 & 0,86 & 0,84 & 0,0000 \\
\hline 1998 & 2005 & $(100)(011)$ & 639 & 2534 & 1547 & 4 & 21 & 0,83 & 0,80 & 0,0000 \\
\hline 1998 & 2006 & $(100)(011)$ & 689 & 2392 & 1543 & 2 & 21 & 0,85 & 0,82 & 0,0000 \\
\hline 1998 & 2007 & $(100)(011)$ & 1398 & 2867 & 1796 & 12 & 21 & 0,86 & 0,83 & 0,0000 \\
\hline 1998 & 2008 & $(100)(011)$ & 412 & 2649 & 1674 & 2 & 21 & 0,82 & 0,79 & 0,0000 \\
\hline
\end{tabular}

Ao verificar os valores nos gráficos a seguir, observa-se que as previsões do modelo oficial NEWAVE apresentam previsões muito aproximadas de um ano para outro, na Tabela 7-28, são apresentados, no início, o valor observado registrado pelo ONS e, em seguida, os valores dos decks de previsão do modelo NEWAVE.

Tabela 7-28 Dados validação NEWAVE Região Norte Decks 2003 a 2009

\begin{tabular}{rrrrrr}
\hline Deck & ME & RMSE & MAE & MPE & MAPE \\
\hline $\mathbf{2 0 0 3}$ & 1.243 & 3.069 & 1.731 & $4 \%$ & $19 \%$ \\
\hline $\mathbf{2 0 0 4}$ & 1.428 & 3.418 & 1.917 & $6 \%$ & $21 \%$ \\
\hline $\mathbf{2 0 0 5}$ & 1.161 & 2.710 & 1.687 & $6 \%$ & $22 \%$ \\
\hline $\mathbf{2 0 0 6}$ & 824 & 2.552 & 1.558 & $2 \%$ & $22 \%$ \\
\hline $\mathbf{2 0 0 7}$ & 1.092 & 2.466 & 1.570 & $\mathbf{7} \%$ & $20 \%$ \\
\hline $\mathbf{2 0 0 8}$ & 1.218 & 2.720 & 1.774 & $\mathbf{7} \%$ & $21 \%$ \\
\hline $\mathbf{2 0 0 9}$ & 873 & 2.542 & 1.605 & $3 \%$ & $20 \%$ \\
\hline
\end{tabular}




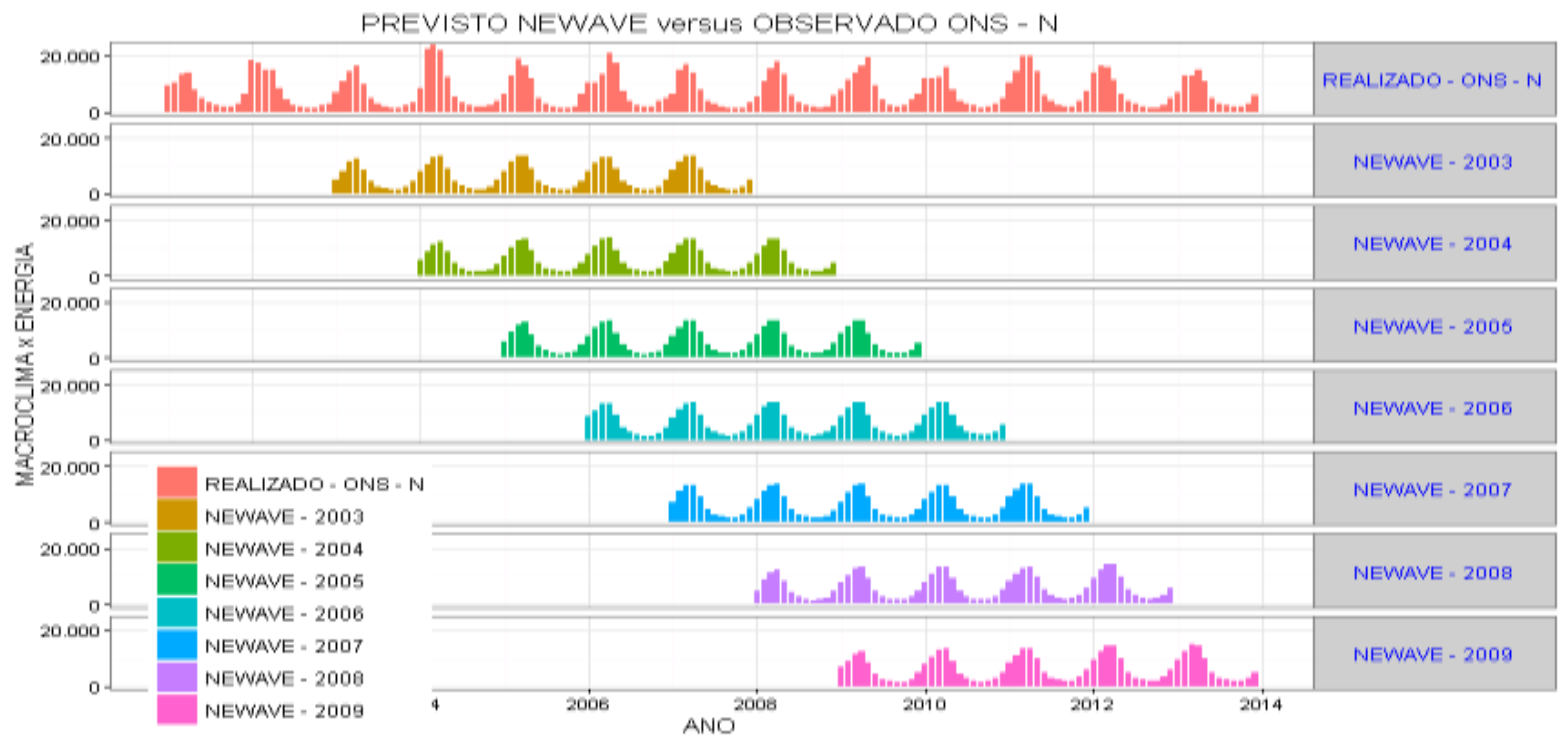

Figura 7-45 Validação Cruzada NEWAVE Região Norte :: Decks 2003 a 2009.

Na Figura 7-46, apresenta-se a diferença ou erro entre o observado e o previsto. Nota-se que os valores de erro são aproximados nos mesmos meses, apesar de serem previsões realizadas com decks diferentes.

Mai/09: 19.464 MWmédios

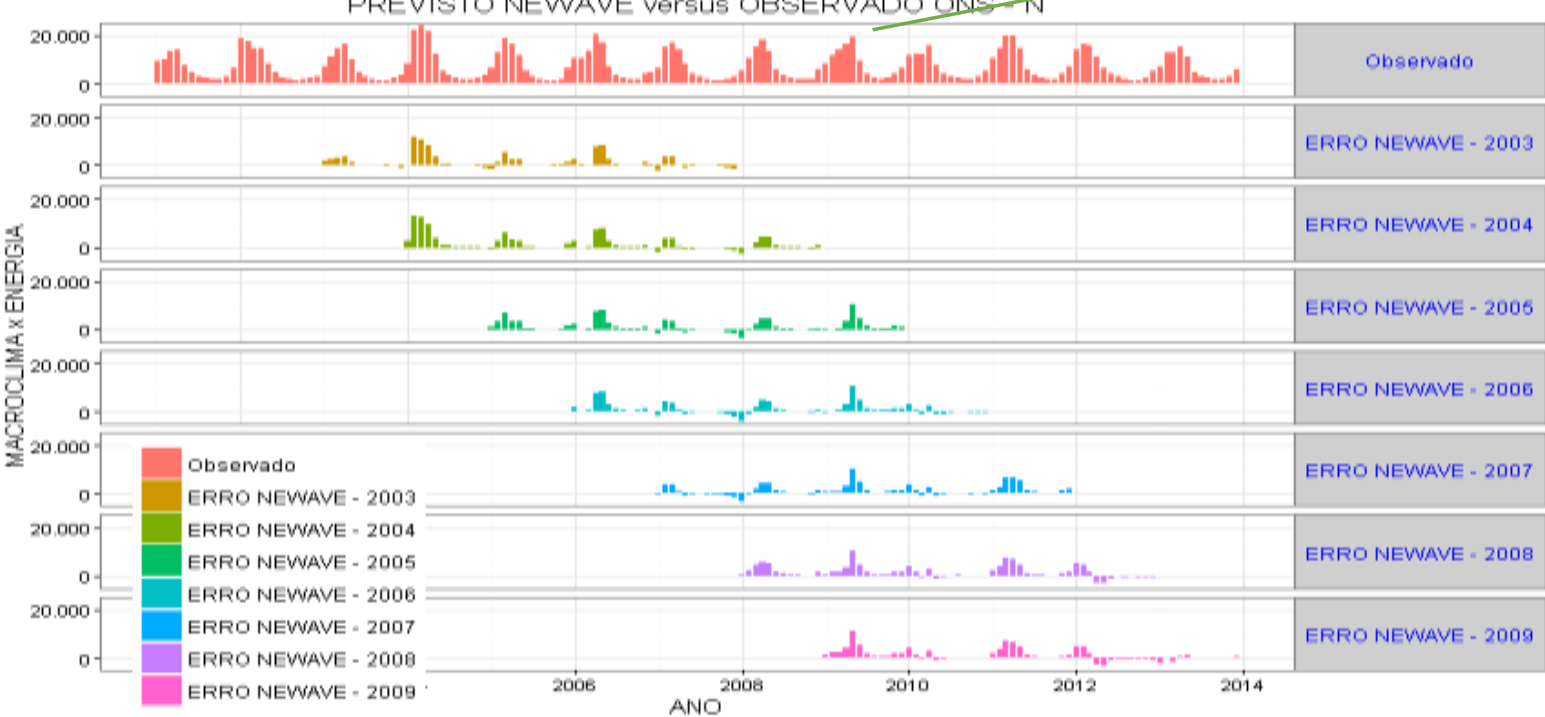

Figura 7-46 Validação Cruzada Erro =NEWAVE- ONS Região Norte:: Decks 2003 a 2009. 
O modelo SARIMAX(100)(011) é apresentado nas Figura 7-47 e Figura 7-48, e o resultado de erros são melhores do que o NEWAVE. Nota-se, também, que apresentam-se resultados com valores de erro similares nos mesmos meses para diferentes conjuntos ou decks de testes.

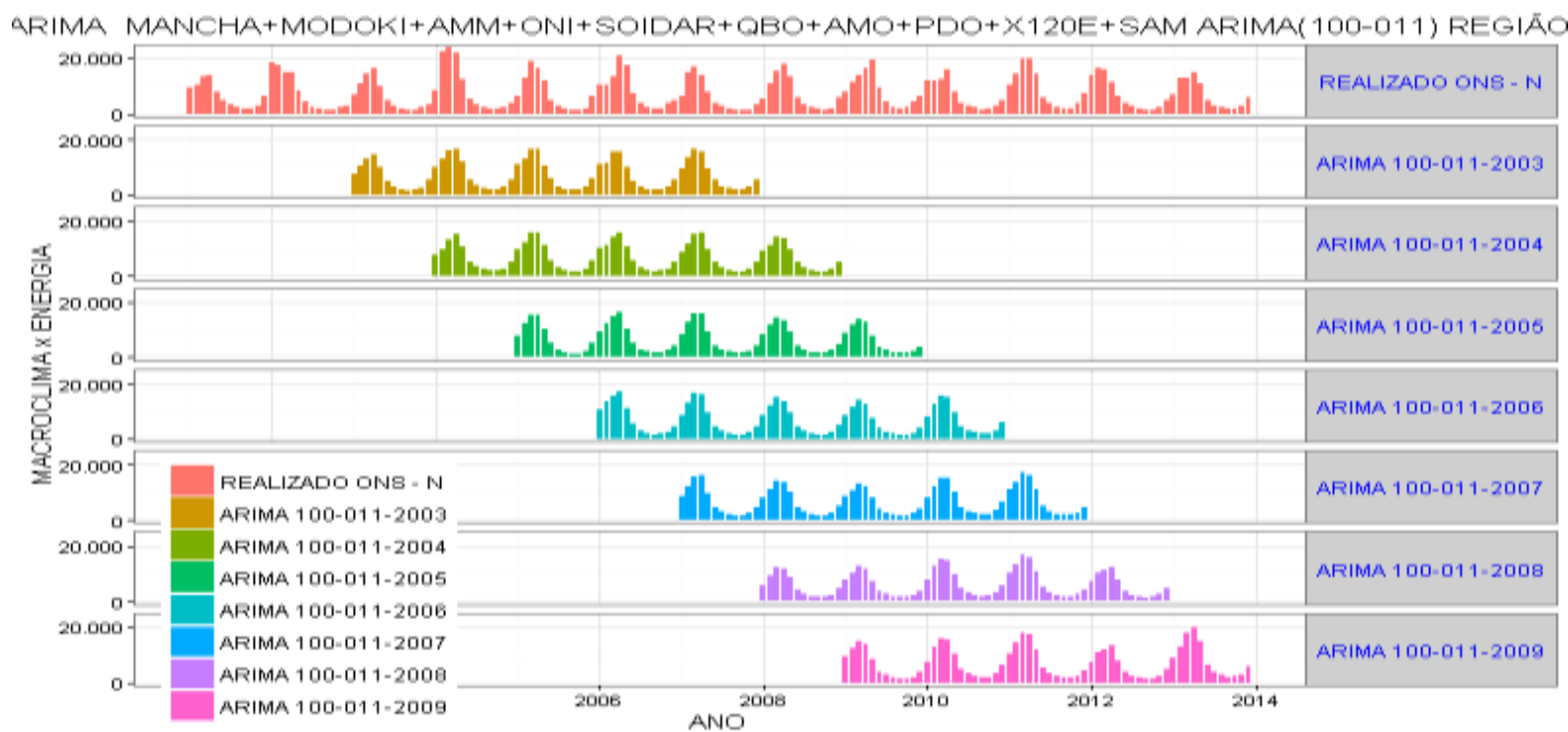

Figura 7-47 Validação cruzada modelos SARIMAX (100)(011) Região Norte

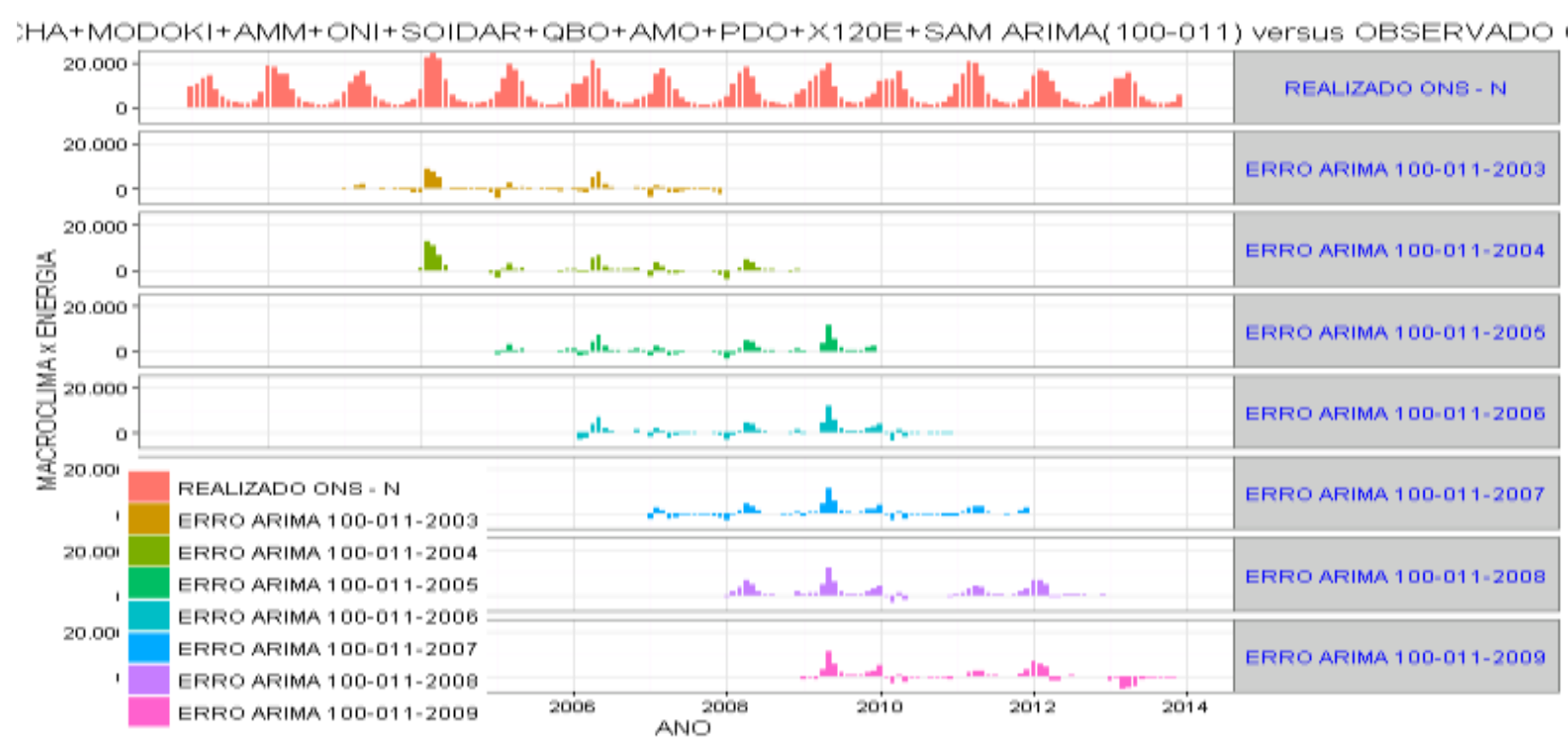

Figura 7-48 Validação Cruzada Erro =SARIMAX(100)(011) :: Conjuntos de teste 2003 a 2009 Região Norte 


\section{CAPÍtulo 8}

\section{SUMÁRIO, CONCLUSÕES}

\section{RECOMENDAÇÕES}

Nessa tese, foi proposta a problemática e os objetivos nos Capítulos 1 e 2, no Capítulo 3, uma revisão do referencial teórico e bibliográfico, pertinente ao tema de pesquisa, foi executada (p. 83). No Capítulo 4, uma base de dados foi organizada com diversas fontes de dados de índices e variáveis macroclimáticas, e dados de ENA, todos de acesso público (p. 133). As variáveis macroclimáticas como TSM das regiões do Oceano Pacífico chamadas Niño 1+2, Niño 3, Niño 4 e Niño 3.4; diversos índices calculados sobre áreas de larga escala dos oceanos, como o Índice Oscilação Decadal do Pacífico (PDO), Oscilação Madden-Julian (MJO), Índice Oscilação Multidecadal do Atlântico (AMO) e demais índices. Em seguida, Capítulo 5, a análise gráfica das variáveis macroclimáticas e de energia, bem como análise de correlações simples, e a aplicação de diferenças para tornar as séries estacionárias; quando necessário, foram feitas com as variáveis climáticas e as séries históricas de ENA das regiões Sudeste, Sul, Norte e Nordeste. A variável de número de manchas solares foi mantida e, uma vez que sua sazonalidade tem uma componente muito acentuada em 11 anos, pensou-se em avaliar essa variável mesmo sem correlações preliminares expressivas, pois, a série pode ser transformada com as wavelets, de acordo com a literatura, apesar das variáveis de energia terem somente 85 anos de registro, até o momento de publicação dessa tese. Diversos mapas e gráficos foram gerados e serviram para confirmar algumas informações encontradas na literatura, e estão listados no apêndice. No Capítulo 6, apresenta-se o método utilizado para a modelagem. O Capítulo 7, apresenta-se a elaboração dos modelos SARIMAX e previsão de energia. Seus resultados foram avaliados, através da validação cruzada e indicadores de erro, cuja teoria está descrita no apêndice. Nesse Capítulo 8, ao fim, apresentam-se o sumário, as conclusões e recomendações da tese, a seguir. Quatro modelos SARIMAX, para as quatro regiões brasileiras, foram especificados, identificados, estimados, verificados e validados. $\mathrm{O}$ Modelo SARIMAX ENA-SE foi o que apresentou melhores resultados e foi aquele que convergiu mais facilmente. O SARIMAX ENA-N, por outro lado, foi necessário diminuir o período da série histórica para treinamento inicial do ano de 1978 para o ano de 1998, e, assim, foi possível ajustar o modelo. 
O modelo SARIMAX ENA-N, também, não atendeu uma das suposições e apresentou heterocedásticidade frente ao modelo ajustado. O motivo desse comportamento, pode ser devido uma parte da série histórica ser sintética.

As ENA-S e ENA-NE, apresentaram-se como a ENA-SE, atenderam todas as suposições do modelo SARIMAX .

A metodologia foi desenvolvida com a combinação de diferentes ferramentas de análise de correlação e causalidade em Grange, a modelagem e ajustes com o modelo ARIMA, modelo de previsão, modelo de regressão dinâmica e a validação cruzada.

Com a verificação e dignóstico, através dos resíduos, pode-se escolher as variáveis, mesmo sem ter a análise de correlação preliminar, pois o dignóstico do modelo, já, avalia se uma variável é significativa ou não, e portanto, o modelo apresenta-se completo para fazer as predições ou cenarizações em foco, com qualquer variável de interesse, e permite selecionar as variáveis e experimentar, ao inserir ou retirar, os resultados de diferentes combinações de variáveis explicativas.

\subsection{Sumário}

Na seções seguintes, esse sumário apresenta um versão compactada de toda a tese, e destacase os principais elementos utilizados no seu desenvolvimento, com o objetivo de facilitar o acesso as principais informações.

\subsubsection{Introdução}

Na Figura 8-1, apresentam-se a evolução das usinas e a importância das hidrelétricas no Setor Elétrico Brasileiro (SEB). Em termos de capacidade de geração instalada no Brasil, havia aproximadamente $142 \mathrm{GW}$ no ano de 2015. As usinas de fonte renovável correspondem a 113,3 GW (75,3\%) e as de fonte não renovável equivalem a 29,1 GW (19,33\%), Tabela 3-2, p. 99. As usinas de fontes renováveis são mais dependentes das condições do tempo, como por exemplo, as hidrelétricas e as termoelétricas a biomassa, que dependem da chuva, e as eólicas, que dependem da força resultante dos ventos. As renováveis têm como vantagem a energia potencial proveniente das chuvas ou mesmo do processo de fotossíntese que não oferecem nenhum custo às usinas, como por exemplo, o custo de combustível para as usinas termelétricas movidas com combustíveis fósseis. A principal desvantagem é sua dependência a fatores climáticos provocados pela variabilidade climática que pode resultar em secas, cheias, geadas e outros que de certa forma podem ser impactantes. 


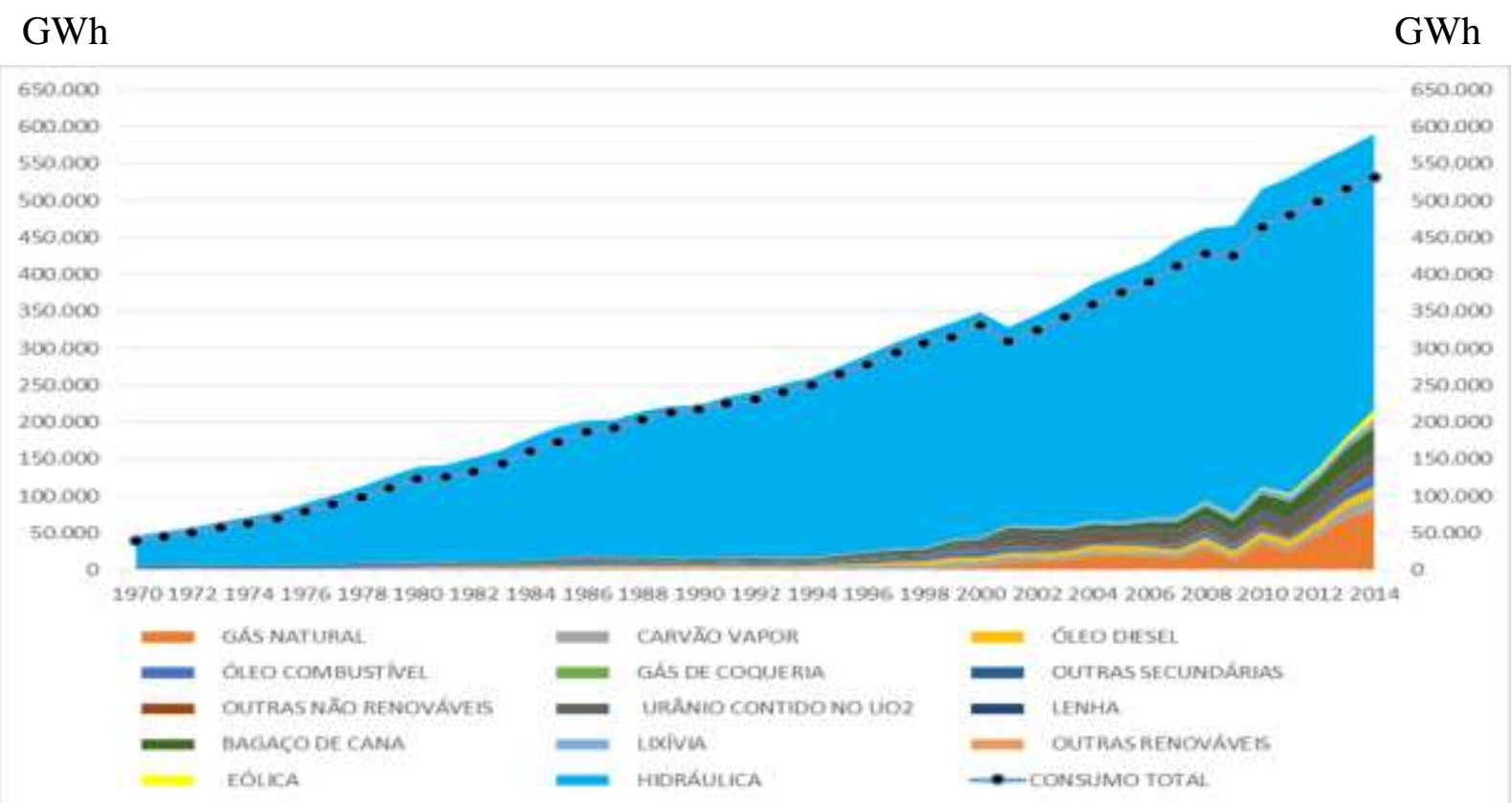

Figura 8-1 Evolução da Produção versos Consumo de Energia Elétrica no Brasil em GWh. Fonte: BEN, 2015.

Desse modo, não obstante os recursos renováveis como chuva, sol e o vento serem fornecidos pela natureza, o Operador Nacional do Sistema Elétrico (ONS) planeja e opera os reservatórios das usinas que compõe o Sistema Interligado Nacional (SIN) por intermédio de um conjunto de modelos que valoriza monetariamente a oportunidade de usar ou não as águas represadas. Mesmo com a grande importância das chuvas, os modelos utilizados pelo ONS, para operação e planejamento da expansão e construção das hidrelétricas, não consideram os efeitos do clima em seus cálculos.

Um indicador de possíveis chuvas na região Sudeste é o fenômeno chamado El Niño, onde geralmente, quando ocorre, há maior incidência de chuvas nas regiões Sul, Sudeste e Centro Oeste e favorecimento dos grandes reservatórios. Já, para o Norte e Nordeste, geralmente, ocorre períodos de estiagem.

Na Figura 8-2, apresentam-se (no gráfico de área) a série histórica de Energia Natural Afluente (ENA) medidas aqui em Terawatt-hora (TWh) dos submercados Sudeste (ENA-SE) e Sul (ENA-S) de 1931 a 2015, frente às ocorrências do fenômeno El Niño ou La Niña, (gráfico de barras). Para a ENA-SE constata-se que, nos anos de 1957, 1965, 1982, 1983, 1997, 1998 e 2015, ocorreram fenômenos El Niño forte ou muito forte, com os aumentos expressivos da Temperatura da Superfície do Mar (TSM), e na ENA-SE há coincidências em picos e vales que indicam possíveis correlações entre ambas, as séries históricas de ENA e os eventos do El Niño. Mais adiante uma análise com o uso de ferramenta de correlação é elaborada na seção 8.1.4.2 Correlação das Séries históricas, p. 263. 


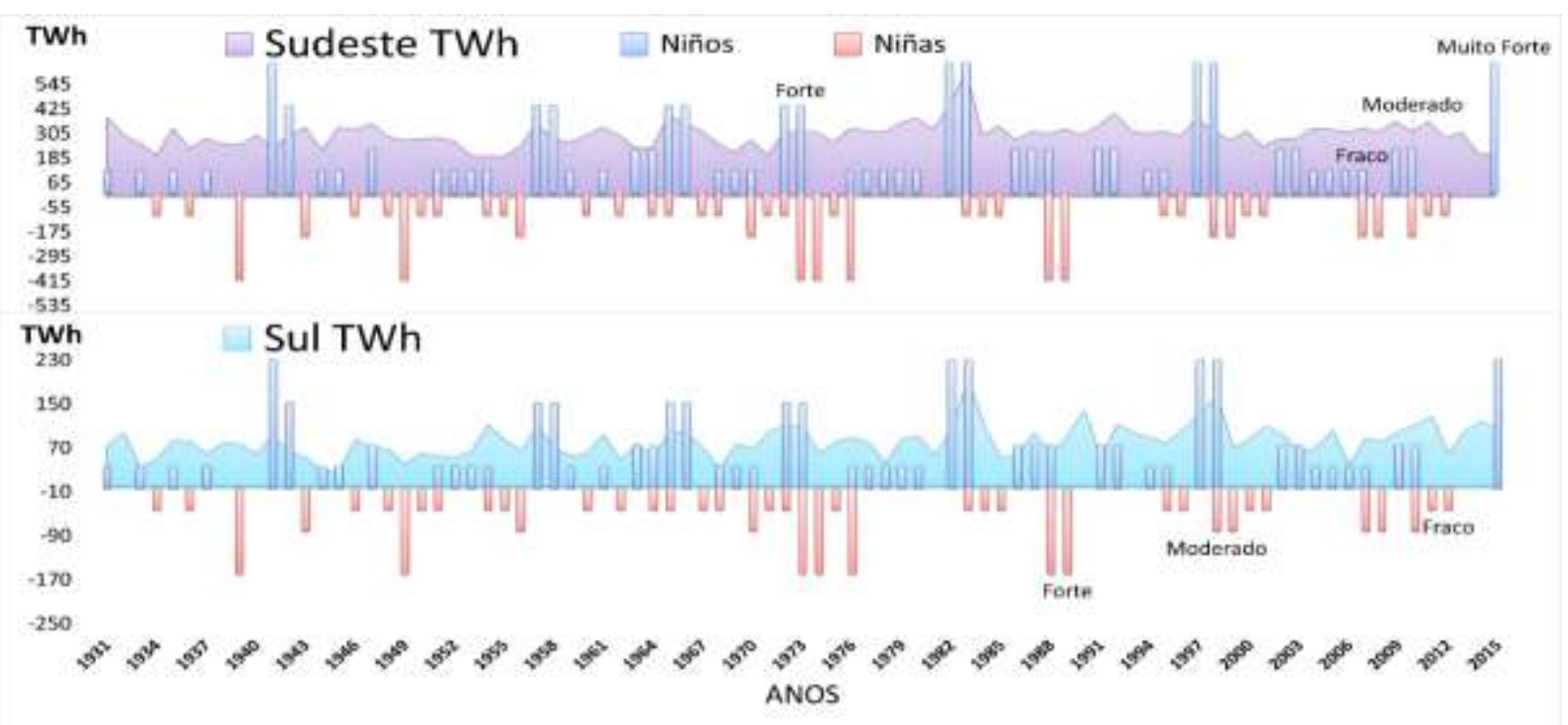

Figura 8-2 - Fenômenos El Niño e La Niña versos ENA Sudeste e Sul em TWh. Elaboração própria com dados do ONS.

O planejamento se empenha em criar um sistema para longo prazo e faz projeções com base no crescimento populacional, econômico e nas previsões de afluências por intermédio de seus modelos de otimização de operação do setor.

Usufruir de variáveis climáticas para reduzir o risco hidrológico é um caso particular onde se procura minimizar o impacto da variabilidade de sua oferta. Desse modo, o Brasil pode ser caracterizado como laboratório de um sistema elétrico largamente dependente de fontes renováveis que é capaz de ser operado para minimizar os riscos associados à utilização de tais fontes.

O planejamento operacional das usinas do SEB é realizado por intermédio do uso dos sistemas do Modelo de Planejamento da Operação de Sistemas Hidrotérmicos Interligados de Longo e Médio Prazo (NEWAVE) e o Determinação da Coordenação da Operação à Curto Prazo (DECOMP), atualizados pelo ONS e pela Câmara Comercializadora de Energia Elétrica (CCEE), é de suma importância para o planejamento do setor com os objetivos de manter e expandir o sistema. Um indicador gerado nesses sistemas é o Custo Marginal de Operação (CMO). Na Figura 8-3, apresenta-se o valor do CMO, que em geral, apresenta alta volatilidade em seus valores, frente aos valores de Armazenamento, nos anos mais secos, com os reservatórios deplecionados, e, com valores moderados e estáveis, em anos com reservatórios cheios. As previsões desses custos estam associado ao preço do Custo Variável Unitário (CVU) das usinas térmicas, nível dos reservatórios, afluências históricas e futuras, todos incluídos no NEWAVE/DECOMP, e que evidenciam a necessidade de inúmeras pesquisas na ciência do funcionamento e aperfeiçoamento dessas ferramentas ou mesmo 
elaboração de novas (RODRIGUES, 2009), para se evitar a volatilidade inerente em sistemas dinâmicos e estocásticos e melhorar seus resultados.

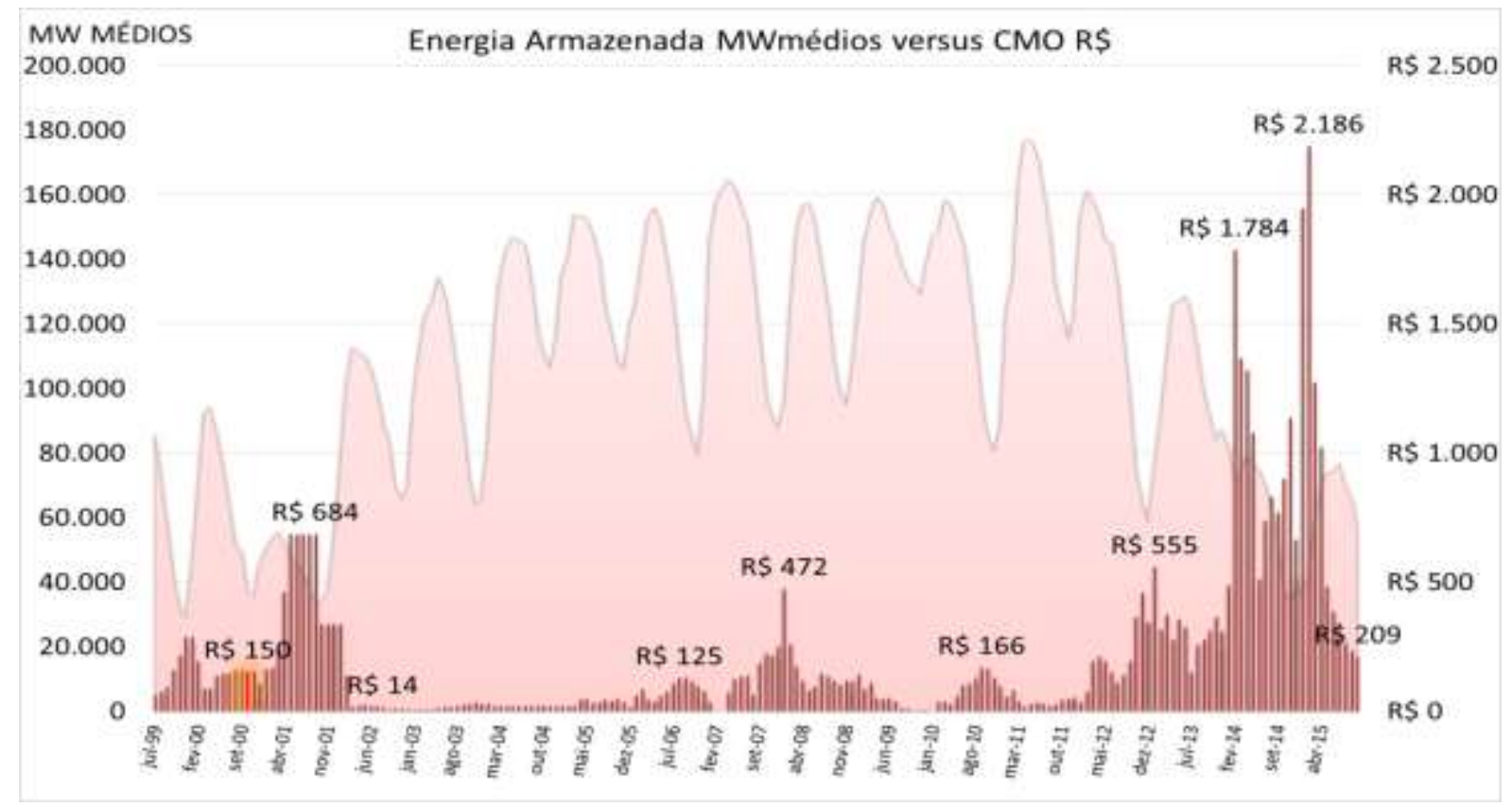

Figura 8-3 - Energia Armazenada (MWmédios) versos Custo Marginal de Operação (CMO - R\$) para o patamar pesado - Região Sudeste. Fonte ONS \& CCEE, 2015. ${ }^{116}$

Nessa tese, o problema a ser abordado é justamente como melhorar a predição ou construção de cenários da disponibilidade de água e energia futuras, com a inclusão das informações climáticas. Na Figura 8-4, descreve-se o dilema da tomada de decisão da operação de usinas, utilizar ou não utilizar as águas armazenadas para gerar energia. Torna-se evidente que, a decisão depende de mecanismos climatológicos, além dos hidrológicos, uma vez que a afluência futura, de forma simplificada, traduz-se na ocorrência das chuvas que dependem de estudos meteorológicos e climatológicos para sua predição.

\footnotetext{
116 Fonte
}

http://www2.aneel.gov.br/aplicacoes/Audiencia_Publica/audiencia_proton/2001/ap002/Nota\%20Tecnica.pdf 
Na Figura 8-4, apresenta-se o dilema do ONS em utilizar ou não a água dos reservatórios.

\begin{tabular}{|c|c|c|c|}
\hline INÍCIO & DECISÃO ONS & CONSEQUENCIAS \\
OPERATIVAS
\end{tabular}

Figura 8-4 Dilema do ONS na decisão de despachar ou não usinas hidrelétricas - elaboração própria

\subsubsection{Objetivos}

\subsubsection{Objetivo Geral}

Essa tese tem como objetivo geral propor uma metodologia para cenarização ou predição de energia (vazões x produtibilidade usina), com a aplicação de informações macroclimáticas como variáveis exógenas. O trabalho aqui apresentado foca em elaborar um modelo paramétrico que tem como função calcular a oferta de energia para um período de cinco anos e, assim, obter modelos interpretáveis e com sentido climatológico para, dessa maneira, determinar o efeito causal do clima na energia resultante das afluências.

\subsubsection{Objetivos Específicos}

Para alcançar o objetivo geral apresentado anteriormente são considerados os seguintes objetivos específicos:

- Analisar séries históricas com ferramentas matemáticas e gráficas para melhor compreender variáveis explicativas que refletem o comportamento do macroclima

- Incorporar, na construção do modelo, variáveis explicativas que refletem o comportamento climático de larga escala.

- Desenvolver e aplicar um protótipo de software para a predição de vazões com base em modelos matemáticos. 


\subsubsection{Questão central e hipótese}

A questão central que essa tese busca responder pode ser resumida da seguinte forma: É possível calcular e prever as afluências dos rios e, como consequência, a energia produzida pelas usinas hidrelétricas, através de informações climáticas de larga escala?

Esse trabalho pretende demonstrar que a modelagem de dados macroclimáticos, relacionados de alguma forma com as fontes de ENA (energia potencial que pode ser futuramente convertida em eletricidade), fornece elementos suficientes para prover cenários do potencial de incorporação desses dados nas ferramentas de planejamento e operação da matriz elétrica brasileira e contribui para mostrar como e quais variáveis podem ser utilizadas.

\subsubsection{Revisão Bibliográfica}

Nesta revisão são apresentadas as variáveis utilizadas na modelagem, como são criadas e quais são suas fontes.

\subsubsection{Número de Manchas Solares - SSN}

As manchas solares são manchas escuras na superfície do sol em razão uma temperatura inferior a local. As temperaturas no centro das manchas solares decrescem para cerca de 3.700 $\mathrm{K}$ (em comparação com $5.700 \mathrm{~K}$ para a fotosfera circundante). Elas duram vários dias e normalmente podem persistir por várias semanas. As manchas solares são regiões do Sol com fortes campos magnéticos (milhares de vezes mais fortes que o campo magnético da Terra), normalmente surgem em grupos com dois conjuntos de pontos.

O índice número de manchas solares (sunspot number) é dado pela soma do número de manchas solares individuais, multiplicada por 10. Como muitos grupos apresentam em média cerca de 10 pontos de manchas, utiliza-se essa fórmula para contar as manchas e obter um resultado confiável, mesmo que as condições de observação não sejam ideais e pequenas manchas sejam difíceis de observar. Atualmente há dois relatórios oficiais do número de manchas solares calculado pelo Solar Influences Data Analysis Center ${ }^{117}$ na Bélgica e pelos US National Oceanic and Atmospheric Administration (NOAA).

\subsubsection{Energia Natural Afluente - ENA}

Um ponto essencial para demonstrar a ligação entre o "mundo" da eletricidade e o "mundo" da climatologia é o conceito de ENA. Para sua existência é necessária a presença de uma usina implantada em um rio, que possua um reservatório, receba água de outros rios abastecidos pela chuva, originada na atmosfera, que é resultante da interação de fenômenos

\footnotetext{
$117 \mathrm{http}: / /$ solarscience.msfc.nasa.gov/SunspotCycle.shtml
} 
físicos (momentum angular, balanço termodinâmico, e mudança de estado da água) com os sistemas terrestres da biosfera, criosfera, hidrosfera que por sua vez são acionados pela energia da radiação solar incidente no equador (PEIXOTO \& ORT, 1992).

A ENA é a "energia afluente a um sistema de aproveitamentos hidrelétricos, calculada a partir da energia produzível pelas vazões naturais afluentes a estes aproveitamentos, em seus níveis a $65 \%$ dos volumes úteis operativos", (ONS, 2016, p.5).

Na Figura 8-5, representa-se um modelo simplificado do arranjo de uma usina, seus tipos de vazão e sua nomenclatura.

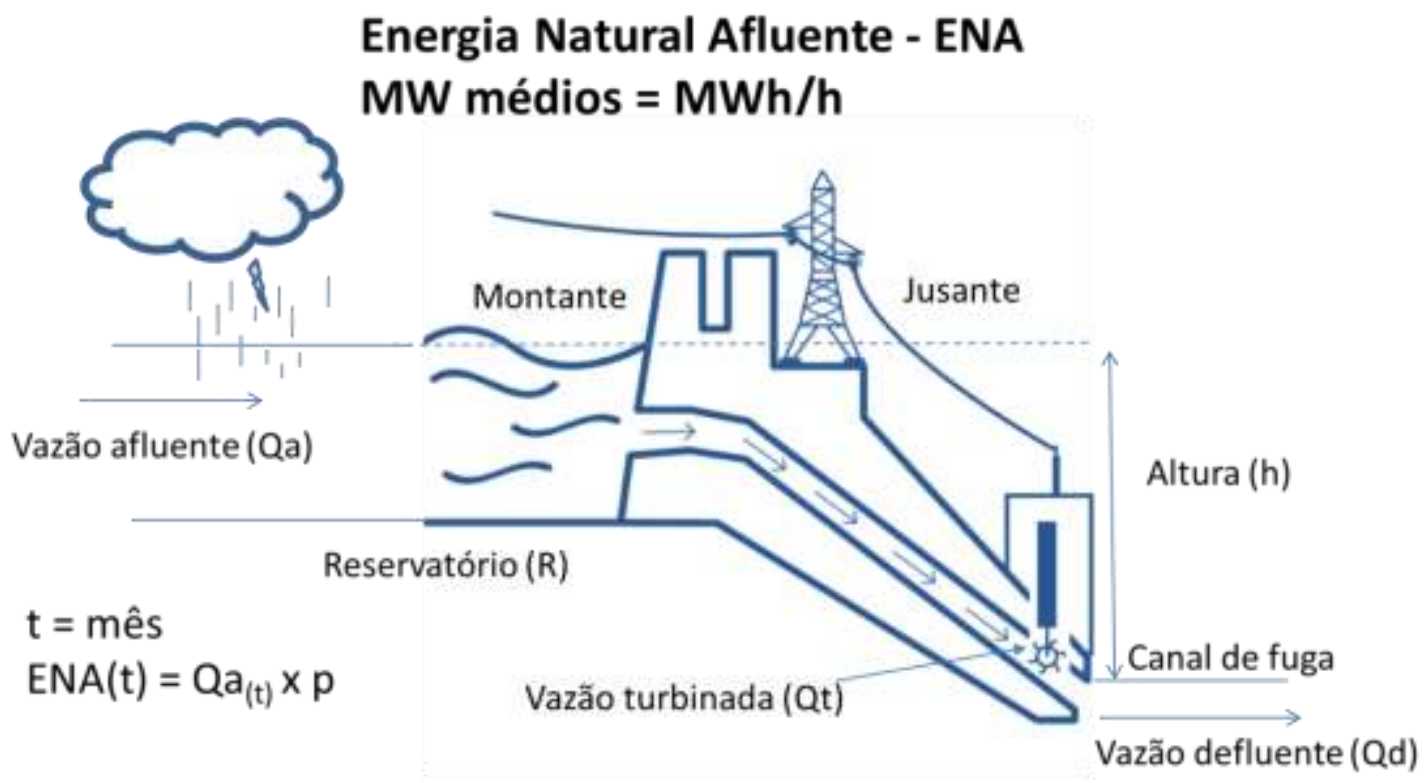

Figura 8-5 Modelo simplificado das partes de uma barragem com usina - adaptação própria ${ }^{118}$

\begin{tabular}{|l|r|}
\hline$E=m \times g \times h \times \eta$ & $8-1$ \\
\hline$\tau=F \times d=m \times a \times d$ & $8-2$ \\
\hline$[\tau]=K g \times \frac{m}{s^{2}} \times m=\frac{K g \times m^{2}}{s^{2}}$ & $8-3$ \\
\hline$E=m \times g \times h \times \eta=\rho \times V \times g \times h \times \eta=\rho \times \frac{V}{t} \times g \times h \times t \times \eta$ & $8-4$ \\
\hline$E=Q \times(\underbrace{\rho \times g \times h \times t) \times \eta}_{Q}$ & $8-5$ \\
\hline$p=\rho \times g \times h \times t \times \eta$ & $8-6$ \\
\hline$[p]=\frac{K g}{m^{3}} \times \frac{m}{s^{2}} \times m \times s \times 1=\frac{K g}{m \times s}$ & $8-7$ \\
\hline
\end{tabular}

\footnotetext{
${ }^{118}$ Fonte imagem: http://br.freepik.com/icones-gratis/usina-hidreletrica-em-producao_733525.htm
} 


\begin{tabular}{|l|r|}
\hline$E=Q \times p$ & $8-8$ \\
\hline$[E]=\frac{m^{3}}{s} \times \frac{K g}{m \times s}=\frac{K g \times m^{2}}{s^{2}}$ & $8-9$ \\
\hline$E N A_{(t)}=Q a_{(t)} \times p$ & $8-10$ \\
\hline
\end{tabular}

em que $t$ corresponde ao mês corrente; a transformação da energia e suas unidades são demonstradas da equação 8-1 até 8-9; a ENA $_{(\mathrm{t})}$, energia natural afluente, correspondente à média de energia do mês t, calculada através da equação 8-10; p é a índice de produtibilidade média do conjunto turbina-gerador; h é valor altura entre o nível do reservatório e o nível do rio a jusante (pós) a barragem; Qa é a vazão afluente medida $\mathrm{em}^{3} \mathrm{~s}^{-1}$; Qt é a vazão turbinada medida em $\mathrm{m}^{3} \mathrm{~s}^{-1}$; e Qd é a vazão defluente medida em $\mathrm{m}^{3} \mathrm{~s}^{-1}$.

\subsubsection{Temperatura da Superfície do Mar (TSM)}

A temperatura da superfície do Mar é um indicador muito utilizado em ciências atmosféricas para analisar padrões de variabilidade do clima. Sua medição é realizada através de leituras de fotografias captadas via satélite, embarcações e boias meteorológicas (tanto na superfície quanto submersas), sinais da superfície, capturados com sistemas de infravermelho ou fotografias feitas por aeronaves, dentre outras. Essas medidas são interpretadas, analisadas, interpoladas, reanalisadas e publicadas em domínio público para uso de instituições das ciências atmosféricas encontradas em todo o mundo. Pode-se utilizar como exemplo o International Comprehensive Ocean-Atmosphere Data Set (ICOADS), que administra de forma organizada três séculos de medidas e cria resumos mensais com grades de $2^{\circ}$ latitude por $2^{\circ}$ de longitude desde 1800 e $1^{\circ}$ x $1^{\circ}$ desde 1960 . Seu acesso é permitido ao mundo todo e é provavelmente a coleção mais completa e heterogênea de dados de superfície do mar existente.

O oceano interfere no sistema climático devido à sua grande capacidade de armazenar calor, e, assim, como a atmosfera, distribui energia da radiação solar que chega ao equador em direção aos polos. Os padrões de variabilidade da temperatura de superfície do mar (TSM) em escalas de tempo interanuais e interdecadais são resultados da combinação de processos acoplados do tipo oceânico-atmosféricos.

\subsubsection{Fenômeno El Niño Oscilação Sul}

O El Niño-Oscilação Sul (ENOS) é um fenômeno de grande escala que ocorre no Oceano Pacífico, formado pelas ocorrências El Niño (fase quente) e La Niña (fase fria). O ENOS apresenta acoplamento entre o oceano (El Niño e La Niña) e a atmosfera (Oscilação Sul) (PHILANDER, 1990). Para monitorar estes fenômenos são feitas medições de Temperatura da Superfície do Mar (TSM) pelo National Oceanic and Atmospheric Administration 
(NOAA) em quatro diferentes regiões de grande escala: NINO1+2, NINO3, NINO4 e NINO3.4. A partir dessas medidas são calculados índices de anomalias que representam os desvios padrões calculados com relação a sua média histórica ou climatológica.

As coordenadas das regiões geográficas relacionadas com ás áreas de medições de temperatura são descritas na Tabela 8.1, a seguir.

Tabela 8.1 Relação das áreas de medição TSM do Pacífico - El Niño

\begin{tabular}{|l|l|l|}
\hline Niño $1+2$ & $0-10^{\circ} \mathrm{Sul}$ & $90^{\circ}$ Oeste $-80^{\circ}$ Oeste \\
\hline Niño 3 & $5^{\circ}$ Norte $-5^{\circ} \mathrm{Sul}$ & $150^{\circ}$ Oeste $-90^{\circ}$ Oeste \\
\hline Niño 4 & $5^{\circ}$ Norte $-5^{\circ} \mathrm{Sul}$ & $160^{\circ}$ Leste $-150^{\circ}$ Oeste \\
\hline Niño 3.4 & $5^{\circ}$ Norte $-5^{\circ} \mathrm{Sul}$ & $170^{\circ}$ Leste $-120^{\circ}$ Oeste \\
\hline
\end{tabular}

\subsubsection{5 Índice de Oscilação Decadal do Pacífico - PDO}

Os valores padronizados do Índice de Oscilação Decadal do Pacífico (PDO) ${ }^{119}$ são calculados a partir da primeira componente principal das TSM do Pacífico no lado polar de $20^{\circ} \mathrm{N}$. Contrariamente ao El Niño, o sinal é mais notado da direção Leste-Oeste, que nos trópicos. A PDO apresenta duas fases uma fria e outra fase quente (ZHANG ET AL 1997, MATUA ET AL 1997).

\subsubsection{6 Índice Multivariado ENOS - MEI}

O índice MEI é calculado com base em seis variáveis principais observadas sobre o Pacífico tropical. Essas seis variáveis que são: pressão do nível do mar $(\mathrm{P})$, componentes do vento de superfície zonal (U) e meridional (V), a temperatura da superfície do mar (S), temperatura do ar na superfície (A) e fração de nebulosidade total do céu (C). Essas observações são coletadas e publicadas em ICOADS ${ }^{120}$ por muitos anos. O MEI é calculado separadamente para cada um dos doze bimestres (DJ, JF, ..., ND).

Após a filtragem espacial dos campos individuais em agrupamentos (WOLTER, 1987), o MEI é calculado como o primeiro componente principal sem rotação (PC) de todos os seis campos combinados. Isso é feito através da normalização da variância total de cada campo e em seguida, a extração do primeiro PC na matriz de covariância dos campos combinados (WOLTER e TIMLIN, 1998). A fim de manter o MEI comparável, todos os valores sazonais são normalizados.

\footnotetext{
${ }^{119}$ Do inglês: Pacific Decadal Oscillation (PDO);

${ }^{120}$ International Comprehensive Ocean-Atmosphere Data Set
} 


\subsubsection{7 Índice Oceânico Niño - ONI - NINO3.4}

O índice Oceânico Niño (ONI) foi criado no International Research Institute for Climate and Society, devido a tendência significativa de aumento de temperatura na região do NINO 3.4, desde 1950, ), e incorpora as tendências de longo prazo, que não se refletem na variabilidade interanual do ENOS. Assim, os cientistas dediciram utilizar médias fixas de 30 anos, para cada 5 anos de medições. Os episódios de El Niño e La Niña são definidos com base em um período de 30 anos (1971 a 2000). Caso o clima não mude, a diferença entre quaisquer das médias de 30 anos será muito pequena, e os impactos sobre a aparente força de episódios El Niño e La Niña seriam insignificantes (L’HEUREUX, COLLINS e HU, 2013).

\subsubsection{8 Índice de Oscilação Sul - SOI}

O Índice de Oscilação Sul (SOI) ${ }^{121}$ é padronizado e baseado nas diferenças das anomalias de pressão ao nível (SLP) ${ }^{122}$ do mar observadas entre Taiti e Darwin, Austrália, dividida pelo desvio-padrão mensal (ROPELEWSKI e JONES, 1987; ALLAN et al 1991; KÖNNEN et al 1998) ${ }^{123}$. O SOI é caracterizado como uma medida das flutuações de grande escala na pressão do ar, que ocorrem entre o Pacífico tropical ocidental e oriental (ou seja, o estado da Oscilação do Sul), durante os episódios de El Niño e La Niña. Em geral, séries temporais suavizadas do SOI correspondem muito bem com mudanças na temperatura dos oceanos em todo leste do Pacífico tropical. A fase negativa do SOI representa a pressão do ar abaixo do normal no Tahiti e acima do normal em Darwin. Períodos prolongados de valores SOI negativos (positivos), coincidem com águas anômalas quentes (frias) do mar em toda a faixa leste do Pacífico tropical típico de El Niño (La Niña). Sua base de dados é atualizada pelo NOAA. Encontra-se atualmente, mais dois índices que representam, cada um, pontos de pressão em Darwin o SOI_DAR, e em Taiti o SOI_TAH.

\subsubsection{EI Niño Modoki - MODOKI}

El Niño Modoki é um fenômeno acoplado oceano-atmosfera, no Pacífico tropical, e está associado com o forte aquecimento anômalo no Pacífico Tropical Central e arrefecimento no Leste e Oeste do Pacífico Tropical. As teleconexões associadas aos padrões de aquecimento e arrefecimento do El Niño Modoki são muito diferentes dos padrões de teleconexões do El Niño (L’HEUREUX, COLLINS e HU, 2013).

\footnotetext{
${ }^{121} \mathrm{https} / / / \mathrm{www} . \mathrm{ncdc}$. noaa.gov/teleconnections/enso/indicators/soi/

${ }^{122}$ Sea Level Pressure

${ }^{123} \mathrm{https}$ ://crudata.uea.ac.uk/cru/data/soi/
} 


\subsubsection{Atlântico Tropical Norte - TNA e Atlântico Tropical Sul - TSA}

A TNA e a TSA são índices, onde há padrões dipolares ao longo do Atlântico Tropical, e são identificados com periodicidade de 8 a 12 meses para o inverno-outono boreal, e 2 a 3 anos para o verão-inverno boreal (ENFIELD, 1999). Os índices são calculados com o uso de dados de reanálises Reynolds OIv2 SST ${ }^{124}$ (REYNOLDS ET AL, 2002).

\subsubsection{Modo Meridional do Atlântico - AMM}

O padrão espacial TSM Modo Meridional do Atlântico $\mathrm{AMM}^{125}$ é definido, através de aplicação da análise de covariância máxima (MCA) à TSM e os componentes zonal e meridional do campo vento a 10m de altura ao longo do período 1950-2005, a partir da base de dados de reanálise do NCEP / NCAR. A área analisada no Atlântico corresponde a região $\left(21^{\circ} \mathrm{S}-32^{\circ} \mathrm{N}, 74^{\circ} \mathrm{W}-15^{\circ} \mathrm{E}\right)$, e espacialmente suavizados (três pontos de longitude por dois pontos de latitude).

\subsubsection{TSM do Sudoeste do Atlântico Sul - SWA}

O artigo de Kayano et a. (2009) aponta diferentes padrões entre os diferentes períodos antes e depois do ano de 1976 através do exame de correlações entre as TSM e as precipitações da AS. Utiliza diferentes índices de TSM como: Pacifico Equatorial Leste (EEP), Atlântico Tropical Sul (TSA), Sudoeste do Atlântico Sul (SWA). Esses índices de TSM apresentam correlações que aparentam serem influencias pelas teleconexões do ENOS e também possivelmente as diferentes fases do PDO, embora os autores afirmem que não é possível concluir essa influência do PDO e mais estudos são necessários.

\subsubsection{3 Índice Oscilação Quase-Bianaual - QBO}

O QBO é uma oscilação quase periódica dos ventos zonais na estratosfera tropical caracterizada por regimes de ventos descendentes de Leste e Oeste, com períodos entre de 2234 meses (BALDWIN et al., 2001).

\subsubsection{Oscilação Madden-Julian MJO}

Shimizu e Ambrizzi (2011) pesquisaram sobre a influência do fenômeno Oscilação Madden Julian (MJO) sobre o ENOS e apresentaram que os fenômenos combinados durante o verão ou inverno austral podem fortalecer ou enfraquecer o ENOS e, portanto, influenciar as precipitações na América do Sul.

\footnotetext{
${ }^{124} \mathrm{http} / / / \mathrm{www} . e m c . n c e p . n o a a . g o v /$ research/cmb/sst_analysis/

$125 \mathrm{http}: / /$ www.esrl.noaa.gov/psd/data/timeseries/monthly/AMM/
} 
A Oscilação Madden-Julian (MJO) é uma perturbação tropical, que propaga-se de Oeste para Leste, através do redor da região do trópico global com um ciclo da ordem de 30 a 60 dias (MADDEN; JULIAN, 1972). O MJO impacta os padrões de precipitação tropical e extratropical, circulação atmosférica e temperatura de superfície. Existem evidências que a MJO influencie o ciclo do ENOS e contribui para acelerar o desenvolvimento e intensidade dos fenômenos de El Niño e La Niña. ${ }^{126}$. Sobre a América do Sul, a MJO, em períodos de El Niño e La Niña moderados, pode inibir ou intensificar a formação de nuvens de chuva. A identificação da ocorrência do MJO acontece por meio de medições de velocidade potencial, pressão atmosférica a 200 mbar (aproximadamente 12 km de altura), (HIGGINS e MO, 1997; HIGGINS e SCHUBERT, 1996; KOUSKY e KAYANO, 1994).

O índice da MJO é formado por oito fases, onde cada fase corresponde a uma posição de convecção do MJO sobre a Índia e o Oceano Pacifico entre $15^{\circ} \mathrm{S}$ e $15^{\circ} \mathrm{N}$ (WHEELER e HENDON, 2004). Sobre a América do Sul, a MJO está relacionada com o a intensidade da Zona de Convergência Atlântico Sul - ZACS (DE SOUZA e AMBRIZZI, 2006).

Nesta trabalho, destacaram-se as varíaveis com longitude $70^{\circ} \mathrm{E}, 120^{\circ} \mathrm{E}$ e $40^{\circ} \mathrm{W}$.

\subsubsection{Materiais e Métodos}

\subsubsection{Fonte de Dados}

Na Tabela 8-2, estão relacionadas as variáveis macroclimáticas, que representam as medidas de TSM e alguns índices que tratam de diferentes partes do globo terrestre, relacionadas aos padrões climáticos utilizados como indicadores. Sua localização, na Internet, está relacionada nos endereços da Tabela 8-3. O critério de escolha dessas variáveis foi adotado com base na literatura sobre climatologia e testes de correlação realizados conforme a seção 8.1.4.2 Correlação das Séries históricas, p.263. Já, os dados de vazões publicados pelo ONS, apresentam periodicidade mensal e compreendem o período de 1931 a 2014. Os dados de vazão são organizados por usina em uma planilha fornecida pelo ONS, e utiliza-se o pacote de programas R para sua leitura e organização. São encontrados também dados agregados por bacias e macrorregiões Norte, Sul, Sudeste / Centro-Oeste e Nordeste, que correspondem aos quatro submercados onde o SIN é organizado. Não há dados agregados por vazões, pois essas são informações registradas por usinas hidrelétricas, diferente de energia, não podem ser integradas por escalas espaciais maiores, como vazões por bacia, ou vazões por região.

\footnotetext{
${ }^{126}$ http://www.cpc.ncep.noaa.gov/products/precip/CWlink/MJO/MJO_1page_factsheet.pdf
} 
As variáveis NINO 1+2 e AMO foram as que apresentaram valores de correlação com as variáveis de vazões superiores a 0,6. Embora na literatura a variável PDO seja relacionada aos eventos na América do Norte e se correlacione às regiões do Niño, essa análise de dados não apresenta correlações expressivas, nas vazões ou ENA do Brasil. Os outros índices também apresentaram correlações menores que 0,6, são eles: aa, número de manchas solares e manchas solares por área, QBO, MEI, SOI, ONI, NAO, TNA, TSA e MODOKI.

Tabela 8-2 - Fontes de dados coletados para análise

\begin{tabular}{|c|c|c|c|c|}
\hline Nome original & Sigla & Unid. & Escala temporal & Período \\
\hline Número de Manchas solares & SSN & Quant. & Interdecadal & 1749-presente \\
\hline Atlantic Meridional Mode & AMM & Idx & Sazonal & 1948 - presente \\
\hline Tropical Southern Atlantic Index & TSA & Idx & Interanual & 1948-presente \\
\hline El Niño $1+2$ & NINO $1+2$ & ${ }^{\circ} \mathrm{C}$ & Interanual & 1870 - presente \\
\hline El Niño 3 & NINO 3 & ${ }^{\circ} \mathrm{C}$ & Interanual & 1870 - presente \\
\hline Quasi-Biennial Oscillation & QBO & ${ }^{\circ} \mathrm{C}$ & Interanual & 1948 - presente \\
\hline Pacific Decadal Oscillation & PDO & ${ }^{\circ} \mathrm{C}$ & Interdecadal & 1854 - presente \\
\hline Oscilação Madden-Jullian ${ }^{127}$ & $\mathrm{MJO}$ & Idx & Intrassazonal & 1978-presente \\
\hline Multivariate ENSO Index & MEI & $\operatorname{Idx}$ & Interanual & 1950-2014 (bim.) \\
\hline Oceanic Niño Index & ONI & Idx & Interanual & 1950 -presente \\
\hline El Niño Modoki & MODOKI & Idx & Interanual & 1870-presente \\
\hline Energia Natural Afluente Regiões & ENA & MWmed & Sazonal & 1931-presente \\
\hline Energia Natural Afluente Bacias & BACIAS & MWmed & Sazonal & 1931-presente \\
\hline
\end{tabular}

Tabela 8-3 Localização original das variáveis macroclimáticas coletadas. ${ }^{128}$ \begin{tabular}{l|ll} 
Sigla & URL
\end{tabular}

\begin{tabular}{|l|l|}
\hline SSN & http://solarscience.msfc.nasa.gov/greenwch/spot_num.txt \\
\hline AMM & http://www.esrl.noaa.gov/psd/data/timeseries/monthly/AMM/ \\
\hline TSA & http://www.esrl.noaa.gov/psd/data/correlation/tsa.data \\
\hline NINO 1+2 & http://www.esrl.noaa.gov/psd/gcos_wgsp/Timeseries/Data/nino12.long.data \\
\hline NINO 3 & http://www.esrl.noaa.gov/psd/gcos_wgsp/Timeseries/Data/nino3.long.data \\
\hline QBO & http://www.esrl.noaa.gov/psd/data/correlation/qbo.data \\
\hline PDO & http://jisao.washington.edu/pdo/PDO.latest \\
\hline MJO & http://www.cpc.ncep.noaa.gov/products/precip/CWlink/daily_mjo_index/proj_norm_order.ascii \\
\hline Mei & http://www.esrl.noaa.gov/psd/enso/mei/table.html \\
\hline ONI & http://www.cpc.ncep.noaa.gov/data/indices/oni.ascii.txt \\
\hline NAO & $\begin{array}{l}\text { http://www.cpc.ncep.noaa.gov/products/precip/CWlink/pna/ } \\
\text { norm.nao.monthly.b5001.current.ascii.table }\end{array}$ \\
\hline MODOKI & http://www.jamstec.go.jp/frcgc/research/d1/iod/DATA/emi.monthly.txt \\
\hline ENA & http://www.ons.org.br/download/operacao/hidrologia/Enas_Subsistemas_1931_2014.xls \\
\hline BACIAS & http://www.ons.org.br/download/operacao/hidrologia/Enas_Bacias_1931_2014.xls \\
\hline VAZ & http://www.ons.org.br/download/operacao/hidrologia/Vazões_Mensais_1931_2014. xls \\
\hline
\end{tabular}

\footnotetext{
${ }^{127}$ Formado por dez índices engloba latitude entre 30N e a linha do Equador e longitudes centradas em: 20E, $70 \mathrm{E}, 80 \mathrm{E}, 100 \mathrm{E} 120 \mathrm{E}, 140 \mathrm{E}, 160 \mathrm{E}, 120 \mathrm{~W}, 40 \mathrm{~W}$ and $10 \mathrm{~W}$ Fonte: http://gcmd.nasa.gov/records/GCMD_NOAA_NWS_CPC_MJO.html

${ }^{128}$ Fonte: http://www.esrl.noaa.gov/psd/data/climateindices/list/ Acesso em 25/09/2015.
} 


\subsubsection{Correlação das Séries históricas}

Nessa seção, são apresentadas análises de correlação feitas entre as variáveis escolhidas para o estudo. O objetivo é verificar se os dados de vazões ou ENA têm alguma relação direta com os dados climáticos. Para verificar a correlação foi utilizado o coeficiente de correlação de Pearson (PEARSON, 1901), que é apresentada na seção 1.1.1.1APÊNDICE C Correlação de Pearson, p. 319. Ademais, tendo em vista que a análise das correlações é feita sem adotar nenhum modelo físico, a aplicação do método de causalidade Granger (GRANGER, 1969, GREENE, 2003, FEIGL. 1953, p.408, Apud. GRILICHES \& INTRILIGATOR, 2007 GUJARATI e PORTER, 2009). Fez-se necessária, para identificar eventuais correlações espúrias (BOUDJELLABA et al., 1992).

As séries históricas disponíveis são as amostras de dados utilizadas nas análises estatísticas. Na correlação de Pearson, o teste de hipóteses aplicado assume-se que $h_{0}: \rho=0$ e $h_{1}: \rho \neq 0$. No teste de causalidade Granger o teste de hipóteses (em que $\mathrm{h}_{0}=n \tilde{a} o$ existe causalidade Granger e $\mathrm{h}_{1}=$ existe causalidade Granger) assume uma distribuição $\mathrm{F}$. Em ambos os testes ${ }^{129}$, para valores $\mathrm{p}$ menores que 0,05 rejeita-se $\mathrm{h}_{0}$.

Os gráficos são do tipo matricial, apresentam em sua diagonal principal o nome e o histograma das variáveis. A matriz é dividida, pela diagonal principal, em duas partes, conforme indicado pela abaixo:

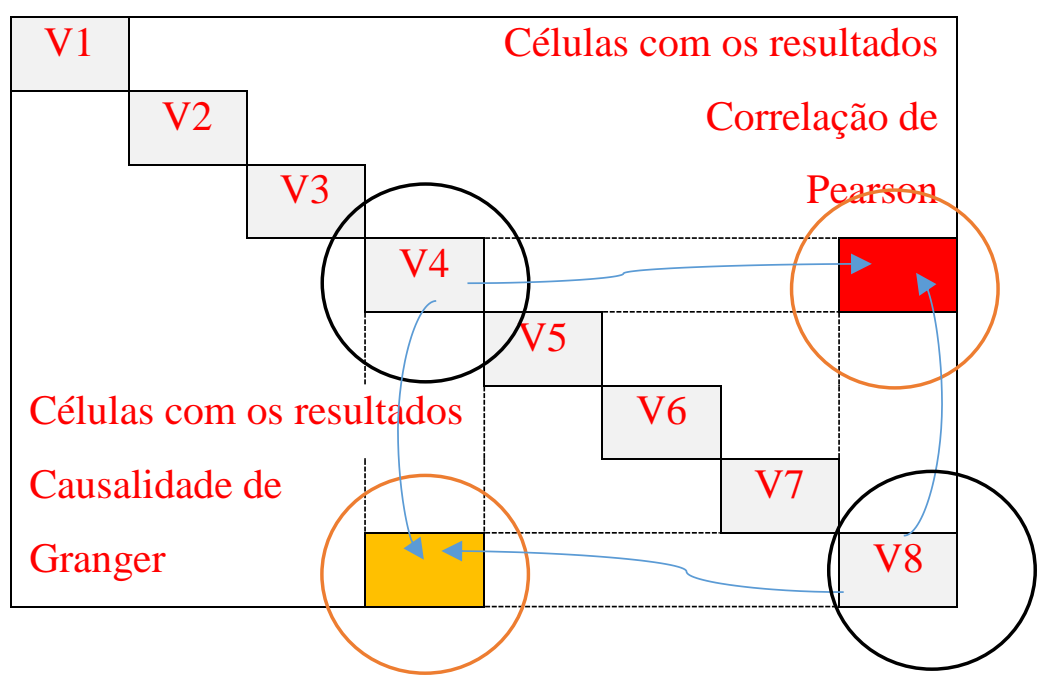

Figura 8-6 - Matrix de correlações e causalidades. Exemplo V4 versos V8

\footnotetext{
${ }^{129}$ Maiores detalhes sobre a teoria de correlação e causalidade de Granger ver no apêndice: 1.1.1.1APÊNDICE C Correlação de Pearson, p. 352 e 1.1.1.1APÊNDICE E Causalidade de Granger, p. 356
} 
Na parte superior da diagonal são indicadas as medidas referentes à correção de Pearson (correlação $r$, p-valor e atraso para o qual ocorre a melhor correlação). Rejeita-se ho caso valor de p seja menor que 0,05; o lag (ou atraso) referente ao mês de melhor correlação obtido através da aplicação da função de correlação cruzada. As figuras utilizadas para avaliar a correlação entre os dados das séries históricas possuem a seguinte estrutura de apresentação, indicada na Figura 8-7:

azul: resultados de correlação aceitáveis $(\mathrm{p}<0,05 \text { e }|\mathrm{r}|>0,5)^{130}$;

roxo: resultados de correlação parcialmente aceitáveis ( $\mathrm{p}<0,05$ e $|\mathrm{r}|<0,5)$;

vermelho: resultados de correlação inaceitáveis ( $\mathrm{p}>0,05$ e $|\mathrm{r}|<0,5)$.

\begin{tabular}{|c|c|c|}
\hline $\begin{array}{c}\text { r: } 0.59 \\
\text { pvalue }=0.23 \\
\text { lag: }-0.75\end{array}$ & $\begin{array}{c}r: 0.59 \\
\text { pvalue }=0.036 \\
\text { lag: }-0.75\end{array}$ \\
\end{tabular}

Figura 8-7 - Correlação de Pearson e respectivos valores p e atraso (lag) entre as variáveis. Em roxo o valor p > 0,05. Em azul os valores $r$ e p aceitáveis. Em vermelho valores $r$ e p ambos não aceitáveis.

Os elementos que permanecem abaixo da diagonal principal da matriz (parte inferior na Figura 8-8) detalham a causalidade Granger ${ }^{131}$, com os respectivos p-valor e direções de causalidade. Por convenção:

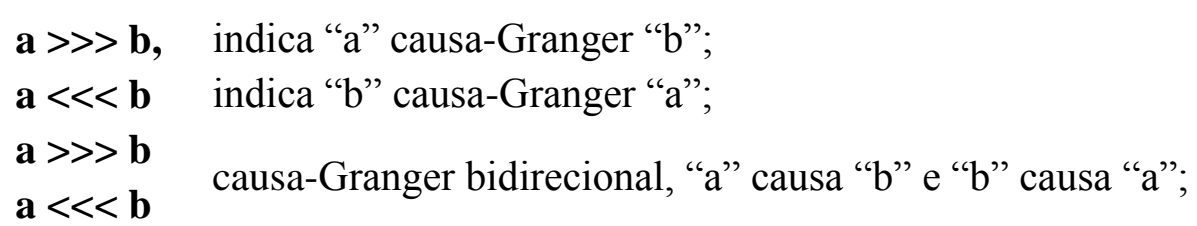

onde $\mathrm{a}$ e b são respectivamente variáveis à esquerda e variável à direita, posicionadas na matriz. Assim como no caso da análise de correlação, adota-se o nível de significância de 5\% para rejeitar $\mathrm{h}_{0}$ quando $\left(\mathrm{h}_{0}=\right.$ ão existe causalidade e $\mathrm{h}_{1}=$ existe causalidade $)$ a análise de causalidade Granger é adotada seguindo um critério de cores da seguinte maneira:

azul: causalidade bidirecional;

roxo: causalidade unidirecional; e

vermelho: não há causalidade.

\begin{tabular}{|l|}
\hline pvalue granger \\
$\mathrm{a}>>>\mathrm{b}:<0.0001$ \\
$\mathrm{a}<<<\mathrm{b}: 0.00049$
\end{tabular}

pvalue granger
$\mathrm{a} \gg>$ b: 0.038
$\mathrm{a}<\ll<$ b: 0.22

pvalue granger

$a \gg>$ b: 0.38

$\mathrm{a} \ll<$ b: 0.45

\footnotetext{
${ }^{130}$ Adotou-se um critério de correlações acima de 50\% serem aceitáveis, ou seja, um critério binário.

131 A causalidade Granger não é a rigor nexo causal, ou o sentido de causa aristotélico, e sim uma técnica para previsão que segue algumas suposições.
} 
Figura 8-8 - Causalidade de Granger. Em azul, causalidade bidirecional. Em roxo, causalidade unidirecional. Em vermelho não há causalidade.

\subsubsection{Método SARIMAX}

O modelo escolhido foi o Sazonal Autorregressivo Integrado e de Médias Móveis com acréscimo de variáveis explicativas regressivas (SARIMAX). O motivo dessa escolha, baseiase nesse modelo que foi feito para tratar com séries temporais, as quais apresentam algumas propriedades como autocorrelação, tendências e sazonalidade. Modelos alternativos foram testados com o uso das ferramentas desenvolvidas por Hernández (2011), todavia os resultados apresentados, aproximaram-se aos do Modelo SARIMAX ${ }^{132}$ e, em vista disso não são utilizados nessa tese.

A estrutura do modelo é denominada $\operatorname{SARIMAX}(\mathrm{p}, \mathrm{d}, \mathrm{q})(\mathrm{P}, \mathrm{D}, \mathrm{Q})^{\mathrm{m}} \mathrm{x}$, onde:

$\mathrm{m}$ é a periodicidade da sazonalidade no ano;

p: número de valores passados dos parâmetros autorregressivos $\phi$;

d: valor de diferença, utilizado quando a série possui tendência;

q: número de valores defasados dos parâmetros de médias móveis $\theta$;

P: número de valores de parâmetros autorregressivos sazonais $\Phi$;

D: valor de diferença, quando a série sazonal possui tendências sazonais;

Q: número de valores defasados dos parâmetros de médias móveis sazonais $\Theta$;

$\mathrm{B}$ : operador de atraso (backshift), onde $\mathrm{BY} \mathrm{t}_{\mathrm{t}}=\mathrm{Y}_{\mathrm{t}-1 ; \mathrm{e}}$

x: valor de variável ou variáveis exógenas utilizadas como variáveis regressivas no modelo.

$$
\begin{gathered}
\underbrace{\left(1-\phi_{1} B-\cdots \phi_{p} B^{p}\right)}_{A R_{(p)} \text { não sazonal }} \underbrace{\left(1-\Phi_{1} B^{m}-\cdots \Phi_{P} B^{m P}\right)}_{A R_{(P)} \text { sazonal }} \underbrace{\left(1-B^{m}\right)^{D}}_{\begin{array}{c}
\text { diferença } \\
\text { não sazonal }
\end{array} \underbrace{(1-\mathrm{B})^{d}}_{\begin{array}{c}
\text { diferença } \\
\text { sazonal }
\end{array}} y_{\text {regressor } X} \underbrace{\beta x_{t}}} y_{M A_{(q)} \text { não sazonal }}^{\left(1+\theta_{1} B+\cdots \theta_{q} B^{q}\right)} \underbrace{\left(1+\Theta_{1} B^{m}+\cdots+\Theta_{Q} B^{m Q}\right)}_{M A_{(Q)} \text { sazonal }} e_{t}
\end{gathered}
$$

Os parâmetros $\phi_{1}, . ., \phi_{\mathrm{p}}$ e $\theta_{1}, \ldots \theta_{\mathrm{q}}$ são, respectivamente, autorregressivos de ordem $\mathrm{p}$ e de médias móveis de ordem q e os parâmetros $\Phi_{1}, \ldots, \Phi_{P}$ e $\Theta_{1}, \ldots, \Theta_{Q}$ são autorregressivos sazonais de ordem P e de médias móveis sazonais de ordem Q.

\footnotetext{
132 Fonte: Adaptado de (HYNDMAN, R.J. and ATHANASOPOULOS, 2013) Acesso em 19/01/2016 url: https://www.otexts.org/fpp/8/9,
} 
Os parâmetros $(1-B)^{d}$ e $\left(1-B^{m}\right)^{\mathrm{D}}$ são, respectivamente, a diferença ordinária e a diferença sazonal.

$\beta \mathrm{x}_{\mathrm{t}}$ representa a variável ou variáveis exógenas acrescidas no modelo.

O modelo geral pode ser apresentado como (BOX; JENKINS; REINSEL, 2008 ; HYNDMAN, R.J. \& ATHANASOPOULOS, 2013):

$\phi_{p}(B) \Phi_{P}\left(B^{m}\right)(1-B)^{d}\left(1-B^{m}\right)^{D} Z_{t}=\theta_{0}+\theta_{q}(B) \Theta_{Q}\left(B^{m}\right) \beta x_{t} e_{t}$

As suposições sobre o modelo sazonal consistem em apresentar média zero, variância constante, erros $e_{t}$ aleatórios, independentes e igualmente distribuídos (i.i.d.) A identificação das ordens dos parâmetros, estimação de seus valores e suas predições são análogas às do modelo ARIMA (WEI, 2006; PANKRATZ, 1991; BOX; JENKINS; REINSEL, 2008; COWPERTWAIT \& METCALFE, 2009; SHUMWAY \& STOFFER, 2011), e tendo em vista sua realização pelas funções Arima() e auto.arima() do pacote estatístico R.

As etapas para elaboração do modelo são especificação, identificação, estimação e verificação ou diagnóstico demonstradas, através de sua aplicação sobre as variáveis macroclimáticas e a previsão das ENA das quatro regiões, no Capítulo 7.

1) Especificação

Nessa etapa, são definidas as variáveis a serem utilizadas no modelo, o conjunto de dados para sua identificação e estimação e outro para verificação e diagnóstico. Em Hyndman \& Athanasopoulos (2013), os conjuntos de dados para estimação e identificação foram denominados dados para treinamento e os conjuntos de dados para verificação ou diagnóstico foram denominados dados para testes. Outras referências chamam o conjunto de dados de treinamento de variáveis "in sample" e as variáveis de teste conjunto de variáveis "out of sample" ${ }^{133}$ (TASHMAN, 2000).

Para esse trabalho, o uso das variáveis climáticas energia é aplicado no Capítulo 7, seções 7.1.1, 7.2.1, 7.3.1 e 7.4.1, somado às variáveis de energia.

2) Identificação

A etapa de identificação tem como objetivo determinar a ordem dos parâmetros do modelo, através de uma descrição visual dos critérios para identificar a ordem dos parâmetros (BROOKS, 2002), pelo o uso de gráficos da Função de Autocorrelação (FAC) e Função de Autocorrelação Parcial (FACP). Nesse exemplo, os valores da ordem de $\phi$ e de $\theta$ são iguais a

\footnotetext{
${ }^{133}$ Acesso em 15/01/2016: http://people.duke.edu/ rnau/three.htm
} 
1. Em modelos autorregressivos, AR(p) puros, o gráfico da FAC apresenta suas barras com um decaimento exponencialmente ou uma curva senoidal amortecida. O padrão exato depende do valor do sinal de $\phi 1, \ldots, \phi$ p. Já, no gráfico da FACP, apresenta-se as barras com defasagens de 1 até $\mathrm{p}$, depois corta para zero.

Para ordens maiores, os padrões aumentam e sua interpretação se torna mais complicada, o que depende da experiência do analista para identificar a ordem p e os sinais dos parâmetros AR.

A Função de autocorrelação estendida (eaf) é uma ferramenta capaz de identificar a ordem dos parâmetros, exemplo Tabela 8-4, que cruza os parâmetros AR com os parâmetros MA. Sua estrutura matemática é descrita em Wei (2008) e Pankratz (1991).

O comando TSA::eacf() do R para os dados da ENA do Sudeste é apresentado na Tabela 8-4, onde um triângulo formado pelos zeros, indica a posição da ordem do modeloARIMA(2,0,1), com limite de médias móveis com 13 meses e autorregressivos com 7 meses.

Tabela 8-4 Resultado do comando TSA::eacf() para dados ENA Sudeste 1931-2015 indica ARIMA(2,0,1)

\begin{tabular}{|c|c|c|c|c|c|c|c|c|c|c|c|c|c|c|c|}
\hline & 0 & 1 & 2 & 3 & 4 & 5 & 6 & 7 & 8 & 9 & 10 & 11 & 12 & 13 & MA \\
\hline 0 & $x$ & $x$ & $x$ & $x$ & $X$ & $x$ & $x$ & $x$ & 0 & $x$ & $x$ & $x$ & $x$ & $x$ & \\
\hline 1 & $x$ & $x$ & $x$ & $x$ & $X$ & $x$ & $x$ & $x$ & 0 & $x$ & $x$ & $x$ & $x$ & $x$ & \\
\hline 2 & $x$ & 0 & 0 & 0 & 0 & 0 & 0 & 0 & 0 & 0 & 0 & 0 & 0 & 0 & \\
\hline 3 & $x$ & $x$ & 0 & 0 & 0 & 0 & $x$ & 0 & 0 & 0 & 0 & 0 & $x$ & 0 & \\
\hline 4 & $x$ & $x$ & 0 & 0 & 0 & 0 & 0 & 0 & 0 & 0 & 0 & 0 & $x$ & 0 & \\
\hline 5 & $x$ & $x$ & 0 & $x$ & 0 & 0 & 0 & 0 & 0 & 0 & 0 & 0 & 0 & 0 & \\
\hline 6 & $x$ & $x$ & 0 & 0 & 0 & 0 & 0 & 0 & 0 & 0 & 0 & 0 & 0 & 0 & \\
\hline 7 & $x$ & $x$ & $x$ & $x$ & 0 & 0 & 0 & 0 & 0 & 0 & 0 & 0 & 0 & 0 & \\
\hline AR & & & & & & & & & & & & & & & \\
\hline
\end{tabular}

3) Estimação

Uma vez identificada a ordem dos parâmetros, seus valores são estimados através da aplicação de métodos de máxima verossimilhança ou métodos dos mínimos quadrados ordinários. No R, utiliza-se os comandos Arima ou Sarima para estimação.

4) Verificação ou diagnóstico

Para a verificação ou diagnóstico, faz-se a análise de resíduos. Segundo o esquema de Hyndman \& Athanasopoulos (2013), os gráficos gerados para analisar os resíduos foram: 1) gráfico de dispersão dos resíduos, 2) Gráfico de autororrelação dos resíduos; 3) Gráfico QQPlot e; 4) Histograma dos resíduos (Figura 8-9). 
Resid vs ajust(p-valor McLeod-Li: $<0.0001)$
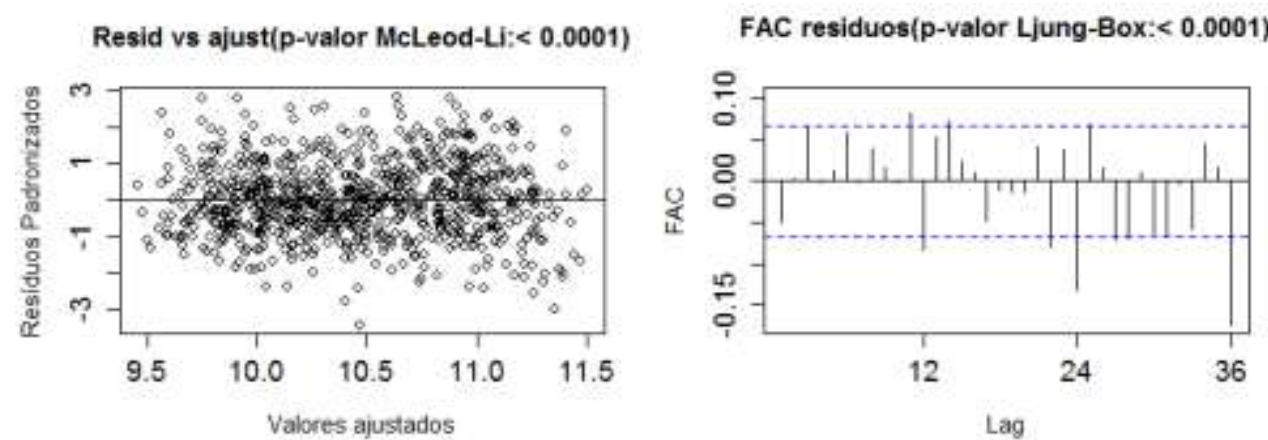

Q-Q plot normal(p-valor shapiro:0.041)

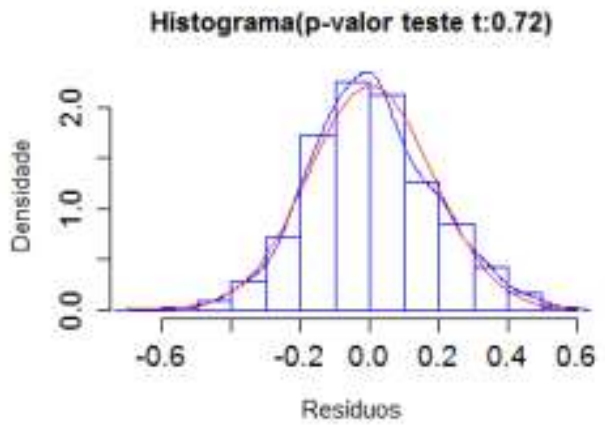

Figura 8-9 Exemplo gráficos para avaliar os resíduos do modelo SARIMA(111300) com AMO e NINO1+2

a. Gráfico de dispersão de resíduos contra os valores ajustados. Verifica a presença de padrões que indica ou rejeita a heterocedasticidade, com o p-valor do teste de MclLeod-Li, equivale ao teste de Ljung-Box para os resíduos ao quadrado, obtendo a hipótese nula de que não há efeito de heterocedasticidade nos erros (BOX e PIERCE,1970, LJUNG e BOX,1978, e HARVEY, 1993).

b. Gráfico de autocorrelação (FAC) dos resíduos. Verifica-se a existência de correlações entre os lags dos resíduos, significativamente diferentes de zero. Logo é possível constatar que existem informações não consideradas pelo modelo obtendo a hipótese nula de que os resíduos não são correlacionados;

c. Gráfico Q-Q normal. Verifica-se a distribuição normal dos resíduos, com o pvalor do teste de Shapiro-Wilk obtendo a hipótese nula de uma normalidade na distribuição dos erros (ROYSTON, 1982a; ROYSTON, 1982b; e ROYSTON, 1995);

d. Histograma dos resíduos. Apresenta as densidades estimadas parametricamente, em vermelho, supondo uma distribuição normal dos erros, e não parametricamente, em azul, utilizando estimativa via kernels gaussianos, além do p-valor do teste t Student e obtém-se a hipótese nula de que a média dos erros é igual a zero. 


\subsubsection{Análise Séries Históricas}

$\mathrm{Na}$ análise das séries históricas, neste sumário, apresenta-se a ENA-SE. As análises das regiões $\mathrm{S}, \mathrm{N}$ e NE encontram-se no Capítulo 7.

\subsubsection{Energia Natural Afluente do Sudeste (ENA-SE)}

Nessa seção, são apresentadas de forma gráfica e descritiva a variável dependente ENA do Sudeste (ENA-SE) que corresponde à soma da ENA de todas as bacias que pertencem a região ou submercado Sudeste e tem como unidade MWmédios ${ }^{134}$, Figura 8-10. Seu registro inicia-se em janeiro de 1931 e termina em dezembro de 2014. Posteriormente, são feitas análises de comparação e correlação, como já mencionado.

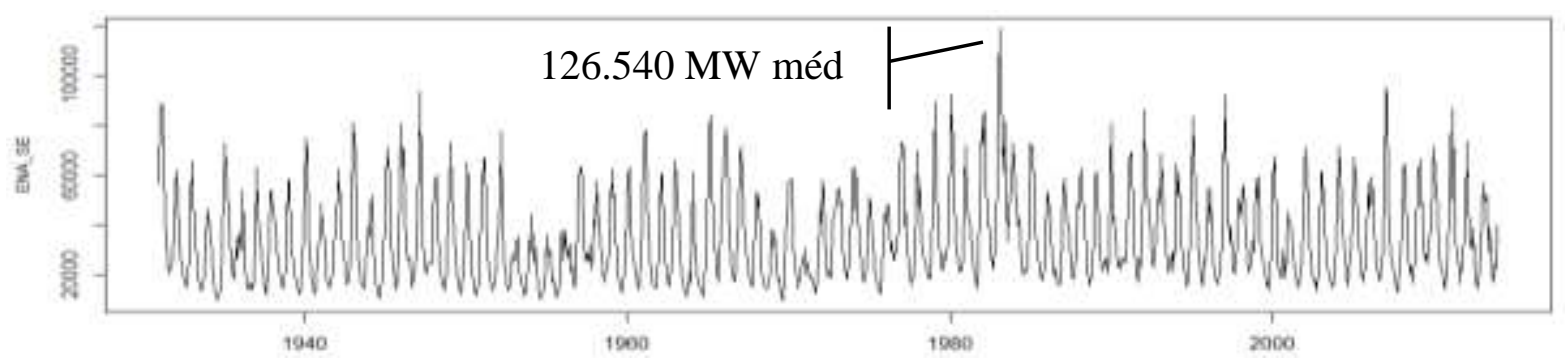

Figura 8-10 - Variável dependente ENA-SE - Médias mensais expressas em MWMédios

Nesse período há uma variação expressiva, que começa de um mínimo de 10.730 MWmédios até 126.500 MWmédios, com mediana em torno de 34.660 MWmédios como apresentado na Figura 8-11, além da distribuição mensal das medianas e quartis no gráfico boxplot dos meses de janeiro a dezembro bem como sua descrição estatística.

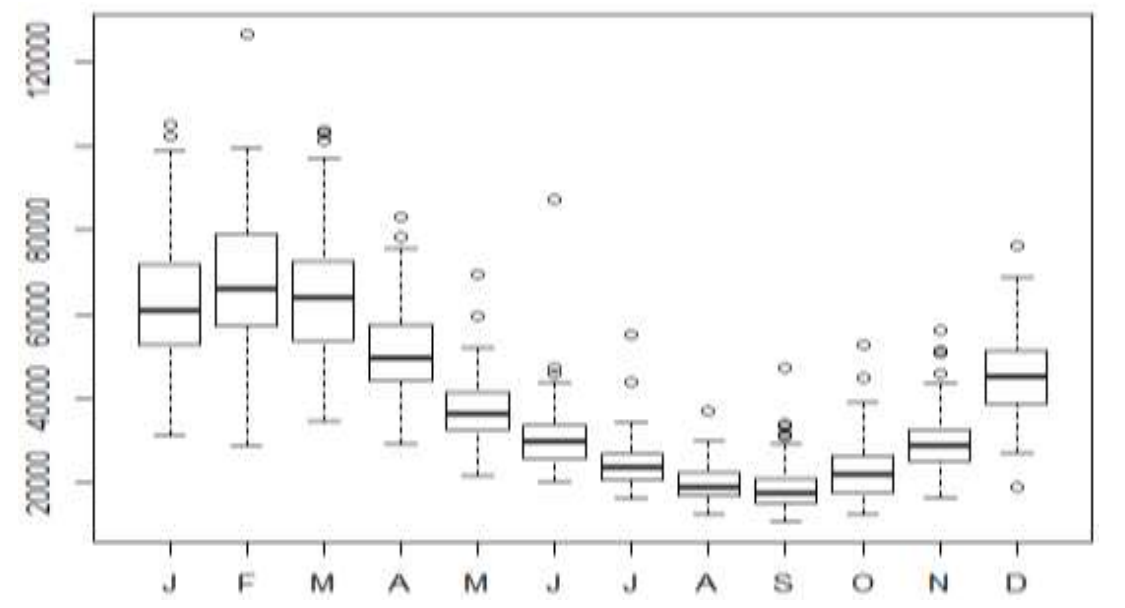

Mínimo: $\quad 10.730$

$1^{\circ}$. quartil: $\quad 23.440$

Mediana: $\quad 34.660$

Média: $\quad 39.680$

$3^{\circ}$. quartil: $\quad 53.510$

Máximo: $\quad 126.540$

Unidade: MW Médios

Figura 8-11 Boxplot ENA SE por mês e Descrição Estatística

\footnotetext{
${ }^{134}$ Megawatts-médios em um mês ou milhões de Watts médios em um mês
} 
Na Figura 8-12, apresentam-se três gráficos da ENA-SE, em a) apresenta-se uma série normalizada, b) ${ }^{135}$ apresenta-se a aplicação de uma diferença que, aparentemente, retira as tendências locais e c) apresenta-se suavização da série com a aplicação de uma transformada wavelet. A transformada wavelet mostra a magnitude dos dados, dentro de ciclos entre 1 e 32 anos, com IC de 95\%, e a variância combinada dos diferentes ciclos é represetanda.

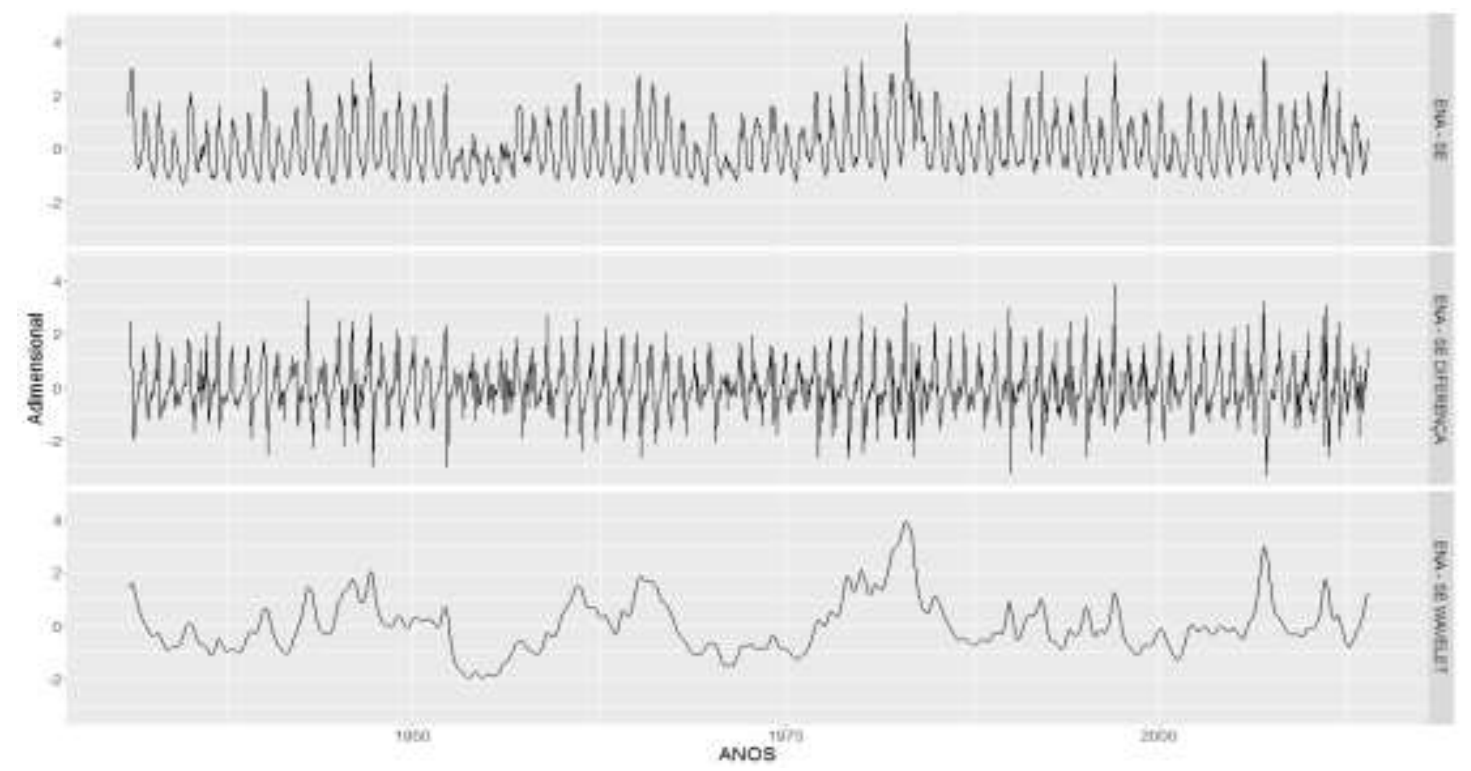

Figura 8-12- Submercado do Sudeste - ENA-SE - Médias mensais a) normalizadas, b) com uma diferença sobre a série normalizada e c) suavizada com wavelets

Os máximos anuais da ENA-SE são apresentadas na Figura 8-13. Observa-se um pico em 1983, com quase cinco desvios padrões acima da média, enquanto a maior parte dos demais pontos situa-se no intervalo $[-2 \sigma ;+2 \sigma]$ ( $\sigma$ é o desvio padrão). Esse pico explica-se pela a grande quantidade de chuvas devido ao fenômeno de ENOS muito forte que ocorreu entre 82 e 83. Posteriormente será abordado estes efeitos com mais detalhes, através da análise de correlação.

\footnotetext{
${ }^{135}$ Apesar das séries temporais geofísicas não são estacionárias, para o período de 1931 a 2014, é necessário aplicar a diferença para atender as suposições determinadas no modelo SARIMAX e tem o único objetivo de eliminar as tendêndias, e tornar a média da série histórica constante. Há maiores detalhes na seção 5.1.1 Diferenciação, p. 248.
} 


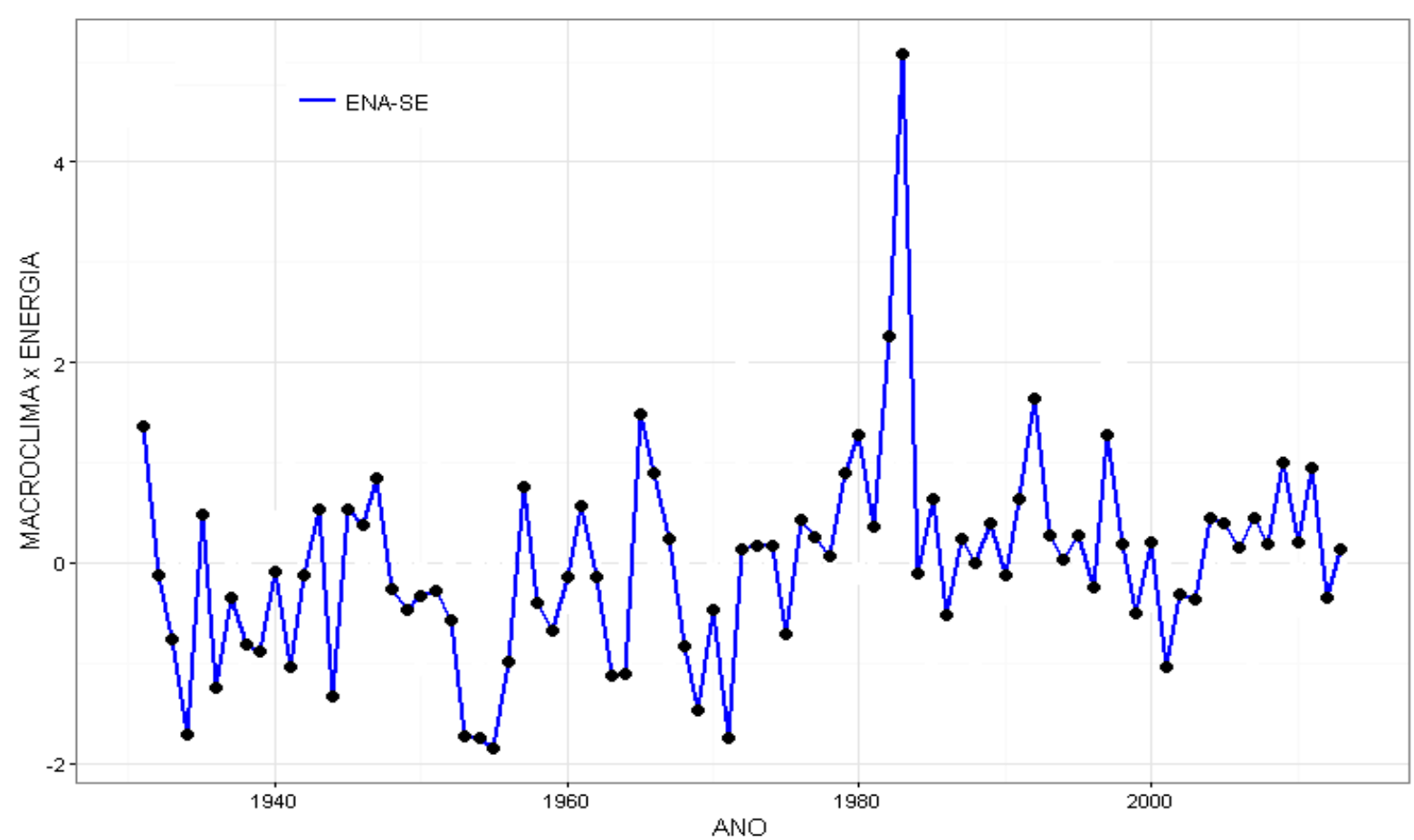

Figura 8-13 - Variável dependente ENA-SE Máximos Anuais normalizadoss MWmédios

\subsubsection{Correlação ENA-SE $x$ variáveis Macroclimáticas}

Na Figura 8-14, a seguir, verificam-se o resultado do teste de causalidade de Granger com os valores de p, atrasos (lags) e correlação de Pearson associados à variável dependente ENASE. Nas células, que apresentam-se resultados entre variáveis independentes versos ENA-SE somente NINO1+2, apresenta-se correlação com seus valores na cor azul (rejeita $h_{0}$ ) e as causalidades de Granger aceitáveis, conforme critérios de cores, explicados anterioremente, e bidirecionais. Para o Pacífico (PDO), apresenta-se teste de Granger aceitável frente à ENASE, porém a correlação foi abaixo de 0,5 .

Para o Atlântico (AMO), apresenta-se causalidade de Granger unidirecional sendo caracterizado como causa em Granger da ENA-SE, porém, apresentam-se correlações abaixo de 0,5. No mesmo gráfico, apresentam-se, também, a variável número de manchas solares (MANCHAS) em vermelho, ou seja, não aceitáveis.

Para o índice ONI, não apresentam-se valores aceitáveis, exceto em relação ao AMO. Como o objetivo é verificar relações com ENA-SE, o ONI é ignorado. Para o gelo acumulado no Polo Antártico, apresentam-se valores de Granger aceitáveis, porém apesar da correlação ser acima de $0,5 \mathrm{seu}$ p-valor correspondente foi de 0,23 o que está acima de 0,05 e, portanto, $\mathrm{h}_{0}$ é aceita, lembrando $\mathrm{h}_{0}: \rho=0$, ou seja, não há correlação, para um IC de $95 \%$. 


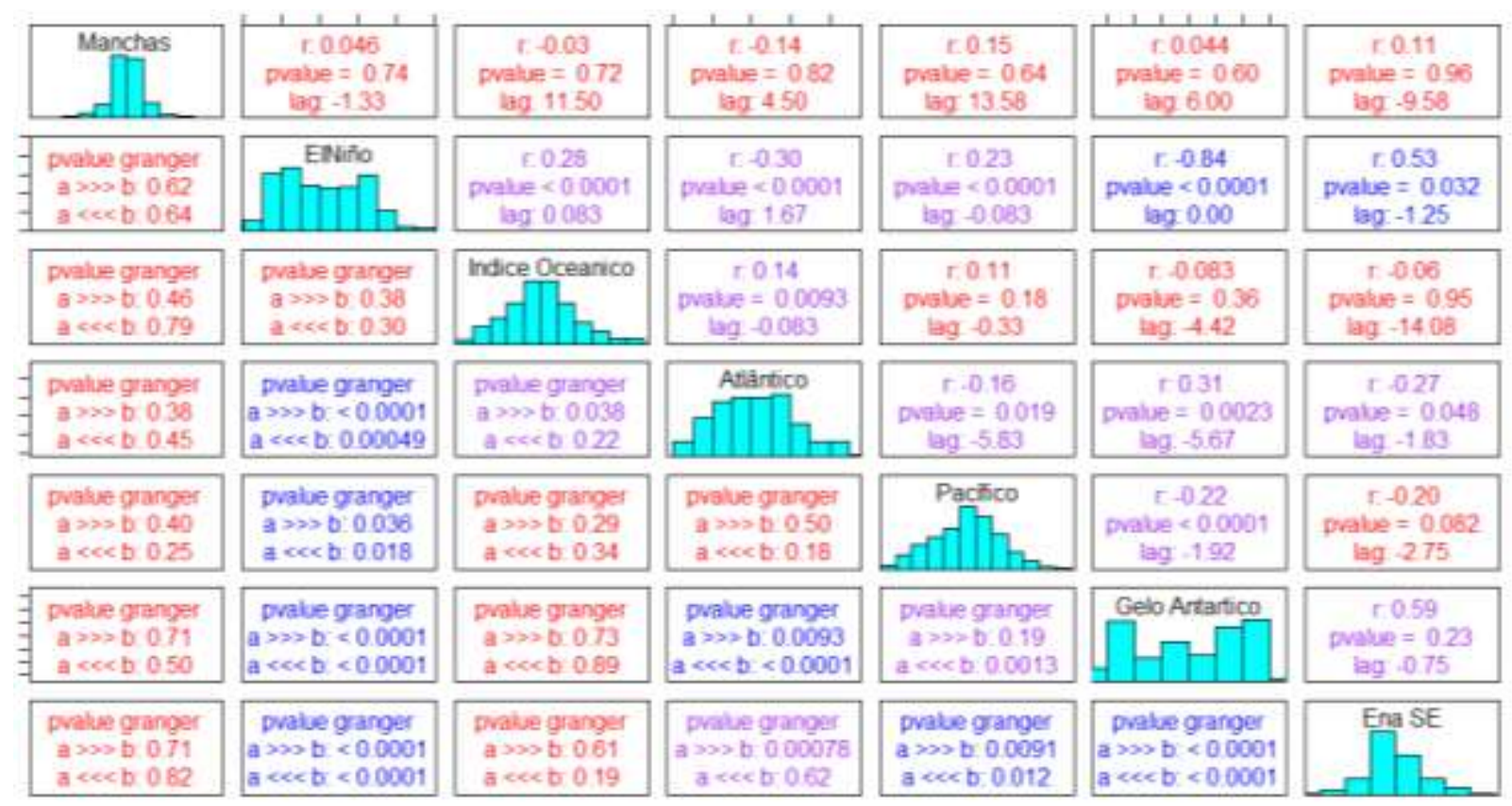

Figura 8-14 - Gráficos de relação entre as séries independentes e dependentes.

\subsubsection{Modelagem SARIMAX de ENA-SE}

1) Especificação

Ao examinar os gráficos, os mapas e as análises de séries históricas escolheram-se as variáveis explicativas NINO1+2, AMO, PDO, TSA, SWA, EEP, X70E, X120E, X40W, AO e SAM frente variável dependente ENA do Sudeste (Figura 8-15). Essas varáveis são descritas na seção 8.1.4.1 Fonte de Dados, p. 261.

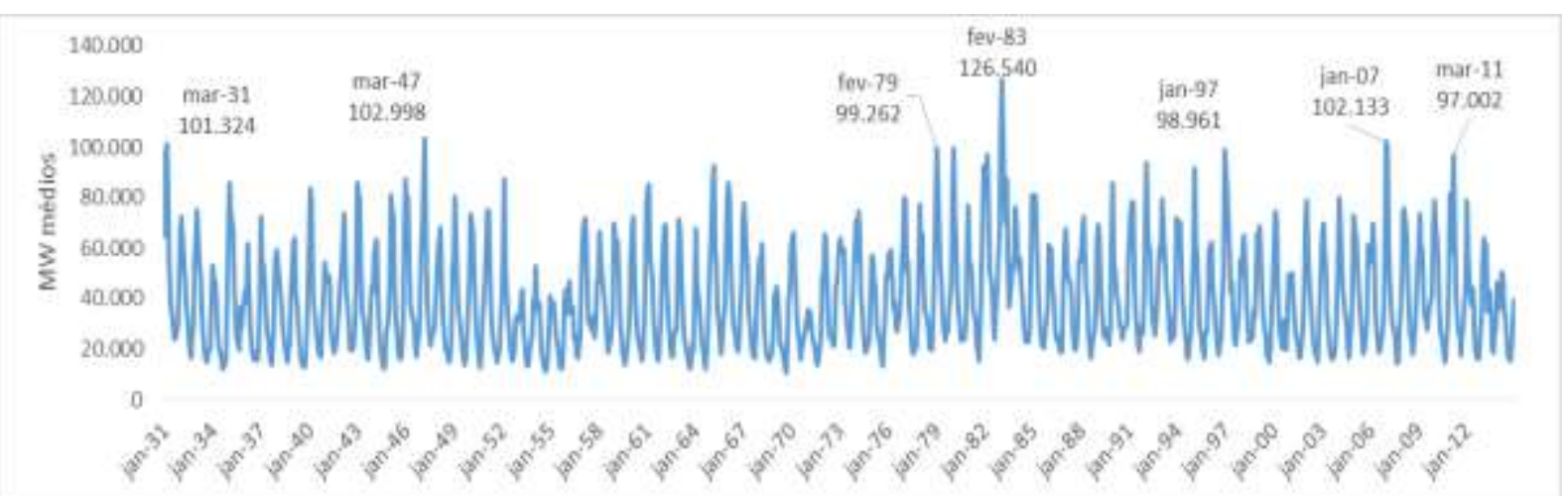

Figura 8-15 - Série Histórica ENA Sudeste expressas em MW Médios- Período de Jan/1931 a Dez/2014

Na Figura 8-16, apresenta-se a série histórica que exibe sazonalidade e tendências localizadas, que são explicadas pela dinâmica sazonal das chuvas e a localização geográfica das bacias hidrográficas, na região onde geralmente há formação das ZCAS, que integram o submercado do Sudeste. Com o objetivo de estabilizar a variância e atender as suposições do modelo, foi aplicada uma transformação logarítmica. 


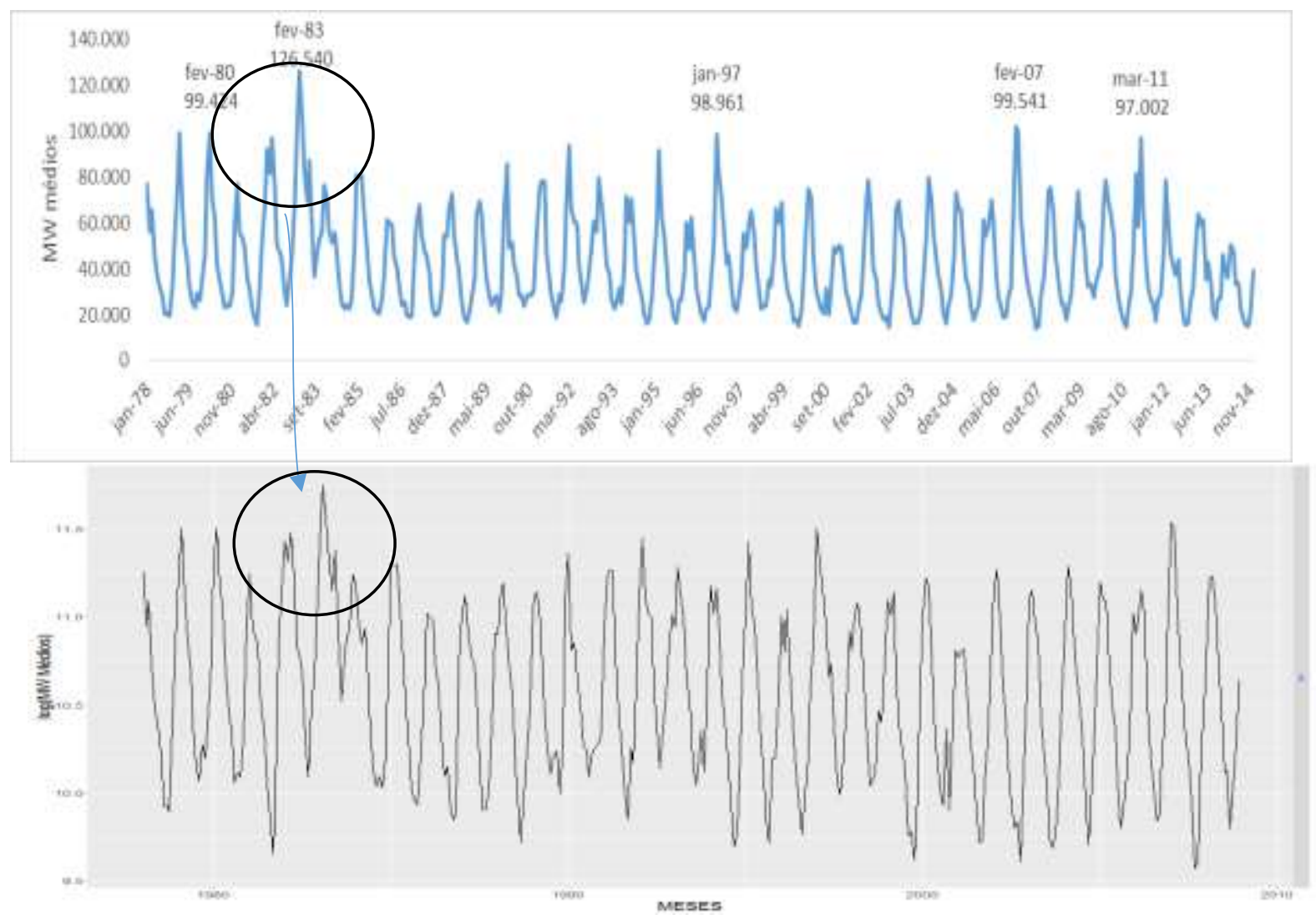

Figura 8-16 - Série Histórica em MW Médios ENA Sudeste e transformada logarítmica dos dados- Período de Jan/1978 a Dez/2008 ${ }^{136}$

${ }^{136}$ Comentário Prof. Molion: "Tranformação de log reduz valores altos e aumenta os valores baixos adjacentes". Nota autor: Aqui procurou-se atender as suposições do modelo, e o log é utilizado, segundo o modelo SARIMAX, para estabilizar a variância da série histórica, o que também é explicado na seção 5.1.3 Estabilização da variância, p. 250. 
Na Figura 8-17, apresenta-se a decomposição aditiva da série observada em sazonalidade, tendência e aleatório. Nota-se que na sazonalidade, a amplitude está aumentando, e a tendência é decrescente no geral, e crescente mais para o final, o que pode indicar a necessidade de transformações com diferenças, na série histórica.

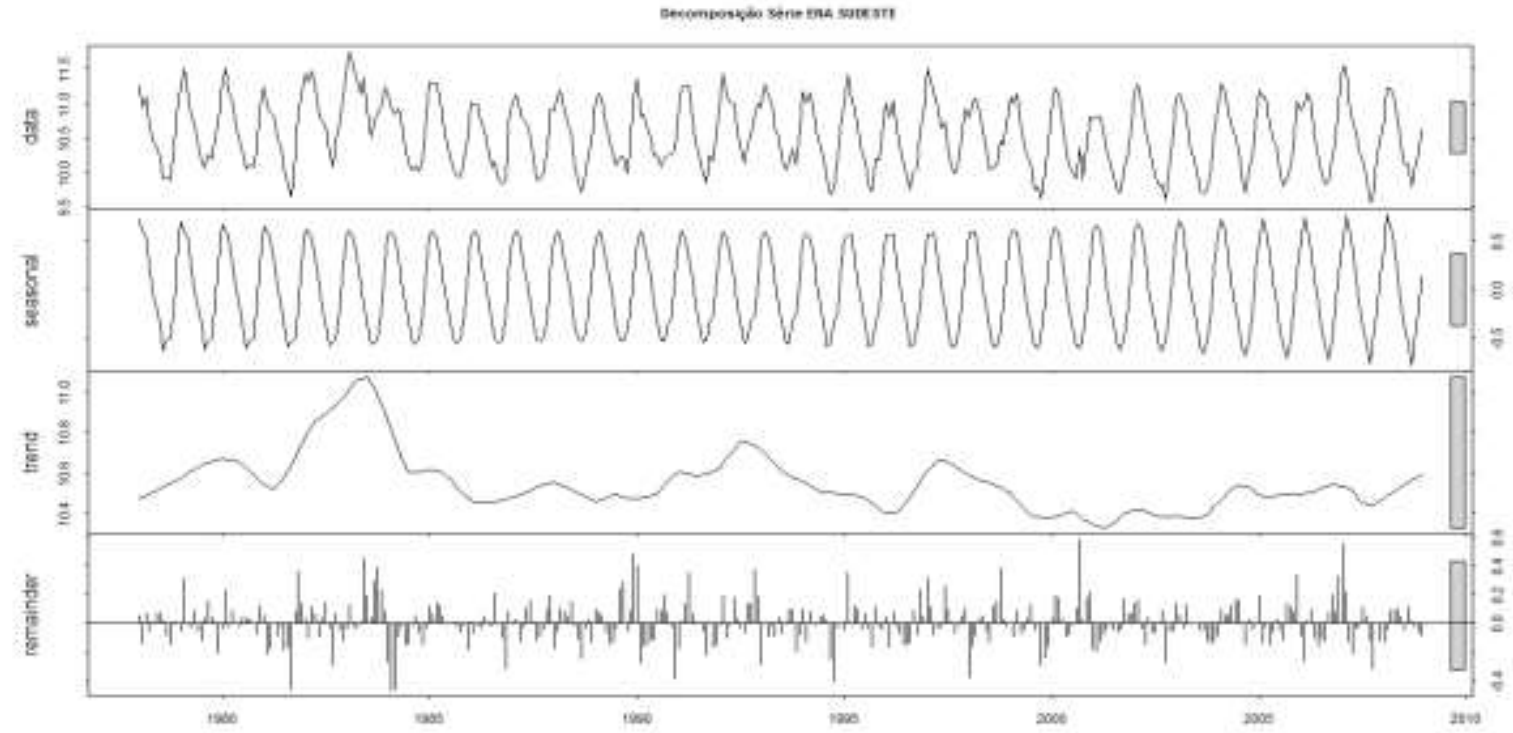

Figura 8-17 - Decomposição: Original, Sazonal, Tendência e Aleatório. ENA Sudeste - Período de Jan/1978 a Dez/2008

Na Figura 8-18, apresenta-se o componente sazonal mês a mês mostrando valores da variabilidade crescente entre os meses de setembro a março (período úmido) e decrescentes de abril a outubro (período seco), o que corrobora com a formação de ZCAS, em geral, na época do verão austral.

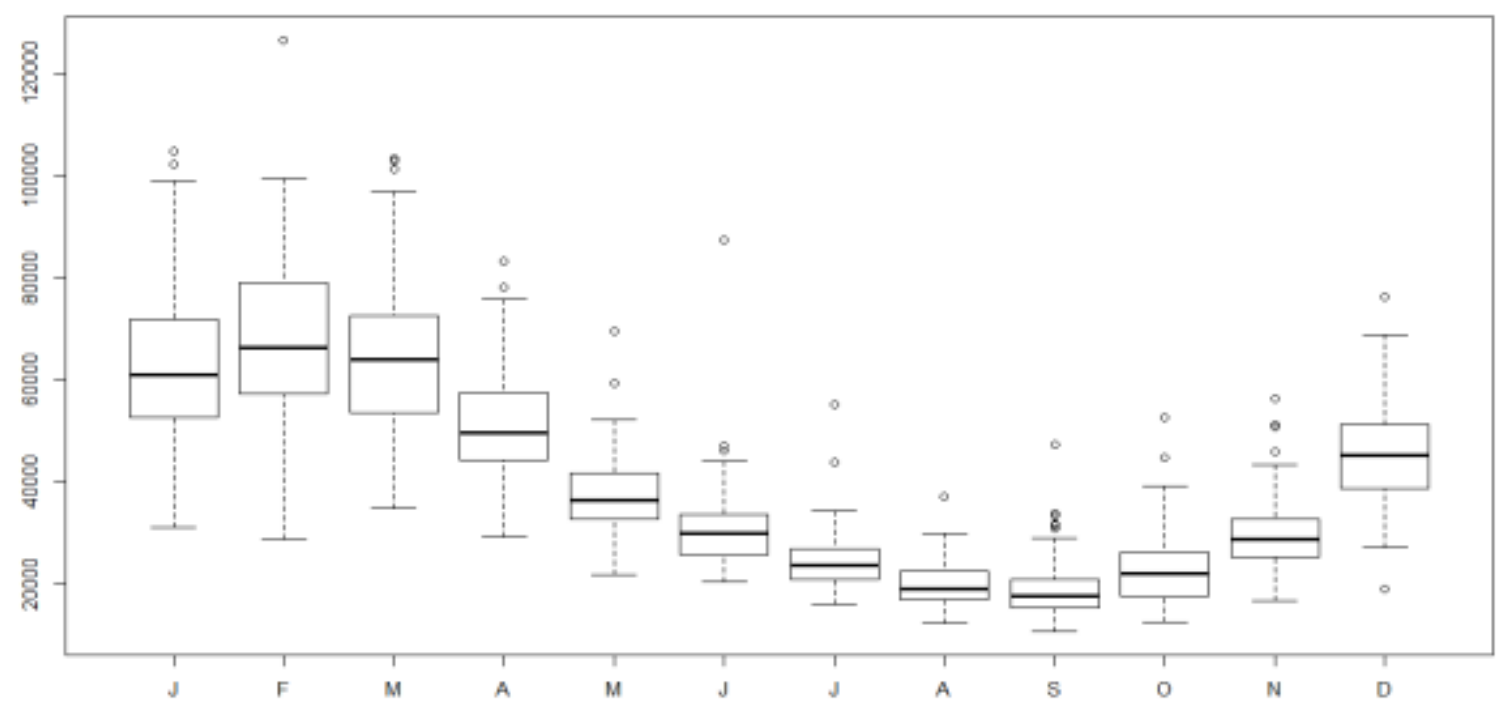

Figura 8-18 - Gráfico Caixa Série Histórica log (MW Médios) ENA Sudeste - Período de Jan/1931 a Dez/2014 
2) Identificação

Nessa fase, são avaliadas as funções de autocorrelação (ACF) e autocorrelação parcial (PACF) para se estimar a ordem em que apresentam-ser os parâmetros do modelo. A seguir, a avaliação inicial da série histórica da ENA-SE.

A série é aparentemente estacionária, para o período de 1978 a 2008, e. foi aplicada uma transformação de log e também as funções ACF e PACF e seus gráficos são apresentados na Figura 8-19. Os resultados indicam um pico significativo no lag 1, o que indica um modelo $\mathrm{AR}(1)$, e componentes sazonais nos lags múltiplos de 12 e, assim, indicam o uso de modelos SARIMAX(100)(100).
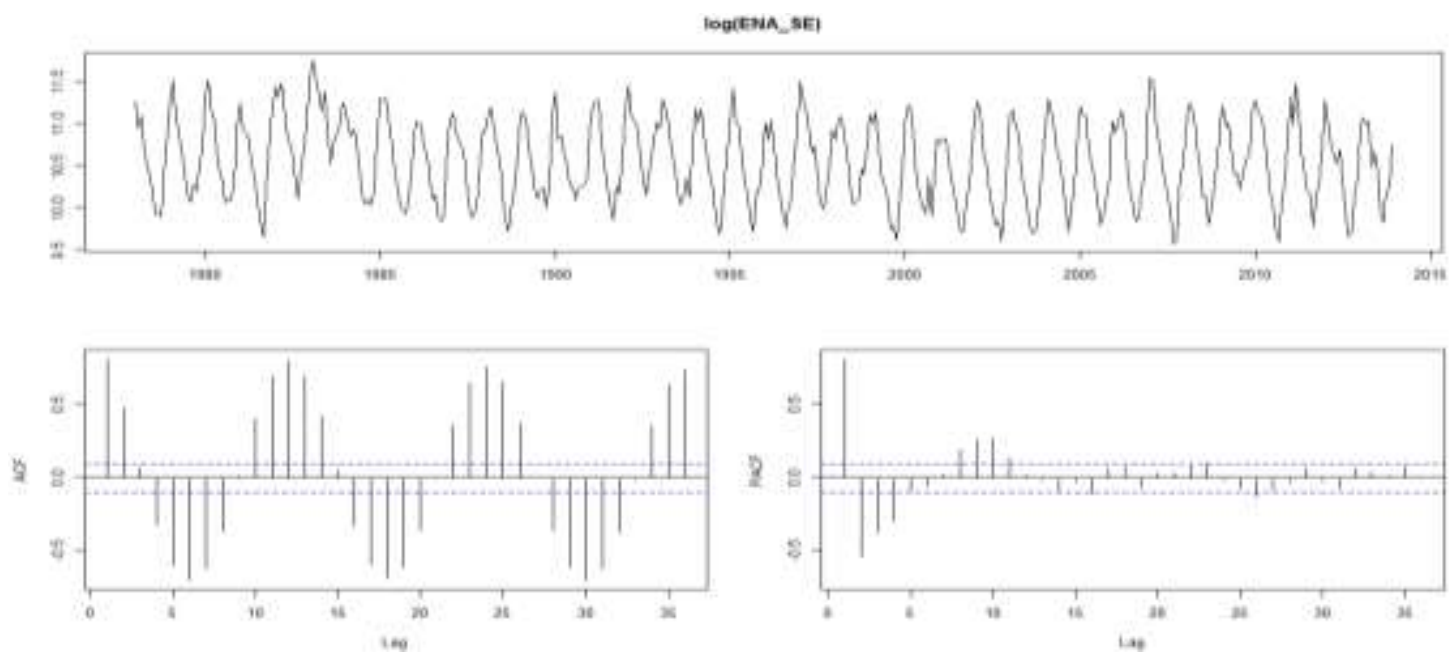

Figura 8-19 - Gráficos: a) Série Transformada com log, ACF e PACF

Ao aplicar a Função de Autocorrelação Estendida (EACF), indica-se um modelo AR(2) e uma média móvel MA(1) que corroboram com as análises anteriores, Tabela 8-5.

Tabela 8-5 Resultado da Função de Autocorrelação estendida - eacf - ENA-SE

\begin{tabular}{|c|c|c|c|c|c|c|c|c|c|c|c|c|c|c|}
\hline AR/MA & 0 & 1 & 2 & 3 & 4 & 5 & 6 & 7 & 8 & 9 & 10 & 11 & 12 & 13 \\
\hline 0 & $x$ & $x$ & $x$ & $x$ & $x$ & $x$ & $x$ & $x$ & 0 & $x$ & $x$ & $x$ & $x$ & $x$ \\
\hline 1 & $x$ & $x$ & $x$ & $x$ & $x$ & $x$ & $x$ & $x$ & 0 & $x$ & $x$ & $x$ & $x$ & $x$ \\
\hline 2 & $x$ & 0 & 0 & 0 & 0 & $x$ & 0 & 0 & 0 & 0 & 0 & 0 & 0 & 0 \\
\hline 3 & $x$ & $x$ & 0 & 0 & 0 & 0 & $x$ & 0 & 0 & 0 & 0 & 0 & $x$ & 0 \\
\hline 4 & $x$ & $x$ & $x$ & 0 & 0 & 0 & 0 & 0 & 0 & 0 & 0 & 0 & $x$ & 0 \\
\hline 5 & $x$ & $x$ & 0 & $x$ & 0 & $x$ & 0 & 0 & 0 & 0 & 0 & 0 & 0 & 0 \\
\hline 6 & 0 & $x$ & 0 & $x$ & 0 & 0 & 0 & 0 & 0 & 0 & 0 & 0 & 0 & 0 \\
\hline 7 & 0 & $x$ & $x$ & $x$ & $x$ & 0 & 0 & 0 & 0 & 0 & 0 & 0 & 0 & 0 \\
\hline
\end{tabular}

Em modelos tipo ARMA, essa configuração indica um modelo com p e q iguais a 2 e 1 , respectivamente. Com o objetivo de auxiliar o processo de identificação, foram também utilizadas duas funções do pacote estatística $R$, os comandos auto.arima e get.best.arima (COWPERTWAIT \& METCALFE, 2009; R, 2005) para identificar os parâmetros. O comando auto.arima retornou o modelo SARIMAX(212)(102). Já, o comando get.best.arima retornou o modelo SARIMAX(022)(221). Todos os possíveis modelos foram testados sendo 
selecionados somente os melhores conforme o critério de AIC e o valor de Sigma ${ }^{2}$, apresentados na Tabela 8-6 onde também há coeficiente de determinação, para avaliar a relação entre as variáveis explicativas e os valores do modelo ajustado. Diferente do que foi apresentado pelos comandos auto.arima e get.best.arima, o melhor modelo foi o SARIMAX(100)(103), que apresentou o menor AIC, igual a -268,9 e sigma ${ }^{2}$ igual a 0,02.

Tabela 8-6 Critérios de adequação dos modelos ENA SE (AIC, AICc, BIC, Sigma2, R2, R2a, R2p-valor) ${ }^{137}$

\begin{tabular}{cccccccc}
\hline $\begin{array}{c}\text { Modelo } \\
\text { SARIMAX }\end{array}$ & AIC & AAIC & BIC & Sigma $^{\mathbf{2}}$ & $\mathbf{R}^{\mathbf{2}}$ & $\mathbf{R}^{\mathbf{2} a}$ & $\mathbf{R}^{\mathbf{2}} \mathbf{p}$-valor \\
\hline $\mathbf{( 1 0 0 ) ( 1 0 3 )}$ & $-268,9$ & $-266,7$ & $-194,4$ & 0,02 & 0,96 & 0,95 & 0,0000 \\
\hline $\mathbf{( 1 0 0 ) ( 0 0 3 )}$ & $-253,6$ & $-251,6$ & $-183,0$ & 0,03 & 0,96 & 0,95 & 0,0000 \\
\hline $\mathbf{( 2 1 1 ) ( 1 0 2 )}$ & $-253,1$ & $-252,3$ & $-210,0$ & 0,03 & 0,95 & 0,95 & 0,0000 \\
\hline $\mathbf{( 2 1 1 ) ( 1 0 2 )}$ & $-253,1$ & $-252,3$ & $-210,0$ & 0,03 & 0,95 & 0,95 & 0,0000 \\
\hline $\mathbf{( 2 1 2 ) ( 1 0 2 )}$ & $-251,8$ & $-250,9$ & $-204,8$ & 0,03 & 0,95 & 0,95 & 0,0000 \\
\hline $\mathbf{( 1 0 0 ) ( 0 0 4 )}$ & $-251,6$ & $-249,5$ & $-177,2$ & 0,03 & 0,96 & 0,95 & 0,0000 \\
\hline
\end{tabular}

\section{3) Estimação}

Após a fase de identificação, partiu-se para a estimação dos valores dos parâmetros que devem cumprir com as condições de estacionariedade e invertibilidade (valores em módulo dos parâmetros menores do que 1).

As análises da fase de identificação sugerem um ajuste de modelos do tipo SARIMAX (p,d,q) $(\mathrm{P}, \mathrm{D}, \mathrm{Q})$, por se tratarem de dados mensais, e apresentarem sazonalidade.

Para identificação das ordens do modelo, foram utilizadas evidências empíricas da ACF, PACF e EACF (lags não nulos 1 e 12 e seus múltiplos). Experimentalmente, ajustaram-se vários modelos sendo que um em especial apresentou resultados AIC melhores, o modelo da classe SARIMAX $(1,0,0)(1,0,3)$ da forma:

$\left(1-\phi_{1} B\right)\left(1-\phi_{1} B\right) Y_{t}=e_{t}\left(1-\theta_{1} B\right)\left(1-\Theta_{1} B\right)\left(1-\Theta_{2} B\right)\left({ }_{1}-\Theta_{3} B\right)$,

onde $\mathrm{e}_{\mathrm{t}} \sim \mathrm{RB}^{138}\left(0, \sigma^{2}\right), \sim \mathrm{N}^{139}$

As estimativas dos parâmetros do modelo ajustado são apresentadas na Tabela 8-7, e na Tabela 8-8 são apresentados os resultados do modelo de regressão dinâmica, que compara os

\footnotetext{
${ }^{137}$ Siglas cabeçalho:

AIC -Akaike's Information Criterion (Critério de Informação de Akaike)

AICc-Corrected Akaike's Information Criterion (Critério de Informação de Akaike corrigida)

BIC -Schwarz Bayesian Information Criterion (Critério Bayesiano de Schwarz)

$\mathrm{R}^{2}$ - Coeficiente de determinação

$\mathrm{R}^{2} \mathrm{a}$ - Coeficiente de determinação ajustado

$\mathrm{R}^{2} \mathrm{p}$ - Valor $\mathrm{p}$ nível de significância estatística

138 Ruído branco

${ }^{139}$ Distribuição Normal
} 
dados gerados pelo modelo ajustado e os dados utilizados para treinamento, considerando o IC de $95 \%$.

Tabela 8-7 Valores parâmetros estimados e estatísticas correspondentes

\section{Modelo}

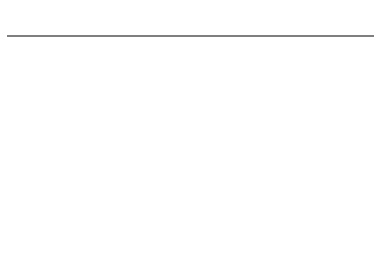

SARIMAX(100)(103)
Parâmetros Estimativas Erro Padrão

\begin{tabular}{crrr}
$\phi_{1}$ & 0,64 & 0,05 & 0,0000 \\
\hline$\phi_{1}$ & 1,00 & 0,00 & 0,0000 \\
\hline$\Theta_{1}$ & $-1,18$ & 0,06 & 2,0000 \\
\hline$\Theta_{2}$ & 0,21 & 0,09 & 0,0219 \\
\hline$\Theta_{3}$ & $-0,01$ & 0,06 & 1,1560 \\
\hline Intercepto & $-1,77$ & 8,66 & 1,1620 \\
\hline NINO12 & 0,09 & 0,02 & 0,0000 \\
\hline TSA & 0,06 & 0,03 & 0,0705 \\
\hline SWA & 0,09 & 0,02 & 0,0000 \\
\hline X70E & 1,05 & 0,26 & 0,0001 \\
\hline X120E & 2,25 & 0,56 & 0,0001 \\
\hline X40W & 2,78 & 0,69 & 0,0001 \\
\hline SAM & 0,01 & 0,01 & 0,3270
\end{tabular}

$\sigma^{2}$

0,02

Na Tabela 8-8, são apresentados os valores estimados e as estatísticas associadas ao modelo de regressão dinâmica. As variáveis NINO1+2, SWA, EEP, X70E, X120E, X40W e SAM apresentaram significância estatística, diversamente as variáveis AMO, PDO, TSA, AO e SAM2.

Tabela 8-8 Valores parâmetros estimados dos coeficientes das variáveis explicativas e as estatísticas correspondentes

\begin{tabular}{lrrrrl}
\hline Parâmetros & Estimativas & Erro Padrão & Estatística t & Valor p & $\#^{140}$ \\
\hline NINO12 & $6.162,48$ & 487,12 & 12,651 & 0,0000 & $* * *$ \\
\hline AMO & $-2.588,44$ & 2098,79 & $-1,233$ & 0,2183 & \\
\hline PDO & 187,14 & 437,00 & 0,428 & 0,6687 & \\
\hline TSA & $1.023,66$ & 653,37 & 1,567 & 0,1181 & \\
\hline SWA & $3.527,95$ & 346,77 & 10,174 & 0,0000 & $* * *$ \\
\hline EEP & $-3.868,86$ & 675,61 & $-5,726$ & 0,0000 & $* * *$ \\
\hline X70E & $68.731,69$ & $11.643,17$ & 5,903 & 0,0000 & $* * *$ \\
\hline X120E & $142.878,10$ & $25.223,89$ & 5,664 & 0,0000 & $* * *$ \\
\hline X40W & $178.098,10$ & $30.858,21$ & 5,771 & 0,0000 & $* * *$ \\
\hline AO & $-815,52$ & 414,35 & $-1,968$ & 0,0498 & $*$ \\
\hline SAM & $-96,36$ & 12,72 & $-7,574$ & 0,0000 & $* * *$ \\
\hline SAM2 & $-149,18$ & 219,34 & $-0,680$ & 0,4969 & \\
\hline
\end{tabular}

\footnotetext{
140 Significado dos asteriscos: 0 ***’ $0,001^{\prime * * \prime} 0,01^{\prime * \prime} 0,05^{\prime \prime}, 0,1^{\prime \prime} 1$

$0>={ }^{\prime * * * \prime}<0,001$

$0,001>={ }^{* * *}<0,01$

$0,01>={ }^{*} * \prime<0,05$

$0,05>=", \quad<0,1$

$0,1>={ }^{\prime} \prime<1$
} 
4) Verificação ou diagnóstico

A análise dos resíduos é utilizada para verificar a adequação dos modelos e o potencial sucesso para modelagem. Os diagnósticos dos erros do modelo são apresentados na Figura 8-20, nos resultados da análise dos resíduos do modelo em a) indica-se a aceitação da hipótese do modelo não ser heterocedástico; em b) o gráfico ACF indica que os resíduos apresentam um comportamento aleatório (ruído branco) e o valor de Ljung-Box aceita a hipótese que as autocorrelações estimadas são gaussianas com média zero e variância $1 / \mathrm{n}$; em c) o Gráfico QQ indica aceitação da hipótese de normalidade, pois se ajusta a uma linha reta e dentro das fronteiras estabelecidas; e em d) indica-se que a média é zero e há normalidade. Todos os valores da inferência estatística apresentaram p-valor com nível de significância maior que 0,05, o que caracteriza aceitação das hipóteses nulas.

a) Resid vs ajust(p-valor McLeod-LI: 0.11 )

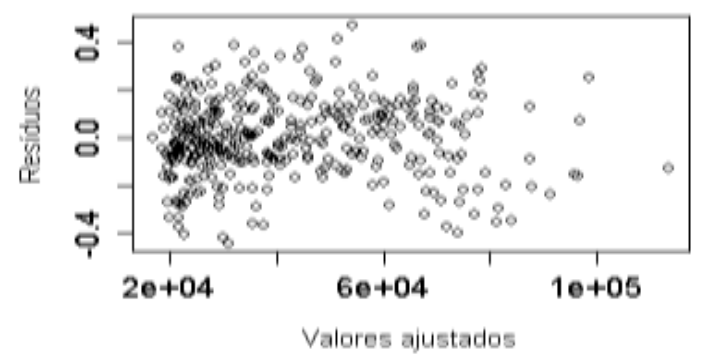

c) Q-Q plot normal (p-valor Shapiro-Wilk:0.65)

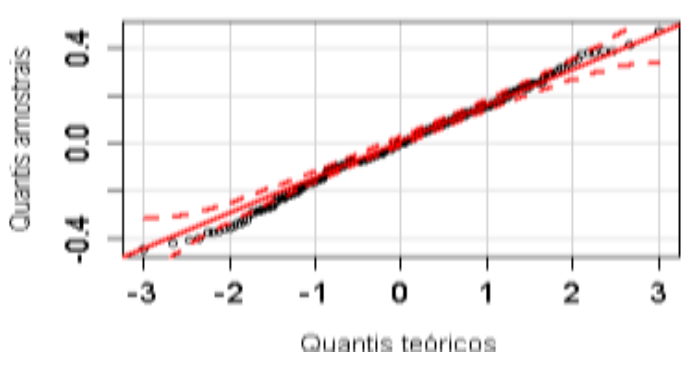

b) FAC residuos(p-valor Ljung-Box:0.16)

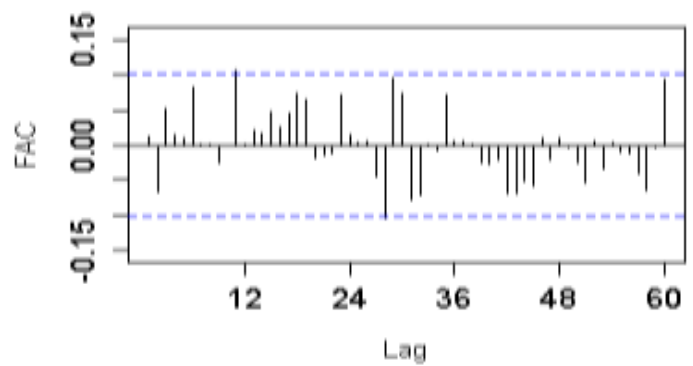

d) Histograma(p-valor teste t:0.96)

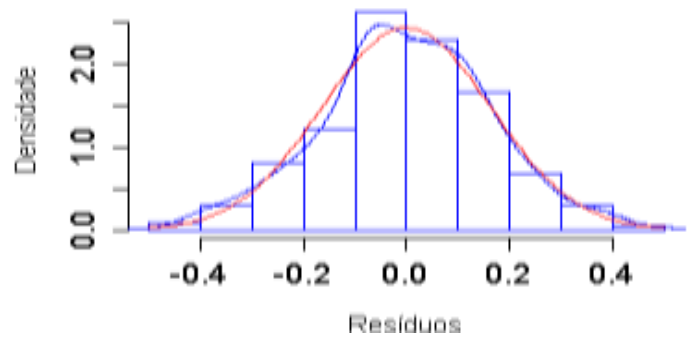

Figura 8-20 - Gráfico análise de resíduos modelo SARIMAX (100)(003): a) Resíduos versos modelo ajustado. b) FAC c) QQ-Plot d) Histograma

Assim, o modelo cumpre com as suposições dos erros: $e_{t}$ independentes, $E\left(e_{t}\right)=0$, variância constante, e autocorrelação constante seguindo a distribuição normal. Os critérios AIC, AICc e BIC são muito similares, com uma leve melhora no Erro Médio Quadrático (RMSE), como apresenta-se na Tabela 8-9. Estes indicadores de erro, e qualidade do modelo são gerados através do comando accuracy do R. A teoria sobre avaliação de qualidade e erros de resíduos encontram-se na 1.1.1.1APÊNDICE B Validação dos modelos de previsão, 314. Ao analisar os resíduos, verifica-se que os p-valores correspondentes às respectivas hipóteses nulas são aceitáveis para os modelos SARIMAX (100)(103) SARIMAX (100)(004). Os valores p-valor são apresentados na Tabela 8-9, com os critérios de informação e resíduos. 
Observa-se que nem sempre um modelo com um valor AIC menor tem também os p-valores aceitáveis. Somente os modelos da primeira e última linha atendem as suposições.

Tabela 8-9 Análise de Erros de Resíduos ${ }^{141}$

\begin{tabular}{lllllllllllll}
\hline SARIMAX & \multirow{2}{*}{ AIC } & \multirow{2}{*}{ AAIC } & \multirow{2}{*}{ BIC } & ME & RMSE & MAE & MPE & MAPE & $\begin{array}{l}\text { Shapiro } \\
\text { Wilk }\end{array}$ & $\begin{array}{l}\text { Teste } \\
\text { t }\end{array}$ & $\begin{array}{l}\text { McLeod } \\
\text { Li }\end{array}$ & $\begin{array}{l}\text { Ljung } \\
\text { Box }\end{array}$ \\
\hline $\mathbf{( 1 0 0 ) ( 1 0 3 )}$ & $-253,6$ & $-251,6$ & $-183,0$ & 688 & 8.286 & 5.812 & -1 & 13 & 0,55 & 0,96 & 0,11 & 0,16 \\
\hline $\mathbf{( 2 1 1 ) ( 1 0 2 )}$ & $-253,1$ & $-252,3$ & $-210,0$ & 673 & 8.100 & 5.658 & -2 & 13 & 0,28 & 0,75 & 0,00 & 0,38 \\
\hline $\mathbf{( 2 1 1 ) ( 1 0 2 )}$ & $-253,1$ & $-252,3$ & $-210,0$ & 673 & 8.100 & 5.658 & -2 & 13 & 0,28 & 0,75 & 0,00 & 0,38 \\
\hline $\mathbf{( 2 1 1 ) ( 1 0 2 )}$ & $-253,1$ & $-252,3$ & $-210,0$ & 673 & 8.100 & 5.658 & -2 & 13 & 0,28 & 0,75 & 0,00 & 0,38 \\
\hline $\mathbf{( 2 1 2 ) ( 1 0 2 )}$ & $-251,8$ & $-250,9$ & $-204,8$ & 674 & 8.088 & 5.649 & -2 & 13 & 0,33 & 0,75 & 0,00 & 0,40 \\
\hline $\mathbf{( 1 0 0 ) ( 0 0 4 )}$ & $-251,6$ & $-249,5$ & $-177,2$ & 690 & 8.282 & 5.810 & -1 & 13 & 0,54 & 0,97 & 0,11 & 0,13 \\
\hline
\end{tabular}

5) Validação Cruzada

Na validação cruzada são realizadas "previsões retroativas" com dados do passado prevendo o passado, e os erros médios absolutos, calculados entre o previsto e o realizado, são armazenados, e a média dos erros é calculada, posteriormente, para cada mês previsto, para um período de 60 meses a frente.

$\mathrm{Na}$ validação cruzada são experimentados quatro modelos com variáveis explicativas diferentes e com a ordem do modelo SARIMAX(101)(103). O modelo com variáveis explicativas tem vantagem em relação aos modelos com uma única ou mesmo nenhuma variável explicativa, como visto na Figura 8-21. Nesta figura, há quatro resultados da média de erros padrões das previsões retroativas da validação cruzada, conforme explicação feita anteriormente, de modelos com diferentes configurações das variáveis macroclimáticas, que são: um modelo sem variáveis explicativas, um modelo com todas as variáveis explicativas SWA, EEP, X70E, X120E, X40W e SAM, um modelo somente com a variável explicativa AMO e outro modelo somente com a variável explicativa NINO1+2.

\footnotetext{
${ }^{141}$ AIC -Akaike's Information Criterion (Critério de Informação de Akaike)

AICc - Corrected Akaike's Information Criterion (Critério de Informação de Akaike corrigida)

BIC - Schwarz Bayesian Information Criterion (Critério Bayesiano de Schwarz)

ME - Mean Error (Erro médio)

RMSE - Root Mean Squared Error (Erro médio quadrático)

MAE - Mean Absolute Error (Erro Médio Absoluto)

MPE - Mean Percentage Error (Percentual Erro Médio)

MAPE - Mean Absolute Percentage Error (Percentual Erro Absoluto)

MASE - Mean Absolute Scaled Error (Escala de Erro Médio Absoluto)

ACF1 - Autocorrelation of errors at lag 1 (Autocorrelaçao de erros com 1 atraso)
} 


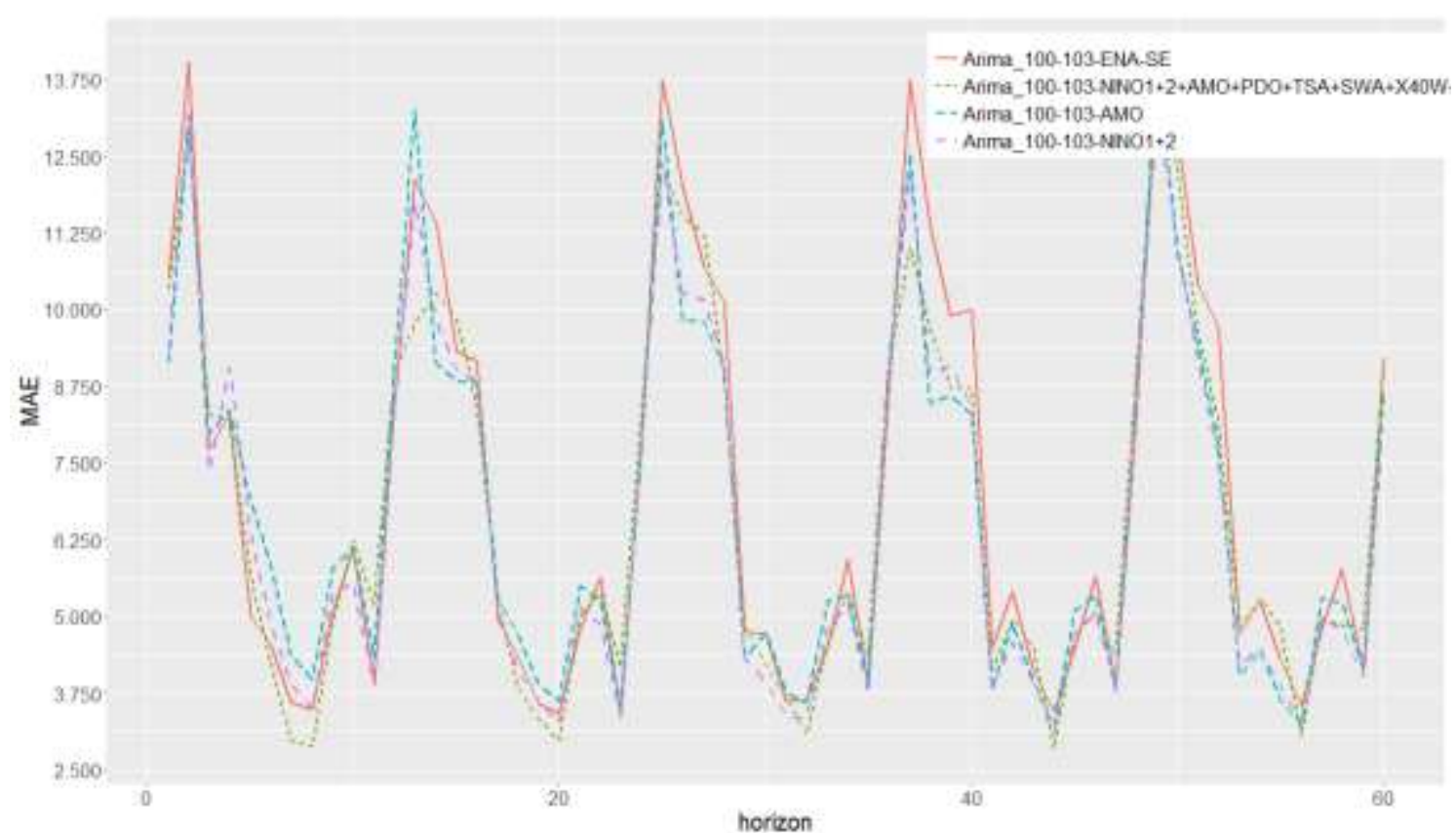

Figura 8-21 Erros médios absolutos resultados da validação cruzada com o modelo SARIMAX (101)(103)

Na validação (Tabela 8-10) com RMSE e R2, é possível observar um resultado com o maior erro dentre os demais (1978-1997: 10.531 MWmédios), lembrando que em 1979, 1980, 1982, 1983, 1992, 1995 e 1997 há picos (outliers), todos relacionados com El Niño, que podem explicar esses erros. Os demais agrupamentos apresentam erro menores, assim como o menor erro absoluto (1978-2004: 5.914). Todos os valores de coeficiente de determinação e ajustados são iguais ou próximos a 1. Os valores p são menores que 0,0001 o que indica que os coeficientes de determinação são significativos. 
Tabela 8-10 Dados validação modelo de regressão dinâmica SARIMAX (101)(103)

\begin{tabular}{rrrrrrrrrc}
\multicolumn{2}{c}{ JANEL } & ME & RMSE & MAE & MPE & MAPE & R2 & R2a & R2p \\
\hline $\mathbf{1 9 7 8}$ & 1997 & -6.898 & 10.531 & 8.190 & $-22 \%$ & $25 \%$ & 1,00 & 1,00 & 0,0000 \\
\hline $\mathbf{1 9 7 8}$ & 1998 & -5.821 & 9.121 & 7.340 & $-21 \%$ & $24 \%$ & 1,00 & 1,00 & 0,0000 \\
\hline $\mathbf{1 9 7 8}$ & 1999 & -3.523 & 8.650 & 7.152 & $-15 \%$ & $22 \%$ & 1,00 & 1,00 & 0,0000 \\
\hline $\mathbf{1 9 7 8}$ & 2000 & -4.037 & 8.891 & 7.179 & $-16 \%$ & $22 \%$ & 1,00 & 1,00 & 0,0000 \\
\hline $\mathbf{1 9 7 8}$ & 2001 & -1.845 & 7.560 & 6.294 & $-11 \%$ & $19 \%$ & 1,00 & 0,99 & 0,0000 \\
\hline $\mathbf{1 9 7 8}$ & 2002 & 1.378 & 8.707 & 6.018 & $-3 \%$ & $15 \%$ & 1,00 & 1,00 & 0,0000 \\
\hline $\mathbf{1 9 7 8}$ & 2003 & 3.301 & 9.322 & 6.236 & $3 \%$ & $14 \%$ & 1,00 & 1,00 & 0,0000 \\
\hline $\mathbf{1 9 7 8}$ & 2004 & 2.640 & 8.785 & 5.914 & $\mathbf{2} \%$ & $13 \%$ & 1,00 & 1,00 & 0,0000 \\
\hline $\mathbf{1 9 7 8}$ & 2005 & 390 & 9.149 & 6.068 & $-2 \%$ & $14 \%$ & 0,99 & 0,99 & 0,0000 \\
\hline $\mathbf{1 9 7 8}$ & 2006 & 2.137 & 8.669 & 6.341 & $1 \%$ & $15 \%$ & 0,99 & 0,99 & 0,0000 \\
\hline $\mathbf{1 9 7 8}$ & 2007 & 1.700 & 9.393 & 7.116 & $1 \%$ & $17 \%$ & 0,99 & 0,99 & 0,0000 \\
\hline $\mathbf{1 9 7 8}$ & 2008 & 2.087 & 8.867 & 6.380 & $3 \%$ & $15 \%$ & 0,99 & 0,99 & 0,0000 \\
\hline
\end{tabular}

Ao verificar os valores nos gráficos a seguir, observa-se que as previsões, do modelo oficial NEWAVE, apresentam valores muito próximos de um ano para outro. Na Figura 8-22, são apresentados, no início, o valor observado registrado pelo ONS e, em seguida, os valores dos decks de previsão do modelo NEWAVE. Cada deck faz uma previsão de 5 anos à frente, ou seja, se o deck é de 2003 fará a previsão de 2003 a 2007, e assim, sucessivamente. Esses resultados podem ser avaliados com os indicadores de erro apresentados na Tabela 8-11, a seguir:

Tabela 8-11 Dados validação NEWAVE Região Sudeste Decks 2003 a 2009

\begin{tabular}{llllrr}
\hline Deck & ME & RMSE & MAE & MPE & MAPE \\
\hline $\mathbf{2 0 0 3}$ & 5.126 & 10.615 & 6.416 & $9 \%$ & $15 \%$ \\
\hline $\mathbf{2 0 0 4}$ & 5.565 & 10.955 & 7.057 & $11 \%$ & $16 \%$ \\
\hline $\mathbf{2 0 0 5}$ & 5.172 & 10.847 & 7.084 & $10 \%$ & $17 \%$ \\
\hline $\mathbf{2 0 0 6}$ & 3.751 & 10.475 & 6.729 & $5 \%$ & $16 \%$ \\
\hline $\mathbf{2 0 0 7}$ & 4.454 & 10.438 & 7.170 & $7 \%$ & $17 \%$ \\
\hline $\mathbf{2 0 0 8}$ & 4.449 & 10.039 & 7.302 & $8 \%$ & $18 \%$ \\
\hline $\mathbf{2 0 0 9}$ & 3.786 & 9.738 & 6.988 & $7 \%$ & $18 \%$ \\
\hline
\end{tabular}


Na Figura 8-22, são apresentados os valores de ENA-SE observados e na sequência as previsões feitas pelo NEWAVE a partir dos decks de dados 2003, 2004, 2005, 2006, 2007, 2008 e 2009, para 5 anos à frente ${ }^{142}$.

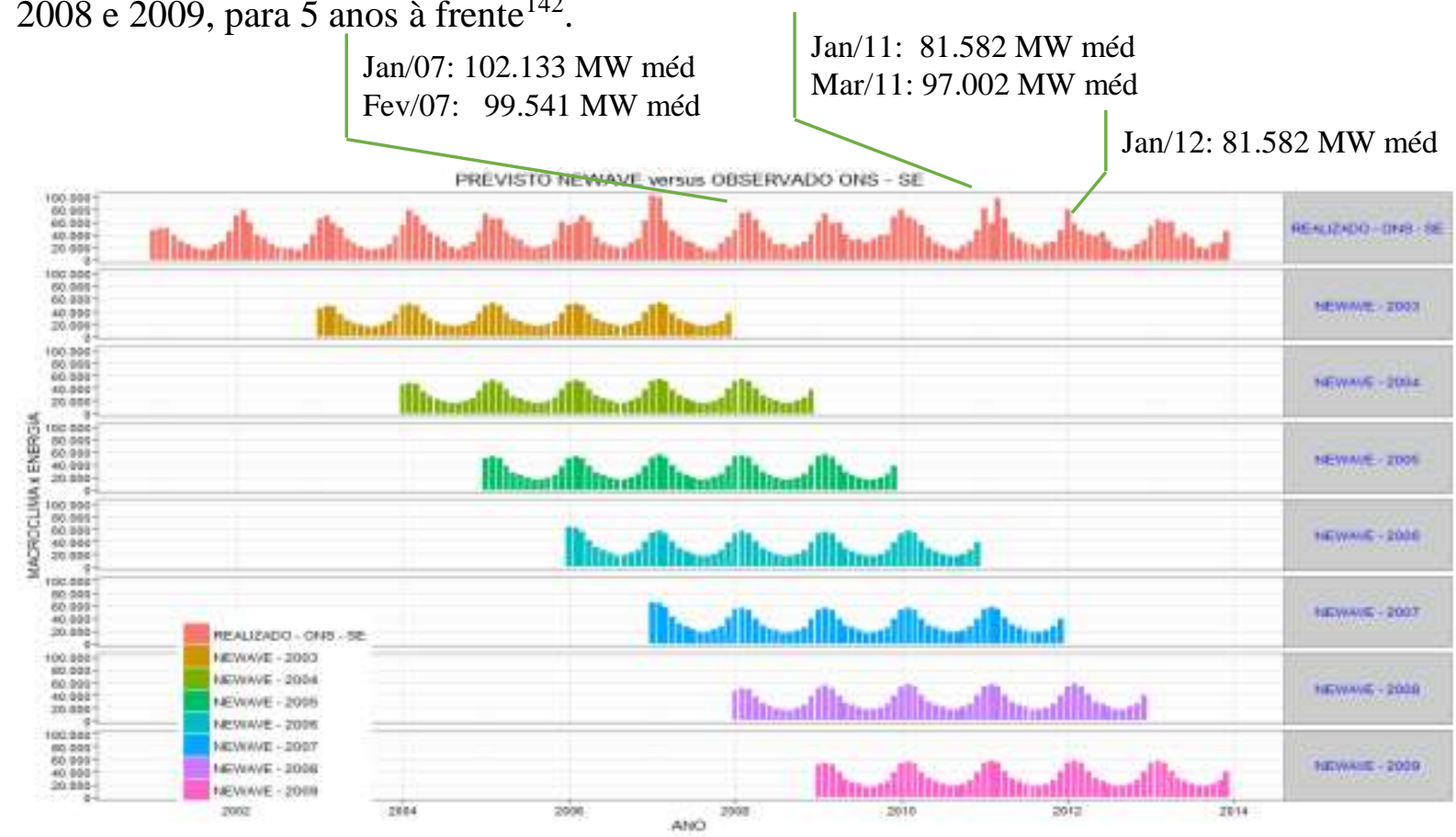

Figura 8-22 Validação Cruzada NEWAVE :: Decks 2003 a 2009.

Na Figura 8-23, apresenta-se a diferença, ou erro, entre o observado e o previsto. Nota-se que os valores de erro são aproximados nos meses de jan. e fev.2007, apesar de serem previsões realizadas com decks diferentes.

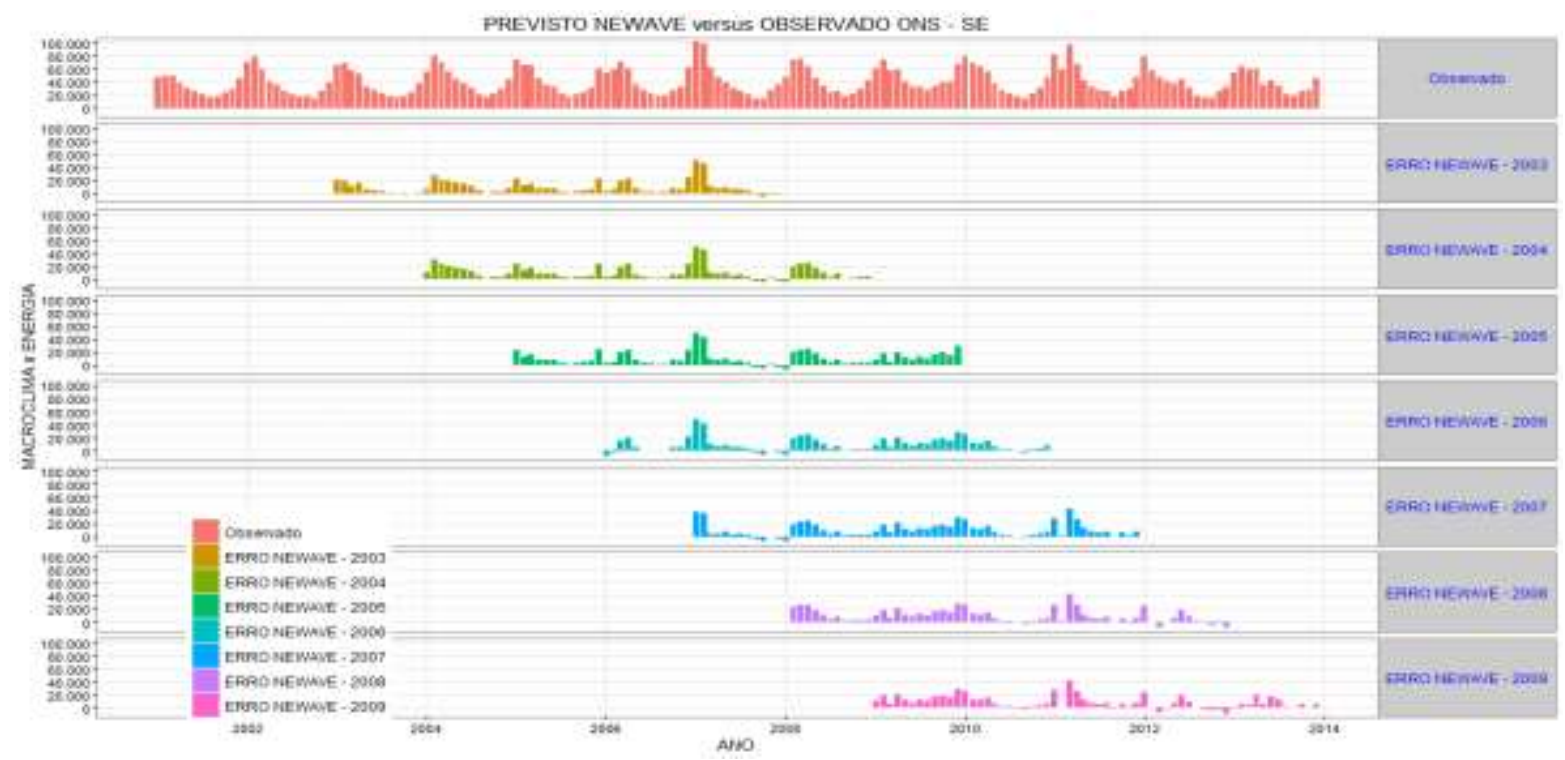

Figura 8-23 Validação Cruzada Erro =NEWAVE - ONS :: Decks 2003 a 2009.

${ }^{142}$ Comentário Prof. Molion: “ Nota-se que o NEWAVE corta todos os picos e parece uma janela móvel e não um previsor." 
O modelo SARIMAX(100)(103) é apresentado nas Figura 8-24 e Figura 8-25, e os resultados são melhores do que o NEWAVE. Nota-se que também apresentam erros similares nos mesmos meses, apesar de utilizarem conjuntos de testes diferentes.

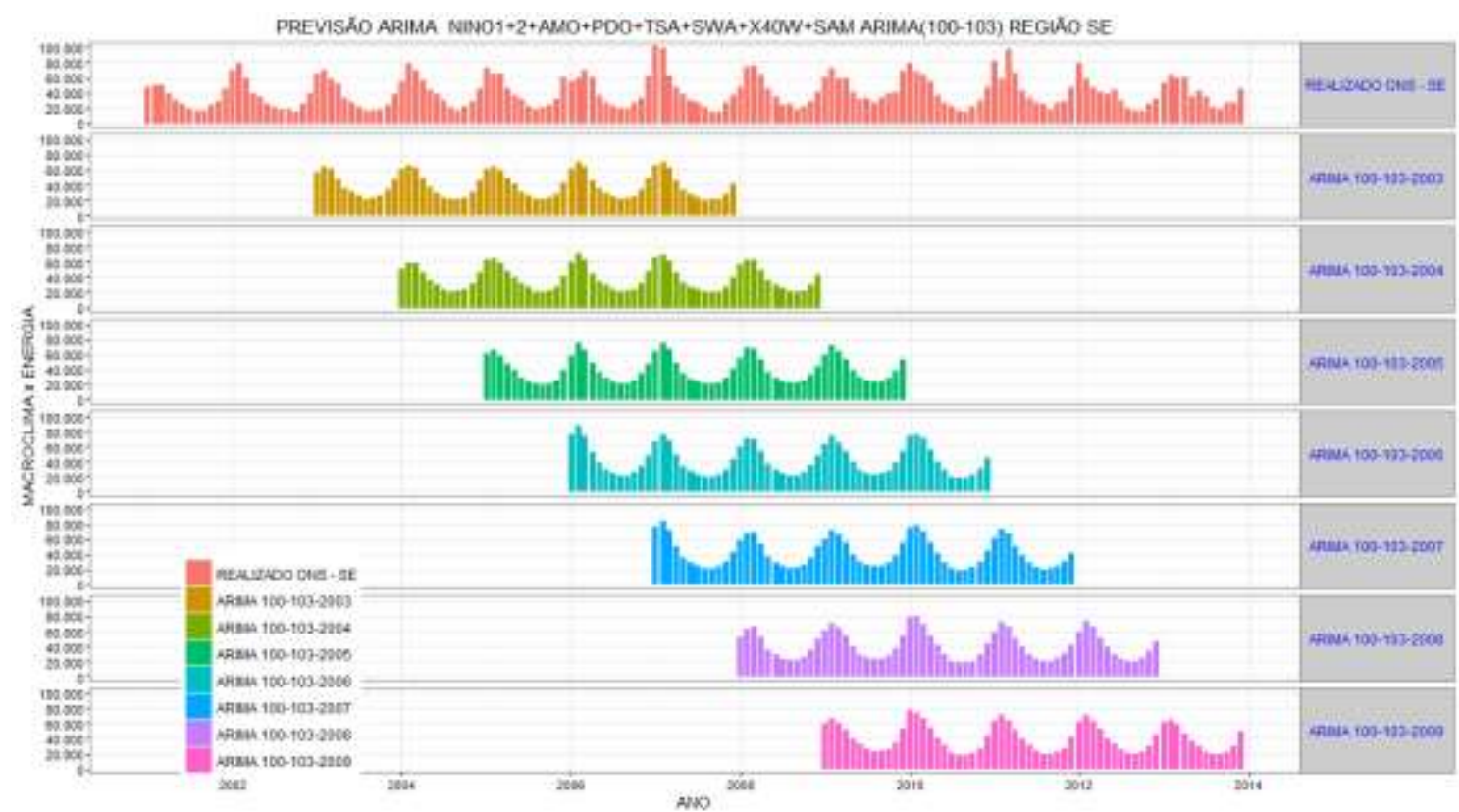

Figura 8-24 Validação cruzada modelos SARIMAX (100)(103) Região Sudeste

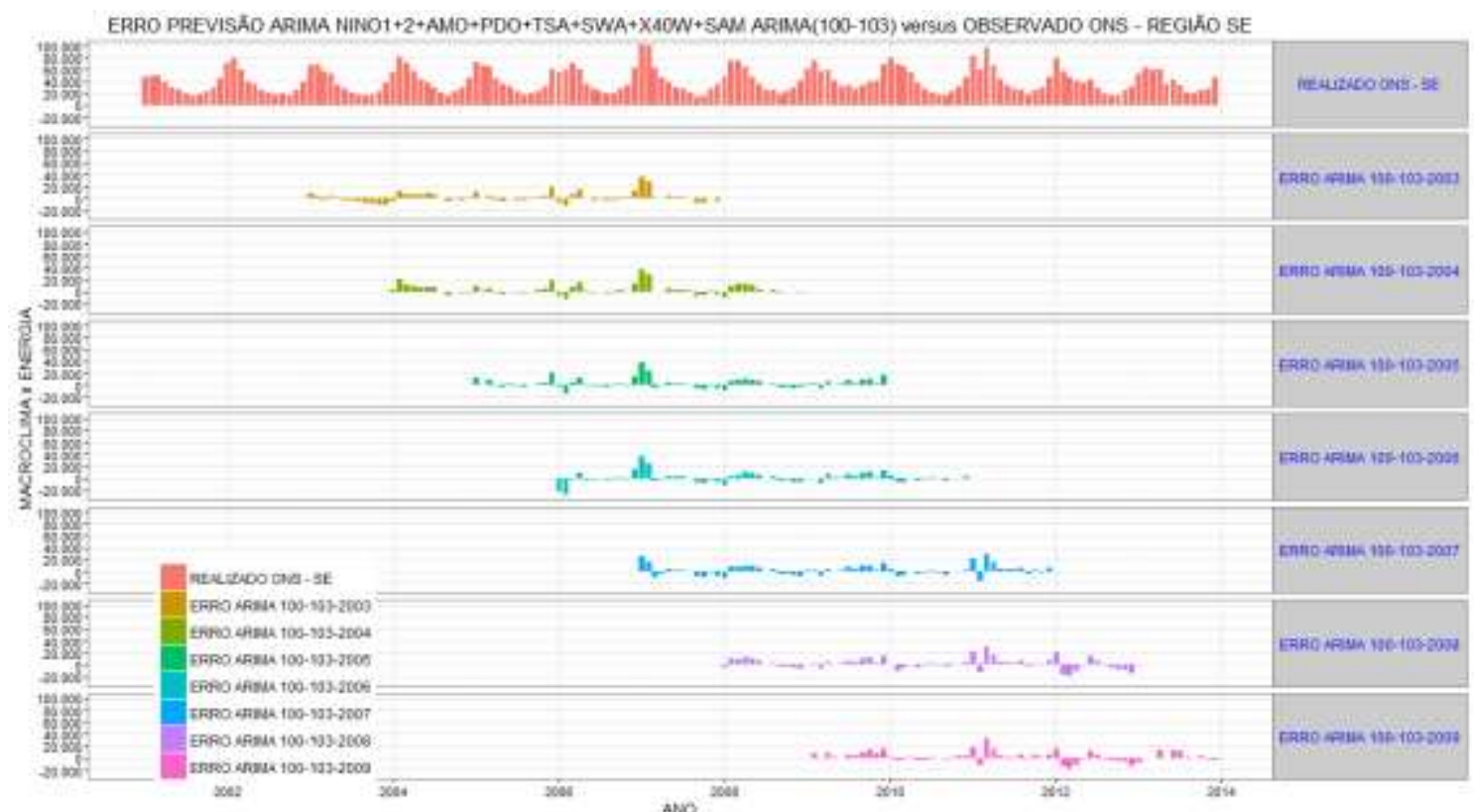

Figura 8-25 Validação Cruzada Erro = SARIMAX(100)(103) :: Conjuntos de teste 2003 a 2009 Região Sudeste. 


\subsection{Conclusões}

Os modelos de previsão de ENA para o Sudeste, Sul, Nordeste e Norte apresentaram, dos 24 erros medidos, entre os valores previstos pelos modelos e os valores observados e publicados pelo ONS, somente três valores foram inferiores, frente aos resultados do modelo oficial NEWAVE, Tabela 8-12, que estão destacados em vermelho. Os demais valores de erro, foram iguais ou melhores, indicando que o modelo é aderente e até superior ao NEWAVE, na maioria das situações.

Tabela 8-12 Indicador MAPE NEWAVE Regiões brasileiras Decks 2003 a 2009 versos MAPE modelos Tese

\begin{tabular}{ccccccccc}
\hline \multirow{2}{*}{ ANO } & \multicolumn{2}{c}{ Sudeste } & \multicolumn{2}{c}{ Sul } & \multicolumn{2}{c}{ Nordeste } & \multicolumn{2}{c}{ Norte } \\
\cline { 2 - 9 } & NEWAVE & Tese & NEWAVE & Tese & NEWAVE & Tese & NEWAVE & Tese \\
\hline $\mathbf{2 0 0 3}$ & $15 \%$ & $14 \%$ & $52 \%$ & $51 \%$ & $36 \%$ & $36 \%$ & $19 \%$ & $20 \%$ \\
\hline $\mathbf{2 0 0 4}$ & $16 \%$ & $13 \%$ & $49 \%$ & $55 \%$ & $35 \%$ & $34 \%$ & $21 \%$ & $20 \%$ \\
\hline $\mathbf{2 0 0 5}$ & $17 \%$ & $14 \%$ & $57 \%$ & $52 \%$ & $34 \%$ & $33 \%$ & $22 \%$ & $21 \%$ \\
\hline $\mathbf{2 0 0 6}$ & $16 \%$ & $15 \%$ & $52 \%$ & $40 \%$ & $44 \%$ & $37 \%$ & $22 \%$ & $21 \%$ \\
\hline $\mathbf{2 0 0 7}$ & $17 \%$ & $17 \%$ & $45 \%$ & $45 \%$ & $43 \%$ & $27 \%$ & $20 \%$ & $21 \%$ \\
\hline $\mathbf{2 0 0 8}$ & $18 \%$ & $15 \%$ & $49 \%$ & $49 \%$ & $42 \%$ & $30 \%$ & $21 \%$ & $21 \%$ \\
\hline
\end{tabular}

$\mathrm{Na}$ elaboração dos modelos, que utilizavam variáveis explicativas, na avaliação da significância, quase sempre apresentam valores de resíduos com os seus p-valores em conformidade às suposições das hipóteses de inferência estatística, comparados com aqueles modelos que não as utilizavam.

Nesses resultados, pode-se destacar algumas variáveis macroclimáticas que ocorrem em mais de uma região, como AMM e TSA, índices medidos no Oceano Atlântico; ONI, índice relaciono ao Pacífico Equatorial, mais precisamente a área de TSM NINO 3.4, e X70E, X40W, índices relacionados a fenômeno MJO, e SAM, índice relacionado ao Polo Antártico. Também algumas variáveis que podem ser ignoradas, pois apresentam p-valor maior que 0,04, o que indica a h0 é aceita, onde $\rho=0$ é verdadeira. São elas, MANCHAS (número de manchas solares, $\mathrm{p}$-valor $=0,1290), \operatorname{MODOKI}(\mathrm{p}$-valor $=0,0413)$, TSA $(\mathrm{p}$-valor $=0,07)$, ONI ( $\mathrm{p}$-valor $=0,874$, para ENA-SUL), PDO (p-valor $=0,08$, para ENA-SE e p-valor = 1,3993, para ENA-S), MJO X120E (p-valor = 0,6283, para ENA-N), e SAM (p-valor = 0,0686 para ENA-N).

Apesar de não apresentarem significância para um IC de 95\%, algumas delas podem ser utilizadas para um IC menor, de $90 \%$. 
A variável NINO3wl, transformada com wavelets, ajudou a modelar a ENA-SUL como também o índice AO, que apesar de ser pouco significativo(p-valor $=0,24)$, melhorou o resultado de previsão e a inferência dos resíduos ao elaborar modelos para essa região.

Para a Região Sudeste, as variáveis NINO1+2, SWA, MJO (X70E - X120E - X40W), AO e SAM foram utilizadas para modelagem, todas são significativas, e as variáveis TSA, AMO, PDO, AO e SAM não foram significativas. Nota-se que as variáveis não significativas são AO e SAM, que apresentam correlação positiva com os valores do modelo ajustado, porém apresentaram p-valor acima de 0,05, e portanto, não atende o IC de 95\%. Os resultados indicam que os fenômenos do El Niño, MJO e a TSM do Atlântico Sul (SWA) podem explicar ENA do Sudeste, o que poderá ser confirmado com um modelo físico, considerando a periodicidade mensal.

Para a Região Sul, as variáveis NINO3wl e MJO X40W são significativas, e TSI, TSA, ONI, PDO, AO e SAM não são significativas. Nota-se que as variáveis TSI e ONI não significativas, apresentam correlação positiva com os valores do modelo ajustado e a variável TSA, poderia ser significativa para um IC menor, exemplo de 90\%. Assim parece que os fenômenos associados a El Niño 3 e MJO explicam a ENA da Região Sul, lembrando que com uma probabilidade menor que $95 \%$ e maior que $90 \%$ de IC.

Para a Região Nordeste, as variáveis AMM, TNA2, MJO (X70E - X120E - X40W) são significativas, porém, MANCHAS e AMO não são significativas. Nota-se que AMO, apesar de pouco significativa, apresenta correlação positiva com os valores do modelo ajustado. Isso sugere que os fenômenos do Atlântico Meridional e Norte e MJO explicam ENA do Nordeste, apesar de que a suposição, da hipótese nula, de que o modelo não é heterocedástico foi rejeitada, o que fere somente uma das suposições iniciais e, portanto, os resultados deste modelo devem ser analisados com ressalvas.

Para a Região Norte, as variáveis AMM, ONI, QBO e PDO são significativas, e MANCHA, MODOKI, SOIDAR, AMO, X120E e SAM, não são. Nota-se que, dessas, somente SOIDAR, AMO e X120E não fornecem nenhuma condição de significância, mesmo diminuído o IC. As demais variáveis podem ser utilizadas com IC menores, exemplo $90 \%$ ou 85\%. Aparentemente, os fenômenos de Oscilação do Pacífico e do Atlântico Meridional explicam a ENA da Região Norte. 
As variáveis macroclimáticas, descritas e utilizadas como variáveis explicativas, são apresentadas na Tabela 8-13.

Tabela 8-13 Inferência estatística p-valores das variáveis explicativas modelos da Tese

\begin{tabular}{|c|c|c|c|c|}
\hline \multirow{2}{*}{ Variáveis Explicativas } & \multicolumn{4}{|c|}{ Valores p modelo SARIMAX } \\
\hline & ENA-SE & ENA-S & ENA-NE & ENA-N \\
\hline MANCHA & & & & 0,1290 \\
\hline NINO12 & 0,0000 & & & \\
\hline MODOKI & & & & 0,0413 \\
\hline NINO3 & & 0,0004 & & \\
\hline AMM & & & 0,0040 & 0,0141 \\
\hline TSA & 0,0705 & 0,0705 & & \\
\hline MEI & & 0,0333 & & \\
\hline ONI & & 0,8740 & & 0,0034 \\
\hline QBO & & & & 0,0003 \\
\hline AMO & 1,8880 & & 0,2604 & 0,8813 \\
\hline PDO & 0,0873 & 1,3993 & & 0,0269 \\
\hline TNA2 & & & 0,0000 & \\
\hline SWA & 0,0000 & & & \\
\hline MJO X70E & 0,0001 & & 0,0000 & \\
\hline MJO X120E & 0,0001 & & 0,0000 & 0,6283 \\
\hline MJO X40W & 0,0001 & 0,0050 & 0,0000 & \\
\hline AO & 1,9069 & 0,2490 & & \\
\hline SAM & 0,3270 & 1,8854 & & 0,0686 \\
\hline
\end{tabular}

Finalmente a hipótese da tese é confirmada e os objetivos foram alcançados, pois foram realizadas análises das séries históricas com ferramentas matemáticas e gráficas, e a compreenção dessas variáveis explicativas refletem o comportamento do macroclima.

As variáveis explicativas foram incorporaradas no modelo para melhorar a previsibilidade ou cenarização e refletem o comportamento climático de larga escala, na estrutura dos modelos elaborados.

O protótipo de software foi desenvolvido para a predição de energia com base em modelos matemáticos, com o uso do pacote estatístico R.

\subsection{Recomendações para trabalhos futuros}

$\mathrm{Na}$ análise de mapas, identificou-se áreas com correlações acima 0,4 que podem servir como novas variáveis explicativas a leste da África, sul Austrália, sul da Índia, sul do Atlântico. 
O teste de validação cruzada não pode ser utilizado com exclusões de observações, como é comum em regressões, pois uma vez que o modelo utilizado é de séries temporais, e, portanto, dependente do tempo e ocorre dependência autoregressiva. Assim, foi utilizado o método de dobras ( $K$-fold $)$ o qual mostrou-se adequado. Esse teste mostrou que nem sempre o modelo tem resultados aceitáveis para diferentes amostras de tempo do passado, para as previsões retroativas, mas, em sua maioria, os resultados foram aceitáveis. Assim, recomenda-se que novos testes com diferentes períodos de "dobras" sejam feitos para melhor avaliar a robustez dos modelos.

Nessa tese há indicações de causalidade em Granger de fenômenos climáticas de larga escala e oferta de energia das hidrelétricas. Estas relações podem ser validadas com a elaboração de modelos climáticas, pelos profissionais que tem domínio e conhecimento de tais modelos gerais da atmosfera, acomplados com os oceanos e a biosfera, por exemplo.

Mais pesquisa com métodos não lineares, como por exemplo modelo ARFIMA ${ }^{143}$, onde para tornar a série histórica estacionaria, são aplicados valores de diferenças fracionários no lugar de números inteiros, e são utilizados na literatura para tratar da chamada "memória de longo termo" e poderiam ser utilizados para os dados de ENA e vazões do Brasil, desde que fosse possível alongar as séries históricas para bem antes de 1931, talvez centenas de anos, não séries sintéticas, mas através de séries associadas, como, por exemplo, os testemunhos de espelhotemas de cavernas, anéis de árvores, ou outras séries que fossem encontradas nas regiões de interesse (dados paleoclimáticos). Também há trabalhos que elaboram regressão simples com diferentes atrasos de até 18 meses, e agregação anual, e ou, sazonal, dos dados diários ou mensais, que também poderiam ser aplicados para as séries de energia, dos rios brasileiros. Lembrando que regressão simples não implica em restrições encontradas nas séries temporais, e testes de validação cruzada, podem ser elaborados com a retirada de observações de maneira aleatória, em um eventual teste de validação cruzada.

Outro trabalho que pode ser seguido é o estudo dos modelos heterocedásticos, uma vez que o modelo para a região Nordeste apresentou esse comportamento da variância, e, portanto, há necessidade de realização de experimentos com a parte aleatória que não o ruído branco do modelo, lembrando que as séries históricas desta região possuem partes sintéticas.

Também há necessidade de elaboração de modelos físicos, para verificar se os resultados dos modelos SARIMAX podem ser explicados para as regiões e bacias brasileiras, nessa tese

\footnotetext{
${ }^{143}$ Autoregressive fractionally integrated moving average
} 
estudados e modelados, o que pode ser trabalhado por profissionais e pesquisadores da área das ciências atmosféricas. 


\section{REFERÊNCIAS BIBLIOGRÁFICAS}

AGOSTA, E. A. The 18.6-year nodal tidal cycle and the bi-decadal precipitation oscillation over the plains to the east of subtropical Andes, South America. International Journal of Climatology, v. 34, n. 5, p. 1606-1614. doi: 10.1002/joc.3787, 2014.

AKAIKE, H. A Bayesian Analysis of the Minimum AIC Procedure. In: E. Parzen; K. Tanabe; G. Kitagawa (Orgs.); Selected Papers of Hirotugu Akaike, Springer Series in Statistics. p.275-280. Springer New York. Recuperado de http://dx.doi.org/10.1007/978-1-4612-16940_21, 1998.

AKAIKE, H. A new look at the statistical model identification. IEEE Transactions on Automatic Control, v. 19, n. 6, p. 716-723. doi: 10.1109/TAC.1974.1100705, 1974.

ALLAN, R. J.; LINDESAY, J.; PARKER, D. E. El Niño, southern oscillation, and climatic variability. CSIRO, 1996.

ALLAN, R. J.; NICHOLLS, N.; JONES, P. D.; BUTTERWORTH, I. J. A Further Extension of the Tahiti-Darwin SOI, Early ENSO Events and Darwin Pressure. Journal of Climate, v. 4, n. 7, p. 743-749. doi: 10.1175/1520-0442(1991)004<0743:AFEOTT>2.0.CO;2, 1991.

ALMEIDA, Antônio Carlos Aido de. Estudo das correlações entre a atividade solar e processos atmosféricos. Dissertação (Mestrado).-Instituto de Física. Universidade Estadual de Campinas - UNICAMP, Campinas, 2001.

AMBRIZZI, T. et al. Cenários regionalizados de clima no Brasil para o século XXI: Projeções de clima usando três modelos regionais. Relatório 3. Ministério do Meio Ambiente (MMA), Secretaria de Biodiversidade e Florestas (SBF), Diretoria de Conservação da Biodiversidade (DCBio). Mudanças Climáticas Globais e Efeitos sobre a Biodiversidade - Subprojeto: Caracterização do clima atual e definição das alterações climáticas para o território brasileiro ao longo do século XXI. Brasília, fevereiro 2007.

AMBRIZZI, T.; HOSKINS, B. J.; HSU, H.-H. Rossby Wave Propagation and Teleconnection Patterns in the Austral Winter. Journal of the Atmospheric Sciences, nov. 1995. v. 52, n. 21, p. 3661-3672. 
AMBRIZZI, Tércio. El Niño Oscilação sul e teleconexões atmosféricas no hemisfério austral. 2003.201 f. Tese (Livre Docência) 2003.

ANTICO, A.; KRÖHLING, D. M. Solar motion and discharge of Paraná River, South America: Evidence for a link: SOLAR MOTION AND PARANA RIVER DISCHARGE.

Geophysical Research Letters, v. 38, n. 19, p. n/a-n/a. doi: 10.1029/2011GL048851, 2011.

ASHOK, K.; YAMAGATA, T. Climate change: The El Niño with a difference. Nature, v. 461, n. 7263, p. 481-484. doi: 10.1038/461481a, 2009.

AUSTRALIAN BUREAU OF METEOROLOGY (BOM). Record-Breaking La Niña Events an Analysis of the La Niña Life Cycle and the Impacts and Significance of 2010-11 and 201112 La Niña Events in Australia. Melbourne, Vic.: Bureau of Meteorology, 2012. URL acesso em 14/01/2016: http://www.bom.gov.au/climate/enso/history/ln-2010-12/three-phases-ofENSO.shtml

BALDWIN, M. P.; GRAY, L. J.; DUNKERTON, T. J.; et al. The quasi-biennial oscillation. Reviews of Geophysics, v. 39, n. 2, p. 179-229. doi: 10.1029/1999RG000073, 2001.

BARbOSA, H. M. J. Vapor de Água Na Atmosfera: Do Efeito Estufa às Mudanças Climáticas. Revista USP, n. 103, p.67-80, Nov, 2014. doi:10.11606/issn.23169036.v0i103p67-80.

BARNSTON, A. G.; LIVEZEY, R. E. Classification, Seasonality and Persistence of LowFrequency Atmospheric Circulation Patterns. Monthly Weather Review, v. 115, n. 6, p. 1083-1126. doi: 10.1175/1520-0493(1987)115<1083:CSAPOL>2.0.CO;2, 1987.

BARROS, M. T. L.; LOPES, J. E. G.; ZAMBON, R. C.; et al. Climate Flow Forecast Model for the Brazilian Hydropower System. . p.1-9. American Society of Civil Engineers. doi: 10.1061/41036(342)476, 2009.

BARROS, M. T. L.; ZAMBON, R. C.; BARBOSA, P. S. F.; YEH, W. W.-G. Planning and Operation of Large-Scale Water Distribution Systems with Preemptive Priorities. Journal of Water Resources Planning and Management, v. 134, n. 3, p. 247-256. doi: 10.1061/(ASCE)0733-9496(2008)134:3(247), 2008. 
BOUDJELLABA, H.; DUFOUR, J.-M.; ROY, R. Testing Causality Between Two Vectors in Multivariate Autoregressive Moving Average Models. Journal of the American Statistical Association, v. 87, n. 420, p. 1082. doi: 10.2307/2290645, 1992.

BOULANGER, J.-P.; LELOUP, J.; PENALBA, O.; et al. Observed precipitation in the Paraná-Plata hydrological basin: long-term trends, extreme conditions and ENSO teleconnections. Climate Dynamics, v. 24, n. 4, p. 393-413. doi: 10.1007/s00382-004-0514x, 2005.

BOX, G. E. P. and PIERCE, D. A. (1970), Distribution of residual correlations in autoregressive-integrated moving average time series models. Journal of the American Statistical Association, 65, 1509-1526.

BOX, G. E. P.; JENKINS, G. M.; REINSEL, G. C. Time series analysis: forecasting and control. 4th ed ed. Hoboken, N.J: John Wiley, 2008.

BRASIL. MINISTÉRIO DE MINAS E ENERGIA. Empresa de Pesquisa Energética. BEN, 2015. Balanço Energético Nacional 2015: Ano base 2014: Sumário Executivo / Ministério de Minas e Energia. Empresa de Pesquisa Energética. - Rio de Janeiro: EPE, 2005. CDU 620.9:553.04(81)

BROOKS, Chris. Introductory Econometrics for Finance. 2nd ed. Cambridge [England] ; New York: Cambridge University Press, ISBN 978-0-521-69468-1. 2008.

CANOVA, F.; HANSEN, B. E. Are Seasonal Patterns Constant Over Time? A Test for Seasonal Stability. Journal of Business \& Economic Statistics, v. 13, n. 3, p. 237-252. doi: 10.1080/07350015.1995.10524598, 1995.

CASTILLO, Rodrigo; NIETO, Raquel; Drumond, Anita; GIMENO, Luis. The role of the enso cycle in the modulation of moisture transport from major oceanic moisture sources. Water Resources Research v. 50, n. 2, p. 1046-58, Feb., 2014. doi:10.1002/2013WR013900.

CAVALCANTI, I. F. A.; MARENGO, J. A.; SATYAMURTY, P.; et al. Global Climatological Features in a Simulation Using the CPTEC-COLA AGCM. Journal of Climate, v. $15, \quad$ n. 21 , p. 2965-2988. doi: 10.1175/15200442(2002)015<2965:GCFIAS>2.0.CO;2, 2002. 
CAVAlCANTI, Iracema Fonseca de Albuquerque et al. Tempo e clima no Brasil. São Paulo,: Oficina de Textos, 2009.

CAVALIERI, D. J.; PARKINSON, C. L. Arctic sea ice variability and trends, 1979\&amp;ndash;2010. The Cryosphere, v. 6, n. 4, p. 881-889. doi: 10.5194/tc-6-881-2012, 2012.

CAVALIERI, D. J.; PARKINSON, C. L.; DIGIROLAMO, N.; IVANOFF, A. Intersensor Calibration Between F13 SSMI and F17 SSMIS for Global Sea Ice Data Records. IEEE Geoscience and Remote Sensing Letters, v. 9, n. 2, p. 233-236. doi: 10.1109/LGRS.2011.2166754, 2012.

CAVALIERI, D. J.; PARKINSON, C. L.; GLOERSEN, P.; COMISO, J. C.; ZWALLY, H. J. Deriving long-term time series of sea ice cover from satellite passive-microwave multisensor data sets. Journal of Geophysical Research: Oceans, v. 104, n. C7, p. 15803-15814. doi: 10.1029/1999JC900081, 1999.

CAYAN, D. R.; PETERSON, D. H. The Influence of North Pacific Atmospheric Circulation on Streamflow in the West. In: D. H. Peterson (Org.); Geophysical Monograph Series. p.375-397. Washington, D. C.: American Geophysical Union. Recuperado 15, janeiro, 2016, de http://doi.wiley.com/10.1029/GM055p0375, 2013.

CAYAN, D. R.; WEBB, R. H. El Nino/Southern Oscillation and streamflow in the western United States. In: Henry F. Diaz; Vera Markgraf (Orgs.); El Niño: historical and Paleoclimatic aspects of the Southern Oscillation. p.29-68. Cambridge University Press. Recuperado de http://pubs.er.usgs.gov/publication/70157146, 1993.

CHEN, W. Y.; VAN DEN DOOL, H. Sensitivity of Teleconnection Patterns to the Sign of Their Primary Action Center. Monthly Weather Review, v. 131, n. 11, p. 2885-2899. doi: 10.1175/1520-0493(2003)131<2885:SOTPTT>2.0.CO;2, 2003.

CHIANG, J. C. H.; VIMONT, D. J. Analogous Pacific and Atlantic Meridional Modes of Tropical Atmosphere-Ocean Variability*. Journal of Climate, v. 17, n. 21, p. 4143-4158. doi: 10.1175/JCLI4953.1, 2004. 
CIONCO, R. G.; ABUIN, P. On planetary torque signals and sub-decadal frequencies in the discharges of large rivers. Advances in Space Research. doi: 10.1016/j.asr.2015.05.046, 2015.

ClEVElAND, R. B.; CLEVELAND, W. S.; MCRAE, J. E.; TERPENNING, I. STL: A seasonal-trend decomposition procedure based on loess. Journal of Official Statistics, v. 6, n. 1, p. 3-73, 1990.

CLEVELAND, W. S.; GROSSE, E.; SHYU, W. M. Local regression models. Statistical models in S, v. 2, p. 309-376, 1992.

CLUTZ, R. Dynamic Duo: The Ocean-Air Partnership. Science Matters. Recuperado junho 11, 2016, de https://rclutz.wordpress.com/2015/05/11/dynamic-duo-the-ocean-airpartnership/, 2015, maio 11.

COELHO, C. A. S.; DE OLIVEIRA, C. P.; AMBRIZZI, T.; et al. The 2014 southeast Brazil austral summer drought: regional scale mechanisms and teleconnections. Climate Dynamics. doi: 10.1007/s00382-015-2800-1, 2015.

COELHO, S. C. A.; UVO, B. C.; AMBRIZZI, T. Exploring the impacts of the tropical Pacific SST on the precipitation patterns over South America during ENSO periods. Theoretical and Applied Climatology, fev 2002. v. 71, n. 3, p. 185-197. doi: 10.1007/s007040200004.

COMPAGNUCCI, Rosa Hilda; BERMAN, Ana Laura; HERRERA, Victor Velasco; SILVESTRI, Gabriel. Are Southern South American Rivers Linked to the Solar Variability? International Journal of Climatology v.34, n. 5, p. 1706-14, abril, 2014.doi:10.1002/joc.3784.

COULIBALY, P. Spatial and temporal variability of Canadian seasonal precipitation (19002000). Advances in Water Resources, v. 29, n. 12, p. 1846-1865. doi:

10.1016/j.advwatres.2005.12.013, 2006.

COWPERTWAIT, Paul S. P., and Andrew V. METCALFE. Introductory Time Series with R. Use R! Dordrecht; New York: Springer, 2009.

DE MELO, Alberto, Hydropower in a Brasilian Perspective. IEA NEET Workshop. Brasília, 19-20 Nov, 2007 
DE SOUZA, E. B.; AMBRIZZI, T. Modulation of the intraseasonal rainfall over tropical Brazil by the Madden-Julian oscillation. International Journal of Climatology, v. 26, n. 13, p. 1759-1776. doi: 10.1002/joc.1331, 2006.

de TOMA, G. Observing a Quieter Sun: A Weak Cycle Offers Opportunity for Expanding Solar Understanding. National Center for Atmospheric Research. 2014-12-23. Acesso 14/09/2015 endereço: https://ncar.ucar.edu/press/observing-a-quieter-sun-a-weak-cycleoffers-opportunity-for-expanding-solar-understanding

DEMUTE, H.; BEALE, M. Neural network toobox. for use with Matlab®: user's guide. Version 4. Release 13. S.1: Massachussets: The Math Works, 2002.

DES, L. A.; DE BARROS, M. T. L.; ZAMBON, R. C.; YEH, W. W.-G. Trade-Off Analysis among Multiple Water Uses in a Hydropower System: Case of São Francisco River Basin, Brazil. Journal of Water Resources Planning and Management, v. 141, n. 10, p. 4015014. doi: 10.1061/(ASCE)WR.1943-5452.0000527, 2015.

DESER, C.; ALEXANDER, M. A.; XIE, S.-P.; PHILlIPS, A. S. Sea Surface Temperature Variability: Patterns and Mechanisms. Annual Review of Marine Science, v. 2, n. 1, p. 115143. doi: 10.1146/annurev-marine-120408-151453, 2010.

DETTINGER, MD, CAYAN DR, MCCABE GM, MARENGO JA.2000.Multiscale streamflow variability associated with El Niño/Southern Oscillation. El Niño and the southern oscillation: multiscale variability and global and regional impacts. (Diaz HF, MARKGRAF V, Eds.).:113-146., Cambridge; New York, NY: Cambridge University Press.

DOE/EIA. International energy outlook 2013 with projections to 2040. DOE/EIA0484(2013). U.S. Energy Information Administration, 2013.

DRACUP, J. A.; KAHYA, E. The relationships between U.S. streamflow and La Niña Events. Water Resources Research, v. 30, n. 7, p. 2133-2141. doi: 10.1029/94WR00751, 1994. 
ELSANABARY, M. H.; GAN, T. Y. Weekly Streamflow Forecasting Using a Statistical Disaggregation Model for the Upper Blue Nile Basin, Ethiopia. Journal of Hydrologic Engineering, v. 20, n. 5, p. 4014064. doi: 10.1061/(ASCE)HE.1943-5584.0001072, 2015.

ELSANABARY, M. H.; GAN, T. Y.; MWALE, D. Application of wavelet empirical orthogonal function analysis to investigate the nonstationary character of Ethiopian rainfall and its teleconnection to nonstationary global sea surface temperature variations for 19001998: TELECONNECTING ETHIOPIAN RAINFALL TO SEA SURFACE TEMPERATURE. International Journal of Climatology, v. 34, n. 6, p. 1798-1813. doi: 10.1002/joc.3802, 2014.

ELTAHIR, E. A. B. El Niño and the Natural Variability in the Flow of the Nile River. Water Resources Research, v. 32, n. 1, p. 131-137. doi: 10.1029/95WR02968, 1996.

ENERGIAS do Brasil. Discussão sobre as alternativas para a formação de preços no setor elétrico brasileiro. Energias do Brasil. Reunião SRG - SEM/ANEEL. São Paulo, 27 Junho de 2008.

ENFIELD, D. B.; MESTAS-NUÑEZ, A. M.; MAYER, D. A.; CID-SERRANO, L. How ubiquitous is the dipole relationship in tropical Atlantic sea surface temperatures? Journal of Geophysical Research: Oceans, v. 104, n. C4, p. 7841-7848. doi: 10.1029/1998JC900109, 1999.

ENFIELD, D. B.; MESTAS-NUÑEZ, A. M.; TRIMBLE, P. J. The Atlantic Multidecadal Oscillation and its relation to rainfall and river flows in the continental U.S. Geophysical Research Letters, v. 28, n. 10, p. 2077-2080. doi: 10.1029/2000GL012745, 2001.

FARIAS, William Cossich Marcial de. Aplicação de um modelo autoregressivo multivariado para geração de cenários de afluências incorporando informações climáticas. Rio de Janeiro: UFRJ/COPPE, 2012.

FAYAL, Marcelo Alfredo de Assis. Previsão de vazão por redes neurais artificiais e transformada wavelet.2008. Dissertação (Mestrado) - Pontífícia Universidade Católica do Rio de Janeiro - PUC. 2008. 
GARDNER, H.; HATCH, T. Multiple Intelligences Go to School: Educational Implications of the Theory of Multiple Intelligences. Educational Researcher, v. 18, n. 8, p. 4. doi: 10.2307/1176460, 1989.

GRANGER, C. W. J. Investigating Causal Relations by Econometric Models and Crossspectral Methods. Econometrica, v. 37, n. 3, p. 424. doi: 10.2307/1912791, 1969.

GRANTZ, K.; RAJAGOPALAN, B.; ZAGONA, E.; CLARK, M. Water Management Applications of Climate-Based Hydrologic Forecasts: Case Study of the Truckee-Carson River Basin. Journal of Water Resources Planning and Management, v. 133, n. 4, p. 339350. doi: 10.1061/(ASCE)0733-9496(2007)133:4(339), 2007.

GREENE, W. H. Econometric analysis. 5th ed ed. Upper Saddle River, N.J: Prentice Hall, 2003.

GRILICHES, Z. (ORG.). Handbook of econometrics. Vol. 2: [...], Handbook in economics. 6. ed., reprint ed. Amsterdam: North Holland, 2007.

GRINSTED, A., Moore, J.C., JEVREJEVA, S. (2004) Application of the cross wavelet transform and wavelet coherence to geophysical time series, Nonlin. Processes Geophys., 11, 561-566, doi:10.5194/npg-11-561-2004

GUARNIER, E; RAMOS, D.S.; BARILLARI, S.N.; PELEGRINI, M.A.; QUEEN, A.S.; CAMARGO, L.A.S. Projeção de Preços no Mercado de Curto Prazo: Análise por Clusterização de Energias Naturais Afluentes e Incorporação de Fenômenos Climatológicos. IV Simpósio Brasileiro de Sistemas Elétricos (SBSE 2012). ISSN 21776164.

GUJARATI, D. N.; PORTER, D. C. Basic econometrics. 5th ed ed. Boston: McGraw-Hill Irwin, 2009.

HARVEY, A. C. (1993) Time Series Models. 2nd Edition, Harvester Wheatsheaf, NY, pp. $44,45$.

HATHAWAY, D. H. The Solar Cycle. Living Reviews in Solar Physics, v. 7. doi: 10.12942/lrsp-2010-1, 2010. 
HERNÁNDEZ, Julián David Rojo. Desarrollo de un sistema experto para La predicción de caudales medios mensuales en Colombia. Universidad Nacional de Colombia. Facultad de Minas - Escuela de Geociencias y Medio Ambiente. Medellín, Colombia, 2011.

HIGGINS, R. W.; LEETMAA, A.; KOUSKY, V. E. Relationships between Climate Variability and Winter Temperature Extremes in the United States. Journal of Climate, v. 15, n. 13, p. 1555-1572. doi: 10.1175/1520-0442(2002)015<1555:RBCVAW>2.0.CO;2, 2002.

HIGGINS, R. W.; MO, K. C. Persistent North Pacific Circulation Anomalies and the Tropical Intraseasonal Oscillation. Journal of Climate, v. 10, n. 2, p. 223-244. doi: 10.1175/15200442(1997)010<0223:PNPCAA>2.0.CO;2, 1997.

HIGGINS, R. W.; SCHUBERT, S. D. Simulations of Persistent North Pacific Circulation Anomalies and Interhemispheric Teleconnections. Journal of the Atmospheric Sciences, v. 53, n. 1, p. 188-207. doi: 10.1175/1520-0469(1996)053<0188:SOPNPC>2.0.CO;2, 1996.

HOTELLING, H. Analysis of a complex of statistical variables into principal components. Journal of Educational Psychology, v. 24, n. 6, p. 417-441. doi: 10.1037/h0071325, 1933.

HUNTER, T.; TOOTLE, G.; PIECHOTA, T. Oceanic-atmospheric variability and western U.S. snowfall. Geophysical Research Letters, v. 33, n. 13. doi: 10.1029/2006GL026600, 2006.

HURVICH, C. M.; TSAI, C.-L. Regression and time series model selection in small samples. Biometrika, v. 76, n. 2, p. 297-307. doi: 10.1093/biomet/76.2.297, 1989.

HYNDMAN, R.J. and ATHANASOPOULOS, G. (2013). Forecasting: principles and practice. Disponível em: http://otexts.org/fpp/. Acesso em: 16 de junho de 2015.

INSTITUTO BRASILEIRO DE GEOGRAFIA E ESTATÍSTICA. Projeção da população do Brasil por sexo e idade para o período 2000-2060. Diretoria de Pesquisas. Coordenação de População e Indicadores Sociais. Gerência de Estudos e Análises da Dinâmica Demográfica. $2013 . \quad$ Disponível em: http://www.ibge.gov.br/home/estatistica/populacao/projecao_da_populacao/2013/default_tab. shtm. Acesso em: 10 fev. 2015. 
IPCC, 2013: Climate Change 2013: The Physical Science Basis. Contribution of Working Group I to the Fifth Assessment Report of the Intergovernmental Panel on Climate Change [STOCKER, T.F., D. QIN, G.-K. PlATTNER, M. TIGNOR, S.K. Allen, J. BOSCHUNG, A. NAUELS, Y. Xia, V. BEX and P.M. MIDGLEY (eds.)]. Cambridge University Press, Cambridge, United Kingdom and New York, NY, USA, .1535p

IVAHNENKO AG. Polynomial theory of complex system (1971). IEEE Trans Systems Man Cybernet; SMC-1:364-78.

JACOBSON, Mark Z. Fundamentals of Atmospheric Modeling. 2nd ed. Cambridge, UK ; New York: Cambridge University Press, 2005.

JEVREJEVA, S., MOORE, J.C., GRINSTED, A. . Influence of the Arctic Oscillation and El Niño-Southern Oscillation (ENSO) on ice conditions in the Baltic Sea: The wavelet approach. Journal of Geophysical Research, v. 108, n. D21. doi: 10.1029/2003JD003417, 2003.

JOHNSON, R. A.; WICHERN, D. W. Applied multivariate statistical analysis. $6^{\text {th }}$ ed ed. Upper Saddle River, N.J: Pearson Prentice Hall, 2007.

KAHYA, E.; DRACUP, J. A. The Influences of Type 1 El Niño and La Niña Events on Streamflows in the Pacific Southwest of the United States. Journal of Climate, v. 7, n. 6, p. 965-976. doi: 10.1175/1520-0442(1994)007<0965:TIOTEN>2.0.CO;2, 1994.

KAHYA, E.; DRACUP, J. A. U.S. streamflow patterns in relation to the El Niño/Southern Oscillation. Water Resources Research, v. 29, n. 8, p. 2491-2503. doi: 10.1029/93WR00744, 1993.

KAYANO, M. T.; DE OLIVEIRA, C. P.; ANDREOLI, R. V. Interannual relations between South American rainfall and tropical sea surface temperature anomalies before and after 1976. International Journal of Climatology, v. 29, n. 10, p. 1439-1448. doi: 10.1002/joc.1824, 2009.

KELMAN, J. et al. Hidreletricidade. In. REBOUÇAS, A.C.; BRAGA, B; TUNDISI, J.G.(Org.). Águas Doces no Brasil: capital ecológico, uso e conservação $3^{\text {a }}$. Ed. São Paulo: Escrituras Editora, 2006. Cap. 16, p. 507-543. 
KIEHL, J. T.; TRENBERTH, K. E. Earth's Annual Global Mean Energy Budget. Bulletin of the American Meteorological Society, v. 78, n. 2, p. 197-208. doi: 10.1175/15200477(1997)078<0197:EAGMEB>2.0.CO;2, 1997.

KÖNNEN, G. P.; JONES, P. D.; KALTOFEN, M. H.; ALLAN, R. J. Pre-1866 Extensions of the Southern Oscillation Index Using Early Indonesian and Tahitian Meteorological Readings. Journal of Climate, v. 11, n. 9, p. 2325-2339. doi: 10.1175/15200442(1998)011<2325:PEOTSO>2.0.CO;2, 1998.

KOUSKY, V. E.; KAYANO, M. T. Principal Modes of Outgoing Longwave Radiation and 250-mb Circulation for the South American Sector. Journal of Climate, v. 7, n. 7, p. 11311143. doi: 10.1175/1520-0442(1994)007<1131:PMOOLR>2.0.CO;2, 1994.

KWIATKOWSKI, D.; PHILLIPS, P. C. B.; SCHMIDT, P.; SHIN, Y. Testing the null hypothesis of stationarity against the alternative of a unit root. Journal of Econometrics, v. 54, n. 1-3, p. 159-178. doi: 10.1016/0304-4076(92)90104-Y, 1992.

KWON, H.-H.; DE ASSIS DE SOUZA FILHO, F.; BLOCK, P.; et al. Uncertainty assessment of hydrologic and climate forecast models in Northeastern Brazil: CLIMATE FORECAST MODEL IN NORTHERN BRAZIL. Hydrological Processes, v. 26, n. 25, p. 3875-3885. doi: 10.1002/hyp.8433, 2012.

L'HEUREUX, M. L.; COLLINS, D. C.; HU, Z.-Z. Linear trends in sea surface temperature of the tropical Pacific Ocean and implications for the El Niño-Southern Oscillation. Climate Dynamics, v. 40, n. 5-6, p. 1223-1236. doi: 10.1007/s00382-012-1331-2, 2013.

LABADIE, J. W. Optimal Operation of Multireservoir Systems: State-of-the-Art Review. Journal of Water Resources Planning and Management,v. 130, $\mathrm{n}^{\mathrm{o}} 2$,p.93-111, Mar., 2004doi:10.1061/(ASCE)0733-9496.

LIMA, J. W. M.; COLISCHONN, W.; MARENGO, J. A. (ORGS.). Efeitos das mudanças climáticas na geração de energia elétrica. Brazil: Hunter Books Editora, ISBN 9788568717004. 2014.

LJUNG, G. M. and BOX, G. E. P. (1978). On a measure of lack of fit in time series models. Biometrika 65, 297-303. 
LOPES, J. E. G.; BRAGA, B. P. F.; CONEJO, J. G. L. SMAP: A simplified hydrological model. In: V. P. Singh (Org.); Applied modeling in catchment hydrology. Littleton, Colo: Water Resources Publications, 1982.

LOPES, J.E.G.L. Modelo de planejamento da operação de sistemas hidrotérmicos de produção de energia elétrica. São Paulo, 2007. 141 f. (Tese Doutorado). Escola Politécnica - Engenharia Hidráulica e Sanitária, Universidade de São Paulo.São Paulo, 2007.

LORENZ, E. N. Seasonal and Irregular Variations of the Northern Hemisphere Sea-Level Pressure Profile. Journal of Meteorology, fev. 1951. v. 8, n. 1, p. 52-59.

LUZ, G.. Oceano Atlântico Sul e a precipitação no Estado de São Paulo. 2010. Dissertação (Mestrado) - Faculdade de Filosofia, Letras e Ciências Humanas, Universidade de São Paulo. São Paulo,2010.

MACEIRA, M.E.P.; COSTA, A.P.C.; MARCATO, A.L.M. NEWAVE: Especificação Funcional. Rio de Janeiro:: CEPEL. NEWAVE I: Planejamento da Operação a Longo Prazo de Subsistemas Hidrotérmicos Interligados, 1999.

MACHADO, F., et al.. Monthly rainfall-runoff modelling using artificial neural networks. Hydrological Sciences Journal 56, $\mathrm{n}^{\mathrm{o}} \quad 3, \quad$ p. 349-361, Abr., 2011 doi:10.1080/02626667.2011.559949.

MADDEN, R. A.; JULIAN, P. R. Description of Global-Scale Circulation Cells in the Tropics with a 40-50 Day Period. Journal of the Atmospheric Sciences, v. 29, n. 6, p. 1109-1123. doi: 10.1175/1520-0469(1972)029<1109:DOGSCC>2.0.CO;2, 1972.

MANTUA, N.J. and S.R. HARE, Y. ZHANG, J.M. WALLACE, and R.C. FRANCIS, 1997: A Pacific interdecadal climate oscillation with impacts on salmon production. Bulletin of the American Meteorological Society, 78, pp. 1069-1079. (available via the internet at url: http://www.atmos.washington.edu/ mantua/abst.PDO.html)

MARENGO, J. A. Água e mudanças climáticas. Estudos Avançados, v. 22, n. 63, p. 83-96. doi: 10.1590/S0103-40142008000200006, 2008.

MARENGO, J. A., B., et al. Recent developments on the South American monsoon system. International Journal of Climatology, 32, nº 1, p.1-21, Jan., 2012 doi:10.1002/joc.2254. 
MAREngO, José A. Mudanças Climáticas Globais E Seus Efeitos Sobre a

Biodiversidade: Caracterização Do Clima Atual E Definição Das Alterações Climáticas Para O Território Brasileiro Ao Longo Do Século XXI. Biodiversidade 26. Brasília, DF: Ministério do Meio Ambiente, Secretaria de Biodiversidade e Florestas, 2006.

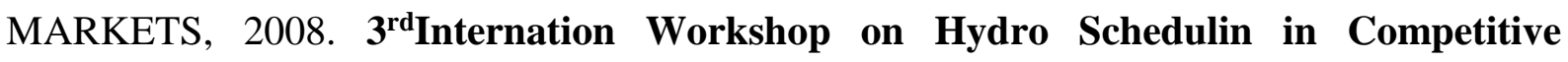
Electricity Markets. OSLO, 9-10 June, 2008.

MATTER, M. A.; GARCIA, L. A.; FOnTANE, D. G.; BLEDSOE, B. Characterizing hydroclimatic variability in tributaries of the Upper Colorado River Basin-WY1911-2001. Journal of Hydrology, v. 380, n. 3-4, p. 260-276. doi: 10.1016/j.jhydrol.2009.10.040, 2010.

MAUAS, P. J. D.; BUCCINO, A. P.; FLAMENCO, E. Long-term solar activity influences on South American rivers. Journal of Atmospheric and Solar-Terrestrial Physics, v. 73, n. 23, p. 377-382. doi: 10.1016/j.jastp.2010.02.019, 2011.

MAUAS, P. J. D.; FLAMENCO, E.; BUCCINO, A. P. Solar Forcing of the Stream Flow of a Continental Scale South American River. Physical Review Letters, v. 101, n. 16. doi: 10.1103/PhysRevLett.101.168501, 2008.

MAURER, E. P.; LETTENMAIER, D. P.; MANTUA, N. J. Variability and potential sources of predictability of North American runoff: RUNOFF VARIABILITY. Water Resources Research, v. 40, n. 9, p. n/a-n/a. doi: 10.1029/2003WR002789, 2004.

MCCABE, G. J.; PAlECKI, M. A.; BetANCOURT, J. L. Pacific and Atlantic Ocean influences on multidecadal drought frequency in the United States. Proceedings of the National Academy of Sciences, v. 101, n. 12, p. 4136-4141. doi: 10.1073/pnas.0306738101, 2004.

MENDES, L. A.. O Impacto dos usos consuntivos na operação de sistemas de reservatórios para produção de energia elétrica. São Paulo. Tese ( Doutorado) -. Escola Politécnica. Departamento de Engenharia Hidráulica e Ambiental ,Universidade de São Paulo. 2010.

METZ, B.. Intergovernmental Panel on Climate Change, Intergovernmental Panel on Climate Change, and Working Group III. Climate Change 2007 Mitigation of Climate Change: Contribution of Working Group III to the Fourth Assessment Report of the 
Intergovernmental Panel on Climate Change. Cambridge; New York: Cambridge University Press, 2007. http://dx.doi.org/10.1017/CBO9780511546013.

MILANKOVITCH, M. Mathematische Klimalehre Und Astronomische Theorie Der Kilimaschwankungen, in Handbuch Der Klimatologie. W. Köppen and R. Geiger. Vol. 1, Pt. A. Berlin, Borntraeger, 1930, pp. 1-176.

MISHRA, A. K.; SINGH, V. P.; ÖZGER, M. Seasonal streamflow extremes in Texas river basins: Uncertainty, trends, and teleconnections. Journal of Geophysical Research, v. 116, n. D8. doi: 10.1029/2010JD014597, 2011.

MO, K. C. Relationships between Low-Frequency Variability in the Southern Hemisphere and Sea Surface Temperature Anomalies. Journal of Climate, v. 13, n. 20, p. 3599-3610. doi: 10.1175/1520-0442(2000)013<3599:RBLFVI>2.0.CO;2, 2000.

MO, K. C.; WHITE, G. H. Teleconnections in the Southern Hemisphere. Monthly Weather Review, jan. 1985. v. 113, n. 1, p. 22-37.

MOLION, L. C. .; IMBUZEIRO, H. M. A.; CAVAlCANTI, I. F. A. Chuvas intensas no Leste da Amazônia: Fevereiro de 1980. Revista Climanálise, v. 3, n. 1, p. 1-9, 2006.

MORAIS, B. S.; da SILVA, G. B. L., SANTOS, C. A. G.. Análise da influência do ENOS na precipitação da Paraíba e Santa Catarina através da cross wavelet transform. XVIII Simpósio Brasileiro de Recursos Hídricos. 2009.

MOREtTIN, P. A.; TOLOI, C. M. C.. Análise de séries temporais. São Paulo: Edgard Blucher, 2006.

MOROMISATO, G. D. Y.. Programação dinâmica aplicada ao cálculo da energia firme de usinas hidrelétricas. 2012 .Dissertação ( Mestrado)- Universidade Federal de Juiz de Fora. 2012.

MÜLLER, G.V. e AMBRIZZI, T. (2007). Teleconnection Patterns and Rossby Wave Propagation Associated to Generalized Frosts over Southern South America. Climate Dynamics., 29, No. 6, 633- 645. 
NAJAFI, M. R., MORADKHANI , H., e PIECHOTA ,T. C.. Ensemble streamflow prediction: climate signal weighting methods vs. Climate Forecast System Reanalysis. Journal of Hydrology, 442-443, p.105-116, June,2012: doi:10.1016/j.jhydrol.2012.04.003.

NASCIMENTO JÚNIOR, L.. Aspectos observacionais das teleconexões climáticas no contexto da variabilidade. OBSERVATORIUM: Revista Eletrônica de Geografia, v.6, n.16, p. 46-58, mai. 2014.http://www.observatorium.ig.ufu.br/pdfs/6edicao/n16/3.pdf Acesso em 22/09/2015.

NATIONAL RESEARCH COUNCIL (U.S.); AMERICAN GEOPHYSICAL UNION (ORGS.). Solar variability, weather, and climate, Studies in geophysics. Washington, D.C: National Academy Press, 1982.

NATIONAL RESEARCH COUNCIL (U.S.); NATIONAL RESEARCH COUNCIL (U.S.) (ORGS.). The Effects of solar variability on Earth's Climate: a workshop report. Washington, D.C: National Academies Press, 2012. doi: 10.17226/13519

NIGAM, S., BAXTER, S., 2015. Teleconnections.In: NORTH, G. R. Encyclopedia of atmospheric sciences. 2. ed ed. Amsterdam: Elsevier, Acad. Press, 2015.

NÓBILE, T., A. C.. Influências da temperatura da superfície do mar e da umidade do solo na precipitação associada à Zona de Convergência do Atlântico Sul. 2010. Dissertação (Mestrado em Meteorologia) - Instituto de Astronomia, Geofísica e Ciências Atmosféricas, Universidade de São Paulo, 2010.

NORDEMANN, D. J. R. Periodicidades, tendencias e previsao a partir da analise espectral dinamica da serie dos niveis do rio Paraguai, em Ladario (1990/1995). Artigo em periódico indexado ALICE. Recuperado 11, agosto, 2016, de http://www.alice.cnptia.embrapa.br/alice/handle/doc/95334?mode=full, 1999 5, março.

OPERADOR NACIONAL DO SISTEMA ELÉTRICO - ONS. O ONS. Disponível em: < http://www.ons.org.br/institucional/o_que_e_o_ons.aspx >. Acesso em: 19 maio 2012.

OPERADOR NACIONAL DO SISTEMA ELÉTRICO. Histórico da Operação. Recuperado em fevereiro, 2016 de http://www.ons.org.br/historico/geracao_energia.aspx. 
OPERADOR NACIONAL DO SISTEMA ELÉTRICO. ONS, 2007. 1' Workshop de Previsão de Vazões. Operador Nacional de Sistema. ONS. Rio de Janeiro. 20 e 21 de setembro de 2007. Acesso endereço em 03/10/2015. http://www.ons.org.br/home/previsao_vazoes.htm

OPERADOR NACIONAL DO SISTEMA ELÉTRICO. Procedimentos de rede. Acompanhamento e previsão meteorológica e climática - submódulo 9.6. revisão 2.0. 11 de novembro de 2011.

OPERADOR NACIONAL DO SISTEMA ELÉTRICO.OPHEN - Acompanhamento Diário da Operação Hidroenergética. Operador Nacional do Sistema. Recuperado maio 19, 2015, de http://www.ons.org.br/resultados_operacao /ophen.aspx, 2016, março 15.

ORGANIZAÇÃO DAS NAÇÕES UNIDAS. ONU. Population Reference Bureau Projeção População Mundial para 2050. 1998. Disponível em: <http://www.prb.org/presentations/gb-poptrends_all.ppt.> Acesso em: 10 fev. 2015

ORGANIZAÇÃO DAS NAÇÕES UNIDAS. ONU. World population projections to 2300. Department of Economic and Social Affairs. Population Division.United Nations, 2004.. Disponível em: <http://www.un.org/esa/population/publications/longrange2/WorldPop2300final.pdf >

ÖZGER, M.; MISHRA, A. K.; SINGH, V. P. Low frequency drought variability associated with climate indices. Journal of Hydrology, v. 364, n. 1-2, p. 152-162. doi: 10.1016/j.jhydrol.2008.10.018, 2009.

PAMPUCH, L. A.; DRUMOND, A.; GIMENO, L.; AMBRIZZI, T. Anomalous patterns of SST and moisture sources in the South Atlantic Ocean associated with dry events in southeastern Brazil: ANOMALOUS PATTERNS IN SAO IN DRY PERIODS OVER SOUTHEASTERN BRAZIL. International Journal of Climatology, doi: 10.1002/joc.4679, 2016.

PANKRATZ, A.; WILEY INTERSCIENCE (ONLINE SERVICE). Forecasting with dynamic regression models. New York: Wiley. Recuperado fevereiro 22, 2016, de http://site.ebrary.com/id/10529335, 1991. 
PARKINSON, C. L.; CAVALIERI, D. J. Antarctic sea ice variability and trends, 1979\&amp;ndash;2010. The Cryosphere, v. 6, n. 4, p. 871-880. doi: 10.5194/tc-6-871-2012, 2012.

PARKINSON, C. L.; CAVALIERI, D. J.; GLOERSEN, P.; ZWALLY, H. J.; COMISO, J. C. Arctic sea ice extents, areas, and trends, 1978-1996. Journal of Geophysical Research: Oceans, v. 104, n. C9, p. 20837-20856. doi: 10.1029/1999JC900082, 1999.

PEARSON, K. LIII. On lines and planes of closest fit to systems of points in space. Philosophical Magazine Series 6, v. 2, n. 11, p. 559-572. doi: 10.1080/14786440109462720, 1901.

PEIXOTO, José Pinto, and Abraham H. OORT. Physics of Climate. New York: American Institute of Physics, 1992.

PHILANDER, S. G. (1990), El Niño, La Niña and the Southern Oscillation, Academic, San Diego, Calif.

PINTO, E. J. DE A. Hidrologia Estatística. Belo Horizonte: CPRM, 2007.

PRADO, L. F.. Oscilação Interdecadal do Pacífico e seus impactos no regime de precipitação no Estado de São Paulo. Biblioteca do IAG-USP, 2011 (Dissertação de mestrado).

PRADO, L. F.; WAINER, I. Planetary-scale climatic indices and relationship between decadal variability of rainfall in northeastern and southern Brazil. Revista Brasileira de Geofísica, v. 31, n. 1, p. 31-41, 2013.

R. DEVELOPMENT CORE TEAM, R: A language and environment for statistical computing. R Foundation for Statistical Computing, Vienna, Austria. ISBN 3-900051-070. . Recuperado de http://www.R-project.org, 2005.

RAJAGOPALAN, B.; COOK, E.; LALL, U.; RAY, B. K. Spatiotemporal Variability of ENSO and SST Teleconnections to Summer Drought over the United States during the Twentieth Century. Journal of Climate, v. 13, n. 24, p. 4244-4255. doi: 10.1175/15200442(2000)013<4244:SVOEAS>2.0.CO;2, 2000. 
RAMOS, D. S. ; SILVA FILHO, D.. Formação de preços no mercados de curto e longo prazos: aspectos conceituais e de modelagem. Escola Politécnica . . Depto de Engenharia de Energia e Automação Elétricas da Escola Paulista, Universidade de SÃO Paulo, São Paulo. 2009. Notas de aula da disciplina PEA 5917

RAYNER, N. A. Global analyses of sea surface temperature, sea ice, and night marine air temperature since the late nineteenth century. Journal of Geophysical Research, v. 108, n. D14. doi: 10.1029/2002JD002670, 2003.

REBOITA, M. S.; GAN, M. A.; ROCHA, R. P. DA; AMBRIZZI, T. Regimes de precipitação na América do Sul: uma revisão bibliográfica. Revista Brasileira de Meteorologia, v. 25, n. 2. doi: 10.1590/S0102-77862010000200004, 2010.

REDMOND, K. T.; KOCH, R. W. Surface Climate and Streamflow Variability in the Western United States and Their Relationship to Large-Scale Circulation Indices. Water Resources Research, v. 27, n. 9, p. 2381-2399. doi: 10.1029/91WR00690, 1991.

REYNOLDS, R. W.; RAYNER, N. A.; SMITH, T. M.; STOKES, D. C.; WANG, W. An Improved In Situ and Satellite SST Analysis for Climate. Journal of Climate, v. 15, n. 13, p. 1609-1625. doi: 10.1175/1520-0442(2002)015<1609:AIISAS>2.0.CO;2, 2002.

ROB J HYNDMAN. Why every statistician should know about cross-validation. Hyndsight. Recuperado 21, janeiro, 2016, de http://robjhyndman.com/hyndsight/crossvalidation/, 20104 , outubro.

RODRIGUES, A. L.. Redes neurais artificiais aplicadas na previsão de preços do mercado spot de energia elétrica. 2009. 179 f. Dissertação (Mestrado em Energia) Programa de Pós-Graduação em Energia da Universidade de São Paulo, São Paulo, 2009.

ROGERS, J. C.; COLEMAN, J. S. M. Interactions between the Atlantic Multidecadal Oscillation, El Niño/La Niña, and the PNA in winter Mississippi Valley stream flow: U.S. WINTER STREAM FLOW VARIABILITY. Geophysical Research Letters, v. 30, n. 10, p. n/a-n/a. doi: 10.1029/2003GL017216, 2003.

ROPELEWSKI, C. F.; HALPERT, M. S. North American Precipitation and Temperature Patterns Associated with the El Niño/Southern Oscillation (ENSO). Monthly Weather 
Review, v. $114, \quad$ n. $12, \quad$ p. 2352-2362. doi: 10.1175/15200493(1986)114<2352:NAPATP>2.0.CO;2, 1986.

ROPELEWSKI, C. F.; JONES, P. D. An Extension of the Tahiti-Darwin Southern Oscillation Index. Monthly Weather Review, v. 115, n. 9, p. 2161-2165. doi: 10.1175/15200493(1987)115<2161:AEOTTS>2.0.CO;2, 1987.

ROYSTON , P. (1982a) Algorithm AS 181: The W test for Normality. Applied Statistics, 31, 176-180.

ROYSTON , P. (1982b) An extension of Shapiro and Wilk's W test for normality to large samples. Applied Statistics, 31, 115-124.

ROYSTON, P. (1995) Remark AS R94: A remark on Algorithm AS 181: The W test for normality. Applied Statistics, 44, 547-551.

SÁ, L. D. DE A.; SAMBATTI, S. B. M.; GALVÃO, G. P. Ondeleta de Morlet aplicada ao estudo da variabilidade do nível do rio Paraguai em Ladário, MS. Pesquisa Agropecuária Brasileira, v. 33, n. 13, p. 1775-1785, 1998.

SAITO, O. T. Distribuição típica de Temperatura e Salinidade (TS) nos Oceanos Globais. Termoclina, Diagrama TS, Massas d'água. Notas de aula. Instituto Oceanográfico da Universidade de São Paulo. 2012. Acesso em 25/01/2016 ftp://io.usp.br/los/IOF5841/aula03_ts.pdf.

SAMPAIO, G.; DIAS, P. L. DA S. Evolução dos Modelos Climáticos e de Previsão de Tempo e Clima. Revista USP, , n. 103, p. 41. doi: 10.11606/issn.2316-9036.v0i103p41-54, 2014.

SATYAMURTY, P.; NOBRE, C. A.; DIAS, P. L. S. South America. In: P. D. J. Karoly; P. D. G. Vincent (Orgs.); Meteorology of the Southern Hemisphere, Meteorological Monographs. p.119-139. American Meteorological Society. Recuperado 3, setembro, 2016, de http://link.springer.com/chapter/10.1007/978-1-935704-10-2_5, 1998.

SAUER, I. L., ed. A Reconstrução Do Setor Elétrico Brasileiro. São Paulo, SP: Campo Grande, MS: Paz e Terra ; Editora UFMS, 2003. 
SHIMIZU, M. H.; AMBRIZZI, T. MJO influence on ENSO effects in precipitation and temperature over South America. Theoretical and Applied Climatology, v. 124, n. 1-2, p. 291-301. doi: 10.1007/s00704-015-1421-2, 2016.

SHUMWAY, Robert H., and David S. STOFFER. Time Series Analysis and Its Applications: With R Examples. 3rd ed. Springer Texts in Statistics. New York: Springer, 2011.

SILVA, E.L. Formação de Preços em Mercados de Energia Elétrica. Porto Alegre: Editora Sagra Luzzato, 2001.

SILVA, G. A. M. DA; DRUMOND, A.; AMBRIZZI, T. The impact of El Niño on South American summer climate during different phases of the Pacific Decadal Oscillation. Theoretical and Applied Climatology, v. 106, n. 3-4, p. 307-319. doi: 10.1007/s00704-0110427-7, 2011.

SIQUEIRA, A. H. B. Oscilação Madden-Julian e seus impactos nas chuvas sobre a América do Sul. Panorama Comerc. Comercial. Recuperado junho 11, 2016, de http://www.panoramacomerc.com.br/?p=3535.

SMITH, T. M.; REYNOLDS, R. W.; PETERSON, T. C.; LAWRIMORE, J. Improvements to NOAA's Historical Merged Land-Ocean Surface Temperature Analysis (1880-2006). Journal of Climate, v. 21, n. 10, p. 2283-2296. doi: 10.1175/2007JCLI2100.1, 2008.

SOUKUP, T. L.; AZIZ, O. A.; TOOTLE, G. A.; PIECHOTA, T. C.; WULFF, S. S. Long lead-time streamflow forecasting of the North Platte River incorporating oceanic-atmospheric climate variability. Journal of Hydrology, v. 368, n. 1-4, p. 131-142. doi: 10.1016/j.jhydrol.2008.11.047, 2009.

SOUZA ECHER, M. P.; ECHER, E.; NORDEMANN, D. J.; RIGOZO, N. R.; PRESTES, A. Wavelet analysis of a centennial (1895-1994) southern Brazil rainfall series (Pelotas, $\left.31^{\circ} 46^{\prime} 19^{\prime \prime} \mathrm{S} 52^{\circ} 20^{\prime} 33^{\prime \prime} \mathrm{W}\right)$. Climatic Change, v. 87, n. 3, p. 489-497. doi: 10.1007/s10584007-9296-6, 2007.

SOUZA FILHO, F. A.; LALL, U. Seasonal to interannual ensemble streamflow forecasts for Ceara, Brazil: Applications of a multivariate, semiparametric algorithm: STREAMFLOW 
FORECASTING. Water Resources Research, v. 39, n. 11, p. n/a-n/a. doi: 10.1029/2002WR001373, 2003.

SOUZA, R. C.; OLIVEIRA, F. L. C.. Modelos de otimização do despacho hidrotérmico. In: SEMINÁRIO ENERGIA SUSTENTÁVEL. INICIATIVA ENERGIA PARA A SUSTENTABILIDADE. Coimbra. Anais. Portugal, Universidade de. Coimbra, 2012.

STEPHENSON, D. B., COELHO, C. FERRO, C, STEINSKOG, D.J... RClim Initiative. Climate Analysis Group of the University Exter. 2005. Acesso em Jan/2016 url: http://www1.secam.ex.ac.uk/rclim-initiative.dhtml.

STONE, M. An Asymptotic Equivalence of Choice of Model by Cross-Validation and Akaike's Criterion. Journal of the Royal Statistical Society. Series B (Methodological), v. 39, n. 1, p. 44-47, 1977.

TASHMAN, L. J. Out-of-sample tests of forecasting accuracy: an analysis and review. International Journal of Forecasting, v. 16, n. 4, p. 437-450. doi: 10.1016/S01692070(00)00065-0, 2000.

TERRY, L. A. et al. Coordinating the energy generation of the brazilian national hydrothermal electrical generating system.Interfaces 16, n.. 1, p. 16-38, Feb.,1986. doi:10.1287/inte.16.1.16.

THOMPSON, D. W. J.; WALLACE, J. M. The Arctic oscillation signature in the wintertime geopotential height and temperature fields. Geophysical Research Letters, v. 25, n. 9, p. 1297-1300. doi: 10.1029/98GL00950, 1998.

THURMAN, W. N.; FISHER, M. E. Chickens, Eggs, and Causality, or Which Came First? American Journal of Agricultural Economics, v. 70, n. 2, p. 237. doi: 10.2307/1242062, 1988.

TOOTLE, G. A.; PIECHOTA, T. C. Relationships between Pacific and Atlantic ocean sea surface temperatures and U.S. streamflow variability: SEA SURFACE TEMPERATURES AND U.S. STREAMFLOW. Water Resources Research, v. 42, n. 7, p. n/a-n/a. doi: 10.1029/2005WR004184, 2006. 
TORRENCE, C.; COMPO, G. P. A Practical Guide to Wavelet Analysis. Bulletin of the American Meteorological Society, v. 79, n. 1, p. 61-78. doi: 10.1175/15200477(1998)079<0061:APGTWA>2.0.CO;2, 1998.

TORRENCE, C.; WEBSTER, P. J. Interdecadal Changes in the ENSO-Monsoon System. Journal of Climate, v. $12, \quad$ n. $\quad 8$, p. 2679-2690. doi: 10.1175/15200442(1999)012<2679:ICITEM>2.0.CO;2, 1999.

TUCCI, C.E.M. Modelos Hidrológicos. 2a ed. Editora UFRGS - ABRH. 2005.

VAN DEN DOOL, H. M.; SAHA, S.; JOHANSSON, A. Empirical Orthogonal Teleconnections. Journal of Climate, v. 13, n. 8, p. 1421-1435. doi: 10.1175/15200442(2000)013<1421:EOT>2.0.CO;2, 2000.

WAINER, I.; PRADO, L. F.; KHODRI, M.; OTTO-BLIESNER, B. Reconstruction of the South Atlantic Subtropical Dipole index for the past 12,000 years from surface temperature proxy. Scientific Reports, v. 4. doi: 10.1038/srep05291, 2014.

WALKER, G.T. and BLISS, E.W., 1932. World Weather V, Memoirs of the Royal Meteorological Society, 4, (36), 53-84.

WALLACE, J. M.; GUTZLER, D. S. Teleconnections in the Geopotential Height Field during the Northern Hemisphere Winter. Monthly Weather Review, abr. 1981. v. 109, n. 4, p. 784-812.

WEGENER, A. Die Entstehung der Kontinente und Ozeane [The Origin of Continents and Oceans] (in German), 1922.

WEI, W. W. S. Time series analysis: univariate and multivariate methods. 2nd ed. Boston: Pearson Addison Wesley, 2006.

WHEELER, M. C.; HENDON, H. H. An All-Season Real-Time Multivariate MJO Index: Development of an Index for Monitoring and Prediction. Monthly Weather Review, v. 132, n. 8, p. 1917-1932. doi: 10.1175/1520-0493(2004)132<1917:AARMMI>2.0.CO;2, 2004.

WHITAKER, D. W.; WASIMI, S. A.; ISLAM, S. The El Niño southern oscillation and longrange forecasting of flows in the Ganges. International Journal of Climatology, v. 21, n. 1, p. 77-87. doi: 10.1002/joc.583, 2001. 
WILKS, D. S. Statistical methods in the atmospheric sciences, International geophysics series. 2nd ed ed. Amsterdam ; Boston: Academic Press, 2006.

WOLTER, K. The Southern Oscillation in Surface Circulation and Climate over the Tropical Atlantic, Eastern Pacific, and Indian Oceans as Captured by Cluster Analysis. Journal of Climate and Applied Meteorology, v. 26, n. 4, p. 540-558. doi: 10.1175/15200450(1987)026<0540:TSOISC>2.0.CO;2, 1987.

WOLTER, K.; TIMLIN, M. S. El Niño/Southern Oscillation behaviour since 1871 as diagnosed in an extended multivariate ENSO index (MEI.ext). International Journal of Climatology, v. 31, n. 7, p. 1074-1087. doi: 10.1002/joc.2336, 2011.

WOLTER, K.; TIMLIN, M. S. Measuring the strength of ENSO events: How does 1997/98 rank? Weather, v. 53, n. 9, p. 315-324. doi: 10.1002/j.1477-8696.1998.tb06408.x, 1998.

WOOLDRIDGE, J. M. Introductory econometrics: a modern approach. 4th ed ed. Mason, OH: South Western, Cengage Learning, 2009.

YAFFEE, R.; MCGEE, M. An Introduction to Time Series Analysis and Forecasting With Applications of SAS® and SPSS $®$. Burlington: Elsevier. Recuperado março 3, 2016, de http://public.eblib.com/choice/publicfullrecord.aspx?p=293985, 2000.

YEH, S.-W.; KUG, J.-S.; DEWITTE, B.; et al. El Niño in a changing climate. Nature, v. 461, n. 7263, p. 511-514. doi: 10.1038/nature08316, 2009.

ZAMBON, R. C.; BARROS, M. T. L.; LOPES, J. E. G.; et al. Optimization of Large-Scale Hydrothermal System Operation. Journal of Water Resources Planning and Management, v. 138, n. 2, p. 135-143. doi: 10.1061/(ASCE)WR.1943-5452.0000149, 2012.

ZHANG, Y., J.M. WALLACE, D.S. BATTISTI. ENSO-like interdecadal variability: 190093. J. Climate, 10, 1004-1020, 1997.

ZUFFO, A. C.. O Sol, o motor das variabilidades climáticas. Revista DAE 63, no 198, p.624, 2015. doi:10.4322/dae.2014.142.

ZWALLY, H. J. Variability of Antarctic sea ice 1979-1998. Journal of Geophysical Research, v. 107, n. C5. doi: 10.1029/2000JC000733, 2002. 


\section{APÊNDICES}

\section{APÊNDICE A Métodos de apoio}

Os pacotes computacionais adotados pelo ONS para operação do SIN buscam maximizar a produção de energia elétrica pelas usinas, porém somente são utilizadas as informações das afluências como variáveis explicativas para esse cálculo. Esse trabalho propõe analisar a possibilidade do uso de variáveis climáticas para o cálculo da previsão de vazões e oferta de energia futuras.

Os procedimentos da metodologia proposta estão organizados conforme a Figura APÊNDICE A-1e são descritos nas seções desse capítulo.

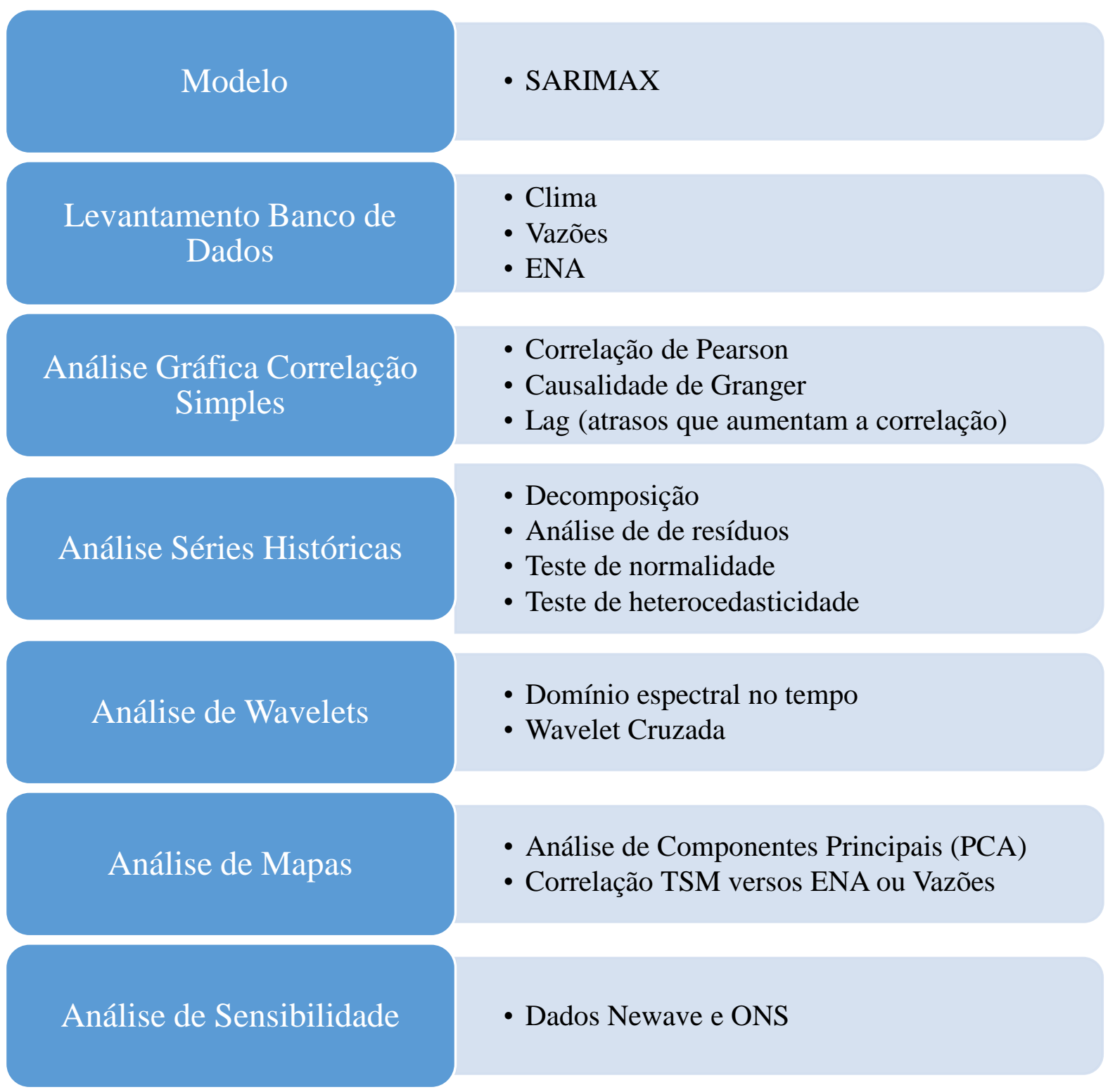

Figura APÊNDICE A-1- Procedimentos metodológicos 
APÊNDICE B Validação dos modelos de previsão

$\mathrm{O}$ objeto de análise de regressão é a construção de uma função $\widehat{f}\left(X_{1}, X_{2}, X_{3}, \ldots, X_{n}\right)$ de aproximação $f\left(X_{1}, X_{2}, X_{3}, \ldots, X_{n}\right)$ no domínio $D$ de interesse. A noção de grau de aproximação depende do propósito para o qual a função aproximada $\widehat{f}$ é utilizada nas aplicações e está relacionada a uma medida de precisão dada por erro integral:

$$
I=\int_{D} w(x) \Delta[\hat{f}(x), f(x)] d x
$$

APÊNDICE B-1

O erro esperado:

$$
E=\frac{1}{N} \sum_{i=1}^{N} w\left(x_{i}\right) \Delta\left[\hat{f}\left(x_{i}\right), f\left(x_{i}\right)\right]
$$

APÊNDICE B-2

$\Delta$ onde $\Delta$ é um operador de distância e $w$ é uma função de ponderação. $\mathrm{O}$ erro integral APÊNDICE B-1 caracteriza a aproximação sobre todo o domínio de interesse, enquanto a discretização APÊNDICE B-2 reflete somente a precisão em relação ao conjunto de pontos $\left(X_{1}, X_{2}, X_{3}, \ldots, X_{n}\right)$ que compõe a amostra de informação. O objetivo dos modelos de previsão é estimar valores futuros que, por omissão, não se encontram no histórico sendo o erro APÊNDICE B-1 mais importante. Então, é necessário definir uma estratégia de validação que permita confrontar a habilidade de previsão de $\widehat{f}$ quando os dados são encontrados na amostra usada para calibrar os parâmetros do modelo.

A precisão das previsões durante o período de validação pode-se estimar mediante as diferentes medidas de erro apresentadas na literatura de séries de tempo, cujo cálculo se baseia na $y_{t}$, APÊNDICE B-3, em que $y_{t}$ denota a observação histórica no tempo $t$ e $\widehat{y_{t}}$ corresponde ao valor esperado da previsão para o período $t$ onde $t=1,2, \ldots, T$ define-se, então, o erro (o resíduo) da previsão como:

$e_{t}=y_{t-} \hat{y}_{t}$

APÊNDICE B-3

$e$ o erro percentual como:

$p_{t}=100 \times e_{t} \div y_{t}$

APÊNDICE B-4

Com base na notação anterior, se definem as seguintes medidas de erro:

Erro médio absoluto:

$M A E=\frac{1}{T} \sum_{t=1}^{T} e_{t}$ 
Somatória de erros ao quadrado:

$S S E=\sum_{t=1}^{T} e_{t}^{2}$

APÊNDICE B-6

Erro quadrático médio ou variação do previsor:

$M S E=\frac{S S E}{T}$

APÊNDICE B-7

A raiz do erro quadrado médio:

$R M S E=\sqrt{M S E}$

APÊNDICE B-8

Se $y$ corresponde ao valor médio da série de dados, então o erro médio quadrático, expresso como porcentagem do valor médio dos dados de erro elevado ao quadrado, será:

$\% R M S E=\frac{R M S E}{y} \times 100$

APÊNDICE B-9

E a média do erro percentual absoluto está dada por:

$M A P E=\frac{1}{T} \sum_{t=1}^{T} p_{t}$

APÊNDICE B-10

No software R, utiliza-se o comando accuracy para realizar essas verificações.

APÊNDICE B.1 Coeficiente de determinação $\left(\mathrm{R}^{2}\right)$

$\mathrm{R}^{2}$ é o quadrado da correlação os valores atuais pelos valores previstos. $\mathrm{O}$ valor $\mathrm{R}^{2}$ pode ser calculado como a proporção da variância na variável prevista que é explicada pelo modelo de regressão (Hyndman \& George Athanasopoulos, 2014). ${ }^{144}$

$$
R^{2}=\frac{\sum\left(\hat{y}_{i}-\bar{y}\right)^{2}}{\sum\left(y_{i}-\bar{y}\right)^{2}}
$$

APÊNDICE B-11

$\mathrm{R}^{2}$ não é uma boa medida para avaliar a capacidade de previsão do modelo e também não permite graus de liberdade. Adicionar variáveis pode aumentar o valor de $\mathrm{R}^{2}$, mesmo que a variável seja irrelevante. Uma ideia equivalente é selecionar o modelo que apresente o menor valor dos erros mínimos quadráticos, SSE.

Minimizar o SSE é equivalente a maximizar o $\mathrm{R}^{2}$.

${ }^{144}$ http://www2.hawaii.edu/ fuleky/econ427/5_Multiple_regression.html\#1 


\section{APÊNDICE B.2 $\quad \mathrm{R}^{2}$ ajustado}

Uma alternativa ao $\mathrm{R}^{2}$ é $\mathrm{R}^{2}$ ajustado que busca auxiliar na escolha os previsores, pois o uso de muitos previsores não necessariamente equivale a um bom modelo.

$$
\bar{R}^{2}=1-\left(1-R^{2}\right) \frac{N-1}{N-k-1}
$$

APÊNDICE B-12

onde $\mathrm{N}$ é o número de observações e $\mathrm{k}$ é o número de previsores. Essa é uma melhoria do $\mathrm{R}^{2}$ que não melhora com o acréscimo de previsores. Maximizar $\bar{R}^{2}$ é equivalente a minimizar a variância estimada, $\hat{\sigma}^{2}$, dos erros previstos:

$$
\hat{\sigma}^{2}=\frac{S S E}{N-k-1}
$$

APÊNDICE B-13

Maximizar $\bar{R}^{2}$ funciona, também, como um método de seleção de previsores, embora tenda a errar mais com a escolha de muitos previsores.

APÊNDICE B.3 Critério de Informação de Akaike (AIC)

Os critérios de seleção utilizados foram o AIC (Akaike Information Criterion) proposto por Akaike (1974).

AIC é definido como:

$A I C=N \log \left(\frac{S S E}{N}\right)+2(k+2)$

APÊNDICE B-14

onde $\mathrm{N}$ é o número de observações usado para estimativa e $\mathrm{k}$ é o número de previsores no modelo. A parte $\mathrm{k}+2$ da equação ocorre porque são $\mathrm{k}+2$ parâmetros no modelo, o coeficiente $\mathrm{k}$ para os previsores, o intercepto e variância dos resíduos. O modelo com o menor valor de AIC corresponde ao melhor ajuste do modelo de previsão.

Assintoticamente, minimizar o AIC é minimizar o valor de Validação Cruzada (Cross validation - CV). Isso é verdadeiro para qualquer modelo (STONE, 1977), linear ou não linear. Essa propriedade tornou o AIC útil para selecionar modelos com propósito de previsão.

\section{APÊNDICE B.4 AIC Corrigido $\left(\mathrm{AIC}_{\mathrm{c}}\right)$}

O AICc proposto por Hurvich \& Tsai (1989) para tratar com valores pequenos para N, pois o AIC tende a selecionar muito previsores, assim, uma versão para corrigir o viés é criada:

$A I C_{c}=A I C \frac{2(k+2)(k+3)}{N-k-3}$

APÊNDICE B-15

Como o AIC, o AICc deve ser minimizado. 


\section{APÊNDICE B.5 Critério de Informação Bayesiana Schwarz (BIC)}

O BIC (Bayesian Information Criterion) desenvolvido por Akaike (1998) penaliza a SSE mais que o AIC e, portanto, o modelo escolhido pelo BIC é também o mesmo escolhido pelo AIC, ou outro modelo com menor quantidade de termos.

$$
B I C=N \log \left(\frac{S S E}{N}\right)+(k+2) \log (N)
$$

APÊNDICE B-16

$\mathrm{Na}$ teoria, o BIC busca encontrar um modelo subjacente verdadeiro, mas isso ocorre raramente ou nunca, pois, caso contrário, não seria necessário escolher o melhor modelo de previsão, uma vez que os parâmetros estimados podem não ser precisos.

\section{APÊNDICE B.6 Validação Cruzada}

Como encontrar o erro em todos os pontos do domínio é uma tarefa quase impossível, necessita-se construir um procedimento que permita avaliar a qualidade do ajuste dos modelos para os dados que não se encontram no histórico, e, assim, extrai-se um conjunto de dados do histórico para se calibrar um determinado modelo para ser usado em sua validação. Os procedimentos básicos para verificação dos modelos de previsão são: validação cruzada e validação retroativa.

Na validação cruzada, omite-se um período de informação com tamanho igual ao do período de previsão para um ano específico, o resto da informação utiliza-se na calibração do modelo, logo se elabora previsões para os anos omitidos e, no final, os dados previstos são comparados com os dados históricos a fim de se estimar o erro de ajuste. Exemplo, na Figura APÊNDICE B-2, apresenta-se um arranjo com intervalo de treinamento com ano inicial fixo em 1931 e ano final variando em um ano a cada interação do modelo.

\begin{tabular}{|c|c|c|c|c|c|c|c|c|c|c|c|c|c|c|}
\hline 1931 & $\ldots$ & 1945 & $\rightarrow$ & 1946 & 1950 & & & & & & & & & \\
\hline 1931 & $\ldots$ & $\ldots$ & 1946 & $\rightarrow$ & 1947 & 1951 & & & & & & & & \\
\hline 1931 & $\ldots$ & $\ldots$ & $\ldots$ & 1947 & $\rightarrow$ & 1948 & 1952 & & & & & & & \\
\hline 1931 & $\ldots$ & $\ldots$ & $\ldots$ & $\ldots$ & 1948 & $\rightarrow$ & 1949 & 1953 & & & & & & \\
\hline 1931 & $\ldots$ & $\ldots$ & $\ldots$ & $\ldots$ & $\ldots$ & 1949 & $\rightarrow$ & 1950 & 1954 & & & & & \\
\hline 1931 & $\ldots$ & $\ldots$ & $\ldots$ & $\ldots$ & $\ldots$ & $\ldots$ & 1950 & $\rightarrow$ & 1951 & 1955 & & & & \\
\hline 1931 & $\ldots$ & $\ldots$ & $\ldots$ & $\ldots$ & $\ldots$ & $\ldots$ & $\ldots$ & 1951 & $\rightarrow$ & 1952 & 1956 & & & \\
\hline 1931 & $\ldots$ & $\ldots$ & $\ldots$ & $\ldots$ & $\ldots$ & $\ldots$ & $\ldots$ & $\ldots$ & 1952 & $\rightarrow$ & 1953 & 1957 & & \\
\hline 1931 & $\ldots$ & $\ldots$ & $\ldots$ & $\ldots$ & $\ldots$ & $\ldots$ & $\ldots$ & $\ldots$ & $\ldots$ & $\ldots$ & $\rightarrow$ & $\ldots$ & $\ldots$ & \\
\hline 1931 & $\ldots$ & $\ldots$ & $\ldots$ & $\ldots$ & $\ldots$ & $\ldots$ & $\ldots$ & $\ldots$ & $\ldots$ & $\ldots$ & 2008 & $\rightarrow$ & 2009 & 2013 \\
\hline
\end{tabular}

Figura APÊNDICE B-2 Esquema de validação cruzada k-fold com intervalos de treinamento com o ano inicial fixo em 1931

A Validação cruzada $(\mathrm{CV})$ é uma forma de medir a destreza de predição do modelo através do teste de um conjunto de dados não usados para a estimação. Uma versão de CV muito 
utilizada é a que organização os dados com a separação de pelo menos um registro da amostra de dados fora da validação cruzada (LOOCV) ${ }^{145}$. Também há variações (K-Fold) ${ }^{146}$, onde a série original é aleatoriamente particionada em k sub-amostras e uma ou várias partes são deixadas de fora em cada interação (HYNDMAN, 2010), exemplo Figura APÊNDICE B-3, apresenta-se um arranjo com intervalo de treinamento fixo em 30 anos.

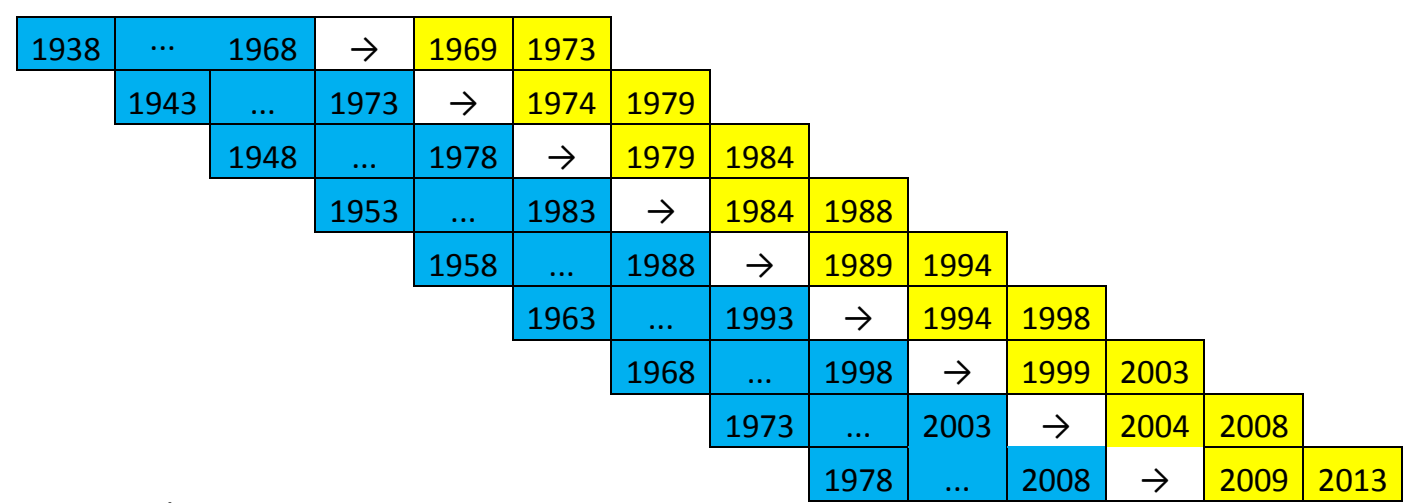

Figura APÊNDICE B-3 Esquema de validação cruzada k-fold com amostras intervalos treinamento fixo em 30 anos

Segundo Hyndman (2010), a Validação Cruzada para séries temporais não permite deixar uma observação intermediária de fora, pois, os dados de uma série temporal não são independentes e também devido a correlação entre observações. Para séries de previsão de tempo, uma estatística de Validação Cruzada é obtida com o seguinte algoritmo:

- Ajustar o modelo para $y_{1}, \ldots, y_{t}$ e fazer a previsão $\hat{y}_{t+1}$ e comparar com o observado. Então calcular o erro $\left(e_{t+1}^{*}=y_{t+1}-\hat{y}_{y+1}\right)$ para a previsão.

- Repetir o passo 1 até $\mathrm{t}=\mathrm{m}, \ldots, \mathrm{n}-1$, onde $\mathrm{m}$ é o número mínimo de observações necessárias para o ajuste do modelo.

- Calcular o MSE para $e_{t+1}^{*}, \ldots, e_{n}^{*} \mathrm{O}$ menor MSE corresponde ao modelo que apresenta melhor acurácia.

\footnotetext{
145 Leave-one-out cross-validation (LOOCV)

${ }^{146} \mathrm{~K}$-fold cross-validation
} 


\section{APÊNDICE C Correlação de Pearson}

A correlação entre duas variáveis x e y é uma medida da variação conjunta dessas variáveis. O coeficiente de correlação é indicado pela letra $r$, sendo um adimensional que varia entre -1 e +1 . No caso de não haver correlação, $r=0$. Quando $r>0$, a correlação é positiva e uma variável aumenta quando a outra cresce; quando $r<0$, a correlação é negativa, ou seja, as variáveis variam em direções opostas. O coeficiente de correlação de Pearson é calculado da seguinte forma:

$r=\frac{\sum_{i=1}^{n}\left(x_{i}-\bar{x}\right)(y i-\bar{y})}{\sum_{i=1}^{n}\left(x_{i}-\bar{x}\right)^{2} \sum_{i=1}^{n}\left(y_{i}-\bar{y}\right)^{2}}$

APÊNDICE C-17

em que $\bar{x}$ e $\bar{y}$ são valores das médias dos valores das variáveis de $\mathrm{x}$ e y. Por exemplo, na análise da correlação entre vazões ENA-SE e variável Temperatura de Superfície do Mar (TSM) na região El Niño $1+2$, as vazões correspondem às varáveis $\mathrm{x}_{\mathrm{i}}$, enquanto as TSM correspondem às variáveis yi na equação 1-17.

APÊNDICE C.1 Testes de hipóteses sobre coeficiente de correlação

O método padrão para medir-se o "significado" de análises empíricas é o valor p. Suponha-se que a relação entre a altura e a inteligência das pessoas seja significativa; então começa-se com a "hipótese nula", que, nesse caso, é a declaração:

"altura e inteligência de pessoas não estão relacionadas".

$\mathrm{O}$ valor de $\mathrm{p}$ ( $\mathrm{p}$-value) é um número entre 0 e 1 que representa a probabilidade de que esses dados teriam surgido se a hipótese nula fosse verdadeira. Um valor baixo de p (como 0,01$)$ é tomado como evidência de que a hipótese nula pode ser "rejeitada". Os estatísticos dizem que um valor p de 0,01 é "altamente significativo" ou que "os dados são significativos ao nível de 0,01 ".

O teste de hipótese para o coeficiente de correlação apresenta as hipóteses nula e alternativa como a seguir (PINTO, 2007, p. 361):

$\mathrm{h}_{0}: \rho=0$

$h_{1}: \rho=1$

E para testar a distribuição estatística utiliza-se o seguinte:

$t_{0}=\frac{r \sqrt{n-2}}{\sqrt{n-r^{2}}}$

APÊNDICE C-18

em que,

$t_{0}$ é a estatística do teste;

$n$ é o tamanho da amostra e 
$r$ é a estimativa do coeficiente de correlação linear.

A estatística do teste, $\mathrm{t}_{0}$, segue uma distribuição t de Student com (n-2) graus de liberdade. A hipótese nula $h_{0}: \rho=0$ é rejeitada se:

$\left|t_{0}\right|>t_{\alpha / 2, n-2}$

APÊNDICE C-19

em que, $t_{\alpha / 2, n-2}$ é o valor crítico para a estatística do teste bilateral para um nível de significância $\alpha$, com (n-2) graus de liberdade.

APÊNDICE C.2 Comando stats::cor.test()

No pacote R, a análise da correlação de Pearson pode ser feita utilizando o comando 'cor'. Para realizar o cálculo da correlação de Pearson das séries utiliza-se o comando stats::ccf() encontrado no pacote estatístico R. Para os testes de hipóteses utiliza-se o comando stats::cor.test(). 


\section{APÊNDICE D Função de autocorrelação (ACF)}

A autocorrelação é a medida da relação linear entre uma série histórica e seus valores atrasados. Há vários coeficientes de autocorrelação e sua quantidade depende do tamanho do número de atrasos. Por exemplo, r1 mede a relação entre yt-1, r2 mede a relação entre yt e yt2, e, assim por diante.

O valor de rk pode ser definido como:

$r_{k}=\frac{\sum_{t=k+1}^{T}\left(y_{t}-\bar{y}\right)\left(y_{t-k}-\bar{y}\right)}{\sum_{t=1}^{T}\left(y_{t}-\bar{y}\right)^{2}}$

APÊNDICE D-20

em que

$\bar{y}$ é a média da série temporal;

k é a defasagem da autocorrelação;

T é tamanho da série temporal.

Um exemplo de ACF pode ser visto na Figura APÊNDICE D-4. Para gerar esse gráfico da ENA-SE foi utilizado o comando do R astsa::lag1.plot(ts_ena_se, max.lag=9).
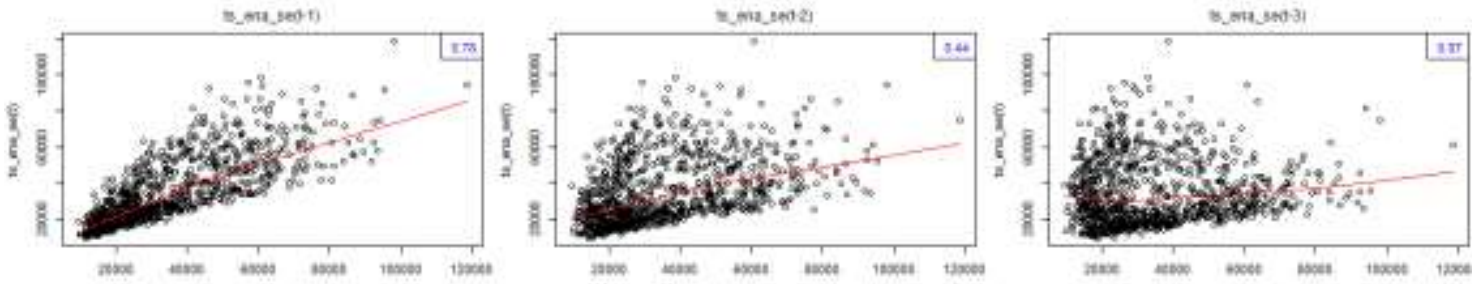
s-ine-6ont

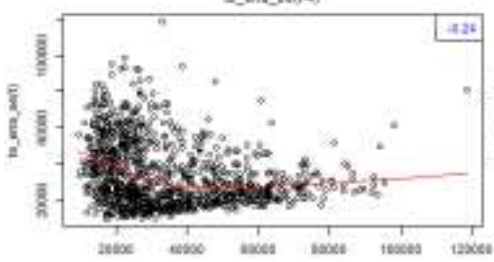
Sina-ions sinumati
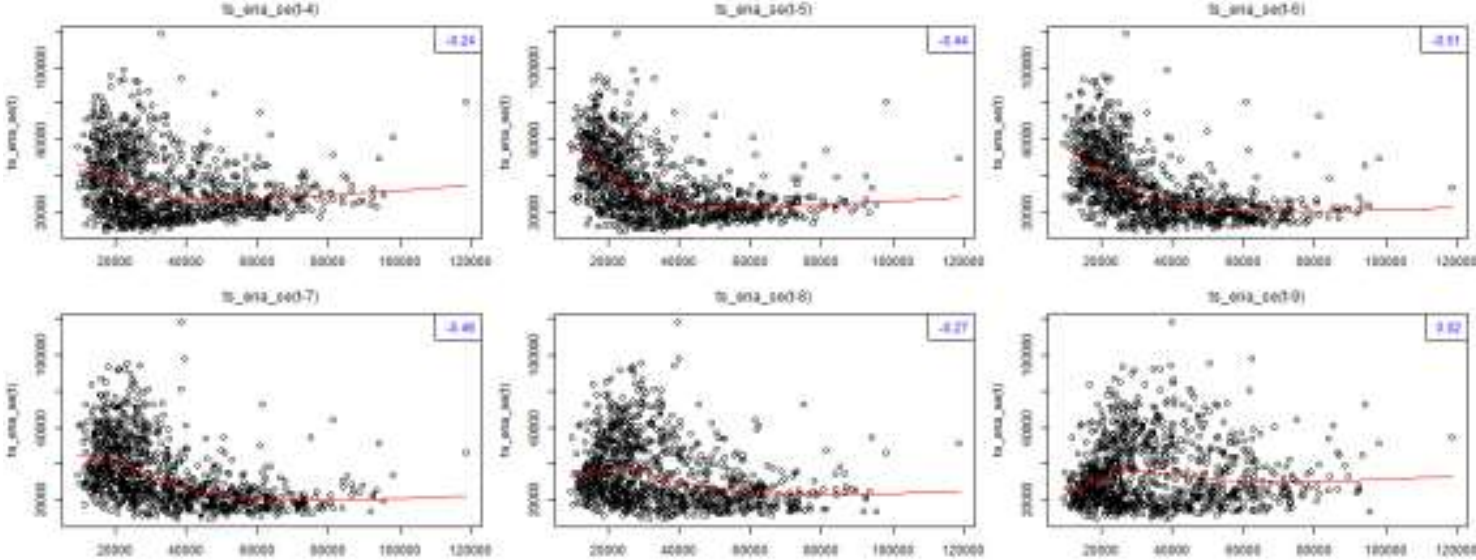

Figura APÊNDICE D-4 Exemplo de autocorrelação da série histórica ENA-SE 
APÊNDICE D.1 Análise de Correlação Cruzada

Uma relação linear entre dois conjuntos de dados pode ser obtida através da análise da função de correlação cruzada $\left(\mathrm{CCF}^{147}\right)$. O coeficiente da $\mathrm{CCF}$ pode ser obtido calculando a seguinte relação

$\rho_{y}(k)=\frac{E\left[\left(x_{t}-\mu_{x}\right)\left(y_{t+k}-\mu_{y}\right)\right]}{\sigma_{x} \sigma_{y}}$

APÊNDICE D-21

em que $\rho_{y}(k)$ é a correlação cruzada no tempo de atraso k entre duas séries temporais, $x_{t} \mathrm{e} y_{t}$ são as séries temporais com sua média $\mu_{x} e \mu_{y} \sigma_{x} \sigma_{y}$ são respectivos desvios padrões. As correlações são significativas ao nível de confiança de $95 \%$, onde foram consideras aquelas maiores que o erro padrão de $\frac{1,96}{\sqrt{n}}$, onde $n$ é o número de valores no conjunto de dados. Isso equivale ao teste de hipótese de não correlação e assume que a variância é finita, distribuição normal e em torno da média zero.

Um exemplo de CCF pode ser visto na. Para gerar esse gráfico de correlação cruzada no pacote $\mathrm{R}$ foi utilizado o comando astsa::lag2.plot().
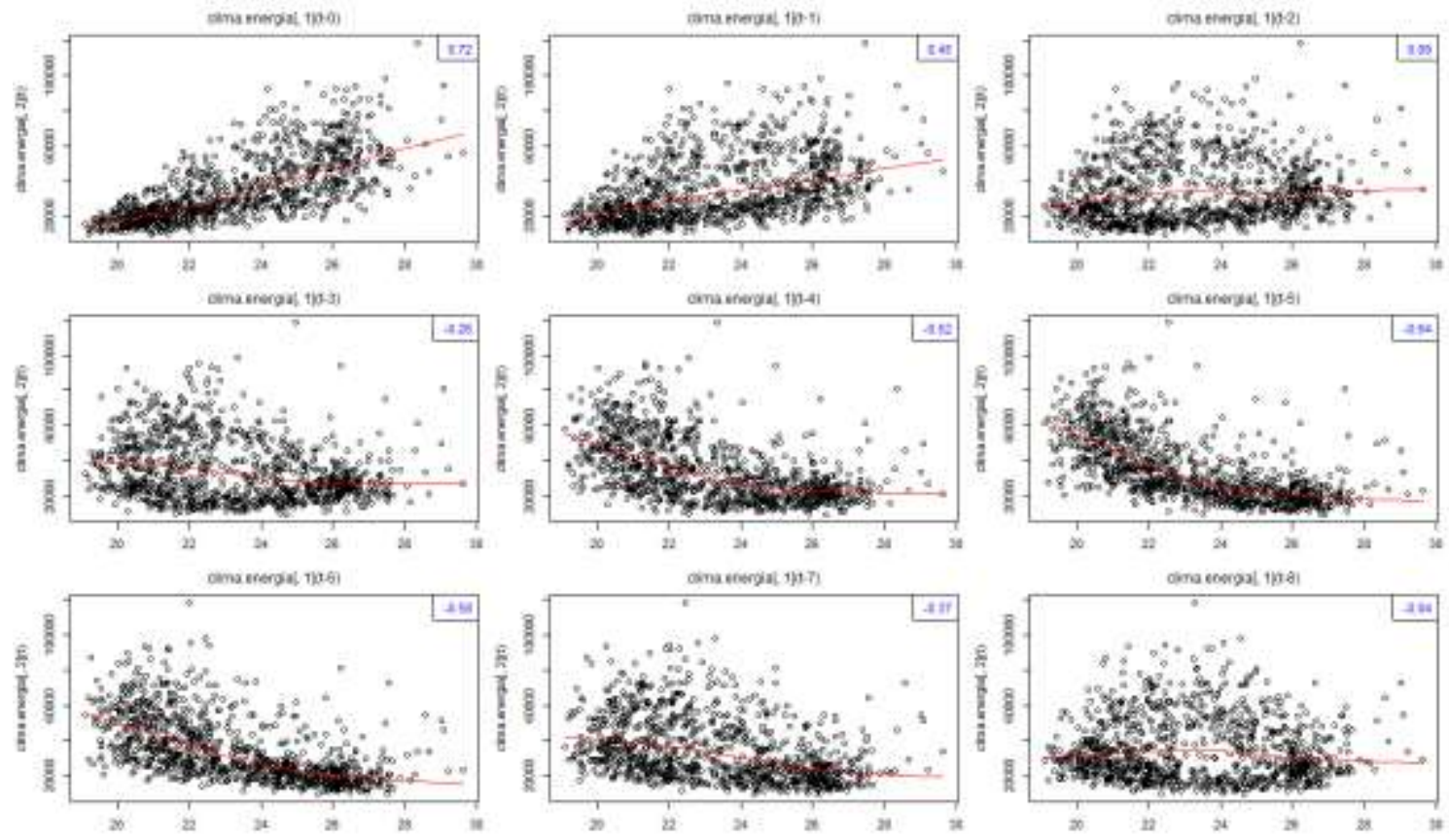

Figura APÊNDICE D-5 Exemplo de correlação cruzada das séries históricas NINO1+2 e ENA-SE

${ }^{147}$ Cross-Correlation Function - CCF 
APÊNDICE E Causalidade de Granger

APÊNDICE E.1 Correlação e Causalidade

A capacidade de reconhecimento de padrões pelos seres humanos serve a um propósito: permite avaliar situações e tomar decisões rapidamente com base em informações limitadas. Há um alto custo para adquirir-se informações relevantes, e o mais comum é que confiar no reconhecimento de padrões. O custo de obtenção de informações suficientes para reconhecer um padrão e tomar uma decisão razoável (embora possivelmente incorreta) pode ser é muito menor do que o custo de obtenção de informação suficiente para tomar a decisão com certeza absoluta, (DAVIES, 2007).

As correlações que são o resultado do acaso conduzem a correlação espúria no lugar da causalidade. Todos os fenômenos que são causais estão correlacionados, mas nem todos os fenômenos que estão correlacionados são causais. A correlação é espúria na medida em que é o resultado do acaso e não o resultado de um mecanismo causal subjacente. Por que importa que a correlação seja espúria? Porque, espera-se tomar decisões com base na correlação observada, então é importante não só a correlação existir, mas também para ela a persistir no futuro. Correlações espúrias geralmente não persistem no futuro. Assim o conceito de causalidade se resumo na capacidade de uma variável auxiliar na previsão do comportamento de outra variável de interesse. Uma maneira de verificar se há relação de causa segundo Granger é o teste de não causalidade.

APÊNDICE E.2 Causalidade de Granger

A causalidade, no sentido definido pela Granger (1969) e Sims (1972, Apud GREENE, 2003, p. 382) é demonstrado quando valores defasados de uma variável, digamos $\mathrm{x}_{\mathrm{t}}$, tem poder explicativo em uma regressão de uma variável $\mathrm{y}_{\mathrm{t}}$ sobre valores defasados de $\mathrm{y}_{\mathrm{t}} \mathrm{e} \mathrm{x}_{\mathrm{t}}$, ou seja, a causalidade de Granger (uma espécie de retorno estatística) está ausente quando $\mathrm{f}\left(\mathrm{x}_{\mathrm{t}} \mid \mathrm{x}_{\mathrm{t}-1}, \mathrm{y}_{\mathrm{t}-}\right.$ 1) é igual a $f\left(x_{t} \mid x_{t-1}\right)$. A definição afirma que na distribuição condicional, valores defasados de $y_{t}$ não acrescentam informações a explicação dos movimentos de $\mathrm{x}_{\mathrm{t}}$ além da fornecida por valores defasados de $\mathrm{x}_{\mathrm{t}}$. esse conceito é útil para a construção de modelos de previsão. Finalmente, se $\mathrm{x}_{\mathrm{t}}$ é fracamente exógena e se $\mathrm{y}_{\mathrm{t}-1}$ não causa Granger $\mathrm{x}_{\mathrm{t}}$, então $\mathrm{x}_{\mathrm{t}}$ é fortemente exógena.

A noção de ceteris paribus, o que significa "outros fatores (relevantes) são iguais" desempenha um papel importante na análise causal. (WOOLDRIDGE, 2009, p. 12), em economia muitos fatores são ceteris paribus por natureza. Por exemplo, ao analisar-se a demanda dos consumidores, o efeito de mudanças na quantidade demandada devido a 
alteração do preço de um bem ocorre enquanto mantém-se todos os outros fatores fixados, tais como o rendimento, preços de outros bens e gostos individuais. Se outros fatores não são mantidos fixos, então não identifica-se se o efeito causal de uma mudança de preço na quantidade demandada.

As variáveis y e x possuem diferentes nomes usados alternadamente, como se segue: y é chamada a variável dependente, a variável dependente, a variável resposta, a variável prevista, ou o regressa; x é chamado a variável independente, a variável explicativa, a variável de controle, a variável previsora, ou regressora. ( $\mathrm{O}$ termo co-variável também é usado para $\mathrm{x}$.) Os termos "variável dependente" e "variável independente" são frequentemente utilizados em econometria. Mas "independente" aqui não refere-se à noção estatística de independência entre variáveis aleatórias (WOOLDRIDGE, 2009, p. 23).

Os termos variáveis "dependente" e "explicativa" são provavelmente os mais descritivos. Os termos variáveis "resposta" e "controle" são usadas principalmente nas ciências experimentais, onde a variável x está sob o controle do experimentador. Nós não vamos usar os termos "variável prevista" e "variável previsora", embora às vezes você vê-los em aplicações que são puramente sobre previsão e não causalidade. A nossa terminologia para a regressão simples está resumida na Tabela APÊNDICE E.1.

Tabela APÊNDICE E.1 Terminologia de uma regressão simples (WOOLDRIDGE, 2009, p. 23)

\begin{tabular}{|c|c|}
\hline Y & $\mathrm{X}$ \\
\hline Variável dependente & Variável independente \\
\hline Variável explicativa & Variável explanatória \\
\hline Variável resposta & Variável de controle \\
\hline Variável prevista & Variável previsora \\
\hline Variável regressa & Variável regressiva \\
\hline
\end{tabular}

A distinção entre "exógena" e variáveis "endógenas" em um modelo é um problema sutil e por vezes controversas. Assim, em um modelo de oferta e demanda, a variável tempo em uma equação de oferta parece, obviamente, ser exógeno em um sentido puro para a determinação do preço e quantidade, ao passo que o preço atual é claramente "endógeno" por qualquer construção razoável. Infelizmente, essa classificação pura é de uso bastante limitado em macroeconomia, onde quase nenhuma variável pode ser dita ser verdadeiramente exógena na forma que a maioria dos observadores entendam o termo. Uma segunda forma de exogeneidade é considerar a exogeneidade forte, que é algumas vezes chamada de não 
causalidade de Granger. Na não causalidade Granger os valores defasados de $x_{t}$ não fornecem informações sobre a média condicional de yt uma vez os valores defasados de yt, em si, são contabilizados.

A Causalidade de Wiener-Granger é definida em termos de previsibilidade, definição não aceita para o sentido filosófico. A causalidade de Wiener-Granger é consistente com definições formais fornecidas pelos filósofos das ciências como uma questão aberta. Algumas definições afirmam que "causa" é semelhante em significado a "força" ou "produção", as quais não são sinônimos com "previsão". Talvez a definição mais próxima para causalidade de Wiener-Granger é a de Feigl em que "causalidade é definida em termos de previsibilidade de acordo com uma lei" (FEIGL. 1953, p.408, Apud. GRILICHES \& INTRILIGATOR, 2007).

A utilidade do conceito da causalidade de Wiener-Granger está na concepção, construção, estimação e manipulação de modelo e é independente de sua consistência ou inconsistência com definições formais (GRILICHES \& INTRILIGATOR, 2007). 


\section{APÊNDICE E.3 Exemplo teste de Granger}

Para explicar o teste Granger considera-se a pergunta: a variação de TSM na região NINO1+2 causa, no sentido de Granger, a variação de ENA da região SE/CO NINO1+2 $(\mathrm{NINO} 1+2 \rightarrow$ ENA SE/CO), ou a variação da ENA SE/CO causa a variação de TSM da região $\mathrm{NINO} 1+2($ ENA $\mathrm{SE} / \mathrm{CO} \rightarrow \mathrm{NINO} 1+2)$, em que a seta indica a direção da causalidade. O teste de causalidade de Granger pressupõe que a informação relevante para a previsão das respectivas variáveis NINO1+2 e ENA SE/CO, está contida unicamente nos dados da série temporal dessas variáveis. O teste envolve a estimação do seguinte par de regressões:

$$
\begin{array}{c|c|}
N I N O 12_{t}=\sum_{i=1}^{n} \alpha_{i} E N A_{-} S E_{-} C O_{t-i}+\sum_{j=1}^{n} \beta_{j} N I N O 12_{t-j}+u_{1 t} & \text { APENDICE E-22 } \\
E N A_{S E_{C O} t}=\sum_{i=1}^{n} \lambda_{i} E N A_{S E_{C O} t-i}+\sum_{j=1}^{n} \delta_{j} N I N O 12_{t-j}+u_{2 t} & \text { APÊNDICE E-23 }
\end{array}
$$

Em que se pressupõe os distúrbios $u_{1 \mathrm{t}}$ e $\mathrm{u}_{2 \mathrm{t}}$ não estão correlacionados. A equação 1-1 postula que NINO1+2 está relacionado aos seus próprios valores passados, bem como ao de ENASE/CO, e equação 1-2 postula um comportamento semelhante para ENA-SE/CO. Assim observa-se quatro casos seguintes (adaptado de GUJARATI e PORTER, 2009):

Uma causalidade unidirecional de ENA_SE_CO e NINO1+2 é indicada se os coeficientes estimados do ENA_SE_CO, defasados em APÊNDICE E-22 são, como um grupo, estatisticamente diferentes de zero, (ou seja, $\sum \alpha_{i} \neq 0$ ) e o conjunto dos coeficientes estimados de NINO1+2 defasado em APÊNDICE E-23 não são estatisticamente diferentes de zero (ou seja, $\left.\sum \delta_{\mathrm{i}}=0\right)$.

No sentido inverso, existe uma causalidade unidirecional NINO1+2 e ENA_SE_CO se o conjunto de coeficientes defasados de ENA_SE_CO em 1-1 não é diferente, do ponto de vista estatístico, de zero (ou seja, $\sum \alpha_{\mathrm{i}}=0$ ) e o conjunto de coeficientes defasados do NINO1+2 em APÊNDICE E-23 é estatisticamente diferente de zero (ou seja, $\sum \delta_{i} \neq 0$ ).

Uma causalidade bilateral ou feedback é sugerida quando os conjuntos de coeficientes de NINO1+2 e ENA_SE_CO estatisticamente diferentes de zero nas duas regressões encontradas em APÊNDICE E-22 e APÊNDICE E-23.

Finalmente, há independência quando os conjuntos de coeficientes de NINO1+2 e ENA_SE_CO não são estatisticamente significativos em nenhuma das regressões. 
De modo mais geral, uma vez que o futuro não pode prever o passado, se a variável $\mathrm{X}$ (Granger) causa a variável $\mathrm{Y}$, então variações em $\mathrm{X}$ deveriam preceder variações em $\mathrm{Y}$. Portanto, em uma regressão de Y contra outras variáveis (incluindo seus valores passados), se incluímos valores passados ou defasados de $\mathrm{X}$ e eles melhoram significativamente a previsão de $Y$, então podemos dizer que X (Granger) causa Y. Uma definição similar se aplica se Y (Granger) causa X (GUJARATI e PORTER, 2009).

As etapas envolvidas na aplicação do teste de causalidade Granger são apresentadas a seguir. Essas etapas têm como base a equação APÊNDICE E-22, (adaptado de GUJARATI e PORTER, 2009):

1. Calcule a regressão de NINO1+2 contra todos os termos do NINO1+2 defasados e outras variáveis, se houver, mas não inclua as variáveis defasadas de ENA_SE_CO nessa regressão. Essa é uma regressão restrita. A partir dela, obtenha soma dos quadrados dos resíduos, $\mathrm{SQR}$.

2. Agora calcule a regressão incluindo os termos de ENA_SE_CO defasados. Essa regressão é sem restrições. A partir dessa regressão, obtenha a SQR ${ }_{U R}$.

3. A hipótese nula é $h_{0}: \sum \alpha_{i}=0$, ou seja, os termos de ENA_SE_CO defasados não cabem na regressão.

4. Para testar essa hipótese, aplique o teste F dados por APÊNDICE E-24, a seguir:

\begin{tabular}{|l|l|}
\hline$F=\frac{\left(S Q R_{R}-S Q R_{U R}\right) / m}{S Q R_{U R}(n-k)}$ & APÊNNDICE E-24 \\
\hline
\end{tabular}

Que segue a distribuição F com m e (n-k) graus de liberdade. No presente caso, m é igual ao número de termos de ENA_SE_CO e k é o número do parâmetros estimados na regressão sem restrição.

5. Se o valor de F calculado for superior ao valor crítico de F no nível de significância selecionado, rejeite-se a hipótese nula e, nesse caso, os termos de ENA_SE_CO defasados cabem na regressão. É outra forma de dizer que a variação de ENA_SE_CO causa a variação do NINO1+2.

6. As etapas de 1 a 5 podem ser repetidas para testar o modelo APÊNDICE E-23, ou seja, para testar se a variação do NINO1+2 causa a variação de ENA_SE_CO.

Antes de ilustrar o teste de causalidade Granger, há vários aspectos que cabe destacar:

1. Supõe-se que as duas variáveis, NINO1+2 e ENA_SE_CO são estacionárias.

2. O número de termos defasados a serem incluídos nos testes de causalidade é uma questão de grande importância prática. Como no caso dos modelos de defasagens distribuídas, pode ser necessário recorrer aos critérios de informação de Akaike ou de Schwarz para fazer a escolha. Mas cabe acrescentar que a direção da causalidade pode depender fundamentalmente do número de termos defasados incluídos.

3. Supõe-se que os termos de erro que entram no teste de causalidade não estão correlacionados. 
4. Como o objetivo é testar a causalidade, não é necessário apresentar os coeficientes estimados dos modelos explicitamente, os resultados do teste F são suficientes.

Antes de serem tratadas as séries, é feita a intersecção entre as duas séries para que as datas fiquem no mesmo período de tempo, 1931 a 2013, pois ENA_SE_CO tem o menor período e os períodos não correspondentes de NINO1+2 são desconsiderados.

No teste as variáveis são verificadas para determinar se são estacionárias ou não. Com esse objetivo utiliza-se o comando ndiffs() do pacote estatístico $\mathrm{R}$ e identifica-se que ENA_SE_CO necessita de diferenças, o comando retorna a quantidade necessária. Também utiliza-se o comando nsdiffs() para identificar as diferenças necessárias para a parte sazonal. Uma vez feita a identificação da quantidade de diferenças para tornar as séries estacionárias, quando necessário.

Para efeito das avaliações de causalidade em Granger Nessa tese, os testes são realizados com a aplicação da função lmtest::grangertest() encontrada no pacote estatístico R. Um exemplo utilizado para apresentar essa função é encontrado no trabalho de Thurman e Fischer (1988) onde empregam o teste no famoso problema: "quem vem primeiro, o ovo ou a galinha?" 


\section{APÊNDICE F Decomposição de Séries Históricas}

Os modelos de séries temporais buscam representar uma forma ou estrutura interna que os dados ordenados através do tempo possuem (a persistência, a tendência e a variação estacional) o que permite elaborar um prognóstico. Na modelagem da trajetória dinâmica de uma variável, pode-se melhorar as previsões mediante a projeção da estrutura interna. A primeira aproximação aos modelos estocásticos é denominada processos autorregressivos.

O propósito dos métodos de suavização é distinguir o padrão de qualquer ruído que possa estar contido nas observações e, então, usar esse padrão para prever valores futuros da série. Isso significa, de maneira geral, obter os componentes de tendência e sazonalidade.

O procedimento de decomposição estacional e tendencial (Seasonal-Trend Decomposition Procedure - STL) com base no algoritmo Local Polynomial Regression Fitting - Loess (CLEVELAND ET. AL, 1990, 1992) é um procedimento de filtro para decompor a série do tempo em três componentes: Tendência, Sazonalidade e Resíduo. Supondo a série de dados, os componentes de tendência, estacionariedade e resíduo são $Y_{t}, T_{t}, S_{t}$ e $R_{t}$, respectivamente, então:

$Y_{t}=T_{t}+S_{t}+R_{t}$

APÊNDICE F-25

A STL consiste em uma sequência de operações de suavização, cada uma delas, a exceção de uma, utiliza a mesma suavização que é uma regressão localmente ponderada (locallyweighted regression) ou loess. 


\section{APÊNDICE G Wavelets (Ondaletas) ${ }^{148}$}

Nesse trabalho, é utilizado um pacote de análise estatístico com wavelets e suas referências são Grinsted e Jevrejeva (2004), Jevrejeva et al (2003), Torrence e Campo 1998 e Torrence e Webster (1999).

O trabalho de Fayal (2008) apresenta uma pesquisa sobre wavelets. Segundo sua interpretação, Jean Baptiste Joseph Fourier (1807) foi o um dos primeiros a lidar com wavelets através de sua análise de frequências. Fourier afirmou que qualquer função periódica $\mathrm{f}(\mathrm{x})$ pode ser expressa como uma soma de senos e/ou cosenos chamada série de Fourier:

$f(x)=a_{0}+\sum_{-\infty}^{+\infty}\left(a_{k} \cos k x+b_{k} \operatorname{sen} k x\right)$

APÊNDICE G-26

A transformada de Fourier é o procedimento matemático que quebra uma função nas frequências que a compõem, de forma similar a um prisma que decompõe a luz do sol em todas as cores, formando, assim, o arco-íris. Ela transforma uma função f de $t$ (tempo) em uma função $\mathrm{F}$ de $\mathrm{k}$ (frequência). Essa nova função é chamada de transformada de Fourier da função (ou, quando a função original é periódica, sua série de Fourier). Para funções ou sinais que variam com o tempo - música, por exemplo, ou as flutuações do mercado de ações- a frequência é mais comumente medida em Hertz, ou ciclos por segundo (FAYAL, 2008).

Diferente das transformadas de Fourier, as transformadas por wavelets (ondaletas) correspondem a uma decomposição de série no duplo domínio tempo-frequência, permitindo a determinação dos principais modos de variabilidade, bem como a forma como estes variam no tempo (MORAIS, SILVA E SANTOS, 2009). Na Figura APÊNDICE G-6 apresenta-se um exemplo da transformação da janela, ou parte de um sinal (a), em um novo sinal a partir da combinação de valores com uma wavelet do tipo Morlet, representada em (b), através de um processo chamado convolução ${ }^{149}$ (TORRENCE e COMPO,1998). O produto resultante gera uma nova função e a área delimitada por essa nova função é o coeficiente wavelet. Em (c) há uma superposição quase perfeita de (b) em relação a uma seção da função tratada, o produto das duas (d) é sempre positivo, pois assumem valores positivos e negativos ao mesmo tempo. Em (e) há um deslocamento da função wavelet, cujo produto de (b) e (e) origina a curva (f) que apresenta áreas negativas (abaixo do eixo das abscissas) e áreas positivas (acima do eixo

\footnotetext{
${ }^{148}$ Maior detalhes sobre análise de Fourier e Wavelets pode ser encontrado no trabalho de Fayal (2008) item 3.3 Wavelets pg. 55 no repositório http://www.maxwell.vrac.puc-rio.br/acessoConteudo.php?nrseqoco=39578. Acesso em 29/09/2015

${ }^{149}$ Convolução é o nome dado a uma operação matemática entre dois sinais, cuja saída é um terceiro sinal e as operações envolvidas são multiplicações e somas. Fonte: http://www.maxwell.vrac.pucrio.br/21581/introducao.html Acesso em 20/01/2015.
} 
das abscissas), fazendo então com que o coeficiente wavelet (igual à soma dessas áreas) seja pequeno. Um sinal pode ser analisado em diferentes escalas, usando wavelets de diferentes larguras.

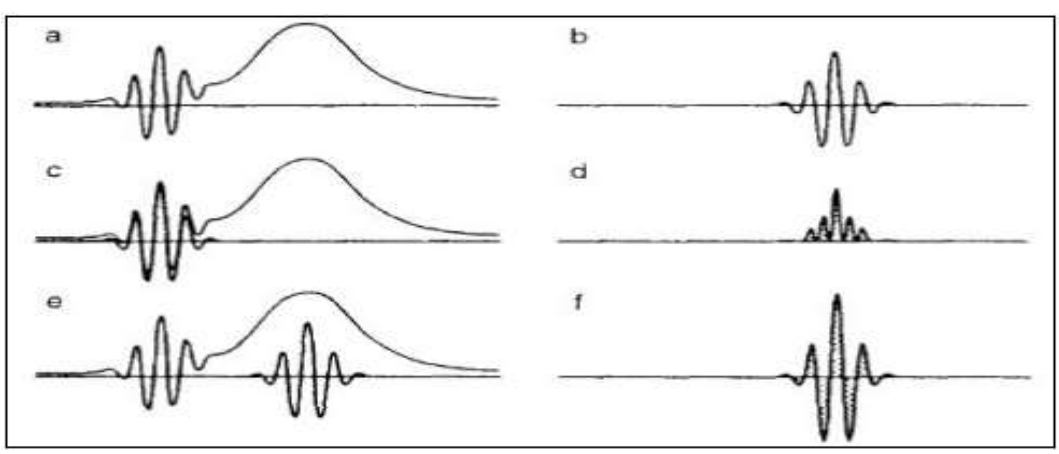

Figura APÊNDICE G-6 Produto uma função de um sinal em (a) pelo sinal da wavelet (b), gerando sinais resultantes (d) e (f), cujas áreas são os coeficientes wavelets. Fonte: (FAYAL, 2008).

Na Figura APÊNDICE G-7, apresentam-se em a) a série original para as vazões da usina de Porto Primavera, compreendidos no período de 1931 a 2014; em b) mostra a potência (valor absoluto ao quadrado) da transformada wavelet e identifica as frequências presentes na série no domínio do tempo; em c) é possível analisar a magnitude do espectro, mantendo a localização temporal e observa-se maior destaque na cor vermelha na faixa de 1 ano e, também, entre as faixas de 8 e 16 anos, o que demonstra existir nessa série com um forte sinal anual; d) a variação dos espectros no período de 8-16 anos possibilita a identificação de períodos secos e chuvosos, ou seja, quando o espectro decresce substancialmente temos a representação de anos secos, enquanto para valores substancialmente maiores, temos a representação de anos chuvosos. Por exemplo, um período seco pode ser identificado entre os anos de 1960 a 1973, enquanto os anos de 1980 e 2005, apresentam-se como anos chuvosos. 

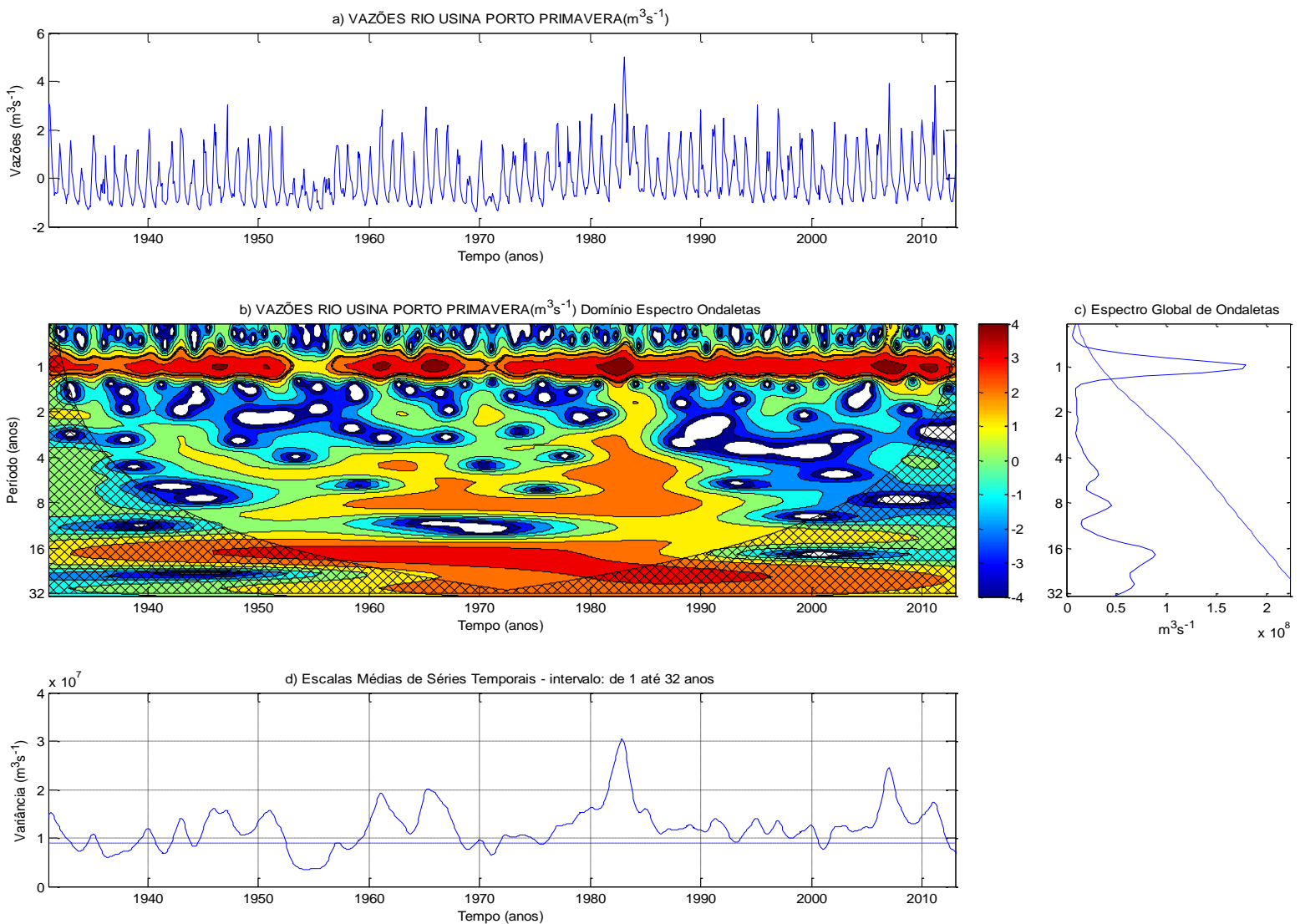

Figura APÊNDICE G-7 Exemplo de wavelet vazões da Usina de Porto Primavera. a) Série original $\mathrm{m}^{3} \mathrm{~s}^{-1} 1931$ a 2013 b) Domínio de espectro de ondaletas c) Espectro global da ondaletas. d) Série temporal de escala média para faixa de 1-32 anos.

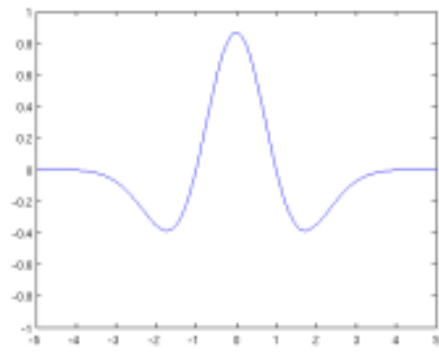

a)

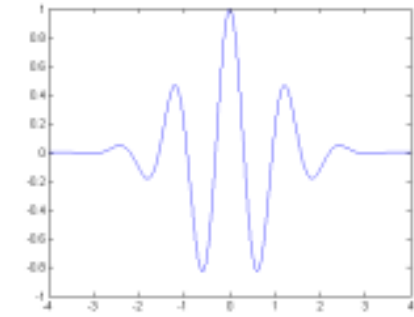

b)

Figura APÊNDICE G-8 a) wavelet "Chapéu Mexicano" b) wavelet Morlet

Nesse trabalho, é utilizada a wavelet de Morlet, Figura APÊNDICE G-8, que é uma função exponencial complexa onde t é o tempo, s é a escala da wavelet, $\omega$ é uma frequência não dimensional considerada, conforme utilizado em Compagnucci et al (2014).

A função wavelet de Morlet tem a seguinte característica, equação APÊNDICE G-27:

$\psi(t)=e^{-t^{2}} \cos \left(\pi t \sqrt{\frac{2}{\ln 2}}\right) \approx e^{-t^{2}} \cos (2.885 \pi t)$ 


\section{APÊNDICE G.1 Transformada cross wavelet}

A transformada cross wavelet (XWT) de duas séries cronológicas $\mathrm{X}$ e $\mathrm{Y}$, com valores de $\mathrm{X}_{\mathrm{n}} \mathrm{e}$ $\mathrm{Y}_{\mathrm{n}}$, respectivamente, conforme definido por Jevrejeva et al (2003) é $\mathrm{W}^{\mathrm{XY}}=\mathrm{W}^{\mathrm{X}} \mathrm{W}^{\mathrm{Y}^{*}}$. O argumento complexo $\arg \left(\mathrm{W}^{\mathrm{XY}}\right)$ pode ser interpretado como a fase relativa entre $\mathrm{X}_{\mathrm{n}}$ e $\mathrm{Y}_{\mathrm{n}}$, no domínio espaço, tempo-frequência. A distribuição teórica da cross wavelet de duas séries temporais com espectros de potência $\mathrm{P}_{\mathrm{k}}{ }^{\mathrm{X}}$ e $\mathrm{P}_{\mathrm{k}}^{\mathrm{Y}}$, segundo Torrence e Compo (1998), é dada por:

$\mathrm{D}\left(\frac{W_{n}^{X}(s) W_{n}^{Y} *(s)}{\sigma_{X} \sigma_{Y}}<p\right)=\frac{Z_{v}(p)}{v} \sqrt{P_{k}^{X} P_{k}^{X Y}}$

APÊNDICE G-28

em que $Z_{v}(p)$ é o nível de confiança associado à média. Dessa forma, o desvio padrão circular é definido por:

$s=\sqrt{-2 \ln \left(\frac{R}{n}\right)}$

APÊNDICE G-29

e também $R=\sqrt{X^{2}+Y^{2}}$ O desvio padrão circular é análogo ao desvio padrão linear, na medida em que varia de zero ao infinito, sendo obtidos resultados bastante semelhantes para os dois quando os ângulos são distribuídos em torno do ângulo médio.

No estudo sobre a influência dos fenômenos El Niño e La Niña sobre as vazões das usinas, faz-se necessário a análise através da cross wavelet, visto tratar-se de uma ferramenta capaz de examinar as relações de frequência existentes no domínio espaço-tempo-frequência entre duas séries distintas, Figura APÊNDICE G-9.

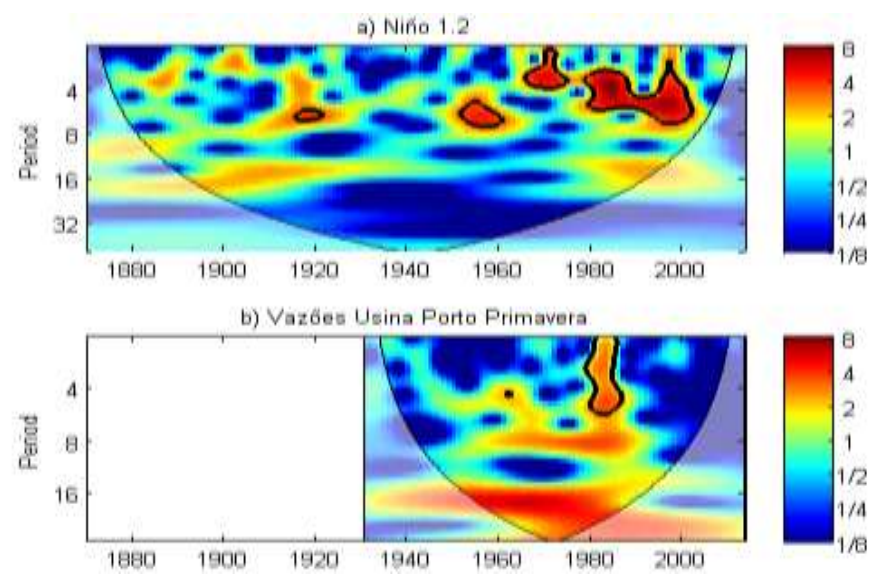

Figura APÊNDICE G-9 Transformada wavelet a) Niño 1+2 b) Vazões Porto Primavera

Na Figura APÊNDICE G-10 traz-se, como exemplo, os resultados obtidos para a análise da cross wavelet correspondentes à Usina de Porto Primavera e às medições de TSM do El Niño 1+2. A relação entre os dados pode ser identificada através da observação do sentido das setas presentes na imagem, quando analisamos os períodos destacados em vermelho, para o nível 
de significância de 5\%. As setas no sentido para a direita indicam que os dois fenômenos estão em fase, as setas para a esquerda indicam que os dois fenômenos estão defasados (em anti-fase), um em relação ao outro, enquanto as setas apontando para baixo (na direção $90^{\circ}$ ) indicam uma forte influência dos eventos El Niño 1+2 sobre as medições de vazões da Usina de Porto Primavera na Figura APÊNDICE G-11. Para auxiliar a interpretação, também é útil o uso da wavelet coherence (WCT), mostrada na Figura APÊNDICE G-11.

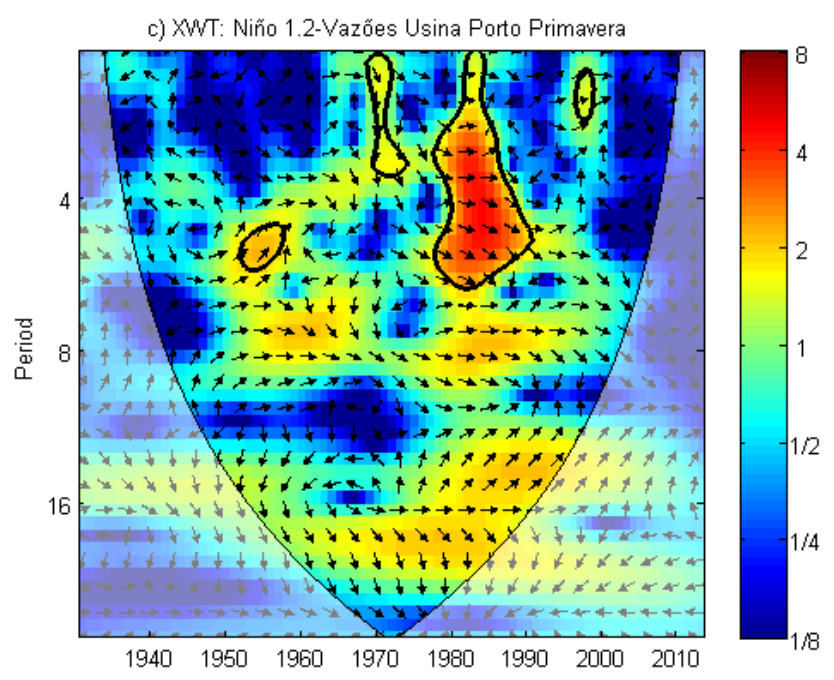

Figura APÊNDICE G-10 Transformada cross wavelet para a precipitação das vazões da Usina de Porto Primavera e as TSM EL Niño 1+2. O nível de significância de 5\% aparece em destaque, na cor vermelha. A relação entre os fenômenos pode ser identificada pelo sentido das setas (com o sentido para a direita indicando que estão em fase, o sentido para a esquerda indicando que estão em anti-fase, ou seja, defasados, e o sentido apontando para baixo mostrando que há forte influência do valor do TSM El Niño 1+2 e medições de vazões da Usina de Porto Primavera)

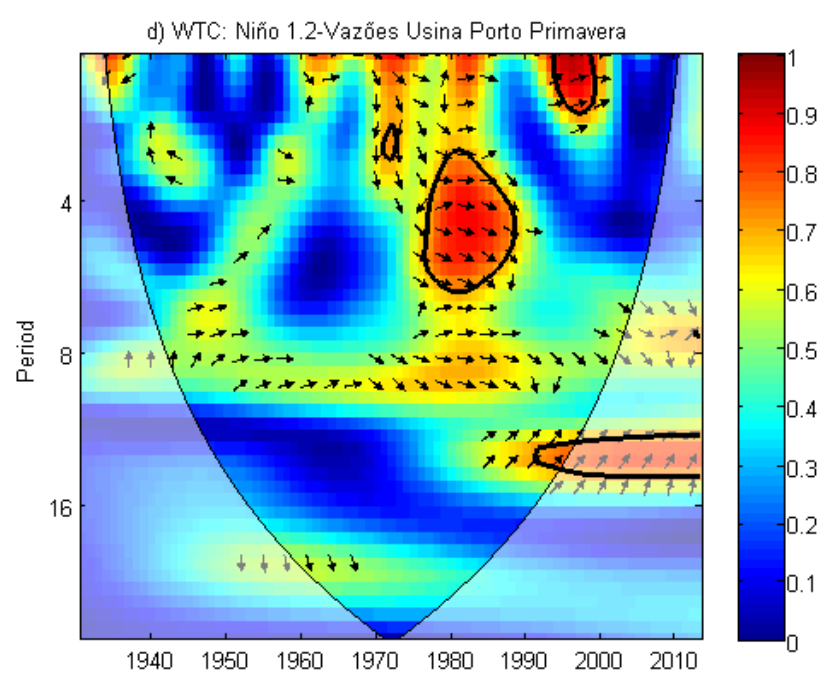

Figura APÊNDICE G-11 Coerência wavelet entre TSM El Niño 1+2 e as vazões Usina de Porto Primavera. O nível de significância de 5\% aparece novamente em vermelho, com o sentido para a direita indicando que estão em fase, o sentido para a esquerda indicando que estão em anti-fase, ou seja, defasados, e o sentido apontando para baixo mostrando que há forte influência do valor do índice TSM NINO 1+2 sobre a média mensal de vazões da usina de Porto Primavera. 


\section{APÊNDICE $\mathrm{H} \quad$ Análise com wavelets}

APÊNDICE H.1 Wavelets número de Manchas Solares

Na Figura APÊNDICE H-12 fez-se um filtro no domínio da frequência de todos os sinais de alta frequência com espectro maior que $1000 \mathrm{MH}$. Nota-se vales bem marcados que coincidem com períodos secos e úmidos no Sudeste brasileiro. O padrão de 11 anos também está marcado pela linha preta com IC de $95 \%$ apesar do filtro e no gráfico d) os anos 80 aparecem com valores superiores na série e no ano 2000 aparecem valores mais baixos.
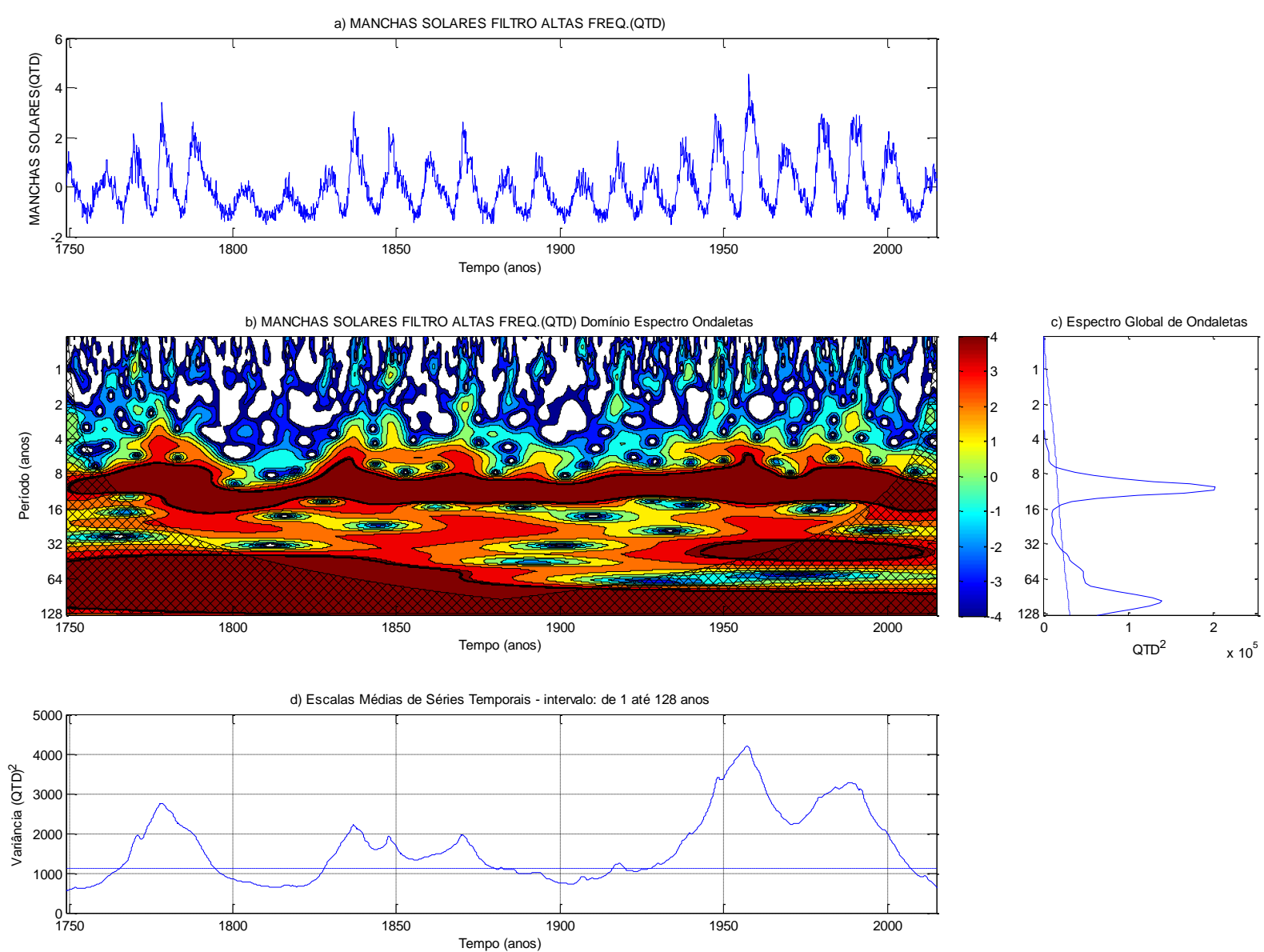

Figura APÊNDICE H-12 Análise por wavelets Manchas Solares por Área com filtro de altas frequências 
APÊNDICE H.2 Wavelets Manchas Solares Total por Área (MH)

Na Figura APÊNDICE H-13, apresentam-se as manchas solares medidas considerando a área total medida em milionésimos de hemisfério (MH). b) o padrão de 11 anos do ciclo solar d) valores maiores por volta dos anos 1930 e 1970 e valores menores em 1980 e 2000 que coincidem com os períodos úmidos no Sudeste brasileiro.
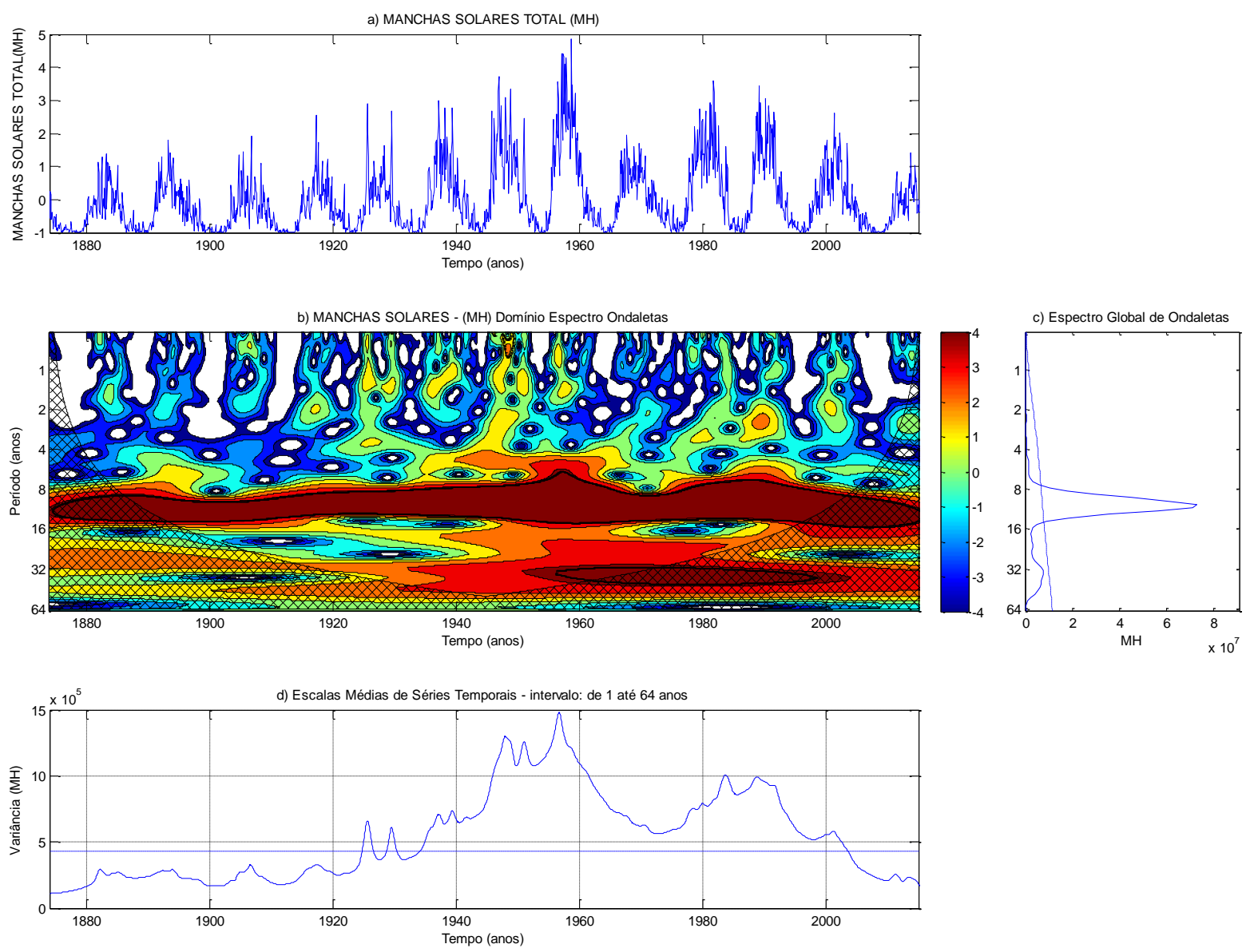

Figura APÊNDICE H-13 Análise por wavelets Manchas Solares por Área 
APÊNDICE H.3 Wavelets Energia Natural Afluente da Bacia do Paraná - ENA PR
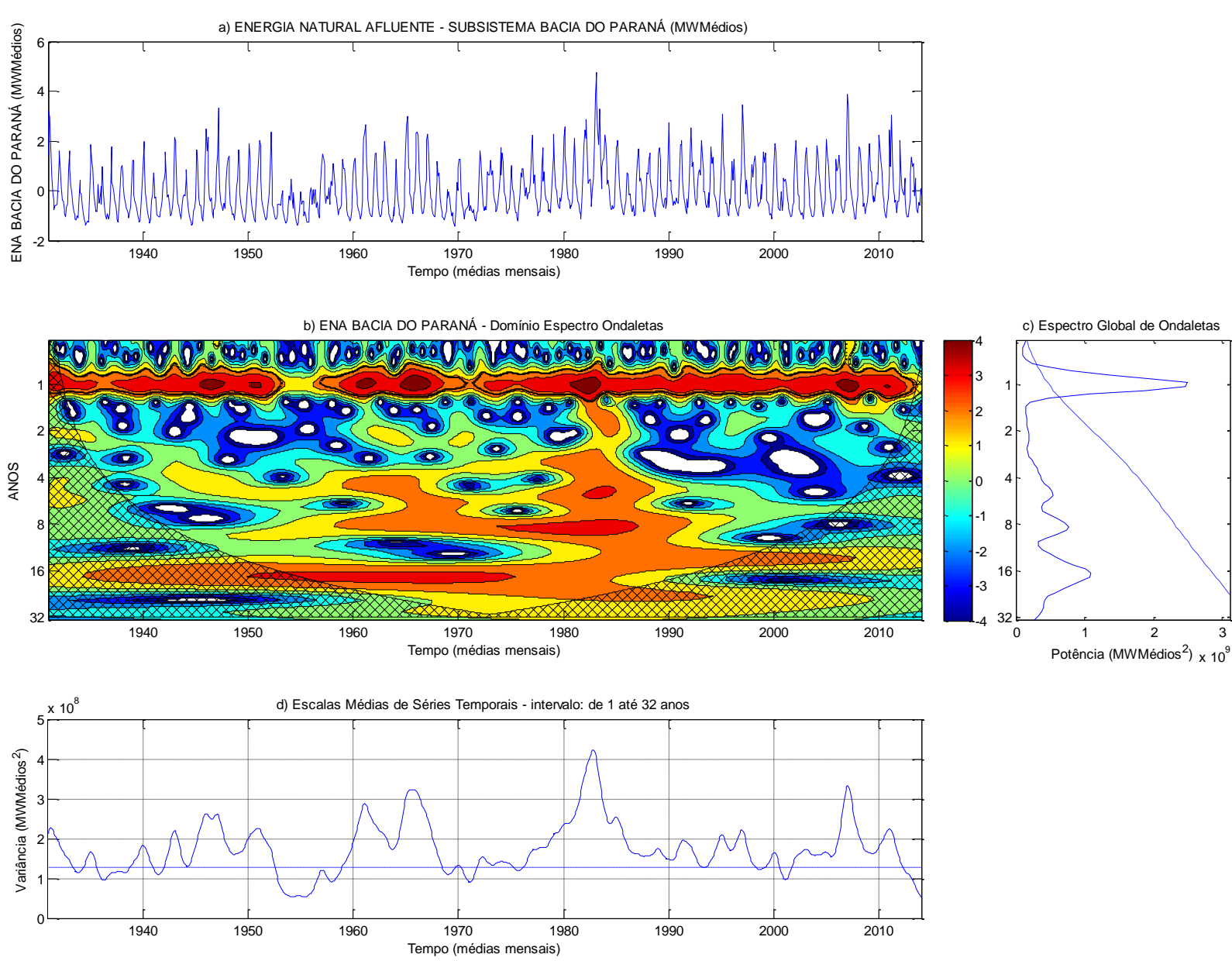

Figura APÊNDICE H-14 Análise por wavelets a) Série Histórica ENA da Bacia do Paraná normalizada. b) Domínio Espectro de Ondaletas. c) Espectro Global de Ondaletas. d) Escalas Médias de Séries Temporais 
APÊNDICE H.3.1 Análise relação variáveis explicativas e ENA PR
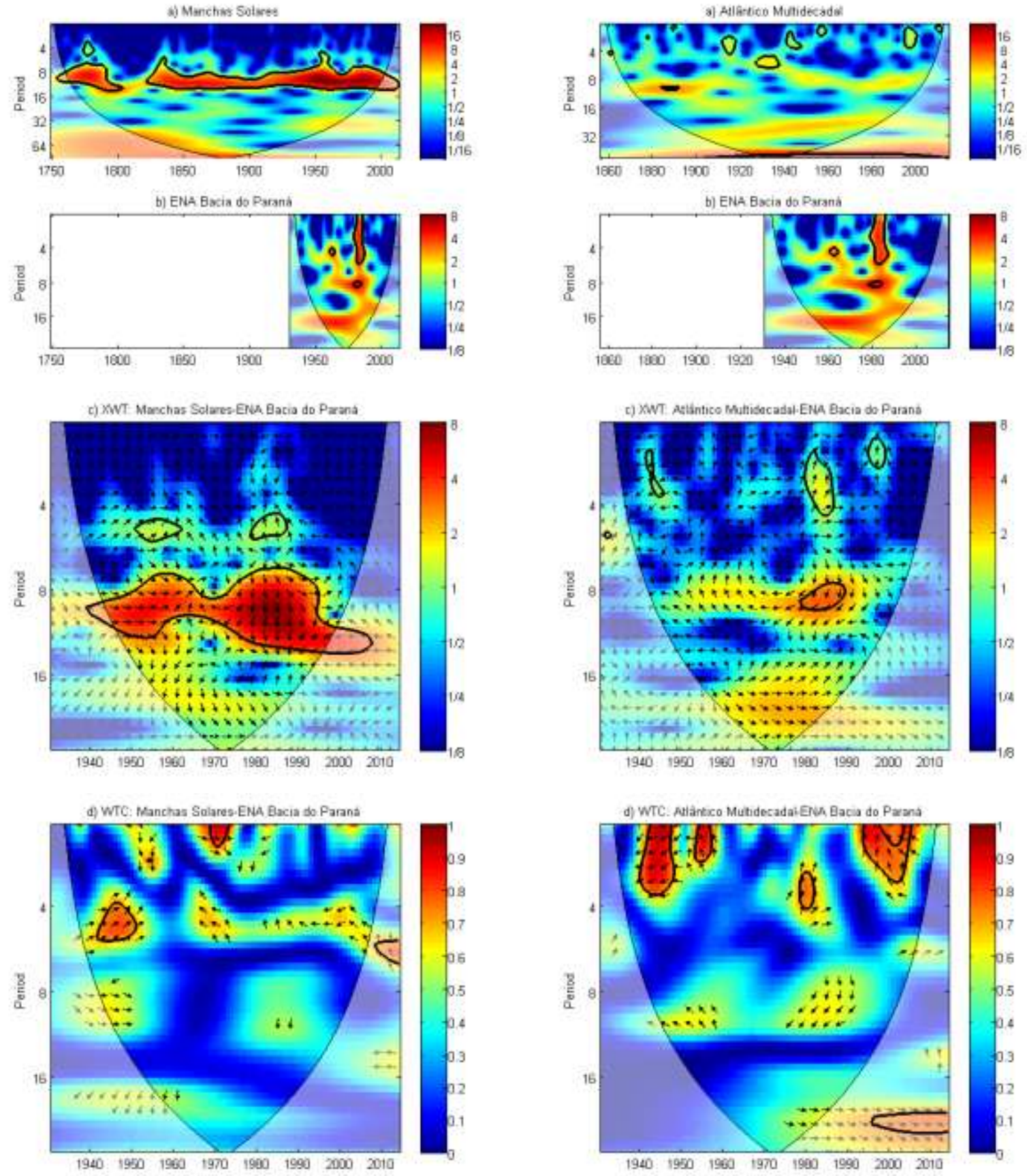

Figura APÊNDICE H-15 Análise por wavelets a) Manchas Solares versos b) ENA da Bacia do Paraná. c) Trans.Cruzada - XWT d) Trans.Contínua - CWT

Figura APÊNDICE H-16 Análise por wavelets a) Multidecadal do Atlântico versos b) ENA da Bacia do Paraná. c) Trans.Cruzada - XWT d) Trans.Contínua CWT 

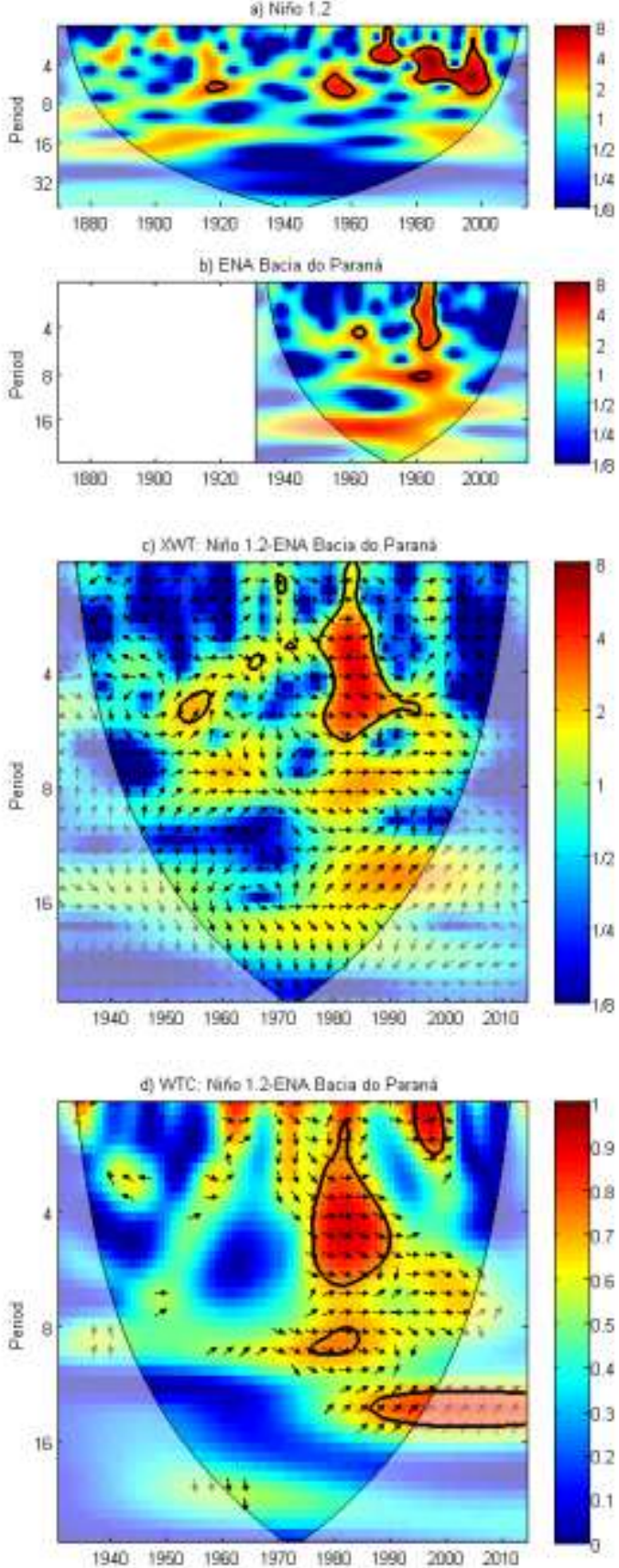

Figura APÊNDICE H-17 Análise por wavelets a) El Niño 1+2 versos b) ENA da Bacia do Paraná. c) Trans.Cruzada - XWT d) Trans.Contínua - CWT
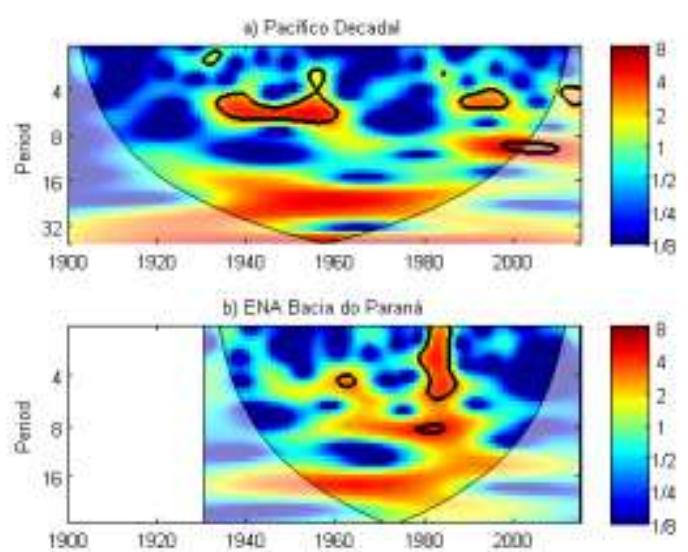

c) XWr Pacfico Decasalenh Eacia do Parana
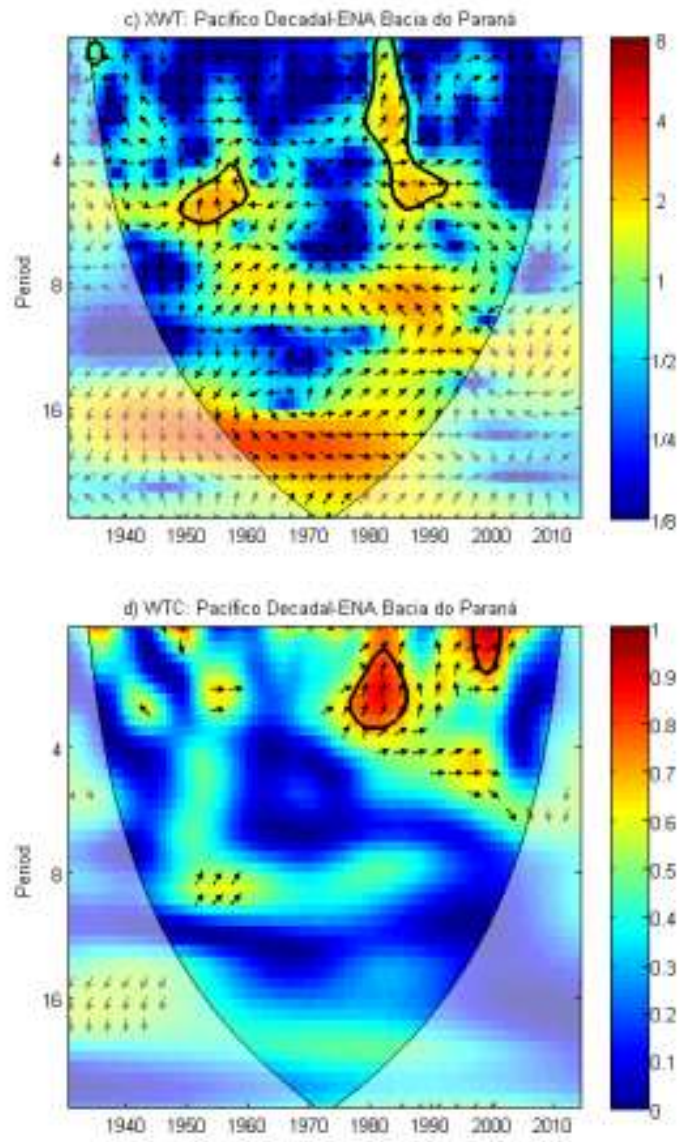

Figura APÊNDICE H-18 Análise por wavelets a) Decadal do Pacífico versos b) ENA da Bacia do Paraná. c) Trans.Cruzada - XWT d) Trans.Contínua CWT 
APÊNDICE H.4 Wavelets Vazão da Usina Barra Bonita
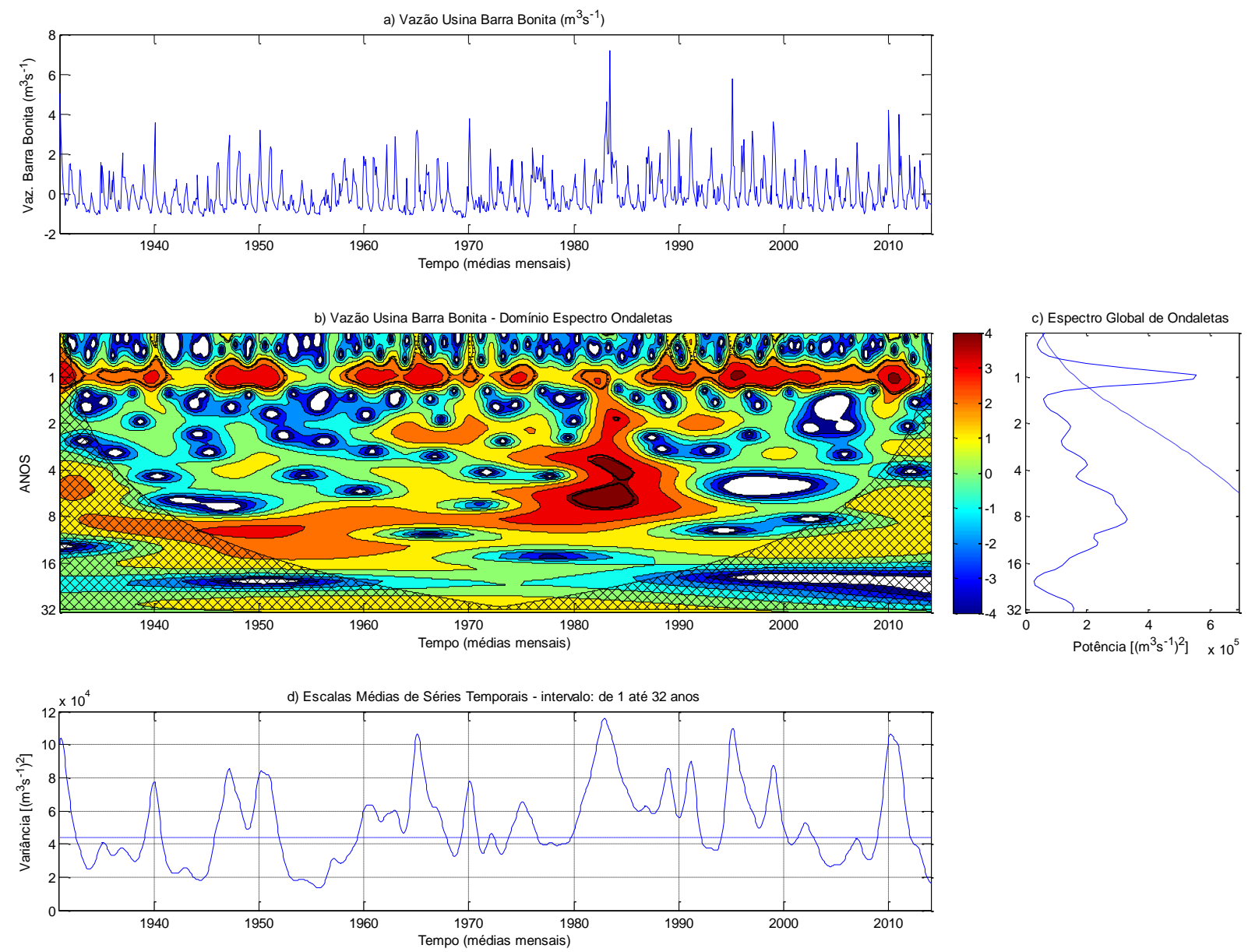

Figura APÊNDICE H-19 Análise por wavelets a) Série Histórica Vazão da Usina Barra Bonita normalizada. b) Domínio Espectro de Ondaletas. c) Espectro Global de Ondaletas. d) Escalas Médias de Séries Temporais 
APÊNDICE H.4.1 Análise relação variáveis explicativas e usina Barra Bonita
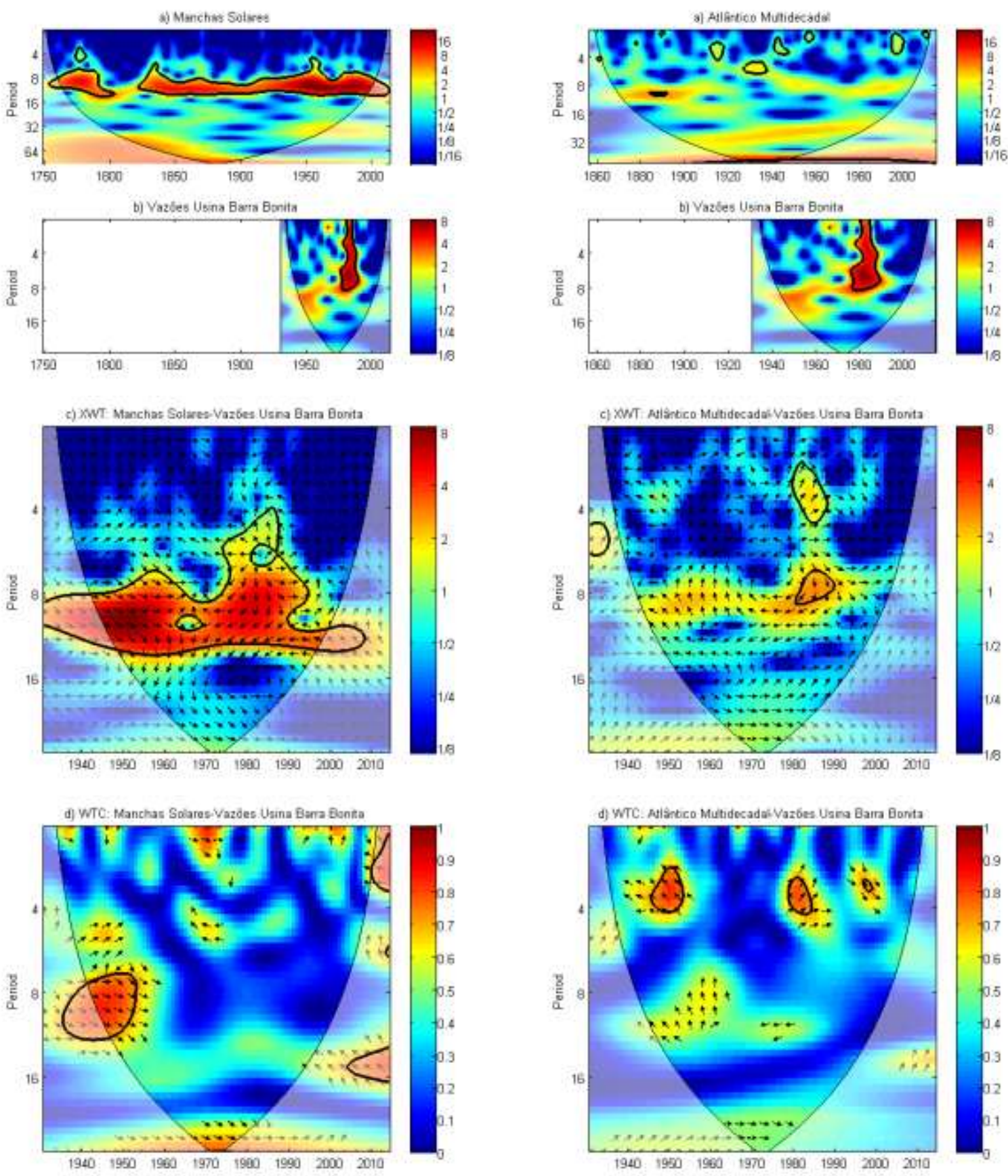

Figura APÊNDICE H-20 Análise por wavelets a) Manchas Solares versos b) Vazões da Usina de Barra Bonita. c) Trans.Cruzada - XWT d) Trans.Contínua CWT

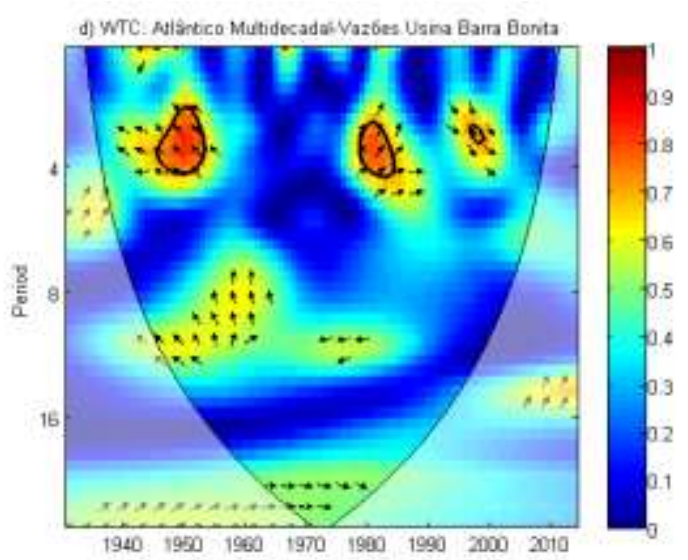

Figura APÊNDICE H-21 Análise por wavelets a) Multidecadal do Atlântico versos b) Vazões da Usina de Barra Bonita. c) Trans.Cruzada - XWT d) Trans.Contínua - CWT 

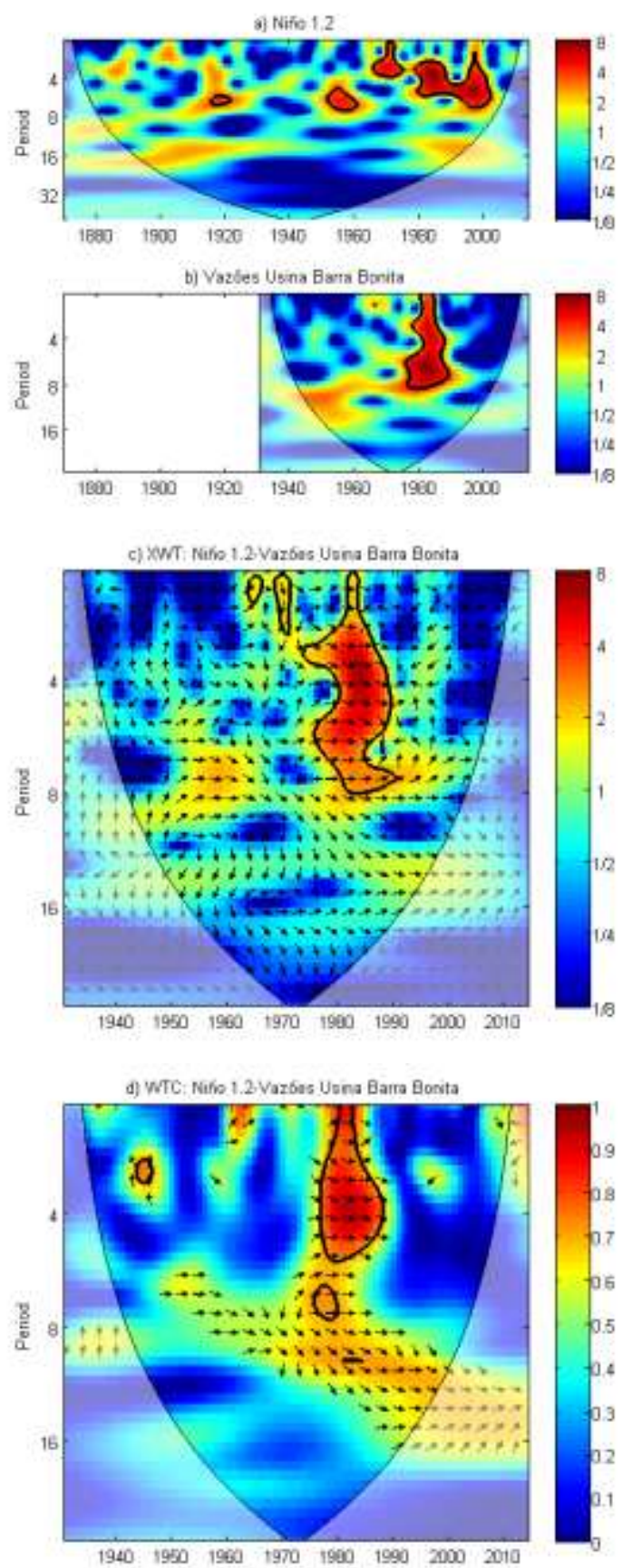

Figura APÊNDICE H-22 Análise por wavelets a) El Niño 1+2 versos b) Vazões da Usina de Barra Bonita. c) Trans.Cruzada - XWT d) Trans.Contínua - CWT
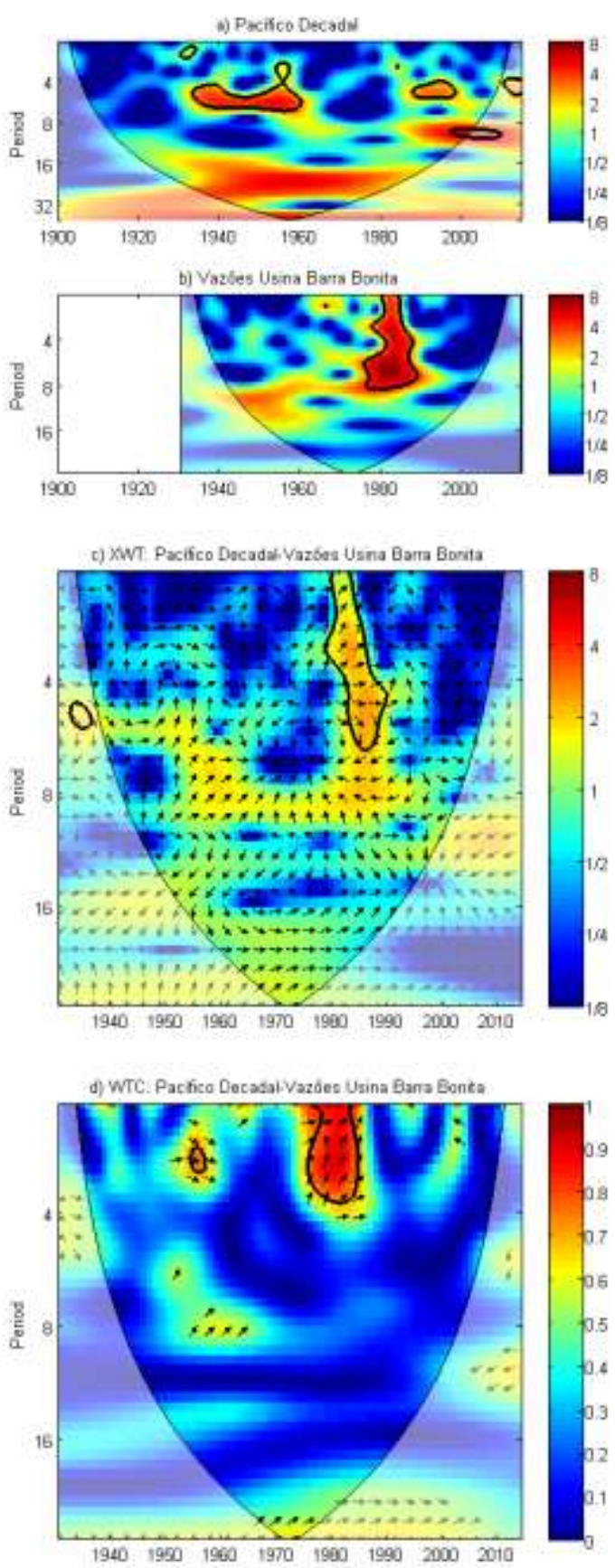

Figura APÊNDICE H-23 Análise por wavelets a) Decadal do Pacífico versos b) Vazões da Usina de Barra Bonita. c) Trans.Cruzada - XWT d) Trans.Contínua - CWT 


\section{APÊNDICE H.5 Wavelets Vazão da Usina Boa Esperança}
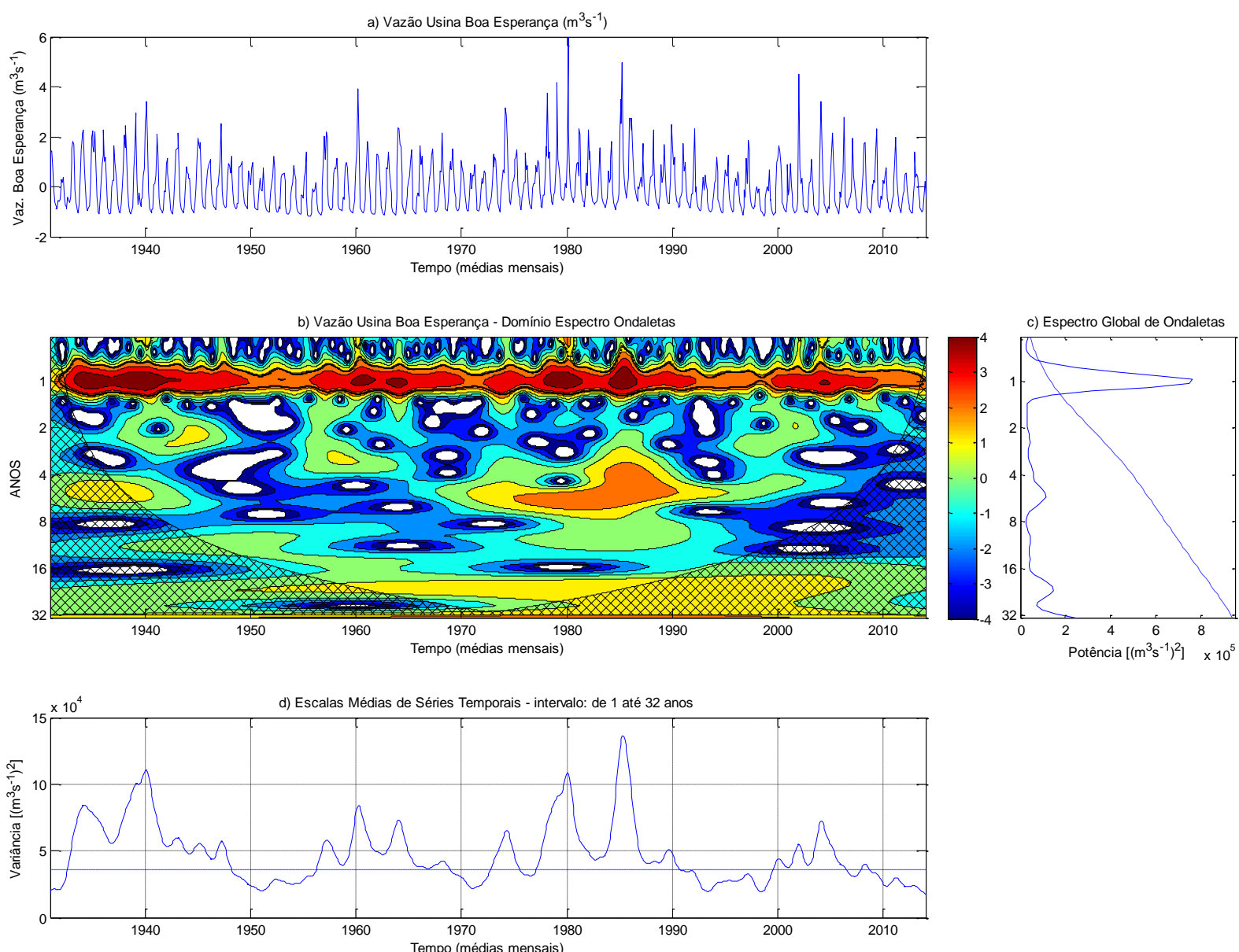

Figura APÊNDICE H-24 Análise por wavelets a) Série Histórica Vazão da Usina Boa Esperança normalizada. b) Domínio Espectro de Ondaletas. c) Espectro Global de Ondaletas. d) Escalas Médias de Séries Temporais 
APÊNDICE H.5.1 Análise relação variáveis explicativas e usina Boa Esperança
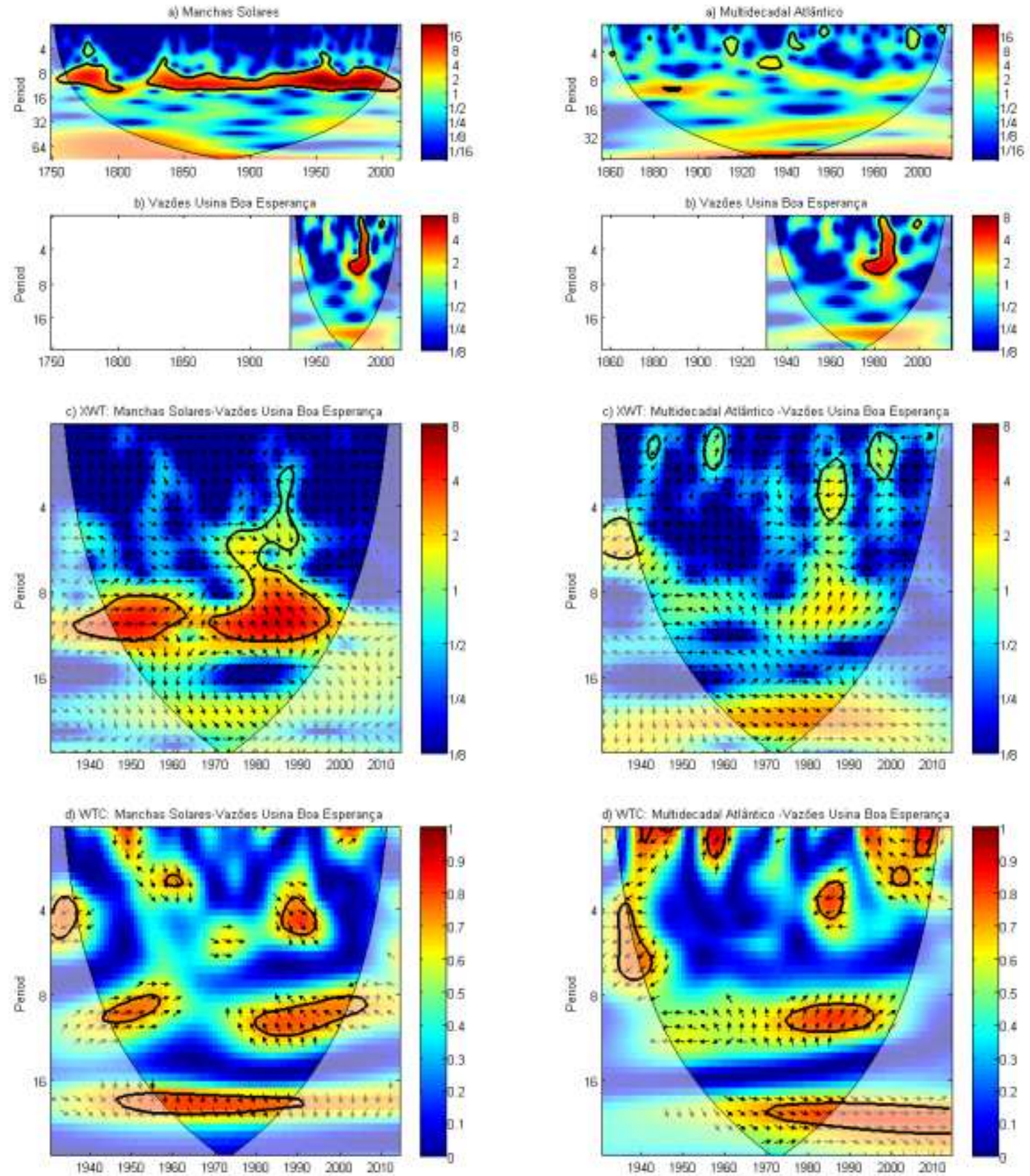

Figura APÊNDICE H-25 Análise por wavelets a) Manchas Solares versos b) Vazões da Usina de Boa Esperança. c) Trans.Cruzada - XWT d) Trans.Contínua - CWT

Figura APÊNDICE H-26 Análise por wavelets a) Multidecadal do Atlântico versos b) Vazões da Usina de Boa Esperança. c) Trans.Cruzada - XWT d) Trans.Contínua - CWT 

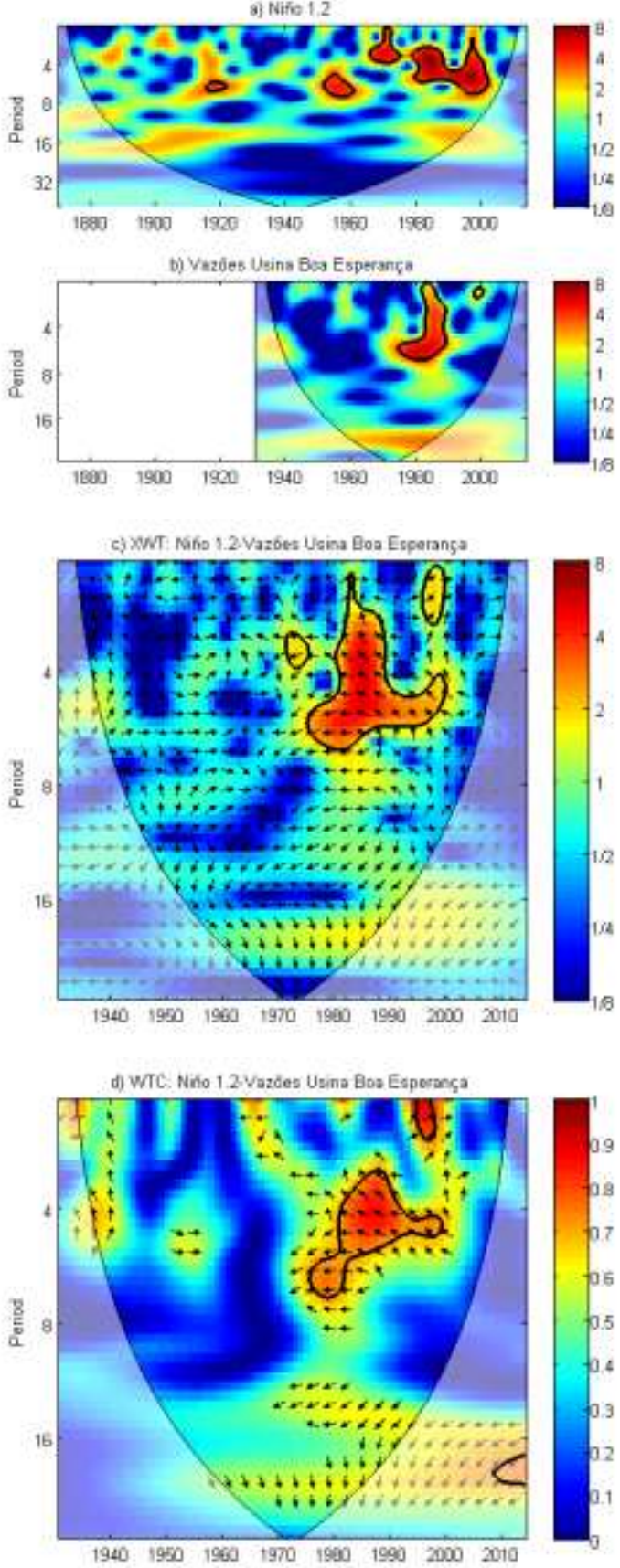

Figura APÊNDICE H-27 Análise por wavelets a) El Niño 1+2 versos b) Vazões da Usina de Boa Esperança. c) Trans.Cruzada - XWT d) Trans.Contínua - CWT
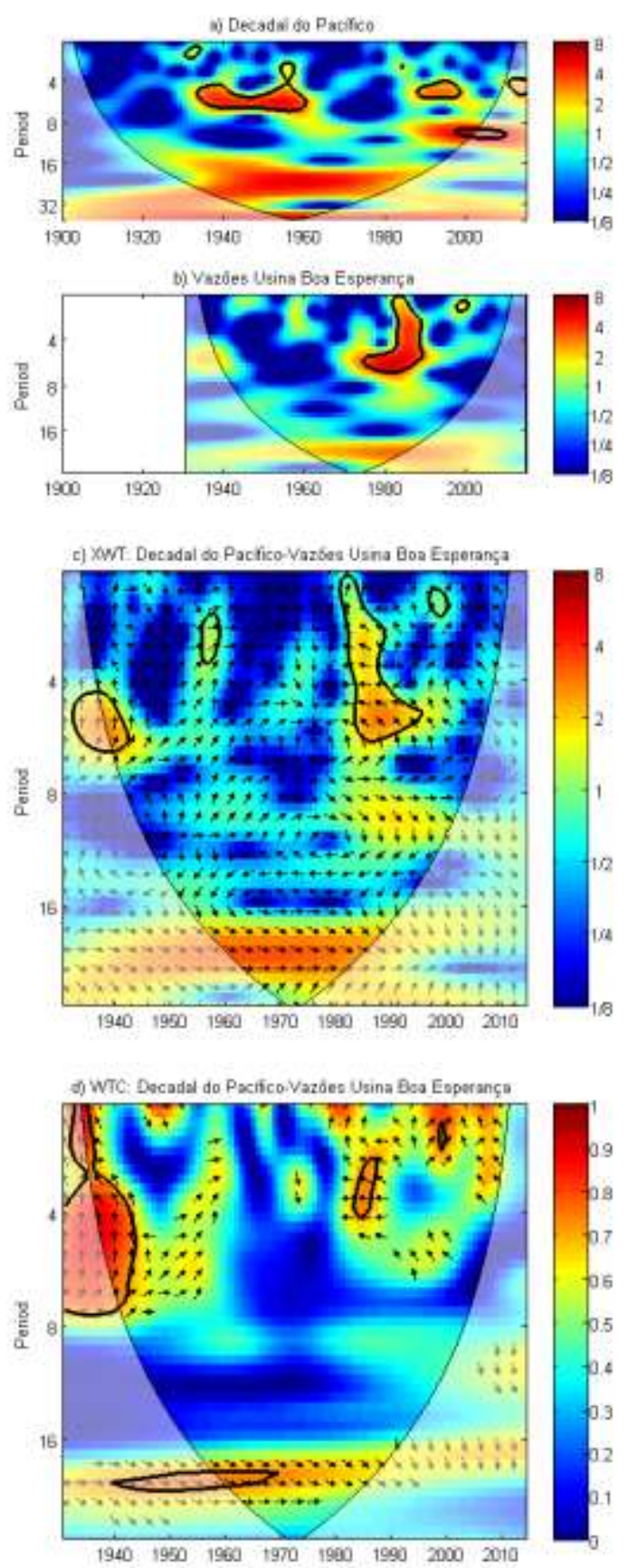

Figura APÊNDICE H-28 Análise por wavelets a) Decadal do Pacífico versos b) Vazões da Usina de Boa Esperança. c) Trans.Cruzada - XWT d) Trans.Contínua - CWT 


\section{APÊNDICE H.6 Wavelets Vazão da Usina Camargos}
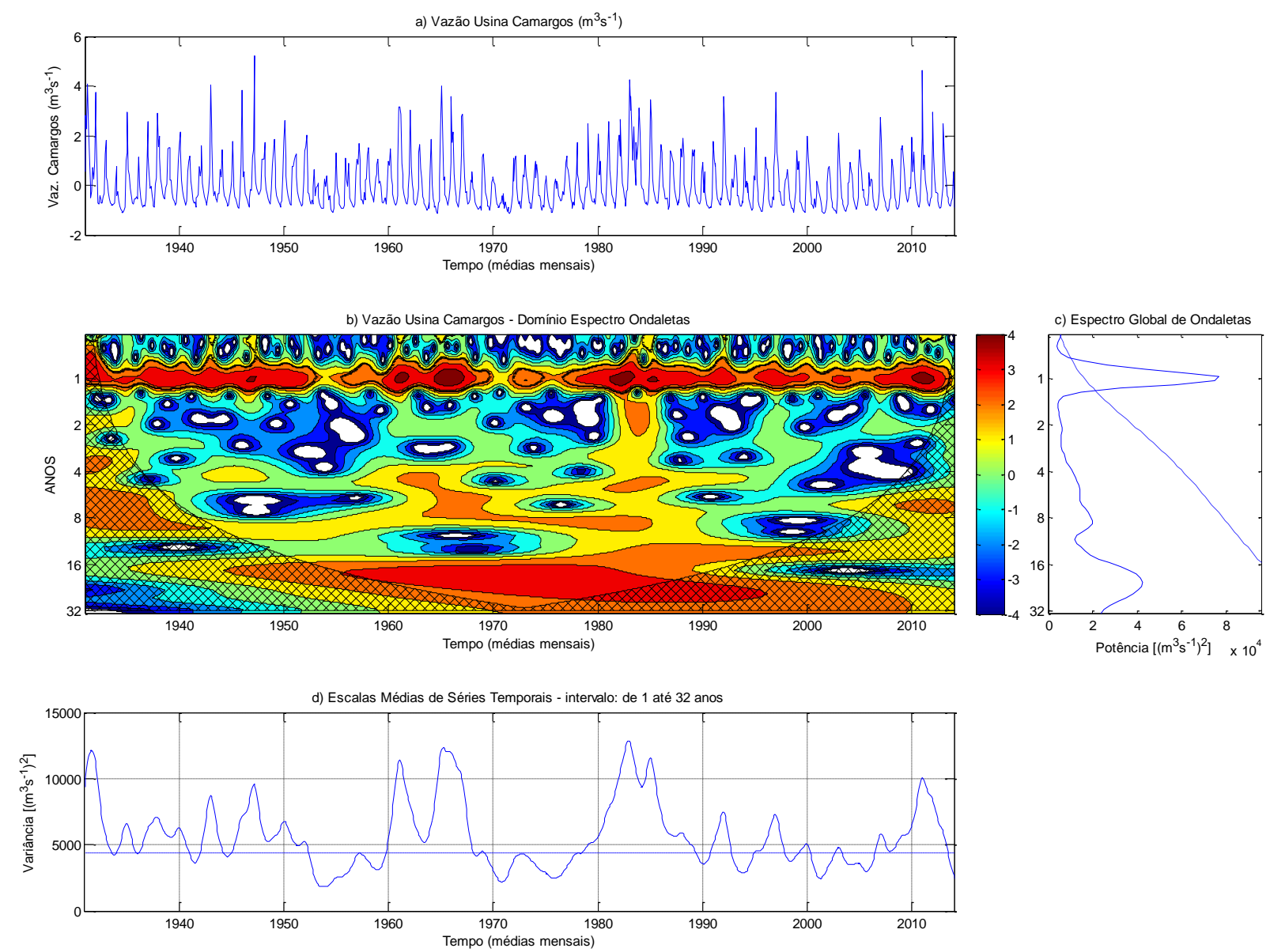

Figura APÊNDICE H-29 Análise por wavelets a) Série Histórica Vazão da Usina Camargos normalizada. b) Domínio Espectro de Ondaletas. c) Espectro Global de Ondaletas. d) Escalas Médias de Séries Temporais 
APÊNDICE H.6.1 Análise relação variáveis explicativas e usina Camargos
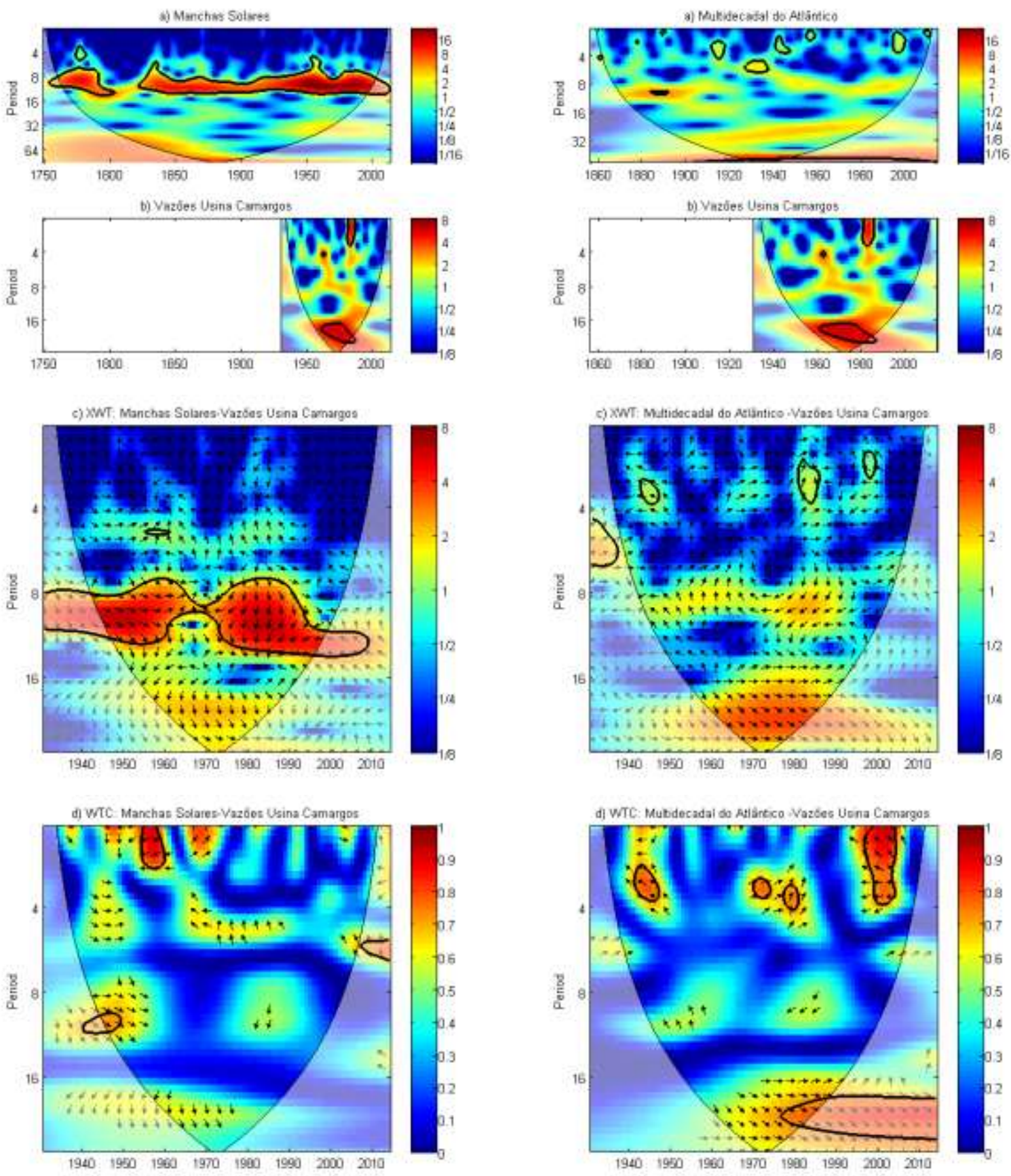

Figura APÊNDICE H-30 Análise por wavelets a) Manchas Solares versos b) Vazões da Usina de Camargos. c) Trans. Cruzada - XWT d) Trans.Contínua - CWT

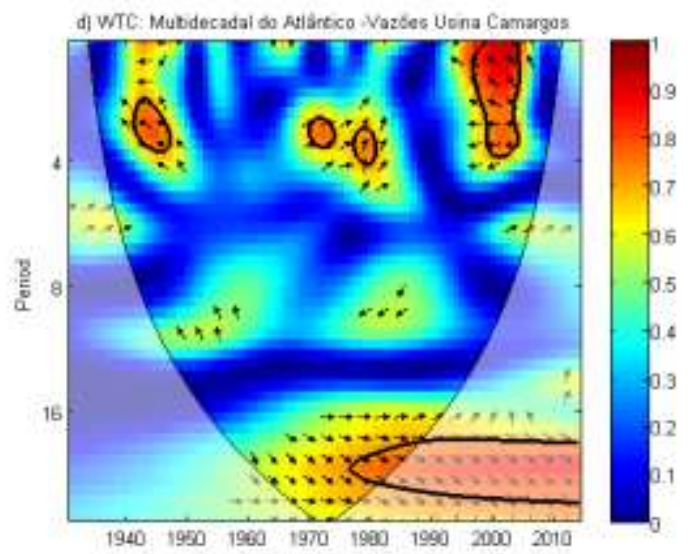

Figura APÊNDICE H-31 Análise por wavelets a) Multidecadal do Atlântico versos b) Vazões da Usina de Camargos. c) Trans. Cruzada - XWT d) Trans.Contínua - CWT 

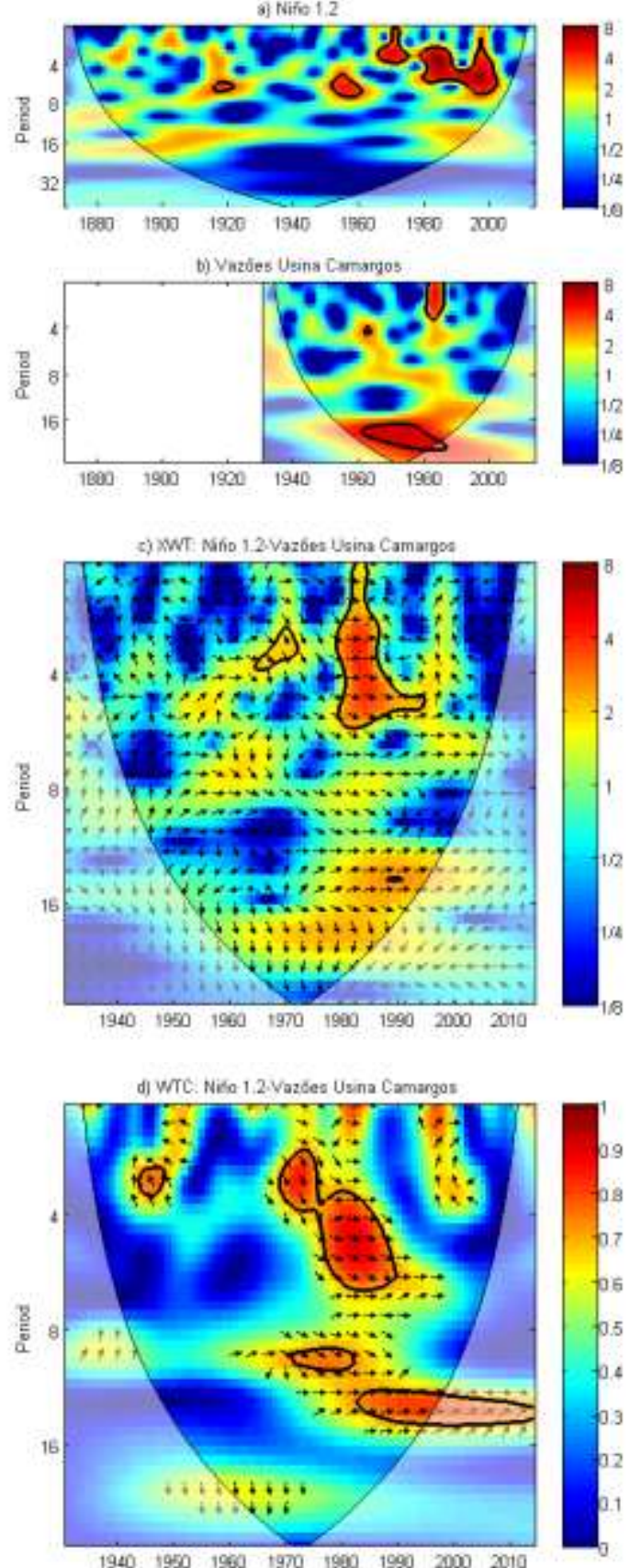

Figura APÊNDICE H-32 Análise por wavelets a) El Niño 1+2 versos b) Vazões da Usina de Camargos. c) Trans. Cruzada - XWT d) Trans.Contínua - CWT
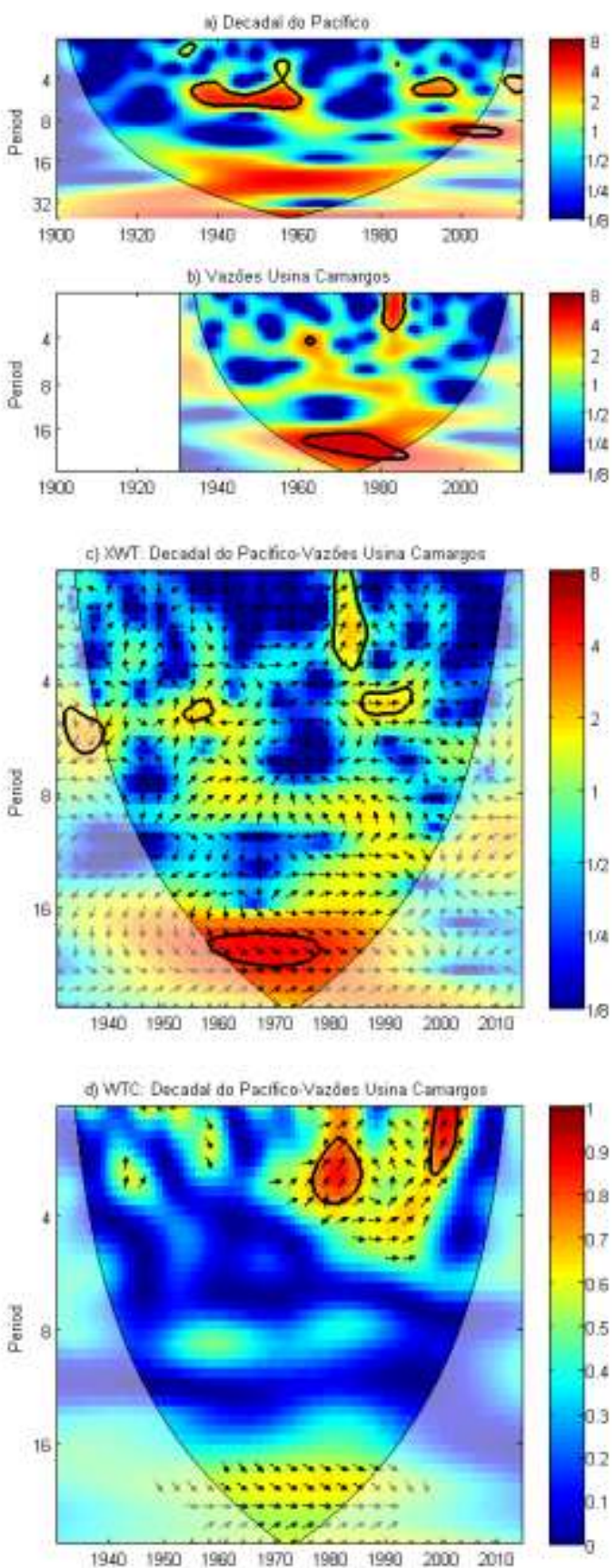

Figura APÊNDICE H-33 Análise por wavelets a) Decadal do Pacífico versos b) Vazões da Usina de Camargos. c) Trans. Cruzada - XWT d) Trans.Contínua - CWT 
APÊNDICE H.7 Wavelets Vazão da Usina Foz do Areia
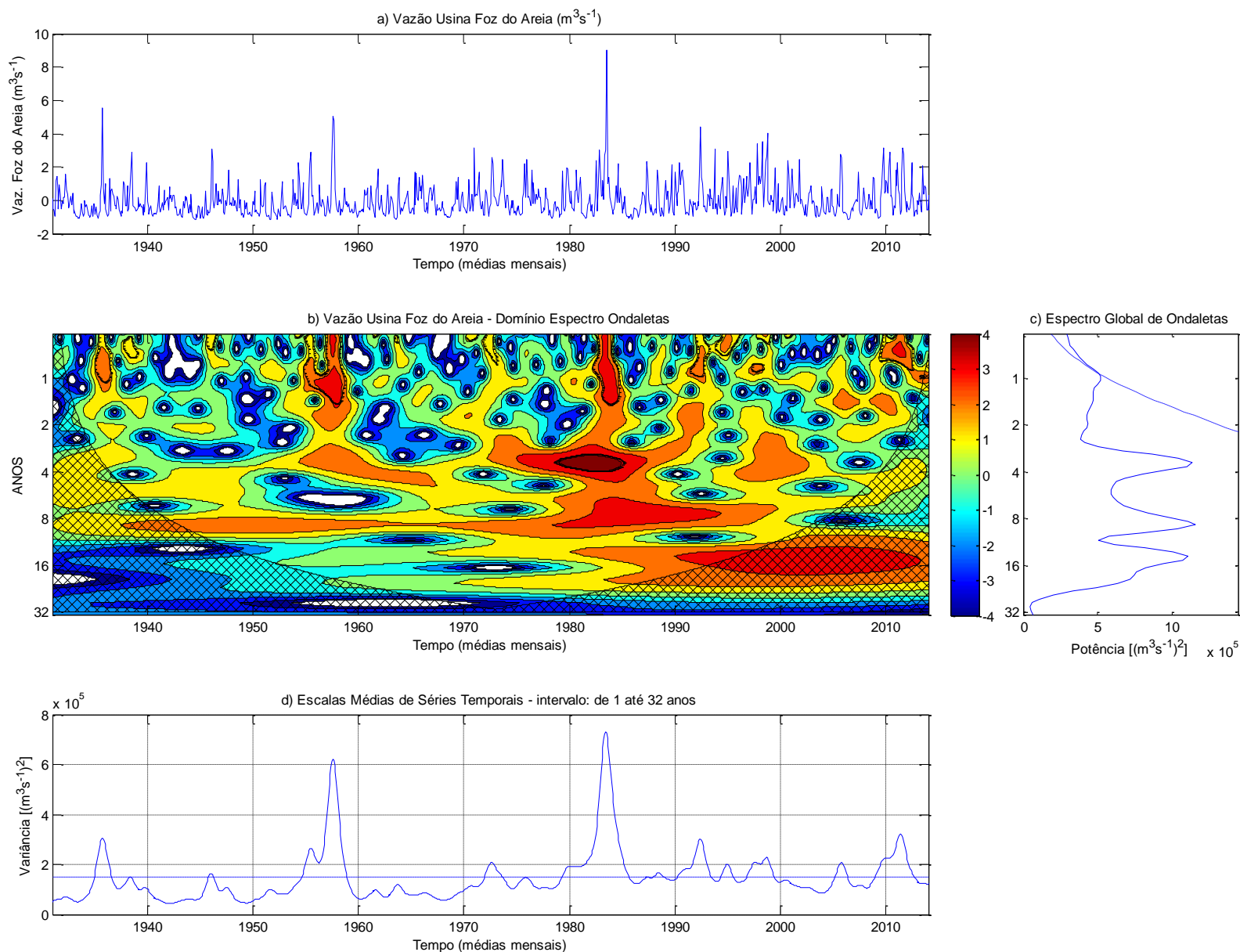

Figura APÊNDICE H-34 Análise por wavelets a) Série Histórica Vazão da Usina Foz do Areia normalizada. b) Domínio Espectro de Ondaletas. c) Espectro Global de Ondaletas. d) Escalas Médias de Séries Temporais 
APÊNDICE H.7.1 Análise relação variáveis explicativas e usina Foz do Areia
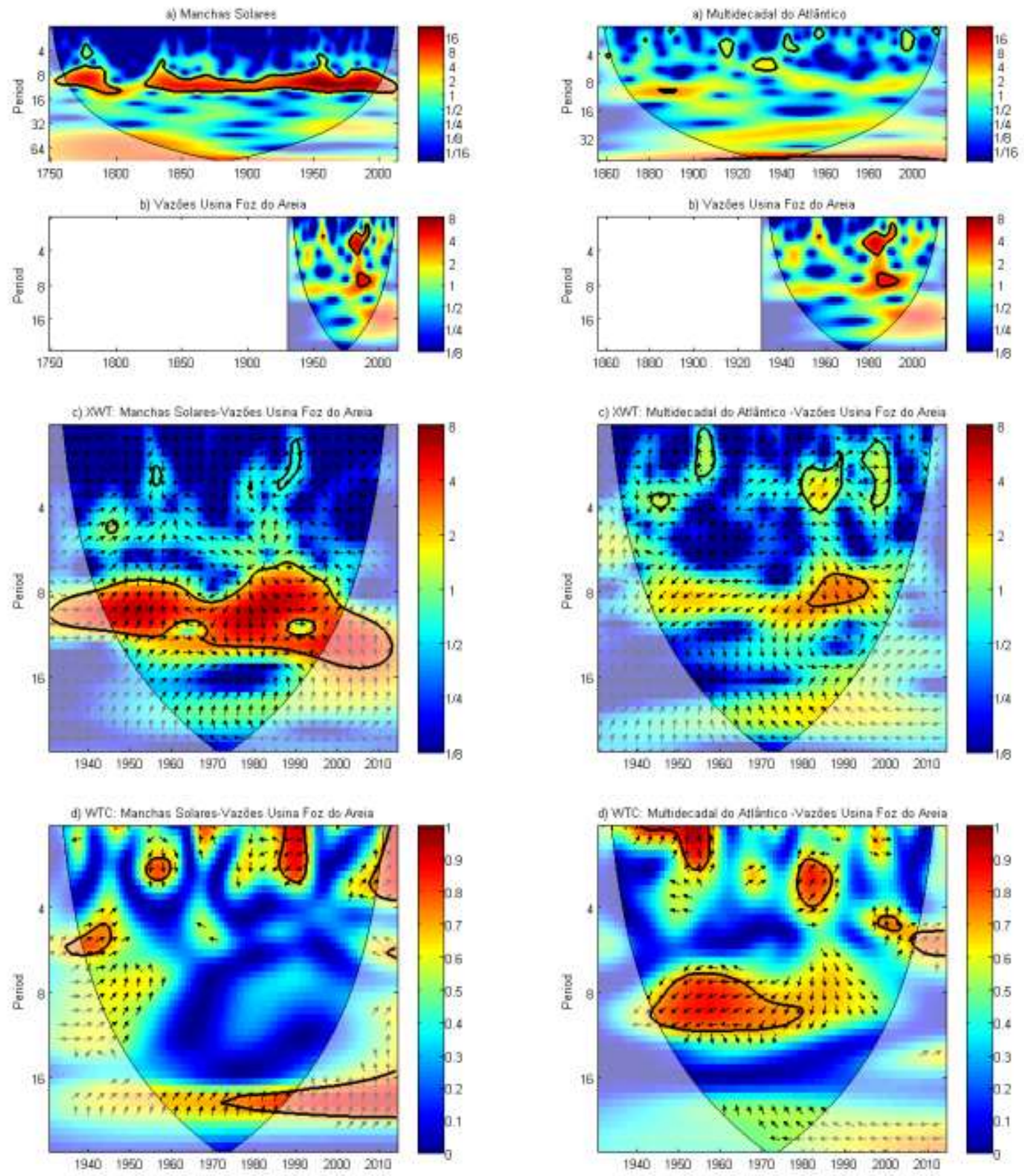

Figura APÊNDICE H-35 Análise por wavelets a) Manchas Solares versos b) Vazões da Usina de Foz do Areia. c) Trans. Cruzada - XWT d) Trans.Contínua CWT

Figura APÊNDICE H-36 Análise por wavelets a) Multidecadal do Atlântico versos b) Vazões da Usina de Foz do Areia. c) Trans. Cruzada - XWT d) Trans.Contínua - CWT 

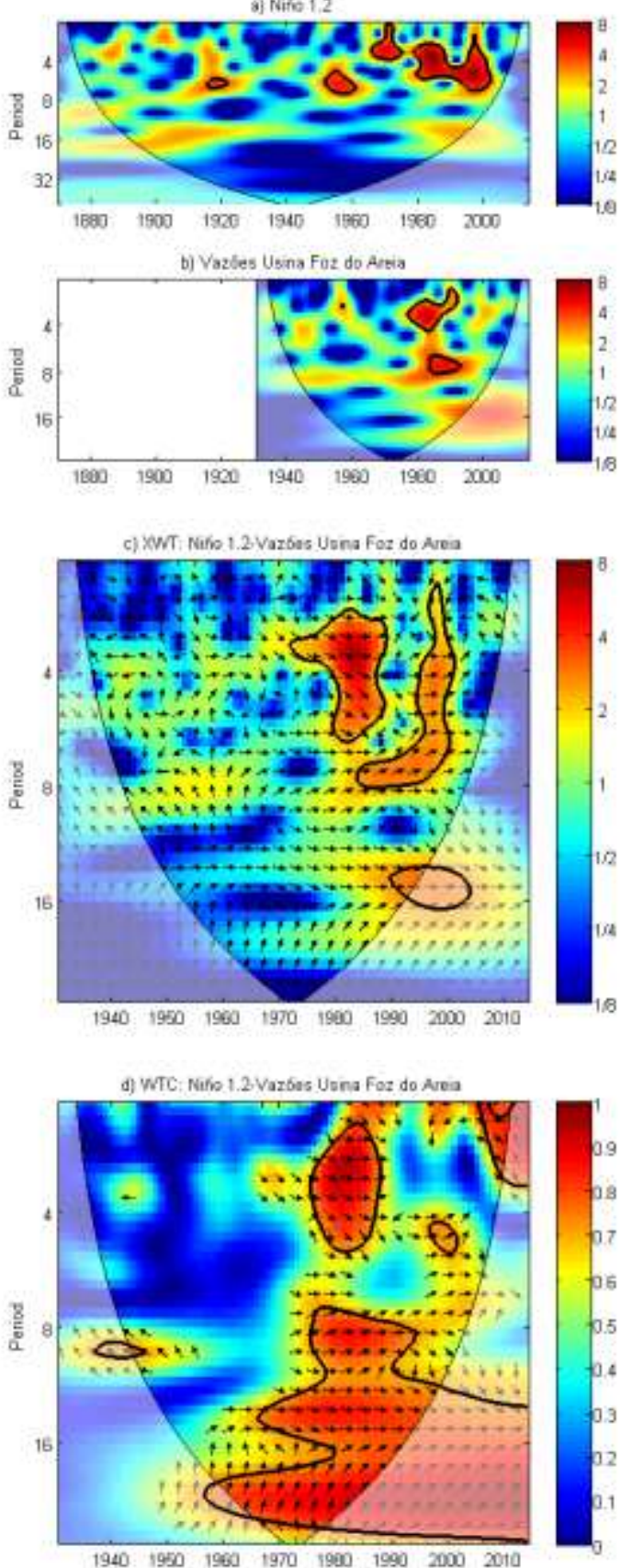

Figura APÊNDICE H-37 Análise por wavelets a) El Niño 1+2 versos b) Vazões da Usina de Foz do Areia. c) Trans. Cruzada - XWT d) Trans.Contínua - CWT
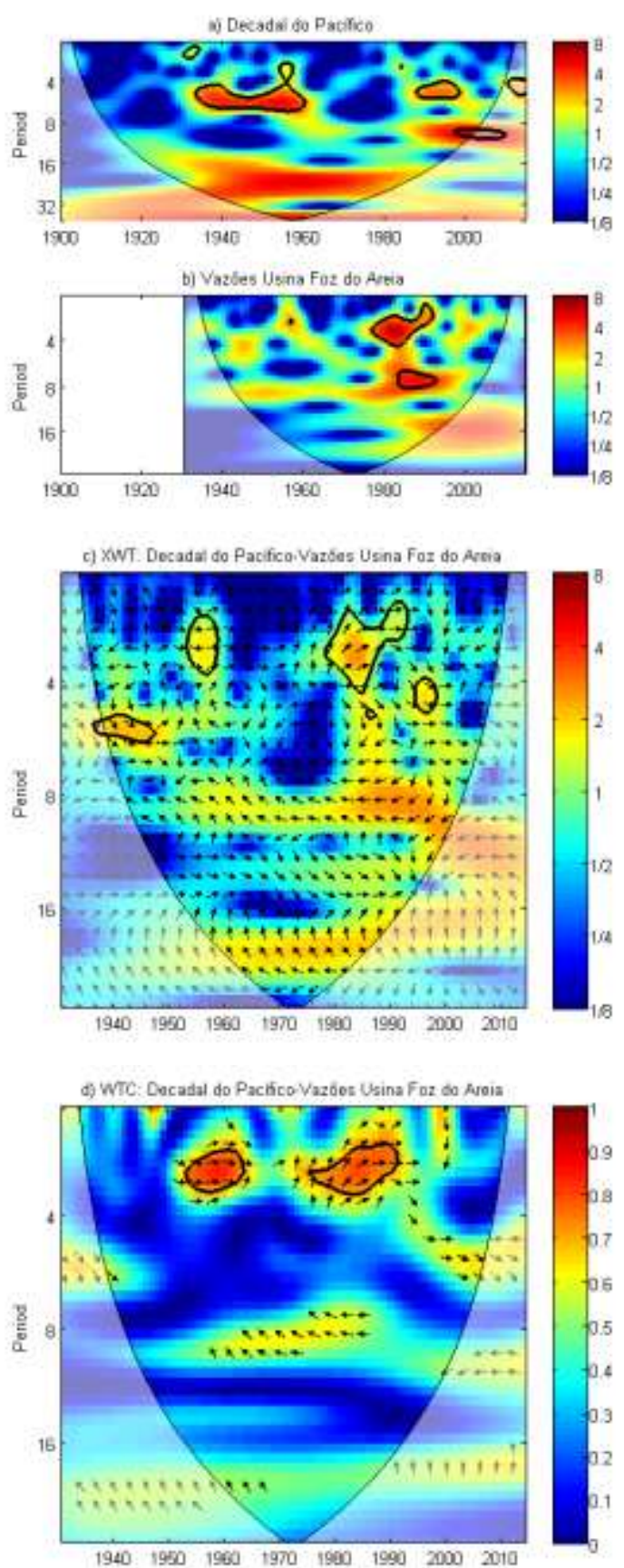

Figura APÊNDICE H-38 Análise por wavelets a) Decadal do Pacífico versos b) Vazões da Usina de Foz do Areia. c) Trans. Cruzada - XWT d) Trans.Contínua - CWT 


\section{APÊNDICE H.8 Wavelets Vazão da Usina Furnas}
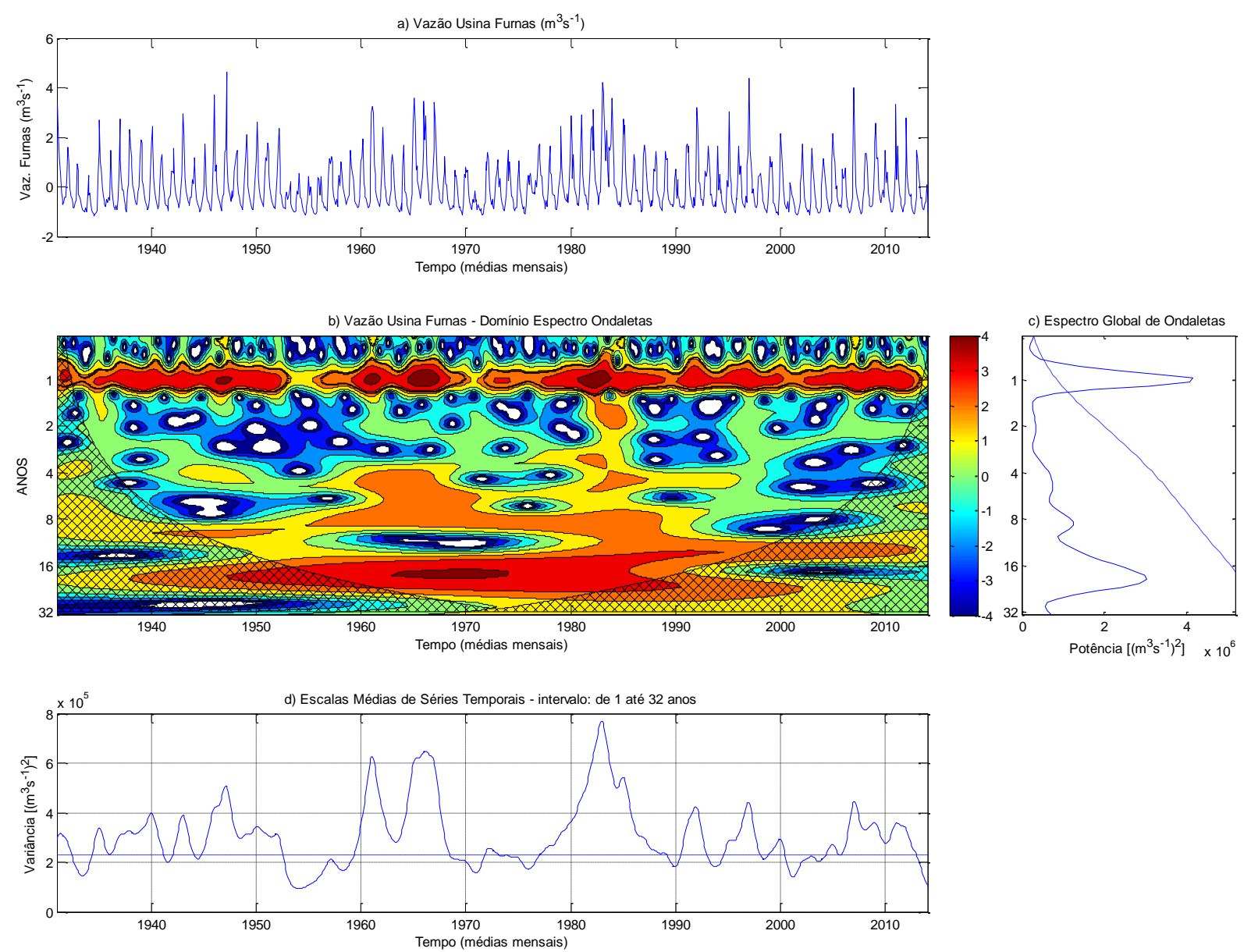

Figura APÊNDICE H-39 Análise por wavelets a) Série Histórica Vazão da Usina Furnas normalizada. b) Domínio Espectro de Ondaletas. c) Espectro Global de Ondaletas. d) Escalas Médias de Séries Temporais 
APÊNDICE H.8.1 Análise relação variáveis explicativas e usina Furnas
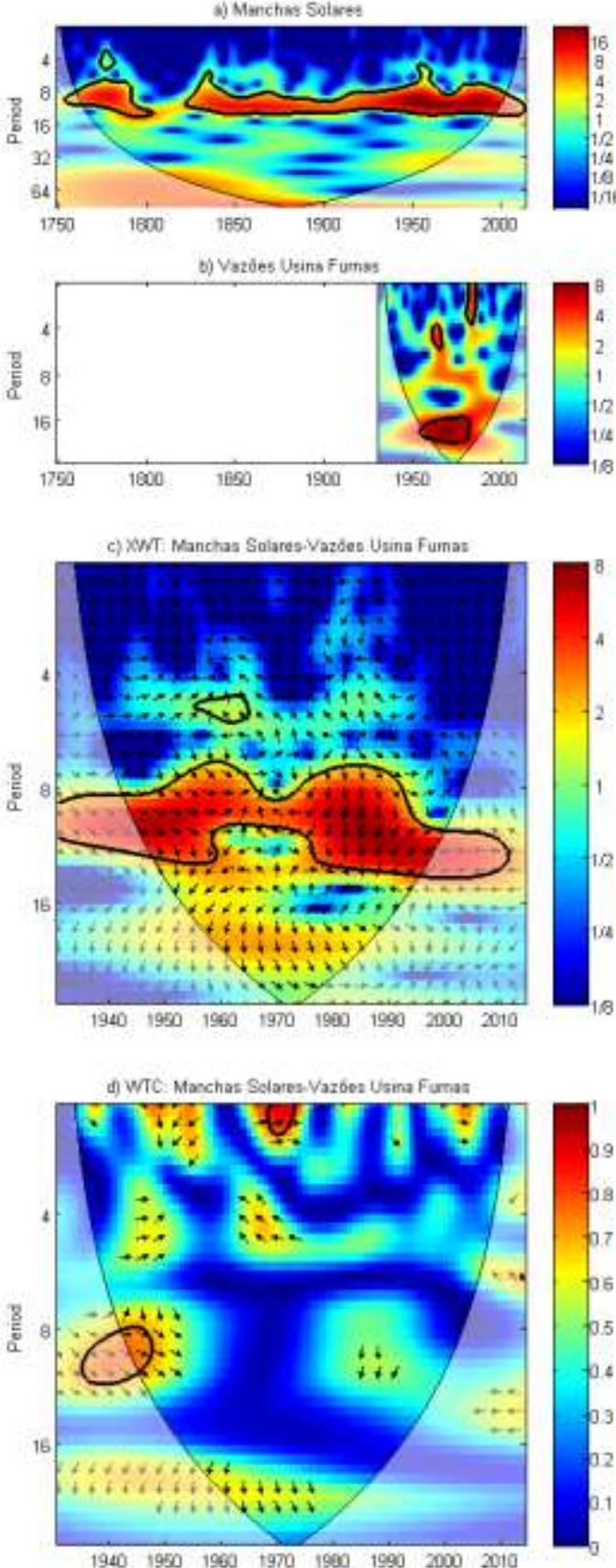

Figura APÊNDICE H-40 Análise por wavelets a) Manchas Solares versos b) Vazões da Usina de Furnas. c) Trans. Cruzada - XWT d) Trans.Contínua - CWT
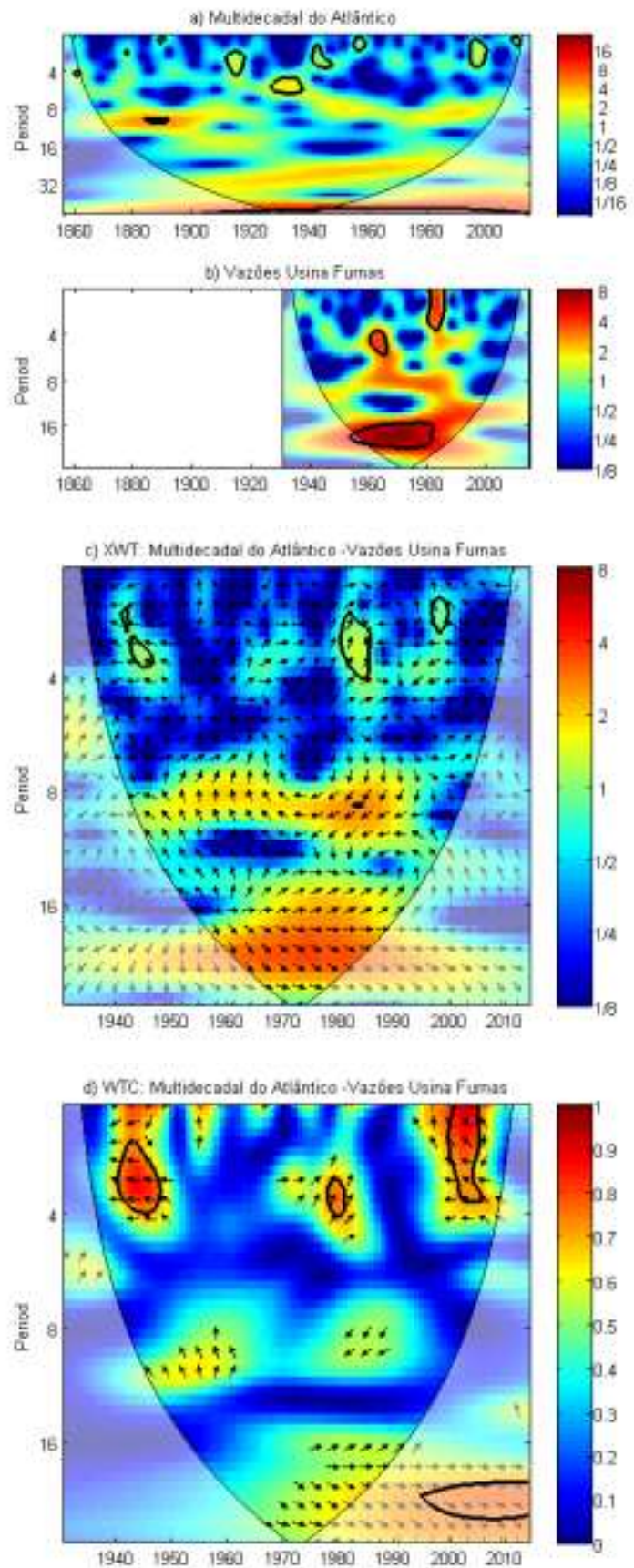

Figura APÊNDICE H-41 Análise por wavelets a) Multidecadal do Atlântico versos b) Vazões da Usina de Furnas. c) Trans. Cruzada - XWT d) Trans.Contínua - CWT 

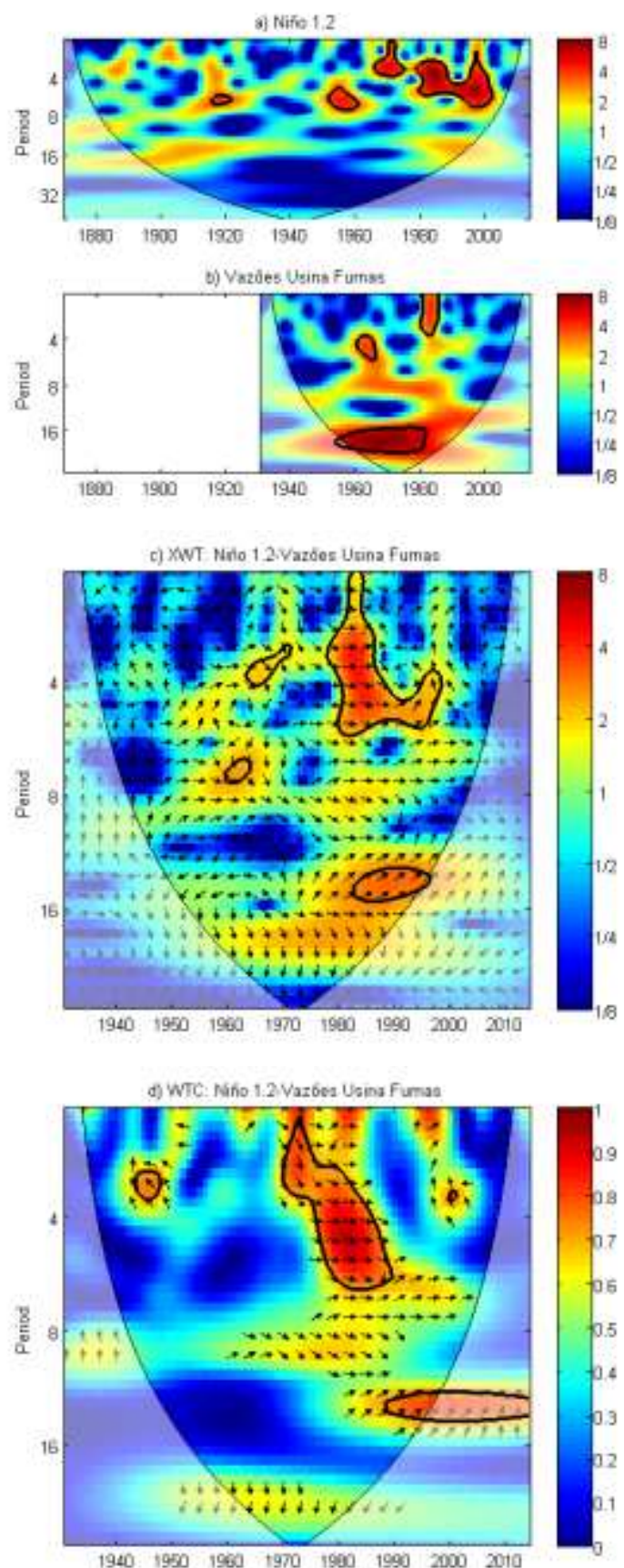

Figura APÊNDICE H-42 Análise por wavelets a) El Niño 1+2 versos b) Vazões da Usina de Furnas. c) Trans. Cruzada - XWT d) Trans.Contínua - CWT
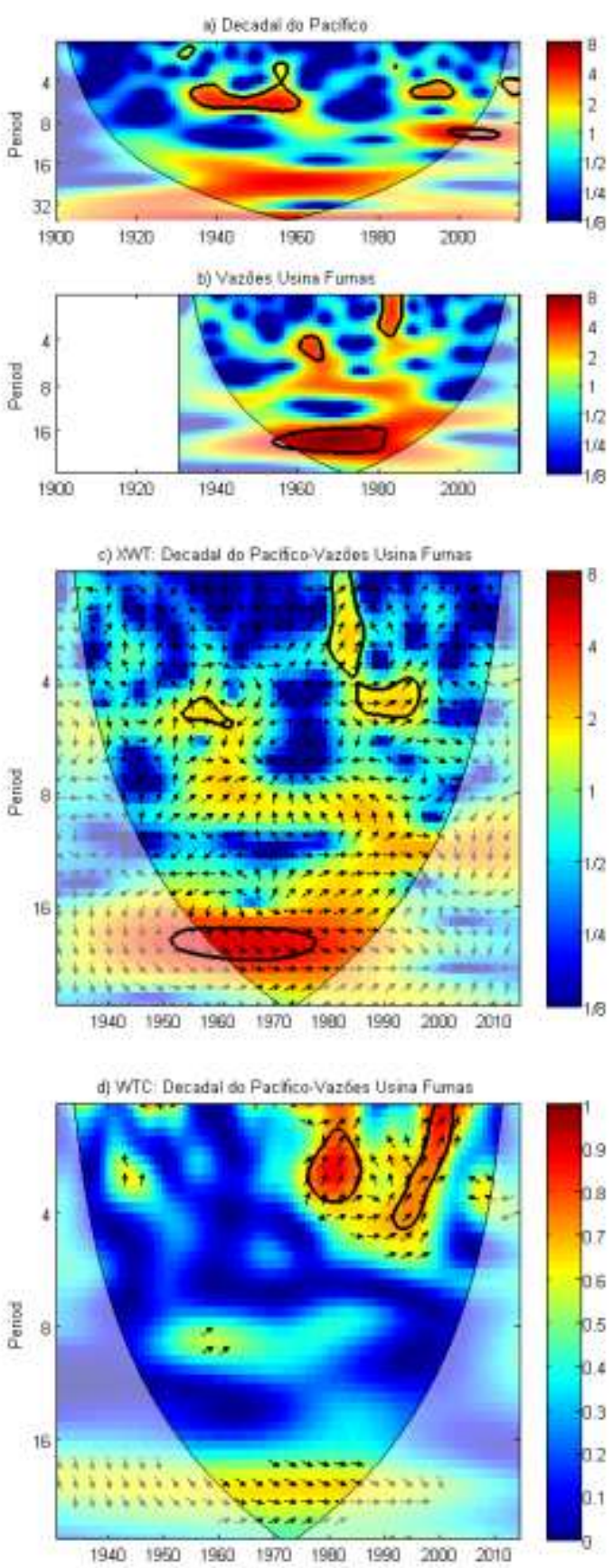

Figura APÊNDICE H-43 Análise por wavelets a) Decadal do Pacífico versos b) Vazões da Usina de Furnas. c) Trans. Cruzada - XWT d) Trans.Contínua CWT 


\section{APÊNDICE H.9 Wavelets Vazão da Usina Guaporé}
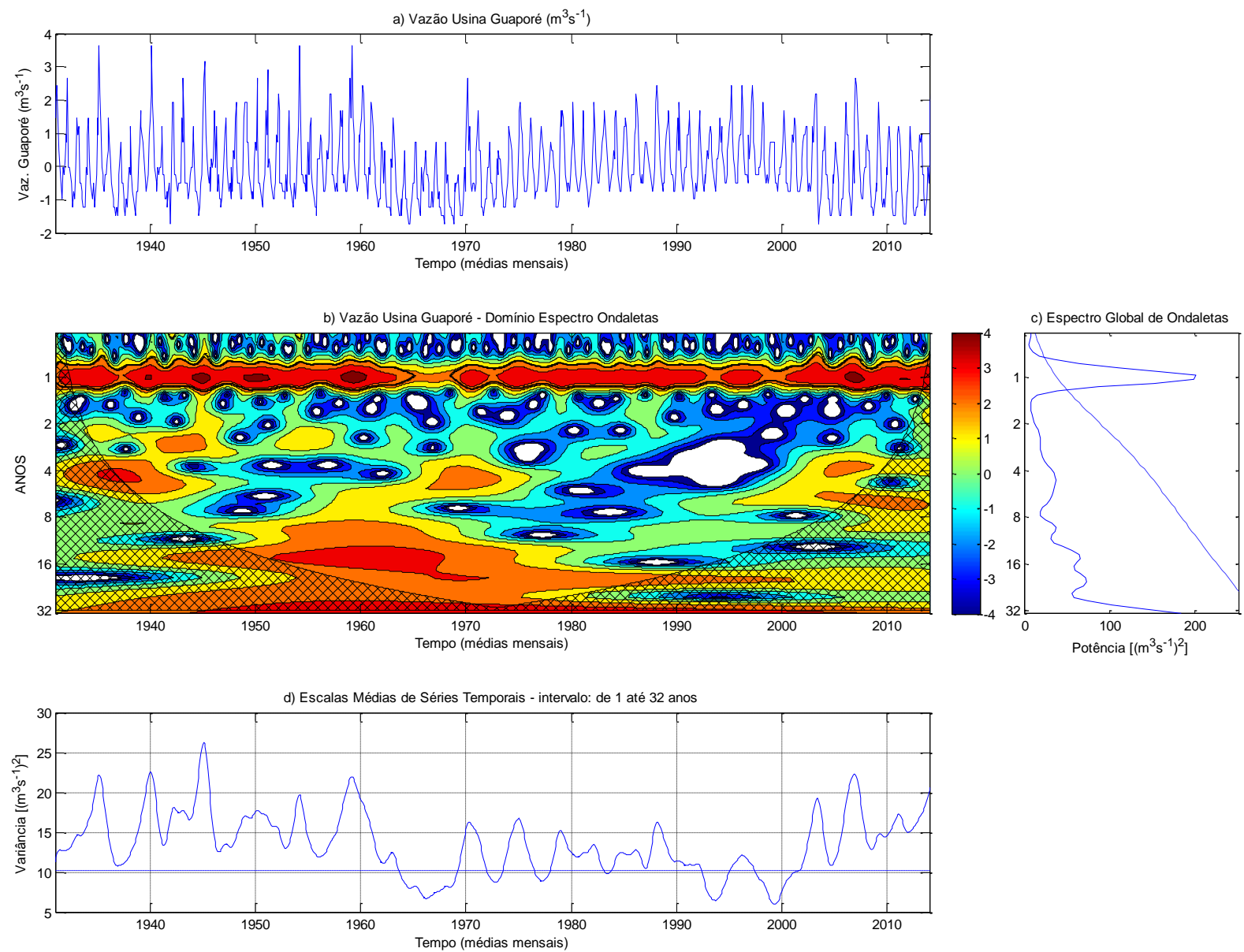

Figura APÊNDICE H-44 Análise por wavelets a) Série Histórica Vazão da Usina Guaporé normalizada. b) Domínio Espectro de Ondaletas. c) Espectro Global de Ondaletas. d) Escalas Médias de Séries Temporais 
APÊNDICE H.9.1 Análise relação variáveis explicativas e usina Guaporé
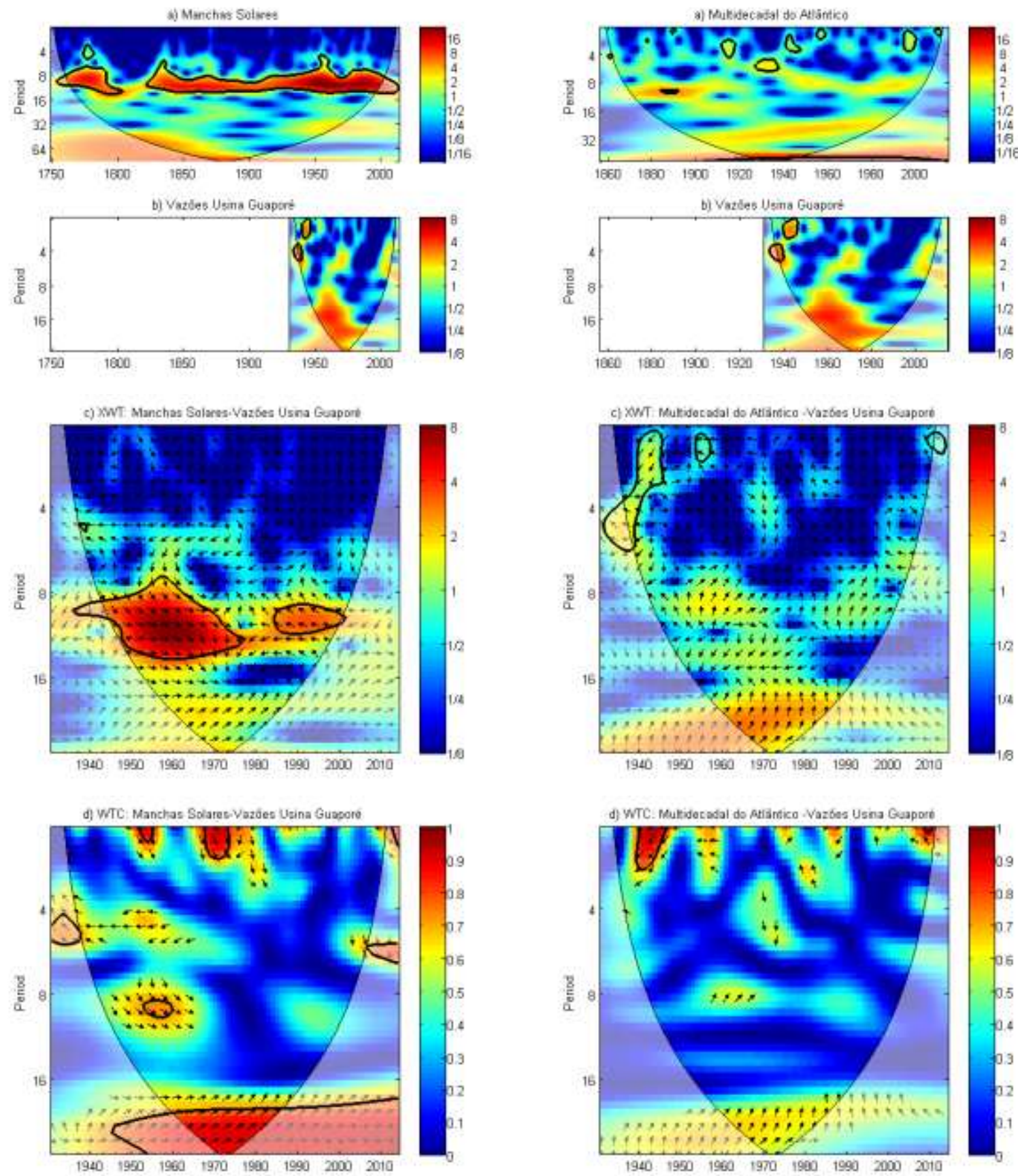

Figura APÊNDICE H-45 Análise por wavelets a) Manchas Solares versos b) Vazões da Usina de Guaporé. c) Trans. Cruzada - XWT d) Trans.Contínua - CWT

Figura APÊNDICE H-46 Análise por wavelets a) Multidecadal do Atlântico versos b) Vazões da Usina de Guaporé. c) Trans. Cruzada - XWT d) Trans.Contínua - CWT 

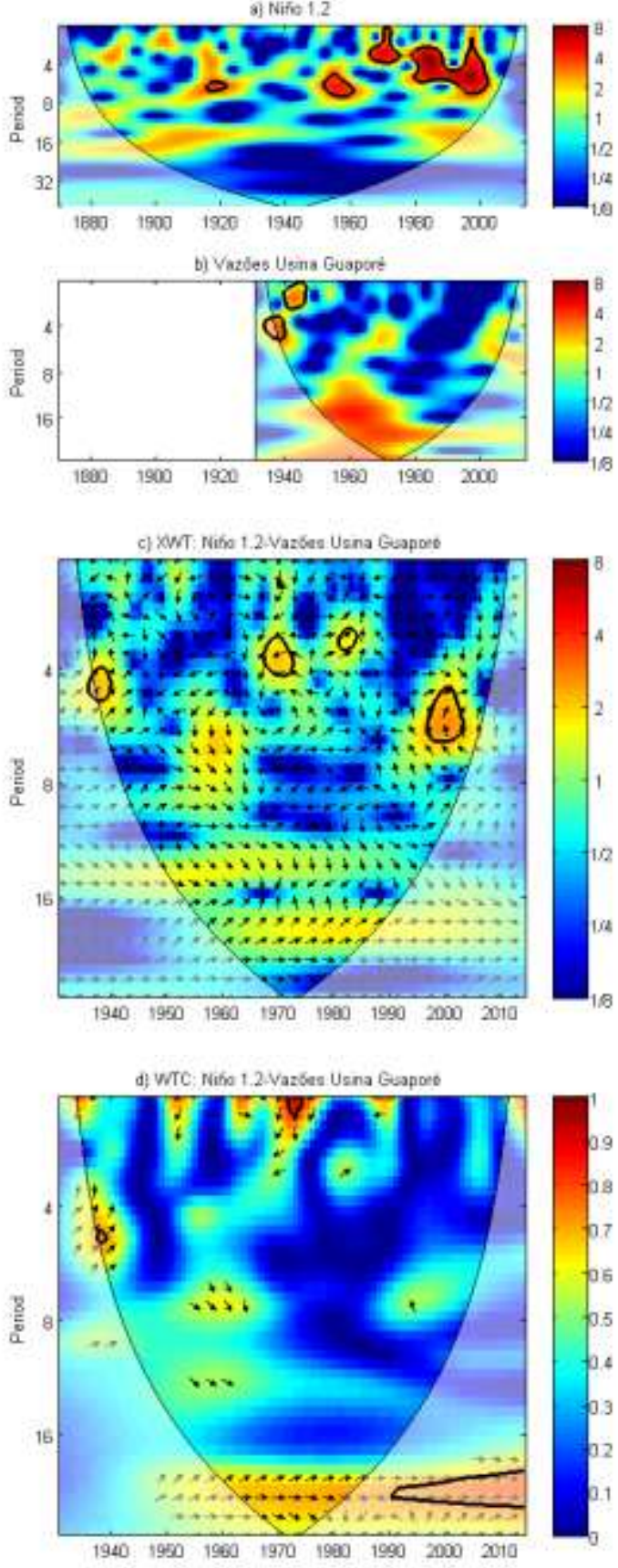

Figura APÊNDICE H-47 Análise por wavelets a) El Niño 1+2 versos b) Vazões da Usina de Guaporé. c) Trans. Cruzada - XWT d) Trans.Contínua - CWT
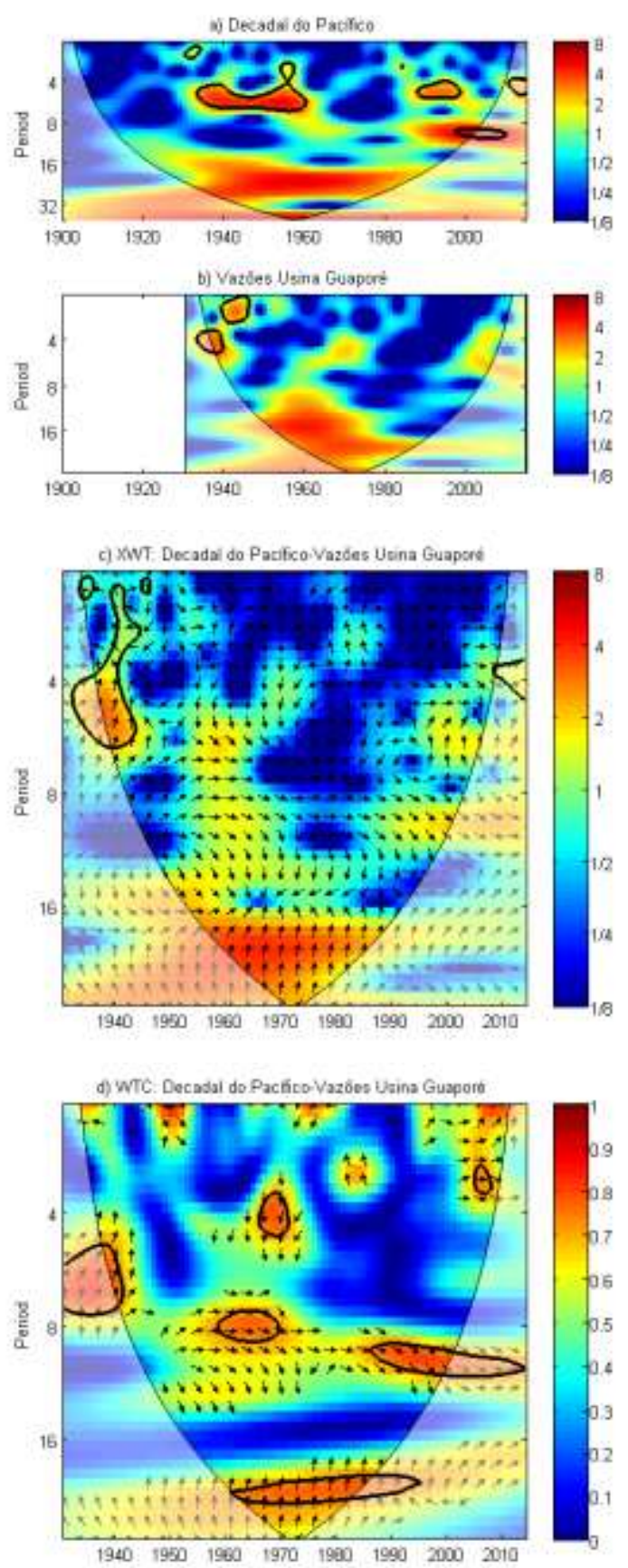

Figura APÊNDICE H-48 Análise por wavelets a) Decadal do Pacífico versos b) Vazões da Usina de Guaporé. c) Trans. Cruzada - XWT d) Trans.Contínua - CWT 


\section{APÊNDICE H.10 Wavelets Vazão da Usina Nova Ponte}
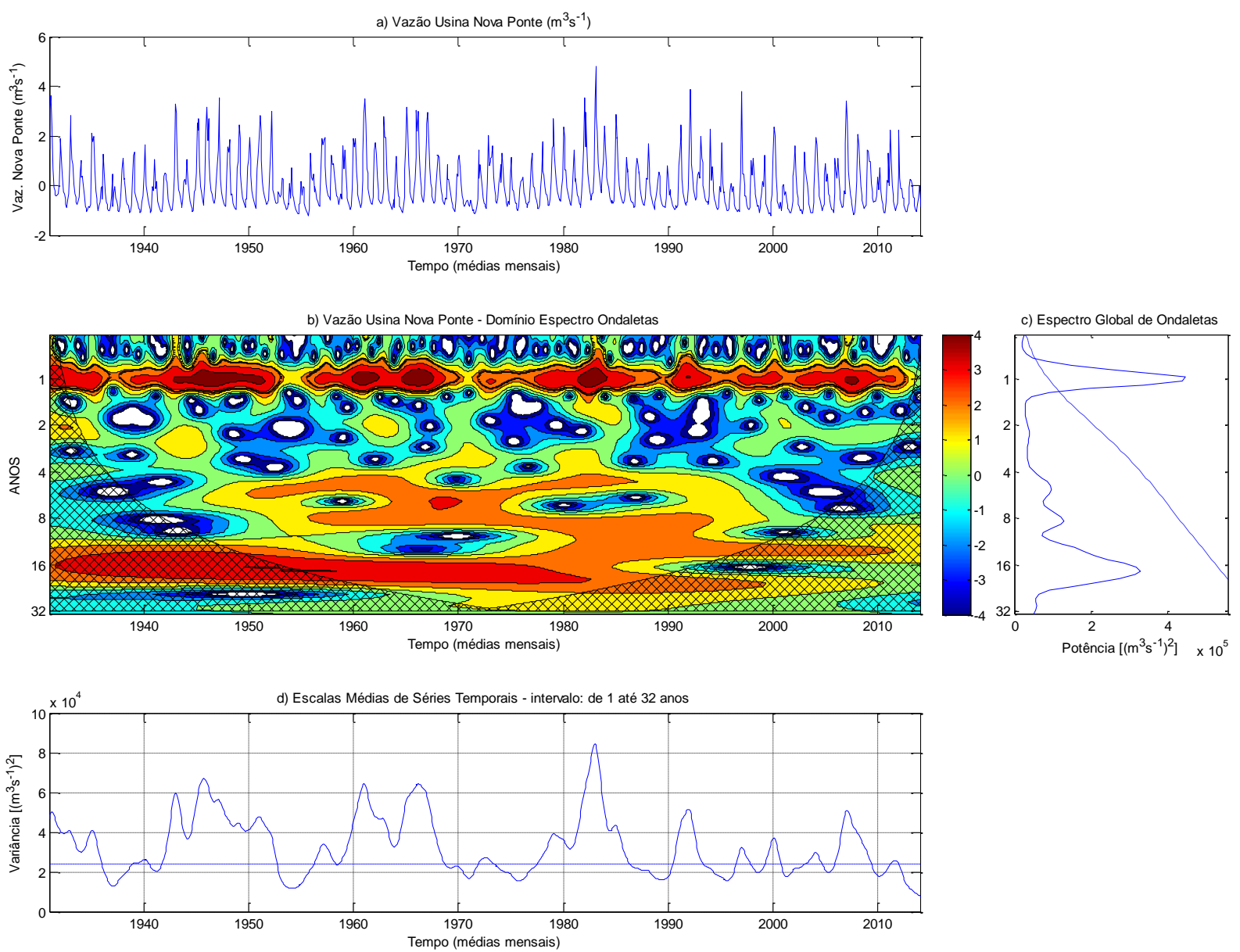

Figura APÊNDICE H-49 Análise por wavelets a) Série Histórica Vazão da Usina Nova Ponte normalizada. b) Domínio Espectro de Ondaletas. c) Espectro Global de Ondaletas. d) Escalas Médias de Séries Temporais 
APÊNDICE H.10.1 Análise relação variáveis explicativas e usina Nova Ponte
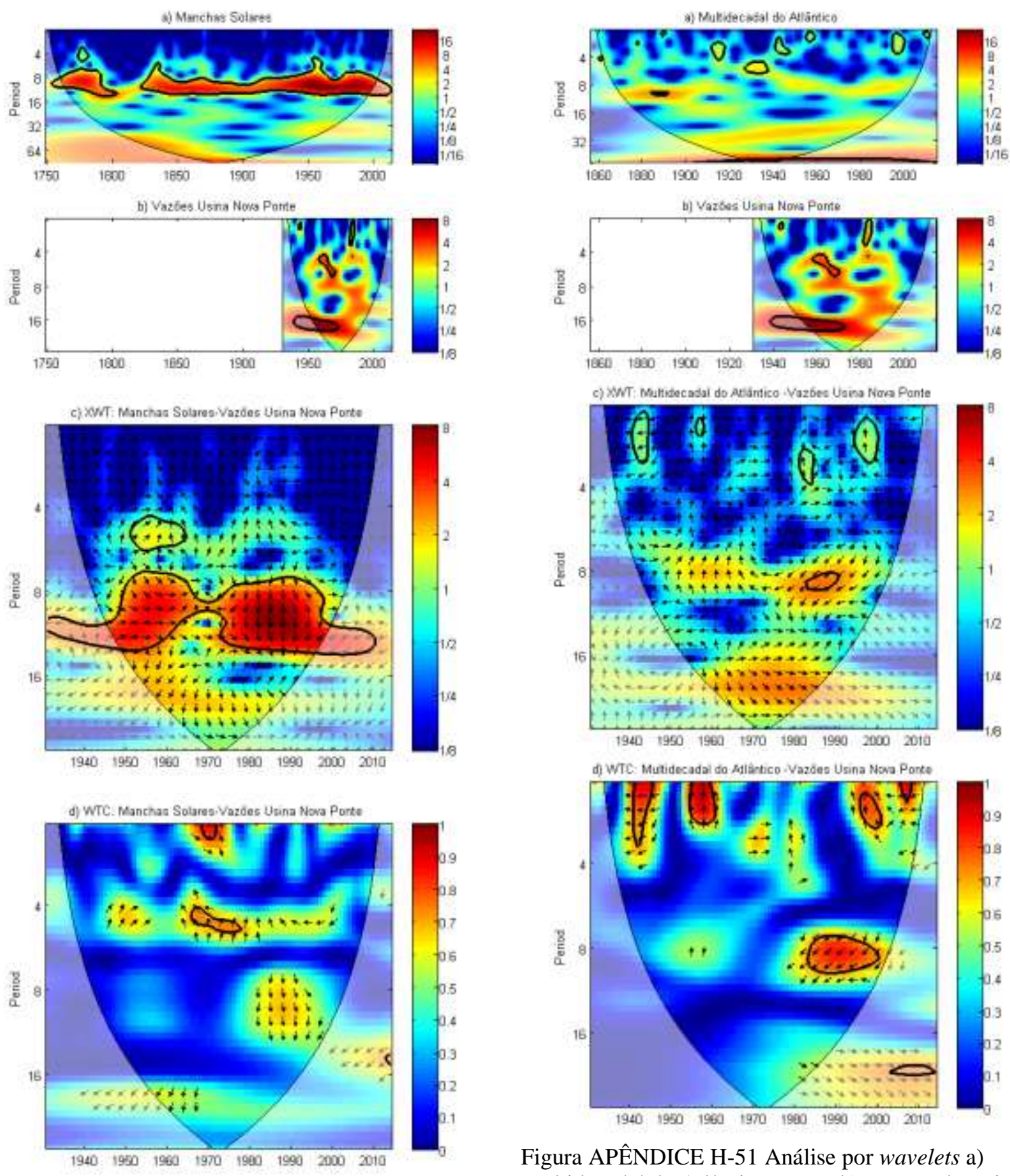

Figura APÊNDICE H-50 Análise por wavelets a) Manchas Solares versos b) Vazões da Usina Nova Ponte. c) Trans. Cruzada - XWT d) Trans.Contínua -

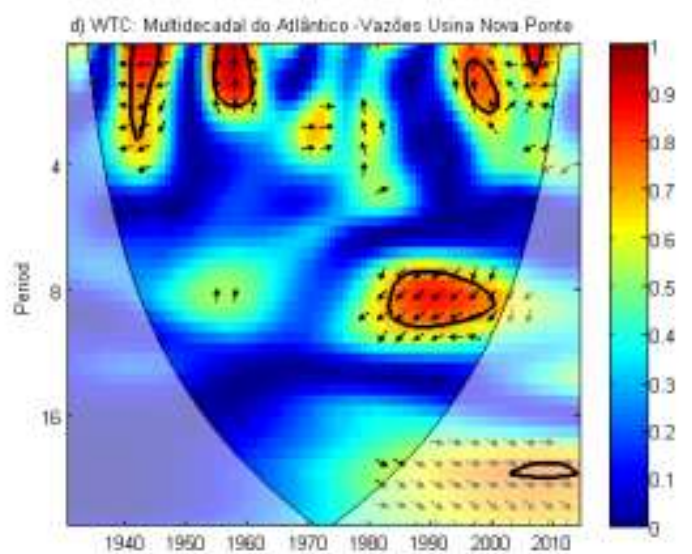

Figura APÊNDICE H-51 Análise por wavelets a) Multidecadal do Atlântico versos b) Vazões da Usina Nova Ponte. c) Trans. Cruzada - XWT d) Trans.Contínua - CWT CWT 

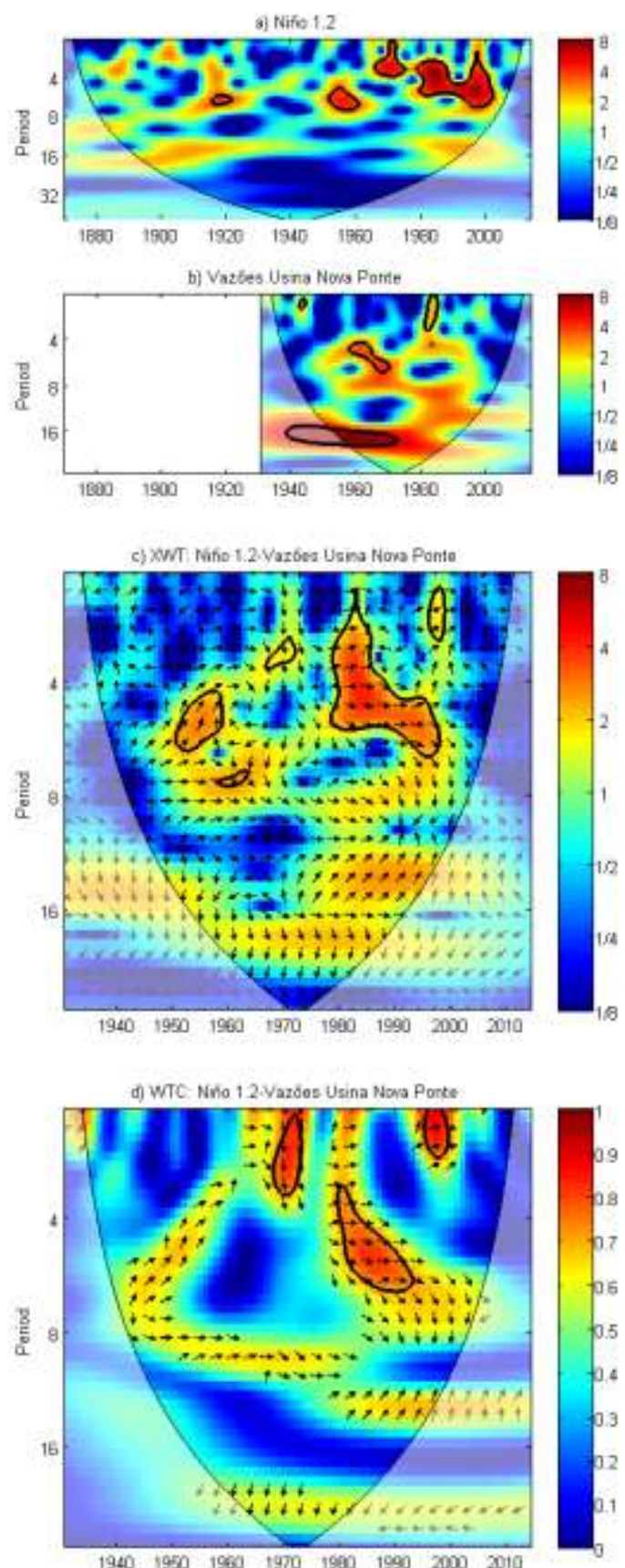

Figura APÊNDICE H-52 Análise por wavelets a) El Niño 1+2 versos b) Vazões da Usina Nova Ponte. c) Trans. Cruzada - XWT d) Trans.Contínua - CWT
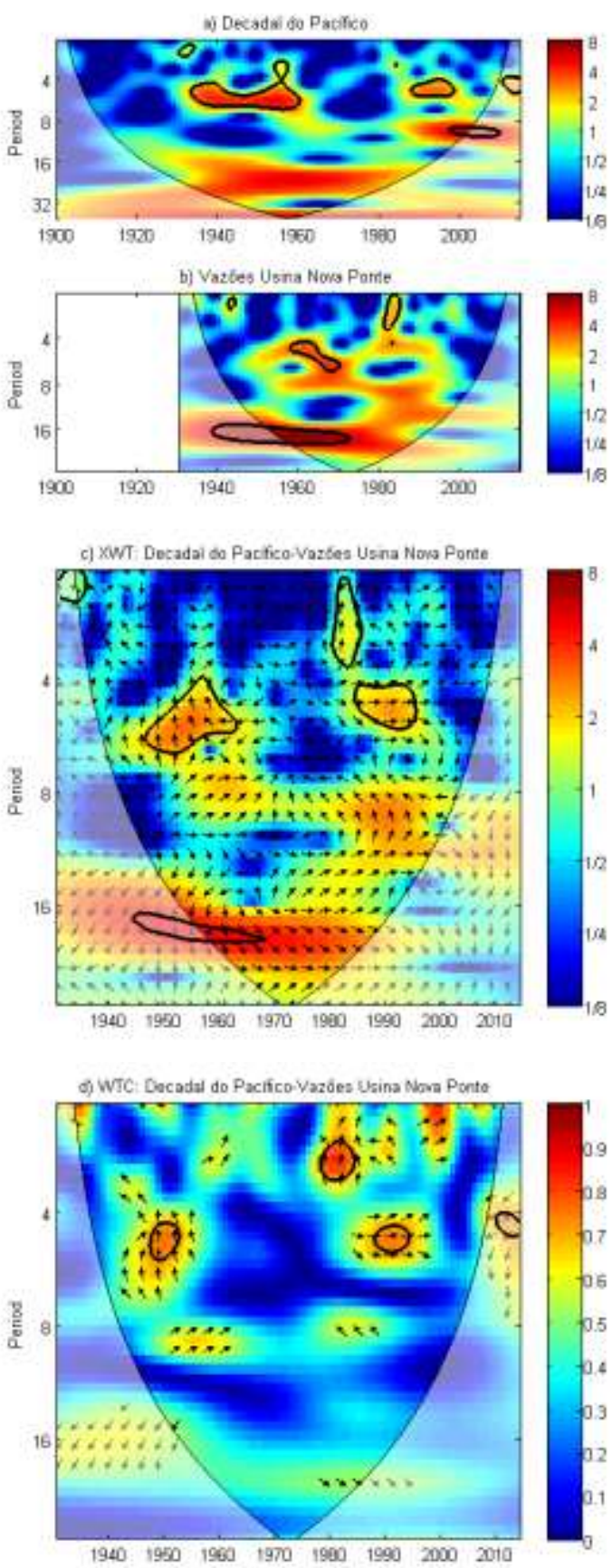

Figura APÊNDICE H-53 Análise por wavelets a) Decadal do Pacífico versos b) Vazões da Usina Nova Ponte. c) Trans. Cruzada - XWT d) Trans.Contínua CWT 
APÊNDICE H.11 Wavelets Vazão da Usina Passo Fundo
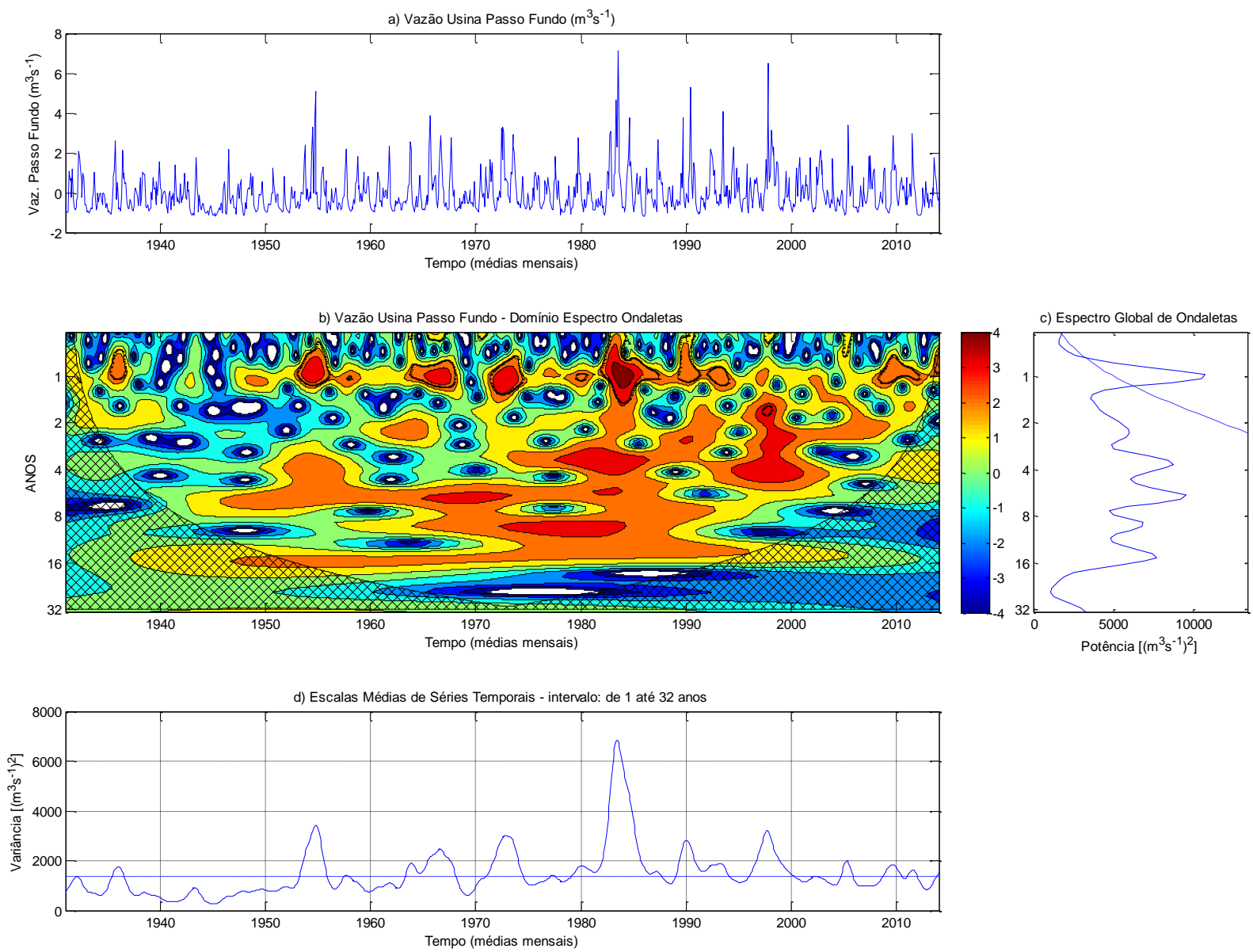

Figura APÊNDICE H-54 Análise por wavelets a) Série Histórica Vazão da Usina Passo Fundo normalizada. b) Domínio Espectro de Ondaletas. c) Espectro Global de Ondaletas. d) Escalas Médias de Séries Temporais 
APÊNDICE H.11.1 Análise relação variáveis explicativas e usina Passo Fundo
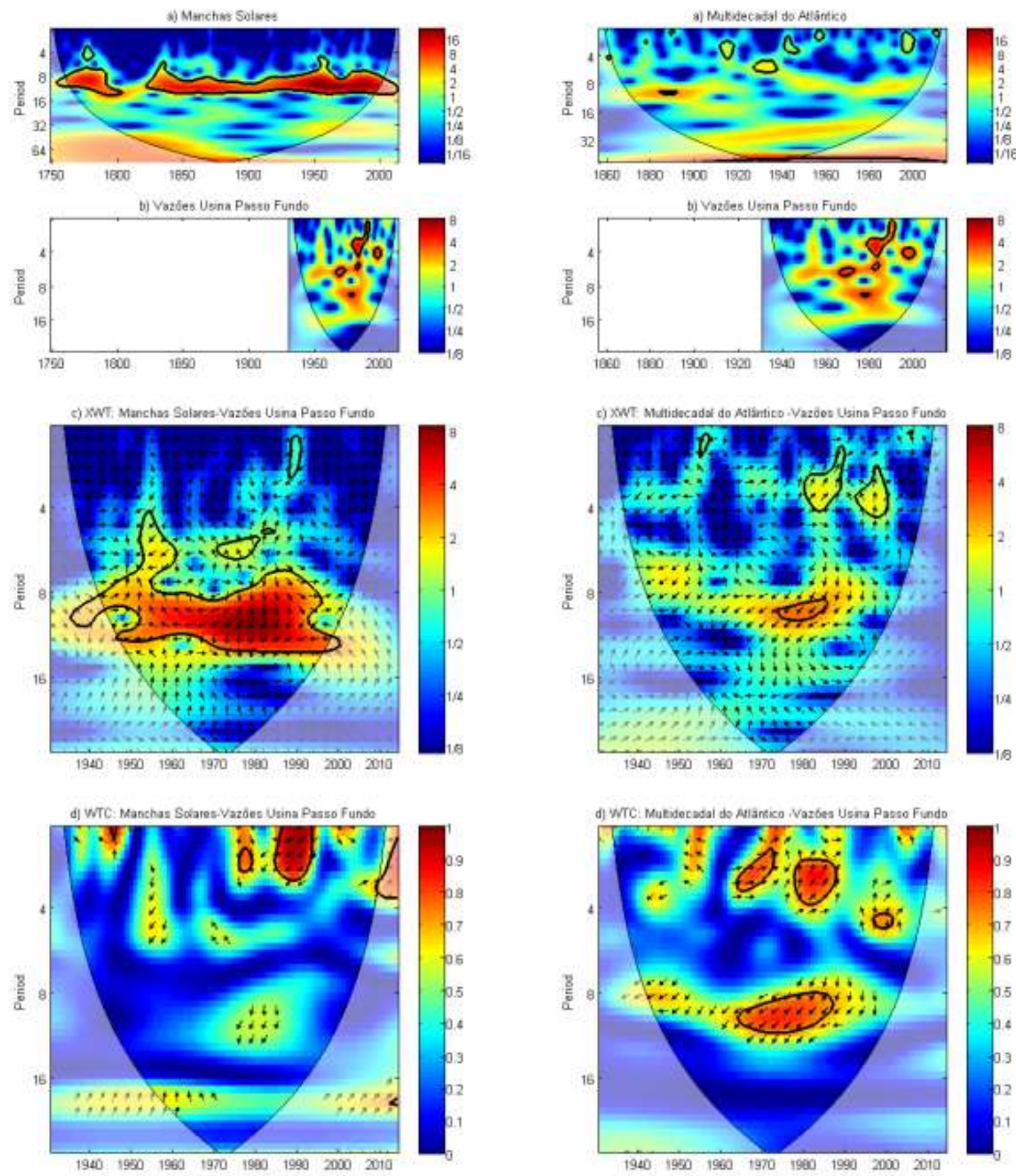

Figura APÊNDICE H-55 Análise por wavelets a) Manchas Solares versos b) Vazões da Usina Passo Fundo. c) Trans. Cruzada - XWT d) Trans.Contínua CWT

Figura APÊNDICE H-56 Análise por wavelets a) Multidecadal do Atlântico versos b) Vazões da Usina Passo Fundo. c) Trans. Cruzada - XWT d) Trans.Contínua - CWT 

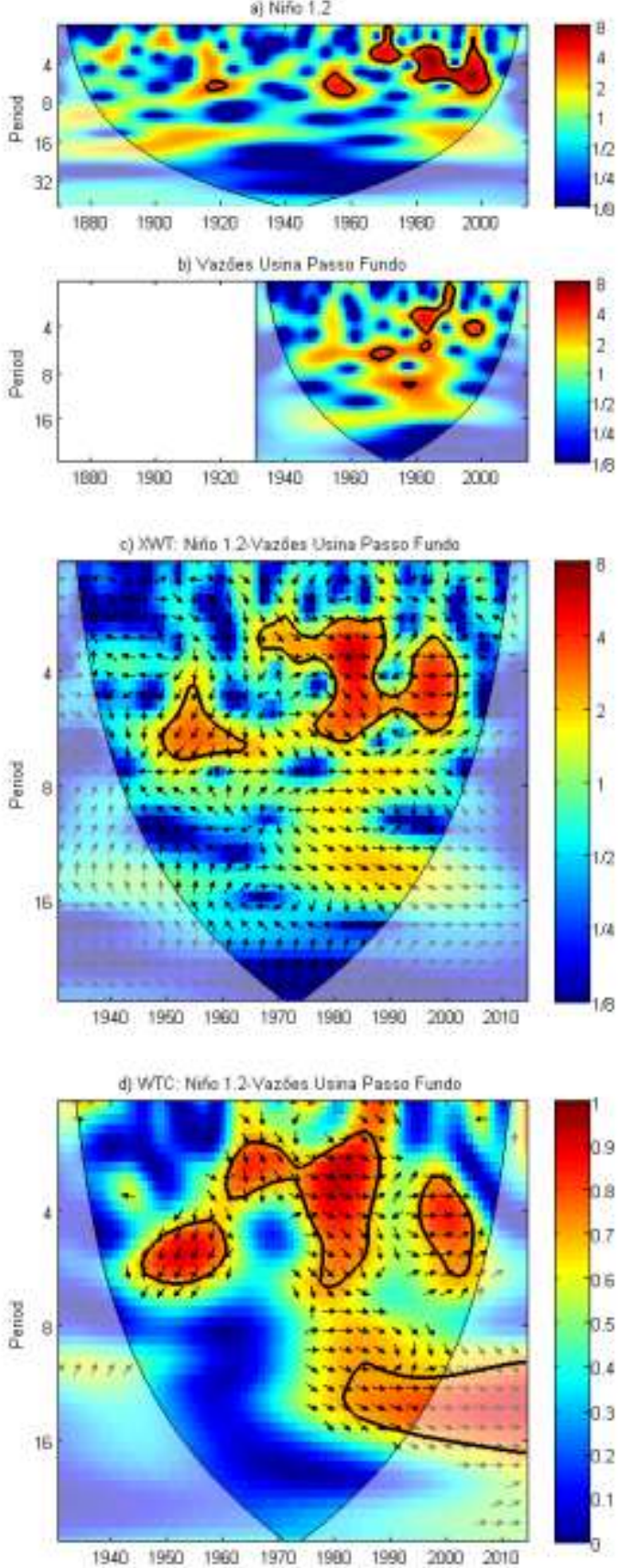

Figura APÊNDICE H-57 Análise por wavelets a) El Niño 1+2 versos b) Vazões da Usina Passo Fundo. c) Trans. Cruzada - XWT d) Trans.Contínua - CWT
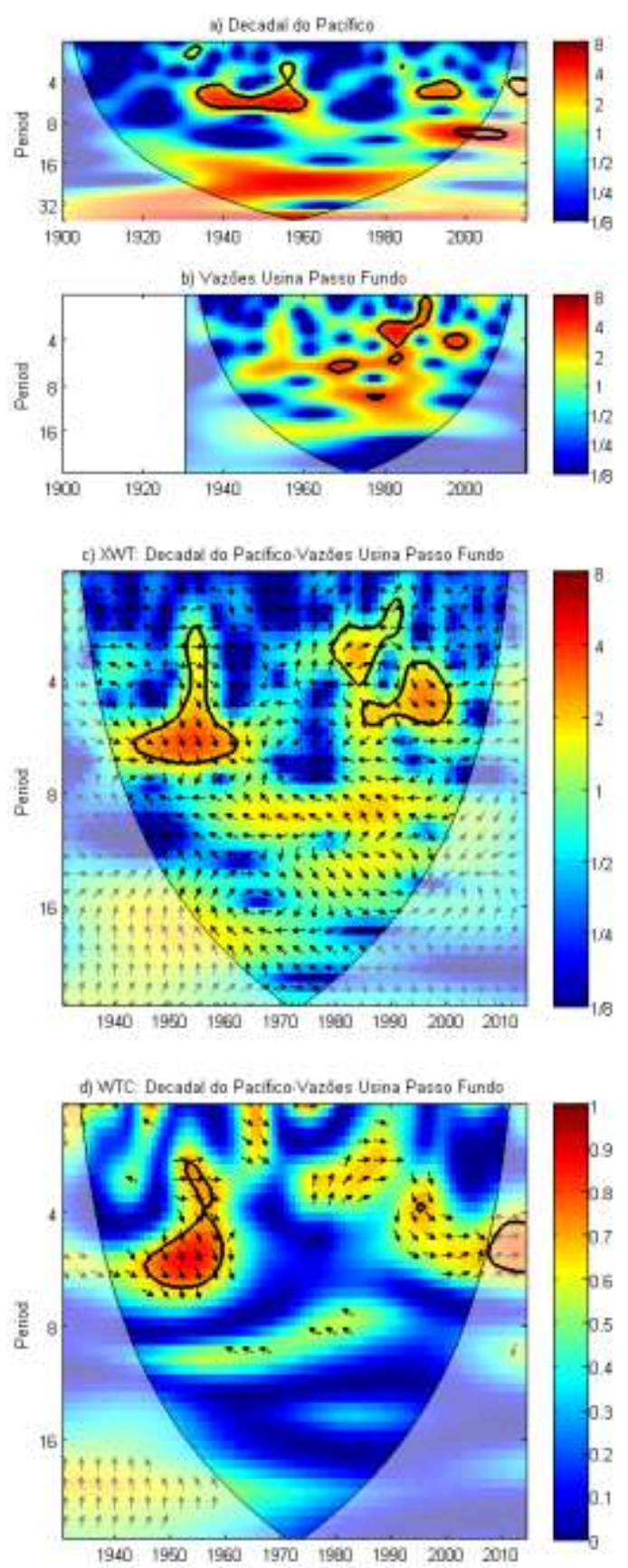

Figura APÊNDICE H-58 Análise por wavelets a) Decadal do Pacífico versos b) Vazões da Usina Passo Fundo. c) Trans. Cruzada - XWT d) Trans.Contínua CWT 


\section{APÊNDICE H.12 Wavelets Vazão da Usina Queimado}
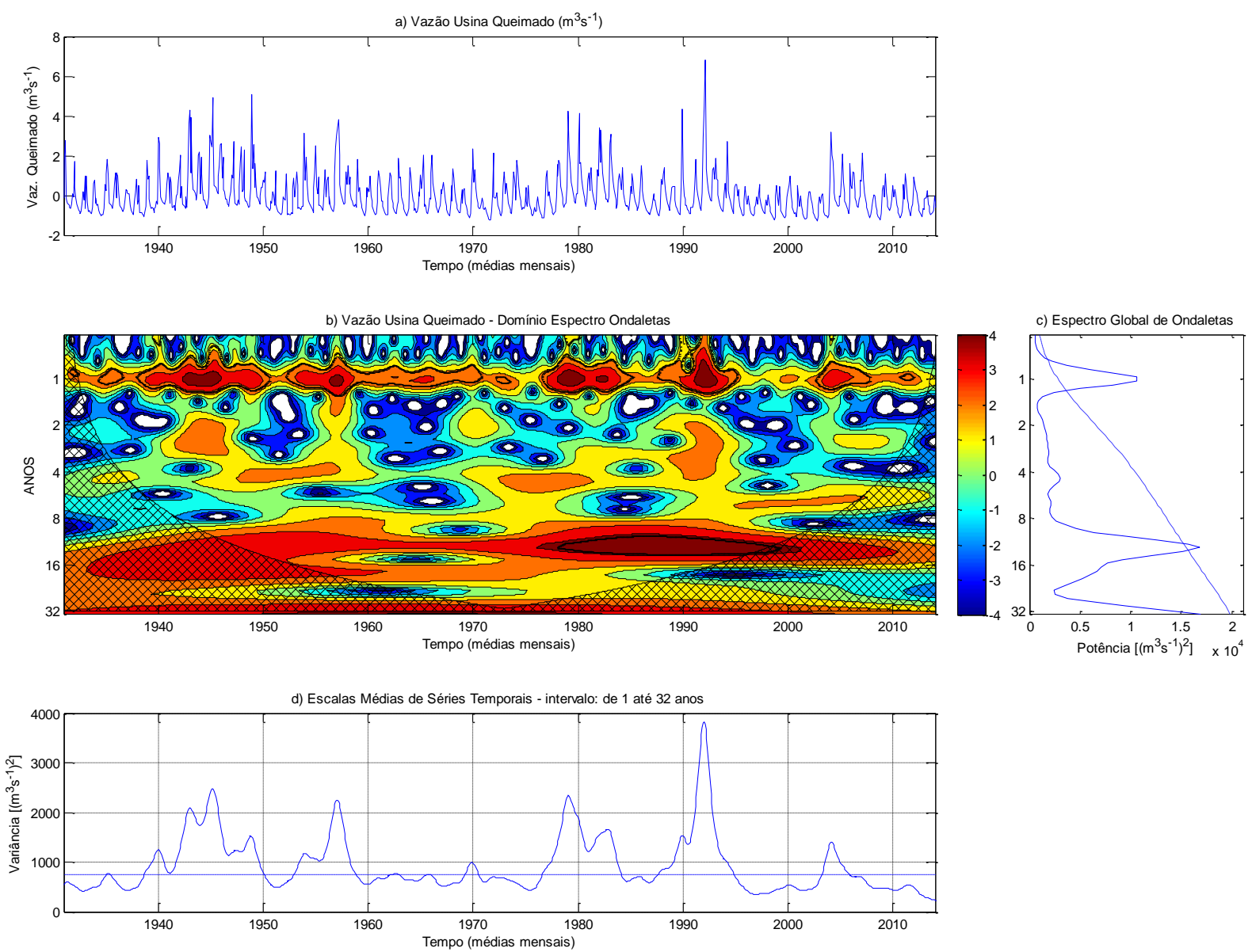

Figura APÊNDICE H-59 Análise por wavelets a) Série Histórica Vazão da Usina Queimado normalizada. b) Domínio Espectro de Ondaletas. c) Espectro Global de Ondaletas. d) Escalas Médias de Séries Temporais 
APÊNDICE H.12.1 Análise relação variáveis explicativas e usina Queimado
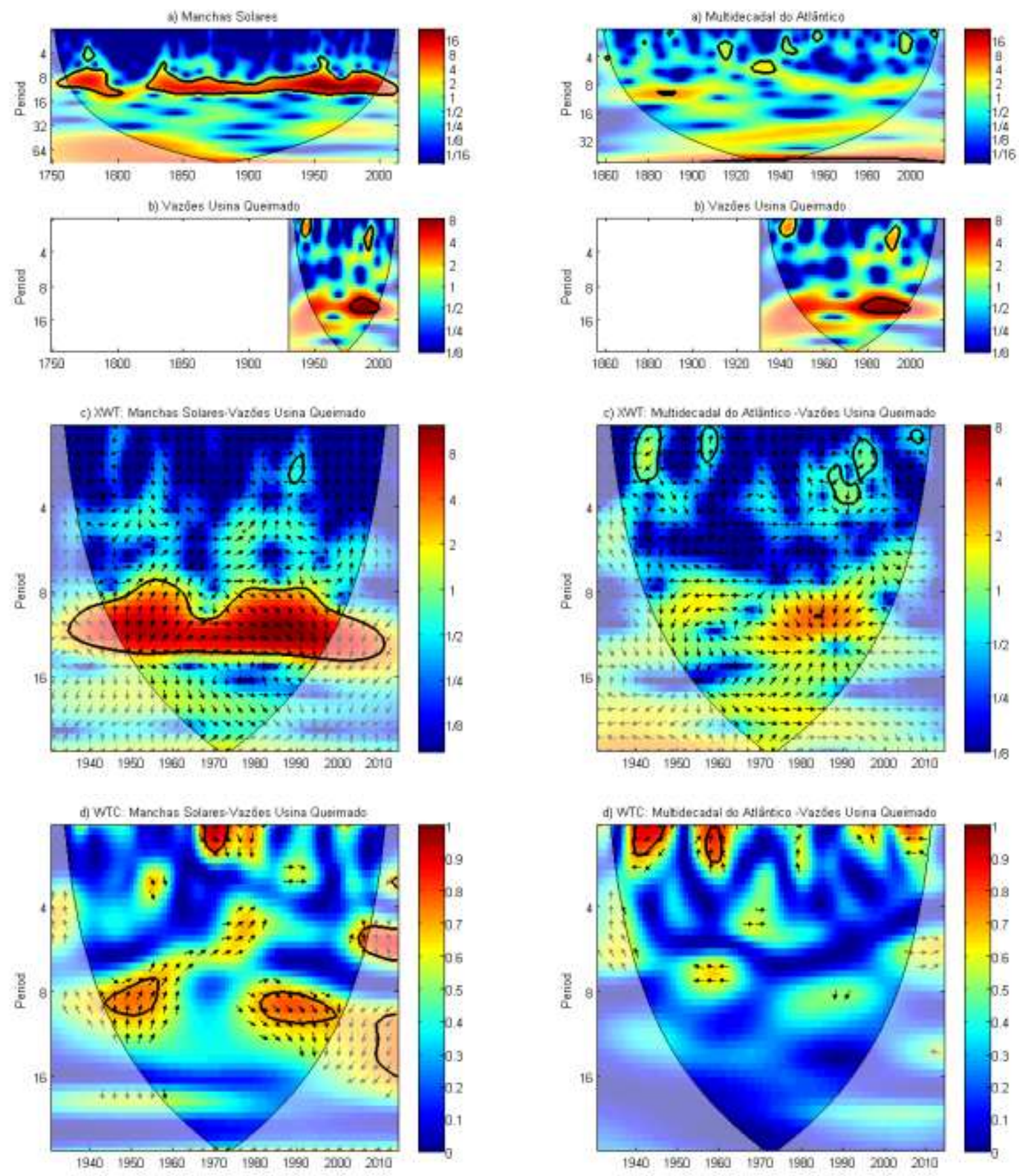

Figura APÊNDICE H-60 Análise por wavelets a) Manchas Solares versos b) Vazões da Usina Queimado. c) Trans. Cruzada - XWT d) Trans.Contínua - CWT Multidecadal do Atlântico versos b) Vazões da Usina Queimado. c) Trans. Cruzada - XWT d) Trans.Contínua - CWT 

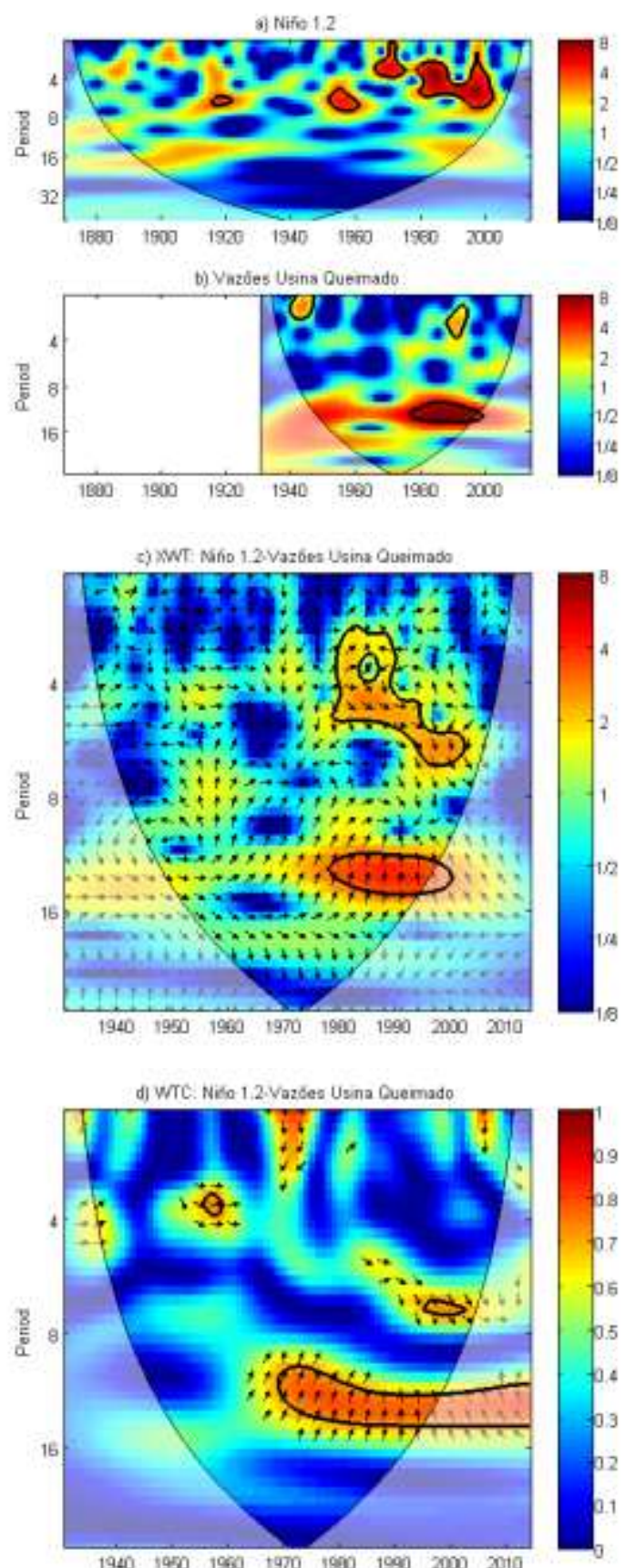

Figura APÊNDICE H-62 Análise por wavelets a) El Niño 1+2 versos b) Vazões da Usina Queimado. c) Trans. Cruzada - XWT d) Trans.Contínua - CWT
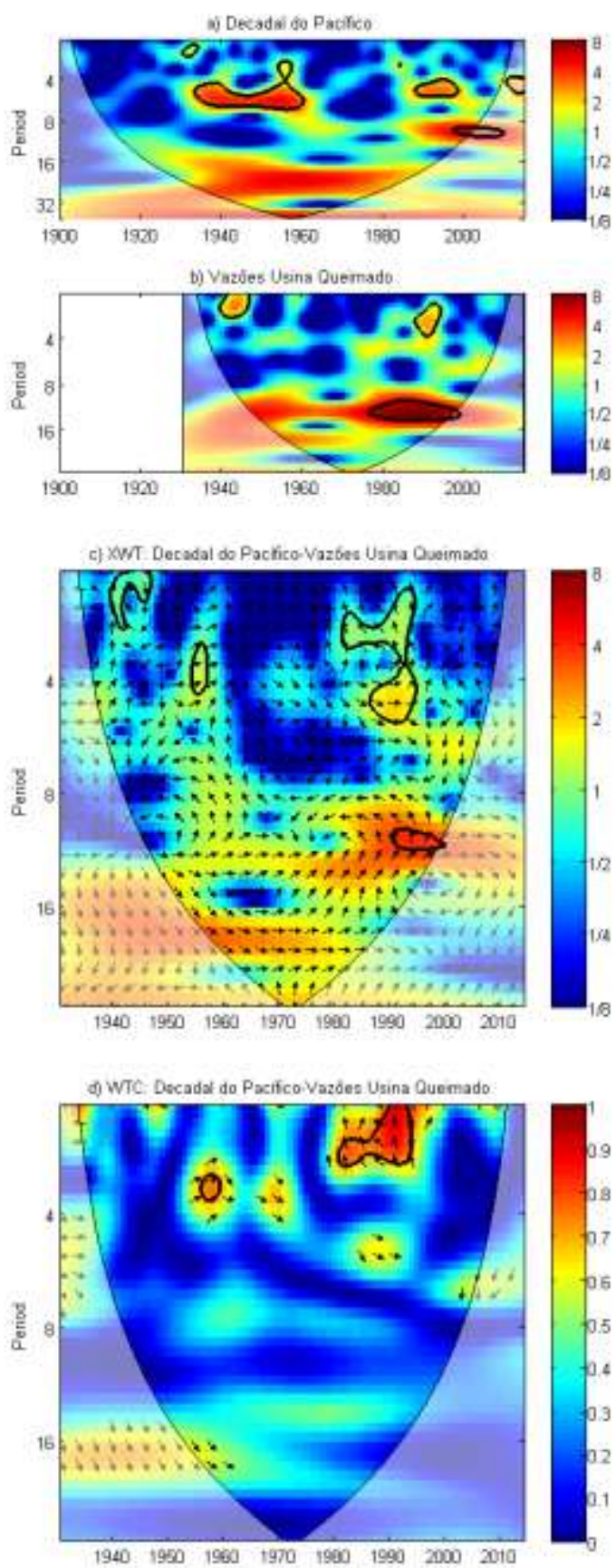

Figura APÊNDICE H-63 Análise por wavelets a) Decadal do Pacífico versos b) Vazões da Usina Queimado. c) Trans. Cruzada - XWT d) Trans.Contínua - CWT 
APÊNDICE H.13 Wavelets Vazão da Usina Retiro Baixo
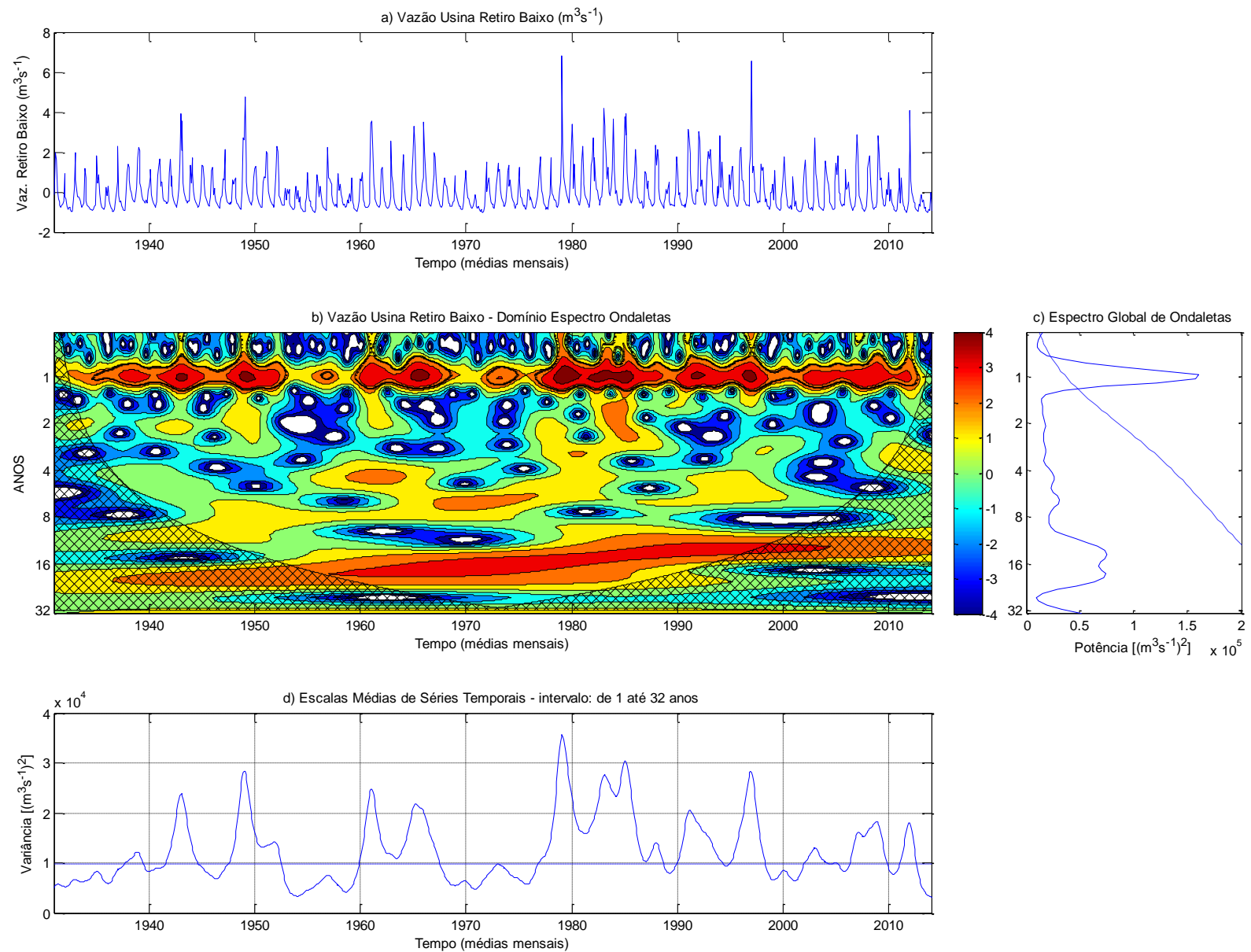

Figura APÊNDICE H-64 Análise por wavelets a) Série Histórica Vazão da Usina Retiro Baixo normalizada. b) Domínio Espectro de Ondaletas. c) Espectro Global de Ondaletas. d) Escalas Médias de Séries Temporais 
APÊNDICE H.13.1 Análise relação variáveis explicativas e usina Retiro Baixo
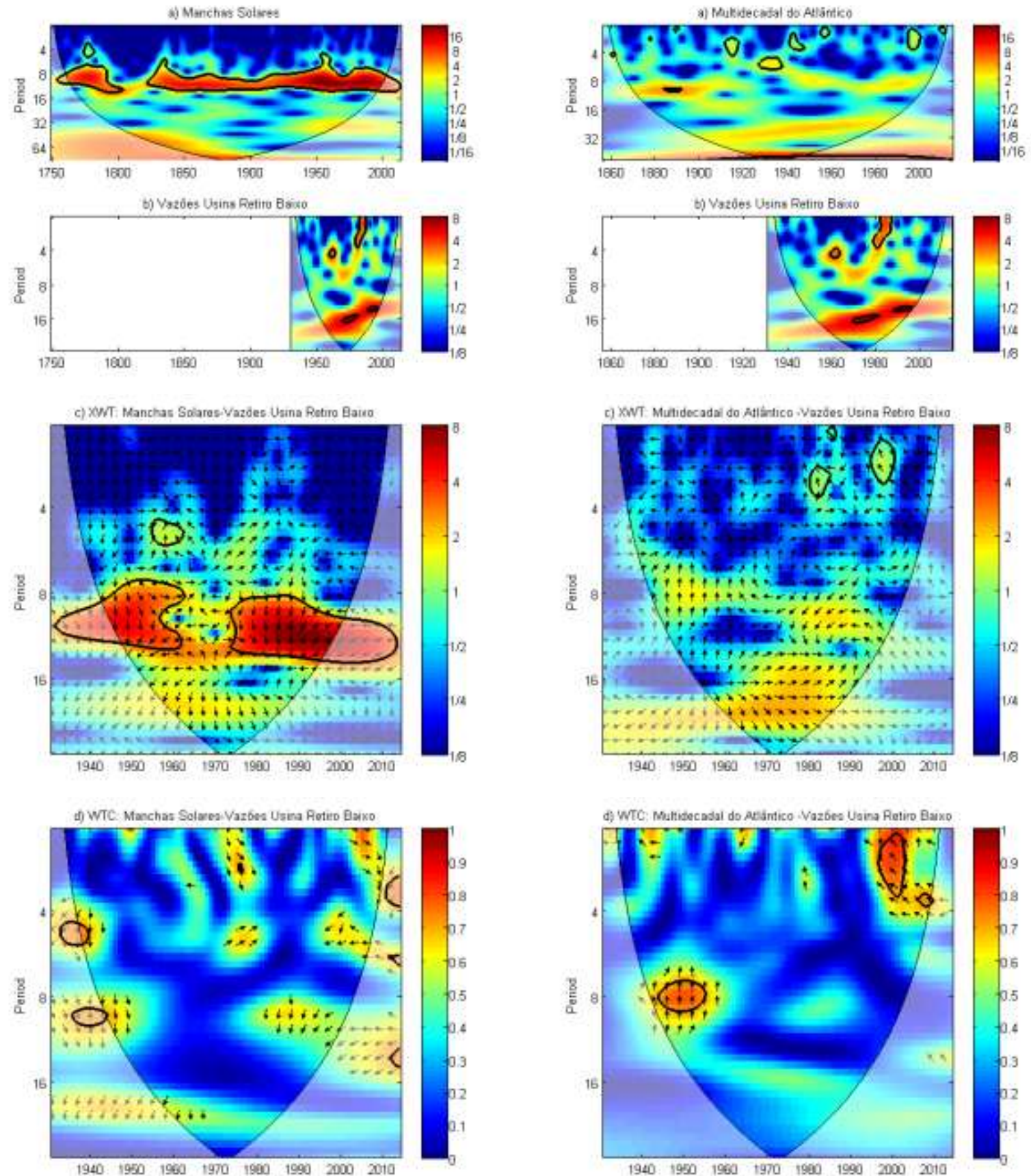

Figura APÊNDICE H-65 Análise por wavelets a) Manchas Solares versos b) Vazões da Usina Retiro Baixo. c) Trans. Cruzada - XWT d) Trans.Contínua CWT

Figura APÊNDICE H-66 Análise por wavelets a) Multidecadal do Atlântico versos b) Vazões da Usina Retiro Baixo. c) Trans. Cruzada - XWT d) Trans.Contínua - CWT 

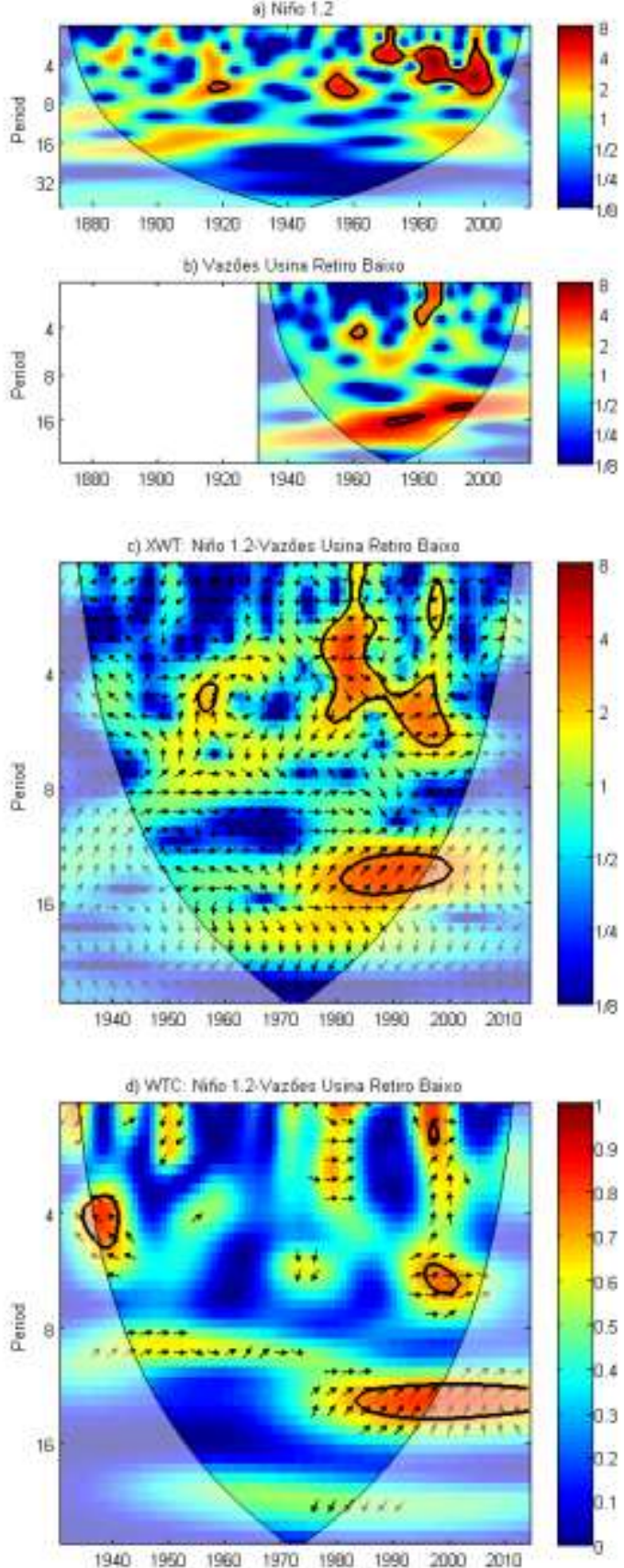

Figura APÊNDICE H-67 Análise por wavelets a) El Niño 1+2 versos b) Vazões da Usina Retiro Baixo. c) Trans. Cruzada - XWT d) Trans.Contínua - CWT
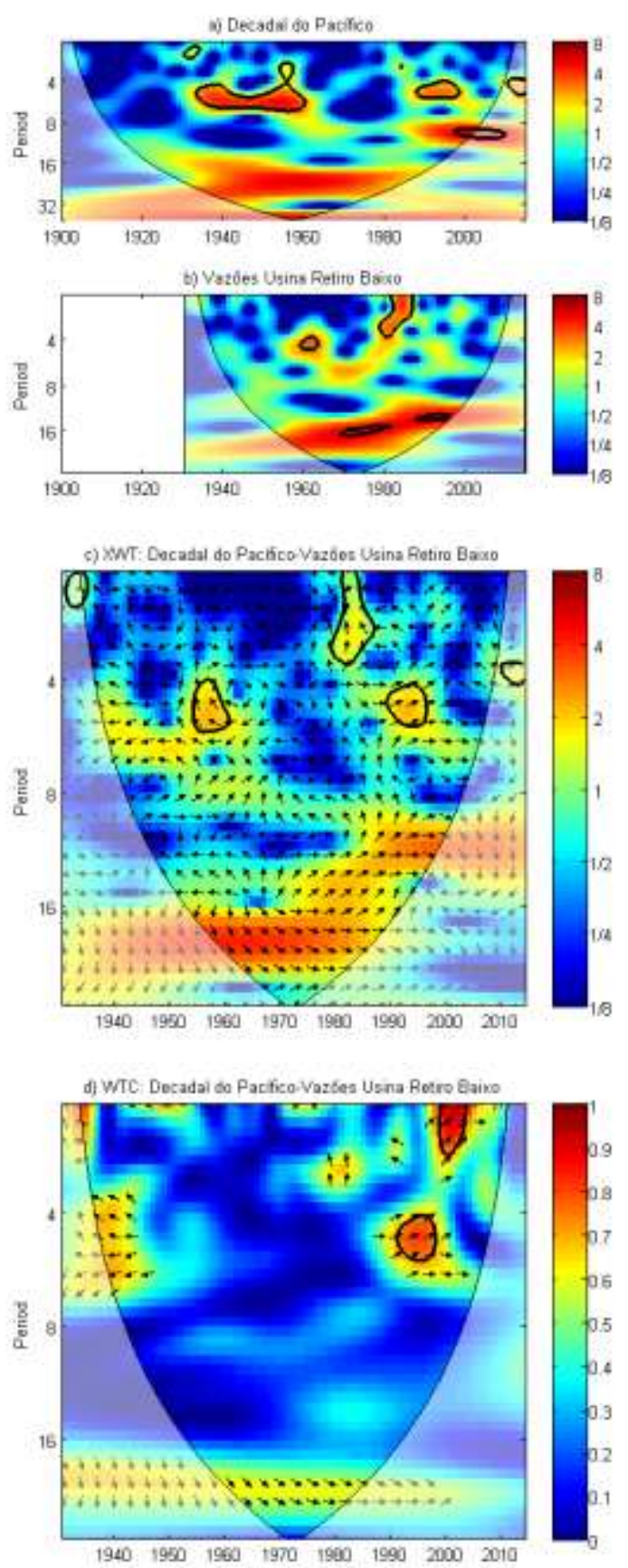

Figura APÊNDICE H-68 Análise por wavelets a) Decadal do Pacífico versos b) Vazões da Usina Retiro Baixo. c) Trans. Cruzada - XWT d) Trans.Contínua CWT 
APÊNDICE H.14 Wavelets Vazão da Usina Samuel
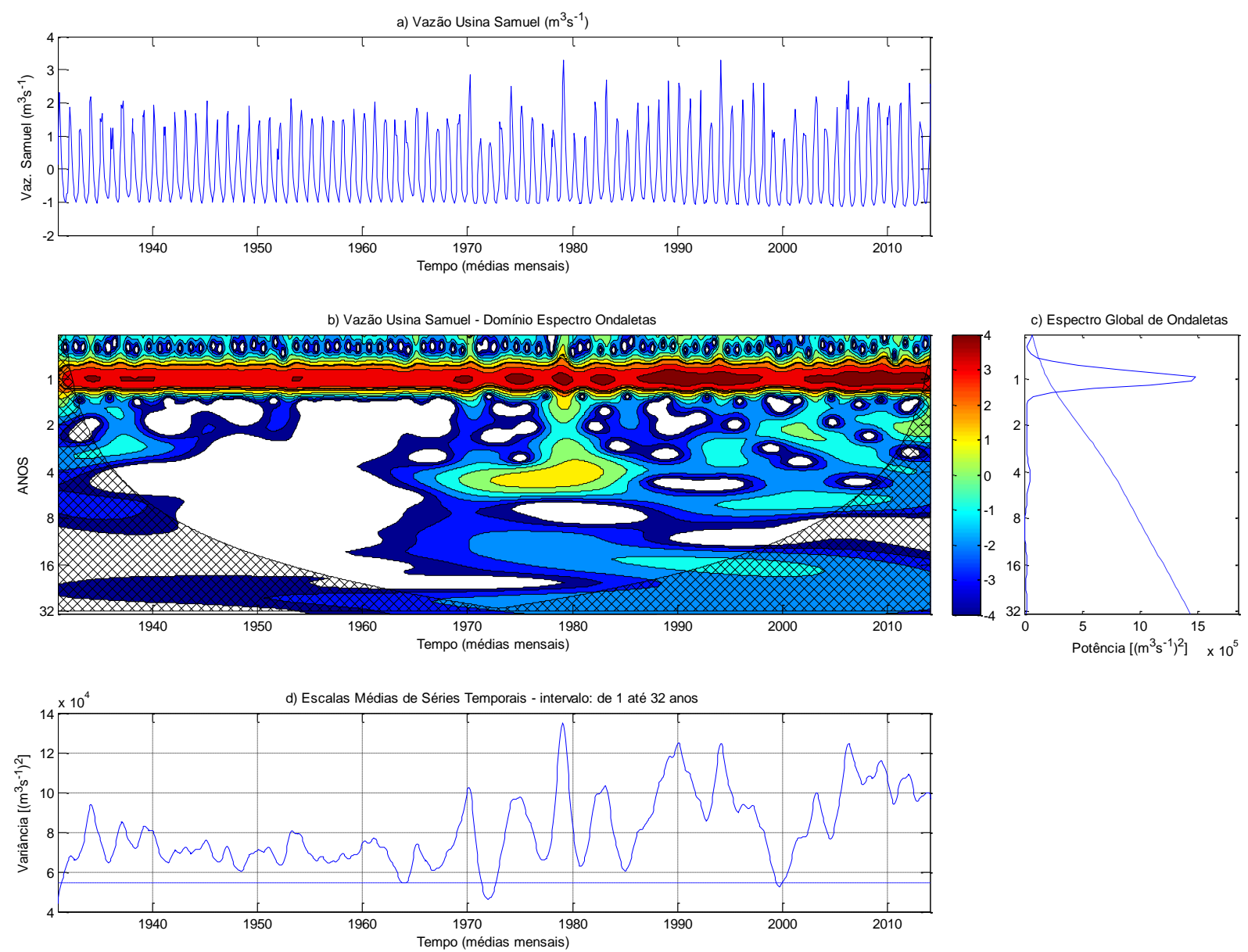

Figura APÊNDICE H-69 Análise por wavelets a) Série Histórica Vazão da Usina Samuel normalizada. b) Domínio Espectro de Ondaletas. c) Espectro Global de Ondaletas. d) Escalas Médias de Séries Temporais 
APÊNDICE H.14.1 Análise relação variáveis explicativas e usina Samuel
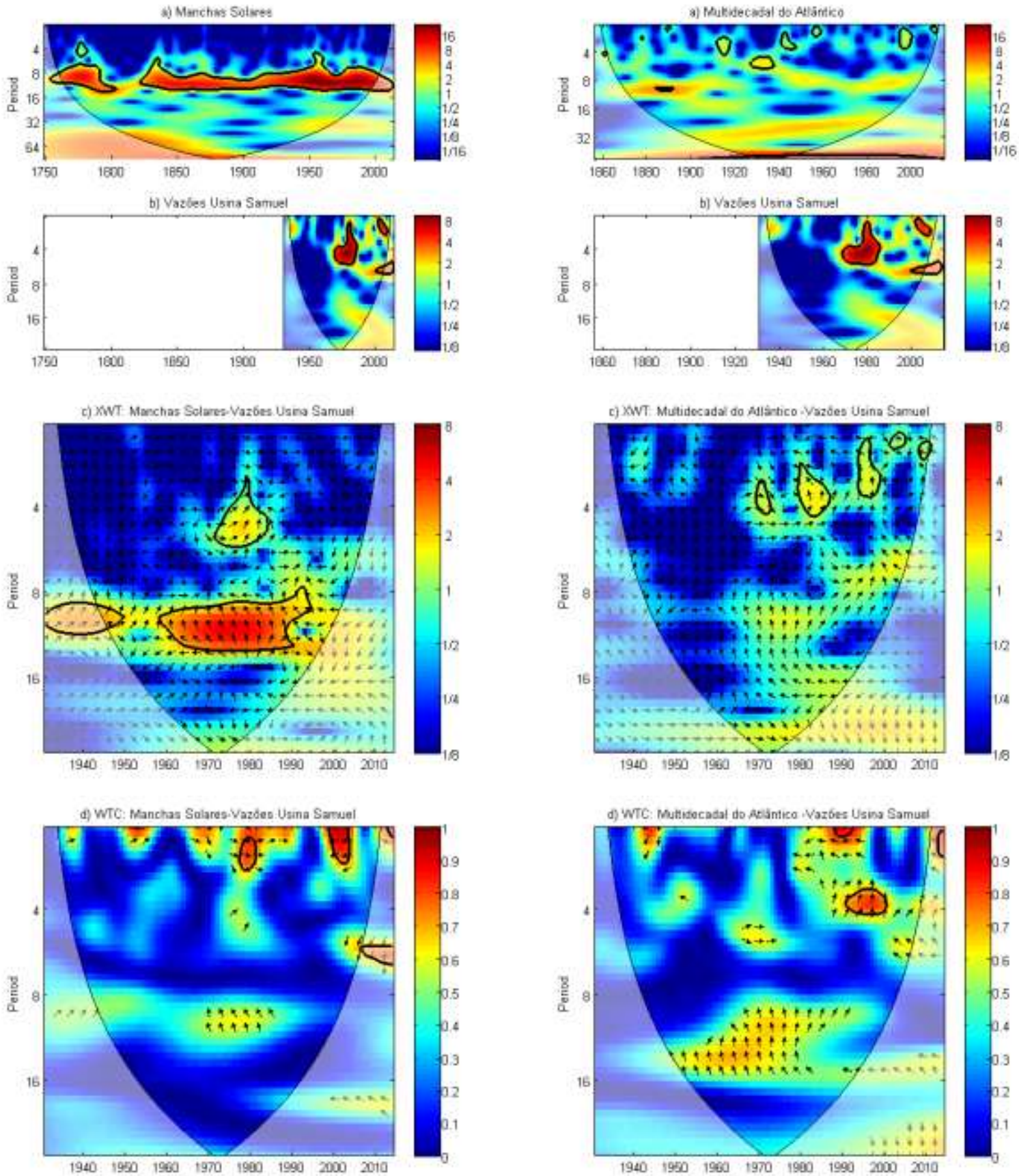

Figura APÊNDICE H-70 Análise por wavelets a) Manchas Solares versos b) Vazões da Usina Samuel. c) Trans. Cruzada - XWT d) Trans.Contínua - CWT

Figura APÊNDICE H-71 Análise por wavelets a) Multidecadal do Atlântico versos b) Vazões da Usina Samuel. c) Trans. Cruzada - XWT d) Trans.Contínua $-\mathrm{CWT}$ 

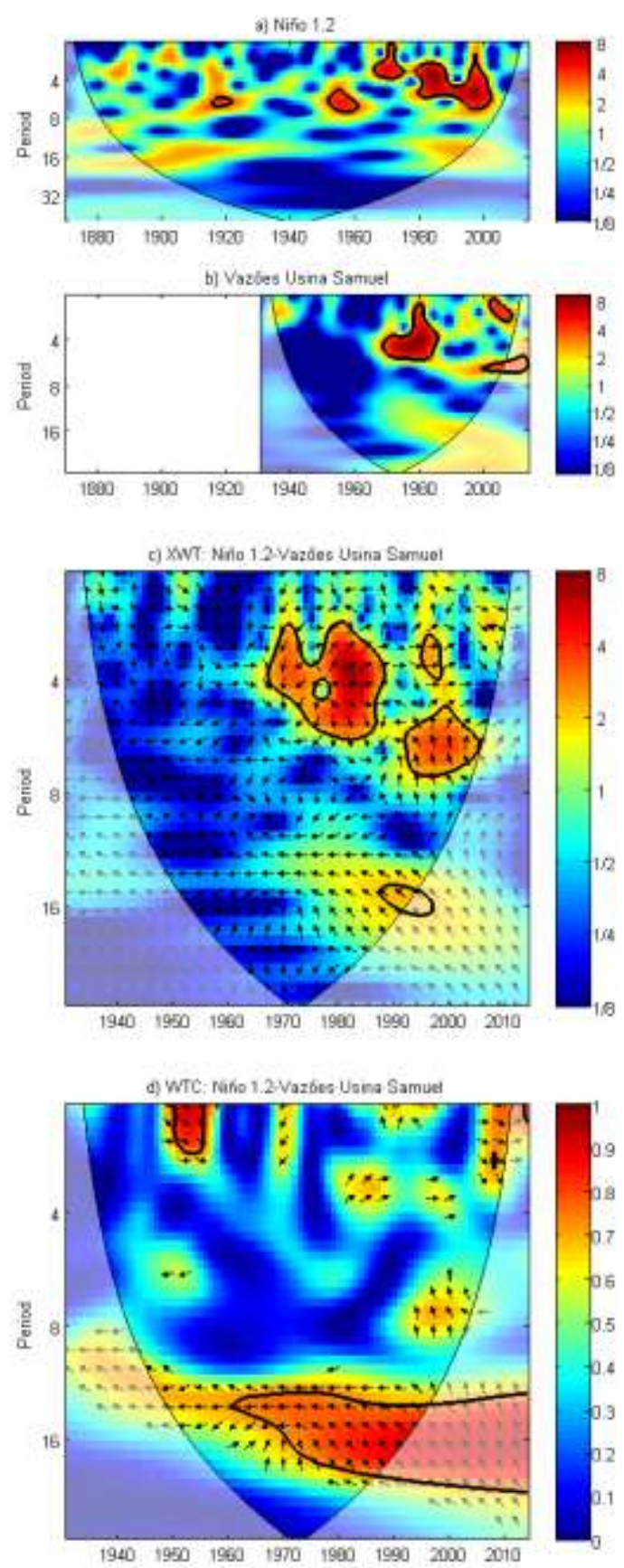

Figura APÊNDICE H-72 Análise por wavelets a) El Niño 1+2 versos b) Vazões da Usina Samuel. c) Trans. Cruzada - XWT d) Trans.Contínua - CWT
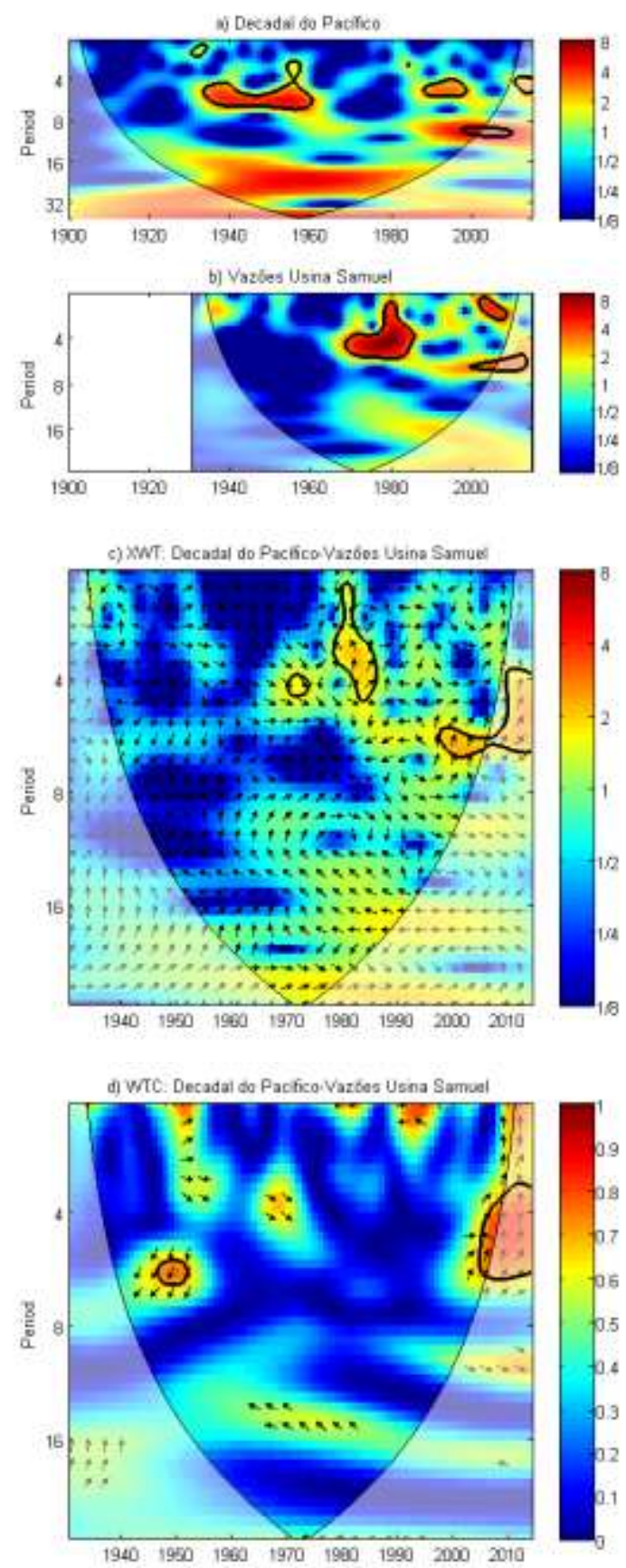

Figura APÊNDICE H-73 Análise por wavelets a) Decadal do Pacífico versos b) Vazões da Usina Samuel. c) Trans. Cruzada - XWT d) Trans.Contínua $-\mathrm{CWT}$ 
APÊNDICE H.15 Wavelets Vazão da Usina Serra da Mesa
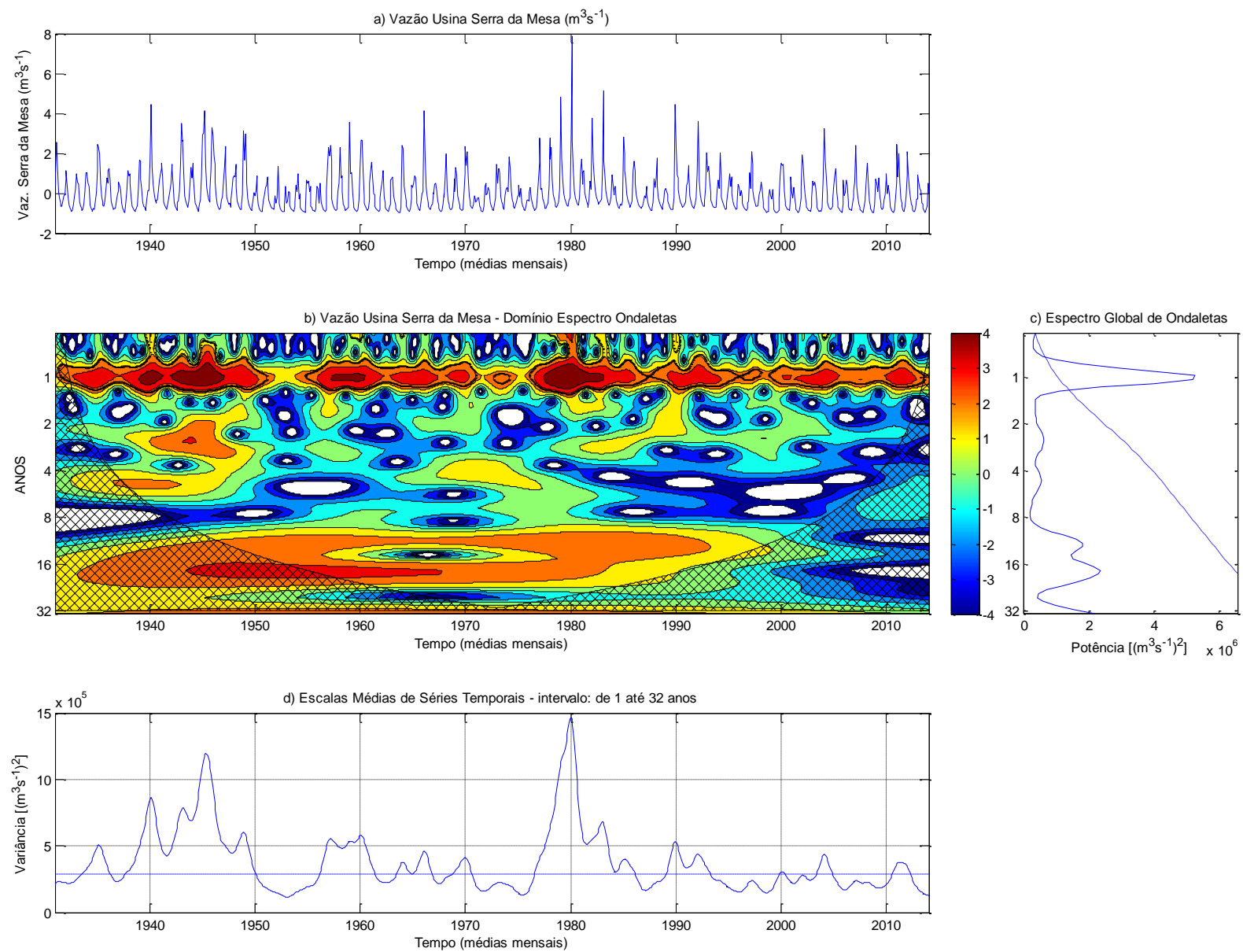

Figura APÊNDICE H-74 Análise por wavelets a) Série Histórica Vazão da Usina Serra da Mesa normalizada. b) Domínio Espectro de Ondaletas. c) Espectro Global de Ondaletas. d) Escalas Médias de Séries Temporais 
APÊNDICE H.15.1 Análise relação variáveis explicativas e usina Serra da Mesa
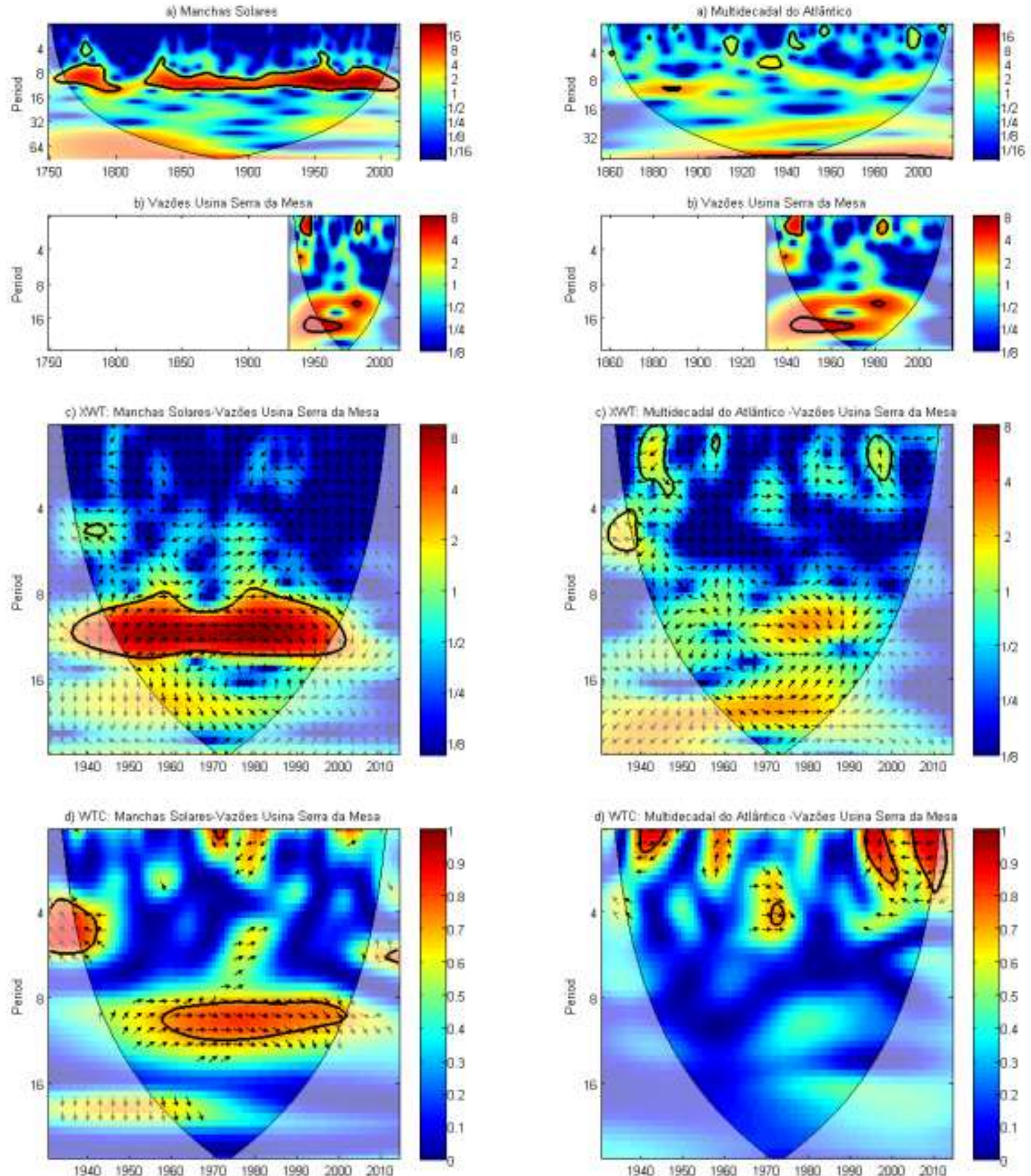

Figura APÊNDICE H-75 Análise por wavelets a) Manchas Solares versos b) Vazões da Usina Serra da Mesa. c) Trans. Cruzada - XWT d) Trans.Contínua CWT

Figura APÊNDICE H-76 Análise por wavelets a) Multidecadal do Atlântico versos b) Vazões da Usina Serra da Mesa. c) Trans. Cruzada - XWT d) Trans.Contínua - CWT 

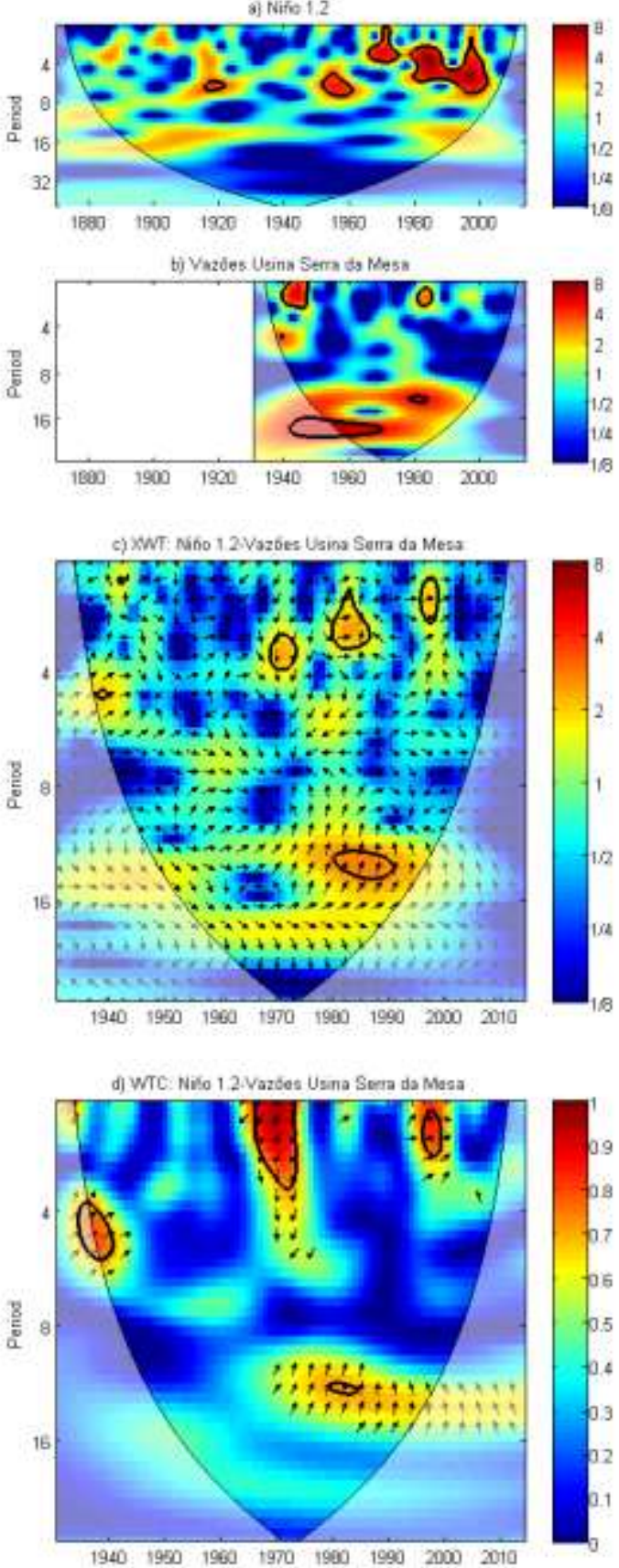

Figura APÊNDICE H-77 Análise por wavelets a) El Niño 1+2 versos b) Vazões da Usina Serra da Mesa. c) Trans. Cruzada - XWT d) Trans.Contínua - CWT
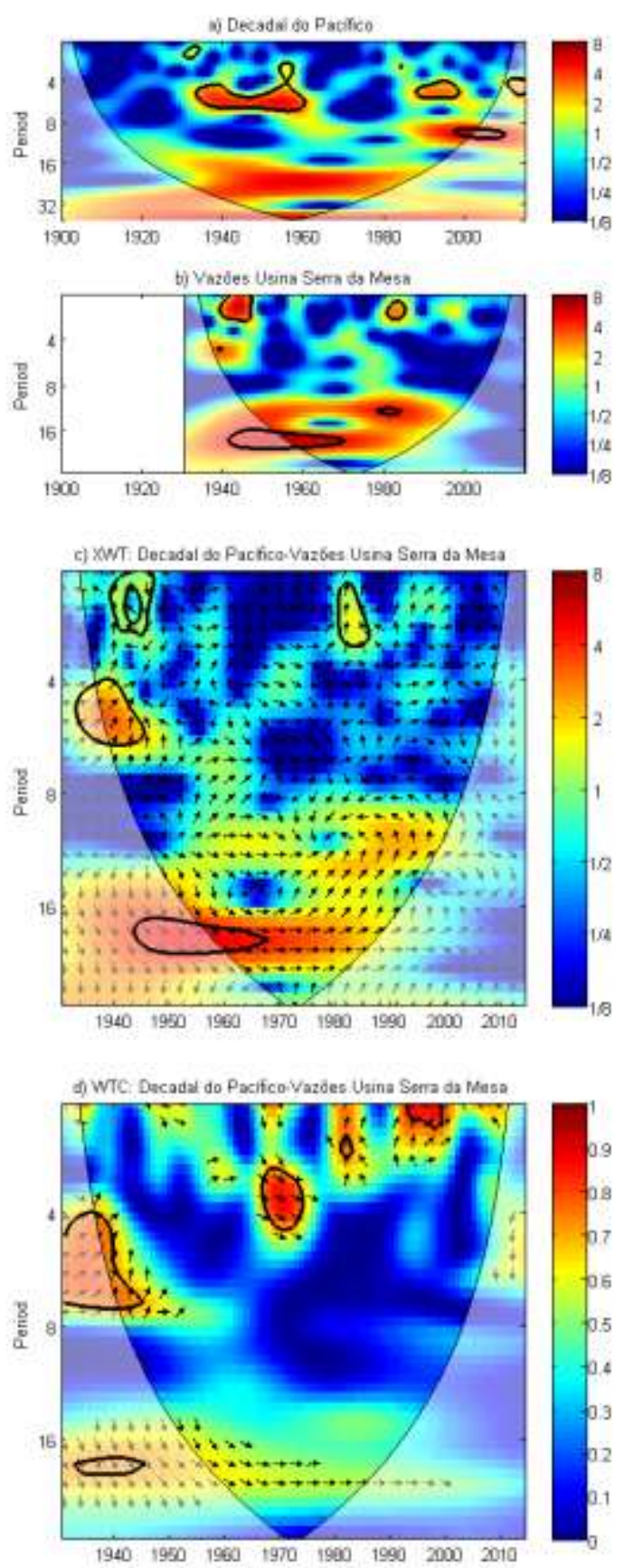

Figura APÊNDICE H-78 Análise por wavelets a) Decadal do Pacífico versos b) Vazões da Usina Serra da Mesa. c) Trans. Cruzada - XWT d) Trans.Contínua - CWT 


\section{APÊNDICE H.16 Wavelets Vazão da Usina Três Marias}
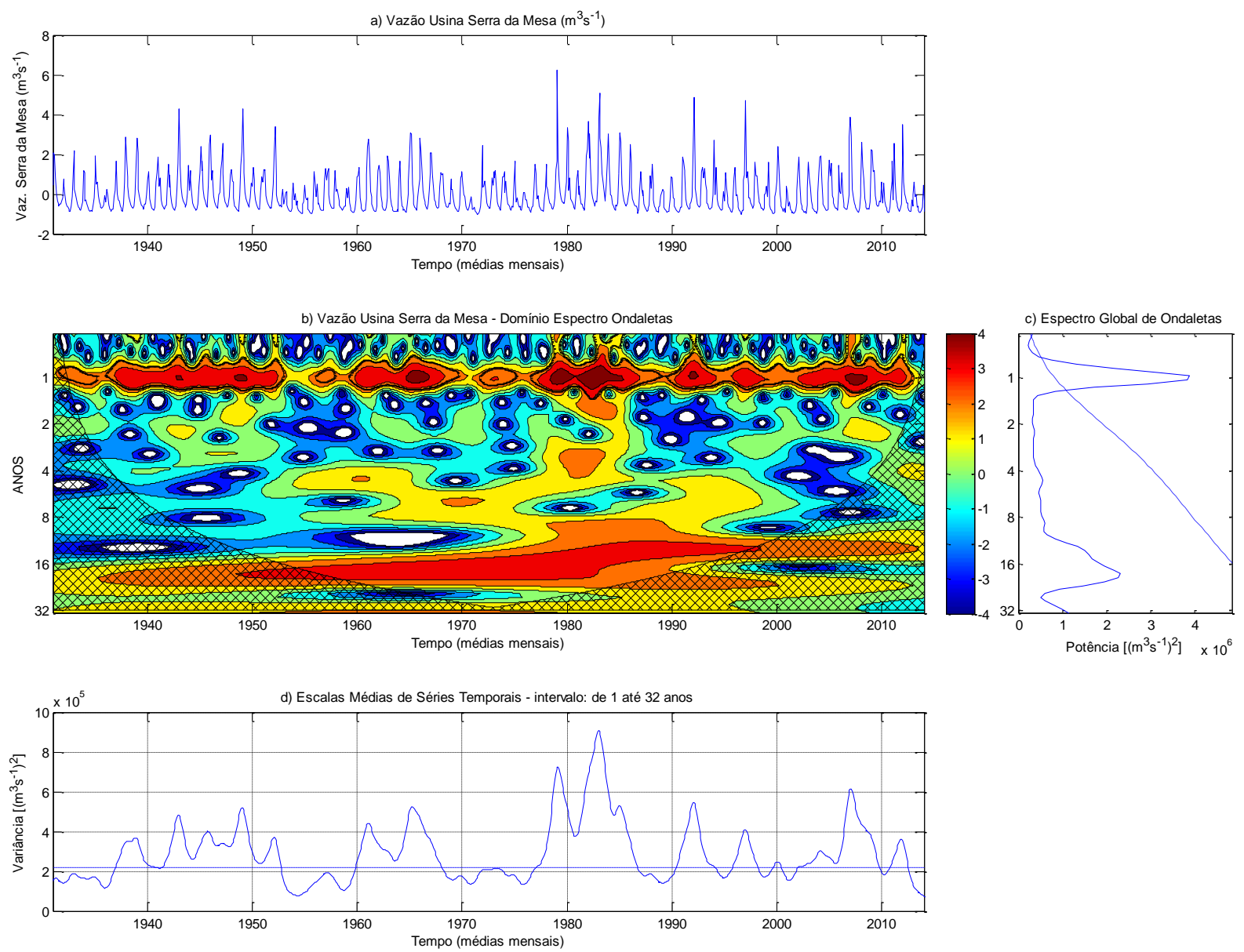

Figura APÊNDICE H-79 Análise por wavelets a) Série Histórica Vazão da Usina Três Marias normalizada. b) Domínio Espectro de Ondaletas. c) Espectro Global de Ondaletas. d) Escalas Médias de Séries Temporais 
APÊNDICE H.16.1 Análise relação variáveis explicativas e usina Três Marias
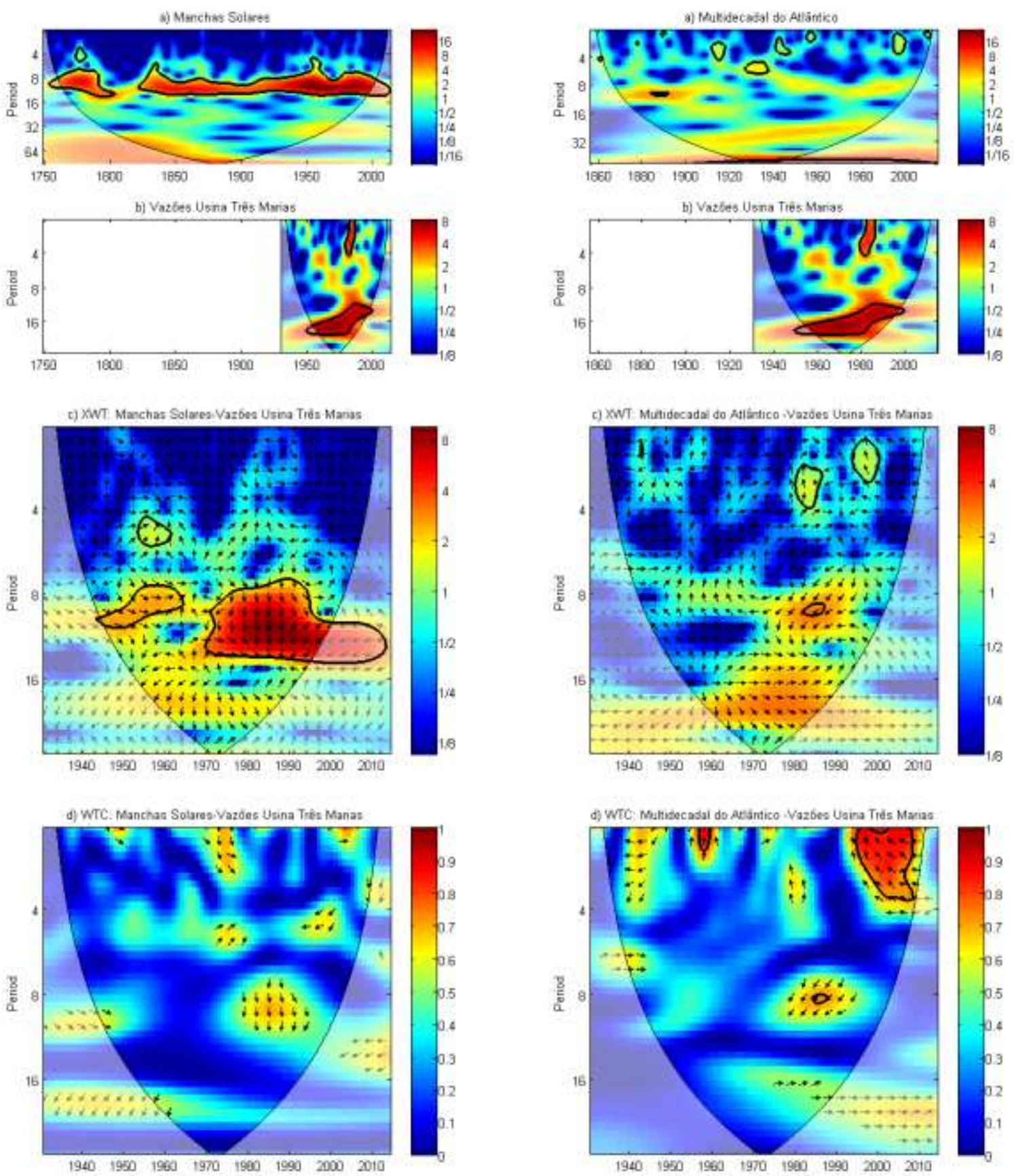

Figura APÊNDICE H-80 Análise por wavelets a) Manchas Solares versos b) Vazões da Usina Três Marias. c) Trans. Cruzada - XWT d) Trans.Contínua CWT

Figura APÊNDICE H-81 Análise por wavelets a) Multidecadal do Atlântico versos b) Vazões da Usina Três Marias. c) Trans. Cruzada - XWT d) Trans.Contínua - CWT 

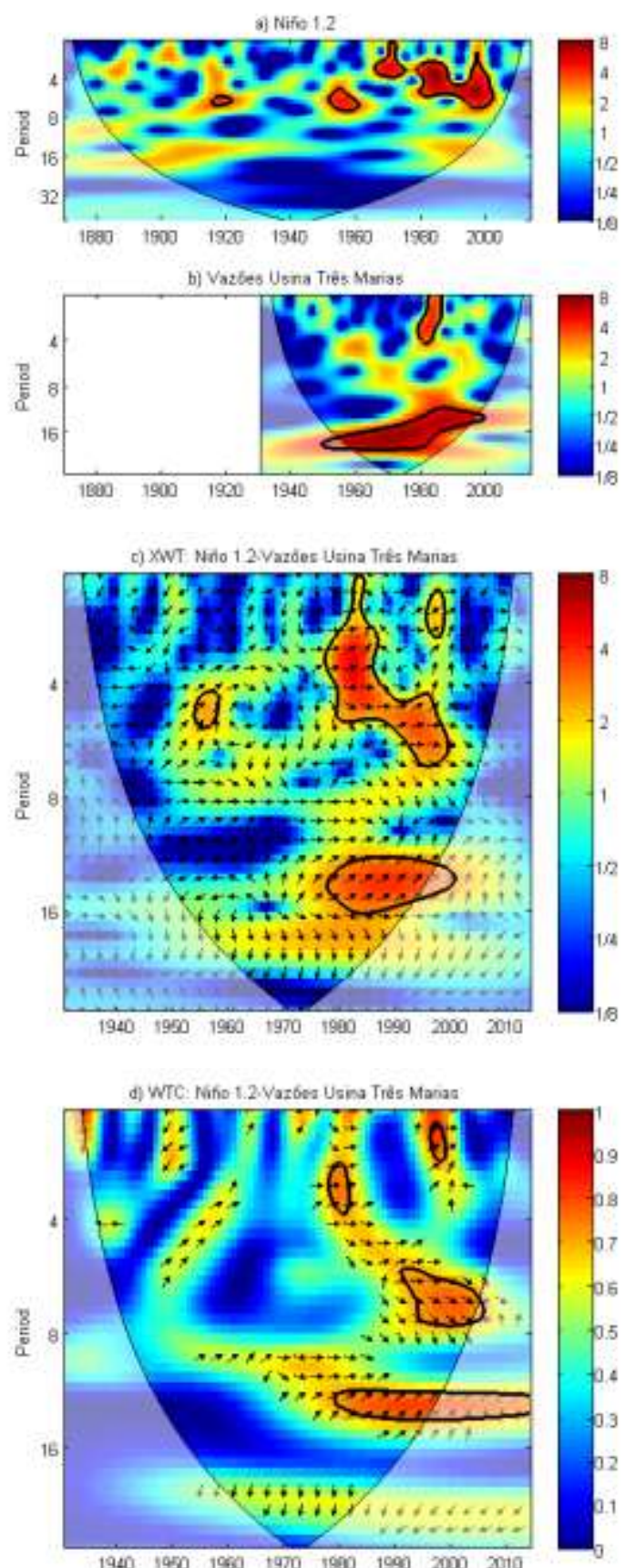

Figura APÊNDICE H-82 Análise por wavelets a) El Niño 1+2 versos b) Vazões da Usina Três Marias. c) Trans. Cruzada - XWT d) Trans.Contínua - CWT
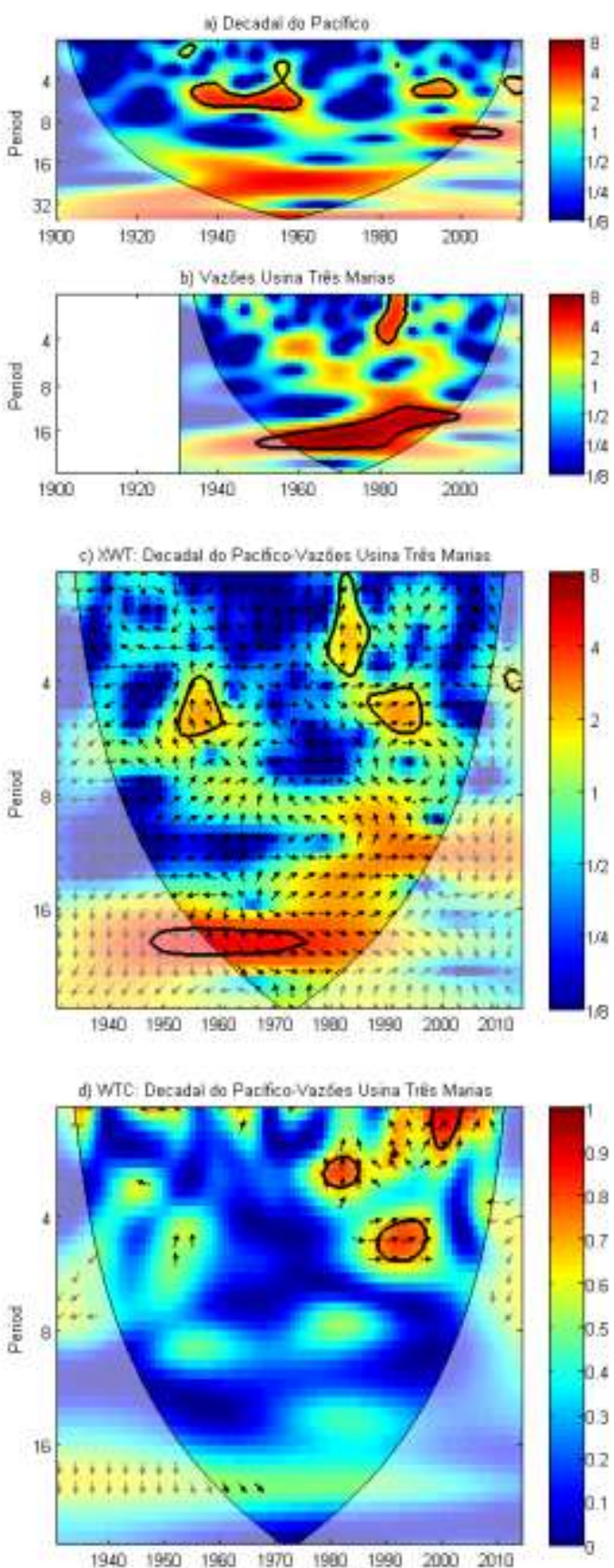

Figura APÊNDICE H-83 Análise por wavelets a) Decadal do Pacífico versos b) Vazões da Usina Três Marias. c) Trans. Cruzada - XWT d) Trans.Contínua CWT 


\section{APÊNDICE H.17 Wavelets Vazões rio Usina Porto Primavera $\left(\mathrm{m}^{3} \mathrm{~s}^{-1}\right)$}

Na Figura APÊNDICE H-84, apresentam-se as vazões em $\mathrm{m}^{3} \mathrm{~s}^{-1}$ da Usina de Porto Primavera do período de 1931 a 2013 em b) e padrões por volta de 1, 8 e 16 anos são identificados em c). Em d) há um pico marcado por volta de 1983 que coincide com período de grandes afluências no Sudeste brasileiro e baixos valores em 2001 que coincide com período do racionamento e estiagem no Sudeste. Também se nota entre 1960 e 1990 com variação entre de periodicidade entre 4 e 8 anos e de 1920 a 2000 periodicidade de 16 a 20 anos com contorno em vermelho.
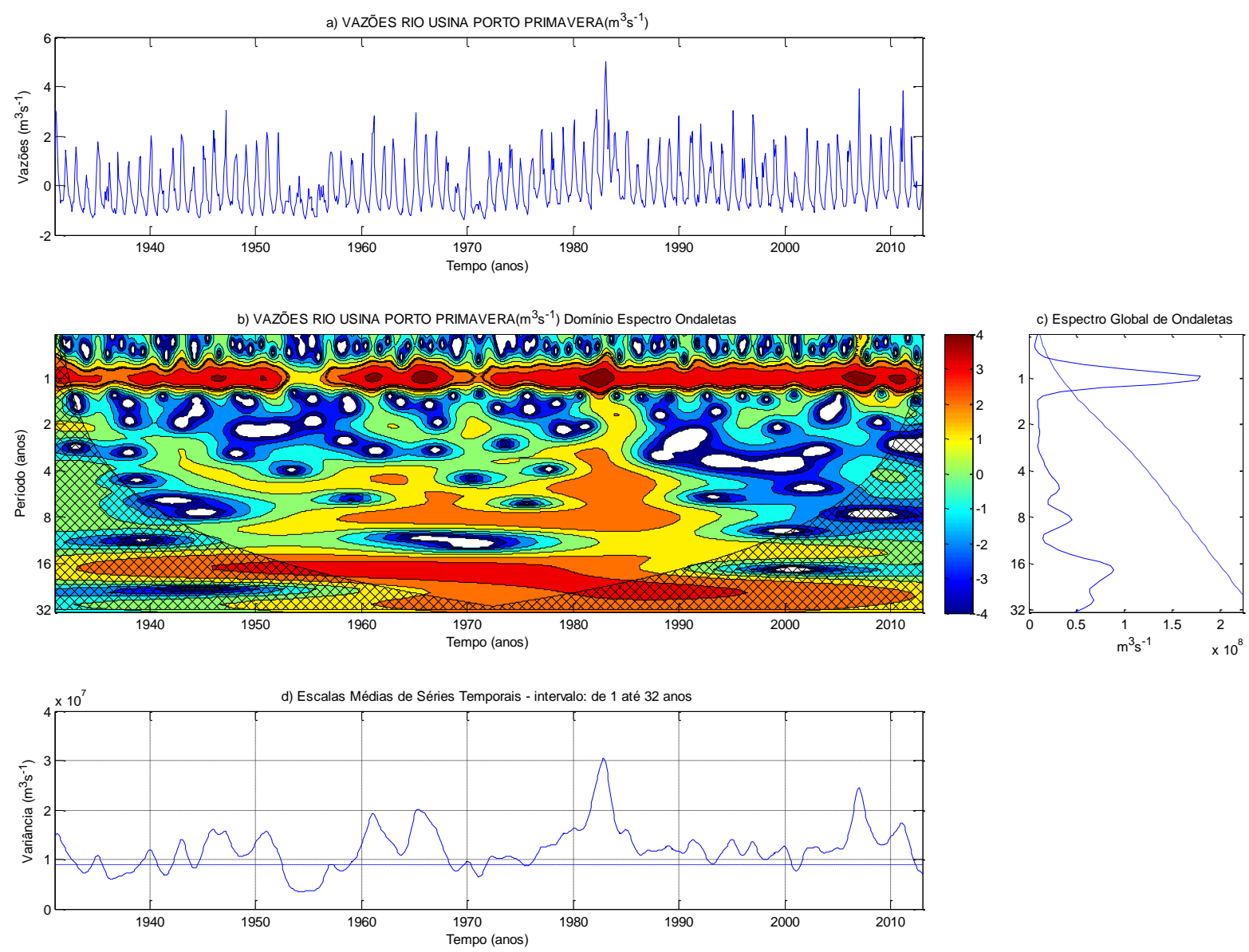

Figura APÊNDICE H-84 Análise por wavelets Vazões de Rio Usina de Porto Primavera 


\section{APÊNDICE H.18 Wavelets Vazões rio Usina Sobradinho $\left(\mathrm{m}^{3} \mathrm{~s}^{-1}\right)$}

Na Figura APÊNDICE H-85, apresentam-se as vazões em $\mathrm{m}^{3} \mathrm{~s}^{-1}$ da Usina de Sobradinho do período de 1931 a 2013 em b) padrões por volta de 1 ano são identificados em c). Em d) há um pico marcado por volta de 1979 e 1995 . Também se nota entre 1920 a 2000 periodicidade de 16 a 20 anos com contorno em vermelho.
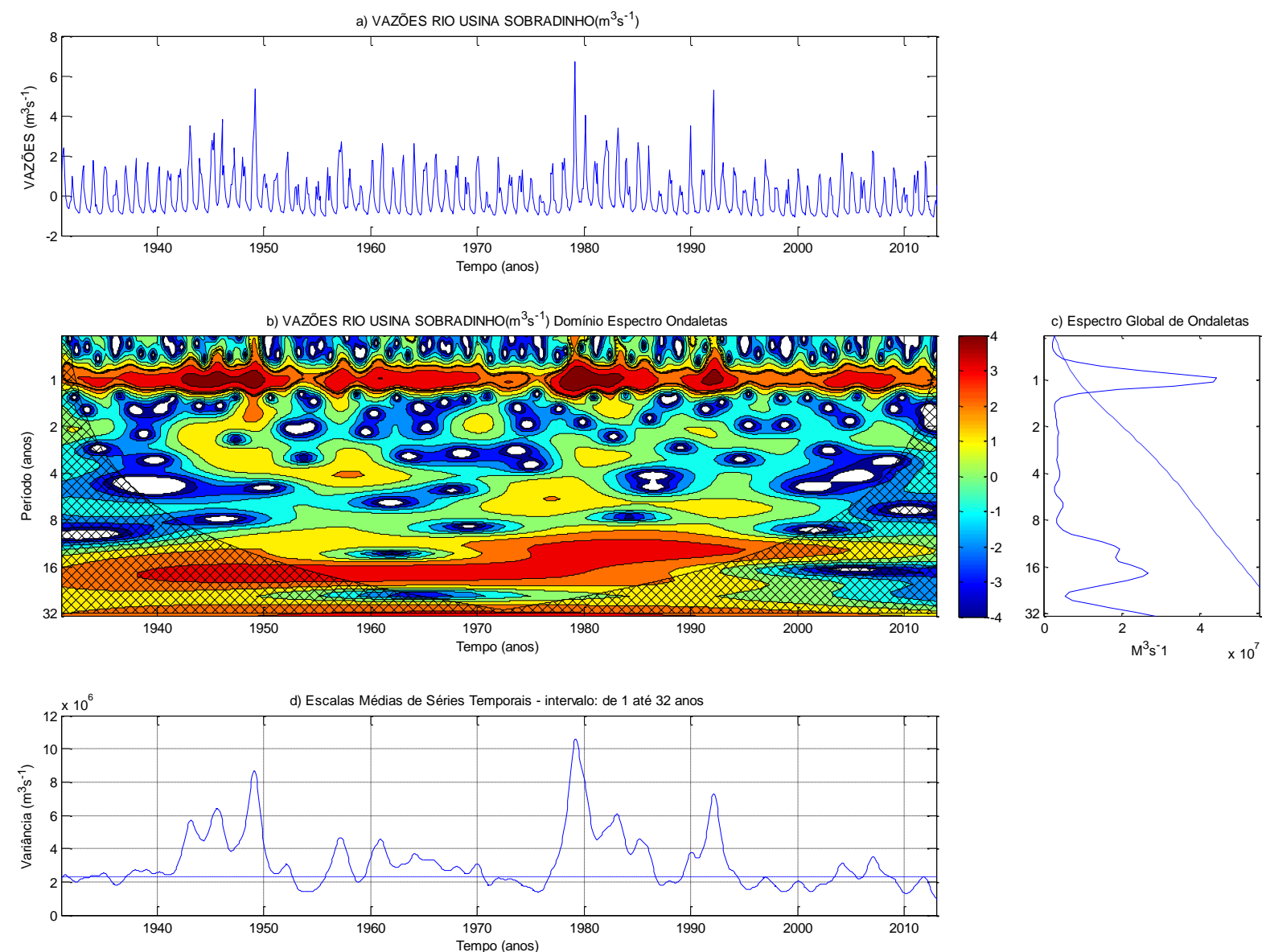

Figura APÊNDICE H-85 Análise por wavelets Vazões de Rio Usina de Sobradinho 
APÊNDICE H.19 Wavelets Vazões rio Usina Boa Esperança $\left(\mathrm{m}^{3} \mathrm{~s}^{-1}\right)$

Na Figura APÊNDICE H-86, apresentam-se as vazões em $\mathrm{m}^{3} \mathrm{~s}^{-1}$ da Usina de Boa Esperança do período de 1931 a 2013 em b) padrões por volta de 1, 6 e 20 anos são identificados em c). Em d) há um pico marcado por volta de 1980 e 1985 que coincide com período de muita precipitação e entre 1930 a 1950 periodicidade de 16 a 20 anos com contorno em vermelho.
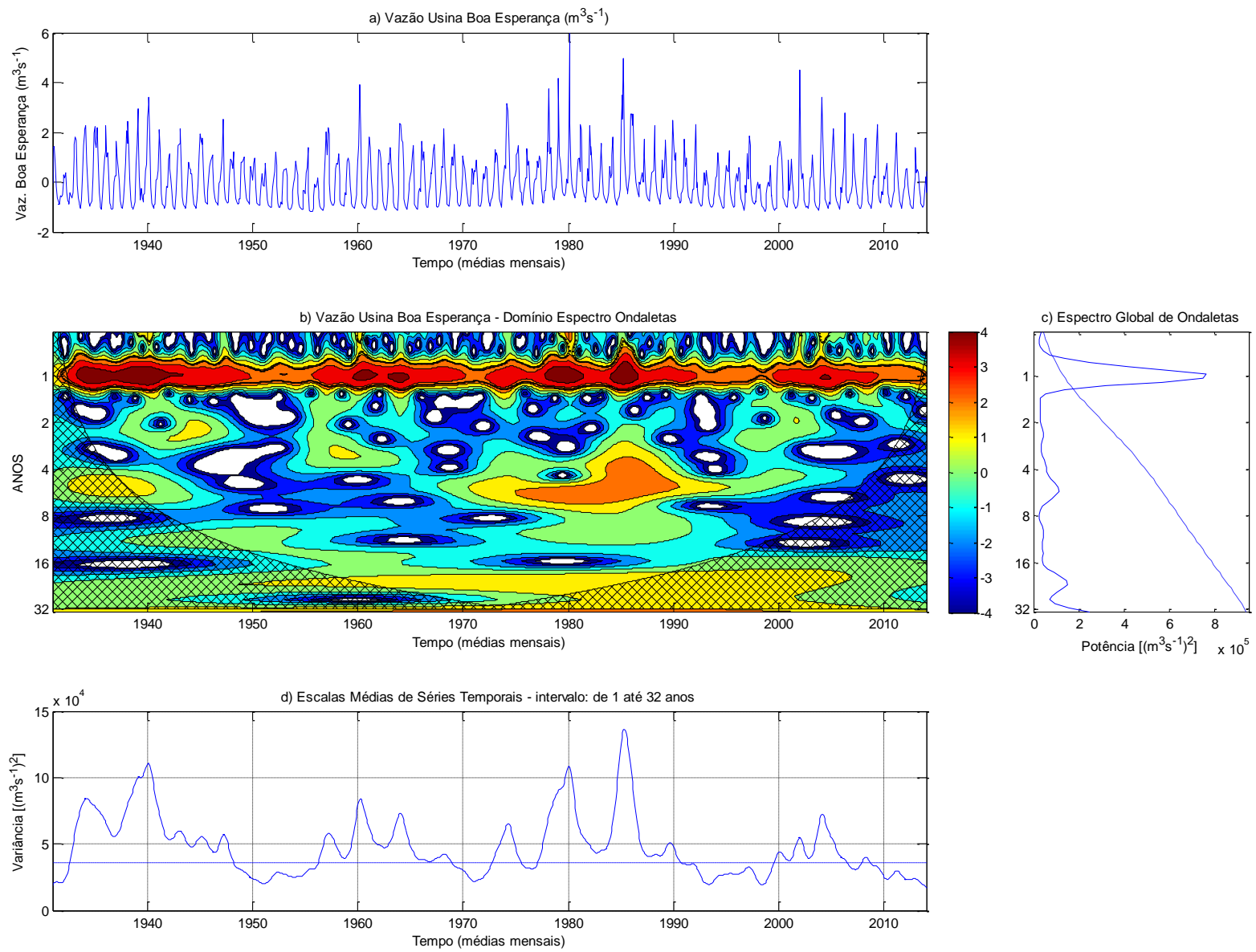

Figura APÊNDICE H-86Análise por wavelets Vazões de Rio Boa Esperança 


\section{APÊNDICE H.20 Wavelets Vazões rio Usina Lajeado $\left(\mathrm{m}^{3} \mathrm{~s}^{-1}\right)$}

Na Figura APÊNDICE H-87, apresentam-se as vazões em $\mathrm{m}^{3} \mathrm{~s}^{-1}$ da Usina de Lajeado do período de 1931 a 2013 em b) padrões por volta de 1, e 16 anos são identificados em c). Em d) há um pico marcado por volta de 1983 que coincide com período de muita precipitação e entre 1930 a 2004 periodicidade de 16 a 20 anos com contorno em vermelho.
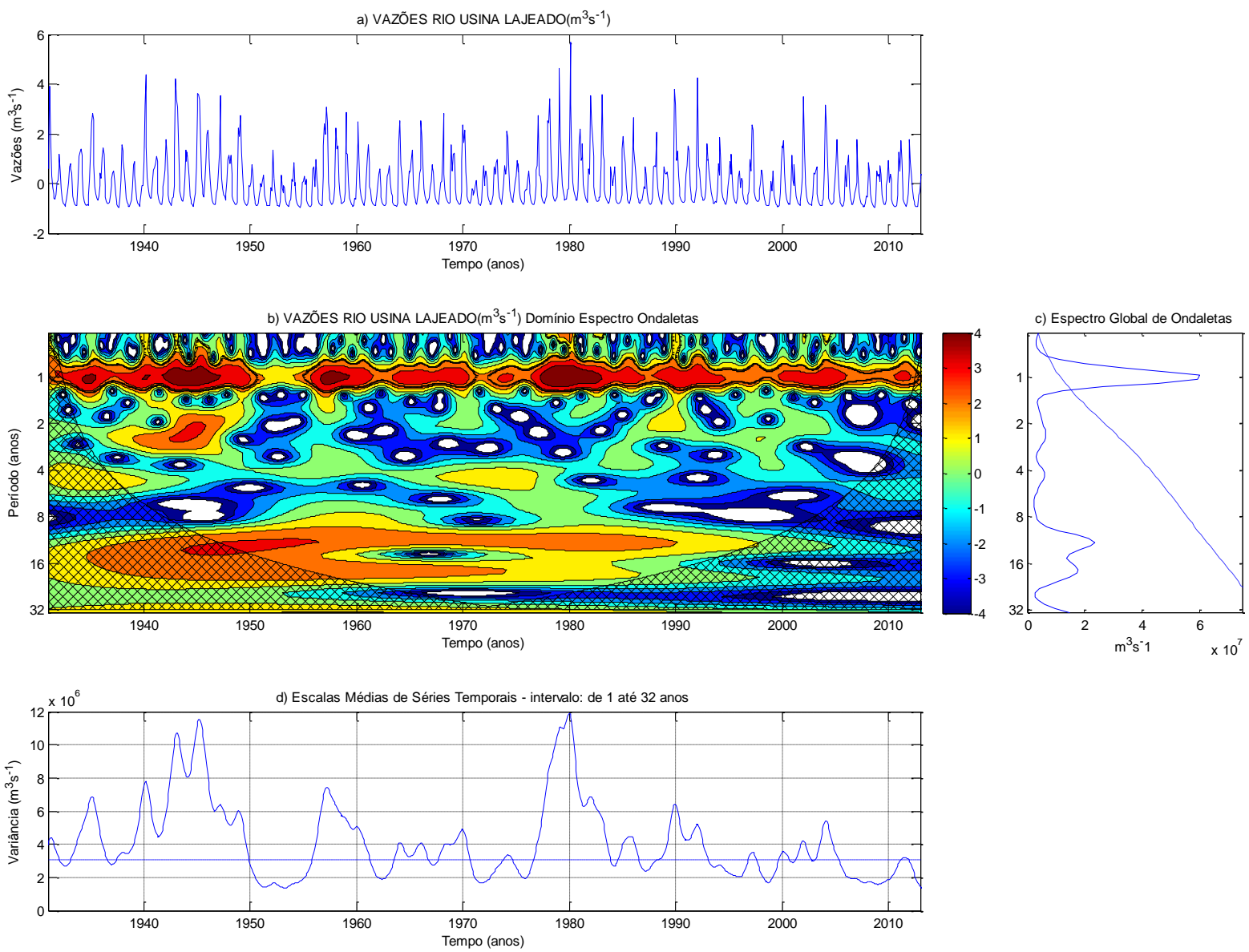

Figura APÊNDICE H-87 Análise por wavelets Vazões de Rio Usina de Lajeado 


\section{APÊNDICE H.21 Número de Manchas Solares}

Na Figura APÊNDICE H-88, apresentam-se a) a série histórica de número de manchas solares, normalizadas ${ }^{150}$, que correspondem ao período de 1749 a 2015. Observa-se um padrão que sobressai dentre os demais por volta dos 11 anos que varia entre 8 e 16 anos e padrões adjacentes. No gráfico d), observa-se que no intervalo de anos entre 1870 e 1930 existe uma tendência de aumento do número de manchas solares que coincide com períodos extremamente úmidos no ano de 1953 nas regiões da Amazônia, Europa e Japão e períodos extremamente secos no Nordeste, Sudeste e Centro Oeste do Brasil, no Oeste Americano, em grande aparte da China (ZUFFO, 2015) e um declínio da tendência em meados do ano 2000, que coincide com o racionamento de 2001, em consequência de uma seca no Sudeste do Brasil.
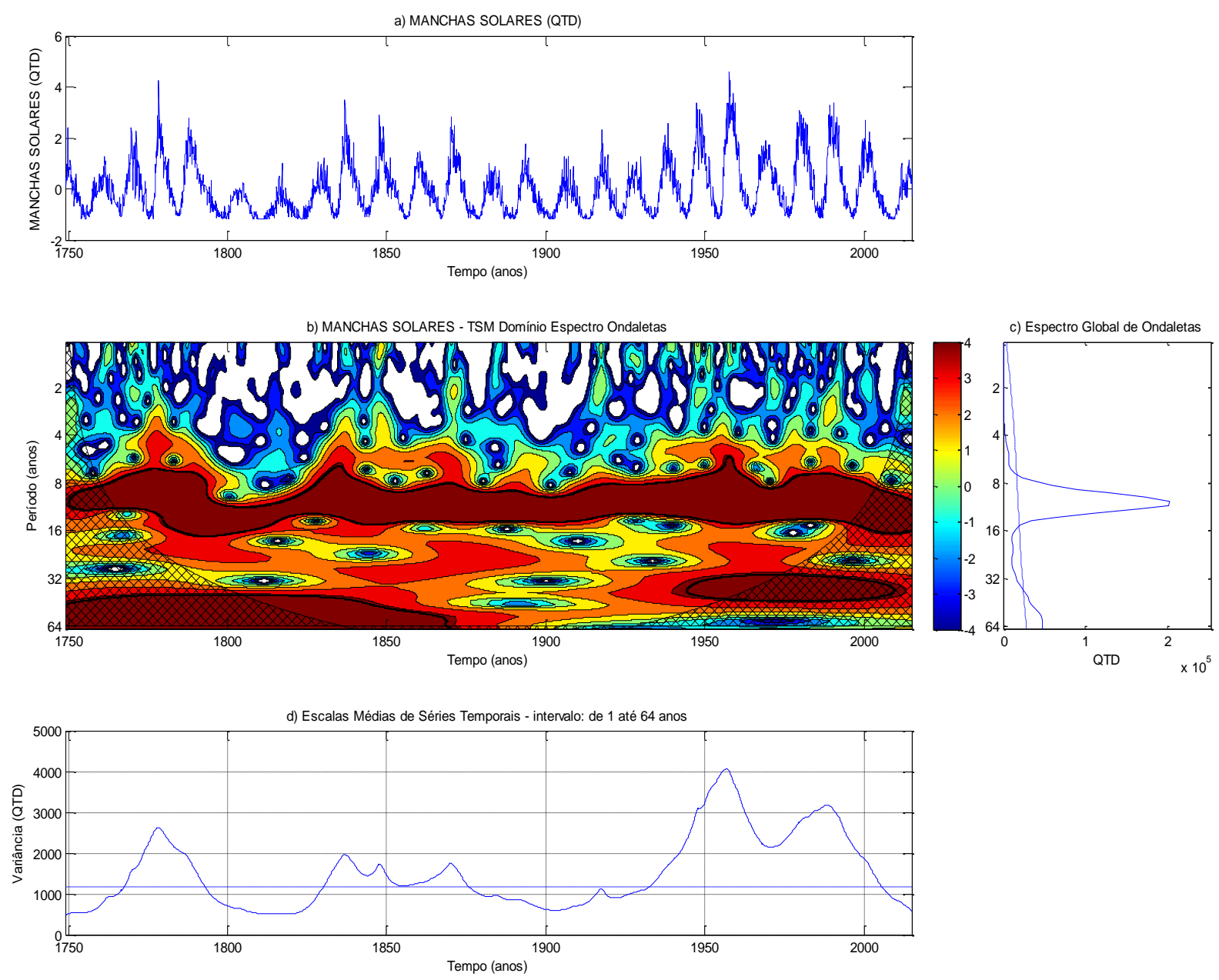

Figura APÊNDICE H-88 Análise por wavelets do número de Manchas Solares

${ }^{150}$ Essa normalização é feita com as medidas de y subtraídas pela média da série histórica completa, $\mu$, e o resultado é divido pelo desvio padrão $\sigma$ das séries históricas completas $[(y-\mu) / \sigma]$. Não tem relação com climatologia de 30 anos, simplesmente uma forma de analisar os dados frente o desvio-padrão. 


\section{APÊNDICE H.22 El Niño Área 1+2 do Oceano Pacífico}

Na Figura APÊNDICE H-89, apresentam-se a) as anomalias da série histórica da área do oceano Pacífico El Niño 1+2 que corresponde ao período de 1870 a 2015 . Em b) observa-se um padrão bem evidenciado em torno de 1 ano que varia entre 9 e 18 meses, padrões de 1 ano com IC acima de 95\% e padrões adjacentes com contorno em vermelho entre o intervalo de 1980 e 2000 com janelas entre 2 e 8 anos. Em c) o pico de um ano sobressai dentre os demais, e em d) é possível observar picos que indicam a periodicidade de 2 a 7 anos entre eventos Nino e os vales eventos Nina.
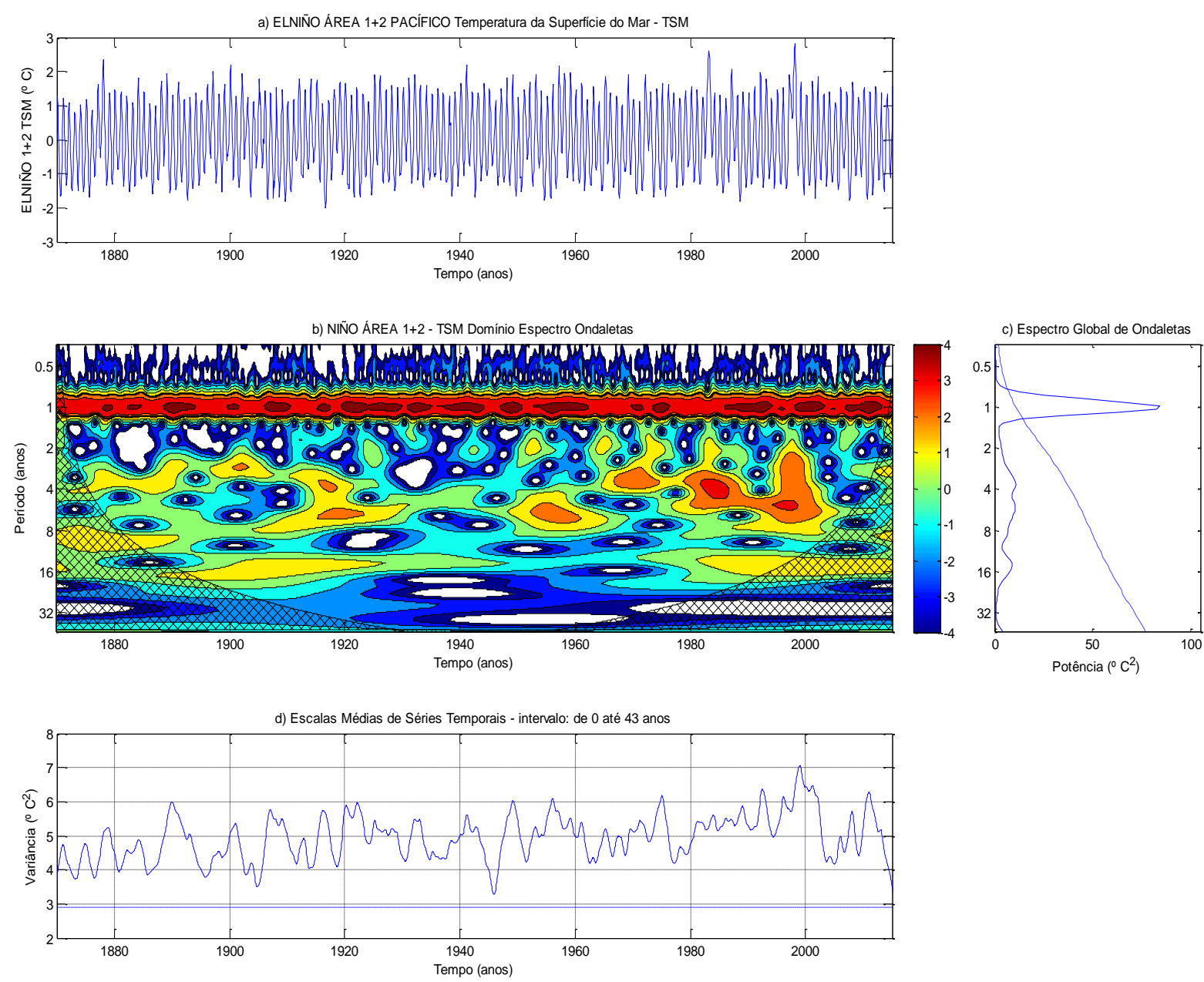

Figura APÊNDICE H-89 Análise por wavelets TSM - Área El Niño 1+2 
APÊNDICE H.23 Índice de Oscilação Multidecadal do Atlântico com transformações

Na Figura APÊNDICE H-90, apresentam-se os padrões da série histórica da área do oceano Atlântico Norte, entre $0^{\circ}$ a $70^{\circ} \mathrm{N}$, do Índice Multidecadal do Atlântico que abrange o período de 1856 a 2015. É apresentada em a) a série original. Em b) verifica-se quatro padrões bem marcados em vermelho em torno 8, 12 e 32 anos com IC acima de 95\% e padrões adjacentes com contorno em vermelho entre 3 e 32 anos espalhados em toda a série. Em c) o pico de um ano é bem marcado entre 32 e 64 anos, porém o cone de influência nesse período está rasurado e portanto, a análise da informação deve ser realizada com ressalvas. Em d) os picos indicam a periodicidade em décadas o que influenciou o nome desse índice.
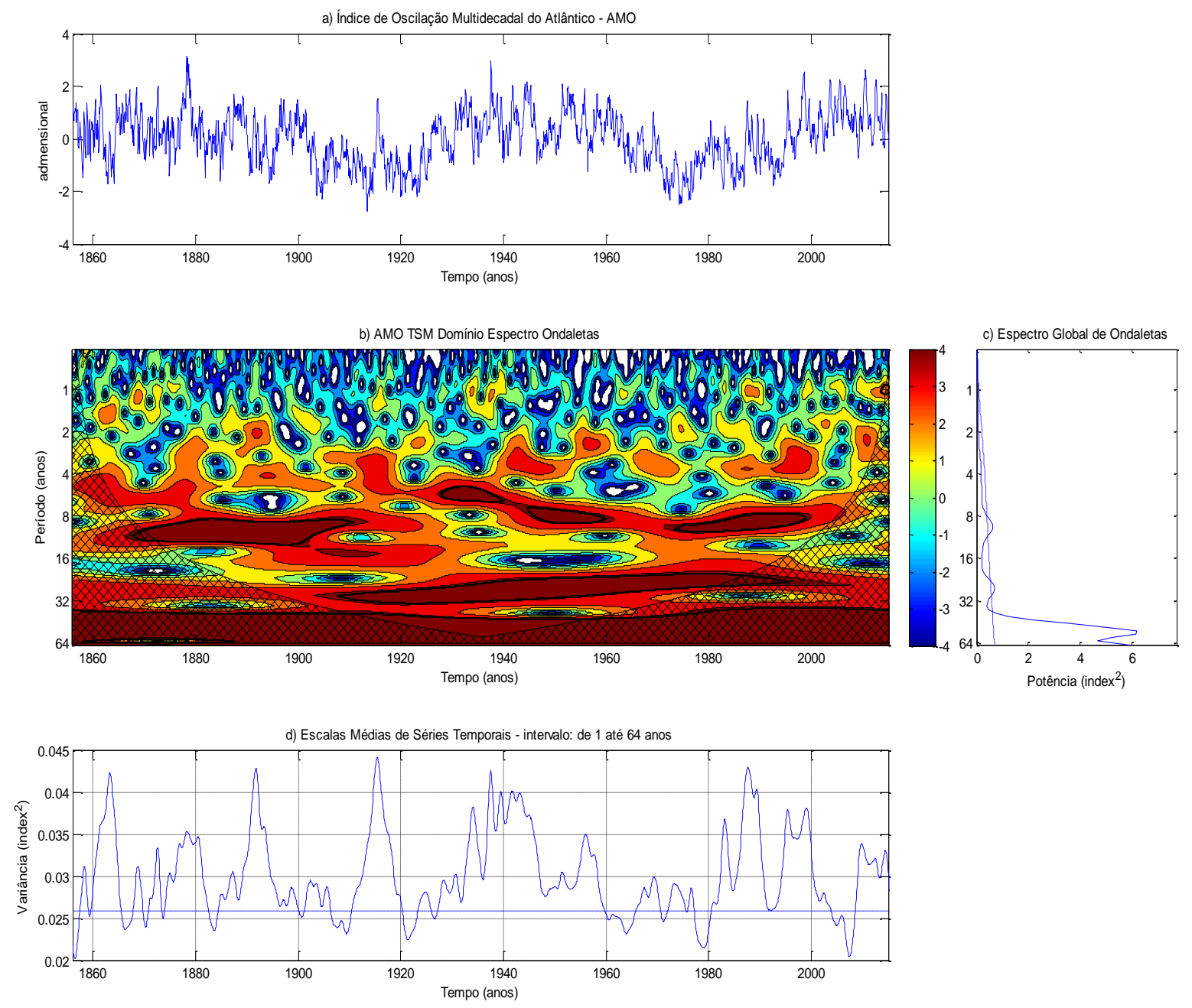

Figura APÊNDICE H-90 Análise por wavelets a) Série Histórica Índice de Oscilação Multidecadal do Atlântico normalizada. b) Domínio Espectro de Ondaletas. c) Espectro Global de Ondaletas. d) Escalas Médias de Séries Temporais 
APÊNDICE H.24 Índice de Oscilação Multidecadal do Atlântico sem transformações

Na Figura APÊNDICE H-91, apresentam-se em a) a série histórica da área do oceano Atlântico Norte, entre $0^{\circ}$ a $70^{\circ} \mathrm{N}$, do Índice Multidecadal do Atlântico que abrange o período de 1856 a 2015. Em b) verifica-se quatro padrões bem marcados em vermelho em torno 1 ano com IC acima de $95 \%$ e padrões adjacentes com contorno em vermelho entre 32 e 64 anos a partir de meados de 1940, porém abaixo do cone de influencia. Em c) o pico de um ano é bem marcado e entre 32 e 64 anos, porém o cone de influência nesse período está rasurado e, portanto, a análise da informação deve ser realizada com ressalvas. Em d) os picos indicam a periodicidade em décadas o que influenciou o nome desse índice.
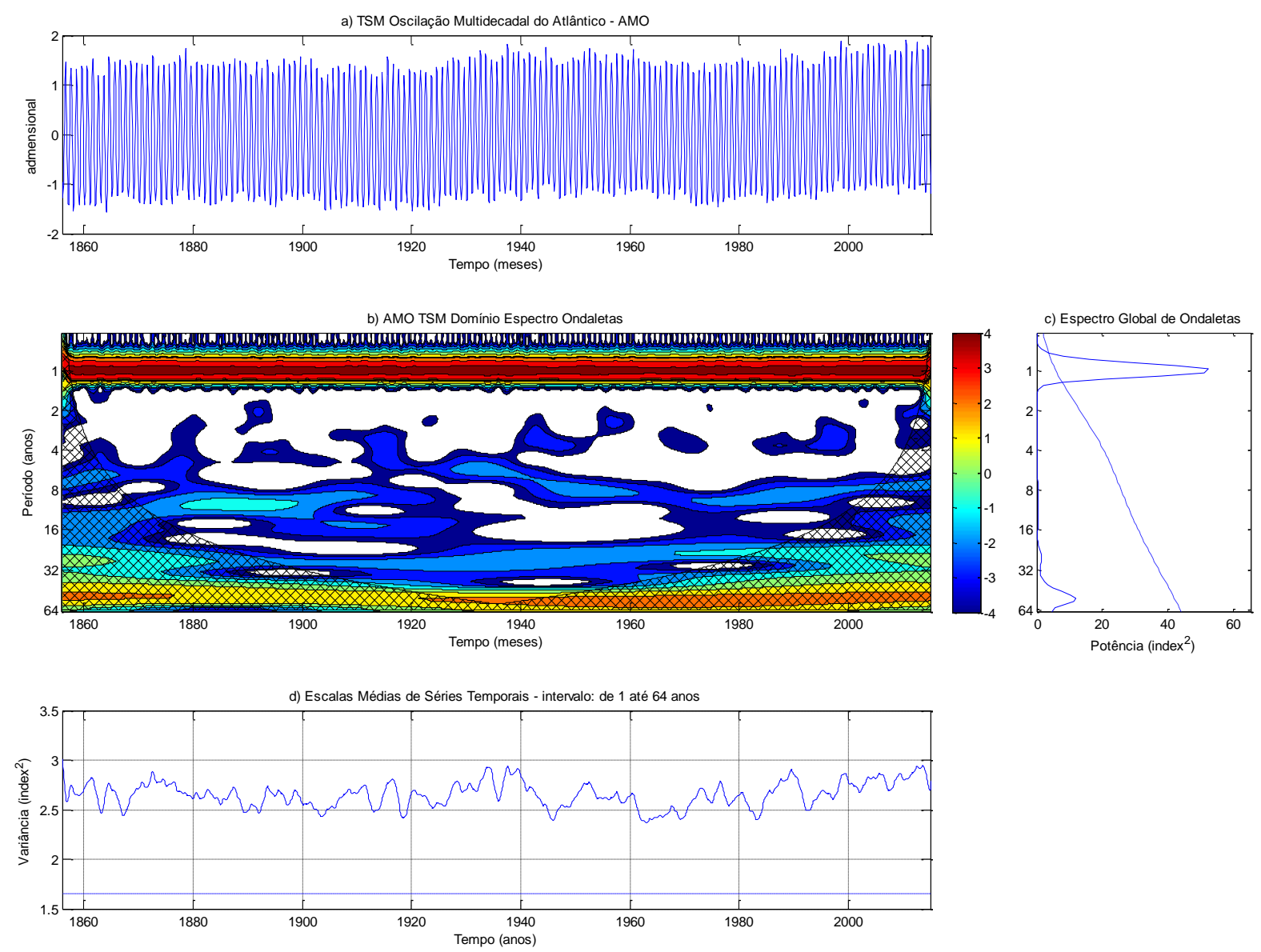

Figura APÊNDICE H-91 Análise por wavelets a) Série Histórica Índice de Oscilação Multidecadal do Atlântico sem transformações e normalizada. b) Domínio Espectro de Ondaletas. c) Espectro Global de Ondaletas. d) Escalas Médias de Séries Temporais 
APÊNDICE H.25 Índice de Oscilação Decadal do Pacífico

Na Figura APÊNDICE H-92, apresentam-se os padrões da série histórica da área do oceano Pacífico Norte Índice Decadal do Pacífico que abrange o período de 1900 a 2015. Em a) é apresentada a série original . Em b) é possível visualizar 4 padrões bem marcados em vermelho em torno 4, 8, 16 e 32 anos com IC acima de 95\% e padrões adjacentes com contorno em vermelho entre 4 e $8 ; 16$ e 32 anos distribuídos por toda a série. Em c) o pico de um ano é bem marcado entre 32 e 64 anos, porém o cone de influência nesse período está rasurado e portanto, a informação deve ser analisa priorizando atenção a essa fronteira, posto que a região exterior do cone tenha seu nível de significância incerto, devido à escassez de dados da fronteira, os testes estatísticos de hipótese são afetados. Em d) os picos indicam a periodicidade em décadas o que influenciou o nome desse índice.
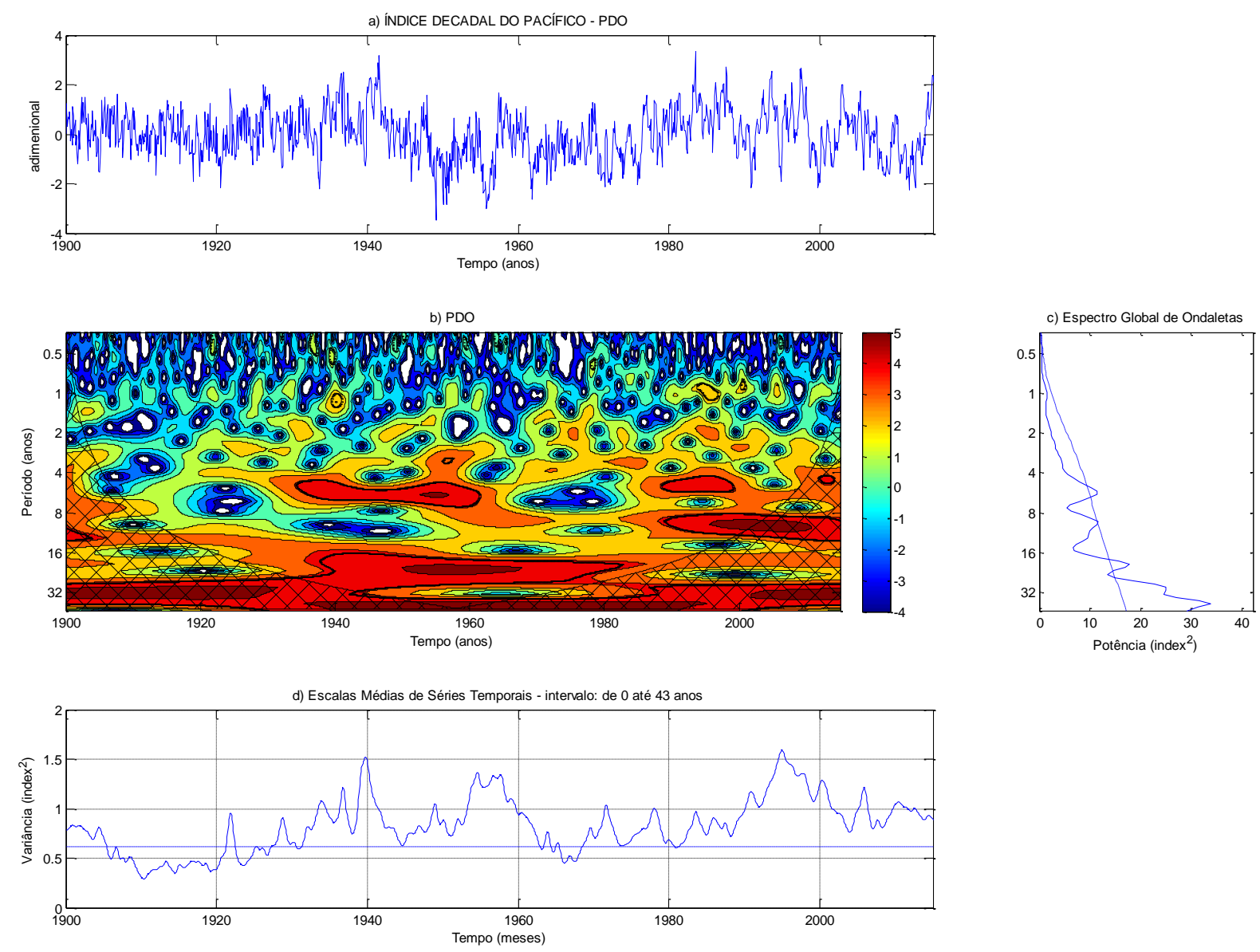

Figura APÊNDICE H-92 Análise por wavelets a) Série Histórica Índice de Oscilação Decadal do Pacífico normalizada. b) Domínio Espectro de Ondaletas. c) Espectro Global de Ondaletas. d) Escalas Médias de Séries Temporais 


\section{APÊNDICE H.26 Wavelets - ENA SE}

Na Figura APÊNDICE H-93, apresentam-se os padrões da série histórica de ENA da área do submercado Sudeste/Centro Oeste que abrangem o período de 1931 a 2015. Em a) é apresentada a série original. Em b) observa-se um padrão bem marcados em vermelho em torno de 1 ano com IC acima de 95\% e padrões adjacentes com contorno em vermelho entre 3 e 32 anos distribuídos em toda a série. Em c) o pico de um ano é bem marcado no período entre 8 e 24 anos, porém o cone de influência está rasurado em alguns anos e portanto, a análise das informação deve ser realizadas com ressalvas. Em d) os picos indicam a periodicidade em décadas que pode ser um indicador de relação com os índices macroclimáticos.
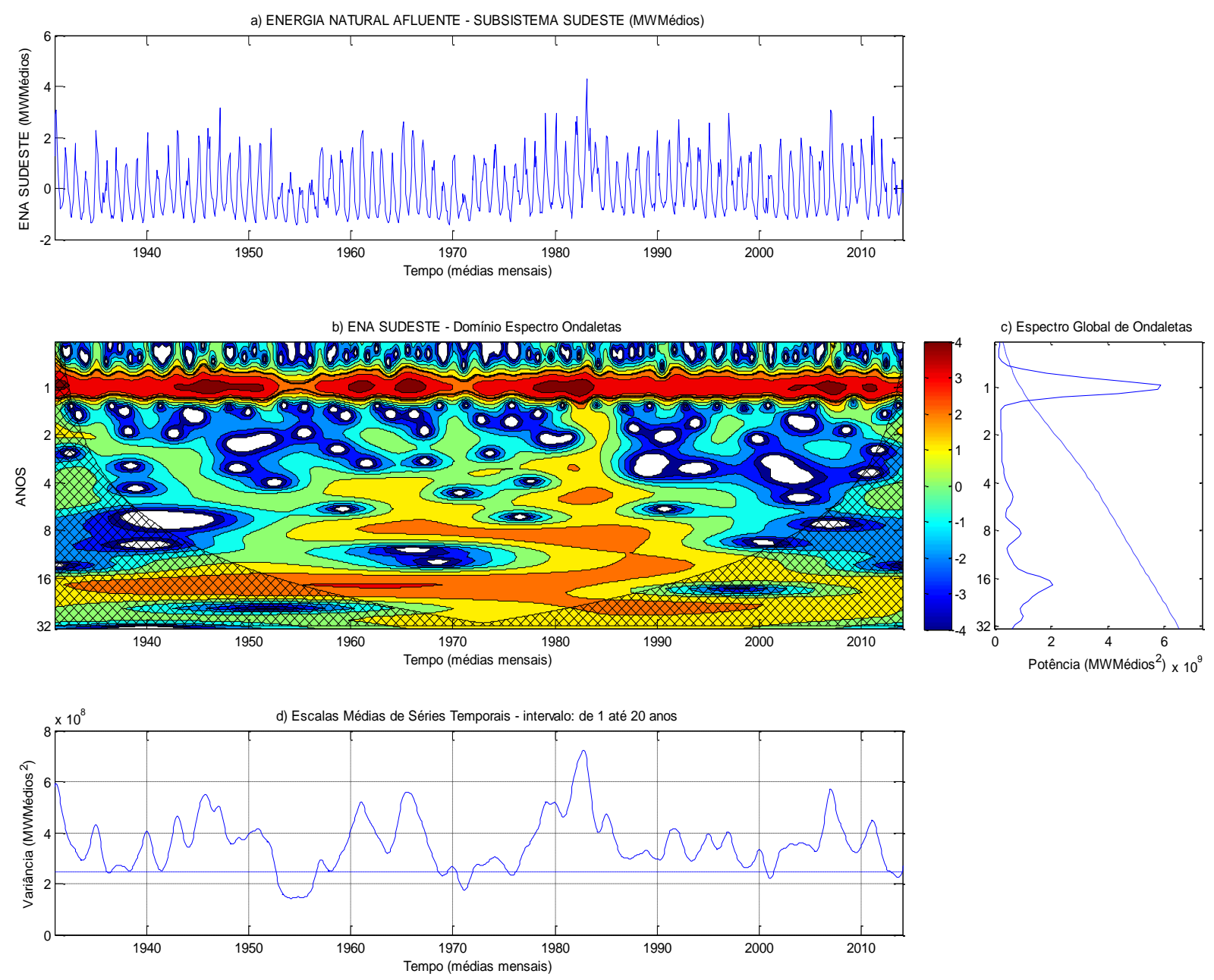

Figura APÊNDICE H-93Análise por wavelets a) Série Histórica ENA do Sudeste normalizada. b) Domínio Espectro de Ondaletas. c) Espectro Global de Ondaletas. d) Escalas Médias de Séries Temporais wavelets Análise relação variáveis explicativas e ENA SE 
APÊNDICE H.26.1 Análise relação variáveis explicativas e ENA SE

A correlação de a) Manchas e ENA SE com o uso de wavelets em b) revela a influência das manchas solares sobre as ENAS entre 8 e 16 anos. Em c) é demostrada a correlações com períodos entre 4 e 6 anos. Em a) correlaciona-se a Multidecadal do Atlântico e ENA SE, em b) é apresentada uma pequena correlação de período de 8 anos por volta de 1985 . O gráfico c) demostra algumas correlações entre 1 e 4 anos que ocorreram por volta de 1940, 1955 e entre 1995 até 2002.
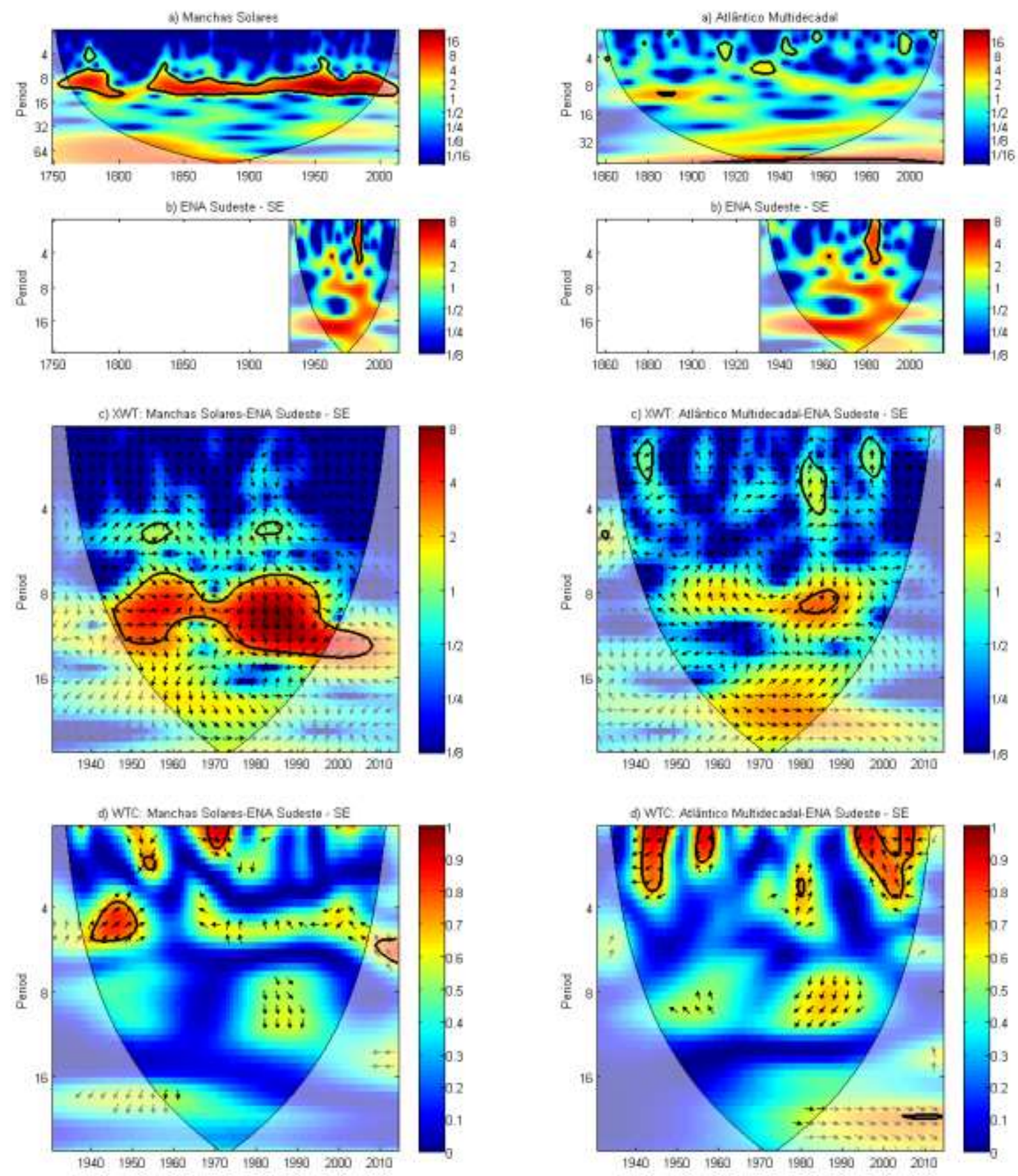

Figura APÊNDICE H-94 Análise por wavelets a) Manchas Solares versos b) ENA do Sudeste. c) Trans. Cruzada - XWT d) Trans.Contínua - CWT.

Figura APÊNDICE H-95 Análise por wavelets a) Multidecadal do Atlântico versos b) ENA do Sudeste. c) Trans.Cruzada - XWT d) Trans. Contínua - CWT. 
Ao analisar conjuntamente os gráficos a) NINO 1+2 e b) ENA SE que revela a influência do NINO1+2 sobre as ENA em um período de 1 a 6 anos entre 1980 e 2000 com o uso de wavelets, é possível correlacioná-los em c) com períodos entre 4 e 6 anos; e por volta de 16 anos na região externa do cone de influência. Ao realizar em a) a correlação com PDO e ENA SE com o uso de wavelets observa-se em b) a influência de PDO sobre as ENA SE por volta de 16 anos entre 1700 e 1990. Em c) são apresentadas correlações com períodos entre 1 e 6 anos; e por volta de 16 anos externamente ao cone de influência, em torno de 1940.
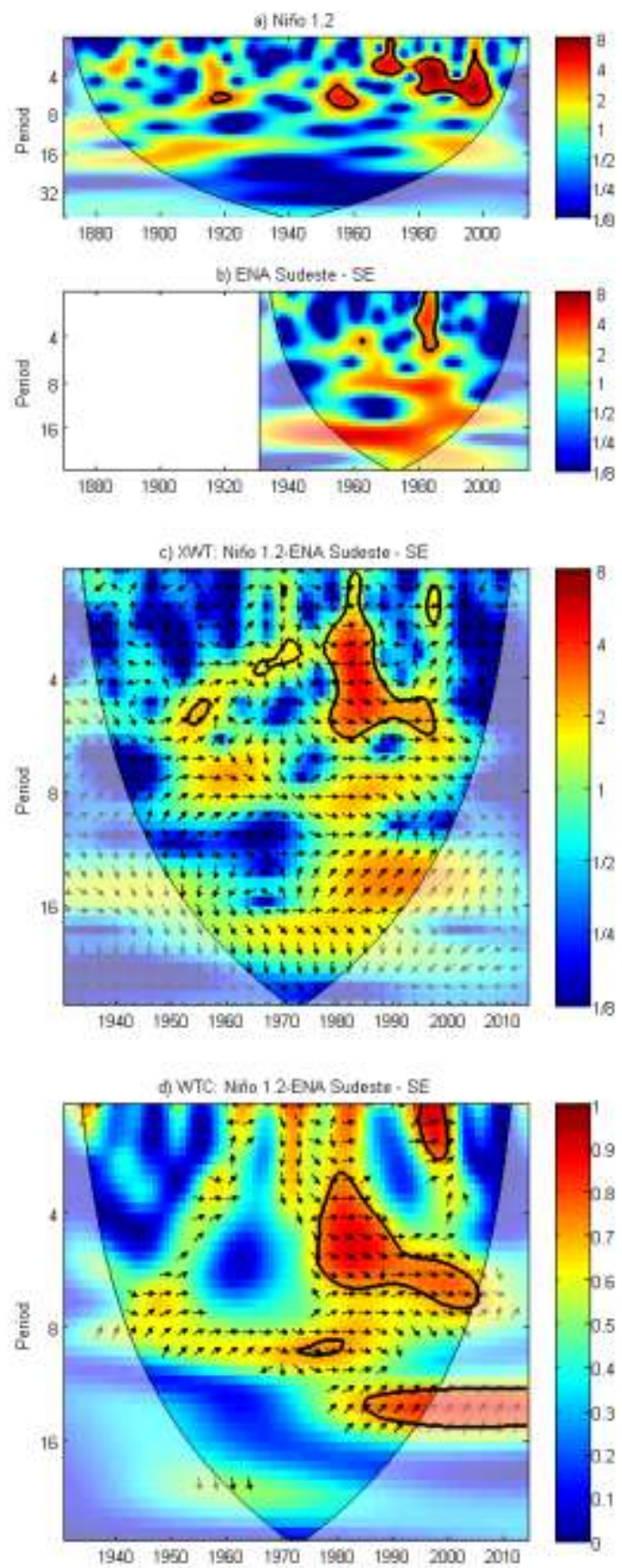

Figura APÊNDICE H-96 Análise por wavelets a) El Niño 1+2 versos b) ENA do Sudeste. c) Trans. Cruzada - XWT d) Trans. Contínua - CWT
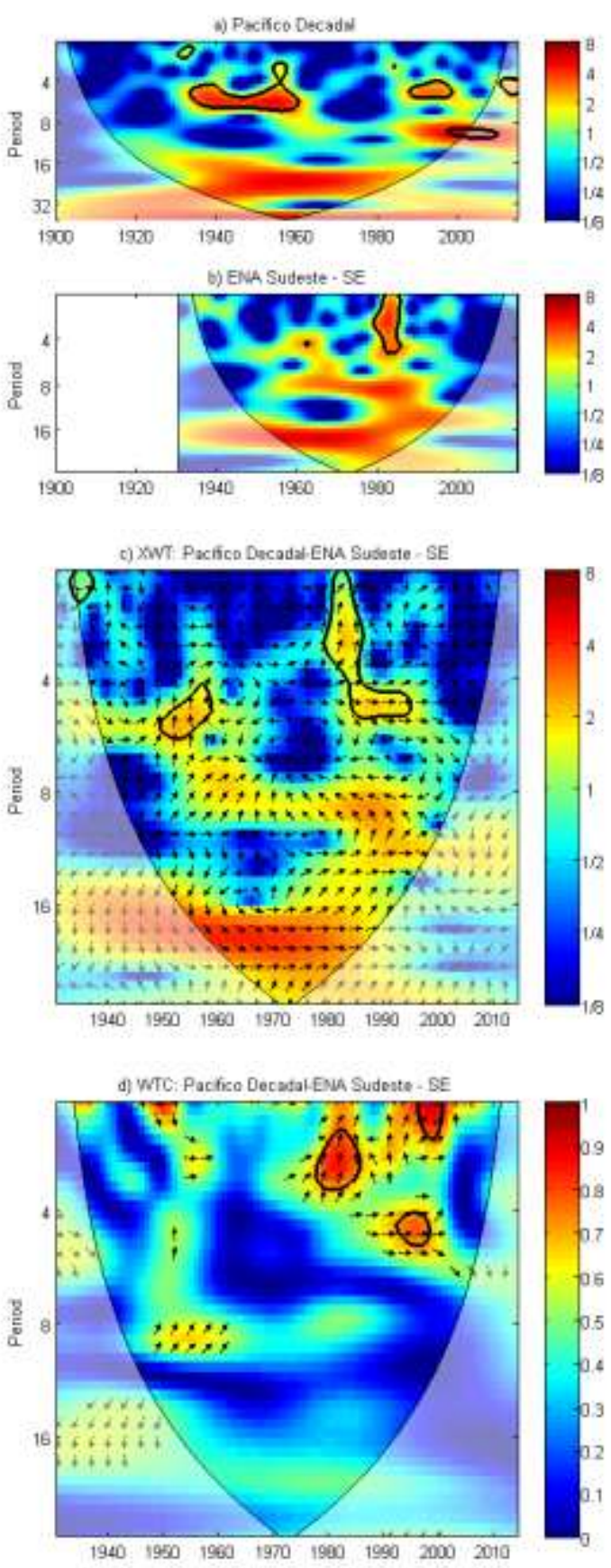

Figura APÊNDICE H-97 Análise por wavelets a) Decadal do Pacífico versos b) ENA do Sudeste. c) Trans. Cruzada - XWT d) Trans. Contínua - CWT 


\section{APÊNDICE H.27 Wavelets - ENA SUL}

Na Figura APÊNDICE H-98, apresentam-se os padrões da série histórica de ENA da área do submercado Sul que tem o período de 1931 a 2013. Série original em a). Em b) observa-se um padrão bem marcados em vermelho em torno do período de 4 anos com IC acima de $95 \%$ e também padrões adjacentes com contorno em vermelho entre 3 e 32 anos espalhados em toda a série. Em c) o pico de um ano é bem marcado entre 1980 e 1985. Em d) os três picos indicam a periodicidade em multidecadas que pode ser um indicador de relação com os índices macroclimáticos.
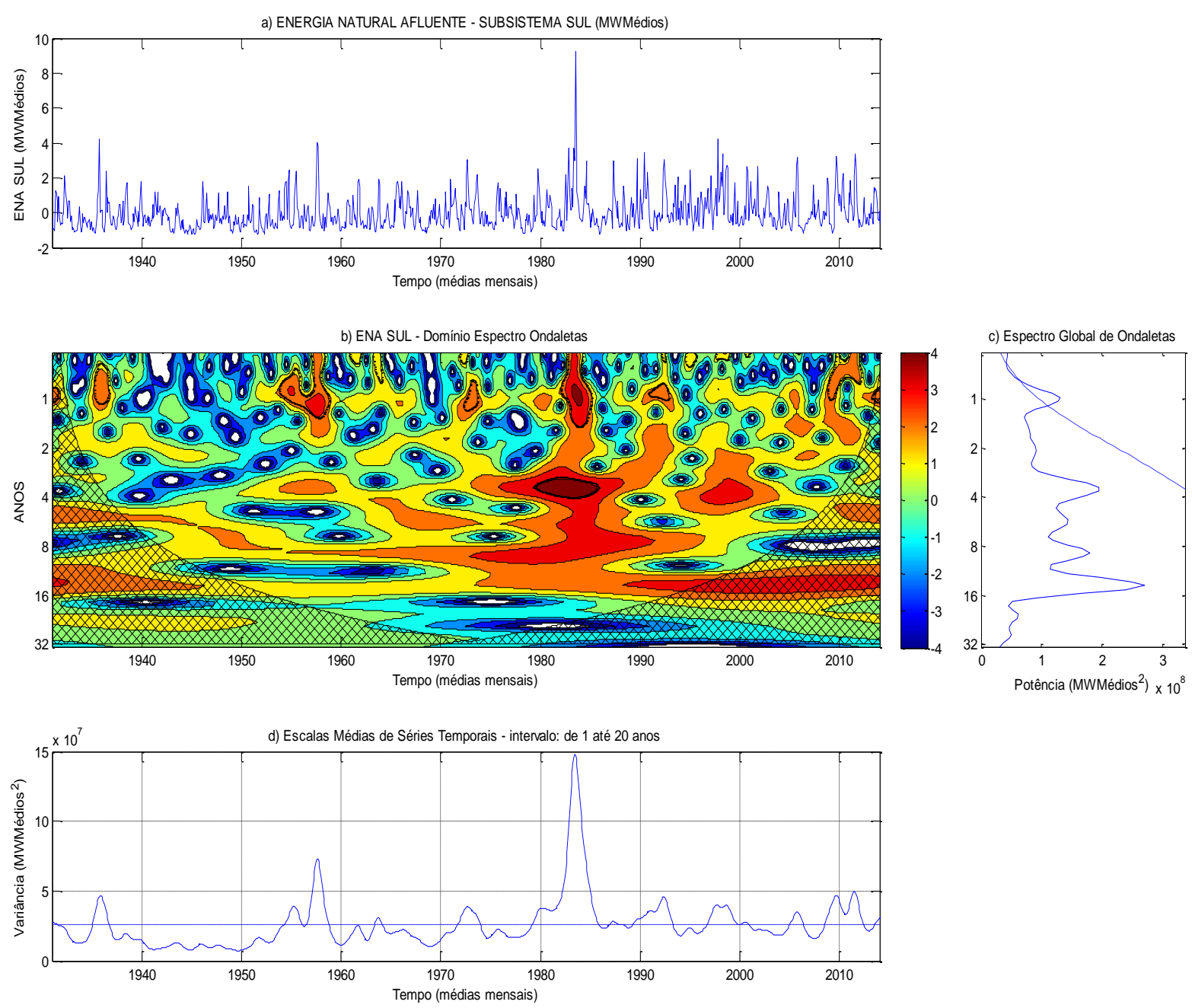

Figura APÊNDICE H-98 Análise por wavelets a) Série Histórica ENA do Sul. b) Domínio Espectro de Ondaletas. c) Espectro Global de Ondaletas. d) Escalas Médias de Séries Temporais wavelets Análise relação variáveis explicativas e ENA $S$ 
APÊNDICE H.27.1 Análise relação variáveis explicativas e ENA S

A correlação de a) e b) Manchas e ENA S com o uso de wavelets. Em c) mostra a influência das manchas solares sobre as ENAS entre 8 e 16 anos. Em d) aparece correlações com períodos entre 2 anos (por volta de 1960, 1990 e 2010 em diante) e entre 16 e 22 anos o qual extrapola abaixo da linha do cone de influência. A correlação a) Multidecadal do Atlântico e ENA S em b) há uma pequena correlação de período de 8 anos por volta de 1985 com nível de significância de 1\%. Em c) mostra algumas correlações entre 1 e 4 anos que ocorreram por volta de 1990 e 2000, e uma correlação com período de aproximadamente 8 anos entre 1995 até 1993.
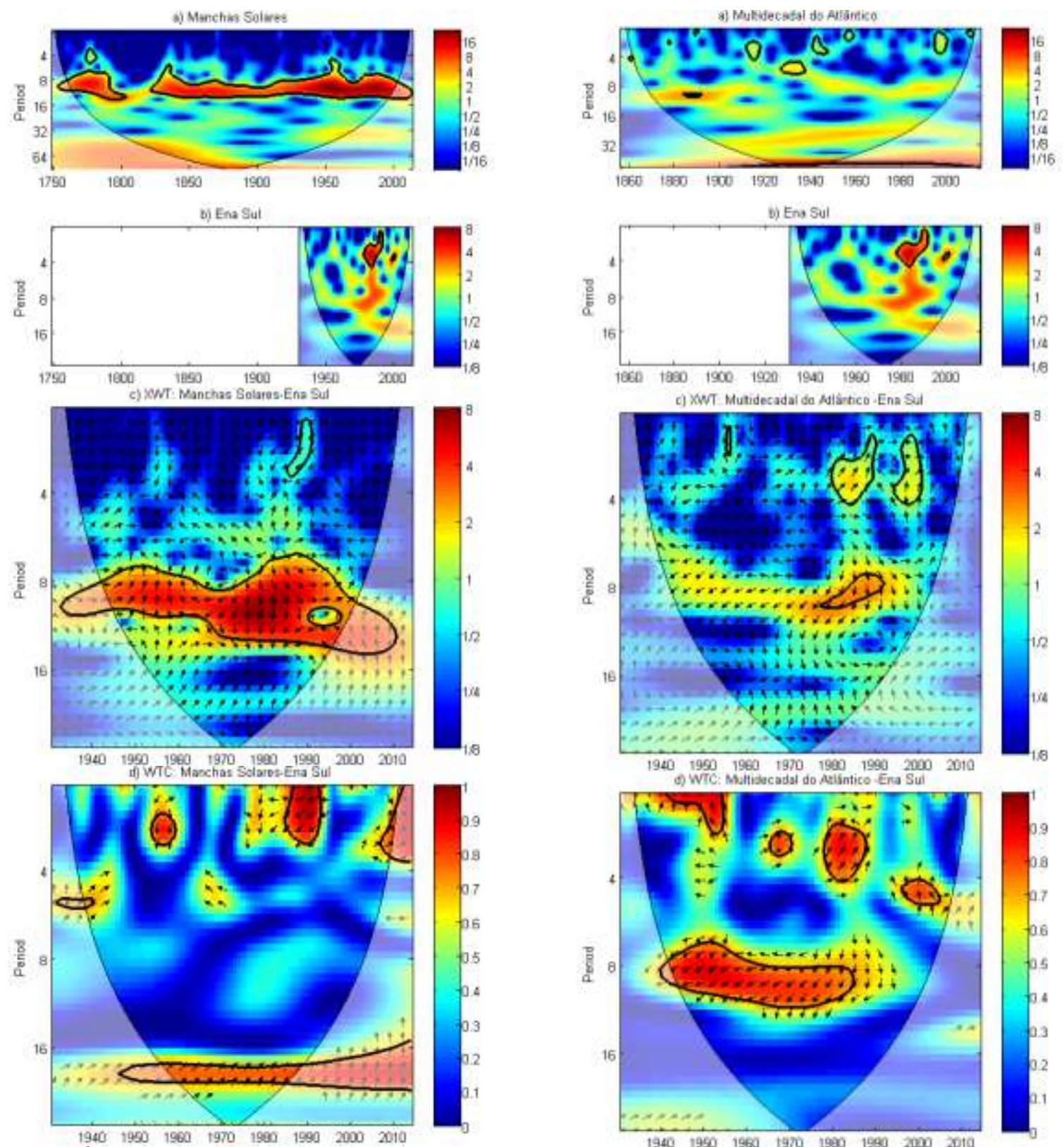

Figura APÊNDICE H-99 Análise por wavelets a) Manchas Solares versos b) ENA do Sul. c) Trans. Cruzada - XWT d) Trans. Contínua - CWT

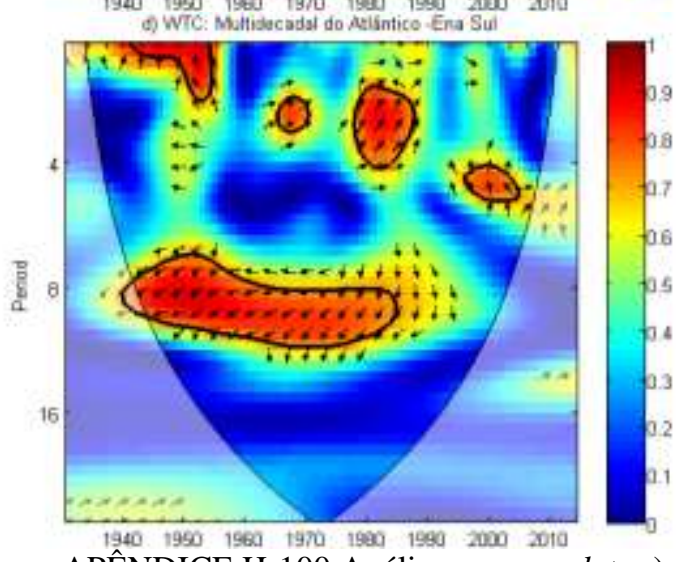

Figura APÊNDICE H-100 Análise por wavelets a) Multidecadal do Atlântico versos b) ENA do Sul. c) Trans. Cruzada - XWT d) Trans. Contínua - CWT 
Ao fazer a) correlação com NINO 1+2 e ENA S com o uso de wavelets em b) mostra a influência de NINO1+2 sobre as ENAS entre 1 e 6 anos entre 1980 e 2000. Em c) aparece correlações com períodos entre 1 e 6 anos; e por volta de 16 anos fora do cone de influência. Ao fazer a) correlação com PDO e ENA S com o uso de wavelets em b) mostra a influência de PDO sobre as ENA SE por volta de 16 entre 1700 e 1990. Em c) aparece correlações com períodos entre 1 e 6 anos; e por volta de 16 anos fora do cone de influência, por volta 1940.
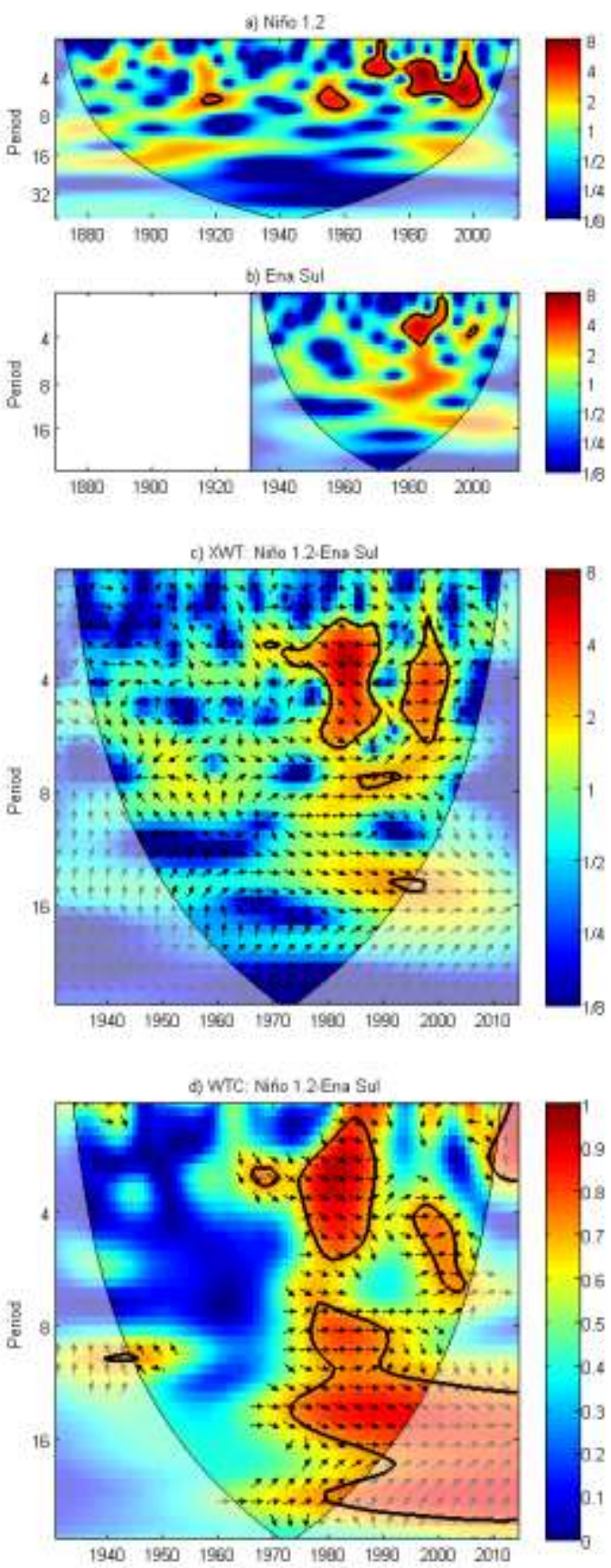

Figura APÊNDICE H-101 Análise por wavelets a) El Niño $1+2$ versos b) ENA do Sul. c) Trans. Cruzada XWT d) Trans. Contínua - CWT
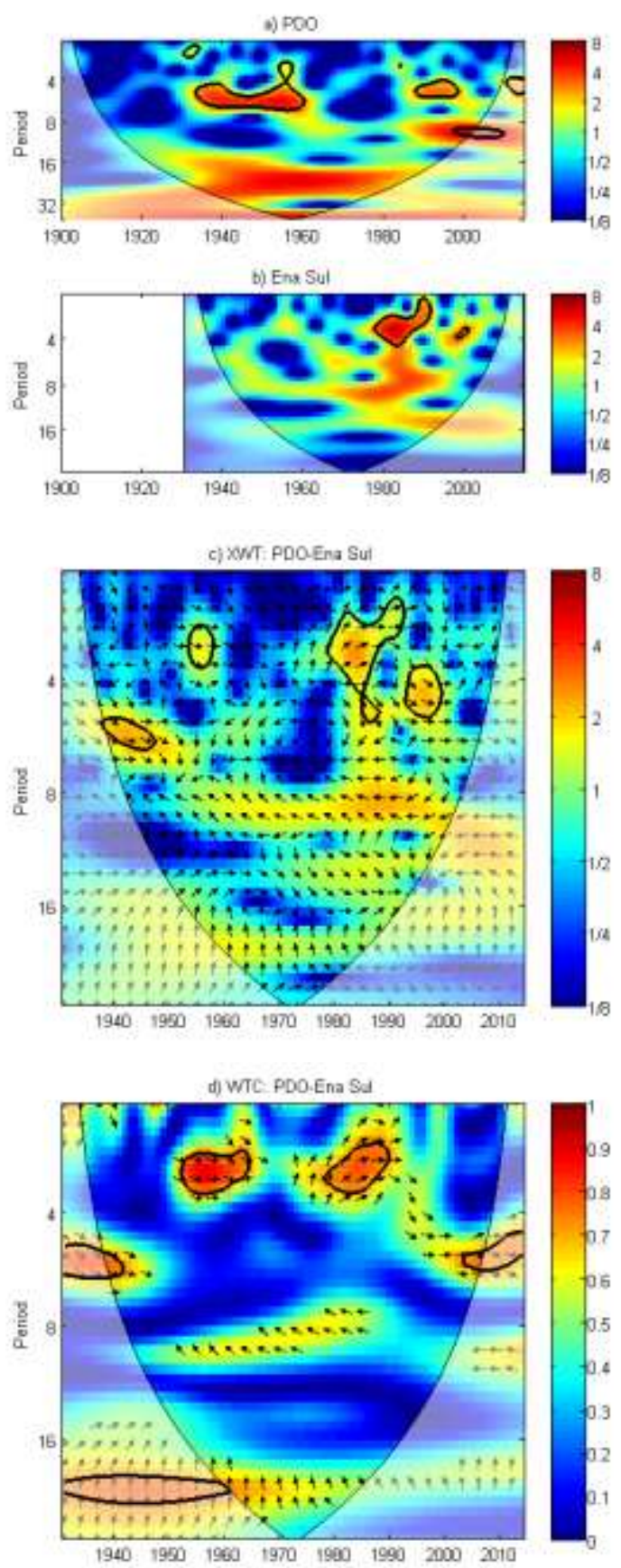

Figura APÊNDICE H-102 Análise por wavelets a) Decadal do Pacífico versos b) ENA do Sul. c) Trans. Cruzada - XWT d) Trans. Contínua - CWT 


\section{APÊNDICE H.28 Wavelets - ENA NORTE}

Na Figura APÊNDICE H-103, apresentam-se os padrões da série histórica de ENA da área do submercado Norte que tem o período de 1931 a 2013. Série original em a). Em b) observa-se um padrão bem marcados em vermelho em torno do período de 1 ano com IC acima de 95\% e também padrões adjacentes com contorno em vermelho entre 12 e 24 entre os anos de 1935 a 1973. Em c) o pico de um ano é bem marcado em toda a série, demonstrando a sazonalidade anual. Em d) os quatro picos indicam a periodicidade multidecadal que pode ser um indicador de relação com os índices macroclimáticos.
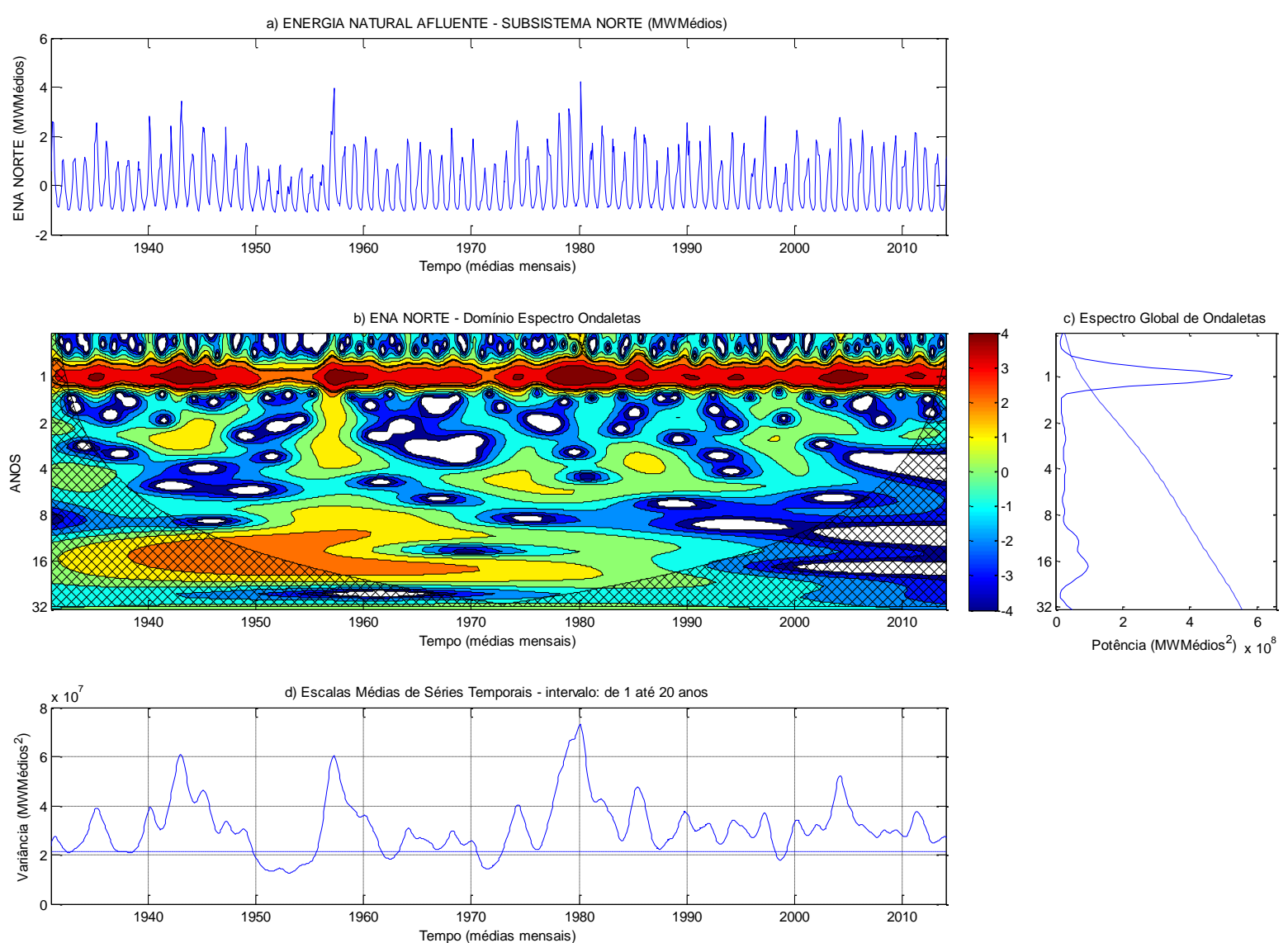

Figura APÊNDICE H-103 Análise por wavelets a) Série Histórica ENA do Norte. b) Domínio Espectro de Ondaletas. c) Espectro Global de Ondaletas. d) Escalas Médias de Séries Temporais Wavelets Análise relação variáveis explicativas e ENA $\mathrm{N}$ 
APÊNDICE H.28.1 Análise relação variáveis explicativas e ENA N

A correlação de a) e b) Manchas e ENA N com o uso de wavelets em c) mostra a influência das manchas solares sobre as ENAS entre 8 e 16 anos. Em d) aparece correlações por volta dos períodos de 1 ano entre 1970 e 1980 e de períodos de 8 anos entre os anos de 1945 a 1970 e entre 1975 a 1990. A correlação a) Multidecadal do Atlântico e ENA N em b) há uma pequena correlação de período de 8 anos por volta de 1985. Em c) mostra algumas correlações entre 1 e 4 anos que ocorreram por volta de 1940, 1955 e entre 1995 até 2002.
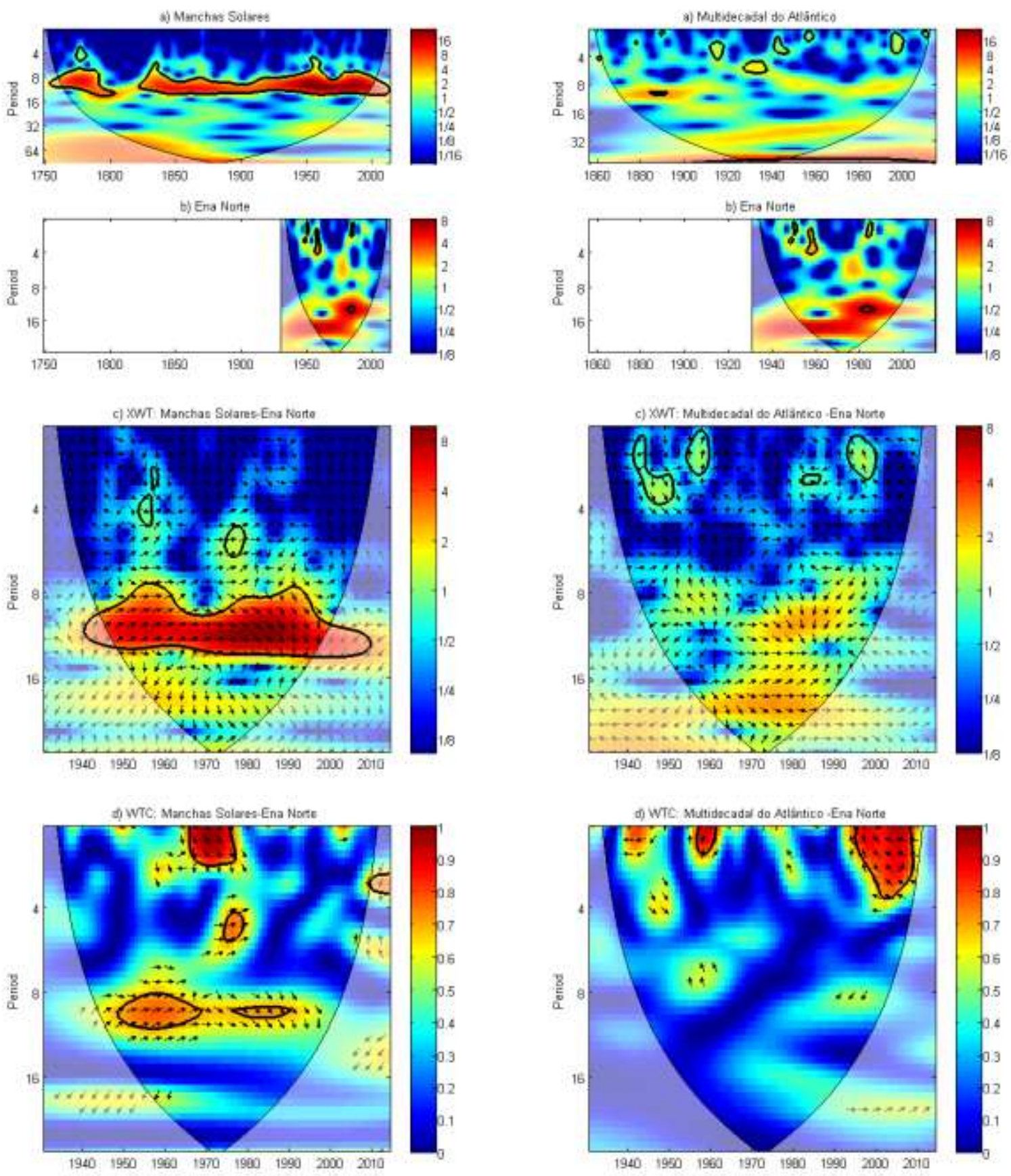

Figura APÊNDICE H-104 Análise por wavelets a) Manchas Solares versos b) ENA do Norte. c) Trans. Cruzada - XWT d) Trans. Contínua - CWT

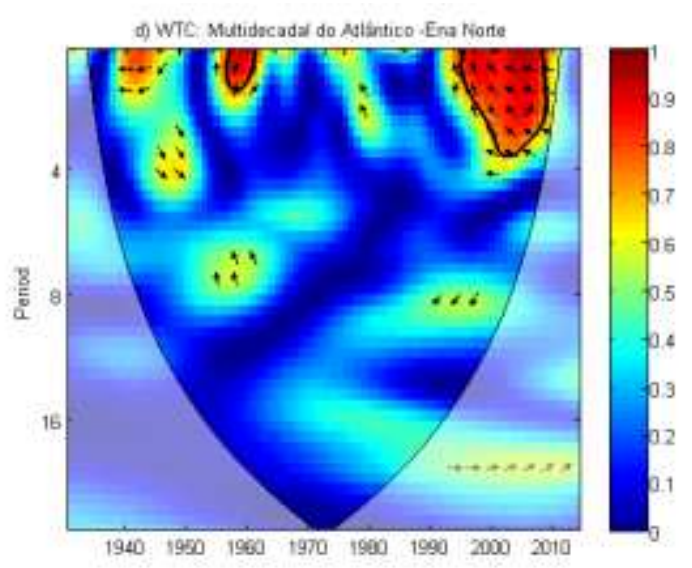

Figura APÊNDICE H-105 Análise por wavelets a) Multidecadal do Atlântico versos b) ENA do Norte. c) Trans. Cruzada - XWT d) Trans. Contínua - CWT 
Ao fazer a) e b) correlação com NINO 1+2 e ENA N com o uso de wavelets em c) mostra a influência de NINO1+2 sobre as ENA N em diferentes períodos que são significativos nos anos de 1950 e entre os anos de 1980 e 2000. Em c) aparece correlações com períodos entre 8 e 16 anos com nível de significância de 95\% entre os anos de 1970 até 2014. Ao fazer a) correlação com PDO e ENA N com o uso de wavelets em c) mostra a influência de PDO sobre as ENA N por volta de 16 entre 1931 e 1990. Em c) aparece correlações com períodos entre 1 e 2 anos; e por volta de 6 anos fora do cone de influência, por volta 2010.
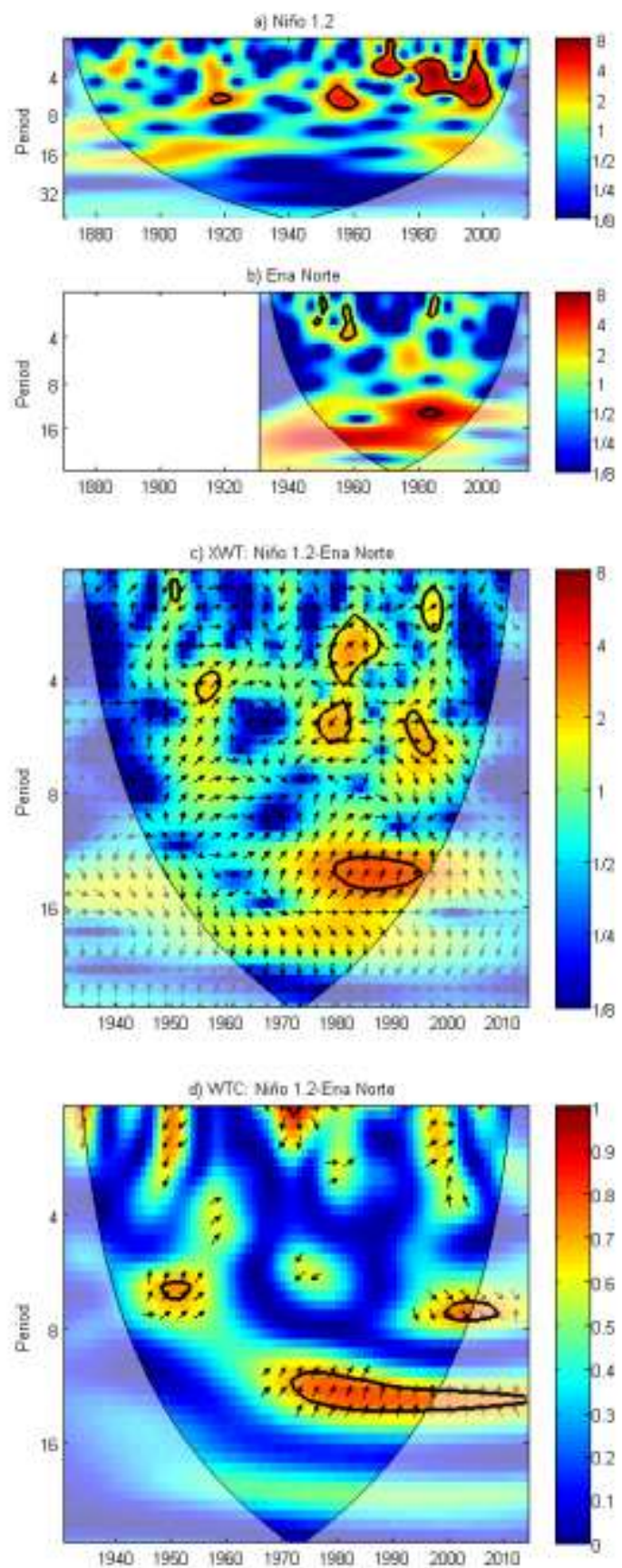

Figura APÊNDICE H-106 Análise por wavelets a) El Niño 1+2 versos b) ENA do Norte. c) Trans. Cruzada - XWT d) Trans. Contínua - CWT
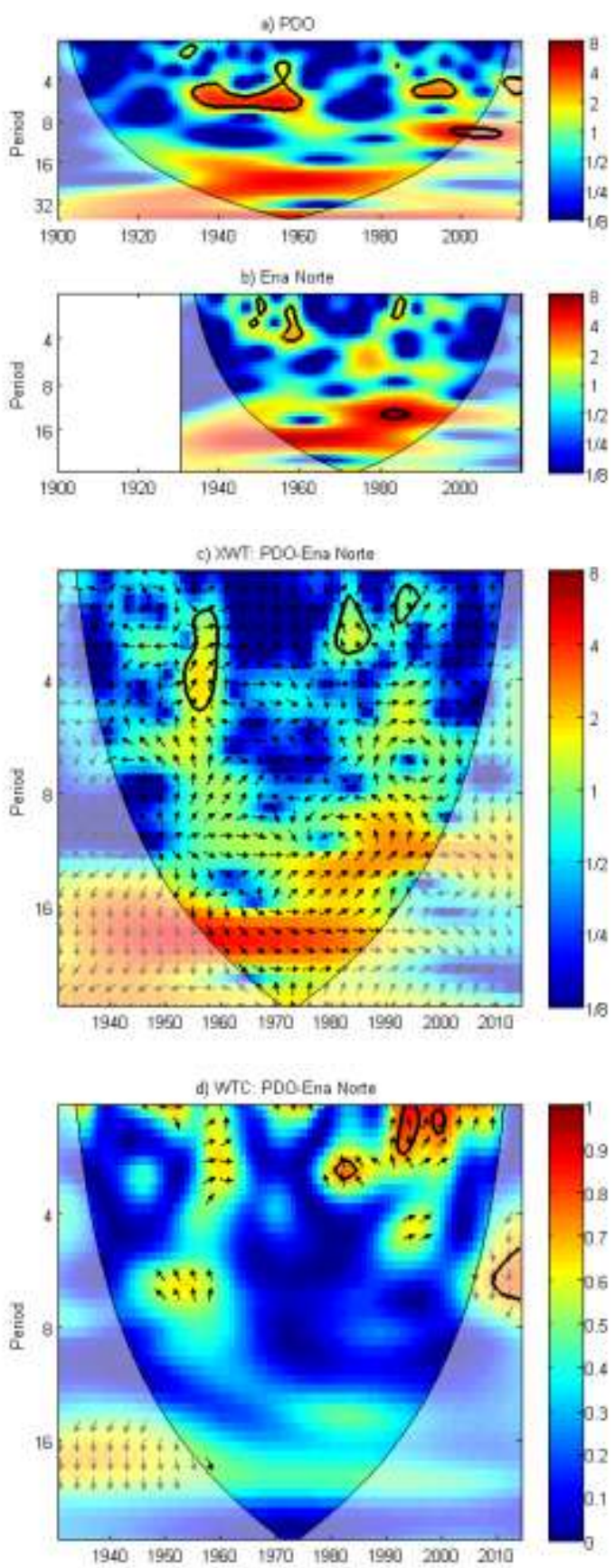

Figura APÊNDICE H-107 Análise por wavelets a) Decadal do Pacífico versos b) ENA do Norte. c) Trans. Cruzada - XWT d) Trans. Contínua - CWT 


\section{APÊNDICE H.29 Wavelets - ENA NORDESTE}

Na Figura APÊNDICE H-108, apresentam-se os padrões da série histórica de ENA da área do submercado Nordeste que tem o período de 1931 a 2013. Série original em a). Em b) observa-se um padrão bem marcados em vermelho em torno do período de 1 ano com IC acima de $95 \%$ e também padrões adjacentes com contorno em vermelho entre 8 e 32 anos espalhados em toda a série. Em c) o pico de um ano é bem marcado entre 1980 e 1985. Em d) os três picos indicam a periodicidade em multidécadas que pode ser um indicador de relação com os índices macroclimáticos.
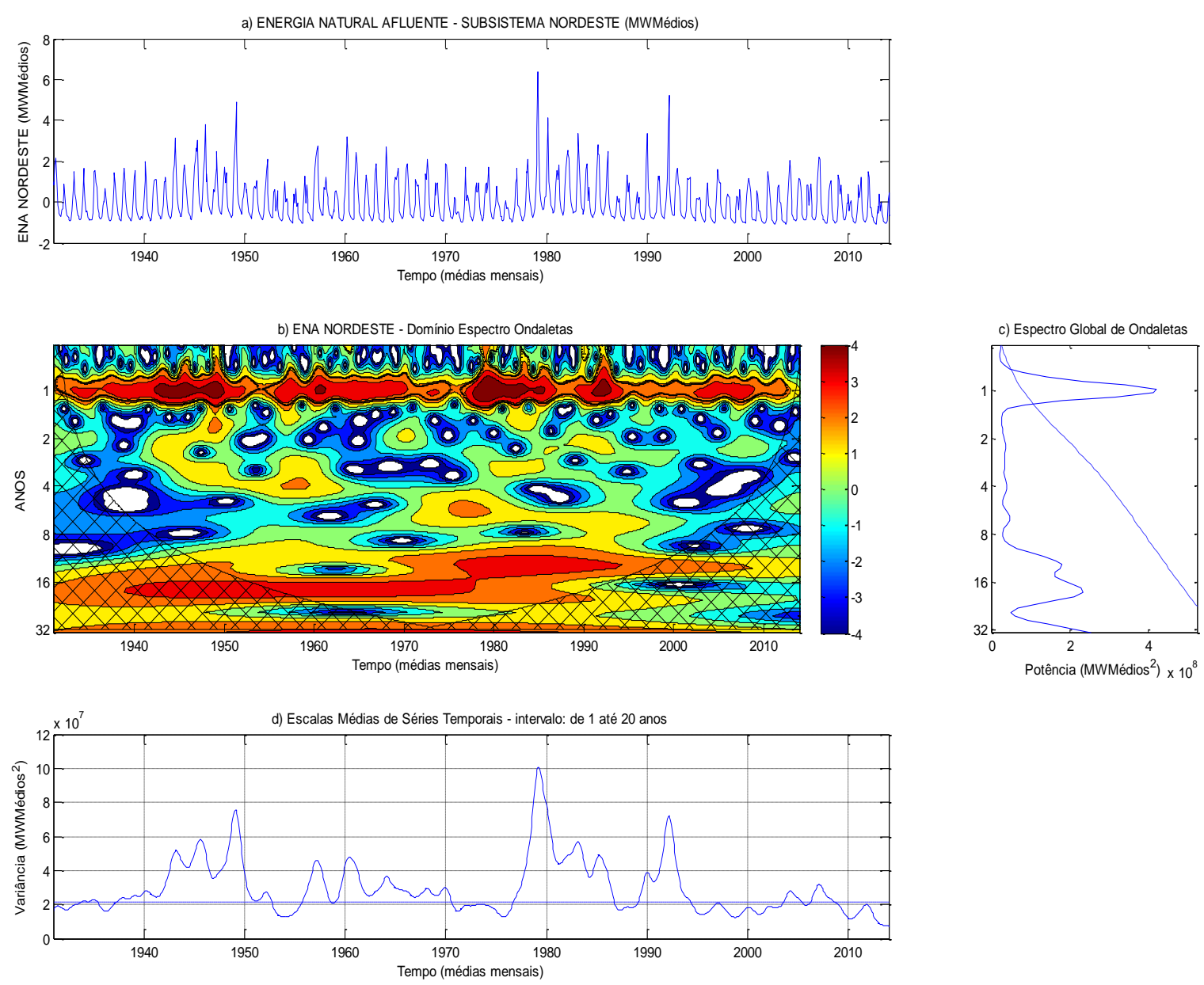

Figura APÊNDICE H-108 Análise por wavelets a) Série Histórica ENA do Nordeste. b) Domínio Espectro de Ondaletas. c) Espectro Global de Ondaletas. d) Escalas Médias de Séries Temporais Wavelets Análise relação variáveis explicativas e ENA NE. 
APÊNDICE H.29.1 Análise relação variáveis explicativas e ENA NE

A correlação de a) e b) Manchas e ENA NE com o uso de wavelets em c) mostra a influência das manchas solares sobre as ENA NE entre 8 e 16 anos. Em d) aparece correlações com períodos entre 16 e 22 anos o qual extrapola a linha do cone de influência. A correlação a) e b) Multidecadal do Atlântico e ENA NE. Em c) mostra algumas correlações entre 1 e 4 anos que ocorreram por volta de 1940, 1955 e entre 1995 até 2002. Em d) ocorrem correlações significativas com períodos entre 1 a 4 anos, por volta de 1957 e entre 1995 a 2002.
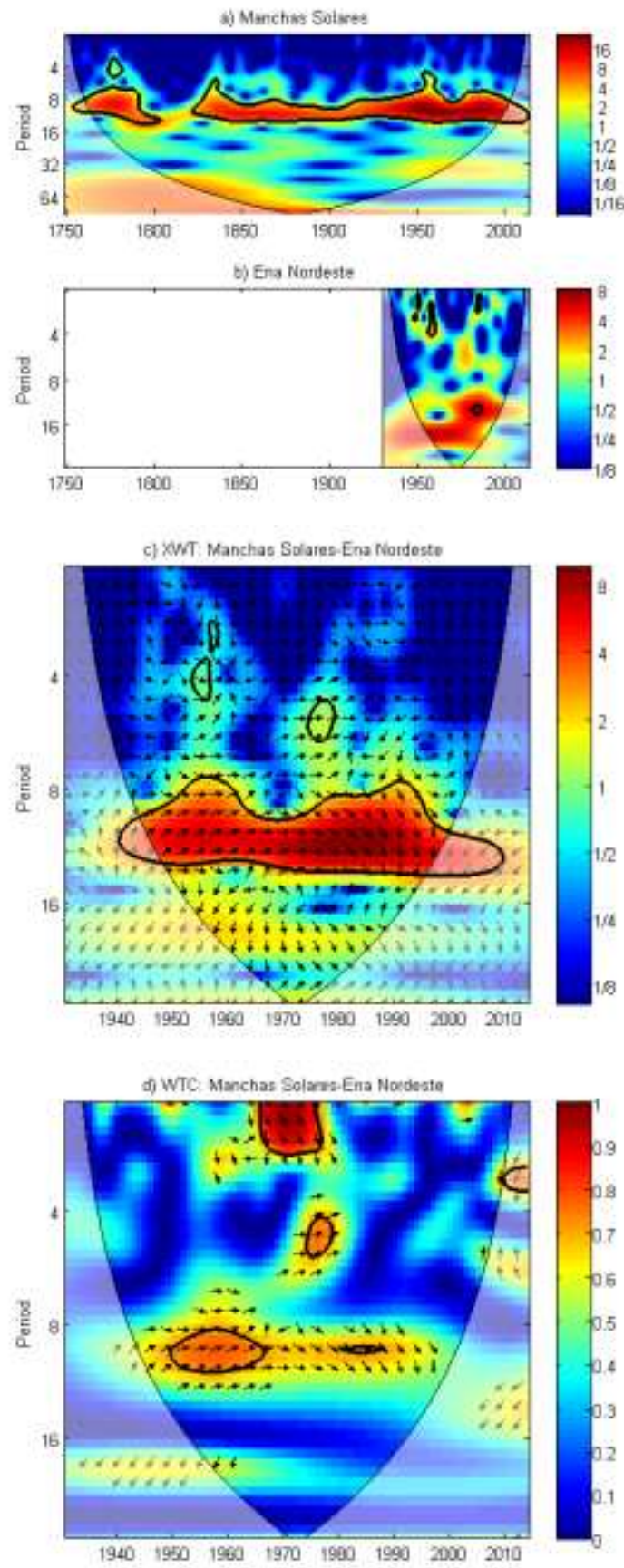

Figura APÊNDICE H-109 Análise por wavelets a) Manchas Solares versos b) ENA do Nordeste. c) Trans. Cruzada - XWT d) Trans. Contínua - CWT
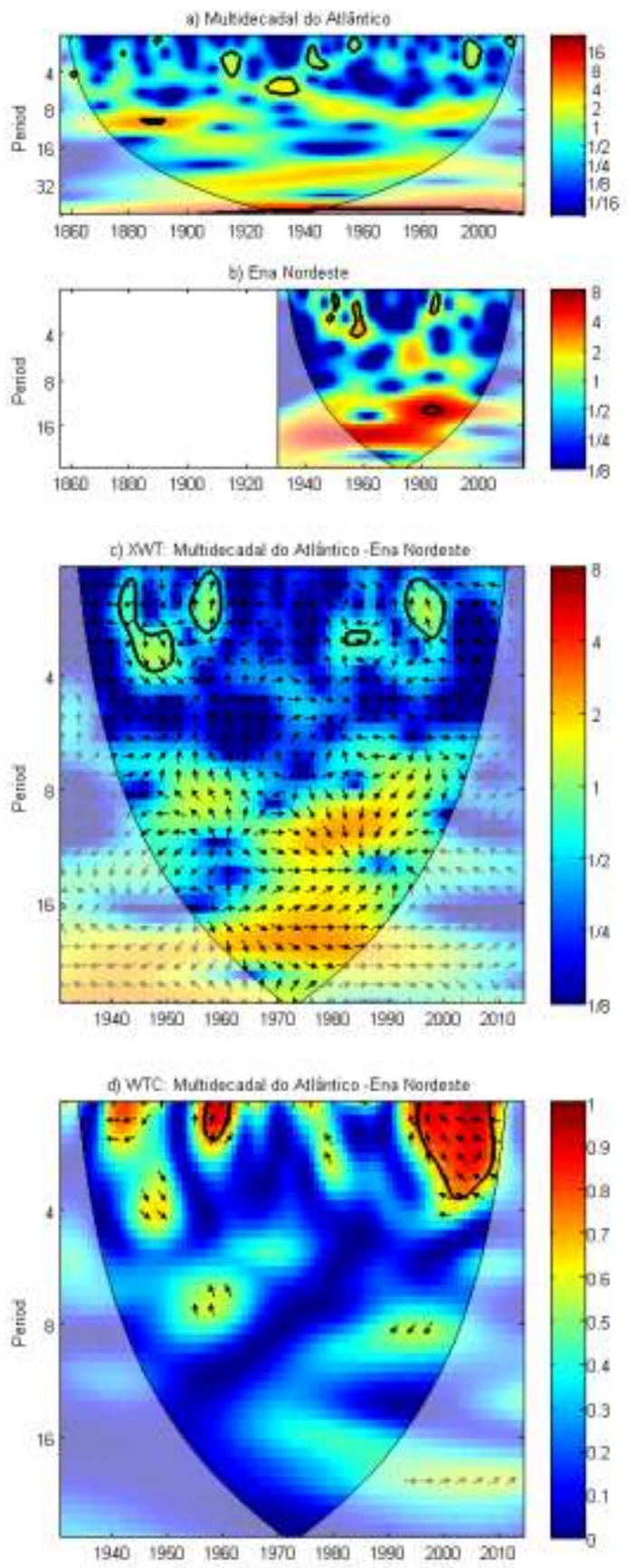

Figura APÊNDICE H-110 Análise por wavelets a) Multidecadal do Atlântico versos b) ENA do Nordeste. c) Trans. Cruzada - XWT d) Trans. Contínua-CWT 
Ao fazer a) e b) correlação com NINO 1+2 e ENA NE com o uso de wavelets em c) mostra a influência de NINO1+2 sobre as ENA NE em diferentes períodos que são significativos nos anos de 1950 e entre os anos de 1980 e 2000. Em c) aparece correlações com períodos entre 8 e 16 anos com nível de significância de 95\% entre os anos de 1970 até 2014. Ao fazer a) correlação com PDO e ENA NE com o uso de wavelets em c) mostra a influência de PDO sobre as ENA NE por volta de 16 entre 1931 e 1990. Em c) aparece correlações com períodos entre 1 e 2 anos; e por volta de 6 anos fora do cone de influência, por volta 2010.
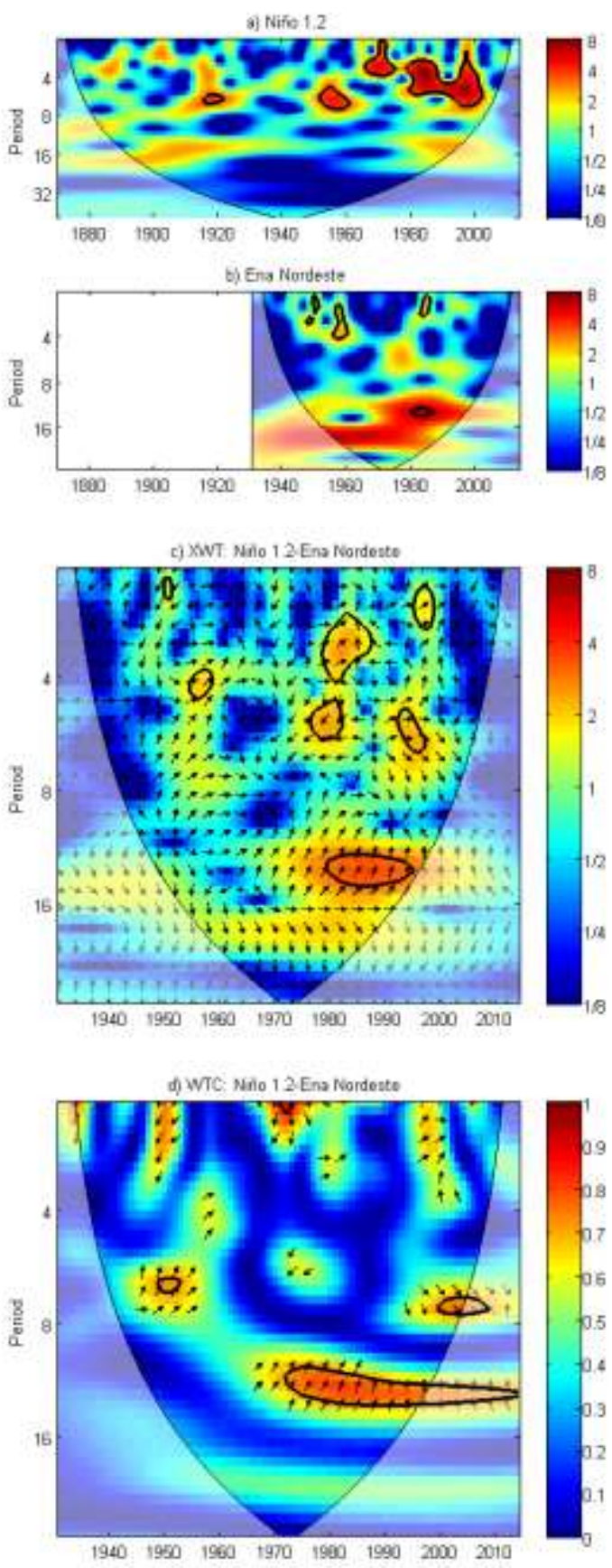

Figura APÊNDICE H-111 Análise por wavelets a) El Niño 1+2 versos b) ENA do Nordeste. c) Trans. Cruzada - XWT d) Trans. Contínua - CWT
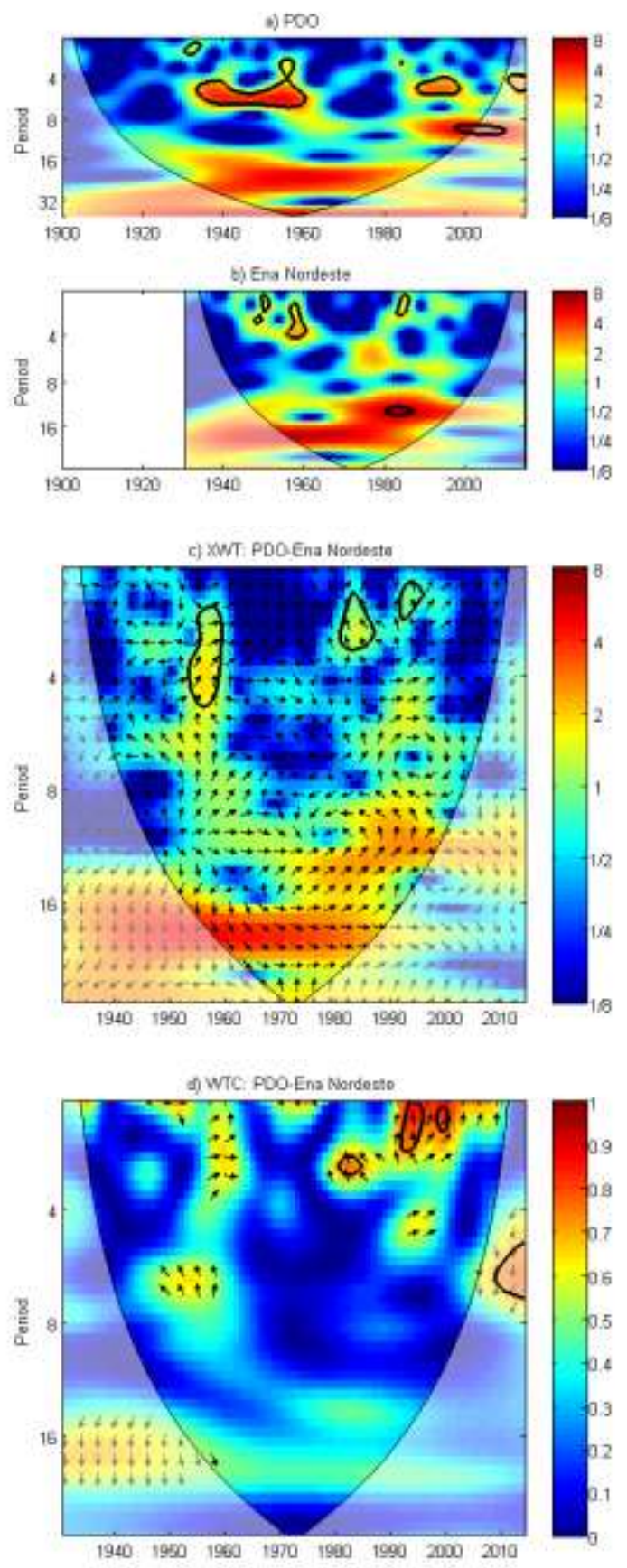

Figura APÊNDICE H-112 Análise por wavelets a) Decadal do Pacífico versos b) ENA do Nordeste. c) Trans. Cruzada - XWT d) Trans. Contínua - CWT 


\section{APÊNDICE I Análise de Componentes Principais}

Embora p variáveis possam ser necessárias para reproduzir o comportamento de um sistema, em muitos casos utilizando um número menor de variáveis poderemos explicar parcela satisfatória da variabilidade exibida pelo sistema. A técnica matemática utilizada para realizar tal tarefa é denominada Análise de Componentes Principais (O termo em inglês - PCA).

Matematicamente, a análise de componentes principais está interessada em explicar a estrutura de variância-covariância de um conjunto de variáveis através de algumas combinações lineares dessas variáveis. Seus objetivos gerais são: (1) redução de dados e (2) interpretação (JOHNSON e WICHERN, 2007). Uma análise de componentes principais muitas vezes revela relacionamentos que não foram previamente identificados e, assim, permite interpretações que dificilmente resultariam normalmente. Frequentemente, a PCA funciona como etapa intermediária para aprofundar investigações posteriores, especialmente quando se opera com grande quantidade de informações.

A PCA também é chamada de Transformada Discreta de Karhunen-Loève (KLT) ou também de Transformada Hotelling. Foi derivada por Hotelling e por ele denominada como Método dos Componentes Principais.

Em 1901 Karl Pearson (1901) publicou um trabalho sobre o ajuste de uma linha ou um plano espacial em um sistema de pontos em um espaço multidimensional. Esse enfoque foi retomado em 1933 por Hotelling (HOTELLING, 1933), que foi o primeiro a formular o conceito da análise de componentes principais, tal como ela é hoje. O trabalho original de Pearson (1901) observa os componentes com combinações lineares das variáveis originais, para a qual a variabilidade não explicada foi mínima. Essa combinação gera um plano em função das variáveis originais, e o melhor ajuste do sistema de pontos, por ser mínima a soma das distâncias de cada ponto ao plano de ajuste.

O enfoque de Hotelling observa na análise de componentes que sintetizam a maior variabilidade do sistema de pontos, que corresponde a componente principal. Por inspeção dessas componentes apresenta-se a maior proporção possível da variabilidade total entre o conjunto de pontos e encontrar-se uma média para classificar ou detectar relações entre os pontos. 
APÊNDICE J Apêndice Análise Gráfica das Séries Temporais

APÊNDICE J.1 Resumo análise das Séries Históricas de Usinas

A análise das séries temporais das usinas está resumida a seguir, as imagens de análise estão no Apêndice. Nota se que a maioria das usinas, apresentam-se gráficos de FAC e FACP parecidos com exceção das usinas Foz do Areia e Passo fundo as demais são idênticas. Isso mostra que as séries possuem padrões parecidos o que corrobora com o trabalho de Reboita et al (2010).

Na Tabela APÊNDICE J-2 e na Tabela APÊNDICE J-3, apresentam-se um resumo da análise feita nos gráficos de decomposição e análise e autocorreção e periodogramas . A análise aborda as variáveis macroclimátias e as variáveis de ENA ou vazões em diferentes escalas espaciais e temporais.

Na Figura APÊNDICE J-113, mostram-se o posicionamento das usinas analisadas e os padrões climatológicos associados. Nota-se que são diferentes, os mecanismos atmosféricos para a formação de chuva.

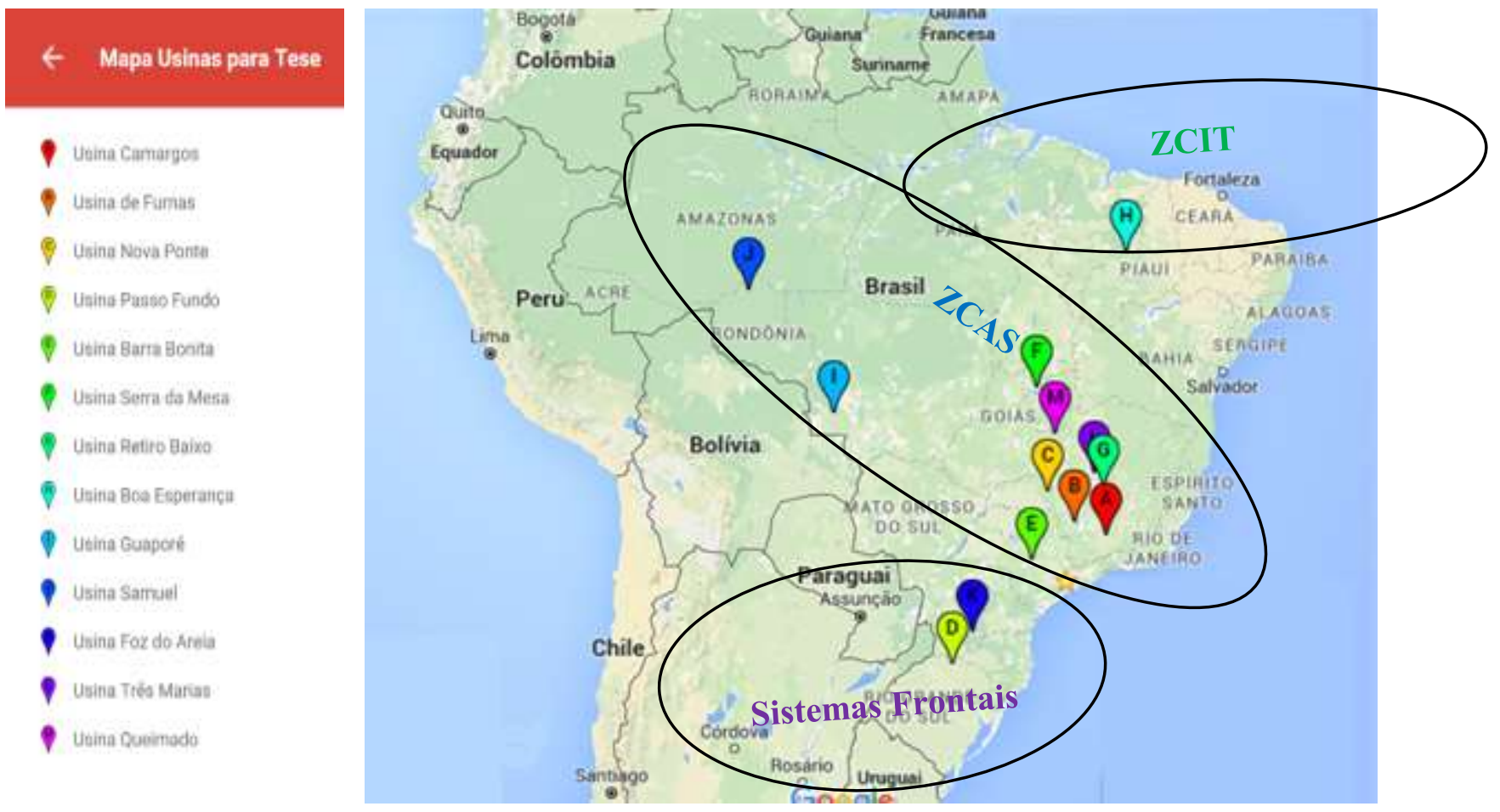

Figura APÊNDICE J-113 Análise das Séries Históricas de Vazões de Usinas de Cabeceira 
Tabela APÊNDICE J-2 Análise gráficos séries históricas das Usinas de Cabeceira

\begin{tabular}{|c|c|c|c|c|}
\hline Usina & Bacia & FAC & FACP & Periodograma \\
\hline $\begin{array}{l}\text { Porto } \\
\text { Primavera }\end{array}$ & PR & Senoidal & $\begin{array}{l}\text { Senoidal, zera por volta } \\
\text { de } 24 \text { meses }\end{array}$ & 12 e 24 meses \\
\hline Sobradinho & São Francisco & Senoidal & $\begin{array}{l}\text { Senoidal, zera por volta } \\
\text { de } 24 \text { meses }\end{array}$ & 12 e 24 e meses \\
\hline Estreito & Tocantins & Senoidal & $\begin{array}{l}\text { Senoidal, zera por volta } \\
\text { de } 24 \text { meses }\end{array}$ & 12,24 e 36 meses \\
\hline Camargos & Rio Grande & Senoidal & $\begin{array}{l}\text { Senoidal, zera por volta } \\
\text { de } 24 \text { meses }\end{array}$ & 12 e 24 meses \\
\hline Nova Ponte & Rio Grande & Senoidal & $\begin{array}{l}\text { Senoidal, zera por volta } \\
\text { de } 12 \text { e } 24 \text { meses }\end{array}$ & 12 e 24 meses \\
\hline Barra Bonita & Tiete & Senoidal & $\begin{array}{l}\text { Senoidal, zera por volta } \\
\text { de } 12 \text { e } 24 \text { meses }\end{array}$ & 12 e 24 meses \\
\hline Foz do Areia & Iguaçu & $\begin{array}{l}\text { Zera } 3 \\
\text { meses }\end{array}$ & Zerada & 46 meses \\
\hline Serra da Mesa & Tocantins & Senoidal & $\begin{array}{l}\text { Senoidal, zera por volta } \\
\text { de } 12 \text { e } 24 \text { meses }\end{array}$ & 12 e 24 meses \\
\hline Queimado & São Francisco & Senoidal & $\begin{array}{l}\text { Senoidal, zera por volta } \\
\text { de } 12 \text { e } 24 \text { meses }\end{array}$ & 12 meses \\
\hline Retiro Baixo & São Francisco & Senoidal & $\begin{array}{l}\text { Senoidal, zera por volta } \\
\text { de } 12 \text { e } 24 \text { meses }\end{array}$ & 12 meses e 24 meses \\
\hline Três Marias & São Francisco & Senoidal & $\begin{array}{l}\text { Senoidal, zera por volta } \\
\text { de } 12 \text { e } 24 \text { meses }\end{array}$ & 12 meses e 24 meses \\
\hline Furnas & Rio Grande & Senoidal & $\begin{array}{l}\text { Senoidal, zera por volta } \\
\text { de } 12 \text { e } 24 \text { meses }\end{array}$ & 12 meses e 24 meses \\
\hline Boa Esperança & Parnaíba & Senoidal & $\begin{array}{l}\text { Senoidal, zera por volta } \\
\text { de } 12 \text { meses }\end{array}$ & 12,24 e 36 meses \\
\hline Guaporé & Amazônica & Senoidal & $\begin{array}{l}\text { Senoidal, zera por volta } \\
\text { de } 12 \text { meses }\end{array}$ & 12,24 e 36 meses \\
\hline Samuel & Amazônica & Senoidal & $\begin{array}{l}\text { Senoidal, zera por volta } \\
\text { de } 12 \text { meses }\end{array}$ & 12,24 e 36 meses \\
\hline Passo Fundo & Uruguai & Senoidal & Zerada & 12 meses \\
\hline
\end{tabular}


Tabela APÊNDICE J-3 Análise gráfico tendência das séries históricas das Usinas de Cabeceira

\begin{tabular}{|c|c|c|}
\hline Usina & Bacia & Obs. \\
\hline Porto Primavera & PR & Linha de tendência apresenta um pico acentuada entre 1980 e 1990 \\
\hline Sobradinho & São Francisco & $\begin{array}{l}\text { Linha de tendência apresenta um pico acentuada entre } 1940 \text { e } 1950 \text {; e } \\
1980 \text { e } 1990\end{array}$ \\
\hline Estreito & Tocantins & $\begin{array}{l}\text { Linha de tendência apresenta um pico acentuada entre 1930, 1950; } \\
1960,1980 \text { e } 1985 \text { e uma calmaria após } 1985\end{array}$ \\
\hline Camargos & Rio Grande & $\begin{array}{l}\text { Linha de tendência apresenta um pico acentuada entre } 1985 \text { e uma } \\
\text { calmaria após } 1985 \text { com um leve pico } 2010\end{array}$ \\
\hline Nova Ponte & Rio Grande & $\begin{array}{l}\text { Linha de tendência apresenta um pico acentuada entre } 1985 \text { e } 1990 \\
\text { uma calmaria após } 1990 \text { com um leve pico } 2010\end{array}$ \\
\hline Barra Bonita & Tiete & $\begin{array}{l}\text { Linha de tendência apresenta um pico acentuada em } 1978 \text { e } 1985 \\
\text { uma calmaria após } 1990 \text { com um leve pico } 2010\end{array}$ \\
\hline Foz do Areia & Iguaçu & $\begin{array}{l}\text { Linha de tendência apresenta um pico acentuada em 1980, } 1990 \text { e } \\
2000 \text { e inclinação positiva após } 2010\end{array}$ \\
\hline Serra da Mesa & Tocantins & $\begin{array}{l}\text { Linha de tendência apresenta um pico acentuada em } 1950 \text { e } 1980 \text { e } \\
\text { calmaria após } 1990 \text { com um leve pico } 2010\end{array}$ \\
\hline Queimado & São Francisco & $\begin{array}{l}\text { Linha de tendência apresenta um pico acentuada em 1950, } 1980 \text { e } \\
1995 \text { calmaria após } 1990 \text { com um leve pico } 2010\end{array}$ \\
\hline Retiro Baixo & São Francisco & $\begin{array}{l}\text { Linha de tendência apresenta um pico acentuada em } 1980 \text { e } 1995 \text { e } \\
\text { tendência negativa após } 1995 \text { com um leve pico } 2010\end{array}$ \\
\hline Três Marias & São Francisco & $\begin{array}{l}\text { Linha de tendência apresenta um pico acentuada em } 1990 \text { tendência } \\
\text { negativa após } 1990 \text { com leves picos em 1990, } 19952010\end{array}$ \\
\hline Furnas & Rio Grande & $\begin{array}{l}\text { Linha de tendência apresenta um pico acentuada em } 1990 \text { tendência } \\
\text { negativa após } 1990 \text { com um leve pico em } 2010\end{array}$ \\
\hline Boa Esperança & Parnaíba & $\begin{array}{l}\text { Linha de tendência apresenta um pico acentuada entre } 1935 \text { e 1945; e } \\
1980 \text { e } 1990 \text { com tendência negativa após } 1990\end{array}$ \\
\hline Guaporé & Amazônica & $\begin{array}{l}\text { Linha de tendência apresenta um pico negativo acentuado entre } 1960 \\
\text { e 1970, tendência positiva até 1990; e declínio até } 2010 \text { e rápida } \\
\text { recuperação após } 2014\end{array}$ \\
\hline Samuel & Amazônica & $\begin{array}{l}\text { Linha de tendência apresenta um pico negativo acentuado entre } 1970 \\
\text { e } 1980,2000 \text {, tendência positiva até } 2015\end{array}$ \\
\hline Passo Fundo & Uruguai & $\begin{array}{l}\text { Linha de tendência apresenta diversos picos positivos e um forte pico } \\
\text { negativo em } 1950\end{array}$ \\
\hline
\end{tabular}




\section{APÊNDICE K Séries Históricas de Usinas}

Nessa seção a análise gráfica das séries temporais tem como objetivo demonstrar no gráfico: ${ }^{151}$

a) as séries decompostas em: série sazonal, séries de tendência e série de resíduos;

b) mostra a série original;

c) o gráfico no domínio das frequências;

d) o resultado da função de autocorrelação (FAC); e

e) o resultado da função de autocorrelação parcial (FACP).

Em seguida, são apresentados os gráficos para análise da sazonalidade anual considerando a) médias nos trimestres e b) apresenta os meses janeiro, abril, julho e outubro isolados. 


\section{APÊNDICE K.1 Séries Históricas Número de Manchas Solares}

A análise das séries temporais de número de manchas solares, exibe-se, no gráfico da Figura APÊNDICE K-114, a) a decomposição na parte sazonal que indica claramente padrões senoidais de acordo com o padrão de 11 anos de oscilação nas emissões de manchas do Sol, e a tendência apresenta bastante ruído e frequências altas. O gráfico d) de autocorrelação revela um possível padrão para médias móveis de 36 meses e de correlação parcial indica um possível padrão autorregressivos de 18 meses.
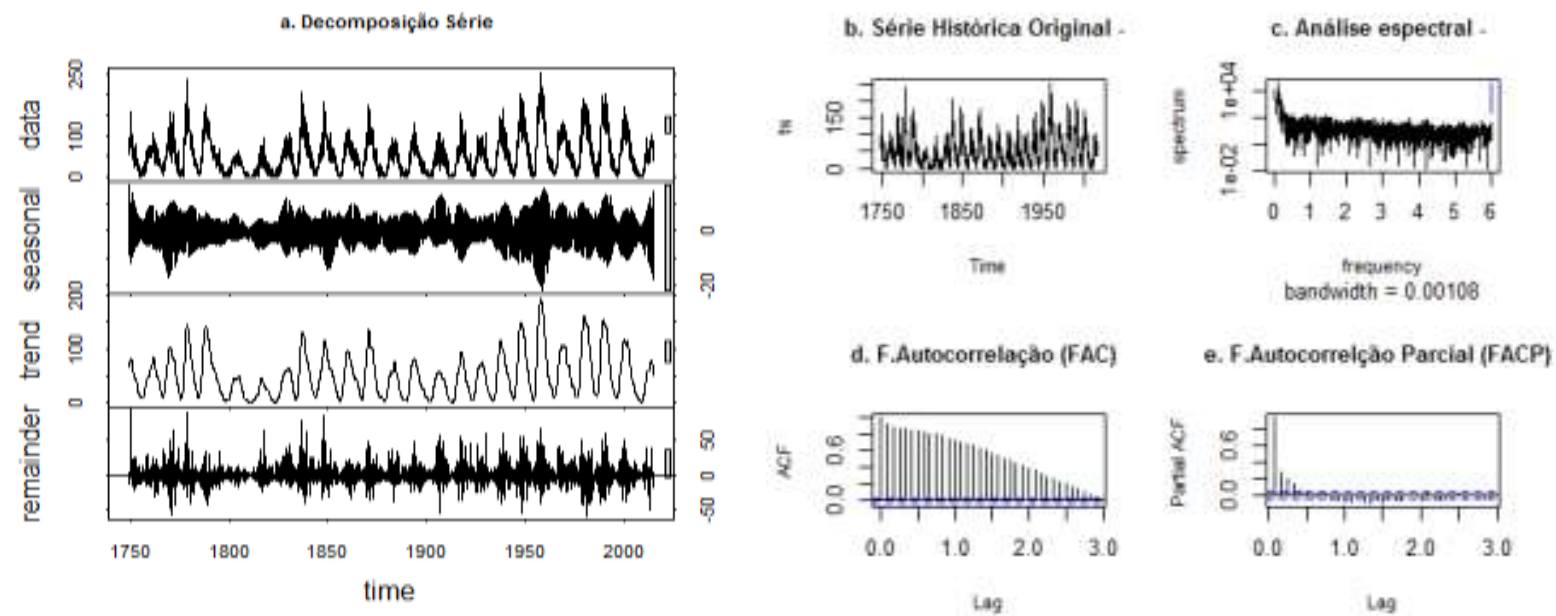

Figura APÊNDICE K-114 Análise gráfica séries temporais Manchas solares a) decomposição da série em sazonalidade, tendência e resíduos b) série original c) domínio frequência d) FAC e) FACP.

Nos gráficos da Figura APÊNDICE K-115, apresentam-se a variabilidade dos registros de número de mancha solares. Em f) destaca-se não ocorrência de sazonalidades anuais.
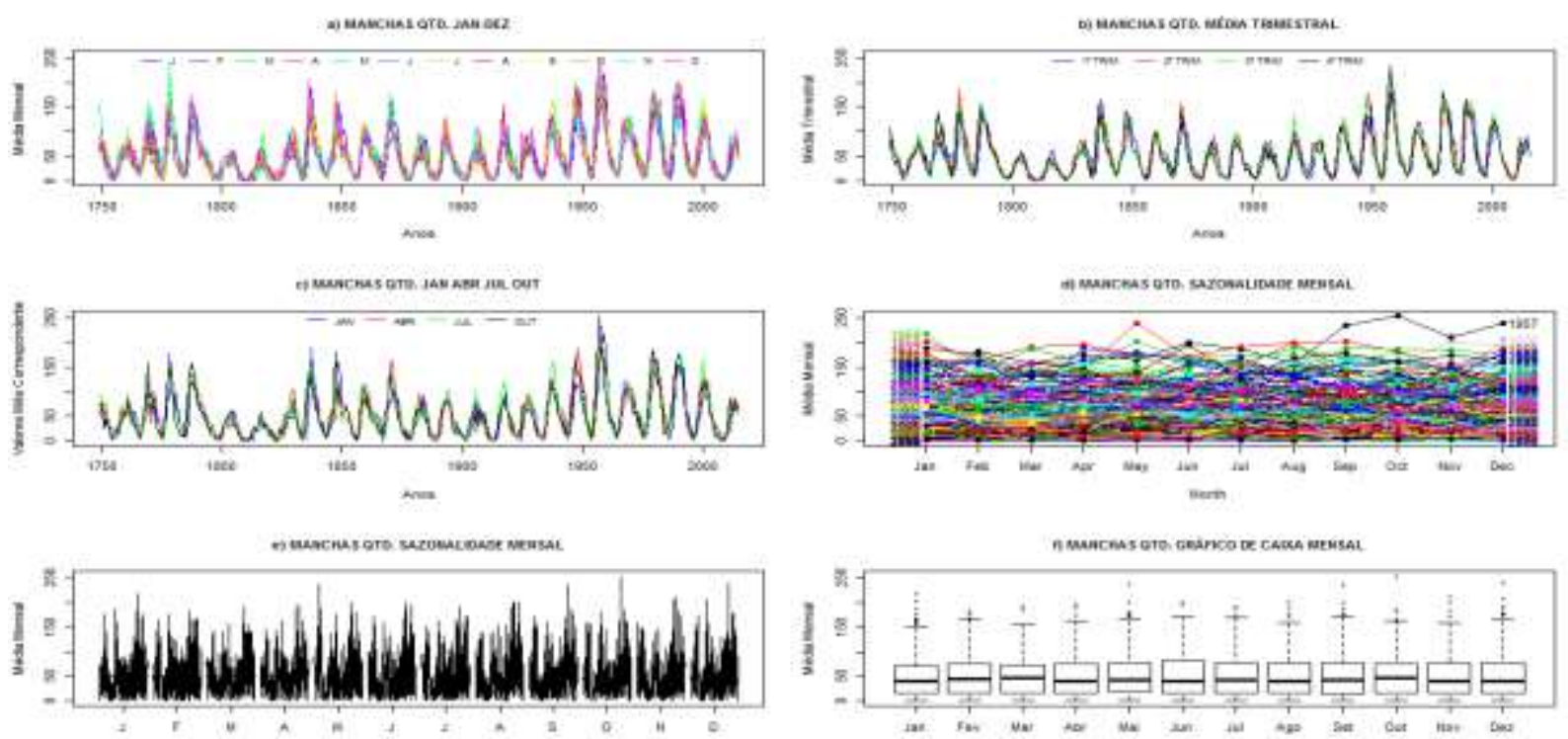

Figura APÊNDICE K-115 Sazonalidade anual das séries temporais número de Manchas solares. a) Meses jan. a dez; b) médias trimestrais; c) somente jan., abr., jun. e out; d) Sazonalidade mensal por ano; e) Variabilidade mês a mês; f) Boxplot do período 


\section{APÊNDICE K.2 Séries Históricas TSM Niño 1+2}

A análise das séries temporais de TSM Niño 1+2 indica no gráfico de decomposição, na parte sazonal, padrões senoidais, em conformidade com a sazonalidade um ano. O gráfico de autocorrelação indica um possível padrão senoidal e de correlação parcial indica um possível padrão autorregressivos de 22 meses.
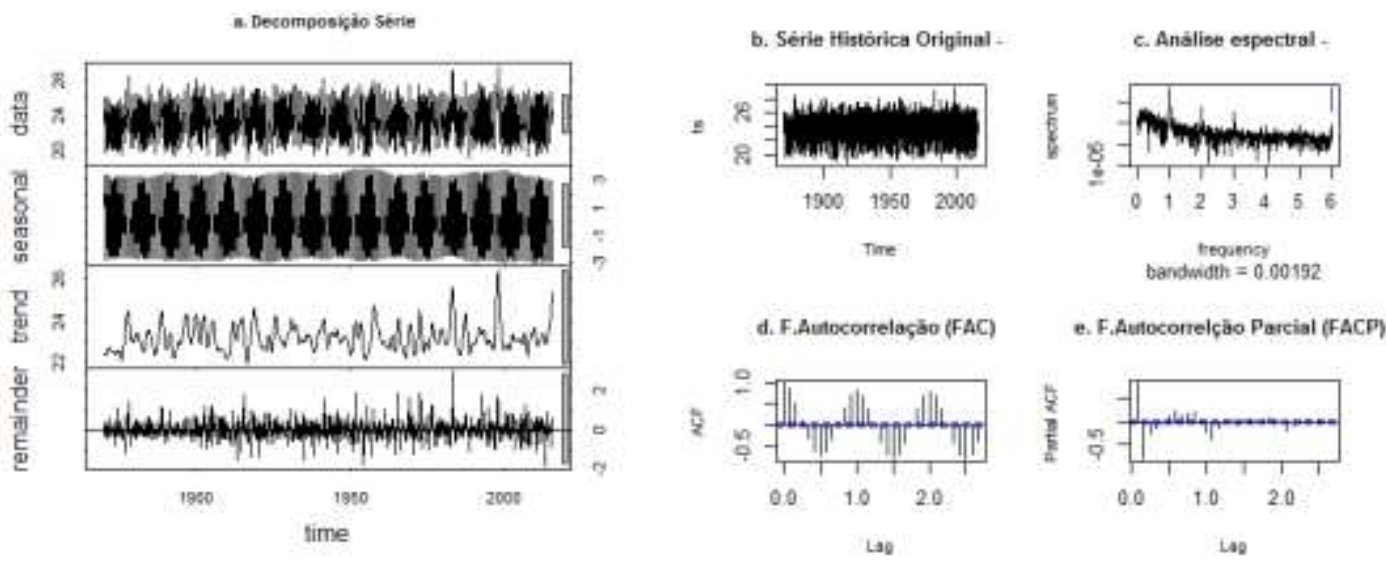

Figura APÊNDICE K-116 Análise gráfica séries temporais El Niño 1+2. a) decomposição da série em sazonalidade, tendência e resíduos b) série original c) domínio frequência d) FAC e) FACP.

Nos gráficos da Figura APÊNDICE K-117, apresentam-se meses com gráficos espaçados; as médias dos $3^{\circ}$ e $4^{\circ}$ trimestres são próximas; janeiro e abril próximos, assim como junho e outubro; sazonalidade mensal com padrões secos e úmidos; variabilidade nos meses com destaques conforme (d); boxplot com destaques.

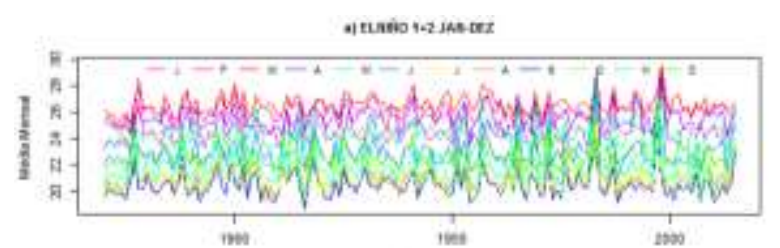

$10 \mathrm{mot}$

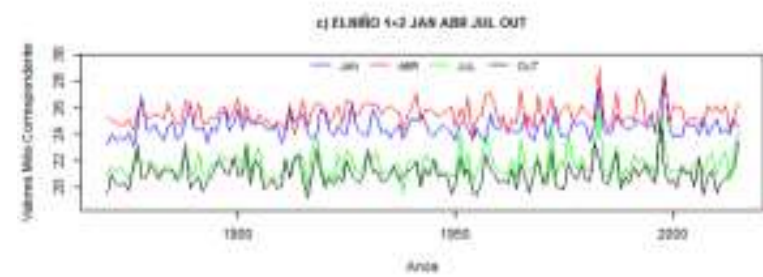

ante

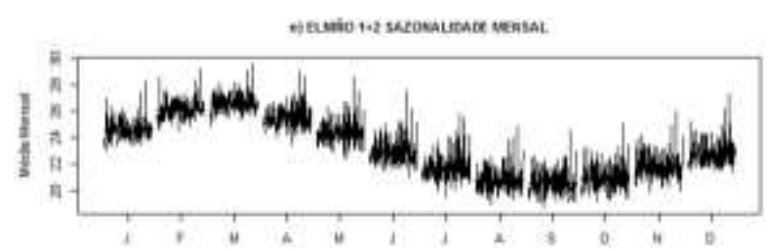

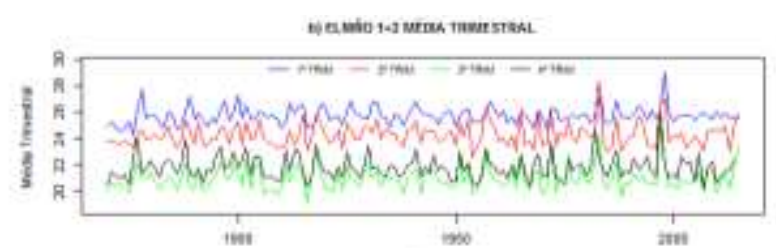

sese.
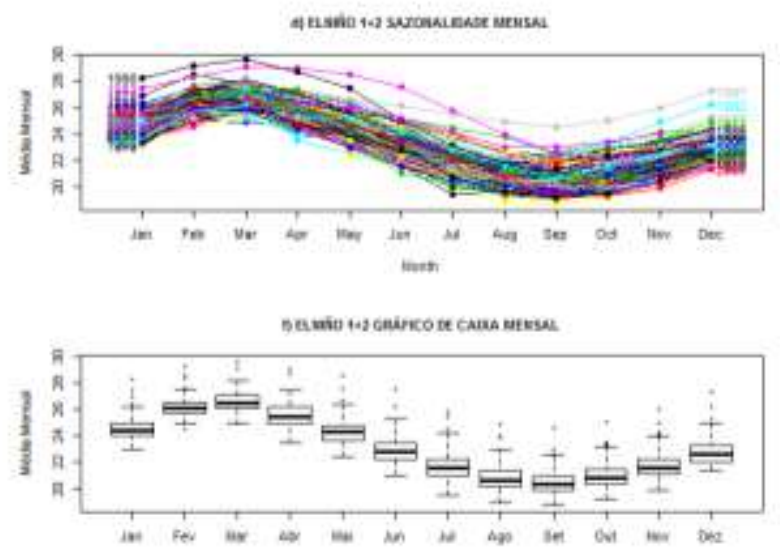

Figura APÊNDICE K-117 Séries temporais El Niño 1+2 a) JAN a DEZ. b) Média Trimestral. c) JAN ABR JUL OUT. d) Sazonalidade mensal todos os anos. e) Gráfico sazonalidade mês a mês. f) Gráfico de caixa. 


\section{APÊNDICE K.3 Séries Históricas Oscilação Multidecadal do Atlântico}

A análise das séries temporais do índice AMO exibem no a) gráfico de decomposição na parte sazonal padrões senoidais, de acordo com o padrão em c) de 1, 2, 3 e 4 anos. O gráfico d) de autocorrelação indica um padrão de decaimento e o e) de correlação parcial indica um possível padrão autorregressivos de 1 ano, conforme o pico significativo no lag 1 .
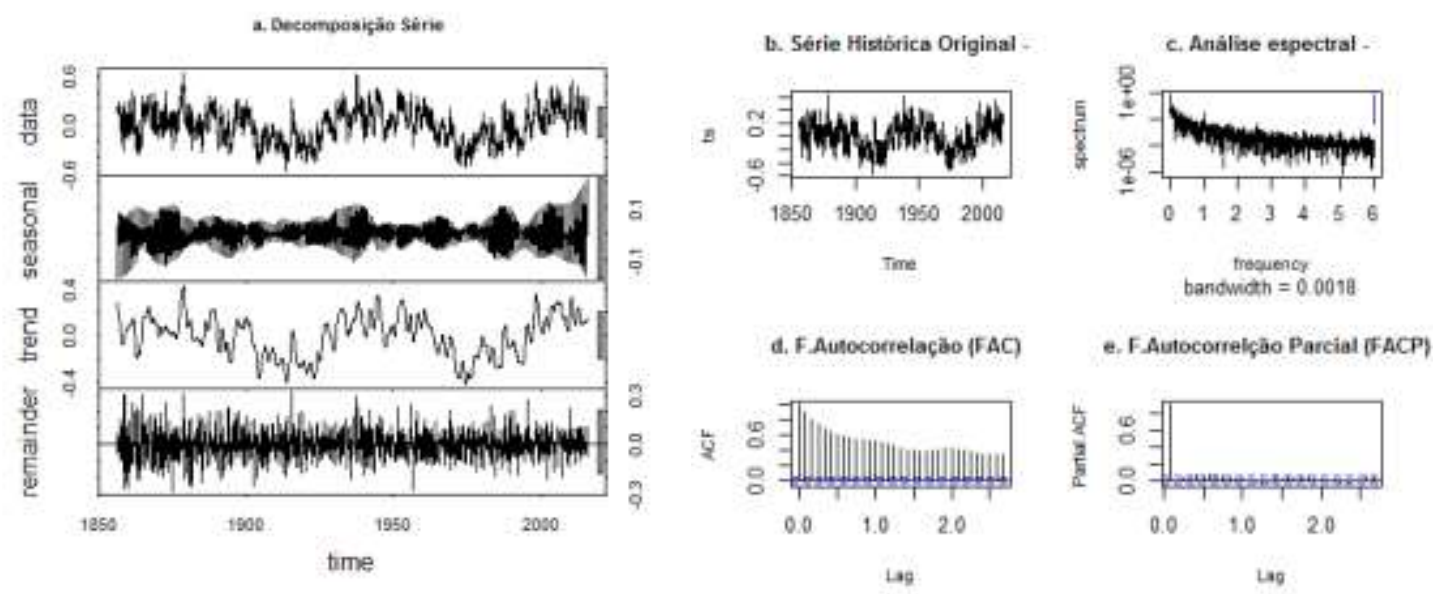

Figura APÊNDICE K-118 Análise gráfica séries temporais Multidecadal do Atlântico. a) decomposição da série em sazonalidade, tendência e resíduos b) série original c) domínio frequência d) FAC e) FACP.

Nos gráficos da Figura APÊNDICE K-118, apresentam-se a) meses com gráficos bem espaçados; b) médias trimestrais bem espaçadas; c) janeiro e abril próximos, assim como junho e outubro; d) sazonalidade mensal com padrões baixa temperatura verão e alta temperatura inverso austral; e) variabilidade nos meses; e f) boxplot também com destaques na sazonalidade
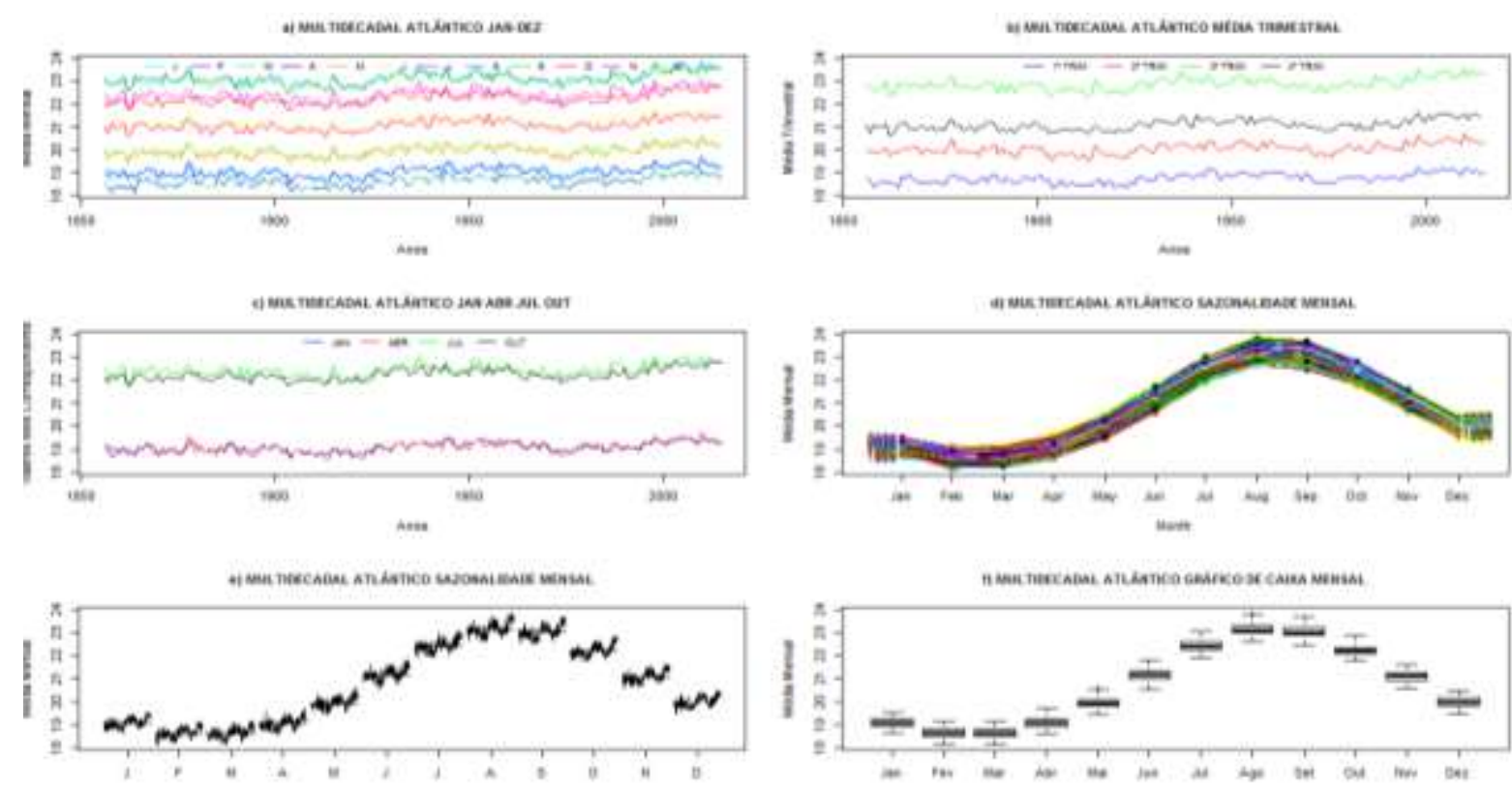

Figura APÊNDICE K-119 Séries temporais Multidecadal do Atlântico a) JAN a DEZ. b) Média Trimestral. c) JAN ABR JUL OUT. d) Sazonalidade mensal todos os anos. e) Gráfico sazonalidade mês a mês. f) Gráfico de caixa 
APÊNDICE K.4 Séries Históricas Manchas solares por áreas

A análise da séries temporais de áreas de manchas solares mostra no gráfico de decomposição na parte sazonal claramente padrões senoidais, de acordo com o padrão de 11 anos. O gráfico de autocorrelação indica um possível padrão para médias móveis de 36 meses e o gráfico de correlação parcial indica um possível padrão autorregressivos de 18 meses.
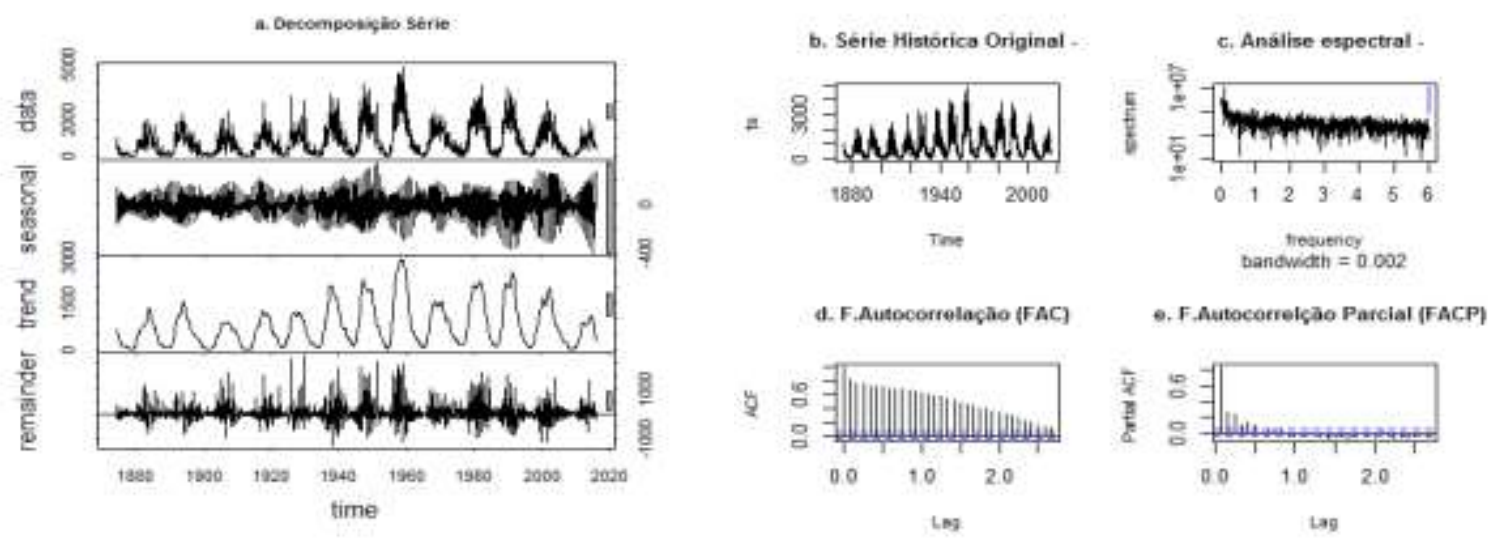

Figura APÊNDICE K-120 Análise gráfica séries temporais Manchas solares por área. a) decomposição da série em sazonalidade, tendência e resíduos b) série original c) domínio frequência d) FAC e) FACP.

Nos gráficos da Figura APÊNDICE K-121, apresentam-se:
a) Meses com gráficos aproximados;
b) As médias trimestrais também são próximas;
c) Janeiro, Abril, Junho e Outubro bem próximos;
d) Sazonalidade mensal dos meses sem padrões destacados;
e) Variabilidade nos meses sem destaques; e
f) Boxplot também sem destaques

Nos gráficos demosntra-se que para série histórica de manchas solares por área não há sazonalidades mensais.
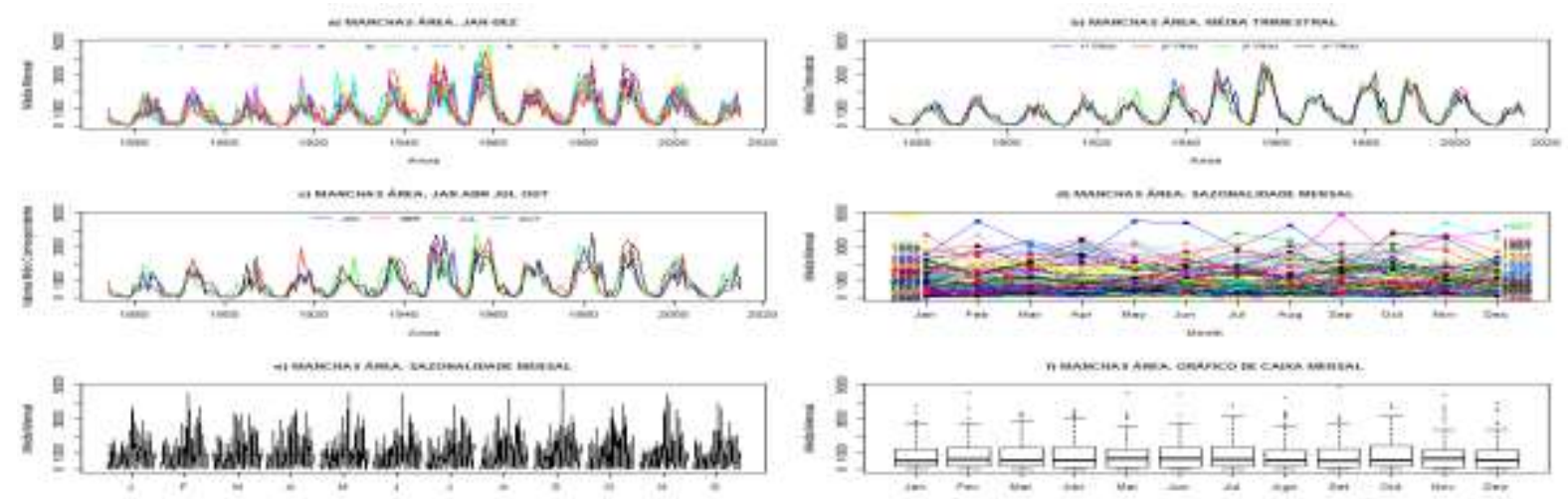

Figura APÊNDICE K-121 Séries temporais manchas solares por área hemisfério Norte a) JAN a DEZ. b) Média Trimestral. c) JAN ABR JUL OUT. d) Sazonalidade mensal todos os anos. e) Gráfico sazonalidade mês a mês. f) Gráfico de caixa 
APÊNDICE K.5 Séries Históricas Áreas manchas do hemisfério norte solar

A análise da séries temporais de Manchas solares por área do hemisfério norte mostra no gráfico de decomposição na parte sazonal claramente padrões senoidais, de acordo com o padrão de 11 anos. O gráfico de autocorrelação indica um possível padrão para médias móveis de 36 meses e o gráfico de correlação parcial indica um possível padrão autorregressivos de 18 meses.
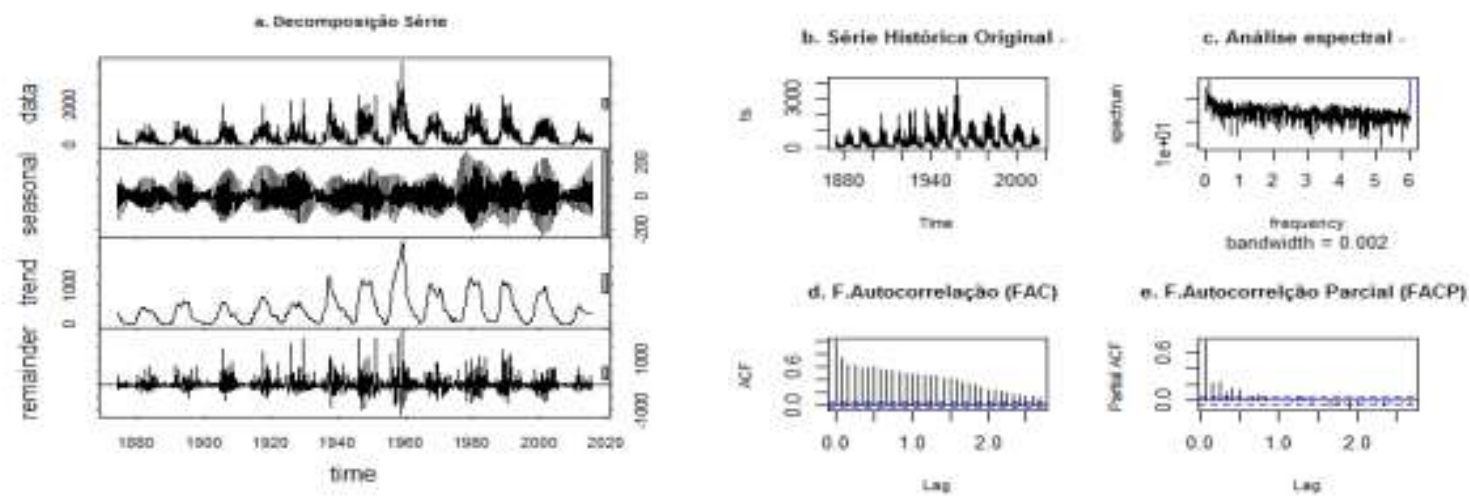

Figura APÊNDICE K-122 Análise gráfica séries temporais Manchas solares hemisfério Norte. a) decomposição da série em sazonalidade, tendência e resíduos b) série original c) domínio frequência d) FAC e) FACP.

Nos gráficos da Figura APÊNDICE K-123, apresentam-se:

a) Meses com gráficos aproximados;

b) As médias trimestrais também são próximas;

c) Janeiro, abril, junho e outubro bem próximos;

d) Sazonalidade mensal dos meses sem padrões destacados;

e) Variabilidade nos meses sem destaques; e

f) Boxplot também sem destaques.

Nos gráficos demonstram que para série histórica de manchas solares por área do hemisfério norte não há sazonalidades mensais.

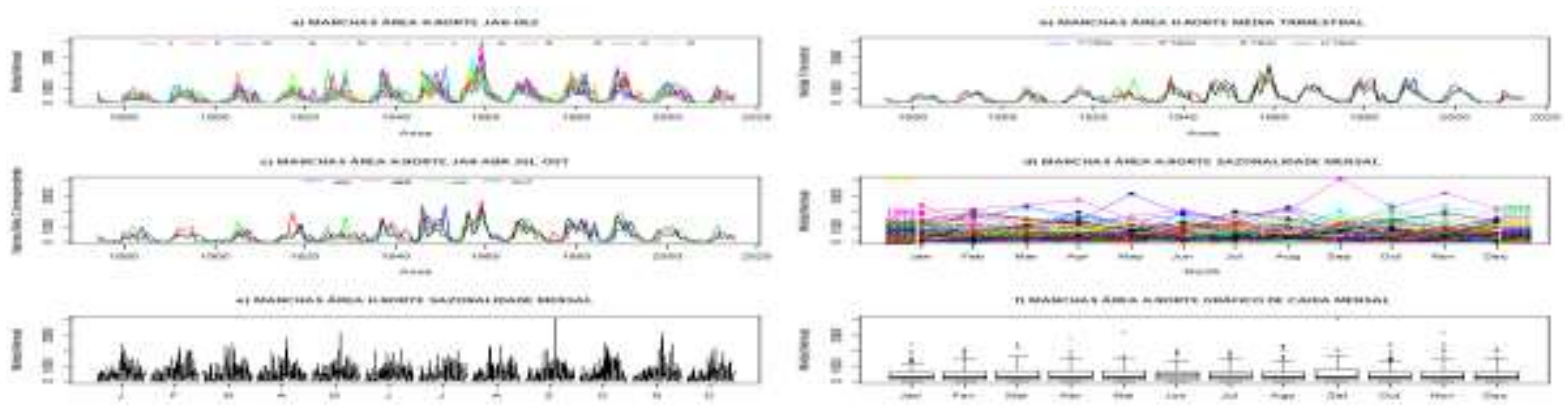

Figura APÊNDICE K-123 Séries temporais manchas solares por área hemisfério Norte a) JAN a DEZ. b) Média Trimestral. c) JAN ABR JUL OUT. d) Sazonalidade mensal todos os anos. e) Gráfico sazonalidade mês a mês. f) Gráfico de caixa. 
APÊNDICE K.6 Séries Históricas Área manchas do hemisfério sul solar

A análise da séries temporais de Manchas solares por área do hemisfério sul mostra no gráfico de decomposição na parte sazonal claramente padrões senoidais, de acordo com o padrão de 11 anos. O gráfico de autocorrelação indica um possível padrão para médias móveis de 36 meses e o gráfico de correlação parcial indica um possível padrão autorregressivos de 18 meses.
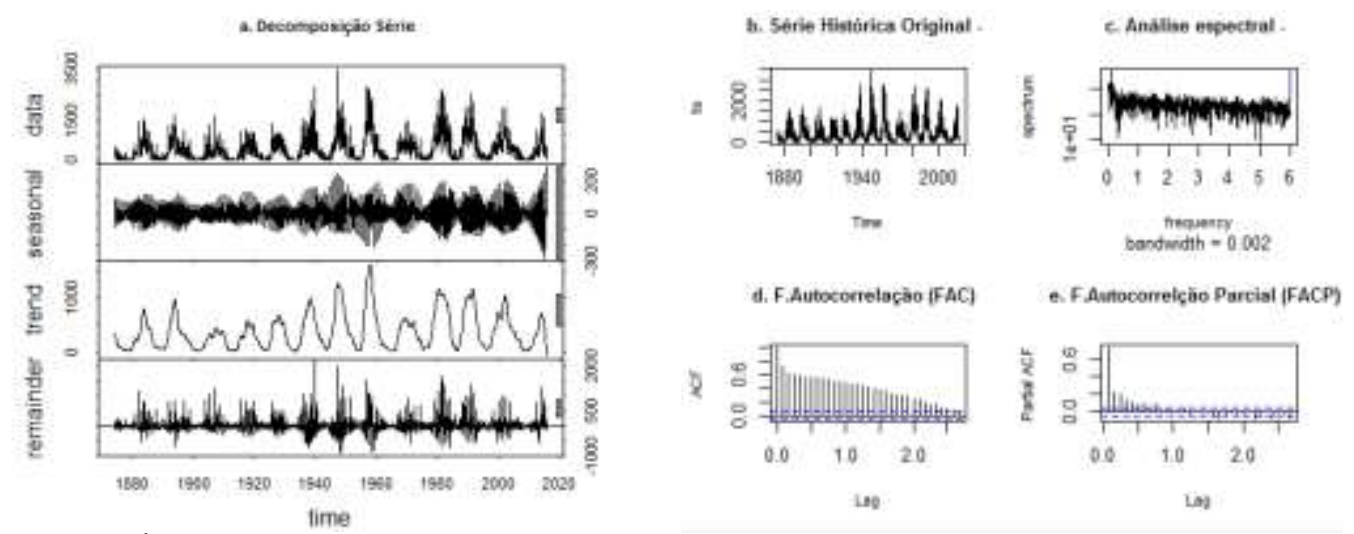

Figura APÊNDICE K-124 Análise gráfica séries temporais Manchas solares hemisfério Sul. a) decomposição da série em sazonalidade, tendência e resíduos b) série original c) domínio frequência d) FAC e) FACP.

Nos gráficos da Figura APÊNDICE K-125, apresentam-se:

a) Meses com gráficos aproximados;

b) As médias trimestrais também são próximas;

c) Janeiro, abril, junho e outubro bem próximos;

d) Sazonalidade mensal dos meses sem padrões destacados;

e) Variabilidade nos meses sem destaques; e

f) Boxplot também sem destaques.

Nos gráficos demonstram que para série histórica de manchas solares por área do hemisfério sul não há sazonalidades mensais.
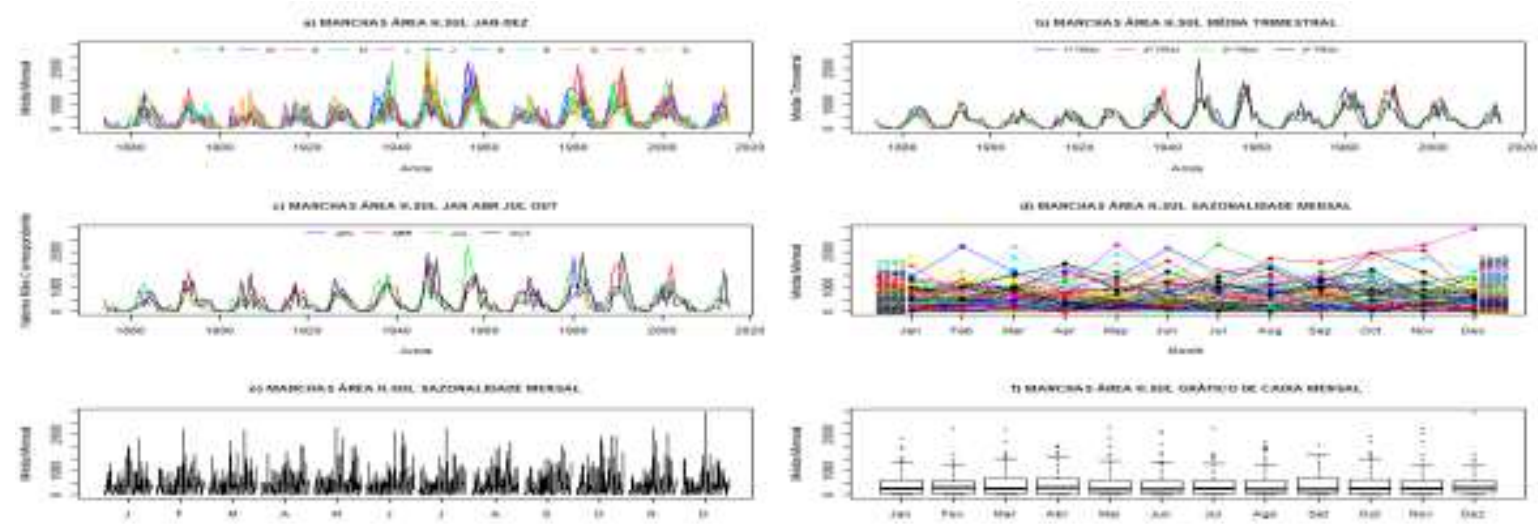

Figura APÊNDICE K-125 Sazonalidade anual das séries temporais Manchas solares por área hemisfério Sul a) JAN a DEZ. b) Média Trimestral. c) JAN ABR JUL OUT. d) Sazonalidade mensal todos os anos. e) Gráfico sazonalidade mês a mês Séries Históricas Bacia do Paraná - Vazões Usina de Porto Primavera 
APÊNDICE K.7 Séries H. Bacia do Paraná - Vazões Usina de Porto Primavera

A análise da séries temporais de vazões da Usina de Porto Primavera mostram no gráfico de decomposição na parte sazonal claramente padrões senoidais, de acordo com o padrão de 1 e 2 anos. O gráfico de autocorrelação indica padrão senoidal e o gráfico de autocorrelação parcial indica um possível padrão autorregressivos de 24 meses.
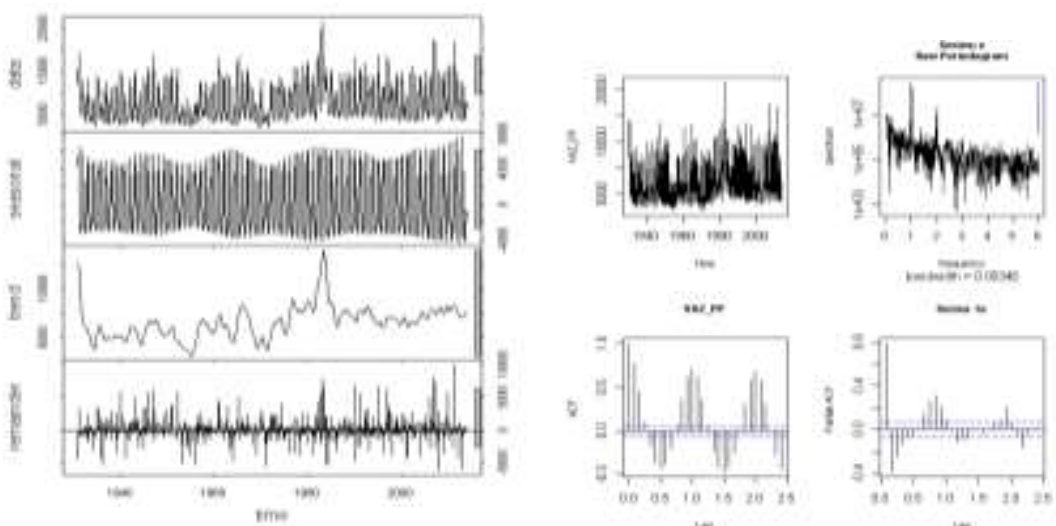

Figura APÊNDICE K-126 Análise gráfica séries temporais Vazões Usina de Porto Primavera. a) decomposição da série em sazonalidade, tendência e resíduos b) série original c) domínio frequência d) FAC e) FACP.

Nos gráficos da Figura APÊNDICE K-127, apresentam-se:

a) Meses com gráficos distanciados;

b) As médias trimestrais apresentam o $1^{\circ}$ trimestre mais destacado;

c) Janeiro e abril estão próximo e distantes de junho e outubro que estão próximos;

d) Sazonalidade mensal dos meses com padrão período úmido de dezembro a março e período seco de abril a novembro;

e) Variabilidade nos meses maior para dezembro a março, comparado a abril a novembro;

f) Boxplot também repete os padrões anteriores com maior variabilidade mês de janeiro.

Nos gráficos demonstram que para série histórica de vazões para Usina de Porto Primavera há sazonalidade mensal.
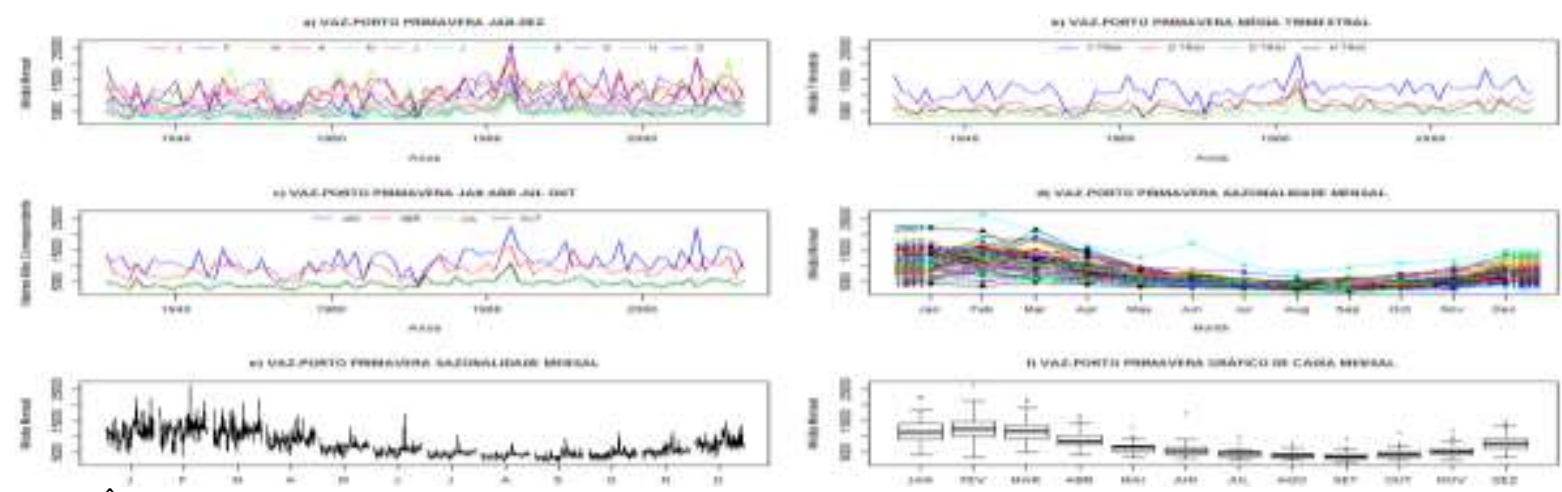

Figura APÊNDICE K-127 Sazonalidade anual das séries temporais Vazões Usina de Porto Primavera a) JAN a DEZ. b) Média Trimestral. c) JAN ABR JUL OUT. d) Sazonalidade mensal todos os anos. e) Gráfico sazonalidade mês a mês. f) Gráfico de caixa 
APÊNDICE K.8 Séries H. Bacia do São Francisco - Vazões Usina de Sobradinho

A análise da séries temporais de Vazões Usina de Sobradinho mostra no gráfico de decomposição na parte sazonal claramente padrões senoidais, de acordo com o padrão de 1 e 2 anos. O gráfico de autocorrelação indica padrão senoidal e o gráfico de autocorrelação parcial indica um possível padrão autorregressivos de 26 meses.
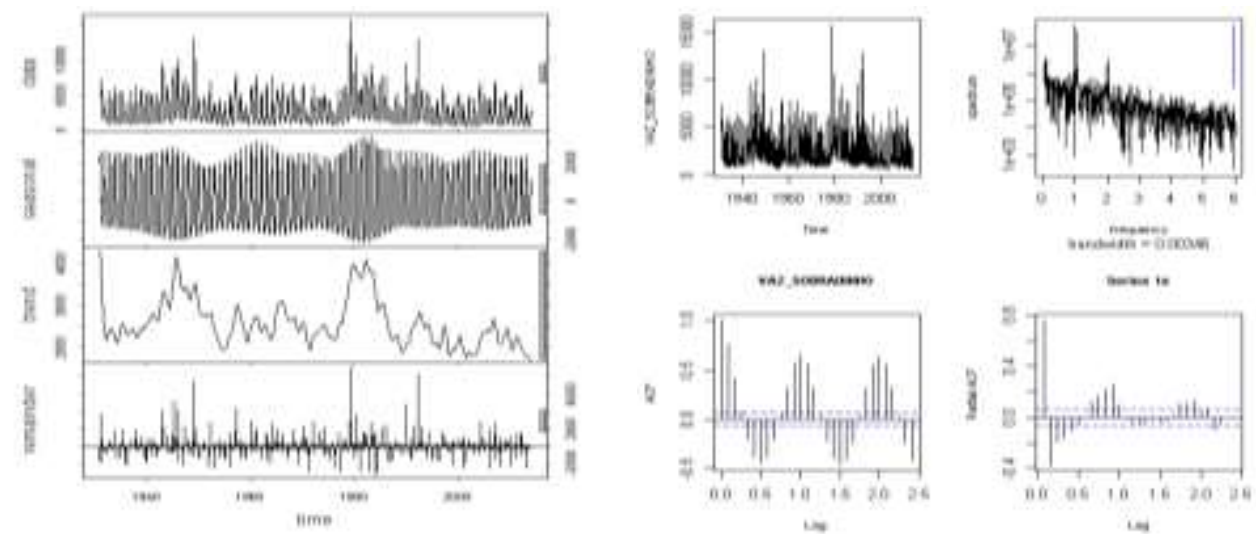

Figura APÊNDICE K-128 Análise gráfica séries temporais Vazões Usina de Sobradinho. a) decomposição da série em sazonalidade, tendência e resíduos b) série original c) domínio frequência d) FAC e) FACP.

Nos gráficos da Figura APÊNDICE K-129, apresentam-se:

a) Meses com gráficos distanciados;

b) As médias trimestrais apresentam-se o $1^{\circ}$ trimestre mais destacado;

c) Janeiro e abril estão próximo e distantes de junho e outubro que estão próximos;

d) Sazonalidade mensal dos meses com padrão período úmido de dezembro a março e período seco de abril a novembro;

e) Variabilidade nos meses maior para dezembro a março, comparado a abril a novembro;

f) Boxplot também repete os padrões anteriores com maior variabilidade mês de janeiro.

Nos gráficos demonstram que para série histórica de vazões para Usina de Sobradinho há sazonalidade mensal.
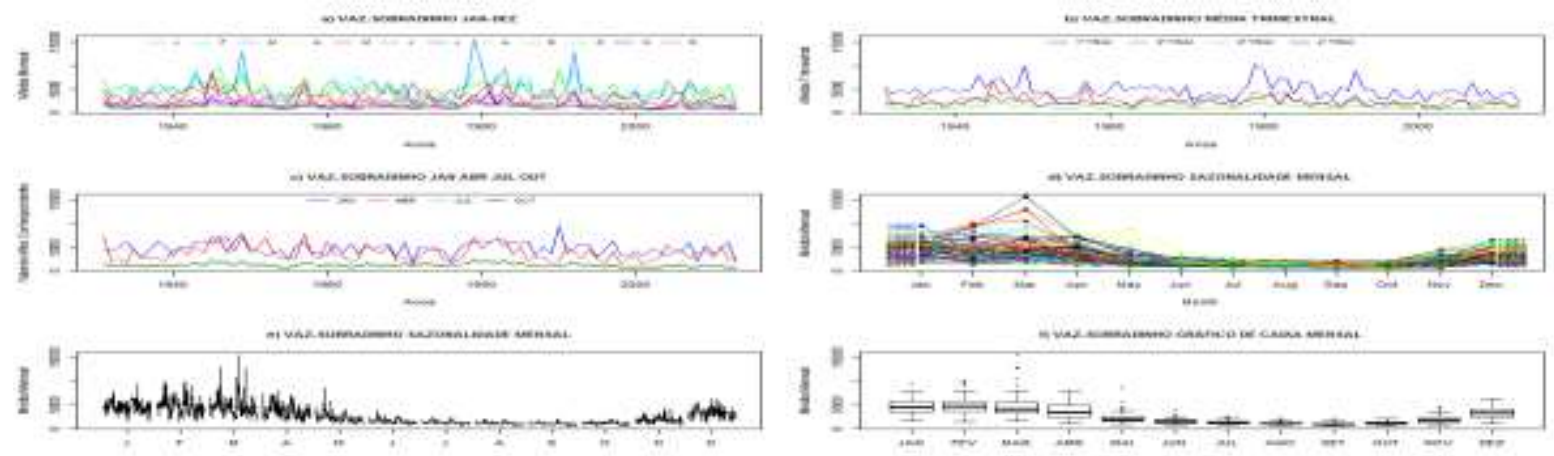

Figura APÊNDICE K-129 Sazonalidade anual das séries temporais Vazões Usina de Sobradinho a) JAN a DEZ. b) Média Trimestral. c) JAN ABR JUL OUT. d) Sazonalidade mensal todos os anos. e) Gráfico sazonalidade mês a mês. f) Gráfico de caixa 
APÊNDICE K.9 Séries H. Bacia do Tocantins-Estreito Tocantins

A análise das séries temporais de Vazões Usina Estreito Tocantins mostra no gráfico de decomposição na parte sazonal claramente padrões senoidais, de acordo com o padrão de $1 \mathrm{e}$ 2 anos. O gráfico de autocorrelação indica padrão senoidal de mudança de fase a 12 meses e o gráfico de correlação parcial indica um possível padrão autorregressivos de 24 meses.
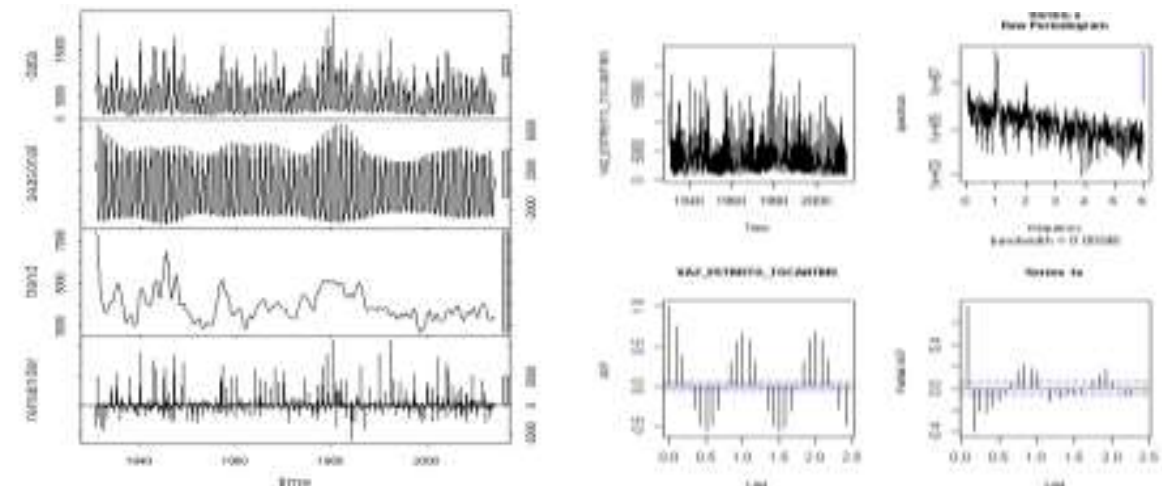

Figura APÊNDICE K-130 Análise gráfica séries temporais Vazões Usina Estreito Tocantins. a) decomposição da série em sazonalidade, tendência e resíduos b) série original c) domínio frequência d) FAC e) FACP.

Nos gráficos da Figura APÊNDICE K-131, apresentam-se:

a) Meses com gráficos distanciados;

b) As médias trimestrais apresentam-se o $1^{\circ}$ trimestre mais destacado;

c) Janeiro e abril estão próximo e distantes de junho e outubro que estão próximos;

d) Sazonalidade mensal dos meses com padrão período úmido de dezembro a março e período seco de abril a novembro;

e) Variabilidade nos meses maior para dezembro a março, comparado a abril a novembro;

f) Boxplot também repete os padrões anteriores com maior variabilidade mês de janeiro.

Nos gráficos demosntra-se que para série histórica de vazões para Usina de Estreito do Tocantins há sazonalidade mensal.
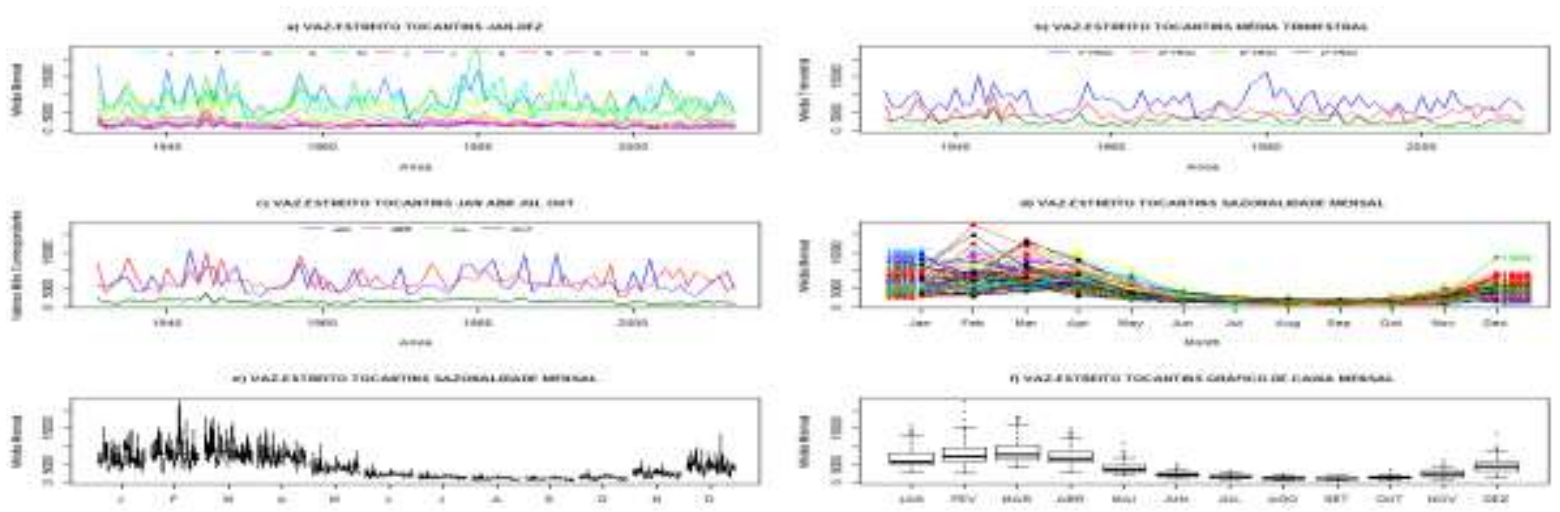

Figura APÊNDICE K-131 Sazonalidade anual das séries temporais Vazões Usina Estreito Tocantins a) JAN a DEZ. b) Média Trimestral. c) JAN ABR JUL OUT. d) Sazonalidade mensal todos os anos. e) Gráfico sazonalidade mês a mês. f) Gráfico de caixa. 
APÊNDICE K.10 Séries Históricas Bacia do Rio Grande - Vazões da Usina Camargos
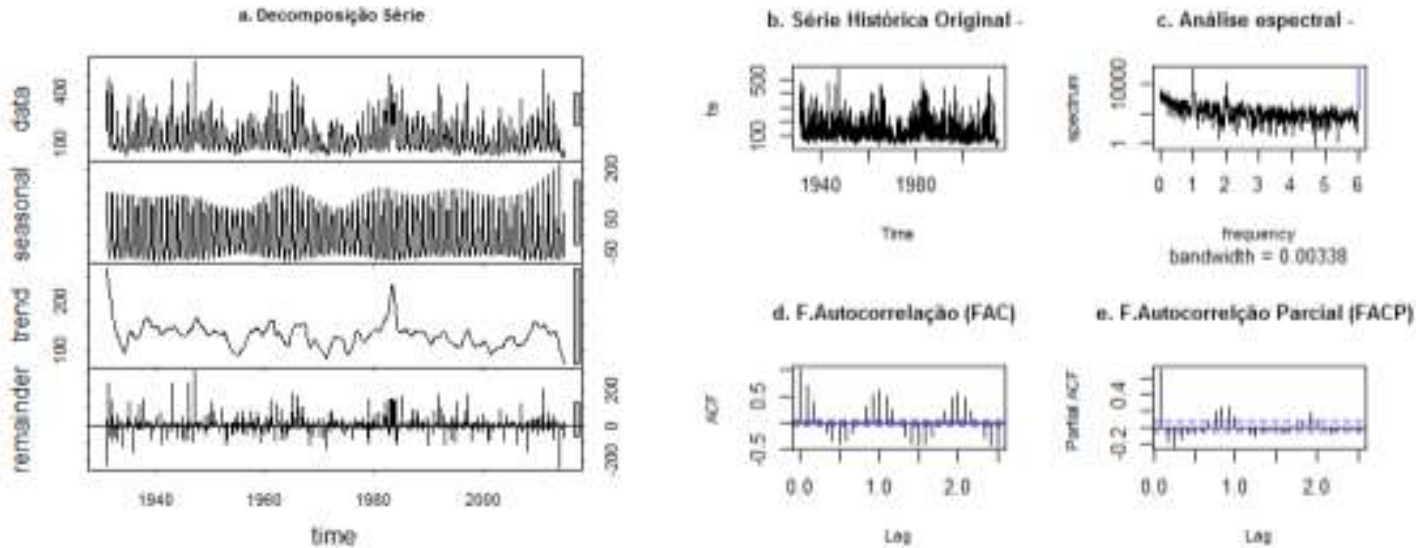

Figura APÊNDICE K-132 Análise gráfica séries temporais Vazões Usina Camargos. a) decomposição da série em sazonalidade, tendência e resíduos b) série original c) domínio frequência d) FAC e) FACP.

Nos gráficos da Figura APÊNDICE K-133, apresentam-se:

a) Meses com gráficos distanciados;

b) As médias trimestrais apresentam-se o $1^{\circ}$ trimestre mais destacado;

c) Janeiro e abril estão separados e distantes de junho e outubro que estão próximos;

d) Sazonalidade mensal dos meses com padrão período úmido de dezembro a março e período seco de abril a novembro;

e) Variabilidade nos meses maior para dezembro a março, comparado a abril a novembro; e

f) Boxplot também repete os padrões anteriores com maior variabilidade mês de janeiro.

Nos gráficos demosntra-se que para série histórica de vazões para Usina de Camargos há sazonalidade mensal.
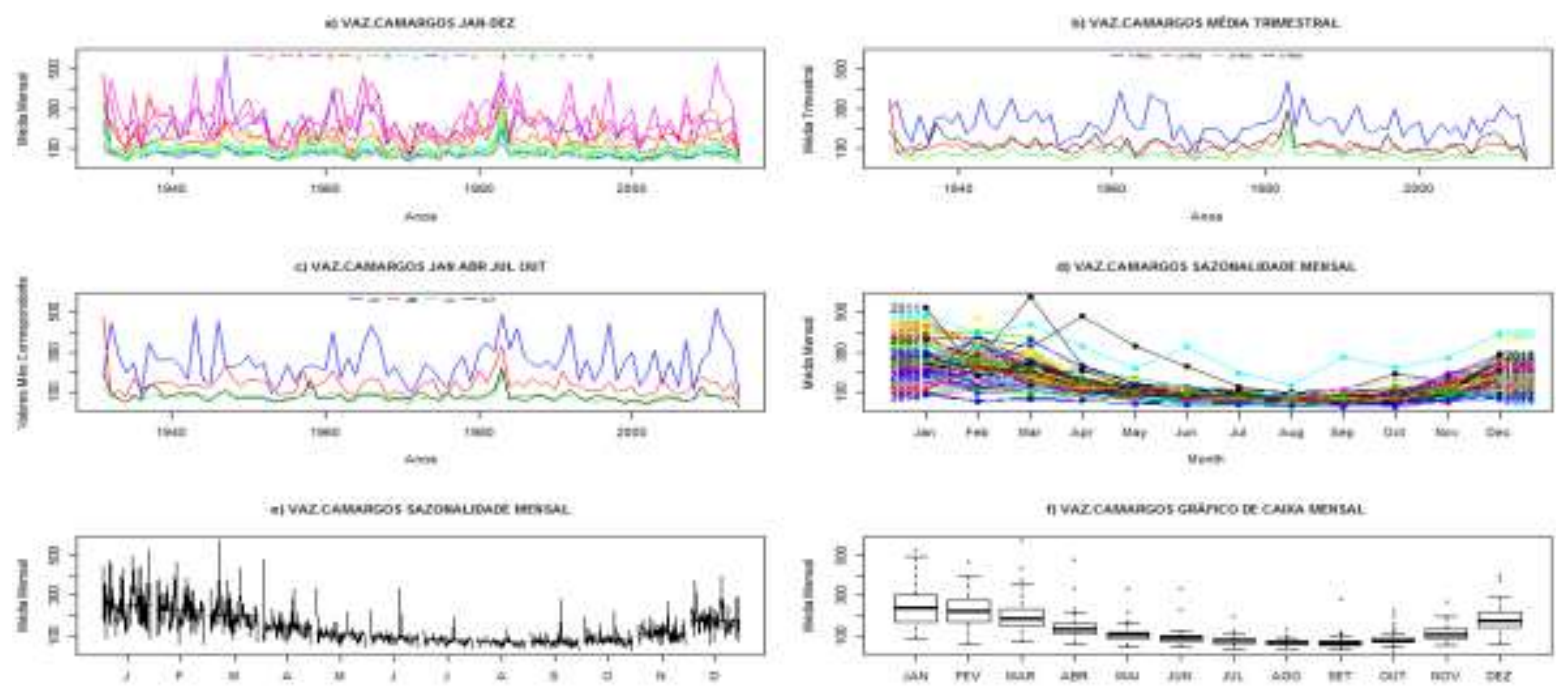

Figura APÊNDICE K-133 Séries temporais Vazões Usina de Camargos. a) JAN a DEZ. b) Média Trimestral. c) JAN ABR JUL OUT. d) Sazonalidade mensal todos os anos. e) Gráfico de sazonalidade mês a mês. f) Gráfico de caixa. 
APÊNDICE K.11 Séries Históricas Bacia do Rio Grande - Vazões da Usina Nova Ponte
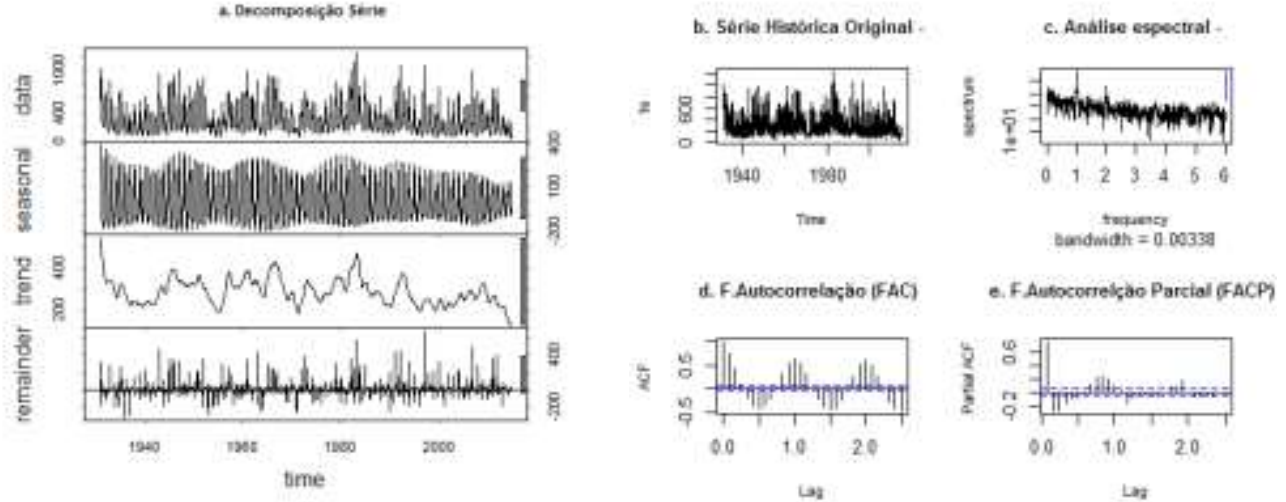

Figura APÊNDICE K-134 Análise gráfica séries temporais Vazões Usina Nova Ponte. a) decomposição da série em sazonalidade, tendência e resíduos b) série original c) domínio frequência d) FAC e) FACP.

Nos gráficos da Figura APÊNDICE K-135, apresentam-se:

a) Meses com gráficos distanciados;

b) As médias trimestrais apresentam-se o $1^{\circ}$ trimestre mais destacado;

c) Janeiro e abril estão próximo e distantes de junho e outubro que estão próximos;

d) Sazonalidade mensal dos meses com padrão período úmido de dezembro a março e período seco de abril a novembro;

e) Variabilidade nos meses maior para dezembro a março, comparado a abril a novembro; e

f) Boxplot também repete os padrões anteriores com maior variabilidade mês de janeiro. Nos gráficos demosntra-se que para série histórica de vazões para Usina de Nova Ponte há sazonalidade mensal.
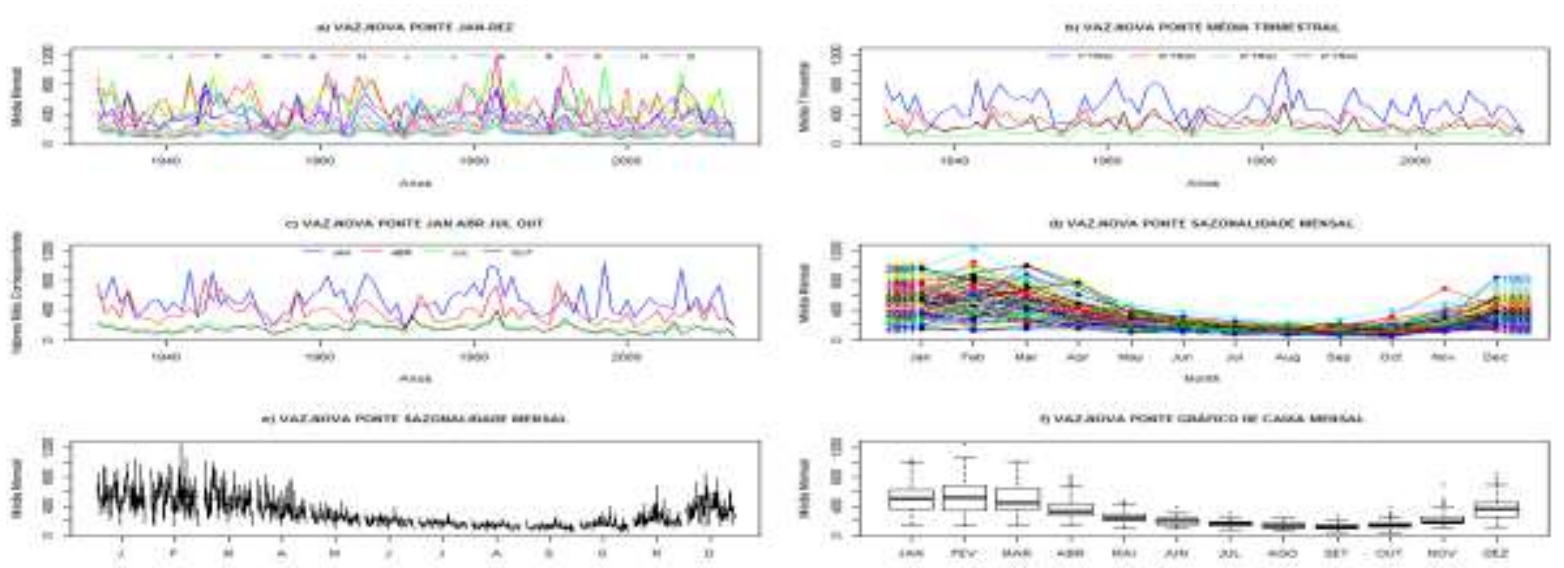

Figura APÊNDICE K-135 Séries temporais Vazões Usina de Nova Ponte a) JAN a DEZ. b) Média Trimestral. c) JAN ABR JUL OUT. d) Sazonalidade mensal todos os anos. e) Gráfico sazonalidade mês a mês. f) Gráfico de caixa. 
APÊNDICE K.12 Séries Históricas Bacia do Rio Grande - Vazões da Furnas
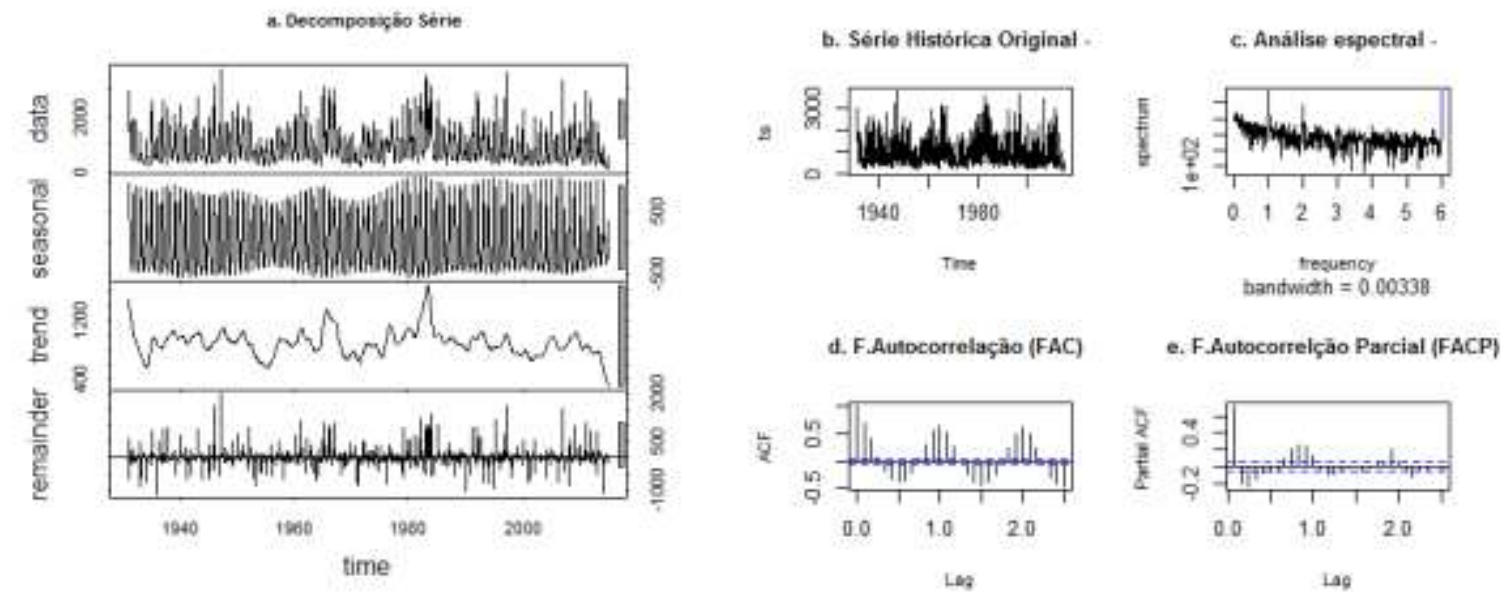

Figura APÊNDICE K-136 Análise gráfica séries temporais Vazões Usina Furnas. a) decomposição da série em sazonalidade, tendência e resíduos b) série original c) domínio frequência d) FAC e) FACP.

Nos gráficos da Figura APÊNDICE K-137, apresentam-se:

a) Meses com gráficos distanciados;

b) As médias trimestrais apresentam o $1^{\circ}$ trimestre mais destacado;

c) Janeiro e abril estão próximo e distantes de junho e outubro que estão próximos;

d) Sazonalidade mensal dos meses com padrão período úmido de dezembro a março e período seco de abril a novembro;

e) Variabilidade nos meses maior para dezembro a março, comparado a abril a novembro; e

f) Boxplot também repete os padrões anteriores com maior variabilidade mês de janeiro.

Nos gráficos demosntra-se que para série histórica de vazões para Usina de Furnas há sazonalidade mensal.
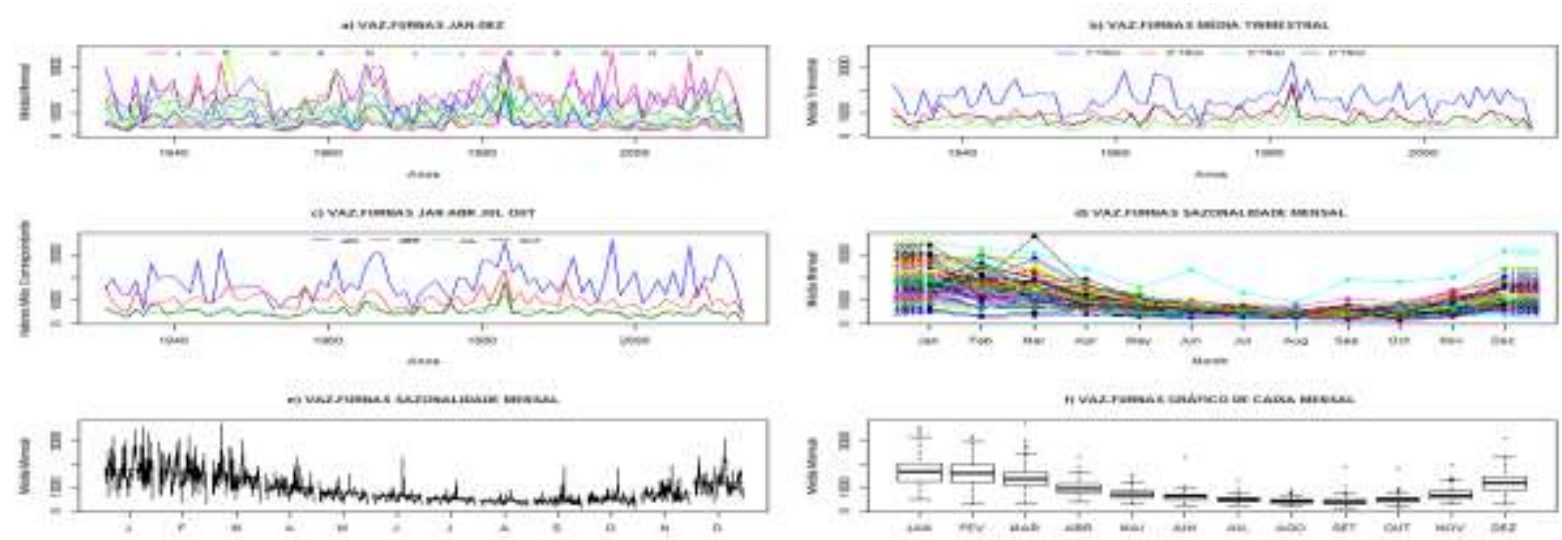

Figura APÊNDICE K-137 Séries temporais Vazões Usina de Furnas a) JAN a DEZ. b) Média Trimestral. c) JAN ABR JUL OUT. d) Sazonalidade mensal todos os anos. e) Gráfico sazonalidade mês a mês. f) Gráfico de caixa Séries Históricas Bacia do Tiete - Vazões da Usina de Barra Bonita 
APÊNDICE K.13 Séries Históricas Bacia do Rio Paraná - Vazões da Usina de Barra Bonita
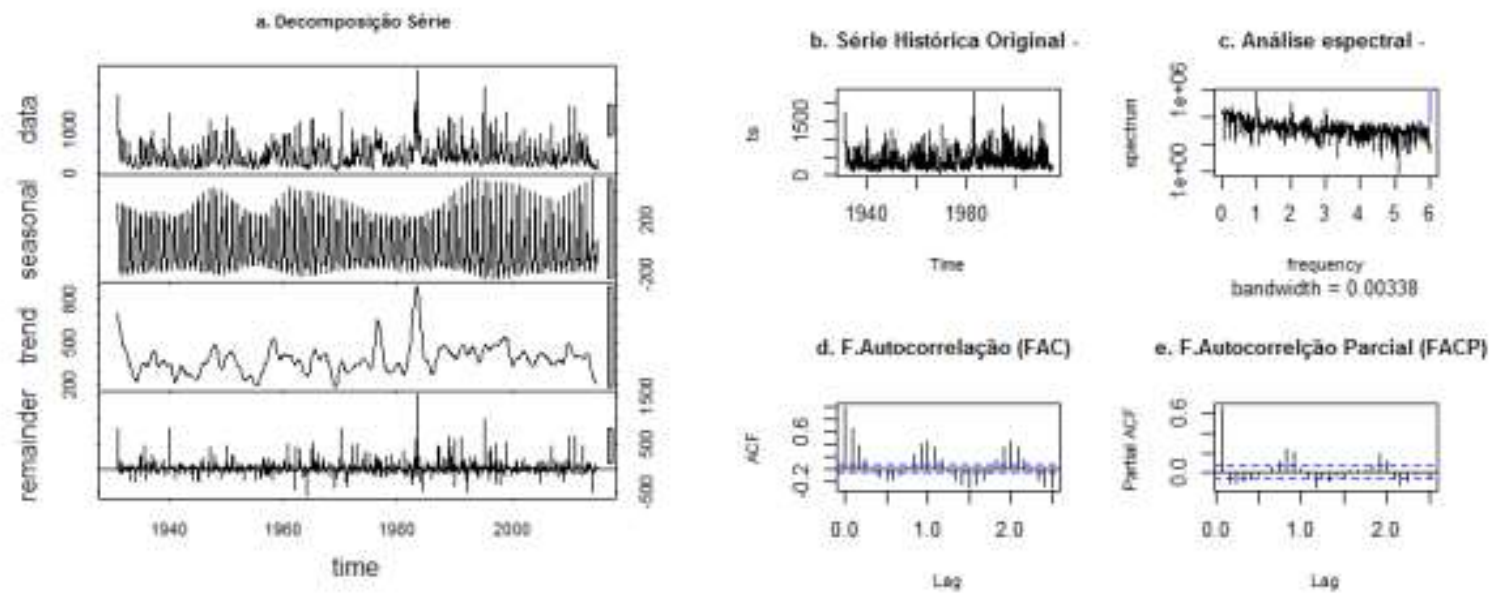

Figura APÊNDICE K-138 Análise gráfica séries temporais Vazões Usina de Barra Bonita. a) decomposição da série em sazonalidade, tendência e resíduos b) série original c) domínio frequência d) FAC e) FACP.

Nos gráficos da Figura APÊNDICE K-139 apresentam-se:

a) Meses com gráficos distanciados;

b) As médias trimestrais apresentam o $1^{\circ}$ trimestre mais destacado;

c) Janeiro e abril estão próximo e distantes de junho e outubro que estão próximos;

d) Sazonalidade mensal dos meses com padrão período úmido de dezembro a março e período seco de abril a novembro;

e) Variabilidade nos meses maior para dezembro a março, comparado a abril a novembro;e

f) Boxplot também repete os padrões anteriores com maior variabilidade mês de janeiro. Nos gráficos demosntra-se que para série histórica de vazões para Usina de Barra Bonita há sazonalidade mensal.
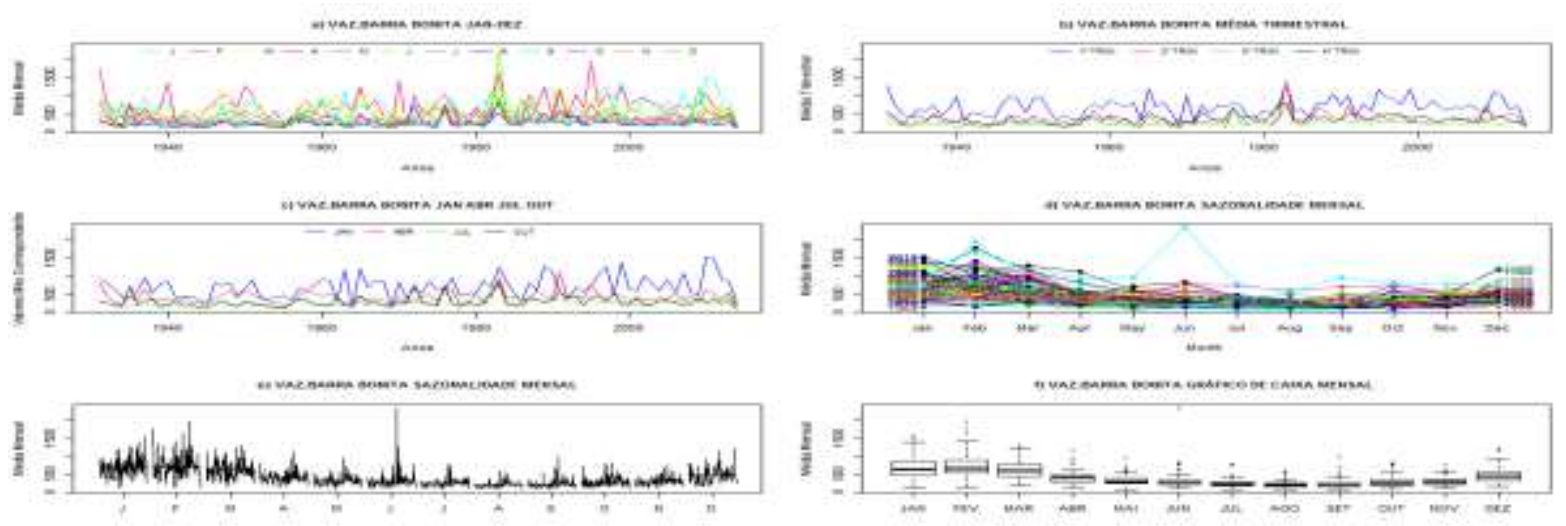

Figura APÊNDICE K-139 Séries temporais Vazões Usina de Barra Bonita a) JAN a DEZ. b) Média Trimestral. c) JAN ABR JUL OUT. d) Sazonalidade mensal todos os anos. e) Gráfico sazonalidade mês a mês. f) Gráfico de caixa. 
APÊNDICE K.14 Séries Históricas Bacia do Iguaçu - Vazões da Usina de Foz do Areia
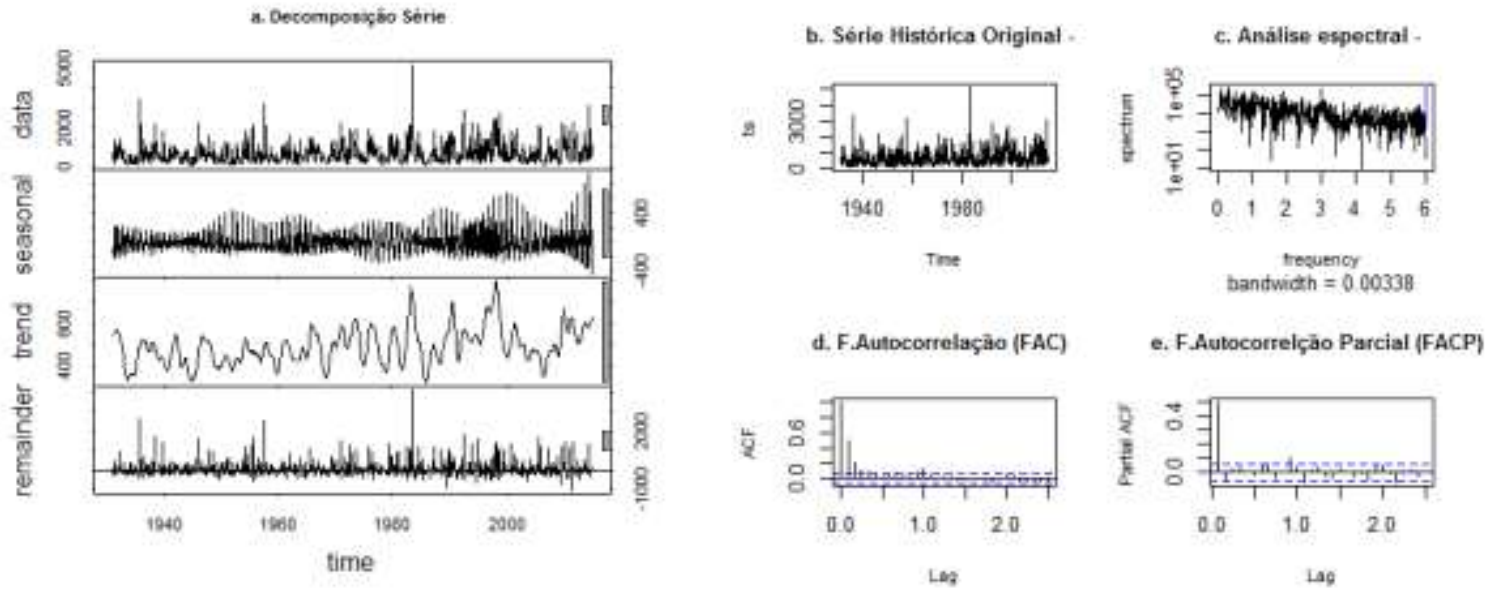

Figura APÊNDICE K-140 Análise gráfica séries temporais Vazões Usina de Foz do Areia. a) decomposição da série em sazonalidade, tendência e resíduos b) série original c) domínio frequência d) FAC e) FACP.

Nos gráficos da Figura APÊNDICE K-141 apresentam-se:

a) Meses com gráficos aproximados;

b) As médias trimestrais não apresentam trimestres com destacado, exceto dois picos um pouco antes de 1960 e outro após 1980;

c) Janeiro, abril, junho e outubro em geral estão próximos;

d) Sazonalidade mensal não se destaca;

e) Variabilidade dos meses parecida com medianas próximas; e

f) Boxplot também repete os padrões anteriores com um maior variabilidade mês de outubro.

Nos gráficos demosntra-se que para série histórica de vazões para Usina de Foz do Areia não há sazonalidade mensal.
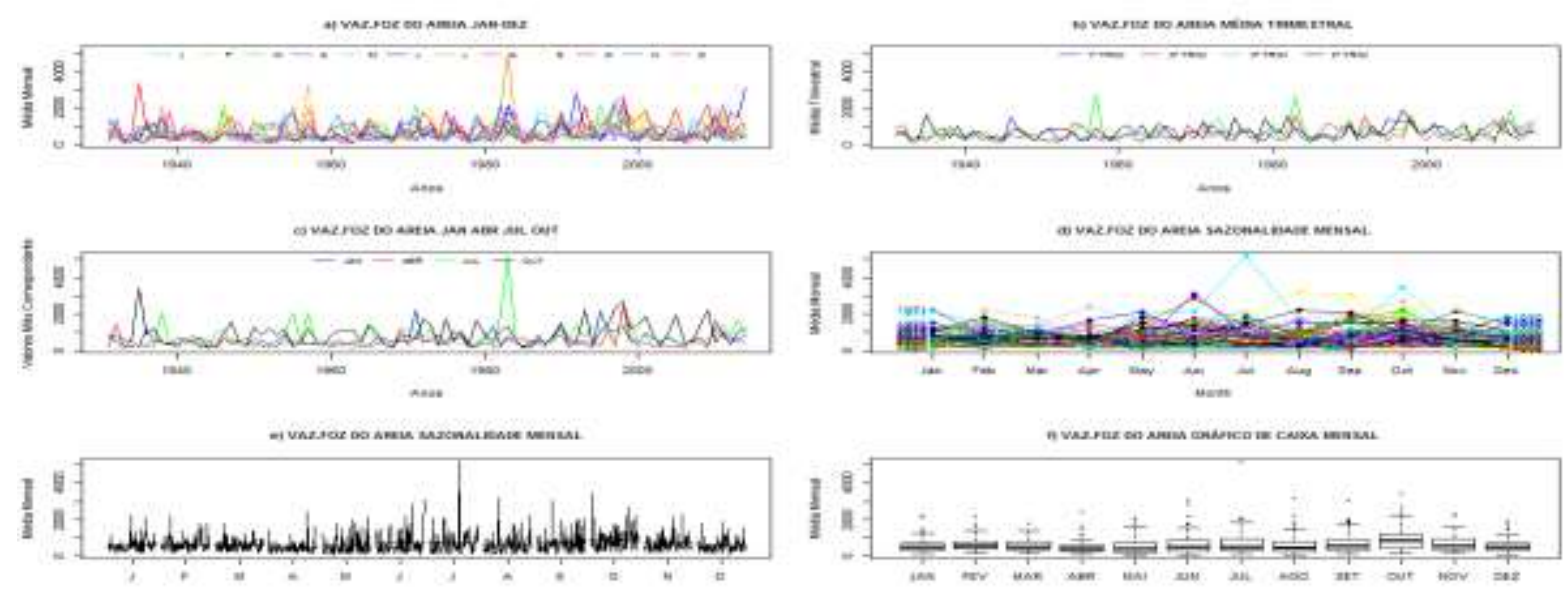

Figura APÊNDICE K-141 Séries temporais Vazões Usina Foz do Areia. a) JAN a DEZ. b) Média Trimestral. c) JAN ABR JUL OUT. d) Sazonalidade mensal todos os anos. e) Gráfico sazonalidade mês a mês. f) Gráfico de caixa. 
APÊNDICE K.15 Séries H. Bacia do Tocantins - Vazões da Usina de Serra da Mesa
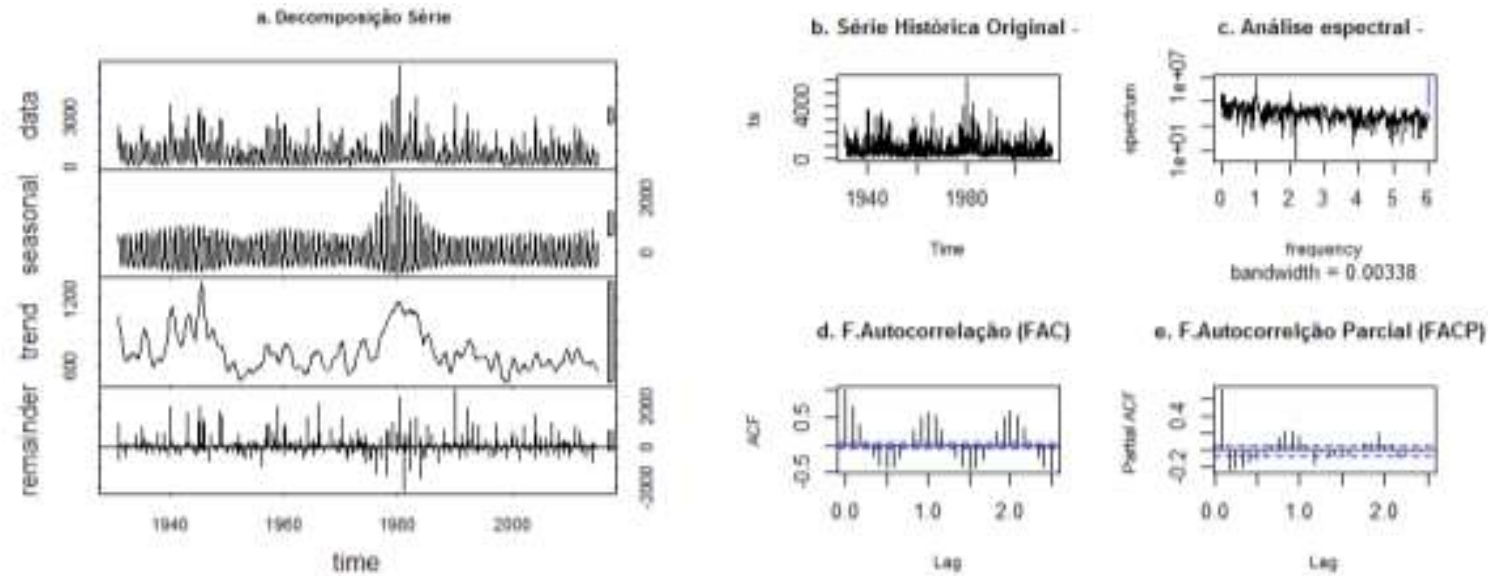

Figura APÊNDICE K-142 Análise gráfica séries temporais Vazões Usina Serra da .Mesa a) decomposição da série em sazonalidade, tendência e resíduos b) série original c) domínio frequência d) FAC e) FACP.

Nos gráficos da Figura APÊNDICE K-143 apresentam-se:

a) Meses com gráficos distanciados;

b) As médias trimestrais apresentam o $1^{\circ}$ trimestre mais destacado;

c) Janeiro e abril estão próximo e distantes de junho e outubro que estão próximos;

d) Sazonalidade mensal dos meses com padrão período úmido de dezembro a março e período seco de abril a novembro;

e) Variabilidade nos meses maior para dezembro a março, comparado a abril a novembro; e

f) Boxplot também repete os padrões anteriores com maior variabilidade mês de janeiro.

Nos gráficos demosntra-se que para série histórica de vazões para Usina de Serra da Mesa há sazonalidade mensal.
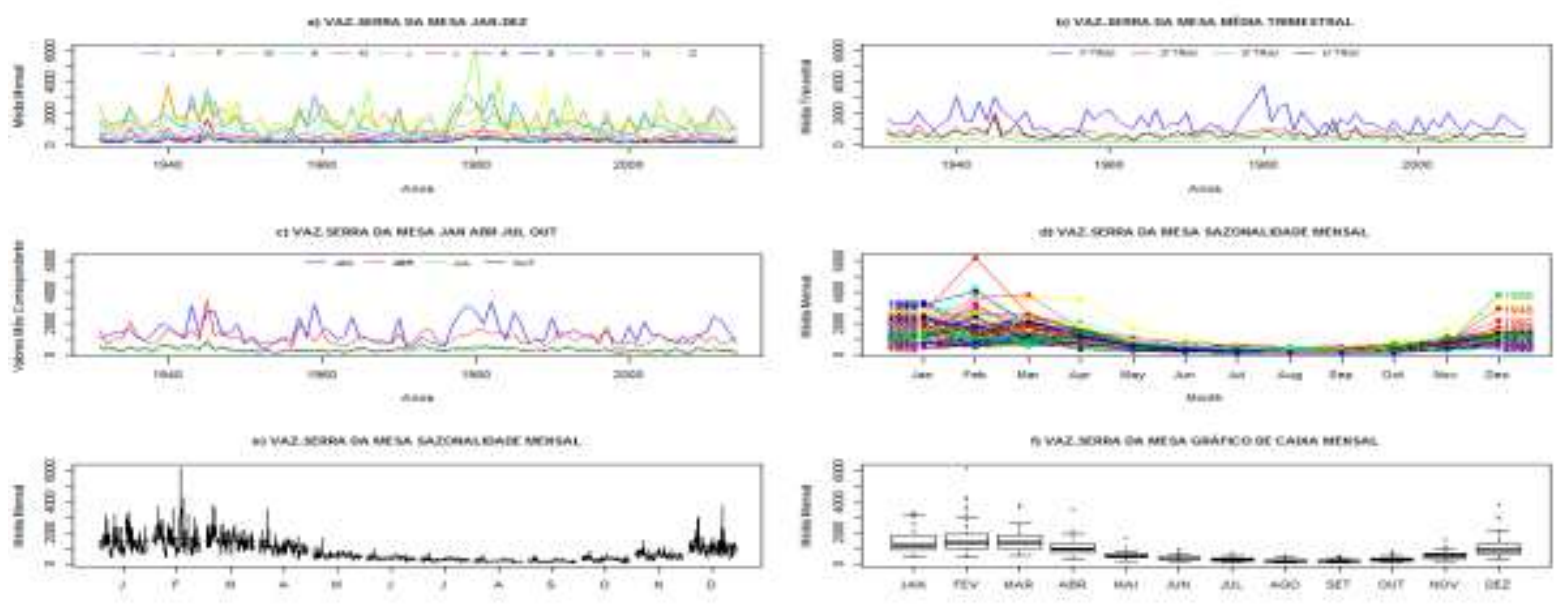

Figura APÊNDICE K-143 Séries temporais Vazões Usina de Serra da Mesa a) JAN a DEZ. b) Média Trimestral. c) JAN ABR JUL OUT. d) Sazonalidade mensal todos os anos. e) Gráfico sazonalidade mês a mês. f) Gráfico de caixa. 
APÊNDICE K.16 Séries Históricas Bacia do São Francisco -Usina de Usina Queimado
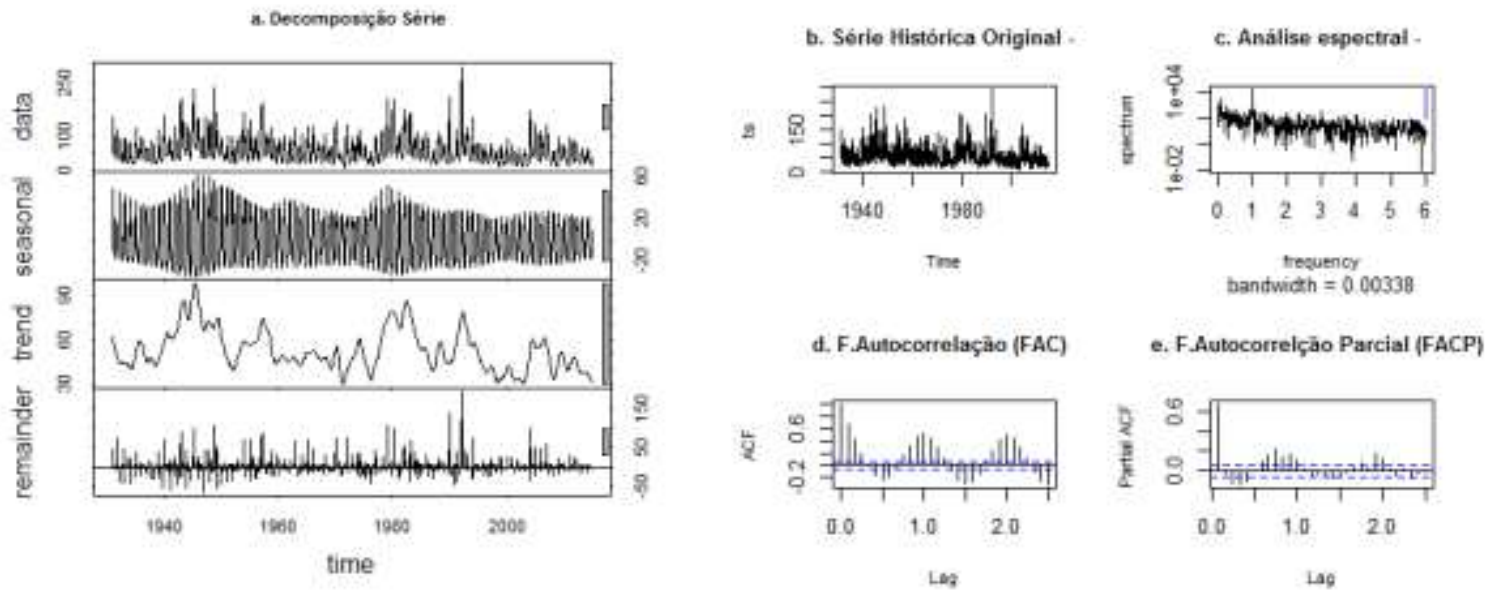

Figura APÊNDICE K-144 Análise gráfica séries temporais Vazões Usina Queimado a) decomposição da série em sazonalidade, tendência e resíduos b) série original c) domínio frequência d) FAC e) FACP.

Nos gráficos da Figura APÊNDICE K-145 apresentam-se:

a) Meses com gráficos distanciados;

b) As médias trimestrais apresentam o $1^{\circ}$ trimestre mais destacado;

c) Janeiro e abril estão próximo e distantes de junho e outubro que estão próximos;

d) Sazonalidade mensal dos meses com padrão período úmido de dezembro a março e período seco de abril a novembro;

e) Variabilidade nos meses maior para dezembro a março, comparado a abril a novembro; e

f) Boxplot também repete os padrões anteriores com maior variabilidade mês de janeiro.

Nos gráficos demosntra-se que para série histórica de vazões para Usina de Queimado há sazonalidade mensal.
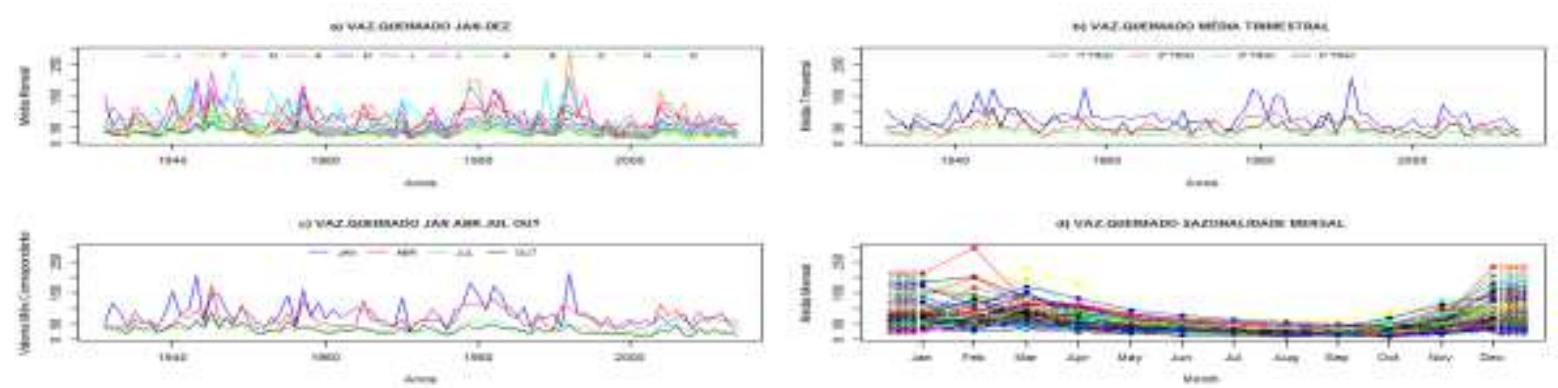

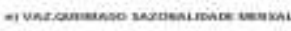

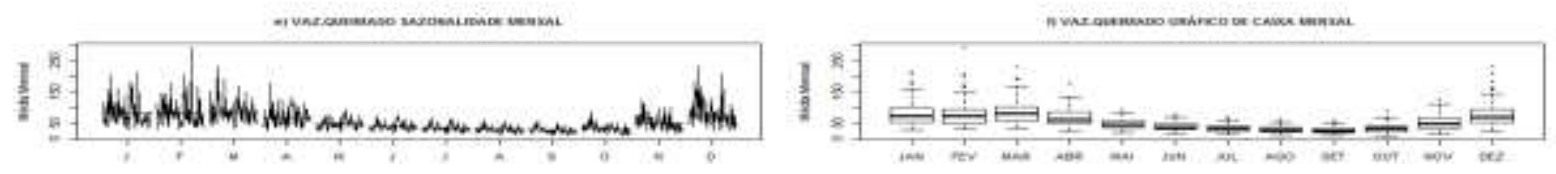

Figura APÊNDICE K-145 Séries temporais Vazões Usina de Queimado a) JAN a DEZ. b) Média Trimestral. c) JAN ABR JUL OUT. d) Sazonalidade mensal todos os anos. e) Gráfico sazonalidade mês a mês. f) Gráfico de caixa 
APÊNDICE K.17 Séries Históricas Bacia do São Francisco-Usina de Retiro Baixo
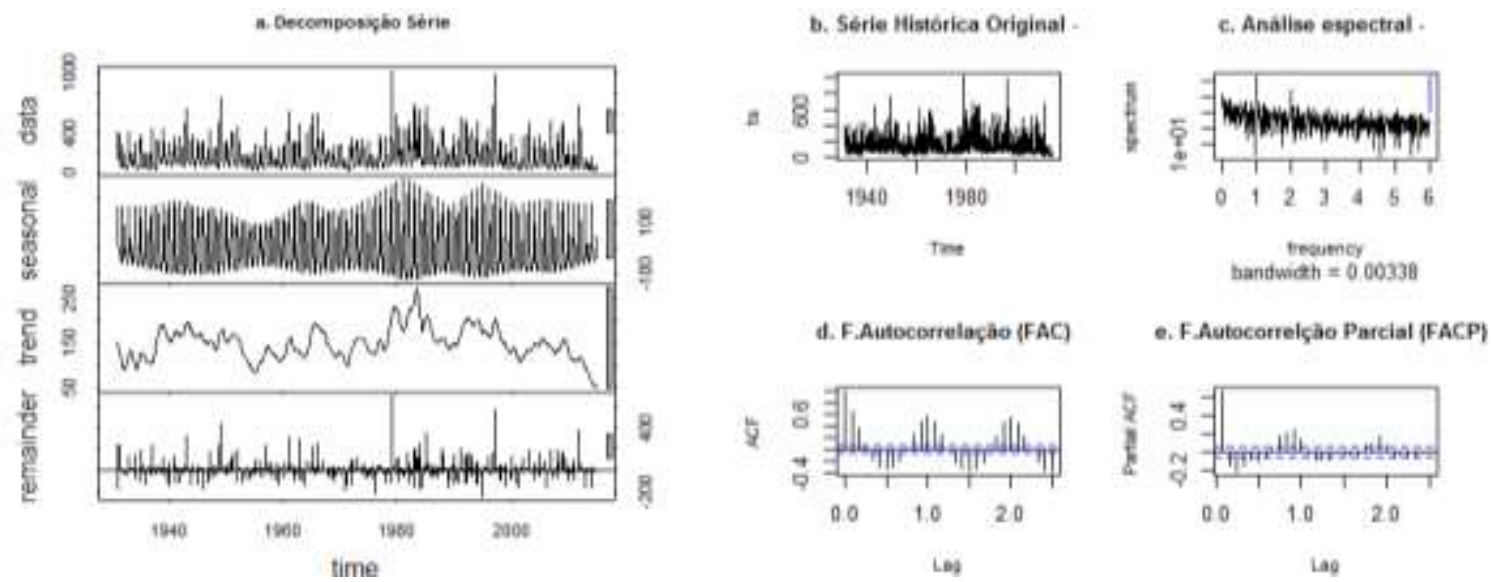

Figura APÊNDICE K-146 Análise gráfica séries temporais Vazões Usina de Bom Retiro a) decomposição da série em sazonalidade, tendência e resíduos b) série original c) domínio frequência d) FAC e) FACP.

Nos gráficos da Figura APÊNDICE K-147 apresentam-se:

a) Meses com gráficos distanciados;

b) As médias trimestrais apresentam o $1^{\circ}$ trimestre mais destacado;

c) Janeiro está distante de abril, junho e outubro que estão próximos;

d) Sazonalidade mensal dos meses com padrão período úmido de dezembro a março e período seco de abril a novembro;

e) Variabilidade nos meses maior para dezembro a março, comparado a abril a novembro;

f) Boxplot também repete os padrões anteriores com maior variabilidade mês de fevereiro.

Nos gráficos demosntra-se que para série histórica de vazões para Usina de Retiro Baixo há sazonalidade mensal.
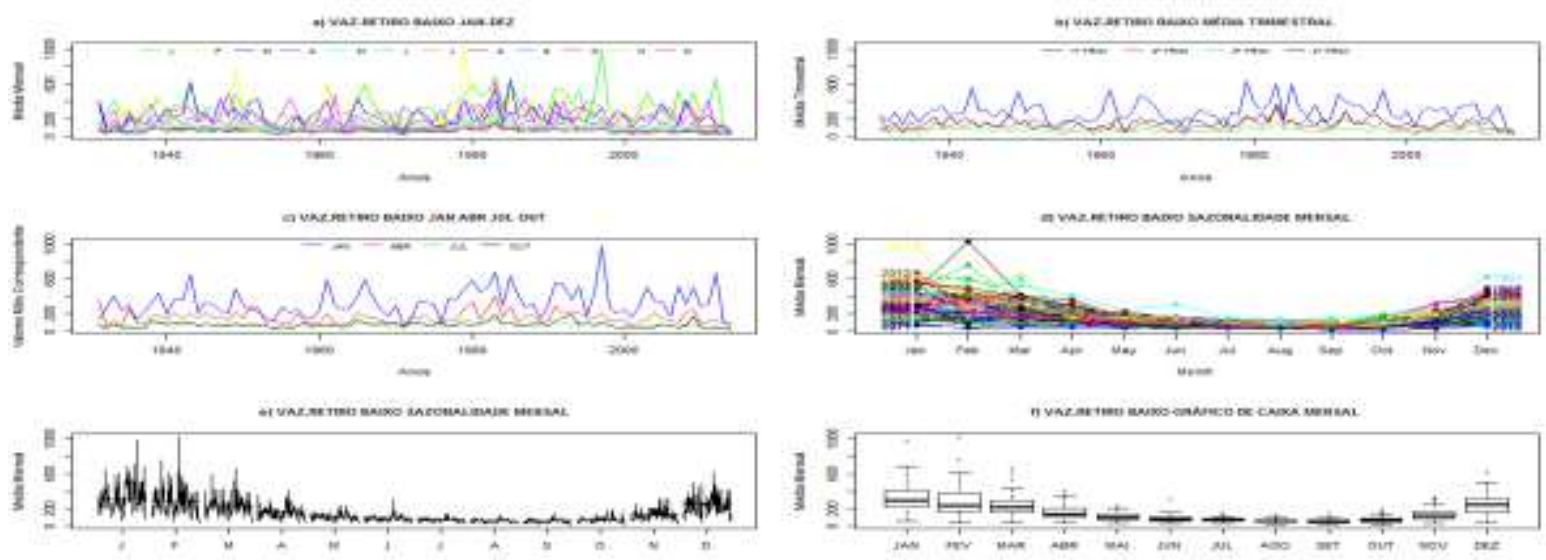

Figura APÊNDICE K-147 Séries temporais Vazões Usina Retiro Baixo a) JAN a DEZ. b) Média Trimestral. c) JAN ABR JUL OUT. d) Sazonalidade mensal todos os anos. e) Gráfico sazonalidade mês a mês. f) Gráfico de caixa 
APÊNDICE K.18 Séries Históricas Bacia do São Francisco - Usina de Três Marias
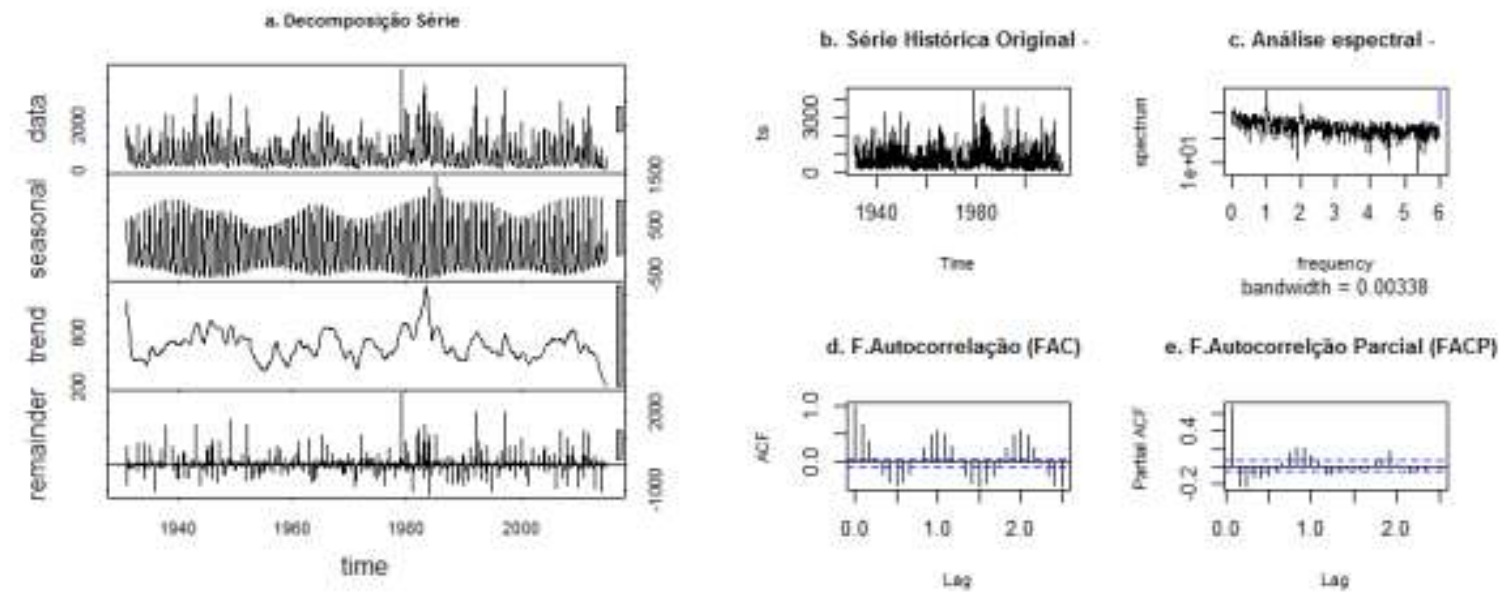

Figura APÊNDICE K-148 Análise gráfica séries temporais Vazões Usina Três Marias. a) decomposição da série em sazonalidade, tendência e resíduos b) série original c) domínio frequência d) FAC e) FACP.

Nos gráficos da Figura APÊNDICE K-149 apresentam-se:

a) Meses com gráficos distanciados;

b) As médias trimestrais apresentam o $1^{\circ}$ trimestre mais destacado;

c) Janeiro e abril estão próximo e distantes de junho e outubro que estão próximos;

d) Sazonalidade mensal dos meses com padrão período úmido de dezembro a março e período seco de abril a novembro;

e) Variabilidade nos meses maior para dezembro a março, comparado a abril a novembro;

f) Boxplot também repete os padrões anteriores com maior variabilidade mês de fevereiro.

Nos gráficos demosntra-se que para série histórica de vazões para Usina de Três Marias há sazonalidade mensal.
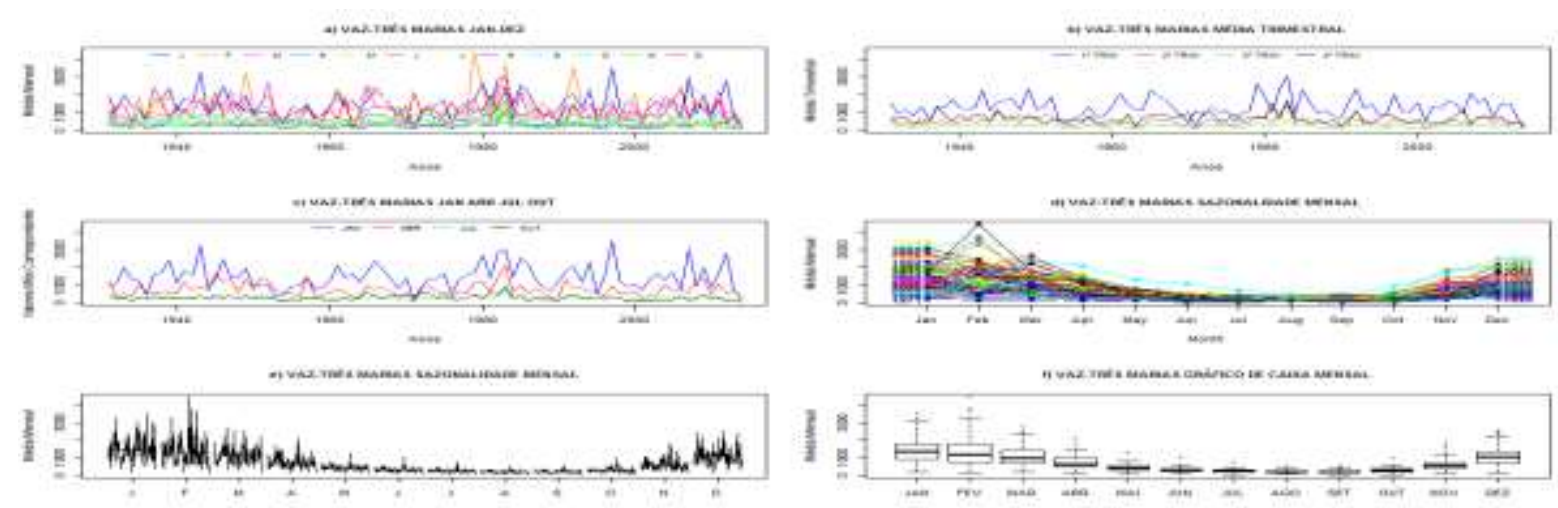

Figura APÊNDICE K-149 Séries temporais Vazões Usina Três Marias. a) JAN a DEZ. b) Média Trimestral. c) JAN ABR JUL OUT. d) Sazonalidade mensal todos os anos. e) Gráfico sazonalidade mês a mês. f) Gráfico de caixa. 
APÊNDICE K.19 Séries Históricas Bacia do Parnaíba - Vazões Usina de Boa Esperança A análise da séries temporais de Vazões Usina de Boa Esperança mostra no gráfico de decomposição na parte sazonal claramente padrões senoidais, de acordo com o padrão de 1, 2 e 3 anos. O gráfico de autocorrelação indica um possível padrão para médias móveis de 36 meses e o gráfico de correlação parcial indica um possível padrão autorregressivos de 18 meses.
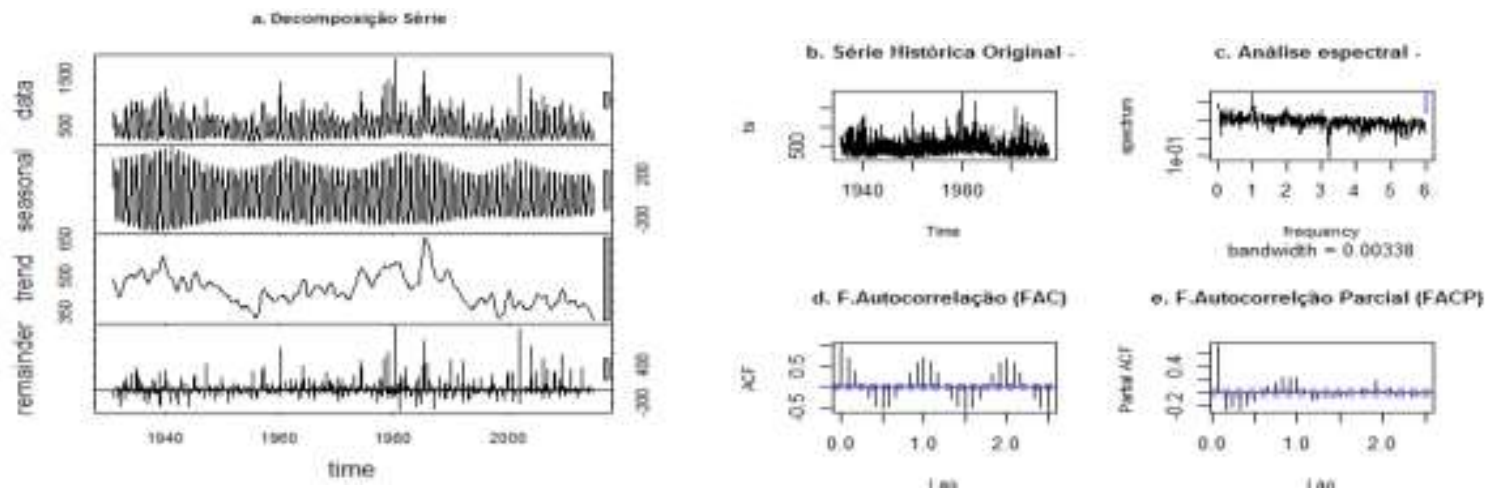

Figura APÊNDICE K-150 Análise gráfica séries temporais Vazões Usina de Boa Esperança. a) decomposição da série em sazonalidade, tendência e resíduos b) série original c) domínio frequência d) FAC e) FACP.

Nos gráficos da Figura APÊNDICE K-151 apresentam-se:

a) Meses com gráficos distanciados;

b) As médias trimestrais apresentam o $1^{\circ}$ trimestre mais destacado;

c) Janeiro e abril estão próximo e distantes de junho e outubro que estão próximos;

d) Sazonalidade mensal dos meses com padrão período úmido de dezembro a março e período seco de abril a novembro;

e) Variabilidade nos meses maior para dezembro a março, comparado a abril a novembro;

f) Boxplot também repete os padrões anteriores com maior variabilidade mês de fevereiro.

Nos gráficos demosntra-se que para série histórica de vazões para Usina de Boa Esperança há sazonalidade mensal.
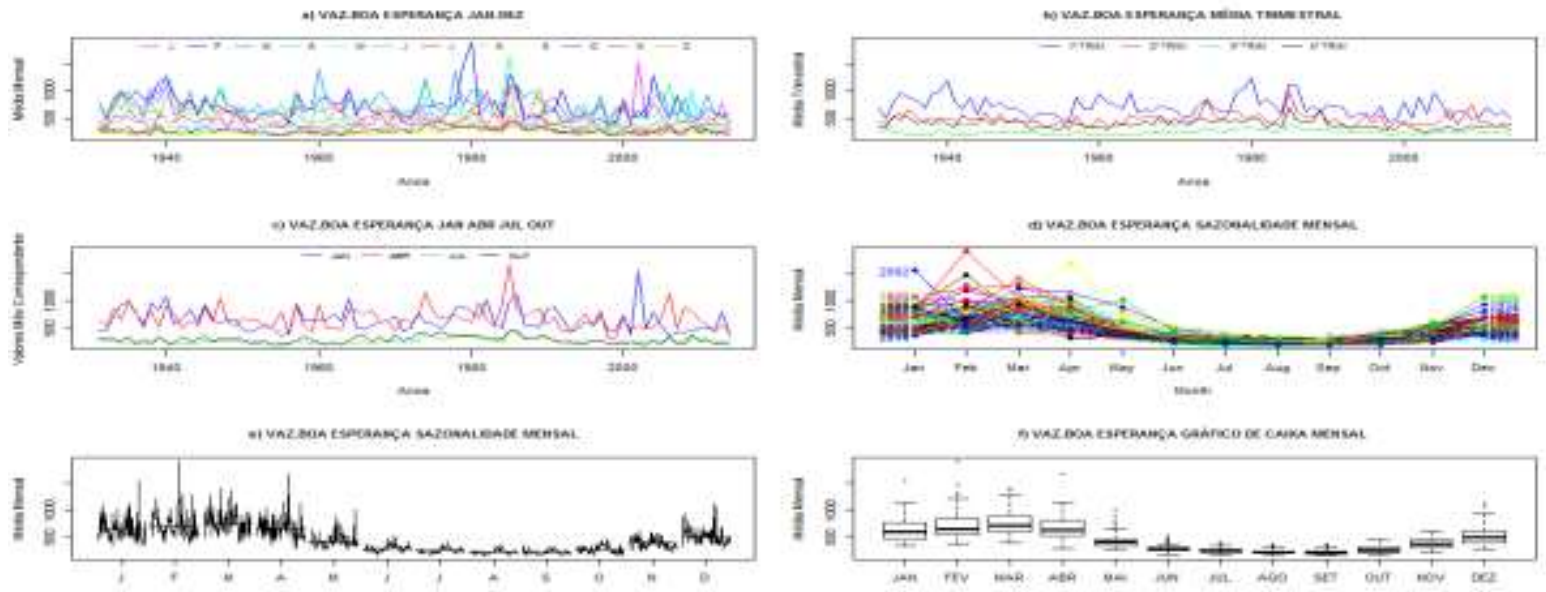

Figura APÊNDICE K-151 Temporais Vazões Usina de Boa Esperança a) JAN a DEZ. b) Média Trimestral. c) JAN ABR JUL OUT. d) Sazonalidade mensal todos os anos. e) Gráfico sazonalidade mês a mês. f) Gráfico de caixa. 
APÊNDICE K.20 Séries Históricas Bacia Amazônica - Vazões Usina de Guaporé
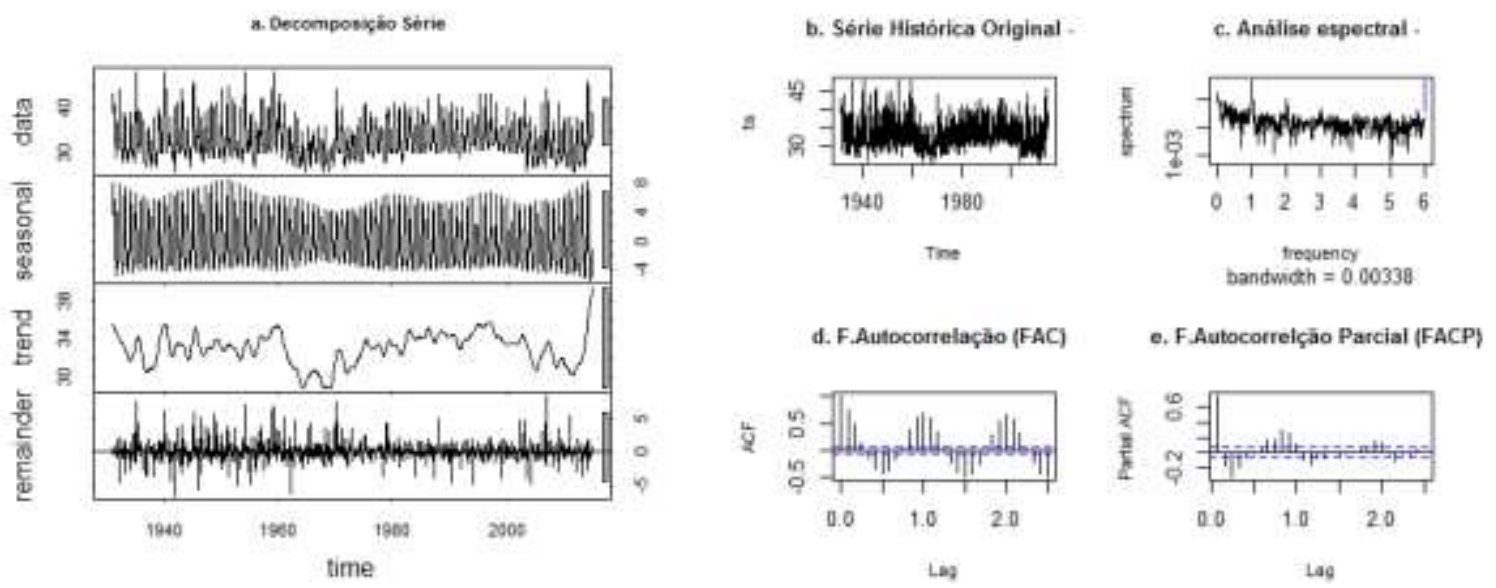

Figura APÊNDICE K-152 Análise gráfica séries temporais Vazões Usina de Guaporé. a) decomposição da série em sazonalidade, tendência e resíduos b) série original c) domínio frequência d) FAC e) FACP.

Nos gráficos da Figura APÊNDICE K-153 apresentam-se:

a) Meses com gráficos distanciados;

b) As médias trimestrais apresentam o $1^{\circ}$ trimestre mais destacado;

c) Janeiro e abril estão próximo e distantes de junho e outubro que estão próximos;

d) Sazonalidade mensal dos meses com padrão período úmido de dezembro a maio e período seco de junho a novembro;

e) Variabilidade nos meses maior para dezembro a maio, comparado a junho a novembro;

f) Boxplot também repete os padrões anteriores com maior variabilidade mês de março.

Nos gráficos demosntra-se que para série histórica de vazões para Usina de Guaporé há sazonalidade mensal.
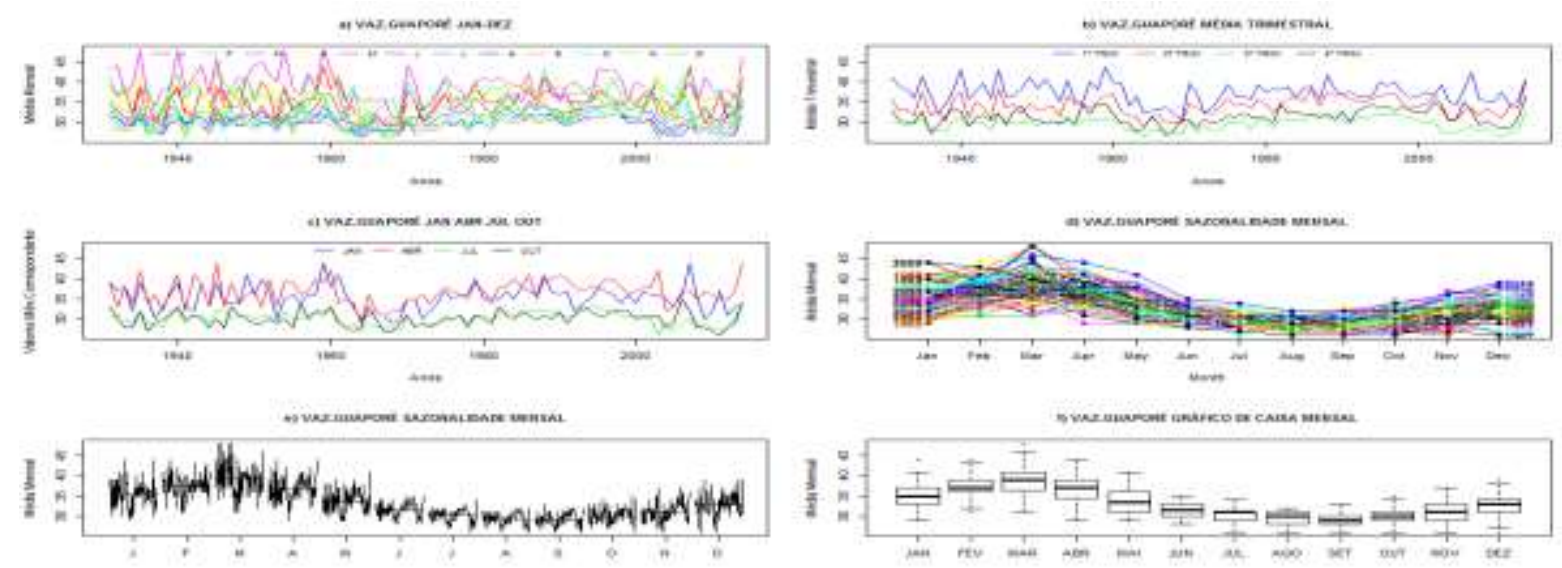

Figura APÊNDICE K-153 Temporais Vazões Usina de Guaporé a) JAN a DEZ. b) Média Trimestral. c) JAN ABR JUL OUT. d) Sazonalidade mensal todos os anos. e) Gráfico sazonalidade mês a mês. f) Gráfico de caixa. Séries Históricas Bacia Amazônica 
APÊNDICE K.21 Séries H. Bacia Amazônica - Vazões Usina de Samuel
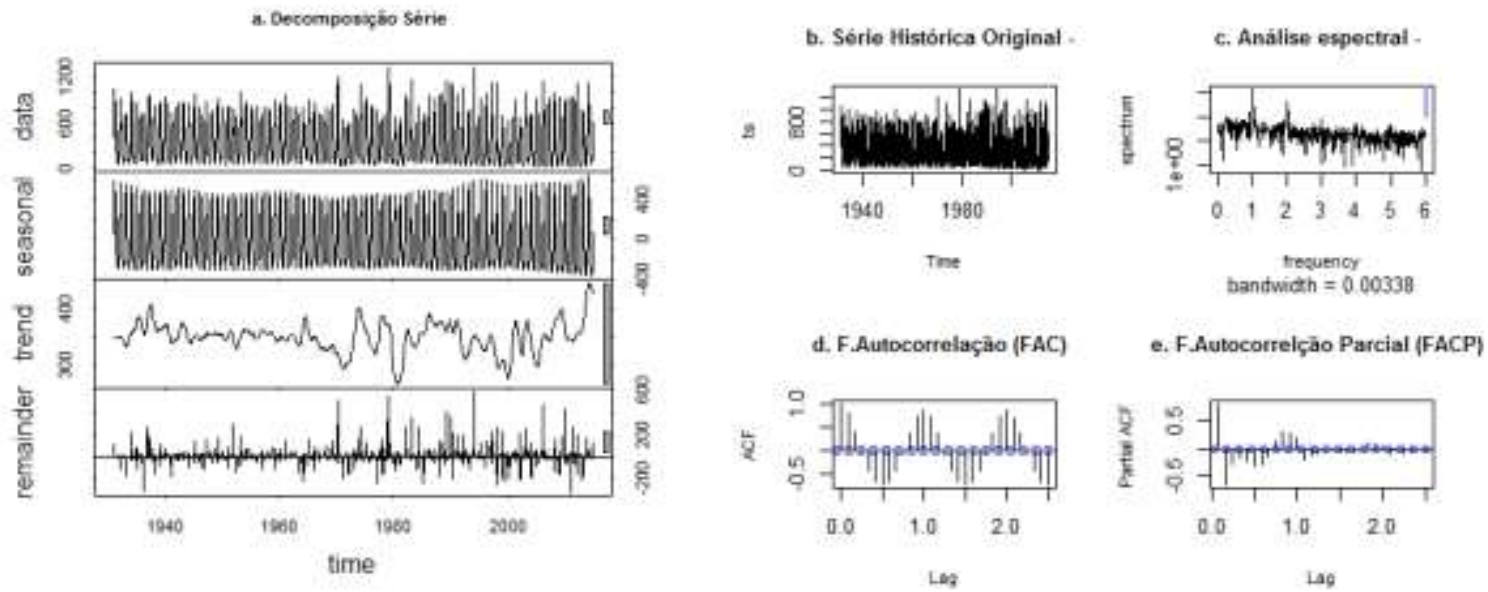

Figura APÊNDICE K-154 Análise gráfica séries temporais Vazões Usina de Samuel. a) decomposição da série em sazonalidade, tendência e resíduos b) série original c) domínio frequência d) FAC e) FACP.

Nos gráficos da Figura APÊNDICE K-155 apresentam-se:

a) Meses com gráficos distanciados;

b) As médias trimestrais apresentam o $1^{\circ}$ trimestre mais destacado;

c) Janeiro e abril estão próximo e distantes de junho e outubro que estão próximos;

d) Sazonalidade mensal dos meses com padrão período úmido de dezembro a março e período seco de abril a novembro;

e) Variabilidade nos meses maior para dezembro a março, comparado a abril a novembro;

f) Boxplot também repete os padrões anteriores com maior variabilidade mês de março.

Nos gráficos demosntra-se que para série histórica de vazões para Usina de Samuel há sazonalidade mensal.

Os dados apresentam um comportamento no período de 1931 a 1970 diferente do período de 1971 a 2013 o que pode ser indicativo de problemas na série histórica.
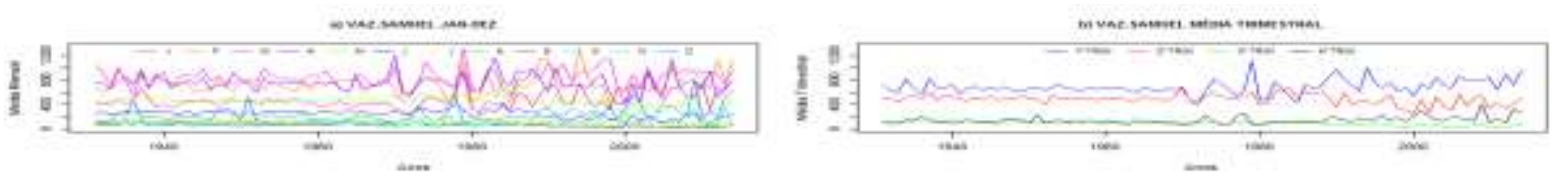

2ax:
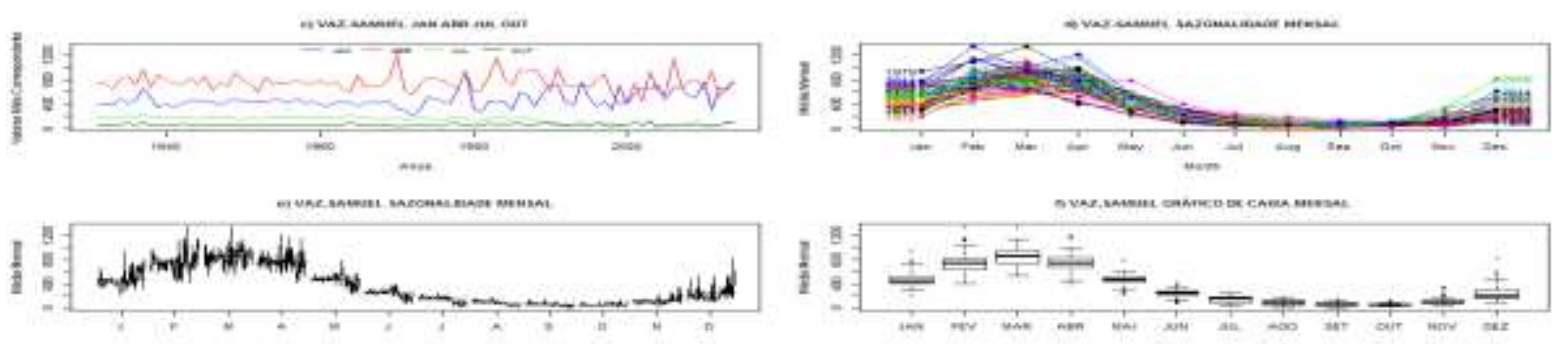

Figura APÊNDICE K-155 Temporais Vazões Usina de Samuel a) JAN a DEZ. b) Média Trimestral. c) JAN ABR JUL OUT. d) Sazonalidade mensal todos os anos. e) Gráfico sazonalidade mês a mês. f) Gráfico de caixa. 
APÊNDICE K.22 Séries Históricas Bacia do Uruguai - Vazões Usina de Passo Fundo
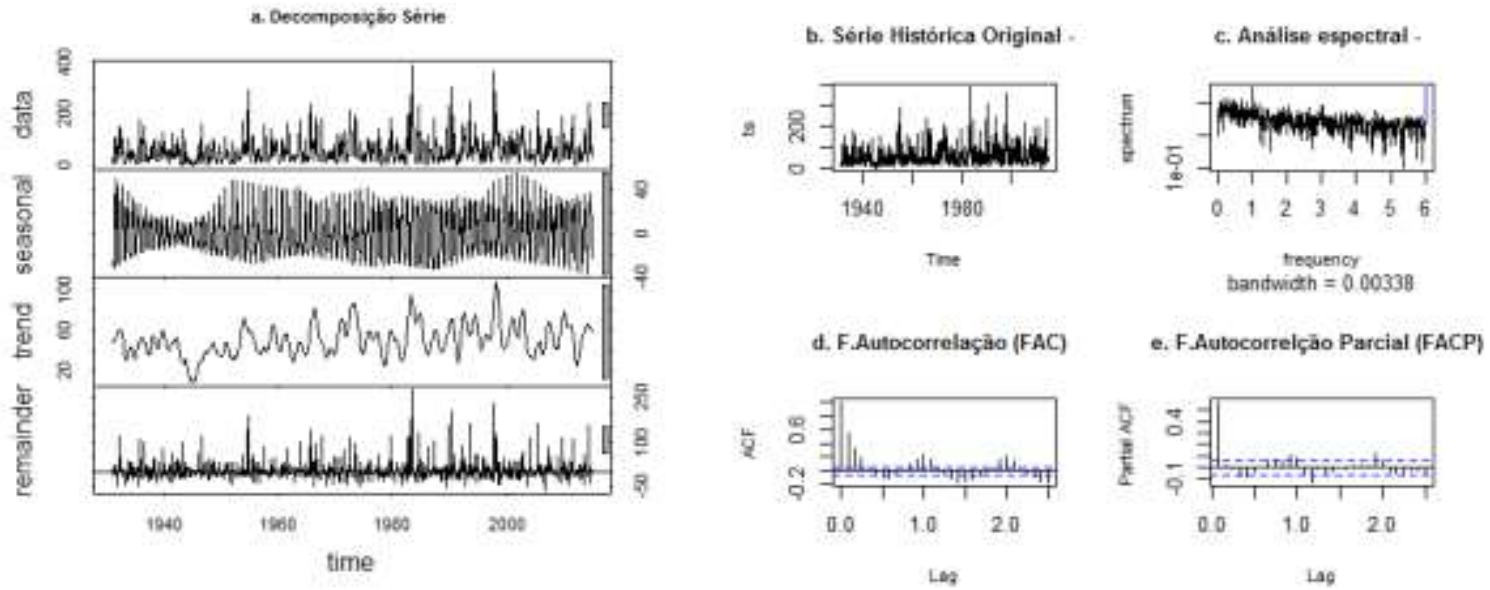

Figura APÊNDICE K-156 Análise gráfica séries temporais Vazões Usina de Passo Fundo. a) decomposição da série em sazonalidade, tendência e resíduos b) série original c) domínio frequência d) FAC e) FACP.

Nos gráficos da Figura APÊNDICE K-157 apresentam-se:

a) Meses com gráficos aproximados;

b) As médias trimestrais apresentam os trimestres aproximados, sem destaques;

c) Janeiro, abril, junho e outubro estão próximos;

d) Sazonalidade mensal dos meses com padrão período úmido de abril a novembro e período seco de dezembro a março;

e) Variabilidade nos meses maior para abril a novembro, comparado a dezembro a março; e

f) Boxplot também repete os padrões anteriores com maior variabilidade mês de outubro.

Nos gráficos demosntra-se que para série histórica de vazões para Usina de Passo Fundo há sazonalidade mensal.
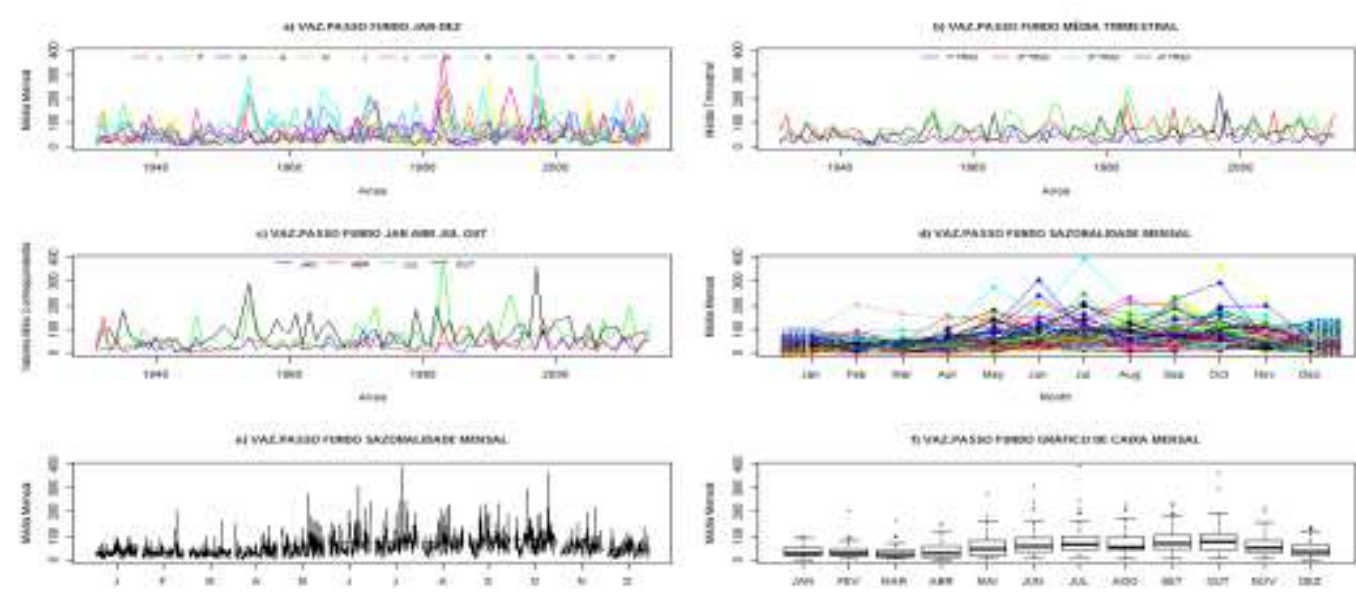

Figura APÊNDICE K-157 Temporais Vazões Usina de Passo Fundo a) JAN a DEZ. b) Média Trimestral. c) JAN ABR JUL OUT. d) Sazonalidade mensal todos os anos. e) Gráfico sazonalidade mês a mês. f) Gráfico de caixa 


\section{APÊNDICE L Análise de mapas de TSM georreferenciada}

Nessa seção, são apresentados mapas com a descrição de TSM no globo. Esses mapas são utilizados para identificar áreas dos oceanos de todo o globo terrestre que tenham correlações com as variáveis dependentes ENA ou vazões, além das áreas como El Niño e Pacífico Norte ou Atlântico Norte que já foram analisadas. Nos mapas as áreas dos continentes estão na cor branca. A descrição dessas bases encontra-se na seção 4.3 Fontes de dados georreferenciadas HadISST e ERSST, p.138.

\section{APÊNDICE L.1 ACP TSM HadISST versos TSM ERSST}

As correlações entre as bases HadISST e ERSST contra a ENA-SE eram maiores quando utilizadas médias mensais, uma vez que o período úmido coincide em sua maior parte ao $1^{\circ}$ semestre. Na Tabela APÊNDICE L-4, apresenta-se a análise por componentes principais sobre as duas bases de TSM. Devido à diferença de resolução das duas bases HadISST com um grau lat. x lon. e ERSST v3 com dois graus, coincidem com as áreas do oceano Pacífico principalmente as dos NINO1+2 e Atlântico Norte, o que corrobora com a importância desses índices de variáveis na climatologia e os estudos abordados por essa tese.

Da Figura APÊNDICE L-158 até a Figura APÊNDICE L-161 são apresentadas quatro componentes principais encontradas nos mapas a) base HadISST e b) ERSST.A comparação entre as bases revela que diferentes áreas apresentam diferentes pesos (loadings). Isso ocorre devido à diferença nas metodologias de construção e resolução das bases.

Na Tabela APÊNDICE L-4, encontram-se as componentes que apresentam o percentual de variabilidade associado.

Tabela APÊNDICE L-4 Percentual de variabilidade por componente principal

\begin{tabular}{|c|c|c|c|}
\hline$\#$ & Componente Principal & HadISST & ERSST \\
\hline Figura APÊNDICE L-158 & $1^{\mathrm{a}}$. & $11,83 \%$ & $15,71 \%$ \\
\hline Figura APÊNDICE L-159 & $2^{\mathrm{a}}$ & $9,55 \%$ & $11,36 \%$ \\
\hline Figura APÊNDICE L-160 & $3^{\mathrm{a}}$. & $3,42 \%$ & $8,89 \%$ \\
\hline Figura APÊNDICE L-161 & $4^{\mathrm{a}}$ & $3,27 \%$ & $3,91 \%$ \\
\hline
\end{tabular}

Na Figura APÊNDICE L-158, apresentam-se em a) maiores pesos na região do Niño no equador e no Norte em $25^{\circ} \mathrm{N} \mathrm{e}-150^{\circ}$, e em b) maiores pesos no oceano Atlântico a Leste dos EUA e oceano Pacífico a Leste da Rússia. 

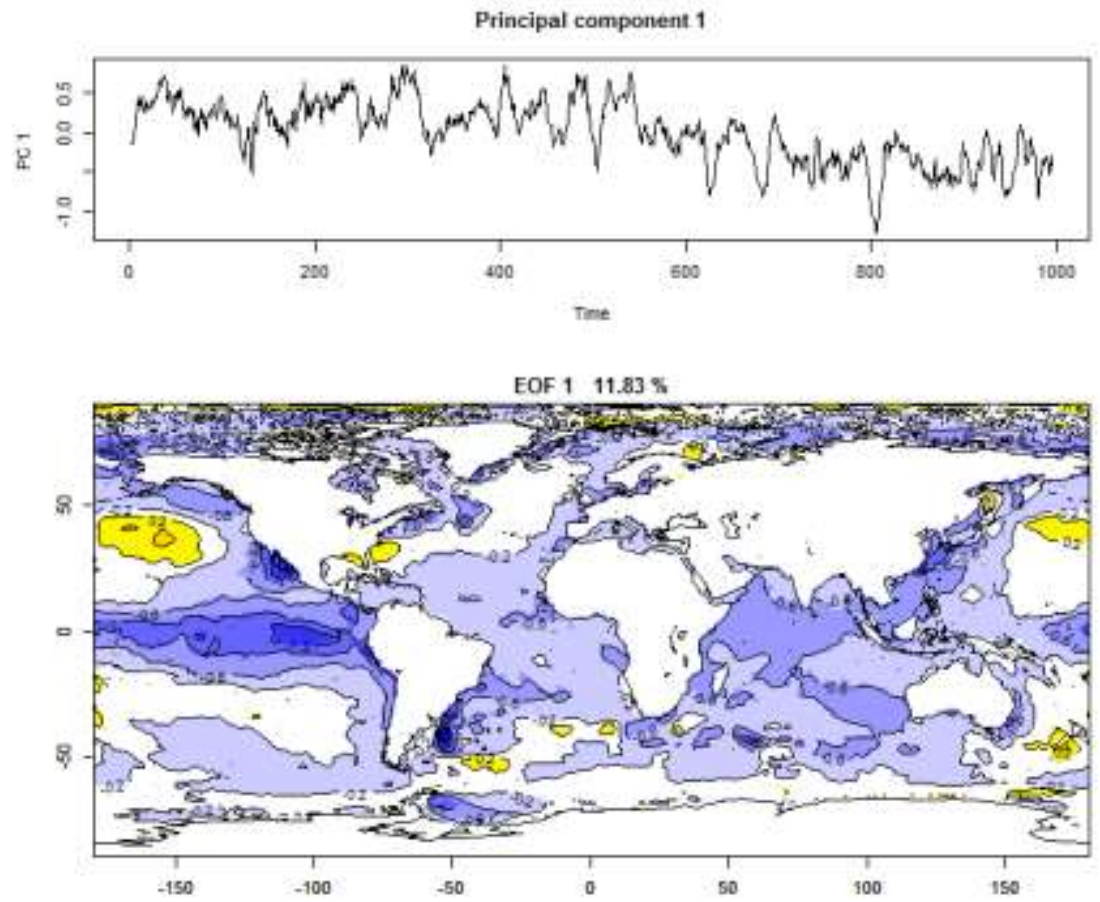

a)

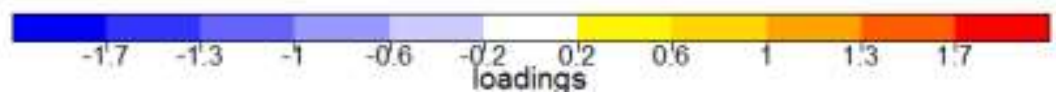

Principal component 1

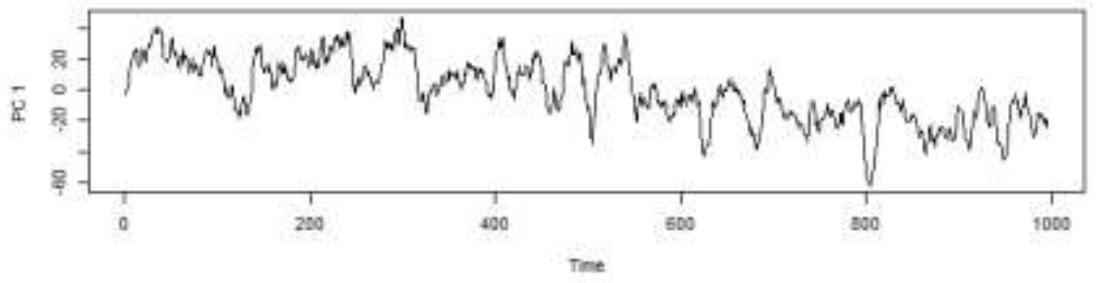

EOF $1 \quad 15.71 \%$

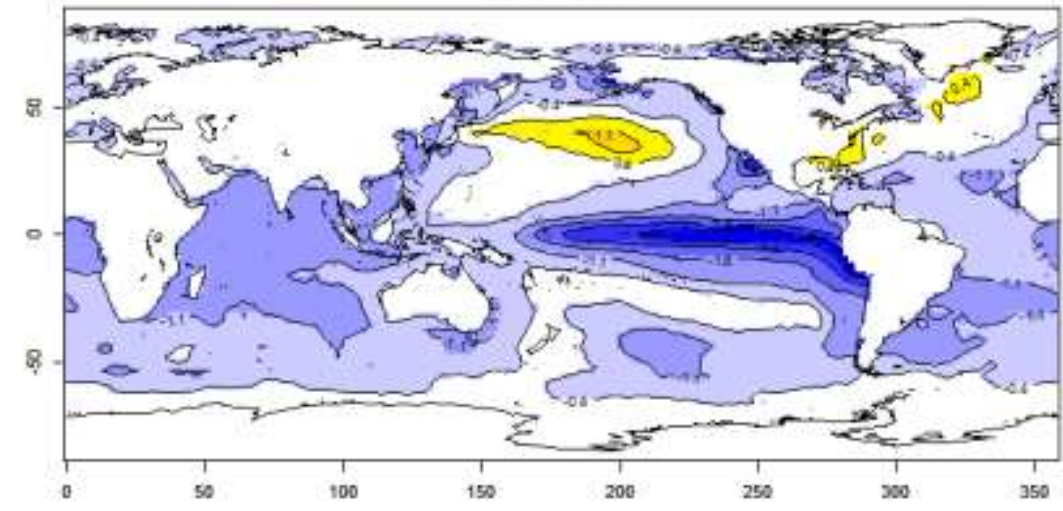

b)

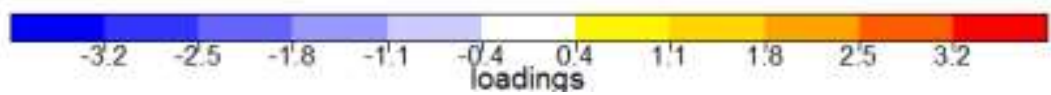

Figura APÊNDICE L-158 Análise por componentes principais $1^{a}$ Componente Principal a) TSM HadISST b) ERSST. Média $1^{\circ}$. Semestre 
Na Figura APÊNDICE L-159, apresentam-se a) maiores pesos no Ártico e b) maiores pesos na área El Niño no equador.
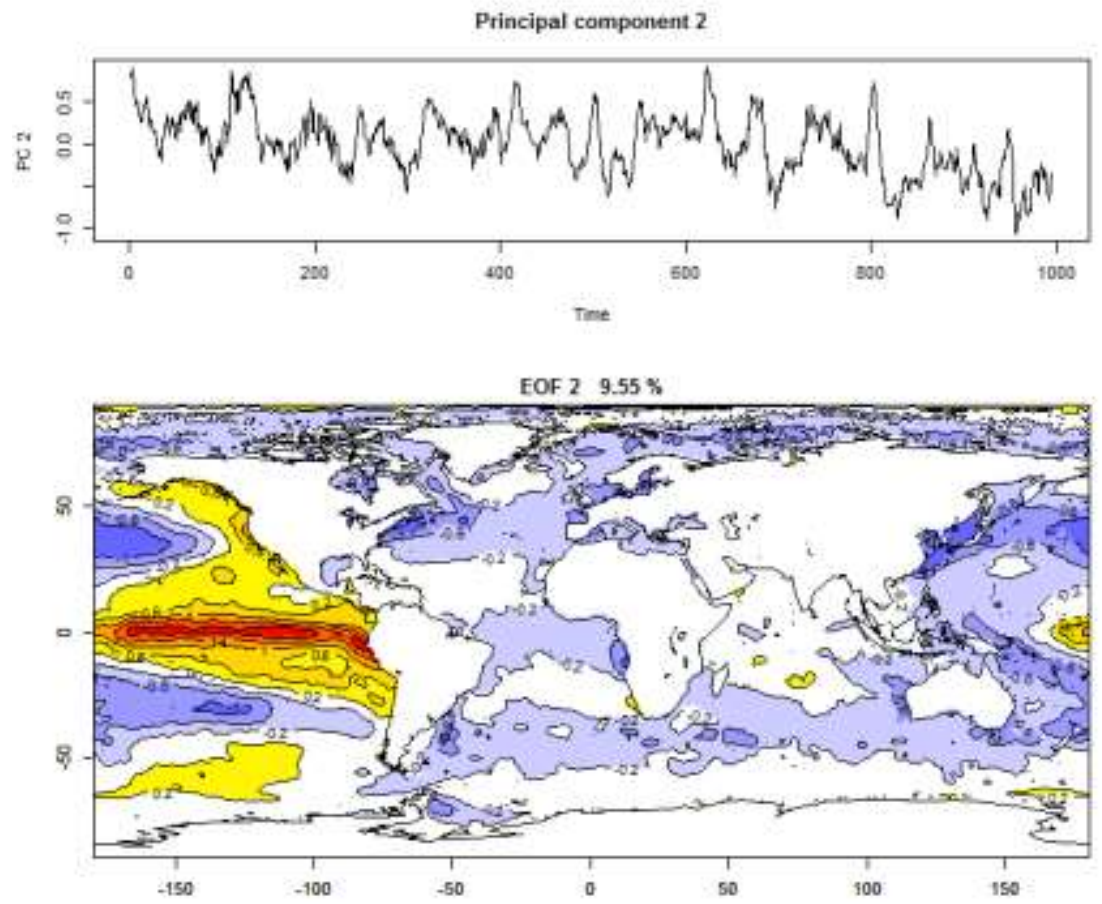

a)

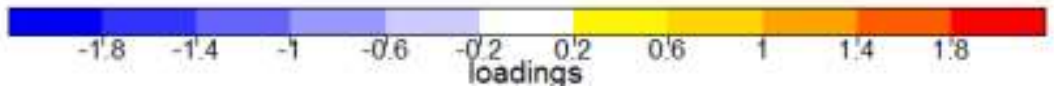

Principal component 2
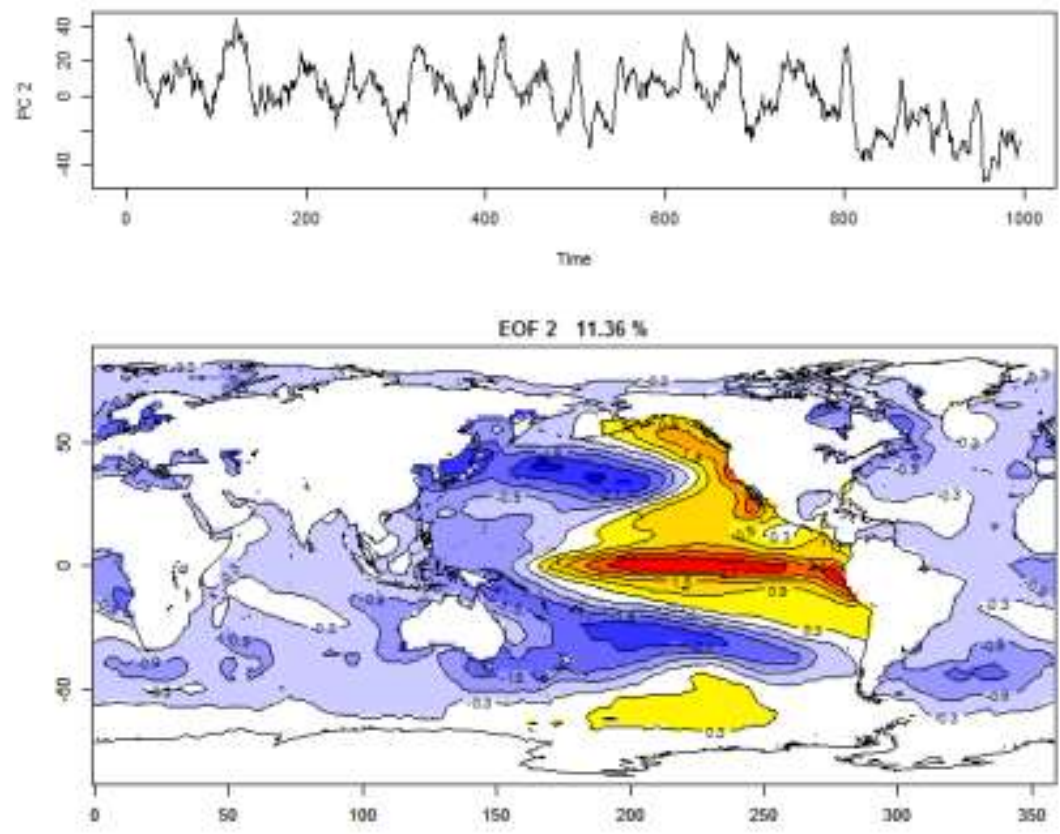

b)

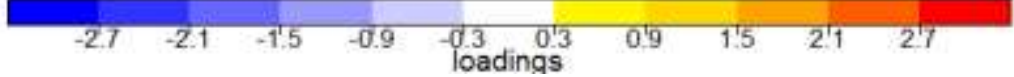

Figura APÊNDICE L-159 Análise por componentes principais 2a Componente Principal a) TSM HadISST b) ERSST. Média $1^{\circ}$. Semestre 
Na Figura APÊNDICE L-160, apresenta-se a) maiores pesos área El Niño, Oceano Pacífico $20^{\circ} \mathrm{N}$ e áreas do Polo Ártico, e b) áreas do oceano Pacífico a oeste dos EUA.
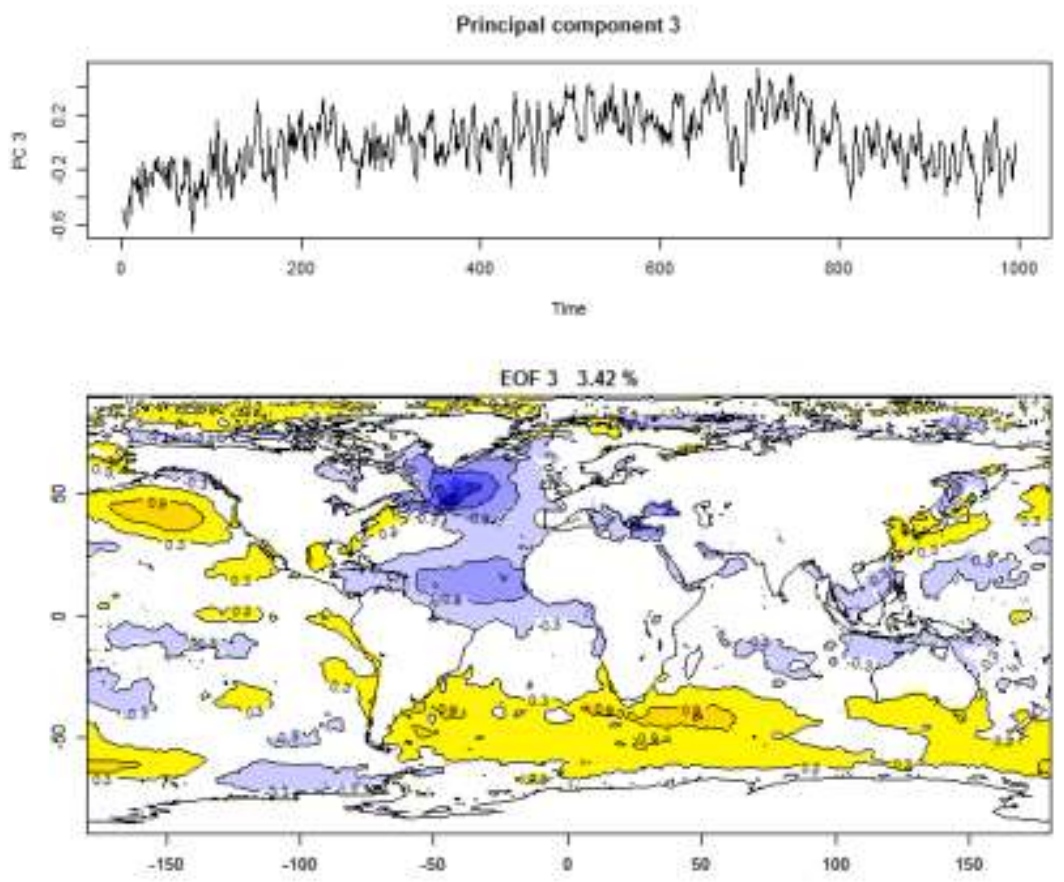

a)
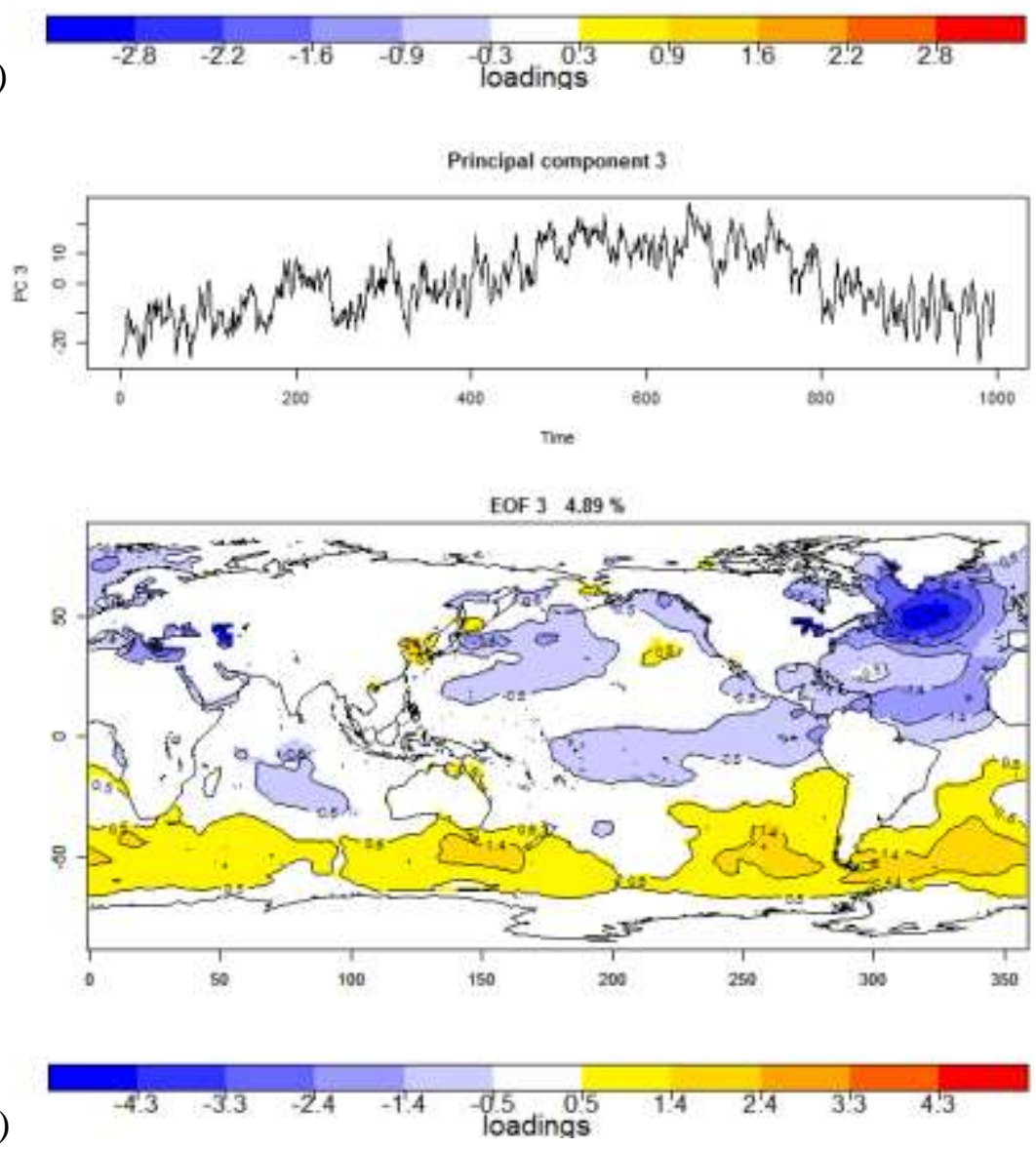

Figura APÊNDICE L-160 Análise por componentes principais $3{ }^{a}$ Componente Principal a) TSM HadISST b) ERSST. Média $1^{\circ}$. Semestre 
Na Figura APÊNDICE L-161, apresentam-se a) maiores pesos área do El Niño 1+2, oceanos Atlântico, Oeste da África e oceano Pacífico a Nordeste da Austrália em b) Atlântico Norte, $\mathrm{NINO} 1+2$.
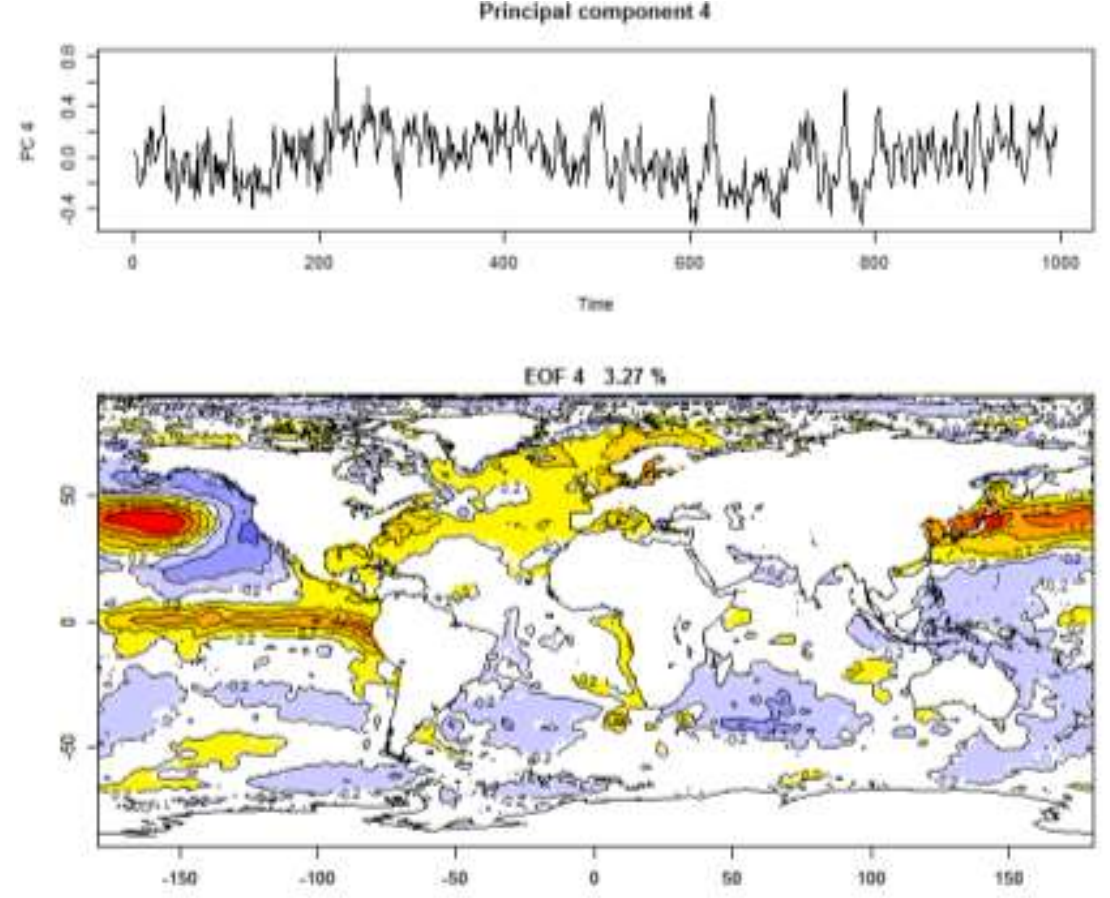

a)
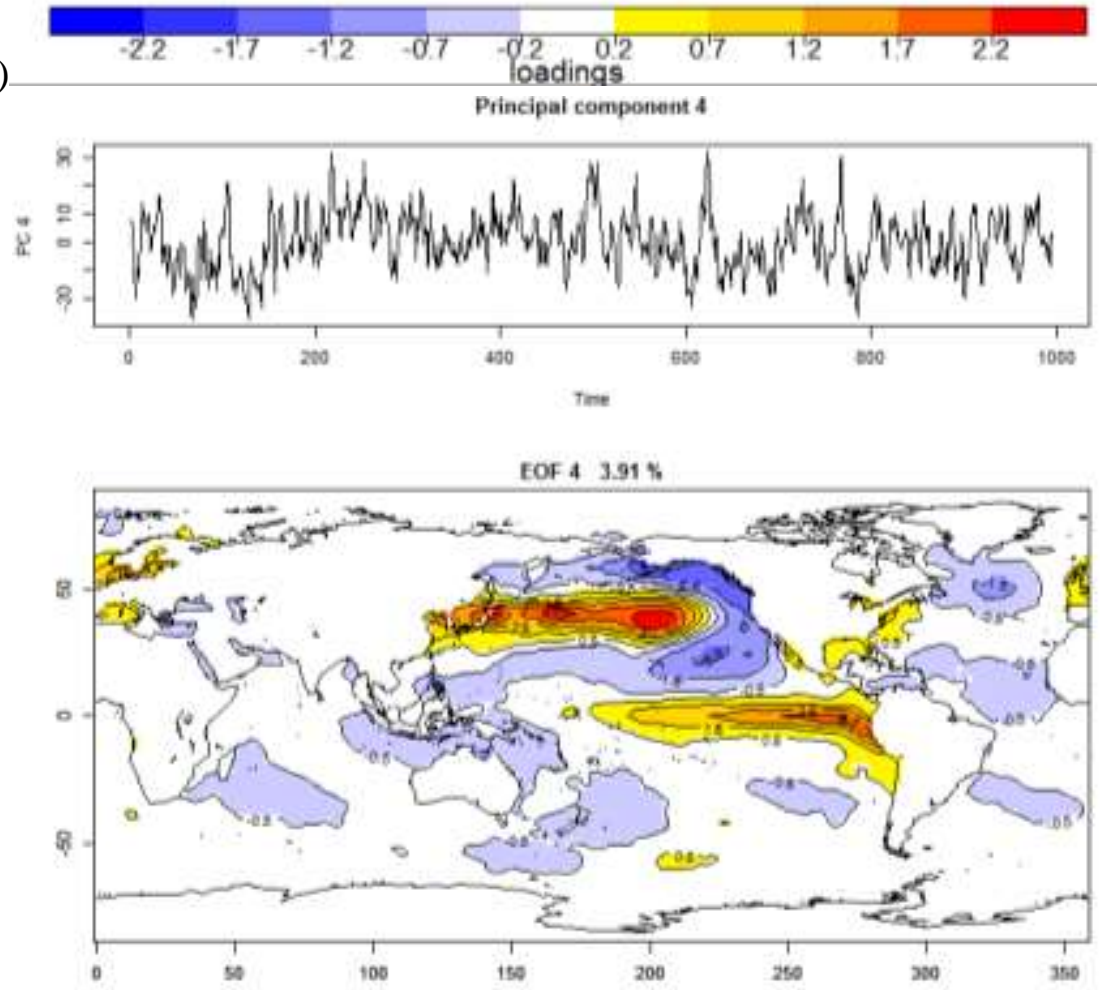

b)

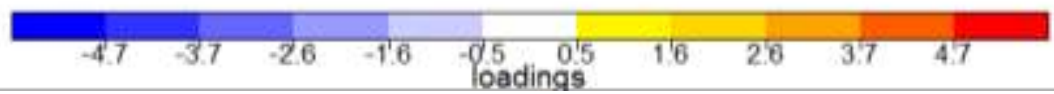

Figura APÊNDICE L-161 Análise por componentes principais $4^{a}$ Componente Principal a) TSM HadISST b) ERSST. Média $1^{\circ}$. Semestre 
APÊNDICE L.2 Correlação ENA Região Sudeste versos TSM oceanos mundo Observa-se que as regiões típicas do El-Nino, Sudeste da Austrália, Sul da Índia e Leste da África e Atlântico Sul, apresentam-se correlações positivas. O norte do Oceano Atlântico apresenta correlação negativa, apesar de serem valores em torno de 0,24. Como a escala é global, essa correlação pode servir como uma "pista" dos fenômenos climáticos que influenciam as vazões e também a ENA de determinada usina, bacia ou região. Ademais, correlações com as variáveis macroclimáticas NINO1+2 são positivas acima de 0,6 e Atlântico Multidecadal Correlação negativa abaixo de - 0,6 confirma as correlações realizadas com índices NINO 1+2 e Atlântico Norte Tropical e são apresentados a seguir. 


\section{APÊNDICE L.2.1 1931-2014 HadISST}

Ao correlacionar a TSM dos oceanos do mundo originária da base HadISST no segundo semestre do período de 1931 a 2014 e da ENA do Sudeste na Figura APÊNDICE L-162, apresentam-se a (a) correlação e o (b) nível de significância p-valor. É possível notar correlações em regiões do Oceano Pacífico equatorial e ao longo da América do Sul, Sul e Norte do Oceano Índico, Oceano Atlântico, próximo à Groelândia e a Sudoeste da Austrália e da África

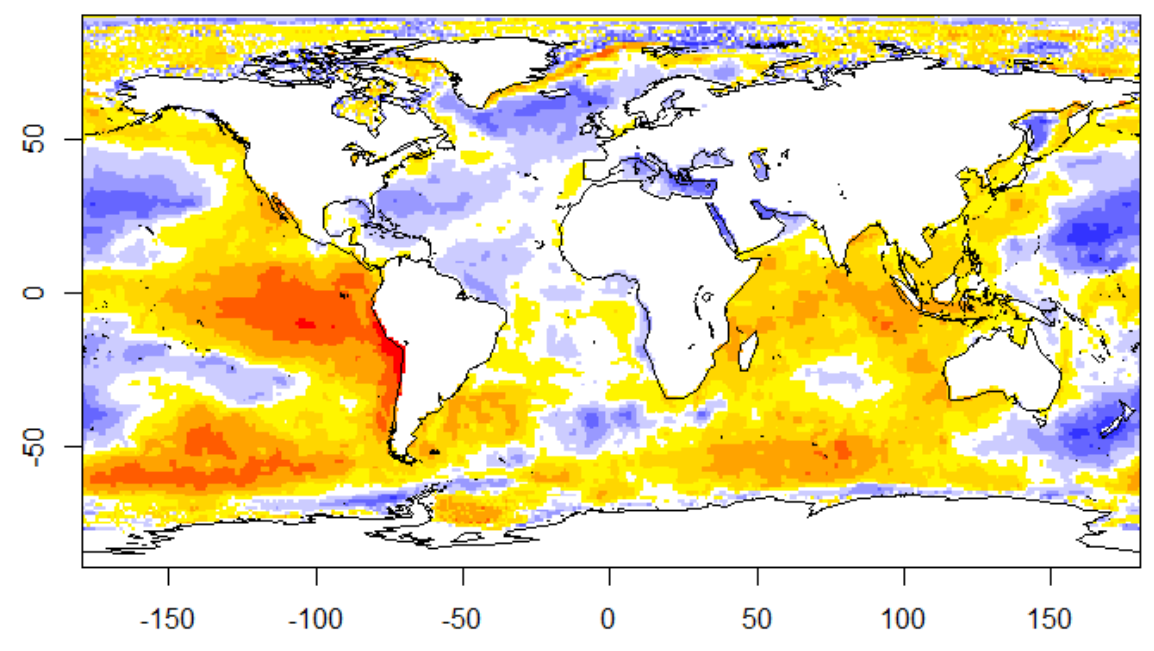

a)
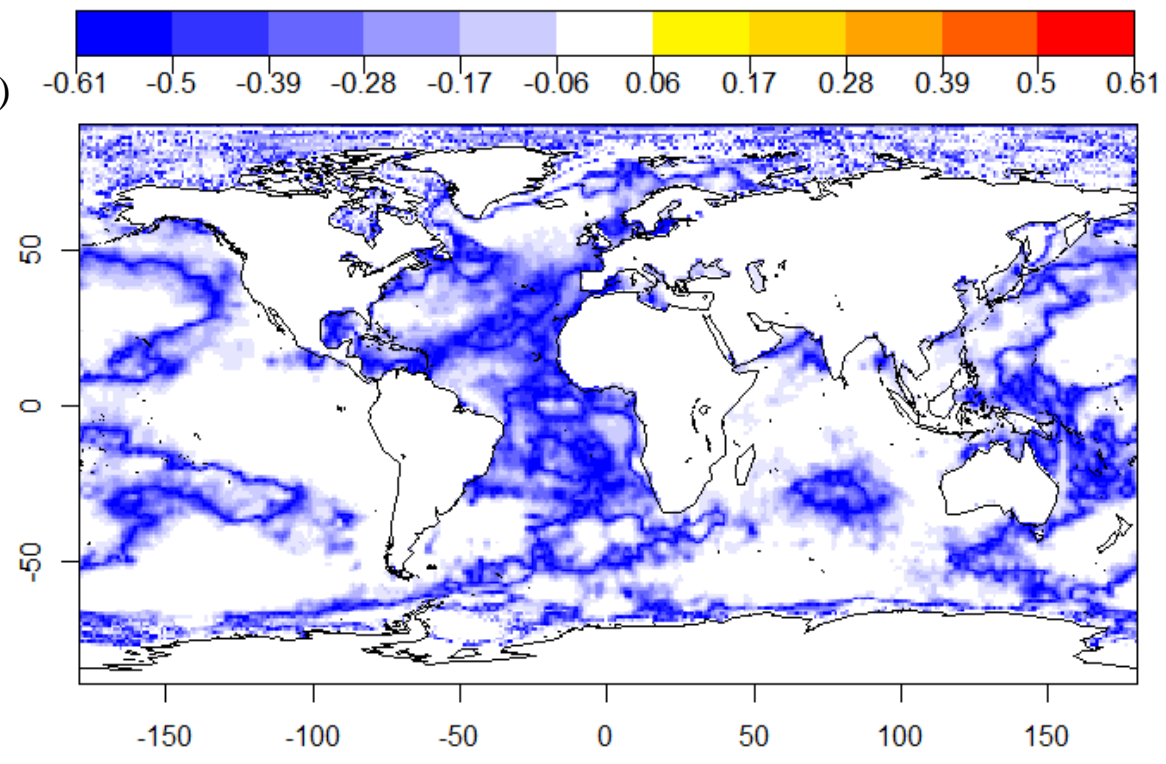

b) $\quad \begin{array}{lllllllllll}0 & 0.69 & 0.18 & 0.27 & 0.36 & 0.45 & 0.55 & 0.64 & 0.73 & 0.82 & 0.91\end{array}$

Figura APÊNDICE L-162 Correlação TSM HadISST versos ENA SE a) Correlação b) P-Valor 1931 - 2014 


\section{APÊNDICE L.2.2 1931-2014 ERSST}

Ao correlacionar a TSM dos oceanos do mundo originária da base ERSST e da ENA do Sudeste, na Figura APÊNDICE L-163, é apresentada a (a) correlação e o (b) nível de significância p-valor. É possível notar coeficientes de correlação acima de 0,4, em módulo, em regiões do Oceano Pacífico equatorial e ao longo da América do Sul, sul Índico, próximo à Groelândia e ao sul da Austrália e da África. Observa-se que nessa base os maiores valores de significância concentraram-se no Pacífico e em área ao Norte e ao Sul do Atlântico, no Oceano Índico a leste da África e Sul da Austrália.

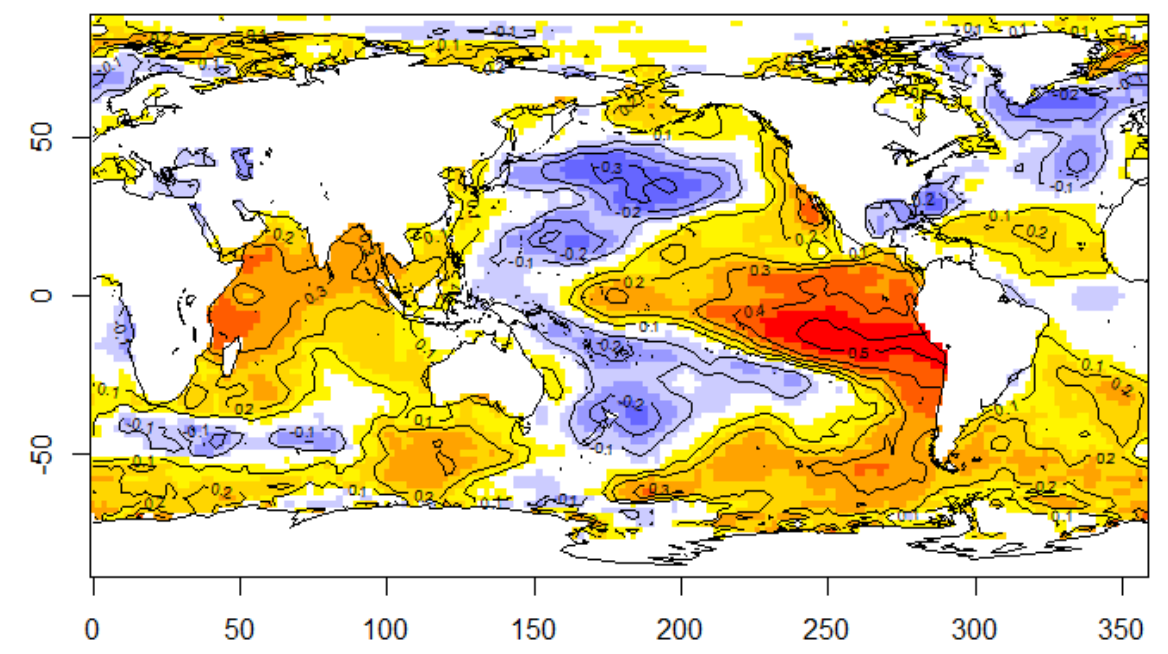

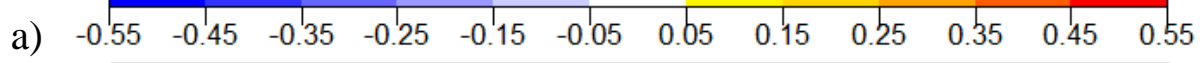

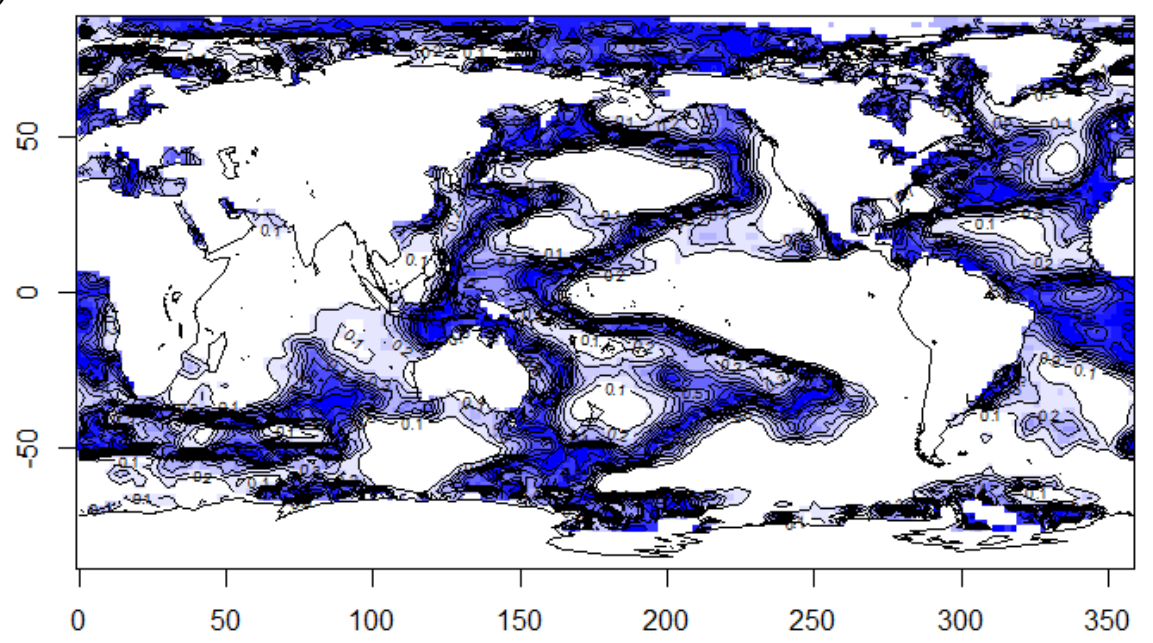

b)

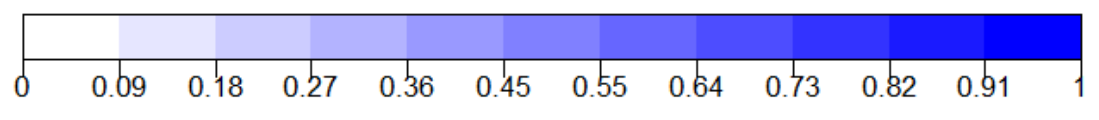

Figura APÊNDICE L-163 Correlação TSM ERSST versos ENA SE a) Correlação b) P-Valor 1931 - 2014 


\section{APÊNDICE L.2.3 1973-2014 HadISST}

Ao correlacionar a TSM dos oceanos do mundo originária da base HadISST no segundo semestre do período de 1973 a 2014 e da ENA do Sudeste, na Figura APÊNDICE L-164, apresentam-se a (a) correlação e o (b) nível de significância p-valor. É possível notar coeficientes de correlação acima de 0,5, em módulo, em regiões do Oceano Pacífico equatorial e ao longo da América do Sul, Sul do Oceano Índico, Norte Oceano Atlântico, próximo à Groelândia e a Sudoeste da Austrália e Sul da África, próximo a Antártica.
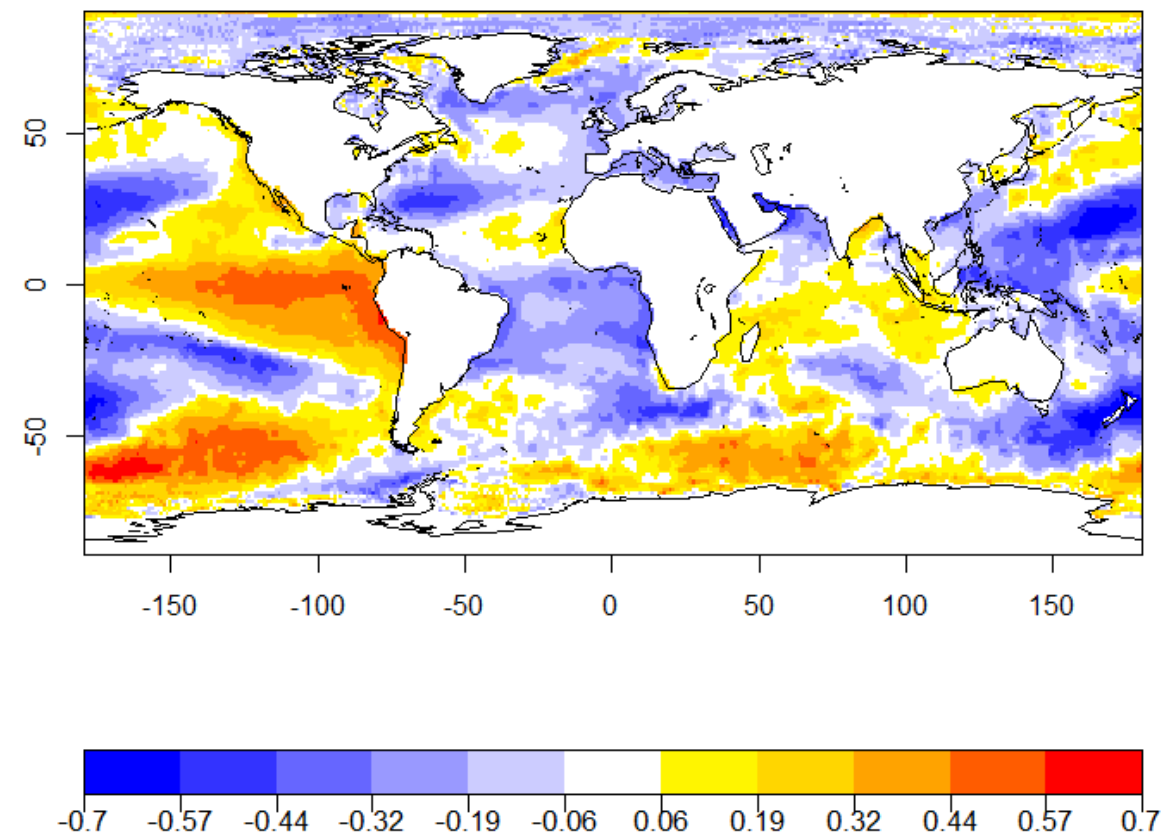

a)
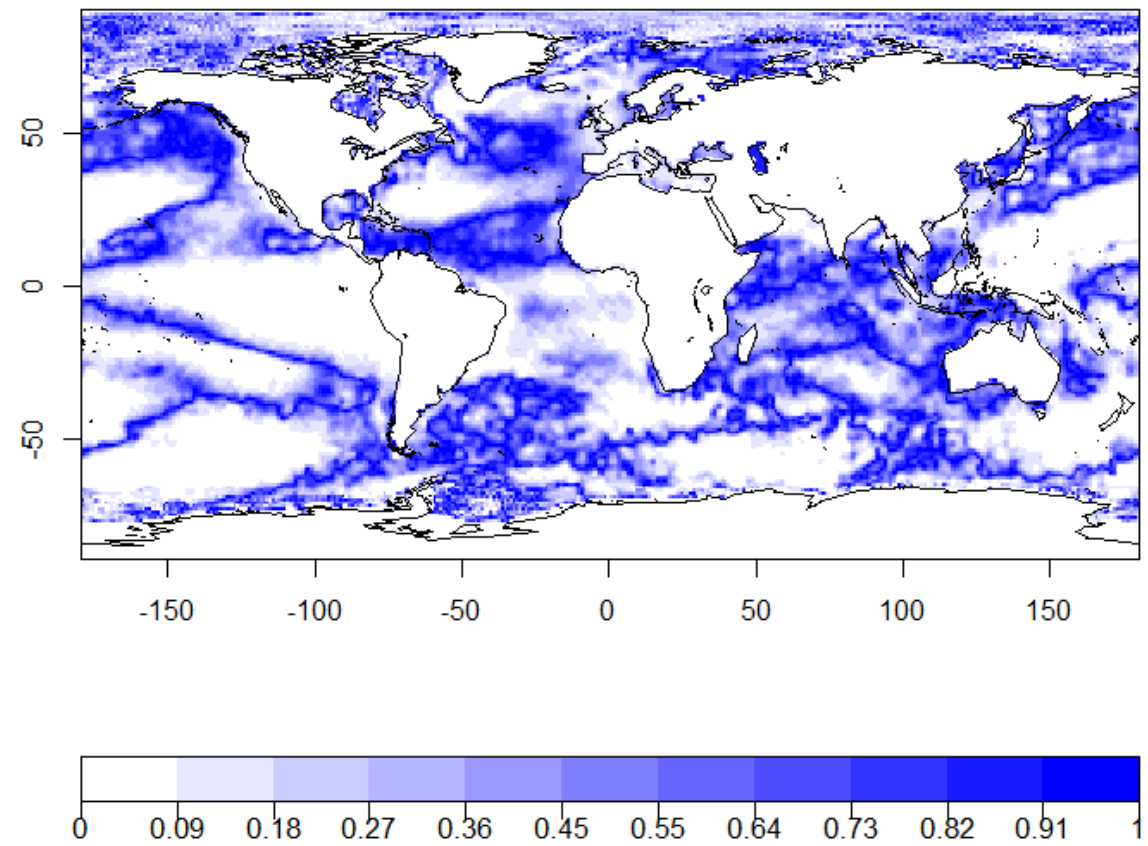

b)

Figura APÊNDICE L-164 Correlação TSM HadISST versos ENA SE a) Correlação b) P-Valor 1973 - 2014 


\section{APÊNDICE L.2.4 1973-2014 ERSST}

Ao correlacionar a TSM dos oceanos do mundo originária da base ERSST no segundo semestre do período de 1973 a 2014 e da ENA do Sudeste na Figura APÊNDICE L-164, apresentam-se a (a) correlação e o (b) nível de significância p-valor. É possível notar coeficientes de correlação acima de 0,5, em módulo, em regiões do Oceano Pacífico equatorial e ao longo da América do Sul e a Sudoeste e Nordeste da Austrália e Sul da África; e Norte Oceano Atlântico, próximo à Groelândia.
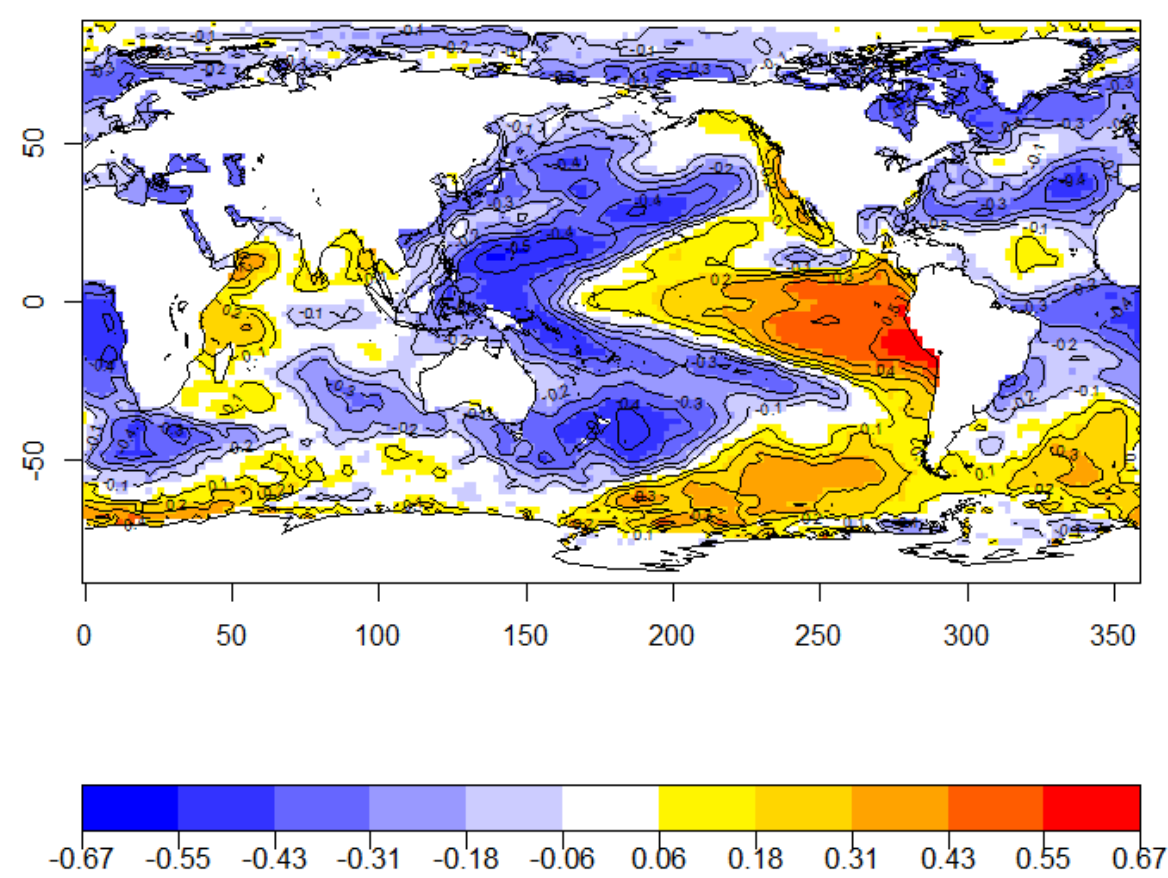

a)
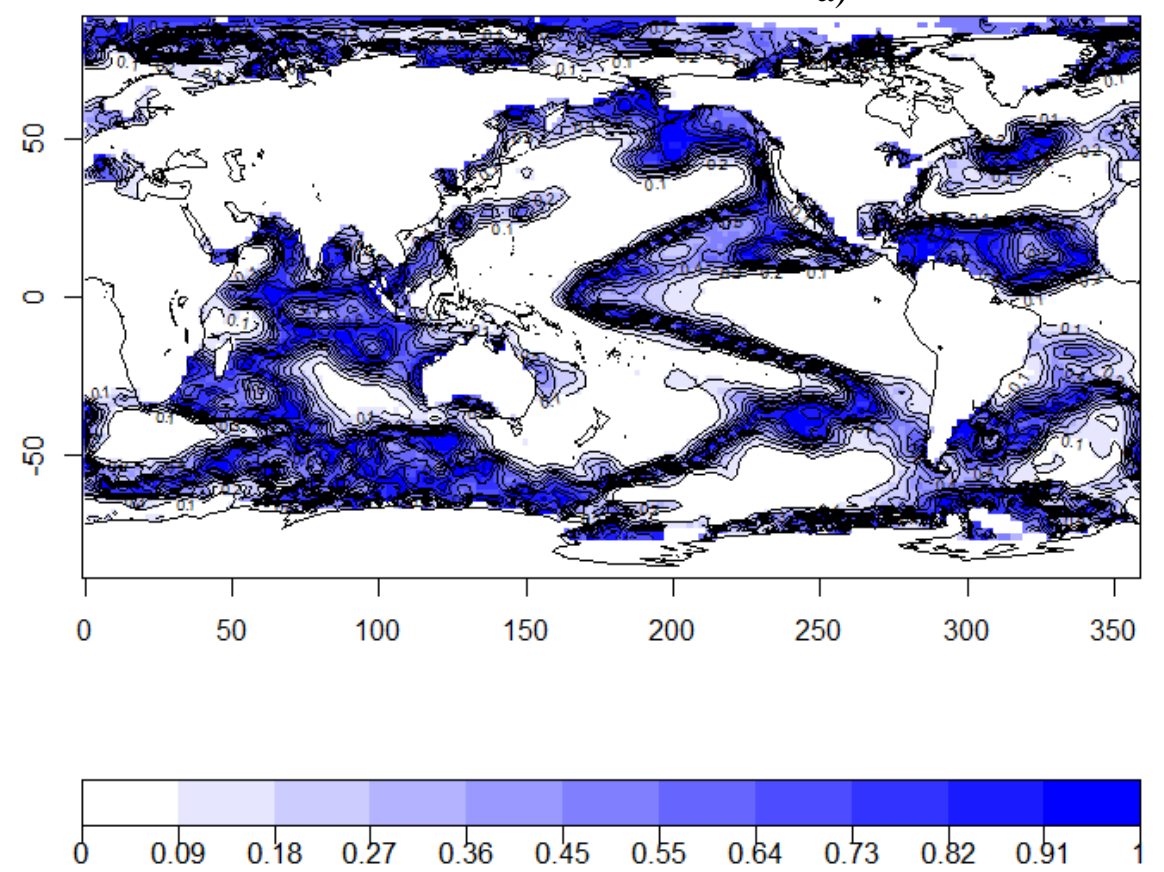

b)

Figura APÊNDICE L-165 Correlação TSM ERSST versos ENA SE a) Correlação b) P-Valor 1973 - 2014 


\section{APÊNDICE L.2.5 1984-2014 HadISST}

Em uma base de dados com o período menor de 1984 a 2014 é possível observar uma diminuição na significância dos dados, porém continua a semelhança entre as correlações nas áreas norte e sudeste em torno da Austrália, sul do Atlântico e norte do Atlântico, junto à costa do EUA e também as mesmas áreas do NINO e AMO, porém com módulos menores.

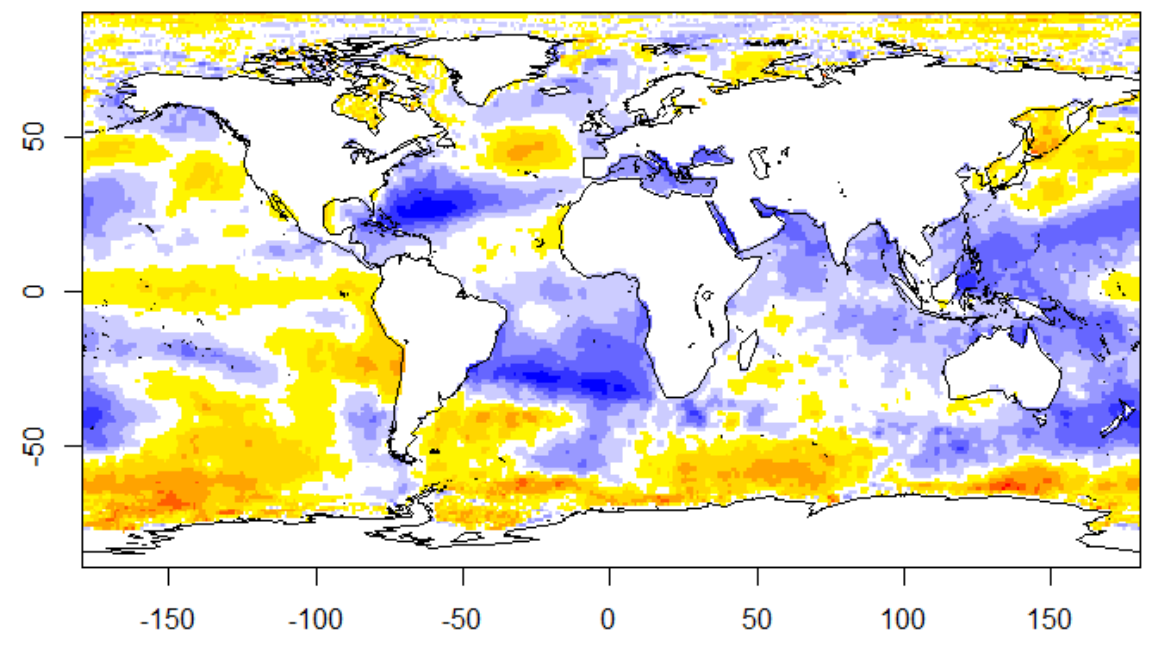

a)
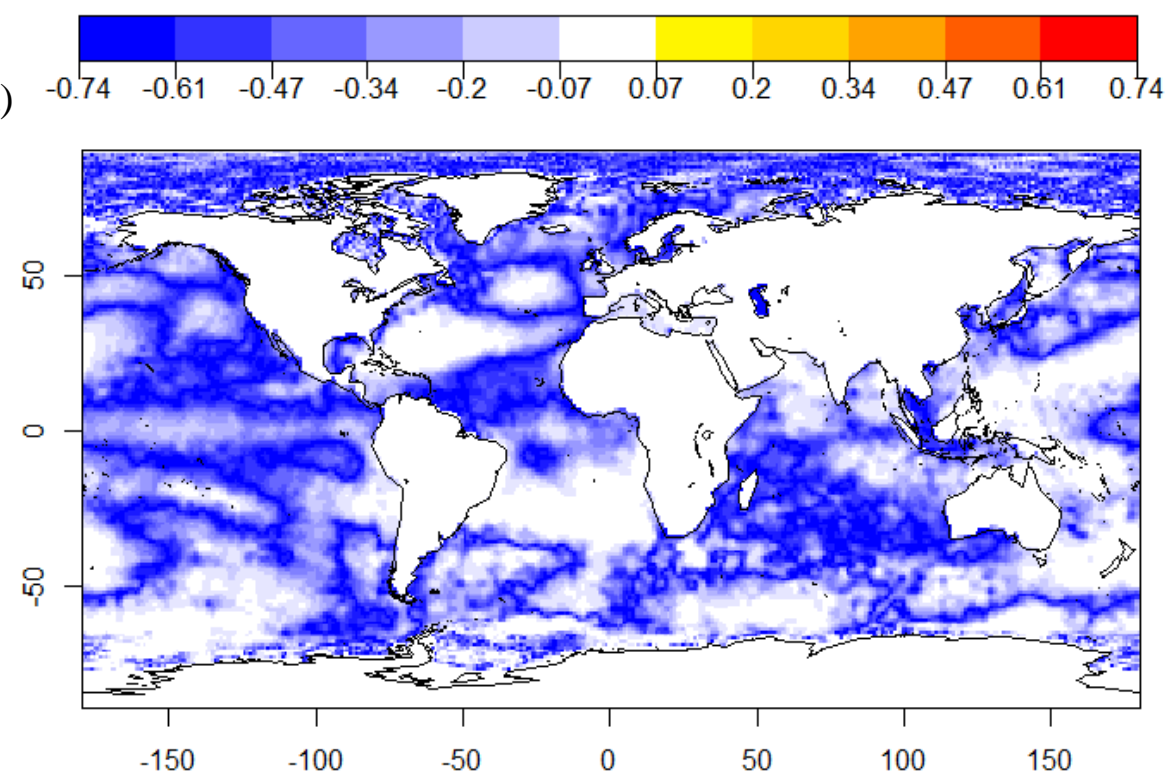

b)

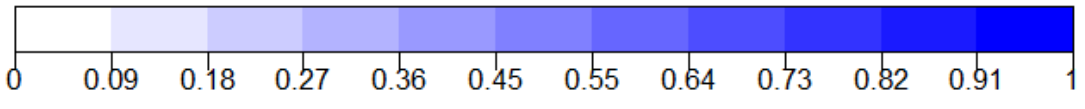

Figura APÊNDICE L-166 Correlação TSM HadISST versos ENA SE a) Correlação b) P-Valor 1984 - 2014 
APÊNDICE L.2.6 1984-2014 ERSST

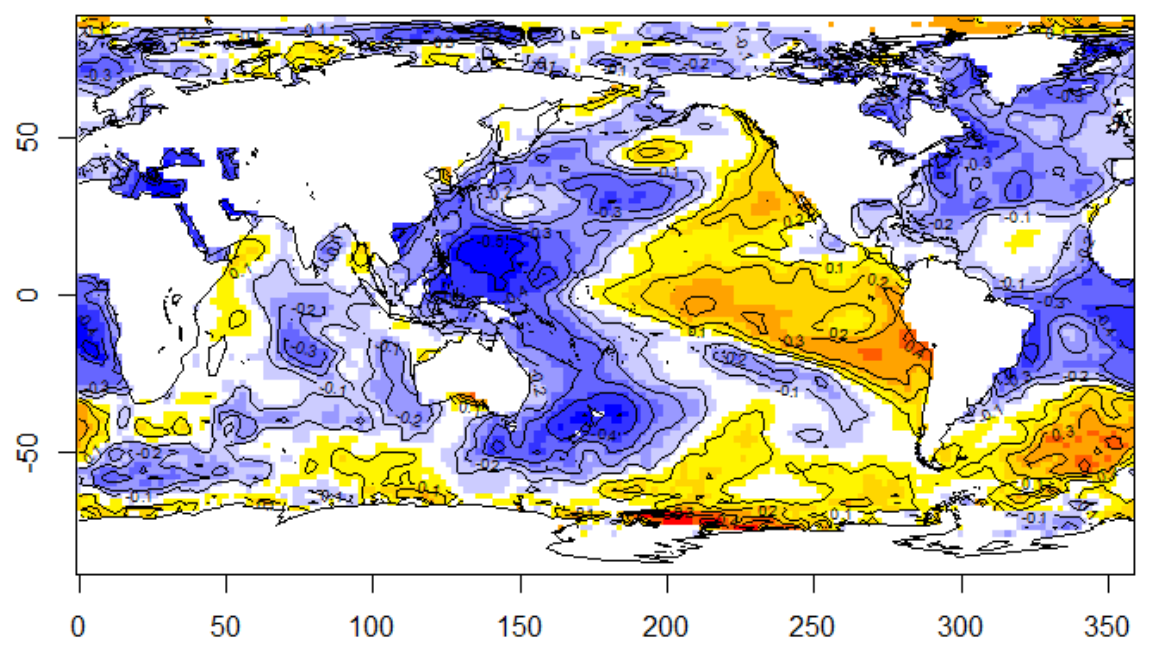

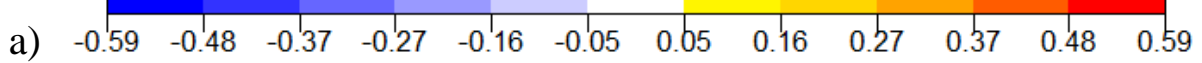

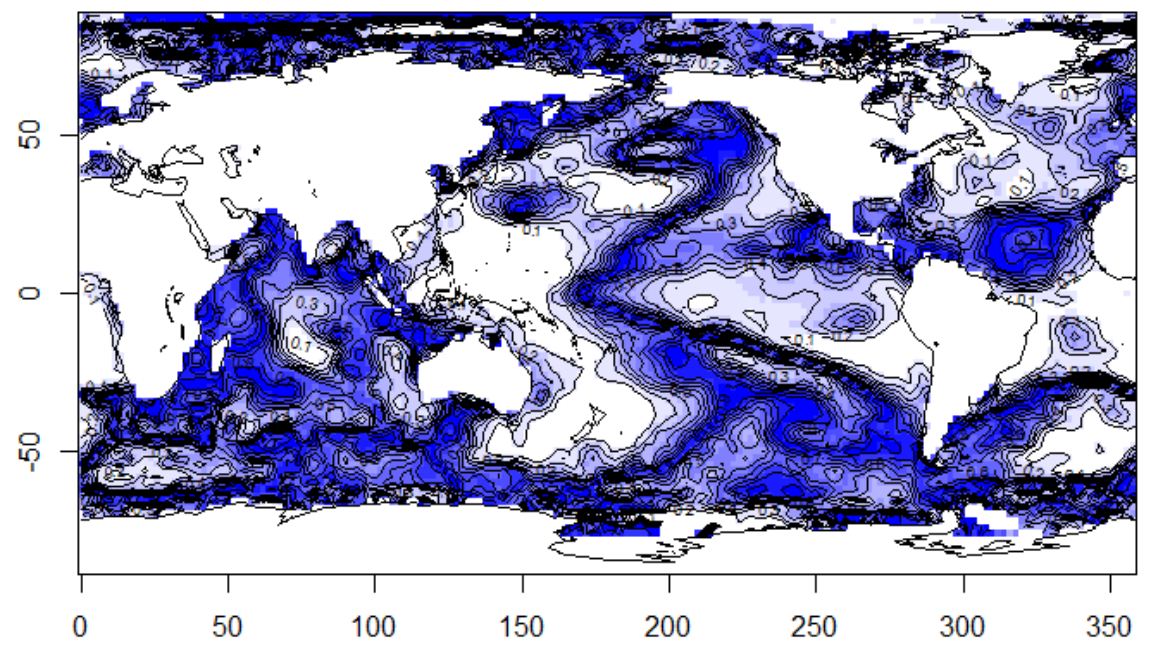

b)

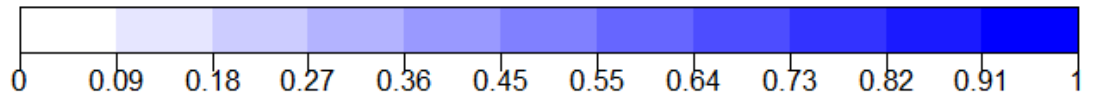

Figura APÊNDICE L-167 Correlação TSM ERSST versos ENA SE a) Correlação b) P-Valor 1984 - 2014 
APÊNDICE L.3 Correlação ENA Região Sul versos TSM dos oceanos

\section{APÊNDICE L.3.1 1931-2013 HadISST}

Ao correlacionar a TSM dos oceanos do mundo originária da base HadISST mensal do período de 1931 a 2013 e da ENA do Sul na Figura APÊNDICE L-168, apresentam-se a (a) correlação e o (b) nível de significância p-valor. É possível notar correlações em regiões do Oceano Pacífico equatorial e ao longo do litoral do Nordeste do Brasil em conjunto com a costa Leste da África. Notam-se correlações negativas no Oceano Pacífico a Oeste dos EUA, e positivas e negativas no mesmo por volta de $-50^{\circ} \mathrm{S}$.

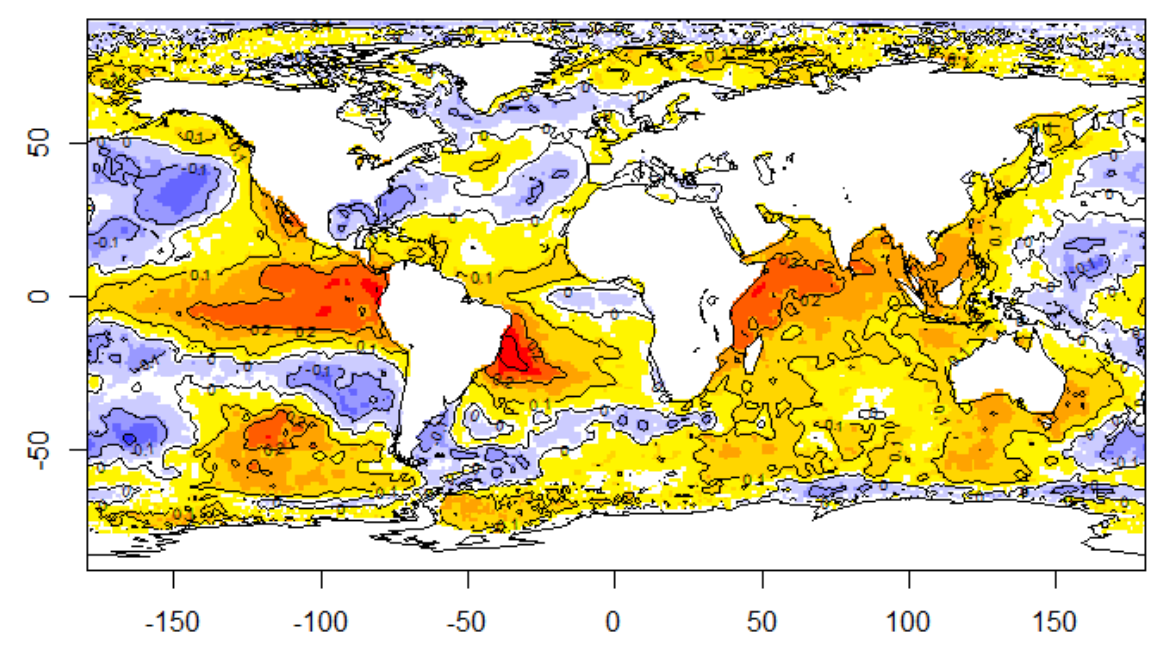

a)
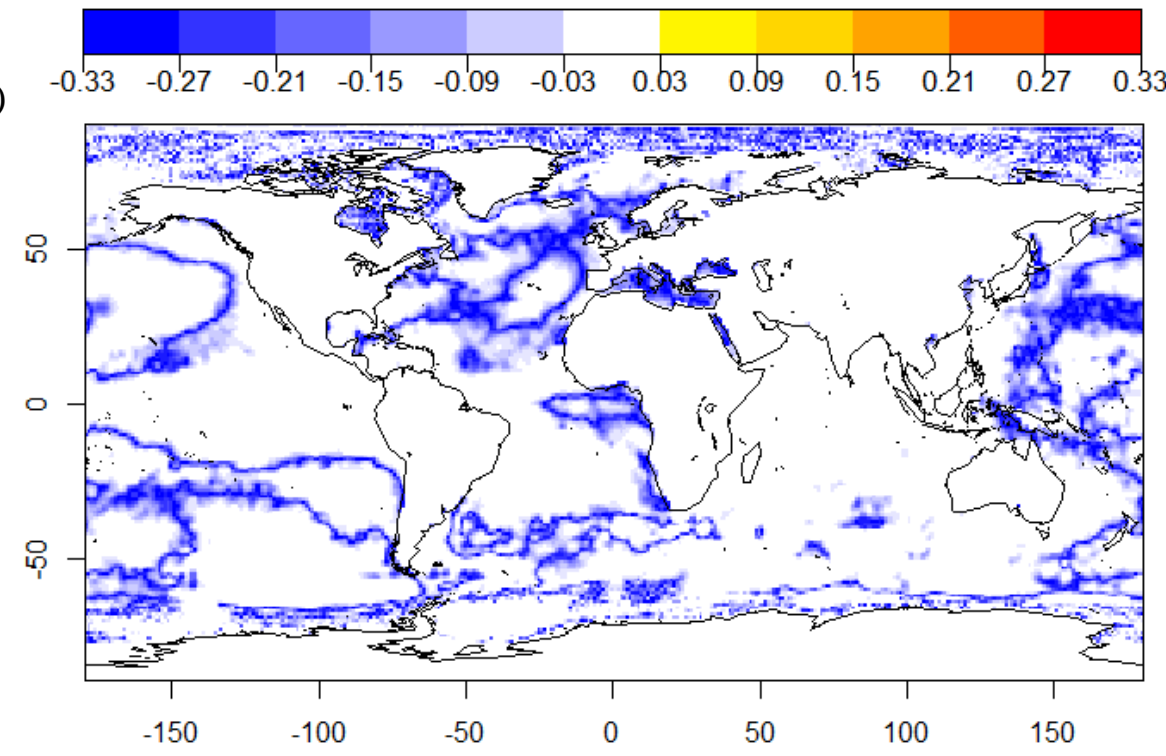

b)

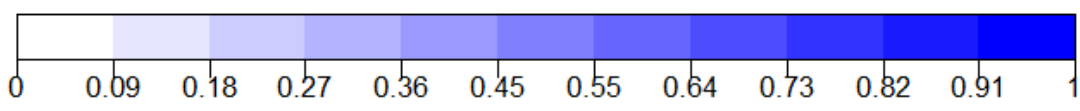

Figura APÊNDICE L-168 Correlação TSM HadISST versos ENA SUL a) Correlação b) P-Valor 1931 - 2013 


\section{APÊNDICE L.3.2 1931-2013 ERSST}

Ao correlacionar a TSM dos oceanos do mundo originária da base ERSST e da ENA do Sul na Figura APÊNDICE L-169, apresentam-se a (a) correlação e o (b) nível de significância pvalor. É possível notar correlações em regiões do Oceano Pacífico equatorial, sul entre $200^{\circ} \mathrm{e}$ $290^{\circ}$ de longitude e ao longo do litoral do Nordeste do Brasil, sul da Índia e Bangladesh. Correlações negativas são encontradas próximo ao Sul da Groelândia e litoral Leste dos EUA. Observa-se a significância concentrou-se no Pacífico, nas regiões ao Norte e ao Sul do Atlântico, no Oceano Índico a leste da África e Sul da Austrália.
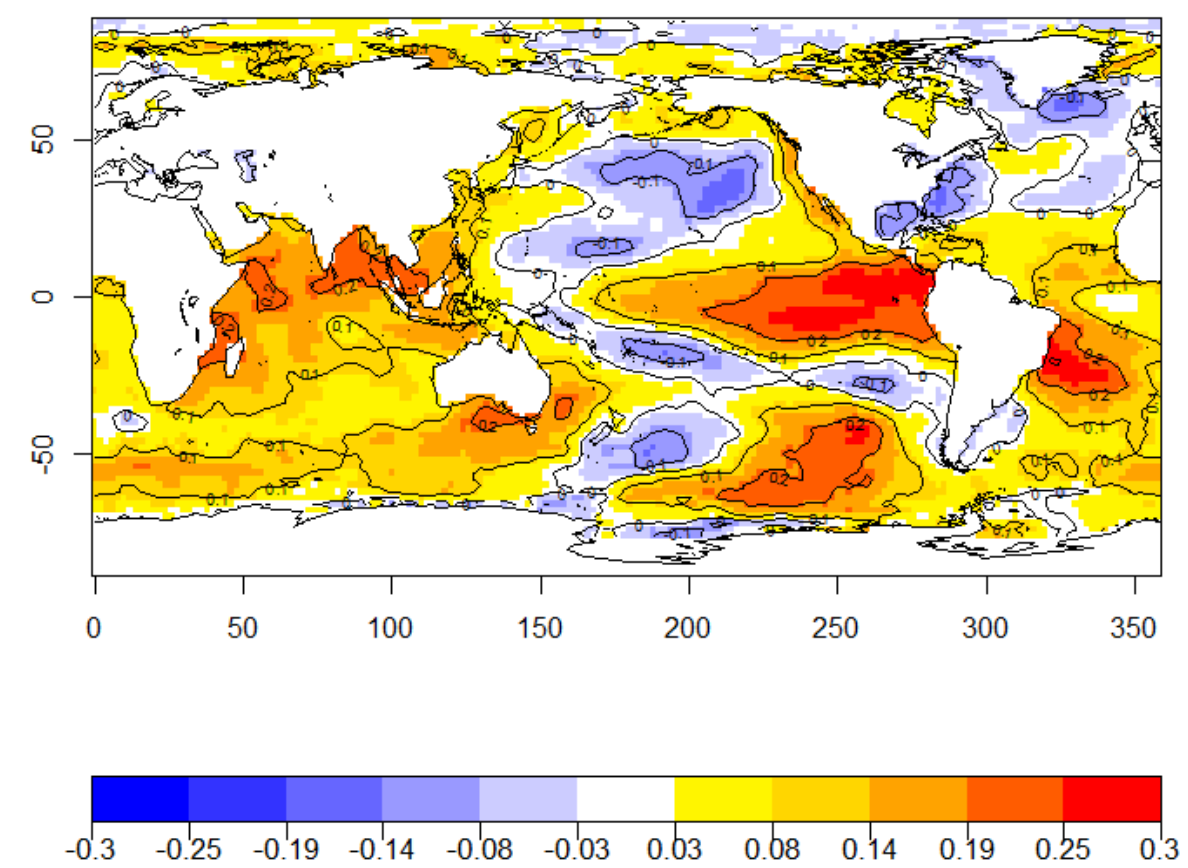

a)
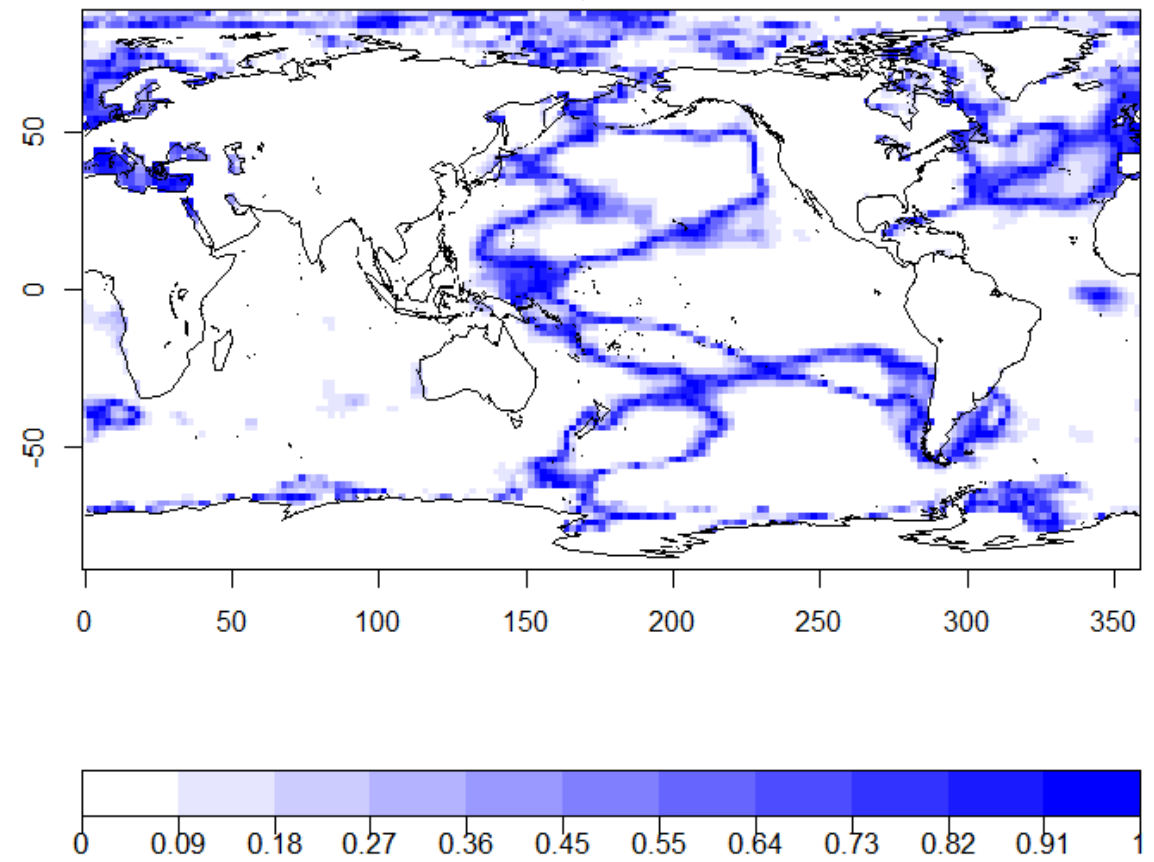

b)

Figura APÊNDICE L-169 Correlação TSM ERSST versos ENA SUL a) Correlação b) P-Valor 1931 - 2013 


\section{APÊNDICE L.3.3 1973-2013 HadISST}

Ao correlacionar a TSM dos oceanos do mundo originária da base HadISST mensal do período de 1973 a 2013 e da ENA do Sul, na Figura APÊNDICE L-170, apresentam-se a (a) correlação e o (b) nível de significância p-valor. É possível notar correlações em regiões do Oceano Pacífico equatorial, ao longo do litoral do Nordeste do Brasil e litoral Leste da África no Oceano Índico.

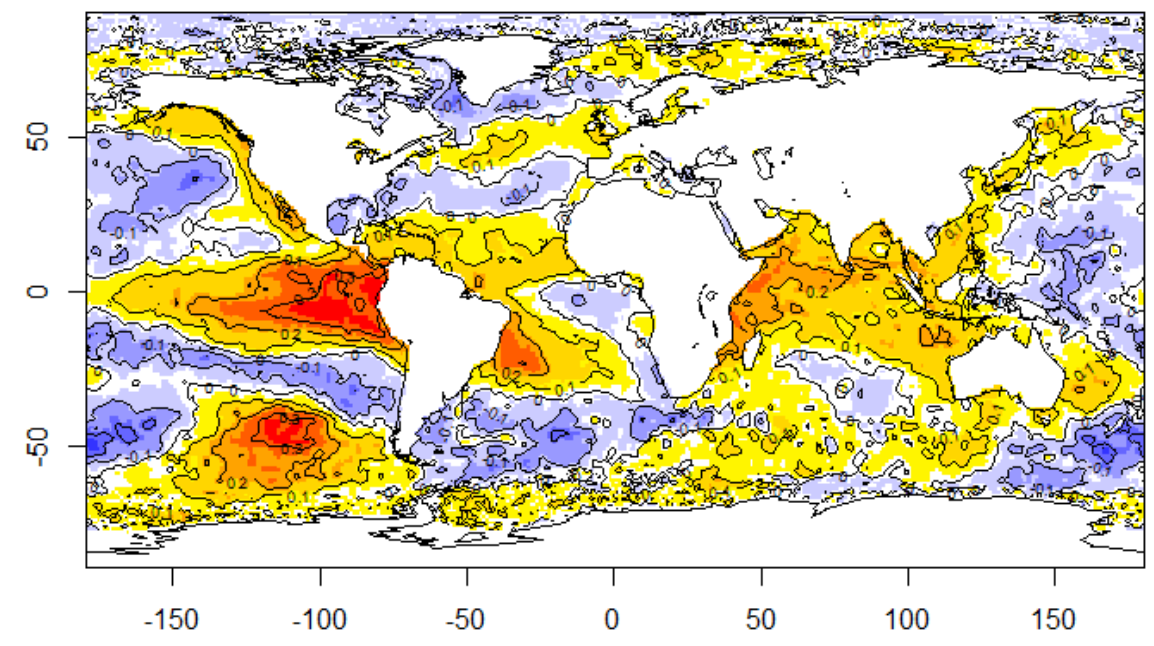

a)
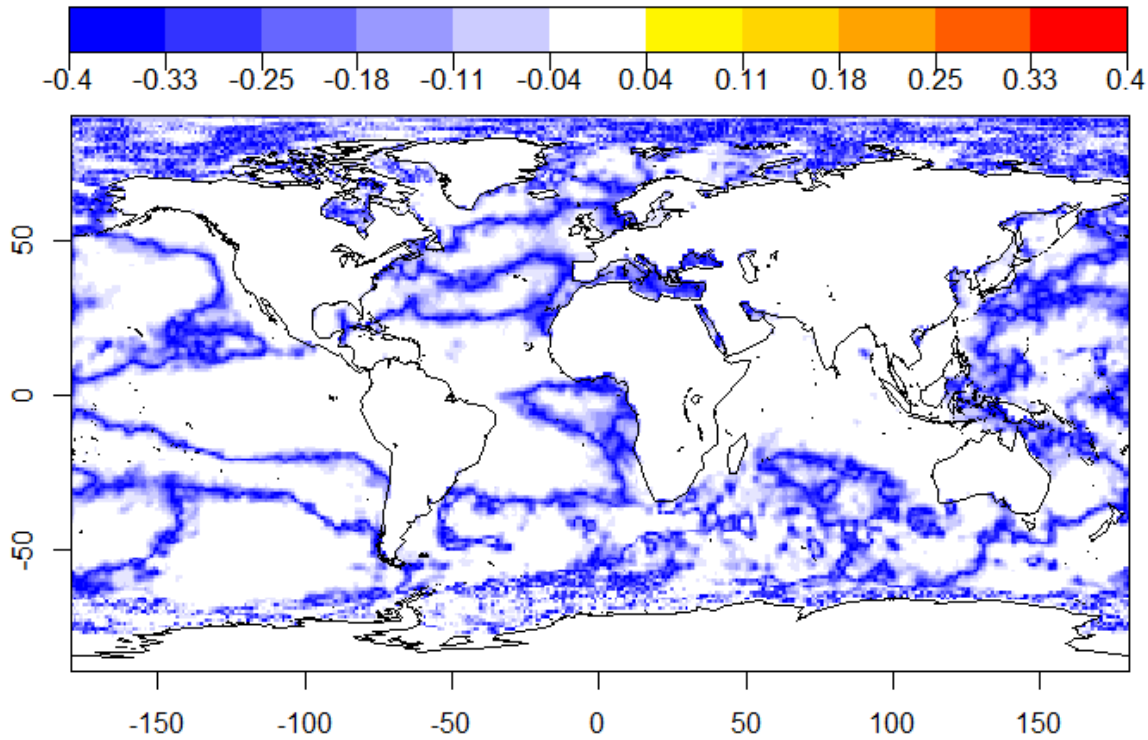

b)

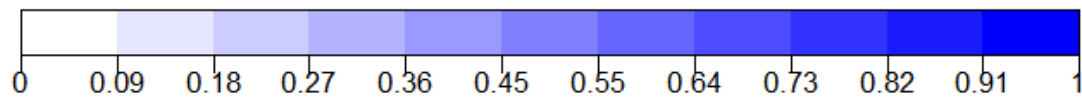

Figura APÊNDICE L-170 Correlação TSM HadISST versos ENA Sul a) Correlação b) P-Valor 1973 - 2013 


\section{APÊNDICE L.3.4 1973-2013 ERSST}

Ao correlacionar a TSM dos oceanos do mundo originária da base ERSST mensal do período de 1973 a 2013 e da ENA do Sul, na Figura APÊNDICE L-171, apresentam-se a (a) correlação e o (b) nível de significância p-valor. É possível notar correlações em regiões do Oceano Pacífico equatorial, Pacífico Sul e ao longo do litoral da Bahia no Brasil. A correlação negativa é encontrada no Oceano Pacífico a Sudeste da Austrália.

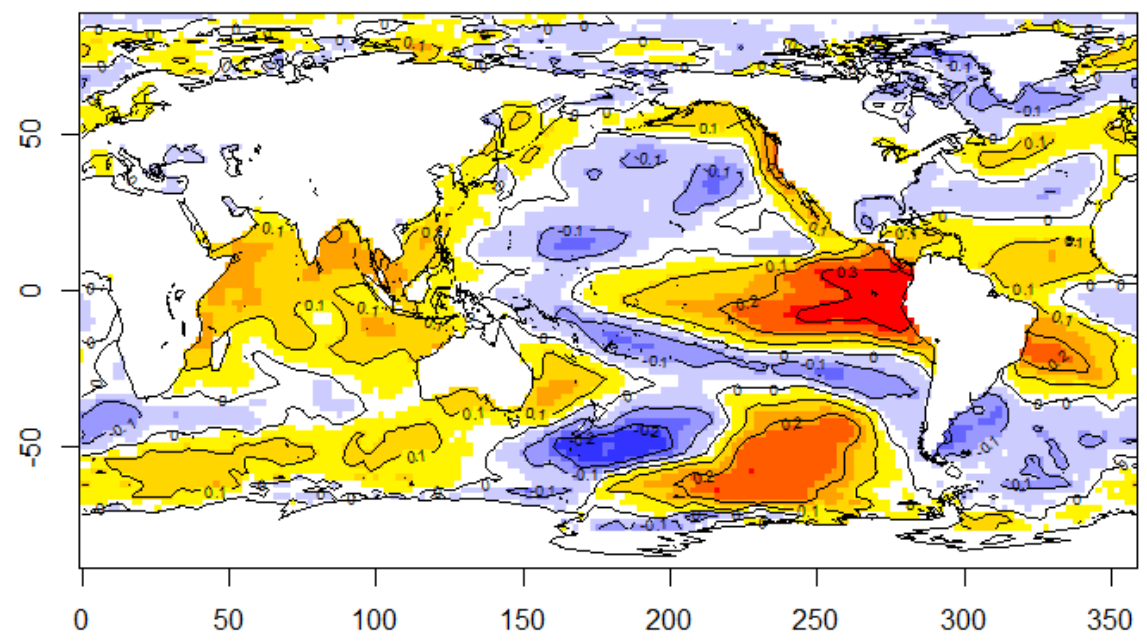

a)
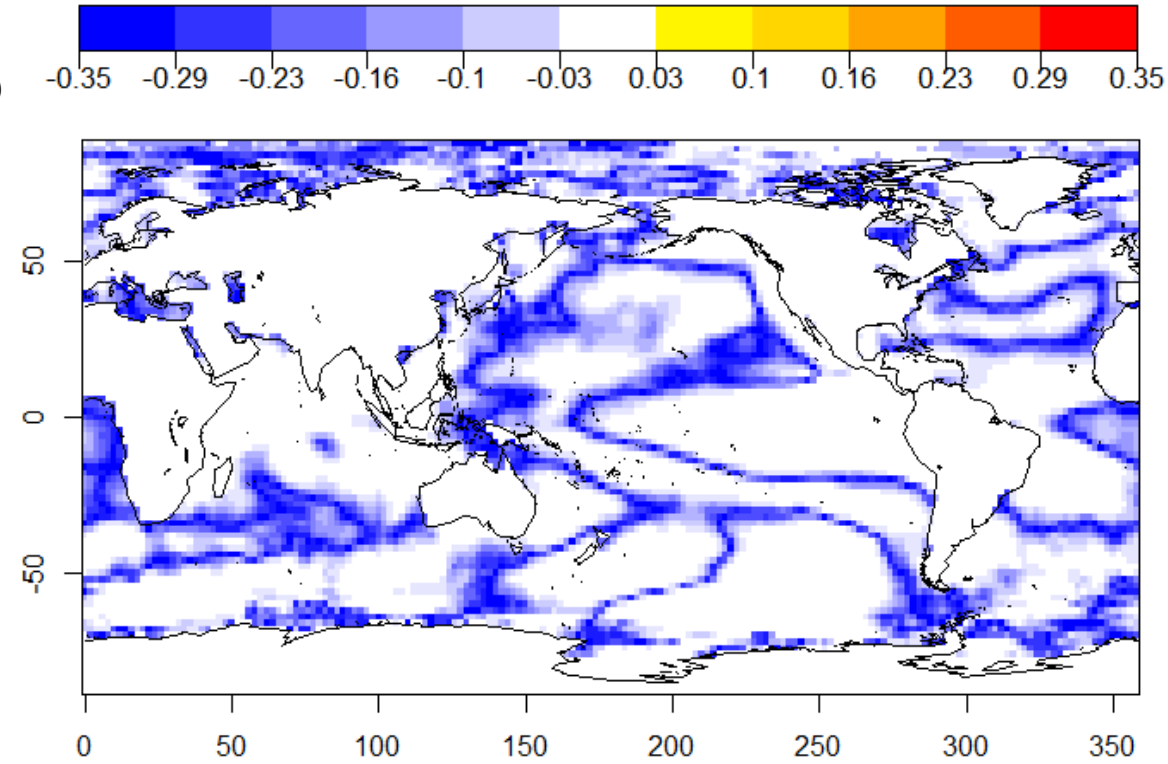

b)

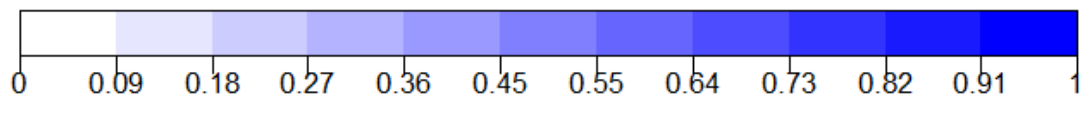

Figura APÊNDICE L-171 Correlação TSM ERSST versos ENA SUL a) Correlação b) P-Valor 1973 - 2013 


\section{APÊNDICE L.3.5 1983-2013 HadISST}

Ao correlacionar a TSM dos oceanos do mundo originária da base HadISST mensal do período de 1973 a 2013 e da ENA do Sul, na Figura APÊNDICE L-172, apresentam-se a (a) correlação e o (b) nível de significância p-valor. É possível notar correlações em regiões do Oceano Pacífico equatorial e Pacífico Sul, ao no Oceano Atlântico, próximo o litoral do Nordeste do Brasil e litoral Leste da África, no Oceano Índico e áreas com correlações negativas no Pacifico Sul, próxima ao Sudeste da Austrália.

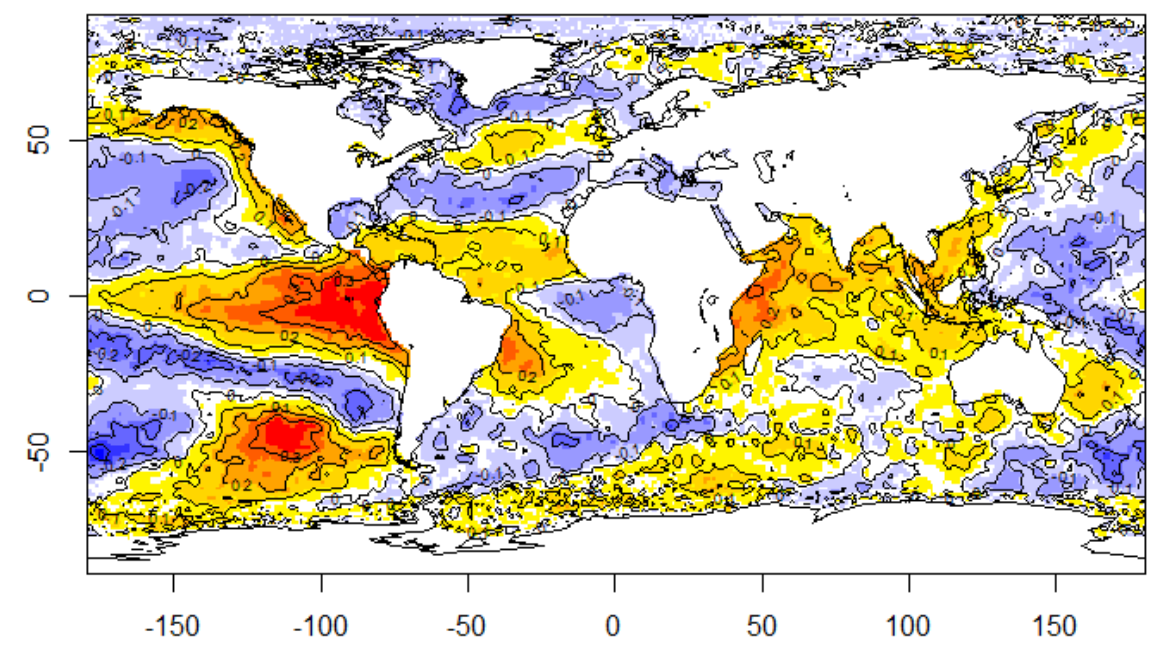

a)
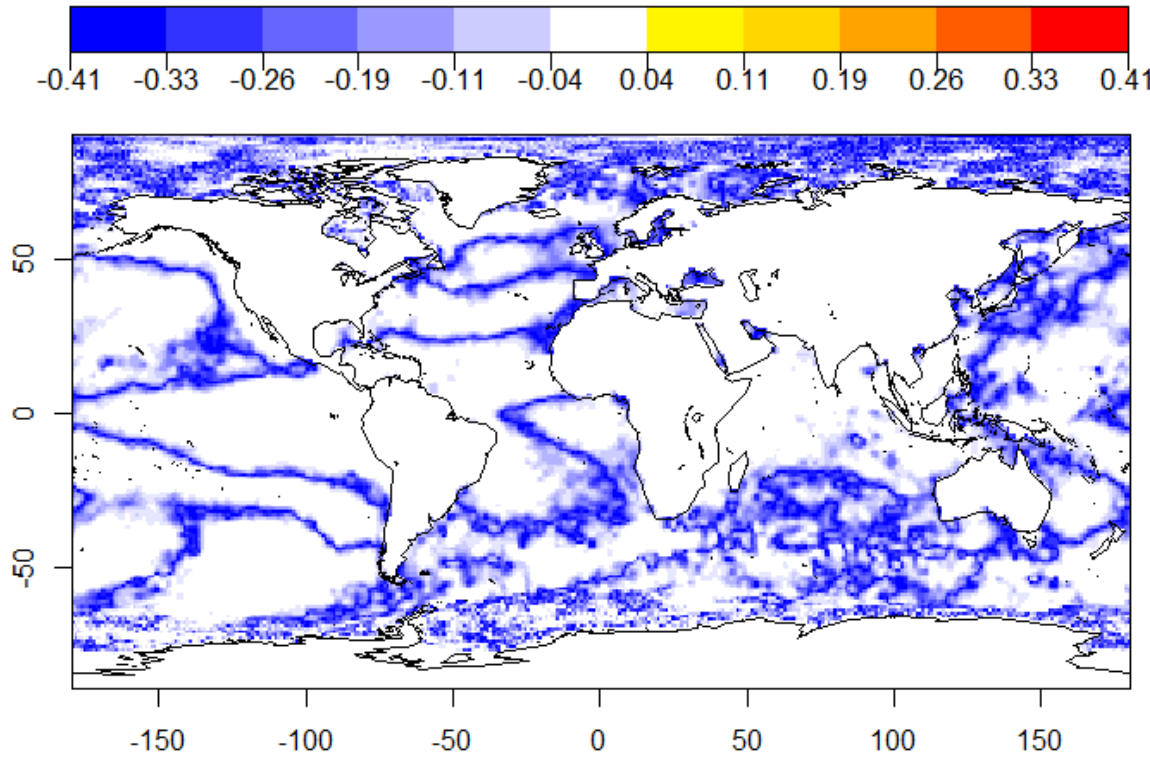

b)

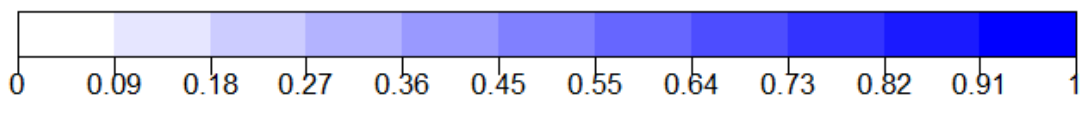

Figura APÊNDICE L-172 Correlação TSM HadISST versos ENA SUL a) Correlação b) P-Valor 1983 - 2013 


\section{APÊNDICE L.3.6 1983-2013 ERSST}

Ao correlacionar a TSM dos oceanos do mundo originária da base ERSST mensal do período de 1983 a 2013 e da ENA do Sul, na Figura APÊNDICE L-173, apresentam-se a (a) correlação e o (b) nível de significância p-valor. É possível notar correlações em regiões do Oceano Pacífico equatorial, Pacífico Sul e ao longo do litoral da Bahia no Brasil. A correlação negativa é encontrada no Oceano Pacífico a Sudeste da Austrália.

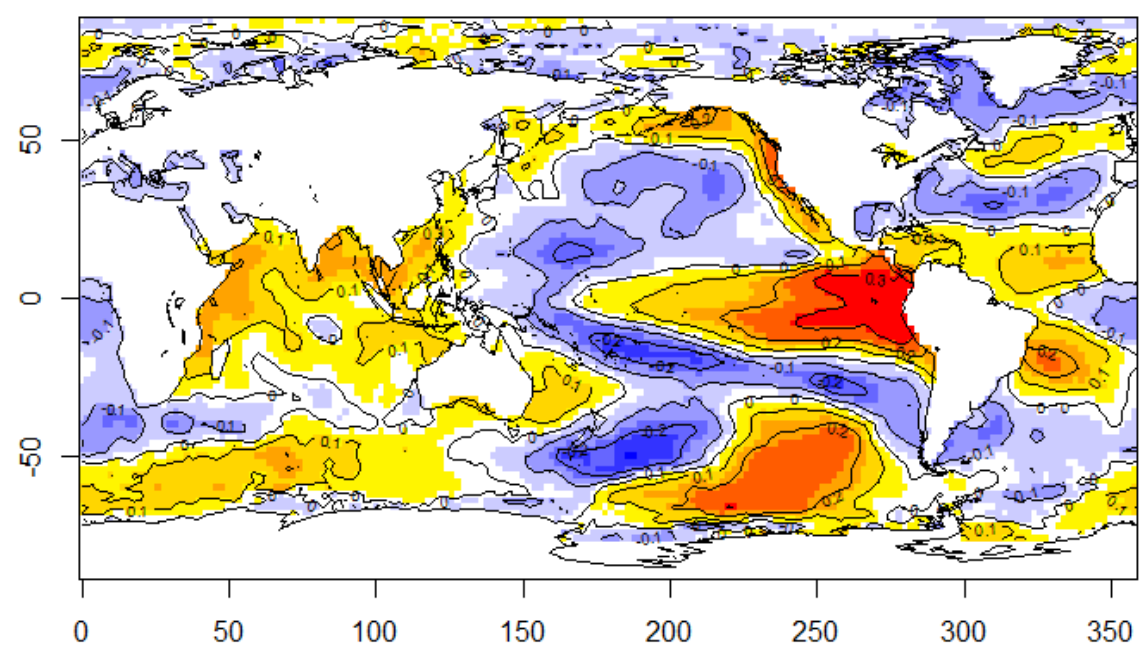

a)
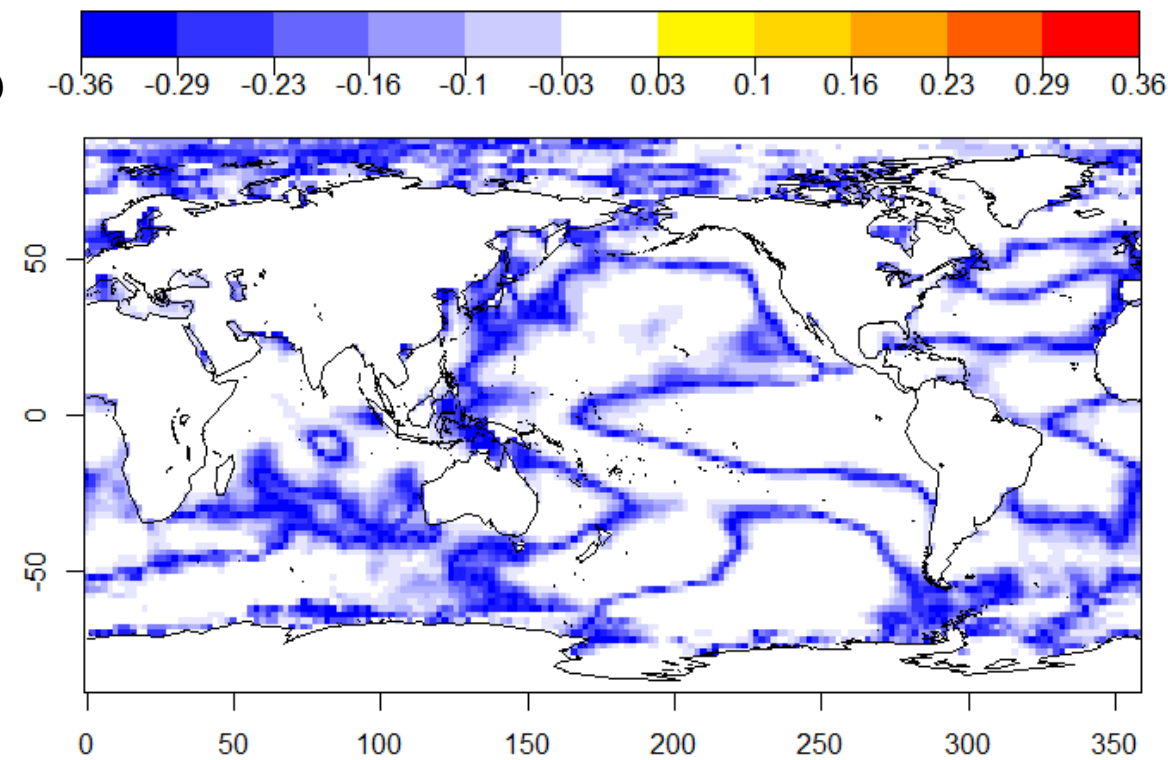

b)

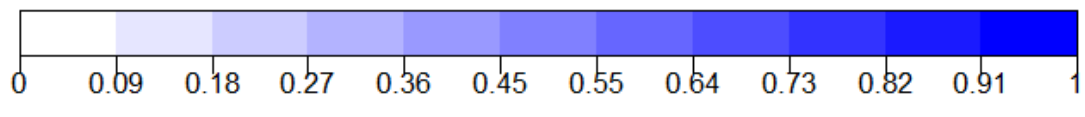

Figura APÊNDICE L-173 Correlação TSM ERSST versos ENA SUL a) Correlação b) P-Valor 1983 - 2013 
APÊNDICE L.4 Correlação ENA Região Norte versos TSM dos oceanos

APÊNDICE L.4.1 1931-2013 HadISST

Ao correlacionar a TSM dos oceanos do mundo originária da base HadISST mensal do período de 1931 a 2013 e da ENA da Região Norte, na Figura APÊNDICE L-174, apresentam-se a (a) correlação e o (b) nível de significância p-valor. É possível notar correlações em regiões do Oceano Pacífico Norte, próximo aos EUA, ao Sul Próximo a América Sul e ao Sul do Atlântico. São encontradas correlações negativas no Norte do Pacífico, Oceano Atlântico Leste dos EUA, próximo ao litoral do Nordeste de Brasil, Oceano Indico, Nordeste da Austrália e positivas e negativas no mesmo oceano por volta de $-50^{\circ} \mathrm{S}$.

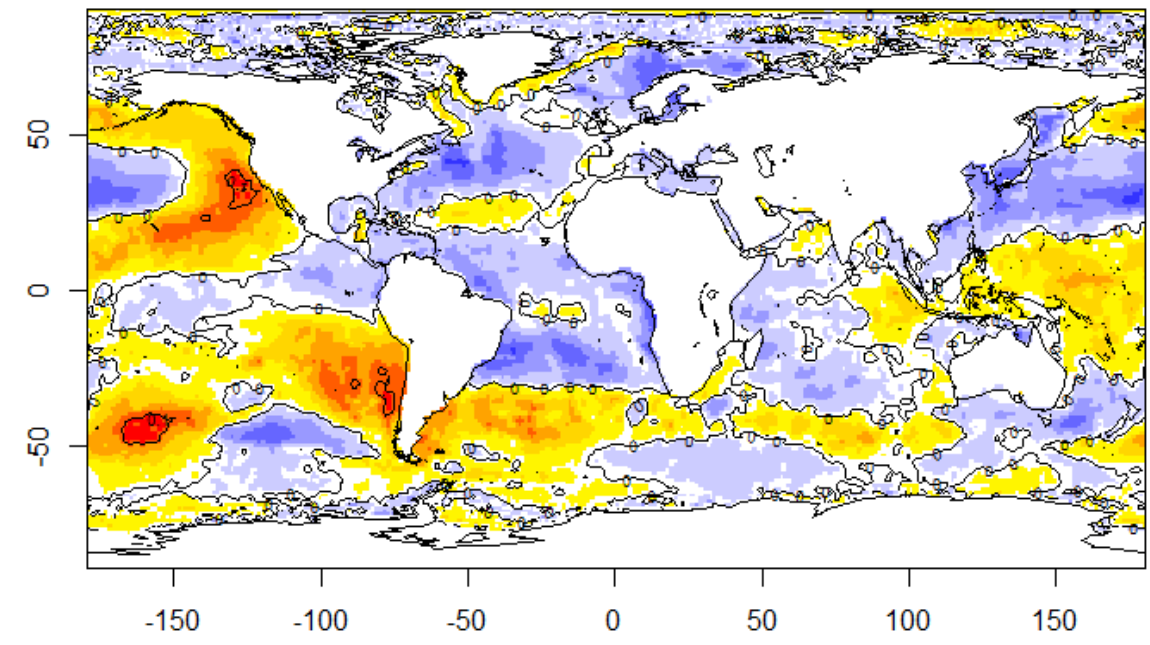

a)
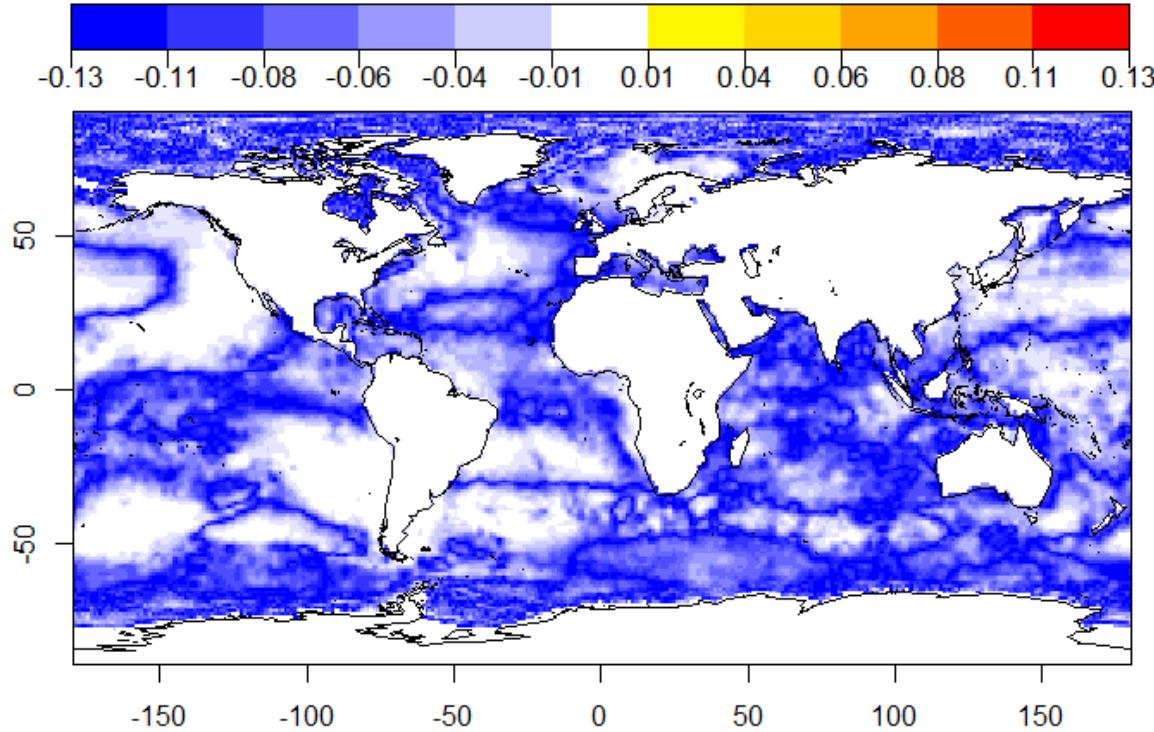

b)

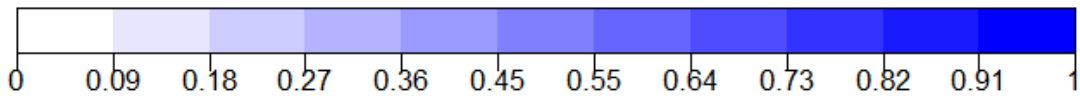

Figura APÊNDICE L-174 Correlação TSM HadISST versos ENA NORTE a) Correlação b) P-Valor 1931 - 2013 


\section{APÊNDICE L.4.2 1931-2013 ERSST}

Ao correlacionar a TSM dos oceanos do mundo originária da base ERSST e da ENA do Norte, na Figura APÊNDICE L-175, apresentam-se a (a) correlação e o (b) nível de significância p-valor. É possível notar correlações em regiões do Oceano Pacífico Norte e Sul tendo esse correlações positivas e negativas.

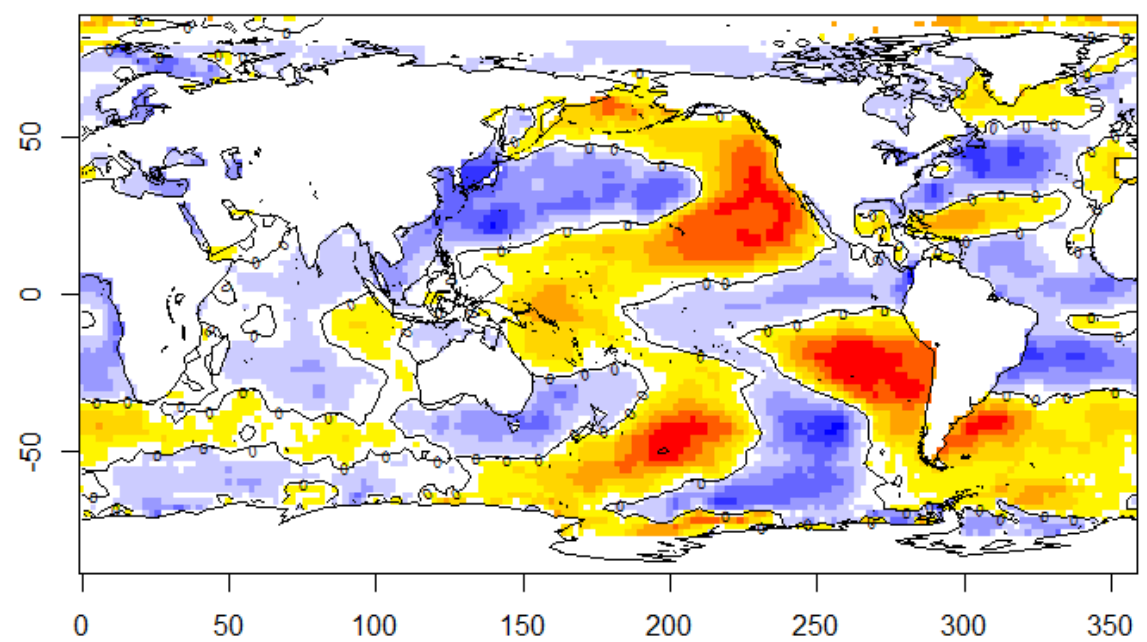

a)
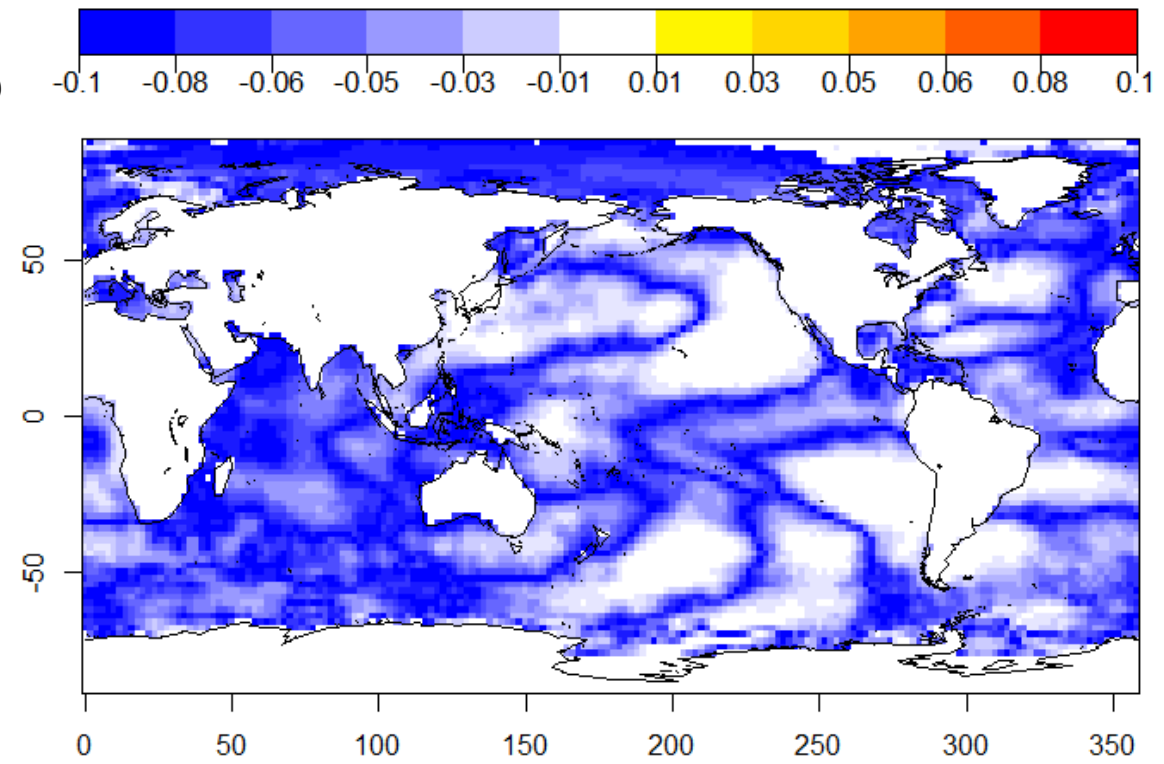

b)

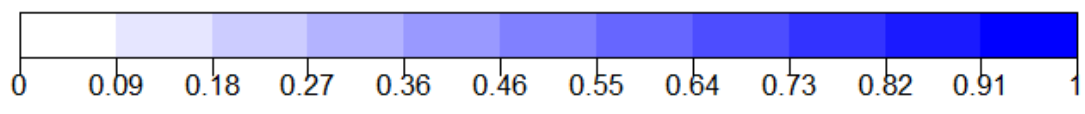

Figura APÊNDICE L-175 Correlação TSM ERSST versos ENA NORTE a) Correlação b) P-Valor 1931 - 2013 


\section{APÊNDICE L.4.3 1973-2013 HadISST}

Ao correlacionar a TSM dos oceanos do mundo originária da base HadISST mensal do período de 1973 a 2013 e da ENA do Norte, na Figura APÊNDICE L-176, apresentam-se a (a) correlação e o (b) nível de significância p-valor. É possível notar correlações em regiões do Oceano Pacífico equatorial e negativas ao longo do litoral Oeste da África e Norte e Sul do Oceano Pacífico mais ao Leste próximo da Austrália.

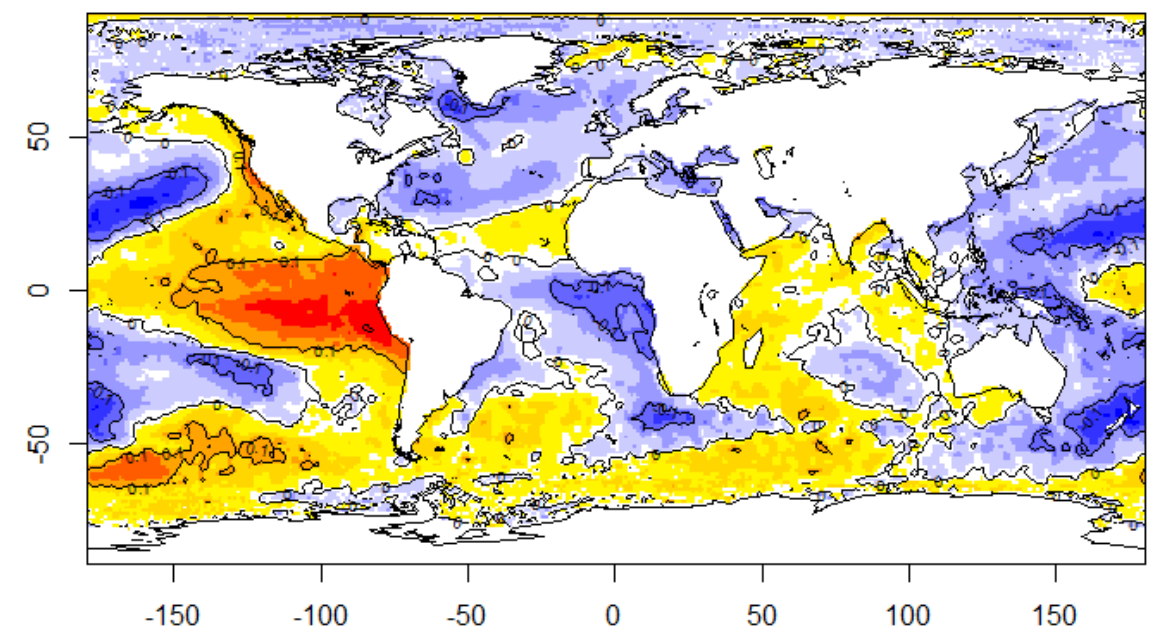

a)
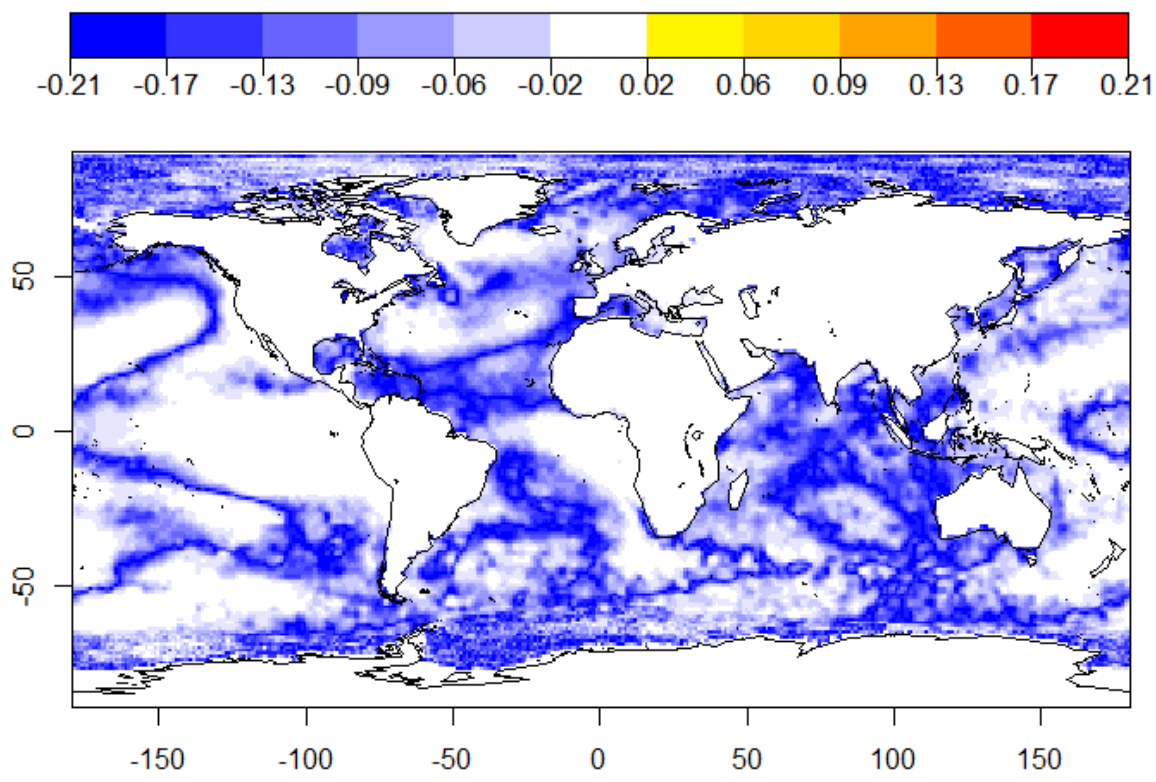

b)

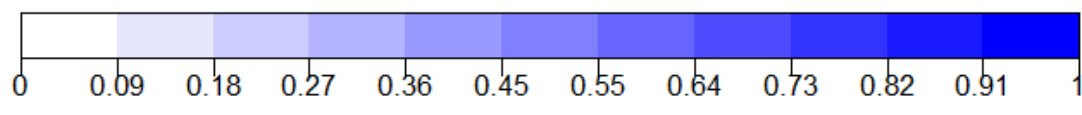

Figura APÊNDICE L-176 Correlação TSM HadISST versos ENA NORTE a) Correlação b) P-Valor 1973 - 2013 


\section{APÊNDICE L.4.4 1973-2013 ERSST}

Ao correlacionar a TSM dos oceanos do mundo originária da base ERSST mensal do período de 1973 a 2013 e da ENA da Região Norte, na Figura APÊNDICE L-177, apresentam-se a (a) correlação e o (b) nível de significância p-valor. É possível notar correlações em regiões do Oceano Pacífico equatorial próximo ao Peru, Pacífico Sul em torno de $250^{\circ}$ de longitude e ao longo do litoral da Bahia no Brasil. São encontradas correlação negativa no Oceano Pacífico a Sudeste da Austrália e Oceano Índico ao Sul da Índia e Norte do Japão.

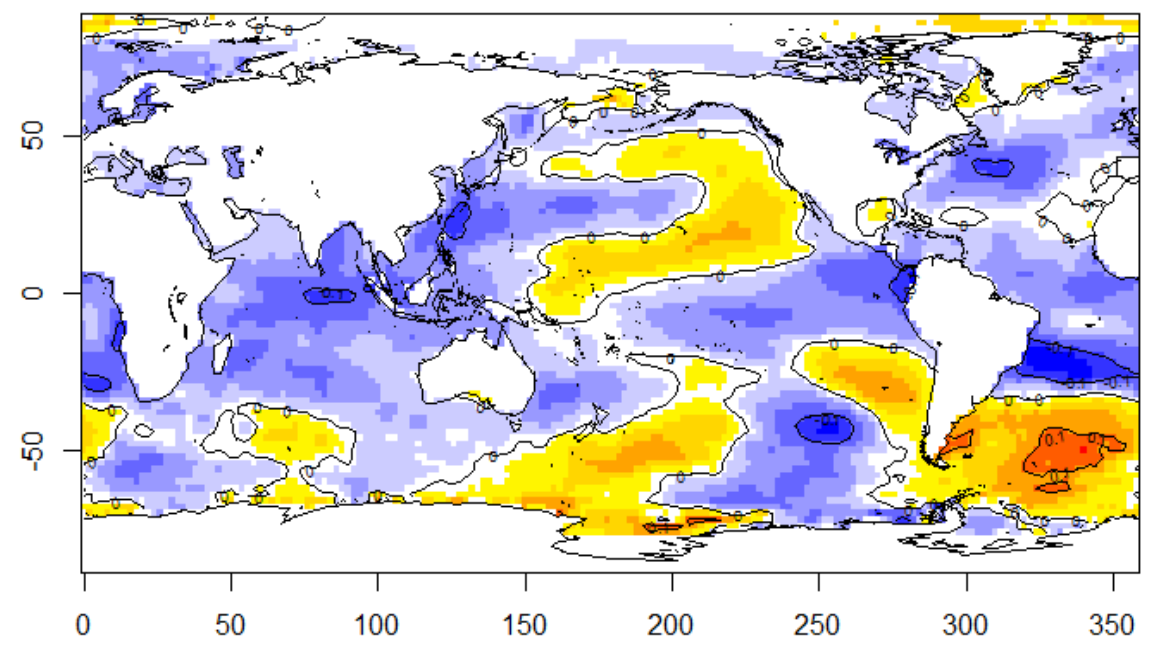

a)
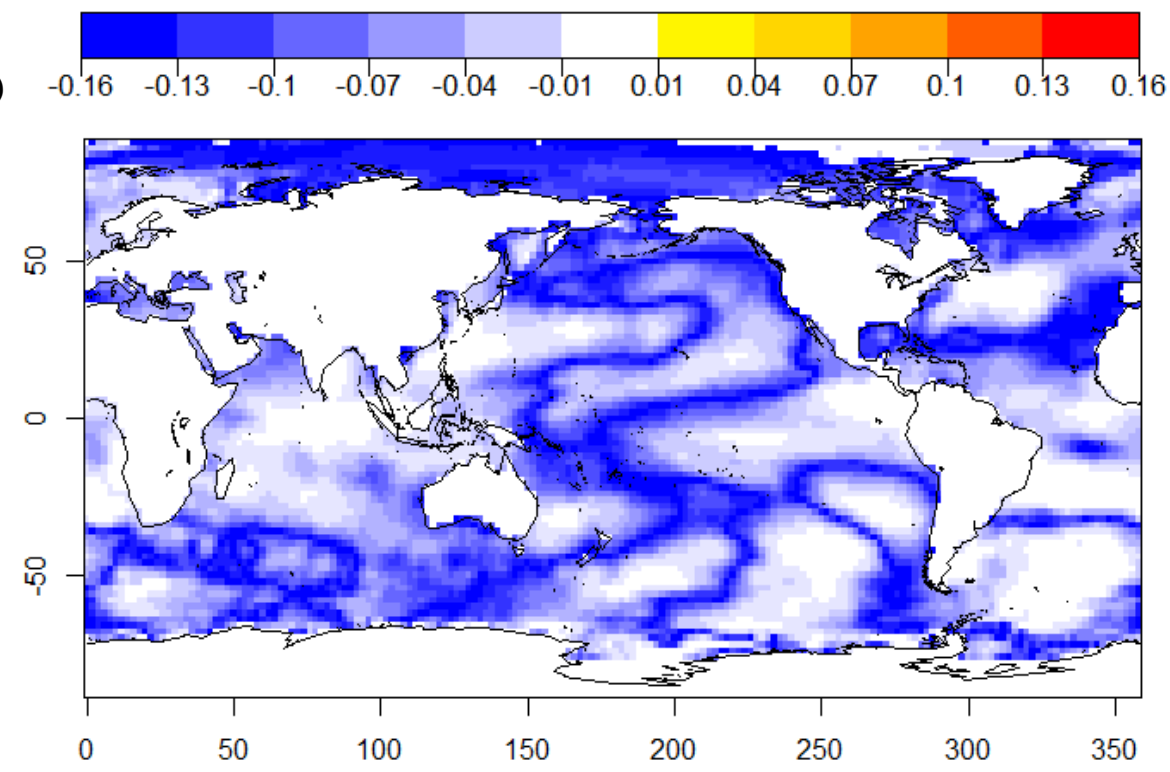

b)

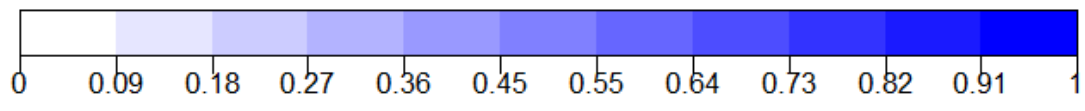

Figura APÊNDICE L-177 Correlação TSM ERSST versos ENA NORTE a) Correlação b) P-Valor 1973 - 2013 


\section{APÊNDICE L.4.5 1983-2013 HadISST}

Ao correlacionar a TSM dos oceanos do mundo originária da base HadISST mensal do período de 1973 a 2013 e da ENA do Norte, na Figura APÊNDICE L-178, apresentam-se a (a) correlação e o (b) nível de significância p-valor. É possível notar correlações negativas em regiões do Oceano Pacífico equatorial e Pacífico Sul, Oceano Atlântico próximo ao litoral do Nordeste do Brasil e litoral Leste da África, Oceano Índico e áreas com correlações positivas no Atlântico Sul.

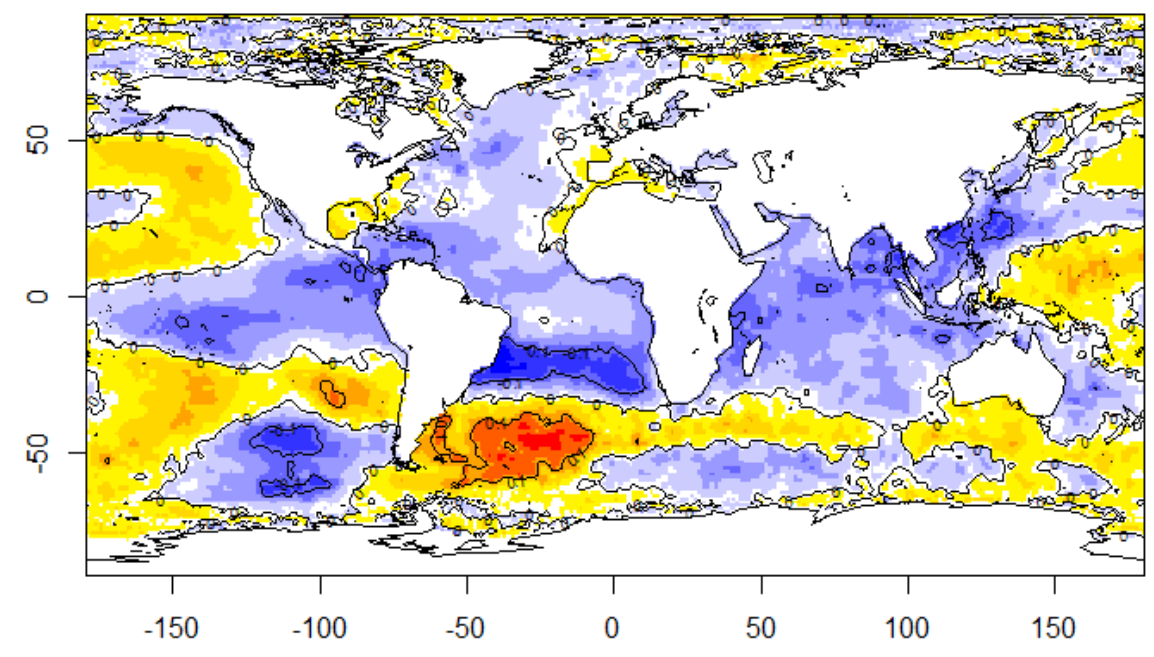

a)
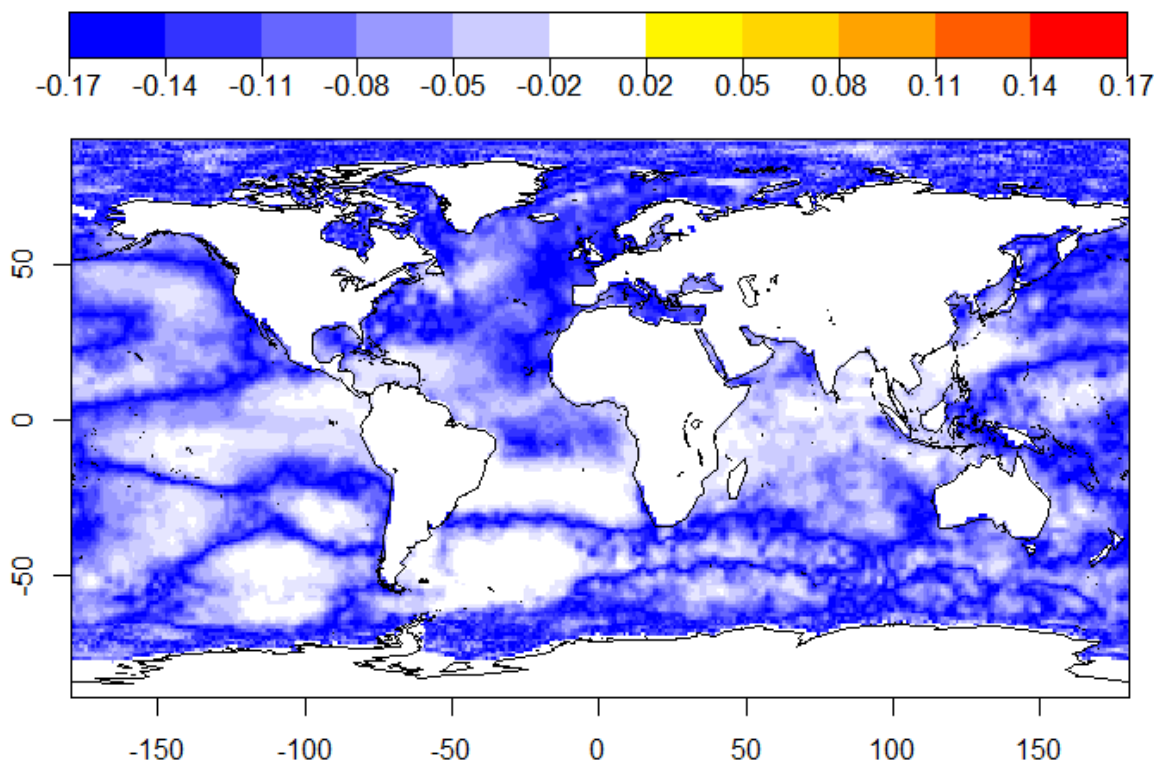

b)

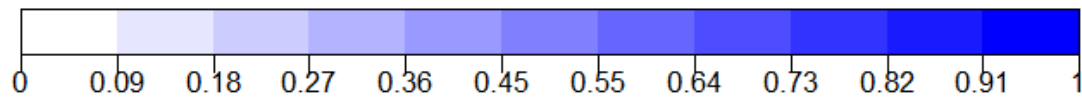

Figura APÊNDICE L-178 Correlação TSM HadISST versos ENA NORTE a) Correlação b) P-Valor 1983 - 2013 


\section{APÊNDICE L.4.6 1983-2013 ERSST}

Ao correlacionar a TSM dos oceanos do mundo originária da base ERSST mensal do período de 1983 a 2013 e da ENA do Norte, na Figura APÊNDICE L-179, apresentam-se a (a) correlação e o (b) nível de significância p-valor. É possível notar correlações negativas em regiões do Oceano Pacífico Sul e Pacífico Norte, próximo ao Peru, e positivas ao Sul do Oceano Atlântico.

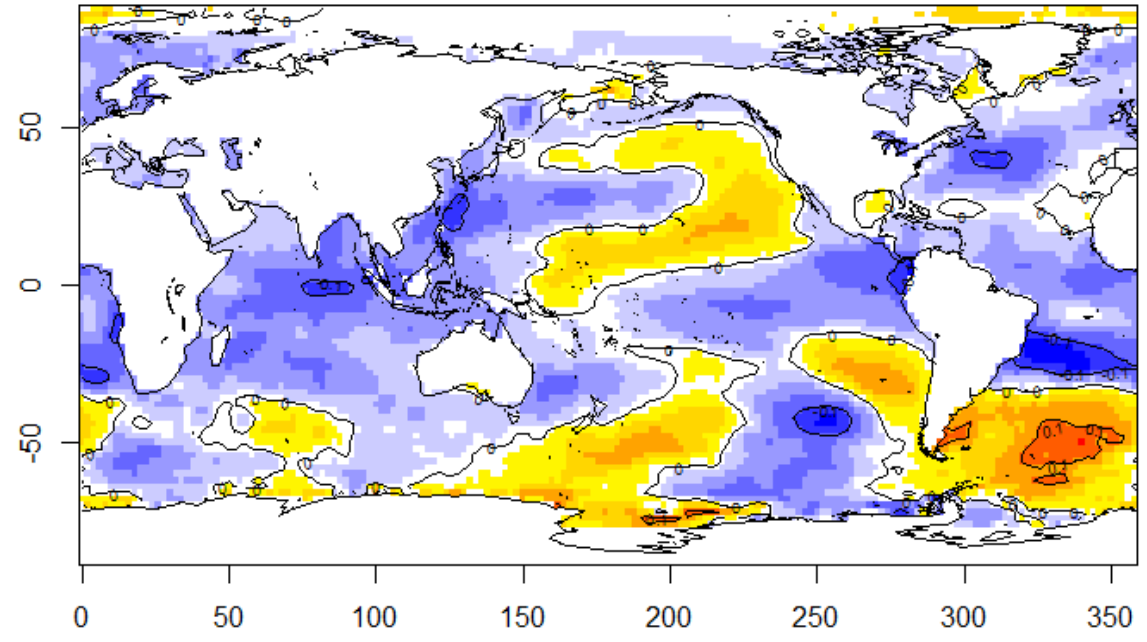

a)
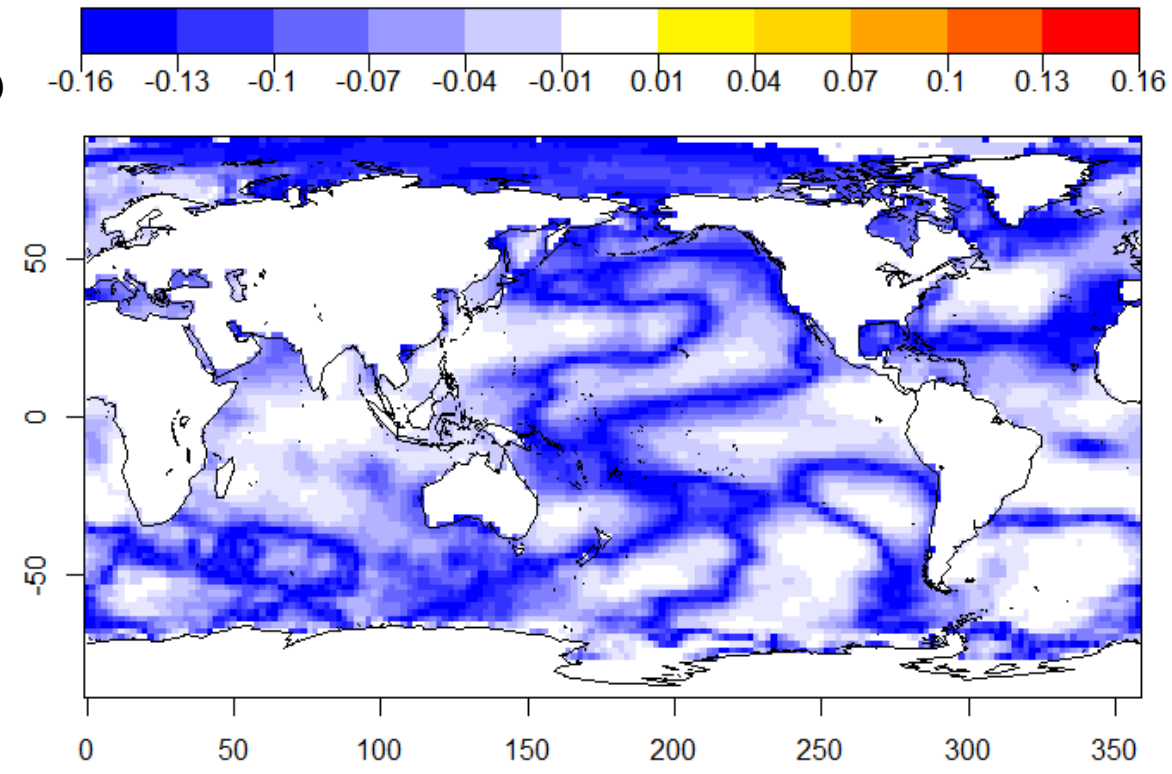

b)

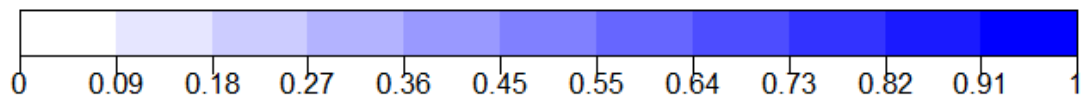

Figura APÊNDICE L-179 Correlação TSM ERSST versos ENA NORTE a) Correlação b) P-Valor 1983 - 2013 
APÊNDICE L.5 Correlação ENA Região Nordeste versos TSM dos oceanos

APÊNDICE L.5.1 1931-2013 HadISST

Ao correlacionar a TSM dos oceanos do mundo originária da base HadISST mensal do período de 1931 a 2013 e da ENA da Região Nordeste, na Figura APÊNDICE L-180 , apresentam-se a (a) correlação e o (b) nível de significância p-valor. É possível notar correlações em regiões do Oceano Pacífico Sul, próximo à costa Oeste da América do Sul e na altura da longitude $-150^{\circ}$. As correlações negativas são encontradas próximo ao litoral do Nordeste de Brasil, Oceano Indico e Sudeste da Austrália.

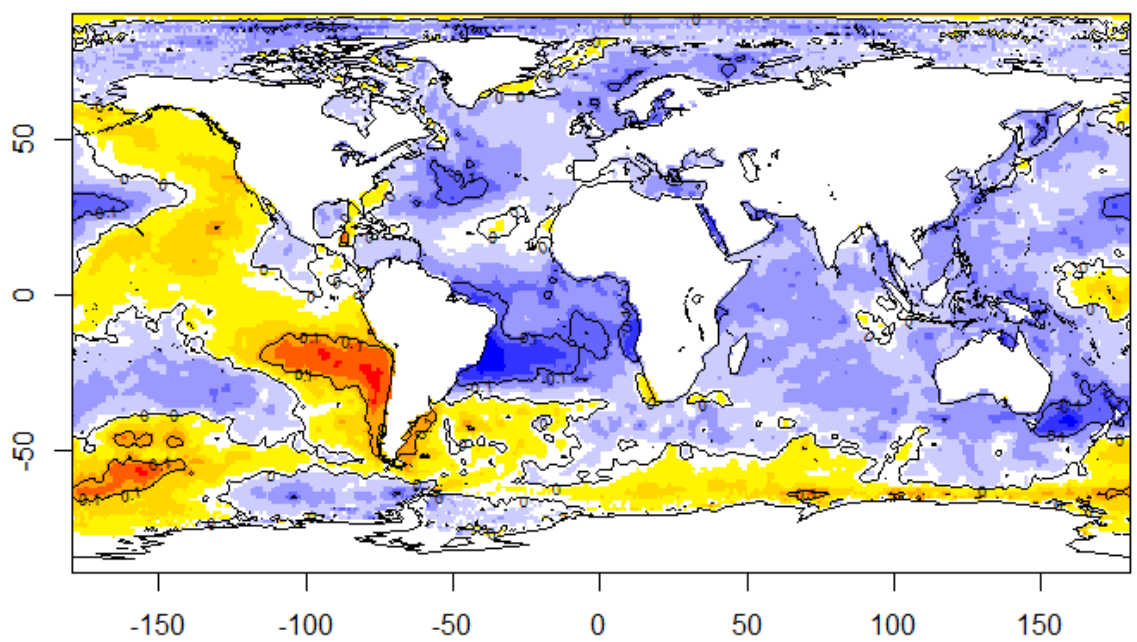

a)
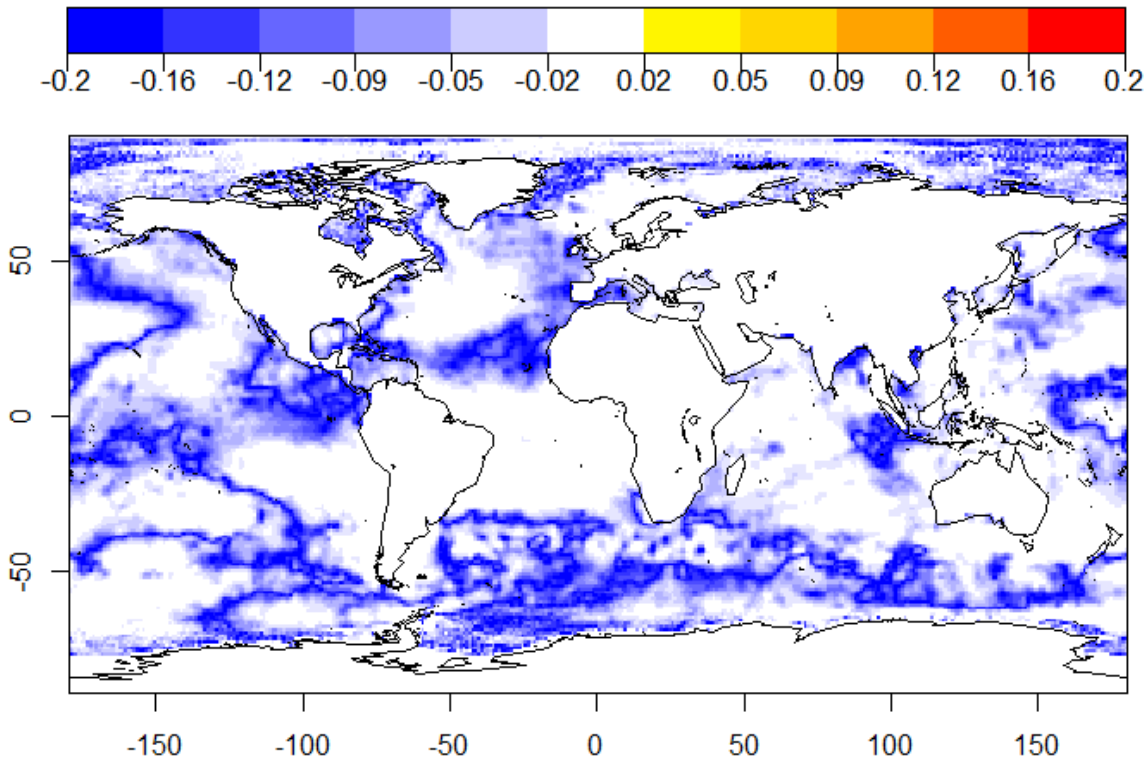

b)

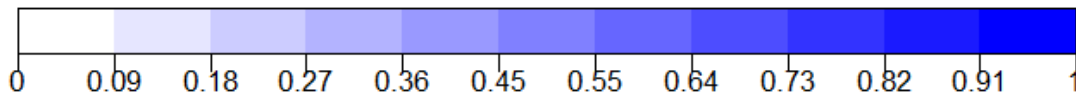

Figura APÊNDICE L-180 Correlação TSM HadISST versos ENA NORDESTE a) Correlação b) P-Valor 1931 2013 


\section{APÊNDICE L.5.2 1931-2013 ERSST}

Ao correlacionar a TSM dos oceanos do mundo originária da base ERSST e da ENA do Nordeste, na Figura APÊNDICE L-181, apresentam-se a (a) correlação e o (b) nível de significância p-valor. É possível notar correlações negativas em regiões do Oceano Pacífico Sul entre as longitudes $150^{\circ}$ e $250^{\circ}$ e no Atlântico Sul. As correlações positivas são encontradas no Pacífico Sul próximo a América do Sul.

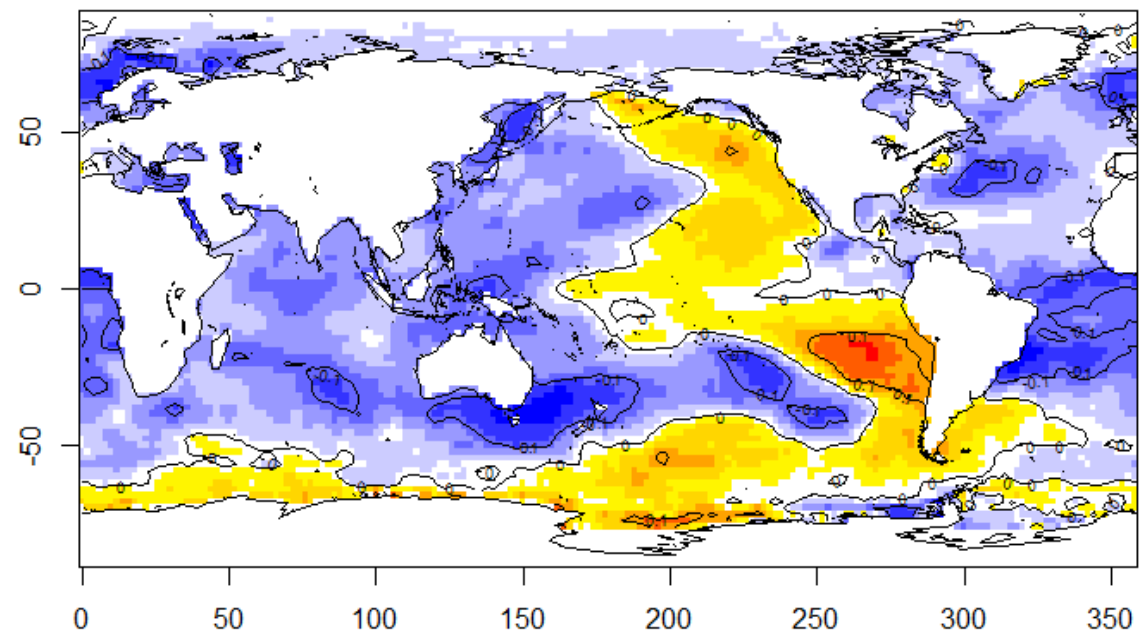

a)
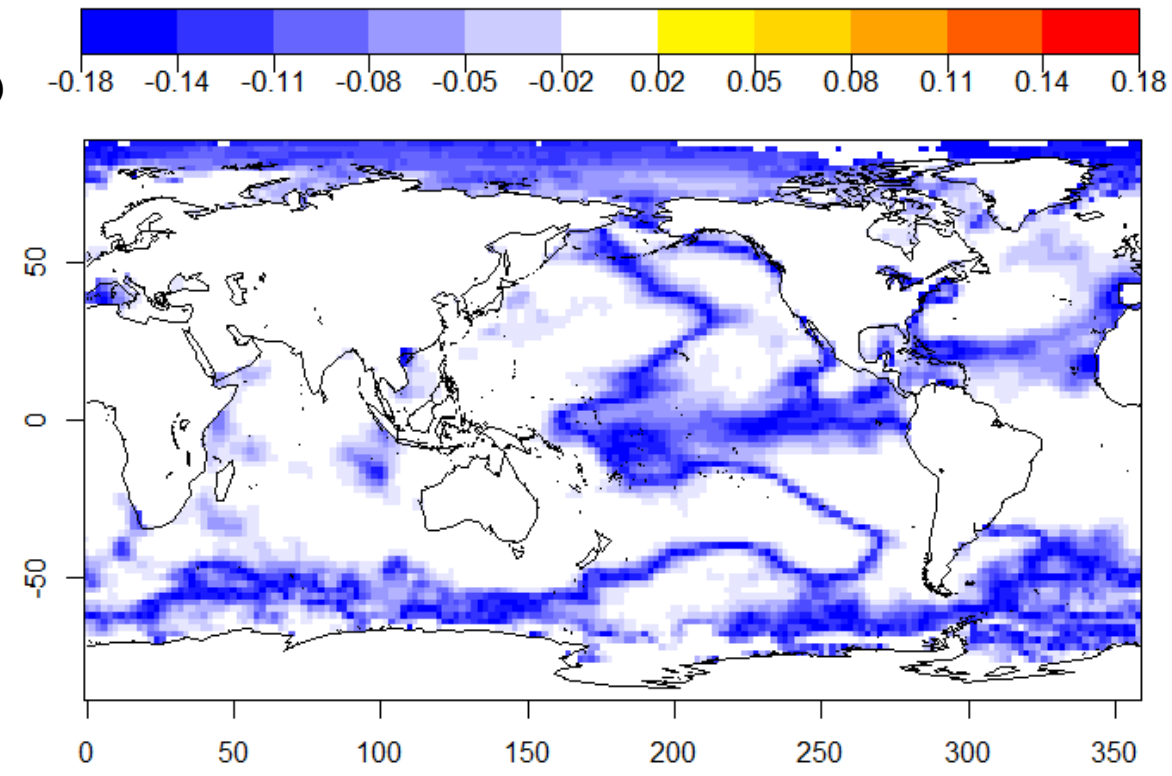

b)

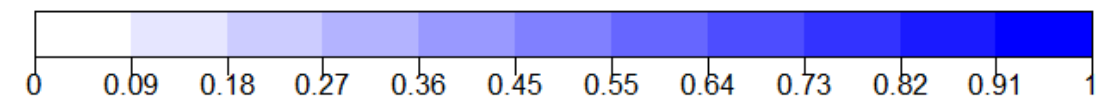

Figura APÊNDICE L-181 Correlação TSM ERSST versos ENA NORDESTE a) Correlação b) P-Valor 1931 - 2013 


\section{APÊNDICE L.5.3 1973-2013 HadISST}

Ao correlacionar a TSM dos oceanos do mundo originária da base HadISST mensal do período de 1973 a 2013 e da ENA do Nordeste, na Figura APÊNDICE L-182, apresentam-se a (a) correlação e o (b) nível de significância p-valor. É possível notar correlações em regiões do Oceano Pacífico Sul, próximo à costa Oeste da América do Sul e na altura da longitude $150^{\circ}$. Nota-se correlações negativas próximo ao litoral Nordeste de Brasil, Oceano Indico, Sudeste e Sudoeste da Austrália.

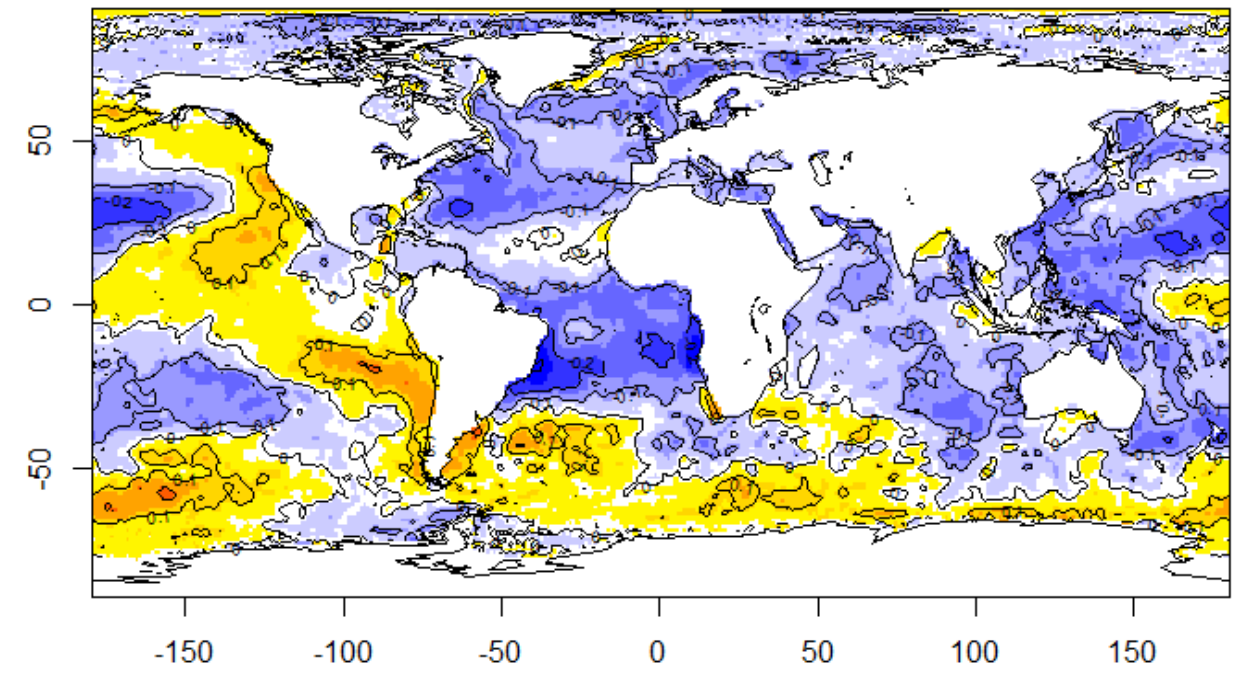

a)
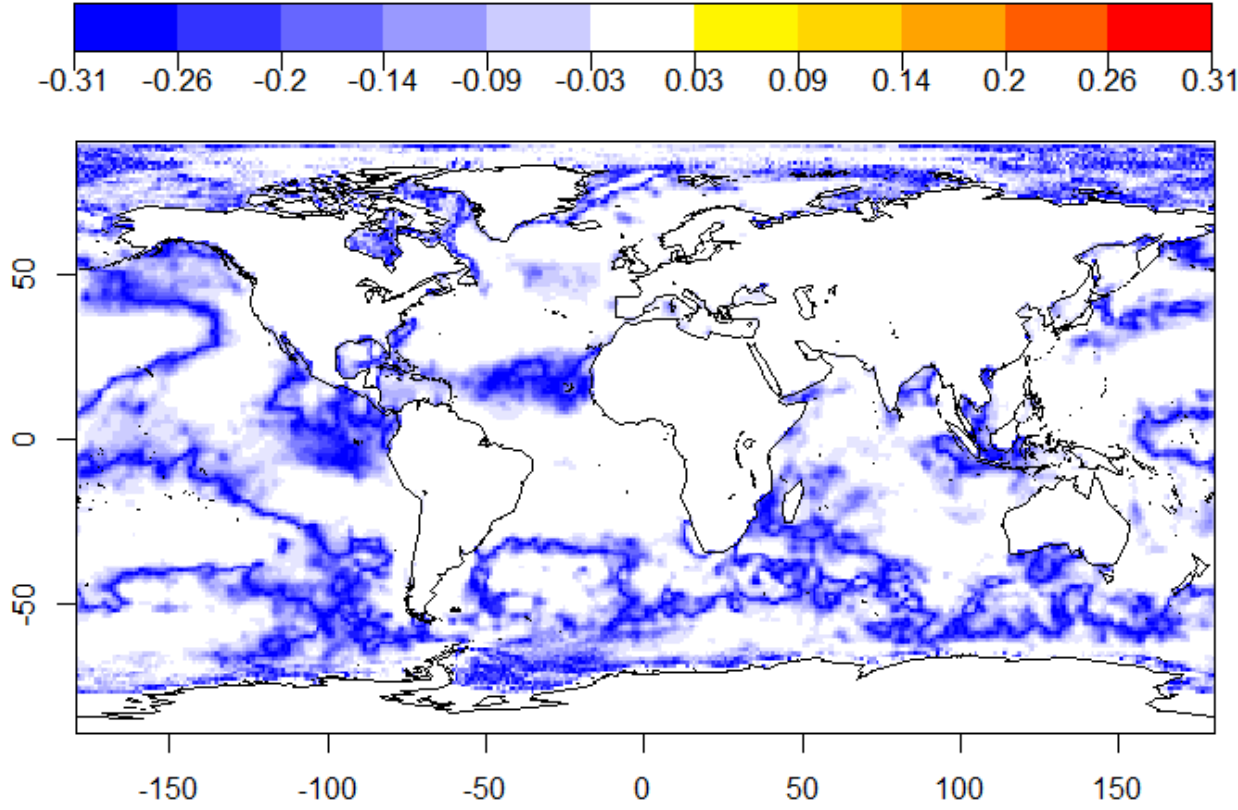

b)

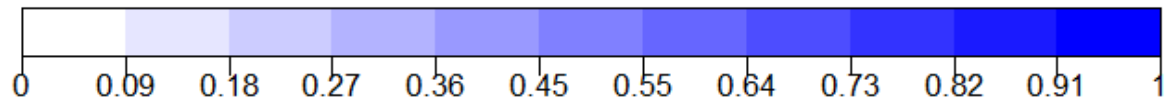

Figura APÊNDICE L-182 Correlação TSM HadISST versos ENA Nordeste a) Correlação b) P-Valor 1973 - 2013 


\section{APÊNDICE L.5.4 1973-2013 ERSST}

Ao correlacionar a TSM dos oceanos do mundo originária da base ERSST mensal do período de 1973 a 2013 e da ENA da Região Nordeste, na Figura APÊNDICE L-183, apresentam-se a (a) correlação e o (b) nível de significância p-valor. É possível notar correlações negativas em regiões do Oceano Pacífico Norte e Sul entre as longitudes $150^{\circ}$ e $250^{\circ}$ e no Atlântico Sul. As correlações positivas são encontradas no Pacífico Sul próximo a América do Sul.

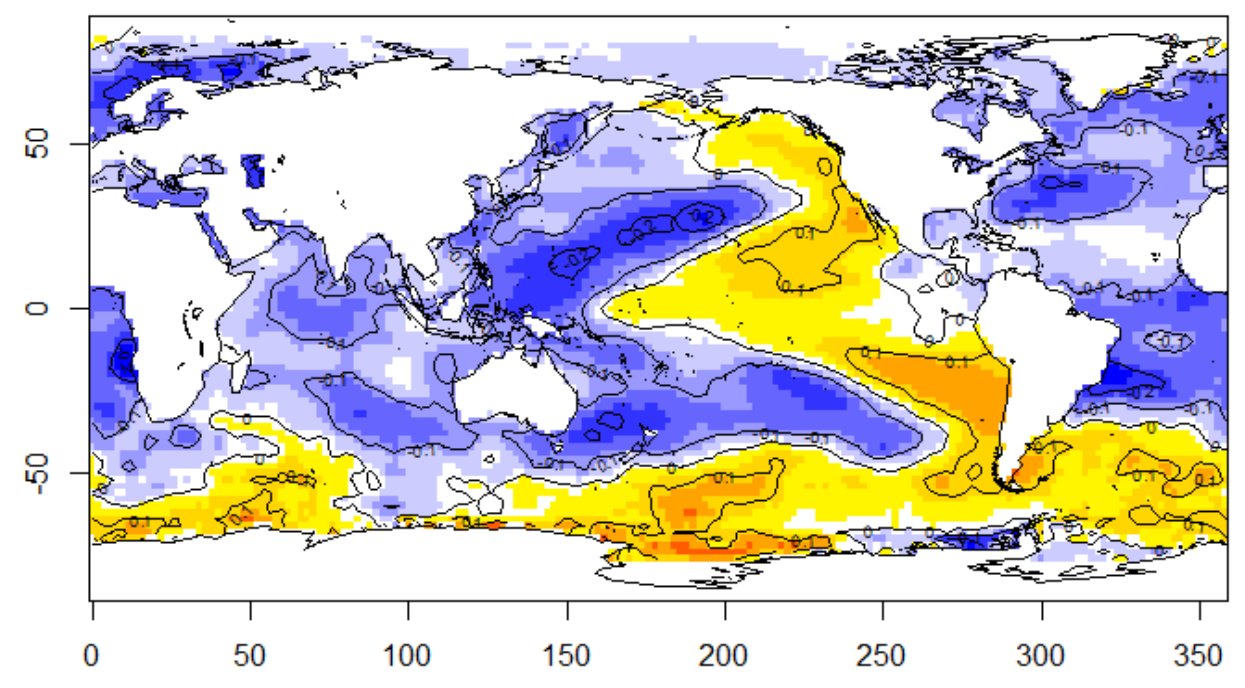

a)
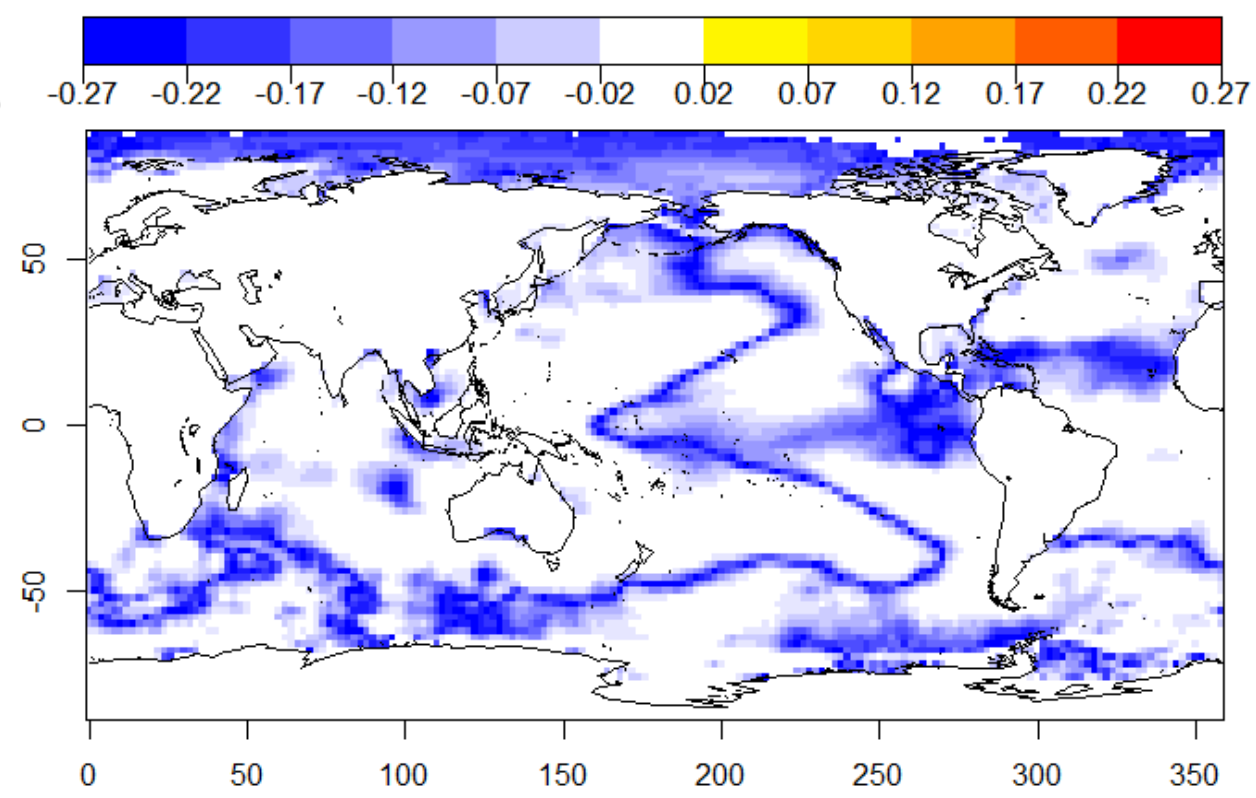

b)

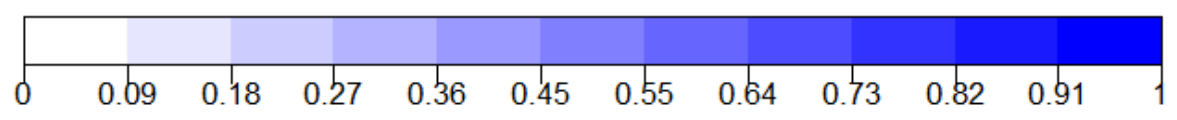

Figura APÊNDICE L-183 Correlação TSM ERSST versos ENA Nordeste a) Correlação b) P-Valor 1973 - 2013 
APÊNDICE L.5.5 1983-2013 HadISST

Ao correlacionar a TSM dos oceanos do mundo originária da base HadISST mensal do período de 1983 a 2013 e da ENA do Nordeste, na Figura APÊNDICE L-184, apresentam-se a (a) correlação e o (b) nível de significância p-valor. É possível notar correlações em regiões do Oceano Pacífico Sul, próximo à costa Oeste da América do Sul e na altura da longitude $150^{\circ}$, no Sul do Oceano Atlântico na altura de $-50^{\circ}$ de latitude, e correlações negativas próximo ao litoral Sudeste e Nordeste de Brasil, Oceano Índico, Sudeste, Norte e Sudoeste da Austrália.

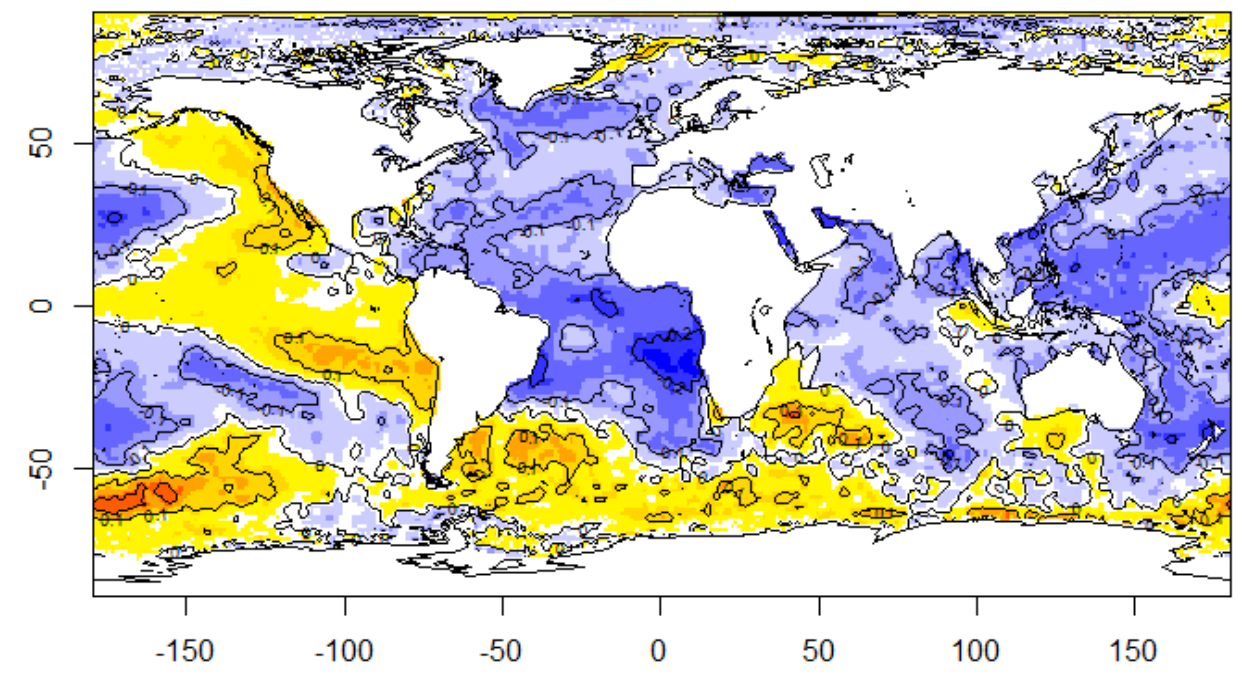

a)
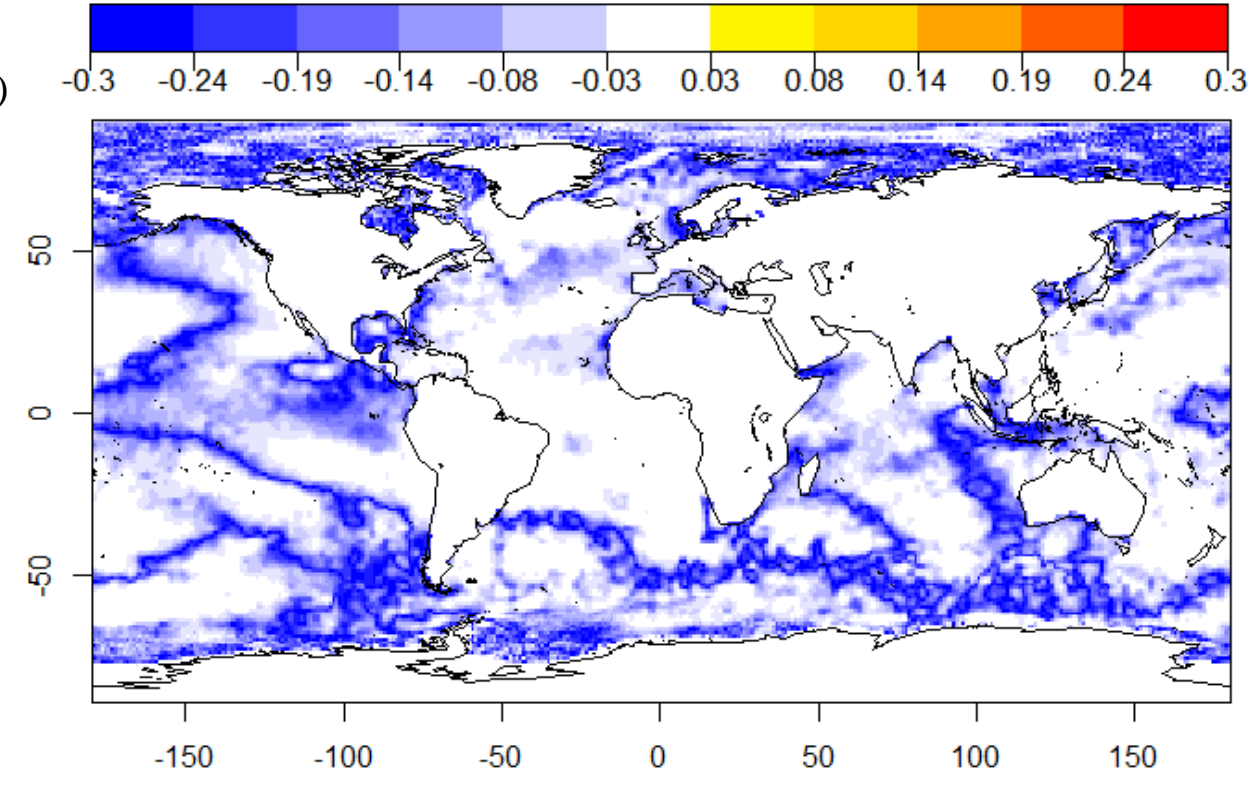

b)

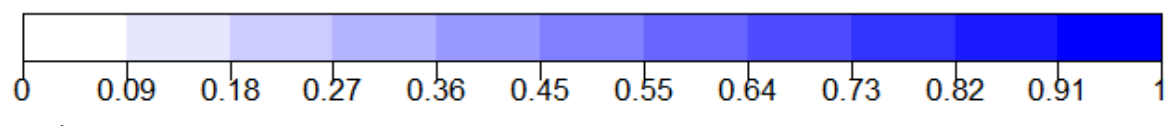

Figura APÊNDICE L-184 Correlação TSM HadISST versos ENA NORDESTE a) Correlação b) P-Valor 1983 2013 


\section{APÊNDICE L.5.6 1983-2013 ERSST}

Ao correlacionar a TSM dos oceanos do mundo originária da base ERSST mensal do período de 1983 a 2013 e da ENA do Nordeste a apresenta a (a) correlação e o (b) nível de significância p-valor. É possível notar correlações negativas em regiões do Oceano Pacífico Norte e Sul entre as longitudes $150^{\circ}$ e $250^{\circ}$ e no Atlântico Sul, e correlações positivas no Pacífico Sul e Atlântico Sul próximo a América do Sul.

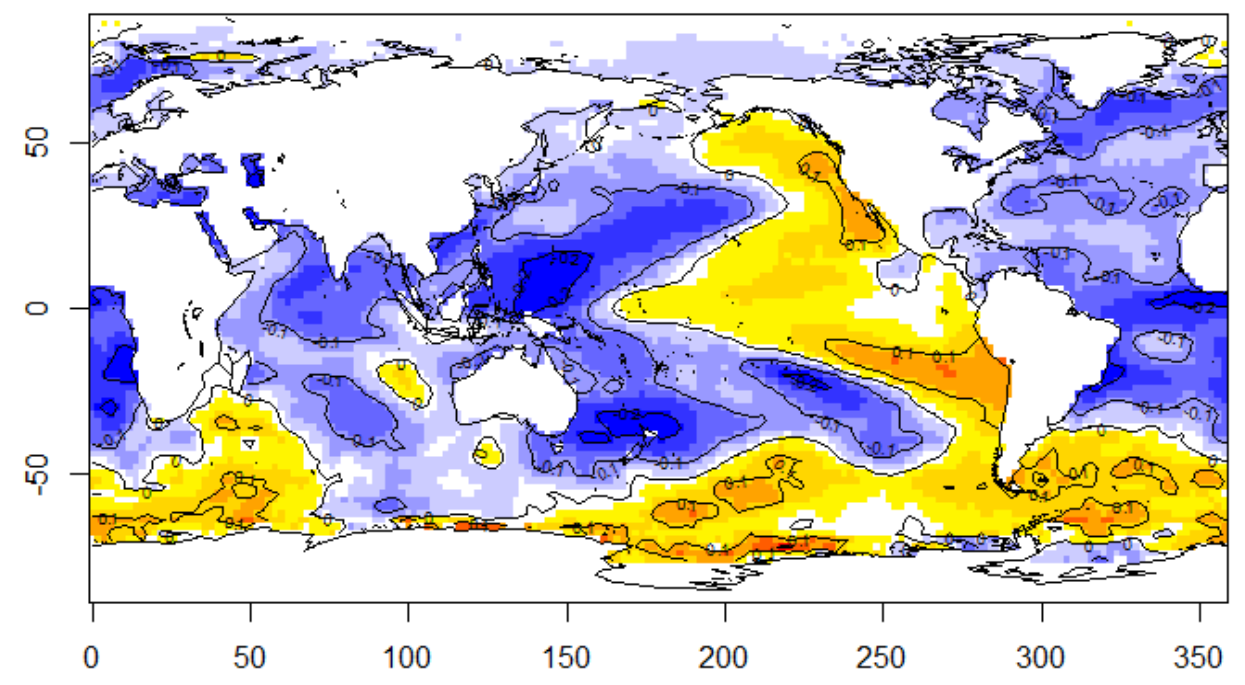

a)
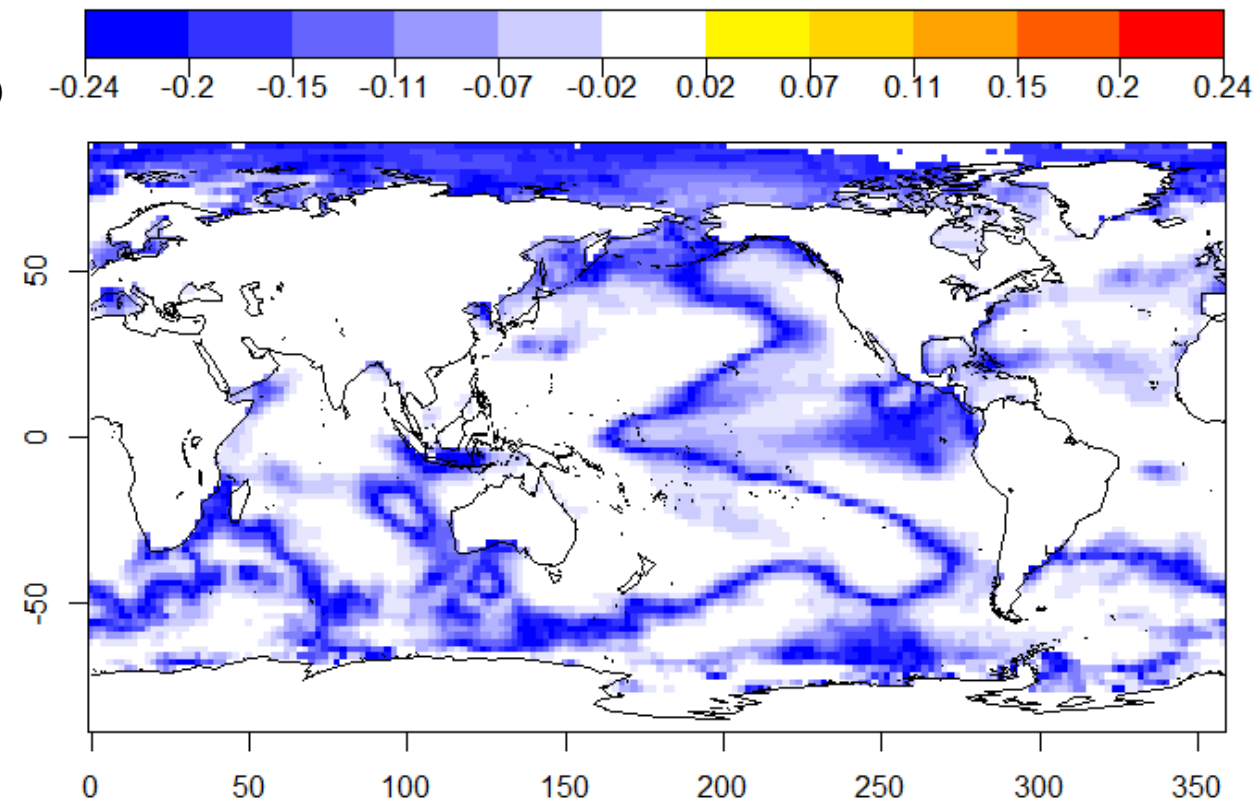

b)

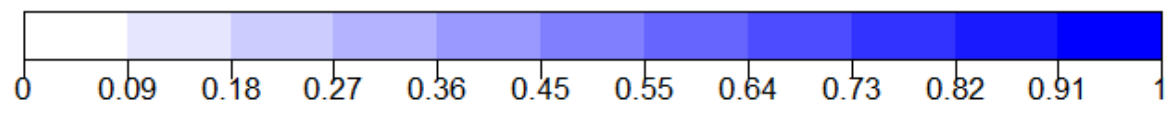

Figura APÊNDICE L-185 Correlação TSM ERSST versos ENA NORDESTE a) Correlação b) P-Valor 1983 - 2013 


\section{APÊNDICE M Análise de Mapas versos Usinas}

A iniciativa RCLIM busca disponibilizar ferramentas computacionais para auxiliar na análise do clima. Está organizada na Faculdade de Engenharia, Matemática e Ciências Físicas da Universidade de Exeter localizada no Reino Unido. Na página da Faculdade é possível baixar os pacotes do software. Nessa tese, foram utilizados os pacotes RClim desenvolvidos por Stephenson et al (2005) para análise de dados de TSM em forma de grade de mapas. O pacote RClim foi desenvolvido com a linguagem estatística R (2005) que tem a vantagem de ser disponível livremente.

Para análise dos mapas o pacote permite:

- leitura e escrita em bases de dados de mapas no formato netcdf (formato muito utilizado pela comunidade científica em Ciências Atmosféricas);

- análise exploratória clima em conjuntos de dados em grade; e

- análise do clima de extremos em conjunto de dados em grade.

No site http://www1.secam.ex.ac.uk/rclim-initiative.dhtml, é possível fazer o download do pacote que contém, além das bibliotecas que o compõe, também exemplos de como usá-lo. 
APÊNDICE M.1 HadISST e ERSST - JAN/DEZ

Principal component 1
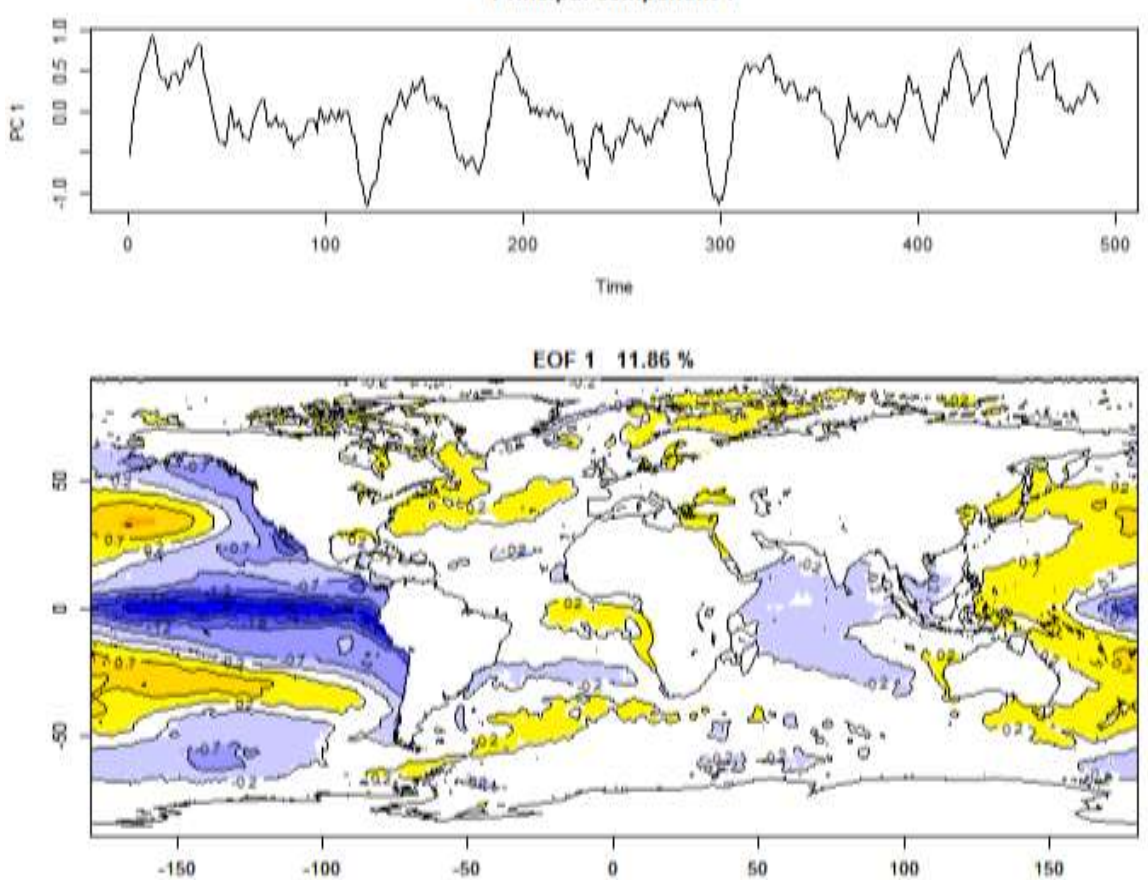

a)
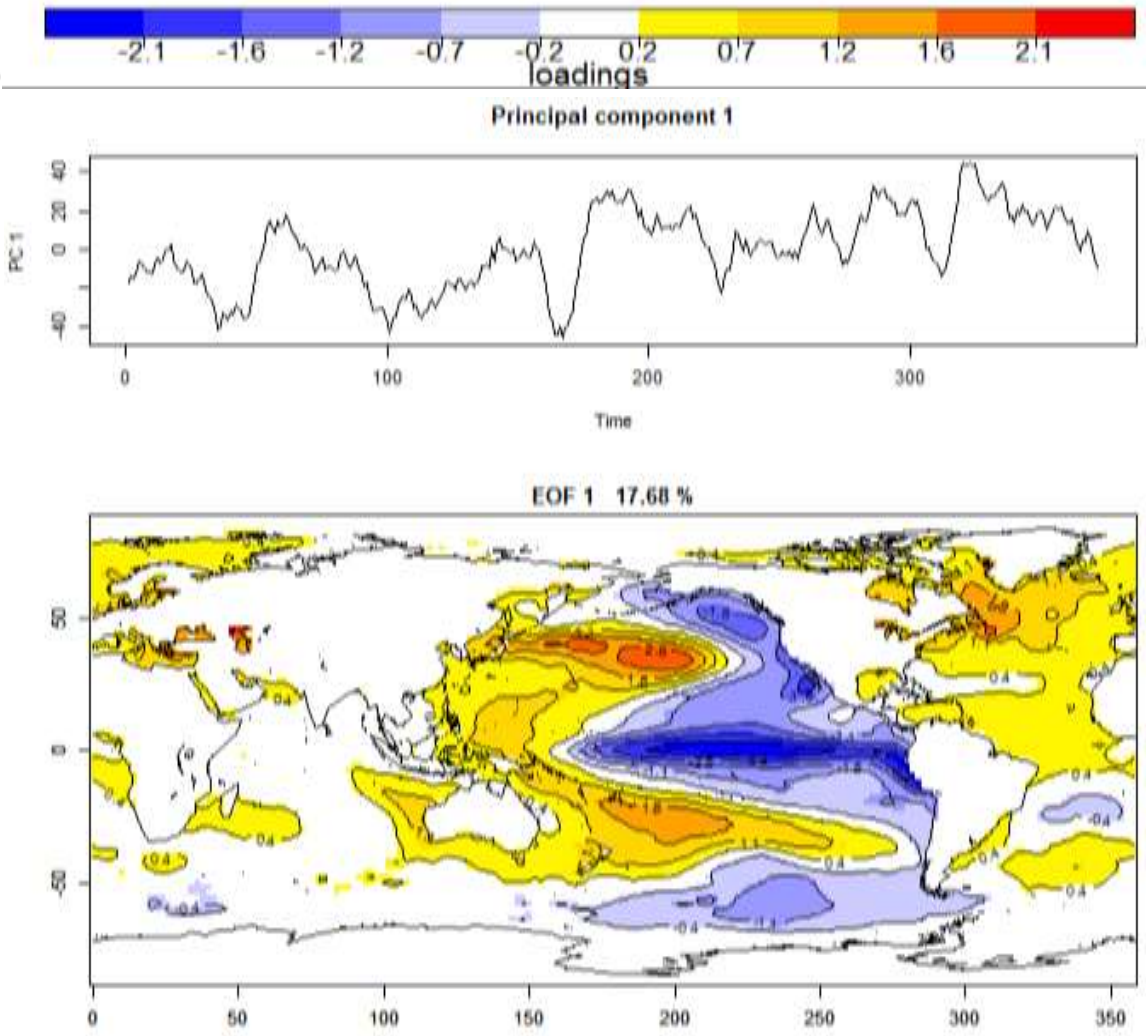

b)

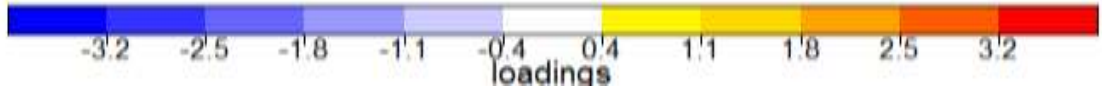

Figura APÊNDICE M-186 Análise por componentes principais $1^{\mathrm{a} C}$ Componente Principal a) TSM HadISST b) ERSST. 
Principal component 2
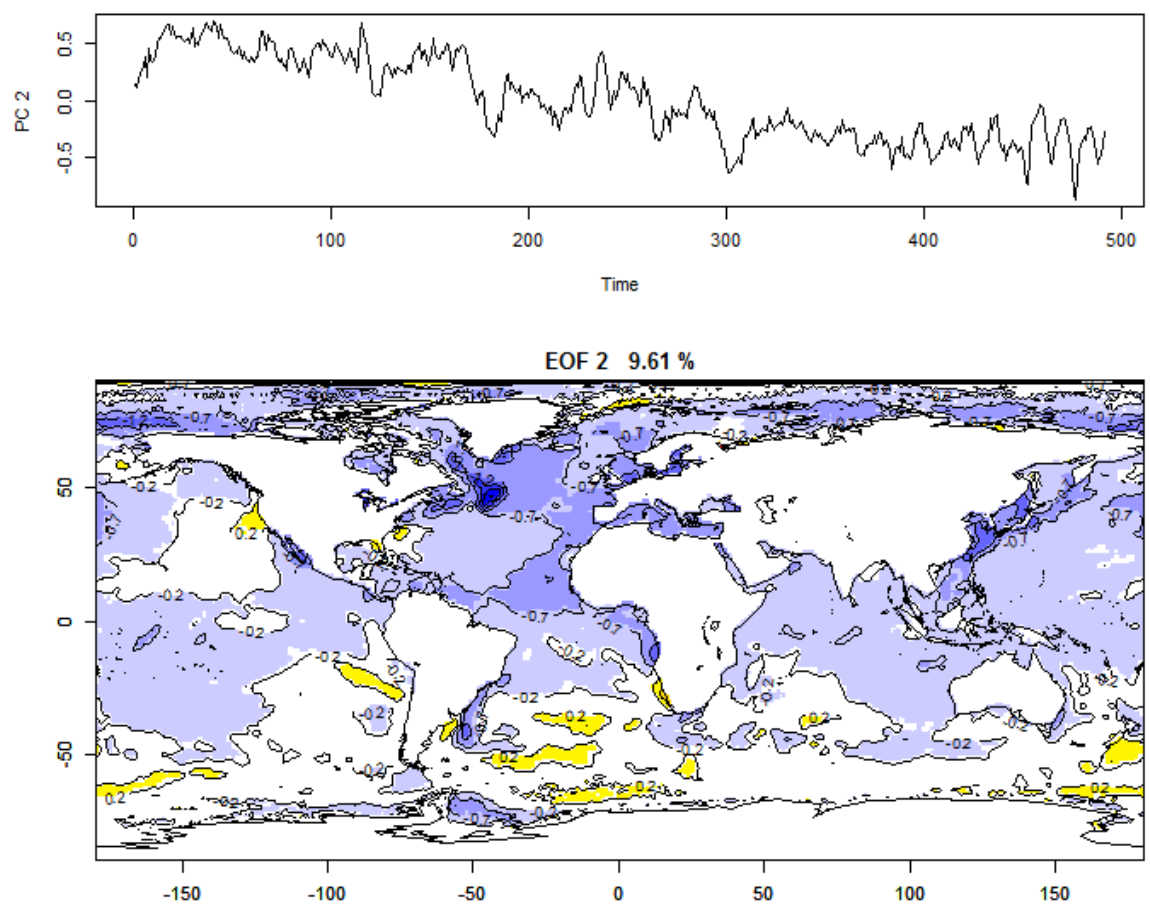

a)

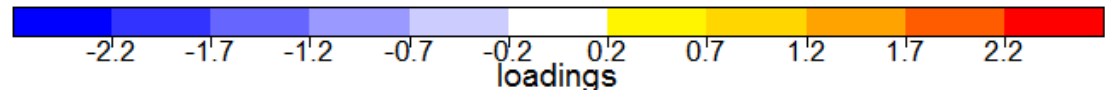

Principal component 2

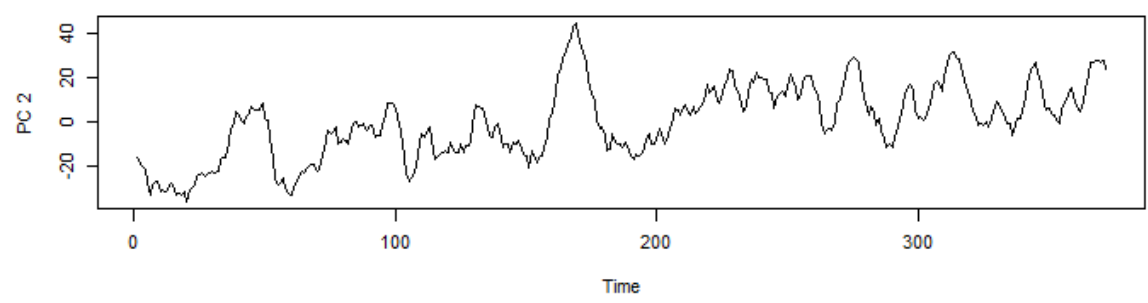

EOF $2 \quad 12.37 \%$

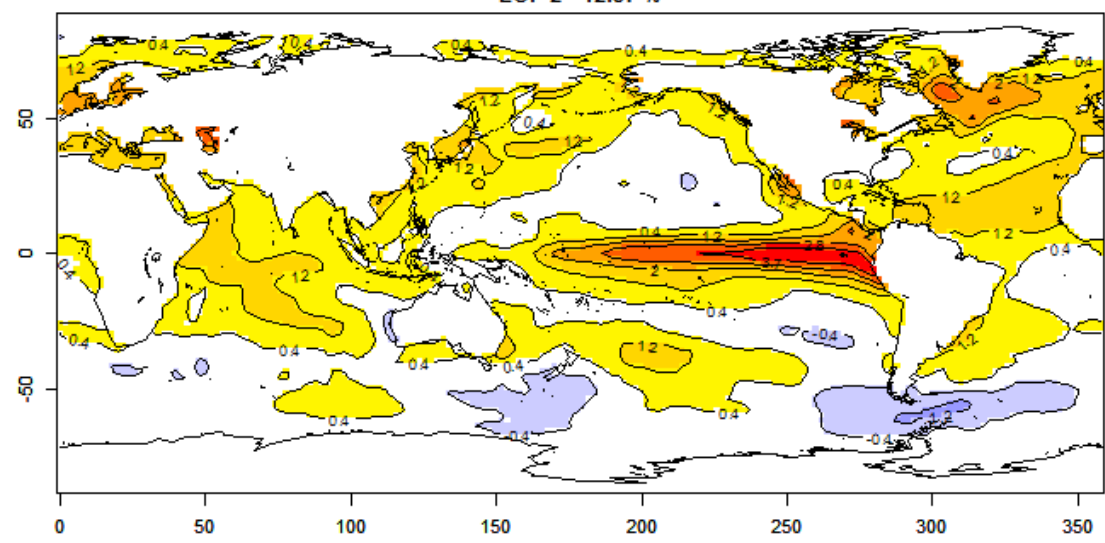

b)

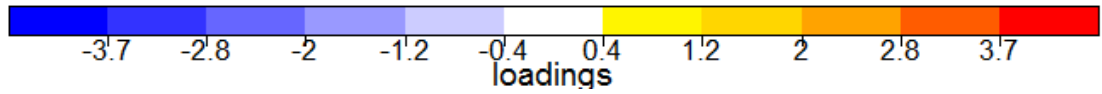

Figura APÊNDICE M-187 Análise por componentes principais 2a Componente Principal a) TSM HadISST b) ERSST 
Principal component 3

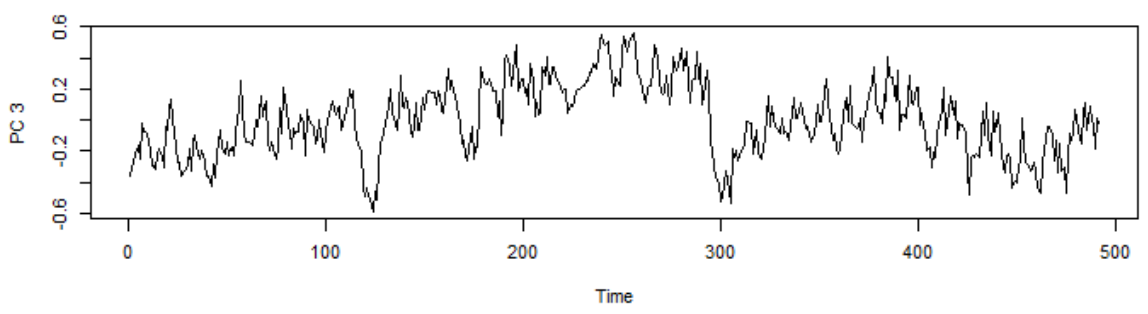

EOF $3 \quad 3.83 \%$

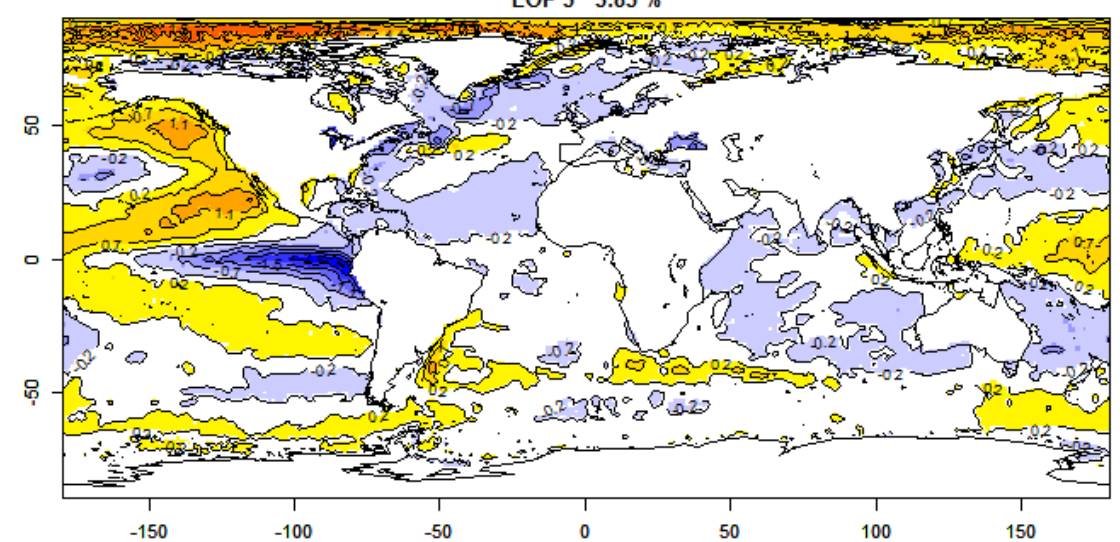

a)

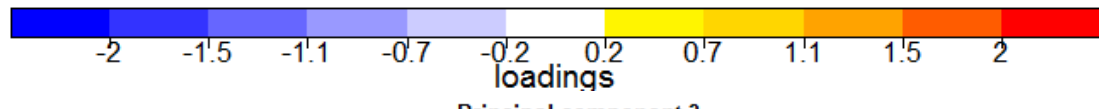

Principal component 3

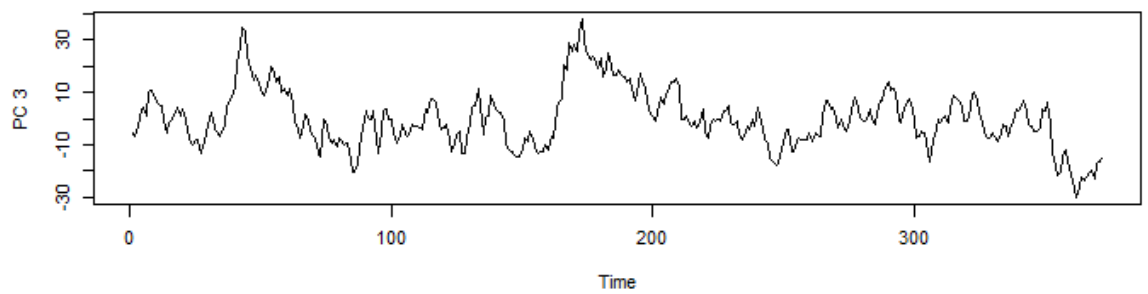

EOF $3 \quad 5.6 \%$

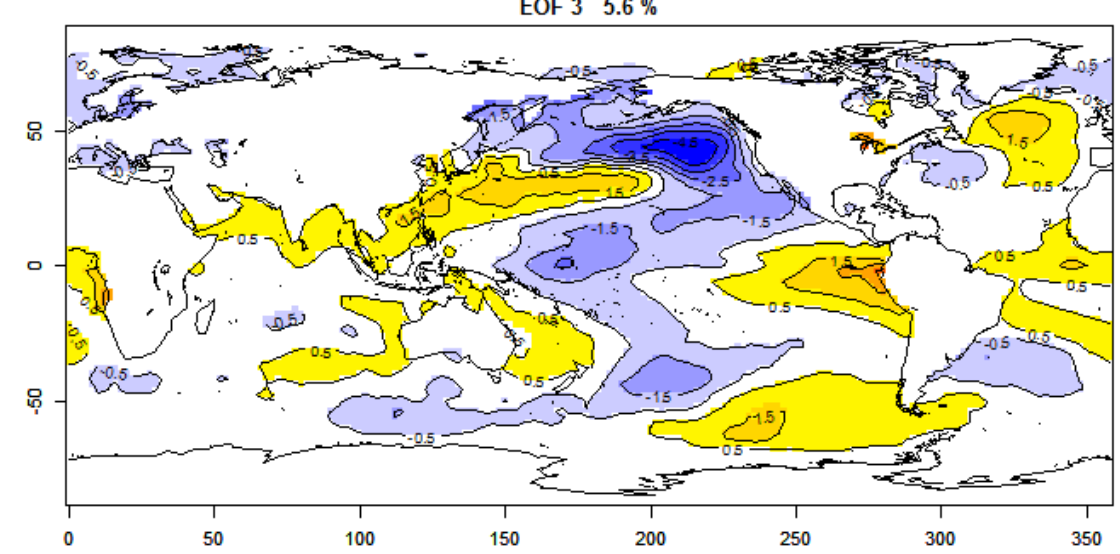

b)

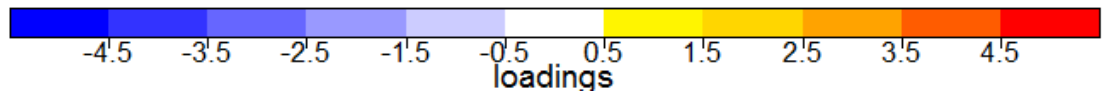

Figura APÊNDICE M-188 Análise por componentes principais $3{ }^{a}$ Componente Principal a) TSM HadISST b) ERSST 
Principal component 4
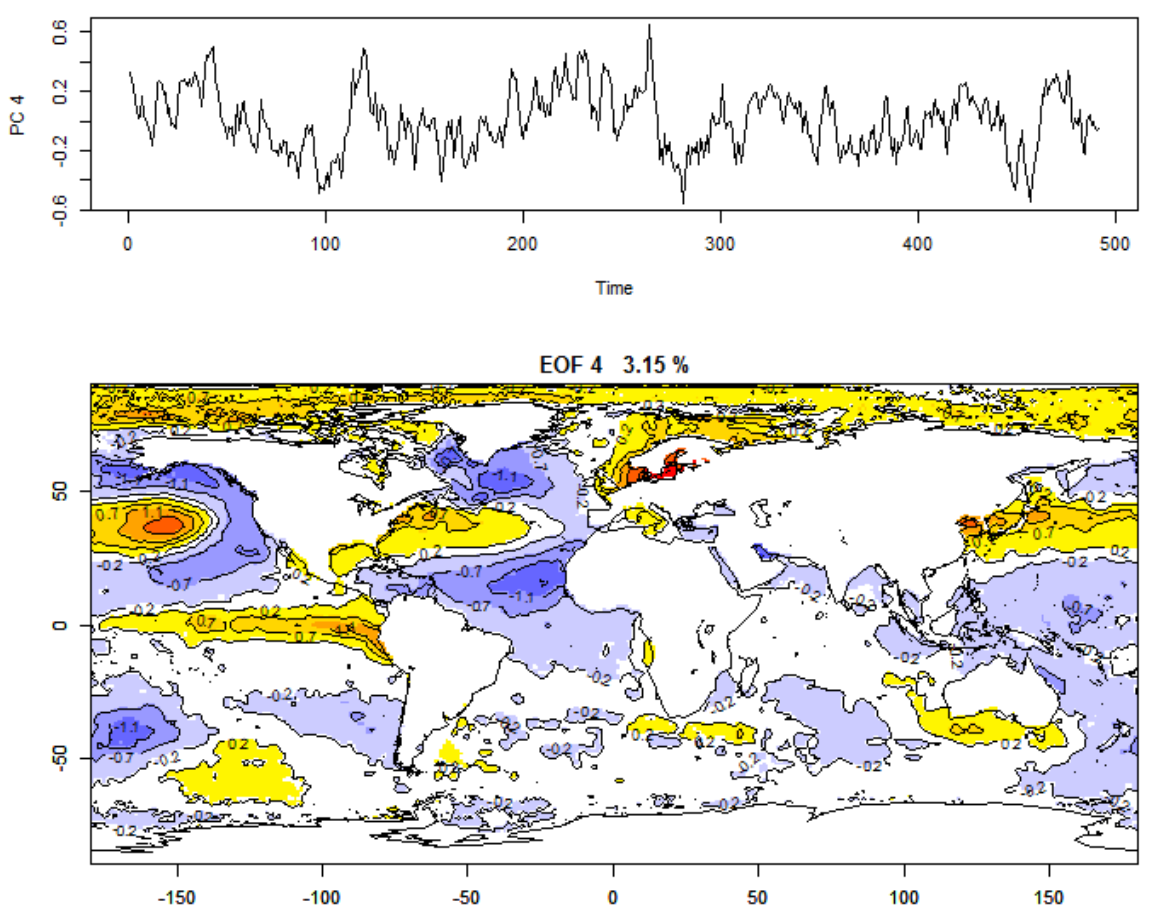

a)

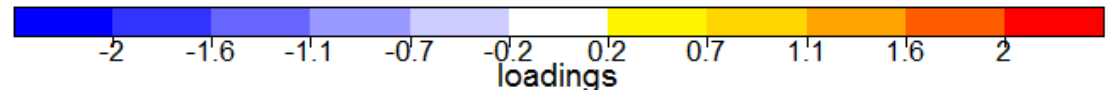

Principal component 4

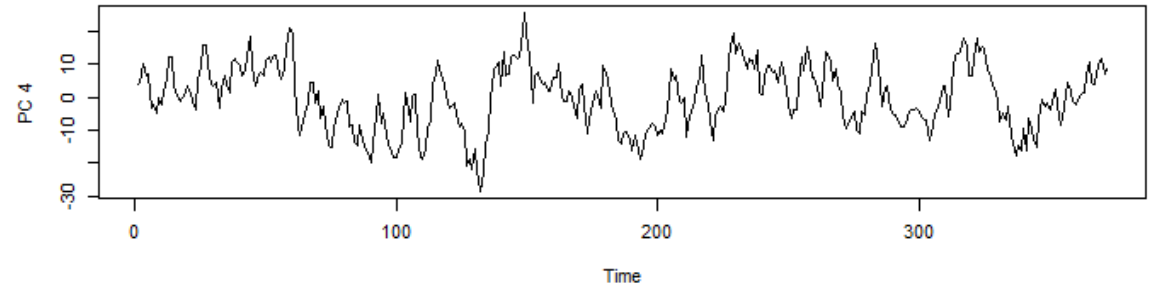

EOF $4 \quad 4.05 \%$

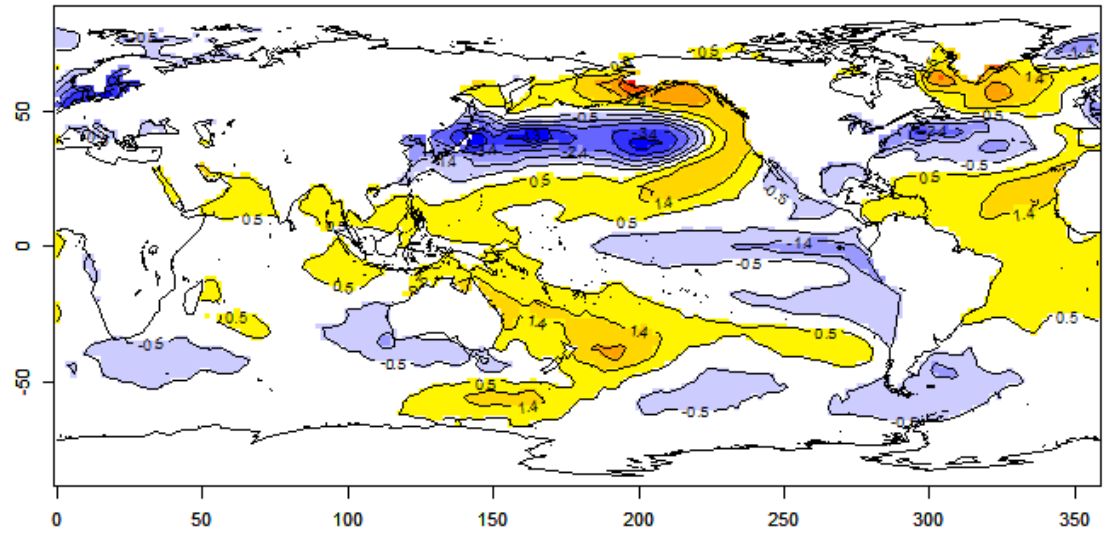

b)

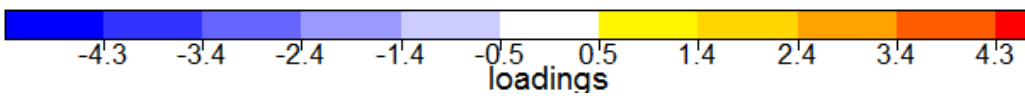

Figura APÊNDICE M-189 Análise por componentes principais $4^{\mathrm{a} C}$ Componente Principal a) TSM HadISST b) ERSST 
APÊNDICE M.1.1 Sudeste

APÊNDICE M.1.1.1 $1931-2014$ HadISST

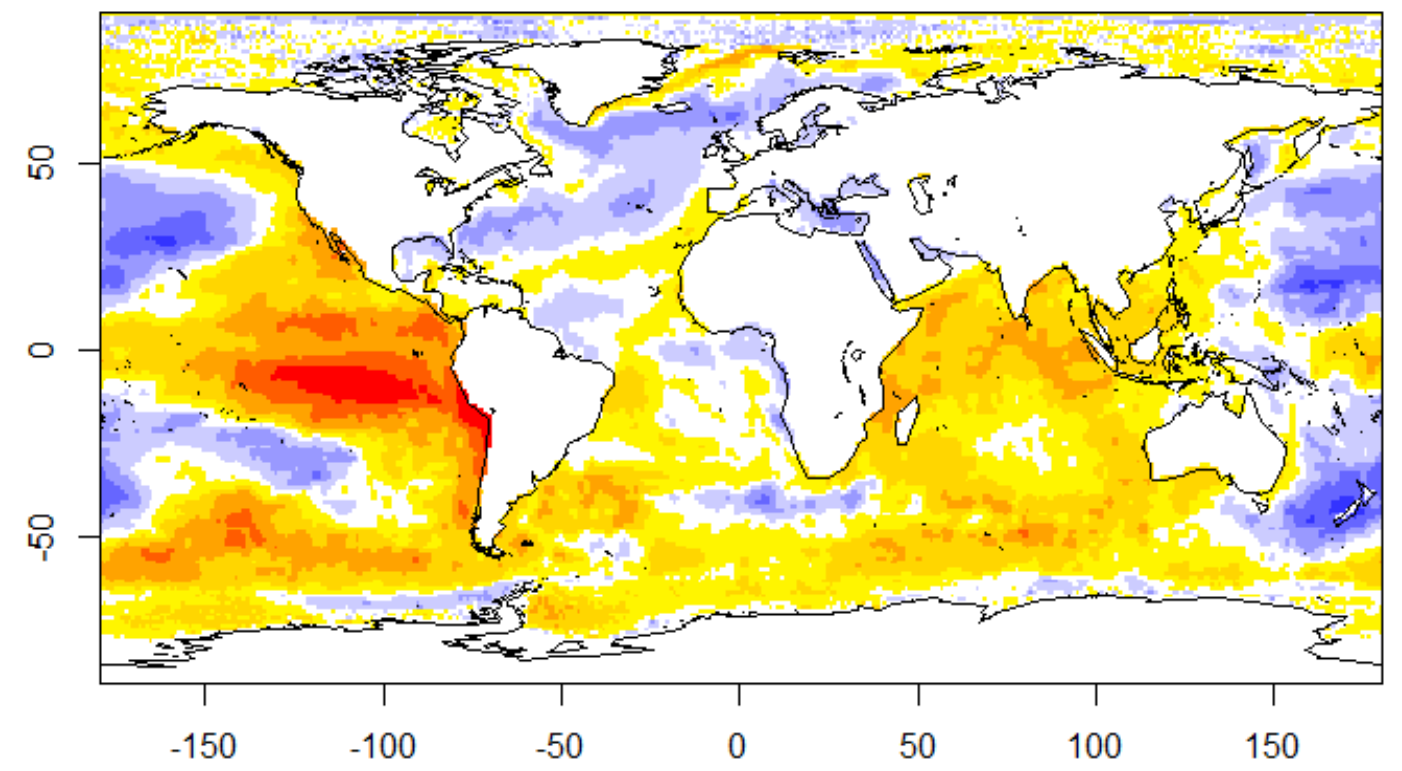

a)
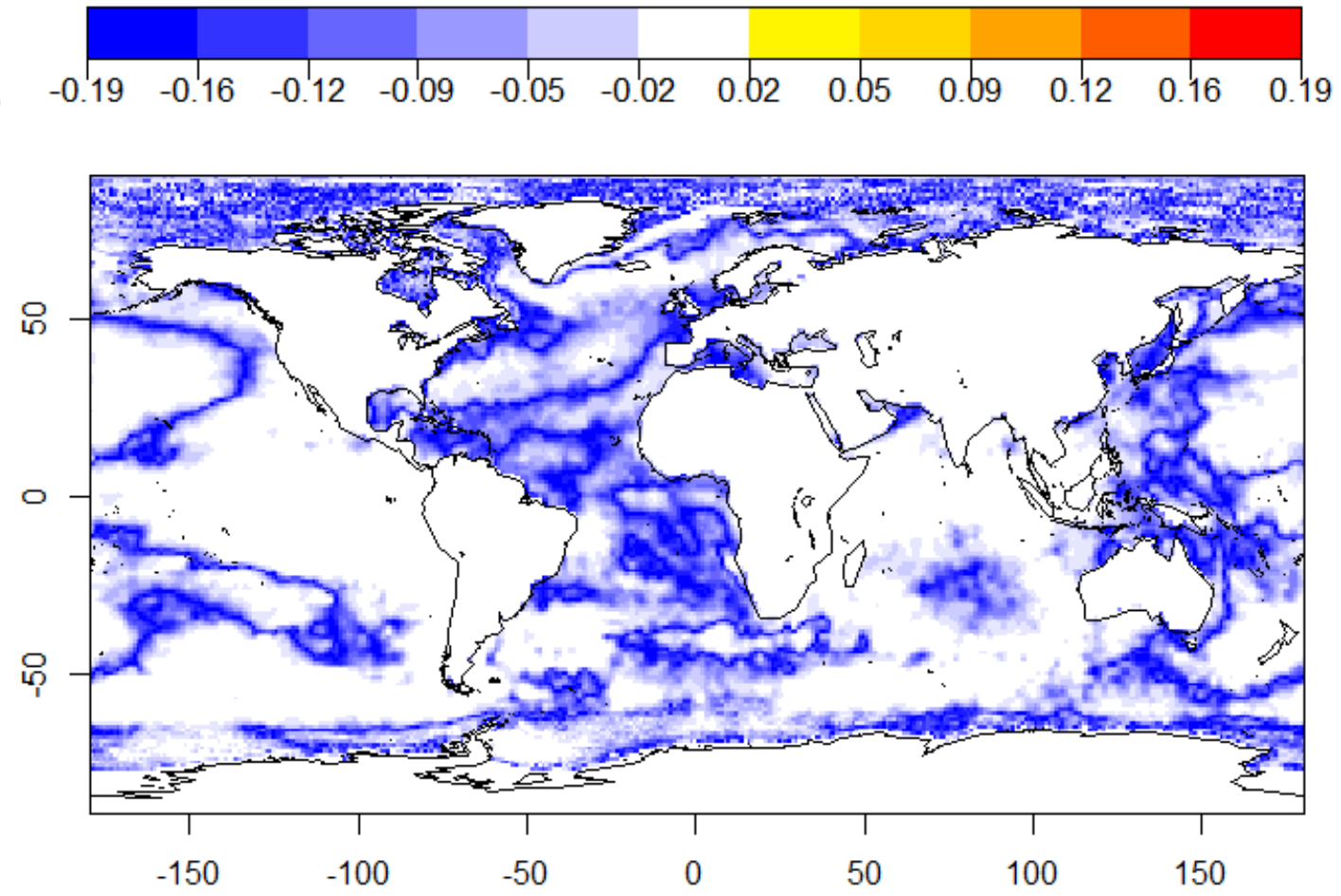

b) $\quad \begin{array}{lllllllllll}0 & 0.69 & 0.18 & 0.27 & 0.36 & 0.45 & 0.55 & 0.64 & 0.73 & 0.82 & 0.91\end{array}$

Figura APÊNDICE M-190 Correlação TSM HadISST versos ENA SE a) Correlação b) P-Valor. 1931 - 2014 
APÊNDICE M.1.1.2 $1931-2014$ ERSST

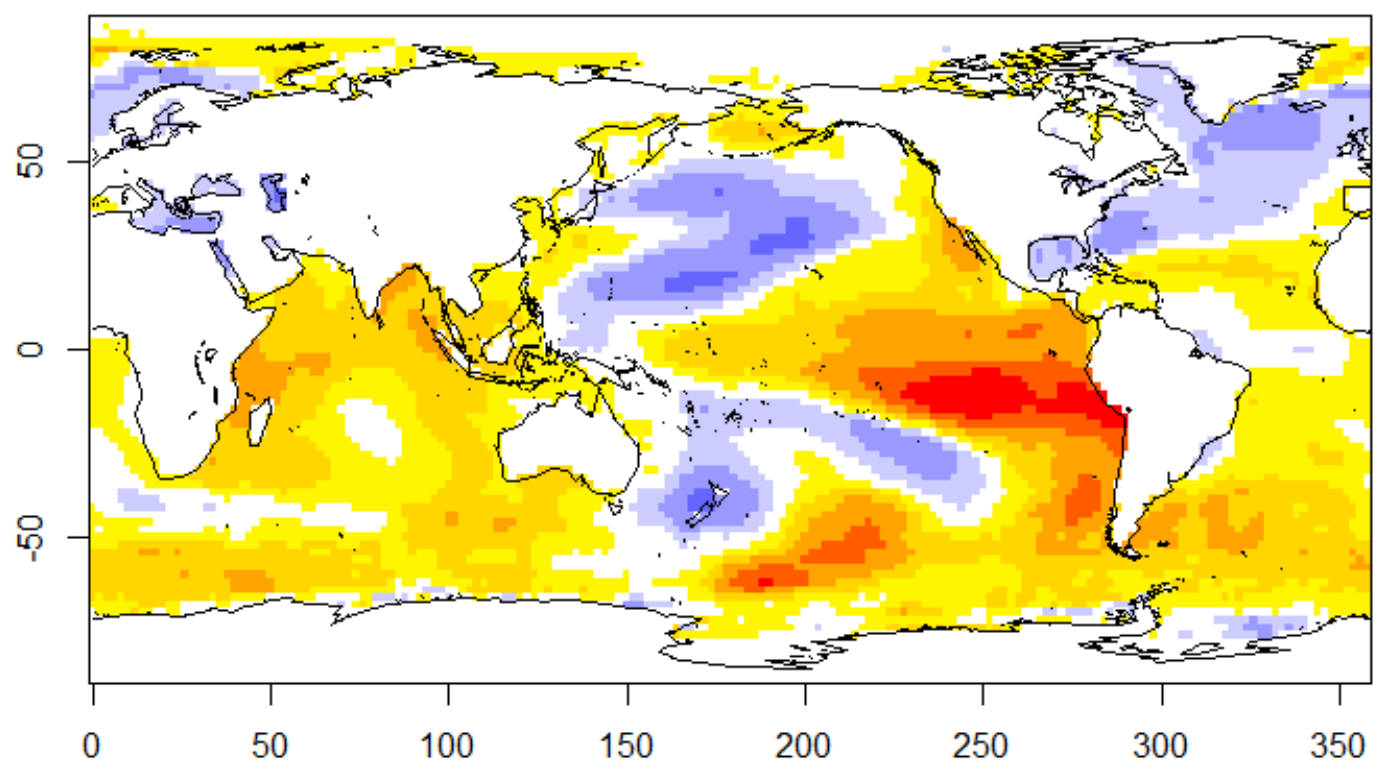

a)

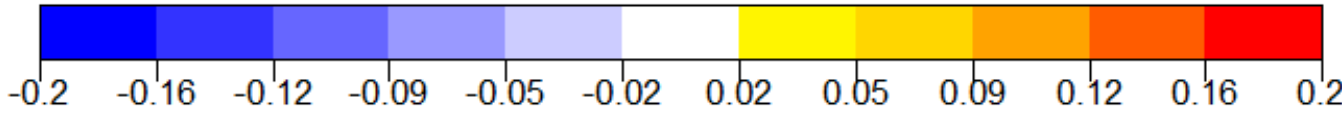

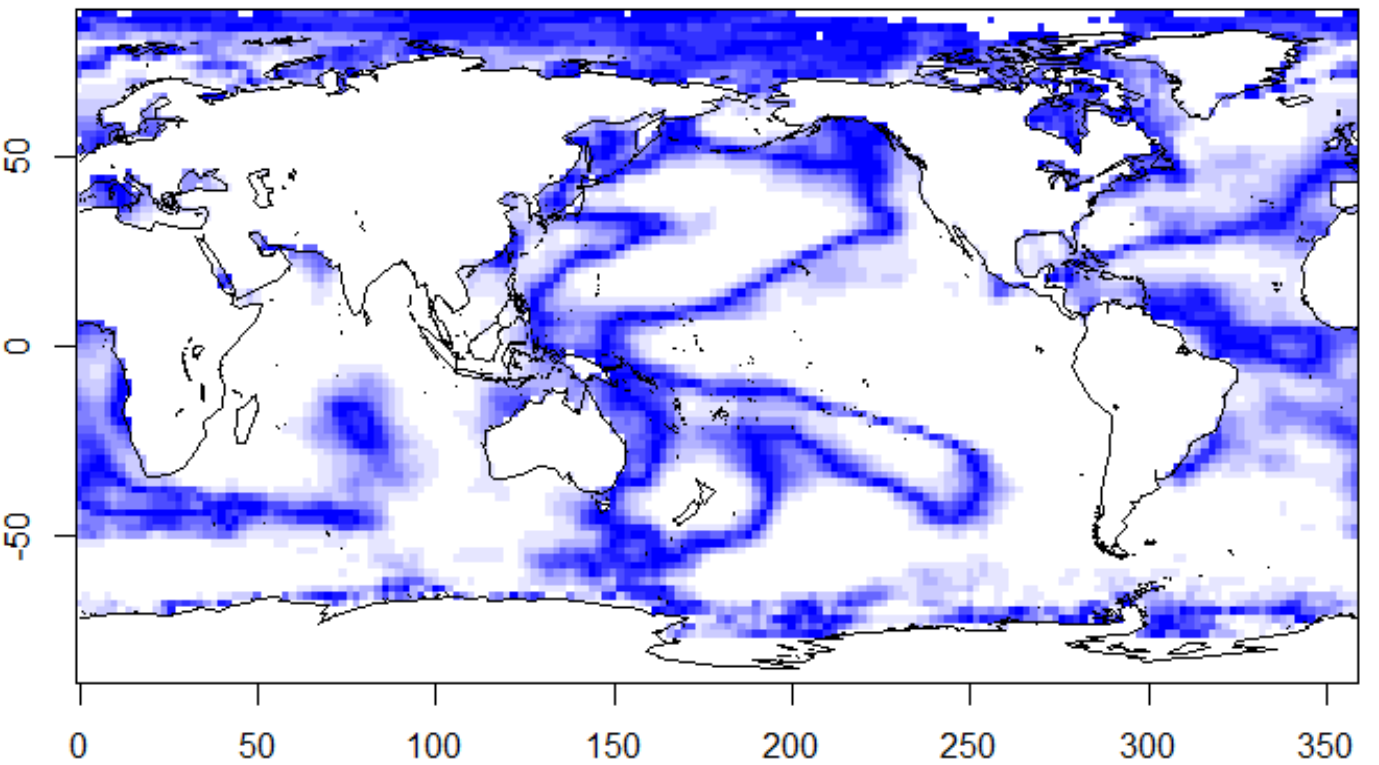

b) $\begin{array}{llllllllllll}0 & 0.69 & 0.18 & 0.27 & 0.36 & 0.45 & 0.55 & 0.64 & 0.73 & 0.82 & 0.91\end{array}$

Figura APÊNDICE M-191 Correlação TSM ERSST versos ENA SE a) Correlação b) P-Valor. 1931 - 2014. 
APÊNDICE M.1.1.3 $\quad 1974-2014$ HadISST

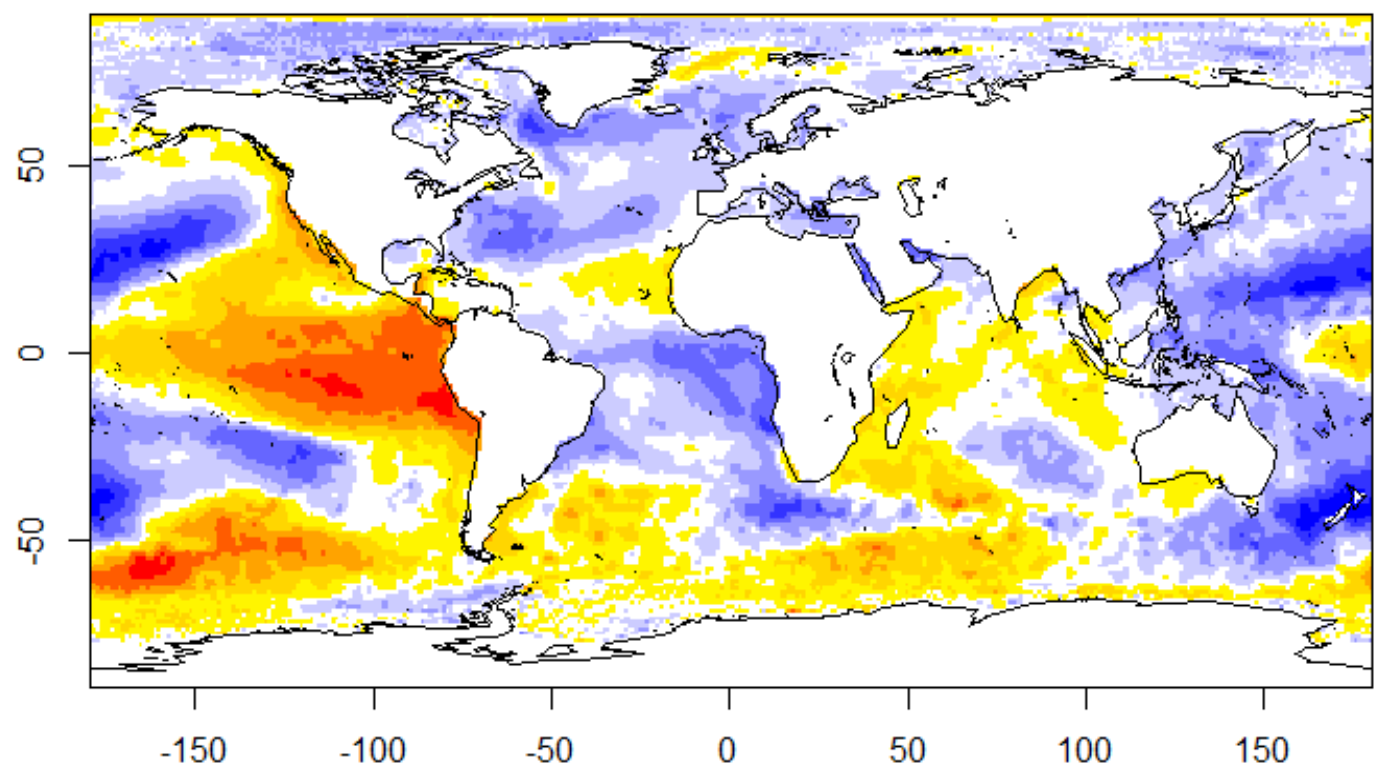

a)
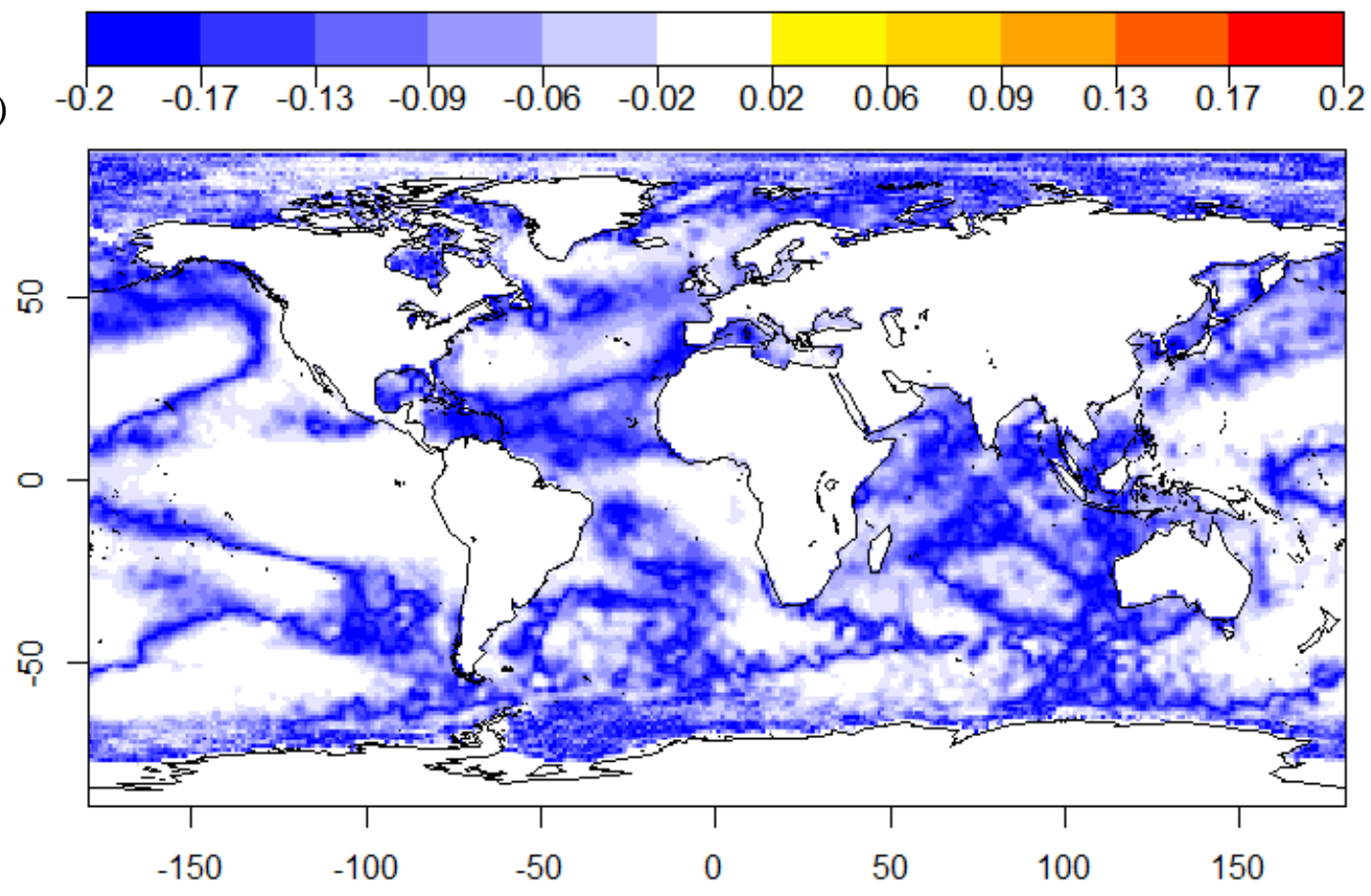

b) $\begin{array}{lllllllllll}0 & 0.09 & 0.18 & 0.27 & 0.36 & 0.45 & 0.55 & 0.64 & 0.73 & 0.82 & 0.91\end{array}$

Figura APÊNDICE M-192 Correlação TSM HadISST versos ENA SE a) Correlação b) P-Valor 1974 - 2014 


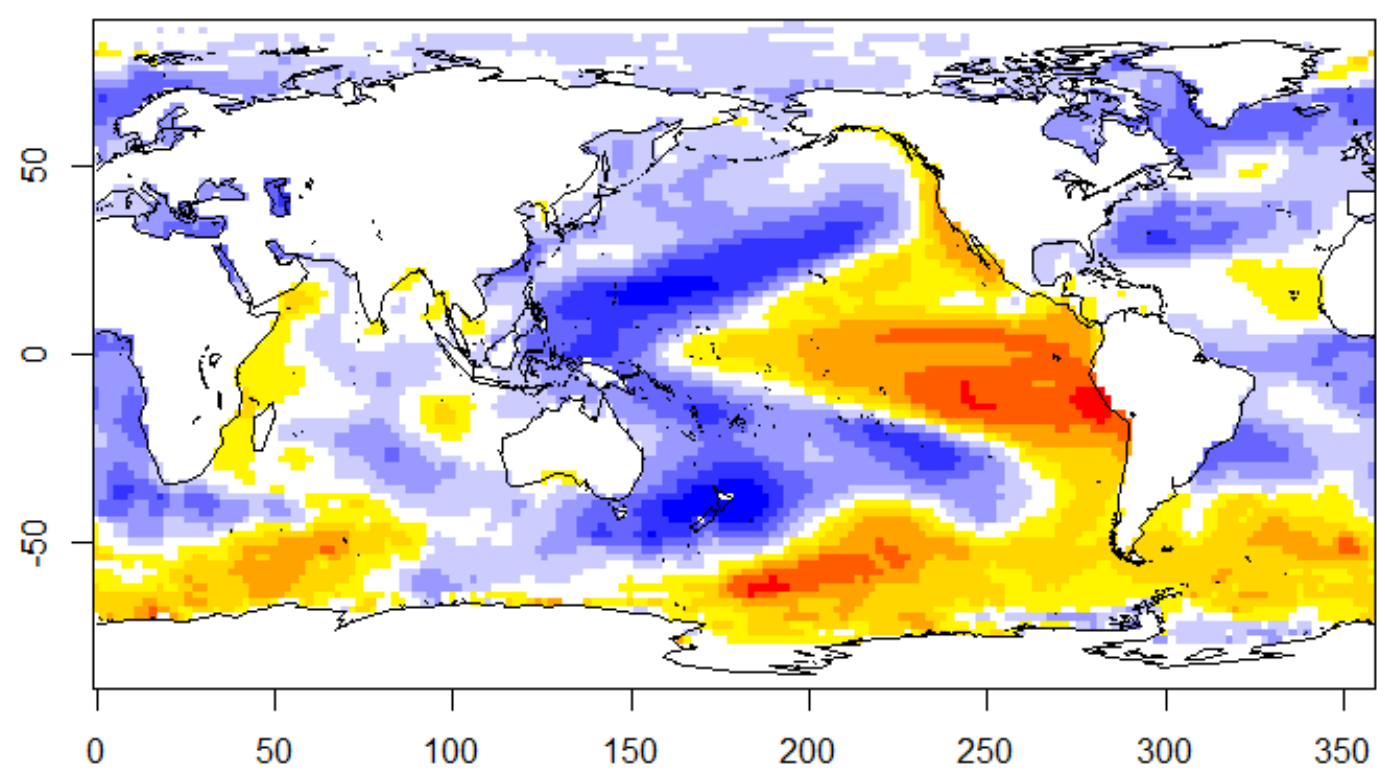

a)
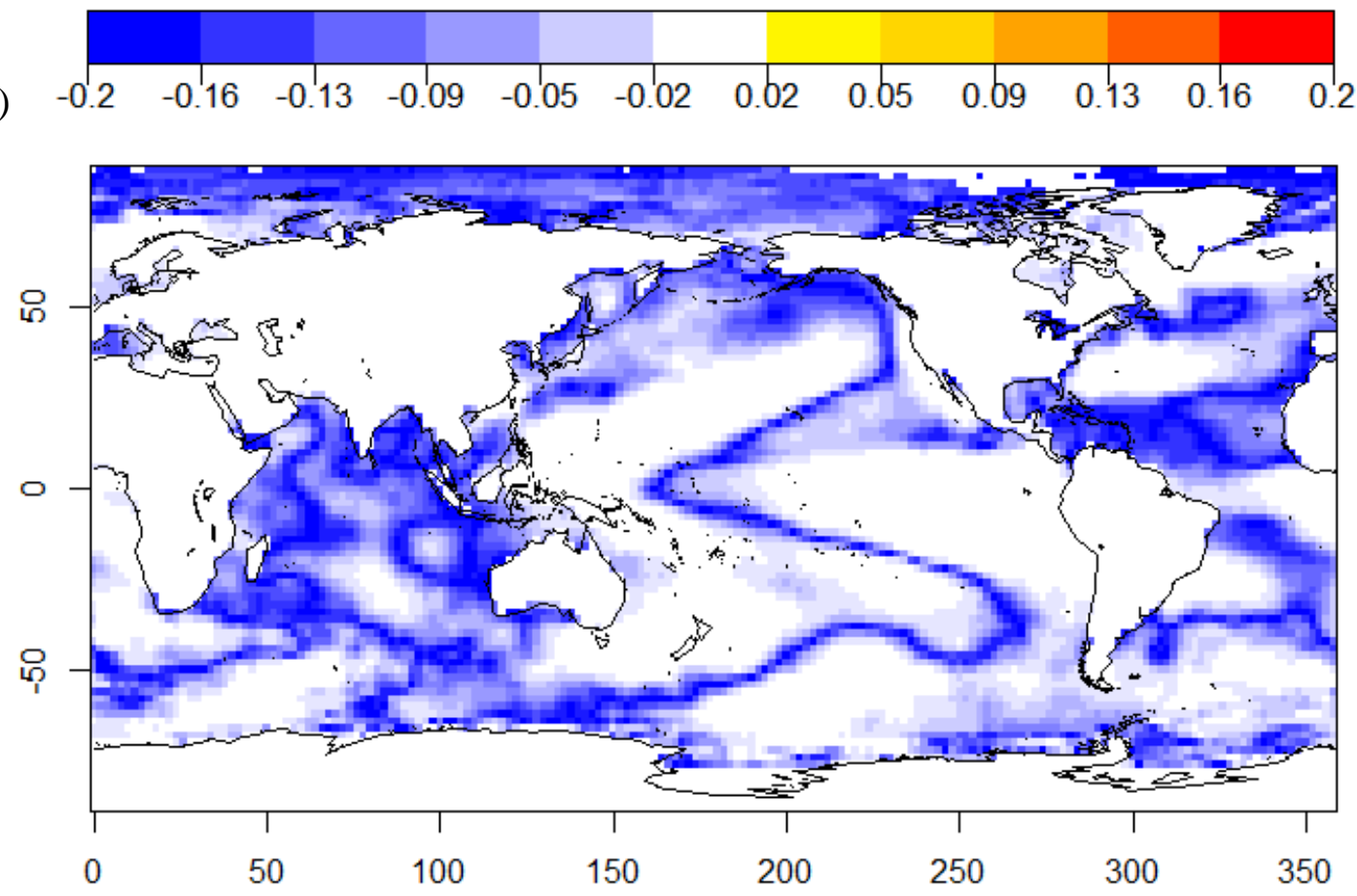

b)

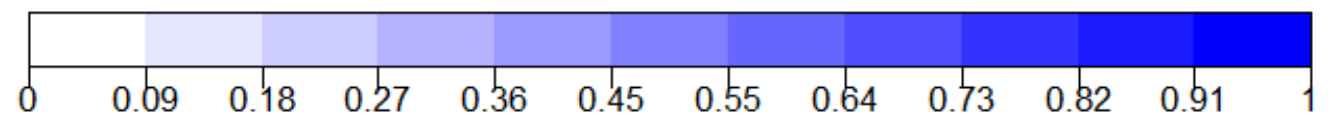

Figura APÊNDICE M-193 Correlação TSM ERSST versos ENA SE a) Correlação b) P-Valor 1974 - 2014 
APÊNDICE M.1.1.5 $1984-2014$ HadISST

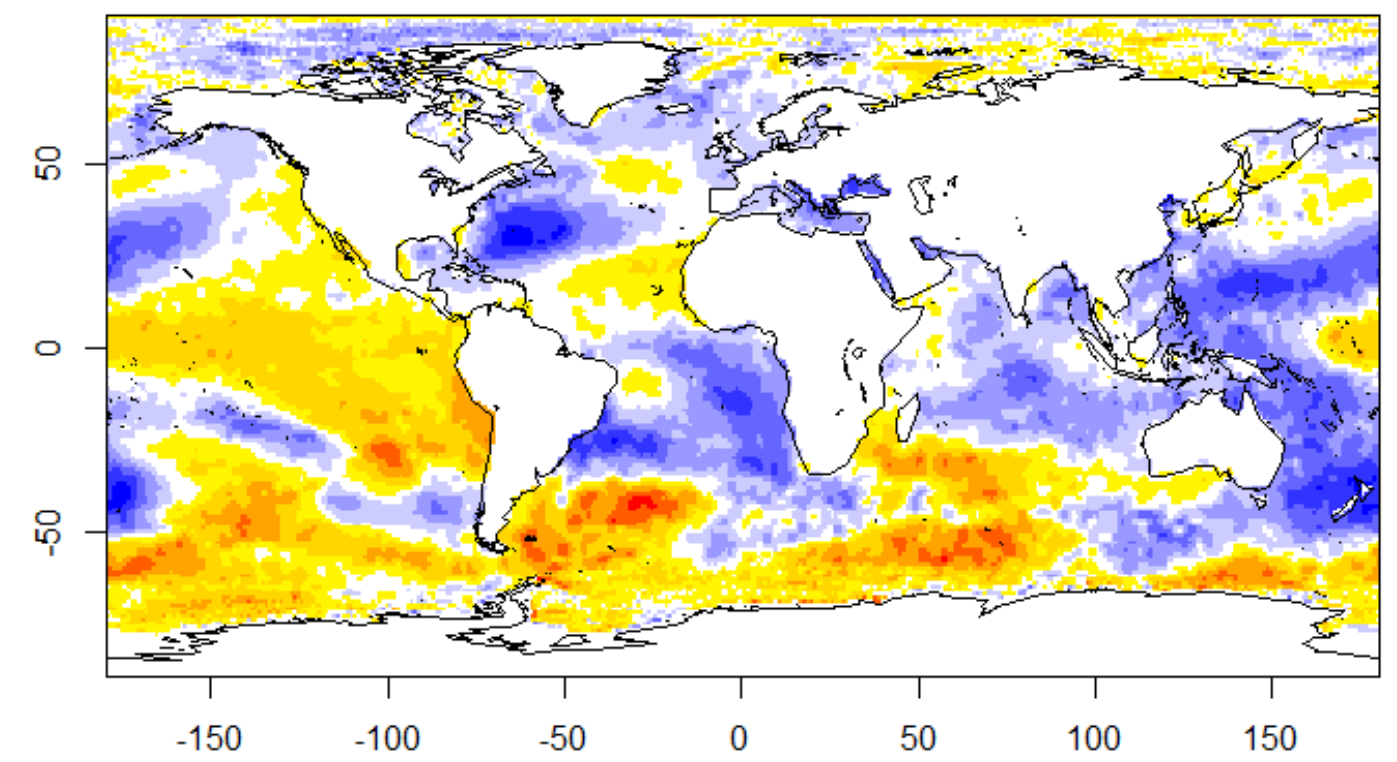

a)
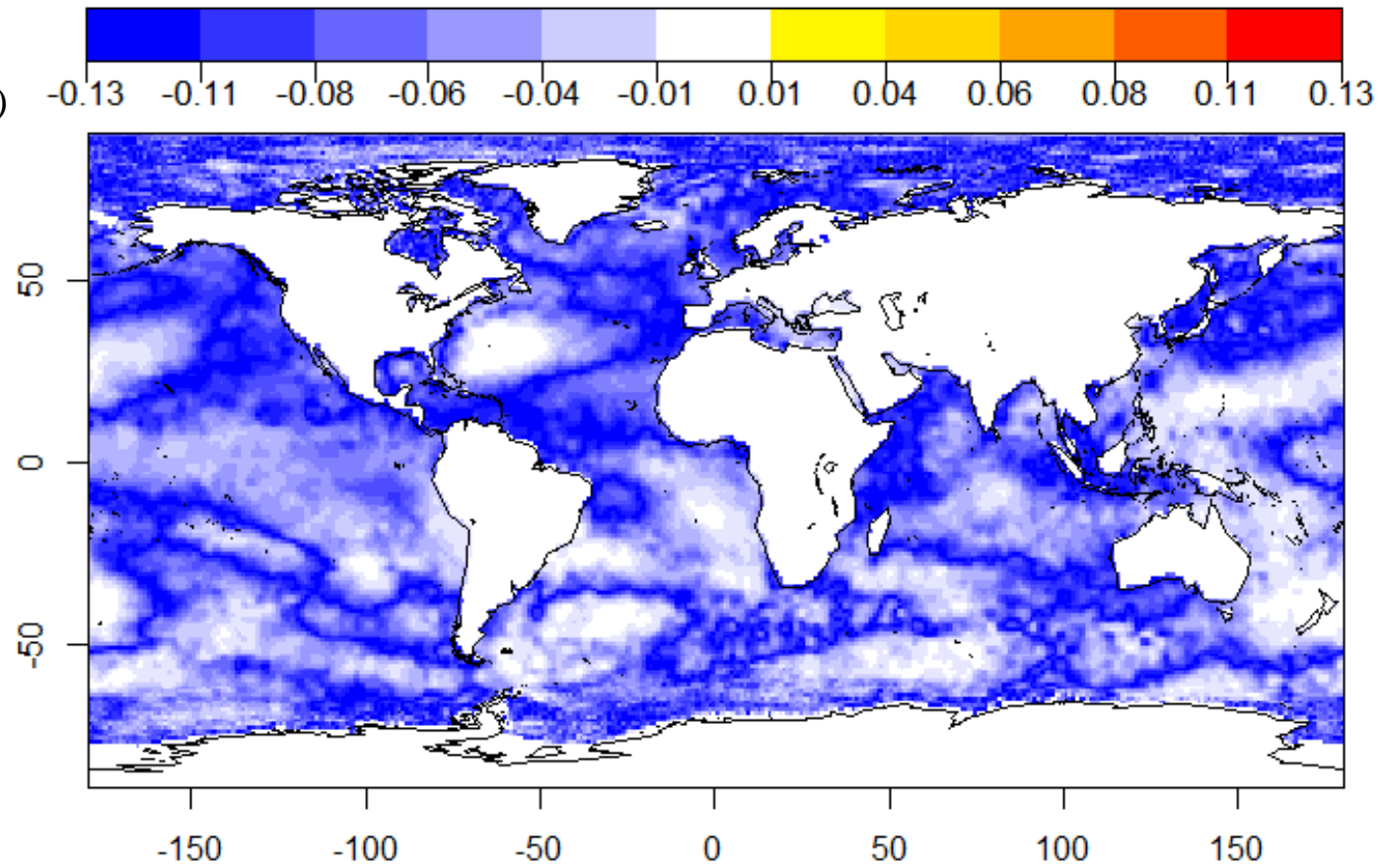

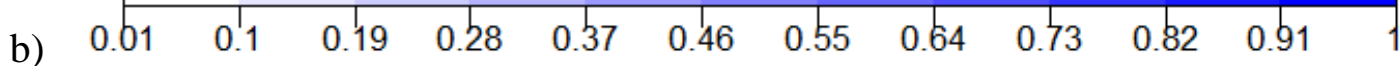

Figura APÊNDICE M-194 Correlação TSM HadISST versos ENA SE a) Correlação b) P-Valor 1984 - 2014 
APÊNDICE M.1.1.6 $1984-2014$ ERSST

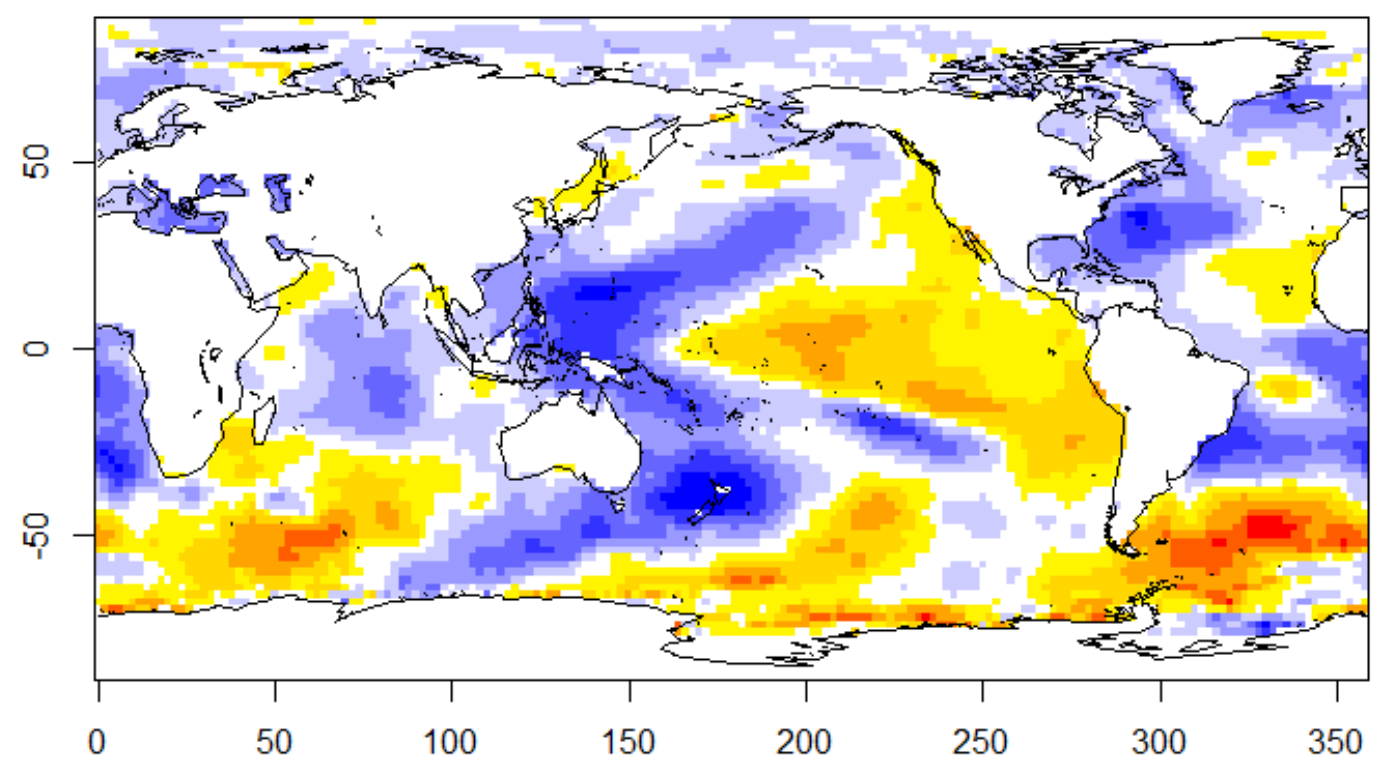

a)
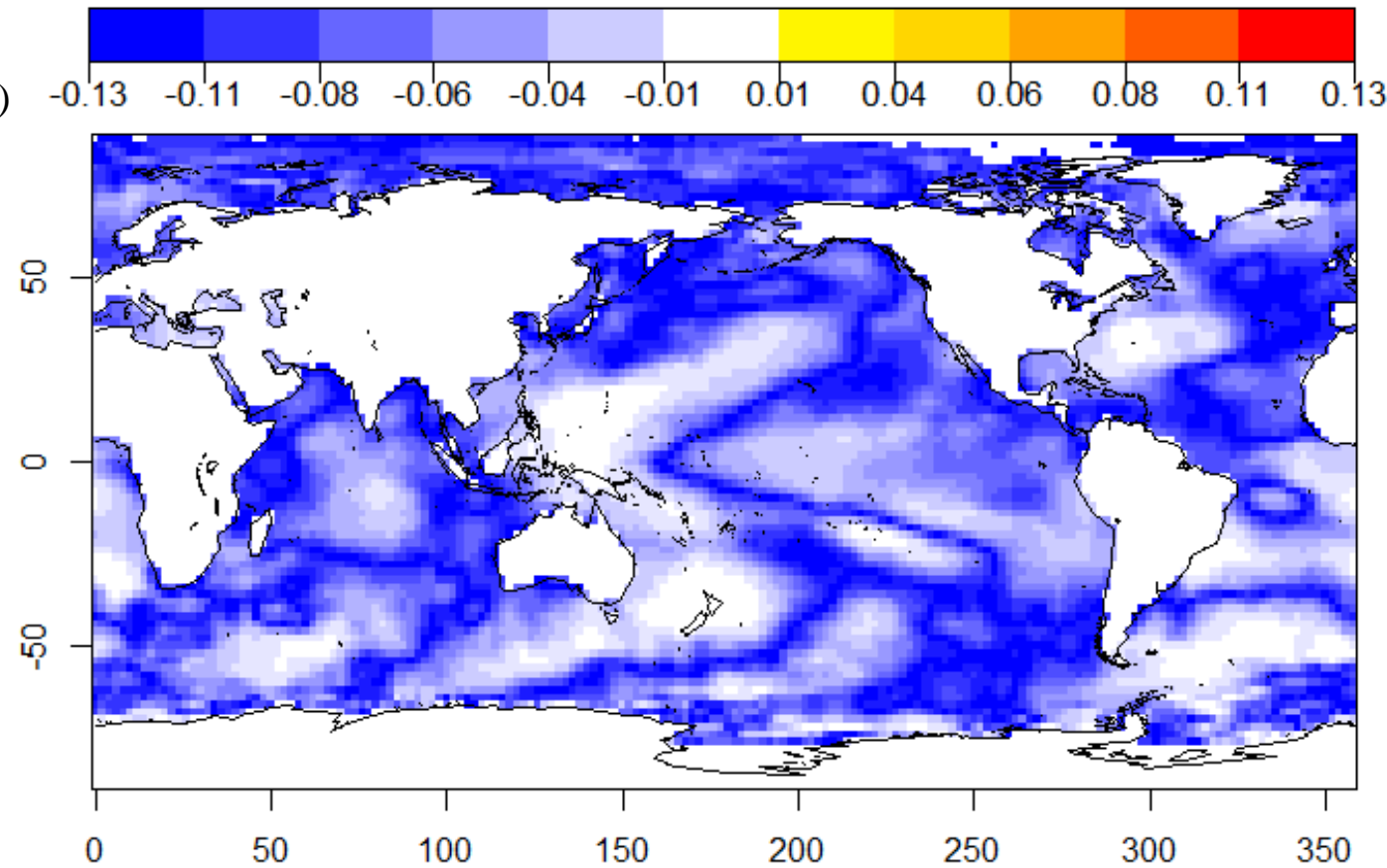

b) $\quad \begin{array}{lllllllllll}0.01 & 0.1 & 0.19 & 0.28 & 0.37 & 0.46 & 0.55 & 0.64 & 0.73 & 0.82 & 0.91\end{array}$

Figura APÊNDICE M-195 Correlação TSM ERSST versos ENA SE a) Correlação b) P-Valor 1984 - 2014 
APÊNDICE M.2 HadISST e ERSST - JAN/DEZ

APÊNDICE M.2.1 Bacia Paraná

APÊNDICE M.2.1.1 1931-2014 HadISST

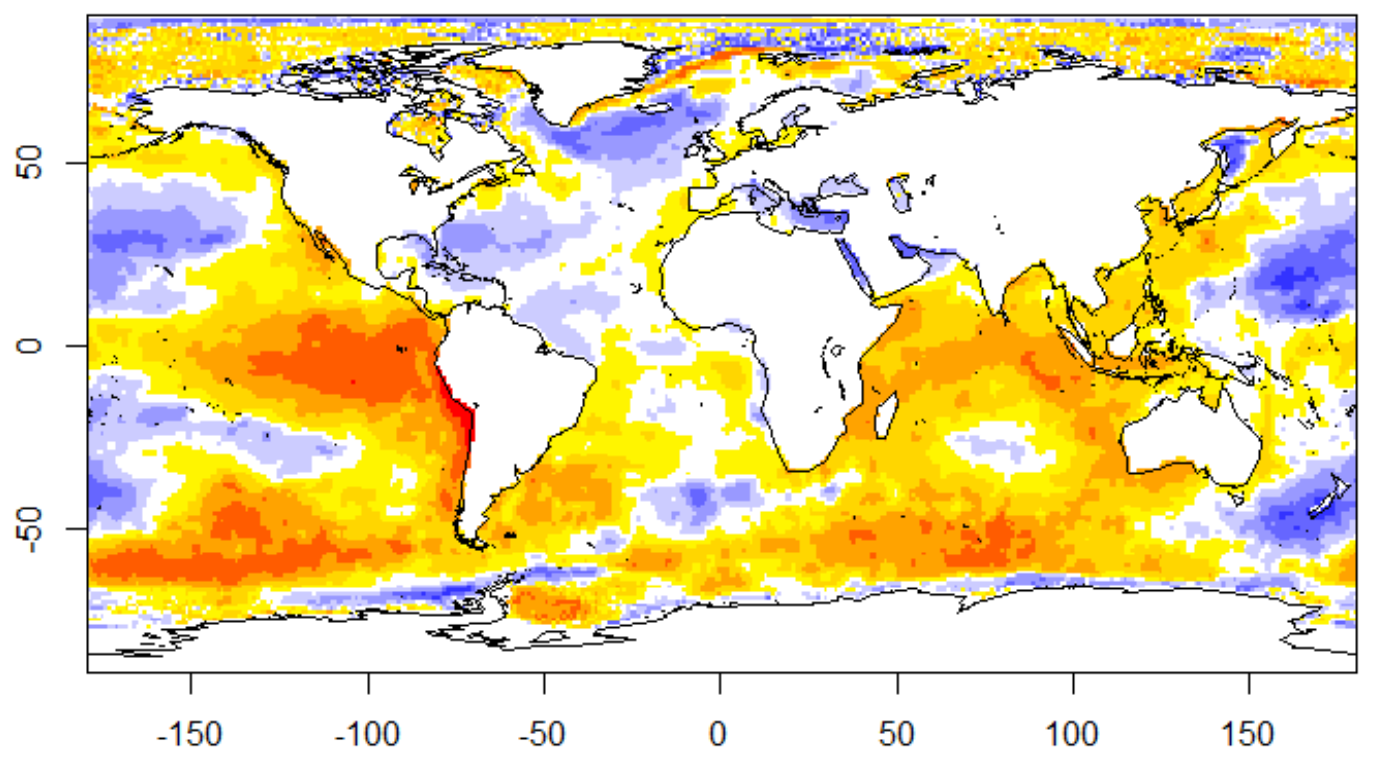

a)
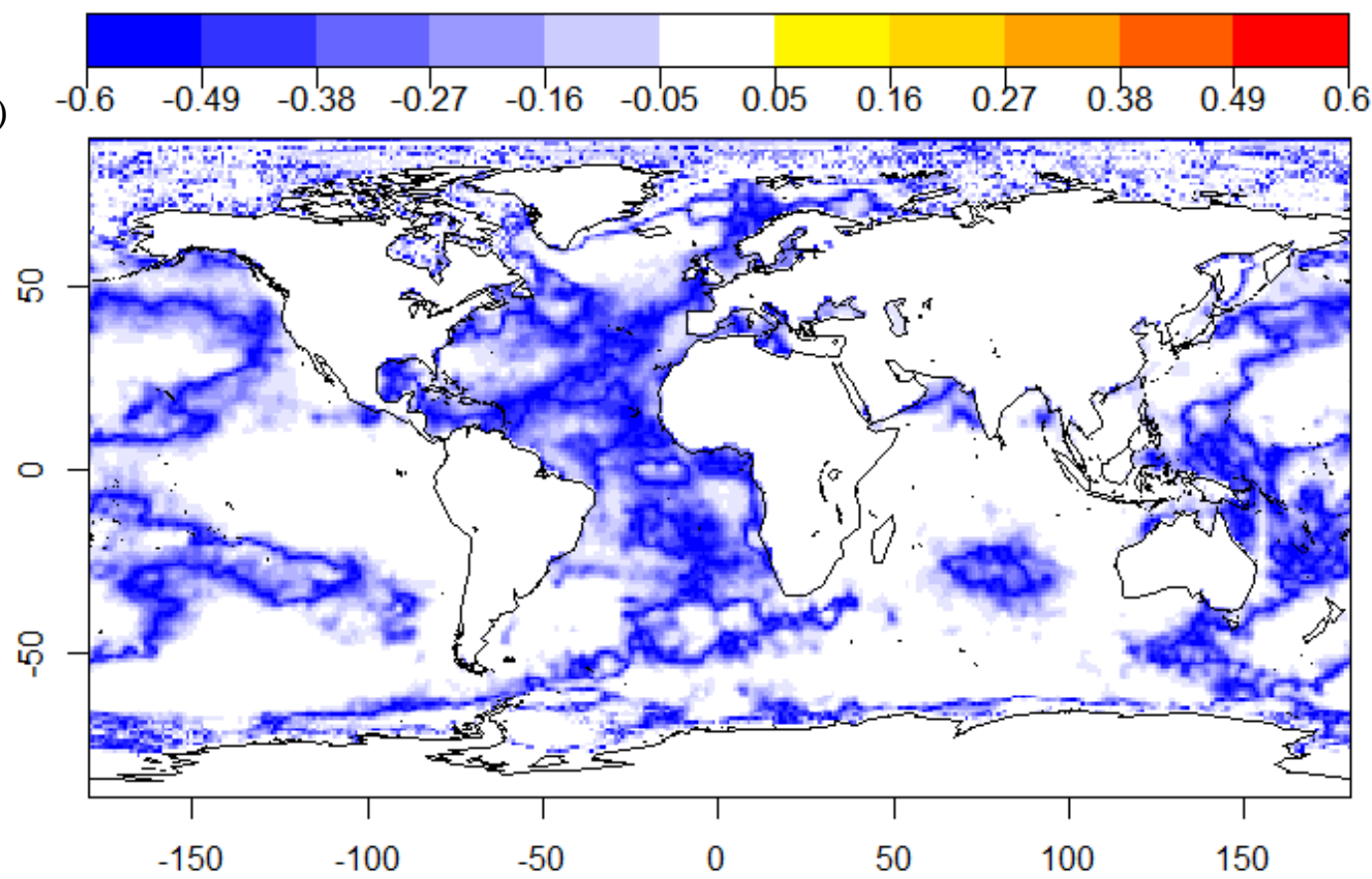

b)

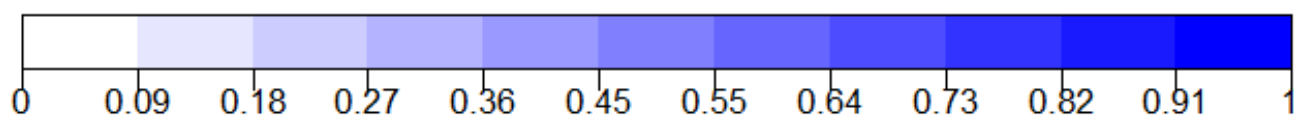

Figura APÊNDICE M-196 Correlação TSM HadISST versos ENA Bacia do Paraná a) Correlação b) P-Valor. 1931 2014 
APÊNDICE M.2.1.2 1931-2014 ERSST

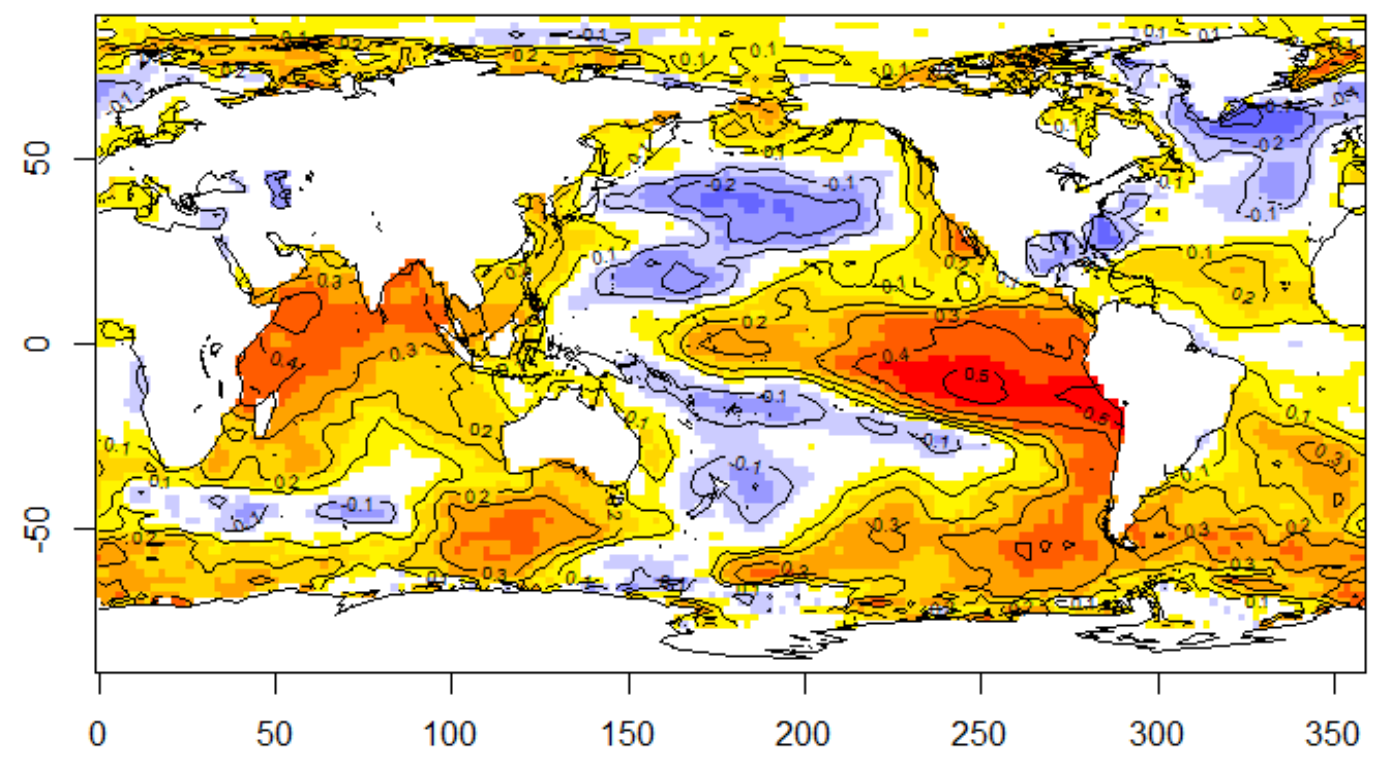

a)
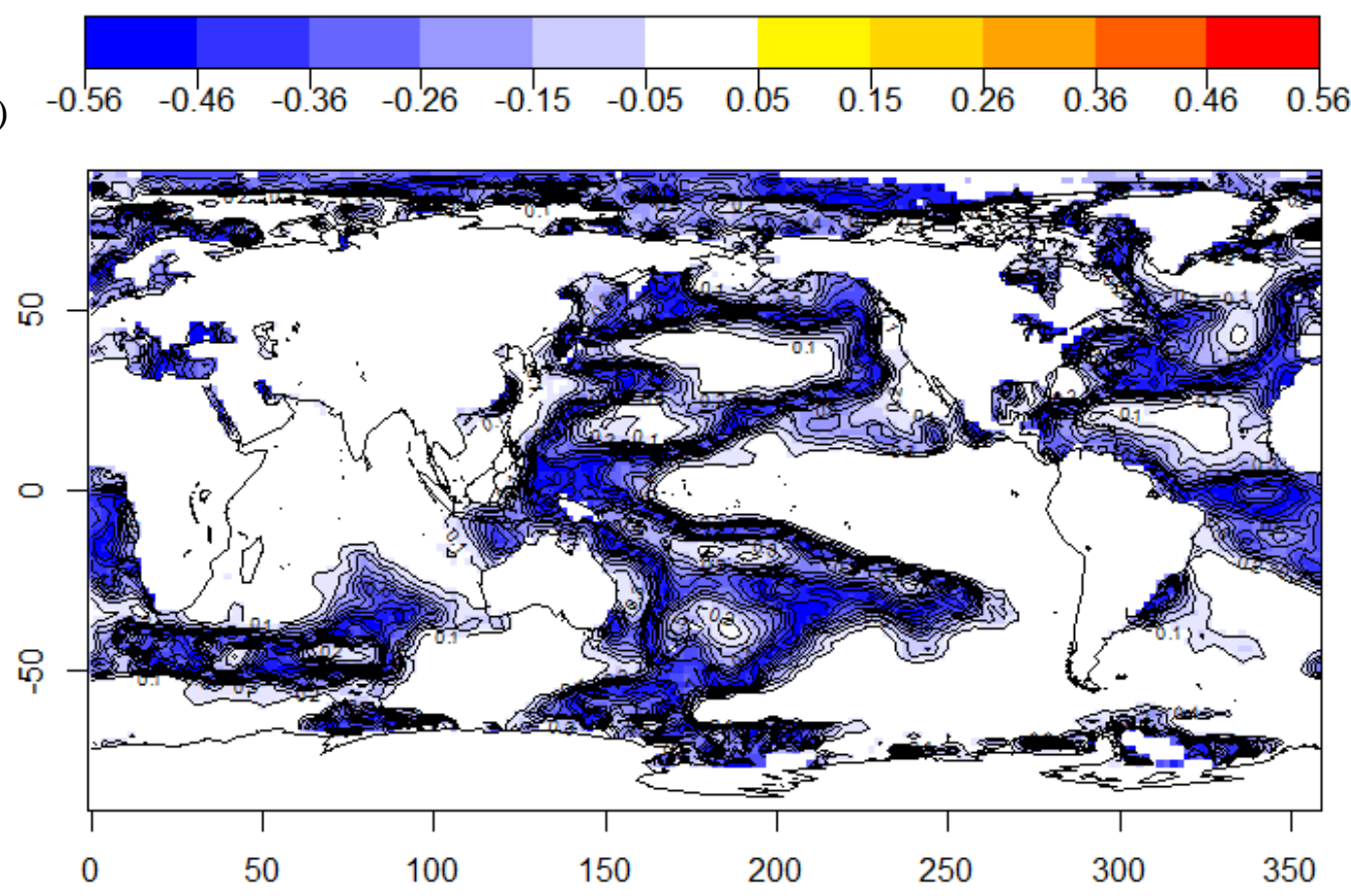

b)

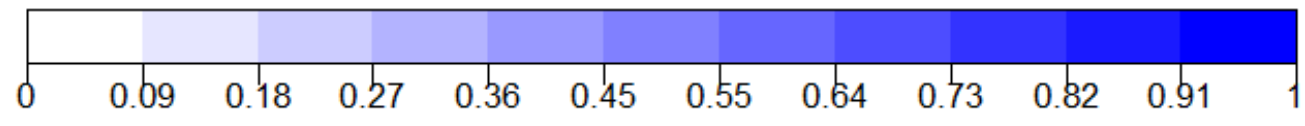

Figura APÊNDICE M-197 Correlação TSM ERSST versos ENA Bacia do Paraná a) Correlação b) P-Valor. 1931 2014 
APÊNDICE M.2.1.3 1973-2014 HadISST

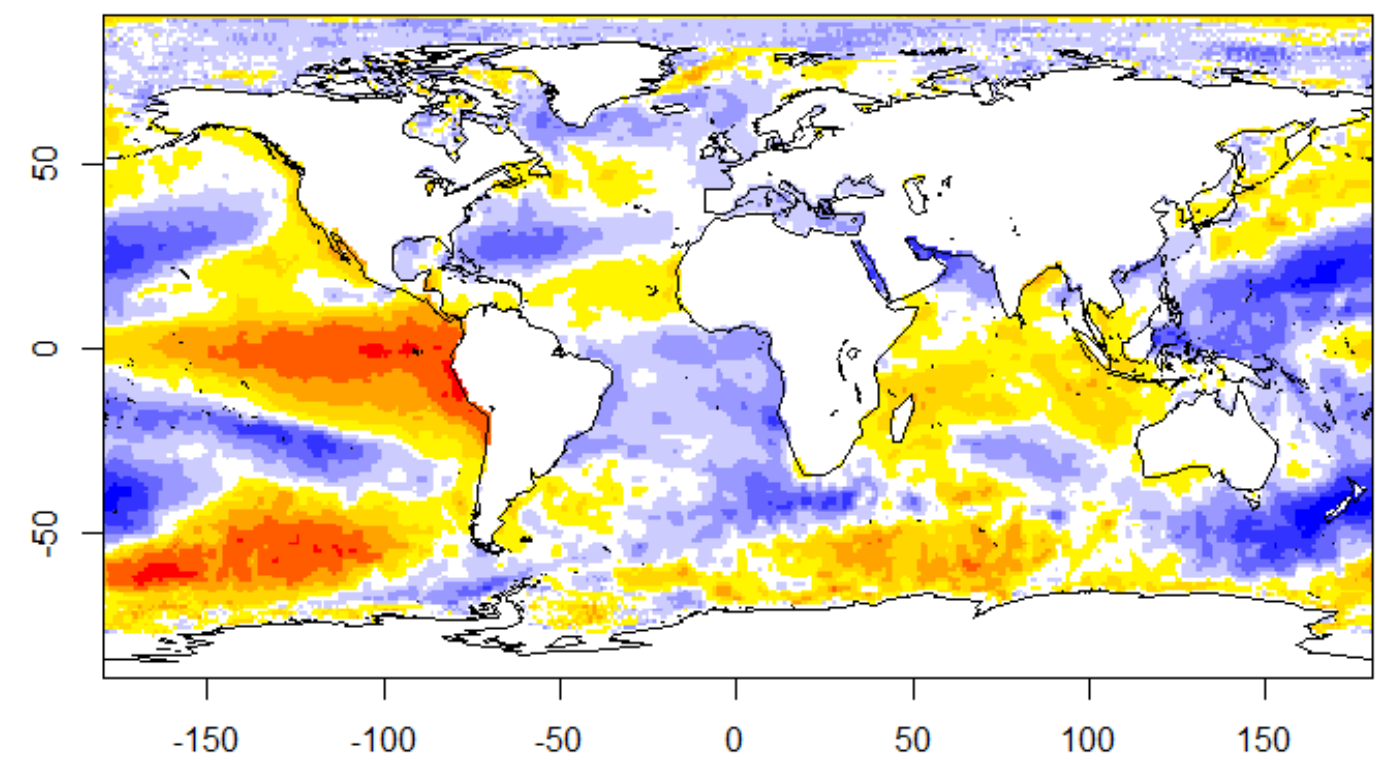

a)
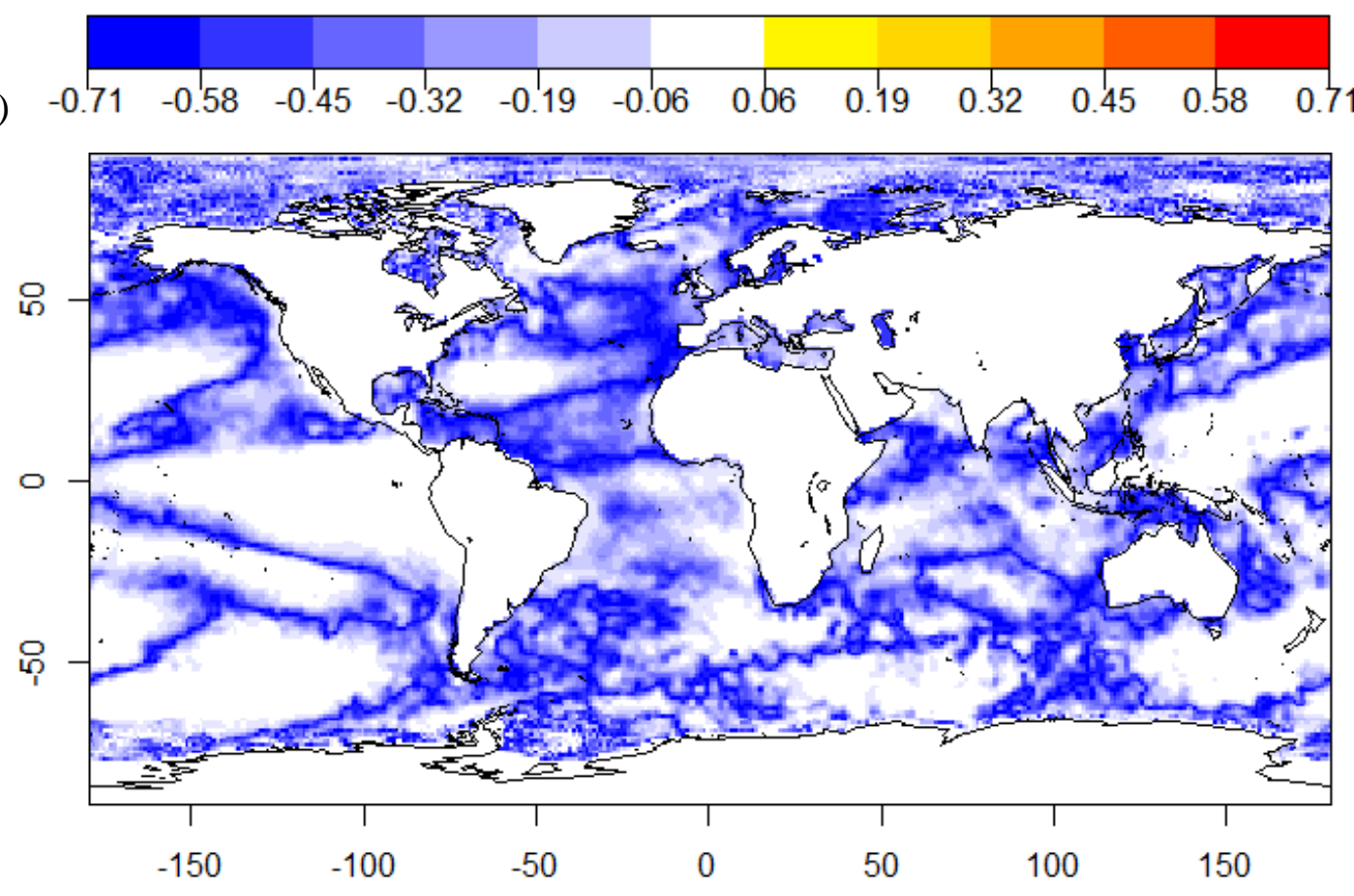

b)

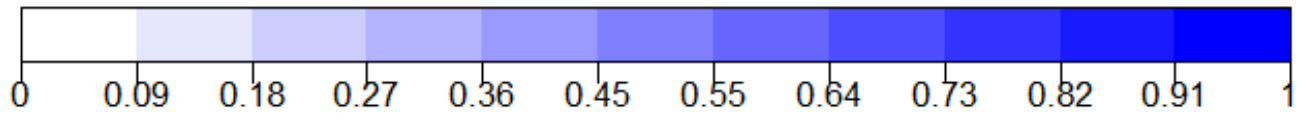

Figura APÊNDICE M-198 Correlação TSM HadISST versos ENA Bacia do Paraná a) Correlação b) P-Valor. 1973 2014 
APÊNDICE M.2.1.4 1973-2014 ERSST

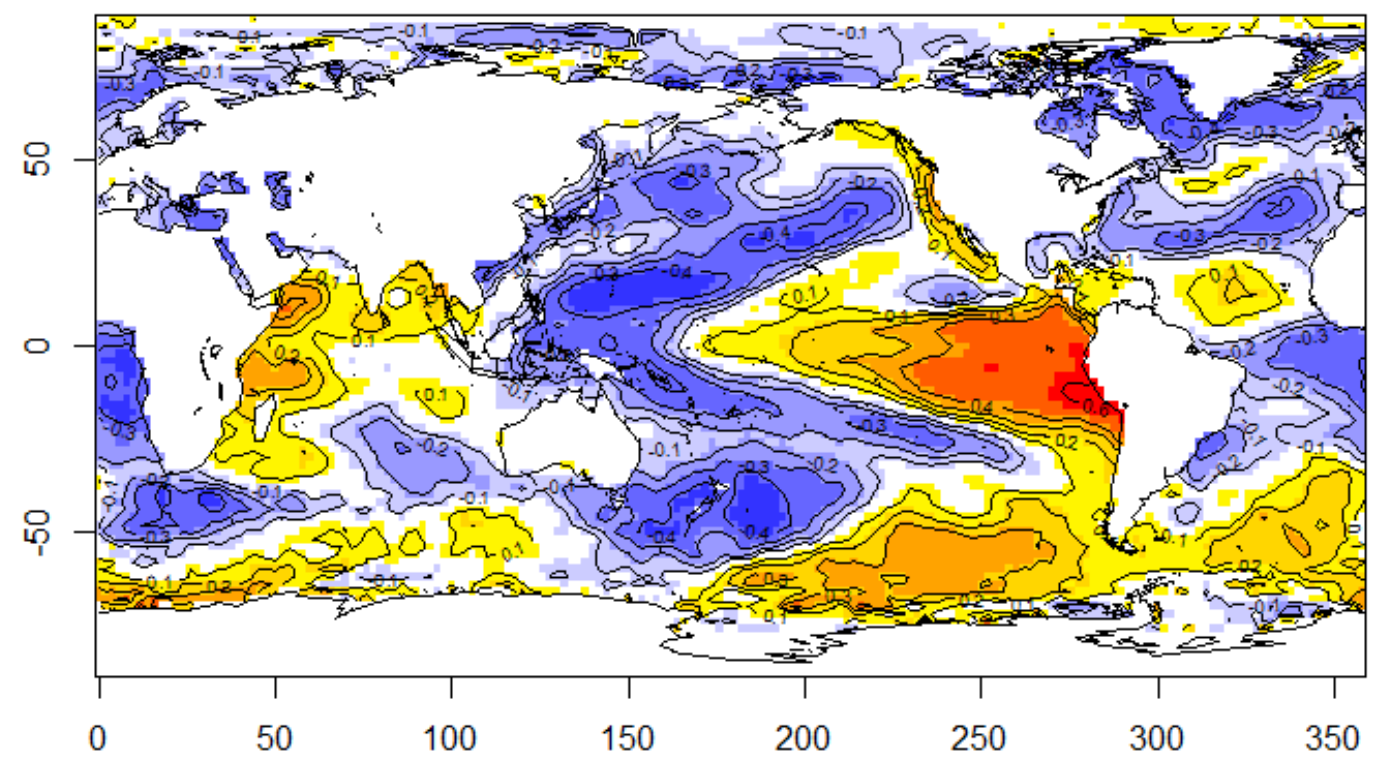

a)
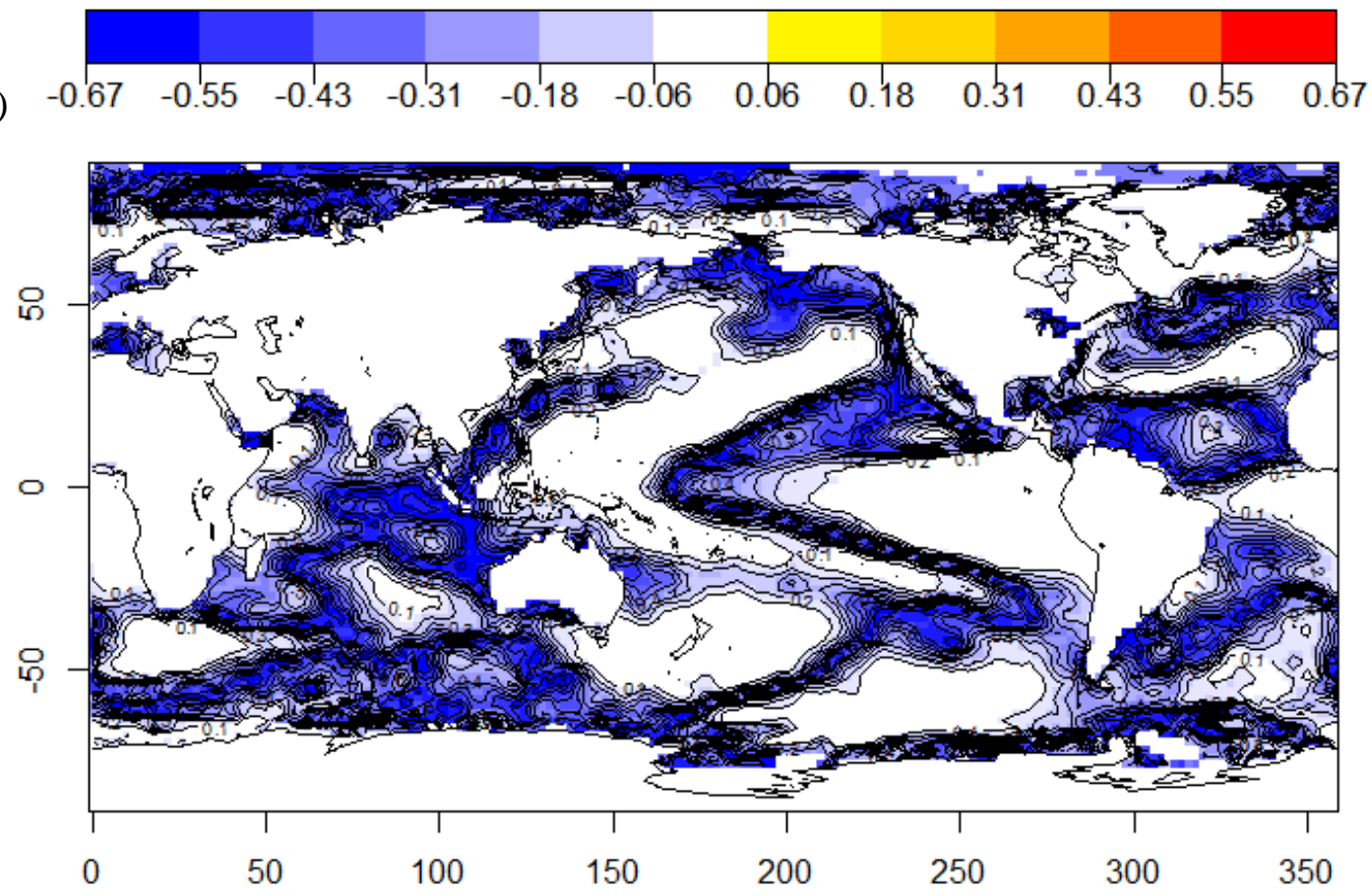

b)

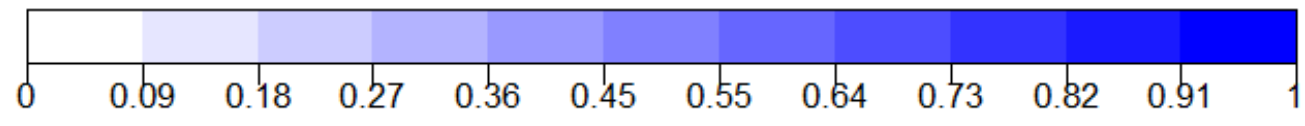

Figura APÊNDICE M-199 Correlação TSM ERSST versos ENA Bacia do Paraná a) Correlação b) P-Valor. 1973 2014 
APÊNDICE M.2.1.5 1984-2014 HadISST

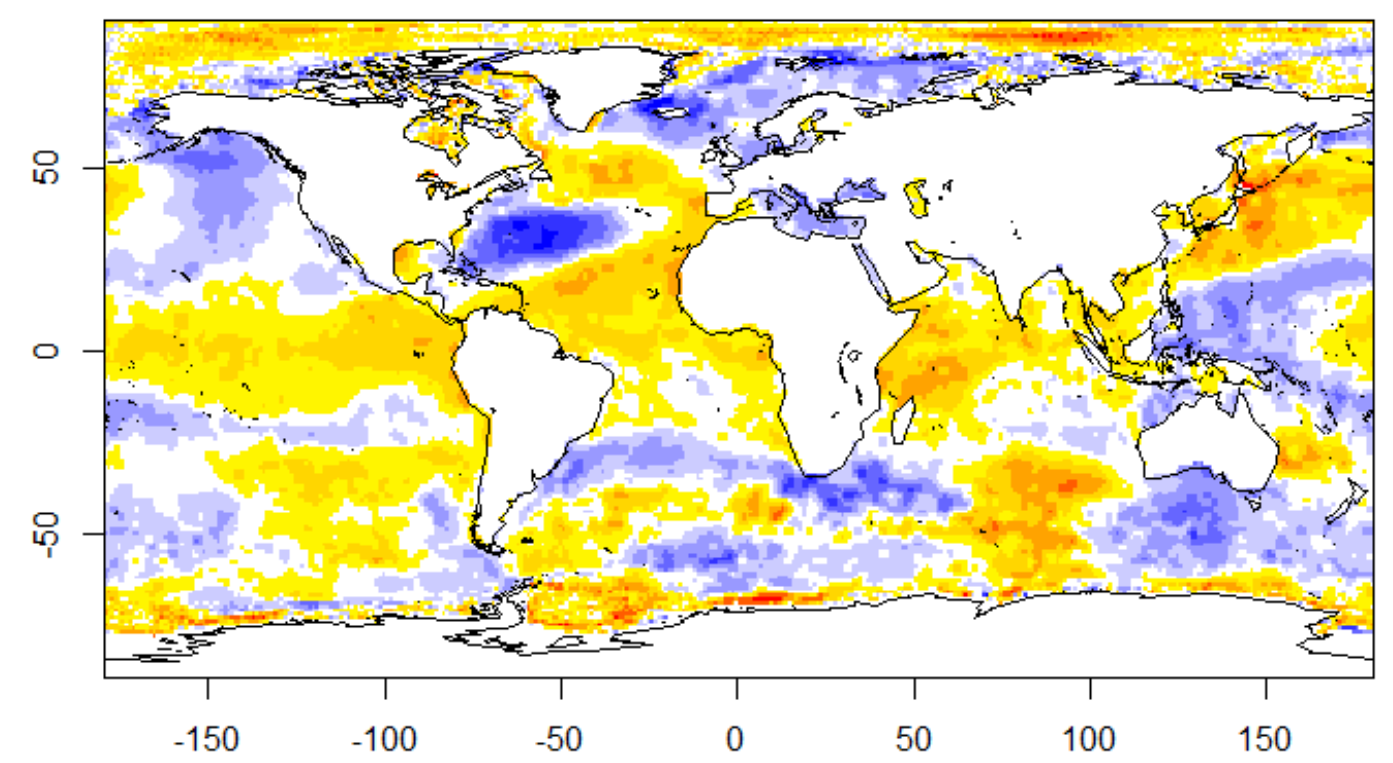

a)
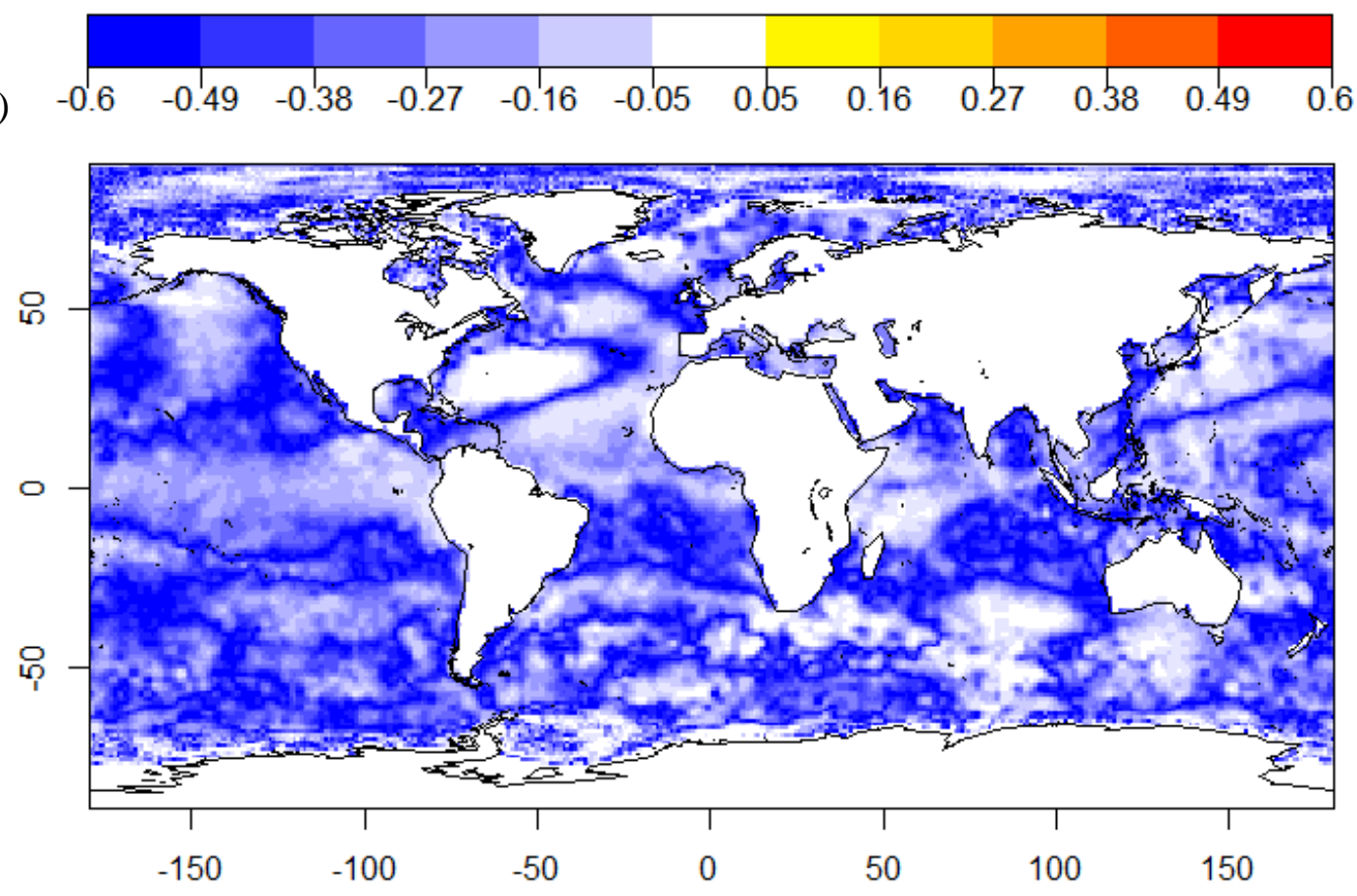

b)

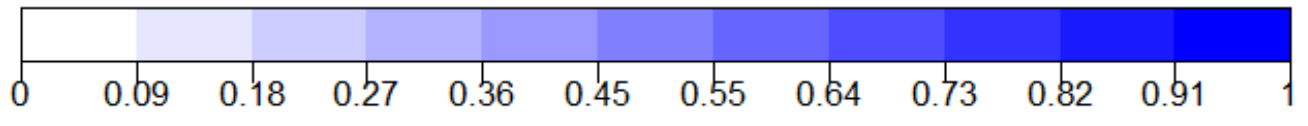

Figura APÊNDICE M-200 Correlação TSM HadISST versos ENA Bacia do Paraná a) Correlação b) P-Valor. 1984 2014 
APÊNDICE M.2.1.6 $1984-2014$ ERSST

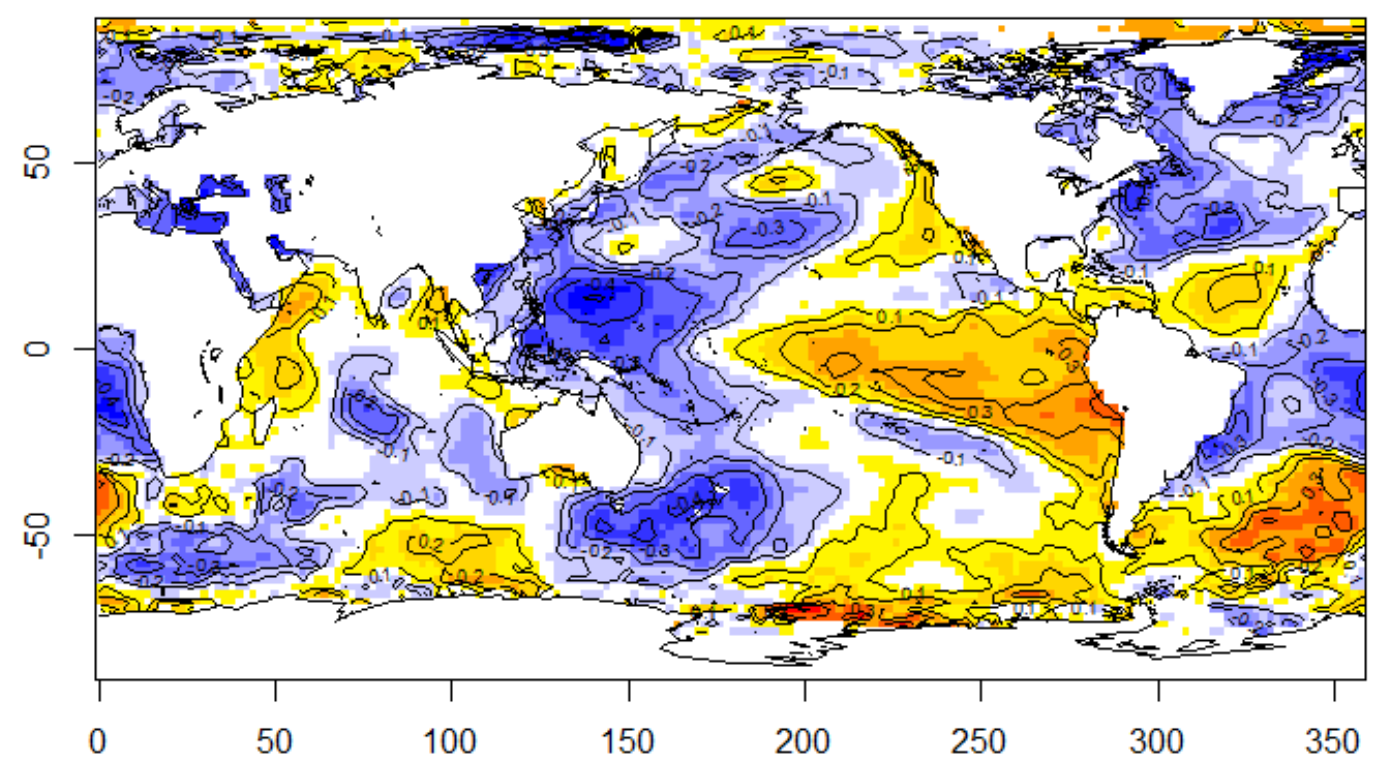

a)
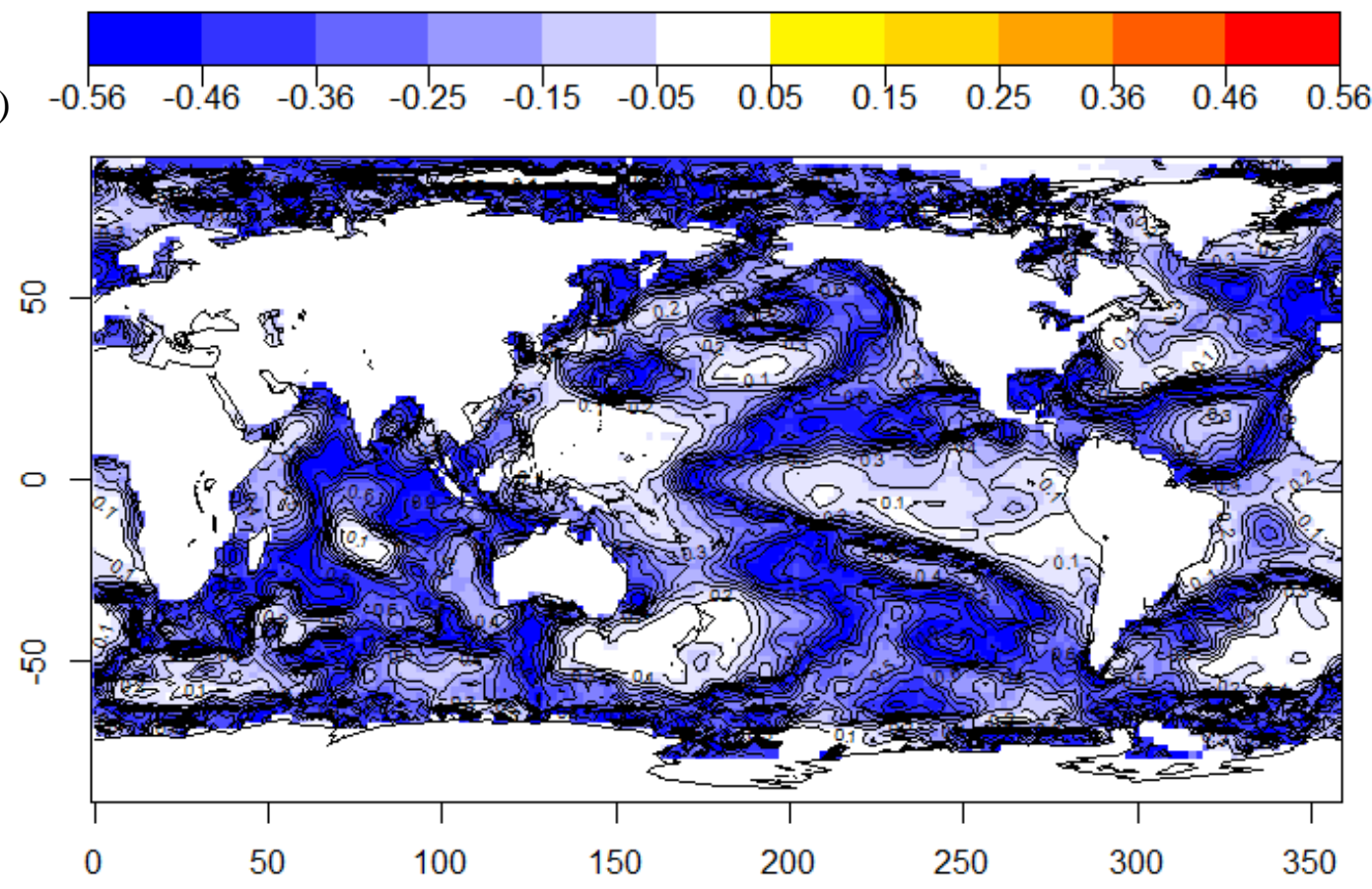

b)

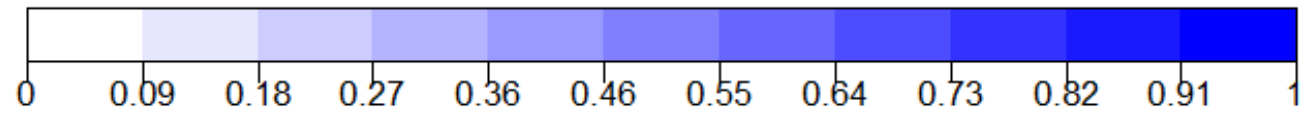

Figura APÊNDICE M-201 Correlação TSM ERSST versos Vazão Usina Barra Bonita a) Correlação b) P-Valor. $1984-2014$ 
APÊNDICE M.2.2 Usina Barra Bonita

APÊNDICE M.2.2.1 $1931-2014$ HadISST

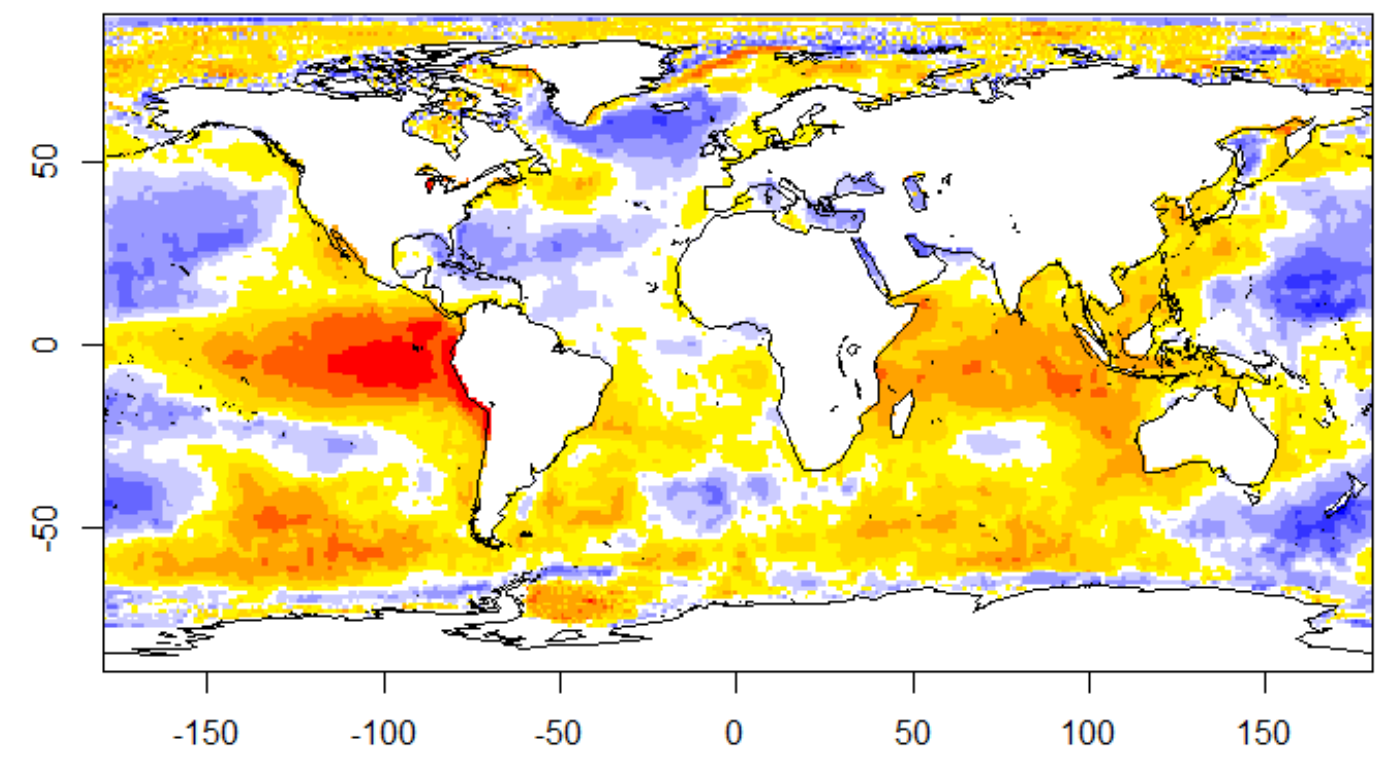

a)
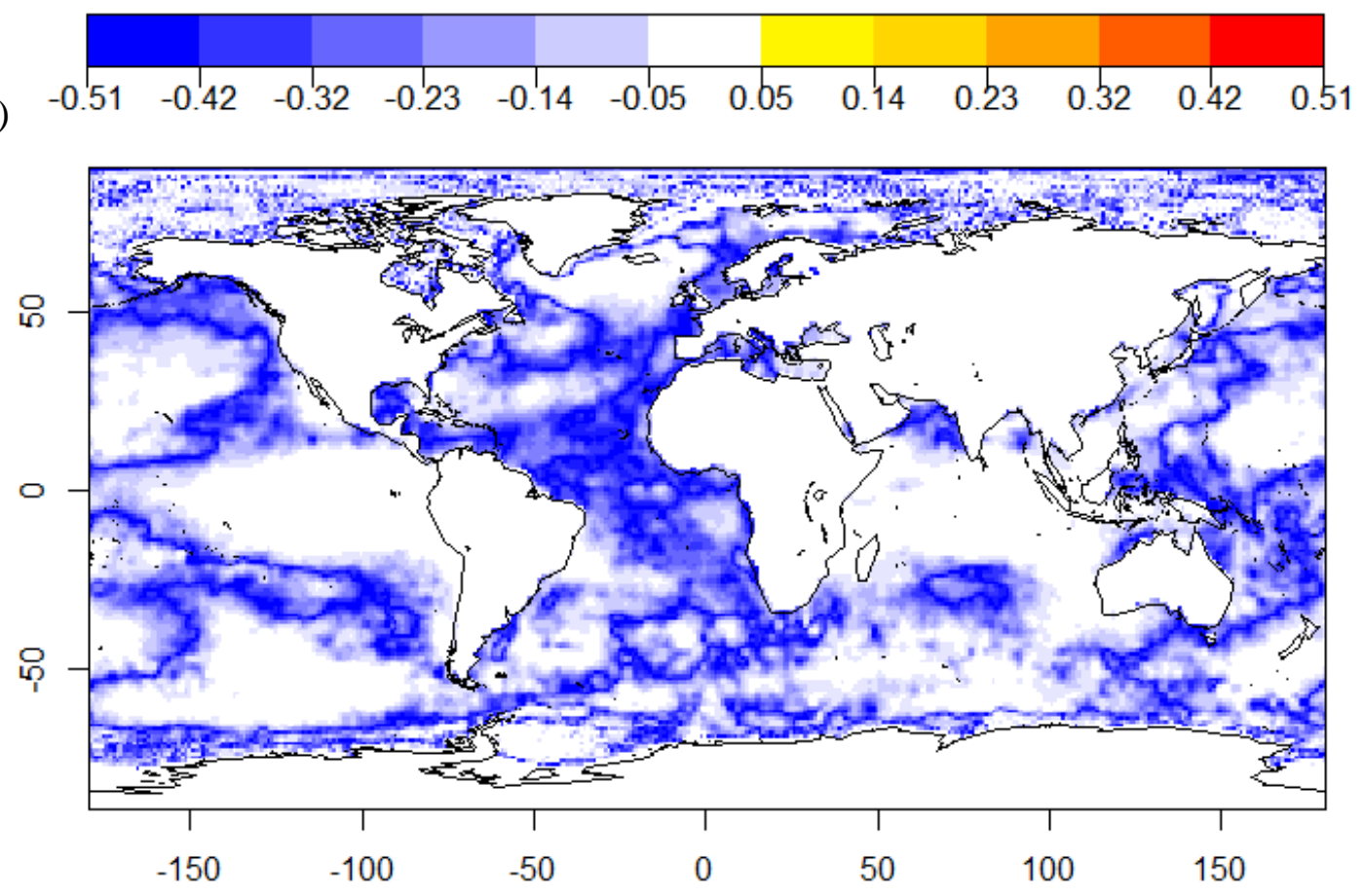

b)

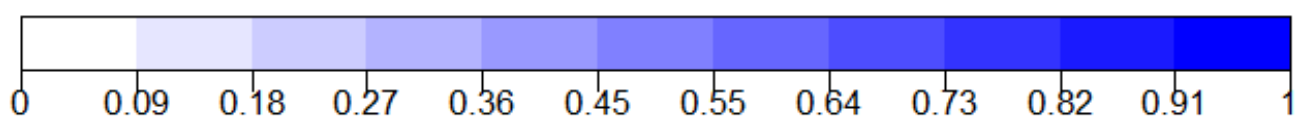

Figura APÊNDICE M-202 Correlação TSM HadISST versos Vazão Usina Barra Bonita a) Correlação b) P-Valor. $1931-2014$ 
APÊNDICE M.2.2.2 1931-2014 ERSST

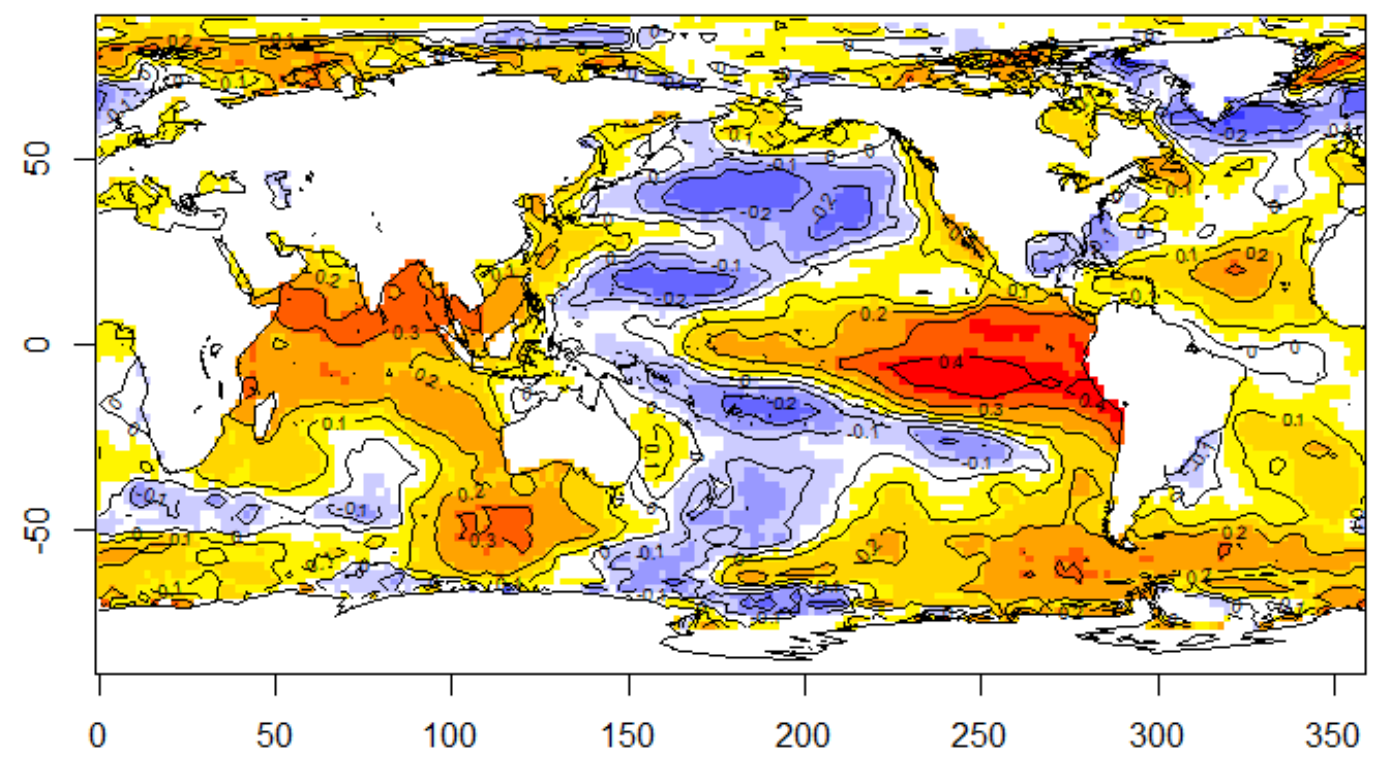

a)
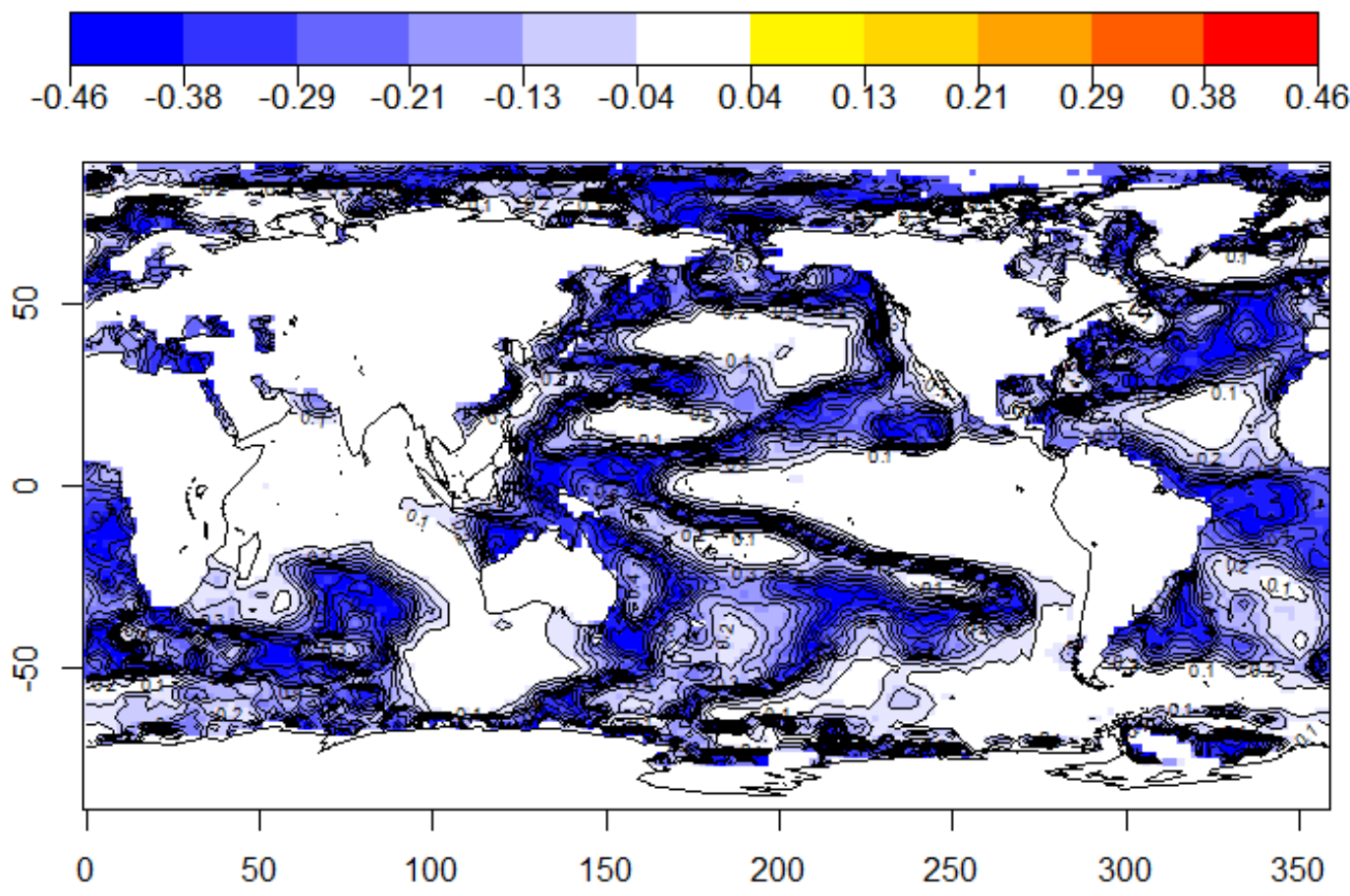

b)

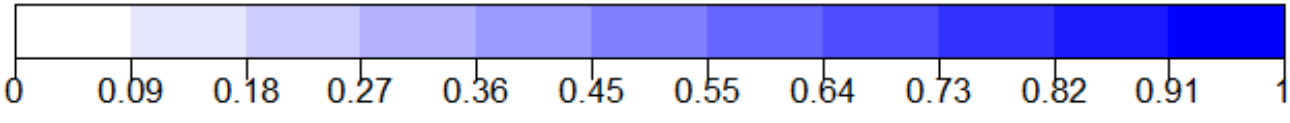

Figura APÊNDICE M-203 Correlação TSM ERSST versos Vazão Usina Barra Bonita a) Correlação b) P-Valor. $1931-2014$ 
APÊNDICE M.2.2.3 $\quad 1973-2014$ HadISST

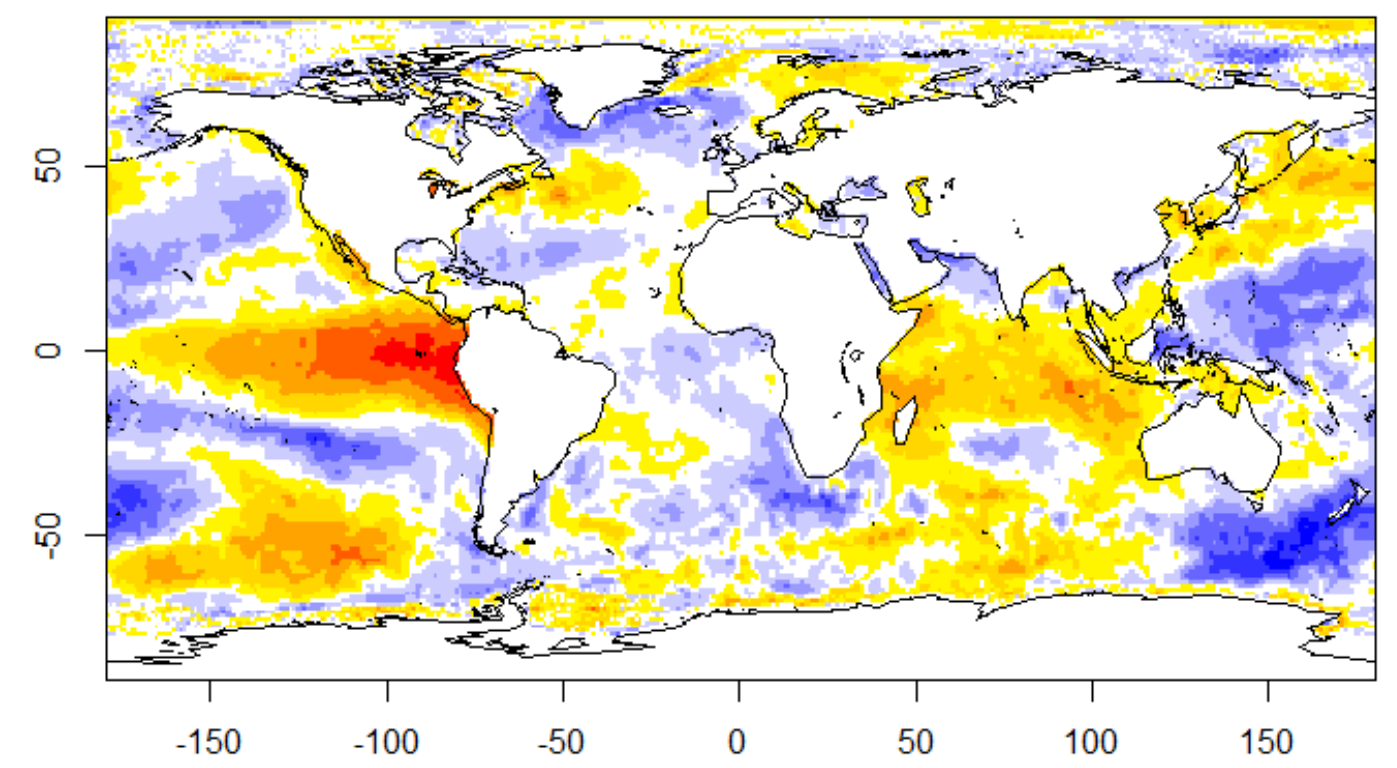

a)
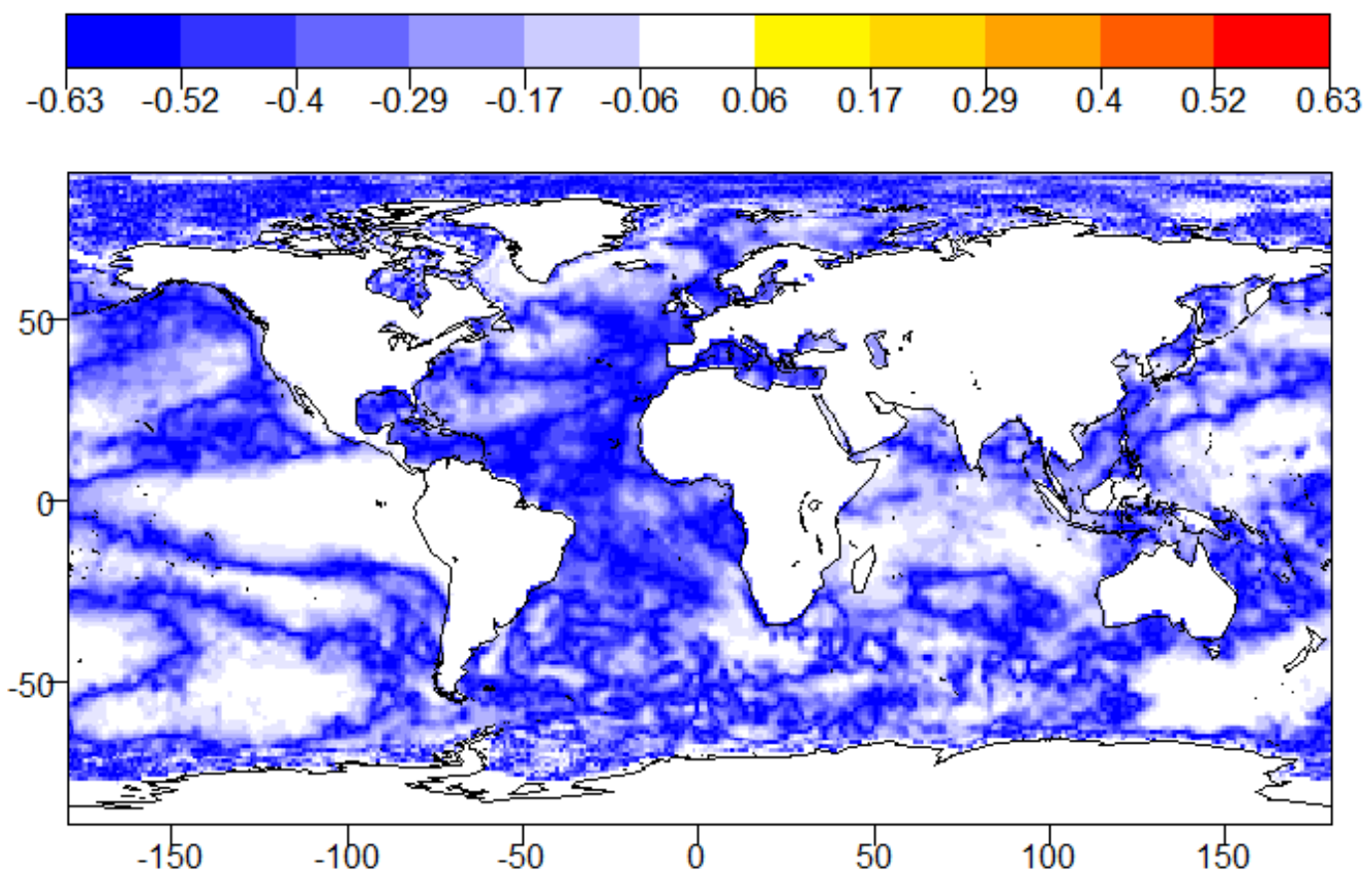

b)

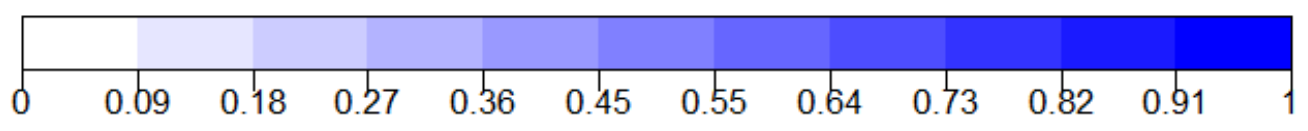

Figura APÊNDICE M-204 Correlação TSM HadISST versos Vazão Usina Barra Bonita a) Correlação b) P-Valor $1973-2014$ 
APÊNDICE M.2.2.4 1973-2014 ERSST

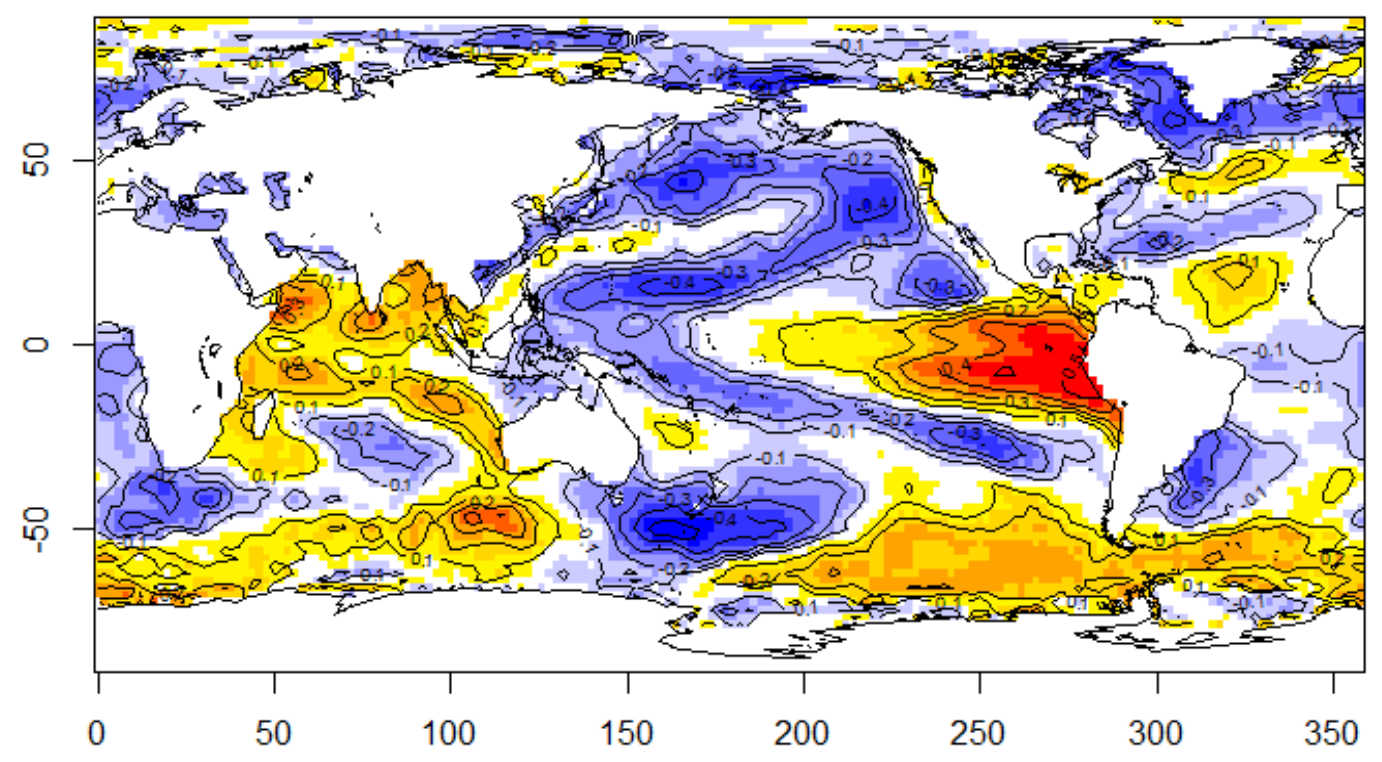

a)
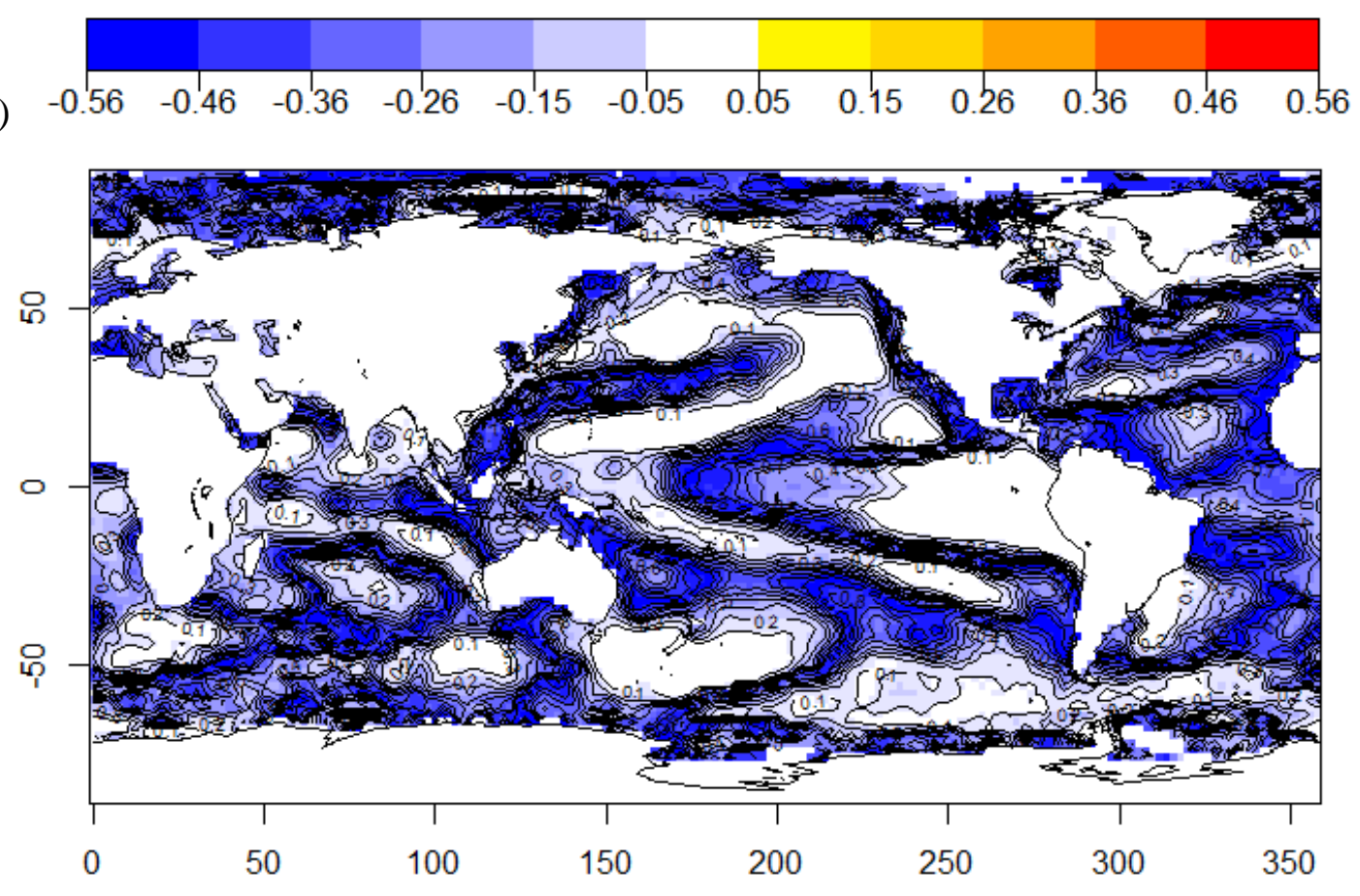

b)

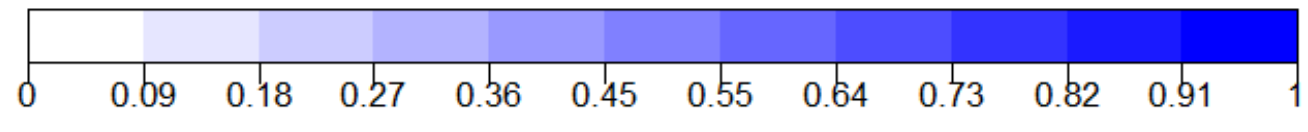

Figura APÊNDICE M-205 Correlação TSM ERSST versos Vazão Usina Barra Bonita a) Correlação b) P-Valor $1973-2014$ 
APÊNDICE M.2.2.5 $1984-2014$ HadISST

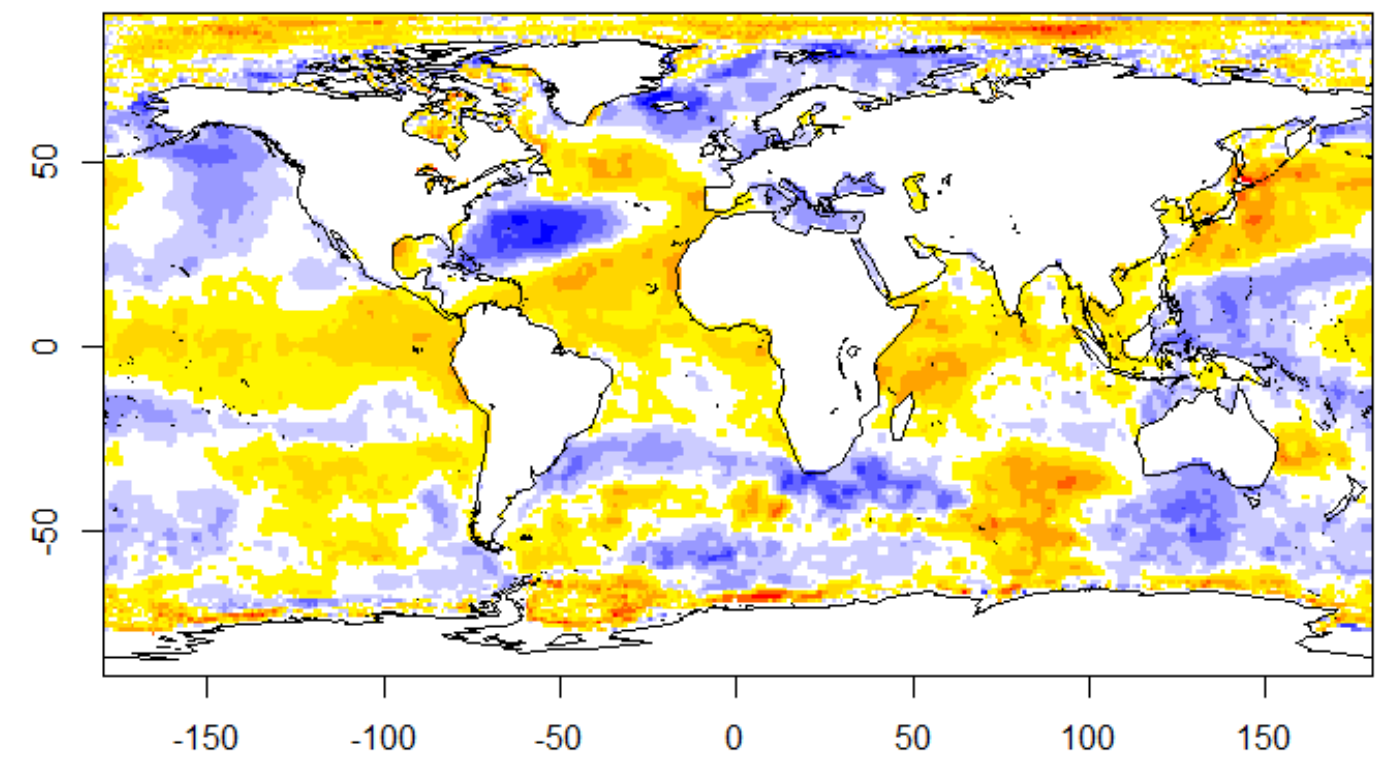

a)
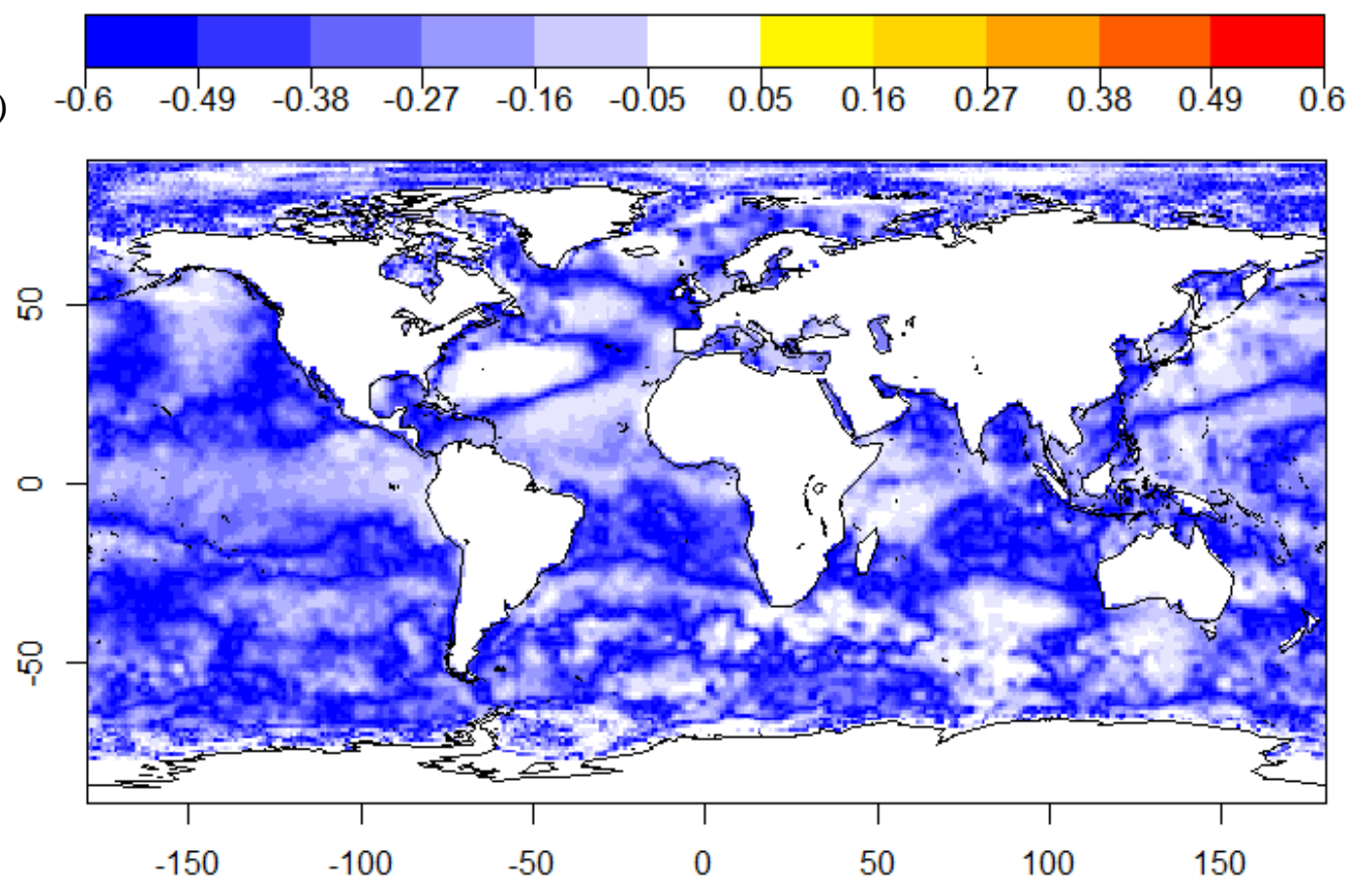

b)

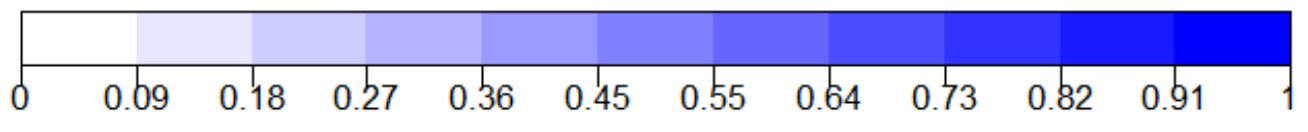

Figura APÊNDICE M-206 Correlação TSM HadISST versos Vazão Usina Barra Bonita a) Correlação b) P-Valor $1984-2014$ 
APÊNDICE M.2.2.6 1984-2014 ERSST

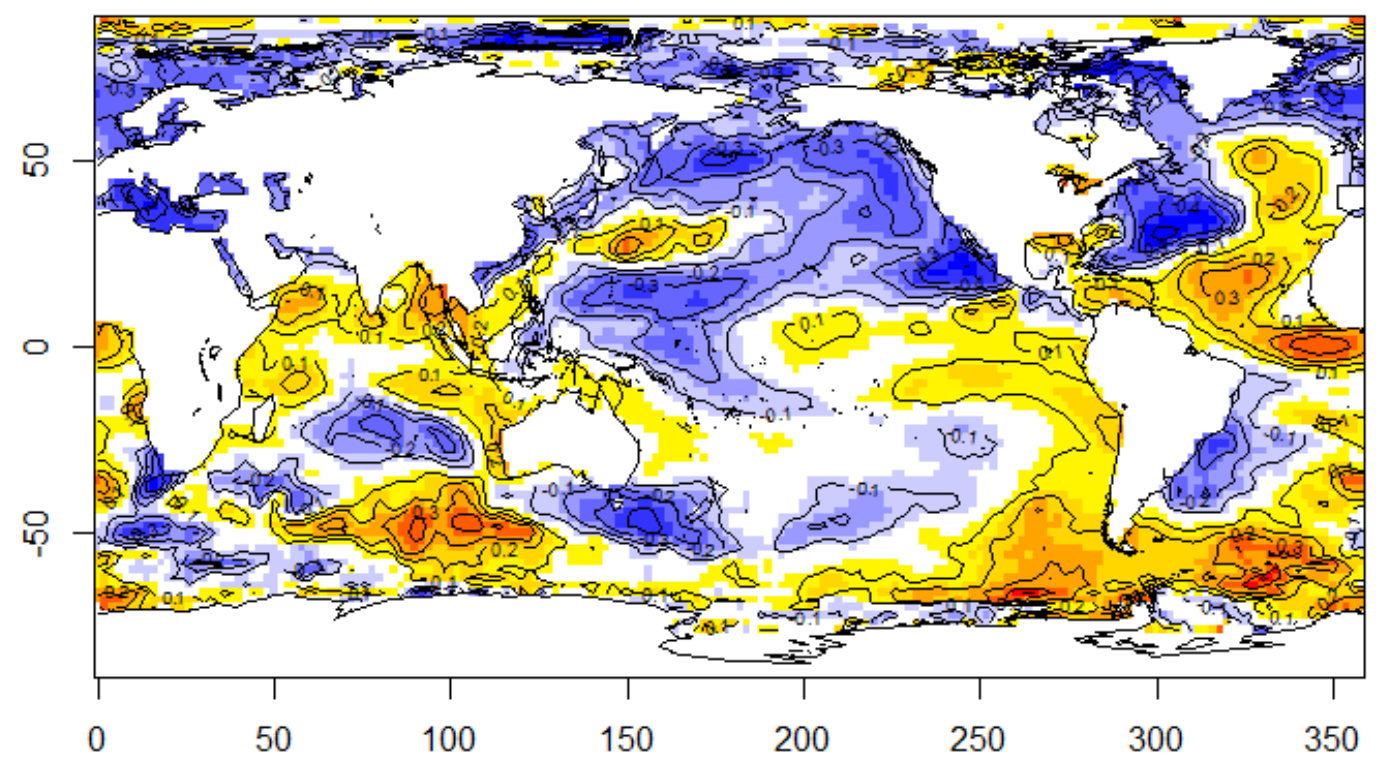

a)
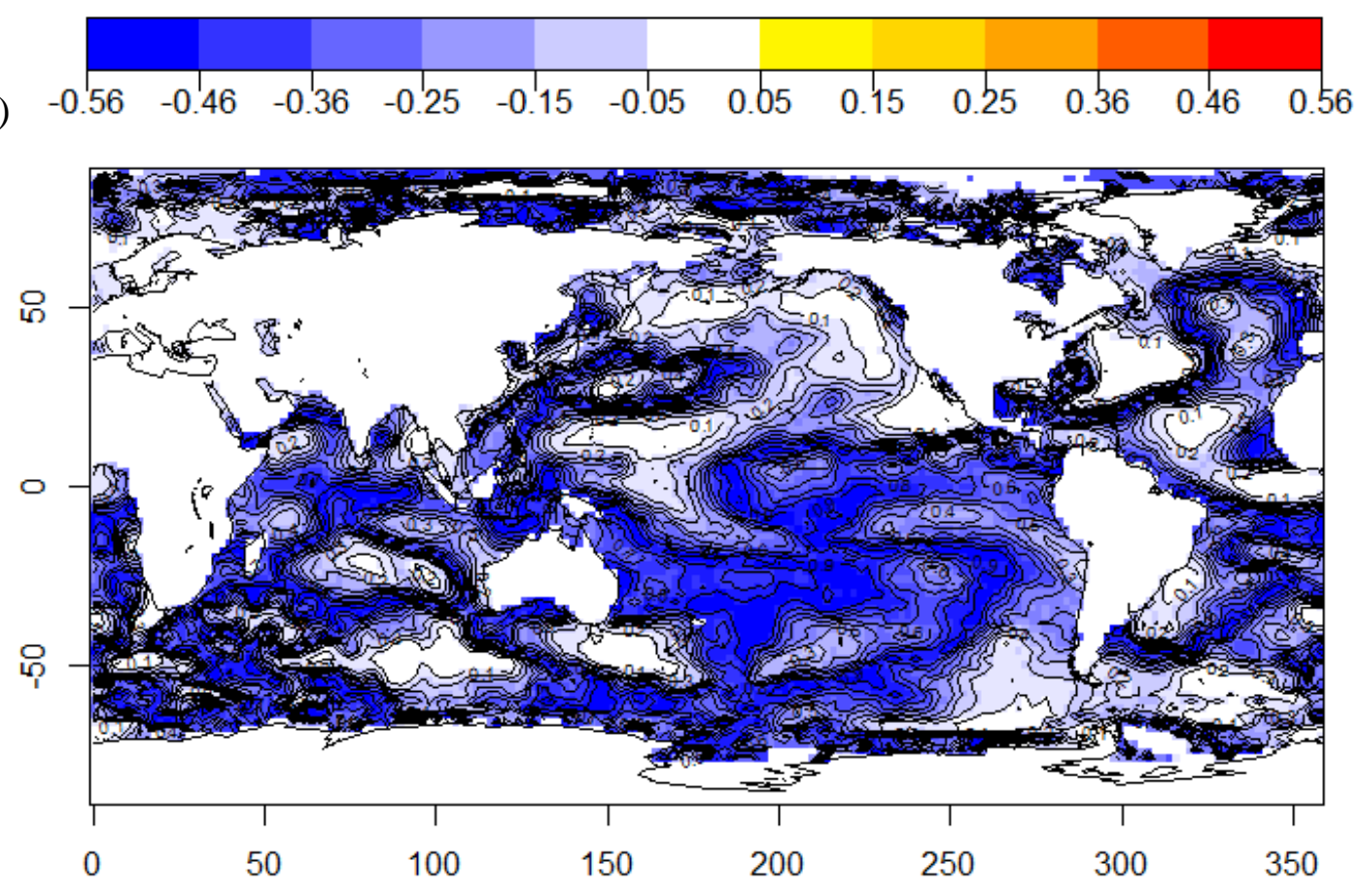

b)

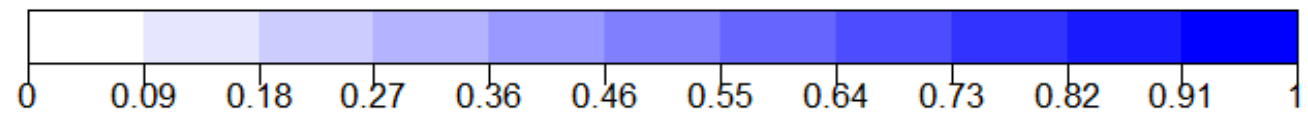

Figura APÊNDICE M-207 Correlação TSM ERSST versos Vazão Usina Barra Bonita a) Correlação b) P-Valor $1984-2014$ 


\section{APÊNDICE N Correlação Clima x Energia}

\section{APÊNDICE N.1 Correlações Entre Usinas}

Os gráficos seguem os critérios de análise que são apresentados a seguir:

As usinas estão na seguinte ordem nos gráficos:

(a) Usinas da Bacia do rio Paraná: 243 Três Irmãos, 244 Ilha Solteira, 45 Jupiá, 46 Porto Primavera, 66 Itaipu.

(b) Usinas da Bacia do Rio São Francisco: 155 Retiro Baixo, 156 Três Marias, 158 Queimado, 169 Sobradinho e 172 Itaparica.

(c) Usinas da Bacia do Rio Tocantins: 270 Serra da Mesa, 257 Peixe Angical, 273 Lajeado, 271 Estreito Tocantins e 275 Tucuruí.

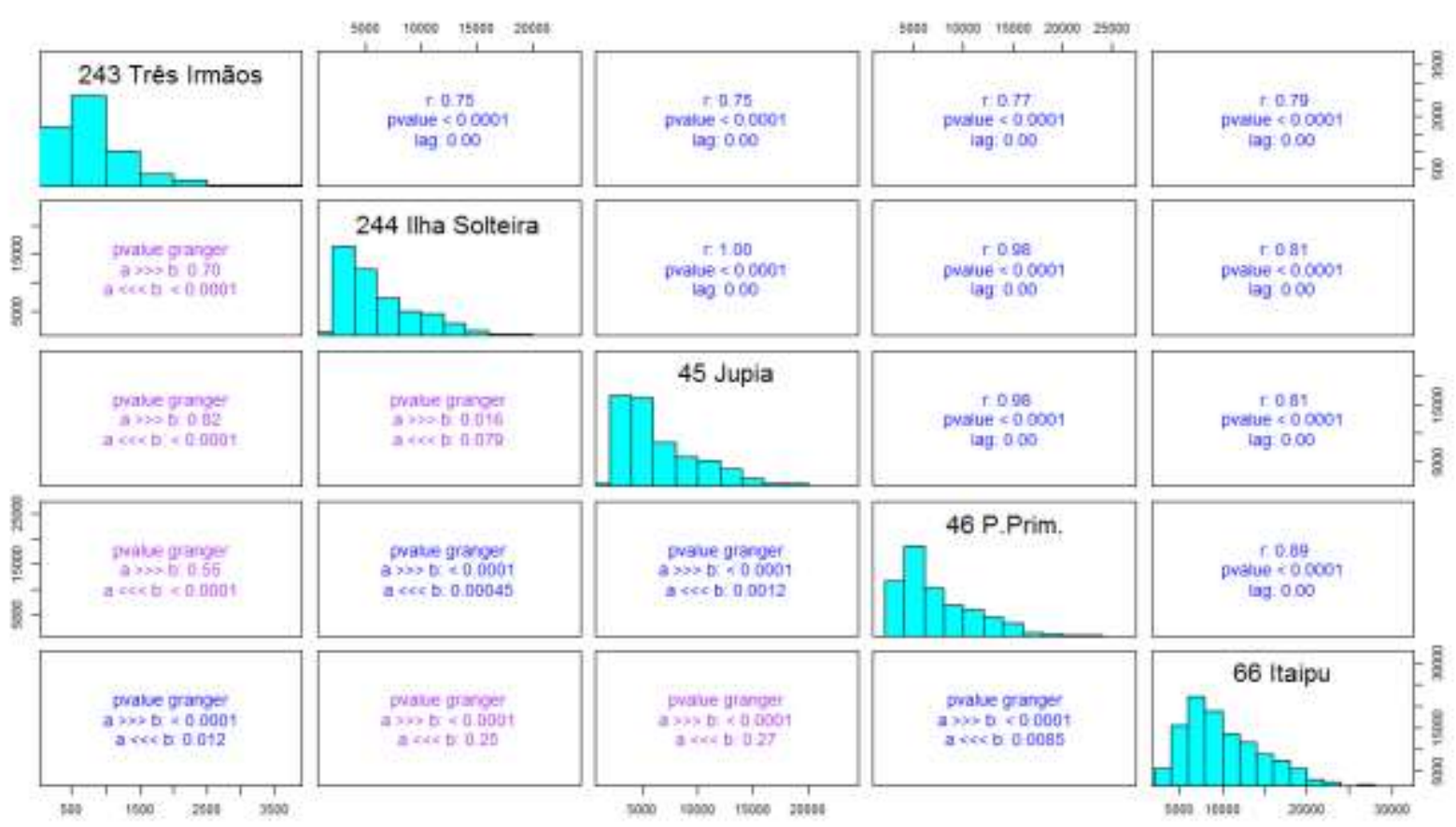

(a) 


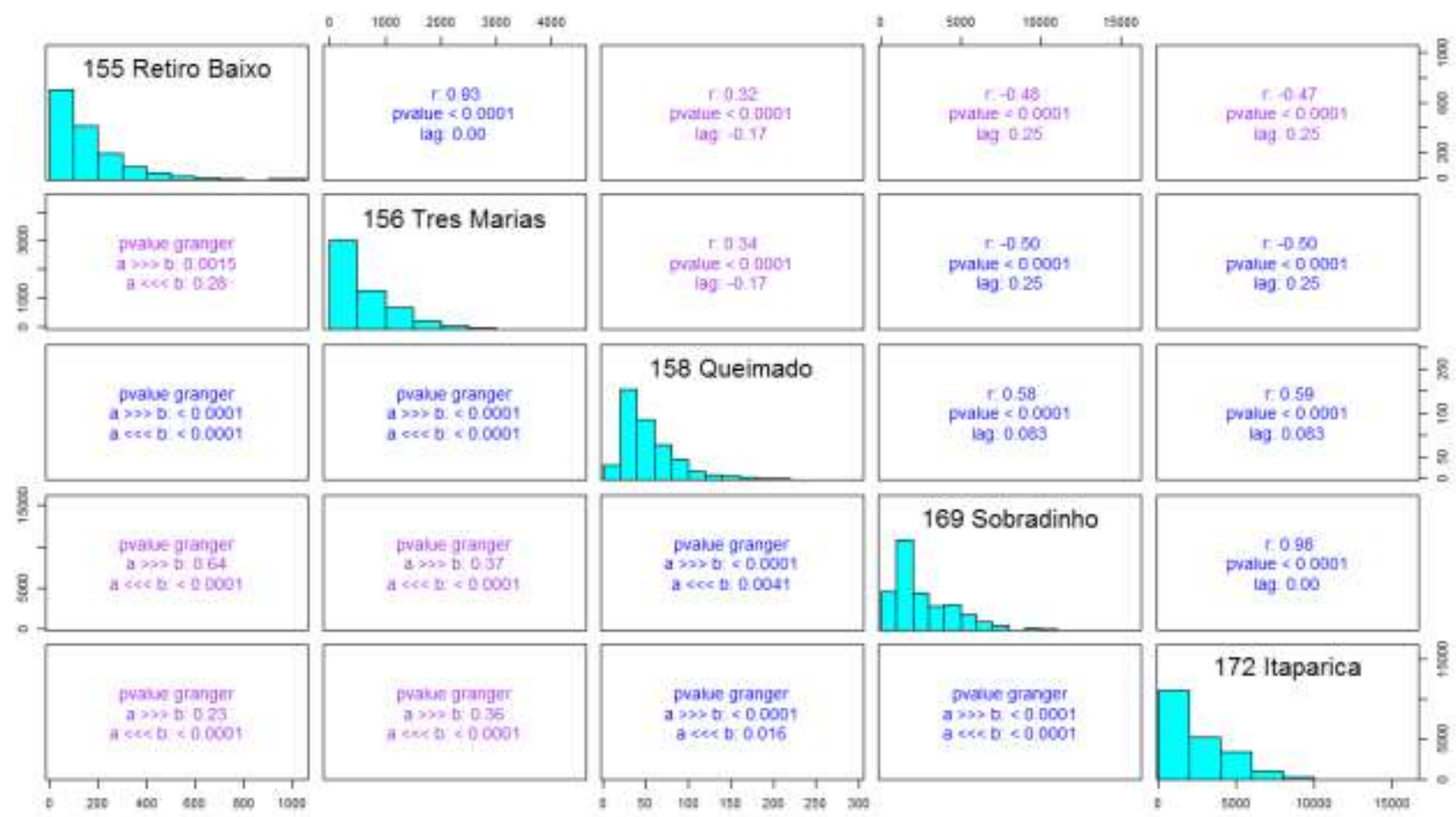

(b)

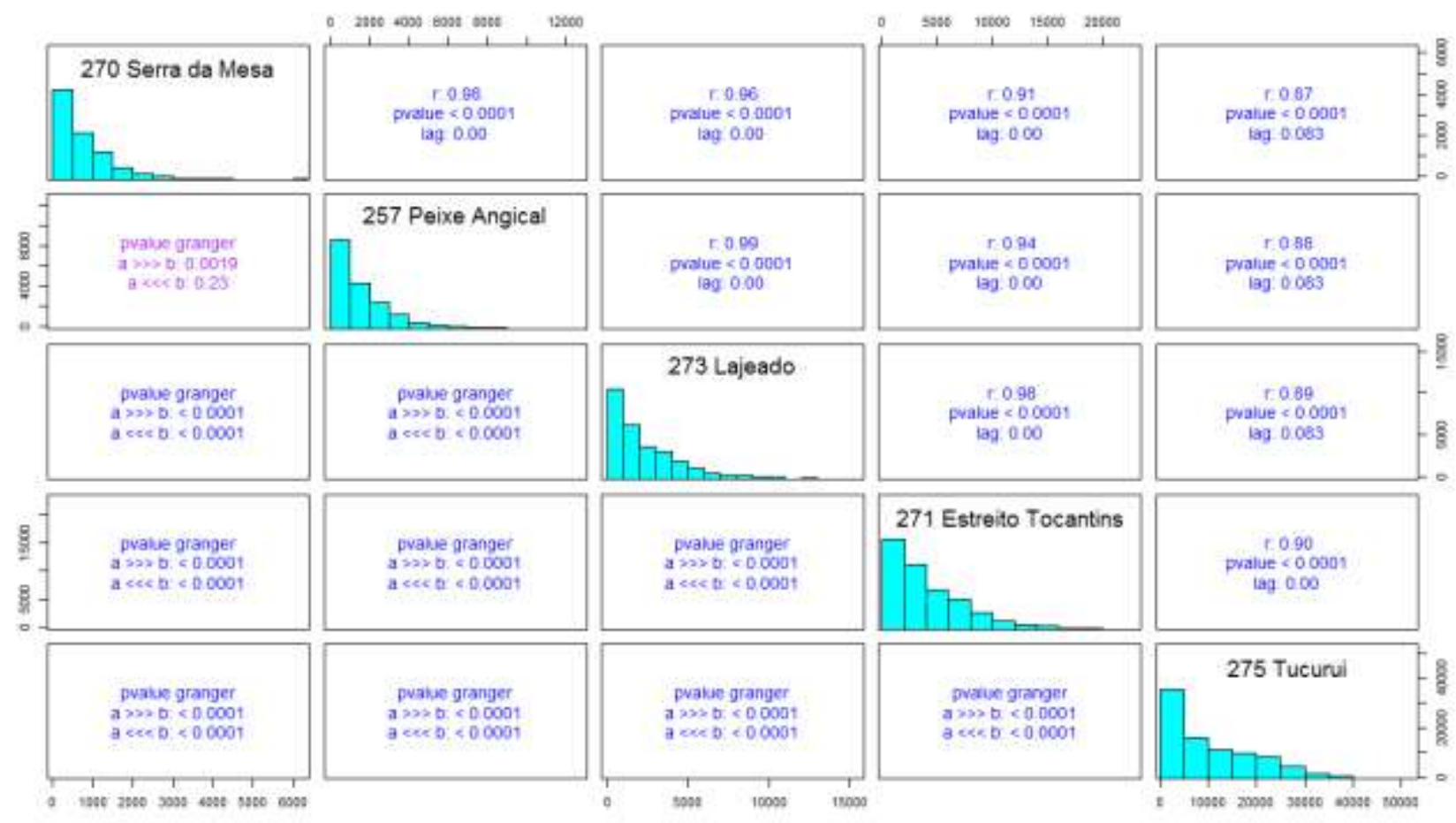

(c)

Figura APÊNDICE N-208 Correlação entre as vazões das Usinas da Bacia dos rios a) Paraná, b) São Francisco e c) Tocantins

Na bacia do rio Parnaíba na fonte de dados do ONS só há dados de uma usina que é Boa Esperança. 


\section{APÊNDICE N.1.1 ONI e MEI versos ENA}

São realizadas análises de correlação e causalidade de Granger entre estes índices e as variáveis dependentes ENA-SE, ENA-PR e VAZ.U. BARRA BONITA, para avaliar se há correlações que podem servir para a construção de um modelo.

Observa-se nestes gráficos que entre as variáveis de índices de ONI e MEI e as vazões das usinas nenhum apresentou correlação expressiva.
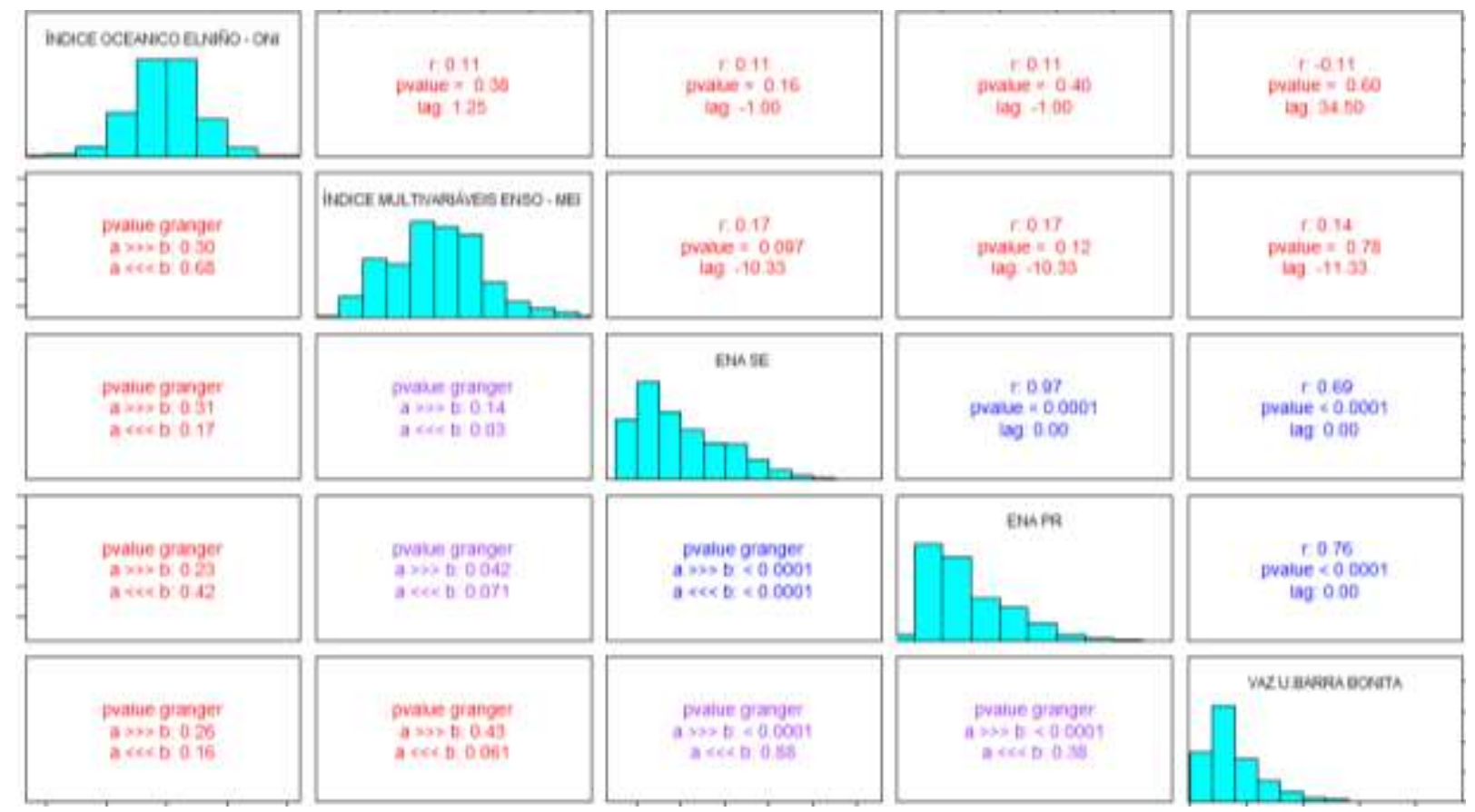

(a)
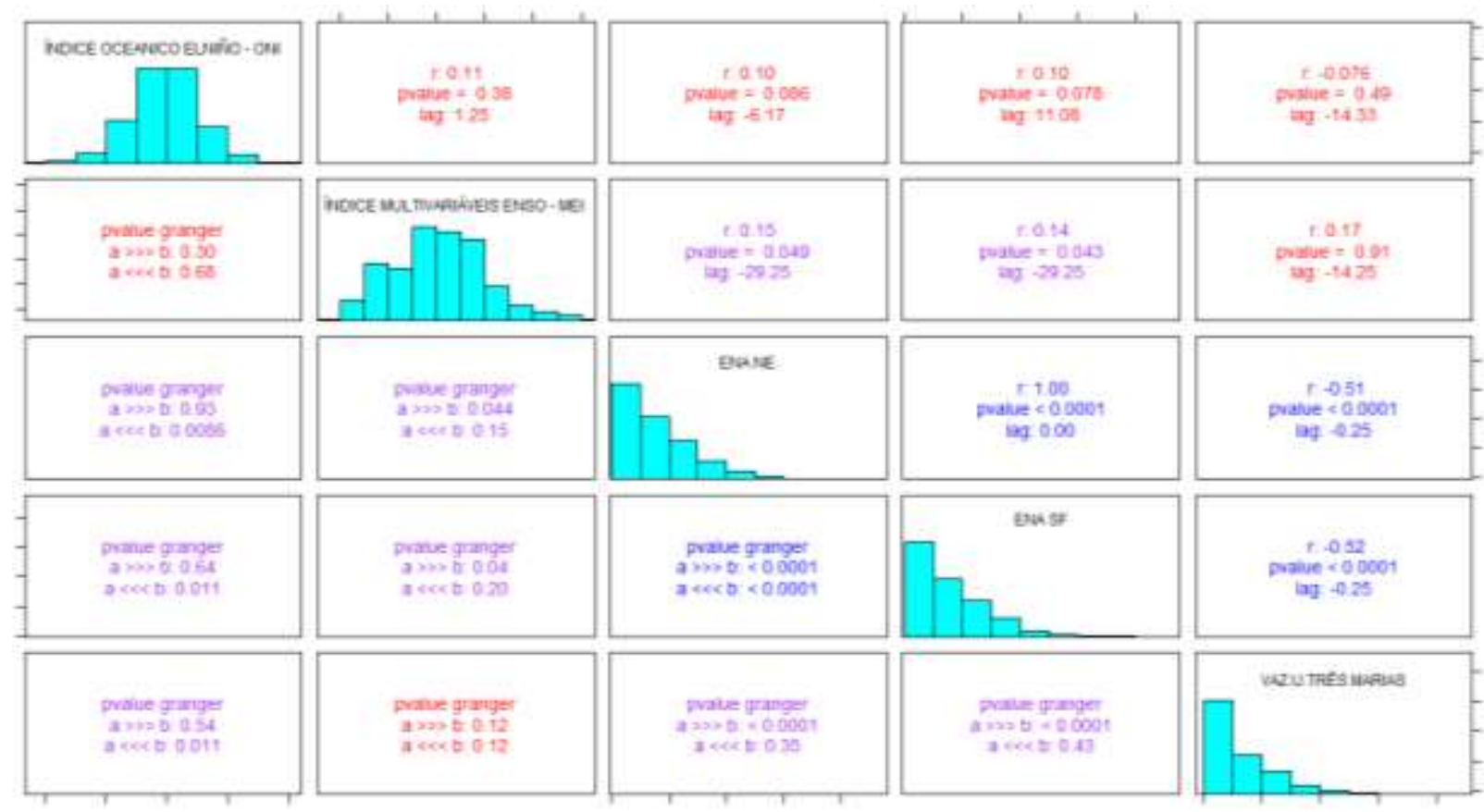

(b) 

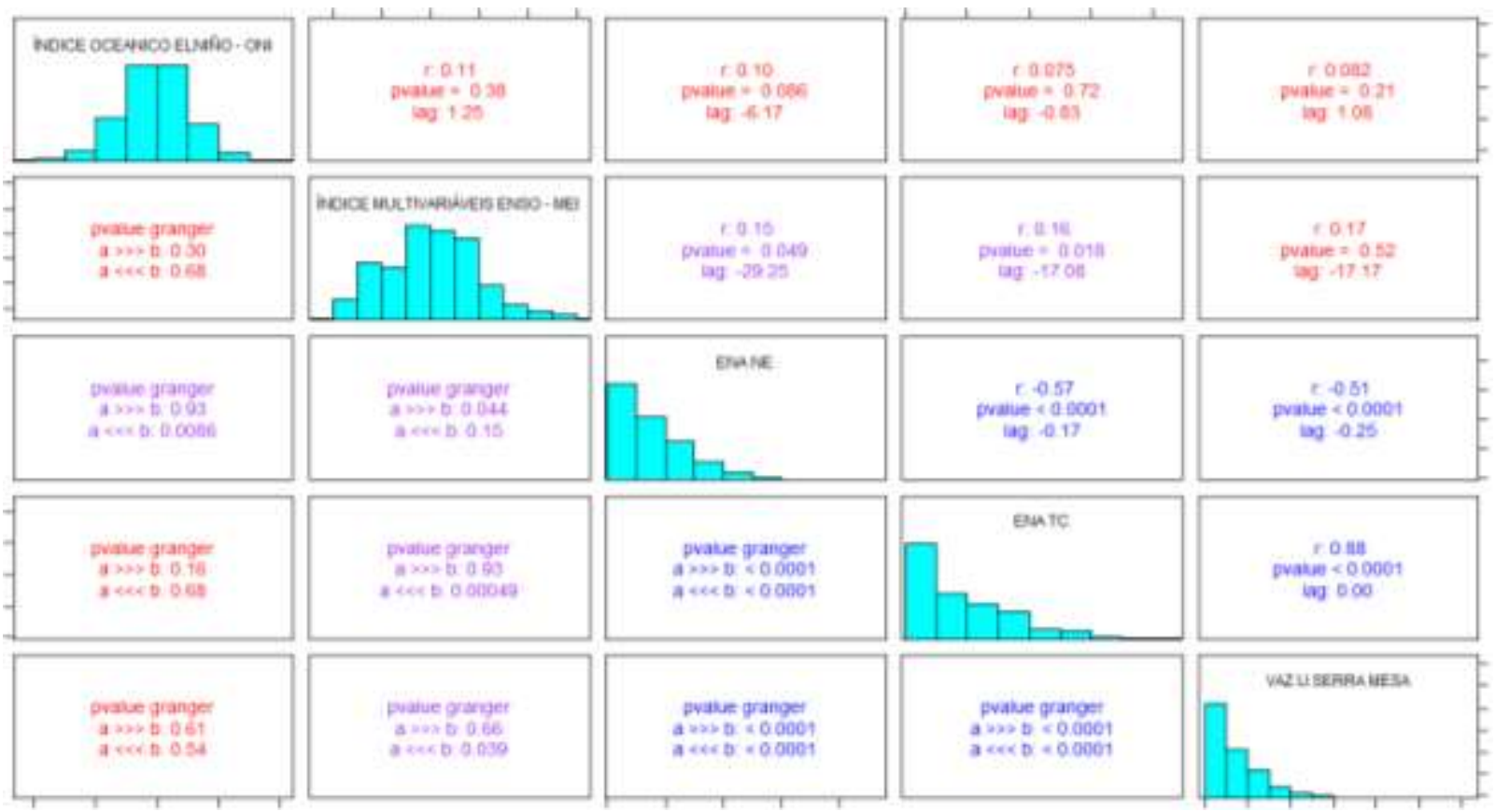

pvatue granger a was b < < 0.00e $a$ ex< $D=00001$

(c)
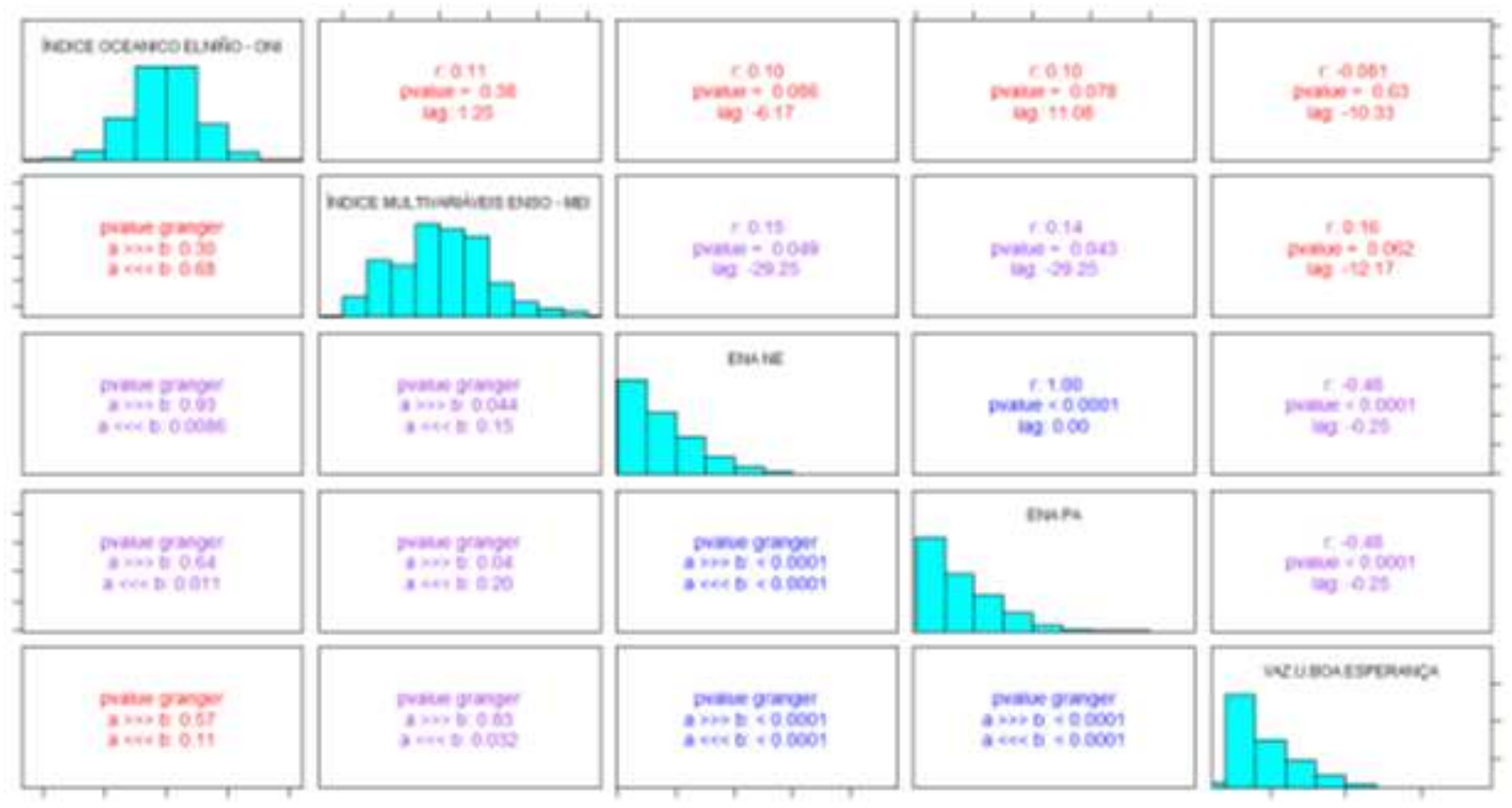

(d)

Figura APÊNDICE N-209 Correlação entre as variáveis de índice SOI MEI de ENOS e as vazões das Usinas das Bacias a) Paraná, b) São Francisco, c) Tocantins e d) Parnaíba Correlação áreas TSM Pacífico El Niño 1+2, 3, 3.4 e 4 
APÊNDICE N.1.2 El Niño 1+2 versos usinas

O gráfico Figura APÊNDICE N-210, apresentam-se as correlações cruzadas entre as vazões das usinas e a TSM do El Niño 1+2.

Todas as correlações foram expressivas e as análises de séries temporais são realizadas com essa variável climática.

\begin{tabular}{|c|c|c|c|c|c|c|c|}
\hline NINO12 & $\begin{array}{c}\text { E } 0.70 \\
\text { pvaue }<0.0001 \\
\text { lag }-0.083\end{array}$ & $\begin{array}{c}r=0.72 \\
\text { prasue }<0.0004 \\
\text { lag }-0.083\end{array}$ & $\begin{array}{c}r 0.72 \\
\text { pvakue }<0.0004 \\
\text { tag }-0.083\end{array}$ & $\begin{array}{c}r .0 .34 \\
\text { pralue }=0.00061 \\
\text { lag } 0.77\end{array}$ & $\begin{array}{c}\text { c. }-0.061 \\
\text { pualue }=0.00 \\
\text { lag } 4.75\end{array}$ & $\begin{array}{c}c-0.22 \\
\text { pvake }=0.25 \\
\text { bg } 0.75\end{array}$ & $\begin{array}{c}\text { r. } 066 \\
\text { pvave }<0.0001 \\
\text { tag }-6003\end{array}$ \\
\hline $\begin{array}{l}\text { pralue granger } \\
\text { a }>00 \text { b }<0.0001 \\
\text { a <ce } b<0.0001\end{array}$ & Camargos & $\begin{array}{c}\text { r. } 0.05 \\
\text { Dralue }<0.0004 \\
\text { lag } 0.00\end{array}$ & $\begin{array}{c}r 0.85 \\
\text { puatue }<0.0001 \\
\text { lap: } 0.00\end{array}$ & $\begin{array}{c}f-0.35 \\
\text { walve }<0.0001 \\
\text { lag } 025\end{array}$ & $\begin{array}{c}c=0.069 \\
\text { pwalue }=0.17 \\
\text { lag. } 7492\end{array}$ & $\begin{array}{c}c-0.19 \\
\text { pwakw }=0.0031 \\
\text { log }-0.17\end{array}$ & $\begin{array}{c}\text { c.0.83 } \\
\text { pusue }=0.0001 \\
\text { latg } 0.00\end{array}$ \\
\hline 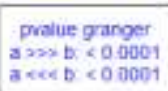 & $\begin{array}{l}\text { pwalue granger } \\
\text { a >0> b. } 0.009 \\
\text { a eec b } 090\end{array}$ & Furnas & $\begin{array}{c}\text { ro alo } \\
\text { puatue < o oodst } \\
\text { b] } 000\end{array}$ & $\begin{array}{c}r-033 \\
\text { pualue }-00001 \\
\text { lay } 0225\end{array}$ & $\begin{array}{c}r-11000 \\
\text { pualue }=0.27 \\
621789\end{array}$ & $\begin{array}{c}r,-0.10 \\
\text { pvatus }=0.0034 \\
\text { ing }=0.17\end{array}$ & $\begin{array}{c}\text { r. } 086 \\
\text { pvatue }<0.0001 \\
\text { lag } 000\end{array}$ \\
\hline $\begin{array}{l}\text { prasue granger } \\
\text { a } 39 \times b<0.0001 \\
a<<<b<0.0001\end{array}$ & 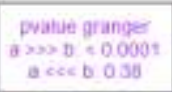 & 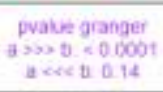 & NovaPonte & $\begin{array}{l}r 0.32 \\
\text { protue }<0.0004 \\
\text { tag } 407 ?\end{array}$ & $\begin{array}{c}c=0.002 \\
\text { pwatue }=0.065 \\
\text { bay } 71.85\end{array}$ & $\begin{array}{c}r .0 .19 \\
\text { watue }=0.0090 \\
\text { lag } 4.103\end{array}$ & $\begin{array}{c}\text { c. } 0.82 \\
\text { pvaras }<0.0001 \\
\text { lap } 0.00\end{array}$ \\
\hline $\begin{array}{l}\text { pvalue granger } \\
\text { a }>s>b \text { b e } 00001 \\
\text { a <ee b } b \text { < } 0.0001\end{array}$ & $\begin{array}{l}\text { puaiue granger } \\
\text { a sso b }<0000 t \\
\text { a ece b }<00000 \text {. }\end{array}$ & $\begin{array}{l}\text { pvatye granger } \\
a \gg>0<<0<0001 \\
\text { a }<<<0<0,0001\end{array}$ & $\begin{array}{l}\text { pvalue grargor } \\
\text { a }>>>\text { D }<0.0001 \\
\text { a <ee D }<0.000 \text { t }\end{array}$ & Barra Bonita & $\begin{array}{c}r-9.16 \\
\text { pvatue }<0.0001 \\
\text { lag } 0.77\end{array}$ & $\begin{array}{c}\text { to.15 } \\
\text { gvase - } 0 \text { co0s3 } \\
\text { log }-0.33\end{array}$ & $\begin{array}{c}r-0.031 \\
\text { prave }<0.0001 \\
\text { iag }-0.25\end{array}$ \\
\hline $\begin{array}{l}\text { praiue granger } \\
\text { a }>0>\text { b } 0.0090 \\
\text { a }<e<\text { b o at6 }\end{array}$ & $\begin{array}{l}\text { Pualue grange } \\
\text { a >>> t } 0.045 \\
\text { a ses b. } 0.058\end{array}$ & 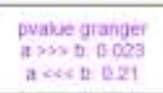 & $\begin{array}{l}\text { prave granger } \\
\text { a }>>2 \text { b a } 16 \\
\text { a cret. a } 19\end{array}$ & 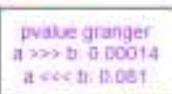 & Foz de Areia & $\begin{array}{c}\text { r. } 0.52 \\
\text { pvatue }<0.0001 \\
\text { lag } 000\end{array}$ & $\begin{array}{c}\text { Y. } 0.002 \\
\text { pvasue }=0.018 \\
\text { lagy }-17.42\end{array}$ \\
\hline $\begin{array}{l}\text { prave granger } \\
\text { a >s> } D<0<0001 \\
\text { a sec } b<0<0001\end{array}$ & 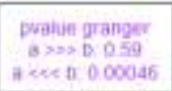 & $\begin{array}{c}\text { bvake granger } \\
a>>\text { to } 0.53 \\
\text { a cec b } 0.00051\end{array}$ & $\begin{array}{l}\text { pvaue granger } \\
a>>>b<0.0001 \\
\text { a ces b } 0.025\end{array}$ & 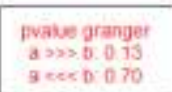 & $\begin{array}{l}\text { pwave grarger } \\
\text { a } \rightarrow>>\text { b } 4.25 \\
\text { a eec o } 0.02 .4\end{array}$ & Passo Fundo & $\begin{array}{c}r 019 \\
\text { grave }-0.00017 \\
\text { ing }+67\end{array}$ \\
\hline $\begin{array}{l}\text { praiue ganges } \\
\text { a } x a \times b \text { b }<00001 \\
\text { a }<<<b<0.0001\end{array}$ & 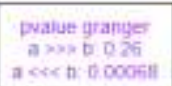 & $\begin{array}{l}\text { puake granger } \\
a \leqslant b>\text { b } 0: 22 \\
a<<<0<00001\end{array}$ & $\begin{array}{l}\text { pvarue grasger } \\
a>>>0 \\
a \quad 024 \\
a<<<b<0 \text { ox }\end{array}$ & 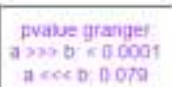 & $\begin{array}{l}\text { prave grarget } \\
\text { a mos o of is } \\
\text { a eec b ta } 29\end{array}$ & 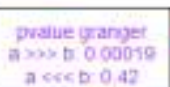 & iro Baixo \\
\hline
\end{tabular}

Figura APÊNDICE N-210 Relação entre variável NINO 1+2 Usinas escolhidas

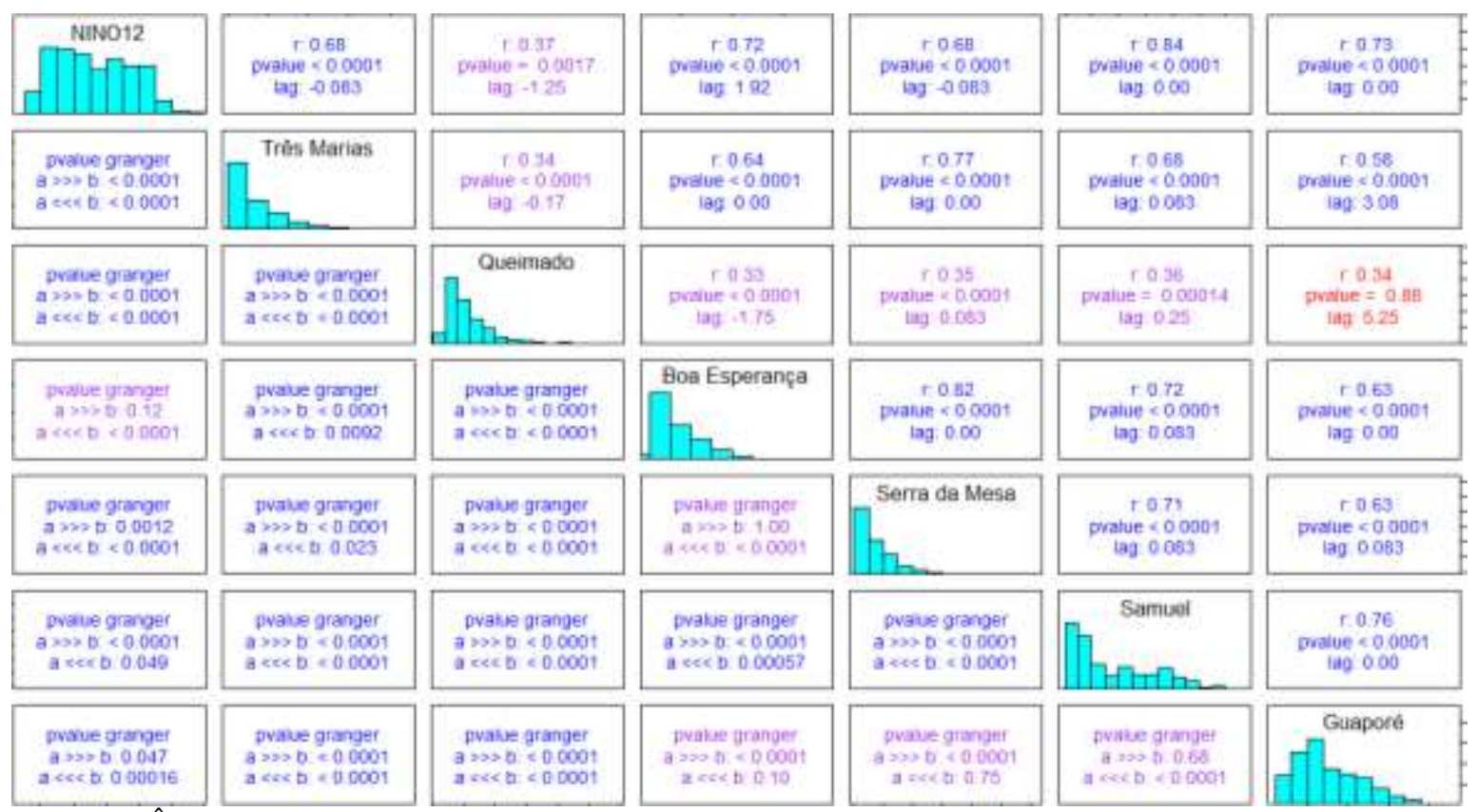

Figura APÊNDICE N-211 Relação entre variável NINO 1+2 Usinas escolhidas 
APÊNDICE N.1.3 TSM El Niño $1+2,3,3.4 \mathrm{e} 4$

APÊNDICE N.1.4 Índices de TSM EINiño 1+2, 3, 3.4 e 4 versos ENA e bacias
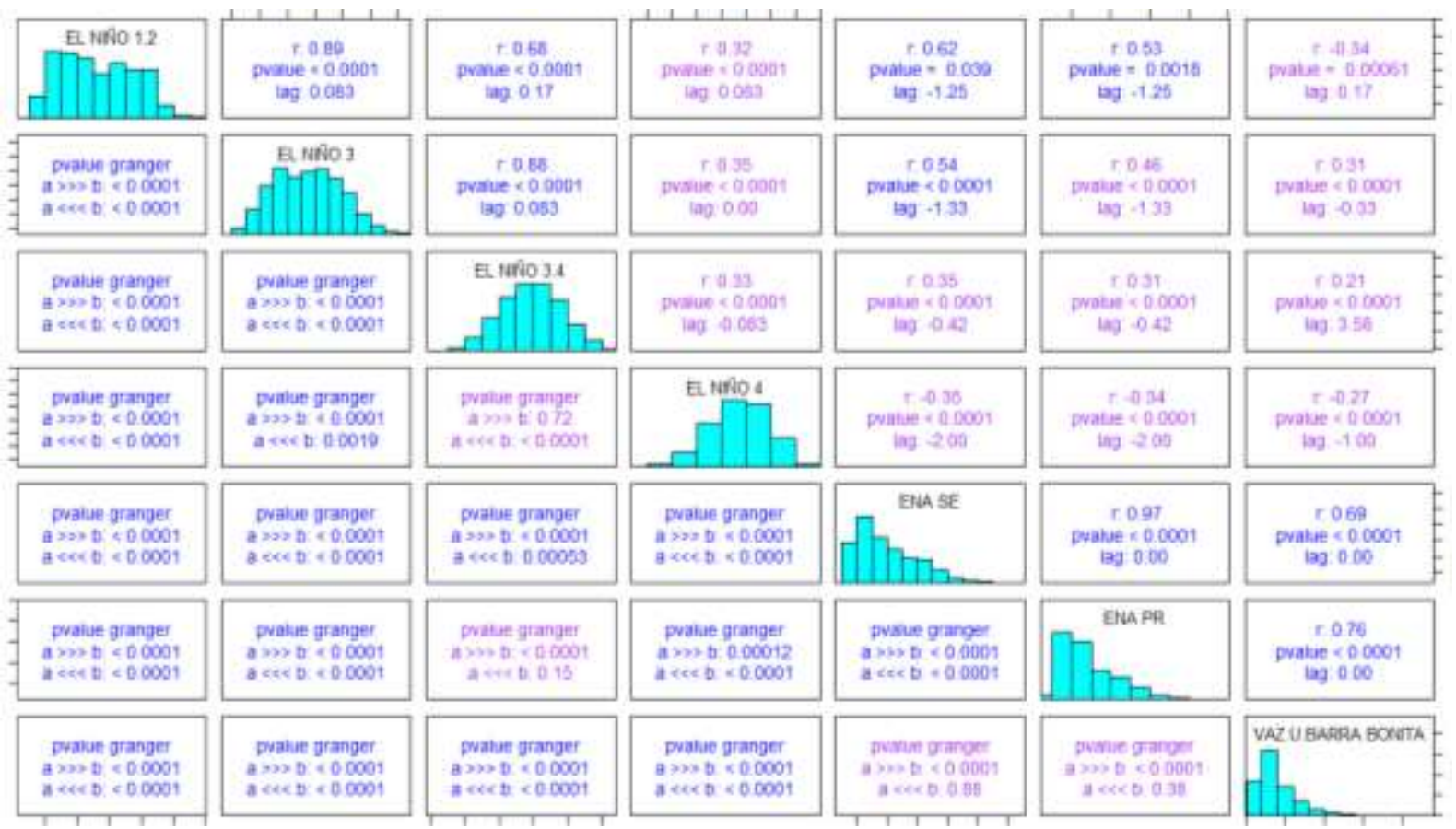

(a)
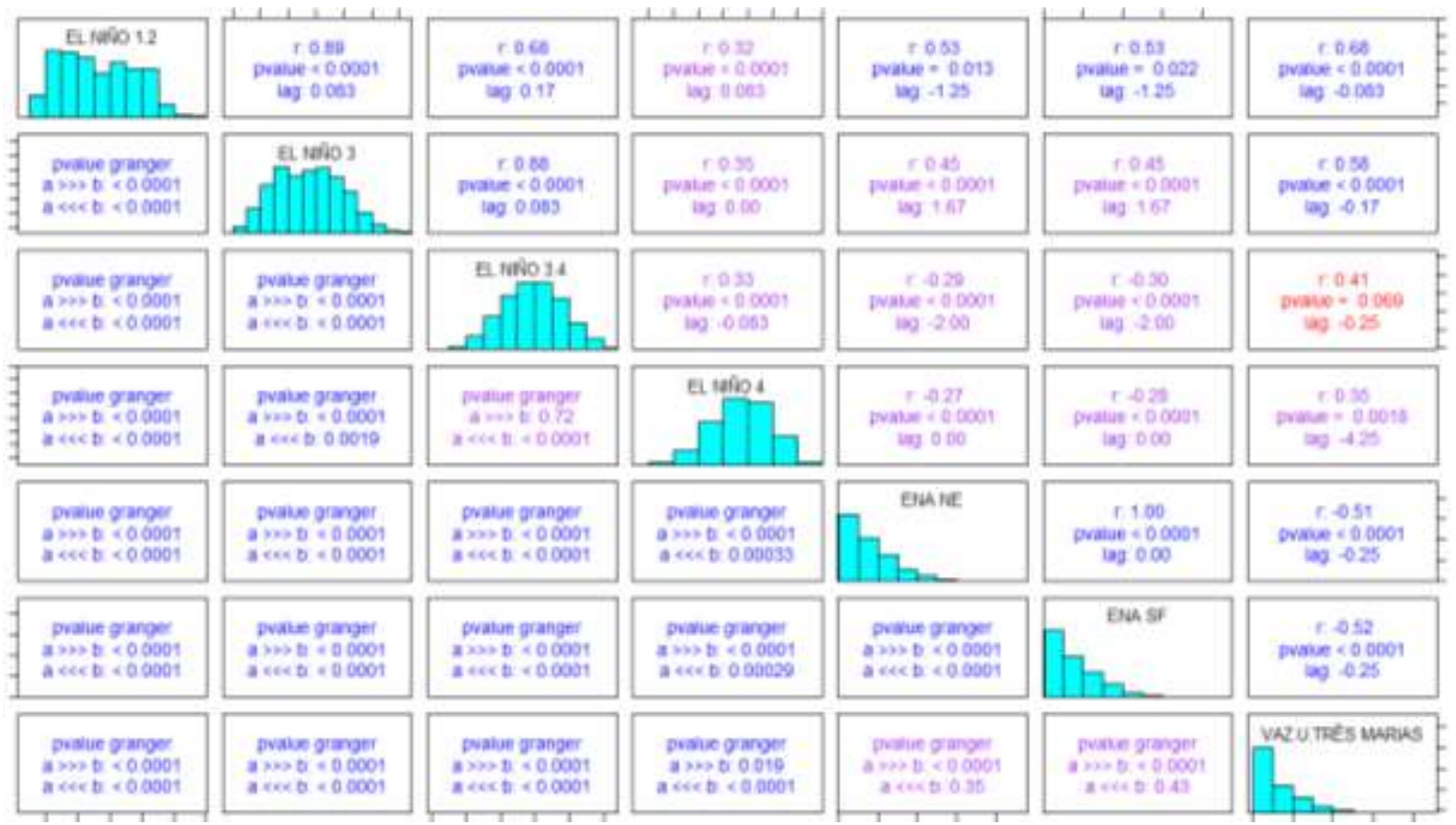

(b) 


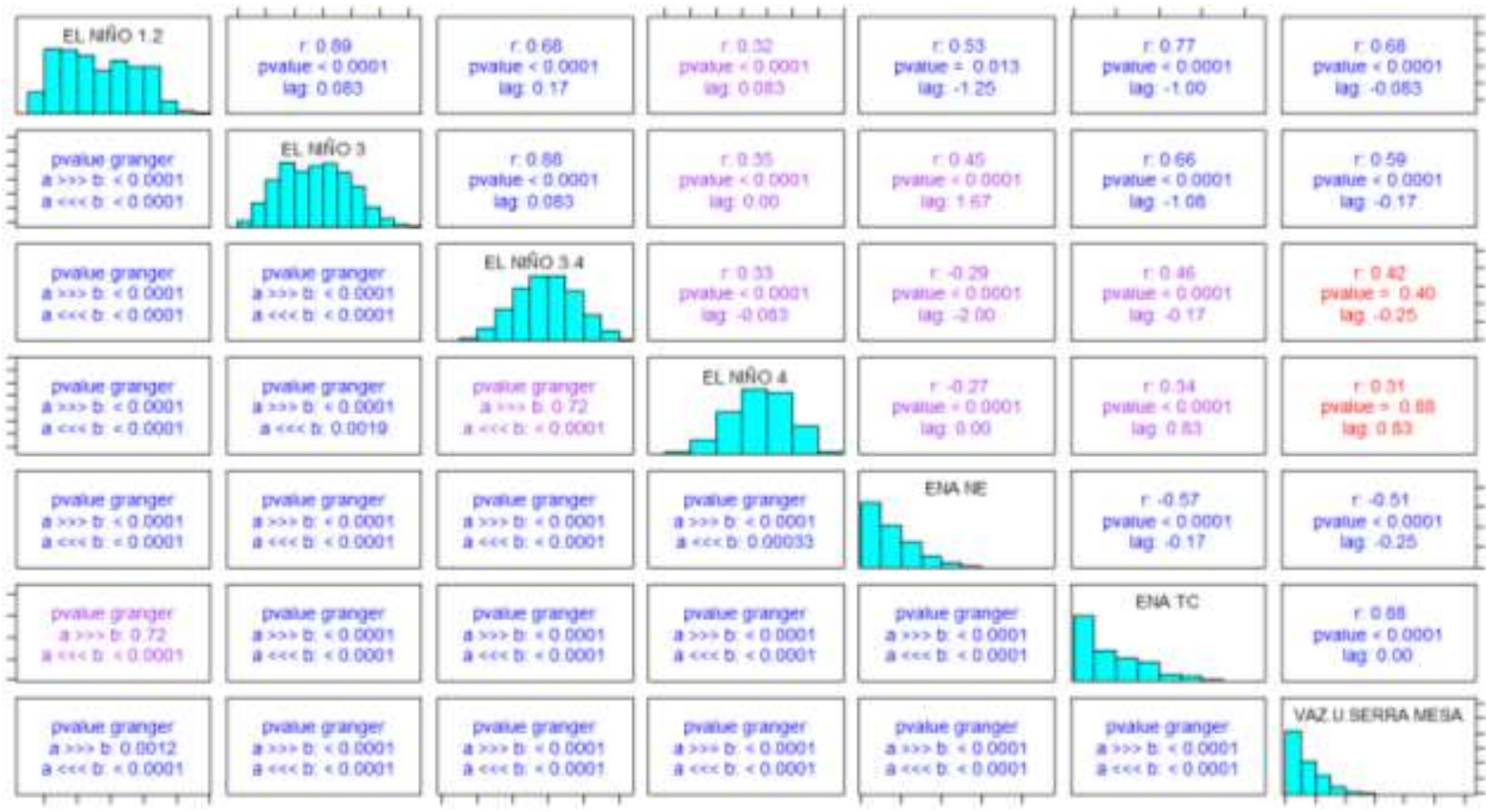

(c)
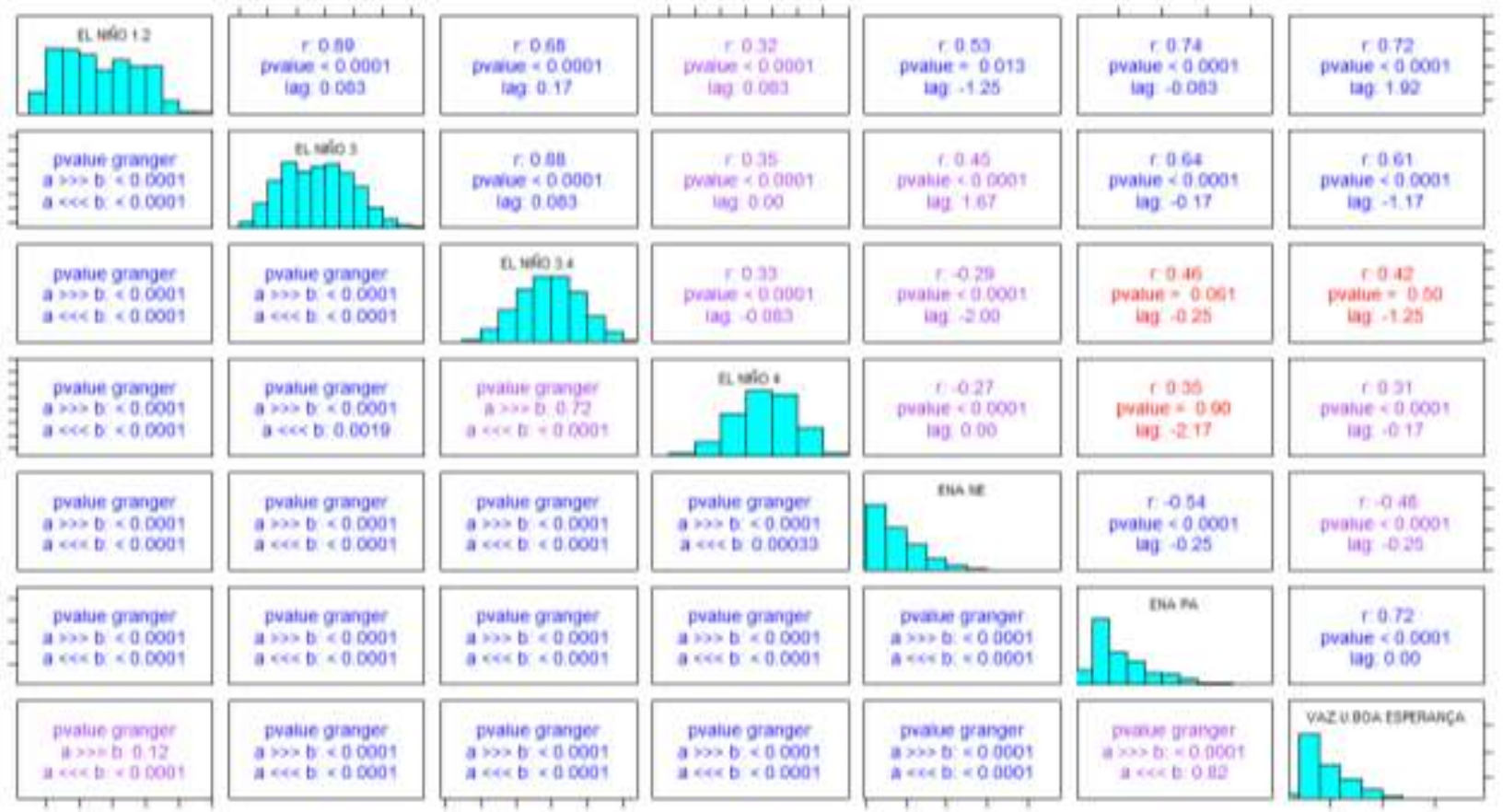

(d)

APÊNDICE N-212 Correlação entre as variáveis de TSM El Niño regiões 1+2, 3, 3.4 e 4 e vazões da Usinas da Bacia dos rios a) Paraná, b) São Francisco, c) Parnaíba e d) Tocantins 
APÊNDICE N.1.5 Índices de AMO

APÊNDICE N.1.5.1 Índices de AMO versos usinas

O gráfico Figura APÊNDICE N-213, apresentam-se as correlações cruzadas entre as vazões das usinas e a TSM do Atlântico Multidecadal.

As correlações foram parcialmente expressivas e as usinas com correlação acima de 0,6 as análises de séries temporais são realizadas com essa variável climática.

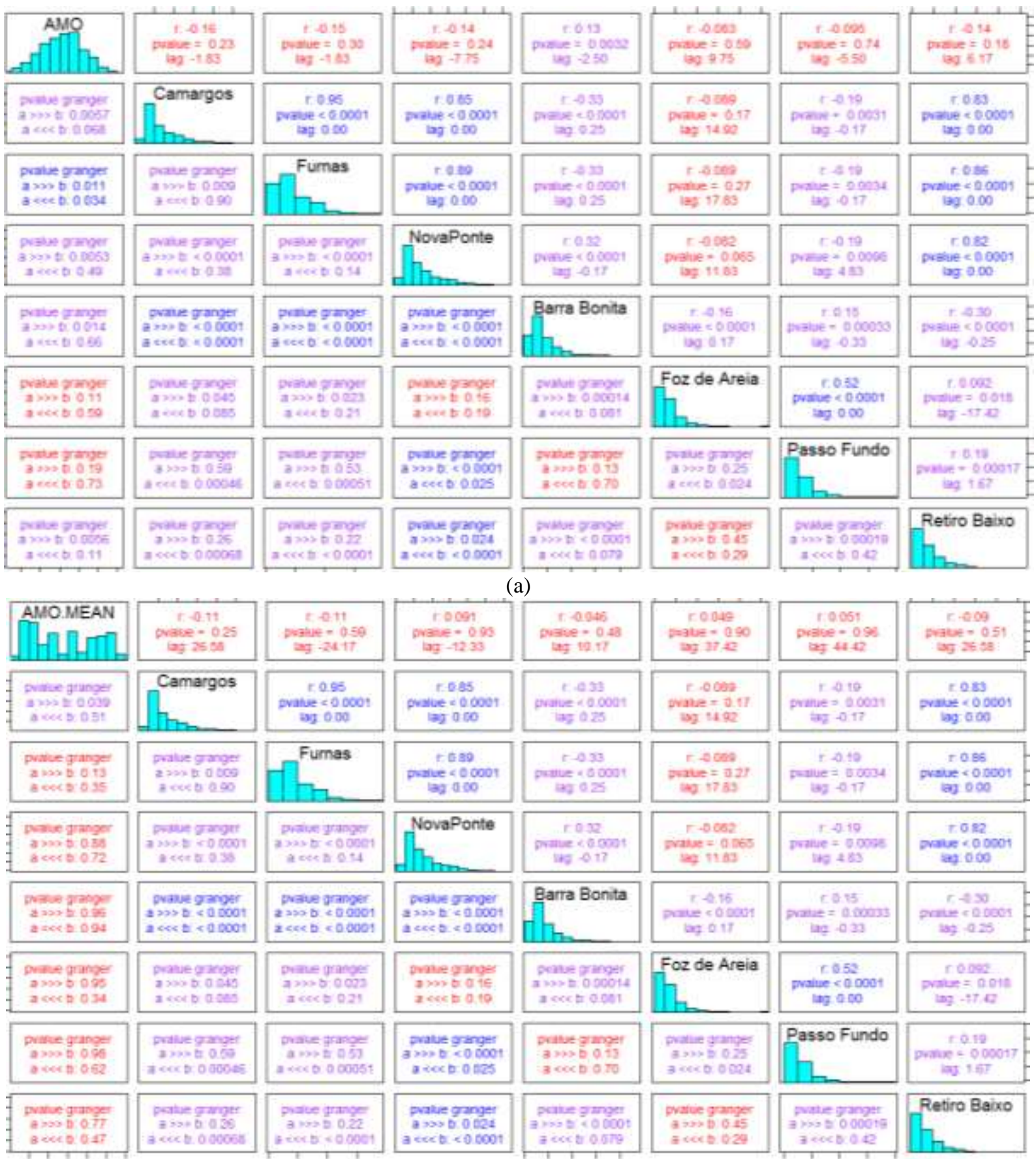

(b)

Figura APÊNDICE N-213 Relação entre variável Atlântico Multidecadal e Usinas escolhidas 

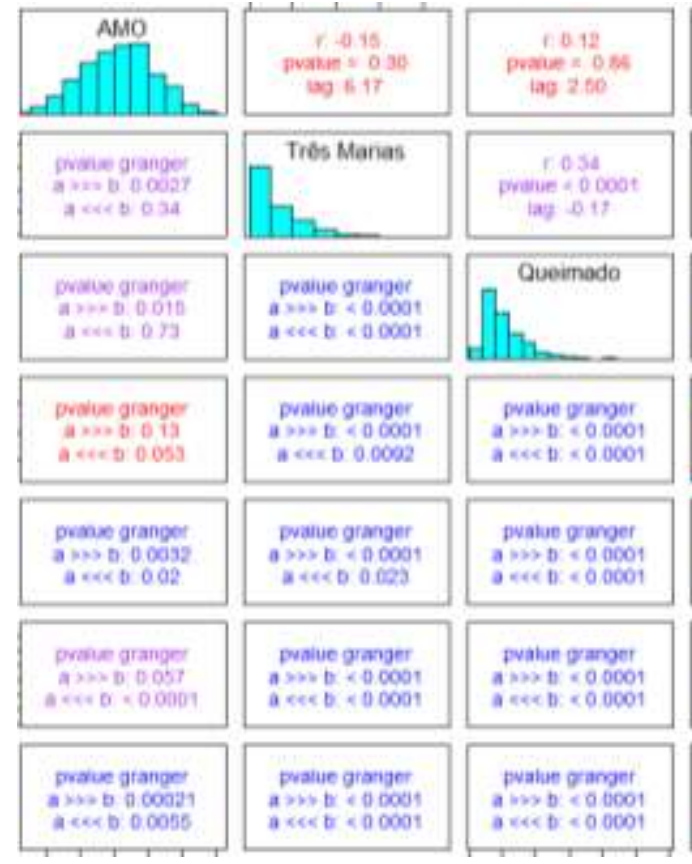
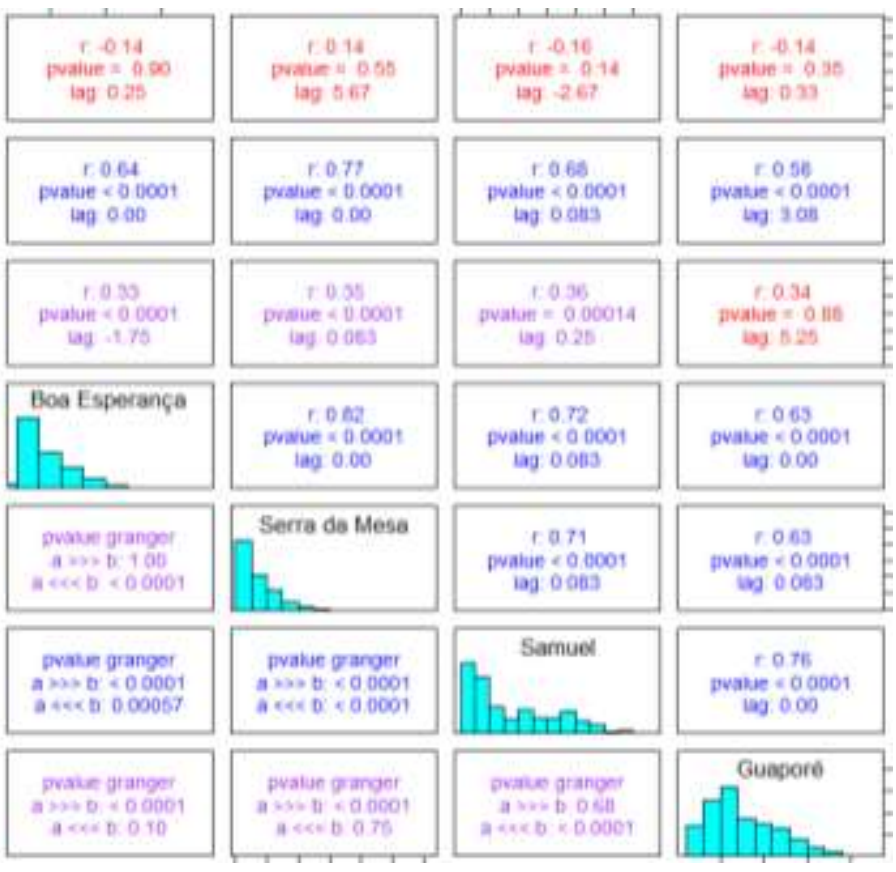

aरtरा
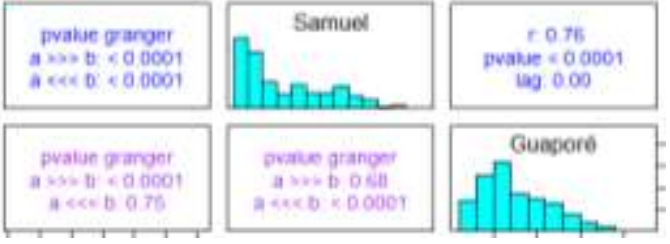

(a)
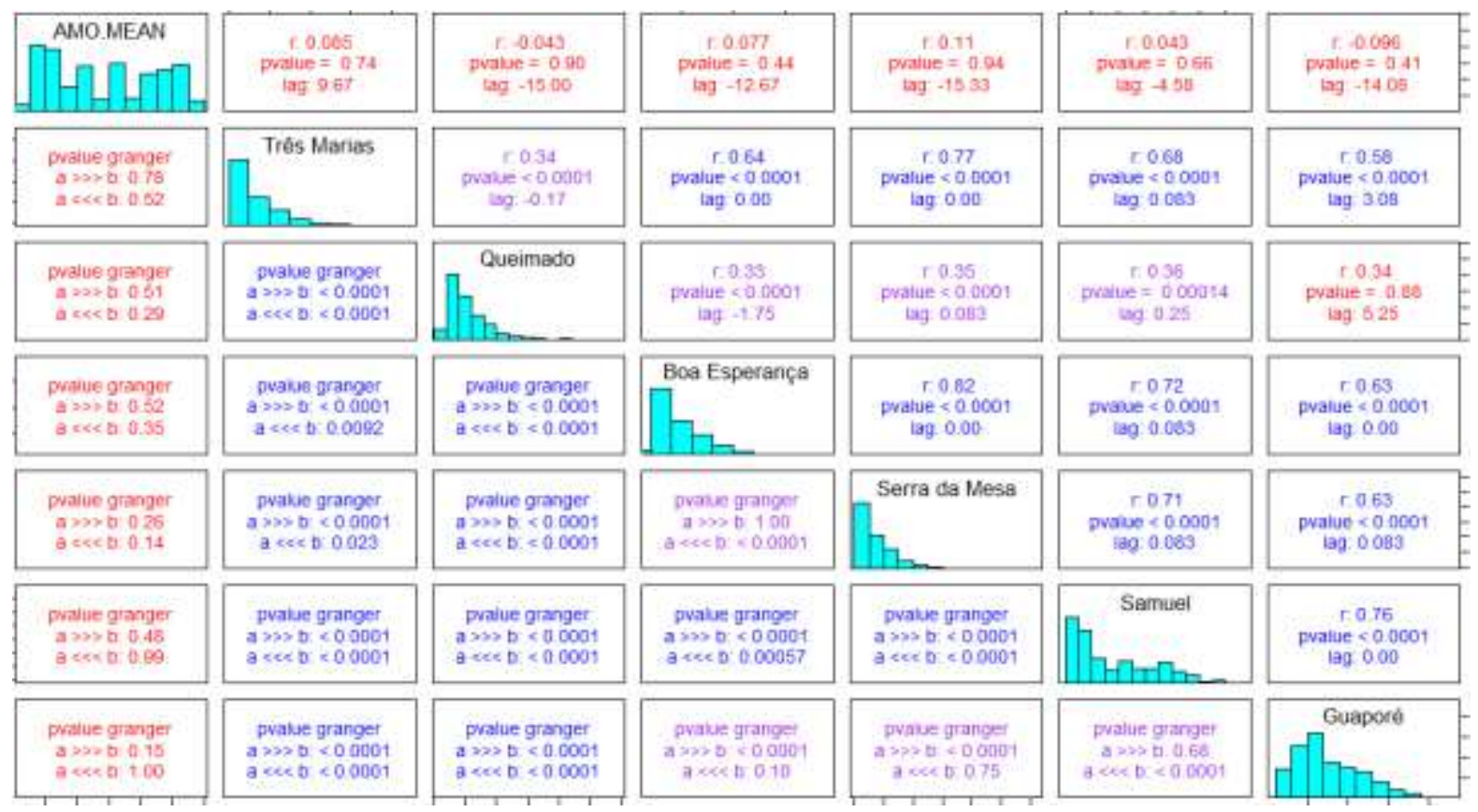

(b)

Figura APÊNDICE N-214 Relação entre variável Atlântico Multidecadal e Usinas escolhidas com função de autocorrelação cruzada. 
APÊNDICE N.1.5.2 Índices de AMO versos ENA e bacias
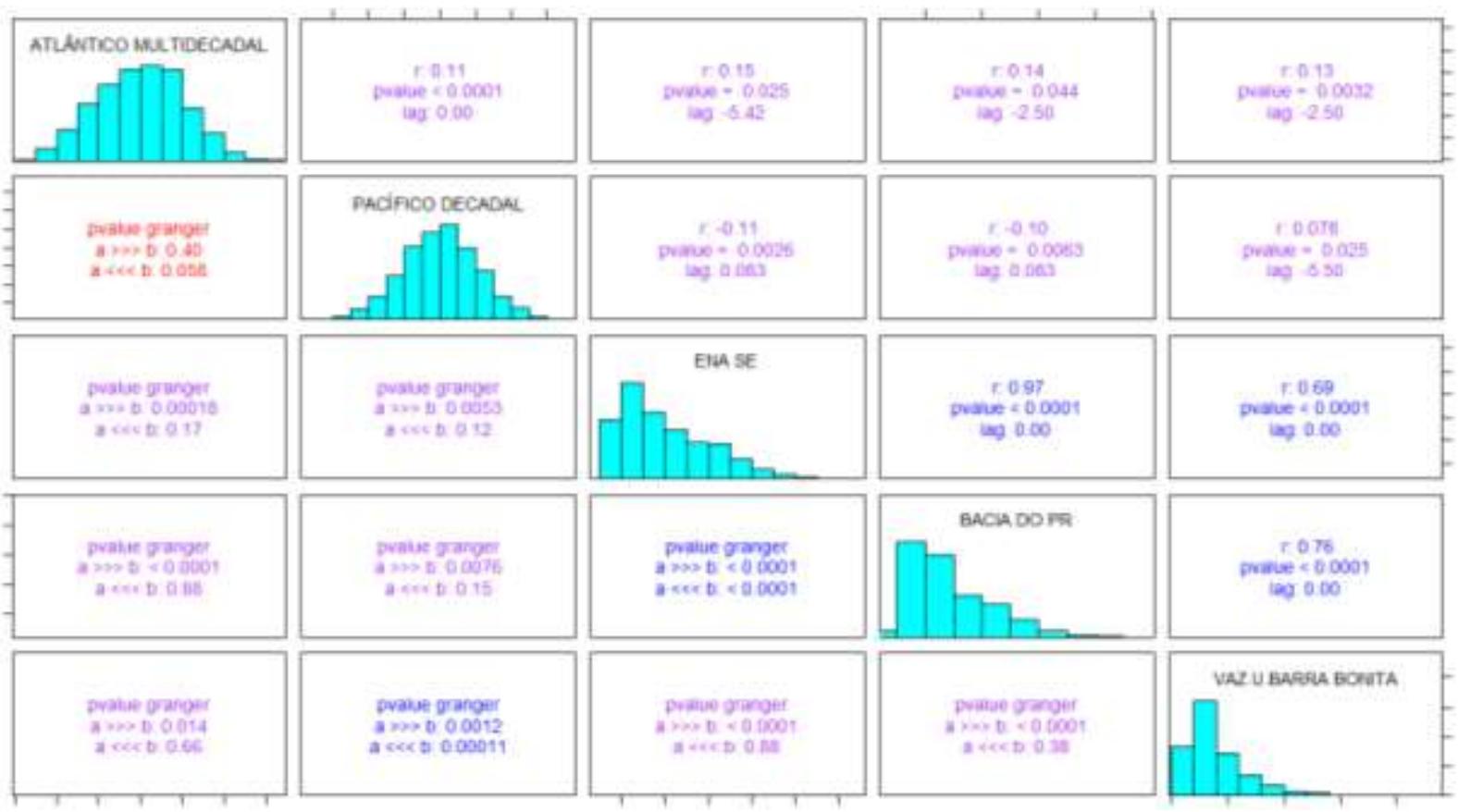

(a)
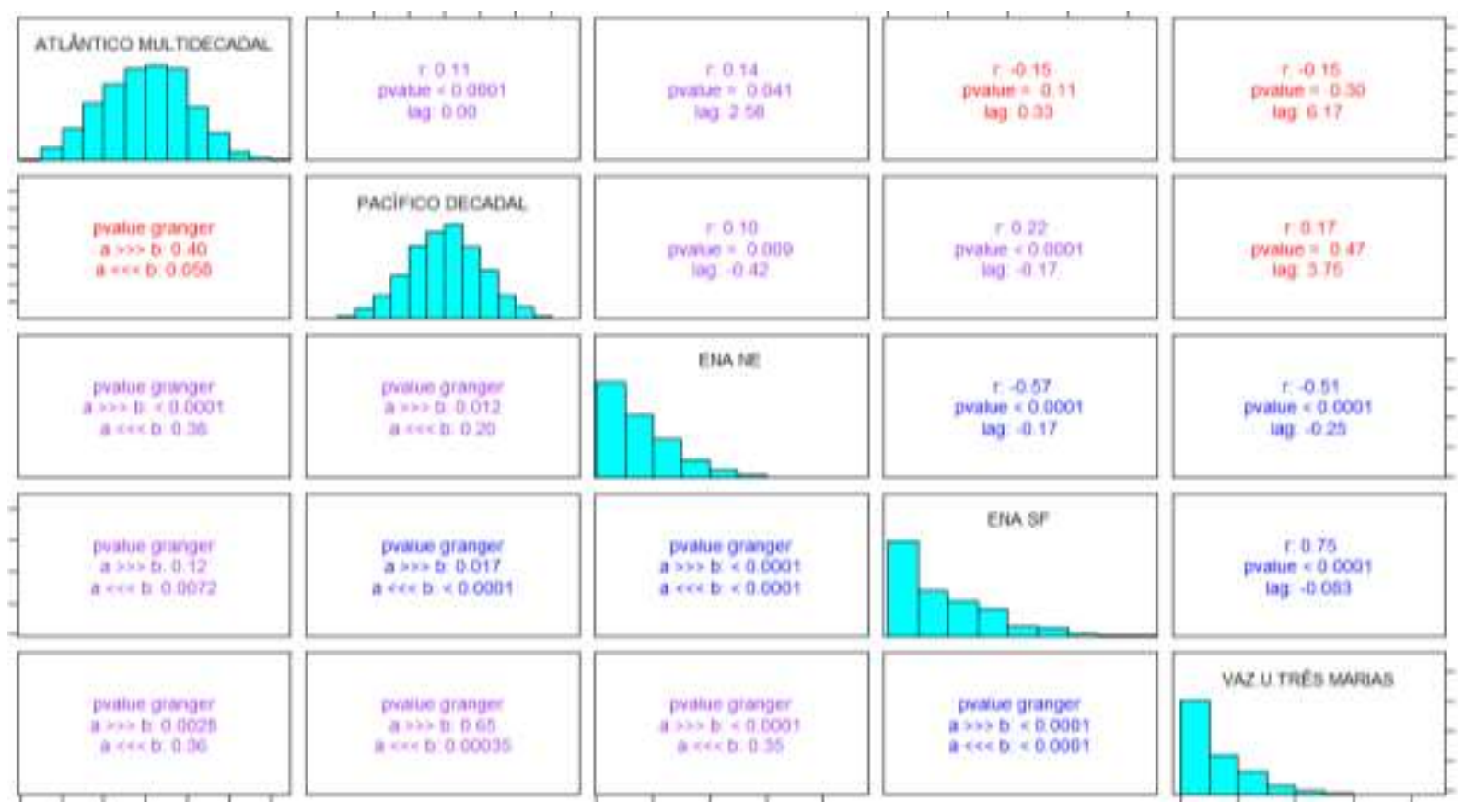

pwase granger

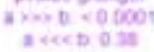

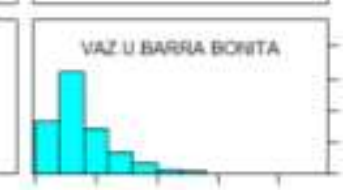



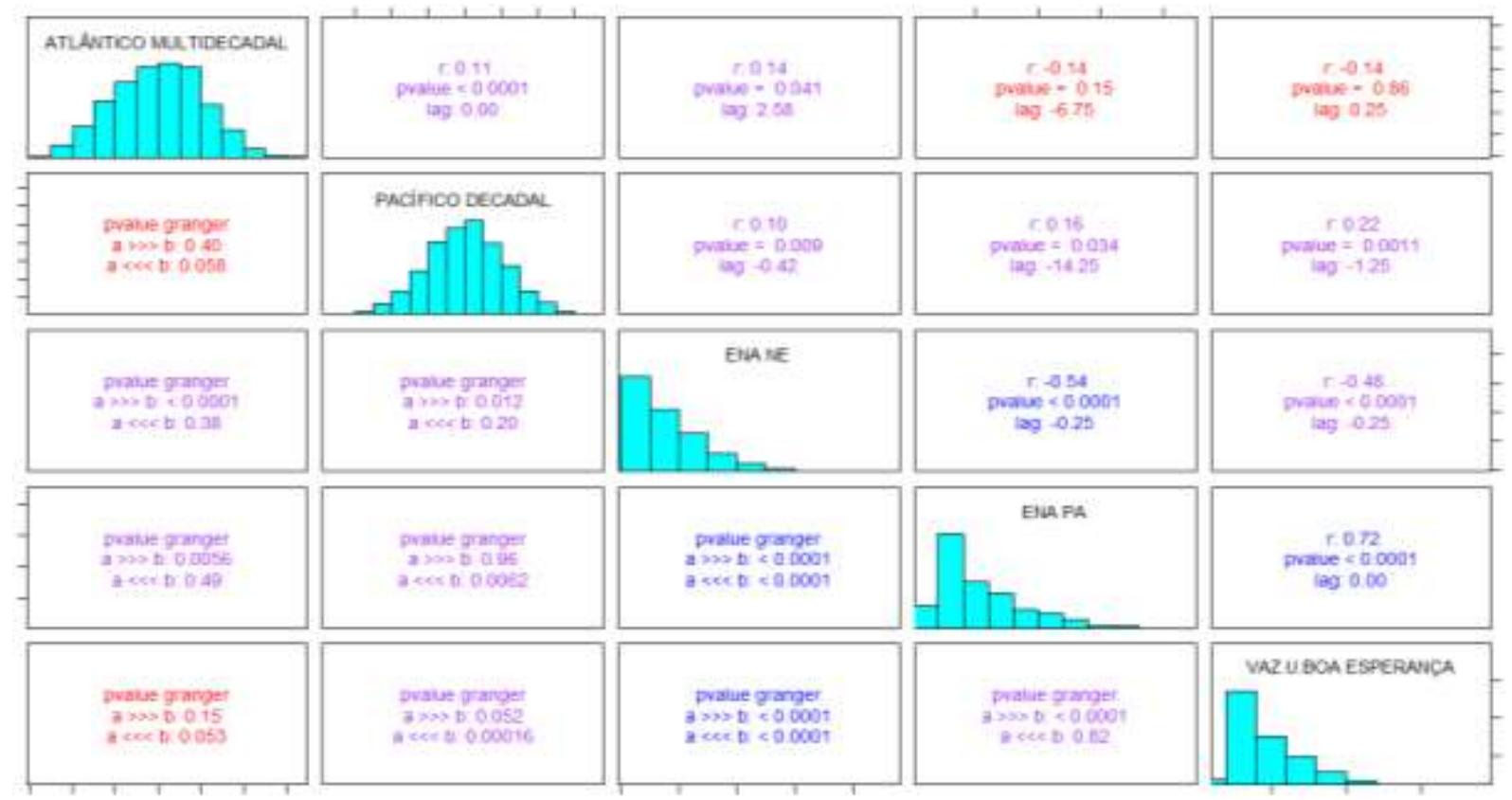

(c)
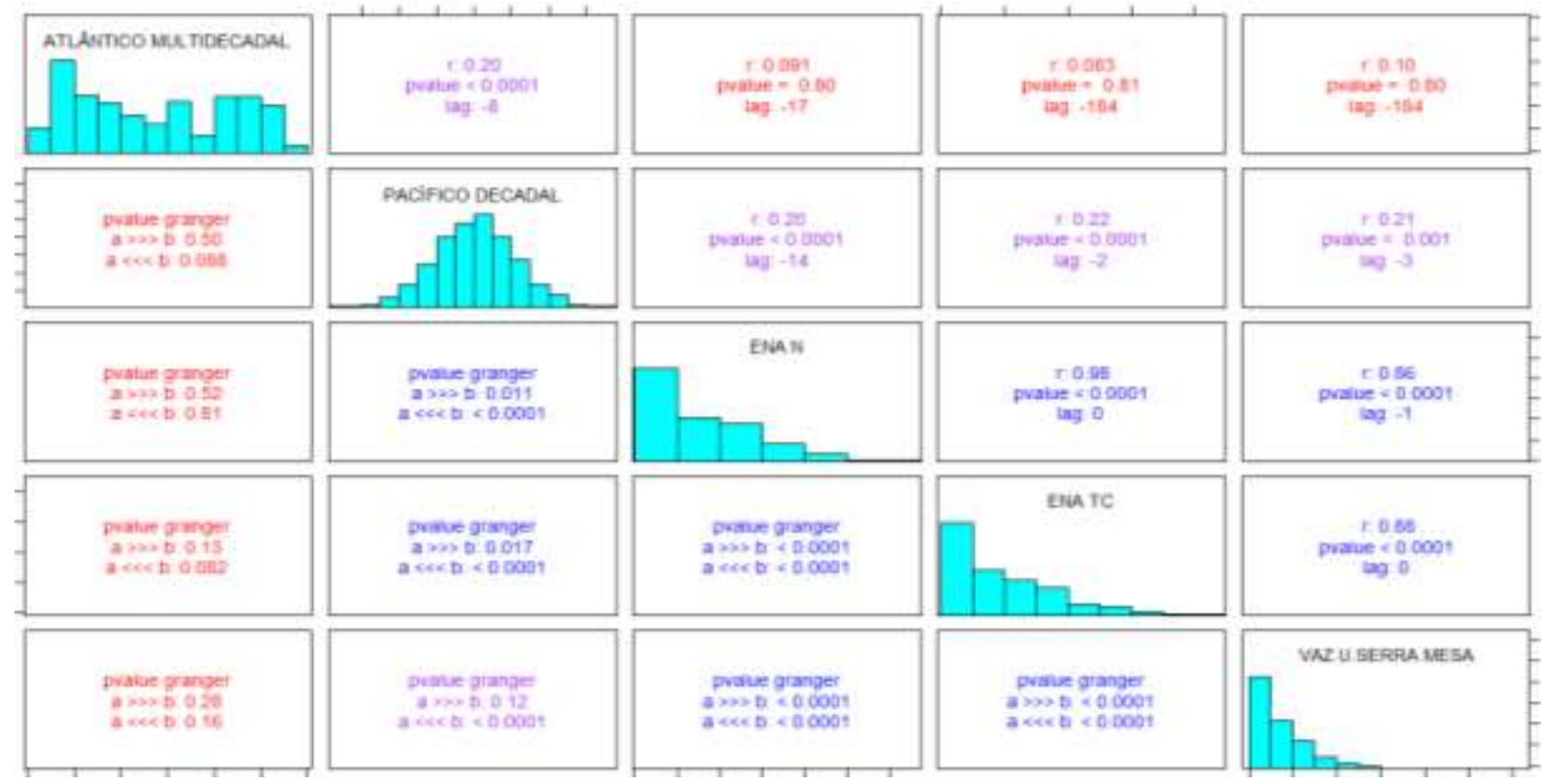

(d)

Figura APÊNDICE N-215 Correlação entre as variáveis Decadal do Pacífico e Multidecadal do Atlântico e vazões das Usinas da Bacia dos rios a) Paraná, b) São Francisco c) Parnaíba d) Tocantins. 
APÊNDICE N.1.5.3 Índices de Oscilação dos Polos
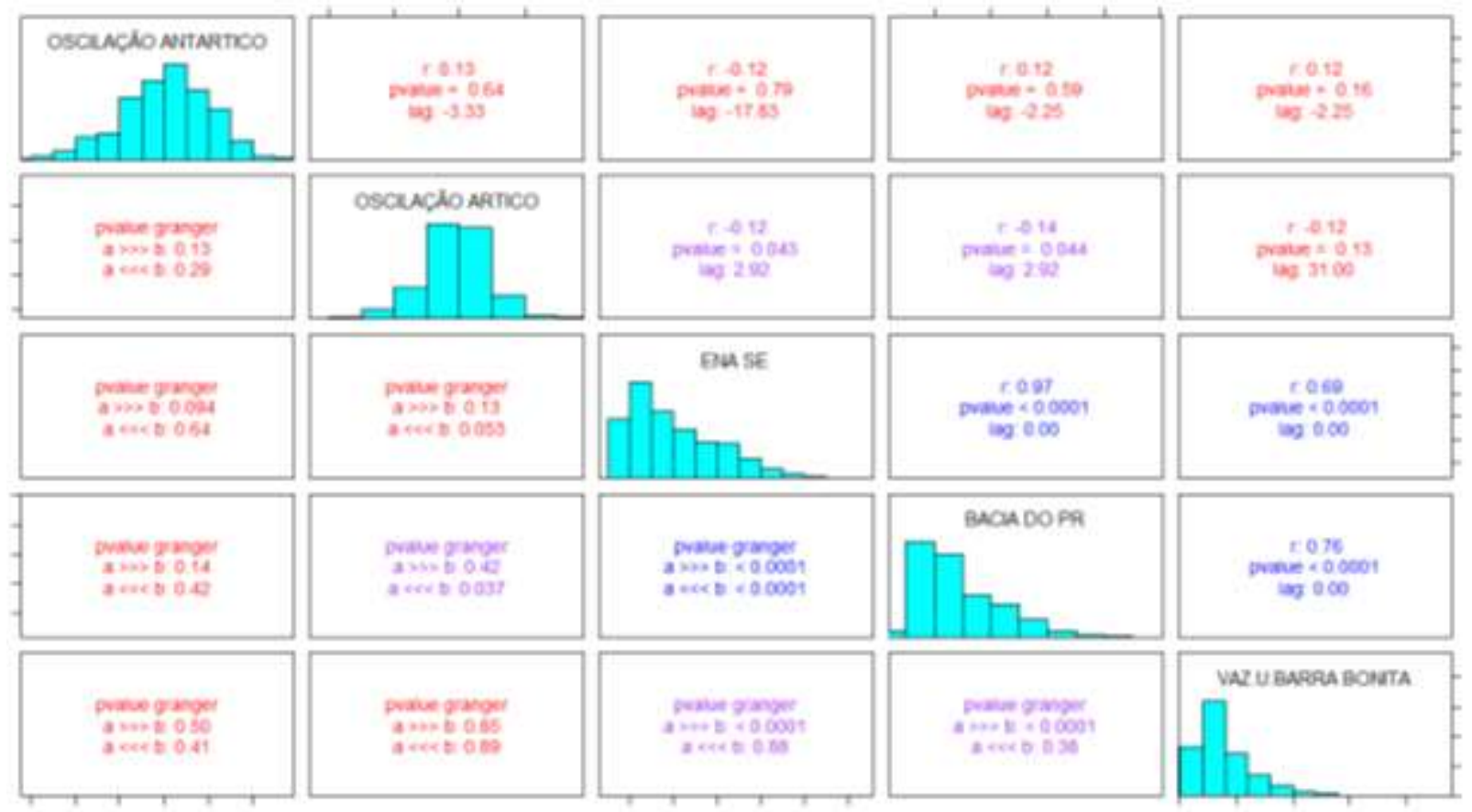

(a)
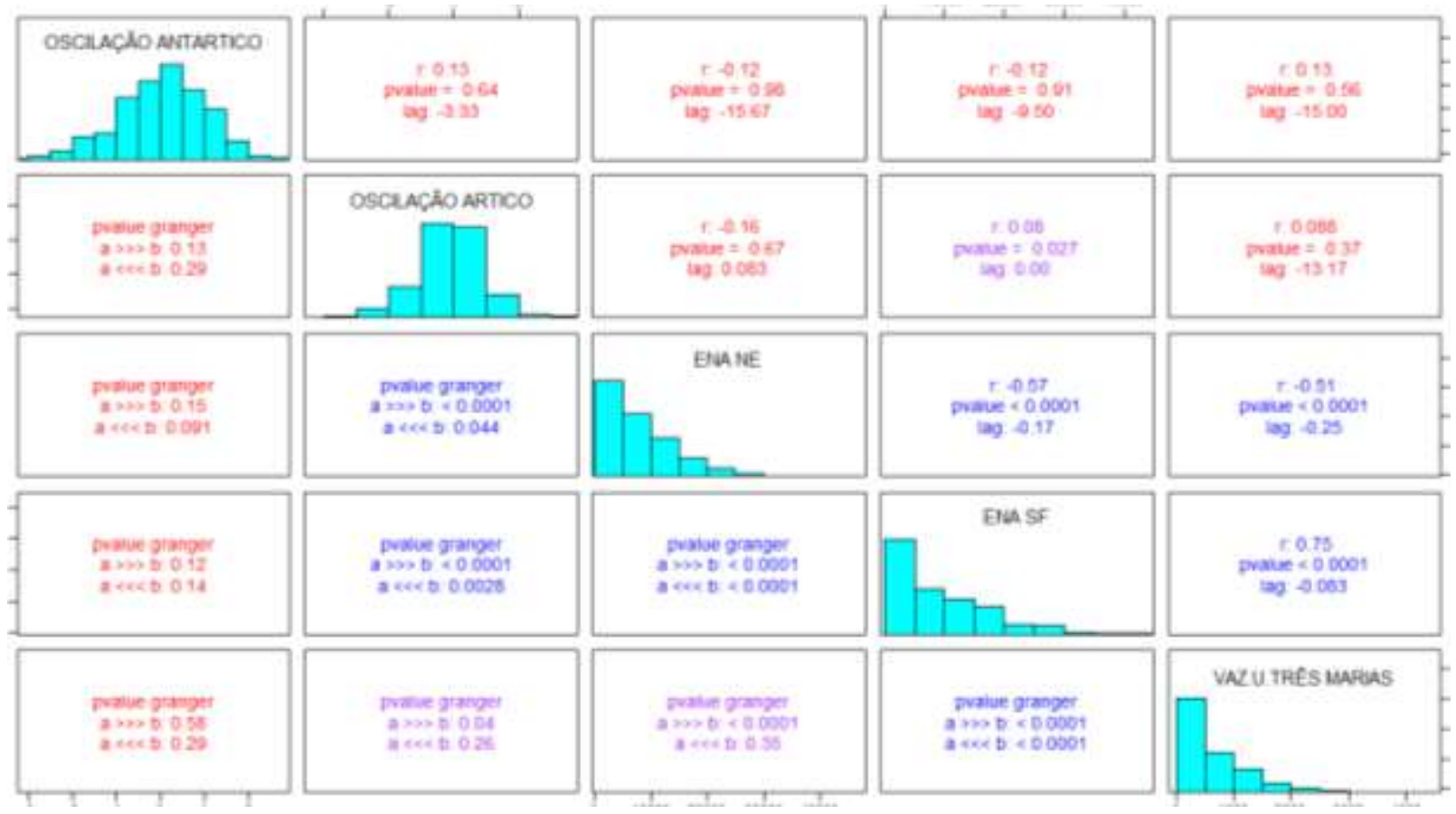

(b) 

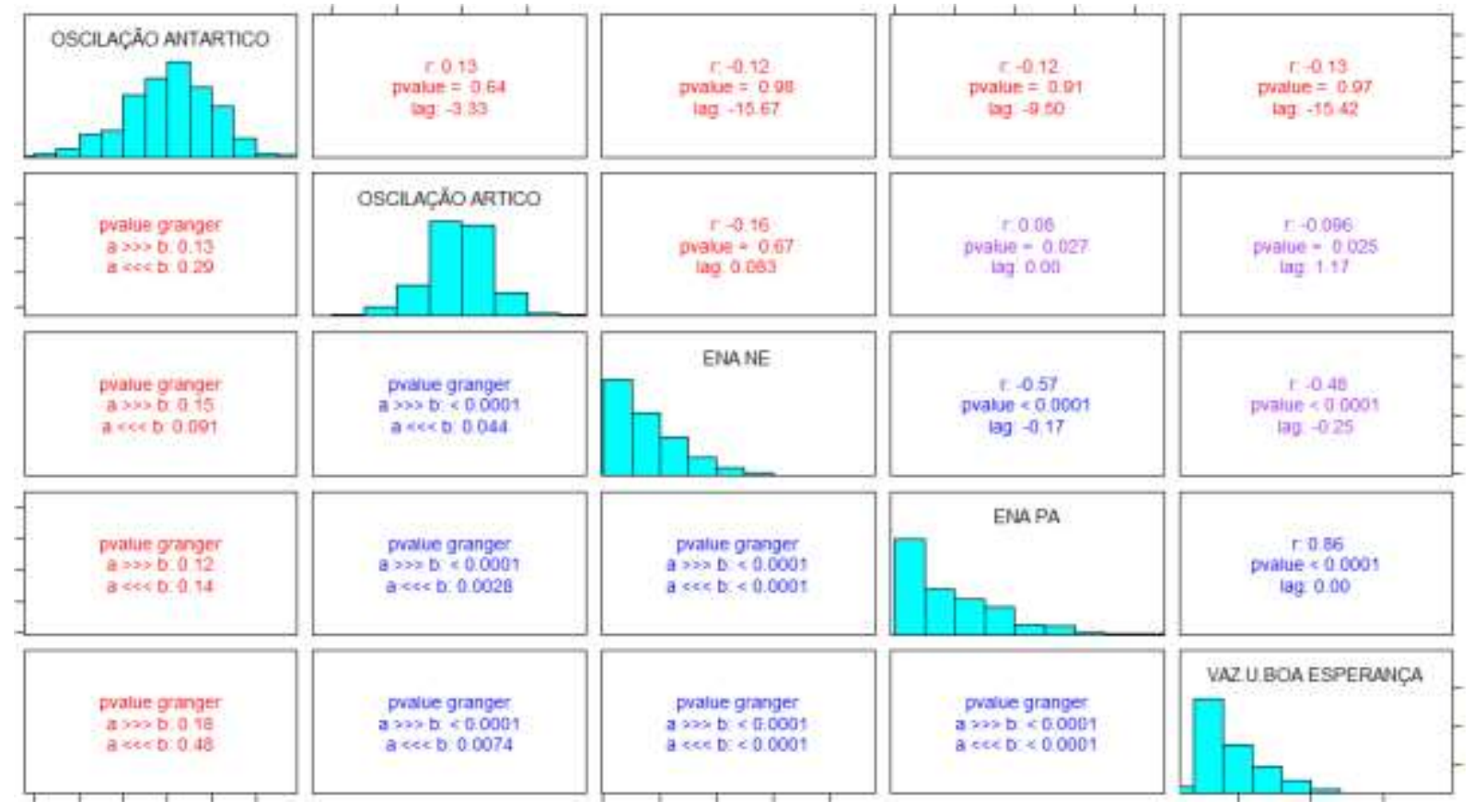

(c)
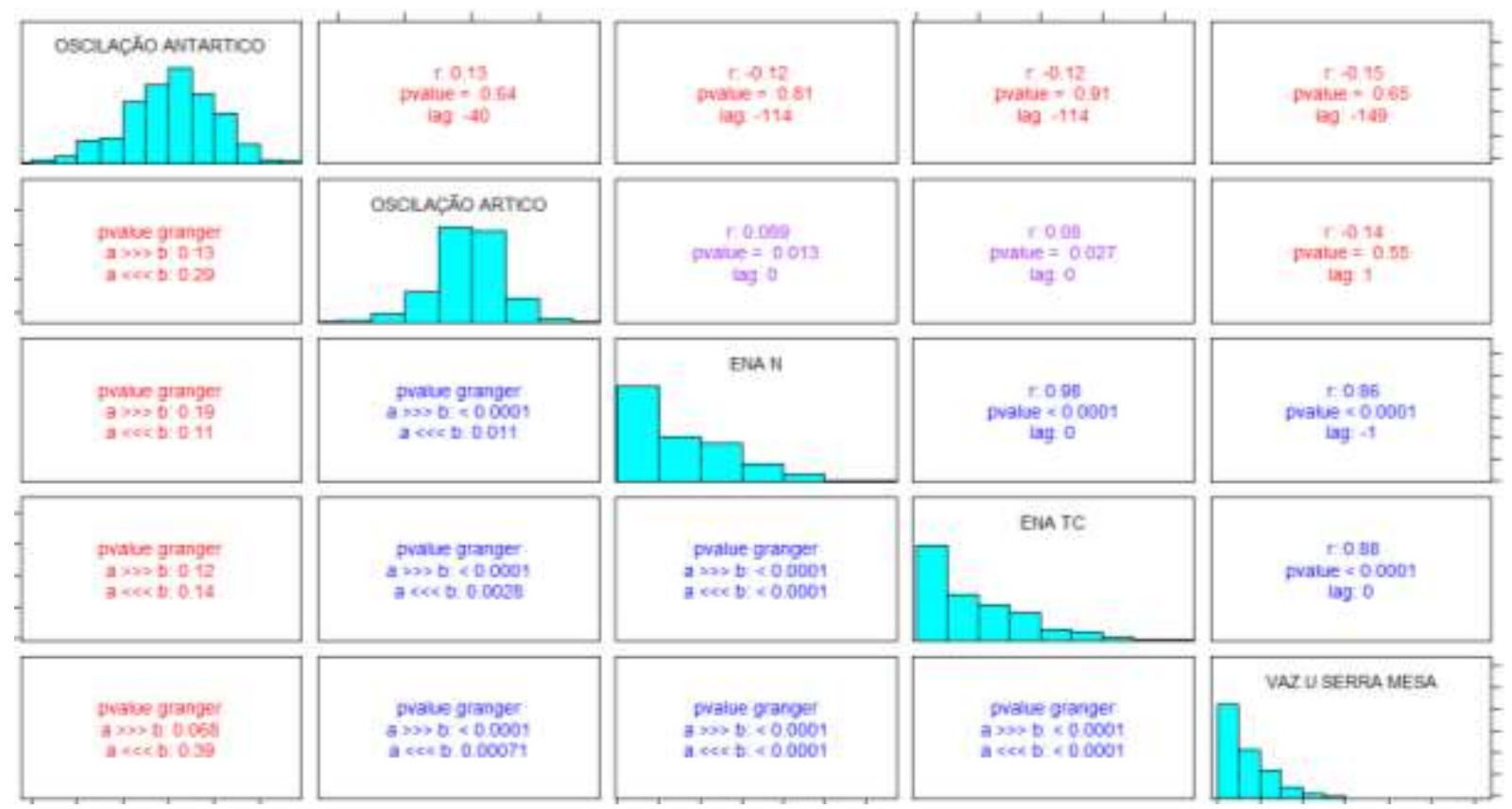

(d)

Figura APÊNDICE N-216 Correlação entre as variáveis dos Polos Ártico e Antártico e vazões das Usinas da Bacia dos rios a) Paraná, b) São Francisco, c) Parnaíba e d) Tocantins. 
APÊNDICE N.1.6 Solar

APÊNDICE N.1.6.1 Número de Machas Solares

O gráfico, apresentam-se as correlações cruzadas entre as vazões das usinas e Manchas Solares.

Todas as correlações não foram expressivas, e, porém, as análises de séries temporais são realizadas com essa variável climática uma vez que sua sazonalidade é diferente, cerca de 11 anos enquanto que o El Niño 1+2 é de 12 meses.

APÊNDICE N.1.6.2 Machas Solares versos Usinas

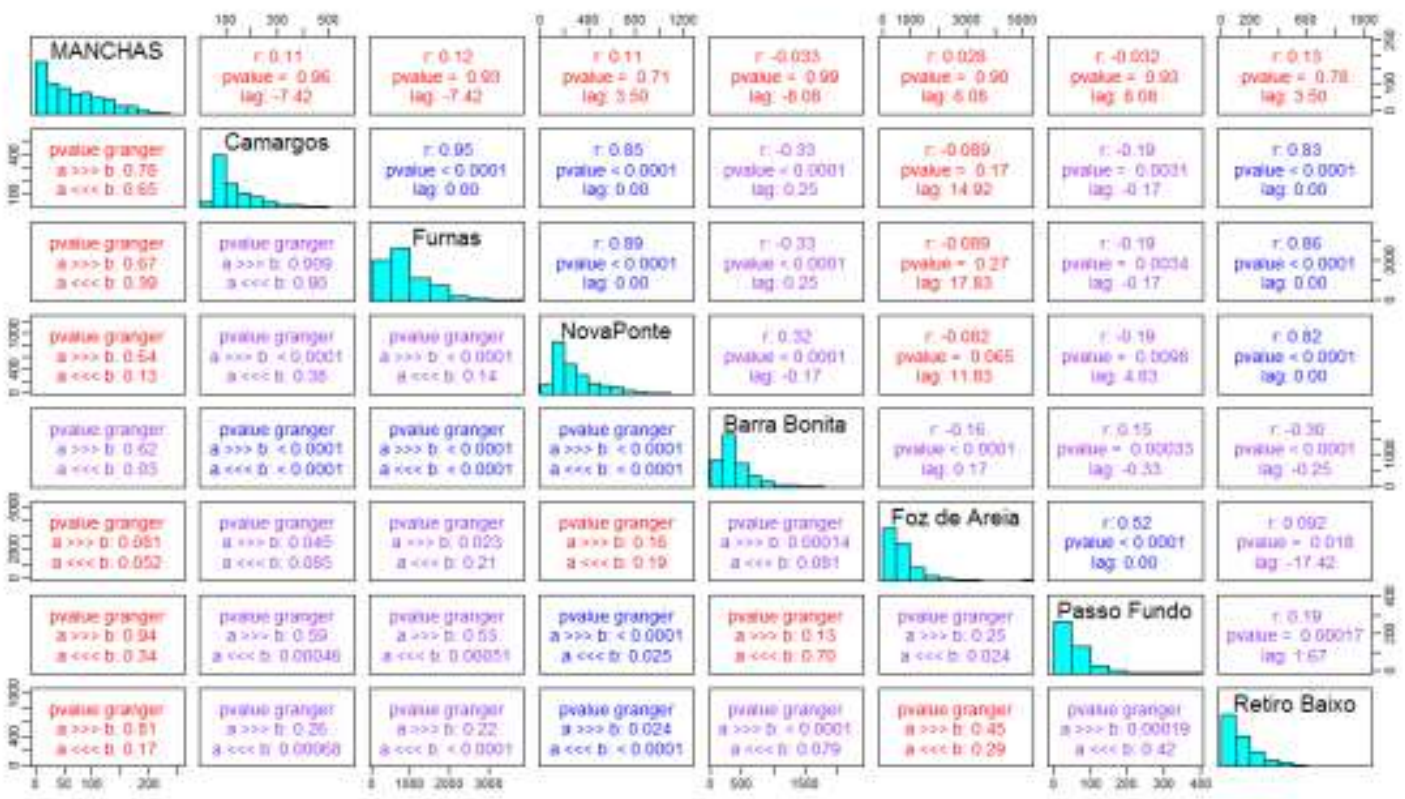

(a)

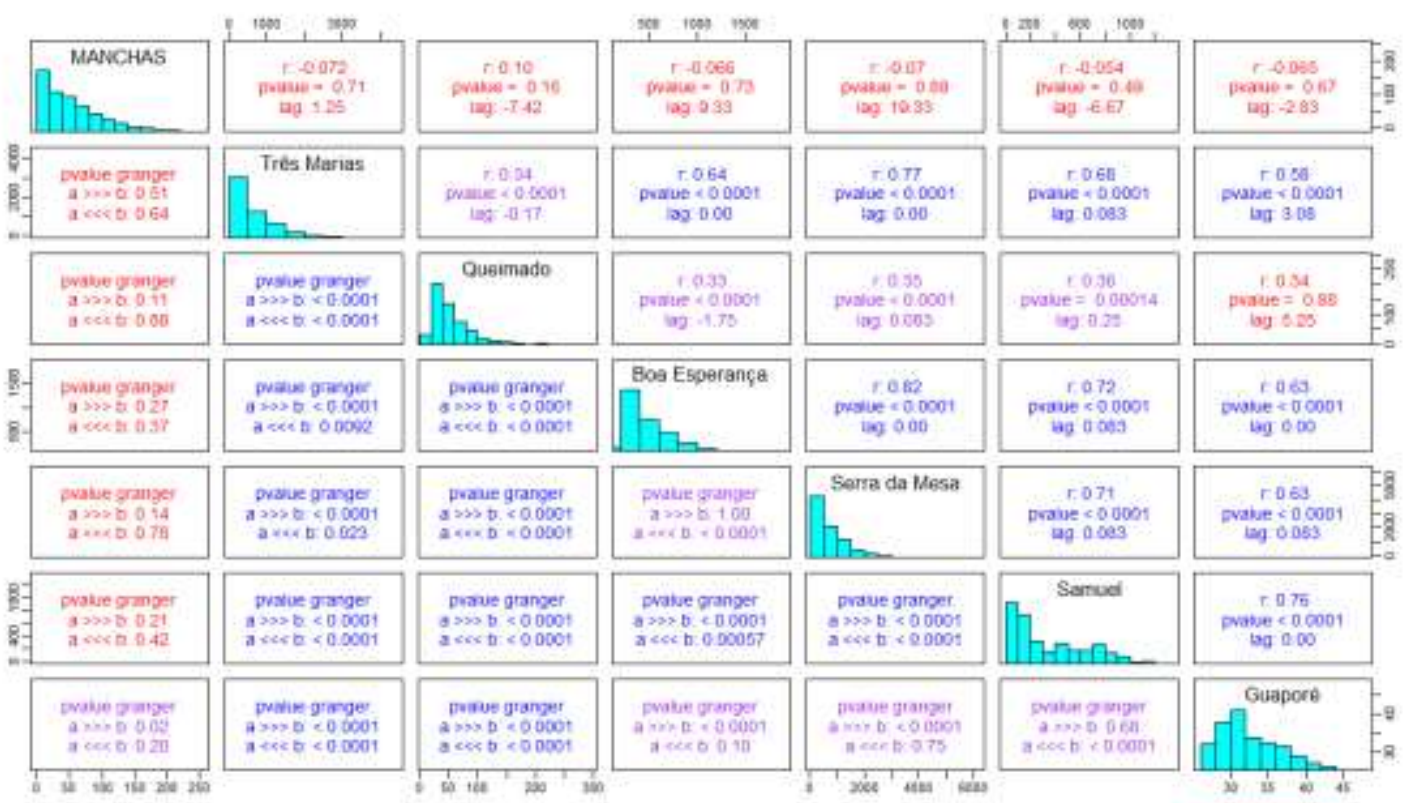

(b)

Figura APÊNDICE N-217 Relação entre variável Manchas Solares e Usinas escolhidas com função de autocorrelação cruzada. 
APÊNDICE N.1.6.3 Machas Solares versos ENA e Bacias

Nas próximas figuras de análise de correlação e causalidade de Granger são feitas análises das variáveis macroclimáticas frente a quatro usinas apresentadas com as respectivas letras nas figuras seguintes: a) Barra Bonita, b) Três Marias, c) Boa Esperança e d) Serra da Mesa.A escolha das usinas em questão pode ser explicada por serem de cabeceira tendo como intensão minimizar os efeitos de usos de solo e ocupação urbana a qual sofre bastante influencia, podese citar como exemplo a usina de Itaipu.

Observa-se, nos próximos gráficos da Figura APÊNDICE N-218, as letras a) Manchas versos ENA-SE, ENA-PR e Usina Barra Bonita, b) Manchas versos ENA-NE, ENA-SF e Usina Três Marias, c) Manchas versos ENA-NE, ENA-PA e Usina Boa Esperança e d) Manchas versos ENA-NE, ENA-TC e Usina Serra da Mesa. Entre as variáveis de manchas solares e as vazões das usinas nenhum dos gráficos apresentou correlação expressiva. A melhor correlação foi de 0,13 entre a variável Manchas Solares do Hemisfério Sul e da Usina de Três Marias, porém com $p$-valor $=0,08$, maior que nível de significância 0,05 . 

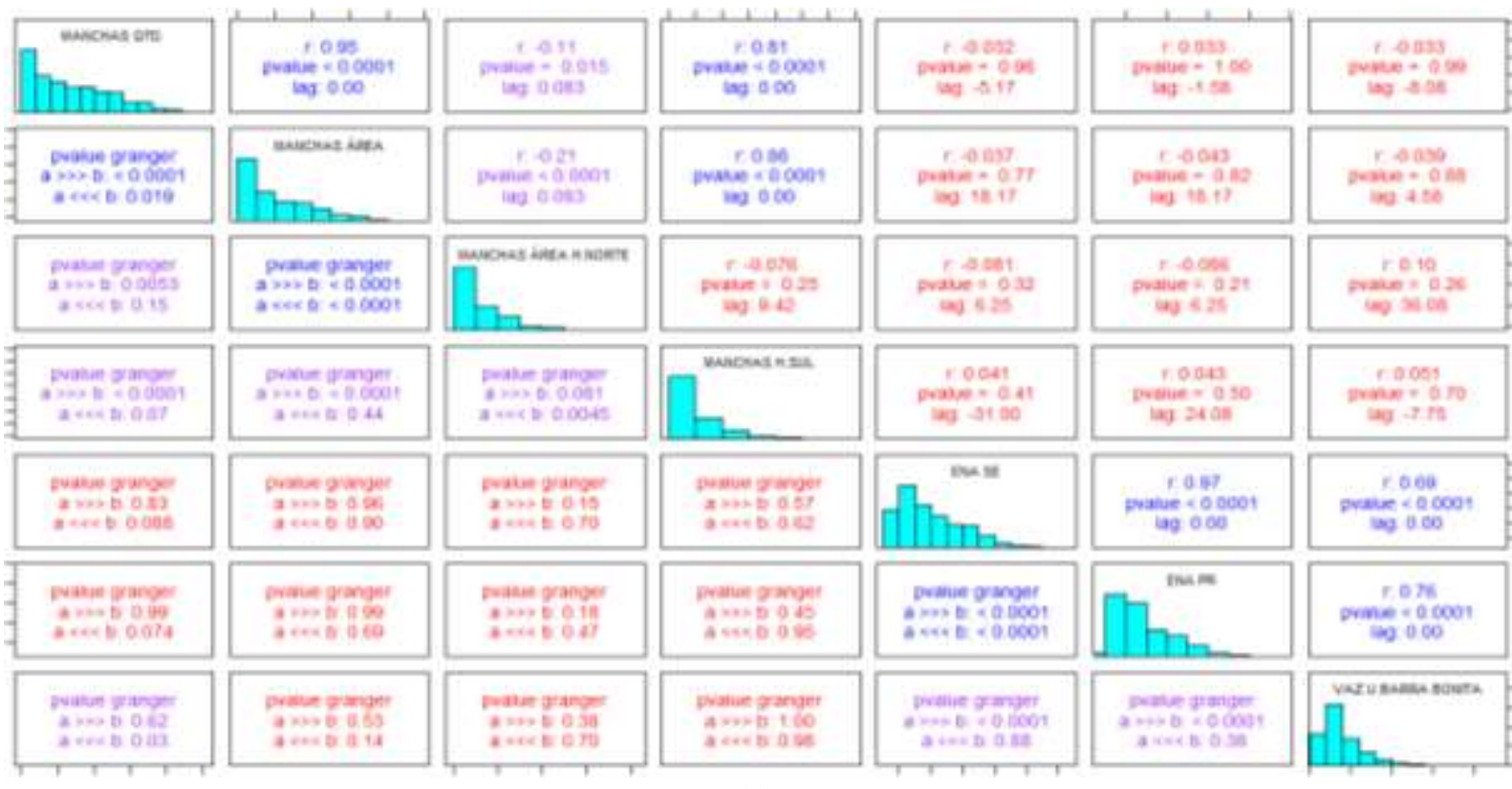

(a)
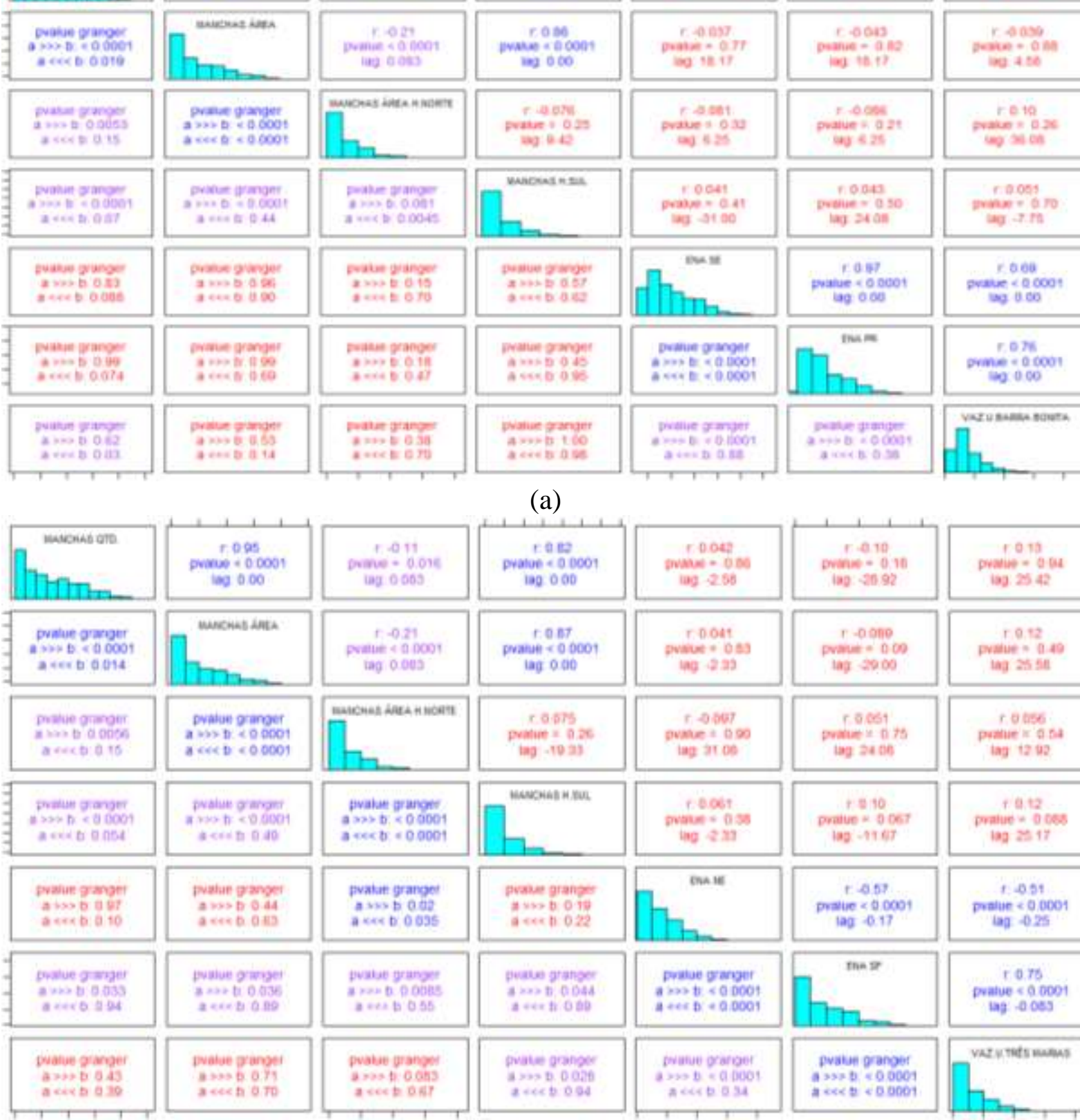
iog in in

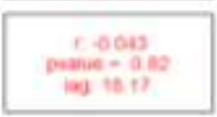
an
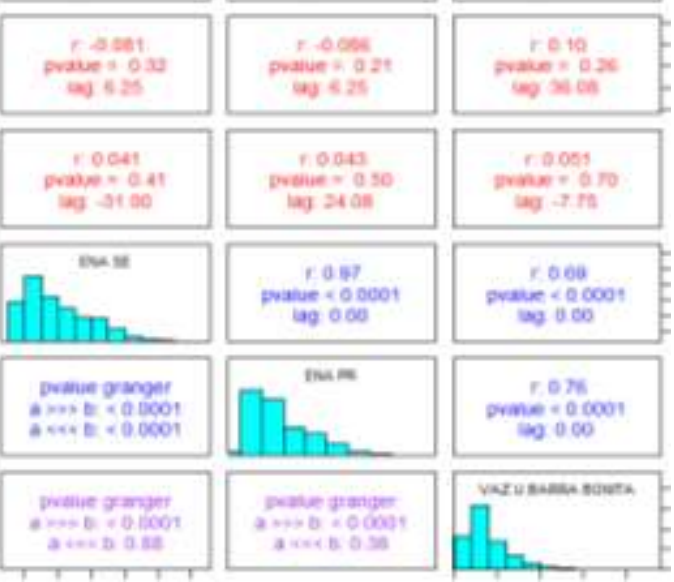

a)
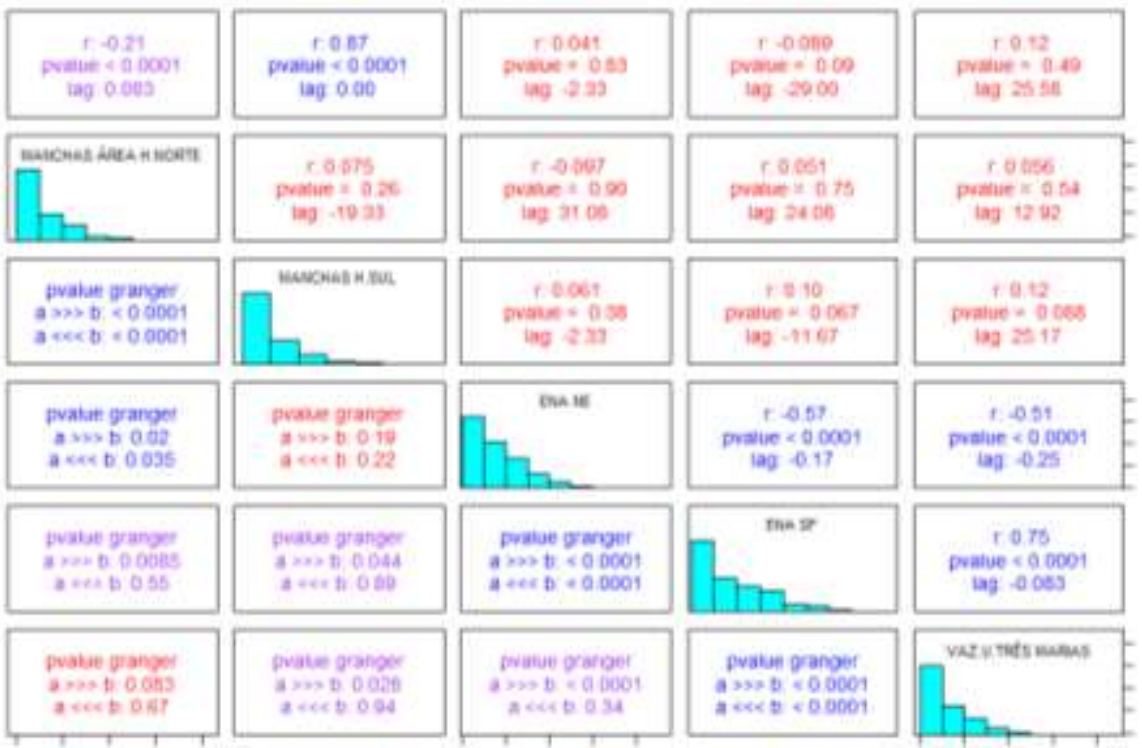

$r 070$ Dvalue 500001
lag a dos

(b) 


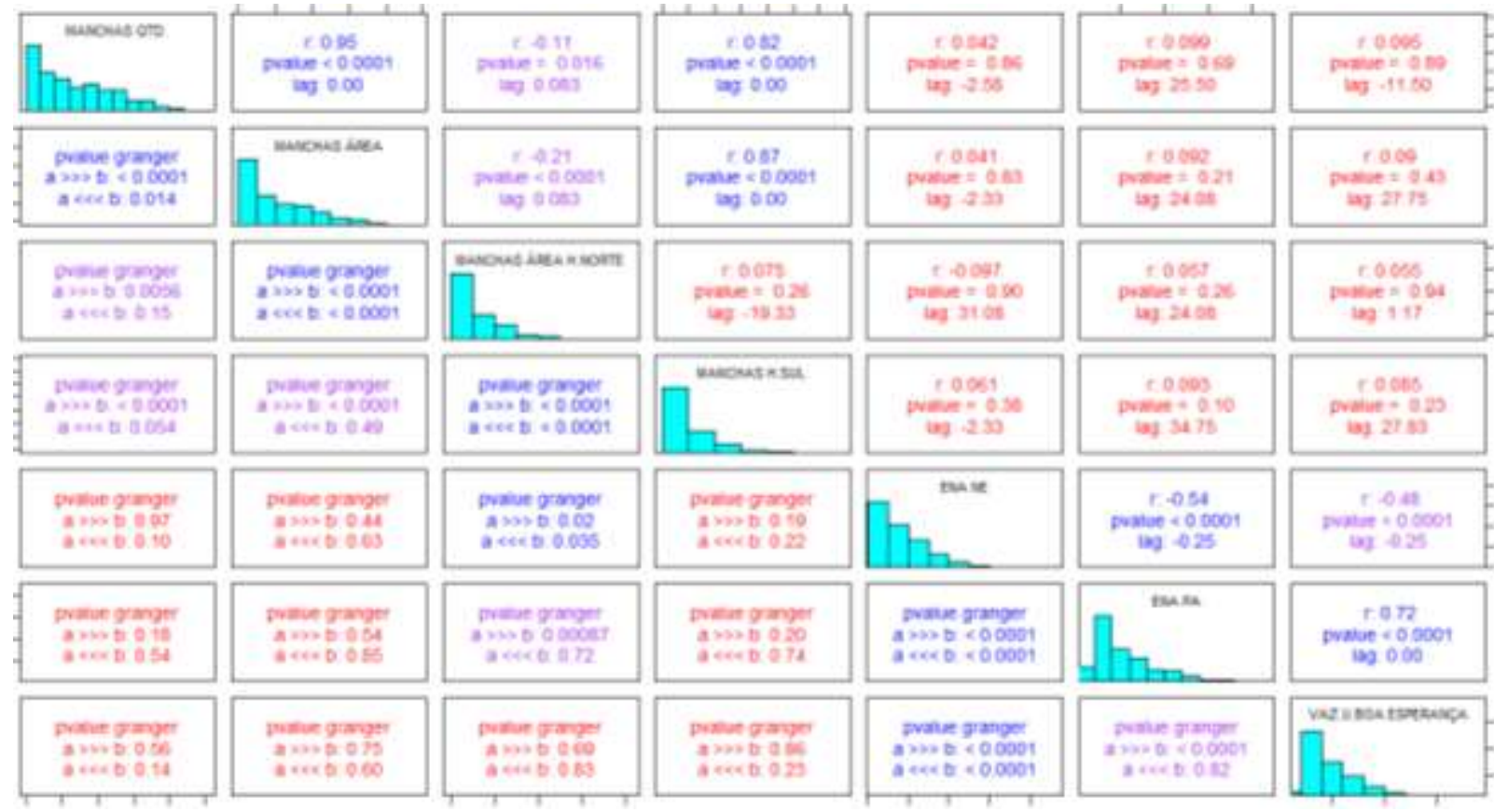

(c)
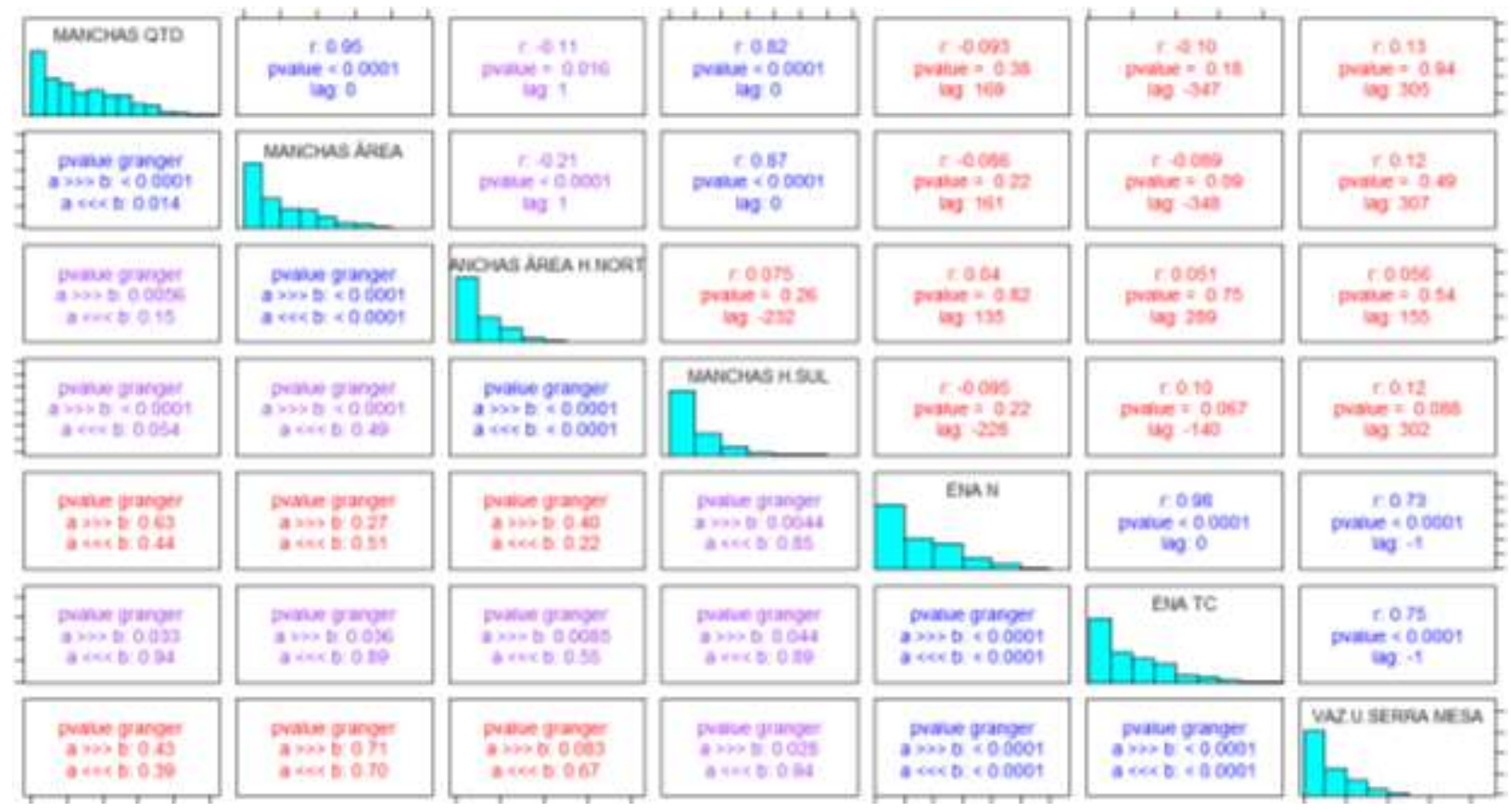

(d)

Figura APÊNDICE N-218 Correlação entre as variáveis quantidade de manchas solares e as vazões das Usinas das Bacia a) Paraná, b) São Francisco, c) Parnaíba e d) Tocantins. 
APÊNDICE N.2 Análise de resíduos dos parâmetros

APÊNDICE N.2.1 Intercepto

Nos modelos com aplicação de diferenças não aparece o intercepto. Na fase de estimação somente os modelos com variáveis explicativas AMO, NINO ou AMO+NINO apresentaram valores de intercepto com o p-valor menor que 0,05, para o modelo SARIMAX (100101).

Tabela APÊNDICE N-5 Análise de Resíduos Intercepto

$\begin{array}{lrrrrrrrrrrr}\text { Modelo } & \text { Inicio } & \text { Final } & \mathbf{p} & \mathbf{d} & \mathbf{q} & \mathbf{P} & \mathbf{D} & \mathbf{Q} & \text { Intercepto } & \text { se intercepto } & \text { p-valor intercepto } \\ \text { ENA+SE } & 1931 & 2008 & 1 & 0 & 0 & 0 & 0 & 0 & 0,00 & 0,02 & 0,99 \\ \text { ENA+SE } & 1931 & 2008 & 1 & 0 & 0 & 1 & 0 & 0 & -0,00 & 0,02 & 1,00 \\ \text { ENA+SE } & 1931 & 2008 & 1 & 1 & 0 & 1 & 0 & 0 & & \\ \text { ENA+SE } & 1931 & 2008 & 1 & 0 & 0 & 1 & 0 & 1 & 0,00 & 0,07 & \\ \text { NINO\&ENA+SE } & 1931 & 2008 & 1 & 1 & 1 & 3 & 0 & 0 & & \\ \text { AMO\&ENA+SE } & 1931 & 2008 & 1 & 0 & 1 & 3 & 1 & 0 & & \\ \text { AMO+NINO\&ENA+SE } & 1931 & 2008 & 1 & 1 & 1 & 3 & 0 & 0 & & \\ \text { AMO\&ENA+SE } & 1931 & 2008 & 1 & 1 & 1 & 3 & 0 & 0 & & \\ \text { NINO\&ENA+SE } & 1931 & 2008 & 1 & 0 & 1 & 3 & 1 & 0 & & \\ \text { AMO+NINO\&ENA+SE } & 1931 & 2008 & 1 & 0 & 1 & 3 & 1 & 0 & & \\ \text { AMO\&ENA+SE } & 1931 & 2008 & 1 & 0 & 0 & 1 & 0 & 1 & 10,46 & 0,25 & 0,33 \\ \text { NINO\&ENA+SE } & 1931 & 2008 & 1 & 0 & 0 & 1 & 0 & 1 & 9,59 & 0,33 \\ \text { AMO+NINO\&ENA+SE } & 1931 & 2008 & 1 & 0 & 0 & 1 & 0 & 1 & 9,59 & \\ \text { AMO\&ENA+SE } & 1931 & 2008 & 1 & 1 & 0 & 1 & 0 & 1 & & \\ \text { AMO\&ENA+SE } & 1931 & 2008 & 1 & 0 & 0 & 1 & 1 & 1 & & \\ \text { AMO\&ENA+SE } & 1931 & 2008 & 1 & 0 & 0 & 1 & 1 & 1 & & \end{array}$

Tabela APÊNDICE N-6 Análise de Resíduos parâmetro phi

\begin{tabular}{lrrrrrrrrrrr} 
Modelo & Inicio & Final & $\mathbf{p}$ & $\mathbf{d}$ & $\mathbf{q}$ & $\mathbf{P}$ & $\mathbf{D}$ & $\mathbf{Q}$ & $\mathbf{p 1}$ & $\mathbf{s e - p 1}$ & $\mathbf{p}$-valor1 \\
-o-\&ENA+SE & 1931 & 2008 & 1 & 0 & 0 & 0 & 0 & 0 & 0,47 & $\mathbf{0 , 0 2 9}$ & 0 \\
-o-\&ENA+SE & 1931 & 2008 & 1 & 0 & 0 & 1 & 0 & 1 & $-0,19$ & 0,032 & $<0,0001$ \\
\hline NINO\&ENA+SE & 1931 & 2008 & 1 & 1 & 1 & 3 & 0 & 0 & 0,68 & $\mathbf{0 , 0 2 5}$ & 0 \\
AMO\&ENA+SE & 1931 & 2008 & 1 & 0 & 1 & 3 & 1 & 0 & 0,78 & 0,032 & 0 \\
AMO+NINO\&ENA+SE & 1931 & 2008 & 1 & 1 & 1 & 3 & 0 & 0 & 0,68 & $\mathbf{0 , 0 2 5}$ & 0 \\
AMO\&ENA+SE & 1931 & 2008 & 1 & 1 & 1 & 3 & 0 & 0 & 0,71 & $\mathbf{0 , 0 2 3}$ & 0 \\
NINO\&ENA+SE & 1931 & 2008 & 1 & 0 & 1 & 3 & 1 & 0 & 0,76 & 0,036 & 0 \\
AMO+NINO\&ENA+SE & 1931 & 2008 & 1 & 0 & 1 & 3 & 1 & 0 & 0,76 & 0,036 & 0 \\
AMO\&ENA+SE & 1931 & 2008 & 1 & 0 & 0 & 1 & 0 & 1 & 0,72 & $\mathbf{0 , 0 2 3}$ & 0 \\
NINO\&ENA+SE & 1931 & 2008 & 1 & 0 & 0 & 1 & 0 & 1 & 0,71 & $\mathbf{0 , 0 2 4}$ & 0 \\
AMO+NINO\&ENA+SE & 1931 & 2008 & 1 & 0 & 0 & 1 & 0 & 1 & 0,7 & $\mathbf{0 , 0 2 5}$ & 0 \\
AMO\&ENA+SE & 1931 & 2008 & 1 & 1 & 0 & 1 & 0 & 1 & $-0,19$ & 0,032 & $<0,0001$ \\
\hline AMO\&ENA+SE & 1931 & 2008 & 1 & 0 & 0 & 1 & 1 & 1 & 0,72 & $\mathbf{0 , 0 2 4}$ & 0 \\
AMO\&ENA+SE & 1931 & 2008 & 1 & 0 & 0 & 1 & 1 & 1 & 0,72 & $\mathbf{0 , 0 2 4}$ & 0 \\
NINO\&ENA+SE & 1931 & 2008 & 1 & 0 & 0 & 1 & 1 & 1 & 0,71 & $\mathbf{0 , 0 2 5}$ & 0 \\
AMO+NINO\&ENA+SE & 1931 & 2008 & 1 & 0 & 0 & 1 & 1 & 1 & 0,71 & $\mathbf{0 , 0 2 5}$ & 0 \\
& & & & & & & & & & &
\end{tabular}


APÊNDICE N.2.3 Parâmetros médias móveis $\Theta$

Tabela APÊNDICE N-7 Análise de Resíduos Parâmetros PHI

$\begin{array}{lrllllllllll}\text { Modelo } & \text { Inicio } & \text { Final } & \mathbf{p} & \mathbf{d} & \mathbf{q} & \mathbf{P} & \mathbf{D} & \mathbf{Q} & \mathbf{p} 1 & \text { se-p1 } & \text { p-valor1 } \\ \text {-o-\&ENA+SE } & 1931 & 2008 & 1 & 0 & 0 & 0 & 0 & 0 & & & \\ \text {-o-\&ENA+SE } & 1931 & 2008 & 1 & 0 & 0 & 1 & 0 & 0 & & & \\ \text {-o-\&ENA+SE } & 1931 & 2008 & 1 & 1 & 0 & 1 & 0 & 0 & & & \\ \text {-o-\&ENA+SE } & 1931 & 2008 & 1 & 0 & 0 & 1 & 0 & 1 & & & \\ \text { NINO\&ENA+SE } & 1931 & 2008 & 1 & 1 & 1 & 3 & 0 & 0 & -1,00 & 0,00 & 0,0000 \\ \text { AMO\&ENA+SE } & 1931 & 2008 & 1 & 0 & 1 & 3 & 1 & 0 & -0,14 & 0,06 & 0,0108 \\ \text { AMO+NINO\&ENA+SE } & 1931 & 2008 & 1 & 1 & 1 & 3 & 0 & 0 & -1,00 & 0,00 & 0,0000 \\ \text { AMO\&ENA+SE } & 1931 & 2008 & 1 & 1 & 1 & 3 & 0 & 0 & -1,00 & \mathbf{0 , 0 0} & 0,0000 \\ \text { NINO\&ENA+SE } & 1931 & 2008 & 1 & 0 & 1 & 3 & 1 & 0 & -0,12 & 0,06 & 0,0292 \\ \text { AMO+NINO\&ENA+SE } & 1931 & 2008 & 1 & 0 & 1 & 3 & 1 & 0 & -0,12 & 0,06 & 0,0308 \\ \text { AMO\&ENA+SE } & 1931 & 2008 & 1 & 0 & 0 & 1 & 0 & 1 & & & \\ \text { NINO\&ENA+SE } & 1931 & 2008 & 1 & 0 & 0 & 1 & 0 & 1 & & & \\ \text { AMO+NINO\&ENA+SE } & 1931 & 2008 & 1 & 0 & 0 & 1 & 0 & 1 & & & \\ \text { AMO\&ENA+SE } & 1931 & 2008 & 1 & 1 & 0 & 1 & 0 & 1 & & & \\ \text { AMO\&ENA+SE } & 1931 & 2008 & 1 & 0 & 0 & 1 & 1 & 1 & & & \\ \text { AMO\&ENA+SE } & 1931 & 2008 & 1 & 0 & 0 & 1 & 1 & 1 & & & \\ \text { NINO\&ENA+SE } & 1931 & 2008 & 1 & 0 & 0 & 1 & 1 & 1 & & & \\ \text { AMO+NINO\&ENA+SE } & 1931 & 2008 & 1 & 0 & 0 & 1 & 1 & 1 & & & \end{array}$

APÊNDICE N.2.4 Parâmetros autorregressivos sazonais $\Phi$

Tabela APÊNDICE N-8 Análise de Resíduos parâmetros theta

\begin{tabular}{|c|c|c|c|c|c|c|c|c|c|c|c|c|c|c|c|c|c|}
\hline Modelo & Inicio & Final & $\mathbf{p}$ & d & $q$ & $\mathbf{P}$ & D & $\mathbf{Q}$ & p1 & $\begin{array}{l}\text { se- } \\
\text { p1 }\end{array}$ & p-valor1 & p2 & $\begin{array}{l}\text { se- } \\
\text { p2 }\end{array}$ & $\begin{array}{l}\mathrm{p}- \\
\text { valor2 }\end{array}$ & p3 & $\begin{array}{l}\text { se- } \\
\text { p3 }\end{array}$ & p-valor3 \\
\hline -o-\&ENA+SE & 1931 & 2008 & 1 & 0 & 0 & 0 & 0 & 0 & & & & & & & & & \\
\hline -o-\&ENA+SE & 1931 & 2008 & 1 & 0 & 0 & 1 & 0 & 0 & 0,68 & 0,03 & 0,000 & & & & & & \\
\hline -o-\&ENA+SE & 1931 & 2008 & 1 & 1 & 0 & 1 & 0 & 0 & 0,36 & 0,03 & 0,000 & & & & & & \\
\hline -o-\&ENA+SE & 1931 & 2008 & 1 & 0 & 0 & 1 & 0 & 1 & 1,00 & 0,00 & 0,000 & & & & & & \\
\hline NINO\&ENA+SE & 1931 & 2008 & 1 & 1 & 1 & 3 & 0 & 0 & 0,23 & 0,03 & $<0.0001$ & 0,29 & 0,03 & 0,00 & 0,31 & 0,03 & 0,0000 \\
\hline AMO\&ENA+SE & 1931 & 2008 & 1 & 0 & 1 & 3 & 1 & 0 & $-0,82$ & 0,03 & 0,000 & $-0,55$ & 0,04 & 0,00 & $-0,26$ & 0,03 & $<0.0001$ \\
\hline AMO+NINO\&ENA+SE & 1931 & 2008 & 1 & 1 & 1 & 3 & 0 & 0 & 0,23 & 0,03 & $<0.0001$ & 0,29 & 0,03 & 0,00 & 0,31 & 0,03 & 0,0000 \\
\hline AMO\&ENA+SE & 1931 & 2008 & 1 & 1 & 1 & 3 & 0 & 0 & 0,25 & 0,03 & $<0.0001$ & 0,31 & 0,03 & 0,00 & 0,32 & 0,03 & 0,0000 \\
\hline NINO\&ENA+SE & 1931 & 2008 & 1 & 0 & 1 & 3 & 1 & 0 & $-0,82$ & 0,03 & 0,000 & $-0,55$ & 0,04 & 0,00 & $-0,26$ & 0,03 & $<0.0001$ \\
\hline $\mathrm{AMO}+\mathrm{NINO \& ENA+SE}$ & 1931 & 2008 & 1 & 0 & 1 & 3 & 1 & 0 & $-0,82$ & 0,03 & 0,000 & $-0,55$ & 0,04 & 0,00 & $-0,26$ & 0,03 & $<0.0001$ \\
\hline AMO\&ENA+SE & 1931 & 2008 & 1 & 0 & 0 & 1 & 0 & 1 & 1,00 & 0,00 & 0,000 & & & & & & \\
\hline NINO\&ENA+SE & 1931 & 2008 & 1 & 0 & 0 & 1 & 0 & 1 & 1,00 & 0,00 & 0,000 & & & & & & \\
\hline $\mathrm{AMO}+\mathrm{NINO} \& \mathrm{ENA}+\mathrm{SE}$ & 1931 & 2008 & 1 & 0 & 0 & 1 & 0 & 1 & 1,00 & 0,00 & 0,000 & & & & & & \\
\hline AMO\&ENA+SE & 1931 & 2008 & 1 & 1 & 0 & 1 & 0 & 1 & 1,00 & 0,00 & 0,000 & & & & & & \\
\hline AMO\&ENA+SE & 1931 & 2008 & 1 & 0 & 0 & 1 & 1 & 1 & $-0,03$ & 0,04 & 0,447 & & & & & & \\
\hline AMO\&ENA+SE & 1931 & 2008 & 1 & 0 & 0 & 1 & 1 & 1 & $-0,03$ & 0,04 & 0,447 & & & & & & \\
\hline NINO\&ENA+SE & 1931 & 2008 & 1 & 0 & 0 & 1 & 1 & 1 & $-0,03$ & 0,04 & 0,468 & & & & & & \\
\hline $\mathrm{AMO}+\mathrm{NINO \& ENA+SE}$ & 1931 & 2008 & 1 & 0 & 0 & 1 & 1 & 1 & $-0,03$ & 0,04 & 0,481 & & & & & & \\
\hline
\end{tabular}


APÊNDICE N.2.5 Parâmetros médias móveis sazonais $\Theta$

Não há esse tipo de parâmetro.

APÊNDICE N.2.6 Parâmetros de regressão

Tabela APÊNDICE N-9 Análise de Resíduos Parâmetros de Regressão

\begin{tabular}{|c|c|c|c|c|c|c|c|c|c|c|c|c|c|c|}
\hline Modelo & Inicio & Final & $\mathbf{p}$ & d & $\mathbf{q}$ & $\mathbf{P}$ & D & $\mathbf{Q}$ & nino & se-nino & p-valor_nino & amo & se-amo & $\begin{array}{l}\text { p-valor } \\
\text { amo }\end{array}$ \\
\hline NINO\&ENA+SE & 1931 & 2008 & 1 & 1 & 1 & 3 & 0 & 0 & 0,05 & 0,01 & $<0,0001$ & & & \\
\hline AMO\&ENA+SE & 1931 & 2008 & 1 & 0 & 1 & 3 & 1 & 0 & & & & 0,00 & 0,07 & 0,98 \\
\hline $\mathrm{AMO}+\mathrm{NINO \& ENA+SE}$ & 1931 & 2008 & 1 & 1 & 1 & 3 & 0 & 0 & 0,06 & 0,01 & $<0,0001$ & $-0,04$ & 0,07 & 0,52 \\
\hline $\mathrm{AMO \& ENA+SE}$ & 1931 & 2008 & 1 & 1 & 1 & 3 & 0 & 0 & & & & $-0,02$ & 0,07 & 0,81 \\
\hline NINO\&ENA+SE & 1931 & 2008 & 1 & 0 & 1 & 3 & 1 & 0 & 0,02 & 0,01 & 0,0539 & & & \\
\hline $\mathrm{AMO}+\mathrm{NINO \& ENA+SE}$ & 1931 & 2008 & 1 & 0 & 1 & 3 & 1 & 0 & 0,02 & 0,01 & 0,0536 & $-0,01$ & 0,07 & 0,90 \\
\hline $\mathrm{AMO \& ENA+SE}$ & 1931 & 2008 & 1 & 0 & 0 & 1 & 0 & 1 & & & & $-0,04$ & 0,06 & 0,58 \\
\hline NINO\&ENA+SE & 1931 & 2008 & 1 & 0 & 0 & 1 & 0 & 1 & 0,04 & 0,01 & 0,0011 & & & \\
\hline $\mathrm{AMO}+\mathrm{NINO \& ENA+SE}$ & 1931 & 2008 & 1 & 0 & 0 & 1 & 0 & 1 & 0,04 & 0,01 & 0,0011 & $-0,05$ & 0,06 & 0,40 \\
\hline $\mathrm{AMO} \& \mathrm{ENA}+\mathrm{SE}$ & 1931 & 2008 & 1 & 1 & 0 & 1 & 0 & 1 & & & & 0,05 & 0,07 & 0,44 \\
\hline AMO\&ENA+SE & 1931 & 2008 & 1 & 0 & 0 & 1 & 1 & 1 & & & & $-0,03$ & 0,06 & 0,61 \\
\hline AMO\&ENA+SE & 1931 & 2008 & 1 & 0 & 0 & 1 & 1 & 1 & & & & $-0,03$ & 0,06 & 0,61 \\
\hline NINO\&ENA+SE & 1931 & 2008 & 1 & 0 & 0 & 1 & 1 & 1 & 0,03 & 0,01 & 0,0095 & & & \\
\hline $\mathrm{AMO}+\mathrm{NINO \& ENA+SE}$ & 1931 & 2008 & 1 & 0 & 0 & 1 & 1 & 1 & 0,03 & 0,01 & 0,0079 & $-0,05$ & 0,06 & 0,46 \\
\hline
\end{tabular}

\section{APÊNDICE O Validação Cruzada}

Na Figura APÊNDICE O-219 são comparados três diferentes modelos do tipo SARIMAX, dois com variáveis exógenas e um sem. Os dois modelos com variáveis exógenas são melhores que o modelo sem, como visto na figura. O modelo com menor erro é SARIMAX (101300).

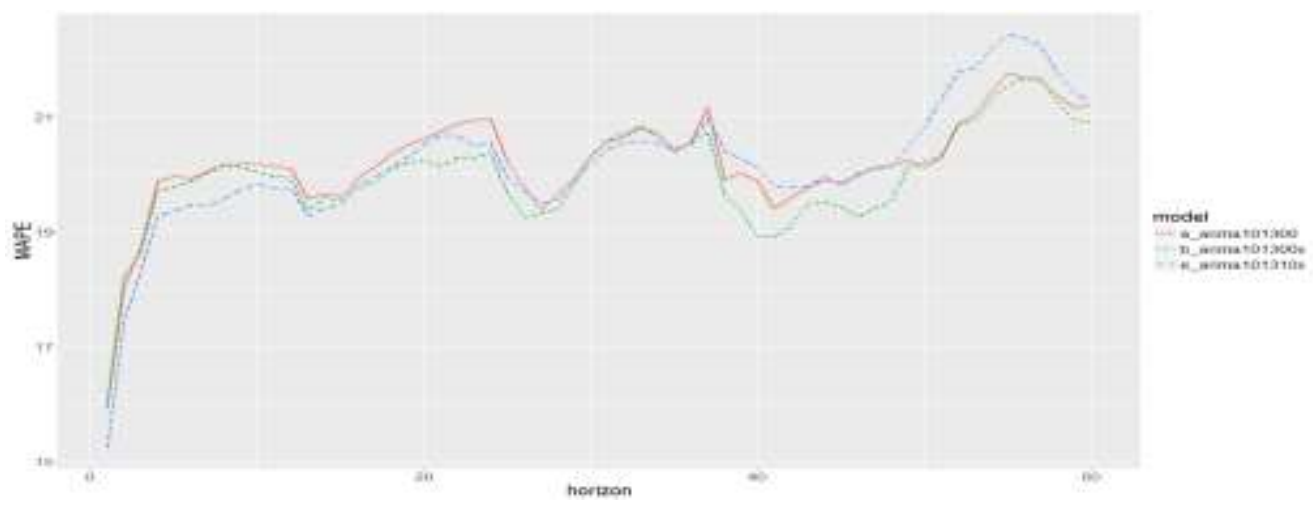

Figura APÊNDICE O-219 Validação Cruzada Modelos SARIMAX 101300, 101300x e 101310x

A seguintes tabelas, Tabela APÊNDICE O-10, Tabela APÊNDICE O-11, Tabela APÊNDICE O-12, Tabela APÊNDICE O-13 e O parâmetro $\Phi_{3}$ apresentou erros padrões (s.e.) entre 0,03 a 0,05 e os valores p-valor menores que 0,05 e, assim, apresenta-se como um parâmetro robusto dentro do teste de validação cruzada, Tabela APÊNDICE O-14. 
Tabela APÊNDICE O-14, apresentam-se respectivamente a validação cruzada de cada um dos parâmetros do modelo SARIMAX (101300). Todas possuem as colunas Modelo, Início, Final, Parâmetro, Erro padrão (s.e) e p-valor.

$\mathrm{O}$ parâmetro $\varphi_{1}$ apresentou erros padrões (s.e.) entre 0,03 a 0,15 e todos os valores p-valor iguais a zero e, assim, apresenta-se como um parâmetro robusto dentro do teste de validação cruzada, Tabela APÊNDICE O-10.

Tabela APÊNDICE O-10 Análise de Resíduos Parâmetros phi 1

$\begin{array}{lrllll}\text { Modelo } & \text { Inicio } & \text { Final } & \phi_{1} & \text { s.e. } & \text { p-valor } \\ \text { amo+nino } & 1938 & 1968 & 0,68 & 0,04 & 0,00 \\ \text { amo+nino } & 1943 & 1973 & 0,71 & 0,04 & 0,00 \\ \text { amo+nino } & 1948 & 1978 & 0,70 & 0,04 & 0,00 \\ \text { amo+nino } & 1953 & 1983 & 0,58 & 0,15 & 0,00 \\ \text { amo+nino } & 1958 & 1988 & 0,75 & 0,04 & 0,00 \\ \text { amo+nino } & 1963 & 1993 & 0,71 & 0,04 & 0,00 \\ \text { amo+nino } & 1968 & 1998 & 0,63 & 0,05 & 0,00 \\ \text { amo+nino } & 1973 & 2003 & 0,60 & 0,04 & 0,00 \\ \text { amo+nino } & 1978 & 2008 & 0,59 & 0,04 & 0,00 \\ \text { amo+nino } & 1938 & 2008 & 0,66 & 0,03 & 0,00\end{array}$

$\mathrm{O}$ parâmetro $\theta_{1}$ apresentou erros padrões (s.e.) entre 0,004 a 0,104 e todos os valores p-valor iguais a zero e, assim, apresenta-se como um parâmetro robusto dentro do teste de validação cruzada, Tabela APÊNDICE O-11.

Tabela APÊNDICE O-11 Análise de Resíduos Parâmetros theta 1

$\begin{array}{lrrrll}\text { modelo } & \text { inicio } & \text { final } & \theta 1 & \text { s.e. } & \text { p-valor } \\ \text { amo+nino } & 1938 & 1968 & -1.00 & 0,007 & 0,00 \\ \text { amo+nino } & 1943 & 1973 & -1.00 & 0,008 & 0,00 \\ \text { amo+nino } & 1948 & 1978 & -1.00 & 0,008 & 0,00 \\ \text { amo+nino } & 1953 & 1983 & -0,89 & 0,104 & 0,00 \\ \text { amo+nino } & 1958 & 1988 & -1.00 & 0,016 & 0,00 \\ \text { amo+nino } & 1963 & 1993 & -0,99 & 0,010 & 0,00 \\ \text { amo+nino } & 1968 & 1998 & -0,98 & 0,016 & 0,00 \\ \text { amo+nino } & 1973 & 2003 & -1.00 & 0,024 & 0,00 \\ \text { amo+nino } & 1978 & 2008 & -1.00 & 0,020 & 0,00 \\ \text { amo+nino } & 1938 & 2008 & -0,99 & 0,004 & 0,00\end{array}$

O parâmetro $\Phi_{1}$ apresentou erros padrões (s.e.) entre 0,03 a 0,05 e os valores p-valor iguais a zero, exceto os períodos de 1968 a 1998, 1973 a 2003 e 1978 a 2008 com valores p maiores que 0,05 , e, assim, apresenta-se como um parâmetro não tão robusto dentro do teste de validação cruzada, Tabela APÊNDICE O-12, porém não prejudicou os resultados no geral. 
Tabela APÊNDICE O-12 Análise de Resíduos Parâmetros THETA 1

$\begin{array}{lrrlll}\text { modelo } & \text { inicio } & \text { final } & \Phi_{1} & \text { s.e. } & \text { p-valor } \\ \text { amo+nino } & 1938 & 1968 & 0,17 & 0,05 & 0,00 \\ \text { amo+nino } & 1943 & 1973 & 0,16 & 0,05 & 0,00 \\ \text { amo+nino } & 1948 & 1978 & 0,15 & 0,05 & 0,00 \\ \text { amo+nino } & 1953 & 1983 & 0,11 & 0,05 & 0,03 \\ \text { amo+nino } & 1958 & 1988 & 0,13 & 0,05 & 0,01 \\ \text { amo+nino } & 1963 & 1993 & 0,14 & 0,05 & 0,01 \\ \text { amo+nino } & 1968 & 1998 & 0,03 & 0,05 & 0,51 \\ \text { amo+nino } & 1973 & 2003 & 0,06 & 0,05 & 0,23 \\ \text { amo+nino } & 1978 & 2008 & 0,05 & 0,05 & 0,33 \\ \text { amo+nino } & 1938 & 2008 & 0,10 & 0,03 & 0,00\end{array}$

O parâmetro $\Phi_{2}$ apresentou erros padrões (s.e.) entre 0,03 a 0,05 e os valores p-valor menores que 0,05 e, assim, apresenta-se como um parâmetro robusto dentro do teste de validação cruzada, Tabela APÊNDICE O-13.

Tabela APÊNDICE O-13 Análise de Resíduos Parâmetros THETA 2

$\begin{array}{lrllll}\text { modelo } & \text { inicio } & \text { final } & \text { Ф2 } & \text { s.e. } & \text { p-valor } \\ \text { amo+nino } & 1938 & 1968 & 0,14 & 0,05 & 0,01 \\ \text { amo+nino } & 1943 & 1973 & 0,14 & 0,05 & 0,01 \\ \text { amo+nino } & 1948 & 1978 & 0,16 & 0,05 & 0,00 \\ \text { amo+nino } & 1953 & 1983 & 0,15 & 0,06 & 0,01 \\ \text { amo+nino } & 1958 & 1988 & 0,14 & 0,05 & 0,01 \\ \text { amo+nino } & 1963 & 1993 & 0,10 & 0,05 & 0,05 \\ \text { amo+nino } & 1968 & 1998 & 0,15 & 0,05 & 0,01 \\ \text { amo+nino } & 1973 & 2003 & 0,16 & 0,05 & 0,00 \\ \text { amo+nino } & 1978 & 2008 & 0,13 & 0,05 & 0,01 \\ \text { amo+nino } & 1938 & 2008 & 0,15 & 0,03 & 0,00\end{array}$

$\mathrm{O}$ parâmetro $\Phi_{3}$ apresentou erros padrões (s.e.) entre 0,03 a 0,05 e os valores p-valor menores que 0,05 e, assim, apresenta-se como um parâmetro robusto dentro do teste de validação cruzada, Tabela APÊNDICE O-14.

Tabela APÊNDICE O-14 Análise de Resíduos Parâmetros THETA 3

$\begin{array}{lrrlll}\text { modelo } & \text { inicio } & \text { final } & \text { Ф3 } & \text { s.e. } & \text { p-valor } \\ \text { amo+nino } & 1938 & 1968 & 0,11 & 0,05 & 0,05 \\ \text { amo+nino } & 1943 & 1973 & 0,15 & 0,05 & 0,01 \\ \text { amo+nino } & 1948 & 1978 & 0,16 & 0,05 & 0,00 \\ \text { amo+nino } & 1953 & 1983 & 0,22 & 0,05 & 0,00 \\ \text { amo+nino } & 1958 & 1988 & 0,24 & 0,05 & 0,00 \\ \text { amo+nino } & 1963 & 1993 & 0,25 & 0,05 & 0,00 \\ \text { amo+nino } & 1968 & 1998 & 0,24 & 0,05 & 0,00 \\ \text { amo+nino } & 1973 & 2003 & 0,24 & 0,05 & 0,00 \\ \text { amo+nino } & 1978 & 2008 & 0,22 & 0,05 & 0,00 \\ \text { amo+nino } & 1938 & 2008 & 0,20 & 0,03 & 0,00\end{array}$


O parâmetro regressão Niño apresentou erros padrões (s.e.) entre 0,01 a 0,02 e os valores pvalor menores que 0,071 e, assim, apresenta-se como um parâmetro robusto dentro do teste de validação cruzada, Tabela APÊNDICE O-15.

Tabela APÊNDICE O-15 Análise de Resíduos Parâmetros de Regressão Nino

$\begin{array}{lrrlll}\text { modelo } & \text { inicio } & \text { final } & \text { nino } & \text { s.e. } & \text { p-valor } \\ \text { amo+nino } & 1938 & 1968 & 0,04 & 0,02 & 0,01 \\ \text { amo+nino } & 1943 & 1973 & 0,05 & 0,02 & 0,01 \\ \text { amo+nino } & 1948 & 1978 & 0,04 & 0,02 & 0,03 \\ \text { amo+nino } & 1953 & 1983 & 0,03 & 0,02 & 0,07 \\ \text { amo+nino } & 1958 & 1988 & 0,03 & 0,02 & 0,07 \\ \text { amo+nino } & 1963 & 1993 & 0,04 & 0,02 & 0,04 \\ \text { amo+nino } & 1968 & 1998 & 0,04 & 0,02 & 0,01 \\ \text { amo+nino } & 1973 & 2003 & 0,05 & 0,02 & 0,00 \\ \text { amo+nino } & 1978 & 2008 & 0,06 & 0,02 & 0,00 \\ \text { amo+nino } & 1938 & 2008 & 0,05 & 0,01 & 0,00\end{array}$

O parâmetro regressão AMO apresentou erros padrões (s.e.) entre 0,02 a 0,03 e os valores pvalor menores que zero e, assim, apresenta-se como um parâmetro robusto dentro do teste de validação cruzada, Tabela APÊNDICE O-16.

Tabela APÊNDICE O-16 Análise de Resíduos Parâmetros de Regressão AMO

$\begin{array}{lrrrrl}\text { modelo } & \text { inicio } & \text { final } & \text { amo } & \text { s.e. } & \text { p-valor } \\ \text { amo+nino } & 1938 & 1968 & -0,22 & 0,03 & - \\ \text { amo+nino } & 1943 & 1973 & -0,20 & 0,03 & 0,00 \\ \text { amo+nino } & 1948 & 1978 & -0,20 & 0,03 & 0,00 \\ \text { amo+nino } & 1953 & 1983 & -0,21 & 0,03 & 0,00 \\ \text { amo+nino } & 1958 & 1988 & -0,20 & 0,03 & 0,00 \\ \text { amo+nino } & 1963 & 1993 & -0,19 & 0,03 & 0,00 \\ \text { amo+nino } & 1968 & 1998 & -0,18 & 0,03 & 0,00 \\ \text { amo+nino } & 1973 & 2003 & -0,17 & 0,03 & 0,00 \\ \text { amo+nino } & 1978 & 2008 & -0,17 & 0,02 & 0,00 \\ \text { amo+nino } & 1938 & 2008 & -0,19 & 0,02 & -\end{array}$


ANEXO - A SOLAR UNDERSTANDING

https://ncar.ucar.edu/press/observing-a-quieter-sun-a-weak-cycle-offers-opportunity-forexpanding-solar-understanding

Since the dawn of the Space Age in the 1950s, solar maxima have coincided with strong upticks in sunspot activity but the current cycle, Cycle 24, which was expected to peak in Spring of 2013, has been unusually quiet. Solar activity remained at a moderate level, making it one of the weakest cycles in the past 100 years, as evidenced by the low number of sunspots appearing on the Sun's surface. With fewer and smaller sunspots, weaker magnetic fields that are associated with the sunspots, and less outgoing (radiative)

energy, many wonder what might be causing the Sun's quiescence. Some have suggested that the decline in solar activity may be a result of the 100-year Gleissberg Cycle. Others have speculated that sunspots and solar activity may be changing, with these changes potentially marking the beginning of a new Maunder Minimum.

Because of the close connection between Earth and Sun, scientists are interested in better understanding the Sun's variable output, particularly when the star is not acting in a manner that people have come to expect.

"Cycle 24 is different from recent cycles. You need to go back almost a century, to 1928 , to find a cycle as weak as this," says Giuliana de Toma, a scientist at the National Center for Atmospheric Research's High Altitude Observatory (HAO). "Weak cycles have happened before, but this is the first time we have had an opportunity to observe a weak cycle with modern instrumentation, which makes Cycle 24 very interesting." Since the 1950s, the Sun's activity has been high, with the largest cycle in the historical record (Cycle 19) occurring during this time
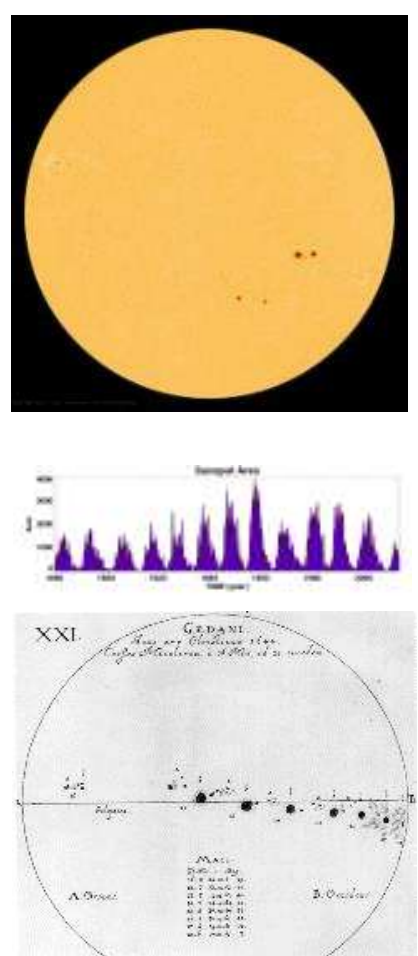

C..DDD

Top: Image of the Sun taken on October 152013 by the Atmospheric Imaging Assembly (AIA) telescope that flies on the NASA Solar Dynamics Observatory (SDO) satellite. Most of the sunspot activity in this image can be seen in the Sun's Southern Hemisphere, while the Northern Hemisphere seems to have already gone through its peak in activity. Middle: Shows a record of sunspot area measures going back to solar cycle 12 in 1898. Areas are measured in millionth of solar hemisphere and averaged over three solar rotations.

Bottom: A drawing by Johannes Hevelius created in 1644 , one year before the start of the Maunder Minimum, shows the passage of a large spot across the solar disk, which occurred over eight consecutive days. frame. But beginning with Cycle 23 in 1996, things started to change. While still an aboveaverage cycle, Cycle 23 was noticeably weaker than the preceding ones and had fewer very 
large sunspots. Then, with Cycle 24, solar activity declined even more. Sunspots of all sizes have decreased in number, with large sunspots particularly scarce.

"This does not make Cycle 24 anomalous" says de Toma. "Weak cycles have fewer sunspots, and especially fewer of the largest sunspots - this is why weak cycles are weak."

A possible explanation for the recent decline in solar activity is that the Sun is near the minimum of a "Gleissberg Cycle." While regular sunspot observations began in the $18^{\text {th }}$ century, scientists turn to cosmic rays as a proxy to understanding solar activity that occurred prior to having a direct observational record. Isotopes (Berrylium-10 and Carbon14), which provide insight on the variation in cosmic radiation incident on Earth, indicate that the amount of radiative energy emitted by the Sun seems to change over a period of about 80100 years. Known as the Gleissberg cycle, this pattern is believed to be of solar origin. While this theory is consistent with the fact that sunspot cycle patterns were similarly weak at the beginning of the 1800 and 1900, given the brevity of a direct solar observational record, scientists are unsure if this is a real phenomenon and, if real, what might cause such modulation in solar activity every 100 years. If valid, a Gleissberg Cycle might explain why the Sun is currently quieter.

Matt Penn and Bill Livingston at the Solar National Observatory have put forward the suggestion that the Sun may be entering a period of inactivity. They reported a decline in magnetic field and darkness of sunspots, independent of the current weak solar cycle. According to their analysis, observations taken with the McMath-Pierce telescope located at the Sonoran Desert-based Kitt Peak Solar Observatory show that sunspots are becoming less dark at a worrisome rate of about $2 \%$ a year since the early '90s. If true, in extrapolating this trend forward in time, the Sun will experience a new Maunder Minimum by the year 2022.

The Maunder Minimum, which lasted from 1645 to 1715, was a period when sunspots rarely appeared. While little is known about the causes of the Maunder Minimum, one interesting aspect of this period is that it coincided with lower than average temperatures in Europe and North America. However, this was also a period of high volcanic activity that likely contributed to the observed cooling. Despite happening only once in the hundreds of years that humans have been counting sunspots, by using cosmic rays as a proxy of pre-historic solar activity, the Maunder Minimum is not a unique occurrence.

So is the Sun on course for a long period of low activity? The decline found in the McMath- 
Pierce data occurs mostly in the early years, when only a very few measurements were collected. This decline has not been confirmed by other observations, in spite of the fact that other groups have looked for similar trends in different data sets. To better understand the recent slowdown in solar activity, de Toma and her colleagues at the California State University, Northridge examined the solar observations collected at the San Fernando Observatory (SFO) with the Cartesian Full Disk Telescope (CFDT1) that goes back to 1986. This data set includes more than 20,000 sunspot observations and is the longest record of accurate photometric sunspot measures, that is, accurate measurements of sunspot brightness.

"While the total area and number of sunspots have decreased in Cycles 23 and 24, the relationship between the area and brightness of the sunspots has not changed," de Toma says. "We do not find that sunspots are getting less dark during the 27-year period spanned by the SFO observations. Sunspots are not different now than they were in Cycle 22, when activity was high."

This evidence suggests that while the Sun's quiet has not been seen within recent history, it does not imply that the Earth will experience a Maunder Minimum, or that sunspots are disappearing.

The quiet solar maximum provides astrophysicists with a unique opportunity to hone their understanding of the solar dynamo and their ability to predict the strength of upcoming solar cycles. As for predicting a Maunder Minimum, this is still out of our reach, according to de Toma.

"We still do not know how and why the Maunder Minimum started, so we cannot predict when another one will occur," she says. "We know from drawings made by Johannes Hevelius in the $17^{\text {th }}$ century that there were large sunspots on the Sun shortly before the Maunder Minimum stated, so the lack of large spots is not an omen of an incoming Maunder Minimum."

In addition to the intellectual challenge, another benefit of this weaker solar activity is that fewer coronal mass ejections occur during these quieter cycles. This results in quieter space weather, which can affect communications and electrical grids on Earth, as well as space missions.

“That said, space weather does not go away when the Sun is quiet. Powerful solar eruptions can still occur. The 1859 Carrington flare, which caused the strongest geomagnetic storm on 
record, occurred during a normal cycle, not a very active one" cautions de Toma. "Indeed, in July 2012 we observed the fastest coronal mass ejection ever recorded, which blasted away from the Sun at a record speed of about 3,000 kilometer-per-second - luckily, it was not directed toward the Earth." 